FROM THE LIERARY OF

REV. LOUIS FITZ GERALD BENSON, D. D.

BEQUEATHED BY HIM TO

THE LIBRARY OF

PRINCETON THEOLOGICAL SEMINARY 
. 


$$
\int_{\mu} q^{4}
$$




\title{
BRITISH
}

MUSICAL BIOGRAPHY :

A DICTIONARY OF

MUSICAL ARTISTS, AUTHORS AND COMPOSERS, BORN IN

BRITAIN AND ITS COLONIES.

\author{
BY \\ JAMES D. BROWN, \\ AUTHOR OF A "HOGRAPHCAL DICTIONARY OF MESICIANS," hTC, \\ AND \\ STEPHEN S. STRATTON.
}

\section{BIRMINGHAM :}

S. S. Stratton, 247 , Monument Road.

PRINTED HY CHALFIEII) AND SON, 1.TD., DERBY.

1897. 
TO THE INCORPORATED SOCIETY OF MLSICLANS

THIS WURK Is

DEDICATED

BY THE AUTHORS. 



\section{PREFACE.}

In undertaking this work, the anthors have been animated by the desire to present the true position of the British Empire in the world of music. A country is musical only by the music it produces for itself, not by what it takes from others. In this work, therefore, only what has been done by Iritain's own sons and dangliters is placed on record. It is probable that in $n$ other nation is there, at the present time, greater musical activity, creative or executive, than is to be witnessed in our own; and this not only in the great centres of population and culture, but everywhere throughont the Empire. In this connection the work of provincial and colonial musicians has received its proper share of attention. The greater masters, already noticed at length in other similar publications, hase been treated with brevity in order to afford space for mention of many worthy if obseure, workers in the canse of Art, litherto passed over by writers of biography. The very large number (probably over 40,000) of persons engaged in the musical profession at the present time will explain the apparent preponderance of notices devoted to living musicians. This part of the work, however, is intented rather to be representative than complete; and from varions canses, in many cases only a bare ontline conld be accomplished. While some names may seem to have but slight claim to inchusion, it is hoped that no artist of eminence has been omitted. The book being written from an independent standpoint, matters of opinion have been subordinated to the presentment of facts; and its nsefulness as a work of reference has been one of the main objects of the authors. Accuracy has been striven for as regards dates of birth and death; first performance of important works; and first appearances of artists, which have been carchully collated, where possible, from contemporary notices. Many of these difter from tates hitherto accepted. Still, faults and omissions may be detected, and any information in correction thereof will be gladly received. The work is 
issted by the authors themselves as a lind of experiment in publishing, their object being a patriotic desire to record the achievements of British worker's in the field of musical art.

The anthors are indebted to the following gentlemen for information or aid rendered during the progress of the work:-Mr. Reginald B. Moore, Exeter; Mr. J. A. Browne, editor of the British Musiciun; Dr. James C. Culwick, Dublin; Mr. Spencer Curwen, London; Mr. T. B. Dowling, Cape Torns, South Africa; Mr. Emlyn Evans, Cemmes, Montgomery; Mr. Joln Glen, Edinburgh ; Mr. W. J. Ions, King's Norton; Mr. E. P. Jones, Brisbane, Australia; Mr. J. A. Natthews, Clreltenham; Mr. C. F. South, Salisbury; Mr. C. J. B. Tirbntt, Reading; Mr. Herbert Thompson, Leeds; and Mr. F. H. Torrington, Toronto, Canada. Also to those artists who responded to the applications made to them for personal information. In addition to the catalognes of the British Museum and other public libraries, general newspapers, and other sources of information, the following works have been drawn upon for particular details:-Brown's Biographical Dictionary of Musicians; Grove's Dictionary of Music and Musicians; the works of Fétis and Mendel-Reissmann; Dictionary of National liography; Love's S'cottish Church Music; Baptie's Musicians of All Times, and Musical Scotland; Roll of the Union of Gradnates in Music; Degrees in Mnsic, Abdy Williams, etc. The chief authorities for dates within their period have been the Wusical Wrorld, 1836-91; Dramatic

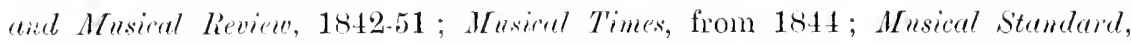
from 1862; besides the musical journals of more reeent date. For many particulars of less-known mnsicians, bandmasters, and teachers, much has been gleaned from the Orchestral T'imes, British Musician, the Musical Herceld, and other papers.

STEPIIEN S. STRATTON,

247, Monument Roud,

Birmingham.
Janes 1). Brown,

Pablic Library,

Clerkenwell, London, E.C. 


\title{
ABBREVIATIONS.
}

\author{
C.M. .. .. Choirmaster. \\ F.C.O.. . . Fellow of the College of Organists. \\ G.S.M. . G Guildhall sehool of Minsic. \\ I.S.M. . . . Ineorporated Society of Musicians. \\ Mus. B. . . Bachelor of Music. \\ Mus. D. . . Doetor of Musie. \\ R.A.M. . R Royal Academy of Music; \\ A.-Associate ; F--Fellow ; L.-Licentiate. \\ R.C.M. $\quad$. R Royal College of Music. \\ A.-Associate of the same. \\ R.C.()... .. Royal College of Organists; \\ F.-Fellnw of the same. \\ R.I.A.M. . R Royal Irish Aealemy of Music. \\ T.C.L... .. Trinity Cellege, Lomdon; \\ L.-Licentiate of the same. \\ Pf. .. . . Pianoforte. \\ P's. . . . . Psalm.
}

Dates or words within square brackets, thus - [1840] are approximations, or have been supplied from other sourees to supplement midated title-pages, ete. 


\section{BRITISH MUSICAL BIOGRAPHI}

AARON.

Aaron. Scottish writer, who was consecrated Abbot of St. Martin, Cologne, in 1042. He wrote a work on chanting in public worship, entitled, "De Utilitale cantus vocalis et de modo cantandi'atque psallendi " He died in 1052 .

Abbott, Rev. Henry. IVriter. Was lecturer of the Church of St. John the Baptist, Bristol. Author of "The use and benefit of Church musick towards quick'ning our devotion. A sermon." London, 1724.

Abbott, Thomas Moreton, violinist, born at Bilston, Staffordshire, August 13, 1843. Studied under Henry Hayward, of Wolverhampton. Resident for some years at Walsall; he ultimately settled in Birming. ham. His repertory is large, and he is in wide demand as a soloist. As orchestral principal violin he lias been associated with Mr. Stockley's orchestral concerts since 1873, first as colleague with Henry Hayward, and then with F. Ward; also, at the concerts of the Birmingham Festival Choral Society, and societies at Oxford, Wolverhampton, and other festivals. He is an accomplished violoncellist and pianist, but in these capacities restricts limself to teaching.

Abell, John, alto singer and song collector, born, probably, about 1660 . In May, 1679 , he became a gentleman extraordinary of the Chapel Royal, and was shortly afterwards sent to Italy by Charles II., to study music and singing. He returned to England in 1681.2, and re-entered the Chapel Royal, where he remained till 1688. He was made a Bachelor of Music at Cambridge, in 1681. In 1688 he was dismissed on account of his being a Roman Catholic, and he went to Holland and Germany, where he became known as a lnte-player and singer. He sang also in Poland, and it is related of him that on refusing to sing before the King at TTarsaw, he was seized and suspended in a chair over a bear-pit, when the threat of being lowered into its midst compelled a display of his vocal powers. In 1698-9 he was Intendant at Cassel, and in 1700 he returned to England. He afterwards resided at Cambridge, and is supposed to have died there about 1724 .

Works.-Collection of songs in several languages, London, 1701. Collection of songs in English, London, 1701 (contains To all lovers of musick, a poem by Abell). Song on Queen Ann's coronation [1702]. Collection of - . Scotch songs, etc. [1740], containing songs by Abell. Two songs in "Pills to purge melancholy" [1719].

Abingdon, Willoughby Bertie, Earl of, amateur composer and flute-player, was born on Jannary 16, 1710, and died September $26,1799 . \quad \mathrm{He}$ established concerts in London, and composed "Representation of the execntion of Queen Mary of Scots, in seven views, the music composed and adapted to each view by the Earl of Abingdon," "Twelve sentimental catches and glees for three voices;" Duets, songs, flute music, etc.

Abram, John, organist and composer, born at Margate, August 7, 1840; graduated Mus. Bac., Oxon., 1868; Mus. Doe., Oxon., 1874; Fellow of the Royal College of Organists. Has lield appointments as organist at St. John's, Torquay, 1864 ; St. Peter and Paul, Wantage, 1865; St. Paul's, St. Leonards-on-Sea, 1869; and is at present organist of All Saints', Hastings. Conductor of St. Leonards and Hastings Choral Lnion, a society that, under his direction, has done much for the canse of music in the locality. He is also director of the Hastings Pier Summer concerts.

His compositions include an oratorio. The Widow of Nain: cantatas, Jerusalem, and a Military Ballade, 1892; anthems, services; Festival March for organ and roices, to the lymm Onward Clnistian Soldiers; pianoforte pieces, ete.

Abrams, Harriet, soprano vocalist and composer, was lorn in 1760. She studied under Dr. T. A. Ame, and made her first appearance at Drury Lane in his "May Day," in 1775 . In 1776 she appeared with her sister Theodosia at the Concert of Ancient Music, and in 1784 she sang at the great Handel Commemoration. She afterwards sang at the principal London concerts during her time. She died abont 1825.

Works.-Eight Italian and English Canzonets for one and two voices. London, 1785. Second sett of . . Canzonets . . [1805]. Collection of Scotch Airs harmonized for three voices [1790]. Collection of twelve Songs, London, 1803. Songs - Crazy Jane; The Felon [1800]; Female hardship; Friend of 
ABYNGDON.

my heart; Orphan's l'rayer; Smile and a tear; Tom IIalliard; William and Mary. Also, Little Boy blue, glee; All nature mourns, duet [1805]; And must we part? dnet [1810].

Her sisters, Eliza and Tileonosia (17601834, afterwards Miss. Garrow) were also vocalists of some reputation, the latter possessing a fiue mezzo-soprano voiee.

Abyngdon, Menry (also Habyngton and Abyngtoni), composer, of the 15 th eentury. He was suecentor of Wells Cathedral in 1447 . 97; Nus. Bac., Cambridge, 1463; Master of song in the Chapel Royal, London, 1465; Master of St. Catherine's Hospital, Bristol, 1478. He was celebrated as an organist and singer. Died Septenber $1,1497$.

Ackroyd, Thomas, musieian, compiler of "An original set of 51 Psalm and liymn tunes, for four roiees, witl organ or pianoforte accompaniment." Halifax, $18 \pm 8$.

Acland, Arthur H. D., See Troyte, Arthur H. D.

Acland, T. G., anthor of "Chanting simplified," London, $18+3$.

Acton, John, composer and teacher of singing, horn 1863. Studied music privately, Manchester; later, singing under Franceseo Lamperti, of Milan. F.C.O. 1882; qualified for 11 us. Bare, Oxford, 1893 . Held various organ appointments 1882-93; now devoted entirely to teacling singing and directing choral soeieties. Professor of singing at the Manchester R.C.M. sinee its opening, 1893 ; conduetor of the St. Ceeilia Choral Society, Manchester, 1894. He has composed two cantatas for ladies' voices: Forest bells, [1888]; The rose and the nightingale [1893]. Was awarded the prize offered by the South London Musical Club, 1888, for Chorus, men's voices, with pf. ol,bligato, For liome and liberty. Other works are ducts for ladies' voices: six duets; Songs on the river (six); The fairies (six); and Songs of wood and fairyland (six). He has also written pieces for pf. \&c.

Adam, Alexander, printer, established in Glasgow at the end of last century. He published "The Psalms of David in netre, newly translated ... allowed by the authority of the general assembly of the Kirk of Scotland and appointed to besung in eongregations and families, with twenty-three seleet psaln-tumes particularly adapted to the subject of the psalms to which they are set." Glasgow, 1773. "The Musical Repository, a collection of favourite Scotch, English, and Irish songs set to musie." Glasgow, 1799, also Edinburgh, 1802, etc.

Adams, Abraluam, organist and composer, who flourished at the end of the $17 \mathrm{th}$ and beginning of the 18 th eenturies. He was organist of the parish chureh of St. Mary-lebone, London, in 1710, and compiled "The Psalmist's New Companion," London, n.d., of which a 6 th edition appeared about 1720 .
ADCOCK.

Adams, James B., musician, who flourislied in the latter part of the 18th and beginning of the present century. He published a large number of songs and pianoforte pieces, anlong which may be named the following:The Paphian Doves [1753], a musical play. Three sonatas for the pf. or harpsichord and flute and violin op. 4 [1790]. A eollection of songs, ete., London [1770]. Select songs set to musie [1803]. Songs: Bacehanalian ; Come gentle god of soft repose; Daphne; Invocation; Myrtilla; Power of music; The request; etc.

Adams, John S., writer, author of "Five thousand musical terms." London, 1861.

Adams, Stephen, see MArBrick, MiCHAEL).

Adams, Thomas, organist and composer, was born at [London?], on September 5, 1785. He studied under Dr. T. Busby, and became organist of Carlisle Chapel, Lambeth, 1802-14. Organist of St. Paul, Ieptford, 1814; of St. George, camberwell, 1824; and of St. Dunstan's, 1833. Ife died in London on September 5,1858 .

Wonfs. - A grand mareh and quick step, composed for the regiment of loyal London volunteers [1808]. Six fugues for organ or pianoforte $[1820]$. Six voluntaries for the organ [1820]. Grand organ piece [1824]. 'Three voluntaries for the organ [1894]. Six organ pieces [1825]. Three organ pieces [1835]. Fantasias, interludes, and transeriptions for organ and pianoforte. Anthems and hymms.

An organist of much celebrity in his day, who was a very remarkable extempore player.

Adams, Thomas Julian, composer and conductor, was born at London, January 28, 1824. He studied under Moscheles and at Paris, and settled in England as a teacher and conductor. In 1851 he formed an orchestra and visited Edinburgh, Glasgow, and Greenock, giving a series of weekly concerts. In 1853 he performed at Paris, and in 1855 organised another orchestra, with which he travelled in England, giving concerts of high-class music. He afterwards resided at Searborough, Tynemouth, and Buxton as concert-conductor. In 1877 he settled at Eastboume as conductor of the Devonshire Park concerts. He died at Eastbourne, May 7, 1887.

He introduced Debain's harmonium into England, and wrote for it a work entitled Method for the patent harmonium (1855). He also eomposed fantasias, studies, marehes, and concert-pieces for the orchestra.

Adcock, James, composer, born ai Eton, June 29, 1778. He was a chorister in St. George's Chapel, Windsor, 1786, and a layclerk in 1797. Member of Trinity, St. John's, and King's Colleges, Cambridge. Schoolmaster to the choristers of King's College, Cambridge. He died at Cambridge April 30 , 1860. 


\section{ADCOCK.}

Works.-Evening sevice in B flat. Anthems. Three glees for three and four voices, dedicated to Sir Patrick Hake (1815). Hark how the hees, glee for four voices. Welcome mirth and festive song, glee for three roices. Sungs-Lucy, Queen of pleasure's languid smile, etc. Pudiments of music, N.D.

Adcock, John, author of "The singers' guide to pronumciation, with an appendix consisting of a pronouneing dictionary of musical terms, etc.," Nottingham. [1873]. Mr. Adeock is choirmaster of Castle Gate Chapel, aud conductor of the Sacred Harmonic Society, Nottingham.

Addington, Rev. Stephen, Independent clergyman and musician, born at Northampton Jume9th, 1729. Ife was successively minister at Spalding, Market Harborough, and Miles' Lane Meeting House, Cannou Street, London, 1781. He died at London, February 6th, 1796. Compiler of "A collection of Psalm-tunes for publick worship," 1780 ; 6th ed., 1786; snpplement, 1800 . "A collection of approved anthems sellected from the most eminent masters" [1795].

Addison, John, composer and double-bass player, was born at London in 176.5 . He played the 'cello at Tauxhall Gardens, and was double-bass player at the Italian Opera, the Concerts of Ancient Music, and the Vocal Concerts. He married Miss Willems, the voealist, in 1793. In the latter part of his career he embarked in commercial speculations and was greatly reduced in circumstances. Hc died at London, January 30, 1844.

Works.-The sleeping beauty, 1805. The Russian imposter, 1809. My aunt, 1813. Two words, 1816. Free and easy, 1816. My uncle, 1817. Bobinet, the bandit, 1818: Musical Dramas. Elijah, a sacred drama. Songs-Songs of Almacks (with Bishop and Bayley), 1s31; Allen-a-dale; Clay cold dwelling; Cupid's frolic; Zephyr's reply; and many others. Singing practically treated in a series of instructions, London [1836].

Addison was a successful teacher of singing and numbered Alex. Lee and Pearman among his pupils. His wife, Miss Willems, who was a niece of Reinhold the vocalist, was a singer, and made her first appearance in 1796, in "Love in a village." She sang at Tauxhall, Covent Garden, and other concerts in London, and appeared also at Liverpool, Dublin, etc.

Addison, Robert Brydges, composer, born at Dorchester, Oxford. Studied at R.A.M. under C. A. Macfarren, to whom he was subprofessor for four years. A.P.A.MI., 1882, and professor of harmony and eomposition. Professor, Trinity College, London, 1892. While at the R.A.M. he composed some works noticeable for high aim and finish, tlie chief being a symphony in $\mathrm{G}$ minor (two movements from which were performed at R.A.M. concert, De-
AGUILAR,

comber 15, 18s1); eoncert allegro in $\mathbf{G}$, orchestra. Sonata in A minor, pf.; andante and variations, $\mathrm{pf}^{\mathrm{f}}$; cantata, "A vision," for contralto solo, ehorus, orchestra, and organ (R.A.M., June 1S40); I's. 126, four voices; Hotet, Save me, O God; two albums for childron - "Please sing me a song," and "Children's voices." But be is more widely known by his songs, tasteful and fresh in feeling, Fandering wishes; Two doves; Io I love thee? O mushing wind; and others, also a trio for female voices, "Quiet hours."

Adlington, William, pianist, teacher, and publisher, born at Southwell, Notts, in 1838. He was edueated at the R.A.M., of which be beeame an Associate in 1865, and a Fellow in 1852. In 1864 he settled in Edinburgh, and held various important teaching appointments. Afterwards he resided at Aberdeen, where he was conductor of the University Orchestral Society. He is now engaged in musieselling and publishing. Author of "Elementary principles of music and elements of hamony adapted for those studying the pianoforte." Eainburgh, 18Rl.

Adye, Willett, amateur musician, author of "Mnsieal notes," London, 1869, a work on violinists.

Agabeg, Mrs., see Wrane, Sarah Edith.

Aguilar, Emanuel A., composer and pianist, born in Clapham, London, August 23, 1824. Son of E. Aguilar, a West Indian of Spanish extraction, and brother of Iiss Grace Aguilar, the novelist. Resident in London as teacher and concert-giver. Has also given eoncerts in Germany, where some of his most important works have been produced. His pianoforte reeitals have been, for many years, a regular feature of the London musical season. Played at the Gewandhaus concerts, Leipzig, March 30th, 1848.

Works.-Psalm I., voices and orehestra, 1861 (MS). Operus - Wave king, 1855 (MS); The bridal wreath, 1863. Cantatas, The bridal of Triermain, Bedford, 1880 ; Summer night, 1875, Goblin market, 1880, both for treble voices. Songs - The stars are brightly beaming, The appeal, etc. Symphonies-No. 1, in C, 1844 (MS.), Frankfort on Main; No. 2, in E minor, 1844, Frankfort, 1851, London; No. 3, in D minor, 1854, London. OeerturesAlpheus, 1853, London; St. George, 1875, London; also at Kissingen and elsewhere on the continent. Pianoforte works - Allegro maestoso, p. and orehestra, 1852, London; Septet, pf., wind, and strings, $188^{2}$; Sextet, pf. and wind, 1860 ; Quartet, pf. and strings, 1888; Quartets in $\mathrm{A}$ and $\mathrm{D}$ minor, strings, 1884-5. These have been performed at concerts of the Musical Artists' Society, the septet excepted. Trios, pf. and strings, in G minor, 1853 ; E major, 1856; A minol, 1889, performed at various concerts. Fantasia for 


\section{AGUTTER.}

organ, two pianos, and violin, 1880; Duo concertante, in C, two pianos, 187 ; Sonata, pf. duet, 1885; Six sonatas, many smaller pieces, and a little book, How to learn the pianoforte, 1883.

Agutter, Benjamin, organist and composer, born at St. Albans, April 2, 1844. Studied singing under Manuel Gareia; orgau and composition with E. J. Hopkins; and harmony and eounterpoint with Dr. Wylde. Graduated Mus. B., Oxon., 1870 ; Mus. D., Cantuar, 1891; F.R.C.O., etc. Since 1867, precentor, organist, and choirmaster, St. Peter's, Streatham. He has eomposed a Missa de Saneto Albans; Missa de Saneto Petro ; and six other services for Holy Communion; sequence, To the Paschal victim (scored for orchestra); anthems; morning and evening services in D and A flat; hymus, carols, \&e., de.

Ainley, William Clark, organist and composer, born at Kirkheaton, Yorkshire, July 13,1834 . Was a chorister at the Parish Chureh when ten years old; pursued his musical studies privately. A.R.C.O., Mus. B., Cambridge, 1885. Has been organist and choirmaster successively at Kirkburton Parish Church, 1856; Kirkheaton, 1863; Mold Green Parish Chureh, 1865; and Mirfield Parish Chureh, 1874 to present time. Conductor of the Mirfield Choral Soeiety. His composi. tions are:-Ps. 46, for soli, ehorus, and organ [1885]; eantata, The great day of the Lord, produced Nirfield, 1891. Anthems-O give thanks; Behold, O God our defender (written for the Queen's jubilee, 1887); and others. Te Deum, communion serviee in $G$, evening service in $\mathbf{E}$, introits, organ pieces, \&c.

Aird, James, music publisher of the last half of the 18th century, was established in business in Glasgow, where he died in September, 1795. He issued among other works "A selection of Scots, English, Irish, and foreign ains adapted for the fife, riolin, and German flute," Glasgow, 1784, etc.. 6 vols. He was succeeded in business by J. McFadyen, who published new editions or contiuuations of Aird's publications.

Airy, Sir (ieorge Biddell, astronomer, born at Alnwick, June 21, 1s01. He was edueated at Cambridge, ete., and in 1835 was appointed astronomer-royal. He died on January 1, 1892. Author of "On sound and atmospheric vibrations, with the mathematical elements of music," London, 1864 ; also many works on astronomical and mathematieal subjects.

Akeroyd, Artluur Thomas, Organist and composer, born at Bradford, March 10th, 1862. Articled pupil of F. C. Atkinson, A.R C.M. Organist and choirmaster, St. Paul's Bradford ; music master, firls' Grammar School, Bradford; aud conductor of the

\section{ALBERT.}

Ilkley Vocal Soeiety. Hon. See. Yorkshire Section of the Incorporated Society of Musieians. He has composed an opera, "The Professor" (book by G. W. Harwin, produced Theatre Royal, Bradford, 1891); an operetta, "The Doctor's Dilemma" (Teehnical College, 1893); an anthem for Christmas; songs and part-songs; minuet and trio for organ, and pieces for $p f$.

Akeroyde, Samnel, composer, born in Yorkshire at end of 17 th century. He composed many songs in the "Theater of Musick," 1685-87; "Banquet of musick," 1688 ; and in other collections of the same period. Among his single songs may be mentioned, Give me kind Heaven [1700]; Thursday in the morn [1730]; Rays of dear Clarinda's eyes [1700]; etc. He died early in the 18 th century.

Alaw, Ddu. See Rees, Villiam Thomas. Alawydd. See Roberts, David.

Albani. See La Jeunesse.

Albert, Prince Francis C. A. A. E. (Prince Consort), amateur musician, born Rosenau, Coburg, August 26,1819. Married Queen Victoria, February, 1840. Died Windsor, Deeember 14, 1861.

He eomposed a number of anthems, services, songs, psalm-tunes, ete., most of which have been colleeted in "Songs and ballads written and set to musie by their Royal Highnesses, Albert and Ernest, Princes of Saxe-Coburg and Gotha." Edited by E. J. Loder, Loudon, 1840; and "Tocal compositions of H.R.H. the Prinee Consort." London, 1862. In 1849 and 1855 his piece, entitled L'Invocazione all' Armonia was produced at the Birmingham Festival. Most of the members of his family are musical.

Albert, Eugene Frangois Charles d', pianist and composer (son of Charles Louis Napoleon d' Albert, famous dance-music composer, who died in 1886), born at Glasgow, April 10, 1864. His mother, nes Annie liowell, of Newcastle-on Tyne, was his first musie teacher. After a few pf. lessons from the late G. A. Osborne, d' Albert gained the Newcastle scholarship at the National Trainiug School of Music, in 1876 , and later on was elected to the Queen's Scholarship, which he held until 1881. His teachers were Arthur Sullivan, Johu Stainer, E. Pront, and E. Paner. In 1881, he was nominated to the Mendelssohn Seholarship, which he only held for one year, failing to comply with the regulations. While still a student he made his debut at the Nonday Popular Concerts, November 22,1880 , playing Schumann's Etudes Symphoniques; and at the Crystal Palaee, February 5, 1ss1, taking the solo part in Schumann's pf. concerto in A minor. In Oetober, 18s1, he appeared at a Richter Concert as a composer, with his own Coneerto in A. As a pianist he gained a high 


\section{ALBERTAZZI.}

reputation. Hans Richter then took hin to Vienna, but he played again in London in the spring of 1882. He now became a pupil of Liszt, and was appointed Court pianist to the Graud Duke of Weimar. I) Juing the next four years he made artistic tours through Ger many; visited Russia, Italy, Spain ; and twice undertook concert tours in America. He held various appointments, the last being that of Kapellmeister at Weimar; 1895, which he did not hold long. He reappeared in London, April 28, 1896, at one of the Mottl concerts; began a series of Recitals, May 1; and played Liszt's concerto in E flat at the Philharmonic concert, May 6 , being most enthusiastically received.

Works. - Operas: Ghismonda (Dresden, 1895); Der Rubin (composed 1892); A work for chorus and orchestra, founded on Otto Ludwig's Man and Life (1893); songs, ete. Symphony in F (1885); Coucerto in B minor, op. 2(1884); in E, op. 12 (Berlin, Jan. 1893), for $\mathrm{pf}$. and orchestra. Overtures: Hyperion (Berlin, 1885); Dramatic overture in A, op. 9 (Cologne, 1887); Esther (Viema, 1888); String quartets, in A minor, op. 8; in E tlat, op. i1 ; Suite for pf., op. 1; Sonata, F sharp minor, op. 10 , de.

Albertazzi, Emma (born Howson), contralto vocalist, born in Loudon, Nay 1, 1813 [1814]. She was a daughter of Francis Howson, musician of London. In 1827 she studied under Costa, and in November, 1 s'g slye was married to Siguor Albertazzi. She first appeared in the Argyle Rooms, London, in 18y9, and in 1830 she sang at the King's Theatre. In 1832 she appeared at Milan, and afterwards at Madrid and Paris. She reappeared at Lon. don in La Cenerentola, April, 18:37, and in 1838 sang at Drury Lane in La Gazza Ladra. She frequently appeared as a concert vocalist, and died in London, September 27, 1847.

Alcock or Allcock, John, composer and organist, born at London, April 11, 1715. He was a chorister in St. Paul's Cathedral under Charles King, and afterwards stuaied under John Stanley, the blind organist. He lield successively the appointment of organist at All Hallows Church, London, 1735; St. Andrew's, Plymouth, 1737; St. Lawrence's Reading, 1742-49; and Lichfield Cathedral, 1749-60, where he was also vicar-choral and master of the choristers. In 1755 he gracluated as MIus. Bac. Oxford, and in 1761 or 1765 proceeded to Mus. Doc. Oxford. He held the appointment of organist at Sutton Coldfield parish chureh, 1761-86; and at Tamworth parish chureh, 1766-90. He gained a prize med:al of the Catch Club in 1770 . He retained the post of layvicar at Lichfield till his death at Lichfield on February 23, 1806.

Works.--Morning and Evening Service in Eminor, 1753; Six-and-twenty select anthems

\section{ALDRICH.}

in score . . . to which are added a burial service for 4 voices and part of the last verse of the 150 th Psalm for 8 voices and instruments, London, 21 parts, 1771. Miserere, or the 51st Psalm in Latin for 4 voices, 1771. Fifty select portions collected from the singing Psalms, Reading, 1748. The Pious Soul's heavenly exercise, or divine harmony; being a choice collection of those excellent psalm tunes which are used in the parish cliurches in London, etc., Lichfield, n.d. Harmony of Sion, or a collection of all the capital psalm tunes that are used in London, Derby, n d. Divine Harmony, or a collection of 55 double and single chants for 4 voices, as they are sung at the cathedral of Lichfield, 175\%. Parochial Harmony, 1777. Harmony of Jerusalem, being a collection of 106 psalms and liymus in score, 1801. Harmonia Festi, or a collection of camons, cheerful and serious glees, and catches for 4 and 5 voices, Lichfield, 1791. Hail, everpleasing solitude! (prize glee), 1770. Twelve English songs, 17t0. Eight easy voluntaries for the organ, 1760. Six suites of easy lessons for the harpsichord or spinnet, with a trum pet piece, Reading, 174?. Six easy solos for the German flute or violin, 1750. Life of Miss Fanny Brown (a novel).

Alcock, John, son of the above, was bom probably at l'lymoutl about 1740 , and studied under his father. He became organist of St. Mary Magdalene, Newark-on-Trent, in 1758, and remained there till 1768 . In 1773 , he became organist of the Parish Church, Walsall, and died there, March 30, 1791. In 1766 he graduated as Mus. Bac. at Oxford. He composed some anthems, songs, and harpsichord music, among which are-A cantata and six songs [1770]; Venus and Bacchus, a two-part song: Let me sink to regions of shade (song); Three sonatas for two violins and violoncello; The chace (pianoforte piece).

Alcock, William Bennis, organist. Studied under - ir R. P. Stewart. Graduated Mus. B., Oxford, 1879. Was appointed the first organist of Christ Chureh, Momingside, Elinburgh, in 1876, where he worked up the musical service to a high pitch of excellence. He was a most skilful organist. In 189 he resigned his post at Christ Chureh, and was appointed music master in Speir's School, Beith, Ayrshire, where he taught with much snccess. He died, of congestion of the lungs, October, 1892. Madrigals and glees, he made a study of, and lectured upon the subject in Morningside Athenreum.

Aldrich, Henry, divine and composer, born at Westminster in 1647. He was edueated at Westminster School, and at Christ Church, Oxford, from $166 \%$. He hecame B.A., 1666 ; M.A., 1669 : Canon of Clrrist Church, 1681; D.D., 1682; and Dean of Christ Church, 1689, all of Oxford. He died at 


\section{ALEXANDER.}

Oxford, December 14, 1710, and left his musical library to Christ Chureh.

Worrs.-Services in G and A. AnthemsI am vell pleased; Not unto us, O Lord; Out of the deep; $O$ give thanlis; $O$ praise the Lord; Thy beauty, O Israel; We liave heard with our ears. Glees-Hark, the bonny Christ Church bells, for three voices; A catch on tobacco, ete. Works on logic, ete.

Another musician of this name, viz., BEn. FOrD ALDRICH, composed and published a number of sougs in the first half of the 18th century.

Alexander, Alfred, organist and composer, born at Rochester, Kent, May 6, 1844. Chorister at the Cathedral, pupil of, and, later, assistant to, Joln Hopkins, the Cathedral organist. Took the Toronto degree of Mus. B. in 1889. When seventeen, succeeded J. F. Bridge as ormanist of Shorne Church, near Rochester; then appointed to Strood Parish Clurch, and afterwards offered the post of organist to the Earl of Mar and Kellie. When Dr. Colborne left St. Michael's College, Tenbury, Sir Frederick Ouseley in vited $\mathrm{Mr}$. Alexander to fill the vacancy. He afterwards went to Wigan Parish Church; then (1891-2) to Nice, as organist of the American Church; and is now at St. Andrew's, Southport. Has given organ recitals, and conducted concerts of the Wigan Choral Society. His compositions include a cantata; Ps. 126, for soprano solo, chorus of women's voices, and orchestra; services, anthems, songs, part-songs, ete. Triumphal march, orchestra; Sonata in B flat, for string quarlet; Romances, violin ; Sonata in D minor, for organ (published in Novello's original organ cumpositions, 1899).

Alexander, James, writer and performer, published various worls, of which the following are the most important:-Alexander's Book of instructions for the accordion, London, 2 pts. [1845]. Complete instructions for the harmonicun, etc., London [1865]. Various arrangements, waltzes, etc., for accordion and pianoforte.

Alford, John, lutenist of the 16th century, published a translation of Adrian Le Roy's book on the Lute as "A Briefe and Easye Introduction to learne the tablature, to conduct and dispose the hands unto the Lute." London, 1568.

Alford, Marmaduke, vocalist an $\mathrm{com}$. poser, was horn in Somer'setshire in 1647. He was a yeoman and sergeant of the restry of the Chapel hoyal, and died in May, 1715.

Allan, Archibald, violinist and eompose $\mathrm{r}^{\prime}$ of dance music, was boru at Forfar about 1790. Ile was a member of Nathanial Gow's band, and played at balls and other gatherings in Scolland. Ile died at Forfar 1831. He composed strathspeys and other sicots dance
ALLCHIN.

tunes, His brother, Thomas R. Allan (born Forfar, 1807, died Dysart, Fife, 1851), was also a violinist and composer of dance music; and JAIES AlLAN, cousin of the above (boin Forfar, October 17,1800; died there August 18, 1877), was another nember of the same family of violinists which at one time was well-known all over the centre and south of Scotland.

Allan, David Skea, tonic sol-fa teacher, born at Calfsound, Island of Eday, Orkneys, March 14,1sto. Son of a crofter-fisherman, his humble home was brightened by music; and the boy worked hard at his musical studies, overcoming difficulties of no ordinary nature. In 1864 he settled in Glasgow, where he has ever since remained. After holding several appointments as I'recentor, he was asked, in 1877 , to take the practical classes at Auderson's College. These were trausferred to the Christian Institute in 1881, and under the auspices of the Sunday School Union, continue to be popular and successful. I He is also conductor of St. Andrew's Choir, and has charge of the music in many of the drasgow board schools. Ile is a Fellow of the Educational Irstitute of Scotland, and is favourably known as a writer of delicate, tasteful ver'se. I I is publications consist of books of school songs; part-sougs, the Gloaming, \&e.

Allan, James, the "celebrated Northumberlaud piper," was born at Rothbury, March 1734, and died in I urham jail on November 13, 1810. He was well-known all over the borders as a strolling vagrant, and lis biography lyy James Thompson was issued as the "Life of James Allan, the celebrated Northumberland Piper, detailing his surprising adventures, etc." Newcastle, 1817. This has been frequently reprinted as a cliap-book.

Allan, James, baritone singer and conductor, was born near Falkink, July 27, 1842. He became a lithographer in Glasgow and was succesnively preccntor in sydney Place U.P. Church and Kelvinside Free Church in that city. He held the position of conductor of the Glasgow Select Choir from 1880 to 1885, during which time it gave successful concerts in Scotland and England. IJe died at Glasgow, August 10, 1885. He composed various liymu tunes, of which "Vevay "was printed in the Free Church Hymnal, and arranged various songs and airs for choir and schoul use.

Allchin, William Thomas Howell, organist and composer, born 18t3. He luecame IIns. Bac., Oxford, 1869, and conductor of the Oxford Choral Soc. in the same year. Organist of St. Jolm's College, Oxford, 1875, and local examiner for R.A.M. in 1881. He died at Oxfork, January 8, 1883.

Works - The Relellion of Korah, sacred cantata, composed and produced for the degree of Mus. Bac., June 1869 (ms.). Songs-Christ- 
ALLEN.

mas greeting, The forsaken, Lament for the Summer, O but to see her face again, Prythee why so pale, Rainy day, Sea song, A shadow, Song for November, The wreeked hope, etc.

Allen, Alfred Benjamin, pianist and composer, born at Kingsland, London, September 4, 1850. Began the study of the pianoforte at the age of five, afterwards becoming a student at the London Academy of Music. Settled in London as performer and teacher. His eompositions inelude a eantata and a number of orehestral pieces still in MS. Among his published works are the songs, Lead, kindly light; She sang to lier harp; Sweet birdie, mine, and many others. Pianoforte music-Minuet in C; Gavotte in D; Egyptian Court Danee, etc. Also pieces for the organ.

Allen, Edward Heron=, author, born St. John's Wood, London, December 17, 1861. Edueated at Elstree and Harrow. In 1878 he began the formation of his library of works on the violin. In 1879-1881 he studied violin making under Chanot. Admitted a solicitor 1884. Special commissioner to Italy on behalf of Historic Loan Department of Music and Inventions Exhibition, 1885, for which service he was awarded a silver medal. Lectured in United States, 1886-89. Married to Marianna, daughter of lindolph, Lelmann, the artist. Eleeted "Socio onorario e henemerito" of the Accademia of Sta. Ceeilia of Rome, for Bibliography of the Violin.

Works.-De Fidiculis Bibliographia : being the basis of a bibliography of the violin and all other instruments played with a bow. Lond. 1890-93, 12 parts. Yiolin-making as it was and is. Lond. 18st. Manual of Cheirosophy. Lond. 1885. Poems, tales, translations, etc.

Allen, George Benjamin, composer and voealist, born $\mathrm{m}$ I ondon, April 21, 1822. Chorister, St. Martin-in-the-fields, 1830 ; the same in Westminster Abley, 1832. Estal, lished the "Abbey Glee Chub," in 1841, and two years later was appointed to the choir of Armagh Cathedral as a lass. Conductor of Classieal Harmonists' Society, Belfast, and originated and exeented the scheme for building the Ulster Hall, Belfast. Graduated as Mus. Bae., Oxon., in 1852. Left Armagh, and became organist at All Saints', Fensington, and later went to Australia, where he was organist at Toorak, Melboume, and conduetor of Lyster's Opera Company. Returning to England, he established a Comedy Opera Company, and produced the Gilbert and sullivan operas, "The Sorcerer," "H.MI.S. Pinafore," and "The Pirates of Penzance." He had previously made successful to: rs with his pupil, Miss Alice May (tied L.S.A., 18-7), in Australia, New Zealand, and India, lis opera company being admirably organised
ALLISON.

Since 1890 he has been settled in Trislane, New S. Wales

Woris.-Operas - Castle Grim, two acts, London, 1865. The Viking, five acts. 'The Wicklow rose, Manchester, 1982. Fayette (J. Brunton Stephens), not yet (1s95) produced; and others in MIS. Cuntatas-llarvest home, 1863; The Vintage of the lihine, 1865; Ministering (female voices,) 188t. Te Deums in $\mathrm{D}$ and $\mathrm{F}$. Introits and Anthems-A book of fifteen anthems, 1853, and eight others. Concerted rocal music-six four-part songs [1861]; Morning; May; and others. Simens A Shadow: The arrow and the song; and settings of many of Longfellow's ly'ries, the total amounting to about 300 . Pianoforte and organ music. The sicales in music and colourstheir analogy: from the Musical Horld. New pianoforte school. London [1684].

Allen, Henry Robinson, tenor vocalist and composer, born at Cork in 1809 . He studied at the R.A.MI, and first appeared in Mozart's "Figaro" in 1831. Afterwards he sang in opera, ehiefly in London, till about 1856, when he ocenpied himself as a teacher of singing. He died at Hammersmith, London, November 27, 1876. He composed many songs, of which the following are lest known: Adaline; As steals the dew; Bella doma, would'st thou know; Broken spell; Dearest, wake; Dear halls of my fathers; Green are thy hills; Maid of Athens [1861]; Mine, only mine; Pilgrim's lanent; Sea is calm; When first we met; When we two parted, ete.

Allen, James Vaughan, musieian, publislıed "Ten Cathedral Chants in score, with an aecompaniment for tlye organ. London [1842].

Allen, John, organist and composer of latter part of 16 th and carly part of 17 th centuries. He was organist of Chester Cuthedral, and in 1612 he graduated Mus. Bac., Oxford.

Allen, John, violinist, boru in London, and began his carcer as a leader in 1841. Subsequently he went to America, and for thirty years was identified with the San Franciseo theatres. His fom daughter's, Ricea, Ray, Louise, and Amna, are well-known dan cers. He died at Brookisn, New Yurk, about August 1892, at the age of seventy-two.

Allen, Richard, writer, who flourished at the end of the 17th and begining of the 1sth centuries. Author of "An Essay to prove the singing of psalms with conjoint voices a christian duty." London, 1696. "IBrief vindication of an Essay to prove the singing of psalms with conjoint roices a christian duty, from Dr. Rassell's Animadversions and Mr. Marlow's remarks." loudon, 1694 .

Allison, Horton Claridge, comploser, organist, and pianist, lorm in 1ondon, July 25, 1846. Entered the Tin yal Acadenn of Minsic in 1856, and appeared as a pianist at Willis's fooms in May lister, as a pupil of W. H. 


\section{ALLISON.}

Holmes. Studied at Leipzig Cons. 1862-65, gaining, in the last year, the first prize for general profieieney, his teachers being Plaidy, F. F. Richter, C. Reinecke, Hauptmann, and Moscheles. Commenced giving concerts in London, July, 1865, and has since appeared in various towns in the provinces. Resident as teaclier in Manchester. Was elected Associate of the R.A.M., 1862, and Nember in 1880. Graduated Mus. Bac., Cantab., 1877; Mus. Doc., Dublin, the same year. Appointed one of Her Majesty's Examiners in Musie, Intermediate Education Board for Ireland, 1884.

Works.-Cantatas - 1871-74. Setting of Psalms cx., cxvii., and cxxxiv., for soli, chorus, and string orchestra, 1876 , all in MS. Anthems, songs, and part-songs. Symphony for Orchestra, 1875. Suite for Orchestra. Concerto in I. Pf, and Orchestra, composed in 1870 , performed 1877 , and at the concert of the Westminster Orchestral Society, Decenber 9,1891 , and a second concerto, pelformed Manchester, Febrnary 1894, all in MS. Quartet, strings, 1865. Concert Duet for two Pianofortes, 1865. Studies and Coneert Pieces. Sonata for the Organ, 1865, published 1879. Marches and various other pieces.

Allison, or Alison, Richard, composer, who flourished in the latter part of the 16th century, and died early in the 17th century. lle published "The Psalmes of David in meter, the plaine song being the common tunne to be sung and plaide vpon the lute, orpharyon, citterne or base violl, severally or altogether, the singing part to be either tenor or treble to the instrument, according to the nature of the voyce, or for foure royces, cte. Lond. 1599." "An houre's recreation in Musicke, apt for instruments and royees . . . Lond. 1606. He was one of the composers who hamonised the tunes in Thomas Este's "Whole liooke of Psalmes," 1592.

Allitsen, Frances, voealist and composer of the present time. Made her debut at Grosvenor Hall, July, 1882; and has since sung at various concerts. She has composed six songs (Tennyson); eight songs (Heine); After long years; Mary IJamilton; In times of old: Warming; False or true, and others. Ema Allitsen, her sister, is a contralto focalist, pupil of the late J. P. Goldberg. Has appeared at, and given concerts in London. Was a professor of singing at the Blackheat] Conservatoire.

Allon, Rev. Henry, Congregational ninister and musician, born at Welton, near Hull, October 13,181s. Ife was educated at Cheshnnt College, Herts, and was minister of Union Chapel, Islington, from 1844 till 1892. He also acted as editor of the British Quarterly lirriew. Ife died at Islington, Lomdon, April 16, 1892.

Works. - Congregational l'salmist, edited

\section{ALPRESS.}

with Dr. Gauntlett, Lond. 1858 ; also 1860-79 four sections, and numerous other editions. l3ook of chants, 1860. Book of ehurch anthems, 1872. Children's worship hymms, 1878. Chureh song in its relations to church life, Lond. 1862. The worship of the church, 1870 (In Reynolds' "Ecclesia").

Allon, Erskine, composer, son of Dr. Henry Allon, born at Canonbury, London, 1864. Educated at Reading and Trin. Coll. Cambridge. Studied music under IV. H. Birch and other masters, and later under F. Corder. Resident in London.

Works.-Comic opera, MS. CantatasMay Margaret, Op. 17, 1889; Annie of Lochroyan, Op. 20, 1890, produced by the Philharmonie Society, May 18, 1893 ; The Childe of Flle, Op. 23, 1891, produced Islington, Dec. 18, 1891; The Maid of Colonsay, Op. 25, 1894; Sir Nicholas (ehoral ballad), 1895; and The Oak of Geismar, 1895 (MIS.). Songs-Op. 3, 5 ; Twelve songs. Op. 7 ; Albums of old English songs, Op. 15, 18, 24, 28, and 34; Ten love songs, Op. 13; Six pastorals, Op. 34; Albums of songs (words by Dolly Radford), Op. 9, 27, 29, and 33; various songs, duets, and part-songs. Instrumental-Chamber music; Quintet in C, pf. and strings, Op. 35 ; Trio, Op. 22 ; Sonatas, pf. and violin, in F, Op. 19, in G, Op. 21. Pianoforte SoloSonatas, in $\mathrm{C}$ and $\mathrm{r}$ minor, Op. 11 and 12 ; The Months, twelve pieces, Op. 8; Three sets of European dances, Op. 16, 30, and 31 (also for orchestra); Suite in F minor, Op. 26 ; Ballet musie, and other pieces, in dance rhythms, \&c.

Allum, Charles Edward, organist and conductor, born at Great Marlow, Bucks., June 27, 1852. Studied under Mr. Yates, organist of Bisham Albey, and afterwards was pupil and assistant of the late W. W. Ringrose. Graduated Mus. Bac., 1883, Mus. Doc., 1847, Dublin. In 1874 he was appointed organist and choirmaster of Holy Trinity Episeopal Church, Stiring, and also conduetor of the Stirling Choral Society. By his energy and ability the musical services of the church were greatly improved, and the Choral Society raised to more than local importance. The first performance in Scotland of Gounod's Mors ct vita, took place under his direction, December 11, 18.5.5. He holds the appointments of organist of the Public Halls, Stirling, and Town Hall, Alloa. His eompositions include a setting of Ps. 84, and a short oratorio, "The Deliverence of Israel "; only some ehurch music, and transcriptions for the organ, have been published. Author of The Complete Seale and Arpeggio Manuel (Wickins). Dr. Allum holds the rank of Captain in the th Stirlingshire Volunteer Battalion.

Alpress H. G. Rivers, violinist, born in Bendigo, Victoria, Australia, in 1864. He 


\section{ALQUIN.}

founded the Sydney Orpheus Society, and for some years was conductor of the Sydney Liedertafel. He is now associated with the Sydney Amateur Orchestral Society, and is heard at the principal coneerts. As a solo player his reputation is very high, and his repertory embraces the concertos of the great masters, and the principal works of all schools for the violin.

Alquin, Frank C. d', bass voealist, born in London, of German parentage. Studied at Milan, under Visoni and Nava. Sang with suceess in Italy and Germany; and has been heard in eoncerts in various parts of Britain. Now resident at Brighton as teacher of singing. When a ehild he studied the violoneello under Piatti, and at his concerts in Brighton he frequently plays solos upon that instrument. He is well-known as a song composer, his publications including The earol singers; Romanza Pastorale; I' Aube Nait (Vietor Hugo); and numerous others; also the "Preparatory Exereise for the Shake."

Alsop, John, composer of present time, of Newton Abbey, was awarded the Sir Michael Costa Prize of ten guineas, Trinity College, London, with the gold medal, 1888, for an orehestral overture in F. He is also the com. poser of a cantata, "The Sower" [1895].

Alston, John, educationist, was born at Glasgow in 1777. He was a merehant and magistrate of Glasgow, and identified himself with the Blind Asylum, of which he beeame a director and honorary treasurer. In 1837 he published specimens of printing for the blind in raised Roman type, and from that date he issued a large number of books, chietly educational, for use among the blind. His two works on musie in raised type for the blind are the earliest of the kind known to us. The first was "Musical eatechism, with tumes, for the blind." Glasgow [18:38]; and the second "A selection of Scottish songs, embossed for the use of the blind." Glasgow (printed in the Asylum at the Institution Press), $18 t t$. This work is stated to be " the first book of songs, set to music, printed in relief for the instruction of the blind." In 1843 a bust of Alston from the ehisel of James Fillans was unveiled in the Glasgow Asylum for the blind, the inseription on which records the fact that he printed the firsi bible "in raised leters for the use of the blind." He died at Glasgow, August 20, 1846, after a career of usefulness and distinetion.

Ambler, Sarah, see Brereton, Mrs. W. H.

Ames, John Carlowitz, composer and pianist, born at Westbury-on-Trym, near Bristol, January \&, 1860 . His father, Geo. A. Ames (born May 10, 18.7; died in London, January $3,1893)$, was a talented amateur violinist, pupil of Molique, and, under an assumed name, played in the orehestra of the Jimingham Festival of 1846, when Mendelsson's "Elijah"
AMOTT.

was produced. He was the composer of a string quartet, and other works. J. C. Ames first studied under Sir Herbert Oakeley, who persuaded his father to let him take up music as a profession. He then went to Stuttgart, 1878 , remaining there mntil 1881, studying the pf. under Lebert and Pruckner, and eomposition under Goetschius and Faisst. Afterwards he beeame a pupil of Franz Wiillner at Dresden. One of the early advocates of the Janko Keyboard, he exhibited its powers at a coneert at the Burlington Hall, London, in December, 1888 , and has given recitals at the Conferenees of the Ineorporated Soeiety of Musicians in London, 1893, and Searborough, 1894 , and sinee in several towns in the provinees.

Works.-Psalm 130, for soli, ehorus, and orehestra, Dresden, 1877. Consertstïck, Dresden, 188s; Coneerto in C minor, Op. 8, Crystal Palace (Oscar Beringer), 1889, both for pf. and orchestra. Concerto in D minor, violin and orehestra, London, 1892; Quartet in E minor, strings (Uresden); Trio in E, pf. and strings; Sonata, pf. and violin; pianoforte pieces, ete.

Marie Milured Ames, sister of the preceding, was born June 20, 1867. Studied under her brother for three years, and then at the R.A.XI., instrumentation with F. Corder; later at Berlin. Won the Charles Mortimer Prize for composition at R.A.M., 1894. Has written an Andante and Rondo for clarionet and pf.; Andante in G, Barcarolle, and other pieces for violin and pf., ete.

Amner, John, composer and organist, was born about the end of the 16th century. He was appointed organist and choirmaster of Ely Cathedral in 1610, and took the degree of Mus. Bac. Oxford in 1613. He died at Ely in 1641.

Works. - Saered hyoms of $3,4.5$, and 6 parts for royces and ryols. London, 1615. Some of his anthems and other musie for the church service are preserved in ms. at Ely, Cambridge (Peterhouse and Christ Church), Oxford, and in the British M usem. According to Burney he published sone madrigals.

RALPH AMNER, a bass singer, probably a relative of the above, was a lay elerk at Ely Cathedral in 1604 , and gentleman of the Chapel Royal in 1623. He was a minor canon of sit. George's Chapel, Windsor. He died at IVindsor, March 3, 1664 .

Amott, John, eomposer and organist, born at Mommouth in 1798 , was organist of Abbey Church, Shrewsbury, from 18.2 to 1832 ; and organist of Gloncester Cathedral in succession to Mutlow, 1832-65. He died at Gloucester, February 9, 1865. He composed services, anthems, ete., and acted as conductor of the Gloucester Musical Festivals. He edited a second edition of Lysons' work on the 'Three choirs festivals, entitled "The Anuals of the Three Choirs, etc." London [1864]. 


\section{AMIPS.}

Amps, William, organist and composer of the present time. Was conductor, for some years, of the Cambridge University Musical Society, the concerts of which he distinguished by the production of choral works-Mendelssolnn's "Elijah" (185:3); Antigone, and others. $\mathrm{He}$ was organist of St. Peter's Church, Cambridge. Of his compositions, two pf. sonatas, and two sonatinas have been published, as also six vocal quartets (1850), and six partsougs (1865).

Anchors, William, musician of early part of 1 sth century, published "A Choice Collec. tion of Psaln-Tunes, Hymms, and Anthems." London [1720].

Anderson, Andrew, compiler of "Sacred Harmony .... adapted to the version of the psalms, paraphrases, and hymus used in l'resbyterian churches and chapels . . . London [18407.

Anderson, George Frederick, violinist, born London, 1793. He married Miss Luey Philpot, the pianist, in July, 1820. Je held the appointments of conductor of Royal Private Band, and hon. treasurer of Phillarmonic Society and Royal Society of MInsicians. He died at London, December 14, 1876. He published "Statement of Mr. G. F. Anderson, in reply to calumnious charges against him as Director of Her Majesty's Private land." Norwich [1855]. Privately printed.

Anderson, James Smith, organist and composer, born at Crail, Fifeshire, Jume 30 , 1853. Mlusical training, private. F.R.C.O.; Mus. Bac., Oxon., 1878. Has held various organ appointments. including the Parish Church, Abley, 1877-9, and St. Andrew's Parish Church. Edinburgh, from 1881. He is teacher of pf. at Moray House Training College and School; and lecturer on harmony and counterpoint at St. Creorge's Classes, Edinburgh; both positions dating from 1892. A skilful organist, he las rendered valuable service at concerts. His compositions comprise Psahm 100, for soli, chorus, and orchestra; operetas, "Hearts and homes" and "Land of romance," which are published; as also some songs and pf. pieces. $\mathrm{He}$ also revised the harmonies of the "Blackbur" tune book," and composed hymm tunes.

Anderson, John, violinist and composer, born 17:5; died at Inverness, Jume 5, 1808. He published "Selection of the most approved Highland strathspeys, country dances, Eng. lish and French dances, with a harpsichord or violoncello bass." Edinburgh [1790], two collections. "Budget of strathspeys, reels, and country dances for the German flute or violin," Edimburgh, n.d.

Anderson, Josephine, bom Bartorozzi, mezzo-soprano singer, hom at London in 1 sor, She was a younger sister of Madame Testris, and studied mider Corri, etc. In 1828 she

\section{ANDERSON.}

made lrer début as Rosina in the "Barber of Seville," at the Haymarket Theatre, London, and afterwards sang at London and provincial concerts. She died of consumption, on May 1, 1848, aged 49 .

Anderson, Lucy, born Philpot, wife of G. F. Anderson, was born at Bath, December, 1790. She was instructed in music by her father and James IV. Windsor, and became a pianist of great promise. She appeared at the Philharmonic Society concert in London, April 29, 1822, being the first lady pianist who ever did so, and afterwarls played at many of the principal concerts. She was teacher of Queen Victoria and several other members of the royal family. Died at London, December 24, 1878.

Anderson, Robert, amateur musician, was horn in Fraserburgh, Aberdcenshire, May 6,1835 , and died there on November 22, 1882. He was a solicitor in Fraserburgh and composed several part-songs of which the "Herring Song" is best known. He also composed "Songs of Zion" in 12 numbers, published by Novello.

Anderson, Rev. William, clergyman and musician, born at Kilsyth, Stirlingshire, January 6,1799 . He was a popular minister of the United Preshyterian Church in Glasgow, and for many years was pastor of Joln Street It nited I resbyterian Cliurch. He died at Uddinguton, near Glasgow, September 15, 1872.

Early in his career he edited and published anonymonsly, "The Sacred Choir": a collection of music adapted to the psalms, paraplirases and lymus in general use in Scotland, and specially to the collection of hymns sanctioned by the symod of Relief," Glasgow [1811]. This contains "Thanksgiving," "Trinity," and the "Sacred Choir," tures by himself. The harmonies were revised by Samuel Barr. He also compiled "A selection of psalm and hymntumes, adapted to various measures." Glasgow [1844]. For "The Choir: a collection of psalm and hymm tunes... selected and composed by Alex. Duncan." Glasgow, 18.8, he wrote a preface. Among other literary works he wrote "Apology for the Organ as an assistance of congregational psalmody." Glasgow, 1829.

Anderson, William, writer and musician, born at Aberdeen [1817]. He was a clothier in Aberdecn and held the appointment of precentor in the South Parish Church from 1835, and in the Free Sonth Church from 1843 to 1871. 1Te died at Aberdeen, Angust 6, 1875.

Author of "Pemarks on congregational Psamody." Aberdeen, 1855. "Precentors and Insical Professor's: being brief sketches of som of those more worthy of notice who flourished in Aberdeen in the course of the last hundred years." Aberdeen, 1876. This work contaius 26 notices and is prefaced by a memoir of the author. 


\section{ANDERTON.}

Anderton, Thomas, composer, organist, and pianist, born in Birmingham, April 15, 1836. Teaeher of musie in that eity, and organist of Parish Church, Solihull. Mrus. Bac., Cambridge, 1865. Conducted the first singing class established at the Biminglram and Midland Institute, and for some years carried on a series of high-class orchestral concerts at the Exchange Assembly Rooms. Musical critic of the Birmingham Daily Gazctte. Becoming part proprietor and editor of the Midland Connties' Herald, lie retired from the musical profession in 187!, but continued to eompose and occasionally gave lectures on musieal subjects.

Woris.-Cantatas: The song of Deborah and Barak, Solihull, 1871; The wise and foolish virgins; The Wreek of the Hesperus; John Gilpin; The three jovial huntsmen, 1881: The Norman Baron. 1881; Yule Tide, Birmingham Festival, 1885. An Englislı requien, 1890. Prize glee, Mat o' the Mill. Songs: Come to me, $O$ ye children: The felling of the trees, and many others. Orchestral: Symphony in D; Orertmes; Marehes; Allemande in F; Quartet in F, strings, 1854 . Pianoforte: Allemande; Play hours, ete. Literary: Letters from a country house, 1891.

His brother, JoHn Anderton, is a librettist and dramatic author, and las furnished more than one "book" tor the composer.

Andrews, F. H. Canadian (?) musieian. Published "Collection of original sacred music, with organ or pianoforte aceompaniment," Montreal, 18ts.

Andrews, John Charles Bond=, pianist and composer, born at Birkenhead. At eleven years of age, began his musical eareer hy giving a series of pf. recitals; and two years afterwards was sent to Leipzig, where he studied under Reinecke and others. He also had lessons from Sterndale Bennett, at the R.A.M., and studied at Vienna. In $18 \pi 6$ he gave recitals at Birkenhead, and has appeared with success as a pianist in London and other cities; he has also officiated as conductor to touring opera companies. He has composed several operas-_" Herne's Oak," produced at Liverpool, Oetober, 1887; "The Rose of Windsor" (both books by Walter Parke), decrington, August, 1889 ; and an operetta, "A Pair of Lunatics" (1892). Quartet in P flat; Trio in D minor, pf. and strings; Sonata in G minor; "Nay Pole" suite; and many other pieees for pf., \&c.

Andrews, Mrs。 John Holman, born JeNNy Constant, a teacher of singing and composer, born in 1817. She resided in London as a teacher, and died there April 29, 1878. She published "Two part exereises" (for the roice) $(186)]$. Songs-Adien: Antumn's golden leaf; Go lovely rose: Prince Charley's farewell to Scotland, ete. Nocturne
APTOMNAS

for pf., and other instrumental music.

Andrews, Richard Hoffmann, writer and composer, horn in London, Norember z., 1803. Appeared as a child actor on the stage at the Theatre Royal, Birmingham, and in 1809 played the part of Pistol's boy in Henry $Y$.. at Liverpool. At the age of nine he was apprenticed to the leader of the Manchester Theatre band, and continned to reside in that city as teacher, and later as musie publisher. He gave a eoncert so late as February 23, 1885 , when he played a riolin solo. $\mathrm{He}$ edited and arranged a rast $110 \mathrm{mber}$ of works for the pianoforte, and wrote several glees which enjoyed great popnlarity - "Hail fair peace" being one of the earhest. He was author of "Music as a seience," 1.485; "Saered music, adapted for public and private devotion " and edited "The Family Voealist," "Songs of the Hearth," "Handel's Congs," "The German Choral Harmonist," ete. He died at Longsight, Manehester. June 8, 1891. His sons, Richari Hoffunax (hom at Mancliester, May 24, 1881), and Enitail HofFMaNy (born at Manehester, February 7, 1836), are settled in the United States as pianists and composers.

Angel, Alfred, organist and composer, was born in 1s16. Hekd apnointment of organist of Exeter Cathechal 1;42-1876. He died at Exeter, May 24, 1876. Composer of "Arise my fair and come away." part song, songs, and other rocal music. A son of his was drowned in the wreck of the "London," in 1865 .

Anger, Joseph Humfrey, organist and conmoser. Musical trainin private; graduated Mus. Bac., Oxford, 18s?. Organist at Bristol and, in 1891, of Lndlun parish church, and musie master in King Edward VI. sehool there. Appointed, 189:. prineipal in theory department of Toronto Conservatoire of MInsie and organist and C.M. of the church of the Ascension. Hlis setting of Psaln 96, for soli, chorus, and orchestra, gained the gold medal of the Bath Philharmonie Society, and was performed by that Society, ipril 11, 1888. Other compositions are "liomnie Relle," madrigal for six voiees, Iondon Madrigal soeiety prize, 1890 ; madrigal, "All on a summer's morning;" Pianoforte piects, de.

Ansell, J. K., musician. Published "Collection of saer.d music for the service of the Catholie Church..." London [1818]. "Ave Regina, for four voices and choms." Songs, Cavalry march, \&e.

Anstey, Thomas, musieian. Issued a collection of "Saered musie . . . in solo, dnet, trio, and quartett." London [1s:30]. 2 rols.

Aptommas, Thomas Thomas, harpist (brother of John Thomas), lomn at Fridgend, Glamorgan, 18:9. Has made fours throughout the Enited Kingdom, and ple reat at many 


\section{AQUILA.}

musical centres on the continent, appearing at the celebrated Gewandhaus Concerts, Leipzig, Jamuary 18, 1872 . Has a wide reputation as a brilliant performer on the harp. Author of a "History of the Harp," 1859 , and many Fantasias and other pieces for that instrument.

Aquila, pseudonym, of EDwin Ransford.

Archer, Frederic, composer and organist, born at Oxford, June 16, 1838. Chorister at All Saints', Margaret Street, London, and afterwards studied at Leipzig. He succeeded Dr. Chipp as organist at the Panopticon, and held simlar positions at Merion College, Oxford, and the Alexandra Palace, Muswell Hill, following $\mathrm{Mr}$. Weist Hill as conductor at the latter, a post he held until 18\$0. Conductor, 187 A. S I, of the Glasgow Select Choir, for which he arranged several Seutch air's as part-songs. Aloont the same time he was also conductor of the Blanche Cole Opera Company on its provincial tours. In 1881 he was appointed organist of the liev. H. Ward Beecher's Church, Brooklyn, L.S.A., but left the next year for the Episcopal Church of the Incarnation. Since then he has been organist of several different churches, his latest post heing at Pittsburs, with an anuual stipend of $£ 800$. He was organist at Mapleson's New York season of Italian Opera, 1882, and at the Toronto Festival, Jume, 1886. For some years he was editur of the New York Musical paper, the Kim note, and contributed many articles to the earlier volumes of Musical Oprinion, London, and other papers.

Wolks.--The Organ : a theoretical and practical treatise (Novello \& Co.); The college organist (Wtekes); (rrand fantasia in F; Concert variations; March triomphale; and many pirces for the organ. Dno concertante, flute and pf.; Three impromptus; Two gavottes; and other pieces for pf, Songs, part-songs, ete.

Argent, William Ignatius, organist, composer, and conductor, born at Colchester, August 26, 1844. Organist of Little Oratory, Brompton, 1859-60. Since 1868 resident in Liverpoul and Birkenleat. Organist successively at St. Lawrence, Birkenhead, and St. Ame's (R.C.), Edge Hill. Conductor at different periods of musical societies at Widnes, Frodsliam, Garston, and of the St. Cecilia Society, Liverpool. Musical critic of the Liremont Allion, 1873-80, and Mercury, 188690. Contributor to the Musical Times and other papers. One of the founders of the Liverponl Sunday Society, in connection with which he las not only delivered lectures, lut organised an orchestra of seventy performers, and for years given series of Sunday Concerts in Sit. George's Hall.

Woklis. Mass in A (1875); Mass in J' flat (1887); Tantum ergo and O Salutaris hostia, for chorus and orchestra; Motets, anthems,

\section{ARMITT.}

etc. An opera di camera (1863), and other works in ms. Author of "Half-a-century of music in Liverpool," 1889.

Arkwright, Mrs. Robert, was a daughter of Stephen Kemble, the actor (1758-1822). She appeared as an actress at Newcastle and Fdinburgh, and was married to a Captain Arkwright.

Work-_- Set of six ancient Spanish ballads ... London [1832], 2nd set [1835]. Set of six songs, the words from Mrs. Henans, Mrs. Opie, Sir Walter Scott, etc., with pf. accompaniment by 'I'. Cooke [1835]. Three other similar sets. Six sacred songs [186i]. BalladsBeloved one, Beth Gelert, Repentence. Sabbath bell at sea, Sailor's grave, Pirate's farewell, Zara's ear-rings, etc.

Armes, Philip, composer and organist, born at Norwich, March 29, 18.36. Chorister at Norwich Cathedral, 1846-48, and at Rochester Catlredral, 1818-50. Was articled to Dr. J. L. Hopkins in 1850, and was assistant organist at the Cathedral up to 1856 . In 1855 he was appointed organist at Trinity Church, Milton, Gravesend, and two years later went to St. Andrew's, Wells Street, London. Here he remained till 1861, when he was appointed organist of Chichester Cathedral, a post he left a year later for Durham Cathedral, which position he still holds. He graduated Mus. Bac. Oxon., 18.58, and Mus. Hoc. 1864. In addition he has received the degrees of Mus. Bac. ad eundem, Durham, 186; ; Mus. Doc., 1874; M.A. Honuris causâ, 1891; and was elected Fellow of the (Royal) College of Organists in 1892. Resident Fxaminer in Music to University of Durham, 1890: Examiner in Music to Tniversity of Oxford, 1894.

Works.-Hezekiah, an oratorio, produced at Newcastle-on-Tyne, 1877, and revised and enlarged at the Worcester Festival, 1s7s. Church oratorios: St. Joln the Evangelist, produced at St. Peter's Church, Bramlev, Leeds, July 5,1881 , and at the Choir Festival, York Minster, July 7 ; St Barnabas, produced at Durham Cathedral, July 30, 1891. Communion services, in A and B flat Anthems: The Lord preserveth (Harvest); Rejoice in the Lord, etc. Cantata and Deus for Festival in Durham Cathedral, July, 1894. Paper on English church music of l'urcell's period, read at the Church Congress, Norwich, October 10, 1895.

Armitt, Mary Louisa, writer on music, born at Salford, September 24, 1851. Her father, of a musical family, was assistant overseer of Salford. Her own tastes being of an antiquarian turn in connection with music, slie has spent much time in exploring the Bodleian, Cambridge University, and other libriries in Fngland and on the continent; and her contributions to the press have real historical value. She wrote the musical sketches, "The Choirman of Grayford " and 


\section{ARMSTRONG.}

"A Stranger's visit" for the Quarterly Musical Review (edited by Dr. Hiles), and also papers on Anthony a' Wood, and Old English Viol Mnsic. In the Musical Times (November, 1091), "A Richmond Idyll" reveals facts not generally known concerning Charles Coleman's domestie life; a paper on "Old English Fingering" (March, 1895), in the same journal, should be also mentioned. Miss Armitt has also contributed to The Queen, Mrusical Standard, Musical World, Musical News, and acted as musical critic for some time for the Mancluester City News. She is now resident at Ambleside, Westmorland.

Armstrong, Helen Porter, born MIT. CHELL, known professionally as MADANE Melba, soprano vocalist, born at Melbourne, Australia, 1859. Daughter of David Mitchell, contractor. Sang in the choir of St. Francis' Roman Catholic Church, Melbourne, and appeared at the Melbourne Liedertafel con. certs, 1884. Made her first appearance in Europe at Emil Bach's concert, Prince's Hall, London, June 1, 1886. A pupil of Iadame Marchesi, her operatic début took place at the Theâtre de la Monnaie, Brussels, as "Gilàa,"in " Rigoletto," October 12, 1887. She appeared at the Royal Opera, Covent Garden, May" 24, 1888, as "Lucia," in the "Bride of Lammermoor," and has in subsequent seasons been heard in a variety of parts. She sang at La Scala, Milan, in 1893; at the Handel Festival, Crystal Palace, June 27, 1894 (Selection Day); in opera, New York, and elsewhere, and has established herself as a prima don?a of the first rank. In 1882 she married Mr. Cliarles Armstrong, of Queensland.

Her sister, Frederica Mitchele, is considered one of the most accomplished roealists in Melbourne. In 1891 she was principal soprano in the Roman Catbolie Chuich (St. George's) Carlton, Melbonme. She sang, November 24, 1883, in Dublin, at a concert of the University Choral Society.

Arne, Michael, composer, natural son of Thomas A. Ame, born London, 17t1. He was educated for the stage by his aunt, MIrs. Cibber. In 1751 he first appeared as a vocalist. He married Elizabeth Wright, the soprano singer, in November, 1766, and in 1779 became director of music at a theatre in Dublin. He returned to London and was director of oratorios in 17S4. He devoted bimself latterly to the study of alcheny and lost his fortune in the pursuit. Died at Lambeth, London, January 14, 1786.

Works. - Masical dramas: The fairy tale, 1763; Almena (with Battishill) 1764; Positive man, 1764; Hymen, 1764; Cymon, 1767; The Father, 1778; The Belle's stratagen, 1780; Choice of Harlequin, 1781; Tristram Shandy, 1783. The flow'ret, a new collection of English songs. Glees, many single songs, ete.
ARNE.

His wife Elizabeth Wright (born abont 1743, died?) soprano singer, sang at the principal concerts of her day.

\section{Anne, Susanna Maria, see Cibber} (Susanna M.)

Arne, Thomas Augustine, composer, borm in King Street, Covent Garden, London, May 28, 1710, son of an upholsterer. He was educated at Eton College, being intended for the legal profession, but his natural aptitude for music led him to study privately, and he had lessons on the spinnet, and private lessons on the violin, from Festing. In 1736 he married Cecilia Young. daughter of Charles Young, an organist, and in 1738 became composer to Drury Lane Theatre. From 1742 to 1744 he resided in Dublin, and on his return to London in 1745 he became composer to Tauxhall Gardens, Covent Garden Theatre, and the prineipal London theatres. Doc. Mus., Oxford, 1759. He died, London, Mareh 5, 1778, and is buried in St. Paul's, Covent Garden.

Wonis.-Operas ane Musical Iramas: Rosamond (Addison), Lineoln's Inn Field's Theatre, March 7, 1733; Opera of operas, or Tom Thumb, 1733; Dido and Eneas, 1734: Conus, a masque, London, 1738; Judgment of Paris, a masque, 1740; Alfred, a masque, London, 1740 [by Thomson and IIallet, in which is the celebrated national song "Rule, Britannia," written by Thomson]; Britannia, a masque, Dublin, 1743 ; Eliza, opera. Dublin, 1743; Artaxerxes, opera, London, 1762 the well-known psalm-tune "Artaxerxes" is taken from the minuet at the end of the overture to this opera, and was first adapted by $R$. Harrison in vol. 1 of his "Saered harmony," 1784]; The fairies, 1762; Olimpiade, 1765. Music to Plays: Fall of Phaeton, London, 1736; Zara, 1736; Blind beggar of Bethnall Green, 1741; Thomas and Sally, Dublin, 1743; Temple of Dulness, 1745; King Pepin's campaign, 1745; Neptune and Amphitrite, 1746; Don Saverio, 1749; The Prophetess, 1759 ; The Sultan, 1759 ; Lore in a village, 1762; Birth of Hereules (never producel) 1763; Guardian outwitted, 1764; Ladies' frolie (with Wr, Bates), 1750; Fairy prince, 1771; The Cooper, 17T2; Elfrida (by IIason) 1772; The Rose, 1773; Contest of beauty and virtue, 1773; Achilles in petticoats, 1773 ; May-Day, 1775; Phebe at court, 1776; Caractacus (by MIason), $17 T 6$ (MSS. lost). Music to Shakespeare's As you like it, 1740: Twelfth Night, 17 17 ; Nerehant of Venice, 1742; Tempest, 1746; Romeo and Juliet, 1750. Oretorios: Abel, London, March, 1755 ; Judith, London, February, 1761. Ode on Shakespeare, composed for the stratford Jubilee, 1769. Songs, etc.: Lyric hammony, for voice, harpsichord and violin; The syren. a collection of favourite songs; Vucal grove; 


\section{ARNE.}

Summer amusement; Winter amusement: Vocal melody, 1760; Glees, catches, etc., in Warren's collection and elsewhere. Over. tures for orehestra. Sonatas for violin. Concertos for organ. Sonatas for harpsichord. The compleat musiciau, . . . being a collection of vocal and instrumental music

London [1760].

Arne, Mrs. born Cecilia Young (borm 1711, died October 6, 1789), was a singer of mueh note in lier day and appeared in many of her luusband's works, as well as at most of the leading concerts.

Arnold, George Benjamin, composer and organist, born at I'etworth, Sussex, December 22, 1892. Studied under Dr. S. Sebastian Wesley, and graduated Mus. Bac., Oxon., 1855, and Mus. Doc., 1861. Organist successively at St. Columba's College, 1852; St. Mary's, Torquay, 1850; New College, Oxford, 1560 ; and Winchester Cathedral, 1865 , in which city he is resident at the present time. He has given concerts with his specially fomed choir, and appeared with suecess as a pianist.

Works.-Oratorios: Alrab, Exeter Itall, London, by the National Choral Society, April 6, 1864; The second coming of our Lord (MS.) Cantutus: The Song of David (IIS.); Sennacherih, Gloucester FestivaI, 1883; The Song of the redeented, written for St. James's cliurch, New York, and produced there, 1891. Communion Service in G; Te Deum and Jubilate in D, etc. Anthems : Praise the Lord; Let the rightcous be glad; The night is far spent, ete. Part Songs: Thou soft flowing Avon; Live like the rose, etc. Songs: Go, sit by the summer sea. Harmony (Lancashire Choral Union Prize Glee), and other's. Piunoforte Music: Sonata in F minor; Sonata in D; Prelude and Fugue, etc.

Arnold, John, "Philo Musicae," composer, of Great Warley, Essex, born [c. 1715-20]; died in Feloruary, 1792. He issued the folluwing collections:-The Compleat Psalmodist, or organist's parish clerk's and psalm-singer's companion, in four books, 1741 ; also London, $1750 ;$ 4th ed., 1756; 5 th ed., 1761 ; 6th ed., 1769 ; 7th ed., 1779. The Psalmist's recreation . . . 1757. The Leicestershire harmony, containing a set of excellent psalm tunes and anthems composed in modern taste for 4 voices, by an eminent master of the county of Leicester, and now first published by J. Arnold, London, 1759 ; also 2nd ed., 1771. Essex Harmony : being a choice collection of the most celebrated songs, catches, canons, epigrams, canzonets and glees, for 2, 3, 4, and 5 voices vol. 1., 1750 ; vol. 2, 1769 ; various editions of both volumes.

Arnold, Matthew, organist and con-

\section{ARNOLD.}

ductor. Was organist at Leeds; in 1865 appointed to Wesleyan Chapel, Eccleshill, near Bradford; and of Emniskillen Parish Church in 1875 . IIe very soon established a choral socicty there, and for nearly twenty years conducted a series of concerts, appearing likewise as violinist and pianist, and occasionally as lecturer on musical topics. An active and useful career was closed by his death, at Enniskillen, March 24, 1894. His son, Charles HAYDN ARNOLD, born 1871, is a pianist and organist. He made his début at his father's concert, September 11, 1884 (with his sister Edith, two years his junior), and at the age of seventeen, in 1888, was appointed organist and eloirmaster of St. Flannan's (cathedral) Church, Killaloe, near Limerick, where he is engaged as teacher, and also conductor of choral classes, \&c.

Arnold, Samuel, organist and composer, born London, August 10, 1740. He was educated in the Chapel Royal, under Bernard Gates and Nares. In 1763 he was composer to Covent Garden Theatre, and he afterwards becane orwner of Marylebone Gardens, in 1769 , at which he produced rarious dramatic entertaimments, of which two were writteu by Thomas Chatterton. Ile retired from this enterprise in 1771, after much loss. In 1771 he married Miss Napier. He was made Mus. Bac. and Doc., Oxford, 1773. In 1783 he succecded Dr. Nares as organist and composer to the Chapel Royal, and in the following year acted as sub-director of the Handel commemoration. He was conductor of the Academy of Ancient Music from 1789, and organist of Westminster Abbey from 1793. In conjunction with Dr. Callcott he established the Glce Club, and was connected with many of the musical enterprises of his time. He died at London, October 22, 1802, and is buried in Westminster Abbey, where a monument to his memory is placed.

Works.-Musical Dramas, dec--Maid of the Mill, 1765; Rosamond, 1767; Portrait, 1770 ; Mother Shipton, 1770 ; Son-in-law, 1779 ; Summer amusements, 1779; Fire and water, 1780; Wedding night, 1780; Silver tankard, 1780; Dead alive, 1781; Castle of Andalusia, 1782; Harlequin Teague, 1782; Gretna Green, 1783; Hunt the slipper, 1784; Two to one, 1784; Turk and no Turk, 1785; Siege of Cuzzola, 1785; Inkle and Yarico, 1787; Enraged musician, 1788; Battle of Hexham, 1789; New Spain, 1790; Basket maker, 1790 ; Surrender of Calais, 1791; Harlequin and Faustus, 1793; Children in the wood, 1793; Auld Robin Grey, 1794; Zorinski, 1795; Mountaineers, 1795 ; Love and money, 1795; Who pays the reckoning? 1795 ; Shipwreck, comic opera, 1796, Op. 40; Bannian Day, 1796; Italian monk, 1797; False and true, 1798; Cambro-Britains, 1798; 


\section{ARNOLD.}

Throw physic to the dogs, 1798; Obi, 1800, The Review, 1801; Corsair, 1801; Veteran Tar, 1801; Sixty-third letter, 1802; Fairies' revels, 1802; The Revenge; Woman of spirit. Oratorios-Cure of saul, 176r; Abimelech, 1768 ; l'rodigal Son, 1773; Resurrection, 1777; Redemption (compiled from Handel's works), 1786; Elijah, 1795. Two services in $A$ and B flat. Anthems. Cathedral music, a collection in score of the most valuable and useful compositions by the English masters of the 17 tin and 18th centuries. London, 1790. The Psalms of Darid, for the use of Parish Churches, edited with J. IV. Callcott. London, 1791. O e for the anniversary of the London Hospital. Anacreontic songs for one, two, three, and four voices. London, 1785. Songs composed for Vauxhall Crardens, several sets. Concertos, overtures, lessons, and sonatas for harpsichord or pf. Edited works of Handel, in 36 vols.

Arnold, Thomas, musician. Published "The Celestial Vreath, a collection of favourite Psalms and Hymns." Lundon [1810]. Daily Exercises for a soprano voice, etc. London [1861]. Songs. Selection of popular airs for two performers on the pianoforte, etc. London [1862]. 12 nos. "The Union," a collection of easy duets for pf. [1866].

Arnott, Archibald Davidson, composer and organist, bom in Glasgow, February 25, 1870. His parents removel to London when he was ten year's old, but, though passionately fond of music, he did not begin the serious study of the art until he entered his twentyfirst year. He graduated Mus. liac., Durham, 1891, being the first graduate by examination at that University. His exercise was a Gloria in four movements, for solo, chorus, and orchestra, parts of which have frequently been given since as an anthem in Durham Cathedral. Studied for a year at the R.C.M., under Drs. Parry and Stanford, and afterwards with Mr. F. Corder. Organist of St. George's, Perry Vale; Trinity Church, Forest Hill; St. Gabriel's, Pimlico; and, since 1893, organist to the Hon. Soc. of Gray's Inn.

Works.-Operas: Angelo, a Noble of Venice (two acts, composed Januars, 1895); Marie Ancel (four acts, music and libretto, composed July, 1895); Cantatas: Young Lochinvar, op. 6, for chorus and orchestra (composed 1893, produced Crystal Palace, March 16, 1895); The ballad of Camilhan, for baritone solo, chorus, and orchestra (composed 1894, produced Queen's Hall, February 26, 1895); The Lost galleon, poem by Bret Harte, for the same combination (1896); Vita Christi, a sacred mystery (1896). Scena: The Stilling of the tempest, op. 8, for baritone and orchestra. 4 Cycles of songs, words by Edith M. Dunaway and others, op. 1, 2, 12, 13; various songs, etc. Two concert overtures for orch-

\section{ASHLEY.}

estra, op. 3, in D minor, op. 5, in D major; Trio in A, op. 4 , for pf. and strings, produced Mus. Artists' Society, March 16, 1896.

Arthur, J., musician, author of "The moclern Art of Flute Playing." London, 1827.

Ascher, Joseph, composer and pianist, born of German parents at London in 1s:31. He studied the pianoforte under Moscheles and at Paris, where he chiefly resided. He held the appoinment of pianist to the Empress Engenie. He died London, June 20, 1869.

Worlis. - Pianoforte: Op. 1 Tarentella; Talses: Op. 2, 4, 18, 46, 100, 10s; Nocturnes: Op. 3, 125; Nances: Op. 6, 24, 61; Op. 7; La Fileuse, Reveries, etc.: Op. 9, 10, 12, 7s, 89, 110, 124, 127; Nazurkas: Op. 11, 41,98, 107; Impromptus: Op. 12, 26, 65, 81, 82, 99, 105; Polkas, Galops: Op. 13, 31, 49, 83, 91, 96; Op. 14, Barcarolle; Caprices: Op. 17, 22, 30, 109.111, 113; Op. 21, L'orgie: Harches: Op. 25, 43, 62, 72; Idylles: Op. 29, 39, 128; Op. 3.) Le Papillon; Op. 35, Styrienne: 11p. 38, 64, Souvenirs; Op. 40, Fanfare; Op. 42, Prière; Op. 48, Les Clocheites; Op. 51, La Suvillana; Op. 52, La Fanchonette; Op 5s, Tyrolienne; Op. 66, Ave Maria; Op. 73, La Zingara; Op. 74, La Favorite; Op. 80, La Cascale de lioses; Op. 88, Berceuse; Op. 90, Fantasia; Op. 92, Serenade; Op. 93, La Plialène; Op. 94, Le Chalet;Op. 102, Rhapsodie: Op. 104, Rondedes Elfes; Op. 106, La Cloche da Convent; Op. 112, I Lazzaroni ; Op. 119, Les Sylphes des Bois; Op. 121, Volhynia; Op. 126, Marinilla. Transcriptions and other arrangements: Op. $16,19,20,27,28,33-37,44,45,50,53,55,56$, $60,63,67-71,75-77,87,101,103,114-118,12-2$, etc. Sonas: Alice, where art thou?; Bygone love; I'll think of thee; Melanie: Twilight drem, etc.

Ashe, Andrew, flute-player, born Lisburn, 1758 [1756]? He was edncated at Woolwich, where he learned the violin, and was afterwards adopted by General Bentinck, with whom he went to Minorca, and subsequently to Spain, Portugal, France, Germany, and Holland. At the Hague he received lessons on the flute from Wendling, and became family musician to Lord Torrington at Brussels, where lie gained the post of first flute-player at the Opera House, in competition with Vanhall, 1779. He resided in Dublin, 178t-91, and appeard at London, 1792, at Saloman's second concert, where he played a flute concerto of his own. In 1799 he married Miss Comer, a vocalist. He held the position of principal flute-player at the Italian Opera, London, and was director of the Bath concerts from 1810 to 1822 . He died at Dublin, April, 1838. He composed concertos, etc. for the flute.

Ashley, John, musician and conductor, born in first half of the 18 th century. He was assistant-conductor under Joah Bates of the Handel commemoration, 1784, director of ora- 


\section{ASHLEY.}

torio at Covent Garden Theatre, 1795, and a performer on the double-bass. He organized a band, in which his sons were performers, which gave concerts of instrumental music in various parts of England. He died March 2, 1805.

His sons, all of whom played in his band, were General Charles (1769-August 28, 1818), a violinist; JoHN James (1771-London, January 5, 1815), an olganist and teacher of singing, who numbered among his pupils Mrs. Salmon, Mrs. Vaughan, and others. He composed "Three Canzonets, Op. 5," songs, and instrumental music. CHARLES JANE (1773-August 20,1843), violoncellist, was one of the founder's of the Glee Club, and Sec, to Royal Soc. of Musicians. He was also a member of the Philharmonic Soc, and became proprietor of the Tivoli Gardens in 1843. For nearly twenty years he was a prisoner for debt in King's Bench Prison, London. His brother RichaRI $(1775-1836)$ was a violinist, and played ehiefly in provincial orchestras.

Ashley, Josiah or John, composer and vocalist, born Bath, 1780. He resided chiefly at Bath, where he was a teacher and concert vocalist. Died at Bath in 1830.

Works._Songs; Honest Ben; Heart that o'erflows with good nature; Origin of old bachelors; Poor Joe, the marine; Poor orplian maid, ete. Reminiscences and observations respecting the origin of our national anthem . 1827. Letter to the Rev. W. L. Bowles, supplementary to the observations . . . 1827. Both tracts in answer to Richard Clark's work. In the "Batl and Bristol Magazine," October, 18:34, the artiele on "God save the king" is reprinted.

Ashton, Algernon Bennet Langton, composer and pianist, third son of charles Ashton (q. 2.$)$, horn at Durham, December 9, 1859. On the death of his father, the family went to reside at Leipzig, and Moscheles took a great interest in the boy, whose talent was manifested at a very early age. His first instructors at Leipzig were Franz $\mathrm{H}$ einig and Iran Knorr. At the age of fifteen he entered the Conservatorimm, his teachers being Reinecke, E. F. Richter, Jadassohn, R. Papperitz, and Coccius. On leaving, in 1879, he was awarded the Jelbig prize, having on two previous oecasions taken the yearly prizes for composition. He then visited England for a short time, returning to Germany for further study under Raff, at Frankfort, 1880-1. After that time he took up his residence in London, and in $1 \times 85$ was appointed Professor of the pianoforte at the Royal College of Musie. He has given many concerts in London and elsewhere, and has appeared as pianist at Leipzig, and in 1894 toured on the Continent with $\mathrm{Mr}$. Ben Davies, the vocalist. His compositions are very numerous, the following list including the most important of them.

\section{ASHTON.}

Works.-Orchestral: Three concert overtures (one in F, produced at the Hanley Festival, 1889); Concerto, pf, and orchestra; Concerto, violin and orchestra. Chamber Music: Quintets in C, op. 25; in E minor; Quartets, F sharp minor, op. 34; C minor; Trios, in E flat; in A, op. 58 , all for pf. and strings; Quartet in B flat, strings (Musical Artists' Society Prize, 1886) ; Sonatas in F, op. 6 ; in $\mathrm{G}$, pf. and violoncello; in A minor, op. 14; in E, op. 3S; in C minor, op. S6, pf. and violin; Op. 44, pf. and viola; and many pieces in smaller form. Pianoforte: Suite in F, for two pianos; Six sets of duets; Three pieces, op. 63; “Aquarellen," seven pieces, op. 87, etc. Tocal: Salvum fac regem, for chorus, op. 27 ; Part-songs for men's voices, and for mixed choirs; Duets; Four songs (Geibel), op. 16 ; Six songs, op. 52; Nine songs, op. 89, etc. Organ: Interludium, op. 11 ; Minuet in $\mathrm{C}$, op. 81 , ete.

Ashton, Charles, tenor singer, born at Liucohn, Feb. 1, 1815. In 1822 he became a chorister in the cathedral under Benjamin Whall, the choirmaster. Appointed first tenor at Lincoln Cathedral, 1831, and held the post till 1811. He also acted as organist in the churches of St. Peter's at Gowts, aud St. Peter's in Eastgate, Lincoln. He was leading tenor at Durham Cathedral from 1841 till 1.862. He was a suceessful teacher of singing, and sang at many of the provineial festivals. Died at London, July 11, 1862, when there seeking medical alvice. He published several anthems arranged fjom Beethoven, Mozart, ete., and issued "Services of the church . . . consisting of the P'reces, Responses, etc., as sung in Durham Cathedral. . ." London, 1844. Several of his children inherited his musical tasle, among whom are Algernon and Diana, separately noticed.

Ashton, Diana Uvedale, daughter of the preceding, born at Durham, Uctolier 21, 1810. Studied at first with her father, and, shewing great ability, was sent to Leipzig, where she received instruction from Moscheles, Hauptmann, and E. F. Richter. Returning after three years' stay in Leipzig, she intended settling in London, but the mexpected death of her father necessitated a change in the plans of the family. For some time she remained in Durham, occupied in teaching; but seeking a wider sphere for her talent she went to New York, and later to Chicago, where she married a German mnsician, Louis Staab. She lost all her property in the great fire at Chicago in 1871, and never recovering the slook of that terrible event, this accomplished artist died in New York, December 21 , 1873. E. F. Richter dedicated his fine pf. Sonata, op. 27, to Miss Ashton.
Ashton, WILLIAM. 


\section{ASHTON}

Ashton, Gertrude Cave $=$, born Holman ANDREW's, soprano vocalist, born in London, April 17, 1855. Studied under her mother (Mrs. J. Holman Andrews), and Thorpe Pede. Début at Alexandra Palace Theatre, 1s73; the Popular Concerts, 1876. Sang in the provinces with Mr. Sims Reeves: and in opera with the Hersee Opera Company, 1877, and the Blanche Cole Company, 1879- Has also appeared at the principal concerts in many provincial towns, and in London. In 1875 she was married to Mr. Frank H. Cave.

Ashton, or Aston, Hugh, composer who flourished during the 16 th century and held the appointment of organist to Henry VIII. He composed several masses and anthems which are preserved in the Music School at Oxford.

Ashwell, Thomas, composer who flourished during the first half of the 16th century. He composed "Twenty Songs." 1530, and various motets, ete., preserved in MS. in the Musie School at Oxford.

Ashworth, Caleb, musician. born at Clough-Fold, Rossendale, Lancashire, in 172.2. He was edueated under Doddridge, at Northamptor, and was Baptist minister and tutor at Daventry. He died at Daventry July 18, 1775. He compiled "A Collection of Tumes, suited to the several metres commonly used in public worship, set in four parts . . [1760], 3rd edition, 1766 ; and wrote an "Introduction to the Art of Singing," London, 1770, prefixed to the later editions of the Collection of Tunes. He also published a Hebrew Grammar, Sermons, etc.

Aspa, Edwin, composer and teacher, was born in London in May, 1835. of Italian parents. He died at Lincoln, Aupust 17, 1983. Composer of "The Gipsies" and "Endymion," cantatas; songs, pf. music, ete.

Aspull,George, pianist and composer, borm, Mauchester, June, 1813. He first appeard at a concert in 1822, and in 1823 appeared at Lon. don. Afterwards he grave concerts in England and Ireland, and in 1825 played at Paris, being everywhere hailed as a precocions genius of exceptional brilliancy. He died at Leaming. ton, August 19, 1832. His works were published as "Posthumous Works of George Aspull," edited by his father (Thoma. Aspull), Book 1. London [1837].

Aspull, WVillam, composer, bom Nottingham, 179s. Teacher and singer in London. Died in London, January 16, 1475.

Works. - Songs for the drawing room [1840]. Songs: Bird of the forest; Bright eres; Come, let us sing; Eastern love-letter; Good-night; I think of thee; Lonely heart; We have met; The wreckers, ete. Various transcriptions and other works for pf. Translations of Lemoine's harmony, Nauenburg's vocal exercises, Rink's Orgau school, etc,

\section{ATTEY.}

Asquith, John, organist and composer of the present time. (Hraduated Mus. Bac., Cambridge, 187s. Organist of Parish Church, Barnsley. Has published chureh services, anthems, pieces for pf., organ, songs, etc. Is author of a pampllet "On Ecclesiastical Music."

Aston, Hugh, see Ashton, Htgh.

Atkins, Robert Augustus, organist and composer, was born in 1n12. lle became organist of St. Asaph's Cathedral, and held the post for over 50 years. He died at St. Asaph, August 3,1889 . If is compositions consist of anthems and other church music.

Atkinson, Frederick Cook, organist and composer, born at Norwich, August 21, 1841. Studied under Dr. Buck, and was assistant organist at the Cathedral until appointed to Manningham Church, Bradford. IIe graduated Mus. Bac., Cambridge, 1867 , and in 1881 was appointed organist of Norwich Cathedral, a post he resigned in 1885 . From 1886, he has been organist of St. Mary's Parish Church, Lewisham. He has eomposed some services and anthems; a rolume of Masonie music; songs and part-songs; and pianoforte pieces.

Atkinson, G. G., musician. Published "The Abbey Bell, a collection of original Psalm and hymutumes . . ." London[1.661].

Atkyns, B. K., author. Issued "A Choirmaster's Manual : containing full instructions for training a choir." n.d.

Atter, William, musician. Compiled "Collection of sacred music, adapted to the hymns of Burder and Dr. Watts, with ac. companiment for organ or pianoforte." London $[1845]$.

Atterbury, Lufiman, composer, bom London, in first half of listh century [c. 173540]. After being trained in muic he became musician in ortinary to creorge III., and a teacher in London. He sang in the Handel Commemoration, 17st, and gained several prizes from the Catch Club. He diect at Westminster, Loudon, June 11, 1796, while giving a concert

Works.-Mago and Lago (play with music) 1794. Goliath, oratorio, 1773. Collection of 12 glees, rounds, etc., Op. 2 [17s8]. Collection of glees, canzonets, and rounds for 2, 3, and 4 voices, Op. 3. IJondon $[1790]$. Collection of catches and glees. London, n.d. Single Glees, dc.-Come let us all a Maying go; Come mount your fleet coursers; Come ye rural nymplos; Cottagers; Haply we; Lads and lasses hither come: Lay that sullen garland by thee; Let's banish strife and sorrow: Will you go to the fair: With horns and hounds, etc. Sungs-Mark the sweet rosebud; Say why a blush; L'ndaunted Brituns, etc.

Attey, John, composer, hom about 1590; died at Ross, Hereford, about 1640 . He composed "First bookc of ayres of foure parts, 


\section{ATTWATER.}

witly tableture for the lute, so made that all the parts may be plaid together with the lute, or one voyce with the lue and bass viol." Londoll, 162:.

Attwater, Joln Post, pianist, organist, and composer; born at Faversham, Kent, June 26, 1862. In $188+$ he went to London, and is now organist of Clapham Congrega. tional Church. Studied nuder Dr. C.J. Frost, Dr. C. W. l'earce, and others; is a riolinist and vocalist, and F.R.C.U. His compositions include a setting of I'salm 34, for soli, chorus, and organ, and many songs and pieces for pf., reaching to Up. 79.

Attwood, Thomas, composer and organist, born London, November 23, 1765. Entered Chapel Royal as chorister 1774. He studied under Nares and Ayrton 1774-1781. In 1783 he was sent to 1 taly by George IV., then Prince of VVales, to continue his musical studies, and he received instruetion from Latilla at $\backslash$ aples, Mozart at Vienua, ete., from 1783 to 1787 . On his return to England he bccame organist of St. George the Martyr, Holborn, 1787, and a member of the Srince of Wales' private band. From 1792 to 1795 he acted as music master to several members of the royal family. In June, 1796 , he became organist of St. Paul's Cathedral, London, and, in the same year, eomposer to the Chapel Royal. He was a member of the Philharmonie Soeiety, 1813, and held the appointments of organist to George $I V$. at his private chapel at Brighton, 1821, and organist of the Chapel Royal, 1836. He died at Chelsea, London, Marcl 24, 1838, and is buried in St. Paul's Cathedral, nnder the organ.

Works.-Musical Dramas, tec-The Prisoner, 1792; Mariners, 1793 ; Caernarvon Castle, 1793; Adopted child, 1795; Poor sailor, 1795; Smugglers, 1796 ; Devil of a lover, 1798; 1louth of the Nile, 17!S; 1)ay at Rome, 1799; Red Cross Knight, 1799; Castle of Sorrento, 1799; Magie oak, 1799; Old elothesman, 1799 ; Dominion of fancy, 1800 ; True friends, I800; The Eseapes, or the water earrier (from Cherubini), 1801 ; Il Bondocani, Is01; St. David's Day, 1804; Adrian and Orilla (with M. Kelly), 1806; Curfew, 1807. Chnreh services in F, A, D, and C. Anthens - Come Ioly Ghost; Enter not into judgment; Grant, we beseech Thee; I was glad; Let the words of my mouth; $O$ God, who by the leading of a star ; They that go down to the sea; Turn Thee arain O Lord; Turn Thy face from my sins; Withdraw not Thou Thy merry. Nine glees for three, four, five, and six voices. London [18287. SongsDear vale, whose green retreats; The sigh; Soldier's dream ; Spacious firmament; Young Lochinvar, etc.

Audsley, George Ashdown, arehiteet and musieian, was born at Elgin September 6,1838 . Has lectured on Baeh and other

\section{AVISON.}

musical subjects, and is author of a work on the organ. He has also produced a number of finely illustrated books on architeeture and decoration.

Austen, Augusta Amherst (Mrs. T. Anstey Guthlie), composer and organist, born London, August 2, 1527. She studied at the Royal Aeademy of Musie, and was appointed organist of lialing Cinurch in 1844 . This post she held till 1848, when she received a similar appointment at Paddington Chapel. This she resigned in 1557 , and soon after she married Mr. 'I'. A. Guthrie. She died at Glasgow August 5, 1s7T. She composed various hymn-tunes, etc. Her son, F. ANSTEY, is the popular novelist, author of "Vice Versa" and other works.

Austin, John, author, born at Craigton, near (ilasgow, April 17. 175\%. Ile was a manufacturer in Glasgow, where he died about 1830 . He published "A System of Stenographic Music." London, N.1. [1530], in which the proposal is made to substitute one line and six characters for the ordinary five lines and symbols of the existing musical notation. There is a short notiee of Austin, with portrait, in Kay's "Original Portraits," vol. 2. p. 376. Edinburgh, 1838.

Austin, Walter, Amateur composer, born at Leeds. Fingaged in the Civil Service. First came into notice by his Cantata, "The Fire King," accepted for the Leeds Festival of 1877. Ile is also the eomposer of an Operetta, "The Stepmother" (Arthur Sketchley), produeed at St. George's Hall, Loudon, 1850; an overture, "The Camp," performed at the Covent Garden Promenade Coneerts, August, 1880; and some songi and pt. pieees.

Austin, William Frank, organist and composer, born at Lichfield, December 23, 1846. Began his eareer as a chorister, in Lichfield Cathedral, and was afterwards associated with the nusical work of Rugby School, and Trinity College, London. He took up wamly the subject of "English Opera," upon which he leetured and wrote. His last organ appointment was at St. Andrew's, Fulham. He died in London, February 16, 1891. IIs compositions include a chorus, The Crusaders; The Gondolier; Farewell, dear I.ove, and other songs; and a few pieces for pianoforte.

Avison, Charles, composer, author, and organist, born at Neweastle-upon-Tyne, 1710. IIe is supposed to have gone to Italy to study musie, and he certainly had lessons from Geminiani in London. In July, 1736, he beeame organist of St. John's Church, Newcastle, and in Oetober of the same year he was appointed organist of St. Nicholas' Church, Neweastle. From 1736 he gave subscription concerts in Newcastle, and resided there as a teacher. He dier Neweastle-uponTyne, May 9, 1770. 


\section{AYLWARD.}

Wonks.-Twenty-six concertos for four violins, Newcastle, 175s. Eight concertos in seven parts for four violins, one alto-viola, a violoncello, and a thorough-bass for the harpsichord, 1755. Twelve concertos in seven parts for four violins, one alto-violin, violoncello, and thorough-bass for the harpsichord, op. 6. Six concertos in seven parts, op. 10, London, 1769. Six sonatas for the harpsichord, with accompaniments for two violins and violoncello, op. 5, London, 1756 ; another set, op. 7, Nervcastle, 1760; third set, op. 8 , London, 1764. Concertos for organ or harpsichord, op. 9. Songs, etc. An Essay on musical expression, London, 1752. This provoked an acrimonious discussion with Dr. Philip Hayes of Oxford. He replied to Hayes in the second edition, 1753, of his essay, and included in it "A lester to the author concerning the music of the ancients," written by Dr. Jortin. The third edition appeared in 1775 , "with alterations and large additions," and in the same year a German translation was published at Leipzig. He assisted Dr. Garth, of Durham, with his edition of Marcello's Psalms, 1759, after having himself issued proposals for publishing them. His best-remembered composition is "Sound the loud timbrel," otherwise called "Miriam's song." In Robert Browning's poem, "Parleyings with certain people of importance," a part is devoted to Avison.

His eldest son, EDWARD (1747-1776) succeeded him as organist at St. Nicholas', and his second son, CHarles (1750-1793) was organist of St. John's.

Aylward, Theodore, composer and organist, born about 17:31. He was a member of the Royal Society of Musicians in 1763, and gained a prize medal from the Catch Clnb in 1769 . In June, 1771, he was appointed Professor of $11 \mathrm{n}$ sic at Gresham College. In $178+$ he was assistant director of the IIandel commemoration. He held the appointments of organist of St. Lawrence, Jewry, 1762; St. Michael's, Cornhill, 1768; and St. George's Chapel, Windsor, 1758. In 1791 he was Mns. Bac. and Doc., Oxford. He died London, February 27, 1801, and is buried in St. George's Chapel, Windsor.

Wonks.-Musical dramas: Harlequin's invasion [1787]; Midsummer night's dream; Mago and 1)ago, etc. Six lessons for the harpsichord, organ, or pianoforte, op. 1 [1792]; Elegies and glees [175.5]; Eight canzonets for two soprano voices, London [1785]. Songs: Oft Oft have I seen; Sweet tyrant love, etc. Church music in ms.

Aylward. A family of musicians related to the above. Willial Price AYlward, great-nephew, was born at Salisbury, circa, 1810. Was for about thirty years organist of St. Martin's, Salisbury, and in 1565 also appointed to St. Edmunds. Condnctor of the

\section{AYRTON.}

Sarum Choral Society, and Bandmaster of First Wilts. Rifle Volmnteers. He was an excellent flute player. Was elected Mayor of Salisbury, 1868-9. Tied 1890. He lrad seven children in the musical profession:AUgustus Albert, born at Salisbury, organist successively of St. Edmund's and St. 'Thomas', Salisbury. Contrabassist and conductor of orchestral concerts. In 1589 he was appointed organist and choirmaster of St. Peter's, Ashtabula, Ohio, U.S.A., where he gained distinction by his organ recitals. He is now resident at Basingstoke, Hants.-T॥FonorE Price, organist, was born at Salisbury, 1544. Articled pupil of Dr. S. S. Wesley, at Winchester and Gloucester. Organist of St. Matthew's, Cheltenham; St. Columba's College, Rathfarnham, Dublin ; St. Martiu's, Salisbury (during his father's term of office as Mayor); Llandaff Cathedral ; Chichester Cathedral; and since 18s6, of the Park Hall, and St. Andrew's Church, Cardiff. Editor of the Sarmm Hymmal, 1870. - WilLian Henry, violoncellist, born at Salisbury, 1835. Educated at the R.A.M. ; King's Scholar, 1850. Nember of the I'lilharmonic and Royal Italian opera orchestras: also distinguished as a quartet player. Died at Slough, March 1:, 1878.AMY AYLWARD, soprano rocalist, educated at R.A.M., and elected an Associate. Sang at the Monday Popular Coucerts, 1580 ; Cambridge University Society's Concerts ; and elsewhere, and is now resident in London.-CERTRUDE AYLWARD, also a soprano, has sung in London, and given concerts during the last few years.-JANelta AYLward, pianist, King's Scholar, R.A.M., 1852, a brilliant and highly promising student, died June 7, 1853 , in her sixteenth year.--Lerla J. AyLWARD, pianist, and contralto vocalist, student, and Fellow R.A.M., has given some excellent Chamber Concerts in Salisbury; and has for years done good work in the adrancenent of musical education in the district.

Ayrton Edmund, composer and organist, born Ripon, Yorks., 173t. He was a pupil of Dr. Nares, at York Minster, 17tt. Organist of Collegiate Church, Sonthwell, 1754-67. Gentleman of Chapel Royal, I764, and vicarchoral St. Paul's Cathedral, London, 1767. lay-Vicar, Westminster Ab]ey, 1780. Naster of children of Chapel Royal, 1783-1805. Mus. Doc., Cambridge, 178t. Said also to have incorporated Mus. Doc., Oxford, in 1788. Assistant-director of Handel Commemoration, 1784. He died London, May 22, 1808, and is buried in the cloisters of Vestminster Abbey.

Works.-Services for the church in $\mathrm{C}$ and E flat; Anthem, "Begin unto my God," de. gree exercise, 1754. Ode to Harmony [1790]. Canon, five in two [1790]. Songs, ete.

His son Thomas (born 1781, died 152!) was organist of Ripon Cathedral for some years. 


\section{AYRTON.}

Ayrton, William, author and conposer, son of Ednumd Ayrton, born London. Feb. 21, 1757. lle married a daughter of Dr. Samuel Amold, and in iso1 unsuccessfully competed for the Gresham professorship of music. He was successively editor of the Horning Chromicle, 1813-26; Hamonicon, 1823-33; and Examiner, 1837-51. Nember of Royal Society, Antiquarian Society, Athenifum Chul, Philhamonic Society, ete. He died London, May 8, $1 \times 58$.

Worrs. - Sacred Minstriclsy : a collection of sacred musie by the great masters of all ages and nations... with biographies. London, 1835,2 rols. Knight's M usical library (edited), 1834, ete., s vols. Duets: Fair and fair ; Oh! oh! memory. Songs, etc., ete.

Ayton, Fanny, soprano vocalist, bon Macclesfield, 1806. She studied under Manielli at Florence, and first appeared at Venice in opera, 1525, in Coccia's "Clotilda." In Felnuary, 1827, she appeared in London as Ninetta in Rossini's "La Gazza Ladra," at the King's Theatre. She afterwards sang in London, Bimingham, and elstwhere, both in opera and oratorio. The date of her death remains in doub, but was subsequent to 1832 as slie appeared in February of that year in a version of MTeyerbeer's " Robert le Diable."

Babell, William, violinist and composer, born 1690. He studied under Dr. I'epusch, and becane a member of the Royal Band. He was also organist of All llallows Church, Bread Street, London. He died London, Ser. tember 23, 1723.

Works.- XII. solos for a violin or hautboy, with a bass fincr'd for the harpsichord. London [1720]. XI1, solos for a violin, hoboy, or German flute, with a bass figur'd for the harpsichord. London [172:3]. Twelve solos for the flute or holoy, Op. 2. Six concertos for the piccolo, flute, and violins. Suits of har'ssicliord and sp inuet lessonscollected from the most celebrated master's works. London [1712]. Book of t]e lady's entertainment, or banquet of monsick, leing a choice collection of aires and druts curiously set and fitted to the harpsichurd or spinnet (four books witl varying titles). London [1710-25].

Baber, Miss Colbourne (MTis. Harrison Whuts); soprano rucalist of present time, born at IIolrant, Tasmania. Pujil of Madame Lucy Chambers. Apreared at Melbourue Opera House; toured throush India, China, and Jajun. Now settled in Sydney, N.S.W.

Baclue, Constance, pianist and wittr,

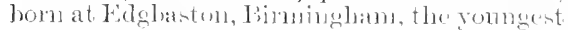

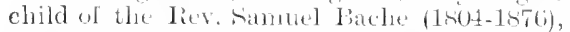

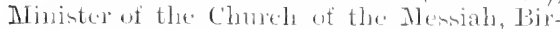
minglame. Jer numical ta] whe was fostered by her lowher, Walter Barle, and shestudied at the Conservatorimo, Junieh, beconims,

\section{$\mathrm{BACHE}$.}

later on, a pupil of Klindworth and Fritz Hatrigson. An accident to her right hand put a stop to the prablic eareer open to her, hut she played occasionally at coneerts in Bir: minglan, up to the year 1883 , when she settled in Londom as a teacher, devoting, lowever, much of her time to musical literature and translations, of which the following are the most important:-Liszt: Oratorio, St. Elizabeth (see BaCHF, Walter); Letters, 2 vols. (Grevel, 1894); words of many of his songs. H. yon Bulow-Letters and literary remains (Unwin, 1896), Wagner:-Deseriptive kietch of Beethoven's Ninth Symphony (for Richter concert programmes). Heintz: Analyses of Wagner"s "Tristan" (1891) ; Meistersinger (1891); "Parsifal" (1892). Schumunn: "The Rose's Pilgrimage ;" Scenes from Goethe's "Faust." Mozart : Libretto of "Bastian and Bastieme" (1894). Humperdinck: Lilnetto of "Hänsel and Gretel;" Lohe's Catechism of Music, and Von Bulow's annotated editions of Cramer, Chopin, ete. Constance Bache is the composer of the somgs, "To ny Love" and "The rain is talling."

Bache, Francis Edward, composer and pianist, eldest son of the Rer. Sammel Bache, hom at Edglastom, Bimmingham, September 14, 1833. In early childhood he showed extraordinary aptitude for nusic, studying the pianoforte, organ, and violin, making such progress in the last, moler Alfred Mellon, that lue was given a place in the Festival Orchestra in 1846 , when Mendelsiosm prodneed "Elijalı." $\mathrm{L}^{+}$wan leaving achow) in 1849, he took lesions from Mr. Jannes Stimpsom, hut soen lett for Londun, where lse studied with sterndale Benmett. In 1859 les went to Leiprigs studying under Hamptmam and Plaidy, and took organ lessons froud J. G. Schnejder at Dresden, in 1854. He gave his first enteret in Bir-

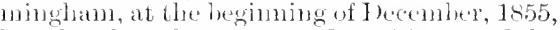
but his hedelh was alleady lailing, and he spent the winter in Algiers. Here he gave a cencert, in March, 1856, and his playing created a marked inmpression. From Algiels le went to Lejpign, and thenes to Rome, where be spent the next wintr. In 1857 he returued home, wintering in Torquat ; back in Pimmingham, April, 1nst, he gractually

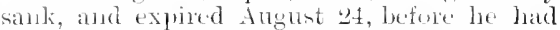
complested his 25th year. Ilis capacity for work knt w no bounds; he wats alwats comlposing; and only a few weelis before lis death he gave a concert, chiefly ol his own wolss, lout he was mable, though present, to talie his part in the perfornanes. $H_{e}$ was a thinker, and ju a series of letters, written in 1856, adroerated the establimbent of a pernianent orehestra in Bimingham, pointing out the great artintie results that should follow. The letters were not consdered suitable for the pages of the journal to which they 


\section{BACHE,}

were addressed, and have only recently been published, and that in comnection with the formation of the Scottish Orchestra at Glasgow, in 1893. His compositions must be looked upon as the promise of what might have been had he lived longer; they prove, however, that in Francis Edward Bache death robbed England of a highly gifted artist.

Works.-Operas: Which is which (1851): Rubezahl (1853). Orchestral: Overture (performed, Adelphi Theatre, November, 1850); Coneerto for pianoforte and orchestra in $\mathbf{E}$ : Andante, Rondo, and Polonaise: Morceau de concert in $\mathrm{F}$, for $\mathrm{pf}$. and orchestra. Trio in $\mathrm{D}$, pf. and strings, Op. 28 ; Two Romances, violin and pf.; Romance in G, flute and pf.; Romance for' $y$ f. and 'eello, Op. 21. Pianoforte: Three Impromptus, Op. 1; Two Romances, Op. 12; Four Mazurkas, Op. 13; Five characteristic pieces, Op. 15; Deux Polkas, Op. 17; Sonvenirs d'Italie, eight pieces, Op 19; Les Clochettas des traineau, Op. 20; La Penseroso e l'Allegra, Op. 24; Souvenirs de Torquay, five pieces, Op. 26; other pieces and transeriptions, more than fifty in all. Introdnction and Allegro, organ. Six songs for voice and pf., Op. 16; Litany, words and music 1862 . Four songs 18597; and single songs - the "Farewell "heing worthy to stand side by side with the lieder of Schnbert and Schmmanm.

Bache, Walter, pianist, born at Edghaston, Birmingham, June 19, 184\%. Fourth son of the Rev, Sammel Bache. Euluated at the Proprietary School, Edglaston. Began the study of music under James Stimpson, and at the age of 16 (August 1858) proceeded to Leipzig, studring at the Conservatorim, under Plaidy, Moscheles, Hanptmann, and Richter. At the end of three years, he left Leipzig, and visited Milan and Florence, where he began to give lessons. In 186\%, he went to Rome and studying for three years with Liszt, formed a life-long friendship with the illnstrious artist. In May, 1865, he settled in London as a teacher and performer. He gave his first eoncert, in conjunction with MIr. Gustave Garcia, in Collard's Rooms, July 4, 1865, and then began that ardent championship of the claims of Liszt as a composer that lasted to the end of his life. The concerts were gradually extended, and the services of an orchestra requisitioned in 1871 , when lache played the Concerto in $\mathrm{E}$ flat, and gave the symphonie poem, "Les Prehudes"-introduced in 1865 for two pianos-with full orchestra. Other modern composers were not overlooked, for works by Wagner, Berlioz, and Schumam, were introdnced from time to time. But his affection for Liszt was strongest and his last recital, October 22, 1847, was exelusively devoted to that master. Lndaunted by hostile criticism, or financial loss, Bache went on with his propagandism, and if

\section{BAILDON.}

he did not snceed in what he felt to be his mission, he did more than any one to break down that conservatism in music that was a positive hindrance to the art in this country, Bache's reception to Liszt at the Grossenor Gallery, April 8, 18 s, was a memorable incident of the great pianist's last sisit to this comntry. He was an active promoter of the Liszt Scholarship at the Roral Academy of Nusic; the Seholarship to his own menory was incorporated in that of the man he so revered. Bache died, after a few days' illness, March 26,1885 , and was interved in the cemetery at Went Hampstead. He had, for some years, been a professor of the pianoforte at the R.A.MI.

Among the works of Liszt brought forward at Bache's concerts, the following were performed in Fngland for the first time:-The "Eanst" Simmphony, March 11, 14so; Simphonic poen, "Les Preludes," May 26,1571 ; scena, "Jeame d'Are au luh her," for soprano solo and orche'stra: Angehus, strings, Fetruary 5, 1885 ; Fantasia quasi Sonata, "Apris me Lecture du Dante," Felumary 21, 18-4. The Legend of Saint filizaleth wis first performed in England, ly the New Philhamonic Societ $y$, Jume 15. 1870, anticipating Bache, who lrought ont the work, Felmary $24,1876$.

Back, Sir George, naval officer, horn Stockport, 1796; died, 1*78. He issued "Canadian Airs, collected by Lient Back, R. N, during the late Aretic expedition under Captain Franklin. With symphonies and aecompaniments by E. Kuight, jun., the words by George Soane." London, 1s23.

Bacon, Richard Mackenzie, author and editor, born Norwich, 1776. He was editor of the "Quarterly Musical Magazine and Review." Died at Norwich, 1st4.

Wo ks. -Science and practice of vocal ormament, London, N.D, Elements of vocal scienee, being a philosophical enquiry into some of the principles of singing. London, 1824. Art of improving the roice and ear, and of inereasing their musical powers on philosophieal principles. London, 1825.

His daughter Loutsa MARY BaCon, born at Norwich, March 4, 1800 ; died February 2, 1885, was also a musician the married a Mr. Barwell.

Bacon, Rev. Robert, clergyman and musieian of the 1sth century. He graduated B.A., Oxford, in 1738: and in 1753 beeame priest viear of Salisbury Cathedral. He died in 1759. Composer of chants, eic.

Badland, Thomas, musieian, published "Set of original Tunes in four parts, adapted to the Hymus of the Rev. J. Wesley, etc. London [1827].

Baildon, Joseph, eomposer and vocalist, bom 1727. He was a Gentleman of the Chapel Royal, and Lay-Vicar of Westminster 


\section{BAILLIE.}

Abbey, about the middle of the 1sth century. He gained prizes given by the Cateh Club in 1763 and 1766 . He held the position of organist of St. Luke's, Old Street, and All Saints, Fulham, London. Died at London, May $7,1774$.

Works - Collection of glees and eatches London [1768 . The laturel, a eolleetion of songs. Ode to Contentment. Numerous single songs, and others in "Love in a Village," etc.

Baillie, Alexander, musieian of the 1sth century. He was an engraver in Edinburgh.

Elitor of "Airs for the Flute, with a thorough hass for the Harpsichord. Edinburgh, 1735 .

Baillie, Peter, commonly called "Pate Baillie," riolinist, was born at Stenhouse, in Liberton parish, Nicllothian, February 25, 1774 , and was a deseendant of the gipsy family of Baillies of the Upper Ward of Lanarkshire, his father being Matthew Banllie of that sept. He was originally a stonemason, and worked for a time at the Edinburgh University builling, but he settled as a violin-player at Loanhead and Bonnyrigg in Nidlothian. He died at Liberton, Midlothian, about 1841, and is buried in the churchyard there. A selection of his eompositions were published as "A Selection of Original Tunes for the pianoforte and violin." Edmburgh, 1825; for the benefit of his family. He was a talented performer of Seots musie, and was widely employed "at penny weadings, kins, and other merry 'splores,' "but seems to have been a rude, offensive fellow, mueh given to bouts of intemperance.

Bain, John, musician and teacher in Glasgow in the latter half of the 1sth c ntury, published "The Vocal Musician, heing a eollection of select Scots and Euglish Songs, arlispted to two, three, or fuur voices" Glasgow, $17 i t$.

Bairstow, Thomas, musician, published "An Original set of Psalm and Hymm Tumes arranged for one or four voices, with an accompaniment for the organ or pf." Halifax [1852]. Fecond set of Original Psalm and Hymu Tumes . . Halifax 1852].

Baker, George, componer, born Exeter alount 175: lle stndied mater Jackison of Exeter and Hugh Bond. Ife entered the family of the barl of Lxhoridge, and received further instruction from Craner and Dussek. Organist sucecssively of st. Mary's, Stafford, 1794; All Maints", lert,y, 1810; and kugeley, 182t. In 1797 he took the degree of Mus. Bac., Oxford., lnut did not proceed to Mus. Doce as is usmally smporsed. He died at Rugeley, Fetruary 19, 1847. He composed "The Caffren," a musical entertaimnent, Lomdon, 1802; Sunatas for the pf.; Organ volnutaries; Songm; six Anthous for 4,5 , and 6 roices; and Glees for 3 and 4 roices.
BALFE.

Baker, Sir Henry Williams, Bart., musician and clergyman, born London, May 27, 1s21. Son of vice-admiral sir Henry Loraine Bilker, C.B.. He was educated at Cambridge Lniversity, and graduated B.A., 1844, and M.A., 1847. Viear of Monkland, near Leominster, 1851. Succeeded his father as a baronet, 1859 . Inied at Monkland Vicarage, Febrtiary 12, 1877. He was the originator and ore of the compilers of "Hymms Ancient and Nodem," 1858, and mumerons later editions, to which he contributed "Stephanos" and "St. Timothy." He published a folmme of "Daily Irayers" and various religions worlis.

Baker, James Andrew, organist and composer, bom Bimingham, November 8, 1824; died there Novernber 17, 1863. He studied at Leiprig, and was organist of St. Lulke's Chnmeli, Bristol Street, Bimingham, from about 1849 to 1863 . His wife was a wellknown and accomplished local singer. He composed a few chants and hymm tines.

Baldwin, W_-, anthor, mblished "The Science of Music." London, 1829.

Balfe, Michael William, composer and vocalist, lom in Pitt Street, Dublin, May 15, 1808. He studied under C. E. Horn, Rooke, and Alex. Lee in Ireland. He acconpanied Hom to England, and became a violinist at Drury Lane, 1824. In 1825 he was adopted by Count Mazzara, whom he accompanied to Italy. He sang in Italy and in Paris in 1827 , and remained on the continent till 1835. There he was married to Mille. Lina Rosen, a Hungarian vocalist. In 1835 he sang in London, and in 1839 he became matrager of the Lveenm Theatre. He conducted at II.XI. Theatre, 1845-52, and directed the National Concerets at I num Lane in 1850. In 1852 he sang in Russia. From 1852 till his death he was ocenpied chiefly as a composer. He died at Rumer Abler, IItertis, Octolser 20, 1870.

Works-Operas: I Rivali di se Stensi, Palermo, 1829; Un Arertimento di Gelosé, 1'avia, 1830; Enrico Gnarto al passo della Mamo, Milan, 1831; siege of Rochelle, London, 1836; Maid of Artois, London, 1836; Catherine Grey, London, 1837; Joan of Arc, London, 1837; 1)iadeste, London, 1838; Falstaff, London, 1838; Keolanthe, London, 1841; Le Puits d'Amonr, l'aris, 1843; Tohemian (firl, London, November 27, 1843; Danghter of St. Tark, Lundon, 184t; Quatre Fils Armon, Paris, 1844; Enchantress, London, 1s45; L'etrile de Séville, I’aris, 1845; Bondnan, London, 1846; The Devil's in it, London, 1847; Majd of honour, London, 1847; Sicilian Bride, Lindon, 1852; Pitture e 1nca, London, 1850 revived as the 'Painter of Antwerp,' 18617: R se of C'astille, London, 1857; Satanella, London, 1858; Bianca, London, 1860; Puntan's danghter, London, 1s61; Blanehe 


\section{BALFE.}

de Nevers, London, 1862: Armonrer of Nantes, London, 1863; Sleeping Queen, London, 1863; Il Talismano, London, June 11, 1874. C'antatas: Mazeppa, London; The Page, ete. Six new songs and a duet (words by Longfellow), 1856, Joore's Irish melodies, harmonized 1859 (Novello). Part-songs: Exelsior' Hark! 'tis the hunter's jovial horn; Trust her not, etc. Songs and ballads: Angels call me; Anmie of Tharaw; Arrow and the song; As the smmshine to the flower: Ah! would that I conkd love thee less; Anabel Lee; Bells; Berleath a portal; Bridal Ballad; Come into the garden, Maud; Daybreak; Defence, not defiance; Evening chime is somding: Fortune at her wheel; Fresh as a rose; Good-night, beloved; Green trees whispered; Hidden voices; I love you: Kathleen Machree: Killarney: Ladv Hildred; Long ago; Lonely Rose; Maggie's Ransom; Mameen; Nerry Mar; Nelly Gray: Phobe, the fair: Sea hath its pearls; Stars of the summer night: Slurit of light: There is a shadow; Three fishers; What does little birdie say; and very many more. 'Trio for pf., violin, and 'cello; Sonata jif. and cello; and other instrumental works. New miversal method of singing without the use of solfuggi, London. The only opera of Balfe's which now survives is the "Bohemian Girl," which continues to draw good audiences wherever produced. This opera and a few of his songs, " Killarmey" and "Come into the garden, Matud," are all that have lived ont of an immense number of able productions. Two hiographies of Balfe have been published-"A Memoir of Michael William Balfe," by Clarles Lamb Kemey, London, 1875: and " Balfe, his life and work," by W. A. Barrett, Londun, 1882.

His wife. Lixa Rosex (bom in Humgary, 1806; died London, Jume 11, 1888), wats a soprano vocalist of considerable ability.

Balfe, Victoire, soprand voralint, born Paris, September 1, 1437. [ langhter of MI. W. Balfe. She studied under $W^{+}$. Stemdale Bennett, MI. Garcia, and hel father. On May 28 , 1857, she first appeared as "Anina," in " La Sommambula," Afterwards sle sang in Ireland and Italy, in the "Bohemian (rirl," "Don Gioyamin," ete. She was married to Sir John F. Crampton, but was divoreed, and afterwards maried to the Duke de Frias, a Spanisl nobleman. She died at Madrid, January 2.2, 1871.

Ball, Edward, see Fitzball, buwart.

Ball, William, anthor and adapter, born 1784: died London, May 14, 1869. He conlposed a nmmber of songs, and wrote the verses of mans more, and contributed much to the musical and peliodical literature of his time. He wrote the tunglish verion of Mendelsiohn's "St. Paul," and provided Englimle remions for a number of works by Rosini, liecthoven, Mozart, Haydu, etc.

\section{BAMBRIDGE.}

Baly, William, comlnetor and composer,

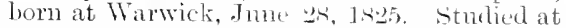
first moler Mr. Claytom, of Warwick, and afterwards entered the li....II., 1st3, where his teachers were Stelndald Bennett, pianoforte, and Cipriani l'otter', hamony. Elected first an Associate, then Fellow, R.A.M. Resided for some veres in London, and taught bamony at the Harly street College for Ladies. In 185.3 lie settled in Fxeter, taking over the teaching comnection of MIr. Kellow Pye. He conducted the Exeter Oratorio Society's concerts for one yerr, and was conductor of the Madrigal suciets for fifteen Years, his last concert taking place May 29 , 1884. On his retirement ho reevived a handsome testimonial from the siociety. He died Jume 4, 1891. His compositions inclucled a Symphony in E flat, produced at the Hanover simare Rooms, July 10, 1947, and at the City of London Institute. Amril, 1st8: Two Concert Oreltures, "Macheth "aud "As you like it,"

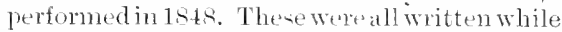
a student at the R.A.M. He libewine composed a Minuet for small orelyestra ; a quartet in $A$ for strings, and pieces for pf. Some part-songs, "Sweet and Low," de., were performed in 1885-6, by the lixeter Marligal society. His wift, nee ADELAme C. BYRx, who smrviveshim, is a pianist, and studied at the R.A.MI. under Gipriani Potter and (r. 1. Macfarren. She is now living in letirement in Exeter.

Bambridge, George Edmund, nrganist and pianist, born at Windsor. April 19, 1842. studied at R.A. MI. moler Chanles Lmeas, G.A., and Walter Macfarren, and C'harles steggall, 1660-65. A.R.A.M. In 1-ist a plpointed profesnor and examine' at Trinity (o)llyese, London, and

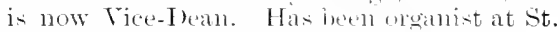
Luke's, Wenthoume Park, since listit, and is widely known as a skilful pianofute teacher. Him published eompmitions a le not numerous, and consist of an Eranims sinvice in F, and some pieces for the pf.

Bambridge, WVilliam Samuel, mganint, cousin of the preceding, lum at the Wamate, New Zealand, July 18, 1st2. When six vears old came to England, and was, for a rear, a supernumery in the chrir of st. Creorge's, Windsor, At the age of ten le was aplointed organist of Clewrer C'hurch. Stmolied at R.A.M. miner H. C. Banister, C. Siteggall. W. Torrell, and W. H. Aylward. Graduated Mns. Bac., Oxford, 1872." F.R.C.(1, and A.R.A.M. Since 1664, he has been organist and mu-ic master of Marlborongh College. Milts, : and is conductor of the College and Mardhomugh C'horal societies. Hin principal (nmplumitim in a setting of Psalm 14t, in ten numernente: and be

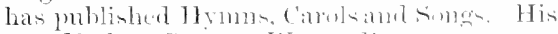

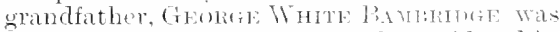
an admirable flute-player, and comsirlered in

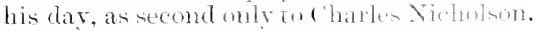




\section{BAILFRD}

Bamford, H. A., musician. Wrote "The Rudiments of the theory of Munic, designed for the use of pupil-teachers and students in training colleges." Nanchester, 1881.

Banestre or Banaster, Gilbert, musician and poet of latter part of 15 th century, He received to marks in 1482 as "Master of the Song, assigned to teach the children of the King's chapel." He contributed to the Fairfax Ms., and wrote varions works and translations in verse.

Banister, Charles William, tomposer and teacher, born 1768, died 1831. He composed "Twelve Prath and Hymm Tumes," London, 1792: "Fonr MLral I'ieces," London [1803 ; "Stal of Bethelhem," song, ete. His son, Henry Joshua, edited "Connplete edition of the Yocal Mnsic of C. IV. Banister," London, 1831-33, in 21 numbers.

His son, Hexre Josnea flom London, 1803; died London, 1847, was a violoneello player and author, who perforned at most of the prineipal concerts in his dar. He putslished "Tutor's Ansintant for the Violoncello," N.r.; (One hundred and fifty Lessons for the Tioloncello," London 1846" ; also "Lennons on I buble-notes" and " Exercises on the nse of the thinmls." He also wote "I)omentic Music for the wealthy, or a plea for the art and its professoms," Lomden 1843

Another sols, Jostery (1812-1890), wals a violinist, and for many vears was a menher of the Philharmonic society.

Banister, Henry Charles, composer, pianist, and writer on music, born in London, Jume 13, 18:31. sion of H. J. Banister (q. r.). Studied, at first moder lis father, and later at the R.A.M., whese he wom a King's Scholarship in 1st6, and again in 1sts. Cipriani Potter was the master he chiefly studied with. In $18.5 \mathrm{l}$ he became Assistant P'rofessor, and in 1853 I'rofesmor of Harmony and Composition, R.A.AI., and is now F.R.A.J. As a singing boy he was leard at concerts of the filee Clinlsis, and in 1 sist he sang donets in "Judas Mareathatls," with Mlisi Imolly and Miss Salilla Novello, at the Rearing Festival of 1846 (vide lixfelen). His string quartet in F sharp minor was produced liy the society of British Mosicians at Erat"s Saloon, I decennler 29, 1847: and he heganconcert giving Novenuluer 20, 1555, at st. Martin's Hall. For many years a pominent figme in the musieal world, of late he has devoted himelf cliefly to tnition and to musical literature. Berides his alpointment at the R.A.MI., he has been a

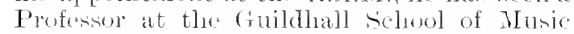
since 1880 , and is I'rofesene of Harmony at the Royal Normal College for the IBlind. Member of the Phillatmonie societs.

Woeks. - In Mis. : Symplonies: No. 1, in I) $(18+7)$; No. 2. in E flat (184tis); No. 3, in $A$ minor (1850); No. t, in A (18583). Oxertures:
BANKS.

No. 1, in E flat (1849); No. 2, "Cymbeline" (1852) ; No. 3, in E minor (1852); No. 4, The Serenade, in E; No. 5, From sorrow to Joy, in P flat (1876). Andante and Rondo in E flat (1852). Capriccio in A minor. Fantasia in I) (written for the Munjeal Society, 1863), for lf. and orchestra. String Quartets in F sharp minor (1847); in $\mathrm{I})(1850)$; in $\mathrm{E}$ minor. Sonatas for pf. dute, in (r minor (1850); in A flat; in A minor; for pf. solo, in E; B flat; F share minor; $\mathrm{F}$ minor; and $\mathrm{F}$ sharp minor. Sacred Cantata (1851). Cantatas for female voices and orchestra: The Sea Fairies (Tempyon - R.A.M., 1861); The Maiden's Holidity, for female voices feomposed for private choir of Madame Banano). Published composition.-Tf. pieces, Op. 2, 4; Seven variations on an original air, Op, 5; Op. 6; Sonata in F wasp minor, duet, produced 1852, ()p. 7: Op. 9, 10, 11, 13, 14, 18, 22, 26, 27, 29; Andante, with rariations, pf. duet, Op. 31 ; Op. 34; Fantasia in F minor, Op. 35 (composed 187t); Camzonets, Op. 1, 3; Partsong, Op. s; Three songs, Op. 16; Anthem, O watisfy us early, Op. 25; I'art-songs, songs, ete. Literary and didactic, including lectures delisered before the Royal NormalCollege, The Nusical Amsuciation, College of Organists, and the Incorjorated society of Musicians (Conferences), etc. Text-book of Music, London, 1872, 14 editions; Sone Nusical Ethics and Analogies, London, 1s84; Lectures on Musical Anulysis, 1887; Musical Artand study, 188s: (reorge Alexander Macfarren: his life, works, and inflnence London, Bell and sons, 1892; Two addresses on the same subject: Helpfnl papers for harmony student London, Ruder, 1895; and many lectures unpublished.

Banister, John, composer and violinist, lorn London, 1630. He was sent loy C'harles II. to France, where he studied the violin, and on him return became leader of the King's land of muvic. He entallikhed a "Musick School" at Whitefriars, and gave concerts from 1672 till 1678 . He was dimisised from the King's laud for maintaining that English riolinists were superior to French ones. $\mathrm{He}$ died London, ()etuber:3, 1679 . Banister composed music for Davenant's "C'irce," 1667 (with I'. Humphres); for Shakespeare's "Tempest:" and pullished "New Arres and Dia. logues composed for voices and riols of two, thice, and fomr parts," Lomelon, 1678 (with Thomas Low). He also composed Lestions for viols, songs, ete.

His som JoHx (?-1735) wath also a violizist and a member of the privinte lands of charles II., James II., and Anne. He was also principal violinist at the Italian Opera, London. Author of "The Gentleman's Tutor for" the Flute," . . 169s, and "The Compleat Tutor for the Violin, . . 1699, etc.

Banks, Ralph, musieian and organist, 


\section{BANNATYNE.}

bom Durham, 1762; died 1841. Pupil of Ebdon, and organist of Rochester Cathedral 52 years. Published "Selection of P'salm and Hrmm Tunes from Purcell, Croft, etc., with interludes to each verse." . . London [1835]. "Te Demm, Jubilate, Sanetus, etc., in score, Rochester [1840]

Bannatyne, Rev. A. M., Scottish author, Free Church minister in Aberdeen, pullished "Hearts and roices the only organs for Christian praises," Edinburgh, 1868. "The Great Imnovation," Aberdcen, N.D., a pamphlet on the organ question.

Banner, John, musician, pulblished " Collection of Sacred Music used at St. Wichael's, Wood Street, with an accompaniment for the organ and pianoforte," London [1840]. Fecond edition "with an additional hymn" by Mism Mommey. Songs, etc.

Bannister, Charles, hass rocalist, horn in Gloncestershire, 1741? He joined a travelling theatrical company, and played "Romeo" and other characters. He also appeard in London as an actor. He sang at Ranelagh and Marylebone Gardens, and at the Royalty Theatre, London, and in the English provinces. He died London, Oetober 19, 1804. He was celebrated for his imitations of other vocalists. Shield composed his song, "The Wolf," specially for Bannister.

Bantock, Granville, compuser, born in London, August $T, 1868$. Internded for the Indian Civil Service, and then for a scientific career. He did not enter upon serions musical study until the year 1889 , when he becante a pupil of Dr. Gordon Saunders, at Trinity Col. lege, London. He entered the R.A.MI. the same year, and obtained the Marefarrew heholarship. While at the Academy he was very productive as a composer, and several works were performed at the Academy concerts. He was engaged as conductor for a provincial tour of the Gaiety Company, and also for nn extended tour in the Lnited States of Ameriea and Australia. In 1893 he undertook the editorship of the new Quarterly Musical Review (R. Cockis).

Works.-Dramatic Cantata, The Fire Worshippers (overture, R.A.M., December. 12, 1890, Crystal Palate, November 11, 1893); Lyrical Drama, in five acts, Rameses II (Ballet suite, R.A.M., December 17, 1891 ; Strolling Players, April, 1892); one-act Opera, Caedmar (R.A.M., July 12, 1892; Olsmpie Theatre, (x)toher 1892); One-act Opera, The Pearl of lan; The Curse of Kehama, for soli, chorus, and orchestra; Thorwenda's Dream, poem for recitation with accompaniment (words and musie hy himself, 1891): Wulstan, scena for lraritore (1892); songs, etc. Pianoforte allom (three piecesis); Two pieces for $p$ f., etc.

Baptie, David, composer and writer, hom in Edinburgh, November 30, 1822. Self-tanght

\section{BARDD.}

in music. He has compiled a Descriptive Catalogue (commenced alout 1846) of upwards of 23,000 secular part-songs, glees, madrigals, trios, quartets, etc. (ms.). Editor of Harmonium Tune Book (with William Hume), 1867-68: Hammonimm (hant Book (do.), 186869; Cnion Song Garland (do.), 1sit; The Scot. tish Book of Praise (with Lambeth), 1576; Academy Vucalint (selected), 1s79; Richard Wemer"s Hymm Book (revised), 1881, etc. Author of A Handbook of Mrusica] Biography, London: Morley, 1883; Musicians of All Times, a concise dictionary of Musical Biography, London, Curwen, 1889; Mnisical Scotland, past and pesent, Paisley, Parlane, 1894; sketches of the English Glee Composers, London. W. Rereves, 1895. He is the composer of MY soul truly waitetlı; sing alond into God, and other anthems; a number of (Hlees and Part-songs; A rosy gift I twine for thee: Beantiful spring; The sum's bright orb; Wind thy hom, my humter loy, ete. Also many songs hamonized. His sun, C'Harles Robertson Baptie, hom in (tlangow, May 29, 1870 , is a pianist and composer. C'horister in St. Mary" Episcopal Clumeh, and from 1885 emplosed in the Nitchell Library, until, in 1858, he left to derote himself to the musical profesion. Studied under John Fulcher, IV. G. Martin, and William Moodie. Has published a children "s operetta, "Floralia," and some part-songs and pf. piecess; and was joint editor, with his father, of a work for children, "Tiur songs for Tiny singers" (1891).

Barber, Abraham, musician, pulliwhed a "Book of Pralm Tumes, in four part," 1686; ith edition, 1715. He was a book-seller in Waliefield.

Barber, Robert, musician, of cantleton, published varions collections of palunody. A Book of Pralnody, containing variety of times, with chanting tunes, ete., London, 1723; 2nd edition, 1733. The Psalm singer's Choice Companion, or a plain and easy introduction to Musick, etc., London, 1727. Indrid's Harp well tumed, or a bosk of Pralnokly, containing rariety of pralm tmmes, ete., Londom, 1753, Brd edition. Thomson's IIym to the Seasons, in score, 0 p. $4[1780]$. Sume of these collections are issued as by R. and J. Barlerer.

Barber, Thomas, musician, published "Sacred Harmony, eontaining two anthems, fifteen praln and hymn tmes, ete." Woodbridge [1s14]

Barcrofte, Thomas, compuser and organist, who flourished during the 16th century. He was organist of Ely Cathedral in 1535. Sone of lis Anthems, and a $T_{t}$ deum, and Benedictus in F, are contained in the Tudway collection in the Britinh Musemm. His son George was organist of Fly Cathedral from 1579, and died in 1610.

Bardd Alaw, see P'ARlis, Jин. 


\section{BARDY}

Bardy Brenin, see JoNes, EDWARD.

Barham, Thomas Foster, mmsician and writer, horn at Bedford, October 8, 1766, died at Leskimick, near Penzance, Felmary 25, 1844. He wrote on theological topies; sacred dramas and poems; and Nusieal meditations, consisting of original compositions, vocal and instrmmental, Lomdon, 1811; and edited and arranged Pergoleni's Stalnat Matex, with English words (1sigy).

Barker, (ieorge Arthur, composer and tenor singer, was horn on April 15, 1812. He sang in opera in London and the provinces, and gave concerts in varions parts of the country. He died at Aylstone, near Leicester, March 2,1876 .

Works.-Ballad Album, twelve books, London 1853. Songs of the army and navy [1855], iswued in numbers. Single songs and ballats: Aline O'Neal; Dublin Bay; Ellen Astore; Imigrant's hride; Emigrant's child; Excelsior: Fare thee woll, my gentle Mary; Irish emigrant ("I'm sitting by the stile," words by Lady Dufferin), London [1846]; Irish peasant; Rate Comor; Lesson of the Water mill; Maleel Gray; Mary! avoumeen; Mary Blane 18467; Mountain Flower; My native nomutain home; Ny sliff is on the shore; Nellie and I; Return of the emigrant; Sands of gold: Sonttish bue bells " Let the prond Indium loast"); Song of the silent land; Take back the ivr leaf; White squall [1835]; Wreck of the enigrant ship, ete. Why do summer roses fade? quartet; waltzes for pef. and other instrumental mosic.

Barker is hest remembered by his three songs, "Irish emigrant," "scottish bhe bells," and "White siquall," which alone survive ont of the large number he composed.

Barker, Laura W., see TAr Lor, Mrs. Tom.

Barnard, Mrs. Charles, (born ('HARLOTTE Alington), "Claribel," anateur soug-writex, lown December 23, 1830; maried Ntr. Charles ('. Pannard, 1854 . She studied music nnder W. H. Hohnes. She died at Dover, January 30, 1869.

Woris. - Songs: All along the vallev : Answer to the dream; Bell's whisper; Blind Alice; Bhe Riblom; Broken sixpence: The Brook; by the blue Alsatian momntains: Children's voices: Crome lack to Frin; Do you remamber?; Dreamland; Irifting; Farewell to Erin; Far away in ]omie scotland; Five o'clock in the morning; Friends for exer; Friendship and love: (rolden dars: Half-mast high; Huswar's parting; I amot sing the old songs; 1 leared ont of the window: 1 remember it; Jumie; Tanet's lridal: Janct's ehoice: Kathleen's answer; The life-loat; Lombland Mary; Magrice's secret; Maggie's welcome; My brilliant and I; Norali's treasure; Old honse on the hill; Only a vear ago; ()ut at sea: Riding thro' the Brome; Sitilor boy; Sinsan's

\section{BARNBY.}

story; Tell it not: Through the Jessamine; Walter's wooing; When I was young and fair; Won't you tell me why, Robin; Vocal duets, trios, quartets. Pianoforte pieces, ete, Thonghts, verses, and songs, 1877. Of the songs composed by Mrs. Barnard, under the name of claribel, only a few survive.

Barnard, Rev. Jonn, divine, pulblished a " Book of Pralms, together with Fifty Tunes to sing them, neatly engraved on copperplates." 1727, "A New version of the Psalms of David, fitted to the Tumes used in the Churches." Boston (L.S.A.), 1752.

Barnard, Rev。John, divine, who lived during the 16 th and 17 th centuries. He was Minor-canon of st. Paul's Cathedral in the time of charles $\mathbf{I}$.

Barnard is famed as having been the first to issue a collection of Cathedral music. His collection of "Cathedral Mnsic" appeared in 16+1, and contains services, anthems, etc., by Tallis, Gibhons, Mundy (WV.), Parsons, Jird, Morley, Tye, Bull, ete. The only perfect copy of this work is contained in the library of Hereford cathedral. Its title is, "l'he First Book of Selected Church Musie, consisting of Servicen and Anthems, such as are now used in the cathedral and collegiate churches of this kingrom; nerer before printed, whereby such books as were leretofore, with much difficulty and charges, transcribed for the use of the (nore, are now, to the saving of mueh fabour and vxpense, published for the general good of all such as shall desire them either for publie or private exercise. Collected ont of divers approved Anthor's, by J. B." London, $16+1$.

Barnby, Sir Joseph, Kt., composer and conductor, born in Fork, Angust 12, 1838. Chorister in York Minster at age of seren; leegan teaching when ten; was an organist at twelve; and music master at a school when fomteen. At the age of sixteen he went to London, and entered the R.A.MI., living with bis brother Robert (q.e.), a vicar-ehoral of Westminster Abber. Soon after his appointment as organist of Nitcham Parish Church, he was called lack to York, where he remained fonr vears. Then he was organist at St. Michael's, (quetnhithe; St. dames the Less, Westminster; and, in 1s63, wasappointed to St. Andrew's, Wolls street. There it was he acruired and exereised the influence that was to work such developments in the Choral Survieen of the Chureh. At the I edication Festival (Nt. Andrew's I ay) of 1866 , his adaptation of Cromond's Mesie solemelle (st. Cecilia) was performer, and the hare introduced. He conducter a performance of Bach's Passion-Music (Nt. Matthew) at Westminster Abber, Mamonday 'Thumblay (April 6) 1871, with lull chorns and orehestra-a nuemorable event in the history of church music in 


\section{BARNBY.}

this country; and, in 1873, he introdneed, at St. Ame's, Soho, where he was then directur of the music, the St. John Passion of the same master. He resigned his position at St. Andrew's in 1871, and that of st. Amne's in 1886. "Mr. Joseph Barnby"s Choir" was formed in 1867, the first rehearsal taking place in the Lower Exeter Hall, February 17, and the first concert given in St. James' Hall, Hay 2:3. From 1869 the performances were given under the title, "The Oratorio Concerts," and great works were revived, notal,k, Handel's "Jephtha" (February 5, 1869); Beethoren's Mass in D (March 9, 1870); and Barli's "Matthew Passion" (April 6, 1870). At the end of 1872 , this choir was amalgamated with that hitherto conducted by $\mathrm{N}$. Golmod; ant, as the Royal Albert Hall Choral Soriety, commmenced giving concerts Felmury i2, 1873. Wagner's "Parsifal" was produced, in concert form, by this Society, Novenuler 10, 18Rt. Bamby conducted the London Musical siociety, 1878-86, and produced Drorik's Stubut Mater, March 10, 1883; he was also cont. ductor, 1886-8, of the R.A.MI. Concerts. In 1875 he was appointed Precentor of Eton College, an office he resigned in 1892, on his clection as Principal of the Guildhall school of Music. For fifteen years, to 1876 , he was musical adviser to the firm of Novello, Ewer, and Co. In November, 188\%, he condncted the ammual performance of the "Mesiah," by the Royal society of Musicians; the perfomance of Dvorak"s "Spectre's Bride" at the Leeds Festival of 1892; conducted the cardiff Festivals, 1892 and 1895; a Halle Concert, Manchester, November 14, 1895 . Wan a Fellow of R.A.M., Nember of the l'hilhammic Society, and, in 1857, was elected Hon. Mermber of Tonic Sol-fa College. In 1892 he received the honour of Knighthood from the Queen. To the grief of the whole musical world, his career, in the midnt of its activi. ties, was suddenly cut short ly his death at London, on Jamnary 28, 1896.

Works.-Rebekah, a Sacred Idyll, produced at the Oratorio Concerts, May 11, and at the Hereford Festival, Angust 23, 1870; 1's. 97, The Lord is King, Leeds Festival, 1883. Stervice in E (Morning, Commmion, and Evening, composed at the age of serenteen); Magnificat and Nume Dimittis in E flat, for roices, orchestra, and organ, for the Festival of the Sons of the C'lergy, St. Paul's Cathedral, May 18, 1881; Services, Preces, Offertory Sentences, etc. Forty-six Anthems, including the Motet, King All Glorious, for soli, six-part chorus, orehestra, and organ. $250 \mathrm{Hrmm}$ Tunes, of which a complete edition is in preparation (1896); Glad Cluristmastide, and other carols; Sweet and low; It was a lorer and his lass (Norwich Fentival, 1884); The haven, and other part-songs. Eton songs (A. C. Ainger).

\section{BARNES}

Songs: How fade the light: My golden ship; When the tide comes in, and ithers. Trius for female voicess. Prieces for organ. Musical editor of The Hymmary (Norello, 11.d.). Music revined for "The Hone and sthool Hrmmal" (Edinburgh, Constable). l'osthmoric puhlications: Anthems, sing to the Lord; O Lamb of God. Part-songs, The Kiss: In laudem Amoris (15!36).

Barnby, Robert, alt, singer, lom in York, 18:1. The brother referred to in the preceding notice. He was alpointed a lay vicar of Westminter Abley abont 1815, and a Crentleman of the (hapel Royal in $1 R+7$, on the death of Eurch Hawkins. These positions he retained motil his death, Jnne 1 , 1875. Another momber of the fanily was Hexry Barspr, bom 1826, who wits for trrenty-eight years a lay clerk of st. Georgè Chapel, Windsor. He was considered one of the finest bassen of his time, his roice being rich in quality, and of rentitialle compass. He sang at the Hereford Festivalin, 1852 and 1855; at the Fimningham Fentival choral Society"s "Messiah" Concert, Iecember 26, 1856 ; in the quartets in "Hlijah," at the Bimingham Festival, 1854; and was well known as an uratorio singer. He died at Slough, April 2, 1s85. SinNer lBarxbr, alto, was elected assintant Ticar Choral of St. Paul's Cathedral, in 1873, a position he still retains.

Barnes, Edwin, organist and teacher of music, lom in the parish of St. Pancras, London, June \&, 1833. Educatedas chorister at King": College, Lundon; studied pf. under Lr. W. Rea, organ and theory unter J. L. Bromnsmith. For many sears professor of music at the London sicicty for teathing the Blind, where he hat done much excellent work. Nember of the Philhatmonic societr. Organist successively of Homey Parish Church; St. George the Martyr, Bhomnshry; and, since 1862 , of Holy Trinty ('hmeln, Paddington. Was assintant organist to the sacred Hamonic soctety, and Conductor of the Dover Choral Society, 1s56-5s. Hlis compusitions include an anthen, songs and pif. piecer.

Barnes, Frederick Edwin Lucy, organint and comporer, som of the alowe', was bom in London, in 185s. Ile sturlied mnder Hemore in the (hapel Ruyal, and at R.A.M. from 1872. Organist silceesisely of $\mathrm{All}$ Saints', Norfolk Siquare, London, 1872; St. Margaret's, Princens square, Liverpol, 1876 ; Nontreal Cathedral, 1s78-9): Trinity (hureh, New York (assintant). Ite was ionductor" of the Nontreal l'hilharmonic siretety, and was married to Mins Leonorat Braham in 1878. He died at Montreal, september 27, 1 ritiol.

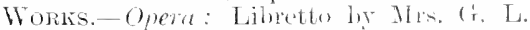
Craik (ms.) operetta for Greman lined com-

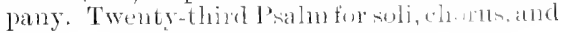




\section{BARNLTT.}

olchestra. Songs: But you know aheady; May song; Nither; Path through the snow; Sun and sipring. Varions pieces for organ and Pianoforte.

Barnett, Alice, see mader Poole, Nadame.

Barrett, Emma, pianist, sister of John Francis barnett, and daughter of Iosepli Alfred liamett, professor of singing, was born in London. Studied entirely under her brother, and made loe debut at the Crystal Palace Saturday Concerts, Feloruary 28, 1874, playing Beethoven's Pianoforte Concerto in (x. December lst of the same vear she plaved J. F. Barnett's Pianoforte Concerto in Is minor at the Royal Ahert Hall Concerts. She gave her tirst recital at St. George's Hall, June 13, 187t, and lere first appearance at the Monday Popular Concerts, St. James's Hall, took place January 28,1882 . Since that time she has given many pianoforte recitals in London and the provinces, introducing the Somata in E, the series of pieces, "Home Scenes," and other of her hrother"s works to public notice. Her compositions are chiefly for the pianoforte, but include a few songs. Only the Gavote in $\mathrm{A}$ is as yet pulished.

Barnett, John, composer, was born at Bedford, July 15, 1802, som of Bernhard Beer, a Prusian watchmaker, who settled in England and changed his name to Bamett. He was articled to s. J. Amold, proprietor of the Lycenm Theatre, and studied nuder C. E. Horn, Price, and Ries. Maried Miss Lindley, daughter of the violoncello plaver, 1837. Studied Togler's system of harmony at Frankfort, under Schnyder yon Wartensee, and returned to London in 1838. He opened st. James's Theatre for Winglish opera in $18: 39$. Retired to Choltenham, where he established himself as a rocal teacher, in 1841. Resided in Leipzis and in Italy for a short time, superintending the education of his children. Died near ('heltenhan, April 17, 1890.

Woris. Operettas and Operas: Before Breakfast, Musical Farce, witten by Richard Peake, Lycemm, 1828; Mnsic in IIiss Mitford's Rienzi, Drury Lane, 1828; Monsieur Mallet, operetta, written hy Thomas Noncrieff, Adelphi Theatre, 1825; Two Seconds, operetta, wittun by R. Peake, Lycemn, 1829; Carnival of Naples, opera, Covent Gatden, 1830 ; Rolert the I) vent (rardun, 18:30; The Picturengue, operetta, written by Thomas Haynes bayley Lycemm, 1830; Baron Trenck, speretta, witten by T. Morton, sen., dentroved in the fire at Covent Garden 'Theatre, 1830; Comntry Quarters, musical farce, Cosent frarden, 18:31; Connt of Gueen's Berch, operetta, UIfmpic Theatre (Vestris), 18:32; P'aphian Bower operetta, written by Planché and C. Dance, Olymuic Theatre, December, 1832; Harlequin Pat, operetta, Covent Garden, 1532; Married

\section{BARNETT.}

Lovers, musical farce, Lycenm, 1832; Promotion, musical farce, Lyceum, 18:33; Pet of the Petticoats, operetta, Sadler's Wells, August, 1832; Win Her and Wear Her, opera, Drury Lane, Decemlser, 18:39; Soldier's Vidow, mnsical drana, written by F. Fitzball, English Opera Company, Adelphi, 1833; Two songs and a march in Nell Gwyme, Covent Garden, 1833; Song in Planché's Charles the Twelfth, Drury Lane, 1833; Deuce is in her, operetta, 1833; Olympic lievets, 1833; Blanche of Jersey, 18:34; Momtain Sylph, opera, written by Thackwray, Lveeum, Alugust 25, 1834: Fair Rosamond, opera. written by C. Z. Bannett, Drury Lane, March 30, 1837 ; Fatinelli, opera, witten by C. K. Barnett, Drury Lane, February 8, 1837 ; Kathleen opera (never produced), composed in 1840; Marie, opera, composed in $18+5$ (unfinished). Oratorios: Omnipresence of the Deity, published in 1829 (never performed); Daniel, unfinished. composed in 1841. A Mass. A Symphony, unfinished, composed in 1840 . Two string quartebs, IS.. composed in 1840. Spare Moments, three slietches for concertina $[1859]$. Part-songs. Twelve Part-songs, mostly published in 1870; Chamber Madrigals, London, 1861: It is summer it is summer; Bend down from thy chariot; Haste not; Farewell to the Flowers; Tic-tac of the mill; Deal peaceful valley; Evening drun ; Merrily, merrily sounds the horn; In the merry greenwood; Wrong not, sweet mistress (madrigal); Chamois Hunter; O Lord, our governor. Duets. Set of six voeal duets $[1845]$; A smile, a tear ; A spring song; Come where the flowers are blooming; Dear maid, my heart is thine; Lown in the dell; The Gleaner"s Bell; Good night; The Hungarian to his lnide: I'll follow thee; Noonlight, music, love, and flowers: My gondola glides: No more, no more: Ob! give to me; Oh! 'tis sweet to meet again; Sinrins; The twilight hour ; There's nut a breeze: When at night; Where are the mountains; Wilt thou tempt the wave? Songs: Ammisentent for leisure bours-seven songs and one duet [1835'; Songs of the Minstrels [1830]. Dreams of a Persian maiden 1842; Twelve Russian Melodies, with words ly Harry stoe van Dyk 1822]; Songs of the Slavonians, containing Bolemian popular airs. with words by John liowring, London, 1824; Twenty-four songs in imitation of the music of various nations, with words ly Van Dỵ, Leon Lee, and Nayhew, 182t; Twelve Songs from Fairy Land, written by Thomas Haynes Bayley, 1827; Lyrie Illustrations of the Modern l'oets, 1834, reprinted in 1877; Adieu to thee fair Rhine; Asts me no more; A day-dream; Banks of Broomsgrove; Break, lreak, break; Bride's farewell; Chase the falling tear; Clansman's ])ride; Come to me, thon gentle child; Dear Napoli ; Days of Chivalry ; Days 


\section{BARNETT.}

that ne'er retum; Flower of my life; Fill up the wine cup ; Flowers of summer; $G$, thou art free; Highlander's bride; Her heart is nine; Highland soldier : Highland minstrel boy; Hark, the fairy bells; Hope for the best ; Here's a health to merry England; The Holly ; Hark, hark to the sound; I have been to the woods; Is the reign of fancy oser.? Knight of the golden erest; Light guitar; Light of heart anl I; Lord, 1 believe; List to my wild guitar; My home beside the Quadalquiver; Minstrel's lament; Memalid's song ; Maid of Athens ; My native land, good night; Maider of sicily; Now the lamp of day has Hed; Normandy maid; Rock me to sleep; Rose of Lncene, 1823; Rise, gentle moon; Swrss shepherd; sing, nightmgale, sing; Salor boy's song; Spirit of love; There sits a lovely maid; The opal ring; The ship; Vesper hour; Up to the Forest; Village bells; Foung moss ruse; Year's last hours. Systems and Singing Master's, a Comment wpon the Wilhem srstem, and remarkis upon Mr. J. Hullali's Mannal, London, 1842, also, 1877. School for the Toice, a theoretical and practieal treatise, London [1845]; since reprinted several times.

Bamett' Monntain sylph was the first English Opera cast in the dranatic form followed by Weler and other manters. It was very popular on its original production in 1834 , and had a run of orer 100 uights. Of the immense number of songs and otlier rocal pieces pullished loy Bamett, anounting in all to nearly 2000 items, only a few are known to the prenent generation of musicians. His eldest daughter married Mr. Rohert E. Franeillon, the well-known novelint.

Barnett, John Francis, pianist and composer, born in London, Oetoler 16, 1835: son of Juseph Alfred Barnett. His first pianoforte teaclier was him mother. In 1849 lie was placed under Ir. Wyde, and in 1850 le won a King's secholarwhip at the R.A.11., ant was re-elected in 1852. He appeared for the first time in public at the New Phillamonic Coneert, June 29, 1853, playing the solo part in Mendelssoln's I'ianofirte Concerto in I) minor. In 1856 he went to Leinzig, and studied at the Conservatorimu, under Hantmann, Rietz, Plaids, and Nosclucles. He played at the Gewandhans concertin, Marcls 22, 1860, the I minor eoncerto of Hendelswoln. At lis reaple arance in London, New Plnilharmonic, April 16, 1860 , he was heard in licethoven's Concerto in E flat; and at the I'hilharmonic Concert, Junte 10, 1861, in that eomposer's Concerto in ( minor. He was afterwards associated with In. Wyde as a teacher of the pianoforte in the London Academy of Music. In 1859, was alppointed a Professor R.A.N., and is F.R.A.II. and Nember of the Philharmonic society. Was

\section{BARNETT.}

for a time condurtor of the Berkshire Musical Society ; and condueted a l'hilliammic concert, April 23,1 , lst. First came into notice as a compones by a somphony produced ly the Musical ruciety of London, 1 stit; and receiving a commission tor the Bimningham Festival of 1867 , he soon attained a pomnent position anmog the younger linglisli composers.

Moliss.-Cantatas: The Ancjent Nariner (Bimingham Festival, 1867); I'aradise and the Peri (the same, 1870); The Raising of Lazarus (Oratorio, New Philharnonic, June 18, 1873: Hereford Festival, 1876); The Good Shepherd (Brighton Festival, 1st6); The Building of the ship (Leted. Festival, 18s0); Ode, The trimmph of labom (C'rrstal P'alace, August, 18-8): 'The wishing bell, Cantata for fentale voices (Norwich Festival, 1693). Partsong's ; Songs, The Harp of Life; The Golden Gate, ete. Orchestral: Symphomy in A minor

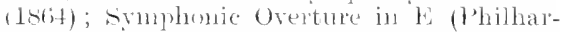
monic, ls(sis); Overture, A Winter's tale (British Grehentral sucicty, February 6, 1873); Suitu, The lay of the last minstre] [Liverpool Festival, 1nti): Smmphone Poem, The Hallent Fentival (Norwich Fentival, 1,sil; and revised as a Yastoral suite. J'hilharmonic, Nay 31, ists); Concerto in D minor, pif. and orehentra; The Ehbing tide; Lieheslined, and wher maller works for orchestra. Chamber Mnsie: quintet in (i minse ; quartet in I) minor', strings: 'Trio in ('minor, fif. and strings: Somata in ( $\mathrm{m}$ minor, Op. 41 , l,f. and flute; in lis miner, pf, and rolin. l'ianoforte solo: sonata in lininor, Op. 45; Thure Impromptus; Honne scenes, nine pieces ; seren characterintic studies; and a large number of shorter pieces, elegant in style and widely popular. Oftertoire in $G$ and other organ pieces.

Barnett, J. Maughan, pianist and ozganist. For sone years resictent at Tunbridge Wrells, where he liedd several organ appeintments, and anmally gave concerts. Thelicate health cansed him, in 1889. to leave lingland for Now Zealand, where he soon entalylinhed a reputations ats a brilliant pianint and organist, giving perfornandetes alou in Tasmania. He holds the office of conductur of the Wellington Musical societr, N.Z. He has written some piecer for pianuforte.

Barnett, Joseph Alfred, tenor rocalint and teacher of singing, Irother of John bialnett, was born in Lunion. Early in life he was articled to Mr. Reeve of the Olympic Theatre, nnd alplealed as a juvenile vocalist. Afterwards he sang ats a tenor vocalist, in Londem and the provinces, but gradnally he retired fron pullic life, and derioted himinelt to voice training. He married a datughter of William Iludwo, the artint, and had in large family, anumb Whon naty be naned Joln Francis and Enma, who alle separately no- 


\section{BARNETT.}

tices. He was for many years mincipal tenor at the Church of the Spanish Embassy, and cloimaster of Warwick sitreet Church, and St. Aloysius, Somel's Town, 1.ondon. Professon of Finging at the London Academy of Music, and teacher in many large schoots. Composer of "Domini halvmin," quartet and chorus: "Ave Maria," quartet; " Exaudi Dens," tenor solo: many duets, songs, and other vocal music.

Barnett, Neville George, organist and musical critic, born in London, March 3, 1854. Pupil of li. Limpus, H. J. Hopkins, and F. H. Turpin. F.R.U.U., 187?. Appointed oryanist and chommaster st. Thilip's Arlingtom sifnare, in 1872. Sulserfuently, he went to Now Zealand, where he held reveral appointments, hut lie finally settled in Sydney, New Sontl Wales. He was arganist of St. Marys Catledral (1ioman Catholie); Muxical Directol at the Jewish Sirnagogute, and instructor at the Blind Fnstitution. For lolind students low invented a type-writer, cmabling them to write according to the Bralile system. Whem he went to Sydney he was appointed musical critic of the Sydizey Horning Herald, then of the Eenung News, and lastly, of the sydne! llatly Thlegranth. He composed an Opera, "Ponnare," on a Tahitan legend, which was performed at Auclinud; a Mass, organ pieces, part-songs, ete. He also wrote some treatises on music, his last work, "The Art Theory of Farmony (dedicated to Sir George Grove), is still in MS. He died at Picton, N.s.II., Septemlex:26, 1895.

Barnett, Robert, pianist and composer, was born at Macelesfield, in 1818. Hestuctied at the K.A.M., and in 1840 was appointed a professor of the pf. there. 1n $15+2$ lie appeared as a pianist at the Quartet Concerts, Hanover Square liooms, and in 1850 at the Society of British Musicians. He was elected an Associate of the Philharmonic Society in 1843. Died at Slongh, Windsor, November, 1875.

Woklis.-Pianists' Companion, Jondon, 1857 (issued in parts). Sonatas, rondos, and airs for pianoforte, 1842 (selected). Useful scale practice for the pianoforte, 1st3. Rondo grazioso and rondoletto scherzando for pf. Edited P'ianoforte works by Mlozart, Pleyel, and Dussek.

11 is eldest son Domenico, born in London, Angust 25, 18t6. Studied at Leipzig Conservatorium under Moscheles, E. F. Piichter, Reinecke, and otliers. Principal professor of pianoforte at the Laclies' College, Cheltenhan. Has composed some music for pf., but nothing is published hitherto.

Barnhill, James, Scottisly author, who graduated MI.A., at Glasgow University. He published "The Statics of Falmony, with an appendix on anticipations, suspensions, and transitions, illustrated by examples from the

\section{BARRETT.}

great masters," London, 1865. Reprinted from the choir. He published varjous other works.

Barr, James, musician, was born at Tarbolton, Ayr, in 17s1. Employed by J. Stephen, music-publisher, Wilson Street, Glasgow, 1812, and was a music teacher in Glasgow. He resided in Canada as farmer, 1832-1855. The "blithe Jamie Barr, frae St. Burchan's toun," of Tammahill. Composer of a few melodies, of which "Thou bonnie wood o' Craigielea (words by 'Tannahill) is well known. He died at Govan, February 24, J $\$ 60$, and is buried at Kilbarchan.

Barr, Samuel, composer and writer, was bom at Glasgow, in 1sot. Self-taught in music. He was a teacher in Glasgow, and precentor in Ir. Wardlaw's (Independent) Church. Professor of Musie in the Mechanies? Institute, Cilasgow. Died, Glasgow, May 16, 1866 .

WorTs. - 1'he Theory and Practice of Halmony and Composition, London, 1861; Art of Singing at sight simplified, Glasgow, is 47 and 1859; Anthems; Psalms. Songs: Hurrals! for the llighlands; The warniug; The land for me; The bridal gem; Naebody kens ye. Part-songs; Miscellaneous writings.

Barr was well known in Glasgow and the West of Scotland as a teacher of merit, and is renerally supposed to have introduced class music teaching into the West of Seotland.

Barraclough, Isaac, musician, of Sheffield. Published "Sacred music, consisting of Psalm and Hymn tumes . . . for four voices, witl an accompaniment for the organ Or pianoforte," Loudon $[1836]$. " Sacred music, consisting of original psalm and hymn tunes. . ", Shefficld $[18 \pm 7 \mid$.

Barratt, John, organist, born near Huddersfield, January $11,18+8$. Received his musical training at York Miuster. Graduated Mus. B., Oxford, 1877. Organist of Paisley Abbey, the Clark Town Hall, and Conductor of Paisley Select Choir. Has published anthems, hymn-tunes, ete. His son, WiLLian ACGLSTUS BARRATT, born 1874, was a scholar of the R.C.M. He first came into notice by his setting of "Sir Patrick spens," for baritone solo, chorus, and orchestra, produced at Edinhmrgh, December 1894. A cautata, "The Death of Cuthulliu," was brought out in that city, Decenber 1895. Ha has also published an Album of ten songs (Paterson), elc.

Barrett. The name of a family honourably distinguished in church music in Bristol. The fatlier, SLATER BARRETT, was in the choir of Bristol Cathedral for nearly sixty years. JoHn BARRETT, the elder som, born at Bristol, 1812, was a chorister in the Catledral, and for many years organist of St. Augustine's Church, and also at the Blind Asylum, the choir of which he raised to a high standard of excellence. He was one of the founders 


\section{BARRETT.}

of the Bristol Madrigal Society (11837), and for some time, until his last illuess, was a Vice-President. He died June 24, 18s0. II is brother, George Barrett, was born at Bristol, March 16, 1814. Chorister in the Cathedral, and in Jautuary, 1839, appointed organist of Holy Trinity Church, Hotwells, an office he held for fifty-two years. Was also a foumder of the Ma irigal Society, and the last surviving original member, and a Vice-President from 1880. He died Narch 5, 1s91, a tablet in Foly Trinity (hurch commemorating his long and faithful service as organist.

Barrett, John, organist and composer, boru in 1674. Pupil of 1)r. Blow. Music teacher at Christ's Hospital $\left[1710^{\circ}\right.$. Organist at Church of St. Mary at Hill, 17iv. He died at London, $1735\lceil 1738$

Wonrs. - Music for Love's Last Slift, 1696; Tumbridge Wells, 1703; Mary, Que 11 of Scols, 1703; Custom of the Manor $1715^{-}$; Wife of Bath. Songs: Celiuda; Cruel charmer, do not grieve me; Fine lady's airs; Gloriana is engaging fair; Haply fail; In the pleasant month of May; Liberia's all my thought; Love is now become a trade; Pilgrim; Three goddessses, etc.

Barrett, John, organist, born at Bristol, March 31, 183\%. Chorister at the C'athedral, 1844 , and in 1853 articled for five years to $\mathrm{J}$. D. Corfe, Cathedral Organist. After that time he was assistant organist at the Cathedral for two years, while holding the post of organist and choirmaster successively at All Saints', Bristol, and at Bedminster l'arish Church. In 1878 he resigned the latter appointment, having been elected to Christ Church, Chifton, a post he still retains. He has been, since 1883, conductor of the Bristol Church Choral Union, which holds its annual festival in the Cathedral. Ile has also formed a special choir, which has produced Sclubert's Mass in E flat, and other important works for the first time in Bristol. A ztalous worker for the Incorporated Society of Musicians, as Hon. Sec. for the Western Section, he has made it one of the most flowrishing of any. It was the first to form a special library of music, which out of compliment to hiur, was named the Barrett Library.

Barrett, William Alexander, writer, rocalist, and organist, born at IIackney, London, October 15, 1836, son of an architect. Chorister at St. Paul's Cathedral, 1846-49, and pupil of George Cooper, W. Bayley tone of the lay-vicars), and John Goss, for composition. First sang in public at a concert given by J. B. Stansell, at St. Philip's Schools, Stepney, November, 18t7. Wheu his voice changed he took to drawing on wood, and in 1854. illustrated Holt's "C'hronicle of the Crimean War," and an edition of shakespeare. From 1855 to '57 he was ergaged in
BARRETT.

jourualistic work on the Horming Chrunicle, book reviewing; and translatir.g stories and poems for different publinlers. Appointed principal alto at St. Andrew's, Wells street, in 1858; and in 1861, lay-vicar, Magdalen College, Oxford. He was also organist at St. John's, Cowley, Oxford, 1s63-(iti. Sul-editor and illustrator of the Pmy Post, Oxford, 1861-67. Graduated Mus. B., Oxford, 1871. Appointed assistant vicar choral, st. Paul's Uathedral, 1867; vicar choral, 1876. I Ie wrote his first musical criticisms while at Oxford, which appeared in the Oxford Times, 186t-66. On his return to London he was offered the pont of nusical critic on the Monning Post (1869), which he retained ill his deatl. He also wrote for the 11 hitchall liferew and the Globe (1874-75). Was elitor of the Honthly Musical Recmil (1857); the Urchestra (1851); and the Musical Times from 18rit. Other appointments were, Assistant Examiner in Music with Tr. John Hullah, 1873; Examiner to the Society of Arts, and to the Comncil of Military Education, 1803. Mr. Barrett was elected Fellow of the College of Organists, 1871; and Fellow of the Royal Society of Literature; Lecturer to the City of London College aud London Institution; Mus. D., Trinity College, Toronto; and, in 1sis, appointed by the Prince of Whales Grand Organist of the United Grand Lodge of Freemasons, in succession to Sir Arthur Sullivan. It was at Walworth, in 1856 , that, with a discourse on the "IIistory of the Gipsies," he began his career as a lecturel, his extensive knowledge enabling him to deal with a great variety of topics. Some of these lectures have been published. In the midst of an active life he was attacked by apoplexy, and to the great loss of the world of music, died Octuber 17, 1891.

Worrs. - Oratorio, Christ before Pilate (MS.) ; Anthems; Madrigals: On a mossy bank (eight voices. Bristol Madrigal Society, 1839). Cynthia. Literary: Flowers aud festivals, or directions for the floral decorations of churches, 18fs; The Chorister's Guide (187.2?); Dictionary of musical terms (with Dr. Stainer), 1875 ; Etymous of musical terms (1876); English glee and madrigal writers, London, 1877; Introduction to form and in. strumentation for begimmers in composition, 1879; Fnglish church composer's ("Great Musicians" series), London, Sarpson Low, 1852 ; Balfe, his life and work, London, Remington, 1882; Editor of English folk sougs; Standard English songs (Novello), etc.

Barrett, William Lewis, flutist, born in London, Jannary 4, 1817. I lis father was a violinist, and his mother came off a wellknown musical family in Merionethshire. Taken to Wales when an infant, he spent his early years there, and when seven years of age commenced to play the violiu, which he 


\section{BARRINGTON.}

afterwards changed for the flute. Destined for a eommercial career, he only took up music as a profession after the deatl of his father. Studied the flute under R. S. Roekstrn, and harmony nuder W. Castell. Mis firs 1 work was deputising for Mr. John Radcliff, and he was soon engaged by Costa as second flute and piccolo at Iler Majesty's Opera, where afterwards, for many years, he was principal flute. Similar appointments were also held at the Royal Italian Opera (five year's), the Carl Rosa I tondon season (seven years); and he has been engaged for Birmingham, Leeds, and Three Choirs Festivals, the chief orehestral coveerts, and is now principal flute of the Philharmonic Society, and Professor at the R.C.M. He toured with Madame Albani in Canada and the United States, and has also appeared. with suceess, on the eontinent. He lias published Flute Studies; solo and important passages; Romance and Tarertella, etc.

Barrington, Hon. Daines, English writer on Law, Music, and Natural History, was born at London, 1727. Judge on Welsh Circuit, 1757. Seeond Tustice at Chester. Retired from the Law and resided in the Temple. He died March 11, 1800 .

Barrington wrote a standard work on the Statutes, a work on the possibility of reaching the North Pole, and several papors dealing with Croteh, the Wesleys, Mornington, and Mozart. See his "Miseellanies," 1781, and the Philosophical Transtetions, 1780. Also anthor of "Experiments and Observations on the Singing of Birds," London, 1773.

Barrington, Rutland, Grolge Rrtuant FLeE', actur and vocalint. First appeared on the stage at the Olympie Theatre; then toned for some years witli Howart Paul. In 1877, he was engaged for the Opera Comique Company, and matic lis dibut as the Vicas, in "The Sorcerer," on its production, November 17, 1877 ; and las sinee taken part in most of the Gilbert and Sullivan Operas, his Pooh Baln, in the "Nikado," leing one of his most remarkalile assumptions. In 1888, he turned theatrieal manager, opening the St. Tames's Theatre in () toler; but the enterprise did not prosper, and he gave it up the January following. Sinee then he has re-appeared at the Saroy Theatre, lis latest character being Ludwig in "The (rrand Inuke" (March, 1896).

Barrow, J., musician of 18 th ecutury. Pullished "Prook of Psalmodiy . . .," 1730 and 1751. "Psalm-singer's choice eompanion, or an imitation of hearen on earth, the beanty of Holiness, being a compleat eomposition of Cliurel musick, containing variety of tumes for all the common metres of the Psalms with a new and compleat introduction to the skill of musick. To which is adcted an alphabetical dictionary. . ." N.11.

\section{BARRY.}

Barrow, Thomas, composer and alto singer of the latter half of the 18 th eentury. He was a choirister and gentleman of the Chapel Royal, and sang in Handel's Oratorios. He died on August 13, 1789. Ile eomposed some Church musie, eliants, etc.

Barry, Charles Ainslie, composer, organist and writer, born in London, June 10, 1830, Educated at Rugby, and Trinity College, Cambridge. While at Cambridge he studied music with Professor T. A. Wa'misley. Graduated B.A, and H.A. By his father's wish he studied for the ministry, and passed the voluntary Theologieal Fxamination at Cambridge; hut musie becane his ultimate choice. At the Cologne Conservatorium he studied under F. Weber, E. Frank, and F. Hiller ; at Leipzig, with Moscheles and E. F. Richter (1856-7); and during his residence at Dresden received valuable hints from Carl Reissiger. Returned to London, 1858, and held an appointment as organist and choirmaster at the Forest School, Leytonstone IIill, 1860) ; but a year earlier began to devote his attention ehiefly to musieal and literary composition. Under the initials "C.A.B." he bas contriluted many artieles to the Guardiu, Monthly Musical Record, Musical Irorkd, Athenrum, and The Meister ; and to the Analytieal programme hooks of the Crystal Palace, Philharmonic, Bache, Richter, and Bimingham Festival Coneerts, ete. Ile was secretary to the Liszt Scholarship Fund, 1886, and is widely known as a enltured musician with sympathetic leanings to the advanced modern school of composition.

Wonks. - ympliony, for orehestra; Two Overtures; March (Festival March, played at the Crystal Palace Concerts, 1862); String Quartet; Cantatas, sacred and seeular. all in Mis. Choral Ilymms for four voices; The story of the Resurrection, a cycle of Hymus; The Christmas story, ditto; Tunes in Hymus Ancient and Modem and the New Mitre Hymnal, ete. Six Songs with English and German words; Four Songs (C. Kirgsley); Two Songs (Tennyson); Elizabeth's Songs from The Saint's 'Tragedy (Kingsley); and many others. O, holy night, five-part song. Thene with variations, pf. duet; A Birthday Marclı; Barcarolle; Tarantella; Nennetto grazioso, and otler pf. pieces. Transeriptions, Overture, Beatrice and Benedict, Berlioz, pf. duet; Andante, from Tschaïkowsky's Quartet in D, pf. solo; Pf. score of Te Deum, Berlioz. Editor of The Child's Book of Praise (Masters), etc.

Barry, William Vipond, pianist, composer, and writer, bom at Bandon. March, 1827. Appeared in Belfast as pianist, 1846, and founded the Belfast Classieal Harmonist Society. He resided for a time in the Potteries, England. He studied under Liszt, 


\section{BARTHELEMION.}

and was M.A. and Ph. D. of Göttingen University honoris causi. Organist of the Cathedral, Port of Spain, Trinadad, and died there March 13, 1872. He composed music for the pianoforte, and wrote a work entitled "Dissertation on the Emotional Nature of Musical Art, and its Media of Operation," London, 1863. His son, William H. Barry, born at Belfast, April, 1858, is a composer and concert giver in Dublin.

Barthelemon, Mrs., see Young, Mary.

Bartholomew, Ann Sheppard, born Mounsey, composer, organist and pianist, born in London, April 17, 1811. Became a pupil of Logier in 1817, and came under the notice of Spohr when he visited Logier's institution in 1820 , her harmonising of a melody being printed in his Antobiography (English ed., Vol. II., p. 100). She afterwards studied under Samuel Wesley and Thomas Attwood, and in 1828 was appointed organist at Clapton. The next year she went to St. Michael's, Wood Street, and in 1837 to St. Vedast's, Foster Lane, a post she held for nearly fifty years. Associate of the Phithammonic Society, 1834; Nember Roral Society of Musicians, 1839. In 1843 she began giving series of Classical Sacred Concerts at Croshy Hall, which were continued until 1848. The first concert took place November 22, 1843, and at that given Jamuary 8, 18t5, Mendelssohn's "Hear my Prayer" (composed for these concerts) was performed for the first time, Miss Rainforth singing the solo part. Several of Mendelssohn's smaller pieces were first introduced at these concerts. Miss Momney was married to Mr. W. Bartholomew, April 28, 1853. Her artistic career was long and distinguished. She was a fine executant, particularly upon the organ. The earliest of her known compositions, a ballad, "Mary, meet me there," was published in 1832; and she issued a set of hymm tunes as late as 1883 . She was the possessor of the original MS. of "Hear my Prayer," which she presented to the South Kensington Museum in 1871; and of the pianoforte score of "Elijah." The last few years of her life she passed in retirement, and died in London, June 24, 1891.

Works.-Oratorio, The Nativity, produced at St. Martin's Hall (Hullah Concerts) January 17, 1855; Sacred Cantata, Supplication and Thanksgiving, dedicated to H.R.H. the Princess of Wales, 186t; Sacred Harmony, Hymns, \&c.; Hymns of Prayer and Praise, (both edited and composed in conjunction with her sister, Elizabeth Mounsey); Thirtyfour original tunes set to favourite hymus (1883), and other sacred pieces. Six songs, composed for the Royal Society of Female Musicians (1845); Six songs of remembrance; many detached songs, \&c. Six duets in canon (1836) ; Six four-part songs, Op. 37; A wreath
BARTON.

for Christmas, \&c. Prelude and gigue, and other pieces for pianoforte. Organ music, \&e. Notes, and umpublished letters of Mendelssolnn, contributed to Lady Wallace's translation of Elise Polko's "Peminiscences of Mendelssohn."

Bartholomew, William, scientist, writer, and violinist, was born in London in 1793. Married to Miss Ann s. Mounsey, April 28 , 1853. Chietly known as the adapter of the librettos of IIendelssohn's works. Died in London, Angast 18, 1867.

Works.-Toy songs for children, written and adapted to pleasing melodies . . London [1849]. English version of the words of Mendelssohn's Antigone, Athalie, Adipus, Lauda Sion, Walpurgisnacht, Loreley, Elijah, Christus; Spohr's Jessonda; Costa's Eli and Naaman; Bartholomew's The Nativity, etc.

Mr. Bartbolomew is best known for his connection with Mendelssohn, with whom his intercourse was friendly and intimate. Mr. Bartholomew wrote many hymms of considerable merit, in addition to the works named above.

Bartleman, James, bass rocalist, was born at Westminster, on September 19, 1769. He studied under Dr. B. Cooke. Bass chorister at the Ancient Music Concerts, 1788-91. Principal bass at the Tocal Concerts, 1791, and at the Concert of Ancient Music, 1795. He died in London, April 15, 1821. This vocalist revived, and by his magnificent performance, created an interest in the music of Henry Purcell which lived for many years.

Bartlett, John, composer, born in latter half of the 16th century. He composed a "Booke of Ayres, with a Triplicitie of Musicke, whereof the first part is for the lute or orpharion, and the viole de Gamba, and four parts to sing; the second part is for two trebles to sing to the lute and viole; the third part is for the lute and one voyce, and the viole de Gamba," London, 1606. Bartlett was a Bachelor of Music, Oxford, in 1610, but his biography is mknown.

Bartolozzi, Josephine, see Anderson, Josephine.

Bartolozzi, Lucia E., see Vestris, LuCia E.

Barton, William, musician, was born about 1598. He was vicar of Mayfield, Staffordshire, and afterwards vicar of St. Martin's, Leicester. He died at Leicester, May, 1678, aged s0. He published the "Book of Psalms in metre, close and proper to the Hebrew, smoth and pleasant for the metre; plain and easie for the tune, with musicall notes, arguments, ammotations, and index. Fitted for the ready use and understanding of all good Christians . . ." London, 1644, 2nd edition, 1645 ; also $1646,1651,1654,1682,1692$, Dublin, 1706. etc. 


\section{BASSANTIN.}

Bassantin, James, astronomer and mathematician, was born in Berwickshire in the reign of James IV. of Scotland. He studied at Glasgow and Paris, and passed his life in scientific pursuits on his estate of Bassendean. He died in 1568. His works are "Astronomia Jacobi Bassantini Scoti, opus absolntissimum . . . " Geneva, 1599; several minor works on mathematics, and "Musica secundum Platonem," published about 1560 . It was issned in French and Latin, lut is of no practical value, being simply an abstract-work on music on the principles of the Platonists.

Bate, Mrs. J. D., musician. Compiler of "The Nortl India Tune-Book, containing Bhajans and Ghazals, with native tumes." London, 1886.

Bates, Frank, organist and composer, born at March, Cambridge, in 1856. Nusical training private. After acting for a short time as assistant organist at the Parish Church, Leamington, he was appointed, in 1874, to St. Baldred's, North Berwick. While there, he graduated Mns. Bac., Dublin, 1880; his Doctor's Degree being conferred in July, 1884. He was organist at st. John's, Edinburgh, from 1882 to 1885 , at the end of which time he received the appointment of organist of Norwich Cathedral. In 1888 he instituted Iusical Services for the people, with special choir, and has been actively engaged as teacher of music in Norwich, where he resides.

His compositions include an Oratorio, Samnel (Dublin, 188t); a setting of Ps. 67, both in MS. He has published a Moming and Evening Service in B flat, an Evening Service in $\mathrm{G}$; God is our hope; I will sing; Hear my Prayer, and other anthems.

Bates, George, organist and composer, was born on July 6, 1802. In 1839 he became organist of Ripon Cathedral, a post he retained till his death at Ripon, on January 24, 1881. He composed "Sacred Music . . . in full score for voices with an accompaniment for the organ or pianoforte." London, [1857]. Hymns, etc.

Bates, Joah, musician, and one of the founders of the Handel Commemoration, was born at Halifax in March, 1749. Instructed in music by Hartley, organist at Rochdale; and R. Wainwright, organist, of Manchester. He resided for a time at Eton and Cambridge, and became private secretary to the Earl of Sandwich. In 1767 he graduated M.A. at Cambridge, and in 1776 he was appointed Commissioner of the Victualling Office. He established the Concert of Ancient Music, 1776, and acted as conductor till 1793. Founded Handel Commemoration (with Sir W. W. Wynn and Viscount Fitzwilliam), 1783. He died in London, Jume S, 1799.

The "Handei Commemoration" with which Bates is chiefly identified was, in its time, a

\section{BATES.}

much talked of enterprise. No such gather ing of a large body of musicians had ever before taken place, and the extensive arrangements undertaken in connection with it caused sufficient stir to assure its success. The vocalists who held the principle parts on the occasion of the first public performance wereMiss Cantelo, Miss Abrams, Mdlle Mara, Miss Harwood, Signors Bartolini and Tasca; and Messrs. Harrison, Dyne, Champness, Bellamy, Corfe, Norris, Knyvett, Clerk, Reinhold, and Mattlieson. Bates conducted, and the festival took enormously. The first performance was in Westminster Abbey, on May 26, 1784. Second and third performances were given on May 27 and 29. The programme included "The Messiah," The Dettingen Te Deum, a Coronation Anthem, and miscellaneons selections from Handel's works.

As regards Bates it can be said that he was a famous conductor, and in every respect a musician of great knowledge and administrative ability. He did not compose anything so far as we can learn, but appears to be widely known among musicians of every grade during his lifetime. He is somewhat roughly handled loy the Scotch poet, A. Macdonald, in "MIonitory Madrigals to Musical Amateurs," Nos. 3 and 4 , contained in his Miscellaneous Works, 1791. He was married to Sarah Harrop, a soprano vocalist, who is noticed under her own name.

Bates, John W., compiler of "The Sacred Lyre, containing original psalm and hymn tunes..." London [1841].

Bates, T. C., author of a "Complete Preceptor for the flageolet," London [1840]; and "Complete Preceptor for the violin," London [1845].

Bates, William, composer of the 18th century, who flourished between 1720 and 1790 . $\mathrm{He}$ was connected with the Marylebone and Vauxhall Gardens, for which he composed much rocal music. In 1760 he acted as singing master to Ann Cateley, the rocalist, and in 1763 he was prosecuted audfined for trying to dispose of or sell the person of his pupil for immoral purposes to Sir Francis Blake Delavel. He died, probably in London, about 1790.

Wonks.-Operas and Musical DramasFlora, or Hob in the well; Pharmaces, an English opera altered from the Italian; The Theatrical candidates, a prelude [1788]; The Ladies frolick (with T. A. Arne), 1770. SongsCollection of songs sung at Vauxhall, London, 1771, also 1776; Songs sung at the Grotto Gardens, 1771; The buck's motto; The butterfly; Ye famed and witty one, etc. Various glees and catches. Six sonatas for two violins, with a thorough bass for the harpsichord or violoncello, London [1750]. Eigh. teen duettinos for two guitars, two French horns or two clarinetts, London [1780]. 


\section{BATESON.}

Bateson, Thomas, composer and organist, was born in the latter half of the the 16th century. Organist of Chester Cathedral, 1599. Resided in Ireland for many years, from 1608 . Organist and vicar choral of Christ Church Cathedral, Dublin, 1608. Mus. Bac., Dublin. (The first on whom the degree was conferred by the University). The date of his death is unknown.

Works.-First set of madrigals, 1604 (reprinted by the Musical Antiquarian Society in 1846); Second set of madrigals, 1618; Two madrigals in the Trimmphs of Oriana.

Bathe, William, Irish Jesuit and writer, was born in Dublin, 1564. Studied at Louvain and Padua, and became rector of the Irish College of salamanca. He died Madrid, June 17th, 1614. Author of "A brief introduction to the true arte of musicke, wherein are set down exact and easie rules for such as seeke to know the trueth, with arguments and there solutions, for such as seeke also to know the reason of the trueth: with rules be means whereby any by his own industrie may shortly, easily, and regularly attaine to all such things as to the arte doe belong: to which otherwise any can hardly attaine without tedious difficult practice, by means of the irregular order now used in teaching; lately set forth by William Bathe, student at Oxenford." London, 1584. Another edition was issued under the title of "A briefe introduction to the skill of song, concerning the practice set forth by Villiam Bathe, gent." London [1590].

Batson, Rev. Arthur Wellesley, composer. Mus. B., Oxford, 1878. Appointed Precentor, St. Anne's, Soho, 1888, and conducted Lenten performance of Bach's "St. John" Passion music in February of that year. Composer of a sacred cantata, "The Vineyard;" music to Fletcher's pastoral, "The Faithful shepherdess ;" comic operetta, "The burglar and the bishop." Has also published anthems, services, madrigals, songs, etc.

Batten, Adrian, composer and organist, was born in latter portion of 16th century [1585-90]. He studied under Holmes, of Winchester Cathedral. Became vicar-choral of IVestminster Abbey, 1614, and vicar-choral of St. Paul's Cathedral, 1624. Organist, St. Paul's Cathedral, 1624. He died about the middle of the 17 th century [1637].

TVorks.-Anthems-Hear my prayer; O praise the Lord; Deliver us, O Lord (in Boyce's Cathedral music); Te Deum, Benedictus, Jubilate, Kyrie, etc., in D (Novello); Thirty-four anthems (words only-Cliffora); Twenty-four anthems in Barnard's Cathedral music.

Battishill, Jonathan, composer and organist, was born in London in May, 1738. Son of Jonathan Battishill, solicitor, and

\section{BAYLEY.}

Mary Leverton, his wife. He became a chor. ister in St. Paul's Cathedral under IV. Savage, 1748. He became deputy organist, under Boyce, of the Chapel Royal. Conductor and accompanist at Corent Garden Theatre. Married to Miss Davies (the original "Madge" in "Love in a Village"), 1763. Organist of united parishes of S. Clement, Eastcheap and S. Martin, Orgar, 1764. Organist of Christ Church, Newgate Street, 1767. Resigned post at Covent Garden. Devoted himself to teaching and composition. Presented with gold medal by the Nobleman's Catch-club, 1771. On the death of his wife in 1777 , he lost taste for music and became addicted to drink. He died at Islington, December 10, 1801, and was buried in St. Paul's Cathedral.

Works.-Almena, an opera (with M. Arne), Drury Lane, 1764: The Rites of Hecate, a musical entertaimment, 176t. Anthems: Behold, how good and jorful; Call to remembrance: I will magnify Thee, O God; O Lord, look down from heaven; Six anthems and ten chants, edited by Page, $180+$ (with memoir by Dr. Busby, and portrait); Twelve hrmms, the words by the Rev. Charles Wesley . . . London [1765]. Glees: Amidst the myrtles: Again my monmful sighs; Here rests his head [1805]; Kate, of Aherdeen; Come, bind my hair. A collection of songs for three and four voices, London [1783] 2 books; Collection of catches. Songs: Collection of favourite songs sung at the publick gardens and theatres [1761]; At eve with the woodlark I rest; Cham of Silvia; Gay Damon; Find request; Shepherd and shepherdess; The Wish. Select pieces for the organ or pianoforte, containing an overture and nine pieces selected from original MISS. by John Page. London [1805].

Battye, James, composer and teacher, was borm at IIuddersfield in 1803, and died there on October 10, 1s58. He published "Twelve glees for four and five voices, with pianoforte accompaniment." London [1854」; "My soul truly waiteth," Gresham prize anthem, 1845; Songs, etc.

Baumer, Henry, composer and teacher, born about 1835 . Head master of Watford School of Mnsic; retired in 1886. He died at Watford, Herts. July 29, 1888. He composed the "Triumph of Labour," a cantata, 1875; Part-songs; and many single songs; String quartet: Three sketches for pf., etc.

Baxter, Rev. J. A., clergyman and musician, published "Harmonia sacra, a collection of introductory sentences, chants, responses, doxologies, with 200 psahm and hymn tunes, arranged for four voices and pf. or organ. Revised by Tincent Novello." London, 1840.

Bayley, William, organist and composer, was borm in $[1810]$. 'Vicar-choral St. Paul's Cathedral, and master of the choristers in succession to Hawes. Organist of St. John's, 


\section{BAYLY.}

Horsleydown, Sulthwark. He died at London, November 8,1858 . He composed many songs and other vocal pieces, and published "The Paneuphonon: a selection of the most popular tumes, with chants for one or four voices .."N.D.

Bayly, Rev. Anselm, writer and divine, born 1719. He matriculated at Exeter College, Oxford, 1740. Lay-vicar at Westminster Abbey, 1741. Gentlenin of the Chapel Royal, 1741. Priest do., 1744. B.C.L., 1749. D.C.L., Oxford, 1764. Sub-dean of Chapel Royal, 1764. He died in 1792.

Works.-Practical Treatise on Singing and Playing with just expression and real elegance, London, 1771; The Alliance of Musiek, Poetry, and Oratory, 1789; The Sacred Singer, containing an Essay on Grammar, the requisites of singing cathedral compositions, etc., London, 1771. Collection of Anthems used in His Majesty's Chapel Royal, and most cathedral churches in England and Ireland, 1769. Sermons, ete.

Bayly, Barre' Dalton, violinist, bom at St. Heliers, Jersey, 1850. Toungest son of the late Captain Edgar Bayly, H.M. 12th Regiment, and his wife, danghter of Lord Charles B. Kerr, second son of the fifth Lord Lothian. Pupil of M. Currie de Hauteville and Ludwig straus. Some time violinist at the Grand Opera House and Steinway Hall, New York. Leader of the orchestra, Exeter Oratorio Society, 1870-1895; prineipal violin at important concerts at Barnstaple (Easter Musical Festivals), and soloist at concerts in London, \&c., and a suceessful teacher.

Bayly, Thomas Haynes, lyrical poet and composer, born at Bath, October 13, 1797; died London, April 22, 1839. He composed the music for a large number of his own ballads, such as The bower, the Carrier dove, The Circassian, The Deserter, Fly away pretty moth, \&e., but most of his more popular songs were set by Bishop, Knight, Lee, Loder, and others.

Baynham, Thomas, published a "Collection of psalm and hymn tunes, single and double chants. . . , London, 1860.

also composed some pianoforte music.

Beale, Charles James, organist and composer, born in 1819 . He was urganist of St. Paul's, Covent Garden, London, for several year's. Died at London, Mareh 19, 1882. Composer of a "Laudate Dominum" and other ehureh and rocal musie.

Beale, George Galloway, organist, born in London, 1868. Chorister, Marlborough College; pupil of Dr. J. F. Bridge; MIus. Bac., Durham, 1891; F.R.C.O.; Organist and assistant master, St. John's School, Leatherhead, 1887-9 ; Organist, St. John's, Paddington, 1890-3, and Conductor of the Paddington Choral and Orchestral Association; in 1894,

\section{BEALE.}

appointed Organist and Choirmaster of Llandaff Cathedral.

Beale, John, composer and pianist, was born in London, about 1776. Pupil of J. B. Cramer, and member of Philharmonic Society, 1820. He was a professor of pianoforte at the R.A.MI., and a teacher in London. He also directed the music at the Argyle Rooms. Died after 1830.

Works.-Lyrieal specimens of German and French composers, adapted to English poetry written and selected by L. S. Costello, London [1822]. Songs: The kiss dear maid; Crusader's return; Russian maiden's song, ete. Rondo for pianoforte, Op. 2; Fortyseven preludes . . for the pianoforte [1827]. Complete Guide to the art of playing the Geman flute, London [1820].

Beale, Thomas Willert (Walter MayNARD), born in London, 1828, son of Frederick Beale, of the firm of Cramer, Beale, and Addison. Studied under Edward Roeckel, G. F. Flowers, and Pugni. Was one of the founders of the New Philhamonic Society, but did not adopt musie as a profession, being called to the bar at Lincoln's Imn, 1863. Besides the works mentioned below, he contributed many articles to different magazines. He died at Gipsy Hill, London, October 3, 1894.

Wonks.-The Enterprising Impresario (Bradbury, Evans, \& Co.), 1867 ; The Light of other days (Bentley), 1890. Operettas : An Easter egg; Matrimonial news. Partsongs and songs, pianoforte pieces, \&c.

Beale, Thurley, baritone voealist, born at Royston, Hertfordshire, April 23, 1849. Studied mider (sir) Joseph Barmby, and was a chorister at st. Andrew's, Wells Street, London, and at it. Paul's Cathedral. A singer of repute, he has been heard at the principal London and Provincial Concerts, the Hereford Festival of 1879 , \&c.

Beale, William, composer, born at Landrake, Cornwall, Jannary 1, 1784. He studied under Dr. Arnold and R. Cooke, and was gentleman of the Chapel Royal, 1816-20. He resided in London as a teacher of musie, and held the appointments of organist of Wandsworth Parish Church, and St. John's, Clapham Rise. From November, 1820, to December, 1821, he was organist of Trinity College, Cambridge. In 1813, he gained the prize cup of the Nadrigal Society with his madrigal, "Awake, sweet muse," and in 1810, a prize from the Adelphi Glee Club. He died in London, May 3, 1854.

Wonks.-Madrigals and Glees: A first book of Madrigals, Glees, ete., for three, four, and five voices, Op. 6, London, 1815; Collection of Glees and Madrigals, London, 1820; Collection of thirteen Glees, edited by E. Plater [1879]; Awake, sweet muse (1813), 


\section{BEALE.}

prize madrigal ; Come let us join the roundelay; This pleasant month of May; What ho! what ho! (1816); etc. Songs. Sonata for the pianoforte, with an accompaniment for the violin $[1815]$; Second Sonata for pianoforte, Op. 8 [1816].

Beale, William George Frederick, published "Congregational Psalmody : a collection of psalm and hymm tunes," London [1852]. He also wrote songs and pianoforte music.

Another Beale, Henry Wolfgang AmaDeus, published a large number of Songs and Pianoforte Pieces between 1854 and 1878, and edited (with IV. T. Wrighton) "Congregational Psalmody" [1858].

Beard, John, tenor vocalist, born in 1716, was a chorister in Chapel Royal, under Bernard Gates. First appeared at Covent Garden in 1736, and at Drury Lane in 1737. Married to Lady Henrietta Herbert, widow of Lnrd Edward Herbert, 1739, and afterwards to Miss Rich (daughter of Rich, of Covent Garden Theatre), 1759. He was one of the proprietors of Covent Garden Theatre, 1761. Retired from public life, 1768. He died at Hampton, Middlesex. February 4, 1791. He composed a few songs.

Beardmore, Mrs., see Parke, Marta H.

Beatson, John, musician. Publish d "A Complete collection of all the tunes sung by the different congregations in Hull. To which is prefixed an introduction to the art of Psalmody" [1750].

Beattie, James, poet and author, born at Laurencekirk, October 25, 1735. Professor of Moral Philosophy, Marischal College, Aberdeen, 1760. He died at Aberdeen, August 18, 1803. Author of "Essays on poetry and music as they affect the mind, etc.," London, 1776 ; second edition, 1779 . " Letter to the Rev. Hugh Blair, D.D., on the improvement of psalmody in Scotland," 17Ts; another edition, Edinburgh, 1829. Poems, Ethical works, etc.

His eldest son, Janes Hay Beattie (bom Aberdeen, 1768-died 1790) was a violinist, and amateur musician of great promise.

Beatty=Kingston, W., see KingsTon, WiLlian.

Beaty, Richard William, musician, was born in Dubliu abont 1799 . IIe was originally a chorister of Christ Church Cathedral, and became organist and teacher at the Molyneux Asylum for Blind Women in 1824. He was organist of the Free Church, Great Charles Street, from 1828 to 1877 , and choirmaster of Christ Church Cathedral, Dublin, from 1830 to 1872. He died at I ublin in 1883.

Vorks.--One hundred and fifty hymms . . [18t4], with Weyman and 1. Smith. Sequel to Melodia Sacra. Songs, etc.

Beaumont, Alexander S., composer of

\section{BEAZLEY.}

the present day. $H$ is works include a Suite for strings (produced, Norwood, 1887); Suite in D, strings and pf.; Lullaby, pf., violin, viola, and hamonium; Gondoliera and Marcia funèbre, for pf. and string quartet; pieces for violin and violoncello. Duets for pf., songs, etc.

Beaumont, Henry, temor vocalist, native of Torkshire. Studied first under Joshua Marshall, of Huddersfield, and later with Luigi Caracciolo, at Dublin. Made his debut at Huddersfield, October 22, 18s1, at a concert of the festival in celebration of the opening of the first Town llall in the borough. He soon made his way in public estimation, and in 1883 was offered a position in the choir of Christ Church Cathedral, Dublin. Here he remained about two years, singing at the principal Dublin concerts, when, in 1885, he joined the Carl Rosa Opera Company. He also sang in Grand Opera in Drury Lane, and joined the Burns-Crotty "Cinderella" tour, 1891-2. II as risited America three times, the first occasion being in 1888, when he was with Mr. Ludwig's party. Now resident in London, and chiefly engaged in concert-singing. Married, April 26,1888 , the Dublin soprano, ADElaide MULLEN $(q \cdot v \cdot)$

Beaumont, John, musician, published "The New Harmonic Magazine, or Compendious Repository of Sacred Music, in full Score," London, 1801.

Beazley, James Charles, pianist, violinist and composer, borm in Ryde, I.IV., 1850. Studied music privately for some years, and then entered the R.A.M., where his masters were H. C. Banister, harmony; Dr. Steggall, counterpoint; W. Sterndale Bennett, composition; and F. B. Jewson, pianoforte. After leaving the Academy he was appointed music-master at the King's School, Sherborne, Dorset, but delicate health compelled his return to Ryde, where he has since resided as teacher and composer. During the last few weeks of Sir Sterndale Bemnett's life, Beazley acted as his private secretary, the most cordial relations existing between them.

Works.-Cantatas: Drusilda (Kyde, 1888); Josiah (1891); The Red divarf; The Golden fliteh. Services of song. Part-songs, songs, The white gondola, etc. Instrumental : Sonatinas in D minor, F, and G minor ; Six sketches; Six bagatelles; Six miniatures; Deux pensées; Elegy, and other pieces for violin and pf., with a large number still in IS.; Thirty-five studies; Four easy sketches; Album of pieces, and other compositions for the pf. Pieces for flute and pf. Albums for American organ or harmonium. Author of "Aids to the violinist: a short treatise in reference to bow-marks" (Cary, London). 


\section{BECHER,}

Becher, Alfred Julius, composer, of German extraction, was born at Nanchester in 1803. Educated at Universities of Heidelberg, Berlin, etc. Resided at Vienna as editor of the Radikale, a democratic sheet, which was filled with seditious articles by Becher. Shot at Vienna for sedition, Nov. 23, 1846

Works.-Op. 1, Songs for solo voice and piano; op. 2, Lyrical pieces for the pf.; op. 3, Six poems for voice and pf.; op. 5, Rondo for the pf.; op. 6, Six songs for voiee and pf.; op. 7. Three sonatas for pf. solo; op. 8, Original theme for pf.; op. 9, Monologue for pf.; op. 10, Six songs for voiee and pf.; op. 11, Sonata for pf.; op. 18, Nine pieces for pf.; A Symphody; String quartet, and varions articles on music.

Beckwith, John Christmas, composer and organist, born at Norwich, December 25, 1750. Studied under Dr. W'm. and Philip Hayes, at St. Magdalen College, Oxford. Organist of St. Peter's, Mancroft, Norwich, 1794. Organist of Norwich Cathedral in succession to Thos. Garland, 1808. Mus. Bac. and Doc. Oxon, 1803. Instructed Thomas Vanghan, the vocalist, in singing. Died at Norwich, June 3, 1809.

Works. - The First verse of every Psalm of David, with an ancient or moden chant in seore, adapted as much as possible to the sentiment of each Psalm. London, 1808. Six Anthems in Score, for $1,2,3,4$, and 5 voices. London [1790]. Glees: Hark, o'er the waves; Chimney sweepers; Favourite concerto for the organ, harpsichord, or pianoforte, op. 4 [1795]; Sonata for the harpsichord or pf., op. 3; Six voluntaries for the organ or harpsichord, London, 1780; Songs, ete.

Beckwith was an organist of much genius, and was famous for his extempure playing. The name, "Christmas," is supposed to be a nicknane given on account of his birthday. His sem, Jonn Chafles (horn 178s, died October 5,1828 ) was an organist of nuch albility, and succeeded to the post at Norwich Cathedral in 1809 . His uncle, John IBEckwtтh (born 1729, died May 14, 1800), was a layclerk in Norwich cathedral. His brother, the Rev. Edward James Beckwith (died January 7,1833 , was succentor of St. Paul's Cathedral, and the composer af some chants.

Bedford, Arthur, divine and writer, was born at Tiddenham, Gloucester, September, 1668. Studied at Oxford. Died at London, 1745.

Works. - The Temple Musick, or an Estay concerning the Method of Singing the Pralns of David in the Temple before the Babronish Captivity, wherein the musick of our Cathedrals is vindicated . . Bristol, 1706; Essay on Singing Darid's Psalms, 170s; The Great abuse of Mnrick, eontaining an account of the nse and design of Musick among the Antient
BEESLEY.

Jews, Greeks, Romans, etc., London, 1711 ; The Excellency of Divine Musick . . . to which is added a specimen of easy grave tunes instead of those which are used in our profane and wanton ballads, London, 1733; Scripture Chronology demonstrated by Astronomical Caleulations, London, 1730; The Present State of the Republick of Letters, London, 1730 ; Serious Reflections on the Scandalous Abuse and Effects of the Stage, Bristol, 1705.

Bedford, Herbert, composer, bom in London, 1867, Miusically educated at the Guildhall School of Music, where he was twice awarded the amnual prize for composition. First came prominently into notice by a concert of his works at the Meistersinger's Club, May 30, 1892. His principal compositions are "La Belle Dame sans merci" (Keats). and "La Joie fait penr," for roice and orchestra ; an opera, "Kit Marlowe," not yet produced; an Are Maria, for contralto solo, contralto chorus, violoneello, pf., harp, and organ; a group of French songs; an Album of English songs (ineluding a setting of shelley's Ode to Music), etc. In 1894 he married Miss Liza Lehmamn, the vocalist and composer $(q, v)$

Bedford, Paul John, comedian and bass vocalist, born at Bath, 1792? Sang at Drury Lane, November 10, 1824, in the first proper or complete performance of Weber's "Der Freischititz," talking the part of Bermhard. From 1833 he sang in opera at Covent Garden; and later in farces at the Adelphi. He had a good, deep hass voice. He died in London, January 11, 1871.

Bedsmore, Thomas, organist and composer, was lrom at Lichfield in 1833. Chorister, Lichfield Cathedral, 1843; articled to Samuel spofforth, the Catbedral organist; and after the death of his teacher, in 1864, he was appointed his snceessor. I)ied at Lichfield, June 9, 1881. Composer of Chureh music, songs, pianoforte music, etc.

Beecroft, George Andus Beaumont, amatenr composer, was born in 1845 . His father was Ml.P. for Leeds. He was educated at Oxford, where he graduated B.A., in 1868, and M.A., in 1872; Mus. Bac., Oxford, 1867. He died on May 3, 1873. He composed some vocal music, and contributed to the Choir and other musical journals. He also published a Magnificat and Nunc dimittis; a Minnet and Trio for Pianoforte; Three casts from the antique for Pianoforte, etc.

Beesley, Mrs., see Sphiner, Mattie.

Beesley, Michael, published "A Book of Psalmody, containing instructions for young heginners, after as plain and familiar a manner as any, with a collection of psalm tumes, anthems, hymms, etc. . . engraved by M. Beesley," 17-.

Begg, Rev. James, Scottish divine, hom 1809, died at Edinburgh, 1883. Author of 


\section{BELCHER.}

"The Use of Organs and other instruments of music in Christian worship indefensible," Glasgow, 1866. "Instrumental Music unwarranted in the worship of God," Edimburgh, N.D. His father, the Rev. James Begg, D.D., minister of New Monkland, Lanarkshire, wrote a tract entitled "Treatise on the use of organs and other instruments of music in the worship of God," Glasgow, 1808, reprinted in his son's tract of 1866 .

Belcher, John, English writer, anthor of "Lectures on the History of Ecclesiastical Music," London, 1872.

Belcher, William Thomas, organist and composer, horn in Birmingham, March 8, 1827. Graduated Mus. B. Oxon., 1867; Mus. D. 1872. Organist of Great Barr Church, 1856, and subsequently of several churches in Birmingham, up to 1884, when he was appointed organist and choir-master at Holy Trinity, Bordesley, a position he still holds. Has given organ recitals in Bimingham and neighbouring towns. His son, IV. E. Belcher, M.A., is deputy organist of the Leeds Town 1[all, and teacher of music at Headingly, near Leeds.

Worrs.-Oratorio, The Sea of Galilee (MS.), Oxford, 1872; Cantata, The Fates, Oxford, 1867: Cantatas composed for the opening of Adderley and Aston Parlis, Birmingham ; Cantatina, Excelsior ; ()pera, Estelle. Church Music: Anthem for double choir, from Psalm 122; Anthems, Hymms, Chants, \&c. Glees and part-songs, including a Jubilee Song-Fifty year's glad blessings bringing - a copy of which was graciously accepted by the Queen, 1887. Pianoforte pieces, ete.

Bell, John, composer and organist, was born at Gourock, in Renfrewshire. Hestudied music from an early age, and became $\mathrm{A}$. Mus. T.C.L.; F.F.S.C.; and MIns. Doc., Trinity College, Toronto. Has held the appointments of organist or conductor of palmody in Westbourne Free Church ; Springburn Parish Church; Anderston Parish Church; and St. Vincent Parish Church, all in Glasgow. He also conducted a Select Choir, and acted as conductor of the Glasgow Temperance Choral Society; Cathcart Musical Association; Tale of Leven Choral Society; Carluke Choral Society; and St. Andrew's Musical Association. For four or five years he was musical critic to the North British Daily Hail. Composer and arranger of about 150 anthems and part-songs ; the 145 th Psalm for soli, double chorus, and orchestra (degree exercise), etc.

Bell, John Montgomerie, amateur composer, was hom at Edinlurgh, May 28, 1837. He is a writer to the signet. His compositions include anthems, songs, and hymm tunes, some of which have been published in varions Scottish Church Hymmals.

Bellamy J., musician, compiled "A
BELLERBY.

System of Divine Musick," 1745.

Bellamy, Richard, bass singer and composer, was born about 1743. In 1771 he was appointed a gentleman of the Chapel Royal, and in 1773 he became a lay-vical of West. minster Abbey. He graduated Mus. Bac., Cambridge, in 1775. He became a vicarchoral of St. Paul's Catherlal, London, in 1793, and succeeded Hudson, as almoner and master of the children, in 1793, a post he held till 1799. He died at London, September 11, 1813. Bellamy was one of the best bass singers of his day, and composed a Te Deum; A set of anthems, 1788; Six glees for three and four voices, 1789; and other works.

Bellamy, 'Thomas Ludford, bass vocalist, son of above, was born at Westminster, I,ondon, in 1770 . He was a chorister in IVestminster Abbey under Cooke. Ile studied singing under Tasca, and appeared as a concert vocalist in London till 1794. Stage manager of theatre in Dublin, 1794-97. He became part-proprietor of Chester, Lichfield, Manchester, and Shrewsbury theatres, 1800. Proprietor of Belfast, Londonderry, and Newry theatres, 1803. Sang in Cuvent Garden theatre, 1807-12, and at Drury Lane theatre, 1812-17. Choir-master at Chapel of Spanish Embassy, London, 1819. Bass Singer at Concert of Ancient Music. He died at London, Jannary 3, 1843.

Works.- Songs and part-songs. Lyric poetry of glees, madrigals, catche's. rounds, canons, and duets. London, 1840.

WILliaM IlenRY BellayY (born in 1799died at London, March 3, 18s0), probably a relative of the above, composed A lady's page; The neglected lute; The pilgrim, and other songs.

Bellasis, Edward, writer, born January 28, 1852. "'Lancaster Herald." 1852. Anthor of Cherubini: memorials illustrative of his life, London, 1874. Tlie Law of arms, 1880; The Machells of Crackenthorpe . . Kendal, 1856.; Memorials of Mr. Serjeant Bellasis, 1800-1873, London, 1893, etc. Songs: Alone I wandered; Ministering spirits; The haven; Consolation; Waiting for the moming; The two worlds; Tyre; Marionette pantomime; Pf. music, etc.

His brother, the Rer. Richard BeLLasis of the Oratory, Edgbaston, Birmingham, is a musician, and occasionally conducts concerts.

Bellerby, Edward Johnson, organist, pianist, and composer, born March 28, 1858, at Pickering, Yorkshire. Studied mider Dr. E. G. Monk, of York Minster, 1876-80, and was assistant organist during most of that time. In 1879 he graduated Mus, Bac., Oxford; and Mus. Doe., 1895. He was organist to Lord Ilotham, 1877-8; of Selhy Abbey Church, 1878-81; then appointed to Margate Parish Church, 1881; and in 188.1 to Holy 


\section{BELVILLE.}

Trinity, Margate, where he remains to the present time. An able executant, both as pianist and organist; he has appeared at various concerts, and his organ recitals are very popular. He lias a considerable reputa. tion as an extempore player.

Wonks.-Psalm 46, for soli, eight-part chorus, and orchestra; Communion service in F. Anthoms: Jesu, my Lord, and others; songs, and a volume of nursery rhymes. Festive overture (Selby Orchestral Society, 1887); Symphonic fantasia (composed 18ss, and produced by Nargate Phitharmonic Socicty, 1895), for orchestra; organ and pf. pieces, ete. Author of a "Primer on Harmonising Melodies."

Belville, Edward (or Jakobowski), composer of the present time. At a concert given at the R.A.M., in conjunction with Mr. Sinclair I $u m$, he introduced his comic opera, The Three Beggars (July 28, 1883), which has been followed by many others: Dick (Globe Theatre, April, 17, 1884); Ermine (book by Bellamy and H. Paulton, Grand Theatre, Birmingham, November 9, 1885); The Palace of pearl (joint composition with Stanislaus, Empire Theatre, June, 1886); Mynheer Jan (Comedy Theatre, February, 1857); Paola (I1. Paulton); La Rosière (Shaftesbury, January, 1893); A Venetian singer (one act, Court Theatre, Nov. 1893), etc. Six songs (Sinclair Dumn), etc., etc.

Bendall, Wilfred Ellington, composer, born in London, April 22. 1850. Studied harmony and composition under Charles Lucas and E. Silas; and at the Conservatorium, Leipzig, 1872-4. Resident in London as composer and teacher of $\mathrm{pf}$.

Woriss.-Sacred Cantata, Parizādel (produced by Willing's Choir, St. James's Hall, April 22, 1884); Cantatas for female voices: The Lady of Shallott; The Rosiere; The Woman of Canaan. Operettas: Lover's knots (St. George's Hall, 1880); Quid proquo (18s0). Trios, for female voices, The fountain, etc. Six vocal duets, part-songs, songs, etc. Six pieces, viohin and pf. In the Tyrol, three pieces for pf. Toccata in E flat, etc.

Bennet, John, composer, who flourished at the end of the 16th and beginning of the 17th centuries [1570-1615].

Works.-.Madrigalls to four voyces, newly published by Jolm Bennett, his first works at London, 1599; Madrigal, "All creatures now are merrily minded," in the Triumphs of Oriana, 1601 ; Songs in a collection published by Ravenscroft; $O$ God of Gods, verse anthem, Sacred Harmonic Society's Library; Anthems and madrigals in MS.

Nothing as to his biography appears to have been chronicled. His book of madrigals was re-published in 1845 by the Musical Antiquarian Society.

\section{BENNETT.}

Bennet, Robert, musician, published "The Psalm-singer's necessary Companion, containing above sixty choice psalm tunes," London, 1718.

Bennet, Saunders, organist, pianist, and composer, born in last quarter of the 18th century. $\mathrm{He}$ was organist of a church at Woodstock, and died at Woodstock, May 25, 1809. He wrote some vocal music (glees and songs), and a number of rondos, sonatas, variations, etc., for the organ and pf. Also edited "Selection of sacred music for three voices, with an accompaniment for the organ," London, 1810.

Bennett, Alfred William, son of Thomas Bemett, organist of Chichester Cathedral, was born in 1805 . He studied under his father. Organist of New College, Oxford, 1825. Mus. Bac., Oxon., 1825. Fíiled by a fall from a coach while on his way to Wurcester Festival, September 12, 1830.

Works.-Church Services and Anthems; Cathedral Chants, 1829, edited with W. Marshall, Mus. Bac.; Cathedral Music . . edited by T. and H. Bennett, London [1830]; Songs; Instructions for the pianoforte, with popular National Airs arranged as Lessons, London, 1825]; Instructions for the spanish guitar, London [1828]: Vocalint's Guide, comprised in a series of instruction and solfeggi, London $[1830]$, also $[1865]$.

Bennett, Charles, organist and composer, was bom about 1740 . He was organist at Truro for 40 years, and died there on Nay 12, 1804. Composer of "Twelve songs and a cantata," London, 1765, etc.

Bennett, Frederick James Went= worth, flutist and composer, horu at Cadbury, Somerset, 1856. Studied at R.A.M. and R.C.MI., also privately under A. I'. Vivian and R. S. Rockstro, L.R.A.M., 1895. Has performed in London and the provinces; and was conductor of the Castle Cary Choral Society, 188:3-90, and the Cadbury Musieal Society, 1887-90. Appointed Professor of the Flute at the Brighton School of Music, 1895. Author of a brochure on "Conducting, and being Conducted" (1889), and now engaged on a work "On Solo Flute-playing." Has contributed articles to the Musical Times and other papers.

Works.-Mass in C minor (1888); Sacred Cantata, Anno Domini (1888); Cantata, " Eurydice" (1884); Operettas: Dr. Whack'm (1880); King Richard I. (1883); King Arthur (1884); The King's Foresters (18s6); and The Black Eagle (1858). Symphony in C, orchestra (1885) ; Rustic Idyll, orchestra (1893). Concerto in E minor, flute and orchestra (1887); Sonata, pf. Many pieces for pf. and flute. Various part-songs, and nearly 200 songs.

Bennett, George John, composer and organist, born at Andover, Hants, May 5, 1863. 


\section{BENNETT.}

Was a chorister at Winchester Cathedral, 1872-78, and entered the Royal Academy of Music in 1879 , stndying mnder Sir G. A. Macfarren. Here he remained until 1884, and at the R.A.MI. concerts the first movement of a symphony, two overtures, a pianoforte concerto, and other works of his were produced. From 1884 to 1887 he was enabledthrough the instrmmentality of the firm of Novello, Ewer, and Co., who were greatly interested in the talented young musician-to study at Berlin, under Friedrich Kiel, and at Munich, nuder Rheinberger. Retuming to England, he was (1888) created a Fellow, and appointed Professor of Harmony, R.A.MI., having, six years previonsly, obtained the diploma, F.(R.)C.O. He graduated Mus. Bac., Cambridge, 1888; Mus. Doc., 1893. He was organist of St. John the Erangelist from 1890 , until his appointment to Lineoh Cathedral in Angust, 1895. Other offices held by him are Conductor, London Organ School Orchestra (1893), and Chmoh Orchestral Society (1895).

Works.-Mass, in $B$ flat minor ; Festival Te Demm in D, for soli, double choir, and orchestra, in MS.; Festival Evening tervice in A, Dedication Festival, St. Paul's Cathedral, 1890 ; Easter Hymn, for soli, chorus, and orchestra, Festival of Sons of the Clergy, sit. Paul's, 1895; Moming, Erening, and Connmunion Services; Anthems, etc. Two Albums of Songs (Novello); Trios for female roices; Part-songs, etc. Urchestral: Serenade, in Srmphonic form; Overture, Jugendtratime, Crystal Palace, March, October, 1887; Orerture, "Leomatus and Imogen," Philharmonic Society, 1895. Trio in F, pf., vn., and 'cello, London, 1893 ; various pf. pieces, Toluntaries for organ, etc.

Bennett, James, composel and writer, bon at Salford, 1804 ; died at Brighton. June, 1870. Author of "A Practical Introduction to part and sight-singing," London, 1843: "Elementary exercises for the cultivation of the voice," London, N.D. Composed songs, ete.

Bennett, Joseph, musical critic, librettist, and journalist, born at Berkeley, Gloucestershire, November 29, 1831. In his routh he studied the organ, violin, viola, and violoncello; went through a course of training for scholastic profession at the Borough Road College, London; acted as precentor at the historical Weigh House Chapel, and was sonetime organist of Westminster Chapel. Finally, adopting musical criticism, he was comnected successively with the Sumday Times, Daily Tclegraph, Pall Mall Gazette, and Graphic. For many years he contributed to the Wusical World, also to the Musical Standard, and Musical Times, devoting himself now to the last-named and the Daily Tolegraph. He was editor of Concordia, 1875-6; and of the Lnte,
BENNETT.

1883-6. In 1855, he was engaged as annotator of the Philhamonic Society's programmes, and succeeded the late J. W. Davison as writer of the analytical programmes for the Saturday and Monday Popular Concerts. He has also done similar work for the Leeds, Bimingham, and other Festivals. He has acted as adjudicator at Eisteddfodan: is a member of the Committee of the Nendelssolm sicholarship Fund; and President of the Gloucester Choral Society. Of his immmerable contributions to the press, the most important are a series of papers on the Great Componers (Musical Times, 1877-91); "Elijah," a comparisun of the original and rerised seores (commenced in the short. lired Concordia, and reprinted and completed in the Musical Times, October, 1882, to April, 1883); and "From my study." Musical Times, (1892 to present time). As a librettist. Joseph Bemlett has dome much. His chief works, adapted or original are, The Golden Legend (Sinllivan); The liose of Sharon, The Dream of Jubal, the Story of Sayd, and Bethlehem (Meckenzie); Ruth, Thorgrim, The Transfiguration (Cowen), Jeanie Deans (MIacCumn), and hooks for I h. J. F. Bridge, C. Lee TVilliams, Barnett, Mancinelli, and others. His chief publications are: Letters from Bayreuth (Novello, 1877); The Musical Year [1883] (Novello, 1884); Prinlers of Musical Biography, five books, enlargements of some of the papers above-named; and History of the Leeds Musical Festivals, 1858-1889 (in conjunction with F. R. Spark, ) Novello, 1892. He is also the author of a number of poetical pieces.

Bennett, Robert, musician, was born at Bakewell, Derbyshire, in January or February, 1788. He hecame a chorister in ling's College, Cambridge, and was articled to Dr. Garke-Whitfield. In 1811 he became organist of the Parish Church, sheftield. He died at Sheffield, November 3,1819 . He was married to Elizabeth Don, daughter of the botanist, and his son was Willam stemdale Bennett, separately noticed. He composed a number of songs and varions hymm tunes.

Bennett, Thomas, organist and composer, born at Fonthill in 1779. Chorister in Salisbury Cathedral moder Joseph Corfe. Organist of Sit. John's Chapel, Chichester, and of Chichester Cathedral, 1803-48. He died at Chichester, March 21, 18ti, and was succeeded by his son Henry, who held the appointment till 1860.

Works.-Introduction to the Art of Singing, London, N.D. : Songs and organ pieces. Sacred Melodies: A collection of prahms and hrmms, sung at the Cathedral and Chapel of St. John, Chichester, Tondon, 18.5; ('athedral selections, consisting of anthens, sanctus commandments, and chants, London; several editions. 


\section{BENNETT.}

Bennett, William, organist and composer, born near Teignmouth, 1767. He studied nnder Jackson of Exeter, and J. C. Bach and Schroeter, London. Organist of St. Andrew's Church, Plymonth. He died about 1830 .

Worris.-Six songs and a glee, London [1799]; anthems and organ music, etc.

Bennett, W. J. E., compiter of a "Psalter, containing a selection of psahm tunes, chants, services, and other ecclesiastical music

arranged for congregational singing in four parts," 1843-4t.

Bennett, William Mineard, composer and painter, bom at Exeter, in 1778, died there October 17, 1858. He composed a number of glees and songs, and was a portrait painter.

Bennett, Sir William Sterndale, composer and pianist, was born at sheffield, April 13, 1816. He studied as a chorister in choir of King's College, Cambridge, under his grandfather, John Bemnett, and received subsequent instruction from Charles Lucas, Dr. Crotch, Cipriani Potter, and W. H. Holmes. He studied at Leipzig Conservatorium moder Moscheles, at the expense and on the suggestion of Messrs. Brondwood and Sons, during 183640. He appeared in England as concert-giver, 1843-1856, and was an unsneeessful candidate for Music I'rufessorship at Edinburgh Lniversity, 1844. He married Miss Mary Amm Wood, 184t. Founded (with others) the Bach Suciety, 18t9. Conducted the Philharmonic Society Concerts, 1856-66. Conducted the Leeds Minsical Fentival, 1858. Professor of Musie at Cambridge, 1856. Mins. Doc., Cambridge, 1856. M.A., Canbridge, 1857. Principal of the R.A.M., 1866. D.C.L., ()xford, 1s70. Knighted, 1871. Presented with testimonial, 1872. He died at London. Febmary $1,1875$.

Wonks--Op. 1, First Concerto for pianoforte and orchestra, in D minor, 1832; Op. 2, Capriceio for pianoforte, in D; Op. 3, Overture for full orchestra, Parisina, 1834-35; Op. 4 , Second Concerto for pianoforte and orchestra, in E flat; ()p. S, Sestet for pianoforte and strings, 18tt; Op. 9, Third Concerto for pianoforte and orchestra, in C minor, 1834; Op. 10, Three musical sketches for pianoforte; Op. 11, Six studies for the pianoforte: Op. 12, Three impromptris for pianoforte; 91. 13, Sonata for pianoforte, 1842; Op. 14, Three romances for pianoforte; ( 11.15 , Overture for full orchestra, 'The Naiads, 1836; Op. 16, Fantasia for pianoforte, 18t2; Op. 17. Three Diversions for pianoforte duet; Op. 18, Allegro Grazioso for pianoforte; O1\% 19, Fourth Concerto for pianoforte and orchestra, in F ninor, 1836 1849 ; Op. 20, Overture for full orchestra, The Wood Nymph, 1840; Op. 22. Caprice in E for pianoforte and orchestra, 1840; Op. 23, six

\section{BENSON.}

songs for solo voice with pianoforte accompaniment; Op. 24, Suite de Pieces, for pianoforte, 1843; Op. 25, Rondo Piacevale for pianoforte; Op. 26, Trio for pianoforte, violin, and 'cello, 1844; Op. 27, Scherzo for pianoforte; Op. 28, Rondino for pianoforte, 1853; Op. 29, Two studies for pianoforte; Op. 30, Four sacred duets; Op. 31, Tena e variazione for pianoforte; Op. 32, Sonata for pianoforte and 'cello, 1852; Op. 33, Sixty preludes and lessons for pianoforte, 1853; Op. 34, Rondo for pianoforte; Op. 35, Six songs (second set) for voice and pianoforte; Op. 36, Flowers of the month; Op. 37, Rondean d̀ la Polonaise pour le pianoforte [1858]; Op. 38, Toceato for pianoforte; Op. 39, The May Queen, a pastoral, by H. F. Chorley (cantata) for solo voices, chorus, and orehestra, Leeds IIusical Festival, 1858: Op. 40, Ode, written for the opening of the International Exhibition, 1862, by (Lord) Alfred Temnyson, 1862; Op. 11, Cambridge Installation Ode, 1862; Op. 42, Fantasie-overture, Iatradise and the Peri, for full orchestra, $1862 ; O_{\mathrm{p}} .43$, Symphony for full orchestra, in i minor; op. 44, The Woman of Samaria, an oratorio, for solo voices, chorus, and olchestra. Bimingham Festival, 1867; op. 45, Music to Sophocles' Ajax; Op. 46, Pianoforte Sonata, The Maid of Orleans.

In addition to the above he wrote overtures, The Men'y Wives of Windsor; Marie du Bois, 1845; A quintet for pianoforte and wind instruments, etc., songs, part-songs, pianoforte music, and collections of chants, etc., most of which have been published.

Benson, George, composer and tenor singer, was born in 1814 . He was a gentleman of the Chapel Royal, and in 1878 he graduated Mus. Bac., Cambridge. He died at London, August 9, 1884. He composed Glees: If music be the food of love (prize, 1863); Orpheus with his lute; True love to win. Sleep little baby, sleep, four-part song. The Wooer, madrigal. NIy God look upon me; I will arise, anthems. Songs, ete.

Benson, John, musician, compiled "Sacred Harmony, a collection of tunes composed and arranged for one, two, three and four voices." London [1840].

Benson, John Allanson, composer, organist and teacher, born near Ripley, Yorkshire, February 8, 1848. Conneeted with the family of the late Archbishop of Canterbury. He was intended, by his father, for an architect, but his love for music nltimately prevailed, and he adopted the art as his profession. He received his earliest instruction as a choir boy after the removal of his family to Harrogate, and afterwards became conductor of the local Philharmonic Society. As organist, teacher, lecturer, and composer, he is a prominent and busy figure in musical life at Harrogate. 


\section{BENTLEY.}

Works.-Oratorio, King Hezekial (composed, 1886, produced, Harrogate, 1891); sacred cantatas, Laudate Dominum ; Christ at Nain (which obtained the $£ 50$ prize offered by Curwen and Sons, 1895); Cantata, Bottreaux bells (1873); Six school cantatas; The crown of roses, Summer holiday, etc., etc. Jubilee ode, Victoria! Victoria! (1887). Services of song, anthems, school songs, etc. In MS. are two comic operas, King Cophetua (produced, 1881), and Endymion (1883), and a dramatic cantata, The water nymph (1885). Organ music contributed to the "Organist's Quarterly Journal" and other publications, and hymn tunes in the "National Tume Book" (London: Patey and Villis), etc., ctc.

Bentley, John Morgan, composer and organist, born at Nanchester, September 3, 1837. Graduated at Cambridge, Mus. Bac., 1877 ; Mus. \oc., 1879. Was organist suecessively at St. Philip's, Salford, 1855 ; St. Stephen's, Manchester, 1860 ; St. Saviour's, 1866; and of Bowden Parish Church, and Cheadle Abbey Church. During that time he conducted choral societies in those districts, and at Blackburn, Win-ford, and Eccles. In 1881 he was appointed local examiner for R.A.M., and in the sane year was made Provincial Grand Organist of East Lancashire.

Wonks.-Oratorio, What is life? (1879); Dramatic cantata, Gethsemane (1877); Cantatas, Yuletide, and The Golden butterflythe latter for female voices. Vesper canticles; Psalter pointed, and Psalter chants (Heywood, Manchester). Symphony and other orchestral works in MIS. Horæ sacre, pieces for violin and pf ; The Two violinists, a series of duets for violins, with pf. accompaniment; Songs, ete., etc.

Benton, Alfred, organist and conductor, born in Leeds. Began his musical career at the age of ten as a choir boy in Leeds Parish Church. His first instructor on the organ and pianoforte was Mr. Wm. Dawson, then deputy organist of the Parish Church. Afterwards he became the pupil of R. S. Burton, and took lessons in counterpoint from W. J. Pritchard (a famous blind organist) and in composition from F. W. Hird. When fourtecn years old he obtained the post of organist at All Saints', Leeds, and subsequently was appointed to Windermere Parish Chureh, Arthington; St. Mark's, Mamningham ; St. Martin's, Potternewtown; and finally, in 1891, succeeding Dr. Creser as organist and choirmaster of Leeds Parish Church. I Here he worthily sustains the high reputation gained for the services. In 1889 he was appointed organist of the Leeas Festival, a position he still retains, with that of chorusmaster, since 1895. I Ie has introduced many important works at the Advent and Lent

\section{BERRY.}

services, including the Requiem by Brahms, Spohr's Last Judgment, and Bach's Matthew Passion. For years past he has been noted as a skilful conductor, societies in Barnsley, Morley, Bramley, and other places being nnder his direction. A permanent orchestra was formed in Leeds, in 1895, and a choral union also, the conductorship of both being entrusted to Mr. Benton, who now occupies a most responsible and honoured position in Leeds. He has also a high reputation as a teacher of singing, many of his pupils now holding appointments in English catledrals.

Berger, Francesco, pianist and composer, born Jume 10, 1834, in London, where his father, an Austrian, had settled as a merchant. Studied in Italy under Luigi Ricci and Carl Lickl, and at Leipzig under Ilauptmann and others. Settled in London, 1855. Appeared at concerts in London and the provinces as solo pianist. In 1868 established the "Après-midi Instrumentales." Was appointed a professor of pf. at the R.A.11. in 1885, and became hon. sec. of the Philharmonic Society in 1887. In 1864 he married Miss Lascelles, contralto vocalist. His works include a mass and an opera; the music to The Frozen deep (Wilkie Collins, 1857) ; a Suite in G, and other pieces for $\mathrm{pf}$. Cavatina for violoncello and pf. P'art-songs: Poor and rich (Leslie's (hoir, 1884), and others. Songs: Amor timido; Fair, but fleeting; Only thyself, ete., ete. Author of "First steps at the pianoforte" (Novello).

Berry, Sarah, contralto vocalist, bom at Bamford, near Manchester, where, from her eighth to her seventeenth year, she was a weaver in a mill. She gained the Courtney scholarship, R.C.M., and pursued her studies under the late Madame Goldschmidt, having lessons also in declamation from Mrs. Kendal. She made her début in Manchester, January 7,1888 , at a concert of 11 . De Jong, and at once achieved success. In October of the same year, she sung in "Elijah" at IIuddersfield, and in that oratorio at the Albert Hall (Royal Choral Society), January 22, 1890. She has also appeared at concerts in Birmingham aud other places; and at the Leeds Festival of 1895 , created a highly favourable impression. She sang at the Norwich Festival of 1896, and is gaining a good position among the singers of the day.

Berry, Thomas, organist and composer, born at Shepley, York, June 21, 1850. He settled in Glasgow abont 1873, and has been a teacher and organist there ever since. Among his appointments may be named the organistship of Trinity Congregational Church and Bellhaven Church, Glasıow. He has also given organ recitals in Glasgow and in various parts of Scotland. Composer of various works preserved in manuscript. 


\section{BERTINI,}

Bertini, Henri Jerome, composer and pianist of French parentage, horn at London, October 2s, 1798. Studied under his father, etc. He travelled through Gemany and Holland, and in England and Scotland. Resided in Paris as teacher and concert-giver from 1821. He died at Meylan, near Grenoble, October 1, 1876.

Works. - Studies for the pf., op. 29, 32, 66, $86,94,100,133,134,134 a, 137,142,147,166$, 175, 176, 177, 178, 180; Trios for pf., violin, and 'cello: Sextets for pf., 2 violins, viola, 'cello, and bass, op. 79, 85, 90, 114; Sonatas for pf. and violin, op. 152, 153, 156,; Nonetto for pf. with wind instruments.

Bervon, Inglis, organist and composer, bom in Bimingham, 1837. Principal bass at St. Andrew's, Wells Street, London, 1861 ; organist of the Parish Church, Aberystwith, 1866 ; thenre to Welshpool, and to St. Mary's Stafford, which last he held till abont 1880. Editor of a "Collection of 201 Chants for Psalms and Canticles, " and composer of organ pieces (published in the Organists' Quarterly Joumal), songs, ete. He died at Shelton, near Hanlev, Staffs., Decemler 18, 1891.

Best, William Thomas, organist and composer, born at Carlisle, August 13, 1826. Took lessous from Young, the cathedral organist, but being intended for the profession of a civil engineer, he only took up the study of music serionsly when in Liverpool, 1840, he decided to ehange his vocation. His first appointment was that of organist at Pembroke Chapel, Liverpool, 1840; then, in 1847, to the Chureh for the Blind; and in 1848, organist to the Liverpool Philharmonic Society. In 1852 he was in London, giving recitals on varions organs, plaving at the Crystal Palace (Hyde Park), April 10. He held the office of organist at Lineoln's Inn Chapel, and in Oetober, 1853, was appointed organist and professor of the organ at the Royal Panopticon. Alont the beginning of 1855 he was appointed to St. Martin-in-the-Fields, and in August of that year he was elected organist of St. George's Hall, Liverpool. He conducted a grand concert, Octoler 10, on the occasion of the visit of the Inike of Cambridge, when the organ was opened, and gave his first popular recital, Octolver 20. For many years he officiated as organist at churches in Birkenhead and Liverpool, and in 1871 was organist at the Roval Albert Hall at Kensington. Throughout the United Kingdom he was recognised as the finest organist of his time, and his recitals were of the most important service to the art of organ-playing. His influence in promoting uniformity in organ construction has been great. He has given recitals in Paris and Rome, and in 1890 (August 9) opened the vast organ in the Town Hall, Sydney, N.S.W. In February, 1894, ill health caused him to re-

\section{BETJEMANN.}

sign his appointment at St. George's Hall, and the famons organist, after fifty odd years of artistic activity, retired into private life. A commemorative bust was mneiled in the Hall, October 20, 1896. As a composer, he was known from 1845, when his Fantasia in two movements was published: he is also a fine pianist, and some compositions for the pianoforte were issued in 1852 . In 1880 he received a Civil List pension of $£ 100$ per annum. He is an Hon. R.A.M.

Works.-Two overtures and a march, orchestra; Morning and Evening Service in F, op. 40. composed for Leeds Parish Church; Services, Kyries, etc.; Belold, I bring you glad tidings; Praise the Lord, and other anthems and hymns; Eighty chorals, selected and newly harmonized for four roices and organ, Novello, 1852. Glee, five voices. What monrnful thonghts. Tarantella, Allegretto pastorale, Notturno, op. 27, marehes, and other pieces for pf. Organ works. The modern school for the organ (1853?); The art of organ playing, parts I. and II. (1870); Thirty progressive studies; Collection of pieces, expressly composed for church use, six books; Six concert pieces; Three preludes and fugues; Sonatas in G and D minor; Fantasias, ete. Arrangements from the scores of the Great Masters, five volumes; Mozart's overture, "Die Zauberflöte" (1846); Editor of "Cecilia," a collection of organ pieces in diverse styles (containing important compositions of his own, festival overture in B flat, etc., 56 books published, still in progress); Organ music by Italian composers; Handel's organ concertos; Handel album; and a bicentenary edition of the organ works of J. S. Bach, commenced in 1885 .

Bestwick, Lavinia, see Fexton Lavinia. Betjemann, Gilbert Henry, violinist and conductor, bern in London. Pupil of $\mathrm{C}$. IV. Dorle. In 1858 was engaged by Costa as a second violin at the Royal Italian Opera, and later played in the orchestra of the Pyne and Harrison Company. For some years connected with the Carl Rosa Opera Company as violinist, condnctor, and director of the mise-enscène. Conducted performances of Royal English Opera Company at Covent Garden Theatre, January, 1884, and Italian Opera at Her Majesty's Theatre in November. Gave Chamber Concerts at Highgate, 188t-5; succeeded Dr. J.F. Bridge as Conductor of the Highbury Philhamonic Society in 1886; and ahout two years later was chosen as director of the operatic class at the R.A.M. In 1893 he was joint conductor and principal violin at the Promenade Concerts, Covent Garden; in 1895 he succeeded the late J. T. Carrodus as principal first violin at Covent Garden Opera; and in 1896 accepted conductorship of the Oxford Orchestral Society. Hon. R.A.M.; 


\section{BETTS.}

Associate of the Philharmonic Society, and musician in ordinary to Her Majesty. His son, Gilbert Richard, A.R.A.MI., boin in London, 1864, was a violinist and composer, and member of the Royal Italian Opera orchestra. His "Song of the Western Men," for chorus and orchestra, was produced by the Highbury Philharmonic, March, 1890. He has also written some songs and pieces for violin. He was killed while descending the Wetterhorn, September 9, 1896, by falling through a snow bridge.

Betts, Arthur, violinist and composer, a native of Lincolnshire, born 1774? Studied under Hindmarsh, Viotti, Dussels, and Steibelt. Was for 49 year's a member of the Royal Society of Musicians, and celebrated as a violin comnoissem. Died in London, September, 1847, aged 73. His danghter was a popular vocalist. Composed sonatas, duets for violin and 'cello, arrangements, etc.

Betts, Edward, musician and writer of 18th century. He compiled "An introduction to the skill of Musick, anthems, hymns, and psam tmnes, in several parts," London, 1724 .

Beugo, John, musician and engraver, bom in 1759; died at Edinburgh in 1841. He was a friend of Bums, the poet, whose portrait he engraved in 1787, partly from special sittings. He was an engraver of portraits and similar works in Edinburgh, and an amateur musician. Among other works he issued " The New Caliope, being a selection cf British and occasionally foreign melodies, newly arranged for the pianoforte, and engraved on copper, by John Bengo." Edinburgh, 1823-25, published in quarterly parts.

Bevan, Frederick Charles, bass vocalist and composer, bom in London, July 3, 1856. Began his career as a chorister at All Saints', Margaret Street, London, and having a fine voice was, at the age of eleven, chosen as solo boy of the choir. Studied the organ under C. E. Willing, and W. S. Hoyte, and held, for a time, appointments at St. Nartin's, Haverstock Hill, and St. Margaret Pattens. Sang in the Henry Leslie and Joseph Barnby choirs, and, after studying with Schira, $\mathrm{H}$. Deacon, and F. Walker, obtained the post of Gentleman of the Chapel Royal, Whitehall, 1877, and succeeded the late William Winm at the Chapel Royal St. James's Palace, 1888. Now widely known as a concert-singer, and the composer of a number of songs - Thesilver path, The sailor's sweetheart, The flight of ages, The dream of my heart, The mighty river, Watching and waiting, My angel, The everlasting day, and others extensively popular.

Bevin, Elway, Welsh composer and organist, was borm about the middle of the $16 \mathrm{th}$ century [1560-70]. He studied under Tallis, and was organist of Bristol Cathedral in 1589 .
BIGGS.

Gentlenan Extraordinary of the Chapel Royal 1605. Lost both places on its leeing aiscuvered that he was a Roman Catholic, 16:37. He died about 1640 .

Works.-A Briefe and short Introduction to the Alt of Musicke, to teach how to make Discant of all Proportions that are in use: very necessary for all such as are desirous to attaine to knowledge in the Art; and may, by Practice, if they can sing, soon le able to compose three, four, and five part ; and also to compose all sorts of Canons that are usuall, by these directions, of two or three parts in one, upon a Plain Song, 1631. A short Service in $\mathrm{D}$ minor, and Praise the Lord, anthem, in Barnard's Collection. Other anthems exist in mannscript. Bevin is nsmally credited with having been the first in England to systematise the rules for the composition of canons.

Bexfield, William Richard, composer and organist, was born at Norwich, April 27, 1824. He studied under Dr. Zacharial Buck. Organist of Boston Church, Linculn, 1815. Mus. Bac., Oxon., 1846. Unsuccessful candidate for the Music Professorship of Oxford University. Organist of St. Helen's Church, Bishopsgate Street, London, 1848. MIns. Doc., Cantab., 1849. He died at London, October $29,1853$.

Works.-Israel Restored, oratorio, produced, Norwich, October 16, 1851; and at the Norwich Festival, September 22, 1852 ; reproduced, Royal Albert Hall, London, April 15, 18s0. Church Anthems, in score, with por. trait, London, [1849]. A set of concert fugues for the organ, London, [1845-1846.] Musica di camera [1848]. Eight Chorales for voices and organ [1845-1817?]. Six songs [1847], part-songs, ete.

Bickham, George, engraver and pemman, flourished in the first part of the 18 th century. He engraved "The Musical Entertainer," London, 2 vols. [c. 1737], a collectiun of songs of some value. He died in 1769.

Bicknell, John Laurence, writer and barrister-at-law, was born in 1740 , and died March 27, 1787. He wrote a poem called "The dying negro," and is the reputed author of "Musical travels through England, by Joel Collier, Licentiate in Music." London, 1774 (various editious). In 1818 appeared "Redivivus, an entirely new edition of that celebrated author's Musical Travels." The work is a satire on Burney, and is an amusing production now getting very scarce. It has also been ascribed to Peter Beckford, a writer on musical and other subjects.

Biggs, Edward Smith, glee composer and pianist, was born during the latter half of the 18th century, and died about 1820 . He was a teacher of music in London.

Works.- Six duets and three trios, London, 


\section{BIGGS.}

1800; Six Sicilian airs for one voice, London, 1805; Six Welsh airs adapted to English words, and harmonized for two, three and four voices, London, two sets; Four sets of twelve Venetian airs for one voice, London, 1800 ; Six songs, written by Mrš. Opie, London, 1800. Glees: Ah! me, with that false one; A poor soul sat sighing; Bring the song; Hark! what sound; Here beneath this willow sleepeth; Here's lawn as white as driven snow; In my cot, tho' small's my store; Lost is my quiet for ever; Now ev'ning's come; $\mathrm{O}$ ! synge unto mie Roundelaie; Under the greenwood tree; Where feeds your floek; Will you buy any tape? Songs : The suicide; Come, my lads, time posts away; Fox and the crow; Barbara Allan; Where are you going my pretty maid? Duets. Pianoforte: Twenty-eight Waltzes; Rondos and marches.

Biggs, Rev. L. C., author of " English Hymnology" (a series of articles reprinted from the "Monthly Packet.")

Biggs, Walter Lyle, organist, composer, and conductor, born at Notting Hill, London, September 16,1857 . Received his first musical instruction from his mother's uncle, the Rev. S. Lillycrop (q.v.), afterwards studied organ and harmony under G. F. Geaussent. WVas organist of All Saints', Child's Hill, Kilburn, 1877-81, and in 1882, elected, after competition, to St. Peter le Bailey, Oxford, since when he has founded a musieal society, given oratorio services in the Church, and concerts in the Old Town Hall. Ile conducted the Holy Trinity Musical Society, 1887-8; and in 1895 founded ihe East Oxford Mrusical Society. He has also given organ recitals ir Wadham, Worcester, and Trinity College Chapels.

Works.-Sacred cantata, Elihu, Op. 3 (produced, Wadham College Chapel, July, 1891); Psalms 147-8-9 and 150, Op. 5, 6, 7, 8, for soli, chorus and orchestra; Epithalamium (Spenser), Op. 4, for soprano and baritone soli, men's chorus, and small orchestra; Church compositions, Op. 2. Fairy opera, Marie (libretto by Mrs. Linsley, produced, Oxford Institute, February, 1896); Set of four songs, Op. 9; Short organ pieces, Op. 1. Of these only the Cantata and Church compositions are yet published.

Bilby, Thomas, musician, was born at Southampton, April 18, 1794. He served for some time in the army, but subsequently entered the teaching profession. For twentyeight years he was parish clerk of St. Mary's, Islington. He died at Islington, London, September 24, 1872. He is only known as the composer of the hymn-tune called "Joyful," which is usually sung to his own words "Here we suffer grief and pain."

Billington, Elizabeth, born WeICHSEL,
BILTON.

soprano vocalist, born in Soho, London, about 1768. She studied under her father, who was a German, and Schroeter, from an early age. In 1782 she sang at Oxford, and in October, 1783 she was married to James Billington, a double-bass player of Drury Lane Theatre. She appeared on the stage at Dublin in 1783 , and sang in different parts of Ireland till 1786. She sang in "Love in a Village" at London, February 13, 1786. Afterwards, she went to Paris, but in 1787 she returned to London. Owing, in part, to anonymous attacks on her character, she went to Italy with her husband in 1794, and appeared in varions cities with much success, In 1799 she married a Frenchman named Felissent (Billington having died in 1794), but left him, owing to his ill-treatment, and returned to London in 1801, when she appeared at Covent ('rarden, King's Theatre, ete. In 1811 she retired, and in 1817 she was reconciled to her hushand. She died at St. Artein, August 25, 1818. Full details of her career will be found in Hogarth's "Memoirs of the Musical Drama," and in "Memoirs of Mrs. Billington from her birth; containing a a variety of matter, ludicrons, theatrical, musical, and with copies of several original letters written by MIrs. Billington to her mother," London, 1792. A suppressed book, to which she replied in "An Answer to the Memoirs of Mrs. Billington," 1792.

Billington, Thomas, pianist, harpist, and composer, was born at Exeter in 1754 . He lived in London as a teacher of the piano and harp, but died at Tunis in 1832.

Wonzs.-Music to Gray's Elegies, Op. 8؛ Pope's Eloisa to Abelard: Prior's Garland; Petrarch's Laura; The Children in the IVood, Morton; Four sets of twelve canzonets for two voices, London, 1784-90; Six songs for roice and pianoforte; Shenstone's Pastorals, consisting of 24 ballads; Music to Young's Night Thoughts, 1790; Music to Pope's Elegy to the Memory of an unfortunate Lady; Numerous glees; Songs; Scotch airs, etc., hamonized, London [1785]; Six sonatas for harpsichord or pianoforte, Op. 5; Three trios for a violin, tenor, and 'cello, Op. 7 [1780].

Bilton, J. Manuel, bandmaster and composer, born at Plymouth, October 8, 1862, son of a master-at-arms in the Royal Nary. Educated at the Royal Naval School, Greenwich, and joining the school band, his playing the baritone at a concert of the band at the Crystal Palace, 1875, attracted the attention of J. Lawson, bandmaster of the Royal Artillery Brass Band, who took him into that baud. He met with a friend in Colonel Hime, who helped him in every way. In 1886 he was appointed Trumpet-Major of a Brigade of Artillery at Limeriek, and studied under Stanislaus Elliott, and in 1887 entered Lineller Hall. After the death of Charles Cousins 


\section{BINFIELD,}

(May 1890) Bilton was made Director pro tem, an office which he filled until his appointment as Bandmaster of the 17th Lancers, in February, 1891 . He began composition very early, and his first attempt was a Grand Overture. This, rewritten and corrected, was performed at Woolwich, in 1878. At the Military Exhibition of 1890 , he was awarded prizes for a Morning Service, Concert Overture, and a work for brass, military, and string band, singly and collectively. He has also written a Wind Quintet, Cantata, "The Wreck of the Hesperus," a Symphony, and Overtures.

Binfield, a musical family of importance, for many years prominent in the town of Reading, Berks, where the first of the name, RichaRd BINField, established a music business in 1799. He was organist of St Laurence Church from 1804 to the time of his death, 1839. The Berkshire Musical Festival, dating back at least to 1786 , was for many years under bis direction, and he conducted a performance of the "Messiah" so late as September 28, 1839, when Balfe sang some of the bass solos. He edited and compiled the Reading Psalmody, and Reading Choral Service, works much in use in the neighbourhood for a long time. His son, John Bilson BinFIELD, born at Reading, 1805, was an organist, and appears to have continued the Triennial Festivals, as they were given up to the year 1846. He was the first to set Dean Milman's "Nartyr" of Antioch" to music (Nilman being vicar of St. Mary's, Reading, 1818-35). He died at Reading, June 8, 1875. Another son, Thomas Binfiesd, settled in London, where he was engaged as a violoncellist. He was also a good violinist and pianist. Nember of the Royal Society of Musicians. Died, London, December 23, 1810.-R. L. Binfield, a third son, was in the business at Reading, and conducted Choral Concerts, but no particulars can be gleaned concerning him.Hannah Rampton Brnfield, born at Reading, 1810 , sister of those preceding, was in her turn proprietor of the business. She was an excellent pianist and harpist, and contributed many hymn tumes and chants to the collections edited by her father, whom she succeeded as organist of St. Laurence, a post she held for forty-five years, Her amnual concerts were the chief events of the Reading musical season, and she played, at the Festival of 1839 , a concerto upon the organ. Her death took place at Reading. May 2, 1887. Fansy Jane daughter of John Bilson Binfield, was a pianist and concert-giver, and an artist of repute. She died at Reading, September 3,1881 . Of other members of the family little can be ascertained, but Louisa BisFIELD, as a performer on the concertina, was often heard at Reading and elsewhere from thirty to forty years ago. Another, Louisa

\section{BIRCH.}

Binfield, third daughter of Richard, died at Reading, November 26, 1856.

Bingley, Rev. William, writer and clergyman, was born at Doncaster in 1774. He studied at Cambridge, where he graduated II.A. He died at London, Narch 11, 1823. Author of "Musical Biography, or Memoirs of the lives and writings of the most eminent musical composers and writers who have flourished in the different countries of Europe during the last three centuries," London, 1814, 2 vols.; 2nd edition, London, 1834, 2 vols. Animal Biography, 1802, 3 vols., ete. He also added "sixty of the most admired Welsh airs, collected by W. Bingley, the basses and variations arranged for the pf. by W. Russell, jun.," Loudon, 1810.

Binney, Thomas, clergyman and author, published "The Service of Song in the House of the Lord," I ondon, 1849. He edited Baird's Liturgies, and wrote numerous other works.

Birch, Charlotte Ann, soprano vocailst, was born at London in 1815; and died there in $185 \%$. She sang chiefly at London and provincial concerts.

Birch, Edward, clergyman, author of "A Tract on Responding, with a postscript on Singing," Manchester, 1862.

Birch, Edward Henry, organist. Received his training in music at the Cathedrals of Gloucester and Winchester. Graduated Mus. Bac., Oxford, 1875. Has held organ appointments successively at St. Saviour's, Eastbourne (1872); st. Gabriel's, Warwick Square, London (1873); All Saints', Kensington Park (1874); St. James's, Notting Hill (1886); Choirmaster, St. Columbas', Notting Hill. His compositions include a cantata, "Tortigern and Rowena" (produced Ladbroke Hall, Notting Hill, April 12, 1891), an Evening service, and other church music, organ pieces, etc.

Birch, James Albert, alto vocalist, borm at Sheffield, 1839. Sang in church choirs in Sheffield, and subsequently was in the choir of Canterbury Cathedral (1873-6); then at Westminster Abbey; and finally at the Chapel Royal, St. James's, a post he retired from in 1892 , owing to ill health. Lecturer on vocal music at the Church Missionary College; founder and conductor of the Temperance Choral Society; and sometime conductor of the London Board School Festival Concerts at the Crystal Palace. Musical editor of the Standard Book of Song, for Temperance Meetings and Home Use, and author of a booklet, The Voice Trainer. A Vice-President of the Tonic Sol-fa Association, he was a zealous worker to the last. $\mathrm{He}$ died somerwhat suddenly, at Hastings, June 22, 1895.

Birch, Samuel, composer and minor poet, was born at London, November 8, 1757 . He served as a Lord Mayor of London in 1815. Died at London, December 10, 1841. 


\section{BIRCH.}

Works.-Musical dramas, etc.: The Mariners, 1793 ; Packet Boat, or a peep behind the veil (a masque), 1794; Adopted child, 1795; Smugglers, 1796 ; Fast asleep, 1795; Albert and Adelaide, 1798. Glees, songs, etc. To some of these musical dramas, Attwood and others wrote the music.

Birch, William, organist and composer, born at Lichfield in 1775. He was an organist at Tamworth, and died November 17, 1815. Another WILLJAM Burch issued "Sacred Music, consisting of psalms, hymns, anthems, etc." London [1825].

Birch, William Henry, organist and conposer, born at Uxbridge, May 5, 1826. He studied under Elvey, Blagrove, and R. Barpett. He became organist of St. Mary's Church, Amersliam, and was a teacher of music at Caversham, near Reading. He died there July $18,1888$.

Works. - The Merry men of Sherwood Forest, operetta, 1872; Wreck of the Argosy, cantata, 1879; Twelve anthems, Reading, 1877. Choruses, glees, quartetts, trios, etc, 1856. Canticles of the Church of England [1875]; Evensong, a selection of hymms and chants [1860]; Gems of sacred harmony [185:3], Sabbath Recreation, a selection of favourite sacred melodies . . . 1857; Standard Psalmist ... [185:-4]. Comic series of juvenile songs, concertina albums, journals, pf. music, songs, etc., etc.

Bird, George, organist, was appointed to the Parish Church, Walthamstow, March 26, 1829, after playing on probation with other candicates from the previous Advent Sunday, November 30,1828 . This post he held till the time of his death, August 14, 1894, a period exceeding 65 years, during which he officiated under three vicals, and assisted at the conse. cration of the first three of the churches which have been added to the district. He edited "A collection of 100 chants" (Novello), and a Hymm Tune-Book, in much use in their day. His son, Ienry Richard Bird, born at Walthamstow, November 14, 1842, was appointed organist of St. John's, Walthamstorv, in 1851. Then for some years he studied with J. Turle, and in 1858 was elected organist of St. Mark's, Clerkenwell ; in 1860 appointed to Holy Trinity, Sloane Street; in 1866 to St. Gabriel's, Pimlico; and in 1872 to St. Mary Abbots, Kensington, a post he retains. He was organist at the Festivals of the London Church Choir Association, at St. Paul's Cathedral in 1880-1; and has for a long time given concerts at Fensington. In 1891 he was appointed accompanist at the Monday and Saturday Popular Concerts, a capacity in which he is in much request. He is a Professor of the pf. at R.C.M., and at Trinity College, London.

Bird, William, musician of Watford, issued "A Set of Psalm and Hymn Tunes with

\section{BISHOP.}

an Anthem for four voices," London, 1807, 2ud edition, 1810; "Original Psalmody, 57 Psalm and Hymn Tumes in score. . . revised by S. Wesley," 1827, also 1830 ; "Gems of metrical Psalmody," London, 1835.

Bird, William Hamilton, musician, published "The Orrental Miscellany, a collection of the most favourite airs of Hindoostan, adapted for the harpsichord," Calcutta, 1789.

Birde, William, see Byrd, Williai.

Birkensha, John, Irish author and musician, who lived in London as a teacher of the viol during the first half of the 17th century. He translated the "Templum Musicun," of Alstedius, as "Templum Musicum, or the musical synopsis of the learned and famous Johannes Henricus, Alstedius: being a compendium of the rudiments both of the mathematical and practical part of musick. ." London, 1664.

Birnie, Patie, or Patrick, violinist and minor poet, who lived at Kinghorn, in Fife, at the end of the 17 th century. He wrote "The auld man's mear's dead" and other songs, and was a fannous fiddler in his day. $\mathrm{He}$ distinguished himself at the Battle of Bothwell Bridge, which he took part in as one of the Fife militia, by ruming away.

Bishenden, Charles James, bass rocalist and teacher, born at Hemel-Hempstead, Herts, in 1848. IJas sung with success in his native town and other places. He was one of the early adrocates for the adoption of the French pitch in this country. In 1882 he married Isabel Mary Beachey, a vocalist, who has appeared with him at various concerts. He is the author of a pamphlet, "The voice, and how to use it," and "How to sing," etc.

Bishop, Anna, born Riviere, wife of the undernoted. A French soprano vocalist, was born in London, I812 [1814-15]. She studied under Moscheles at the R.A.M., and married Sir Heury Bishop, 1832. Début at London, 1837. She sang at the musical festivals of Gloucester, York, and Heleford. She left her husband and travelled with Bochsa in Europe 1839. Appeared in Copenhagen, 1839. She sang in Stockholm in 1840 ; St. Petersburg, 1840; in Russia, 1840-1; in Austria, etc., 1842 ; Italy, 1843. She went to America in 1846, and travelled there and in Australia, etc., 1853-8. She married Martin Schultz, of New York, 1858. Returned to England, 1858, and in 1859 went back to America. She travelled round the world, concert-giving, in 1865-69, and again in 1873-76. Between the years 1839 and 1843 she sang at 260 concerts. She was a cultivated vocalist and member of many musical societies. She died at New York, March 18 [20], 1884.

Bishop, Sir Henry Rowley, composer, was born at London, November 18, 1786. He studied music under F. Bianchi, and became 


\section{BISHOP.}

musical director at Dru y Lane Theatre, 1810 . 11. Founded (with others) the Philharmonic Society, 1813. Visited Dublin, 1820. Conductor at Drury Lane Theatre, 1825. Musical director of Vauxhall Gardens, 1830. He married (1st) Sarah Lyon (died 1831) and (2nd) Amma Revière. Mus. Bac., Oxon., 1839. Musical director at Covent Garden Theatre, 1840-41. Conductor of the Ancient Concerts, 1840-48. Professor of Music at the Edinburgh University (in succession to John Thomson), 1841-3. Knighted, 1842. Professor of Music at Oxford University (in succession to Dr. Croteh), 1848. Mus. Doc., Oxon., 1853. He died at London, April 30, 3855. Buried at Finehley (or Marylebone) Cemetry.

Works.-Operas and Ansical Dramas: Angelina farce, 1804 ; Tamerlan et Bajazet, ballet, 1806; Narcisisa et les Graces, grand Anacreontic ballet, 1806 ; Caractacus, ballet, 1806 ; Love in a tub, a pastoral ballet, 1806; Mysterious bride, 1808 ; Circassian bride, 1809 ; Mora's love, ballet, 1809 ; V'intagers, 1809 ; Maniac, or Swiss banditti, 1810; Knight of Snowdoun, 1811; Virgin of the sun, 1812; Ethiop, or Child of the desert, 1812; lienegade, 1812; Haroun Alraschid (altered from Athiop), 1813: Brazen bust, 1813; Harry Le Roy, 1813; Miller and his men, 1813; For England ho! 1813; Farmer's wife (with Reeve and Davy), 1814; Wandering boys, or the Castle of Olival, 1814; Sadak and Tialasrade, or the Waters of oblivion, 1814; Grand alliance, 1814; Forest of Bondy, or Dog of Montargus, 1814; Naid of the mill, comic opera, 1814; Noble outlaw, 1815; Telemachus, 1815; Midsummer night's dream (Shakespeare), 1816; Guy Mlannering, or the Gypsey's prophecy (from Scott), (with Whittaker), 1816; Heir of Vironi, or Honesty the best poliey, 1817; Don Juan, or the libertine (compiled from Mlozart), 1817; Duke of Savoy, or IVife and mistress, 1817; Barber of Seville (compiled from Rossini), 1818; Marriage of Figaro (compiled from $\mathrm{Moz}-$ art), 1819 ; Heart of Midlothian (from Scott), 1819; A Rowland for an Oliver, 1819; Gnome king. or the Giant mountains, 1819 ; Comedy of errors (Shakespeare), 1819 ; Antiquary (from Scott), 1820; Battle of Bothwell Brigg, 1820; Henri Quatre, or Paris in the olden time, 1820; Twelfth night (Shakespeare), 1820; Don John, or the Two Violettas, 1820; Two gentlemen of Verona (Shakespeare), 1821; Montrose, or the Children of the mist (from Scott), 1820; Law of Java, 1822; Maid Marian, or the Huntress of Arlingford, opera, 1822; Clari, or the Naid of Milan, opera in three acts (J. H. Payne), 1823; Beacon of liberty, 1823; Cortez, or the Conquest of Mexico, 1823; Native land, or Return from slavery, 1824; Charles the Second, operetta, 1824; Fall of Algiers, opera, 3 acts, 1825: Hofer, the Tell of the Tyrol (compiled from Rossini), 1825; Edward the Black Prince,

\section{BISHOP.}

1825; Aladdin, or the Wonderfut lamp, opera (by J. R. Planché), London, 1825; Kuights of the cross, opera, 1826; Under the oak, opera, 1830: Adelaide, or the Royal William, opera, 1832; Home, sweet home, operaiic drama, 2 acts, 1832; Nagie fan, or the Fillip on the nose, operetta, 18:32; Yelva, musical drama, 2 acts, 18:33; Rencontre, operatic comedy, 1833; Doom kiss, opera, 1836 ; Slave, opera in 3 acts (by J.R.P lanché), 1816; As you like it (Shakespeare); Aurora, ballet; Brother and sister, 1814; Cymon (from M. Arne), 1815 ; Comus, 1815: Dr. Sangrado, ballet, 1814; December and NIay; Don Pedro, tragedy (2 glees); Der Freyschutz (compiled from Weber), 1824; Englishman in India, comic opera, 1227; Faustus, 1825 ; Fortmnatus and his sons, 1819; John of Paris (from Boieldieu), 1814; John du Bart (incidental music), 1815; Ninetta, opera, 3 acts ; Bottle of champagne, operetta; Czar of Muscovy, opera; Humorous lieutenant, 1817 ; Romance of a day, operatic drama; Zuma, or the Tree of health, comic opera, 1818. Fallen angel, oratorio; Seventh day, cantata, 1833 . Glees: Six original English glees (poetry by IJemans, Baillie, etc.); Twelve original English glees; Complete collection of glees, \& vols., 1839 (other collections have since appeared, one-Novello's-with orchestral accompaniments). Songs: Songs for the seasons, by T. H. Bayly ; select and rare Scottish melodies, poetry by Hogg; Sungs of the uld chateau, puetry by Bayly; Lays and legends of the Rhine, J. R. Planché; Do. of the Upper Rhine; Melodies of various nations, Bayly ; Songn for leisure hours, W. Walton; Edition of IIandel's trios, choruses, etc.; Grand trimmphal ode, Accession of the king; Fumeral ode; Jolly beggars, eantata by Robert Burns; Single songs in great numbers. Pf. music, and varions pieces of instrumental music. English national melodies, poetry, edited by Chas. Mackay. Syllabus of a course of six lectures on the origin and progress of the lyric drama, or opera... to be delivered in the Manchester Athen:eum, Svo, 1845.

Bishop is now remembered chiefly by his songs and glees, which are among the fimest specimens of the modern English School. None of his operas or musical dramas save "Guy Mannering" are now performed. Many of them were mere occasional pieces, but a number of the songs and concerted rocal pieces scattered through them are in constant use by rocalists and choral societies.

Bishop, John, composer and organist, born in 1665. Studied under Daniel Rosein. grave. In 1687 he was lay-tical at King's College, Cambridge, and in 1688 beeame teacher of choristers. Organist of Winchester College in succession to Jeremiah Clark in 1695 ; lay-vicar of Winchester Cathedral, and in 1729 succeeded Vaughan Richardson as 


\section{BISHOP.}

organist. He died at Winchester, December 19,1737 . He published "A Sett of new Psaln Tumes, in four parts," cantus, medius, tenor and bassus, J. Walsh [1700]; "Supplement to the now Psalm-bork, consisting of 6 new anthems and 6 new I'salm tunes," London, 1725: and some of his compositions in MS. are in the britisl Musenm.

Bishop, John, organist and author, born at Cheltenham. July 31, 1818. He was sueeessively organist of st. Paul's, Cheltenham, 1831 ; Blackhn'n, 1898-39; St. James', Cheltenham; Roman Catholie Chapel, and st. John's, Cheltenham. These appointments he resigned in 1852. He died at Cheltenham, Felmary $8,1890$.

Works - Inthems, organ music, songs, ete. Two collections of (hants, $1852-57$, containing "Renarks on the singing of the daily Psahns." Brief memoir of George Froderick Ifandel, 1856. Remarks on the eamses of the present generally degraded state of music in our churches, 1s60. Repertorimm Mnsicese Antiquar-a miscellaneons conlection of classical componitions l,y the greatest masters of Italy, Germany, ed. (with J. Waren) London, 1818. He edited varions eslections of oman music, anel transtated varions works on musical thenry hy Czerny, Reicha, Cr. Weler, otto, spohi, ete.

Bisse, Thomas, clergyman and anthor, publishet "A termom prothed at I Leveford at the meeting of the choirs of I lereford, Groucester and Forcester, in Septernber. 1726- I got me nem-singers and womensingers and the delights of the sons of men, as musical instruments, and that of all soets,", 1720. I)r. I isse was the virtual founder of the Three ('hoirs Festivals, which he first proposed at Glomenter in 1724.

Bisset, Catherine, pianist, born London in 17!5. She was edest danghter of liobert IBissit, 1.1.1), anthor of a "life of Purke," and other works. She stadied nuder J. 13. Cramer, and firt alpreared at the New Mnniscal Fund Concert in 1811. In 18s? she appeaser at larice, and thereafter was much engaged in Lomolom as pianint at prisate con-

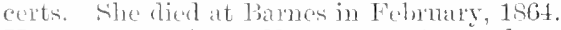

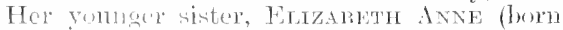
London, 1500; died -?), was a barp-player and componer, who studied under F. Dizi. She pullished a number of armoments and fantatsias for the harp and pianoforte.

Black, Andrew, baritome vocalist, born in Glasson, Janmaty 15, 1859. Was for some time creanist of the Anderston U. P. Church, Glasgow, but devoloping at fine baritone voice, he studied singing muter A. Raurlegger, and J. B. Welch; alterwards receiving instruetion from Domenices Scafati in Milan. From 1881 his singing attracted attention in Scotlund; but it wasat the Crystal Palace Concert,

\section{BLAGROVE.}

July 30, 1887, that he achieved his first great success. He sang there twice during the following month, and from that time his advance was rapid. He made a tomr in America, and sang in opera. His first appearance at a provincial Festival was at Leeds in 1892; and in 1894 he was selected for the title part in "Elijah" at the Bimingham Festival, and was engaged for the same at Gloucester in 1895, and at Norwich, 1896. He has sung at all the most important concerts in the Kingdom. Since its opening, in 1893 , he has been a professor of singing at the Manchester Royal College of Nusic. He is a painter of considerable ability, and his wife is an accomplished pianist.

Blackwell, Isaac, composer, flourished during latter part of 17 th contury. Composed "Choice Ayres, Songs, and Dialognes to the theorbo-lute and bass-violo," London, 1657.

Blackwood, Helen, see DeffFin, Lady. Blagrave, Thomas, composer and musician, was lom in Rerkshire about 1661. He was a Centleman of the (hapel Royal, and a member of the private band of charles II. lle died on Novemuler 21, 168s, and is lomied in the north choister of Westminstex Abbey. He composed a few songs.

Blagrove, Richard, violinist and toacher. Anthor of "A New and Improred system tc the Art of Playing the Violin." Tond., 1828. Fantasias, ete, for pof, concertina, etc. His lorother IVILesam, who died at Lomelon in 1858 , was also a violinist.

Blagrove, Henry Gamble, violinist, was born at Nottingham, October 20th, 1811. Son of above. First appeared in pullic,1816. Taken to London by his father, 1817. Played at Drury Lane Theatre, 1817. Stndied under Spanoletti, 1821 , and hecame a pripil at the R.A.AI., 1823. Gained silver medal, R.A.M., for violin playing, 1894. Menuke of Queen Adelateles private band, 1830-1837. studied under spohr in Germany, 1832-34. Plased at Limdon Concerts and l'rorincial Futivals. He dind at London, December 15th, 1872.

Blagrove, Richard Manning, vinla and concertina player, lrother of the preceding, was ] rern at Nottingham. In 1837 he rntered the R.A.MI, studying the viula nnder II. Hill. He also stndied the concertina, and played a solo on that instrument at the llanover Srpuare Rooms, Narch 12th, 1849. With Giulio Iregondi, George Case, and A. T. Sedgwiek, he formed a concertina fuartet, the first concert taking place in the room just named, June 12th, 18tt. The next year found him engaged at concerts as pianoforte accompanist, and viola player in his brother Honry's quartet concerts. From that time onward he was prominent in musical work. On the death of Henry Hill, in 1856, he 


\section{BLAIKIE.}

succeeded him as principal riola in the Philharmonic orehestra, and at the Three Choirs Festivals, posts he held until 1894. For many years, up to 1890 , he was a professor at the R.A.MI., and a Fellow of that Institution. In 1890, he began a series of concerts at Clapham Hall, assisted by his sons STAXLEY and Arthur, and his wife, née Freeth, a gifted pianist. He died in London, October 21st, 1895. Published Concertina Joumal, 1853, Fantasias, ete., pf. and concertina. It was speeially for him that G. A. Maefarren wrote his eoncertina quintet.

Blaikie, Andrew, engraver and muieian, who flourished in Paisley in the first half of the present century. He noted down and engraved the tunes in "Motherwell's Minstrelsy," 1827 , and was the owner of two 17th century musical manuscripts of considerable value.

Blair, Hugh, organist and composer, eldest son of the late Rer. R. H. Blair, MI.A., F.R.A.S., of Arrshire family. He was bern at Worcester, IIay 26th, 1864, and edncated in Yorkshire, and the Cathedral school, Woreester, studying misic under the late Dr. Done. In 1883 he gained the Choral Scholarship at Christ College, Cambridge, where he was a pupil of Dr. Crarett, and sir G. A. Macfarren. He graduated P.A., 1886, and Mus. Bac., 1887. Deprty organist at Woreester Cathedral, 1887, he was appointed organist-in-charge, 1889 , and succeeded Dr. Done as organist in 1895. He conducted the opening service of the Worcester Fentival in 1890, and the Festivals of 1893-6. He is Conductor of Musical Societies at Worecster and Redditch, and a Vice-President of the London Church Orehestral Societr.

His compositions include two Gantatas:"Harvent Tide" (Trinity Chunch, Parnes, 1892); "Blessed are they who wateh" (Worcester, 1894): Festival Evening Sorviee, eight volees (Worcester Eestival, 19s7); Evening Service in B flat (Gloncenter Festival, 1892); Te Demm and Jubilate in D (Worecster Fentival, 1893); Anthems, Services, ute.

Blair, William, violinist and composer, born at Crathie, Aherdeenshire, Oetolser Deth, 1793, died there Norember 12th, 1sht. He was famous as a player of scots danee music, and was a sort of fiddler to Quncen Victoria from 18t8. He composed some dance music, and is remembered by his strathopery, entitled, "The Queen"s Fiddier"s compliments to MIr. Troup," His sons Johx and JAuts ate also violinists.

Blake, Benjamin, composer, was bom at Kingsland, London, 1751. Festndied munic by himself, and leamed the violin, 1760. Member. of orchestra of Italian opera, London, 1768. Professor of music in Public Sehonl at Kensington, 1789-1810. He died in Londun, 1827.

\section{BLEIV.}

Works. - Three bocks of six duets for violin and viola. Six sonatas for pf. and violin. Collection of sacred musie for voices and organ. Three sclos for viola, with accompaniment for bass. Glees and songs. A musieal dialogue between master and seholar. Six duets for riolin and tenor (1785), and sett; 3rd sett, Op. 3; six sonatas for the pf., Op. 4. Miscellaneous collection of rocal music, Op. 6, 1814.

Blake, Rev. Edward, composer, was born at Salisbury, 1708. Fellow of Oriel College, Oxford. Prebendary of Salinbury Cathedral, and rector of Tortworth, filoncester, 1757. Perpetual Cnrate of St. Thomas' Chureh, Salishury. Vicar of St. Mary the Virgin, Oxford, 175t. He died on June 11, 1765. Composed anthems and instrumental duets.

Blakeley, William, organist and composer, born at Wakefield, February 12, 1852. He studied monder Dr. IV. Spark and Dr. J. F. Bridge. In 1 sog he became organist of Thomes Chneh, Wakefield; Wakefield Choral Society, 1s6-69; and afterwards at Croydom, Batley, Morningide T. P. Church, Edinlumgh, 1s81-40; Qnuen's Park Parish Chnrch, Glasgow, 1890. He in a Mus. Bae. of Toronto.

Comporer of "Jonah," an oratorio; anthems, part-songs, songs, and muic for the organ, te. Alio "Prize Psalmody," a collection of origimal hymm tunes.

Blancks, Edward, composer of tunes in Exte's "Whole bouke of Pralmes," 1592 . He lived during the latter part of the 16th and and beginuing of the $17^{\text {th }}$ centuries.

Bland, Dora, see Jorits, Mrs.

Bland, Maria Theresa, hom Romanzini. soprano rocalist, wat bum in London, of Italian parents in 1769 . First appeared at Roral Circus, London, 1773. Sang at Dublin Theatre. Defont at Irury Lane Theatre, October 24, 17 S0. Narried IIr, Bland, brother to Mrs. Jordan. Sangat 1 Faynarlet Theatre, 1791. Sang in London till 182t. She died at Westminster, Jannary 15, 1\$38, insane.

She was a magnificent ballarl rocalist, and earned mont of her success on the operatic stage.

Blandford, George, Marquis of, 4 th Dnke of Marlborongh, lom Jamnary 26th [1738]. He was comeeted with many of the mnsical enterprises dnung the end of last and beginning of the present centuries. He died on Jannary 13, 1817. Among other: works he publinhed "Trelve Glecs for three and four roicee," Londm [179.8]; a "Collection of rocal music," and rarion sonatas for the piannforte.

Blew, William Charles Arlington, barrinter-at-law and musician, was bom at London in 18.8, and ealled to the har in 1876. Anthor of "Organs and Organists in Parish Churches. A hand-book of the law 


\section{BLEWITT.}

relating to the custody, control, and use of organs, and the duties, rights and disabilities of organists," London, 1878.

Blewitt, Jonas, composer and organist, born in first half of 18th century. He held the appointments of organist to st. Nargaret Pattens, and St. Gabrie], Fenehurch, London, about 1795, and to Sit. Catherine Coleman, Fenchureh strect. He performed in public. Died at London in 1805.

Works.-Ten voluntaries or pieces for the organ, op. 5; Twelve easy and familiar movements for the organ, up. 6; Treatise on the organ with explanatory voluntaries, op. 4, London, n.d.

Blewitt, Jonathan, son of above, composer and organist, born London in 1782. He studied under his fatleer and Battishill, and in 1793 became deputy to his lather. He was snceessively organist of Haverhill, suffoll; ; Brecon ; Sheffield, and of st. Andrew's Church, Jullin, in 1s11. In 1811 he became composer and conductor at the Theatre Royal, Dublin, and soon after was made grand organist to the Masonic Soriety of Iredand. He returned to London in $18 \% 6$, and became musical director at sadler's Wells 'Theatre, 1828-29. Teacher of rocal numic and organist in London. He died at London, sent. 4, 1853.

Wonks-Music to Plays, etc. : Harlequin, or the Man in the Moon, 1sz6, Talimnan of the Elements; Auld Robin Gray; My old Woman; Corsair; Magician; Island of saints; Rory O'More; Mischief Maling, etc. Instrumental: Concerto for pf. and orch.; Somatas and Duets for pf.; Uaprices, fugues, and sonatas for the organ. Yocal Assistant, treatise on singing, London, n.d. Songs: A nice little man: Adieu my monstachios; Bamey BralIaghan; England, merry England; "Let us drink to old friends; My hopes are fixed upon thee; Emerald Isle; The White Cliffs of England; (rood bye; Groves of Blamey; Hamlet; 1 saw him but once: New cries of London; O for a eot; Our jolly stout jackets of blue: Phillis, have you seen my lore?, I'ie-nie; When crowned with sumner roses.

Bliss, Mrs. J. Worthington, bom M. Lindosay, composer of the present time. Has written a large number of songs, some of which attained great popularity in their day. Among them may be named-Airy, fairy Lilian; Alone; Arrow and the song; The Bridge [1856]; Innish Maid; Excelsior [1854]; Far anay [1868]; Home they brought her warrior dead [1858]; Hymm of the Moravian Nuns (Pulasli's Banner) [1854]; Somgs for children, 1871-72, in number's; Part-songs, etc.

Blitheman, William, composer and organist, flowrished in latter half of 16th century. He was master of the chorister's of Christ Chureh, Oxford, in 1564, and one of

\section{BLOW.}

the organists of the Chapel Royal. IIus. Bac., Cantal., 1586. Mus. Doc, do. [15?]. He died at London, in 1591.

Blitheman was the preceptor of Dr. John Bull, and was streceeded by him at the Chapel Royal in 1591. His biography is unknown, but it is believed that he composed church music, and had much celebrity in his time.

Blockley, John, composer, writer, and publisher, was born in 1800 . Engaged in music-publishing business in London. $\mathrm{He}$ died at London, December 24th, 1882.

Works.-The Sabbath Minstrel [collection of sacred music], London, n.d.; The Singer's Compamion, London, n.d. Songs : My childhood's hone; I remember thy voice; We have heen friends together; The absent one; A blessing on thine eyes; The Arab's farewell to his favourite steed; The friend of our early days; Love not; Love on (reply); The Englishman; and numcrous other songs written to words of the Hon. Mrs. Norton, ete. Selection of saered melodies from the Works of the most celebrated eomposer's, n.d. Collection of psahm and hymn tmes for four voices, London, n.d.

Blow, John, composer and organist, was born at Westminster (not North Collingham, Nottingham, as usually stated), 1648. One of Children of Chapel Royal, 1660. He studied under Captain Cook, Hingeston, and Christopher (iibbons. Organist of Westminster Abuey, 1669-80. (ientleman of Chapel Royal, 167i-7t. Master of the Children, do., July, 167t. (Mrganist of Chapel Royal, 1676. Private Musician to King James II., 1685. Ahmoner and master of the ehoristers of St. Paul's Cathedral, 1685-93. Re-appointed organist of Wentminster Abbey, 1695-1708. Married Elizabeth Braddock. Composer to Chapel Royal, 1699. He died at London, October 1st, 170s. Buried in north choir aisle, Westminster.

Works.-Amphion Anglieus, a work of many compositions for one, two, three, and four voices, with several aceompagnements of Instrumental Musick, and a Thorow-Bass to each scng, figur'd for an Organ, Harpsichord, or Theorbe-Lute, Lond. [1700]. Odes: A Second Insical Entertaimment, performed on St. Cecilia's 1)ay, November $22 n d, 16 s t$, words by John Oldham, London, 16st; Great Quire of Heaven, st. Cecilia's Day, 1691; Te Denm and Jubilate, composed for'St. Cecilia's Day, 1695; Trimmphant Fame, St. Cecilia's Day, 1700; Arise, Great Monarch, Now Year's Day, 1681; New Year's Day Ude, 1683; Hail, Monarch, do., 1686; Is it a Iream? do., 1687; Ye Sons of Phobus, do., 168s; others in 1689 and 1693-94; Appear in all thy pomp, appear, do., 1700; Ode on the death of Mr. Henry Purcell, the words by Mr. Dryden, London, 1696; Three Elegies upon the much lamented 


\section{BLOW.}

loss of our late mcst Gracious Queen Mary,sett to Musick by Dr. Blow and Mlr. Henry Purcell, Lond., fol., 1695. Church Services in $A, G$, and $E$ minor, one in triple measure and 10 unedited. Anthems, numbering about 100, published in Boyce's Collection, C'lifford's Collection, Page's Hamonia Sacra, Novello's Series; others existing in MS. A choice Collection of Lessons for the Harpsichord, Spinnett, ete, containing four setts, as grounds, almands, corants, sarabands, minuets, and jiggs, 1698. A choice Collection of Lessons, being excellently sett to the Harpsichord, etc., by Blow and Purcell, 1705. Catches in the "Pleasant Musical Companion," published in various editions; Do. pub. in The Catch Club, or Merry Companions; Songs in D'Urfey's collections, and in others of the same period; Organ music; Chants.

Blow, Rev. William, rector of IaverBreton, Essex. A direct descendant of John Blow. Was esteemed one of the finest anateur violinists in Europe. He possessed the finest collection of violins in Great Britain. Died in January, 1887.

Blower, John Henry, hasis vocalist, horn at Wolverhampton. Studied at the National Training School for Music, under J. B. Welch. He sang in concerts in Bimingham and district from about 1878; appeared at the Crystal Palace Concerts, April 15th, 1882, and at the Leeds Festival of 1883 . Afterwarls he gave himself np, to teaching, and is now a Professor at the R.C.M1. Miss Clara Butt was for some time his pupil.

Bloxsome, Charles, author of " Elementary practice for the Tocal student," Lond., 1857 ; "Elements of singing, chord and soale exercises to develop the voice," london, n.d.

Blyth, Benjamin, composer and organist. who graduated Mirs. Doc., Oxford, in 1si3: He composed church music, "A sunctus, two jubilates, and eight double chants," Jondon, 1841. Pf. music, and songs. Hisson, BexJAMIx Blyth, was organist of Magdalen College, Oxford. M.A., Oxford. Died at Whitchurch, Oxford, July 20th, 1883, aged 58.

Boardman, John George. Published "Sacred Music, a selection of psahm tunes," London, 1844. Thomas James BoArumax issued $₫$ "Collection of psalm and hymn tunes. ancient and modern," London, 1854; "The Copious Tune Book, a collection of psalm and hymm tunes," London [1860]. Two editions. He also composed songs, etc.

Bodda, Louisa Fanny, see Prise, Louisa Fanny.

Bogue, Christina W., see Morison, Christina IV.

Bokwe, John Knox, Kaftir composer. Secretary of the Lovedale Institution, Cape Colony. Composer of Kattir hymm tumes, and a book of part-songs, of which the type-setting

\section{BOOTH.}

and the whole production were the work of coloured sol-faistr.

Bolton, 'Thomas, musician and teacher, who flourished circa 1760-1820. He issued "Collection of Lessons, songs, etc., for the harp, lute, or lyre," London, 1797; "Collection of airs, marches, dances, etc., adapted for the pf., with accompaniments for the lyre or lute," London, 1806; Six Rondeaus, three songs, etc., op. 3; "sielect collection of songs and airs arranged for the harp, lute, etc," 1815; "Treatise on singing," London, 1810.

MARY CATHERIN Bolton (who became Lady Thurlow, in 1813), a soprano vocalist. Born, London, 1790, died, southampton, September 28th, 18:30; and Étrza Bolton, her sister, who was also a soprano singer, appearing at concerts about the same time, were probably daughters of Thomas Bolton.

Bond, Capel, composer and organist, lived in Coventry during middle of last century. He was organist and conductor of the first Birmingham Musical Festival, 1769, and died in $17 \% 0$.

Works. Six anthems in score, one of which is for ('hristmats 1).4, 176\%. Six concertos for \pm violins, tenor, and 'cello, with thorough bass, 1766. (ilees and solng's.

Bond, Hugh, organist and composer, was born at Exeter in the beginning of the 18 th century. Lay-vicar Exeter Cathedral, 1762. Organist of Cihureh of sit. Mary Arches. He died in 1792.

Works.-Twelve hymns and four anthems, for four voices, London, 1776; The pralms of Darid; also an appendix containing select hymns, London, 1780. Glees and songs.

Bond, Jessie, rocalist and actress, born in Liverpool, damghter of John Fond, pianoforte mechanician of that city. Appeared at Hope Hall as a pianist at the age of eight, and was edncated as a pianist at the R.A.MI. But developing a contralto voice she took to singing, and became a pupil of Manuel Garcia. the sang at the Crystal Palace, at Riviere's Concerts, and in the provinces. She was the original Hebe in "IL.M.S. P'inafore" ; and since then has filled a romnd of characters in the Gilbert and Sullivan operas at the savoy Theatre.

Bond=Andrews, see Andrews (J. C. Bond).

Bonnyboots. English singer and dancer of much fame in the reign of Queen Elizabeth hore this nickname. He is noticed in Hawkins" "History, of Music."

Booth, Josialh, organist and composer, bom in Coventry, March 27, 185.2. Situdied under the late Edward sims, Cosentry; Dr. James Taylor, Oxford; and later, at the R.A.MI. mder Brinley Richards, and G. A.MFacfarren. Appointed organist at Banbury, 1867, and has been since 187T, organist and choimaster at Parli Chapel, Crouch End. 


\section{BOOTH}

Wrorks.- Oratorios, Nehemiah produced 1855); Cantata, The Day of Rest, for female voiees. Sehool operettas; The Thabes in the Wood; I)ick Whittington; and The six Princesses. Church services; Anthems, Grant, we beseceh Thee; 'Thou erownest the year, and others. Hymn-tures and chants. Hartsollgs; The Mighty Caravan (produced by Henry Leslie's (hoir, 1883) Al]mm of twelve solrgs, \&c., \&c. MInsical editor of Parts II. and III. of the Congregational Church Hymnal, and anthor of Frerybody's Fuide to Music, Iundon, Saxon.

Bootl, Robert, organist and composer, born at sit. Andrews, I)eember 29, 1802 . Studied at the Madras school there, and under different masters. Organist, Ioly Trinity Chureh, Kilmanock, 1880, and for some time musical direetor of Kimarnock Opera House. In 1887, he was appointed organist and choirmaster of Coltness IIenmeial Church, Newmains.

Monks. - Festival service in G: Gloria in Excelsis; Anthem, The Lord is mus shemherd; Operetta, Sisters Three; or Britamiats lerves, for principals, chorus and orchestra: Fightpart song, with solo, l ochinvar ; Schoul fongbook, in threesart hamony symphony, and overture, orchestra; Internezzo, Alayple dance, for strings. Waltzes, for pif. and or chestra. Author of a book on Nlusical Theor and other didactic works.

Borton, Alice, bianist, and composer. Edueated at R.A.M., of which she is an Associate. Ilas composed Sacrer Choral Music, and songs; an Andante and Rondo for pf. and orchostra; sinite in the oldenstrhe, pf.; Three Scoteh pieces, etc

Borwick, W. Leonard, pianist, Jom at Walthamstow, Hstex, Februar $26,1868$. Comes of an old sitalfordshive tambily, many members of which were musical. Fis disposition for music was shemen at a rery ardy age; and after some vears of study under London manters, he entered the Hoch Conservatorimu, Frankfort, 18st, where he was a pupil of Madane sehumatum for five vears. Ile also studied composition with Primated scholz aud I warl knorl. I [is dobut trok p]alee at the Museme Comeerts, Frankfort, Norenther s, 18se, whon he played the solo part in

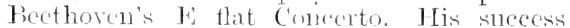
was so malede that he tras engaged for the Jondon l'hilharnomice concerts, and he made

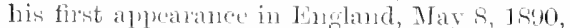
playing Sohumannes Concerto. I a apleared at the Lichter, Crvital l'alace, and I'opmlar Concerts, St. Jinnes's Ilall, tho same veal ; and has now bean hoard at the principal musical centres in Fritain, and fermany, ranking with the great pianists of the dav.

Bosanquet, R. H. M., Fellow if tit. John's College, Oxford. Author of "An Ele-

\section{BOWDLER.}

mentary treatise on musical intervals and temperment, London, 1876; also of various papers rad before the Mnsical Association (1874); the College of Organists; and the R.A.M. In 1881, he accepted the professorship of acoustics, 1i.A.M.

Botting, Herbert William, composer, organist and pianist, born at Brighton, March 28, 1869. Studied for two yars with I)r. F. J. Sawver, during which time he obtained the diplomit of F.R.C.O.; then proceeded to Leipzig Conservatorium, and on his return was articled to Inr. J. F. Bridge, of Westminster Ahbey. Graduated Mus. F., Durham, 1891. In Iesprig, he held the post of organist and choimmater at the English Church (1888); in 1891, he was appointed to St. Luke's, Sonthport, and four yem later to St. Nicholas, Pirighton, and finally to St. Angustine's, Preston Park, Brishtom, 1896. He is founder and conductror of the Prestom Park Choral and Orehestral Socicty; and is known as a pianist, organist, and horn plaver. Ilis eompositions comprise an Ode, ('hrist's Nativity, for soprano solo, chorus and orehestra (Lniv. ex.) ; The Chase, and The Return of Spring, for soli, chorns and orchestra; A spring Idvll, for orchestra; pieces for pf., organ, violin, violoncello: songs, ete.

Bottomley, Joseph, composer, organist, and pianist, was bom at Halifax, Torlishire, 1786. Studied in Manchester, under (rrimshaw, Watts, Yanjewic\%; and at Leeds, monder Lawtous, to whom he was articled pupil. He afterwards studied pf. moder Woelt, at London. Organist of l'arish ('hurch of Bradford, 180T; orwanist of T'arish Chureh, Sheftield, 1820. Ho dicd after 1850.

Works. Tretionary of Music, London, 1816. New šrtrin of Practising and Teaching the l'ian furte, thofficeld, 11.r. [1847]. Six Fxercises for the 1 f. Rondos and airs for pf. Ibivetisements for lof. and flute. Twelve Sonatinas for pf. Songs, (ilces, etc.

Bourne, C. E.., author of "The great eomposert, or stories of the lives of eminent musicians," lundon, 18st. He has also written a number of popular works on biography, cte.

Bowdler, Cyril William, composer, of Welsh deseent on the maternal side, born in Torkshire, September 28th, 18:39. As a boy, he studied music under I) John Camidge, of York, and subseruently with sir R. Prescott Stewart, whose pmpil he remained for a long poriod. Fraduated Mus. 33, and P.A., Inblin, 1864, and 1ـL.I)., Thlilin, 1896. For two vears, $1877-9$, he was hom. organist at $\mathrm{All}$ Siants', lldershot; lout he is chiefly devoted to composition.

Monks.- Music for the divine liturgy of it. John Chryoston (Greek, 1864); complete church services in $\mathrm{E}, \mathrm{F}, \mathrm{G}, \mathrm{P}$ flat, and $\mathrm{C}$; 


\section{BOWIE.}

numerous anthems, lyymm tunes, etc.; "Imelda," three-act Italian opera; CantataThe descent of spring; songs, organ and pf. pieces, ete.

Bowie, John, violinist and composer. Was born near Perth, in 1759, and died there in 1815. He published about the end of last century a "Collection of strathsper reels and country danees, with a bass for the violoncello or harpsichord. Dedicated to the Countess of Kinnoul," Edinburgh [1789]. He also published several dance tunes on single sheets. He was engaged as a music-seller in Perth, and gave balls in conjunction with his brother.

His brothel Peter (1765-1846), was also a violinist, and a teacher of the pianoforte.

Bowley, Robert Kanzow, musician, was borm in London, Mas, 1813, and died in August, 1870. Authol of "Grand Handel Musical Fentival at the Crystal Palace in 1857, a Letter," London, 1856. "The Sacred Harmonic Societs, a thirty-five years retrospect," London, 1867. This musician was connected with the sacred Hamonic society, and he assisted in establishing the Great Handel Celebrations at the Crystal Palace, London.

Bowling, a family of musicians. The father, JoHN Bowlixg, organist, riolinist, and pianist, was born at Leeds, Norember 11th, 1820. At the age of eleven he was aprointed organist of Hecknondwike parish church, and afterwards filled the office of organist of East Parade chapel, Leed, for 34 years. He was conductor of musical societies in several Yorkshire towns, and of the Leeds Madrigal and Motet Society. He died at Leeds, April 16th, 1882.

His son, Johx PEW Bowlixg, born at Leeds, May 26th, 1851, was considered the finest pianist in the eounty. He was also an able violinist, and organist, holding an appointment at All Sonls' (Hook Memorial) Church. Was the first Prineipal of the lorkshire College of Music, Leeds, and conductor of the Leeds Amatem Orehestral Society, and the Inddersfield Orphens Society. He died at Leeds, July 6th, 1856.

Janes Whewall Bowling, the youngest son, was born at Leeds, Jannary 6th, 1860. Besides leing an excellent pianist and oroanist, he showed much ability as a composer. He succeeded his brother as Principal of the College of Mrusic, and was organist to Lady Mary Vyner, Skelton, near Ripon. His conpositions comprised six songs; four songs for tenor, Op. 5; a second set of four songs; suite, Op. 3, for pianoforte, etc. He died December 13th, 1888, under mournful circumstances. His health being delicate, he was spending the winter in Switzerland (the Engadine). Skating on the lake near the hotel, one of the party fell through the ice, and Borting was drowned in attempting a rescue.

\section{BOYCE.}

Bowman, Henry, composer, flourished during latter half of 17 th century. Wrote "Songs for one, two, and three ruyces to the Thorow-Bass. With some short srmphonies. Collected out of some of the select poemis of the incomparable Mr. Cowley, and others, and composed by Henry buwman, I'hiloMusicus," Oxferd. $167 \%$.

Bowman, Rev. Thomas, amatemr musician, born in 17.s. He wals vicar of Martham, Norfolk, and died in 179:2. He composed "A collection of English odes, cantatas, songs, etc." London, 1760. single songs, ete.

Box, Charles, author of "Church music in the Metropolis, its past and present condition, with notes critical and explanatory," London, 1854.

Boyce, Ethel Mary, composer and pianist, born at Chertser, Sinrey, October 5th, 1863. Danghter of George Boyce, J.P. Studied at R.A.MI., pianoforte nnder Walter Nacfarren, and composition muler F. W. Darenport. Was Lady Goldsmid Seholar, 1885; Potter Exhilitioner, 18s6; Wom the sterndale Bennett ['rize the same vear, and the Lneas Medal for compusition, 1kisy. Tiessident in chertsey ats eomposer and teacher. Amoociate, R.A.1I., 18!0.

Works. - Cantatis: The Lay of the brown rosaly (Mrs. Browning), 1s'30; Young Lothinvar, 1891; The sinds of Corriende, female voices, 1895; Nareh in E, orchestra, Westminster Orehestral suciety, 1889; Eight pieces, violin and pianoforte (Novello's albunss). Songs_."So she went drifting," and others. Part-songs: "Lowe has come," ete. Pianoforte pieces: "To I'hyllis" ; Short pieces for children, eic.

Boyce, William, composer and organist, was born in London, 1710. Chorister in st. Paul's Cathedral muder Charles King. Articled pupil to Manrice Greene, organist of St. Paul's. Organist of St. Peter's, Tere Street, 1734. Studied moler. Dr. Peptrsch. Organist (in succession to Kelway) of St. Michael's, Coruhill, 1736-6s. Composer to Chaprel Royal and the King, June, 17.36. Conductor at meetings of choirs of Gloncester, Hereford, and Worcester, 1737. Organist of Allhallows the Great and the Less, Thames street, 171969. Bae. and Doc. of Music, Cambridge, 1749. Master of Royal Band of Music, 1775. One of the organists to Chapel Royal, 175s. He died at Fensington, London, February 7 th, 1779. Buried ju crypt, st. Paul's Cathedral.

Woriss,-Pelerzs and Thetis, masuze, by Lord Lansdowne, 17?'; Solomon, serenata by Dr. Elward Moore, 1747; The Chaplet, a musical drama, Lonton, 1745; Darid's lamentation over sant and Jonathan, oratorio, by Lockman, 1736; Ode for St. Ceeciliat's Day, by Lockman: Ode for St. Cecilia's l bay, by Vidal; Nusic to the sherherd's Lottery, 1750 ; 


\section{BOYCE.}

Ode for the Installation of the Duke of Newcastle as (bancellor of Cambridge University, 1749: Fitteen anthems and a te demm and jubilate, 1780 ; Collection of twelve anthems and a serviee, 1790 ; Ode to charity; Pindar's first Prthian ode, 1749; Masque in the Tempest. Cathedral music, bejng a collection in score of the most valualle and useful compositions for that service, etc. / containing examples of Aldrich, Batten, Berin, Byrd, Blow, Bull, Cluild, Jor. Clark, Croyghton, Croft, Farrant, Giblons, Goldwin, Homphreys, Fing Henry YIIl., Lawes, Locke, Morley, Pureell, lingers, Tallis, Turner, Tye, Weldon, and $M$ ise London, 3 vols. fol., 1760-78; second edition, with nomeir l,y sio J. Hawlins, 1778 , also editions by $T^{\top}$. Novello and J. Warren, 1849. Fight simphonies for varions instruments: Twelve somatas for two violins and bass, 1749. Orean concerto. J yra Britamica, Collection ol songs, duets, and cantatas, n.d. Overtules. Siongs, duets, etc, in contemporary collections.

Boyce, William: omly son of the above, was how March 25th, 176t. He was intended for the chmeh, and sent to Oxford; but committing sone irregularity, was obliged to quit that miversity without obtaining a degree. He then became a donble-bass player at the opera and prineipal concertis, and wats in the orchestra at tho. Bimingham Festivals, 1802-5. Considerable poperty coming to him, he lined in retirement some years lefore his death, which took place early in 1824.

Boyd, Henry, musician of 18 th century, was a teacher of palnody and precentor in the Metho dist Cbapel, John Street, (Hasgow. He died at Glasgow, Noveml)er 17th, 1792.

He compiled "A select collection of psalm and hymm tumes in three parts, adapted to a great varicty of moasures, to which is prefixed an intruduction to the art of singing." . . . Published for the benefit of his widur, 1793.

Boyle, Frank, tenor vocalist, born at Barnstaple, Angust 13th, 1857. His father, William Joyle, has smog in the choir of Barnstaple I'asish Church from his borhood, and is still principal alto there. Frank, as a boy, displayed musical talent. His father tanght him singing, and he had riolin lessons from the late John Frlwards, and orom lessons from [1). J. H. Edwards. Was a ehorister at Holy Trinity Church, and, after leaving school, entered a newpapel office, singing, at times, at local concerts. Ile soon derided to devote himself to music, and wimming the Corporation of London R.holarshjp, entered the Natinat Traning fichool, South Fensington. While there he sang as principal tenor at st. Matthias, Stokt Newington. Sang in the Messiah at the Albert Hall, (rood Friday, 1840 , and at the promenade concerts the sane year. 111882 , was engaged for the
BRADFORD,

Hereford Festival. Joined D'Oyly Carte's Opera Company ; toured in Anstralia, 1885-6; on his return rejoined Doyly Carte, and sang in George Edwards' English Opera Company. In 1891 his health broke down. He burst a blood ressel in the lungs, and died at Barnstaple, Feloruary 6th, 18:2.

Boys, Henry, composer and teacher, was born about 1806 , and dicd at Margate, February 8th, 1851. He composed Cupid and Campaspe, a eantata, 1842, and the following glees: Friar Tuck; The pearl divers; Smuggler's chaunt; War-] bat song of the Crusaders, etc.

Bradberry, Gervas, amatem composer, was lorm abont 1776 , died at Pentonville, London, December s9th, 186:. He composed ghees and songs, and hamonized a mumber of glees ly other composers, as "Twenty-four select melodies of eminent composers hamonized for three voices," London [1825].

Bradbury, Orlando, vocalist and compostr, was born about 1805. He was a Gentleman of the (halpel Royal, St. James' Palace, London; lay-vicar of Westminster Abbey, and a bass singer of some note. He died at London, December 14th, 1872. Composer of ballads and other focal music.

Brade, William, composerand riol-player, who flourished about beginning of $17 \mathrm{th}$ centrury, and died at Frankfort in 1647. He published l'adnanen, galliarden, canzonetten, ete., 1609: New Jaduanen mid gagliarden mit stimmen, 1614: Nene Lustige Volten Comanten, Balletten, ete.

Bradford, Jacob, organist and composer, born at bow, London, Jume 3, 1842. Chorister, Sit. Paul's, Nalworth. To a great extent self-taught in music, lut was a pupil of Sir John Goss, and 1)r. Steggall. Assistant organist to Scotion clark at sit. Helens, and St. Ethelhurga, Bishopsgate; and at the age of twenty, fatined the appointment of organist at st. Philip's, Kemnington. Graduated Mus. 13., 1873; Mus. 1)., 1s78, Oxford. Organist, it. James's, Hatchant, 1868-75, and eonductor of orchestral services he introduced there; and, after holding brims appointments, went to St. Mary's, Nowington, in 1892, holding that position to the present time. Was music master at the Rowal Naval school. New Cross, 1881-90; and is a profesinor at West Kent Grammar School, and conductor of the Newington (horal Society. From 1882 he was for sonnc rears Honl. sece to the Musical Artists' Society. Has contribnted articles to Musical Nex's, and other papers.

Works.-Oratorio, Judith (produced, st. Janes's Hall, Feh. 26. 1888); Cantata, The Song of Jubilee, Op. 44 ; Cantata, Praise the Lord; Harvest Cantata; Anthems, Church Services, ote. Ninforia Ecelesiastiea, for double choir and orehestra; overtures, etc, 


\section{BRADLEY}

in MS. Trio in E flat, pf. and strings; organ Sonata in C minor, Op. 47, etc. Compiler of The Music Pupil's Register (Novello).

Bradley, Charles, organist and eomposer, born at Wakefield, October 20, 1846. Trained under R. s. Burton, I). P. Armes and F. W. Davenport. Organist snceessively of Rt. Miehael's, Wakefield, 1856-66; St. Paul's, Middle'sbrough, 1871-82; St. George's, Edinhurgh, 1882-85; Abbey Parish (hurch, 1885-87; and South Leith Parish Church, 1887. He was organist to the Edinlurgh Choral Lnion, from 1883 to 1890 . Composer of anthems and other Church music, songs, and organ music.

Bradley, Frank H., organist and pianist, horn in Bimmoham. Pupil of A. Deakin, and A. R. Gaul. Organist of St. Bamabas, Bimingham, 1867; at itoke-on-Trent; (suelsec Cathedral, Canada; professor of music, and organist, Tettenhall College, Nolverhampton; St. John's, Wilton Road, London; st. Anclrews, West Kensington (1884). IIas given organ and pianoforte recitals in bimmingham, Paris, South Kensington International Ixhibition, 1858; at the Kimberley Fxhihition, South Africa, 1892-8; also in Australia, and was aeeompanist and conductor during $11 \mathrm{r}$. Santley's tour in Aistralia, 1889-90.

Bradley, Joseph, pianist and conductor, born at Hyde, ('heshire, February $28,1857$. At twelve, he was organist at St. Paul's, Stalybridge; and two years later at Heaton (hapel, Mamehester; F.R.C.U.,1873; Mus. B., Oxford 1875. For six years, 18R1-7, he was organistand deputy ehornis-master to Sir Charles Flalle at Manehester, and conductor of societies at Stockport, stalybridge, and other places. In 1887, he was appointed chorms-master to the Glasgow Choral Lnion, and later, conductor of the Choral concerts. He eomposed "A song of Praise," for chorus and orchestra, expressly for perfonmane when the Queen visited Glasgow Exhibition in August, 1888.

Bradley, Orton, pianist and conductor, born at Greenwich, December 11th, 1858. Educated at Harrow, and Hertford College, Oxford. Pupil of John Famer; scholar and organist of his college; graduated M.A., with classical honours. Organist, King Edward's Sehool, Bromsgrove, 1891, for one year. From 1887 to 1893 , held the position of Mrusical Director to the I'eople's Palace, London, and was the first conduetor of the Natiomal Sunday League Choir. As a pianist, he has devoted much attention to the compesitions of Brahms. In 1893 he went to New York, where he gained a distinguished position as eonductor and pianist. His settings of poems by Jean Ingelow, and Rosietti (The Blexsed Damoscl), for recitation, have heen perfomed at the Lyric Club [1886].

Bradshaw, Ann Maria, born TreE, soprano vocalist and actress, born at London,

\section{BRAINE.}

in Angust, 1801. She first appeared in the "Barber of Seville" at Covent Gardem, in 1818, and continued to act and sing in publie till 1825, when she married Mr. James Bradshaw, and retired. She was sister to Ellen Tree the actress.

Bradshaw, Ralph, musician and compiler, was born in Bolton abont 1776 . He died in 1832. Issued " Twenty-four psaln and hymm tumes, eomposed and arranged for fomr roices ..."[1820]. A frecond set of psath or hymm tunes, London [1825].

Brady, Nicholas, divine and poet, bom at Bandon, 1659, died at Richmond, Surrey, 1726. He was associated with Tate in the production of a metrical version of the I'sahns of David. He also wrote "Church musie vindicated; a sermon preached at Sit. Bride's Church on Nonday, November 22ud, 1697, heing st. Cæcilia's I ar, the ammiversary feast of the lover's of musick," London, 1697 .

Braham, John, tenor vocalint and composer, born in London, of Jewish parents, $1774[1772]$. He studied under Leoni, and first appeared at the Royalty Theatre, Wellclose fquare, London, 1787. He appeared at Covent Garden, April 21st, 1787, and sang at Bath in 1794, where he studied moler Rauzzini. He sang at Drury Lane Theatre in 1796 , and afterwards travelled in Itaty and appeared at Florence, Rome, Naples, Milan, Genoa, Tenice, ete., with Mrs. Billington and others. While in Italy he studied moner Isola, and in 1801 he retimed to London, where he re-appeared at Covent Garden Theatre. He married Miss Bolton, of Ardwick, in 1816. He sang as Huon in Weher's Oberon, in 1826.

Lost his fortune by failure of several speeulations, 1851. I)ied at London, February 17 th, 1856 .

Morks.-Music to Dramas: The Cabinet, 1801; Family Quarels, 1802; The English Fleet, 1802 (eontaining "All's Well," duet, etc.); Thirty Thousand, 1804; Orat of Place, 1805; False Alarms, 1807; Kais, or Love in a I)esert, 1808 (with Reeve); The Devil's Bridge (with C. E. Horn), 1812; The Paragraph ; Narensky, or The Road to Yarostaf: The Americans; The Magicians (with MI. P. King). single songs, gleses, ete. I leath of Nelson, song.

His soms. Johx Hanittox Brahas (Londom, 1818: Rochester, Itecember 22nd, 1852), and Charles Barfyline (London, 1822; London, Jnme 11th, 1884), were both vocalists, the former, a baritone, who first appeared at the Hanover Square Rooms, November 2nd, 1843; and the latter, a tenor. His grandson, EDWARD B. BRAнAM, ajpeared as a cellist in 1885.

Braine, William Richard, organist and composer, horn at London, November 8, 1829 ; died there February 19, 1865. Was for 18 rears organist of sit. Barnabas, Kensington. Compiler of "The st. Bamabas MIusic Book," 


\section{BRANSCOMBE.}

1850; "Hymms for the Church, or home circle," London, 1861. Composer of duets, songs, and pf. music.

Branscombe, Edward, tenor vocalist, born at Camberwell, London. Studiex for three years at the Guildhall School of Nusie; at the R.C.M. for two years, mocer Blume, and later with Sims Reeves. Whem nineteen, he was appointed choimaster and assistant organist of st. Paul's, West Brixton, and formed the Brixton Orpheus Glee Club. A concert he gave in Brixton Hall, Octoler 19, 1885, bronght him into notice as a singer. In 1887, he was appointed to the Church of St. Andrew, Well street; and in December, 1890, lay-ricar, Westminster Abbey. He has sung at the principal London concerts; at the Crystal Palace; and in the chief provincial centres. Ile maried Marin Hooton, the contralto vocalist, who studied at the R.A.ML, wimning the Westmoreland Scholarship, 1n88, and the Parepa Rosa Gold Medal, 1890. The artist patir now rank anong the most suecessful of our younger singers.

Braun, Charles, composel, born in Liverpool, 1868, where his father, an accomplished amateru, was patrer in a lalge business firm. He was edneated at Clifton, and Cambridge. Studiex music at Leipzig, under TIths sitt. Resident in England, and encreged in connposition, Hin cantata, "Sir (Olaf," was produced at the Fhilharmonic Hall, Liverpool, March 5, 1859, and attracted much attention. In Deconber, 1 s'mo, a second eantata, "Sigurd," was produced with success at the same place, both performances boing contucted by Mr. Rodewald, an amatens, whe las dome much for music in Liverpool. Chates Braun has written a good many songs, and is $110 \mathrm{w}$ engaged on an opelit.

Bray, Mrs. Anna Eliza (horlu Komper), writer, lorn at st. Nary, Newingten, Sinlery, December 25, 1790. She died at Lomdum, Jannary 21, 1883. Wrote a mimber of norels and miscollaneons works, and "Handel: his Life, I'tronal and Professional, with Thonghts on Sacred Music," London (Ward \& Co.,) 1857.

Breakspeare, Eustace John, tomposer, writer and pianist, horn in Biminghan, Aprit 22, 1854. Studied under S. S. Straton. I Has appeared at concerts in Bimingham, as solo pianist and accomplnist, but is better lnown as a writer on music. He has read papers on "Mfusical Aesthetics," and other subjects, at meetingson the Musical Asrociation (1840-2-3); the College of Oryanist $(1853)$, and at ratons institutionsin bimingham. Hiscontributions to the Masical Stamlard, Masical Lifcorl, Wusical Times, Musical Opinim, and other papers, are very numerons, and emblace a wide range of sulject matter. Ite has written a suite, ard many pieces for pf., and a number of songs, but hitherto rery little has been published.

\section{BREMA.}

Brechin, William, teacher, and inventor of "Brechin's Stave Sol-fa Notation," was born at Brechin, Forfar, 1824. He held appointments as precentor in Montrose, Furfar, Perth, Leith, and Edinburgh. The principal feature of his system is the employment of letters, as in the ordinary Tonic Sol-fa, to represent the notes, together with eertain signs to mark the duration. The notes are witten on the staff. In addition to the invention of the Stave Sol-fa Notation, Brechin has edited and compiled "Tocal Exercises, Romnds, etc., in the Stave Sol-fa Notation, forming a short course of Lessons in sight Singing in the key of F." "Congregational Iusic, Psalms, Hymms, ete, in Stave Sol-fa Notation." "The Standard Scottish Psalmody" (compiled from the forogoing) "Exercises in sight singing"; "School song Boolis"; "The Stave Rol-fa Journal" (publishing in parts) containing pieces by Croft, Beethoren, Mason, Stevenson, Hlow, Handel, ete." : Two Books of Swedish songs.

Breden, Owen, music mastel at St. Mirlis College, Cheliea, was burn at Norwood in 1841. He was for five years a pupil tacherer at King's sombone Scheol, Hants.; and in 1860, Gained a Quecer's Scholarship at St. Markis College, as a student. He had previonsly learned pianoforteand organ playing; and as the olgan at the College Chapel was put up while he was a student, he has played it from the first, and continues to act as organint and choirmaster. The became suecessibuly master of the npper school, tutor, and vice-principal; and in 1883, gave up the last to mokertake the mulsical work. For this, he had qualified himself by studying pianoforte midar f)r. Wvide, organ under Dr. E. J. Hoplins, and simging moler John Jiwin.

Brekell, John, clergyman, author of "A Discourse on Musick, elijefly Church Musick; occasioned by the opening of the new Organ in St. Peter's Clureh in Liverpool. . . Sermon," London, 1766.

Brema, Marie, originally Brimer, rocalist, mezzo-sopramo, a mative of Liverpool. She studied muder $\mathrm{G}$. Ienschel, and nuade her debut at the Montily Popular Concerts, Feleruary 23, 1891. Inater (October) in the same year, she apreared as Lola in "Cavilleria Rusticuna," at the shafteshury Theatre. She first semg at the Philharmonic Concerts, April 20, 1893, and at the Crrstal Palace, Nareh 24, 1894. She was engaged for the Bayrenth performance of $18 \% 4$, appearing as Ortrud, and in 1896, as Fricka and Lundry. Her Festival début took place at Bimingham, October 3, 1895, when she created at matked impression hy her dramatic rendering of the part of the livil sinit in Hubert Parry's oratorio, "King Satal." She now ranlis among the leading singers of the day. 


\section{BREMNER,}

Bremner, Robert, musician and publisher, born in Scotland about 1720 [1713]. He was a pupil of Geminiani, and tanght music in Edinburgh. On December 13, 1753, he gave a concert in the High School, Leith. He commeneed business as a music-seller and publisher at the Golden Harp, opposite the head of Blackfriars Wynd, Edinburgh, in 1751; in 1755 he ehanged his sign to the Harp and Hantboy; and in 1759 he removed to another shop in the High street. He removed to London, and opened a shop with the Harp and Hautboy sign, in the strand, opposite Somerset House, in 1762. Both businesses were carried on till his death, the Edinburgh one being managed by John Bryson, who succeeded him. He died at kensington Gore, London, on Mar 12, 1789.

Works.-Collection of the best Church tunes, in four parts. Published by Robert Bremmer, by order of the Honourable the Committee for improving Chureh music in the City of Ediuburgh, n.d. Thirty Sicotch songs, some of which are for two voiees, with a thorongh bass for the harpsichord or spinnet... The words from Allan Ramsay, exeept a few never before printed. Edin. [1757] A Second Set of Scots Songh, Edin., n.d. These were re-issued in London about 1762-65. The Songs in the Gentle shepherd, adapted to the guitar, Edin. 1759. The Vocal 1 lamonists' IIagazine, being a collection of catehes, glees, eanons, and canzonets, London, n.d. The Freemasons' songs, with chornses in 3 and $t$ parts... to which is added some other song proper for Lodges, London 1759. A collection of Scots Reels, or Comntry dances, with a bass for the violoncelo or harpsichord

Edin. issued in 8 purts, 1757-61] A second collection of seots Reels or Country dances. . . London [2 parts, 1768]. A enrious collection of see to tunes, with rariations for the riolin, and a bass for the violoncello or harpsichord, Edin. 759. Rudiments of Dlusic, or a short and easy treatise on that subject, to which is added a colleetion of the best Church tunes, eanons and anthems. Fdin, 1756; 2nd ed. Edin., 1762; 3rd ed. London, 1763. Instruetions for the guitar, London, n.d. Thought on the performance of Concert music prefixed to Schetky's Quartets, Op. ( $)$, London, n.d. The Harpsichord or Spinnet Miscellans, London $[1760]$. Select concert pieces for the Harpsichord or Pianoforte... London, 17s0, pub. in numbers.

Brent, Charlotte, see Pixto, Mrr.

Brereton, William Henry, bass vocalist, born at Bedford, in 1860 . Sion of the late Rer. Canon Brereton, reetor of St. Mary's, Bedford. Studied under Nlanzel Garcia, R.A.AL., 1877-80; with Sebastian Ronconi, Nilan, 1881; and had oecasional lessons from the late J. B. Welch, and Alberto Randegger,

\section{BREWSTER.}

1882, and later. He made a snecessful début at the Crystal Palace Saturday Concerts, February 18th, 1882, and appeared at the Three Choirs Festivals in tum, at Gloncester, 1883, Worcester, 188t, and Hereford, 1885, and onwards. He sang at the Leeds Festival for the first time, in 1886; at the Birmingham Festival, in 1888, in which vear he was also engaged for the Handel Festival at the Crystal Palace. Hassung at the principal concerts in the Inited lingdom. In 18s. he was appointed principal hass at the Foundling Hospital ; to St. Paul's Cathedral, 1sso; and a Gentleman of the Chapel Royal, St. James's, 1887. In 188 the married Miss Siarah AnbLer, a soprano vocalist, who has leen heard in London concerts, and at the prorincial festivals.

Brett, Harry, author of The Comet, scales, exercises, etc. (Novellc's primer's, No. 28).

Brewer, Alfred Herbert, organist and composer, hom at (iloncester, Jume 21st, 186.5. Chorister in the Cathedral, and pupil of Dr. C. H. Lloyd. Educated at the Cathedral School, and Exeter College, Oxford. In 18,2, was elected orgmint of st. Giles' Church, ")xord, and in 188:3 gained the first organ scholarnip, R.C.MI., stndying meler Walter Parratt, and other masteris. At the end of this vear he was elected Organ scholar of Exoter College, Oxford; was appinted to St. Wiehael's, Coventry, in 1896; in septemler, 1892, organist and music manter at Tonbridge School; and in Decemler, 1sa6, organist of Cloucester Cathedral. Beyond his organ work, he is known as a conductor, the Corentry Munical suciety having been moder his direction for some sears.

Works.-Five erening services (an orchestral setting in $C$, componed by request, and produced at the Gloncester Festival, 1895); anthems, carolis, hrmm tmes, ete. An operetta, Rusamond; part-songs (Song and summer, Gloucenter Festival, 1892; Sad hearts, Hereford, 1894) ; school song, dnet, songs; three organ pieces, two Romances, violin and pf., pieces for pf. solo, and pf. ducts.

Brewer, Thomas, composer, flominhed during the 17th century [1610-80]. Educated at Christ's Hospital. He was a performer on the viol. Inates of birth and death mulnown.

Works.-Seven fantarias for the riol; Ronnds and eatches in IIilton's " Cateh that catch can": Tum, Amaryllis, to thy swain, part-song in Playford's Musical Companion.

The hiography of this composer is obscure. "Tum, Anaryllis," is a well-linown and pretty piece.

Brewster, Henry, writer. Author of a "Concise Method of playing thoroughbaris," Loudon, 1797. Composer of a Set of leswons for the barpsichord or pf., op. 4, 1785. Vauxhall and grotto song, London, 1771. 


\section{BRIAN.}

Brian, see Bryne (A.)

Briant, Rowland, organist. I'upil of R.A.M., also assoeiate and professor of the organ there. F.C.O. Organist successively of Eceleston Square Church; Westboume Park Chapel; and New Court Chapel, Tollington Park. Conductor of various choral societies. Composer of Hear my prayer; Praise ye the Lord; Cone unto me; Come now, and let us reason together; and other anthems.

Bridge, Frederick Albert, organist, voealist, lecturer and writer; born in London, 1811. Choimaster and solo bass, St. Andrew's Undershaft: Organist, St. Martin's, Ludgate, 1873-8; Choimaster, St. Martin-inthe-Fields, 1878-82; of St. John's, Lewisham. Commenced his Musical Monologue Lecture Entertainment in 1872. Conductor of St. John's Choral Society, Lewisham, 1885-91; and of the North West London M1usieal and Dramatic Society. Anthor of A Brief history of Mr. Henry Leslie's choir (London, 1880). Married, in 1863, Miss Elizabeth Stmuling (q.v.)

Bridge, John Frederick, composer, organist, and didactic writer, born at Oldbury, Worcestershire, Decomber 5,1844 . His father, John Bridge, was for many years a lay-clerk at Rochester Cathedral, and an original member of the Choir Benevolent Fund. 1le died at Chester, September 1, 18937. Entered Rochester Cathedral as a chorister in 1850 , and after being taught for some time by his father, was articled to J. Hopkins, studying later with (Sir) John Goss. F.R.C.O., 1867; Murs. Bate, 1868; Mus. 1)., (Ixford, 1874. Was appointed organtist of Trinity church, Windsor, 1865; Manchester Cathedral, 1869 ; Professor of harmony at Owen's College, 1872; permanent deputy organist at Westminster Abley, 1875, and. after the death of James Turle (1882), organist and master of the choristers. Conductor of the 1Tighbury Philharmonic Soeiety, 187886, and of the Western Madrigal Society Examiner in Mnsic, Oxford Lniversity, 1885, and in London University, 1891 ; Vice-President, Trinity College, London, 1891. Appointed Gresham Professor of Musie, May, 1890, the scope and variety of the "Gresham Lectures" being gratly extended by him. He became conductor of the Royal Choral Society in succession to sir Josepli Barnby in 1896. During his tenure of office at Westminster Abbey he has had some very important functions to discharge. He artanged all the music and composed a special anthem ("Blessed be the lord") for the celebration of the Queen's Jubilee, June 21, 1887; reeeiving the thanks of Her Majesty, and the Silver Jubilee Medal. Other notable musieal arrangements were those for the funeral of Lord Temnyson (Octoler 12, 1892), and the Purcell

\section{BRIDGEMAN.}

Conmemoration (November 21, 1895). Dr. Bridge is Professor of Harmony and Counterpoint, R.C.M.; Hon. R.A.M., and a member of the Philharmonic Society. He has lectured on musical subjects in Birmingham and other places.

Wonks.-Momnt Moriah, oratorio (1874); Boadicea, cantata (Highbury Phil. Soc., May 31,1880 ) ; Hymm to the Creator (Highbury, 1883; Worcester Festival, 1884); Rock of Ages (Mr. Gladstone's Latin translation, Birmingham Festival, 1885); Callirhoë, cantata, Birmingham, 1888; The Repentance of Nineveh, dramatie oratorio (book by Joseph Bennett, Worcester Festival, 1890); The Lord's Prayer (from Dante's Purgatorio, translated by Rev. E. H. Plumpton, Gloncester, 1892); The Cradle of Christ (Staluat Mater Speciosa, Hereford, 1894); ehoral ballads, The Festival (men's voices); The Inchcape bell. Church serviees, anthems, etc. Editor of Westminster Abbey Chant Book; Songs from Shakespeare. Partsongs. Concert overture, Morte d' Arthur (Birmingham, 1886); Minuet and trio, orchestra; Sonata in D, organ, etc. Author of Primer on Counterpoint, Double Counterpoint, Organ accomproniment, and Musical Gestures and Rudiments in Rhymes (Novello).

Bridge, Joseph Cox, composer and organist, brother of the preeeding, born at Rochester, August 16, 1853. Reeeived his musical training at the Cathedral, where he became assistant organist; afterwards acting in a similar eapaeity to his brother at Manehester Catlredral. In 1871 he was appointed organist of Exuter College, Oxford. Graduated B.A., 1875; Mus. B., 1876; M.A., 1878; and Mus. I)., Oxford, 1884. F.C.O., 1879. Appointed Organist of Chester Cathedral, 1877, he has been Conductor of the Triemial Festivals there since their re-establishment in 1879 . For some years, from 1887, he was Conductor of the Bradford Festival Choral Society, His compositions include several works produced at the Chester Festivals: Magnifieat and Nune Dimittis, for voices, orchestra, and organ (1879) ; Oratorio, "Daniel" (1885) ; Cantata, Rudel (1891); and a Symphony in F, orchestra (1894). He has also composed an operetta, "The Belle of the Area"; an anthem for Harrest Festivals; some pieces for pf.; songs; also transeriptions for the organ.

Bridgeman, Charles, organist, was born at Hertford, August 20, 1778. Studied the organ under J. Cubitt Pring, and violin under Francois cramer. In 1823 he founded the Hertford Musical Soeiety, and for many years was teacher of musie at Christ's Hospital, Hertford. He was organist of Hertford Parish Church for the long period of 81 years. Died at Hertford, Angust 3, 1873.

Bridgeman, John Vipon, musician and writer, bor'n in 1819. He was for upwards of 


\section{BRIDGMAN.}

30 years foreign editor of the Musical World. Translated Wagner's "Oper und Drama," Judaism in music, etc. Wrote libretto of Balfe's, Armourer of Nantes, and Puritan's daughter. Also translated various novels and other works from the French and German, such as Freytag's "Soll und Haben" (Debit and Credit), and works by Gantier, Blane, and Hngo. He died at London, September 30, 1889.

Bridgewater, Robert, composer and bass singer, born at York (?) in 1814.? Son of Thomas Bridgewater, organist of St. Saviour's, York, who died January 6, 1831. He died at Windsor, July 24, 1869. Compiler of "Sacred music, consisting of chants, etc." York, 1840. "Chnreh psalmody . . ." London, 1850. He also composed songs, ete.

Bridgman, Frederick William, pianist, borm in London, January 16, 1833. While very young went to reside with his grandfather, Mr. Eager, an esteemed teacher of music, at Edinburgh. He first appeared as a jurenile performer on the concertina, and made his début as a pianist in March, 1840. He continned to play, in Edinburgh and other places, as a musieal prodigy, but in 1851 lie went to Leipzig, and entered npon a thorombly conrse of study, wimning the favour of Moscheles whose pupil he was. In 1854 he returned to England, and appenred as soloist and conductor in London and the provinces. He was for some year's manager of the Metropolitan English Opera Company. He settled in Edin. burgh as a teacher in 1862, where he was highly successful. He was organist of the United Preshrterian Chnrch, College Street, and was accompanist at the Glangow City Hall Satmiday Concerts, celebrating his artistic Jubilee at one of them, March 22, 1890. Died at Edinburgh, December 28, 1892.

Bridson, John, baritone vocalist, born in Liverpool, i837. Engaged in business pursuits, he sang as an amateur for many year's, ultimately, studying under J. B. Welch, adopting singing as a profession. One of his early successes was, as a substitute for Mr. Santley, in the first performance as an oratorio, of Rossini's "MFosè in Egitto," at a concert of the Sacred Harmonic Society, under Sir Michael Costa, May 24th, 187s. The same year he sang in "Judas Naccabeus," in Birmingham, and created a very favourable impression. He afterwards appeared at the principal London and provincial concerts. His roice, if not remarkable for power, was of admirable quality; and he was a singer of culture and refinement. He died in London, December 11th, 1895.

Bright, Dora Estella, pianist and composer, born at Sheffield, Angust 16th, 1863. Upon the death of her father, an excellent amateur violinist, in 1881, she entered the

\section{BRITTON.}

R.A.M., studying the pianoforte under Walter Macfarren, and composition under Ebenezer Pront. She remained at the Academy until 1888, gaining the Potter Exhibition in 1884, and other prizes, including the Lncas Medal, for composition, in 1888, being the first woman to obtain that honour. During this time she wrote several important works. Her progress as a pianist was snch that she was allowed to appear at the Promenade Concerts, Covent Garden, in October, 1882. She hegan her pianoforte recitals in Jannary, 1889, and appeared at the Crystal Palace Concerts, March 28th, 1891, playing her Pianoforte Concerto in A minor. The next year (May 11th), she played her Fantasia in $G$, for pf. and orehestra, at the Philharmonic Concerts, the first instance of an orchestral work by a woman being admitted to the programme of the Socicty. She gave recitals of English music, from Byrd to Cowen, in 1892, and in October, 1895 , began a series of national pianoforte recitals. Her first continental tour was undertaken in the autmm of 1889 , when she appeared with snccess at Dresden, Cologne, and Leipzig. In 1892, she was married to Captaiu Knatchbull, of Batl.

Works.-Air with variations, orchestra, London, 1890 ; Concerto in A minor, pf. and orchestra, London, 1888 ; Concerto, No. 2, Cologne, 18\%2; Fantasia in G, 1892; Quartet in I, pf. and strings, 1893 ; Suite, violin and pf., 1890; Duo, two pianos, Mnuical Artists' Soetety, 1886. Pieces for pf. and flute, pf. solo; Twelve songs (Novello), etc.

Brind, Richard, organist and composer of 17th century. Educated at St. Paul's Cathedral. Organist of St. Panl's Cathedral. Composed a thanksgiving anthem, ete, but is best known as the teacher of Greene. He died abont 1718 .

Britton, Thomas, musician, was born at Higham Ferrers, Northamptonshire, in 1651. He was apprenticed to a coal-dealer in London, aud afterwards commenced business on his own account as a coal-dealer in Aylesbury Street, at the corner of Jerusalem Passage, Clerkenwell. He studied MLusic, Chemistry, and Bibliography, and established weekly concerts in his own house, and formed a musical club. He died at Clerkenwell, London, 27th September, 1714.

The musical chub was formed by Britton for the practice of chamber music, and the performers consisted of Handel, Pepusch, Banister, H. Needler, Hughes (the poet), P. Hart, H. Symonds, A. Whichello, Shuttleworth, Wollaston (the painter), etc. Natthew Dubourg when a child played his first solo in Britton's house. The origin of these concerts and their continuance was due to Britton's personal love for music, together, it is believed, with the mutual love for bibliographical and 


\section{BROADHOUSE.}

other studies held by many members of his audience. 'The admission to these eoneerts was originally free, but afterwards a subseription of 10s. per annum was charged. At the end of 1892 the Britton concerts were established in memory of Thomas Britton, at the Hampden Club, Phouix Street, St. Paneras, London. Britton's books were sold after his death, and the catalogue was published as "The Library of Arr. Thomas Britton, smalkeoahnan, deceas'd, who at his own charge kept up a eonsort of musick above 40 year's in his little eottage, 1714-15. Being a eurious Collection of Books in Divinity, History, Physick, and Chimistry, in all volumes." . . .

His portrait, by J. IVollaston, hangs in the National Portrait Gallery, London.

Broadhouse, John, organist and writer of the present diry. Appointed organist of Christ Church, Balmet, 1876; St. John's, Whet:tone, 1886; and St. Barmahas', Woodside Park, 1889. Editor of the Musical standard, 1878-80; 1886-8; and again snlmequently; and also of the Lomiton Musical Lieriew, 18\$2-3. Author of Facts alsont Fiddles, Violins, Old and New; The Student's Helmholtz (1881); Henly Snart's Compositions for the Organ Analysed (reprinted, 18so, from the Musical Standard). Tramblator "l Thilant's "Purity in MIusie" (London, 1883) ; Schmitt's " 'Te of the Pedal in pef playing"; Bülow's "Notes on Beethoren's P'ianoforte Sonatas." Aathor of "Lose which alters not: a story of to-day," which appeared in the Orchestra (new series), fols. V'III. and IX.

Broadwood, Lucy E., collector, editur, and composer, youngent child of Henry Fowler Broadwood, of the firm of John Broadwood and Sons, was lorn in Seotland. Espeeially interested in singing, she studied mnder W. Shakespeare, and then enstinued the worls of her mncle, the IRev. John Proadwod (which he completed in 18t0), of collecting songs from the comntry people of Snrvey and Sussix. In 1899, collalurated with J. A. Fuller Maitland (q.x.) in editing and aranging "Englich Connty Songs"; also in the serjes of "())d World Songs" ; and is now (1s96) engaged in editing some of Jureell's works. IIas arranged and polblished the okd Scotch airs, "Jess Macfarlane," and "Tn Loyalty," and hascomposed and pollished Nae nair we'll neet; Tammy; When trees did lond; Annie's Tryst, and other soligh.

Brocklesby, Richard, physician of the 18th century. Anthor of "Peflections on Aneiont and Modern Mnsic, with its application to the erne of Diseases," London, 1719.

Broderip, Edmund, urganist and composer, who flom rished in the leginning of the 1 sth century. He was organist of Wells Cathedral alout 1720, and wrote a service, anthems, and glees. He was the son of William Bro-

\section{BROOKS.}

DERIP, born 1683; died Wells, January 31, 1726 , who was an organist and eomposer.

Broderip, John, composer and organist, was born about 1710 , and died in 1771 , was organist of Wells Cathedral, 1740. He wrote various sets of songs, psalms, and "Six Glees for three Voices," London, N.D., "The Flower Garden, a collection of songs, duets, and cantatas"; "Portions of Psalms, in one, two, three, and four parts, adapted to 50 tmes composed by John aud Robert Broderip, London, 1780"; also "Psalms, hymns, and spinitnal songs in score, for publick or private use," London $\lceil 1765]$ n.d.

Broderip, Robert, organist and eomposer, was born about the middle of the 18 th century. He was organist of St. James', Bristol, and died at Bristol, May 14, 1808. Brother of the preceding. Compiled "Miseellaneous Collection of Focal musie," n.d.; "Organist's Jomrnal, selections from great Masters," n.d.; "Cecilian Hammony, a set of the most favourite dnets, rotas, canons, catches, and glees," London, 1790; "Ilain and easy instructions for young performers on the pianoforte or harpsichord, op. 6"; "Eight voluntaries for the organ, op. 5"; "Concerto for the harpsichurd or pianoforte, with aceompaniment for two violins and violoncello, op. 7." He also wrote songr, single glees, and edited a book of psalus with his brother.

Bromley, Robert Anthony, author and clergyman, died 1 ondon, 1806. He pullished a tract entitled "On Opening the Church and Organ, Sermon on Psaln exxii.," Lond., 1771.

Brookbank, Rev. Joseph, clergynian and schoolmaster, born at Halifax in 1612. He was educated at Oxford and ordaned a minister. For some tine he was a preacher in Wycombe, Buels., but in 1651 he settled in London as a schoolnuster and minister. He died after 1668.

Works. - The Well-tun'd organ, or an exercitation wherein this question is discress'd whether or no instrumental and organic MInsick be lawful in holy prlblick assemblies, London, 1660 ; The Organ's Eeho, London, 1641; The Organ's Funcral, I ondon, 16.2; The Holy Hamony, or a plea for the abolishing of $\mathrm{Or}$ gans and other IInick in Chnrelyes, London, 164:; Gorpel Mrusick, loy N. H., London, 16tt; The Compleat Schoolmaster, 1660.

Brooke, Daniel, dergyman and antbor. Pnblished a Sermon preached at Worecster, at the meeting of the three western ehoirs, in September, 17t3; a diseourse on the musiek of the church on the occasion of the performance of IAandel's oratorio, "Athalia," 1743.

Brooks, James, musician and glee composer, who flourished in Bath between 1760 and 1812. He composed "Twelve glees for" three and fonr roices," n.d.; "Second Sett of twelve glees for three and four voices," n.d.; 


\section{BROOKS.}

"Twelve English hallads," op. 5 [1790]. Concerto for the violin, in nine parts, 1797 ; Nocturne for the pf. and 'cello or fiute; Thirty-six select pieces fol' a military band.

Brooks, Walter, organist, bon at Longdon, Worcestershire, April 1st, 1832. Recommended to the Rev. Sir J. H. Seymour, Bart. (preacher at the Gloucester Festival of 1832), he was accepted as a chorister at Gloucester Cathedral, and aftelwards articled to Johm Amott, the organist. On leaving, he was appointed organist and choimaster at Cpton, St. Leonard; then to Christ Church, Hampstead; St. Mary's, Atherstone, and, in 1857, after competition, to St. Nartin's, Bimingham, a post he holds to the present time. Beyond conducting some concerts of the St. Martin's Musical Society, he has not taken part in pullic work, but has deroted himself to church music. and to teaching.

WaLthr William Prooks, eldest som of the ahove, composer, conductor, and writer on mnsic, was born at Edghaston, Bimingham, March 19th, 1861. Received hisearlient musical education from his parents, and was a chorister at St. Mastin's Chulch. Educated at King Wdward's School, ol,taining fint place in all Fugland for music (theory) in the $\mathrm{Ox}$ ford local examinations. From 1879-81, he studied composition at the R.A.M., nuder (Professor) F. Pront, after which he settled in Londom as teacher and writer. Ite has held, since 1889 , the pusition of tualler of pianoforte and singing at the William Ellis Endowed School, Gongel Oak. The has contributed articles to 'The Munthly Musical Record (of which he was sometime editor), Musical Opinion, and other papers, and has had some experience as a drambtic critic on the Lomelon Fiyaro. Hisemporitionsinclude an Allegro, for orchestra (Pri\%e, 1891, T3elfast Philhamonic Socicty); Itenx Norceanx, op. 14 ; Allum Lyrique, op. 48; Truis Moreaux, op. 50, all for violin and pof. Prolnde and Fingue in D minor (derdicated to Sir F. Onseley); "The fanily circle," twalve characteristic lieces; Six porgrensive atudier, and other pieces for pf.; somgs, and part-songs.

Artilur Charles Brootis, the vonnger brotber of preceding, was borre at Jedghantom, May th, 1864. Chorister at St. Malitis's. Edincated at King Edwat's Sehool. Fasly musical training at home; then studied at R.C.MI, under Dr. G. C. Martin, Dr. J. F. Bridge, Franklin Taylor, and others. In 1884, appointed organist and musicmaster at Feaconsfield School, Bucks, and organist of the Parish Church ; in 1890, to St. John's, Sligo, Ireland, which office be resigned in 1896 to return to Birmingham, where he is cngaged in general musical tuition.

Brooksbank, Hugh, organist, bon at Peterborough, September 13th, 1851. Chor-

\section{BROONIE.}

ister at St. George's Chapel Royal, Windsor, and afterwards articled to Dr. Keeton, of Peterborough Cathedral. Organ scholar, Exeter College, Oxford, where he graduated Mus. Bac., 1874, also taking the F.C.O. the same year. In 1881 he was appointed organist to the new church of St. Alban, Birmingham; and in 1882 to Llandaff Cathedral, a post he held till his death, at Cardiff, April 28th, 1894. He was organist at the first Cardiff Musical Festival, 1892. His published workis include Frening Services in E flat, and B flat (unison); a Benedicite, and songs. His brother, OLlver Oldham Brooksbank, was hom at Peterborongh, May 17th, 1859 . Was also chorister at St. George's, Windsor, and pupil of Dr. Keeton. F.R.C.O., Mus. Bac., Durham, 1894. Organist at Flettom, 1877; Altom Jarish Church, 1880 ; Sit. Lcomald's, 1882 ; St. Joln's, Leatherluead, 18s:3; St. Martin's, Bedford, 1895; and Addlestone Parish ('hurch. Has also held appointments as mganist or musicmaster at (hardstock (1880); Highhury and Tombridge Schools (1891); assistant at Trinity College, (rlenalmond (1881), and music-naster, Leamington College (1887). His compositions are: "Stury of the Cross" (1895); church services, offertory sentrinces, set of hymm-tmmes (1891). Songs: If 'tis love; The song' of Mrdora, etc.; lf. and organ pieces, etc.

Broome, Edward, organist and composer, a native of North Nates. For some time ongunist and choimmater, St. Nary's, Pangor. Sincensul competitor as composer and choral conductor at Eistoddfodan. Anomg his compositions is an anthem in momory of Eos Torlais (Robert Rees, q.x.), which won the prize at the listeddfod, Pontynidd, 1893. Now resident as organist and profesisor of munic at Montreal, Canada.

Broome, Michael, musician, was born in 1700 . He was clerk of St. Plilip's Church, Piminglam, lut appears to liave been a singing-nuaster at Inleworth, Middleser, and also a printer or engraver in Birmingliam. According to his tombstone at St. Plilip's, Finminglum, he was "Father of the Musical Society in this town." He died at Bimingham, September 20, 1775 , aged 75.

Works. - Michael Broome's Collection of Cliurcli Mnsick for the use of his Scholars," 11.R. "A Cloice Collection of Psalm Tunes, Hymms and Anthems, all in three or four parts, with the samut and its branches: newly done in a fair large character ; the whole being drawn out in schore: Collceted and printed by Michael Froom, singing-naster, Isleworth, Middlesex" [1731]. Another edition [1738]. "A Choice Collection of Twenty-four Psaln Tunes, all in four parts; and Fifteen Authems, set by different authors... ; the whole collected, engraved and printed by Michael Broome, Bimingham," [1738]. "A Collection of Twenty- 


\section{BROONFIELD.}

eight Psalm Tunes in four parts... for the use of the Churches and Chapels in and near Birmingham," Bimingham, 1753. "The Catch Club, or Pleasant Musical Companion, containing a Choice Collection of Fifty Catches, both Ancient and Modem collected, printed and sold by Michael Broome, near st. l'hilip's Chureh, Bimingham, 1757."

Broomfield, William Robert, composer and writer. Born at Inverary, Argyle, 14th Octoher, 1826. He was for a time in an accountant's office in Glasgow, where he studied music under John Turnbull. About 1850 he settled in Aberdeen as a music teacher, and while there he did much work for William Hamilton, of Glasgow. He was a confimed dipsomaniac, and, in spite of several efforts to cure him, he became victim to his habits, and died at Aberdeen, Octoher 16, 1888. In July, 1889, a monument to his memory was erected over his grave in Allanvale Cemetery, Aberdeen.

Works.-Psalm Tunes: "St. Kilda," "Shandon," "Zion." "Songs: Edited "National Songs, harmonised as vocal quarteties," first series, London, n.d.; second series, Glasgow, 1868. "The Principles of Ancient and Modern Musie, deduced from the Harmonical Numbers of Antiquity," Aloerdeen, 1863. "Mammal of Harmony for the use of Students in Musical Composition," Glasgow, 1872.

Broughton, Alfred, pianist and conductor, born near Iewshury, Iorknhire, January 12, 1853. Stadied at first muder his brother James (q.t.), and then under Lebert, Tod, and Attinger, at Stuttgart Crmservatrium. In 1872 he was alpointed organist to the Leeds l'hilharmonic Society, and in 1884, conductor. He was ateompanist at the Leeds Festival of 1883, and choimaster from 1896. Trained bodies of Leeds choristers have heen under his direction, associater with the Festivals at Wurecster, 1887, and Hereford, 1888; and he has taken detachments of his choir to assist at the Richter and Henschel concerts in London. He was a pianist of high attaimments, as well as a condnctor. He died at Leeds, June 12, 1395. His brother, James Broughtos, bom near Itewslury in 1833, went to Leeds at the age of thirteen, and was appointed crganist of st. Amm's Roman Catholic Chureh, where he remained for over twenty yoars. He was ehorms-master of the Leeds Festival from 1874 to 1889 , and for a period of ten years gave serjes of classical chamber concepts in Leeds. He died March 12, 1887.

Brouncker, William Viscount, writer, born in 1620, died in 1681. Translated "Descarte's Mnsical Compondium," 1653. Published anonymonsly an "Excellent Compendium of Musick; with necessary and judicious animadrersions therempon, by a Person of Honour."

\section{BROWN.}

Brown, Abraham, violinist and composer. Was one of the principal performers at Ranelagh Gardens, where he succeeded Festing, abont 1752, and at the aristocratic concerts. in London abont the middle of last century. His tone is mentioned as having been clear, but loud.

Brown, Arthur Henry, organist and composer, born at Brentwood, Essex, July 24, 1830. Organist of Brentwood Parish Church, 1841 ; St. Edward's, Romford, 1852-7 ; Brentwood, 1857-85; St. Peter's, South Weald, Brentford, 1889. Associated with the revival of Gregorian mnsic, and member of the Committee of the London Gregorian Choral Association.

Worrs.-Cantata, The First Miracle; Missa Seraphica (Communion service, in C); Missa ruinti Toni (plain chant Communion service); Missa Crelestis; A flower service; Children's festival service (compiled by Rev. S. Childs Clarke. M.A.); Harvest Tide, a service of song for Harvest Thanksgivings; A century of Hymu tunes (1880); The (rregorian Canticles and Psalter (1874); Anglican Canticles and Psalter (1877); The Canticles of Holy Chureh (cregerian): The Matin and Vesper (anticles (Anglican); Metrical Litanics: 'Thr Pravel' book noted, with plain chant for all the offices of the C'hureh (1885); Introits for sundays and Frestivals of the Fear (1895); Te leum, Magnificat, and Nune Ininitis; Anthem for Ciristmas, etc.: A Christmats folnme of prose and song (Barbara Wordsworth); lart-songs; Songs: Across the field of barley; Somelndy's darling; (rather ye rosebuds, ete. New Pianoforte Tutor (1882). Pieces for pf. : Sarabande and Gigue; Gavotte and minnet, ete. Organ Harmonies for the Gregurim tones: select compositions from the great Masters (armed); Select overtures from the great Milsters; Twenty original soluntaries for organ or harmonium. Carols and hymm tumes, contributed to Hymus Ancient and Modern, and varions collections.

Brown, Colin, musician and thenretical writer, was bom at Liverpool, August 25, 1818. He was dencended from an Argyleshire fanily. Euing lecturer on Mn Mic in Anderson's College, Glasgow, from 1868. He diech at Hillhead, Crlasgow, 1)ecember 19, 1846.

Works.-Music in Common Things, Part 1.: Analysis of a Musical Sonnd, and the Production therefrom of the Musical Scale, 187t; Part 2: Nathematical and Musical Relations of the Scale, shewing the Principles, Construction, and Tuning of the Natural Fingerboard with Perfect Intonation, 1876; Part 4: Music in Speech and Speech in Music, Glasgow, 1870. Songs of Scotland (with J. Pittman) London, n.d. The Thistle, A Miscellany of Scottish Song, with Notes, Critical and Historical, Instrumental Accompani- 


\section{BROWN}

ments and Hamonies by James Merrylees, Glasgow, 1884 [originally issued in parts].

Mr. Brown eonstrueted an instrument called the Voice Harmonium, founded upon the Monopolytone, to which the principles of perfect intonation were successfully applied. The novel character of the keyboard, fully deseribed in "Musie in Common Things,", part II, will perhaps act as an obstruction to its speedy adoption. The Monopoly tone above mentioned is a small instrument for striking on the keyboard of a pf., producing a perfect unison, thongh sounding every note and discord of the scale. His harmonimm was awarded the first place at an exhibition of instruments illustrating the same principle held in London.

Brown, Edward, organist and condnctor of present time. Graduated Mus. Bac., 1878; Mus. Doe., 1883, Oxford. Organist and choirmaster, St. Jannes', Barrow-in-Furness, and St. Paul's, Grange-over-Sands; choimaster, Furness Association of Church Choirs. Conduetor of choral societies at Barrow, Ulverston and Grange. Ilis setting of Psaln 45 (Tniversity exereise for Mus. Doc.), was performed with suceess, April 9th, 1883. He has pullished some church music, songs, ete.

Brown, H., musician and anthor of present time, resident in Brixton, London. Issued "Ifisturical sketch of music from the most ancient to modern times," Londun [1886]; also "Sonmets by Shakspeare solved."

Brown, J. C., musician of Clerkenwell, London. Compiled "Collection of original sacred music, containing 104 psalm and hymm tunes, and four pieces hamronized for four voices, and arranged for the organ," London, 1818.

Brown, James D., tenor singer, lecturer and teacher, wa born at Aberdeen in 1834. He studied music and singing under James Davie, Sammel Barr, Thomas Macfarlane, H. Kuchler, and Alex. WV. Smith, and wits conductor of psalmody in Free St. Darites Church, Edinlurgh, from 1865 till 1877. Since 1866, he has given many eoncerts and lectures on the ballad music of Seotland, and has done much to aid the movement in favonz' of thorough roice cultivation, and to foster a taste for the old and genuine ballad muse of Scotland. He has composed a few songs to words by Bums, etc. His son, James I Hef Brows, was born at Edinburgh, November 6th, 1862. He was edneated at the Chnich of Seotland Normal school, and afterivards entered the employment of pullishing firms in Edinburgh and Glasgow. From 1878 till 1888 he was an assistant-librarian in the Mitchell Library, Glasgow, and in September, 1888, he was appointed librarian of Clerkenwell Public Library, London, a position he now holds. Author" of "Biographieal diction-

\section{BROWN.}

ary of musicians, with a bibliography of English writing on music," Paisley, 1886. "Handbook of library appliances: the technical equipment of libritries," London, 1892. "Guide to the formation of a music library," London, 1893. Nmmerous paper's on library economy, and on topics connected with bibliography and literature.

Brown John, dergyman and witer, born at Rothbury, Northumberland, 1715. Educated at Cambridge. Vicar of Great Horkesley, Essex, 1754. Viear of st. Nicholas', Nowcastle, 1758. Committed suicide while insane, September $23 r d, 1766$.

Wonks.-Honour, a poem; Essay on satire; Sermons; Essiys on shaftesbury's Charateristics, 1751; Dissertation on the rise, union, and power, the progressions, separations, and corruptions of poetry and musie, to which is prefixed The cure of Saul, a sacred ode, London, 1763; Remarks on some observations on Dr. Brown's dissertation on poetry and musick, London, 1764; An estimate of the manners and principles of the times, 1757.

An Italian colition of the Iissertation was pullished in 1772.

Brown, John, artint and writer, born at Edinburgli, 175\%. Resided in Italy from 1771 till 1781. He died in Seotland, 1791. Author of "Lutters upon the Puetry and Music of the Italian Opera," Edinbmrgh, 1789.

Brown, Robert, of Finckhaven, writer and theorist, was born at (tasgow, 1789-90, and died at Rockhaven, near Fairlie, Ayrshire, 25th August, 1873. Author of The Elements of Insical Sciences, L mdun, 1860. An Introduction to Musical Arithmetic, with its application to Temperament, London, 1865. Rudiments of Harmony and Counterpoint on a New Method... London, 1863. Also a work on Scottish Highland Psalm Tunes.

In the first work Brown adrocates the adoption of a miform clef, and illustrates this in the course of his book. He also suggests certain modifications in the method of expressing harmonical comlinations, ete.

Brown, Thomas, musician of isth century. Author of "The Compleat MIusick Master, leing plain, easie and lamiliar rules for singing and playing" . . London [1704].

Another Thomas Browx, tyled "junior," was organist of st. Murgaret Pattens and st. Gabriel, Fenchureh strect, London, in latter part of the 18th eentury. He publisher a "Collection of somgen, and a Cantata for the harpsichord or pianofortu:" London, 1774.

Brown, Thomas, muician, compiled "Psialms and hymms, as sung at the Sunday evening lectures in the galiles of Duham Cathedral, arranged for fonr voices, with an aceompaniment for the organ or pianoforte," Durham, 1842.

Brown, William, musician, issued a col- 


\section{BIROWN.}

lection of Psilm Thuses, in four patts," (ilasgow, 1700 .

Brown, Willan, musician, of 18th century, was a teacher in Glasgor, and procentur

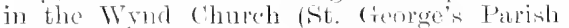
Chureh), which he resigned in 1807 . He contpiled "The l'recentrr, or an easy introduction to Chumele Mnsic, with a cholece collection of Psaln 'Tunes"... fith ext., 1799, originally issued in 1756, hy Juhn Meluachlan.

Brown-Bortiwick, Rev. Robert, clergy-

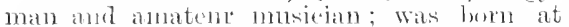
Aberdeen, Nhay 18th, 18to. Som of William Exoms, Hsq., of H.M. Civil service, Aberdeen, who was an amateml musician, well-known at the enncerts of that city. Ordained deacon in 1865. Ordaimed pricist, 1866. Curate of Sudely Mantor, (iloncestershire, and Chaplain to the Wincheomb [nion. ('nratenf ] veshan, Worestershire, and assistant-minister of Quelue ('haprel, Lendon. Mr. Brown-Borthwickassumedadditional sumbmeof loothwick on his matriage in 1808 to Grace (D). 1884), only shoviving dawuhter of the late, and sister of the present, John Prothwick, Enq, of Bosthwirk Cizste, and Croukston, Midlothian. Incunbentof Holy Trinity, Gratuge-in-Formosdale, Comboland, 1869-52. Vicar of All

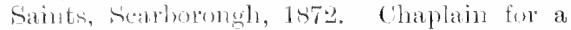
few years to the lishop of Aluederen. Ticar of

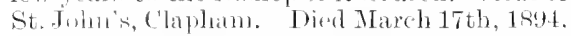

Workis.- sinplenental liymor and tume book (Nosello), containing esmtributions hy Goss, sullivan, Staner, J. J. Ilopkins, and J. B. Calkin, fonl editions, Twelve krries. Frries and Sinctuses, edited. Blensed are the dead, anthem. Wordsol "Chumblimns" (with the bishop of liedford (Dr. W. I Low), Rer. J. Ellerton, Rer. B. ('ompton), the hym book issued by tho S.P.C.K. Select liymmin for chuch and lome, ledin.. 1871. The Histury of the Princes de Gomalé, ly H.R.H. le duc d'Ammale, translated, London, Sro, 2 poli. Life and works of Stephen Heller, by Fl. Barhedotte, transhated, London. Hymms, contributed to varions collections. Semons on various suljects, as "Art in worship," "The praine of God," etc., all pulblished.

Browne, James A., violinist, conductor, and writer on music; born at Woolwich, May 9th, 1838. Joined the Royal Artillery Band in 1848, as a singing-boy, and received instruction on the flute and violin; was appointed solo flutist in the band in 1864 , and from that date was similarly engaged in London theatres, concerts, mal the Handel and other festivals. Appointed band-master, Royal Horse Artillery, in 1870 , retiring on a pension in 1878 , when he actepted the post of band-master to the South Metropolitan Schools, Sutton. Musical Director, Royal Court Theatre, London, 1880-1 ; Conductor of the Orchestral Festival Services, St. Agnes,
BROWNSNITH.

Kenniugton Park, 1881-94; teacher of the violin. Starterl the Surrey Musical Jommal (which existed only for six months), in 1885; lecante sub-editor Mritish Musician, 1893; sole editor, 1895; proprietor and editor, 1896. His pulstished workis include; Military band almugements ; a part-soug, "The dragoons"; songs; Macch, "Cleopatra," an oboe solo. In MS. he las a drawilssoom oratorio; an opera; a string quartet, and some dramatic music. Anthor of The north-west passage [1860": IIistory of the Roral Artillery 1865]; and papers on jands and inusic in the rervice Adrertiser [1884]; and the Surey Insical Iommal, etc., cte.

Browne, Lennox, surgeon and writer on the volee, lom at London, in 1841. He was the son of a distinguished surgenn. Fducated at Edinburgh and Lundon. F.R.C.s., Edin., 1878; M.L.C.M., Eng., 1863. Member of mmmerom modical socioties, and surgeon to varions monsical societies. Author of "The throat and its diseases," Lnndon, 1878, 4th ed., 1893. "Voice, song, and speteh, a completes mannal for singers and speakels," London (Low), 1883; 15 th ed. 18:12. Written in conjunction with $\mathrm{E}$. Behmlie. "The child's vores; its treatment with regand to after development," Lomden, 1885 (with behmke). "Toice, nse, and stimmlantr," 1885. "MTechanism of hearing," 1889 , etc. "seience and singing," $18 \mathrm{st}$.

Browne, Richard, medical writer, who was an apothecary at Oakham. Author of " Nedicina musica; or a meehanical essay on the effects of singing, musick, and dancing, on human bodies; to which is annexed a new essay on the nature and cure of the spleen and vapouss," London, 1729.

Browne, Thomas (Tom), violinist, born at Noweastle in 1812? Studied nnder Eliasom, and theory with T. Severn, and French Flowers. In the band of Her Majesty's Theatie; Sacred Harmonic Society, cte. Popular as a teacher, and composer of dance music, his "Helena Waltz" having had a great cireulation. Of his songs, "On the swelling deep," deserves mention. Died in London, Aligust 10, 1884.

Brownsmith, John Leman, organist, was borm at Westminster, in 1809. Chorister at Westurinster Abley under ( rreatorex, with whom he studied the organ. Organist of St. John's Chnreh, Waterloo Road, London, 1829, an appointment he was compelled to resign when made Lay-vicar of Westminster Abbey, in 1838, because the vestry refused to allow him to have a deputy when on duty at the Abbey. Organist to Sacred Hammonic Society, 1848; organist at Handel Festivals of $1857,1859,1862$, and 1865 ; organist of St. Gabriel, Pimlico. He died at London, Sept. 14,1866 . 


\section{BRUCE.}

Bruce, John, violinist and composer, was a native of Bratemar, ant according to Bums, who knew him well, "a red-wud fi.e., starkmad) Highlander." He settled in I nunfries after the rebellion of 1745 , in which he took part, and died there Inecunber 31.1785 . IIe is generally regarted as the commoser of the air usually sulg to" Whiste o'er the lave o"t."

Bruce, John Collirigwood, M.A., LL.D., D.U.L., F.S.A., histurian of the Romin Wall, and anthor of numerous lowhis on the Roman occupation of Britain, and neetiaval life upon True-side. He was a gleat anthority on the subject of the Northmmbian l'ipes, and read at paper relating to them at the Conference of Musicians, lield at Neweastle-on-Tyne, in Jammary, 1892. He died in that town, April 5, 1892 , aged 86 .

Bruce, Thomas, musician, of 18th century, was a schoolmanter in the Curgate of Ertinburgh. Anthor of " The Common tumes, or Scotland's Chureh Wusick mike plain, with a description of the antiguity, une, authors and inventors of Musicli." Ealinburgh, 1720; 2ud ed. n.d.

Bryan, Cornelius, "rgan ist and compusel, born at Bristol, about 1775. ILe held the appointments of organist of rit. Marrs's, atrut St. Marr, Retheliffe, Bristol. Ired at Bristol, March 18, 1840 , from the cffects of a fall.

Works.-Lundy, operetta, 18t0. Collection of the most esteened Psalm Tunes, ancient and modern. . . interspersed with a lew original compositions, 18:30. Effusions for the organ, containing eight voluntarics, wne humdred interludes and three psalns. 11.d.

Bryce, Rev.? divine and writer who lived in Belfast. Anthor of "A Rational Introduction to Music, being an attenut to simplify the first principles of the science," London, $18 \pm 5$.

Bryne, Albert (or Albertus), composer and organist, who flourished in the 17 th centary, and was born about 1621 , and died in 1669 . He was a pupil of John Tomkins, whom he succeeded as organist of Sit. Paul's C'athedral in 1638. Afterwards, he became organist of Vestminster Albey. His compositions appear in Boyce, Clifford, and some are in MS. in the British IIusem. They consist of services, anthems, and organ music. His name is variously spelt, Brian, Bryan, etc.

Bryson, John, musician, who flourished during latter part of $18 \mathrm{th}$ century. He was manager to Robert Bremner at the Harp and Hautboy, Edinburgh, from 1769, and sneceeded him in the business in 1789 , carrying it on till 1818. Published "A Curious selection of favourite Scots tunes, with rariations; to which are added upwards of fifty farourite Irish airs for a German flute or violin; with a bass for the harpsichord or violincello," Edin. [1791].

\section{BUCKLEY.}

Buchanan, Thomas, surgeon and anthor. Authol' of "Plixsiolugical Illustrations of the organ of hearing, more particularly of the sceretion of cermen and its eflects in rendering auditory perceptions accurate and acute." London, 1828.

Buck, Percy Carter, orgunist, born at West Ham, Esisex, 1571. Eelucated at Merclant Tarlor Selrool. Chorister at West Ham I'arim Clunch. Pupil of In'. C. J. Frost, and F. I)avenport, at (iuilelhall sehool of Music; and later, wimer of an organ seloolarship, R.C.JI., studying meder I)r. IInbert Parry, C. II. Lloyi, and (Sir) Walter Parratt. I'rise-winner for compusition, Stratford Musical Fentivals, 18st-\$. F.1R.C.O., A.R.C.M., Mus. B., Oxford, 1892, and pualified by Examination for Mus. I)., 189:. Organist at Surlitun; Murcenter Collese, Oxford; Musicmaster, lingly school; and on the death of Mr. C. W. Larrington (Oet. 1895), appointed organist and choimnater of Wells Cathedral. He has publisled an trgan sonatio in E flat, and some trios for fermale voices, and has written somsin, and is juint anthor (with Rev. Dr. Mee, and F. ('. Movkls) of "Ten years of Eniversity music in Oxfore" (Oxford: Bowden, 1894).

Buck, Zecharialı, organist and composer, borll at Norwich, Sept. 9, 1798. He was a chorister in Norwich Cathedral, mnder Garland and Becliwith. Organist and choirmaster of Norwich Cathedral, from 1828 to 1877. Mus. Doc., Cantuar, 1853. Ite aequired great fame as a trainer of boys' voices. Died Nemport, Esinex, August 5, 1879.

Works. - Anthens: Come hither, angel tongues invite (1849); I heard a voice from heaven; O Lord, sive Thy holy spirit. Eight chants in Farr's collection.

Buckenham, J_-, of Bramfield, musician of 18th century, isisued “ ''salm-singer's Derout Exelcises, containing (1) new and compleat introduction to the grounds of Musick; (2) Select collection of Church Musick; (3) Two chanting tmues; (f) Sixteen anthems and alphabetical glossary."

Buckland, Henry, tenor rocalist, was a ricar-choral at st. Paul's Cathedral, and master of the choristers. He conducted the ammal festirals of the Charity children, at St. Paul's, 1863-7; also the special evening services held there. A very good concert singer. He died in London, August 13, 1867, at the age of 41 .

Buckley, Mrs., born OLrvid Dussek, pianist and writer, bon in London in 1799. Daughter of J. L. Dussek, was taught by her mother, and appeared in public at the age of eight. Organist of Kensington Parish Church, from 1840. Died in London, in 1847. Author of "Musical Truths," London, 18t3; two books of "Fairy songs and ballads for the 


\section{BUCKNALL.}

young," 1846 ; pf. pieces; arrangement of "Rule Britamia," for pf. and harp, ete.

Bucknall, Cedric, organist and composer. Studied privately, and graduated MIus. Bac., Oxferd, 1878. Organist of All Saints, Clifton, and of the Victoria Rooms. Has published a communion service in B flat; composed, revised, and selected tunes for" "Hymms for" school worship" (Novello, 1893 ?); also composed part-songs, carols, ete.

Budd, George William, partner in the publishing firm of Calkin and Budd, was born in 1806 . 1 He was the founder of the Westem Madrigal Society, and secretary of the Philharmonic Society, 1847-50. Edited, for the Musical Antiquarian society, the second set of madrigals loy John Willye; and was the composer of some glees, ete. He died in London, August 1st, 1850.

Buddicom, Rev. Robert Pedder, clergyman, and musician, born 1770, died July, 1846. Incumbent of Everton, Liverpool. Pulblished "One hundred psalm and hymm tunes, with chants," edited by C. H. Wilton, London, 1827. Re-published as "I)evotional Harmony," consisting of psahms and hymms, Liverpool, 1833.

Buels, William WV. C., violoncellist and author, was principal of the Rensington Sehool of Musie, London. He died in Londen, Dee. 6th, 1890. Author of a "New and improved eatechism of the rudiments of music," London, 1880.

His father, John Buels, was also amusician, as are his brother ED. F., baritone rocalist, and LouIs, riolinist, and his sister MARIAX, pianist.

Bull, John, composer and organist, was born in somersetshire $[15637$. He studied under William Blitheman, and became organist and master of the children of Hereford Cathedral, 1582. Gentleman of the ('hapel Royal, January, 1585. Bac. MIus, Oxom., 1586. Ius. Mus. Oxon., 1552. Organist to Chapel Royal, 1591. Professor of Alusic at Gresham College, 1596. Travelted on the continent, i601-5. Mlarricd to. Elizabeth Walter, 1607. Insician to Prince Henry, 1611. Quitted England without leare from his mployer, 1613. Orgunist at Notre Dame Cathedral, Antwere 1617. He was organist in service of the Arehonke of Austria. 11e died at Jamburg, Liibeck, or Antwerp, Nlarch 19th, 1628.

The productions of this omposer are muntioned loy nearly evory writer as having been voluminos, but eomparatively few of them appear to have been printrd. Specinnens of his style can be seen in Bamard's Collection, Boyce, Leighton's "Teares," the Fitzwilliam music, "P"arthenia," Gueen Elizabeth"s Virginal Book, etc. A motet for five roices is preserved in Bumey's Mnsical Ixtracts,

\section{BUNCE.}

British Musemm. E. Paner gires specimens of his virginal music in "OId English Composers." The extraordinary celebrity which this musician obtained during lis lifetime must have been gronnded on some uncommon degree of merit, either in his compositions or performance. A list of his works is contained in Ward's "Lives of the Gresham Professors," and in addition he wrote a great number of pieces of sacred vocal music." "The strength of thineomposer's talents lay in the production and execution of pieces fully hamonized, and comprising fugues, double-fugues, and the varions species of eanon; and fortunately, for himself, he lived in an age that listened with pleasmre to music of that dereription.

He sumounted old and insented new difficulties; and disdaining to be embarassed, amed, in the provinee of polyphonic fabrication, at a sprecies of ommiputence."-Busby.

The question as to the composition of the English national anthen remains undecided in a general way, thongh Garey appears to have been strongly accredited with the composition. See writings of Chappell, Cummings, Clark, ete. In commection with Gresham College, fr. Bull delivered "The Oration of Maister Jolm 13ull, Doctor of Mnsicke, and one of the frentlenen of hir Mlajesty's Royal Chmpelt, as he promounced the same, before divers workhipind persons, the Aldermen and Commoners of the citie of London, with a great multiturde of other people, the 6th day of (ketolur, 159\%, in the new erected Colledge of Sir Thomas Gresham, Krnt. deceased: made in the commendation of the founder, and the excellent science of Musiclie," London, este $159 \%$.

Bull, T., musicinn, wrote "New and complete moxiern preceptor for the roval kent langle," Lomdun, 1435. "New instructions for the improred Hageolet, ete.," London $18+5$

Bumpus, John S., writer on musie of the presemt time. Has written a $13 m$ mber of valualle antiquarian papers on nusical subjects, anong which may he mamed "A short histery of English Cathedral Mlnsic"; "St. 1'atrick's and Christ ('humch Gathedrals, Dubhin"; and "The (Heanists and Comprosers of st. I'aul"s Cathe dral." These were uriginally contributer to the Musical stamturl, 1884-8.

Bunce, John Thackray, jommalist, born at Farringdom, Porkshire, 1s.s. Removing to Birmingham in 18 '39, he waseducated there; and deroting himmelf to jommalimm, lecante editor of the Biminglum Luily Pest. Anthor of "the History of the Himmingham $\mathrm{Cor}^{-}$ poration"; "History of st. Nartin's ('hurch. limningham"; and other works. Heoriginated the corporatim seloool of Art, and has been identified with the lidueational and scientitic work of the city. Is at J.L', and 


\section{BUNCH.}

F.S.S. He claims notice here as author of "A History of the Bimingham General Hospital and the Murical Festivals, 17681873, Binninghan, Comish, 1873.

Bunch, James, musician, editor of " Ceciliana: a collection of farourite eatches, canons, rondos, and rounds, ly eminent anthors, ancient and modern, in score, with hiographical notes." London, 1825.

Bunn, Alfred, operaticmanagerand librettist, was horn at London, 1798. Stage manager at Drury Lane Theate mnder Flliston, 1823; Manager and Lossee of Drury Lane Theatre trom 1834. He died at lionlogne Dec. 20, 1860. Bumn adapted a great number of pieces for the Emslish stage, and produced the following among other operas: Maid of Artois ; Bohemian Girl ; and Daughter of St. Mark (Balfe): Brides of Tenice (Benedict); Maritana (Wallace), etc. He also wrote a work entitled "The Stage, both before and behind the curtain, from observations taken on the spot." 3 vols., Londom, 18t0. Poents, London, 1816. For a wevere skit on 13mn, see "A word with Bumn, after Burns's Address to the Deil." By J. R. Aram, the ('eemorne Poet, London [1847].

Bunnett, Edward, organist and composer, born at Shipdliam, Norfolk, June 26, 1834. Entered as a chorister at Norwich Catherlral, 1812; articled to Dr. Buck, 1819 , and from 1855 to 1877 wis his assistant organist and partner. Craduated Mus. Bac., 1857 ; Mus. Doc , 1869, Cambridge ; F.C.O., 1870. In January, 1849, sang in the trio "Lift thine eyes," with Jenny Lind and Miss Dolby, at a concert given in Norwich. From 1871 to 1892 he was conductor of the Norwich Musical [Tnjon; has heen organist of the Norwich Mrusical Festivals since 1872; of St. Peter's, Mancroft, from 1875; and Borongh Organist since 188t, his recitals always attracting large audiences. From 1890 he has had clarge of the pier concerts at Lowestoft. He celebrated his musical jubilee, April 18, 1896, when he was presented hy the MLayor (John Moore, Esq.) with an address and handsome testimonial from his fellow citizens. He has occasionally lectured on Oratorio and other subjects

Works.-Song of Praise (Degrce Exercise, $1869)$; Ps. 130, De Profundis (Norwich, 1880); Unison Service in F; Office for the Holy Communion, in E; Services, \&c. Anthems - Blessed be Thou; If we belicve that Jesus died; If ye love me; and others. Twenty. four original tunes to favourite Hymms; Ten Christnas Carols. C'antutas-Rhineland, for soprano solo, chorus, an I orchestra (composed for MIlle. Tietjens, bnt'sung by Florence Lancia, and produced, Norwich Festival, 1872; Lora (WV. W. Turnbull. Produced by Norwich Musical Union, June 1, 1876). Comedietta,

\section{BURGH.}

Incognita (Mrs. Edward Adams, Lowestoft, August, 1892). Part-songs-The Rhine Maiden (Norwich Festival, 1884); Tictoria, soprano solo and chorus (1887), and others. Various Songs. Andante and rondo, p. and orchestra; Trio, pf. and strings; Sonata, pf. and violin (MS. 1873) ; Duet, pf. and clarinet; Pieces for pf., etc. Eight organ pieces; Six original compositions for organ (1884); Twelve sliort and easy pieces for orgau; Largo in E flat, for organ; Are Maria, etc.

Bunning, Herbert, composer of the present time. Studied in France and Italy, chiefly in Milan, under Vincenzo Ferroni. Settled in London about the close of 1891. Of lis compositions, a Scena, for baritone, "Ludovico il Moro," was given at the Cry stal Palace Concerts, February 27, 1892, the late Eugene Ondin heing the singer; and a "Village Suite," in four movements, for orchestra, was produced at the same, April 4, 1896. He luas composed an opera, "The Last days of Pompeii;" Two symphonic poems, and a Rhapsody, for orchestra; a string quartet, and some songs.

Bunting, Edvard, nusician and editor, was horn at Arnagl, in February, 1773. He was articled assistant to Weir, at a church in Belfast, in 1784. Organist of St. Stephen's chapel, Belfast. Narried to Miss Chapman, 1819. He died at Dublin, December 21, 1843.

Works.-A Genelal Collection of the Ancient Irish MLusic; containing a variety of admired airs never before published, and also the compositions of Conolan and Carolan, Lond., 1796. A General Collection of the Ancient Nusic of Ireland, arranged for the Pianoforte; some of the most admired Nelodies are adapted for the Voice, to poetry chiefly translated from the original Irish songs hy 'Thomas Camphell, Esq., and otlier cminent poets; to which is prefaced an Historical and Critical Dissertation on the Egyptian, Pritish, and Irish Harp, London, 1809. The Ancient Music of Ireland, arranged for the Pianoforte; to which is prefixed a Dissertation on the Irish Harps and Harpers, including an account of the Old Nelodies of Ireland. Tublin, 18t0. These collections of Irish music are among the best which have heen made, and Bunting is regarded as a fairly accurate compiler.

Burgess, Alexander, the "Fife Paganini," violinist, and poet, born in Fife, in 1807; drowned at Whin Quarry, Starr, Fife, August 2, 1886. Ife will be best remembered in Scotland, as a contributor of humorous phonetically spelt verses to the People's Journal, under the signature of "Poute." Some of these poems were collected as " Nettercaps, heing pontery, prose, and verse," 1875 . His fame as a violinist was only local.

Burgh, A . . , writer, who graduated 


\section{BURGHERSH}

M.A. at one of the Universities. He compiled "Anecdotes of Music, historical and biographical, in a series of letters from a gentlenan to his dangliter," London, I814, 3 vols.

Burghersh, Lord, see Westuorelind, Earl of.

Burgon, William Henry, bass vocalist, born at Croydon, in 1858. Studied under Manuel Garcia, at the London Academy of Music. Made his début in oratorio, 1881, singing in Bach's Mass in B minor (Bach Choir), June 1st, and in Judas Maccaberens (Sacred IIarmonic Sociuty), in November. Has since sung for the prineipal choral soeieties in London, Liverpool, Glasgow, and elsewhere. Sang in opera at Covent farden, 1884, and afterwards joined the Carl Rosa company. He was the original Ostap in Thorass's " Nadeshda" (produced at I rury Lane, April 16th, 1855), and Count des Grieux, in Nassenet's "Nanon," at its first performance at Jrury Lane, Mlay 7th, 1895. Of his later assumptions are Cedric, in "Ivanhoe," 1891, and Louis XII. in Messager's "La Basoche."

\section{Burgoyne, Montagu, see llarris} (J. Maedonald).

Burnet, Alfred, musician. Published "Instructions for the Spanish guitar, founded on the systems of Carulli, Giuliani, ete." London, 1829.

Burnet, George, amateur musician and herald, who held the office of Lyon king of arms in Edinburgh. Tle died at Edinburgh, Jannary 2 tth, 1890 . He w is an authority on Seottish heraldry, and edited several antiquarian works. For many years he acted as musical critic to the Edinburgh newspapers, and was a very enthusiastic amatenr molician.

Burnett, Alfred, violinist. Fi cated at R.A.M., where he is nuw profusior of the violin, and viola, also lom. li.....1. Has appeared in ehanber concerts, London; was principal violin of the lieading Philharmonic Soc:ety; and, since 1885, has been principal violin in the Bimingham Festival orchestra. Was arl interim conductor of R.A.M. concerts, 1888. In 1893, succeeded $\mathrm{Mr}$. J. T. Carrodus as principal violin at the Worcester Festival; and since the death of that artist, has filled the same post at the other meetings of the Three Choirs. Ile has written some pieces for four violins, for the use of learners.

Burnett, Henry, tenor vocalist. Studied under Sir George Smart, upon whose recommendation he was elected a pupil of the R.A.MI. There he met Fanny Dickens (eldest sister of the great novelist), whom he married. He appeared on the stage with success, and settled for some year's in Manchester, singing at the Gentlemen's Concerts in 1842; at the Liverpool Philharmonic Concerts, 1844, and in many

\section{BURNEY.}

provincial towns. His wife died in 1818, and soon afterwards a delicate little boy, wlio was the original of Panl Dombey. Burnett appears to have retired soon afterwards. He died at his residence, 'Titchfield, Hampshire, in February, 1895, in his 8znd year. He composed a number of songs, published for the most part under an assumed name. His son, IVAITEr J;uretet, a profesinol of music, died at Ilatcham, London, July 27th, 1887, aged 37 .

Burnett, Nathan J., see Sporite (Nathan J.)

Burney, Charles, author, organist, and composer, was born at Shrewsbury, April 7th, 1726. He was the son of James and Amne Macburney, and was haptized as suction May 5th, 1726. He never used the prefix Mac. Educated at the Free Sehool, Shrewsbury, and at Chester Public School. He studied misic under Baker, organist of Chester Cathedral, and in London under Dr. Arne, 174447. Organist of St. Dionis Baek-Church, Fenchurch Street, london, 1749 I Iarpsichord player at the subscription concerts, King's Arms, Cornhill. Organist at LyunRegis, Norfolk, 1751-60. Bac. and Doc. of Music, Oxford, 1769. Ile travelled in Italy, 1770 , and returned to London, 1771. He also travelled in Germany, the Netherlands, cte., during 1779. Flected Fellow of Royal Socicty, 1773. Organist of Chelsea College, 1783. In 1806 , he received a pension of $\$ 300$ from Fox, and in $1 \$ 10$ he was made nrember of the Institute of France. He died at Chelsea, April 12th, 1814.

Works.- Translation of Signor Tartini's Letter to Signor Lombardini, published as an important lesson to performers on the violin, Lundon, 1771. The P'resent state of music in France and Italy, or the journal of a tour through those countries, undertaken to collect materials $f(m$ a general history of music, London, 1771. The Present state of music in Germany, the Netherlands, and United Provinces, or the journal of a tour through those countries, undertaken to eollect materials for a general history of music, London, 1773. 2 vols. A Gencral History of music, from the earliest ages to the present period, to which is prefixed a dissertation on the music of the ancients, London, four vols., 1776-1789. An account of the musical performances in Westminster Abbey and the l'antheon, May 2fith, 27th, 29th, and June the $3 r d$ and 5 th, 1784, in commemoration of Handel, London, 1785; Dublin edition, 1785. A paper on Crot. $h$, the infant musician, presented to the Royal Society, Transactions, 1779. Striking views of Lamia, the eelebrated flute-player, Massachusset's Magazine, 1786. Memoirs of the life and writings of the Abbate Metastasio, in which are incorporated trans- 


\section{BURNS.}

lations of his principal letters, Iondon, 3 vols., 1796. A plan for a music school, London, 1774. An essay towards the listory of comets, London, 1769. Articles on music in Ree's Encyclopiedia. Sonata for two violins and a bass, 1765. Six concert pieces, with an introduction for the diapasons and fugue proper for young organists and practitioners on the harpsichord. Twelve canzonets from Metastasio. Six duets for the German flute. Six concertus for the violin, in eight parts. Two sonatas for pf., violin, and 'cello. Six liarpsichord lessons. Two sonatas for harp or pf., with accomp. for violin or 'cello. An. thems, glees, instrumental numsic, etc.

Burney is best known to musicians of the present day by his "Hintory of music:" a work of much learning and ability. It is written in a pleasant style, but its historical value is somewhat destroyed by a vexatious absence of dates. $11 \mathrm{e}$ has given much space to the glorification of forgotten Italian composers, and comparatively little to the more interesting musicians of other nationalities. The "History" is less valuable thau that of Hawkins, though much superior to it from a literary point of riew. His most success ful musicaleffurt was an adaptation of Roussean's "Devin du Village," produced muder the title of "The cumning man." lis daughter' Frances was the Madame D'Arlulay of English literary renown. It may further be added that Burney was one of the most esteemed organists of his time. His brother JAmEs (born 1709; died 1759), was organist at Shrewsbury for many years.

Burns, Daniel Joseph, Irish organist and writer. Organist of S't. Patrick's Church, and of st. Malachy's Collese, Belfant. Conductor of the Philo-Celtic Society. Author of "Practical Notes upon Harmony and Cunterpoint for Junior Pupils." London [1853]. "Exercises in Figured Bass." London, n.d.

Burns, Georgina (MLs. Lesle CRotTy), soprano vocalist, born in London, 1860. Granddaughter of Rev. Jabez Burns. Displayed musical talent at an early age, and first appeared at the Westminster Aquarium Promenade Concerts. She made her first appearance in the Carl Rosa Opera Company at the Adelphi Theatre, February 11, 1878, when she took the part of Amn Page in "The Merry Wives of Windsor." During the time she remained rvith the Company she sang with success in many operas, creating the part of Filina-in English-in " Mignon," and the titular part of Goring Thomas's "Esmeralda," was written expressly for her. In 1882 , she married Leslie Crotty $(q . x)$, the popular baritone, and when the pair quitted the ('arl liosa Company, they started a light Opera Company, and revived with mucli suc. cess, Rossini's "La Cenerentola," in English,

\section{BLRTON.}

with which they undertook tours throughout the United Kingdom.

Burns, John, Scottish riolimist and composer, of early part of 19th century, pulblished "Strathspeys, reels, jigs, etc., for the pf., v olin and violoncello." Edinlunrgh, n.l.

Burrowes, John Freckleton, writer and composer, was born in Lonton, April 23, 1757. Hestudied under W. Horsler, and was Menber of the Philharmonic Sigciety. Organist of St. James's Chureh, Piccactilly, London. He died at l Jondon, ILarch 31, 1n.2.

Works.-Op. 1. Six English Ballads, for voice and pf. ; Sonatas for pf. and thute, and for pf. and 'cello; Overture for full orch., produced by Philharmonic Society; Six I)ivertissements fo: pf.; Three Sonatas for pf. and violin; Sonata for pf, on Seoteh airs, op. 9; Seleet airs from Mozart's operas, for pf. and flute, 18 nmmbers; Mozart's overtures, ar. ranged for pf., violin, flute, and 'cello; Inets, for halp and other instruments. Collection of Psalm Tunes, with figured bass, n. (1. Burrowes' Pianofurte Primer, containing the rudiments of Nusic, in question and answer, calculated either for privite tuition or teaching in classes: I.ondon, 1822. The Thoroughbass Primer: Lonton, 1618. Companion to the Thorough-bass Primer: London, 1835. Songs, part-songs, etc.

Burstall, Frederick Hampton, organist, born in Liverpool, January 29, 1851. Studied under Ir. Rïhner, and in 1870 was appointed organist of Childwall Parish Church. In 1876 , he obtainca the post of organist at Wallasey Church. When the new Diocese of Liverpool was fomed, in $18 n 0$, he was elected organist and director of the choir at the Cathedral Church. In 1859, he formed a large special choir for oratorio services, and in 1859 undertook the parochial sunday services, resigning his post at Wallasey. He is a clever performer, and has viren organ recitals at St. George's Hall. lie married, in 1875. Mintie, daughter of the late Samuel Martin, shipowner, of Liverpool. His wife is an excellent musician. Of his compositions the principal is a Festival Te Deum; he has also written anthems, motets, songs, and pf. pieces, etc.

Burton, Avery, English composer, who flourished during the 16th century. His compositions are preserved in MS. in the Iusic School of Oxford.

Burton, John, English composer and harpsichord player, born in Yorkshire, in 1730. He studied under Keeble, and died in 178.5.

Works.-Ten sonatas for the harpsichord, organ, or pianoforte; Six trios for the lrarpsichord and violins. Six solos for the harpsichord. Songs, glees, organ music, etc.

Burton, Robert Senior, on'ganist, pianist, and conductor, born at Tewsbury, Yorkshire, 


\section{BURTON.}

in 1820. Studied under Cipriani Totter, and commenced his career in Leeds, in 1840, suc. ceeding Dr. S. S. Wesley as organist of Leeds Parish Clumch in 1849. Was chorus-master of the first MLusical Festival, Iueeds, 1858, and conducted choral societies at different periods in York, Parnsley, Leeds, Wakefield, Braclford, and Halifax. He eventually settled at Harrogate, where lie founded a Choral Society, 1880; he was also musical director at the Spa; and, np to luis death, organist of St. Peter's Church. Ile was a fine performer on the organ, an adniralle accompanist, and had a high reputation as a choir trainer and teacher of singing. He died at Ilarrogate, August 2, 1892 .

Burton, T. Arther, organist and choirmaster of St. Augustine's Church, Bournemouth, and conductor $f$ a musical society in that town, is the composer of an oratorio, "Jonah," produced at Boumemonth, January 28, 1881. He las written a concert march for organ, etc.

Busby, Thomas, composer and author, was bor'n at Westminster, in Necember, 1755. Articled to Thattislill, 1769-7t. Successively Orgarist of \$. MLal'y's, Newington, Surey, and at S. Mary, Woolnotl, Lomliard Street, 1798. Mus. Doc. Cantah., 1800. LL.D., Cambridue. I Le died at Islingtion, I ondon, May $28,18: 3$.

Works. - The Propheey, oratorio, March, 1799 ; Ode-Pritish (Aenius, from Grey; Ode to St. Cecilia's Day, Fope; Comala, a Dramatic Romance from Ossian, 1800; Thanksgiving Ode (Degree exercise), 1800 ; Music to Joamna, drama by R. Cumberlaud, 1800; Music to M. G. Lewis's liugantino, 1805; The Divine Harmonist, a collection of Anthems, ete., 17ss; Melodia Britannica, do., 1790 (unfinished). Sonatas for the pf. Anthem for the Fumeral of Battishill. Niscellaneous antlems, glees, songs; Music to Holcroft's Tale of Mystery, 1802; Music to Porter's Fair Fugitives. Dictionary of Music, with Introduction to the First Principles of that Science, London, 8vo., 1786. A Gram. mar of Music: to which are pretixed Observations explanatory of the Properties and Powers of Music as a Seience, and of the general scope and olject of the work, London, 1818. A General history of Musie, from the earliest times to the present; comprising the Lives of Eminent Composers and Vusical Writers, Londou, 2 vols., 1819 (Whittaker). Concert fioom and Orchestra, Anectotes of Music and MIusicians, Ancient and Moden, 3 vols., London, 1\$25. Musical Manual, or Teclnical linectory, with Teseriptions of various Voices and Instruments, London, 1828.

Bussell, Rev. Frederick William, composer, som of the Rev. F. Bussell, vicar of Great Marlow, bown at Cadmore End, Oxford.

\section{BUTLER.}

shire, April 23, 1862, of a Devonshire family. Educated at Charter House, 1876-81; Demy of Magdalen College, Oxford, 1880; Craven scholar, and B.A., 1885 (First Class Classies, Lit. Flum., Theology) ; M.A., 1887; B.D., 1892: Mus. B., 1899. Nusical training private. Fellow, tutor, chaplaju, junior dean, Brazenose College, Oxford; Select Preacher to the University, Oxford, 1896; and Morley Lecturer at - t. Margaret's, Westminster.

Works.-Magnificat (Latin), for five voices, small orchestra, and organ ; Mass in Gminor, roices, orchestra, and organ (performed at Italian Church, Hatton Garden, Sept. 1892). Incidental music 10 "The Merchant of Venice," composed for Oxford University Dramatic Society, and produced at the New Theatre, Feluruary, 1895. Collaborator in preparation of "Songs of the West" (Methmen), and "English Minstrelsie" (Ediulurgh, Jack). Has published the "School of Plato" (Methuen, 1,955), and other works.

Buswell, John, composer of the 18th century, who was connected with the Chapel lioyal. He graduated MIus. Bac., Cambridge, in 1757, and Nus. Doc., Oxford, in 1759. Composer of songs and other vocal music.

Butler, Charles, musician and author, bor'l at Wycombe, Bucks, in 1559. MI.A., Oxford. Master of the Free school at Basingstoke, Hants. Vicar at IVooton, St Lawrence, Hants. He died on March 29, 1647.

Works.-The Feminine Monarchie; or, the Historie of Bees... proving that in the Bees' song are the grounds of Mnsicke. Oxford, 1609 ; other editions. The Principles of Mnsick in singing and setting: with the twofold use thereof, ecclesiastical and civil. London, 1636. An English Grammar, and other works. The first work is a curious production; the second a learned reatise on theory and on the abuses in sacred and secular music. His works were printed partly in characters taken from the Anglo-Saxon alphabet, partly in others of his own invention, which are described in his Grammar.

Butler, Charles, English musician, and author, of Lincoln's Inn, London, wrote "Reminisences, with a letter to a lady, on ancient and modern music." 1824, th ed.

Butler, Thomas Hamly, composer and pianist, was horn at London, 1762 . He studied under I)r. Nares at the Chapel royal, and under Piceini in Italy. Composer to Drury Lane Theatre, muder Sherilan. Teacher and pianist in Falinburgh. He died at Ediuburgh, $182: 3$.

Works. The Widow of Delphi (R. Cunberland), musical drama, 1780. Rondos on the following Scoteh airs:- Duncan / Gray, Flowers of Fdinburgh, I'll gang nae nair to yon toun, Lewie Gordon, Roy's Wife, There's cauld latil in Alerdeen, etc. (Clementi). A 


\section{BUTT.}

select collection of original Scottish airs, arranged for one and two voiees, with introduetory and concluding symphonies for the flute, violin, and pf., Fdinburgh [1790]. Sonatas for the pf. (various). Songs, paitsongs, single pieces for pf, etc.

Butt, Clara, contralto vocalist, born at Southrick, near Brighton. Studied under D. W. Rootham, Bristol, for some years, and sang at Miss Lock's concert, December, 1889, with success. Entering the 11.C.M., she distinguished herself at the College concerts, and particularly in the pesformances of opera. She made her début at the Albert Hall, as Ursula iu Sullivan's "Golden Legend," Dec. 7. 1892, and sang there in oratorio (Israel in Egypt) the next year. Her Festival debut took pliee at Hanley, October 21, 1893, and she sang at the Bristol Festival, October 25, of the same year. The appeared at the Handel Festival of 1894, and has sung at the principal London and provincial concerts.

Butterworth, Annie, contralto vocalist. Fducated at R.A.M. Westmoreland selolar, 1871; Nilsson prize, 187s. A.R.A.M. Slue won the first prize for eontralto singing at the National Music Meetings at the Crystal Palace, July, 1875, and sang at the Crystal Palace concerts twice in March, 1876, in Beethoven's choral symphony, eta. She soon gained a high position as a eoncert singer, but her career was brief. She died at the age of 33 , at Hendon, December 9th, 1885 .

Button, H. Elliot, alto vocalist, and composer; horn at Clevedon, Somerset, August Sth, 1861. His father was a private schoolmaster and organist, and the whole family were musical, being able to provide both a vocal and a string quartet. In theory Mr. Button is self tanght. IIt is a pianist, organist, and violinist, besides being selo alto at Holy Trinity, Upper Chehea. He was awarded the gold medal for an ode "The song of the sower," performed at the National Co-operative Festival at the Crystal Palace, August 15th, 1891. His compositions include "Ivry," a dramatic balla for luaritone solo, chorus, and orehestra (1892); anfluns, chants, ete.; part-songs; sougs for elilelren; organ pieces, etc. Fdited the third series of the Bristol Tume Book, and other collections.

Butts, Thomas, English musician of the 18th century. Compiler of "Harmonia Sacra, or a choice collection of psalm and hymn tunes . . . in 2, 3, and + parts... made use of in the principal chapels and churches in London." London, 11.d. c. 1776 or 1780 ?

Byrd, or Birde, William, composer and organist, was born [at Lincoln] ahout 1538. Senior ehorister at st. Paul's Cathedral, 1554. He studied under Tallis. Orgarist of Lineoln Cathedral, 1563-72. Gentleman of Chapel Royal, 1569. Organist of Chapel Royal (with

\section{BYRNE.}

Tallis), 1575. He died at London, July 4th, 1623.

Works.-Cantiones quae ab argumento saere vocantur quingue et sex partium, 1575 . Psalmes, sonets, and songs of sadnes and pietie, made into musicke of five partes, London, 1588. Songs of sundrie natures, some of gravitie, and others of myrth, fit for all companies and royees, lately made and composed into musicke of three, four, five, and six parts, Iondon, 1589. Liber primus sacrarum cantionum quartum alie ad quinque, aline uno ad sex voces aedita sunt, London, 1589; reprinted by Musical Antiquarian Society, edited lyy W. Ilorsley. Liber secundus sacrarm cantionum quartum alise ad quinque, alice uno ad sex voces aedita sunt, Loudun, 1591. Fridualia, ae cantiones sacre lil) r primus, 1607. Gradualia, ae cautiones sacme liber secundus, 1610. Psalmes, songs, and sonmets, some solemne, others joyfull, ete., 1611. Parthenia, or the maidenhead of the first musick that ever was printed for the virginals, composed by the three famous masters, William Byrd, Dr. Johm Bull, and Orlando Gibbons, Gentlemen of 1 ler Majestie's Chappell, London, 165.5. Service in D minor (Boyce); Three anthems (Boyce); Mass for five voices (Mus. Ant. Soc., Rimbault), 1841 ; Compositions contained in the royal virginal book; Compositions contained in I ady Nerille's musickbook, 1591 ; Musie in Leighton's "Teares;" Non nobis dominae, in Hitton's Catclies, 1652 . Madrigals in various collections; Two other masses; anthems, etc.

Pyrd vas one of the greatest composers of the 16th century. He lived at a period when the musical glory of England was supreme. Among his contemporaries were such men as Tallis, Tye, Farrant, Dowland, Bull, Morley, Hooper, Gibbons, Willyye, Lawes, Weelkes, and Parsons. lyyrd's claims to recognition rest ehiefly on his sacred musie, which is both dignified and grand without undue elaboration. He was one of the first in Fnglaud to make use of the madrigal as an expressive musical form, though it must be armitted that lis treatment of works of this class is not generally so happy as that of some of his successors. He was an organist of much ability. His compositions for the virginals are somewhat dry and elaborated exercises in counterpoint. Byrd secured with Tallis, in 1575 , by patent, the supreme right to publish musie in England, and nuder this patent they publishel the collection of sacred music furst named in the foregoing list of Byrul's compositions.

Byrn, Adelaide C., see sub BALY, William.

Byrne, Co S., musician. Published a "Selection of Scottish melodies, with words "by George Linley." Tondon, 1827. 


\section{BYRNE.}

Byrne, Patrick, Irish harpist and composer. IVas bom at Famey, about the end of 18th century. Ile died at Dundalk, 1863.

Bywater, Thomas, tenor rocalist and compuser. A native of Staffordshire. Fou many years he was very popular in Birmingham, Wolverhampton, and the midlands. He has sung at the Crystal Palace, and other places. Ile is also a clever organist, and was for some time organist of St. Mark's, Wolverhampton, but is now chiefly engaged as a concert agent. He is blind. Some songs of his have been published; and in 1876 he issued a Collection of twenty-five hymu tunes, and twelve chants (Novello).

Caerwarden, John, composer and teacher of the riolin, who flourished during the 17 th century. He was a member of the private band of Chules I. Hawkins mentions him as having beon a noted teacher but a harsh composer.

Casar, Julius, pliysician and componer, who lived in liochester during part of the 17 th and $18 t h$ centuries. He was an amatenr conposer only, but Hawkins speaks of two of his catches appearing in the "Pleasant Musical Companion," 1726 , as being "inferior to none in that collection."

Calal, John, organist and composer, who was bown in 175s. He was organist of Peterborough Cathedral at the end of the 18th century, and died on Angust 4, 1798. He wrote music for the Church service, hymus, ballaks, and sonatas for the pf, etc.

Caldicott, Alfred James, composer and organist, born at Worcester, November 26, 1842 Of a musical fanily, he, with six brothers, went through a eourse of training in the choir of Worcester Cathedral. At the age of fonrteen he was articled to William Done, the organist, whose assistant he became. IIe afterwards studied at Leipzig Conservatorium, under Moscheles, llauptmann, E. F. Richter, and others, and in 1864 settled in Worcester. Graduated Mus. Bac., Cambridge, 187s. Organist, St. Stephen's Church, and to the Corporation of Worcester; Conductor of the Musical and Instrumental Societies. In 1882 he removed to Torquay, and the followind year settled in London, and was appointed Professor of hav. mony at the IR.C.M. In 1885 he was appointed Musical Director at the Albert Palace, Battersea, composing a Dedication Ode for the opening, June 6. Toured in Ameriea as conductor of the Agnes Huntingdon Opera Company, 1890-91 ; was appointed Principal of the Edueational Department, London College of Mnsic, 1892 ; and Musical Direetor, Comedy Theatre, 1893.

Woris.-Sacred Cantata, The Widow of Nain (Worcester Festival, 1881); Cantatas

\section{CALIIN.}

for female voices-A Rhine Legend; Queen of May. Operettus-Treasure Trove (1583); A Muss Rose Rent (1883); Old Knoutes (1884); In Cupid's Court (1885); A united Pair (1886); The Bo'sun's Mate (1888); producel at the German Reed Entertainments. Operetta, John Smith (Prince of Wales' Theatre, 1889); The Girton Girl and the Milkmaid (1893), etc. Winter Days, prize serious glee (1879, Huddersfield); Humpty Dumpty, prize humorous glee (1878, Manchester Gentleman's Glee Society); PartSongs, various. Story of the Priest Philemon (Marie Colelli), special aecompaniment for reeitation, St. James's Hall, May 2, 1896. A number of songs; The Dickens' series, ete. Eilitor of " Morley's ['art-song Joumal."

Calkin, George, violoncelist and teacher of singing, hron st. Pancras, London, August 10, 1529. Youngest sull of James Calkin. Organist for twenty-five years at St. Mark's, Regent's Part. As corlductor of a Cloral Suciety, gave concerts at the Hampmtead Vestry Hall. Professor at the Lomdon Aeademy of Music. For many years a violoncellist in the orehestra of the Philharmonie ciociety, linyal Italia: Opera, and the Provincial Festivals, ineluding that of Sirmingham in 1stb, when "Elijah" was prodneed. Is the composer of sixteen looks of Soft Toluntaries for the organ; arrangements of airs from "Elijah," two books; and organ transcriptions from Mendelssolm, in eight books (Novello), all very popular with organists.

Calkin, James, pianist and composer, was born at London, in 1786. He sturlied under Thomas Lyon. Assuciate of the Phil. harmonic Suciety, 1823. Wrote symphony for orchestra, pf. music, string quartets, etc. lle died at London in 1862.

Calkin, John Baptiste, composer, pian ist, and organist, born in London, March 16, 1827. Studied under his father, Janes Calkin. Organist, precentor, and choimaster, St. Columba's College, Ireland, 1846-53; Woburn Chapel, London, 1853-7; Camden lioad Chapel, 1s6:-8; St. Thomas' Church, Camden Town, 1870-84. F.C.O. Menher of the Philhamonic Society: Member of the Comneil, Trinity College, London; Professor at Guildlall sehool of Music.

Works.-Moruing and Evening Services in B fla', Op. 43. G, Op. 96, and D; Te Deum in D ; Communion Service in C, Op. 13t; Magnificat and Nune Dinnittis in F. Inthems3ehold, now praise ye the Lord; I will always give thanks; I will magnify Thee; Thou visitest the Farth; and many others. Seven Introits. Glees and Purt-songs-Breathe soft, ye winds; Come, fill my boys ; My Lady is so wondrous fair; and others. Songs-Coming light; Sleep on, ny heart; Oh, lovely night; and others. Quintet and Quartet, 


\section{CALKIN.}

strings; Trio, pf. and strings; Sonata, pf. and violoneello. Duet, pf. "Overture"; Youth and Age, six pieces, pf., Op. 100 ; Rondo grazioso, Op. 93; Les Arpeges, Op. 94 ; The l'ixie's Revel, Op. 95; Les trois graees (Sonata) ; Studies; Concert Study in doublenotes; Transeriptions, ete. Oryan-Andante con moto, Op. 101; Andante varied; Harvest Thanksgiving Mareh; Festal March, etc., ete.

Calkin, Joseph, violinist, born London, 1781. Studied under Thos. lyon and spagnoletti, and was violinist at Drury Iane Theatre from 1798 till 1808 . He married the widow of Mr. Budd, bookseller, and carried on the business under the name of Calkin and Budd, booksellers to the King. In 1821 he was appointed violinist in the King's band. He also played violin in the Philhamonic orchestra Died London, December 30, $18 \pm 6$. Calkin assisted at the eapture of Hatfield, when he fired at George III.

His son, Janes Joskph, born 1813, died London, 1868, was a violinist; and another son JosEPH, known as TENNIELLI CALKIN, born 1816, was a tenor singer; studied under Lamperti at Milan, and appeared at the Philharmonic and other concerts. He retired after a few years, and became a successful voeal teacher, and was also composer of some songs. He died in London, June 6, 1874.

Callcott, John George, pianist and com. poser, born in London, July 9, 1821. Was organist of Eaton Episcopal Chapel, Eatom Square; St. Stephen's, Westminster, for over thirty years, resigning in 1881; and Parish Church, Teddington, to 1895. Accompanist to Henry Leslie's Choir, 1855-82, and was awarded a Medal for his serviees during the visit of the choir to Paris, 1878. He contri. buted to the pasticeio, "Harold Glynde (1881), and composed two eantatas-Hallowe'en, and The Golden Harvest. He also wote part-songs, "Love wakes and weeps," and other's, produced by Leslie's Choir. An excellent pianist; he was almost unrivalled as an aecompanist; whilst as a teacher he was in great request. He died at Teddington, January $7,1895$.

His father, JoHs CALLcotT, entered the band of the Coldstream Guards at an early age. He was one of those who had to beat to arms in Brussels on the eve of Waterloo. He was for some years third hom in the Opera orchestra under Spagnoletti, Costa, and others. He died at Richmond, Surrey, February 16, 1882.

Callcott, John Wall, composer and writer, was born at Kensington, London, November 20,1766 . He was largely self-taught in musie, but he had lessons from Henry Whitney, organist of Kensington Parish Church. Deputy organist to Reinhold, of St. George the Martyr's, Bloomsbur'y, 1783-5.

\section{CALLCOTT.}

Member of orehestra of Academy of Ancient Musie. Unsuccessful competitor for prize offered by the Catch Club, 178t (his first trial). Gained three prizes (medals) out of the foul offered by the Catch Club, 1785. Mus. Bae. Oxon., July, 1785. Gained two medals, Cateh Club, 1786; and two prizes in 1787 (he sent in about 100 compositions). Founded, with other's, the "Glee Club," 1787. Gained all the prizes offered by the Cateh Club, 1789. Joint organist (with C. S. Evans) of St. Paul's, Covent Garden, 178\%. He studied under Haydn in 1790. Organist ef Asylum for Female Orphans, 1793-1802. Gained nine medals for his gles during 1790-93. Nus. Doc. Oxon., 1s00. I,ecturer at the Rotal Institution in suecession to Crotch, 1806. He died at London, May 15, 1s 1 .

Works. - Select Collection of Catches, Canons, and (thees, 3 books (I'Almaine), n.d. (edited); Five Glees for 2 Trebles and bass in Score; Five Glees, chiefly for Treble voices, Op. 12; Six Glees in sicore: Collection of Glees, Canons, aud Catches, inclnding some pitces never before published, with Memoir by W. Horsley (the editor), 22 rols., folio, Lond., 1821. Church Psalmody (selection); Services, Anthems. Ode to Fancy (Warton), degree exercise. Titles of some of his principal Glets and Catch's-- Alellin; Are the white hours; Blow, Warder, blow; Desolate is the dwelling of Morna; 1)ull repining soms of care: Irink to me only; Futher of lieroes; Forwive blest shade: Frl King; Farewell to Lochaber; Friend of fancy; The Frial; Go, iale boy; If happily we wish to live; In the lonely vale of itreans: Lo! where incumbent o'er the hade; Lovely seems the morn's fair lustre: Lordly gallants; The May-fly; Mark the merry elves; Ol, share my eottage: Once upon my cheek; $O$, snatch me sivift; O thou where'er; O fancy, friend of nature; Peace to the souls of the heroes; Queen of the valley: Red Cross Kiught; Suft and safe; See with ivy chaplet; Thyrsis, when he left me; Tho' from thy bank; To all you Ladies now on land; Thalaba; Thou pride of the forest; Triumphant love; Wham battayle; When Arthur first; When time was entwining; Who comes so dark; With sighs, sweet rose; Ye Gentlemen of England. Songs, ete. Grammar of Music, Lond., 1806 (other editions) ; Glees, Catches, and Canons, Op. 4 (Clementi), n.d.; Explanations of the Notes, Marks, Words, ete. used in Music (Clementi), n.d.

Callcott, Maria Hutchins, English musieian, born in 1799; died London, April 3, 1859. Sister of IV. H. Calleott. Author of "The Singer's Alphabet, or hints on the English vowels, ete," London, 1849.

Callcott, Willian Hutchins, composer and pianist, son of J. W. Callcott, was born at Kensington, September 28, 1807. He died at 


\section{CALLOW.}

London, August 5, 1882. Was organist of St. Barnabas', and teacher in London, for a considerable period. Anong his various compositions may be named the following:Pianoforte Elegant Extracts from Mendelssoln; Favourite Marches, etc. An enormous number of arrangements of classical works for pf. solo and duet. A selection of Glees for three roices. Songs, part-songs, etc. "A Few Facts in the Life of Handel," London, 1859.

His son, Williaxe Robert Stuart (borm in 1852; died 1886), was also a musician. Another of the name, Willian Callcott, a violinist, was born about 1800 . He was principal violinist at $H . M$. Theatre for many years, and afterwards musical director of the Adelphi, Olympic, and Astley's Theatres. He died at Gravescud, November 6, 1878. aged 78. He wis father of William and Albert Callcott, the scenic artists.

Callow, Mrs, see sub. Smart, Henry.

Calvert, Thomas, Scottish musician of the latter part of the 18 th and begimning of the 19th centuries. Published "A Collection of marches, quicksteps, strathspeys, and reels," Edinburgh, n.d.

Cambridge, Frederick, organist and composer, born at South Runcton, Norfolk, March 29, 1841. Received his early musical training at Norwich Cathedral under Dr. Buck, subsequently studying harmony under Molique. In 1862, he was appointed organist and choirmaster to St. Columba's College, Dublin; removing to St. Nary's, Leicester, in 1866; and to the Parish Church, Croydon. in 1s68, holding this position to the present time. Conductor of Croydon Vocal Union, and of Festivals of Croydon Chumeh Choirs, 1882 , etc. Is honorary local examiner for R.C.MI. Graduated Mus. Bac., Durham, 1893. He won the prize of ten guineas offered by the Nottingham Anacreontic Society for the best filee, in 1863; and among his published compositions are, a Communion Service in C (186t). Anthems-Not unto us; I was in the Spirit; Offertory sentences, hymn-tunes, chants, etc. Postlude in D, organ ; pianoforte pieces, ete.

Cameron, Andrew Robertson, amatcur musician and physician, born at Logie Coldstone, Scotland, in 1839 Fducated at Aberdeen Tniversity. Settled in Anstralia as a medical practitioner in 1867 . Died at Richmond, near Sydney, N.S.W., October 18, 1876. He composed nome overtures and vocal music and acted as critio for various journals.

Camidge, John, composer and organist. was born ubout 1794. Chorister in York Cathedral. He studied under Greene and Handel, and was organist of York Cathedral, 1750-1803. He died at York, April 25, 1803. Buried S. Olave's Chmrchyard, York.

\section{CAMPBELL.}

Works.-Six Easy Lessons for the Harpsichord, York, n.d.; Glees; Miscellaneous works for the Harpsichord; Church music and songs, etc.

Camidge, Matthew, composer and organist, son of the above, was born at York, in 1758. He studied under Dr. Nares at the the Chapel Royal, and was organist of York Cathedral, 1803-1842. He died at York, October 23, 1844. Buried S. Olave's Churchyard.

Works.-Collection of Tunes adapted to Sandy's version of the Psalms, York, 1789; Sunday Hymns, the words by the Rev. IV. Mason, York [1795ך. Musical Companion to the Psalms used in the Church of St. Michael le Belfry, and most of the churches in York and its vicinity, n.d. [1830]. Method of instruction in music by questions and answers, n.d.; Twenty-four original psalm and hymn tunes, n.d.; Cathedral Music, [1790]; Sonatas for the pf., Op. 8-9, etc. Instructions for the pianoforte or harpsichord and eight sonatas [1795]. Narches for the pf. Glees and songs.

Camidge, John, composer and organist, son of Mattliew, was born at York, in 1790. He studied under his father. Bac. Mus., Camb., 1812. Doc. Mrus., Camb., 1819. Doc. Mus., Lambeth, 1855. Organist of York Cathedral, 18t4-1859. He died at York, September 29, 1859.

Works.-Cathedral Music, consisting of a Service. Anthems and 50 Double Chants, 1828. Six Glees for 3 and 4 voices, n.d., etc.

His son, Thomas Srarpson Camidge, was deputy organist at York Minster from 1848 to 1859 . Afterwards organist of St. Saviour's, York; Hexham Abley, 1882 ; Swindon Parish Church, 1889; and Swansea. JoIn CamIDGE, son of T. S. Camidge, is organist of Beverley Minster, aud has composed "MIarsyas and Apollo," a musical panorama for chorus and orchestra, Bridlington, 1896.

Campbell, Rev. A., author of "Two papers on Church music, read before the Liverpool Ecclesiastical IIusical Society," Liverpool, 1854.

Campbell, Alexander, writer and musician. Was born at Tombea, on Loch Lubmaig, Callander, February 22nd, 1764. Ile was educated at Callander Crammar School. He studied music at Edinburgh under Tenducci, and was a teacher of pf. in Edinburgh. Organist in the non-juring chapel, Nicolson Street, Edinburgh. Was musical instructor of Sir Walter Scott. He died at Edinhurgh, May 15th, 182t.

Works.-An introduction to the history of poetry in Scotland,.... Edinburgh, 1798. Sangs of the Lowlands of Scotland, carefully compared with the original editious, and embelli-hed with characteristic designs com- 


\section{CAMPBELL.}

posed and engraved by the late David Allen, Esq., historical painter, Ediuburgh, 1799. A tour from Edinburgh through parts of North Britain, London, 2 vols., 1802. Another edition, 2 vols., 1811. The Grampians desolate, a poem, 1804. Albyn's Authology, or a select collection of the melodies and voeal poetry peculiar to Scotland and the Isles, hitherto unpublished, collected and arranged by Alex, Campbell, the modem Seottish and English verses adapted to the Highland, Hebridean, and Lowland melodies, written by Walter Scott, Esq., ete., Edinburgh, Oliver \& Boyd, 2 vols., 1816-1818. Collections of Scottish songs, with violin, London, 1792. A second collection arranged for harpsichord, n.d., etc. The fine air now used with Tamnahill's "Gloomy winter's now awa'," was claimed by Campbell as his composition, and it is said to have first appeared in leaflet form long before its alleged first publication by Gow as "Lord Balgonie's favourite."

Campbell, Lady Archibald, musician of present time. Author of "Rainbow music, the philosophy of harmony in colour grouping," London, 1856.

Campbell, Donald, Scottish writer and collector. Anthor of "A Treatise on the language, poetry, and music of the llighland elans, with illustrative traditions and anecdotes, and numerous ancient Highland airs," Edinburgh, 186\%. This work contains a number of ancient Highland melodies badly set to inferior basses. The compiler describes himself as "late lieutenant of the 57th regiment," and appears to have been a resident in Port-Glasgow on the Clycle. Ile was a claimant to the Breadalbane Peerage.

Campbell, Gilbert James, Gilbrito Ghileerti, bass vocalist, son of Major-Gen. eral T. Hay Campbell, R.A. II sang at the Gloucester Festival, 1880, and in opera at Her Majesty's Theatre the same year. Has sung in oratorio and other concerts in various parts of the United Kingdom, and in Ireland. He married, July 31st, 1884, Miss Elcen DE Fonblangue, soprano vocalist, who sang at the Gloncester Festival, 1880, and is linown as an artistic vocalist at the Monday populay and other concerts.

Campbell, Joln, wusic-seller and teacher, who lived in Edinburgh in the latter half of last century. He published a collection of psalmody and other works.

Campbell, John, amateur musician, was born at Paisley in 1807; died at Glasgow, October 7 thl, 1860 . He was a merchant in Glasgow, and issued "The Sacred psaltery in four vocal parts, consisting principally of original psalm and liymm tunes," Glasgow [1854]. Healso edited "Campbell's Selection of anthem's and doxologies, with a separate piano accompaniment," Glasgow, $18 \pm S$; and

\section{CANTELO.}

wrote a few original anthems of mediocre quality, some of which were once very popular in Glasgow and neighbourhood.

Campbell, Joshua, Scottish collector, who was a nusic-seller and bell-ringer in Glasgow, and died there early in the present eentury. He issued, about 1795, "A collection of new Reels and Higliland Strathspeys, with a bass for the violoncello and harpsich ird," Glasgow, n.d. "Collection of favourite tunes," with variations, etc., n.d.

Campbell, Mary Maxwell, musician and poetess, born at Pitlour Ilouse, Fife, in 1812; died at St. Andrew's, January 15, 1886. Fifth daughter of Sir D. J. Campbell. Composer of the words and music of that blatant, though well-known song, "The March of the Cameron MIen," and of "The mole and the bat" (1867), and other vocal pieces.

Campell, William, Scottish collector, who flourished in Loncton, published about 1790, anid later, "Campbell's First Book of New and Favourite Country Dances and Strathspey Reels, for the harpsichord or violin." Afterwards issued a "Collection of the newest and most farourite country dances and reels," London, various dates. Of these collections at least 23 books were issued.

Campion, Thomas, poet, dramatist, composer, and pliysician, flourished in first part of 17th century, and died in February, 1619.

Woriss- Observations on the art of English poesie, 1602: 'The first, second, third, and fourth booke of Ayres, evntaining divine and morrall songs; to be sung to the Lute and Viols, in two, three, and foure pitrts; or by one voyce to an instrument, Londori, 1610-12; Songs of mourning bewailing the untimely death of Prince Henry, 1613. A new way of making foure parts in Counter-point, by a most familiar and infallible rule, 1618 (and 165.5 in Play ford's "Introduction to the skill of MIusick"); Ayres for the Mask of Flower's, 1613.

Campobello, see Minitix, H. II.

Candlish, Rev. Robert Scott, Scottish Free Clunch clergynan, born Ediuburgb, 1807; died 1873. He wrote "The Organ Question: Statements by Dr. Ritchie and Ir. Porteons for and against the use of the Organ in Public Worship, with an introduc. tory notice." Ellinburgh, 1856.

Cantelo, Annie, Mr's. Hafiri Cox, pianist, born in Nottinghann. Studied at K.A.M., being Sterndale Bumett prize-liolder, 18s1, and Lady Goldsmid scholar, 1882. A.P.A. II. 1853. Made her first appearance in public at MIr. Walter Macfarren's concert, St. James's Hall, Narch 25th, 188?, playing the solo part of Schumann's pianoforte concerto. She has given concerts in Nottingham, and recitals in London with much success; and is the composer of a sonata in E minor, and other pieces for $\mathrm{pf}$. 


\section{CAPEL.}

Capel, J. M. Composer of the music to a comedietta, "The composer," 1892 ; also of "Six songs;" songs, various, and pieces for pf.

Capes, Rev. John Moore, composer and writer, was born at Stroud. Was B.A., Oxford, 18:36; M.A., 1846, Died in $188 \%$. He composed "The Druid," a tragic opera, produced at St. (ieorge's Hall, Liverpool, February 2xnd, 1879. This work attained not more than local renown. Capes has also written "An essay on the growtin of the musical scale and of modern harmony," London, 1579.

\section{Caradog, se Jones, Griffith Rhys.}

Card, William, flute player and composer, born at Salisbury, in 17St; died at luondon, Oetober thi, 1861. He composed a large number of jieces of music for the flute, ehitfly arrangements, and published a few pf. works. His som, Euwaris J. Carn, also a flute player, was a member of Her Majesty's private hask, and of the Philhammonic orchestra. He died in London, May 16th, 1875, aged 60 .

Cardigan, Cora, flutist, born in London. Studied under her father, and R. S. Rockstro. Appeared first at the Royal Music Hall, Holhom, then at the Oxford, and the Royal Aquarimu. Her reputation as an artist being now established, she appeared with suceess on the concert platform, and gave a eoncert in Prince's Hall, February 17th, 1885. She has played at St. James's Hall; at the Bow and Bromley recitals; and in the provinces. Toured for two years in America, and has fulfilled engagements in Berlin and Nice. Her playing is remarkable for brilliancy of exeeution, and purity of tone. In 188!), she married Herr Louis Honig, a well-known pianist and composer.

Carew, Miss? English soprano vocalist, who was born in Jondon, October 16th, 1799. She studied under Welsh, and her parents, and originally played small parts in Covent Garden Theatre. She first appeared as an operatic voealist at Covent Garden, in July, 1815. Sang at the English Opera House, 1818 , ete. She was also engaged for the Phillarmonie, and prineipal London and provineial concerts. About 1823 she retired from the stage. Died [

Carey, Henry, composer and minor poet, reputed natural son of George Saville, Marquis of Halifax, was born in 1692 [1685]. Reeeived some instruetion in musie from Roseingrave and Geminiani: otherwise self-taught. $\mathrm{He}$ was for a time a teacher of musie, but was engaged chiefly in writing music for the theatres. He hanged himself in Great Warner Street, Clerkenwell, London, Oetober 4 , 1743.

IVorks.-Musieal Dramas, ete.-The Con-

\section{CARMICHAFL.}

trivanes, 1715; Honest Yorkshireman, 1736; Amelia, 1732; Teraminta, 1732; Chrononhotouihologos, 173t; Dragon of Wantley (words only), 1737; Dragoness (otherwise known as Marjery, or a worse Plague than the Dragon), 1738. Petty, 1739; Nancy, 1739. Poems, 1720: Cantatas, 1732. The Musical Century, in 100 English Ballads on varions Subjects and Occasions, etc., Lond., 2 vols., 1737-1740; Dramatic Wortis (Collected), 17t3. Interlude's-Thomas and Sally, ete. Melody of "God Save the Queen." (?) Carey is now known only as the composer of the fine ballad "Sally in our Alley," and of a few liymm tunes. The "Easter Hymn," usually attributed to Carey, is not his composition. His ballad "Sally in our Alley" appear's to have been first published about 1715 as " (Sally in our Alley) the words and Tune by Mr. Henry Carey." It is a folio broadsheet on one side of a single leaf. aud has a flute part added at the end. The melody differs considerably from more nodern versions. In the 1729 edition of his "Puems on several occasions" it first appears in permanent form with an argument or note explaining the circumstances under which it was written, and referring to it as a juvenile effusion. This doen not give the tune, nor is anything said abont it.

His son George S.rillet CAREY, born 1743 , died 1807 , was a poet and dramatist, who wrote a number of farces and other dramatic pieces.

Cargill, James, Seottish musician of present century, published "Harmonia Sacra: a eollection of the most celebrated tumes and anthems, partly original and partly extracted from some of the best authors ancient and modern..." Aberdeen, n.d.

Carlile James, Seottish elergyman and psalmody editor, was bom about 178t. He was minister of the Seottish Chureh, St. Mary's Abbey, Dublin, 1814-54. He died at Dublin, March 31, 1854. Compiler of a collection of psalmody issued in 1828.

Cariton, Hugh, antlor of "The Genesis of Harmony: an inquiry into the laws which govern musical composition," Lond., 1882.

Carlton, Rev. Richard, elergyman and composer, flourished during end of 16 th and beginning of 17 th centuries. He wrote "Twenty-one Madrigals for five voyces," Lond., 1601 ; and contributed "Calm was the Air," a madrigal for 5 voices, to the "Triumphs of Oriana." His biography is unknowu.

Carmichael, Mary Girant, pianist and eomposer, born at Birkenhead. Pupil of the Academy for the higher development of pianoforte playing, where her teachers were Osear Beringer, Walter Baehe, and Fritz Hartvigson; pupil of E. Prout for harmony and composition. As a pianist she has appeared ehiefly 


\section{CARMICHAEL.}

as an accompanist, at the Monday Popular Concerts, 1884-5, and elsewhere; but she is more widely known as a composer. Her works include many songs, among which may be named "Sing Song," twenty rhymes by C. Rossetti; "The Stream," a series of connected vocal pieces in the manner of a Liederkreis, produced at the Hyric Club, Novenber, 1887; The Flower of the Vale; The Tryst, etc. Duets: A poor soul sat sighing, Who is Sylvia? Daybreak, and others. A suite for pf. Duet (1880) and smaller pf. compositions. She las also written an operetta, "The Snow Queen," and is now engaged on sacred compositions in large forms. Translator of A. Fhrlich's "Celebrated Pianists of the Past and Present," Tondon: Grevel, 1894.

Carmichael, Peter, author of the "Science of Music Simplified," Glasgow, 1860.

Carmichael, $\mathcal{S}$., author of "'l)ictionary of Musieal Terms and Elementary liules," London, 1878.

Carnaby, William, composer and organjst, was born at London, in 177\%. He studied under Nares and Ayrton as chorister in Chapel Royal. Organist at Eye, siuftolk, and at Huntiugdon. Bac. Mus., 1,03. T)c. Mus, C'antab., 1808. Organist at Hanovel Chapel, Regent street, London, 1823. He died at London, Nov. 13, 1839.

Works. - Ude, The Tears of Genius. Twelve Collects for 4 voices, in score, witl organ accompaniment; Sanctus for 5 voices; Six Canzonets for voice and pf. ; Six Songs for voice and pf. Glees, various. Anthems. MS. Works. The Singing Primer, or Rudiments of Siolfeggi, with Exercises in the principal Major and Minor keys, London, 1827.

Carnall, Arthur, composer and organist, bor'n at Peterborough, 185\%, son of John Carnall, an amatem, who was for years choirmaster of St. Mary's, Peterborough. Pupil of Dr. Chipp, at Fly Cathedral. Graduated Mus. B., Cambridge, 1873. Organist of the Parish Church, Penge.

Works.-Overture, orchestra, Oxford, 1888; Quintets, in D and F, for wind instruments; Quartets, in C minor (Oxford, 1887,) and F', performed at the Conference of the Incorporated Society of Musicians, Newcastle, 1892, for strings; Nocturne, for strings, 1894. Album of duets, violin, and pf.; pieces for pf., organ, etc. Anthem for Christmas, "Hail! Thou that art highly favoured," and others ; services glees and madrigals; songs, etc.

Carnie, William, writer and editor, was born at Aberdeen in November, 1824. He was originally a letter engraver, but became precentor of the Established Church, Banchory-Devenick, Aberdeen, in 1845. Inspector of Poor for same Parish, 1847. Sub-editor of the Aberdeen Herald, 1852. Precentor of the West, or High Church, Aberdeen, 1854. Clerk

\section{CARRODUS.}

and treasurer to the managers of Aberdeen Royal Infimary and the Lunatic Asylum, 1861. He acted as local correspondent for a time to the Times and the Scotsman.

Works.-Psalmody in Scotland, a Lecture, Aberdeen, 85t; Northern Psalter, containing 402 Psalm and llymm Tumes, Aberkeen, $1870^{\circ}$ Anthem appendix to do.; Precentor's Companion and Teacher's Indicator; Contributions to periodical literature, etc.

Mr. Carnie's labours did much to promote good psalmody in the North of Scotland. In 1854, at the request of the loral Young Men's Christian Association, he delivered a lecture on Psalmody to an audience numbering over - 000 persons, which inaugurated a very successful effort to improve the psalmody of Aberdeen churches.

Carolan, see O'CAROLAN.

Carr, Beniamin, English musician, born in latter part of 18th century. He settled in Philadelplia, U.S., early in the 19 th century, where he was an organist and teacher. He published "The Spanish Hrmli, arranged and composed for the crncerts of the Musical Fund Society of Philadelphia... The air from an ancient spanish melody... 1826" The hymn-tune called "Madrid," "Spanish melody," etc., is ascribed to Carr, but by a curious misprint, generally appears as by "B. Case."

Carstairs, see MoLesworth, Lady.

Carr, Frank Osmond, composer, born in Yorkshire. Graduated Mus. Bac., 1882 ; Mus. Doc., 1891, Oxford. Mus. Bac., Cam. bridge, 1885 ; M.A., 1886. He is known as the composer of music to a number of farces, burlesques, and comic operas: Joan of Arc, 1891 ; Bhne-eyed Susan, 1s92; In Tow 1, 1892; Iorocco Eound, 1893 ; Go Bang, 1894; His Excellency (W. S. Gilhert), produced at the Lyric Theatre, London, October 27tl, 1894; Biarritz, 1896; Lord Tom Noddy, 1896; The Clergyman's Daughter, Theatre Royal, Birmingham, April, 1896; later, as My Girl, at the Gaiety, I,ondon.

Carr, John, rocal composer, who flowrished at Boxford, Sussex, about the middle of last century. Among other works he issued "The Grove, or rural harnony," containing a variety of songs." London [1760].

Carr, Robert, musician of the 17th century. Issued "The delightful companion, or choice new lessons for the recorder or flute." London, 1686. Two editions.

Carrodus, John Tiplady, violinist, born at Braithwaite, near Keighley, Yorkshire, January 20th, 1836. Received his first lessons from his father, an amatemr violinist, and gave a concert at the Mechanics' Institution, Keighley, in November, 1845. At the age of twelve, he was placed under Molique, with whom he studied at Stuttgart and in London. 


\section{CARROLL.}

He appeared at a concert given by Mr. C. K. Salaman, at the Hanover Square Rooms, June 1st, 1849; and played a solo at the first Bradford Musical Festival, Angust 31st, 1853. He was engaged in the orchestra at Covent Garden Theatre, and nltimately became prineipal violinist in the Philharmonic, Three Choir Festival, and other orchestras, and was also noted as a quartet player, appearing in this capacity as early as 1850 , being second violin at Molique's chantber concerts. He was leader at the Leeds fustivals from 1880 to $189:$, and appeared as soloist at the London Musical Society, April 22, 1863, Crystal Palace, and the leading metropolitan and provincial concerts. When the National Training School for Music was opened, in 1876 , he was appointed a professor of the violin there. He commenced giving violin recitals in 1881, and toured in Sonth Africa, 1890-1. His published compositions include fantasias, and a romance; and he edited a collection of celebrated violin dnets, and some stucties. He died in London, July ISth, 1895. IIis son, BerNhard Moluque, violinist, was educated at home, and at the R.A.M. He has been connectod with the best orchestras, and is making a reputation as a solo player, in the last capacity appearing with success at the Gloueester Festival of 1859. In 1888 he was appointed a professor at Trinity College, London. Enxest Alexaxiner, his brother, is a contrabassist; member of the Philharmonic and other orchestras; J. CARronus is a violoncellist and organist; R. ChIRones, a violinist; and IV. O. Carifones, a flutist, scholar of the R.C.M. The father, with his five sons, were included in the orchestra at the Hereford Festival of 1894.

Carroll, B. Hobson, organist, pianist, and violinist. Graduated Mus. Ioc., Dublin, 1884. He was for some time orgatuist of Christ Church, Belfast, and is now organist and choimaster of 1)unfermline Abbey. Composer of a 'Te Irom in E flat, for' soli, eight part chorus, and orchestra, Jubilate, Magnificat and Nune dimittis, pieces for violin, ete.

Carroll, Walter, organist. Craduated Mus. Bac., Intham, 1891; Mns. Tiac., Manchester, 1896; Organist and chommaster, St. Clement's, (rreenheys, Manchester, 1s.2: Music master, I ay Training College, Owen's College, Munchester, 1892 ; Professor of larrmony, R.C.M., Manchester, 1s93. Works: Psalm 140, for soli, chorus, and orchestra; Two sonatinas, pf., etc.

Carrott, Livesey, Organist and pianist, born at Boston, Lincohnshire. Educated at R.A.M. Was appointed organist and choirmaster at All Saints', Highgate, I882; St. Mattliew's, Bayswater, 1896. Resident in London as performer and teacher. Composer.
CARTER.

of a sacred cantata, Martha, for female voices, 1896 ; songs, etc.

Carte, Richard, flutist and maker of musical instrumeuts, born 1808 (?), son of Richard Cart, quartermaster of the Blues. Orginally intended as a violinist, he was placed under Griesbach, of the Queen's band; afterwards he was a pupil, for the flute, of George Rudall. Abont 1828, he went to Germany, and studied composition under llauptmann. Returning to England he resmmed concert giving, and also lectured on various musical topies, enjoying a high reputation. In 1843, he adopted the Boehm flute, subsequeutly combining his own patent with the Boehm system. He joined the firm of Rudall and Rose in 1850, and in 1853 compiled and produced the first issue of the "Musical Directory, Register, and Almanack." He composed songs, and pieces for the flute; and was author of "A complete course of instruction for the Boehm Flute" (1845?); and "Sketch of the successive Improvenuents made in the Flute" (1851?). He died at Reigate, November $26,1891$.

Carter, (ieorge, organist and composer, born in London, Jinnary 26, 1835). Studied moder Sir John Goss, and was first appointed an organist in 1847 . He was then snceessively organist at St. 'Thumas', Stanford Hill (1r+s); Christ ('hurch, Camberwell (1850); Trinity Chnrch, Upper Chelsea (1 853); St. Luke's, Chelsea $(1860)$; and of Montreal Cathedral (1861-70). As a perforner he was known on the Continent as well as in London and America. For some years he acted as organist at the Albert Llall. His compositions include Operas - "Fair IRosamond," and "Nerone" (Italian), in MIS. Operetta, "Golden Dreams." Cantatas, "Evangeline" (1873); "The fiolden Legend" (comprosed 1883); and a Sinfonia-Cantata, Ps. 116, "I love the Lord" (1572). High Festival Communion Service (1883). Grand Festival Mareh; Tema con variazioni, organ; Songs and miscellaneous works.-Another GEORGE CARTER, tenor yocalist and lay vicar, Westminster Abbey, of repute as a ballad and glee singer, died at Wandsworth, Novenber 17, 1890, at the age of tifty-six.

Carter, Henry, organist and composer, lorother of the preceding, born March $6,1837$. Was some time organist of the Cathedral, Qneber, and in 1882 was appointed organist of Iiev. Henry Ward Beecher's Church, New York, having previously held a similar post at Trinity Church, in that eity. Has composed anthems, songs, organ music, etc.

Another IIfenry Canter published a large number of waltzes and other dance pieces, songs, ete., between 1819 and 1861 .

Carter, Robert, musician. Compiled "A Psalter, containing a selection of Psalm tunes, 


\section{CARTER.}

chants, services, and other ecclesiastical music, the Psalms selected from the new version by the Rev. W. J. E. Bemnett," London, 1843.

Carter, Thomas, composer, was born in Ireland, in 1735 [1758, 1768, also given]. He studied probably in Ireland under his father, and became Organist of S. Werburgh's Church, Dublin, 1751-69. He travelled in Italy for a time [1770-1]. Conductor of Theatre in Bengal [17T1-2], but settled in London as teacker and composer to the theatres, 1773. He died at London, October 12, 1804.

Worrs.-Musical Dramas-Rival Candi. dates, 1775 ; Milesians, 1777 ; Fair American, 1782; Birthday; Constant Maid; Just in Time. Lessons for the Guitar; Concerto for bassoon and pf.; Six Sonatas for the pf. Songs, detached and in collections, etc. The Soldier's farewell on the eve of a battle, song. Carter composed "O Namnie, wilt thou gang wi me," a song which owes its success to its imitation of the Scottish style. Apart from this song his merits as a composer are not great, and none of his other works are now heard.

Carter, William, organist, composer, and conductor, brother of $\mathrm{G}$. and $\mathrm{H}$. Carter, borm in London, December 7, 1838. Stndied under his father and Erust Pauer. Chorister, St. Giles', Camberwell (1845); Chapel Royal, Whitehall; and King's College, London. Organist of Christ Church, Rotherhithe (1848); Little Stamore, Whitehurch (1850); St. Mary, Newington (1854); and St. Helen's, Bishopsgate (1856). In 1859 he acted, for his brother Henry, as Mrganist of Quebec Cathedral, and conducted a grand performance of "Judas Maccaberts," A pril 13, the centenary of the composer's death. The next year he was organist of St. Stephen's, Westbourne Park, London; and, in 186s, of St. Paul's. Onslow Square. He established the Bayswater Musical Society in 1860, and was conductor of the London Choral Lnion, 1861. When the Royal Albert Hall was opened in 1871, he formed a large choir, and has for many years given choral and popular concerts in that building. In 1894 he started choral concerts in the Queen's Hall. He has also appeared with success a a performer upon the organ and pianoforte. His chief compo. sitions are:-Placida, the Christian Martyr, a cantata produced at the Albert Hall, December 5, 1871: a Thanksgiving Anthem for recovery of H.R.H. the Prince of Wales, 1s72; Victoria, an ode, 1857. He has also composed anthems, songs, and part-songs, and arranged national airs for choral-singing.

Cartledge, James, composer, organist, and singer, born at Newark [1791]; died at Manchester September 13, 1864. being the senior chorister of the Cathedral, his appointment dating from 1826. He issued "Sacred
CATLEY.

Music, with an accompanimeut for the organ or pianoforte," Lond. [1840].

Cartwright, Thomas, Puritan divine (1535-1603), who wrote against the use of music in public worship. Full particulars of what views he held will be found in Hawkins' "History of Music."

Case, George Tinkler, concertina player and writer, author of $\mathrm{v}$ irious text-books for different instruments, among which are "Instructions for performing on the Concertina, from the first lindiments to the most difficult style of Perfurmance," Lond. [1848]; Tutor for the Violin; Exercises for Wheatstone's patent concertina [1855]. Baritone concertina, a new method ... Lond. 1857]; Concertina miscellany [1855]. English concertina tutor, n.d. One hundred ballads for the violin [1859].

His wife, born Grace Egerlor, was a soprano vocalist.

Case, John, physician and writer, was born at Woodstock about the middle of the 16th century. Chorister at New College and Christ College, Oxford. Fellow of St. John's College, Oxford. Lecturer at Oxford. $\mathrm{He}$ died in January, 1600.

Worns.-The Praise of Musicke, wherein its Antiquity, Dignity, Delectation, and Use, are discussed, Oxford, 1586. Apologia Musices, tem vocalis quam instrumentalis et mixle, Oxford, 158s. Philosophical works, ete. The "Praise of Musicke" is an exceedingly quaint work, and at the present date of great rarity. The writer was an enthusiast of the highest order.

Cassidy, James, Irish composer and bandmaster, died at I)ublin, March 28, 1869. He composed and published a very large number of galops, quadrilles, and other dance music, for orchestra and pf.

Casson, Margaret, vocalist and composer, who flourished about the begimning of the present century. She wrote a number of vocal pieces of varying merit, among which may be named the songs: The Cuckoo; Attend, ye nymphs [1790]; Snowdrop; Noon [1790]; God save the Queen, etc.; The Pearl, glee. Her biography has not been preserved.

Casson, John, probably a relative of the above, composed mimuets for the pf. Eight favourite airs for the pf., and other works issued between 1794-1820.

Casson, Thomas, bank manager, of Denbigh, amateur organist, and writer. Author of "The Modern Organ, London 18837. Also papers and lectures on the organ. In 1887 he formed a company for building organs on the principle emunciated in his works.

Catley, Ann, soprano vocalist, was born at London, 1745 . She was articled to Bates, the composer, in 1760, and appeared at Vauxhall Gardens in 1762. She sang at Covent 


\section{CAUSTON.}

Garden Theatre, Oct 8, 1762. Involved in a scandalous criminal case, 1763 . Sang in Ireland, 1763-70; Covent Garden Theatre, 1771. Made her last appearance in public in 1784 . Supposed to have been latterly married to General Lascelles, with whom she lived previous to her death. She died near Brentford, Oct. 14, 1789.

The criminal case above alluded to in this singer's life was an action raised at the instance of her father against Bates, Sir Francis Delavel, and an attorney named Fraine for conspiring to prostitute her, by agreement, to the person named Delavel. Her father gained his case. She was a great favourite in London and in Ireland, and was one of the few successful vocalists who at that time made use of the staccato style. Her biography is given in "The Life and Memoirs of Miss Ann Catley, with biographical sketches of Sir F. Blake Delaval, and the Hon. Isabella Pawlet, daughter of the Earl of Thanet," by Miss Ambross, London, 1789, with portrait. Reprinted in 1888.

Causton, Thomas, composer and organist, who flourished during the 16th century. He was a Gentleman of the Chapel Royal during the reigns of Edward VI., Mary, and Elizabeth. He died on October 28, 1569. Contributed to Day's " Certain Notes set forth in four and three parts, to be sung at the Morning, Communion, and Evening Prayer." His compositions appear also in Day's "Psalms," London, 1563.

Cave, William Reginald, violinist, composer and conductor, nephew of Joseph $\mathrm{H}$. Cave, many years lessee and manager of the Marylebone and other theatres. He was born in Marylebone, in 1859, and first appeared as a violinist at the Marylebone theatre in 1864, and afterwards played for three months, during the management of Nelson Lee, 1865, at the Crystal Palace. In conjunction with the late Edward Solomon and James Saunders, he gave concerts. In 1874 he founded the West London Orchestral Society, retaining the conductorship until 1887, and giving many concerts. He then formed the People's Palace Orchestra; and, since 1876, has been a Professor of the violin at Harrow Music School. He wrote incidental music to "Mary, Queen of Scots"; two overtures, one in B flat (at the age of fourteen), for orchestra ; two symphonies; a concerto for violin, and other pieces.

Cave=Ashton, Gertrude, see Ashton, Gertrude Cave-.

Cavendish, Michael, composer, who flourished during the latter portion of the 16th century. He composed "Ayres for four voices," 1599 ; and contributed the five-part madrigal "Come, gentle swains" to the "Triumphs of Oriana," 1601. He also aided in

\section{CELLIER.}

harmonising "The Whole Booke of Psalmes," 1592. His biography has not been preserved.

Cazalet, Rev. William Wahab, M.A., English divine and writer, was born about commencement of present century. He wrote The History of the Royal Acadeny of Music, compiled from authentic sources, London, 1854; On the right management of the voice in speaking and reading, with some remarks on phrasing and accentuation, London, 1855 (3rd edit., 1860); The voice, or the art of singing, London, 1861; On the reading of the Church liturgy, 1862; Exhibition lecture on the musical department of the late Exhibition, London, 1853.

Cecil, Arthur, or Blunt, actor and manager. Destined for the army, be played as an amateur at the Richmond Theatre, and in 1869 joined the German Reed Company, appearing as Mr. Churchmouse in Gilbert's "No Cards," and as Box in the Burnand-Sullivan burlesque, "Cox and Box." He afterwards played in the regular drama at the Globe, Gaiety, and Opera Comique. For some time he was joint manager with John Clayton, of the Court Theatre. He died at Brighton, April $16,1896$.

Cecil, Rev. Richard, clergyman and musician, was born in London, November 8, 1748. He was educated at Oxford, 1773. Deacon, 1775. Priest, 1777. Minister of St. John's Chapel, Bedford Row, London, 1780. Rector of Cobham and Bisley, Surrey, 1800. He died at Hampstead, August 15, 1810.

Works.-Selection of psalms and hymns for the public worship of the Chureh of England, London, n.d.; 32nd edition issued, 1840; Sermons, lectures, etc. Best known by his anthem, "I will arise, and go to my Father." His daughter, Theophania, was born in 1782 , and died in London, November 15, 1879. She was organist of St. John's Chapel; editor of "The psalm and hymn tunes, used at St. John's Chapel, Bedford Row; arranged for four voices, and adapted for the organ or pf., London, 1814.

Celli, F. H., see Standing, Frank.

Cellier, Alfred, composer and conductor, of French extraction, born in London (Hackney), December 1, 1844. Chorister at Chapel Royal, St. James's, 1855-60; organist of All Saints', Blackheath, 1862. In 1866 he succeeded Dr. Chipp as crganist of the Ulster Hall, Belfast, and conductor of the Classical Harmonists, and two years later, was appointed organist of St. Alban's, Holborn. He now turned his attention to composition and conducting, and was engaged at the Prince's Theatre, Manchester, 1871-5; Opera Comique, London, 1877-9; and, with Sir Arthur Sullivan, joint conductor, Promenade Concerts, Covent Garden, 1878-9 ; and held other similar appointments at various times. About 


\section{CHADFIELD.}

this time his health failed, and he lived much abroad, principally in Australia. He died in London, December 28, 1891, while giving the finishing touches to his opera, "The Mountebanks," the overture of which was taken from his Orchestral Suite, the intended movement never having been written. Cellier was a brilliant organist, and was credited with superior literary tastes. He wrote a trenchant little paper, "A nightmare of tradition" (The Theatre, October, 1878), a plea for English opera.

Wonks.-Operettas and Operas: Charity begins at home, 1870 ; The Snltan of Mocha (Prince's Theatre, Manchester, Nov. 16, 1874; revived, Strand Theatre, London, with a new libretto, Sept. 21, 1887); The Tower of London, 1875; Nell Gwymne, 1876; The Foster Brothers, London, 1876 ; Dora's Dream, 1877; The Spectre Knight, Feb., 1878; Bella Donna (Nanchester, April, 1878); After All (London, 1879); In the Sulks, 1880; Pandora, grand opera (Boston, U.S., 1881) ; The Carp (Savoy Theatre, 1886); Dorothy (a fresh arrangement of the music of Nell Gwynne to a new libretto, Gaiety Theatre, Sept. 25, 1886) ; Mrs. Jarramie's Genie (Savoy, Feb., 1888) ; Doris (Lyric, April, 1889); and The Mountebanks (book by W. S. Gilbert, produced, Lyric Theatre, Jan. 1892). He also set Gray's Elegy as a cantata, produced at the Leeds Festival, 1883; wrote incidental music to As Yon Like it, 1885; a Suite Symphonique, for orchestra; Barcarolle, flute and pf.; songs, and pf. pieces.

His brother, Charles Herbert Cellier, is organist of Holy Trinity Church, Anerley; Conductor of Lower Sydenham Choral Society, and Anerley Musical Society. He has, for many years, given concerts in that locality. Francis A. Cellier, musical director, Savoy Theatre, was joint composer of the music to "Mrs. Jarramie's Genie," and composer of an operetta, "Captain Bill," produced at the Savoy Theatre, Sept., 1891.

Chadfield, Edward, pianist, born at Derby, August 1, 1827. At the age of nine, studied under Froude Fritche (organist of All Saints' Church, Derby), but after some years, was required to take the place of a deceased brother in his father's business. From this he was released in time, and he resumed his musical studies mnder Henry Smart, and later, in Paris, with Henri Rosellen, and Korbach. In 1851, he returned to Derby, and established himself as a performer and teacher, founding, with Mr. A. F. Smith, a School of Music there. He held the appointment of organist at St. Werburgh's Church for eleven years, and a similar office at All Saints', which he resigned in 1887 . In the early days of the Incorporated Society of Musicians, Mr. Chadfield was an active worker, and in 1885, he was induced to accept

\section{CHAMBERLAIN.}

the office of Hon. General Secretary. Since that date he has attended meetings and given addresses in all parts of the United Kingdom, and Ireland, and was chosen as a delegate to attend the annual meeting of the MIusic Teachers' National Association (America), held at Philadelphia, July, 1889. After the incorporation of the Society, 1893, Mr. Chadfield was presented with a handsome testimonial during the Conference held in London that year. The office being then removed to London, Mr. Chadfield left Derby for the metropolis, and as the executive officer of the Society devotes the whole of his time to its advancement. He married, in 1858, the yonngest daughter of the late Alderman Madeley, some time Mayor of Derby. His eldest son, Edward Joseph Chadfield, was musically educated first at home, then at the Leipzig Conservatorium. He made his début as a pianist at Derby in 1886 , and succeeded his father as teacher and joint director of the Derby School of Music.

Challoner, Neville Butler, harpist and violinist, born London, 1784. He studied in London, and first appeared as a violinist in 1793. He was violinist at Covent Garden Theatre in 1796 ; at Richmond Theatre, 1799; and subsequently leader at Birmingham, Sadler's Wells Theatre, etc. Harpist at Italian Opera, London, and tenor player at the Philharmonic Society. Latterly, he was a mnsic-seller. Date of death unknown.

Works.-Method for the violin, London, n.d. New Guida di Musica, or instructions for beginners on the pf., n.d. Method for Guitar, n.d.; Method for flute, n.d.; Method for the harp, n. d. Romance and Polacca for harp, op. 14; Two duets on Scotch airs, op. 10 ; Three duets (trans.), op. 15; Duet concertante for harp, op. 22. Miscellaneous works for harp and pf. Harmonia Sacra, 4 books, London, n. d. Lays of harmony, or the musical scrap book, 1830 . National airs [1830], etc.

Chalmers, James, Scottish musician and printer, son of Professor James Chalmers, of Marischal College, was born early in the 18th century; died at Aberdeen in 1764. He compiled a collection of 20 Church tunes [circa 1748], containing "Observations concerning the tunes and manner of singing them," which is now exceedingly scarce. In 1736 be was appointed printer to the town council of Aberdeen, and he published the Aberdeen Journal, etc. His son, JAMEs, born in Aberdeen, March 31, 1742 ; died June 17, 1810, succeeded him in business, and in 1774 was appointed precentor of the West Church, Aberdeen; a position he held till 1797.

Chamberlain, Houston Stewart, writer, author of "Das Drama Richard Wagner's" (Leipzig: Breitkopf and Härtel, 1892); 
CHAMBERLAINE.

"Richard Wagner" (Depót for Art aud Seienee, Munich, 1895); and oecasional contributions to musical papers.

Chamberlaine, Elizabeth, see VoN HOFf, Mrs. H.

Chamberlayne, Miss E. A., composer, of the present time. Studied under Professor Prout and H. C. Banister. Of her compositions a Scherzo for strings, harp, and flute was performed at the Crystal Palace, February 23, 1895. She has published Two Sonatas for pf., op. 16; a Suite, and smaller pieces. Also some music for organ, and songs. She has in MS. two Symphonies, overtures, an opera, and other works.

Chambers, Charles, organist and eon ductor. Graduated Mus. Bac., 1880; 11 us. Doe., 1887, Cambridge. F.P.C.O., 1877. Organist suecessively at St. Peter's, Newcastleon-Tyne, 1870-82; Jesmond Parish Church, 1882-90; All Saints', 1890-3; St. George's, Cullercoats, 1893 . Some time conchetor of Newcastle Harmonic Society. University Exercises-(Bac.) Ps. 109, for soli, chorus, strings, and organ; (Doc.) Cantata, "The Redeemer." Composer of a Concert overture (Neweastle, 1887); offertory seutences, songs, etc.

Chambers, Lucy, contralto vocalist, borm in Sydney, New South Wales, where her father was a lawyer. Her early studies were under Mrs. Logan, a cousin of W. Vincent Wallace; and, eneouraged by Catherine Hayes, at the time in Australia, she decided to adopt the lyric stage as a profession. In Jamuary, 1862, she went to London, and studied under Garcia; then, proceeding to Italy, became a pupil of Luigi Tannuccini, and Romani, at Florence. After a year, slie made her appearance as Azucena, in Il Trovatore, at the Teatro Pagliano. She was then engaged for two seasons at La Scala. Milan, and while there continued her studies with Lamperti. A general tour of Europe followed, and in 1870 she returned to Australia. There she had a long career of unbroken success, her repertory being extensive and varied. She formed an Academy at Melbourne, and died in that city in 1894 .

Chambers, Robert, author and publisher, a member of the well-known firm of $\mathrm{W}$. and R. Chambers, Edinburglı; born 1802, died 1871; edited "The Songs of Seotland prior to Burns, with the tunes," Edin., 1862.

Champness, Samuel, bass siliger, born about 1730 ; died September, 1803. He was a Gentleman of the Chapel Royal, sang at the principal concerts in London during the latter half of the 1sth century, and had a voice of great richness, which was nuch admired.

Champneys, Francis Henry, amateur eomposer, born at London, March 25th, 1818. Edueated at Oxford, where lie graduated M.A.,

\section{CHAPPEL.}

1875. He studied music under Sir John Goss. Fellow of the Royal College of Physieians. Has conducted concerts, and is the eomposer of hymus and other ehurch musie; "Rustie coquette," ballet for four voiees, ete.

Clnaplin. The name of three sisters, instrumentalists of the present day. Nequie, the eldest, is a pianist, born in London, and musically educated at the London Academy of Musie, where, amnng other distinctions, she was awarded the silver medal presented by the Society of Arts. Later, she studied the Deppe method with Frl. Elise Timm, at Hamburg. In 1893 she established a pianoforte school in London, and chiefly devotes herself to tuition. Miss Chaplin is known as a performer, and eommenced giving concerts in 1882. She has played, with suecess, in London and the provinces, and, with her sisters, gained some reputation for the Chaplin trio. Kate Chaplis, violinist, born in London, was also trained at the London Academy, under Mr. Pollitzer, having previonsly received lessons from Niss I unbar Perkins. As a very youthful performer she appeared at Mr. George Gear's concert, St. George's Hall, May 2nd, 1882; and since then has played at many concerts, in London, and the principal eities of the United Kingdom. In 1892, she went to Brussels, to study under Eugen Isaye, and in January, 1893, had the honour, with her sister Nellie, of playing before the Queen, at Osborne, receiving the Royal compliments, and souvenirs of the event. The youngest sister, Mabel Charlix, violoncellist, received her first lessons from Mr. John Boatwright, of the Plithamonie Orchestra; and entering the London Academy, becamea pupil of Signor Tezze. Subsequently she studied at the Brussels Conservatoire, under Edouard Jacobs, gaining, in 1893, the first prize, with distinetion, for violoncello playing, being the first English girl to earry off that honour. She had for some time taken part in the concerts given by her sisters; but gave her first eoncert, with Emil Saner, in the Queen's Hall, Mareh 28, 1895.

Chapman, Rev. James, anthor. Wrote "The music, or melody and rhythmus of language, with the five arcidents of speech, and a musical notation." Edinburgh, 1818.

Chapman, T., musieian. Publisled the "Young gentleman and ladies' musical compauion," $1772-74$. Two vols.

Chappelf, William, writer and antiquary, was born in London, November 20th, 1809. Brought up in music publishing business with his father. Engaged in musical antiquarian studies. Founded (with others) the Percy Society in 1840, and the Musical Antiquarian Society in 1840. F.S.A., 1840. Partner in the firm of Cramer \& Co., 1843. 


\section{CHAPPLE.}

Treasurer of the Camden Society, etc. Was connected with a number of learned and antiquarian societies. He died at London, August 20, 1888.

Works.-A collection of national English airs, consisting of ancient song, ballad, and dance tumes, interspersed with remarks and aneedotes, and preceled by an essay on English minstrelsy; the airs harmonized for the pianoforte by Dr. Crotch, G. A. Macfarren, and J. A. Wade. London, 4to part I., 1838; II., 1839; III., 1840. Popular music of the olden time: a collection of ancient songs, ballads, and dance tumes, illustrative of the national music of Eugland, etc. London, Cramer, 9 vols. [1845-59]. Old English ditties, London, 2 rols., n.d. History of music, art, and science, from the earliest records to the fall of the Roman Empire, with explanations of ancient systems of music, musical instruments, and of the true physiological basis for the science of music, whether ancient or modern, vol. I., London, 1874, all published. Edited works (collections of ancient poetry) for the Ballad, Percy, and Camden Societies. A new edition of his "Popular Music" was issued as "Old English popular music," in 1893, edited by H. Ellis Woolridge. This corrects a number of the statements concerning scots music, which, in his anxiety to prove that England possessed an immense wealth of folk music, Chappell advanced without sufficient proof. Further proofs of $\mathrm{Mr}$. Chappell's want of care in the presentation of evidence have been gathered by Mr. John Glen, and will be published soon.

Chapple, Samuel, organist and composer. Was born at Crediton, Devon, 1775. He was blind from childhood; but after studying the pianoforte lie became organist at Ashburton, 1795-1833. He died at Ashburton, October 3, 1833.

Works.-Five songs and a glee, op. 3 ; Six anthems in score, tigured for the organ or pf., op. 4; A second set of six anthems in score, op. 5; A third set of six anthems and twelve psalm tunes in score, op. 6; The eigliteen anthems, republished. Three sonatas for the pf.; Six songs with pf. accompaniment; Anthem for the coronation of George IV.; Single pf pieces; Single glees, anthems, and songs.

Chard, George William, composer and organist, was born in 1765 . He studied under Robert Hudson in the choir of St. Paul's. Lay-clerk at Winchester Cathedral, 1788, and organi-t of the Cathedral in succession to Peter Fussell, 1802. Organist of Winchester College, 1832. Doc. Mus., Cambridge, 1812. He died at Winchester, May 23, 1849.

Works.-Anthems: Happy is the man; Is there not an appointed time?; O Lord we beseech; To celebrate Thy praise. Services.

\section{CHERRY.}

Chants in Bennett and Narshall's collection. Songs: Twelve glees for three, four, and five voices. London [1811].

Charde, John, composer of the 16th century. In 1518-19 he graduated Mus. Bac. Oxford, for which he composed a mass in five parts. This was the first composition in so many parts written by a bachelor for a degree exercise. He composed other masses.

Charke, Richard, violinist and composer of middle of 18 th century. He married Charlotte Cibber, whom he illtreated, and from whom he soon separated. Notable as the first to compose medley overtures. He died in Jamaica of disorders brought on by dissipated habits.

Charlesworth, J.J., musician, compiler of "Fifty Select Tunes carefully adapted to the best part of the first 96 Psalms ..." London, 1796.

Charlton, R., author, published "Reminiscences and biographical sketches of Insicians." Lincoln, 1836.

Chatfield, Mrs. Henry, see LARge, Eliza R.

Chatterton, John Balsir, harpist and composer, was born at Portsmouth, where his father, John Chatterton, was a teacher of mnsic, in 1802. Ife studied under Bochsa and Labarre, and became Professor of the harp at R.A.II. Harpist to the Queen, ete. He died at London, April, 1871.

Works. - Numerous transeriptions from popular operas for the harp; Songs with harp and pf. accomp., etc.

His brother Frederick was also a harpist and composer. He was born in 1814, and died at London in Narch, 1894. His daughter Josepune made her first appearance as a harpist at Willis' Rooms on June 3, 1857. She lived for some years in America, and estahlished a school for the harp at Chicago in 1892. In December, 1895, she appeared again in London.

Cheese, Griffith James. organist and writer, was born on May 2, 1751. Ite was organist at Lcominster and teacher in London. Author of "Practical rules for playing and teaching the pianoforte and organ, likewise nseful information to teachers and pupils born blind, op. 3," London [1800]. Songs, ete. He died on November 10, 1804 .

Chell, William, writer and musician, was lay-vicar and precentor at Hereford Cathedral in 1554. Mus. Bac, Oxford, 1524. Prebendary of Eigne, 1539, and East Withington 1545. He left two treatises entitled "Musice Practice Compendium" and "De Proportionibus Musicis," which are said to be transcriptions from the works of John Dunstable, etc.

Cherry, John William, composer and teacher, born London, December 10, 18.4. Self-educated in theory and on Pianoforte. 


\section{CHESHIRE.}

He died in London, January, 1889. Has composed over 1,000 pieces, of which the following are the best known:-

Worrs.-Will-o'-the-wisp; Shells of ocean ; Beautiful leaves; The Blacksmith; How beautiful is the sea; My village home; Monarch of the woods; Estelle; Gentle Spring; Sweet Aunie; The Invitation; Silently, silently over the sea; Trees of the forest; Upon the lonely shore; Wanton breezes, whither going; Down by the sea; Fair Glen Lochry; Home again to England; Seventh day; Spirit of the whirlpool; Breathe soft, summer wind; Summer twilight; Come with me to Fairyland. Duets-Elfin revels; Hark! there's music stealing; Let us roam away, etc. Pf. mnsic, dances, etc.

Cheshire, John, harpist and composer, born in Birmingham, Narch 28, 1839. Commenced playing the harp when four years of age. Studied at R.A.M., 1852-55, and afterwards under G. A. Macfarren and J. B. Chatterton. Played at a concert of the Society of British Musicians, February 27, 1855, after which he was presented with a fine harp by the Messrs. Erat. In that year he was appointed harpist at the Royal Italian Opera; and, in 1865, principal harpist at Her Majesty's Theatre. Travelled in South America, 1858-61; Norway and Siveden, 1879. Has been heard in the principal concerts in the United King. dom. From about 1887 resident in America; harpist to the National Opera Company there, 188. His compositions include an opera, "Diana," written in Brazil; Cantatas: "The King and the Maiden" (book by Arthur Matthisons), performed St. James's Hall, A pril 20,1866 ; "The Buccancers," 1886. Three overtures for orchestra. These, excepting the Buccaneers, remain in MS. He has published for the larp--Six Romances; Album of twenty-fonr pieces, etc. A Thet in I3 flat, and a number of pieces fur pf.; Soligs-Cupid the conqueror; The withered violet, etc., etc. In 1871 he married Miss Maria Mlatilda Baxter, an excellent pianist, who appeared with success at many of his concerts.

Chetham, Rev. John, musician and clergyman, born about 1700 . He was master of the Clerk's School. Skipton, in 1737, and curate of Skipton 1799. He died at Skipton in August, 1763. Issmed "A Pook of Psalmody, all set in four parts," 1718 ; 2nd ed., (?) ; 3rd, 1724 ; 4th, 1731; 5th, 1736; 8th, 1752; 9th, $1767 ; 10 t h, 1779 ; 11$ th, Leeds, 1787 ; of which an enlarged and rerised edition by Houldsworth was published at London in 1832, and Halifax in 1868.

Chevalier, Albert Onesime Britanni= cus Gwathveoyd Louis, comedian, and lyric anthor, born at Notting Hill, London, March 21, 1862. Displayed listrionic talent at an early age, and appeared in farce at the

\section{CHILD.}

Prince of Wales' Theatre, Tottenham Street, Sept. 29, 1877, as Mr. Knight. From 1878 to 1887 he was on tour with Mr. and Mrs. Kendal, Mr. Hare, and other combinations, in "Diplomacy," and various dramas. Later, he came out as an entertainer, and in 1890 sang in comic opera at the Avenue Theatre. It was February 5, 1891, that he made his first appearance as a music-hall performer, at the New London Pavilion. His success was phenomenal, and has lasted ever since. His matinees in the provinces have attracted large and enthusiastic audiences, and "The Coster's Laureate," "The Kiphing of the Musichall," has been everywhere recognised as an artist. In 1896, he visited America. Besides his songs, he has written several pieces for the stage. His brother, Auguste, under the nom de plume of Charles Ingle, supplies most of his music. Assisted by Bryan Daly, he has written "Albert Chevalier; a Record by himself," London, Macqueen, 1895. Among the best known of his songs, composed by his brother, John Crook, and others, may be named "Knocked 'em in the Old Kent Road"; "Future Mrs. 'A wkins"; "Coster's serenade"; "My Old Dutch," ete.

Cheyne, Edwin, Scottish author, published "The Amatenr's Vocal Guide and voice trainer... Glasgow, 1879.

Chilcot, Thomas, composer and organist, was born about the beginning of the 18th century. He was organist of Abbey Church, Bath, 1733, and died at Bath, in November, 1766. Chilcot is chiefly noted as having been the master of Thomas Linley. He composed six concertos for the harpsichord, with 4 violins, viola, violoncello and hasso ripieno, London, 1756. two sets; Twelve English songs, the works by Shakespeare and other celebrated puets [1745]; single songs, glees, etc.

Child, William, composer and organist, was born at Bristol, in 1606. He studied under Elway Bevin, as chorister in Bristol Cathedral. Mins. Bac., Oxford, 1631. Organist of St. George's Chapel, Windsor, 16:32. One of organists of Chapel Royal, London. Chanter of Chapel Royal, 1660. Member of King's private band, and composer to the King in 1661. Doc. Mus., Oxon., July, 1663. He died at IVindsor, Jarch 23, 1697, and is buried in St. George's Chapel.

Works.-The first set of Psalmes of 3 voyces, fitt for private chappells, with a continued bass either for the organ or theorbo, composed after the Italian way, London, 1639 (2nd edit., 1650). Divine an thems aud vocal compositions to several pieces of poetry, London; Service in D (Boyce); Service in E (Boyce); Praise the Lord, () my soul, anthem; o Lord, grant the King, anthem; O pray for the peace of Jerusalem, anthem; sing we 


\section{CHILLEY.}

merrily, anthem; Services in G, F, and $A$ minor; Court Ayres (a volume of secular vocal music); Catches and Canons, etc.

Child's compositions are very simple in general style, and approximate in character to the productions of a century later. "At times, however, as in his service in D, his harmony was rich, glowing, and closely worked. Some ferv of his full authems, without any great depth of science or elevation of genius, possess a great degree of warm $h$, and exhibit imagination." He paved at his own expense the body of Windsor Chapel.

Chilley, Charles, tenor vocalist, born in London (Pimlico). He was educated at the Albert Nemorial College, Framlingham, and then was for several years in au office, frequently singing in concerts as an amateur. Eventually he entered the Guildhall School of Music, and became a pupil of the late J. B. Welch. He sang at the Crystal Palace, in Mendelssohn's Walpurgis Nacht, 1883; at a concert of Mr. Willing's choir, 1884; and since then has been heard at the principal London and provincial concerts, having been on tour with Madame Albani, and others.

Chilmead, Edmund, scholar and musician, was born at Stow-in-the-Wold, Gloucester, 1611. Clerk of Magdalen College, Oxford. Canon of Christ Church, 1632. Resided with Este the musician, in London, 1648. He died at London in 1654. Wrote "De Musicâ Antiquâ (Træecâ," priuted at the end of the Oxford edition of "Aratus," 1672. He gave concerts in London, and drew up a catalogue of the Greek MSS. in the Bodleian library. "He was well versed in the old music, and was the best qualified at that time ... . to enter upon this subject."-Hearne.

Chinn, Francis Farrant, composer and organist; born in 1813, died at Liverpool, April 29, 1868. Composer of glees and songs. "Harvest home, a pastoral glee." Liverpool [1844] is one of his best works.

Chipp, Edmund Thomas, composer and organist; was born at London, December 25, 1823. Son of Thomas Paul Chipp, the well-known performer on the kettledrums and harp. Chorister in Chapel Royal moder William Hawes. He studied the violin under W. Thomas, J. B. Nadaud, etc., 1832-40. Organist (voluntary) of Albany Chapel, Regent's Park, London, 1843-6. Member of H. M. private band, as violinist, 1843-55. Organis? St. John's Chapel, Downshire Hill, Hampstead, 1846-7; St. Olave's, Southwark (in succession to H. J. Gauntlett), 1847-52; St. Mary-at-Hill, East-Cheap, 1852-6; Royal Panopticon (in succession to W. T. Best), 1855; Holy Trinity Church, Paddington (in succession to C. E. Stephens), 1856-62. Mus. Bac. Cantab., March 17th, 1859. Mus. Doc., do., Jume 21st, 1860. Organist Ulster Hall,

\section{CHIVERS.}

and St. George's Church, Belfast, 1862-6. Conductor of the Avacreontic, Classical Har. monists, and Vocal Union Societies, Beifast. Orgauist of Kinnaird Hall, Dundee, Feb.-Nov., 1866 ; St. Paul's, Edinburgh, May to Nov., 1866. Organist, and Masier of Choristers, Ely Cathedral, November, 1866. Was also member of the Royal Italian Opera, the Philharmonic, and Sacred Harmonic Society Bands. He died at Nice, December $17,1886$.

WoRks.-Job, an Oratorio, for solo voices, chorus, and orchestra; Naomi, a Sacred Idyll, for solo voices, chorus, and orchestra. Music for the Church Service and home circle, containing 10 Sentences, 24 single and 41 double Chants, 4 Te Demms, 2 Jubilate. 2 Benedictus, 1 Te Dem in unison, 2 Sanctus, 12 Kyrie, 4 Gloria, 2 Magninicat, Nunc Dimittis, 4 Cantate Domine, Deus Misereatur, and 108 Church Alelodies, in short, common, long, and irregular measures, by varions authors. Te Deum, Jubilate, Sanctins and Ky rie in D; Church Service in A; Te Deum in D; Gloria for male voices. Three Studies for the Organ, op. 7; Introduction and six variations upon Handel's Harmorious blacksmith, for organ ; Do. and seven variations on frod preserve the Emperor, for organ; Lord of all power and might, anthem; Part-songs; Songs, and miscellaneous Church and chamber music.

Chipp, Thomas Paul, English harpist, father of the foregoing, was born in London, May 23, 1793, and died on June 19, 1870. $\mathrm{He}$ was well-known as a drum player and harpist, and as a leading performer at all the principal festivals. He retired in 1866 . His compositions include a string quintet in E minor, 1836 ; quartet, 1845 ; Fantasias, ete., for harp.

Chisholm, James, commonly called Marquis Chisholm, musician and entertainer, born Neilston, Renfrew, abont 1837; died Toronto, Canada, December, 1877. He was a fair pianist, and travelled much in Australia, Asia, Scotland, and America with a Chinese giant named Chang. He composed the somewhat vulgar song entitled "The Battle of Stirling," which has been frequently parodied in Scotland, and published "The Adventures of a travelling musician in Australia, China, and Japan," Glasgow, 1865, reprinted from the Glasgow" Herald. He also published "Gems of Scottish melody" [1869], and the "ChinChin-Chang" Galop; "Great Chang Polkas," and similar works.

Chisney, E., author of a work entitled "Concertina Instruction," London, 1853.

Chivers.G. M. S., musician and dancingmaster of first half of the present century. He published a number of works, among which may be named-Recueil de danses Espagnoles, or Spanish country dances, arranged 


\section{CHOPE.}

for pf., London, 1819; First set of Chiverian quadrilles [1820], New set of contre dances; The Modern dancing-master, London, 1822, ete.

Chope, Richard Robert, clergyman and musician, born September, 1830 . Vicar of St. Angustine's, South Kensington. Editor of "Iymm and Tune Book," 1857-62;" "Choir and Musical Record," 1s6\%; Tersicles, Canticles, Litany. Psalter (Gregorian), 1862. Choral Communion (Narbecke, etc.), 1863. Carols for use in Church, 1868-76. Easter and Harvest Carols, 1884.

Chorley, Henry Fothergill, musieian, jounalist, general writer, ete, was born at Blackley Hurst, near Fillinge, Lancashire, December 15th, 1808. Prought up for mercantile life. Commenced connection with the "Athentum," 1830. Member of the "Athen: 11 m" staff, 1833-1871. He died at Londen, February 16, 1872.

Torks.- Slictiches of a sea-port town, 3 vols., 1835 (novel); Conti the disearded, a novel, 3 vols., 1835; Memorials of Mrs. Hemans, 2 vols., 18:36; The Lion, a tale of the coteries, 3 vols., 1839; Nusie and mamners in France and Germany, 3 vols., I ondon, 1841 ; Pomfret, a novel, 18t5; Old love and new fortmne, a play, 1850; Modern Cerman music, recollections and eriticisnus, London, 3 vols., 1854 ; Poccabella, a novel, 1859 ; Thirty years' musical recollections, Londou, '2 vols., 1862 ; Prodigy, a tale of music, London, 3 vols., 1866; Handel studies, 2 parts, 1859; National music of the world, edited by H. G. Hewlett, 1880 ; Librettos for Wallace's Amber Witch; Bennett's May Gueen, ete.; Translations of Mercadante's Flena da Feltre; Cimarosa's Il Natrimonio segreto; IIérold's Zampa; Anber's Haydée; Mendelssolnn's Son and Stranger, etc.

Chorley was too many-sided ever to attain great distinction in any one of the numerous walkis he attempted. His musical writings possess greater literary merit than most of the English work of the same period, but the judgments formed in them, especially with regard to Mendelssoln, have long since been overturned. His "Attobiograpliy, Nemoir, and Letters," edited by Henry G. Hewlett, was published in London, 2 vols., 1873, with a photograpl].

Christie, William, violinistand composer, was boln about 1778 , and died 1819 . He resided at (moninestown, Monquhitter, Aberdeenshire, as a dancing-master and teacher. Composer of a "Collection of Reels, etc." Edinburgh.

His son WILLIAM was born at Monquhitter in 1817, and died at Bellie, near Fochabers, December 12, 1685. 1 Ie studied at Aberkeen University, and was ordained in 1839 as incumbent of the Scottish Episcopal Church

\section{CIANCHETTINI.}

of Arradoul and Puckie. In 1861 he was appointed Dean of the United Diocese of Moray, Ross, and Caithness. He compiled "Traditional Ballad Airs, arranged and harmonised for the Pianoforte and Hamonium, from copies procured in the comnties of Aberdeen, Banff, and Noray, by IV. Clnistie, M.A., and the late WVilliam Christie, Monquhitter, edited by IV. Christie, M.A., Dean of Moray," ete. Fdinburgh, 's vols., 1876-81. A very handsome and interesting work, containing a number of previonsly uncollected airs.

Church, John, composer, born at IVindsor in 1675. He was a chorister of St. John's College, Oxford. Gentleman of Chapel Royal, 1696. Lay-vicar Westminster Abluey; Choirmaster, 1704-41. He died at Westminster, Jannary 6, 1741. Antlior of an "Introluction to Psalmody, containing useful Instructions for young Beginners, explained in a familiar and casie manner," London, 1733. Service in F, in Ouseley's "Cathedral Services." Anthems. Fonr clunts in Vanderuan's "Divine Harmony." Songs, etc.

Churchill, William, pianist and fomposer, who flourished in London at the end of last and beginuing of the present century. He wote a momber of works for his instrument, including Three Sonatas for pf. and violin; Six Duos for 2 violins, op. 2; Six Dnos for violin and alto; T'en Progresisive Lessons for pf., op. 5 and 10 . Six trios, fonc for a violin, tenor and violoncello obligito, and two for two violins and rioloncello obligato, op. 1 1780 ; Favorite Sonata for the harpsikhord [1785]. Another musician of this name, probalily a relative, was JosepH CHURCHILL, who issried "A selectjon of Cathedral Chants," I ondon [1841]. Songs, dance music, etc.

Churclyyard, Thomas, poet and musician, who flomished during the 16th centmry. Wrote "The Uommendation of Mnsylie by Churehrarde," 1562. For other works see Hazlitt's "Fandlook of T'oetical Literature," 1867.

Cianchettini Pio, composer, wat born at London, Decemher 11, 1779. Son of Francesco Cianchettini. Appeared as infant prodigy, 1804. Travelled through Fermany, Holland, and France. Returned to London, 1805. Accompanist and conductor to Catalani. Teacher and composer in London. He died at Cheltembam, July 20, 1851.

Works.-Pope's Ode to Solituare. Sixty Italian catches, for two, three, and fomr voices (Martini), edited. Cantata for two voices from "Milton's Paradise Lost." "Take, O take those lips away," somy. Music by Mrzart, and Beethoven, edited, and a large nmmber of fantasias, eoncertos, rondos, divertimentos, etc, for $\mathrm{pf}$. II mother was Veronica Rosalem Dusser (1779-1838), sister 


\section{CIBBER.}

of J. L. Dussek, and his sister, Yeronica Elisabeth Ciachettini, was a composer of overtures, rondos, sonatas, waltzes, ete.

Cibber, Susanna Maria, born ARxe, soprano veealist, bom London, Febmary, 1714. Sister of Thomas A. Arme, muter whom she studiod music. She first apreared in Lampers "Amelie," in 1732. Married to Thomas Cibber in 17:34. She appeared as an actrexis in Hill's "Zara," in 1736, and afterwards samg at concerts in London and elserhere. Died, Lonklon, Jannary $30,1760$.

Clagget, Charles, musian, born London, 1755. Was a riolinist, and areted as leader at a theatre in Duldin. Infented varions instruments, $1776-90$, which ho exhibited in lemdon in 1791. I Ie Tied in 1820.

Irokks.- Six duos for 2 fluter ; Sis duos for two violins; Six duon for violin and rioloneello, op. 6. Musical Phomonntar: an Organ made withont pipes, strings, hells or glasses, the only instrument in the world that will neser require to be retumed. A cromatic trumpet, capalile of producing just jntervals and pegnlar melodies in all litys, without molergoing any change whateres. I French horn, answering the alowe dencription of the trumpet. London, 1793.

Clagget, Walter, Euglis] rumposel' and pianist, who lived in latter half of the 1sth century. He gave concerts in Nomich and Londuin.

Works.-A New Medler overture, comsisting entirely of scots tumes and thirty-six of the most favourite Scots airs... fur g violius or 2 German flutes and a violoncello. six solus and six Scots airs, with variations for the viola or violoncello. (1). 2. Discombes on Musick, to be delivered at Clagrect's Attic Consurt, October 31, 1793.

Clapliam, Jonathan, clergsman and anthor. Riector of Wramplingham, Norfolk, in the 17th century. Ile wote " A hort and full vindication of that sweet and comportable ordinance of singing of Prilnus," Inondun, 1656 .

Clare, Edward, organist and anthor, whe died Lombon] April !th, 1869. Imsned "Analysis of pratical Thorombh-bass," Lomelon [1835]. A simple gaide for chanting, for the nise of amateurs. . . Lomdon, n.d. He teomposed a large number of ballads, transcriptions foi lif., etc.

Claribel, see BARstru, Mrs.

Clark, Rev. Frederick Scotson, organist and composer, hun in Lmom, Nowember 16th, 18to. He studied under his mother (a purpil of Mrs. Anderson and (hopin), and the pianoforte and hammo mder sergent, organist of Notre Dame. Organist of Regent Square C'hurch, London, 1855. situdied organ under E. J. Hopkins: music at R.A.MI., mider Bemnett, Goss, Engel, Pinsuti, and Pettit.
CLARK.

Organist successively of a mumber of London churches. Fomnded a College of Music in London, 1865. He studied for the ministry at Osford, and lucame organist of Exeter College, Oxford. Bac. Mus., Oxon., 1867. Head master of St. Miehat's Grammar School, Brightom, 1967. C'urate of Lewes, Sussex. For a time he studied at Leiparg Comservatorimm under Richtel, Reinecke, ete., and was assistant in Euglinh rhurch there. Healso studied moder Lebert, Pruckinr, and Krouger at stuttgart. He returned to Lendom, 18T3, and resumed his comnection with the college or London Organ School, 1875. Represented English organ-playing at Paris Exhibition, 1878. He died at London, July 5, 1883.

Works.-Organ: Toluntaries: Pastorale; Dunce Pennee; Andantes in F and D: Melodies in [)$, A, F$, and $F$ flat: Postlude. Marches: Anglaise, anx Flambeanx, des Fantônes, des Girmendins, des . Tacolnins, Mlilitaire, belgian, Commemeration, Festal, I'rucesion, Roman, Russian, Viemma, ete. : (ommuntons in D minor, E, C'minor, I minor, G and E; Offertoires in F, I), A, (, and C: Meditation, in B flat; Fantasiasin F, ete, Improsisations in $\mathrm{B}$ flat, $\mathrm{C}, \mathrm{C}, \mathrm{F}$; Impromptus, prayers, romances: Garottes; Minnets, airs. Harmomium: Toluntariess Reverie, Garotte, Ave Maria, songs. Meditation, in P Hat, for violin, hammomm and yf. Pionoforte: ('hinese malloh; Indian match ; Turkish march, cte.; Mazunlias, polkas, gillops, valses, and minuets; Bacombles, stmdies, noctmones, melodies. Tocal: Kivie Fleison and sanctus in F, from commnnism service No. 1: Do. from No. 2; Magnificat and munc Dimittis, chant service in F. C'upid, part-kng fongs.

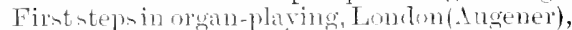
11.d. ; First steps in harmunimm-playing (To.) 11.t.; First steps in pianoforte-pluying. do.

Clark, J. Moir=, esmposer, him at Aberdeen. Situdied at R.A.M. under F. Prout, and later in Germany. He gave concerts in Dresden, 18,2, when soreral of his compositions wele produced. Among his chief works ate a seot h sinite, for orehentia, performed by the stoek fichange orehostral soejety at the

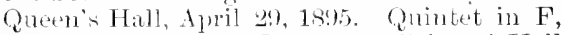
pf. and strings, Imenten, 18:2 ; 'Princes' Hall (Miss Dora Fright's concert), Ipril 19, 1898; and the Monday Pupular Concerts, November 5th, 1894. IIc has also witten a suite, and other pieces for flate and pe., produced by Mr. F. Griftith, 1893; a Polonaise, violin and pf.; Tariations on an original theme, pf., played by Miss Dora Pright at her recital, January 30,1889 - the first public performance of any of his worlss; Pf. (Iuets; songs, we.

Clark, Jeremiah, composer and organist, horn in London, 1696 [or villier]. Hestudied mder Plow as a chorister in the Chapel Royal. Organist of Winchester College, 1692- 


\section{CLARK.}

1695. Almoner and master of the Choristers of St. Paul's Cathedral, London, 1693. Organist and Vicar-Choral of St. Paul's, 1695; (rentleman of Chapel Royal, 1700. Joint organist of Chapel Royal with Croft, 1704 . He committed suicide by shooting himself in st. Panl's ehurchyard, London, December 1, 1707.

Works. - Music to the following plays Antony and Cleopatra (Sedley), 1677; Fond Husband, 1676; Titus Andronicus, 1687; World in the Moon (with D. Purcell), 1697; Campaigners, 1698: Island Princess (with D. Purcell and Leveridge), 1699; All for the better, 170\%; The Committee, 1706. OdesAlexander's Feast, Dryden; Ode in Praise of the Island of Barloadoes. Services in G and C minor. Antherns-I'raise the Lord, O Jerusalem; How long wilt Thon forget nue?; I will love Thee, $O$ Lord ; O Lord God of my Salvation; Bow down Thine Ear. Songs in D'Urfey's "Pills to Purge Melancholy." The Assmotion, Cantata; Lessons for the Harpsichord: Ten Siongs, op. 4 ; Secular music, miseellaneous.

Clark is now best remennbered by a few of his anthems and the psalm-tune" "st. Magnus." His dramatic music is completely forgotten, and none of his other secular worlis are in use.

Clark, John, Seottish collector and riolinist of the 1sth century. Published "Flores Musica, or the Scots Mrisician, being a general collection of the most celelrated sicots Tunes, Reels, Minucts, and Marehes, adapted for the Violin, Hauthoy, or German Flute, with a Bass for the violoncello or Harpsichord." Edinburgh, 1773.

A musician of the same name, probalis the same individual or a relative, published at Perth "A Collection of new Strathoper recels and country dances, with a lass for the violoneello or harpsichord, dedicated to the Musical society of Perth," 1795.

Clark, Richard, writer and singer, grandson of John Sule, was born at Datchet. Bnteks., April 5, 1780. Chorister in st. Creorge's Chapel, Windwor, under ArIward. 'horister at Ftrm College, muder $\rightarrow$. Heather. Lay-Clerk at Sit. (renge's Chapel, and liton College, 1503-11. Necretary of the (rlee Club. LayVicar of Westminster Abbey and Vicar-Chcral of Sit. I'anl's, 1s11. Fevitlensan of ('hapel Royal, 18z). He died at London, Getober 8, 1850 .

Works.- Words of the most favomite pieces performed at the Glee ('lul), Catch ('lul), and other pmblic societies, Limclon, 1814. First rolmme of poetry, revised, inprosed, and considerably enlarged, containing the mont fivomite piecess performed at the (ilee cluls, ete., Londen, 1824. Continuation, 1833. An accomt of the National Anthem entitled "God save the ling," etc., Iondon, 182..

\section{CLARKE.}

Reminiscences of Handel, His Grace the Duke of Chandos, Powells the Harpers, The Harmonious Blacksmith, and others, London, 1836. Reading and playing from score simplified, London, 1838. An examination into the derivation, etymology, and definition of the word "Madrigale," London, 1852. On the sacred oratorio of "The Messiah" previous to the death of G. F. Handel, 1759, London, 1852. An address to the directors of the Ancient Concerts on the high pitch of the scale, London, 1845. Glees, anthems, chants, etc.

Clark, Thomas, musician, born at Canterbury, 1775; died there, May 30th, 1859. He was conductor of music at the Wesleyan Chapel, and latterly of the Lnitarian Chapel, Canterbury. He published "The Union Harmonist, a selection of sacred music," 1841. "The Union Tume Book, a selection of tumes and chants suitable for use in congregations and simday schools," London [1842]. Psalm and hymn tmes, n.d. Composer of "Crediton," and other hymm tunes.

Clark, Windeyer, organist, pianist, and composer. Began bis studies in a Tonic solfa class. He entered the London Aeademy of Music, studying under Dr. Wylde, and afterwards took organ lessons from J. W. Elliott. From abont 1877 he became amamensis to sir G. A. Macfarren, whose later oratorios he took down from dictation, and also played to the Cambridge Professor the I enree exercises sent in. Held organ appointments at st. Philip's, Padrlington; Curzon Chapel, Mayfair; and Westhourne Grove Chapel. Gave fregment recitals, for some of which Macfarren wrote orwan pieces. In 1889 he was made L.R.A.M. He composed some pieces for pf., and arranged the scores of Macfarren"s "May Day," Haydn's "Creation," Mozart's First Miass, and Mendelssohn's "Landa Zion," for pianoforte and hamonium. Joint translator, with J. T. Hutchinson, of Gounod's commentary on "I) on Giovanni," London, Cocks \& Co., 1895. He died of consmmption, Jume 13, 1896, at the early age of thirti-seven.

Clarke, Charles E. Jo, organist and composer, born at Worcester, 1796. He was a chorister in Worcester Cathedral. Organist successively of lombim ('athedral, 1812, and Worcester Cathedral, 1814. Conductor of the Worcester Festival from 1815 (when only nineteen rears of age), to 1839. Ill health compelled him to relinguish the task in 1842, when Joseph summanwas appointed conduetor. Died at Worcester, April $27,1844$.

Clarke, Frederick William, composer, born in 1852: died in 1883. He graduated Ins. Bac. Oxford in 1880. Composer of Reverie's, polonaices, garvottes, ete., for pef.; Songs and other vocal muic. An Album of his 


\section{CLARKE.}

songs, edited by Rev. W. Mamn, Precentor of Bristol Cathedral, and Charles South, organist of Salisbury Cathedral, was published, In Memoriam, by Novello and Co., 1885 .

Clarke, James, writer and teacher, borm at London, 1793; died at Leeds, 1859 . Author of a "Catechism of Wind Instruments, containing explanations of the scale and compass of each instrument, and particular directions for writing the parts of flutes, elarinets, ete.," London, n.d. "Instruction Book for Children on the Pianoforte," London, n.d. "The Child's Alphabet of Music," London, n.d. "Exercises in Harmony, designed to facilitate the study of the Theory of Music and the Practice of Thorough Bass, London, 1832 (pub. in 24 nos). "Catechism of the Rudiments of Music," London, n.d. " New School of Music, combining the Practice of Singing with that of the Pianoforte," London, n.d.

Clarke, James Hamilton Smee, composer and conductor, born in Birmingham, January 25, 1840. His father was an amateur organist, and encouraged his son's musical studies, but did not intend him to follow the art as a profession. At twelve he was organist of St. Matthew's, Duddeston, and at fifteen was sent as pupil to an analytical chemist, but gave that up and was articled to a land surveyor, 1855-61. At the expiration of his articles he entered the musical profession, and obtained (1862) a post as organist of Parsonstown Parish Chureh, Ireland, changing, a year later, to Zion Church, Rathgar, Dublin. While here he joined the Iublin Philharmonic orchestra as first violin, and frequently assisted Dr. Stewart at Christchurch Cathedral. In $186+$ he was appointed conductor of the Belfast Anacreontic Society, and organist of Caremony ('hurch. This vear he won the first prize offered by the then recently established college of Organists for an anthem. He was appointed organist of Queen's College, Oxford, in June, 1866, after holding office a few months at Llandaff Cathedral, and graduated Mus. Bac., 1867. During his five vears' residence in this city he conducted the Queen's College IInsical siociety, and played the clarinet at several College concerts. He was organist of Kensington Parish ('hurch, 1871, and succeeded (Sir) Arthur sullivan at St. Peter's, South Kiensington, in 1872. From this time he turned his attention to the theatre, and was conductor at the Opera Comique, Comedy, Toole's, (raiety, and other houses; conductor of the D'Orly Carte Company in the provinces, 1878 , and of various concert parties. From 1878, for some rears, he was musical director at the Lrceum Theatre, and ccmposed music for several dramas produced by (Sir) Henry Irving. In 1889 he was appointed conductor of the Tictorian National Orchestra, returning from Austrahia in 1891.

\section{CLARKE.}

While there he acted as inspector of military bands, and had the honorary rank of Captain conferred upon him. In 1893 he accepted the post of principal conductor of the Carl Rosa Company. He is now resident in London. His published works are nearly four hundred in number, and can only be ontlined in the subjoined list. He contributed an important series of papers to Mlusical Society, 1886-7.

Wonks.-Dramatic: Incidental music to Hamlet, 1878 ; Merchant of Venice, 1879; Eugene Aram, 1879; The Iron Chest (partly from Storace), 1879; The Corsican Brothers, 1880; The Cup (Temyson, 1881); King Lear, 1892; and Cymbeline, 1896; all for the Lycemm Theatre, under Henry Irving. MIusic to Vittoria Contanari, and other dramas. Comediettas and operettas for the German Reed Entertainments; Martial Law; Castle Botherem, 1880; A pretty Bequest, etc. School Cantatas and Operettas: Daisy C'hain ; Hornpipe Harry, op. 358, etc. Siacred Cantata: Praise, op. 68; Ode to Industry, op. 90: The Lord is my Light, anthen in 8 parts, op. $4 t$ (College of 'Organists' Prize, 1864); nany anthems, Church services, songs, part-songs, etc. Orchestral: symphony, No.1, in F (Exhibition Concerts, Albert Hall, August, 1873); No. 2, in G minor, op. 122 (1'romenade Concerts, Covent Garden, 1879); six overtures, and other pieces. Concerto, pf. and orchestra, op. 78; Quartets, strings: Quartet, pf. and strings. Sonata and Romance, pf. and flute, etc. Organ: Six sonatas; Three andantes; Three offertories; Three pieces, op. 348, etc., etc.

Clarke, James P., Scottish musician, who held a good teiching pusition in the West of Scotland. For some time he was ansistant to a music-seller in Edinburgh. In 1829, he was leader of psalmody in st. George's C'hurch, Glasgow; and in 1834, he succeeded Thomas Macfarlane, as organist of St. Mary's Episcopal Chapel. In $1 \times 35$, he emigrated to Canada, after which all trace of him seems to be lost. He edited "Parochial Psalmody, a new Collection of approved Psalm tunes, inchuding several composed expressly for this work, to which are prefixed. Lessons in the Art of singing," Glasgow, [c. 1830], 2nd ed., 1832. The Choir: a selection of chornses, anthems, etc., edited by J. P. Clarke, late organist of St. Mary's Chapel, and A. Thomson, organist of st. Andrew's Chapel, Glasgow 1835. He also composed songs in Atkinson's "Chameleon," and in Hogg's "Border Garland" [1829], etc.

Clarke, Jane, musician and organist, published "Select portions of psalms and hymms, adapted to music, as smng at Oxford (hapel," London [1808].

Clarke, Jessie Murray, anthoress of "How to excel in singing and Elocution. A manual for lady students," London, 1884. 


\section{CLARKE.}

Clarke, John Cluarles, musieian of first half of the present century, who resided in Edinburgle as a eonductor and vocalist. TTe published a "Collection of Glees and Choruses," Idimburgh [1840].

Clarke, John, or Clarke=Whitfeld, composerind oromist, was horn at Gloucester, Decomber 13th, 1770. He studied moler Philip llaves, and lecame organist of st. Lawrences, Lndlow, 1759-94. MIns. Bac, Oxon., 179\%. Homist of Amagh Cathedral, 1794-97. Mns. Doc., Dublin, 1795. Master of choristers and organist of Christ Church and st. Patrick's Cathedral, 1) mblin, 1798. Organist and Choimaster of Trinity and St. Juhn's Colleges, Cambridge, 1799-1820. Mrus. Hoe., Cantab., 1799. Mus. Doe., Oxon., 1810. Organist of Hereford Uathedral, 182033. I'rufsisor of MLusie, ('amlnidge Triversity, 18:21. He died at I Tolmer, near Hereford, Felonary 22, 1836, and is huried in Hereford Cathedial.

Works. Cathedral music (comsinting of services and anthems), 4 vols., 1805-1822, reprinted by Novello. Crucifixion and the liesurlection, oraturio, 1822. Twelte Glees, composet and inscribed by permission to 11.12.H. the Elince Regent [18(55]; Twelve vocal pieces, with original peotry, 2 vols., 1.d. Glees, ete. : Alice Brand; The Carpet Wearer ; Celestial 17ore: Come, Osiann, conte; The Coronach; D)awh of l)ay; Fdith of Lorn: Ilym for the dead; Irimu to the moving star; It was a night of lorely June; Merrily boned the lark; Minstrel's tale: lied Cross Kuightis; What tho' the Kinghts; When 1 an domen; Wide orer the brim. Songs: Als: whither, Morphens; Blanche of Ileron's somg; Fommie, bonnie blue; lass that are gone; Illen's somes; The Maid of the MLor ; Heres the row ; lis peace love tines; Know ve the laud; Toungh and rejoice; Minstrel's Hate): Moorland Mary; ()h! sweet is the Terfune; Pour Mary; smile of affection; Suldier, rest; Thon dear native land; Valie, Maid of Loen; With jet blark cres; Young Lochinvar. The Prauties of Turcell. Thirtyfoul favourite anthems, selected from varions Englinh conprosers, 2 vols. The Toeal works composted ly (i. F. Handel, arranged for organ or pianeforte, London, 17 vols. [1809]. Selection of single and double ehants, in seore, 2 vols., n.d.

Clarke, Mary Cowden, born MARY VicTorra Norrleo, witer, dallyhter of Vincent Novello, wats bonn at London, Jume, 1809. She was married in 1828 to Charles Cowdon Clarke. She compiled the famous "Shakespeare Concordance," wote novels and poetry, edited an exition of thakespeare, and wrote the "Life and labours of Tincent Novello." London, 18 fit (portrait). "My long life : an autologgraphic sketeh," London, I'nwin, 1896.

\section{CLAXTON.}

Clarke, Payne, tenor vocalist, born in Manchester', Decenber 23, 1860. 1he sang as a boy at the Church of the Holy Name, Manchester, and sulstequently as an alto and tenor for some years. He studied under Dr. Henry Hiles, and later with Mr. William Shakespeare. After some experienee in opera, he joined Mr. J. IV. Turner's Company in 1886, and later in the same year was a member of the Carl Rosa Opera Company, in which he remained for three years, sustaining a number of characters. Tn 1890 he appenred at Denver, U.S.A., as Manrico, in Il Trovatore, and as Lohengrin at the National Theatre, Mexico, in 1891. He was singing in concerts in London, 189t; but he is more widely known in the north as a concert singer.

Clarke, Stephen, musician, was born at Durham alont the midale of the 18th century. He was organist of the Fpriseopal chapel in the Corgate of Edinburgh, and a teacher there from about 1764 . He died at Fdinlongh, Alugust 6, 1797. He compesed "Two Sonatas for the Pianoforte or Harpsichord, in which are introduced favourite sicoteh airs, composed and respectully dedicated to Mr. Erskine, Jun., of Mar," op. 3. Edinburgh, 1790. He also hammized the airs in Johnson's "Scots Musical Musomm." On his death the work was continued by his som WrLLIA (born Edinburgh [c. 1780]; died Elinburgh, 1820), who was organist of St. Panl's Fiscopal ('hapel, and a teather and writer of some small pieces for the pianoforte and roice. He issued "A collection of the most favourite airs, progressively arranged and fingered for the pianoforte." Edinburgh, n.d.

Clarke, William, mnsician, bom 1740; died Tecember 5, 1820. He was a VicarC'horal of Sit. Laul's Cathedral, and Ninor Canon, 1769. He is buried in the erypt of St. Paul's. He edited "A Collection of Chaunts, Psalm Tunes, Fymns, and an Anthem in four palts," n.d.

Clarkson, John, Soottish dancing-master and violinist, who died at st. Andrews, January 20, 1812. He compiled "Clarlison's Musical Entertainment, being a selection of ralions Tunes and Pieces of MLusie adapted for the l'f. or Harpsichord," n.d.

His son JoHs was a dancing-master and violinist, and published "A Complete Collection of the much-admired Tumes, as Danced at the Balls and Pablics of the late MIs. Strange, Taacher of l tancing in Edinburgh." This work appeared about the beginning of this century.

Claxton, Rev. William, organist of St. Michael's College, Tenbury, graduated B.A., 1876 ; Mus. B., 1882, Oxford, Cmate of Hartley Wintney, 18s7. Composel of a morning commmonion, and erening serviee, in $(\mathrm{i}$; anthens; songs; part-song, "Te little birds 


\section{CLAY.}

that sit and sing" (men's voiees and orehestra), etc.

Clay, Frederick, eomposer, born at Paris, August 3, 1840, Son of James Clay, who was M.P. for Hull, and a famous whist plaver. He studied moler Molique at Paris, and Hauptmam at Leipzig. For a short time he held a post in the Treasury Departnent. He resicled in London as a teacher and composer, but latterly, owing to ill-health, retired to Great Marlow, Bucks, where he died Now. 24, 1889.

Works.-.Operas and Operettas: The Pirate's Isle, 1859; Out of sight, 1860; Court and Cottage, 1862; Constance. 1865; Ages Ago, 1869; Gentleman in Blaek, 1870; Happs Areadia, 1872; Cattarina, 1874; Princesis Toto, 1875; Don Quixote, 1875; Babil and Bijou, 1872 (with others) ; Blaek Crook, 1872; Oriana; Nerry Duchess, 1883; Music to Shakespeare's "Twelfth Night." Cantutas : Knights of the Cross, 1860; Lalla Ronkh, 1877. Part-songs, songs, ete.

Clayton, Eleanor Creathorne (MTr. NEEnHAn), novelist and musical writer, born at Dnblin in 1832. Author of "Queens of Song; being memoirs of some of the most eelelrated female vocalist who have appeared on the lyric stage from the earhiest days of opera to the present time, with a chronological list of all the operas that have leen performed in Europe." London, 186;', 'z vols.

Clayton, Thomas, English composer, born in 1670 . I Le was a member of the Roval Band of Willian and Mary, 1692-1702. After residing in Itals he retumed to England and introduced Italian opera. He died in 1730. He composed music for Addison's Rosammod; Arsinoe; Drvden's Alexander's Feast; The Passion of Sappho, ete., but none of it appears to possess much merit.

Clegg, David, organist of Littleborongh Parish ('hurch (1891), is the eomposer of a eantata, "The Daughter of Jaims," produted at Rochdale, Deeember 8, 1891 ; and an opera, "Cleopatra," seleetions from which were given at the same place and date.

Clegg, John, violinist, bom Ireland, 1714. He studied moder Dubourg and Bumoncini, and first appeared in Londen, 1723. After travelling in Italy, he was appointed prineipal violin at the Oprera, London. He lecame insane towards the end of his eareer, and died in 1746 .

Cleland, George, musicin and organist of the end of $18 \mathrm{th}$ and first half of present century. He was organist of sit. Mary's Chapel, Bath. He published "A selection of ehants never before published, together with a sanctusand kyrie elcison, arranged in score," London 1824$]$

Clench, Leonora, violinist, native of sit. Mary's, Canada. Studied at Leipzig Conserv-
CLIFTON.

atorium, and played at a concert given in that town by Miss Marie Wum, Noveneluer 7, 1886 , and at other concerts in the sane year. In London she made her début at a concert at the Lrric Clul, Jume 24, 1592. Appeared as suloist at the Horingham Festival, Iorkis., 1896.

Cliffe, Frederick, pianist and composer, born at Low Moor, near Bradtord, Yorkishe, May 2, 1857. As quite a child he had a local leputation as pianist and organist, and at sixteen (in 1873) he was appointed urganist to the Bradford Festival Choral siaciets. In 1876 he was elected to a scholarship in the National Training school for Musie, after leaving which he was pianist and aeeompanist on various eoncert toms. He played a eoncerto at the l'romenade concerts, Covent Garden, in 185. ; and on the opening of the Royal College of Mnsic, in 18x?, he was appointed a professor of the pianoforte. He eame into notice as a comproser with a srmphony in (' minor, produced at the ('rrstal Palace, April 20, 18s9. In 1s.10 he composed an orchestra picture, "Clouds and sunshine," for the Jhilhalmonic S'serecr, which was modueed May g. of that rear. For the lueeds

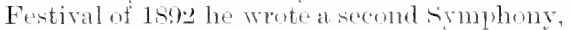
"A summer night," and a vinlin concerto for the Norwich Festival of 1stlf. He has also componed sereral somgs, ete.

Clifford, Rev. James, clerwman and musician, borm at Oxford, 16ry. C'horister of Magdalen Colleges, Oxford, 1692-t2. Minor Canon sit. Panlis Gathechlal, lomolom, 16til. Senior Cardinal, st. P'atul's, London, 168\%. Curate of Parish C'hurch of Sit. Ciregory. Chaplain to siociety of Serjoant's Inm. He died at london, september, 16.ts.

Morks.-A Collection of 1)ivine services and Anthems, usually smo in His Najesty's Chapel, and in all the cathedral and collegiate choirs of England and Ireland, ly James Clifford, 1663, snd edition emlarged, 1664. semons, etc.

Clifford, Walter, baritone rocalist. Sang as a boy in the choir of Holy Trinity C'burch, Hull. Eseane a pupil of lidwin Folland, and made his defont at Mr. Ambuose Anstin's concert at st. James's Hall, 1879, appearing at the Covent rarden I'pomenade Concerts the same vear. He sang in English opera in the provinces, and took the part of be bretigny in Massonet's "Mamon," when the opera was podnced by Carl Rosa at Inury Lane, May 7, 1,85. After singing for sone time at coneertin in varions places, he was engaged, in 1sst, for an American tonr by the Chicago simphonie Urchestral societr.

Clifton, Henry Robert, letter known as "Harry ('lifton," author and eomposer of eomic songs, bom at Iluddesden, Hereford, in 1831, died, Hammersmith, London, July 15, 


\section{CLIFTON.}

1872. Well-known in his day as author and composer of music-hall lyrics of the "motto" variety, among which were "Paddle your own canoe;" "Pulling hard against the stream ; " "Shelling green peas;" "Work, boys, work," and many others. He also wrote "Polly Perkins of Paddington Green" [1865], and other songs of a mock-sentimental type, such as the "Agreeable young man;" "Convivial man;" "Jemima Brown;" "On board of the Kangaroo" [1865], etc. For many year's he resided in Crlasgow as a music-hall singer.

Clifton, John Charles, composer and pianist, born at London, 1781. Studied under R. Bellamy and Charles Wesley. Employed for a time in mercantile pursuits. Resided at Bath as teacher and conductor. Went to Dublin, 1802, and resided there as teacher and composer till 1815. Settled in London, 1816, as teacher of the $\mathrm{pf}$. and advocate of Logier's system. He died at IIammersmith, London, November 18, 1841.

Works. - Edwin, opera, Dublin, 1815; Series of Moral Songs, by W. F. Collard, published in parts, 1823-4; Selection of British Melodies, with appropriate words, by J. F. M. Dovaston, Londen, n.d. ; Collection of French Airs, with symphonies and accompaniments, 2 vols. As pants the hart, canon. GleesThree glees for 3,4 , and 5 voices, 1823 ; A blossom wreath; Maid of Toro; On a rock whose haughty brow; Quick flew the gales of rosy spring; Hushed is the harp; Pray goody. Songs-As through life's early path; First dawn of love; Good-night, my pretty Anne; If music be the food of love (canzonet); Miller's daughter; Sensitive Plant; Soft on the violet bank; With love-fraught eyes; Nay, if you threaten; Sweet choice of my heart; A bumper of sparkling wine, etc. Theory of Harmony Simplified, 1816; Instructions for the Pianoforte; Nemoir of Sir John Stevenson (in a review), etc.

Clifton was a pianist of much ability, and invented, in 1816, an instrument called the "Eidomusicon," which, on being fastened to the keyboard of the pianoforte, produced the notes and chords as they were struck, with a view to displaying them to the eye, and so facilitate sight-singing, etc.

Clinton, George Arthur, clarinettist, born at Newcastle-on-Tyme. For many years a member of the Crystal Palace Orchestra, and a soloist at the concerts there at least since 1876. Principal clarinet in Her Majesty's Private Band, and in the Philhamonic Orchestra. Professor of the Clarinet at R.A.M. Has given Cliamber Concerts of music for wind instruments in various halls in London, 1892-6, and has played at the Saturday Popular Concerts, etc,

Clinton, John, flute player and writer, born in 1810; died at London in 1864. Author

\section{COBB.}

of A Treatise upon the Mechanism and general principles of the Flute, London, n.d.; Complete School for the Boehm Flute, containing everything necessary to learn that instrument, from the elements to the most advanced stage, London, n.d. (5 editions), Ashdown; A Code of Instruction for the Equisonant flute, in which the fingering and resources of that instrument are fully explained by numerous examples; First Set of three Grand Studies for the Flute; Second do.; Universal Flute Tutor (Boosey). Flute music-Trios for two flutes and pf., opp. 2, 3, 10; Trios for three flutes, opp. 7 and 9; Five Notturnos, flute and harp (with Oberthür); Gems of the Italian School; Cavatinas, or songs without words; The Drawing-Room Concert, written by W. Ball; Transcriptions for flute and pf., of which he published an enormous number.

Clipsham, J_, musician, compiled the “Divine Psalmist's Companion," Market Harborough, 1753 ,

Clive, Catherine, born RAFF"OR, soprano vocalist, born in London, of Irish parents, in 1711. She sang at Drury Lane Theatre from 1728. Married to George Clive, a barrister, in 1734, and separated from him in 1769 . Retired from stage. She died at Twickenham, Dec. 6, 1785. See Life of Catherine Clive, with an account of her adventures on and off the stage... by Percy Fitzgerald, London, 1888.

Clive, Franklin F., bass vocalist of the present day. He learnt the violin at nine years of age, and when seventeen entered an office in the city of London. In time his voice developed, and gaining a Scholarship at Trinity College, London, he studied for the profession. About the year 1882 , he was becoming known as a singer" sang in the "Messiah," at Bimingham, Boxing Night, 1883, with success, and in other places. He was on tour with an Opera Company in 1887, and appeared as King Richard, in Sullivan's " Ivanhoe," at the Royal English Opera, in February, 1891.

Clutsam, George $\mathbf{H}$-, pianist and composer, a rative of Australia. He was a member of the Amy Sherwin Concert Party in Australia, 1888; and acted as accompanist during the Melba tour in England, 1893. His compositions include a Symphony (a movement from which was performed at the Covent Garden Promenade Concerts, October 3, 1890), and other works; Songs, etc.

Cobb, Gerard Francis, composer, born at Nettlestead, Kent, October 15, 1838 . Educated at Marlborough College, and Trinity College, Cambridge, of which he was elected Scholar in 1860 ; and, after taking a double First, a Fellow, in 1863. His musical training was chiefly in Dresden. He was President of the Cambridge University Musical Society for 


\section{COBB.}

some ten years, from 1874 ; and Chairman of the University Board of Musical Studies for fifteen years, from 1877. His compositions are very numerons, although, from the claims of his official work at the University, it was many years before he was able to devote his attention to creative art.

Works.-Psalm 62, for soli, chorus, and orchestra, composed for the Festival of the North-Eastern Choir Association, Ripon Cathedral, 1892. Seven Church services, including a full Morning, Communion, and Evening Service in C major, for men's voices, eomposed (by request) for the nse of the Choir of St. George's Chapel, Windsor. Motet, Surge $\mathrm{Il}$ luminare (Leslie's Choir, March, 1887); Seven anthems. Prize Glee (four voices), A Message to Phyllis ; Prize Madrigal (six voices), Sleeping Beauty, ete. Six Songs (W. Fergusson); Lieder und Gesänge (six songs); Three English Ballads; Three Sacred Songs ; Barrack Room Ballads (Rudyard Kipling); Song and silence, with horn obligato, and many other songs. Quintet in C, op. 22, pf. and strings; Suite, violin and pf.; Suite, Voiees of the Sea, pf., etc., etc.

Cobb, Richard, English composer and organist during the 16 th and 17 th centuries. Was organist to Charles I., and eomposed some rocal music. "Smiths are good fellows," a catch, is by him.

Cobb, Richard Barker, haritone voealist, known by the nom de thétre of Richard Temple, made his début in opera at the Crrstal Palace, 1872. Toured in the Gilbert and Sullivan operas, 1879 ; sang at the Savor Theatre in "Princess Ida" and "The Mikado," 1884-5; gave performances of opera in Italian at the Gaiety Theatre, May, 1886, himself taking the title-part in "Rigoletto;" revived Gounod's "The Mock Doctor" at the Grand Theatre, London, 1890 ; and sang at the $\mathrm{Olym}$ pic Theatre, under Signor Lago's management, October, 1892. He turned to the music halls early in that year, and appeared at the Trocadero; sang again in the concert-room, 1893; and recited in MLendelssohn's "Athalic" at the Queen's Hall, November 13, 1895.

Cobbold, William, composer, borm in Parish of St. Andrew, Norwich, January 5, 1559-60. In 1599 he beeame organist of Norwich Cathedral, but in 1608 he became a singing man, while the post of organist was held by Wm. Inglott. He died at Beeeles in Suffolk, November 7, 1639, and was buried in the south aisle of the Parish Church, where a stone marks his grave.

He contributed to Este's "Whole Book of Psalms," 1592, and wrote the madrigal, "With wreaths of rose and laurel" in the "Trimmphs of Oriana." Some of his works remain in IIS., and an anthem, "In Bethlehem town," appears in Clifford's Services, 1663.

\section{COLBORNE.}

Cochran, John, musician, who issued "A Selection of Psalm and Hymn Tunes . . . with Anthems." Dublin, 1811, two editions.

Cock, Arthur, organist and composer of the 16th century. He was organist of Exeter Cathedral, and in 1593 he graduated MIus. Bac., Oxford.

Cogan, Philip, composer, organist, and pianist, born at Cork in 1750[Doncaster 1757?]. Chorister and choirman of Cathedral of st. Finn Barre, Cork. Stipendiary of Christ Church, Dublin, 1772. He died in 1834.

Works.-Anthems, various; Six sonatas for $\mathrm{pf}$. and violin, op. 2, 1788; Sonatas for pf., op. 4 ; Concerto in $\mathrm{E}$ flat for 2 violins, viola, 'cello, 2 flutes, and 2 horns, op. 6, 1792 ; Sonatas for pf. (Clementi), op. 8; Harpsichord Lessons; Songs.

Coggins, Joseph, eomposer and pianist, was born in 1780 . He studied mnder J. W. Calleott. Teacher of pf. in London, where he died, in first half of present century.

Works. - The Mnsical Assistant, containing all that is truly nseful to the theory and practice of the pianoforte, London, 1815; Companion to the Musical Assistant, containing all that is truly useful to the theory and praetice of the pianoforte, also a complete dictionary, London, 8vo, 1824; Admired Hymms....adapted for the use of schools, 2 parts; Pf. music, fantasias, ete.; Songs; Complete instructions for the flute, according to Dronet's system, London, 1830.

Coghlan, J. P., anthor" of "An essay on the Church plain-chant," London, 1782.

Colbeck, William Robert, organist and conductor, born at Bebington, Cheshire, 1852. Studied under Dr. French Flowers, and F. W. Hird. Began his career as an organist at the age of eleven, at Gamston Parish Church, Notts.; afterwards appointed to St. Peter's, Morley, Leeds; St. Mathras, Burley, Leeds. 1869 ; and, in 1876 , to the Parish Chnrch, Folkestone. Later in that year (1876), he left for British Guiana, being appointed to St. Philip's, Georgetown. This appointment he still holds, together with that of organist of the Town Hall, from its opening in 1891. His organ recitals are popular, and an important feature in the season's music. He was conductor for twelve years of the Musical Society, now defunct; and is president and conductor of the recently formed Orchestral Soeiety. He eomposed a march for the opening of the Town Hall organ, Georgetown (1891); and has published some pf. pieces, and songs (including a prize song in Cassell's Magazine, 1884).

Colborne, Langdon, organist and composer, born at Hackney, London, September 15, 1837. Studied under George Cooper. Organist of St. Michael's College, Tenbury, 1860. Mus. Bac., Cantab., 1864. Mus. Doc., Cantuar, 


\section{COLE.}

1883. Organist of Jeverley Minster, 187t; Wigan Parish Church, 1875; Dutking l'arish Chureh, 1877; Hereford Cathedral, 18it. He died at liereford, september 16, 1sis?.

Wokws. Sammel, oratorio, J Iereford, 1889 ; Complete Service in C: Magnificat and Nume Dimittic in D, A, and B flat; Te Derme and Benedictus in F flat. Anthems-I will lay me down: () Lord, onr (iovernor: Ont of the deep; Ponder nuy words, O Jord; Rend youm hearts. I'art-songs: If slumbersweet, I istena; The sienta; The bright-haird morn is glowing; sungs, etc.

Cole, Blanche, see sub. Nislor, Mnines.

Cole, Charlotte, and Susanna, vocalists, formerly known in the musical work as the Misses Cole, were bom at Tarrington, Herefortshire. Therr father came of a musical family, and was for many years organist of the parish ehurch, choir trainer, and teacher of music. The children, from their infancy, were low up in a musical atmosphere, and rese familiar with the works of the great masters. At the R.A.M. they studied nuder Mannes Farcia, and lorth were elected Assiciates of that Institution. Charlotte, the elder, a solranc, was a leading member of the students' choir in Hanover C'bapel, liegent street; and of the semi-choriz of the Concerts of Anciont Music. She sang in the double guartet in: "Flijal " at the Hereford Festival of $18+9$, and IIr. . . W. Jivison at that time hearing the sisters sing Dtendelscohn's twropart songs, advined them to appear in Lundom as duet singern. Their abut trok place at Fxeter Hall, in the Wedneshar Concerts, November 14, 1st?; and for years afterwardis they were in great request, succeding the Misses Willians in publie favomi. They sang at the f'rytal ['alace in 1855 , and at the principal London and provineial coneerts. In $185: 3$ Charlote Cole married Mr. Alfren, Gilbert (q.r.), and after singing at his concerts for some years, devoted her attention chiefly to teaching singing. She is an Associate of the Philharmonic Society, and the composer of some tasteful songs, ete. Susamna, whone voice was a mezzo-soprano of beantiful quality, continned to sing both in opera and concerts; but she also nrarred, and now is engaged in tuaching singing, both for the stage and concert roum.

Cole, James Parry, comporel and comdnctor, lxm at Tarington, Herefordshire, brother of the foregoing. While a child loe was tangh the violin ly his fathor, and at the age of eight bucame a chorister of Hereford Catbedral, and pepil of (r. Townshend smith. When fifteen hrestered the R.A.MI., sturlying under Charles lucas, R. Blagrore, W. lomell, and G. A. Macfaren. On leaving the Acartemy he went to Arman, Sustex, as a teacher of music, and organist of the parish church.
COLERIDGE.

There he remained five vears, and retuming to Lmolom, he has oceupied rarions posts as organist, musical director, and teacher. He has eomposed much, chiefly tevoting his attention to music for the stage. While a chorister be composed an oratorio, "I)e]orah and Tarals," as well as some chuteh servieus. later works are-Cantuta, By the water's of Babylon. Operes and Operettas: Tokin's Tengeance (Nt. (ienrge's Hall, 1S77); The Folden Wedding (1859); All for nothing (1889); Blate and White; a Romance of the Harem (1.887); The Blatel Count (1840; ; The Pillow of Roses; Hypatia (Crand oprera in four acts); Buntll's Bride; Tals seul; Sommence and reality ; The frecian Dancer' Woman's Hombir; T. T.; Give him a rest; The deaf knight, ete. A look of chamber songs; songs, variontis; pieces for $p f$ and violin, pf. picees, cte., cote.

Cole, William, musicin, who was bom about 1764. He was an wganist aud teacher at Colchester, and Jomdon. He died at Pimlico, I mudon, Angust 11, 1818.

Woklis. Momingank erening service, with six antlens in seore, n.d. The Psalmodist's Exercise, ol a sot of palm tumesand anthens, all entirely new, composed for the use of

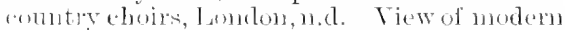
palmexis, being an attempt to reform the pratete of singing in the worship of God. Collohenter, 1819.

Cole, Willam Menry, violinist and con-

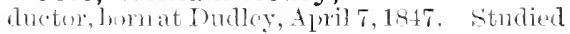
murler llentry llarwaird and J. T. Carrodus. the bas taken a luading part in the monsical

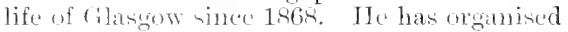
varions quintet proties and bands, which have preformed in Flasgow, and in most of the scostish provincial towns. Mr. Cole is wellknow'n as a tracher of the violin.

Coleire, Riclnard, Enghish clergyman. Wrote "The Antiquity and nsefulness of instrumental mmsick ju the service of God, a semom on erecting an organ at Jskeworth," Limdon, 1799.

Coleman, Charles (m Colmax), composer, whe was horn abont the begimsing of the 17 th exntury [1600). He was a number of the private hand of Chamles I. Thoc. Mus, CarmJuinge, 1651. Je died at London, 1664 .

llomks. The siege of Thodes, Daremant (with I awes, Conk, and 17ndsm), 1657; Mnsicall Ayres ald Jialogtes, 1652; Musick's Rereation on the Irra-violl, 1656; select Iyres, 1650; The Minsical Tocabulary in Thillips New World of Words, 16.58.

Coleman, Edward, hrother of above, was hom in 16.39. Ho ]ecamo (xentleman of Chapel Roval, and dicel at Greenwich, August 29, 166\%. Wrote songs in rarions eollections, ete.

Coleridge, Arthur Duke, anatemr rocalist, locturer, and translator, was born on Feb- 


\section{COLES.}

ruary $1,1830$. He is a M.A., and was ealled to the bar in 1860 . Clerk of the Arraigns for the Midland Cirenit, and nephew of the late Chief Justice, Lord Coleridge. In the days of the Amateur Mnsical Society, nnder Henry Leslie, he occasionally sang at their concerts, having a good tenor voice. He has lectured in various places upon Bach, Weber, Spohr, and Schumamn; and rendered serviee to musical literature by his translations of $\mathrm{K}$. von Hellborn's "Life of Schubert," London, Longmans, 1869, 2 vols.; and the "Life of Moseheles, with selections from his diaries and correspondence," by his wife. London: Hurst and Blackett, 1873, 2 vols. He also contributed articles to Grove's "Dictionary of Music and Musicians.,"

Coles, Sydney George Randolph, organist and composer, horn at Bristol, 1852, Chorister at St. Paul's Church, Clifton, and pupil of the late Alfred Stone. When eighteen he was appointed organist of St. John's, Broad Street, Bristol. In 1873 he became an articled pupil of, and assistant to, the late Dr. IV. H. Monk. F.C.O., 1876; Mus. Bac., Trin. Coll., Toronto, 1887. Resident in Eastloume since 1881, as pianist, teacher ; and was organist of the Parish Church for ten years, now holding a similar office at the Presbyterian Church, and being alsrerganist to the Hadrian Lodge of Freemasons, No. 's,483, When the legality of the in absentia degrees was questioned, Mr. Coles strongly mpheld the bonu fide nature of the exanninations. This subject is heyond the scope of the present work, and readers are referred to the musical press, 1890-93.

Works.-Psalm 23, for soli, chorus, and organ (performed by the Musical Artists' Soeiety, R.A.MI., 1882) ; Communion Service; Offertory Sentences; Carol, The Bellringers (Crystal Palace Sunday School Festival, 1895); an Imperial Hymn, ete. Triumphal mareh for orchestra; March and Postlude, organ; pieees for pf., ete.

Collet, Sophia Dobson, bom in London, 1822, was associated with Eliza and Sarah Flower in the music at Sonth Place Chapel, and composed some of the music still in use there. She died at Highbury Park, March 27,1894 .

Collett, John, instrumental composer, who flourished during the middle of the 18th eentury. 1le composed "Six Solos for the violin, with a thoromgh bass for ye harpsichord, op. 1," Lundon [1770], and other instrumental musie.

Collier, Joel, see Bicknell, John L.

Collins, Isaac, violinist, born in 1797; died Norember " 4,1871 . Was for many years principal second violin in the Crystal Palace Orehestra. In the forties he gave concerts in London, with his five children, of whom the best known were George Collins, violoncellist,
CONINGSBY.

who died in 1869, and Viotti Collins, violinist, who is still actively engaged in his profession.

Collinson, Thomas Henry, organist and conduetor, horn at Anwick, April 24, 1858. Pupil of Dr. Armes', at Inrham Cathedral, and later, deputy organist there. Craduated Mus. Bac., Oxford, 1877. Organist of St. Oswald's, Durham ; and in 1878, appointed to St. Mary's Cathedral, Edinburgh. From 1883 he has been eonductor of the Edinburgh Choral Union. At the Cathedral he has directed special Oratorio Services; and has given organ performances at the Edinburgh Exhibition, 1886, and has a high reputation as an executant. He is Church Music lecturer to the Episcopal Theological College. Of his compositions only some an thems are published.

Collisson, W. A. Houston, pianist and composer, resident in Dublin. His playing attracted attention about 1881, and he began giving Saturday Popular Coneerts in 1885, in the Leinster Hall. Dublin; and in May, 1887, started a series of Saturday Evening Concerts in St. James's Hall, London. He was appointed organist of the Parish C'nurch, Rathfarnham, 1885; and to Holy Trinity, Rathmines, Dublin, 1se6. He graduated MLus. Pac. [1885?]; Mus. 1)oc., Inublin, 18\%0. Of his compositions two conic operas have been produced: The linight of the Road, Dublin, 1891; and strongbow, Dublin, 1892.

Colville, David, musician, born at Campbeltown, January 15, 189!). He published "Graduated course of elementary instruction in singing, on the letter-note method, in twenty-six lessons, with hints on self-instruction, cte." (with (reorge bentley"), 186t; Collections of Part-songs, under the title of "Choral Harmony," "Amphion," ete.

Comon, or Cormac Dall, Irish harper, story-teller, and vocalist, was born at Woodstock, Nayo, May, 1703. He lived an itinerant life, and was famous as a composer of songs and elegies. He died about the end of the 18 th century, or at least after 1786 , at which date he was alive.

Compton, Mrs. A., sce Grar, Louisa,

Condell, Henry, violinist and composer, was born in the latter part of the 18 th century. He was:a violinist at Drury Lane and Covent Farden Theatres. Gained prize at Catch Club with glee, "Lond blowe the wyndes," 1811. He died at Battersea, London, June, 1894

Works.-Enchanted Island, ballet, 1804; Who wins? or The Widow's choice, farce, 1808; Transformation, farce, 1810; Farmer's wife, 1814; Glees; Songs, etc.

Congreve, Benjamin, composcr, was born in 1836, and died at London on March 23, 1871. He composed part-songs and songs.

Coningsby, George, clergynan. Authol' of "A Sermon preached at the Cathedral 


\section{CONRAN.}

Chureh of Hereford, at the anniversary meeting of the Three Choirs, September 6, 1732, Church Musick vindicated," Oxford, 1733.

Conran, D., Irish writer, author of "Musical Research, or General System of Modulation," Dublin, 1840.

Conran, Michael, probably a relative of the above. Organist of St. Patrick's Church, Manchester. Author of "The National Music of Ireland; containing the History of the Irish bards, the national melodies, the harp, etc.," Dulblin, 1846; London, 1850. Collection of admired Hymms and Gregorian Chants, with English words; n.d.

Cook, Aynsley, bass vocalist, boru near Newcastle-on-Tyne, 1836 (?). Was a chorister at St. Paul's Cathedral. Through the generosity of the Marquis of Anglesey he studied in Germany, and there made his de but in opera. He sang at Drury Lane about 1854 , but his name is not noticed. Later he joined the Pyne and Harrison Company; but he reached the full measure of his popularity as a member of the Carl Rosa Company, from 1875 to the end of his earcer. His reprertory was extensive, but his Devilshoof in the "Bohemian Girl" an elaboration of his own in the last act - was his favourite character with the pullic. His last appearance in opera was at Liverpool, February 2, 1894, and he died just a fortnight later. His wife, nóp PAYNe, was a contralto singer, and a memler of the Pyne and Harrison, and Carl Rosa Companies. She also sang on tour" with Mr. Sims Reeves in "The IVaterman," ete. Alice Aynsley Cook, his daughter, has sung in the provinees in the Gilbert and Sullivan operas, burlesques, etc.

Cook, Mrs. Dutton, see Scates, Linda.

Cook, Richard, musician of early part of the present century. Issued "Kentish Psahnodist's Companion," London, n.d.

Cooke, Benjamin, eomposer and organist, was born at London in 1734. He studied under Pepusch, and became deputy-organist at Westminster Alobey in 1746. Conductor of Academy of Ancient Míusic, 1752-1789. Master of the boys at Westminster Abbey, 1757. Layclerk, do., 1758. Full organist, Westminster, 1762, sueeeeding John Robinson. Doc. Mus., Cantab., 1775. Organist of St. Martin-in-theFields, 1782, Sub-director at Handel Commomoration, 1781. 1fe died at Westminster, London, Sept.14,1793. Buried in West Cloister of Westminster Abbey.

Works.-Ode on Handel, for 8 voices. Glees: Ccllection of twenty glees, catches and canons, for 3, 4, 5 and 6 voices, in score, London, 1775; As now the shades; Ere the beams of morning break; Farewell; Hand in hand; Hark, the lark; How sleep the brave; In the merry month of May; I've been young, though now growu old; Now the bright morning star, day's harbinger; Let Rubinelli charm the ear,
COOKE.

duet; Thrysis, when he left me, duet; The Dormouse, glee; Beneath in the dust. Nine glees and two duets, op. 9 [1795]. Ode on the Passions (Collins), 1784, ete. Concertos for combinations of various instruments. Organ and harpsichord music. Anthems and Chureh Services. Morning and Evening Service in G. Songs, etc.

“Dr. Cooke's glees are numerous, and of great beauty. They are remarkable for natural and graceful ease of melody, great simplicity and yet much art in the disposition of parts, and fine expression."-IIogarth. A number of them are still in use among our singing societies; "Hark, the lark," being one of those perennial favourites of which the English school furnishes not a few examples.

Cooke, Henry, composer and teacher, born at the beginning of the 17th century. He was edueated at the Chapel Royal, and obtained a captain's commission during the Civil War, 16+2. Gentleman of Chapel Royal and Master of Children, 1660. Composer to the King, 1664. He died July 13, 1672. Buried in East Cloister, Westminster Abbey.

Works.-Anthems and Services preserved (MS.) in the Collection formed by Dr. AIdrich in Christ Church, Oxford. Madrigals, songs, etc.

Cooke was the teacher of Blow, Wise, Purcell, and Humfrey, and for that alone is entitled to some little credit and esteem.

Cooke, John P., eomposer and conductor, was born at Chester, October 31,1820 . He went to America, and became conductor of various theatre orchestras in New York. He died at New York, November 4, 1865. Composed musie to Shakespeare's Plays, Songs, ete.

\section{Cooke, Miss, see. WaYletT, Mrs.}

Cooke, Nathaniel, composer and organist, born at Bosham, near Chichester, 1773. He studied under his unele, Natthew Cooke, of London (organist). Organist of the Parish Chureh of Brighton. He died sometime after 1820.

Works.-Collection of Psalms and Hymms sung at Brighthelmston, with several Canons, and a Te Deum, arranged for the Organ or Pianoforte, n.d. Glees and Songs. Pianoforte Music.

Cooke was a good organist, and composed the canon, "I have set God always before me."

Cooke, Robert, organist and composer, was a son of Benjamin Cooke, born in 1768 . He studied under his father, and succeeded him as organist of St. Martin-in-the-Fields, 1793. Organist and choir-master at Westminster Abbey, 1802. Drowned in Thames, August 13, 1814. Buried in West Cloister of Westminster Abbey.

Works.-Evening Service in C; Magnificat and Nunc Dimittis in C. Anthems. Glees: In the rose's fragrant shade; Love and folly 
COOKE.

were at play; Mark, where the silver queen of night; Queen of the sea; Round thy pillow; Sweet warbling bird; Why o'er the verdant banks. Collection of Eight Glees (Clementi) [1805]. Songs, etc.

Cooke, Thomas Simpson, vocalist and composer, was born at Dublin in 1782 . He studied under his father and Giordani. In 1803 he acted as conductor of a theatre in Dublin, and made his debut as a vocalist in Storace's "Siege of Belgrade." 1n 1813 he appeared in London, and in the same year was appointed conductor and vocalist at Drury Lane Theatre. He married Miss Howell. Member of the Royal Academy of Music, Philharmonic Society, Noblemans' Catch Club, Glee Club, etc. He died at London, February 26, 1848 .

Works.-Music to Plays: The Count of Anjou; A Tale of the Times, 1822; The Wager, 1825; Oberon, or the Charmed Horn, 1826 ; Malvina, 1826; The Boy of Santillane, 1827; The Brigand, 1829; Peter the Great, 1829 ; The Dragon's Gift, 1830; The Ice Witch, 1831; Hyder Ali, 1831; St. Patrick's Eve, 1832 ; King Arthur, 1835; The King's Proxy; Frederick the Great; The Five Lovers; Numerous Farces. Adaptations of Foreign Operas. Mass in A minor. Glees : Six Glees for 3 and 4 roices, London, 1844; Come Spirits of Air; Fill me, boy, as cleep a dranght ; Strike, strike the lyre; Away with gloom and care; O strike the harp; Take thon this cup. Ducts: Love and War; Army and Nary; Songs. Singing Exemplified in a Series of Solfeggi and exercises, progressively arranged, London, n.d.; Singing in parts, containing progressive instructions, extracts, exercises, and original compositions, London, n.d. [c. 1842], etc.

Cooke, Henry Angelo Michael. GratTAN Cooke, eldest son of the above, born in London in 1809 . He studied at the R.A.M., 1822-28, of which he became a professor. In 1837 he married Niss Kiallmark. He was band-master of the 2nd life guards 1849-56. In 1845 he appeared at the Hanover Square Rooms as a tenor singer, and took part in a glee at the Norwich Festival that year. He lived for nearly twenty years in retirement at Harting, Sussex, and died there September 12, 1889. He composed a number of operettas and songs, and was a fine oboe player. Author of "Statement of facts and correspondence between the Directors of the Philharmonic Society and Mr. Grattan Cooke," London [1850].

Coombe, William Francis, organist and composer, was born at Plymonth, 1786. He studied under his father (a singing master) and W. Jackson of Exeter. Organist at Chard, Somerset, 1800 ; Totnes, Devon, 1802-11; and Chelmsford, 1811.22. He probably died
COOPER.

at Chelmsford about 1850 . He composed a few pianoforte sonatas, and other works.

Coombs, James Morris, organist and composer, born at Salisbury, 1769. Chorister at Salisbury Cathedral, 1776-1784. He studied under Dr. Stephens and Parry. Organist at Chippenham, Wilts., 1789 to 1820 . He died at Chippenham, on March 7, 1820.

Works.-Set of Canzonets; Te Deums; Dirine amusement for churches, families, etc., being hymns, anthems and other sacred pieces, psalms, etc., from the works of Marcello, Handel, Haydn, Mason, etc., etc.; Glees and songs.

Williay Coombs, who flourished at Bristol in the latter part of last century, composed the psalm tune "Oxford," which is sometimes attributed to James Morris Coombs.

Cooney, Edward, organist and teacher. Educated at Christ Church Cathedral, Dublin. Graduated Mus. Bac., 1885; Mus. Doc., 1887, Dublin. Organist, Parish Church, Ballymena; teacher of pf. and singing in Coleraine Academic Institute. Uviversity Exercises : (Bac.) Psalm 145; (Doc.) Psalm 139, for soli, chorns, and orchestra. He has published Church Serrices and Anthems; Songs and part-songs.

Cooper, Alexander Samuel, organist and composer, born in London, April 30, 1835. F.R.C.O. Organist of St. John's, Putney, to 1866; St. Paul's, Covent Garden, later. Awarded a prize by the Ely Diocesan Church Music Society for a setting of the Nicene Creed, 1869. Composer of anthems, music for Holy Communion, chants, hymm tunes, songs, and part-songs. Editor of "Parochial Psalter," and "Parochial Chant Book," both of which have passed throngh several editions.

Cooper, George, composer and organist, born Lambeth. London, July 7, 1820. Successively organist of St. Benet's, Paul's Wharf ; St. Anne and St. Agnes, 1836; St. Sepulchre, 1843 ; Christ's Hospital, and the Chapel Royal, all in London. He was also assistant orgauist for a time at St. Paul's Cathedral. He died, London, October 2, 1876.

Works.-The Organist's Assistant, a series of arrangements... London (Novello). Organist's Ianual ... select morements from the most eminent composers, London (Novello). Organ Arrangements, Londou. Partsongs, sougs, etc.

His father, George Cooper, who died in London, in 1813, was an organist of repute. He was assistant organist of St. Paul's Cathedral, and organist of St. Sepulchre's until his death, when he was succeeded by his son.

Cooper, Henry Christopher, violinist, was born at Bath in 1819 . Studied violin under Spagnoletti. Appeared as solo violinist at Drury Laue Theatre, 1830 . Principal violinist at Royal Italian Opera. Leader at 


\section{COOPER.}

Philhamonic Soeiety. Violinist at Provineial Festivals. Conductor at varions theatres. Latterly conductor at the Gaiety Theatre, Glasgow. He died at Glasgow, Jamnary 26, 1881. He was one of the foremost of the English school of violinists, and at one time well known in London. He was married to Madame Tonnellier, the roealist.

Cooper, Isaac, violinist and composer, born at Banff about 1755 . He was a teacher of music and dancing in Banff, and died there about 1820 .

Works.- Thirty new Strathspey Reels for the violin or harpsichord, Banff, 1780. Collection of Slow airs, Strathspeys, Reels, and Jigs, 1806. New Instruetions for the harpsichord or pianoforte, Banff, 1785.

Cooper, Rev. James, clergyman and writer, anthor of "Musicæ Sacre, being Selections from Bowdler, Heber, ete., set to musie, to which is prefixed an Essay on Church Music." London, 1860.

Cooper, John, called also Coperanio, composer and viol-da-gamba player, was born in latter part of the 16th century. He was music-master to the children of James $\mathbf{I}$, and master of Henry and William Lawes. He died early in the 17 th century.

Works.-Funeral Tears for the death of the Right Honourable the Earle of Devonshire, figured in seaven songs, whereof sixe are soe set forth that the words may be expressed hy a Treble voyce alone to the Lute and Base Voil, or else that the meane part may he added, if any shall affeet more fulnesse of Parts, ete., 1606. Songs of Mourning, bewailing the untimely death of I'rince Henry, London, folio, 1613; Husie in Leighton's "Teares"; Music to Masrue ly Dr. Campion; Songs and Fancies, etc.

Cooper, John Wilbye, tenor voealist and author. He sang at the first Leeds Festival, in 1858, and at the Worcester Festival of 1863. In the concert room he was a favourite for a good many years. He retired for sonse time before his death, in London, March 19, 1885. Author of "The Voice, the Music of Langnage, and the surl of Song," London, 1874. Editor of "Craner's Vocal School."

Cooper, Joseph Thomas, organist and componer, lom at London, May 25, 1819. He was a pupil of Henry firolmes and Moscheles. Organist of Christ Church, Newgate Street. Organist of Christ's Hospital. He was an Asisociate of the Philhamonic Sueiety, Memler of the Suciety of British Musicians, and Fellow of the Royil Astrononical suciety. He died at Londom, Nowembler 17, 1879.

Wonxs. - Orchestral music in MIS. Songs, Part-songs, Sacred music, Organ music, ete.

Cooper or Cowper, Robert, minsician and priest of the 15 th contury. He was a Mus. Bac., Cambridge, and in 1504 proceeded

\section{CORBETT.}

to the degree of Mus. Doe. He composed songs and other secular musie, and is mentioned in Morley's Catalogue of Musieians.

Coote, Charles, composer and bandmaster, born 1809; died London, Mareh 6, 1880. Composer of a large number of waltzes, galops, polkas, ete., chiefly based on popular airs.

Ilis son Crratrles is a bandmaster and composer of popular dance music.

Cope, Samuel, bandmaster, son of a bandmaster in the West of England. As a boy he sang in a Chnrch choir, and played in a drum and fife band, afterwards taking to the cornet, on which he became a proficient perfomer. After holding various appointments he was. offered, and accepted, in 1888, the conductorship of the Queen's Park (West London) Military Band, a position he still holds. He founded the magazine, The British Bandsman (the title has since been changed to The Orchestral Times and British Musician), which he edited for some years. He was also editor of the Champion Joumal, the pioneer of popular band jommal music, founded at Hull, by the late Richard Smith, in 1853; and has composed a large number of pieces, of which only a few have been published.

Copland, Charles, baritone vocalist, born at Brightlingsea, Essex, August 20, 1861. Son of a distinguished London physician. Studied under F. Walker, at the Guildhall school, and R.A.M. Evill prizeholder, 1885. Later, he studied abroad, and took lessons from the late Engène Ondin. During his student days, he sang in London occasionally, 1884-5; and in Otto Pooth's operetta, "Traveller's Rest," 1887, gave the first evidence of his histrionie talent. He appeared at the Promenade Concerts, Her Majesty's Theatre, 1887, and also at Covent Carden Theatre. In the South of France, 1887-8, he sang, by request, to the late Dom Pedro, Emperor of Brazil. He was engaged to play Isuac of York, in "Jvanhoe," at its production, January 31, 1891, a part he sustained through the rm of the opera. In December, 1894, he created the part of the Broom-maker, in "Hänsel and Gretel," when produced at I)aly's Theatre. He has also appeared, with success, at the principal Concerts, Royal Allert Hall, ete.

Corbett, Felix, organist and conductor, born at ('inderford, Forest of Dean, Gloncestershire, July 3, 1861. Son of J. F. Corbett, a colliery poprictor. The family moving to Jimingluan, he studied under Janes Stimpson, of that town. In 1882 he was appointed organist and choirmaster of the Parisl C'hnrch, Middlesbrongh, in which tom be has for some years given a series of excellent concerts, and hats played at Hanrison's Concerts, Birningham and elsewhere. He is the composer of a number of songs; of which one entitled 


\section{CORBETT.}

"Butterflies" (Algemon Swinburne), has cnjoyed great popularity.

Corbett, Samuel, organist and composer, born at Vellington, Shropshire, January 29, 1852. Pupil of James Stimpson (Birmingham), and of Sir G. A. Macfarren and James Coward. F.C.O., 1871; Mus. Bac., 1873; Mus. Doc., 1879, Cambridge. Organist of Christ Church, Wellington, 1867 ; St. Mary's, Bridgenorth, 1875 : All Saints', Derby, 1886; and Holy Trinity, Boumemouth, from 1892. Mr. Corbett lost his sight when only three months old, but he has trained choirs, conducted concerts, and frequently played from memory the whole of such works as the Messiah, Israel, Elijah, ete. He committed to memory the score of Israel in Egypt in six weeks, for his Mus. D. examination, and was the first person so situated to pass. As a teacher he has been eminently successful. His compositions are: "Bethany," a cantata ; Sonata for pf. ; Evening Service in F; Anthem; Songs, and part-songs, etc. $\mathrm{He}$ has acted as press correspondent for the Bimingham and other Festivals, following by ear every note in a score.

Corbett, William, composer and violinist, born ahout 1669 . Nember of King's Pand. Travelled in Italy, Bumey says, on behalf of the Fnglish foremment, who paid him to wateh the movements of the Pretender. Returned to England, 17t0, where he dierd, in $17+8$. He collected a raluable musical library.

Works.-Op. 1, Konata for two violins and bass, London, 1705; Op. 2, Sionata for two flutes and lass, London, 1706; Op. 3, Sonata for two flutes and hass, London, 1707: Op. 4, Six Sonatas, a 30 for two flutes or two German flutes and a bass, consisting of preludes, allemands, corants, sarabands, gavots, and jiggt, Book 1; Six Sonatas for two violins and thoro-bass for the spinet or harpsichord, Book 2, London, n.d. ; Six Sonatas for two oboes or trumpets, two violins, and bass: Concertos, or I'niversal Bizzarries, comprosed on all the new Gustos during many years residence in Italy, op. 5, London, 1741; Twelve Concertos for various instruments: Musie to "Henry IV.," 1700; Mrusic to "Love Betrayed," 1703; Songs in collections, ete.

Corder, Frederick, composer and conductor, lom in Lomdon, Tanuary $26,185 \%$. Though he showed musical talent at an early age, he was intended for a busmess career: and it was not mntil $187 t$ that he entered the R.A.ML as a sturlent. The next vear he gained the Mendelswoh Scholarship, and studied four years with Ferdinand Hiller at Cologne. Soon after his return to England he was appointed conductor at the Brighton Aquarimm, June, 1889, an office he resigned, reptenter,

\section{CORFE.}

1882. He gave many important works during that period, and greatly improved the character of the concerts. The next few years were given up to musical composition and literature. In 1890 he was appointed orchestral director at Trinity College, London; Curator of the R.A.M.; and conductor of the Borough of Hackney Choral Association. In 1891 he was elected a member of the managing conmittee, R.A.M., and in 1892 , a Fellow of the Institution. He was editor of The Overture, a monthly paper published by students of the R.A.M., 1890-4; and, in 1896, lectured at the Royal Institution on Berlioz, Wagner, and Liszt. His contributions to the press have been roluminous and important, including elaborate analyses of Wagner's works, and translations of "I)ie Meistersinger," and "Der Ring des Nilrelungen," in which he was assisted by his accomplished wife, a lady (bom Walford) not unknown in literary and artistic society.

Worrs.-Operas: Morte d'Arthur, in four acts $(187-9)$; Nordisa (prorluted by Carl Rosa, Liverpool, Jannary 26, 1857). Operettas: Philomel (1880) ; A storm in a tea-cup (1880); The Nabols's Pickle (Brighton, september, 1883); The Noble Savage (Brighton, Octoher, 1885). Cantatas: The Crclops (1880); The Bridal of Triermain (Wolverhampton Festival, 1886); The Sword of Argantyr (Leeds Festival, 1889) : Dreamland, ode for chorus and orchestra: The Minstrel's Curse, for declamation and orchestra; The Blind (tivl of Castel, cantata, female voices; Songs, varions. For orchestra: Evening on the sea-shore, Idvl $(1876)$ : Suite, In the Black Forest (composed 1576; pertormed, Crystal Palace, Narch 20, 1880). Oeertures: Ossian (Philharmonic socicty, IIarch, 1882); Prospero (Crystal Palace, Otoler, 1885); Toctume (1882, Brighton Festival); sinite, scenes from the Tempest (14S6); Roumanian snite (composed for, and moduced hy Philhamonic Society, 1857). Rommanian dances, violin and pf. Literary: Exereises in Harmony and Comnterprint (Forsyth, 18!1); A plain and easy introduction to Mlusie, or the new Morley (Fornth, 1893); The Orehentra, and how to write for it (Robert Cocks, 1896): Articles in (Arose's Irictionary of MIusic and MIusicians.

Cordner, William John, organist, born at Imncamon, Wexford, Ireland, 1sen. Went to Anstralia in 1854, and was organist at St. l'atricl's, Sydner, until 1856, when he was appointed to st. Mary's R. (C. Cathedral, an office he held nutil his death, July 15, 1870. He was held in much extimation as a teacher.

Corfe, Joseph, organint, writer, and composer, born at Salishury in 1740. Clorister at Salishury Cathodral. (ientleman of Chapel Rusal, 1783. Organist and choir-master at 


\section{CORFE.}

Salisbury Cathedral, 1792-1804. He died at Salisbury, September, 1820.

Works.-A Treatise on Singing, explaining in the most simple manner all the Rules for learning to Sing by Note without the assistance of an Instrument, with some Observations on Vocal Musie, London, fol., 1791, another ed., 1801; Thorough-bass Simplified, London, n.d. Beauties of Handel, being 154 songs, duetts, and trios with aceompaniment for pf., 3 vols., n.d.: Beauties of Purcell, 2 vols., n.d.; First Set of 12 Glees, n.d.; Second Set of 12 Glees; Third Set of 12 Glees, in score for 3 and 4 voices, from melodies of Sacchini, Paisiello, Haydn, Pleyel, Storace, ete. Sacred Music, consisting of a selection of the most admired pieces. adapted to some of the choicest musie of Jomelii, Pergolesi, Perez, Martini, Biretti, ete., 2 vols., Salisbury, n.d.; Three Collections of Seottish Songs; Anthems; Nine Vocal Trios, harmonized, London, n.d.

Corfe, Arthur Tlomas, composer, organist, and writer, son of above, was born at Salisbury, April 9, 1773. Chorister in Westminster Abbey, 1782. He studied under Dr. Cooke and Clementi. Organist and choirmaster of Salishury Cathedral, 1804. He died at Salisbury, January 28, 1863. Buried in Salisbury Cathedral.

Works.-Anthems; Church Services; Pf. music. The Principles of Harmony and Thorough-Bass explained, London, n.d. Songs; Glees, ete. Anthems adapted from Mozart, etc.

Corfe, Charles William, organist and composer, son of the above, born at Salisbury, July 13,1814 . Studied under lis father, ote. Organist of Christ Church Cathedral, Oxford, December, 18t6. Mus. Bac., Oxon., March, 1847. Condnctor of the Oxford Tniversity Motett and Madrigal Society, 1848. Mus. Doe., Oxon., June, 185'. ('horagus of the University of Oxford, 1860 . He died at Oxford, December 16, 1883.

Wonks.-- Toeal music, as songs, part-songs; Anthems.

Corkine, William, lute player and eom. poser, was born in the latter part of the 16th century, and died in the first part of the $17 \mathrm{th}_{1}$ eentury.

Works.-Ayres to Sing and Play to the Lnte and Basise Violl, with Pavins, Galliards, Almaines, and Corantos for the Lyra Violl, 1610; the Second Booke of Ayres, some to sing and play to the Base violl alone, etc., 1612.

Cornish, William, English poet and musician, flourished ahout 1500 . He wrote a "Parable between Infomation and Mnsike," a poem, which will he found in Hawkins. He was a member of the Chapel Royal choir, and died 1526. Mis compositions exist in MS. His son Willian was also a compuser.

Cornwall, Channon, pianist and tom-

\section{COSYN.}

poser, born at Aberdeen, in 1845. He was organist of St. John's Episcopal Chureh, Glasgow, and in 1880 he beeame accompanist. to the Glasgow Choral Union. Composer of some part-songs, etc. He was drowned in the Forth and Clyde Canal, Glasgow, May 4, 1885.

Corri, Montague, second son of Dominico Corri (Rome, 1746, London, 1825), was born at Edinburgh in 1784. He studied under his father, Winter, and Steibelt, and became eomposer to the Surrey and Astley's Theatres, London. In 1816-17 he was ehorus-master to the English Opera Honse. Afterwards, he resided successively at Edinburgh, Newcastle, Manehester, and Liverpool. He died at London, September 19, 1849. His lrother, HAYis, was born at Edinburgh, in 1785, and resided chiefly in Dublin as a conductor and teaeher. He died at Dublin, February 19, 1860. His wife (loom 1800; died 1867), was an opreratic singer. His sister, SopHe (born at Edinburgh, 1775; died — ?), was a singer and harp player. She married J. L. Dussek (1761-1812), the composer. Frances, or Farri Corit, a mezzo-soprano votalist, was a danghter of Dominico Corri's brother Natale (1765-1822), and was bom at Edinburgh in 1801. She studied under her father, and Braham, and first appeared at the King's Theatre, London. Afterwards, she appeared in Germany, Italy, spain, and Russia, and in 1821 she married Signor Paltoni. Her sister Rosalie (born 180:3), was also a singer, who appeared in Londun from 1820. Other members of this mmsical family were Eugene DusseK (1815; February 4, 1870), a bass vocalist, who maried Avisie ThinLwale (1830; London, October 19, 1881), a soprino singer; Hexne (1822; Philadelphia, February $28,1888)$ a bass singer, son of Haydn the elder; P’atrick Anthony (born Dublin, 1820; died Bradford, Jume 1, 1876), a singer, conductor, and contpostre, another son of Haydn the elder; and Haris, Junr. (born in 1842; died December 19, 1877), a baritone singer.

Costeley, William, Seottish composer, was born in 1531. He settled in France as organist to Henry II. and Charles IX. He was a member of the suciety known as "Pny de musique ì homneur de Ste. Cecile." $\mathrm{He}$ died at Erreux in 1606. His works consist of songs in Le Poy's Collections of Chansons, ete., and a treatise entitled "Mnsique," Paris, 1579.

Cosyn, Benjamin, composer for, and performer on, the Virginals, who flomrished in first part of $17^{\text {th }}$ century. He wrote music of a difficult and complicated style for his instrument, and wits one of the hest performers of his day.

Cosyn, Joln, composer, probably a relation of abore. Wrote? "Musicke of six and five parts made upon the common tunes used in singing of the Psalums," 1585. 


\section{COTES,}

Cotes, Digby, clergyman and writer, author of "Music a rational assistant in the duty of praise when united with charity, a Sermon," 1756.

Cotterill, Thomas, musician and editor, published "Christian Psalmody for congregational or family use, arranged and harmonized by $\mathrm{S}$. Nather and other professors under the direction of Thomas Cotterill," London, 1831.

Cottman, Arthur, amateur composer, born 1842. He was a solicitor by profesion, and died at Ealing on June 3, 1879. He published "Ten Original Tumes," 1872, among which is "Caterham," a hymm tune which has been used in rarious Church hymu-books.

Couldery, Claudius Herbert, composer and pianist, born at Lewisham, Kent, Angust 17, 1842. He learnt to play while a child, but some vears were passed in business pursuits before he was able to derote himself to the art of music. Then he entered the R.A.M., studying harmony under Sir John Goss, composition with Sir IV. S. Bennett, etc. A sacred cantata, "Christ's entry into Jerusalem," was performed at the R.A.MI., and drew attention to the composer's ability. His chief works are-Orerture, Richard I., performed at the Crrstal Palace, February 14, 1885; Overture, To the memory of a hero at the same) February 8, 1890; Suite in ( minor, a romance from which has been given in many places in England and Scotland; and a Cradle Song, in D flat, Crystal Palace, November 18, 1893; Suitc in C, composed 1893-5; Andante religioso, St. (ecilia, for organ, harp, violin, and orchestra, Crystal Palace, Norember 2, 1895. Twelve Reveries, op. 15 ; three series of studies, pf., etc.

Courteville, Raphael, musician, who was born in first part of the 17th century. $\mathrm{He}$ was (rentleman of the Chapel Royal in time of Charles I., and founder of the Conrteville family. He died on December 28, 1675.

Courteville, Raphael, organist and composer, sun of ahore, was born in the latter part of 17 th century. Organist of St. James' Church, Westminster, 1691. He died in June, 1772.

Works.-Don Quixote, opera by D'Lrfey (with Purcell, etc.), 1696; Six Sonatas for two violins: Sonatas for two flutes, 1685 ; Songs in contemporary collections; "St. James" psalm tume, ete. He was a severe political writer, and gained the nickname of Court-eril. He wrote "Memoir's of Lord Burleigh," 1738, and a number of political squibs.

Courteville, John, English song-writer of the 17th century, son of Raphael, the elder. His works alpear in the "Theater of Mrusic," 1685-87, etc.

Courtney, Wililam, tenor vocalist, lyorn in Monmonthshire. Stndied under F. Bodda, Sidney Naylor, and afterwards with Vamme-

\section{COWARD.}

cini, at Florence. Toured with Louisa Pyne and F. Bodda; sang in Cellier's "Nell Gwymne," and Sullivan's "Trial by Jury," when first produced; and was, for a short time, a member of the Carl Rosa Opera Company. Subsequently went to America, singing first at Boston. Settled as a teacher, in Nerv York, removing to Denver, Colorado, 1896.

Cousins, Charles, musician and bandmaster, was born near Portsmouth, Jamuary 2, 1830. Educated at the Royal Hospital Schools, Greenwich, from 1841. Assistant band-master of the Royal Caledonian Asylmm, 1846. Member of band of the 1st Life Gnards, under Mr. James Waddell. Studied at kineller Hall, Hounslow, for a band-mastership. Bandmaster of 2nd Dragoon Gnards, Octoler, 1863. Served with Guards in India, 1864-70. Held appointment till 1874. Inirector of Music at Kneller Hall, November 1, 1874. He died in June, 1890.

Coutts, W. G. 1theriel. Author of "Scottish versus Ulassic Music, and the ethieal and resthetical aspect of the quention," Edinburgh, 1877 (ㄹ eds.).

Coward, Henry, composer and conductor, born in Liverpool. November 26,1849 , but a Yorkshireman by family and descent, and resident in sheffield as conductor and teacher. He is a gradnate of the Tonic Sol-la College; Mus. Bac., 1889) Mus. Doc, 1894, ()xford. Lecturer on Music, Firth College: Teacher of Singing at the Girlw' High School, shettield; Conductor of the Mnsi('al Lnion, 1880; and Amateur Instrmmental society, Sheffield, 1878. Chorns-master, Sleffield Festival, 1896. MInsical critic, for the provincial and Ilandel Festivals, to the sheffield Independent: Condnetor of the festivals of the sheffield smulay School Union, ete.

Works.-Cantutus: Magna Charta, Sheffield, February, 1482; Queen Vietrria, 1885; The Story of Bethany, 1891; The King's Frror (Crystal Palice, Tonic Sol-fa Fentival, July, 1894), and Heroes of Faith (Sheffield, September, 1895). The Fairy Mirror, cantata for ladies' voices, with talleaux rivants. Anthems, Sunday School pieces, Temperance choruses, School songs, Hymn tmes, Flees, ete.

Coward, Hilda, soprano rocalist, daughter of the late James Coward. Pupil of Madame Sainton-Dolby. She made her début at a concert given by $\mathrm{W}$. Lemare, at the Crystal Palace, Monday, Narch 6, 1882, taling part in F. Clay"s "Lalla Rookh"; and alpeared at the Crvistal Palace Saturday Concerts, October 27, 1883 . After singing in various provincial concerts, she was engaged for the Hereford Festival of 1885 , singing in the concerted music in "Elijah," and Gomod's "Redemption," and with great smeens at the concluding Chamber contert. Severe illness 


\section{COIVARD}

compelled her to spend the winter of $1887-8$ in a nilder climate, and her publie appearances since then have not been frequent.

Coward, James, organist and composer, born at London, January 25, 1824. Chorister in Vestuninster Abbey. Organist of Crystal Palace, 1857-80. He died at London, Jannary 22,1880 .

Woris.-Inul] anthem, "O Lord, correct me." Ten glees, for 4 and 5 voices, London, 1857; Tenglees, London, 1871. Numerums dart-songs, songs, etc.

His brother, Willian (bom in London, 1826; died 1873), Was an alto singer in Westminster Abbey.

Coward, James Munro, composer and performer on the Minstel organ, madertoud to be connected with the firn of Metzler \& Co. Has given performances at the South Kensington Exhibition, 1885 (The "Inventions,") Prince's Fall, and other places, exhibiting much slill in inmporimation. He has composed a cantati, "The Fishers," produced at Portman IIall, April!), 1889; A Jubilee Hymm, for choms and military hand (Crystal Palace, 1887); and pieces for American organ, ete. Editor of Amrican Organ Joumal (Netzler).

Cowell, Samuel Haughton, comedian, and comic singer, horn at Lundon, April 5, 1820. Son of Tuseph I eathler Cowell (17921863), the actrix, by whom he was taken to the Unitod sitates in 1832. He resided for a number of years in the Sitates, and appeared there as an atetor ; afterwats he appeared in Edinburgh, where be acted under his nucle, IV. H. MItrray, and where he was maried, in 1842, to Emilic Margnerite Ebsworth. He appeared in London as an actor and singer, and subsegnemtly sang chiefly as a comic vocalist in varionis partic of bitain, laving the. foundation, to a comsidelable extent, of the modern music-hall profesisum. He died at Blandford, I wret, Harch 11, 1864. Hissongst were pethished in many different collections,

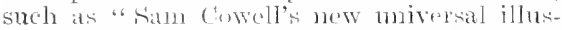

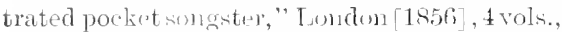
and annong his most sucersiful somgs may be? named "Lom I werl," "Alorzo the Brave," "Billy Barluw," "Rat-Cateher's danghter," "Concin colss," "te.

Cowen, Frederic Hymen, composer, conductor, and pianist, lum at Kinsiston, Jamaica, Jamuary 29. 1852. Inomght to England when fone rears old, and placed under the trition of Julius Exesedict, and John Goss, with whom he remained motil 1865. His "Mina Waltz" was published in 1858. Studied at Leipzig and Berlin, muder Hamptmanu, Mosibeles, Reinecke, and others, returuing to Lenuten in 1868 . Hesoon berame known as a frilliant pianist and composern, giving his first wneert, Jume 24, 1868, at Dudley 1 fonse, and introducing his pianoforte

\section{COWEN.}

trio in A minor. Other works followed, and at his orchestral concert, St. James's Hall, December 9, 1869, he produced his first symphony (in C minor). Shortly after he went on tour, as pianist and aceompanist, with operatic concert parties; gave a series of Saturday Evening Concerts in At. James's Hall, 1880-1; eonducted at the Promenade Concerts, Corent Garden, 1880. During the next two years he appeared at rarious places in Germany, conducting his own compositions. Conducted concerts at the Crystal Palace (December 16, 1882; December 13, 1884, ete.;) Pluilharmonic Society (May 7 and 28, 1884); was given the post of Musical Director of the Melhomme Contemnial Exhilition, 1888; and visited sydney. Conductor of the I'hilhar. momic Siscicty, 1889-92; appointed successor to the late sir Charles Halle ats conductor of the Liverpool Philharmonic Society, and the Inalle Concerts, Manchester, 1896. Condncted various compositions at the principal musical festivals, $1876-95$.

Morks.- Operas: Panline (Lyceum, Carl Roxa, November 22, 1876); Thorgrim (book by Juseph Bennett, produced Imury Lane, April 20, 1890; Rigna (I)al Verme Theatre, Milan, Noxember 12, 1893); I Iarold (book by Sir Er. Malct, produced at Covent Garden, in Fuglish - an mique ocenrence-June 8, 18!15). Operettes: (Tazibaldi (an waly work); (mes too many (German Reed, 1874). Tneidental music to Maid of (Mreans (1871). Oraturios and Cantatas: The loses Matiden (1870): The Gorsair (Bimingham Festival, 187(;: The I) Ange (Brighton Fextival, 1878) ; sit. Irsula (Norwich Fastival, 188f); The Sileping beanty (Birninghan, 18.85); Juth (Vincester, 1885); Sony of Thanksuiving (Molmmme, 148s); St. John's Wre (Crystal I'alace, 1889); The Water Lily (Norwich, 1.49:3): 'Tho Transfiguration (frloncester, 1895). For fomule roices: Sumumer on the river; Christmas sormes; The Rose of Life; A dangliter of the sea, etc. Part-songs, trios, duets, ede. Many somes, among which may lo montioned: Two Roses; Marguerite; The lutter land; The nufinished song; Nore than all to me: The promise of life: Nine somgs (Iongfellow); Songs for children (t8:)6), ste. (rehestral: symphons, No, 1, in (: numor (1869); No. 2, in F (187.2); No. 3, in (: minor,

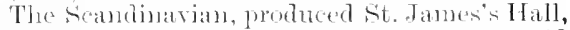
Ifecentuer 18, 1880, and since heard the world wer: No. 4, in B flat minor, l'hillarmonic, Nay 28, 1884; No. 5, in F (Camleydge, 1887). Orentures, ete. I) minor (1sfie); Festival Norwich, 1872); Characterintic orerture, Niagara; and others. Suites: The Language of flowers (1880); Tu the oldem time (for strings, 1883); Tn Fairylated (Philhamonie, Nlay 6, 1896); Fom Finglish dances in the oklen style; Sinfonietta in d; Marches, ete. 
COX.

Concerto in A minor, pf. and orchestra; Quartet in C minor; Trio in A minor, pf. and strings; Sonata fantasia, Allegretto grazioso, Romance and scherzo, Valses, and other pieces for pf., etc.

Cox, Frank Rowland, professor of singing, born at Exeter, September, 1819. Intended to follow his father's profession, a solicitor, but deciding for music, was admitted as an out-student of the Royal Academy of Music in October, 1839, and, later, was a pupil of Domenico Crivelli. In 1849 he was appointed an Assistant Professor of Singing at the Royal Aeademy of Music; in 1852 was made an Associate, and in 1862 elected a Nember. He joined the Committee in 1868, and was elected a Director in 1880. With the exception of a short period passed at Trentham, his whole professional life was devoted to this Institution. He died in London, April 3,1891 , at the age of 71 . Translatur of Crivelli's "L'Arte del Canto," lant edition, 1850.

Cox, Mrs. Harry, see Cixtelo Axrie.

Cox, Rev. John Edmund, D.D., elergyman and writer, was horm at Norwich, October 9, 1812. Vicar of St. Helen's, and St. Martin's, Bishopscate, London, 1849, ete. Anthor of "Musieal Recollections of the last IIalf Century," Londorr, 2 vols., 1872. He was Hon. Chaplain of the Royal Society of Mnsicians. He died at Bath, October 27, 1890.

Coy, Harry, organist and composer. Became F.R.C.O., 187s; graduated Mus. Bac., 1878; Mrts. Doe., 1885, Oxford. Orentuist and choimaster, St. John the Divine, Brokland, near Manchester, from 1878; Conductor of Sale District Mrusical Society, 1s:2. Composer of a sacred cantata, "Esther"; a retting of Psiln 85, for tenor solo, chorus, and orchestria; anthems, etc.

Craig, Adam, feottish violinist and collector, born in latter half of 17 th century. He preformed at the pullic concerts in Edinlongh during his lifetine. Died at Edinburgh, september $3,17+1$.

Works.-A Collection of the choicest scots Tunes, adapted for the Harp or spinnet, and within the compass of the voice, riolin, or Geman Flute, Edinburgh, 1730. I mammseript volume of original compositions ly Cratig was exposed for wale in 1728 .

Craig, John Millar, conductor and haritone rucalint, born in Edmburgh, November 15, 1839. Was apprenticed to a printer, and during that time stadied singing under $\mathrm{A}$. WT. Smith, and signor Bucher. T'hen twentysix years of age, deroted hinself to music as a profersion, and began teaching. He afterwards studied at Milan and Florence, with Leoni and Romani. Held sereral appointmentis as Precentor, and in 1886, sncceeded the late James Allan as conduetor of the famous Glasgow Select Choir. Has sumg in

\section{CRAWFORD.}

many towns in Scotland, and with the Choir has made tours of the United Kingdom, giving an annual concert in London on st. Andrew's Day. He is also conductor of the Edinlurgh Bach Society. As a teacher he has had many pupils who have taken ligh positions as singers. His wife, born Elizabeth Noble, studied singing first with her husband, then under Professor Goetze, in Leipzig. She sings occasionally in concert. in Edinburgh, but is chiefly occippied in teaching, in which she has net with great slecess, Thomas Crarg, brother of J. M. Craig, is a pianist. He was horn in Edinburgh, October 1, is51. Studied at Leipzig Conservatorium. He has played at Chamber concerts in Edinlsurgh, and is teacher of the pf. at George Watson's College, Edinhurgh.

Crament, John Maude, organist, conductor, and composer, lorn at Bolton-Percy, Torkshire, April 2, 1845. Stmdied under (Sir) F. A. Dacfarren, and at the Hoch Sehule, Berlin, under Hanpt, and Kiel. Craduated Mus. Bac., Oxford, 1sqo. Professor of Music at the Church Edncation Soeietr's Training College, Dublin, 1873-5. Organist of Brompton Parish Church, and now of St. Paul's, Kensington. Secer tary and conductor, People's Entertainment Societr, 1879-92: Conductor of Choral societies at Richumond, Surbiton, and Putney; Kensington Oratorio Society, and Orphen Mnsical Society (men's voices), etc. His compositions comprise a setting of Psalm 145, for soli, chorus, and orchestra (1'ichmond, January, 1887). Cantatas: May Yorn ; Little Red Riding 1 rood; The Crystal Cup (for female voices). Inthemr, carols, songs, and part-songt.

Crampton, Thomas, orgunist, composer and editor, horn sheernes, 1N17. Has edited several collections of choral music. and composed anthems, glees, and instrumental music. He was made purchaser of musio to the British Mnsemm in 1875. Felitor of Pitman's Musical Honthly. He died at Chiswiek, April 13, 1885.

Cranford, William, composer of the 17 th century. He was one of the ehorister's of St. Pand's Cathedral, 1 sondon, in 1650 . He composed romds, catches, anr songs, printed in the collections of Hiltom, Plarford, ete.

Craven, John Thomas, witer and teacher, born in 179\%. Anthor of "The Child's First Singing 13ook," Lemdm, nod.; "The Child's First Music: Book, or lutroduction to the Art of Playing the P'ianoforte," Londors, n.d.

Crawford, Major George Arthur, M.A., writer on Misice, forn in Dublin, 1s27. His chief work wat in connection with Chureh mmic, and consisted of articles in the Musical Times; Grove's l)ictionary of Music and Nusicians; and Julian's Dictionary of 


\section{CRAWFORD.}

Hymnology. lle compiled the biographical index in the Frish Church Hymnal. He was a member of the MInsical Association, 1874-91, and frequently spoke at the meetings, his great knowledge giving more than ordinary value to his remarks In 1881, he issued "Snccession of Organists... of the cathedral ehurches of St, Patrick, Armagh; of the Holy Trinity ... and of St. Patrick, Dublin," etc. A small tract of 39 pages, containing brief biographical notices of the organists." He died at Sevenoaks, June 9, 1893.

Crawford, William, composer and pianist, was born in 1848; died at Glasgow, Jarch 2, 1878. I Ie composed a considerable number of pieces for the pianoforte, many of which were issued under the pseudonyns of "Rudolph Rookford," and "Frank B. Ashton. His father, James PaUl Crawford (1825-1857), is best known as a minor poet, his poen, entitled "The Drunkard's raggit wean," being a popular piece of its kind.

Creser, William, organist and composer, born in Fork, 181t, his father being (hoirmaster of St. John's Church in that city. He was a chorister in York Minster at eight, and stndied for some time under (sir) G. A. Macfarren. Graduated Mus. Bac., 1869; Mus. Doc, 18s0, Oxferd. F.R.C.O., and Associate of the Phitharmonic Society. When fifteen, he was organist of Holy Trinity, Micklegate, York; then of St. Paul's; and (1863-75) st. Andrew's, Grinton. In 1875 he was appointed to St. Martin's, Scarborough, and to the Leeds Parish Chureh, 1881. Ilere he remained ten years, maintaining the reputation of the musical servicss, and prodweing Bach's Matthew Passion, and other great works on special occasions. In 1891 he was appointed organist of the Chapel Royal, st. James's, and composer to Her Miajesty's Chapels Royal. Conduetor, Westem Mradrigal Societs, 1896. He has given coneerts at Leeds, and organ recitals at the Edinburgh Exhibition, 1890; Exeter Hall, 1891; Bow and Bromley Institute, 189:, etc. His wife, born AnELia Clanke, is at eontralto rocalist of repute, who has sung at many concerts in Forkshire, and the Iletropolis, with much success.

Works. Oratorio, Micaiah; Mass in C; Psalm 16, motet for double choir: Prahn 145, for soli, chorus, and orchestra ; Luther's hymn (Latin rersion). Cantatas, Eutura (Leeds, 1882); The Golden Legend; The Sucrifice of Freia (look by F. Hurffer, produced at the Leeds Festival, Octuler 10, 1889); and Tegner's Drapa (Longfellow). Operetta, Naxine; varions songs. OR English suite for orchestra (Queen's Hall, Nay, 1896); Quartet in A minor, strings; Trio in A, pf. and strings; Sonata, pf, and riolin; Sonata in A minos, and other pieces for organ.

\section{CROFT.}

Creyghton, Robert, D.D., divine and composer, was born at Cambridge in 1639 . $\mathrm{He}$ became Professor of Greek in the University of Cambridge in 1662; Canon Residentiary and Precentor of Wells Cathedral, 1674. He died at Wells, February 17, 1733.

Wonks.-Services in E flat and B flat. Anthems-Behold now, praise the Lord; I will arise; Praise the Lord, O my soul, ete, Music mostly in MIS.

Creyghton is chiefly remarkable for a cadence which he employed at the close of his compositions, styled by some writers the "Creyghtonian seventh."

Crisp, William, musician, compiled "Divine Harmony, or the Psalm Singer instructed," London, 1755.

Croager, Edward George, organist and conductor, born in London, June 20, 1861. Chorister, St. Andrew's, Wells Street; afterwards studied at R.A.MI., obtaining the Certificate of Merit, and being made an Associate. He was for some years assistant organist at St. Andrew's, and afterwards organist and choirmaster successively at Quebec Chapel, St. Mark's, North Audley Street, and St. Janes's, West Hampstead, which post he now holds. Conductor of the West Hampstead Choral and Orchestral Society, the London Diocesan Choral Union (II.), and Organist to the London llandel society. His patriotic eantata, "Our Watchword," produced in 1888, has been frequently performed. His other compositions are chiefly for Church usehymu tunes, etc.

Croal, George, composer and pianist, born at Edinburgh, Feluruary 28, 1811. Son of Mr. Croal, who was sub-editor of the Caledonian Mercury. He was apprenticed to Alex. Robertson, music-seller, in 1823, and remained with hin till 1833 . He was in business for limself as a music-seller from 1840 till 1848. Afterwards he was a teacher of music in Edinburgh.

Works. - The Centenary Souvenir, six songs by Sir Walter Scott. Sings - Away to the woods; Emigrant's dream; My gramnie's pouch, etc. He also discovered and adapted the airs now known is " When the kye comes hame" (1836), and "My Nannie's awa" (1842). Under the jismulonym of "Carlo Zotti" Mr. Croal has published numerous arrangements, transcriptions, and dances for the pianoforte.

Croft, William, composer and organist, born at Nether-Eatington, Warwiek, 1678. He studied under Dr. Blow, and was chorister in the Chapel Royal. He was organist of St. Anne's, Soho, London, from 1700 to 1711. In 1700 he lecame a Gentleman of the Chapel Royal; in 1704 joint organist with Jeremiah Clark; and in 1707 sole organist, In 1708 he was appointed master of the choristers and composer to the Chapel Royal, also organist. 


\section{CROKER.}

of Westminster Abbey. He resigned his post at St. Anne's to John Isham in 1711. Mus. Doc., Oxon., 1713. Appointed tuner of the regals, a Court office, 1716. Original member of the Academy of Vocal Music, 1725. He died at Bath, August 14, 1727, and was buried in Westminster Abbey.

Wonks. - Operas (incidental music to plays)-Courtship à la mode, 1700; The Funeral, 1702; Twin rivals, 1703; Lying lover, 1704. Divine Harmony, or a new collection of select anthems used at H.M. Chapel Royal, etc., 1712; Cathedral Music, or thirty select anthems in score, consisting of $1,2,3,4,5$, 6,7 , and 8 parts. ... London, 2 vols., 1724; Musica Sacra, or select anthems in score ... 1724. Numerous single anthems. Miscellaneous Odes for public occasions. Musicus Apparatus Academicus, being a composition of two odes, etc., 1713. Three Odes, for degree of Mus. Doc., 1715; Six sets of tunes for two violins and bass; Six Sonatas for two flutes. Six solos for the flute.

Croft introduced the printing of music from pewter plates, a practice which was generally followed afterwards.

Croker, Norris, baritone vocalist of the present time. Has given Englisli song recitals at Steinway Hall, London, 1890, etc. Author of " Handbook for Singers," London, Augener, 1896.

Cromar, Rev. Alexander, writer and clergyman of a Presbyterian congregation in Liverpool, wrote "A Vindication of the Organ-a Review of the Rev. Dr. Candish's publication, entitled "The Organ Question," Edinburgh, 1856.

Crome, Robert, a musician who flourished during the-middle of last century. He published "A Collection of Dr. Watts's divine and moral songs," London [1740]. "The Fiddle new model'd, or a useful introduction for the violin," London [1745]. A Compleat tutor for the violoncello, London [1765]. Songs, etc.

Crompton, John, musician, of Southwold, Suffolk. Edited “The Psalm Singer's Assistant, or a key to psalmody, containing a new, easy, and familiar introduction, with an astronomical account of the two fundamental keys," Loudon, 1778.

Cromwell, Thomas, English writer, author of "Church MIusic; a Sermon on the Antiquity, Excellence, and Propricty of the general adoption of the legitimate Nusic of the Christian Church," London, 1843.

Crook, John, conductor and composer. Sometime musical director, Theatre Royal, Manchester. Composer of music to burlesques "Robinson Crusoe," Avenue Theatre, 1857; and "Lancelot the Lovely," the same, 1889. Operetta, The Transferred Ghost. IInsic to some of Chevaliel's songs, etc.

\section{CROSSLEY.}

Crook, Joseph, musician of the first half of the present century. Published "New Sacred Mrusic, thirty-four psalm and hymn tunes for four voices," London [1839].

Crosdill, John, violoncellist, born at London, 1755 . He was educated at Westminster School, and became a chorister in Westminster Abbey. He studied under B. Cooke and J. Robinson. Nember of the Royal Society of Musicians, 1768-1825. Violinist in Chapel Royal, 1777. Chamber-musician to Queen Charlotte, 1782. Principal violoncellist at the Handel Commemoration, 1784. Principal 'cello at Ancient Concerts, etc. Married, and retired, 1790 . He died at Escrick, Yorkshire, October, 1825.

Crosdill was violoncellist-in-ordinary to King George IV., and a performer on the violoncello of the greatest ability. A number of anecdotes concerning him will be found in Parke's "Musical Memoirs."

Cross, William, musician and organist. born in latter half of 18 th century. He was organist of Christ Church Cathedral, St. John's College, and University Church, Oxford, 1807. He died in 1826.

Worrs.-Collection of Chants, Kyries, and Sanctuses, n.d. A Collection of P'salm Tunes for the Church of England. Loudon [1818].

Cross, William Paterson, conductor and voice-trainer, born at Blairoaks, Caldarvan, Dunbartonshire, October 24, 1837. Studied in Birmingliam, where he was choirmaster for several years of Broad Street Presbyteriau Church. Settled in Greenock, 1862, as conductor and teacher. Conductor of the Choral Union, Greenock, and of other societies in the locality. Has composed many songs, partsongs, and pf. pieces, etc.; arranged Scottish melodies as part songs, and conpiled school song-books, etc.

Crosse, John, writer and musician. Author of "An account of the Grand Musical Festival held in i eptember, 1823 , in the Cathedral Church of York, to which is prefixed a Sketch of the 1Rise and Progress of Musical Festivals in Great Britain, with Biographical and Historical Notes," York, 1825. This is a valuable work, of more than local interest. Crosse died at York, October 20, 1833.

Crossley, Frank Merbert, violinist and conductor, born at Sheffield, May 30, 1864. Studied violin and pf. under private masters. In 1880 went to Natal, where he was appointed Conductor of the Cathedral Choir, and of the Philharmonic Society, Pietermaritzburg. Afterwards went to Berlin (1887), and studied violin under Emile Sauret, and composition with Wilhelm Tappert. In 1890 he was appointed Conductor of the Warrington MIusical Society, and later of similar societies at Runcorn, and Newton-le-Willows, positions 


\section{CROSSLEY.}

he still retains. He has in MS. a cantata, Adéle, for soli, chorus, and orehestra; a string quartet, ete. He has published six songs; Melody in D, violoneello and pf.; Romance in F, violin and pf.; Three sketches, pf., etc.

Crossley, Hastings, amateur composer, born at Glenburn, Antrim, August 1, 1846. Studied under Berthold Tours. Professor of Greek, Queen's College, Belfast. Composer of Reine d'amour; The cottage by the sea; Strew on her roses; Under the star, and other songs.

Crotch, William, writer, composer, and organist, was born at Norwich, July 5, 1775. $\mathrm{He}$ gave early evidence of great talent for music, and was taken to London in 1780 . Assistant organist to Dr. RandaIl, at Canrbridge, 1786. Studied for the Cluurch at Oxford, 1788. Organist of Christ Chureh, Oxford, 1790-1807. Mus. Bae., Oxon., 1794. Organist of St. John's College, Oxford, 17971806. Professor of music at Oxford, Mareh, 1797. Mus. Doc., Oxon., 1799. Lectured in Musie School of Oxford, 1800-4. Lectured at the Royal Institution, London, 1820. First Principal of the Royal Academy of Music, London, 18:2. He died at Tamton, Decem. ber $99,1847$.

Works.-Oratorios: The Captivity of Judah, 1789 ; Palestine, by lishop Heber, 1812; The Captivity of Judah, re-witten, 1834. 1uthems: Ten anthems dedicated to the Dean and Chapter of Christ Church [1798]; Thirty select anthems, ed. by $V$. NoreHo, 2 vols. Collection of serenty-two original single and double cilants, 1842 ; Tunes adapted to the old and new versions of the psalms... .1807; Tie Mereiful unto Me; Comfort, O Lord, the Soul of Thy Serrant; Holy, Holy, Holy; How dear are Thy comusels; In God's Word will I rejoice; Lo! star-led Chiefs; Methinks I hear the full Celestial Choir; Iy $_{y}$ God, look upon me; $O$ come hither, and hearken: O Lord Crod of Hosts; Sing we merrily; The Lord is King; Who is like unto Thee. Three concertos for the organ with accompts.; Fugues for the organ: Sonatas for the pf.; Handel's oratolios (portions) adapted for the organ or pf. Ode on the Accession of George IV., 1827; Ode to Fancy, Warton (Doctor's oxer cise), 1799. Glees, various. Elements of Musical Composition, comprehending the mules of Thorough-bass and the theory of Tuning, Tondon, 1812; 2nd edition, 1433; 3rd edition, Novello, 1856; Practical Thorough-bass, or the art of playiug from a figured hass, Iuondon, n.d. ; Ouestions for the Examination of Pupils who are studying the work called Elements of Musical Composition and Practical Thorough-bass, London [18:30; Substance of several courses of Lectures on Musie, 1831; Specimens of various styles of Insic referred to in a course of Icctures read

\section{CROUCH.}

at Oxford and London, and adapted to keyed Instruments, London, 3 vols., n.d. ; Preludes for the Pianoforte, Compositions in various styles, to which are prefixed the rudiments of playing the instrument [1823].

Crotty, Leslie, baritone vocalist, born at Gakway in 1853. Intended for a commercial life, he entered an office after leaving school, and was then for some years in a bank in Dublin. During this time he studied music under Alessandro Cellini, and frequently sang in concerts as an amateur. As such he also sang at times in opera for Mr. Carl Rosa, during the second visit of his company to Dublin (1875?). He then went to Florence, and studied under Mabellini. Returning to Fngland, he joined, in 1877, the Carl Rosa Opela Company, in which he remained for a little over ten years, his repertory comprising the parts of Rigoletto, Henry Ashton (Lucia di Lammermoor), Count di Luna (Il Trovatore), Danny Mann (Tily of Killarney), Escamillo (Carmen), and others. In 1889 he made his début at Covent Garden, in Italian Opera, as the Count, in I! Trovatore. In 1882 he married Miss Grorgina Burns (q.v.), and about 1890 started a company for the production in English of Rossini's opera, "Cinderella," which successfully toured the provinces for some years.

Crouch, Anna Maria, born Phillips, soprano vocalist, born at l,ondon, April 20 , 1763. She studied under T. Linley, to whom she was articled in 1779, and first appeared at Drury Lane Theatre in Arne's "Artaxerxes," 1780. Appeared in Ireland with great suecess, 1783. Married to Mr. Crouch, a lieutenant in the nary, 1785. Sang at oratorios at Drury Lane, 1787. Separated from Crouck, 1792. Resided afterwards with Michael Kelly. Retired from the stage, 1800 . She lied at Brighton, Oetober 2, 1805.

"She had a remarkably sweet roice, and a naive, affecting style of singing; this, added to extraordinary personal charms, made her a great favourite of the public for many : ears." A most landatory poem on her is entitled "Euphrosyné, an Ode to Beauty: addressed to Mrs. C'rouch, by Silvester Otway [otherwise John Oswald], London, 1788. Ser also " Jemoirs of Mrs. Crouch," by M. Young, London, "2 vols., 1806 , with portrait.

Crouch, Frederick Nicholls, composer, vocalist and violoncellist, born in Warren Sitreet, Fitzroy Square, London, July 31, 1808. Son of F. IV. Croueh, violoncellist (q.u.). At the age of nine he played in the band of the Royal roburg Theatre. Then he travelled in Forkshire and Scotland, and was for two years, through necessity, a eommon seaman on eoasting smacks plying between Isondon and Teith. Throngh the interest of IVilliam Watts, then secretary of the Phillarmonic 


\section{CROUCH.}

Society, he entered the orchestra of Drury Lane Theatre. His voice developing, he studied under William Hawes, and was in the choir of Westminster Abbey and St. Paul's Cathedral. Then, entering the R.A.M., he was for a short time under Crotch, Attwood, Lindley, etc., and member of the Philharmonje, Ancient Concerts, and Royal Italian Opera orchestras. Travelled for a time for a firm of metal brokers, and invented the engraving process known as zincography. Afterwards musical supervisor to D'Almaine and Co., London. About 1838 he was giving an entertainment on the "Songs and Legends of Ireland," and was for years known as the Irish lecturer. The song "Kathleen Mavourneeu" was one of a series, "The Echoes of the Lakes," published about 1838. In 1849 he went to America, and filled various offices, conducting at Portland, Philadelphia, Washington, Richmond, etc. He joined the Confederate army, and served through the Civil War. His last years were spent in Baltimore, where he died, August 19,1896. He published his Autobiography in the Boston Folio, 1887 (?). He wrote the music of two operas - Sir lioger de Coverley, and the Fifth of November, 1670. His published songs comprised-Songs of Erin; Echoes of the Past; Bardic Reminiscences; Songs of the Olden Time; Songs of a Rambler; Wayside Melodies, and many detached songs by various writers, which in their day had great popularity.

Crouch, Frederick William, father of the above, was born in Great Smith Street, Westminster, about the year 1783. He was the eldest son of William Crouch ( $q . v$. . . He received his first instruction from his father, and was afterwards placed under John Smith, a fine player, when his rapid progress soon enabled him to appear in public in concertos, etc. In 1817 he became second prineipal at the Italian Opera House, and was also in the orchestra of the Ancient Concerts and Philharmonic Society. For year's, and up to a few months before his death, he played everywhere with Robert Lindley. II married the daughter of John Nicholls, an eminent barrister. His death took place, July, 1844. He was the author of "A Complete Treatise on the Violoncello" (London, Chapell, 1826), based largely on the authorized Methode of the Paris Conservatoire; a Supplement, with accompanied Scales and Exercises on Double Stops; Duets for two violoncellos; Duets for $\mathrm{p}$ f. and violoncello; Arrangements, songs, ete.

Crouch, William (father of F. W. Croueh, and grandfather of F. N. Crouch), musiciau and organist. He was for upwards of fifty year's organist of St. Luke's Church, Old Strcet, London, and was also at the same time, for many years organist of Clapham

\section{CROWE.}

Parish Church, Compiler of "Selection of Psalm tunes, as sung in Clapham Church," London [1820]; and composer of six sonatas or lessons for the harpsichord or pf., op. 1; six sonatas for pf., op. 7 ; two sonatas for the pf., op. 9; The Triumph of Innocence, an ode; The Maid of Selma, a song, ete.

Crow, Edwin John, organist and composer, born at Sittingbourne, Kent, September 17, 1841. Chorister at Rochester Cathedral, and articled pupil of the organist, MIr. J. L. Hopkins, up to 1856 , when the latter removed to Cambridge. Under his successor, John Hopkins, young Crow remained two years, receiving lessons and also teacining the choir boys. In 1858 he went to Leicester, and studied with G. A. Löhr, whom he succeeded as organist of Trinity Church, after being acting organist for three years. He was then organist successively at St. Andrew's, and St. John's, Leicester ; and in 1873 was appointed organist and choirmaster of Ripon Cathedral, entering upon his duties January 1, 187t, and still retaining those offices. In 1868 , he became F.K.C.O.; graduated Mus. Bac., 1872 ; Mus. Hoe., 188:, Cambridge. lle is an Examiner for the Incorporated Soeiety of Iusicians, and Royal Cullege of Organists, and musie master al Ripon Grammar school; also conductor, in rotation, of the NorthEast Cathedral Choir Association.

His Compositions, besides the Degree exercises, Psalm 146, and a Harvest Oratorio, include a Communion Service in F (College of Organists' Prize, 1872), a Murning Service in $\mathrm{C}$ (written for the opening ot the Cathedral Organ, April 24, 1878), Eveuing Services in G, A, and I. Organ and pf. music. Songs, and Masonic music.

Crowdy, John, writer and editor, born at Lewknor, January 6, 183t. Editor suceessively of The Musician, Musical Standard, and The Artist. Sub-editor of the Guardian from 1854. He died, Addlestone, Surrey, January 12, 1883.

Woris.-A Kalendar of Cadences, in the form called Free Chant, adapted for the recitation of the P'salms, Lomlon, n.cl. The Free Church Canticle Book, n.d. The Psalter, n.d. The Chureh Choimaster ... London, 1864. A sh ret Commentary on IIandel's oratorio, "The Messiah," London [1875].

Crowe, Alfred Gwyllym, bandmaster and composer, horn in Bermula, November 3,1835 . Of a family of soldier's (his father, Captain Crowe, was in the 30th and 50th regiments, and was killed in the Siklı war, 1845), he joined the 30 th regiment at Manchester when he was twetre years old. He entered the band, and played oboe and horn; served in the Crimea, and was present at the battles of the Ama, Inkerman, and the siege of Sebastopol, for which he received medal 


\section{CROWEST.}

and clasps. Returning to England, he raised a new band for the $30 \mathrm{th}$, and afterwards studied for two years at Kneller Hall. Then he was appointed (1860) to the 14th Light Dragoons, retiring on a pension in 1874. Under the management of Mr. Freeman Thomas, he conducted the promenade concerts at Covent Garden, from 1881, lıaving previously been engaged at the Southport Aquarium. In 1893, he was appointed conductor of the Llandudno Pier and Pavilion Concerts. He died March 8, 1894. His compositions were light, ballet music, and waltzes chiefly. The "See-Saw WValtz" (Covent Garden, 1884), was extensively popular.

Crowest, Frederick J., writer on music, organist and choirmaster, born in London, 1850. Has held several appointments in London, and elsewhere, and is now organist and precentor at Christ Church, Kilburn, and choirmaster of St. Mary's, Somers Town. $\mathrm{He}$ has compos d some Church music and songs. For some years he was favourably known as a tenor singer, under the name of Arthur Vitton. Besides contributions to the National Review, and other papers, he has written the following: "The Great Tone Poets," London, Bentley, 1874; "Book of Musical Anecdotes," Bentley, 1878, 2 vols. ; "Phases of Musical England," Remington, 1881; "Musical History and Biography, in the form of Question and Answer," 1883; "Advice to Singers;" "Musical Groundwork," Warne \& Co.; "Cherubini," the Great Musicians' series, Sampson Low; " Dictionary of British Musicians," Jarrold, 1895; and "The Story of British Music," Tol. I., Bentley, 1895.

Crozier, William, oboe-player, pupil of Barrett. Member of Crystal Palace orchestra from 1855-1870. He died December 20, 1870.

Cruickshank, James, Scottish musician and teacher. Author of "Flutina and Accordion Teacher," London, 1851. Cruickshank's Accordion and Flutina Teacher, Aberdeen [1853]. Also issued several books of music for the Accordion, and composed waltzes and other dance music.

Cruickshank, William, Alexander Campbell, organist and composer, son of the late William Cruickshank, M.D., Deputy General Inspector of Hospitals, and of the 52nd Regiment, born at Greenlaw, Berwickshire, June 1, 1854. Educated at Epsom College, where he received his first musical instruction, afterwards becoming a pupil of the late Thomas Hewlett. Graduated Mus. Bac., Oxford, 1885. Was resident musicmaster at Loretto School, Musselburgh, 1874 1875 ; Organist and Choirmaster, St. John's, Selkirk, and Conductor of the Selkirk Choral Union, 1875-6; of St. John's, Alloa, and Conductor of the Alloa Misical Association,

\section{CULLEN.}

1876-80; and of the Parish Church, Burnley, from 1880, and Conductor of Burnley Vocal Union, and of the Ruridecanal Festival Services.

Works.-Psalm 145, "I will magnify Thee, O God," for soli, chorus, and orchestra; Magnificat and Nunc Dimittis in G, composed for the Festival of the London Church Choir Association, and performed in St. Paul's Cathedral, May, 1889; Communion Service in E flat; My heart is fixed; Sing, O ye heavens; Praise the Lord, composed for Annual Festival in aid of Burnley Hospital, 1896; and other anthems. Hymn tunes, chants, etc., contributed to various collections. Songs: An autumn wind; Homeward bound; Waking; Waiting; and others. Part-songs: Waken, lords and ladies gay; and others. Romance for violoncello, pf. and organ pieces, and organ arrangements, etc.

Cruse, Edward, musician and writer, who died in 1879 . He was an organist and teacher in London. Compiled "Psalms of the Church. adapted for four voices, containing a History of Church Nusic and Notation, biographical notices, etc., the whole calculated for general adoption by every sect of the Reformed Religion," London [1835]; Te Deum, and other church music.

Cudmore, Richard, violinist, composer, and pianist, was loorn at Chichester, in 1787 . He studied under a musician named James Fargett, Reinagle, and Salomon. Violinist at Chichester Theatre, 1799. Resided in Chichester as violinist and teacher, 1799-1808. He studied the pianoforte under Woelfl, at London. Member of Philharmonic Band, London. Resided in Manchester as leader of Gentlemen's Concerts. He died at Manchester, December 29, 1840.

Works. - The Martyr of Antioch, oratorio; Concertos for the violin; Concertos for the pf. ; Songs, ete.

Cudworth, William, musician, author of "Musical Reminiscences of Bradford." Reprinted from the Bradford Observer. Bradford [1885].

Cuisset, Frank F., organist and writer, born at London, February 23, 1812. Studied music under Sir H. Bishop, Sir George Smart, etc. Organist of Holy Trinity Church, Coventry; Bishop Ryder's, Bimingham; Selly Oak Church, Birmingham; and Busbridge Church, Godalming. Author of "The Vocalist's Indispensable Practice, a series of exercises for promoting the strength and flexibility of the voice." London [1875]. Composer also of Concerted vocal music, songs, hymn tunes, etc.

Cullen, Rose, Mrs. Albert Tench, vocalist and actress, born near London. Made her début at the Lyceum Theatre, January 22, 1870 , as the Page in "Chilperic," afterwards 


\section{CULWICK}

appeared at the Strand and Olympic, and in the provinces. She died, December, 1888.

Culwick, James C., composer and organist, born at West Bromwich, Staffordshire, in 1845. Chorister (articled, at fourteen, to Thomas Bedsmore), and afterwards assistant organist of Lichfield Cathedral. Organist successively at St. Chad's, Lichfield; Parsonstown, Ireland, 1866; Bray, 1868; St. Ann's, Dublin, 1870; Chapel Royal, Dublin, 1881. Professor of pianoforte and theory, Alexandra College, and Conductor of Harmonic Society, Dublin. Lecturer on Music. In 1893 the degree of Mus. Doc., honoris causâ, Dublin, was conferred upon him.

Works.-Dramatic Cantata, The Legend of Stauffenberg (Ancient Concert Rooms, Dublin, May 3, 1890); Hymn for a May morning, both in MS.; Psalm 104, for soli, chorus, and orchestra. Anthems: Bless the Lord, O my soul, for soli, four, and eight part chorus (1896); Praise the Lord; O Lord. grant the Queen a long life; and others. Church services, including a Te Deum and Benedictus, for men's voices (written by invitation for Lichfield Cathedral, 1892). Various part-songs, and an Elegy in memory of Sir Robert Stewart. Windle straws, a cycle of eight songs; To the Cuckoo, with parts for strings and flutes; duos, etc. Instrumental: Quartet in $\mathrm{E}$ flat, for $\mathrm{pf}$. and strings (Dublin, 1884); Sonata in D minor, organ; Suite, op. 1 ; Sonatina, op. 4 ; Ballade, op. 2, and other pieces for pf. In MS., a concert overture, for orchestra; Quartet and suite for strings; Pieces for violoncello, violin, and pf., etc. Author of the Rudiments of Music, a text-book, Dublin, 1880 ; 2nd ed., 1882; Pamplnlets and papers, I Iandel's Messiah; Discovery of the original word-book used at the first performance in Dublin, with some notes, 1891 ; The study of music and its place in general education, Dublin, 1882 ; Artistic landmarks (Musical Association), London, 1891, etc. Lectures on Folk Song, and what it has done for us. The ethics and practice of Music, etc., etc. Dr. Culwick's father was a tenor vocalist; Lay-clerk of Lichfield Cathedral, a zealous worker in the cause of music, and an oratorio singer of repute in the Midlands.

Cumming, Angus, Scottish violinist and composer who flourished during the latter half of the 18th century. He published "A Collection of Strathspey or Old Highland Reels, with a bass for the violoncello and harpsichord, by Angus Cummiug, musician, at Grantown in Strathspey," Ediuburgh, 1780. A second edition was published at Glasgow some time after.

Cummings, William Hayman, tenor vocalist, composer, conductor and writer, born at Sidbury, Devon, August 22, 1831 . Chor-

\section{CUMMINGS.}

ister at St. Paul's Cathedral in his seventh year, he was placed under William Hawes; afterwards entering the choir of the Temple Church, he studied under E. J. Hopkins, and, on leaving, was appointed organist of Waltham Abbey. While in the Temple choir, he sang amoug the altos in "Elijah," April 16, 1847. After some time he resumed his vocal studies under J. W. Hobbs, whose daughter he married, and soon gained a high position in the concert room, while holding appointments at Westminster Abbey, and the Chapel Royal. Hesang at the Birmingham Festival of 1864 , and at later celebrations; at the Three Choir Festivals, at various times from that at Gloucester, 1865 , to Hereford, 1879 , frequently taking important parts for other singers at the briefest notice. In 1870 , he appeared in opera at the Gaiety Theatre, and later at Drury Lane and elsewhere. Visited America in 1871. singing at the Festival of the Haudel and Haydn Society, early in the year; in "Elijah," at New York, October 31 ; and at various places on tour. He has heen heard at every important concert centre in the United Kingdon and Ireland, and has sung occasionally up to the last few years. In 1879 he became a professor of the R.A.MI., of which he is now an Honorary Nember; and later, joined the staff of the Guildhall School; and many years professor at the Royal Normal College for the Blind. In 1882, he was appointed chorus-master of the Sacred Harmonic Society, and afterwards conductor. He was precentor of St. Annes, Solıo, 1886-88. In 1884, he was elected F.S.A. He is Hon. Treasurer, and was orchestral director of the Philharmonic Society up to 1896; Hon. Treasurer of the Royal Society of Musicians; editor for the Purcell Society's publications; and conductor of the ammual festivals of the Royal Society of Mnsicians. In June, 1896 , he was elected Principal of the Guildhall School of Music. A learned musical antiquary, he has acquired one of the finest musical libraries in private hands, ospecially rich in early printed works and MSS., and is the possessor of the duplicate of Handel's antograph will. He lectured on "English Schools of Composition," at the Royal Institution, 1894, and has frequently lectured and given addresses before the Musical Association; the Incorporated Society of Musicians Conferences; the R.A.M., Trinity College, I,ondon, etc. Author of The Rudiments of Music (London, Novello, 1877), which bas gone through many editions, and has been translated into several languages ; Purcell (Great Musicians' series), Jondon, 1882. Biographical Dictionary of Musicians, London, Novello, 1892. Contributions to Grove's Dictionary of Music and Musicians, the Dictionary of National Biography, and musical periodicals. 


\section{CUMNINS.}

His Compositions include a cantata, The Fairy Ring, produced, St. James's Hall, May 24, 1872; Morming Service in D; anthem, O Lord, give ear ; Sunday part-songs (6 Nos.); part-songs; many songs: Yellow lie the corn rigs; Ask me no more; Hush thy sounds (with 'cello obligato), etc. Glees: O thou sweet bird (Abbey Glee Club Prize, 1850); with four other prize glees, etc.

His son, Norman Percy Cummings, bom at Dulwich, September 12, 1868, musically educated at home, made his début as a pianist at Dulwich College, July, 188t. He then studied at Leipzig, and on his return played at the Crystal Palace IVednesday Concerts, October 24, 1888. He has assisted at his father's lectures, and is professor of pf. at the Royal Normal College, Norwood.

Cummins, Charles, composer, pianist, and violinist, bom at York in 1785 . He studied under Dr. Miller, of Doncaster. Leader and violinist in theatres of the IVest of England. Wrote an anrount of music for dramatic pieces, and a pamphlet against the system of J. B. Logier. The date of his death has not been ascertained.

Cunningliam, Francis, musician. Published "A Selection of Psalm Tunes, adapted to a selection of psalms and hymns extraeted from various authors," London, 1826 ; and "A Selection of Psalm Tunes, designed to assist publie worship." London, 1834.

Currie, Rev. James, LL.D., musician and educationist, born April 24, 1828. He was Iiector of the Chureh of Scotland Training College, Edinburgh, for upwards of thirty years. Ile wrote The Elements of Musical Analysis, Edinuungl, 1858; A First Musical Grammar, Edinburgh, 1873. IVorks on Infant aud Secondary Education; School Songs, etc. He died at Edinburgh, September 26,1886 . A monmment to his memory was erected in Warriston Cemetery, Edinburgh, in 1890 .

Currie, William, violinist and composer, born about 1828; died at Peterhead, Decenber 1, 1881. He was blind. Composer of the "Miller of I)ron," and other reels.

Curtis, Thomas, musician. Compiled "Divine Amusenent, a selection of Psalms and Hymms as sumg in all the principal churches, chapels, ete." Iondon, n.d.

Curwen, Joln, musician and witer, was born at Heckmondwike, Yorks., November 14, 1816. Hducated at Coward College and London University. Ordained minister. Assistant minister at Independent Clrmeh, Basingstoke, Hants., 1838. Co-pastor at Stowmarket, Suffolk, 18ł1. Pastor at Plaistow, Essex, st4. Founded Tonic Sol-Fa Associatious, 1853. Established 'Junic Sol-Fa College, 1862. Resigned ministry, and devoted himself to propagation of the system,

\section{CURWEN.}

1867. Established "Tonic Sol-Fa Reporter," and publishing agency in London. He died at Heaton Mersey Ilouse, near Manchester, May 26, 1880.

Works.-An Account of the Tonic Sol-fa Metlod of Teaching to Sing, London, 1854; Gramunar of Tocal Music, with Lessons and Exercises founded on the Tonic Sol-fa method, and a full introduction to the art of singing at sight from the Old Notation, London, n.d.; Standard Course of Lessons on the Tonic Solfa method of teaching to sing, London, n.d.; Tonic Sol-fa instrumental instruction books; Harmonium and Organ ; Theory of Fingering; The First Pianoforte Book; Reed Band Book; Brass Band Book; String Band Book: separate Works, all London, n.d. Musical Statics; Art of Teaching, being the Teacher's Manual of the Tonic Sol-fa, n.d.; Ausical Theory, London [1879]; The Common-places of Music (Lectures), 10 parts, 1871-3; Primer of Tonic Sol-fa (Novello), n.d.; Music in IVorship and other papers on the People's Psalmody, Loudon, n.d.; The Plesent Crisis of Music in Schools, a Reply to Mr. Hullah, London, [1873]; The Child's own Ilymm-Book; How to Observe Hamony ; Construction Exercises in Elementary Composition; Arrangements, ete.

Curwen, John Spencer, son of the foregoing, was born at Plaistow in 1847. Studied at first under his father and G. Oakey; and later at R.A.M., under G. A. Macfarren, A. Sullivan, and E. Prout. A.R.A.M., 1879 ; F.R.A.MI., 1885. Associate of the Philharmonic Society. He has composed and arranged part-songs, etc., but his life has been devoted to the Tonic Sol-fa movement, and to the promotion of music in elementary schools. He was made President of the Tonic Sol-fa College in 1850, and has taken an active part in the festivals held at Stratford-le-Bow since their establishment in 1883 . 11e has lectured in many places in the United King. dom; visited the Continent, examining the various methods of teaching singing in schools; and in 1887 he made an extended tour in the United States, to enquire into the condition of music there. The results of these undertakings have been embodied in pamphlets, and in papers contributed to the Tonic Sol-fa Rejorter (now the Musical Herald) and other publications. He is author of Studies in Worship Music, London, 1880; a second series, London, 1885; Memorial of John Curwen, Loudon, 1882; Musical Notes in Paris, London, 1882; The Tonic Sol-fa System; a paper read before the Society of Arts, March 22, 1882, ete.

Curwen, Mrs., born Annie Jessy GeEGG, is a native of Inulin, where Trer father practised as a solieitor. Her first composition was published by friends when she was fomteen. 


\section{CUSINS.}

Studied at the Royal Irish Academy of Music, under Mr. and Mrs. Joseph Robinson and Sir Rubert Stewart. Practiced the musical profession in Dublin for some years, and afterwards resided in Scotland, where she first came in contact with the Tonic Sol-fa system. Applying its principles to pianoforte teaching and the Staff Notation, she wrote "The Child Pianist" (London, Curwen, 1866), a work now extensively adopted. She has lectured considerably on the subject. Was an adjudicator at the singing competition of Dublin Schools, 1893.

Cusins, Sir William George, Kt., composer, pianist and conductor, born in London, October 14, 1833. Chorister in Chapel Royal, 1843. Studied at the Brussels Conservatoire, from 1844, piano, violin and harmony. In 1847, he won a King's Scholarship at R.A.M., and was re-elected 1849, studying under Potter, Bennett, Lucas, aud Sainton. Played Mendelssohn's Rondo in B minor, with orchestra, at an Academy Concert at the Hanover Square Rooms, June 6,1849, and the same year was appointed to the Queen's Private Chapel, and entered the orchestra of the Royal Italian Opera. In 1851, made assistant professor at R.A.M., and later professor. Conductor Philharmonic Society, 1867-83; Master of the Queen's Music, 1870-93; Conductor of the London Select Choir, 1885. Professor, Guildhall School of Music, 1885. He conducted the performance of Bennett's oratorio, "The Woman of Samaria," at the Birmingham Festival, 1867. As a piauist, he played at the Gewandhaus Concerts, Leipzig, October 12, 1856; Berlin; at the Philharmonic and Crystal Palace Concerts; Rome, 1883; and at his own annual concerts, London, from 1885. He was elected Hon. Nember of the Academy of St. Cecilia, Rome, 1883 ; received the honour of Knighthood from the Queen, 1892 ; and the Cross of Isabella the Catholic, from the Queen of Spain, 1893. He died, suddenly, from influenza, August, 31, 1893, at Remonchamps, in the Ardennes.

Works.--Royal Wedding Serenata, 1863 ; Gideon, an oratorio (produced at the Gloucester Festival, 1871); Te Deum, for soli, chorns and orchestra (Sacred Harmonic Society, February 24, 1882); Jubilce Cantata, Grant the Queen a Long Life (State Concerts, 1887); anthems; Masonic prayers; Responses to the Commandments, \&c. Editor of, and contributor to, Songs from the published writings of A]fred Tennyson ; songs, and partsongs. Symphony in C, for orchestra (Sarasate Coucert, St. James's Hall, June 18, 1892); two concert overtures-Les Travailleurs de la Mer (1869); and Love's Labour Lost (1875); March, in honour of Prince Albert Victor (Albert Hall, January, 1885) ; Concerto

\section{CUTLER.}

in A Minor, pf. and orchestra; Concert, violin (MS.) ; Septet, for wind instruments and double-bass (1891); Trio in C Minor, $\mathrm{I}^{\mathrm{f}}$. and strings (produced at the composer's concert, June 14,1882); Sonata in A mincr, pf. and violin (1893); pf. pieces, \&c. Author of a pamphlet, Handel's Messiah, an examination of the original and of some contemporary MSS. (Augener), 1874, and contributor to Grove's Dictionary of Music and Musicians.

Custard, Walter Goss, oryanist, pianist, and composer, born, June $9,18 \pm 1$. Nephew of Sir John Goss. Articled pupil of Sir George Elvey, at Windsor, 1857. Organist of Spring Grove Church, Isleworth, 1861 ; Christ Chureh, St. Leonards-on-Sea, 1865, to the present time. Conductor, for some years, of the Hastings and St. Leonards Sacred Harmonic Society, and St. Leonards Vocal Association. Has given pianoforte recitals with much success. His works include The Office of the Holy Commumion, in E flat; Communion Service in F; Te Deum and Benedictus in F' Hymus, various. The Chorister's Daily I'ractice, London, n.d. Pianoforte--Short studies in all the major and minor keys; Twelve studies, op. 22; Nocturne in C minor; Ronaino in A, op. 17, \&c. Triumphal March for organ (with chorus); Songs, \&e.

Cutell, Richard, musician and writer of the fifteenth century, author of a treatise on Comnterpoint, preserved in the Bodleian Library, Oxford (MS. imperfect).

Cutler, Edward, amateur composer and litterateur, born at Cauons Park, the seat of his grandfather, Sir Thomas Plumer, Master of the Rolls, and was educated at Eton and Dresden. Well-known as a Q.C. and Chancery barrister, he is still more widely recoguised as a elever composer. He was for some time organist of Whitchurch, Edgeware; and in 1891 was appointed by the Prince of Wales grand organist of the Freemasons of England - the first amateur to hold that office. $\mathrm{He}$ gave a matinée at Erard's Rooms, February 23,1893 , with a programme of lis own compositions. He has composed a Scherzetto, and other pieces for orchestra; Romance for violin; Postlude in C, \&c., for organ; several pf. pieces. An Arab's Song; Child and Nother; The Rose Walk, and numerous other songs; and has contributed various articles to the musical press.

Cutler, William Henry, pianist, vocalist and composer, born at London, in 1792. He studied under Dr. Arnold and W. Russell, and made his debut as pianist with a concerto by Viotti, in 1800 . Chorister in St. Panl's Cathedral. Mus. Bac., Oxon, 1812. Organist of St. Helen's, Bishopsgate, 1818. Tanght Music by Logier's System. Organist of Quebec Chapel, Portman Square, 1823. He sang at the principal London concerts. 


\section{CUZENS.}

Works.-Church Musie; The I'salms, Te Deum, Jubilate, etc., used at Quebec Chapel, l'ortman Square, n.d.; Pf. music; funtasias, rondos, marches, duets, songs, etc.

Cuzens, Benjamin, composer and organist, who flourished about the end of the cighteentl century. He published "The Portsmonth Harmony," n.d. "Divine Harmony, containilig six anthem and a Christmas ude." Anthems, etc.

Cympson, Edward, eomposer and lyrie author of present time. Teacher of singing in London Board Schools, 1876. He has composed two sacred cantatas, "The Ruler's Danghter" (performed Greenock, 1888); and "The Angel of the Harrest" (London, 1892). Words for temperance songs, de.

Czapek, pssudonym of HATTON, JoHN LiptRuT.

\section{D'Albert, see ALberT.}

Dale, C. J., amateur organist and conduetor, born at Longton, Staffordshire, in Nay, 1812. Educated at Belper, Derby. Studied music with Mr. R. Sharpe (organist of St. Mary's, Sonthampton). Went to Londou in 1860, where he is engaged in business. He was organist of St. John's Square (Clerkenwell) Westeyan Church for nineteen years; of Finsbury Park Wesleyan Chureh for fifteen years; and is now Choirmaster of Holly Park Westeyau Church. Up to 1894 he was conductor of the Finsbury Choral Association, which he raised from small begimnings to a position of artistie importance. In 1889 be established the Metropolitun College of Music, which has fonrishing classes for Tonic Sol-fa and other students. Of this he is still the Principal, and Chairman of Corporation Committees. He has composed a Morning Service, some simple anthems, and a few hymn tunes. Musieal editor of "Psalns and Canticles pointed for chanting," London, Wesleyan Book-room, 1888.

Dale, Isaac, nusician and organist, eompiled "The Mona Melodist, a selection of J'salm and Hymm Tunes suited to all the variations of metrical psalmody, for congregational or family worship, newly harmonised for four voices, with an aceompaniment for the organ or pianoforte." Douglas [1842]. An excessively scarce book.

Dale, Joseph, composer and editor, born in 1750 . He was orgauist of St. Anthony and St. John Baptist, Watling Street, London. He died at Edinburgh, August 21, 1821. Author of "Dale's Collection of Sixty Favourite Scotch Songs, taken from the original manuscripts of the most celebrated Scoteh authors and composers, properly adapted for the German flute," Books I., II., and III., n.d. [1794]. Wrote an "Intro-

\section{DAMIAN.}

duetion to the Pianoforte, Harpsiehord, or Organ," op. 12, n.d. Thirty organ pieees, op. 11, n.d., and many works for pf., ete. Also a collection of Euglish songs.

Dale, Rev. Reginald Francis, clergyman and musician, bom at Sydenham, London, September 12, 1845. Edueated at Oxford, and graduated B.A. and Mus. Bae. in 1866. Clerk in Holy Orders, 1870. Assistant master in Westminster Sehool, 1870-1886. Reetor of Bletchingdon, Oxford, 1885. Joint author with the Rev. John Troutbeck of "Musie Primer for Sehools," 1873, etc ; and composer of hymn tunes, some of which appeared in "Twenty-two original Hymn Tunes, by two Oxford Graduates " [1867].

Dalglish, Robert, eomposer, born at Pollokshaws, Renfrewshire, July, 1806 ; died there, Angust 5, 1875. He was a weaver by trade, and self-edneated in music. Composed a number of anthems, glees, and psalms, of a somewhat feeble class, which were at one time regarded witl some favour in Glasgow.

D'Alquen, Frank C., see Alqu s, Frank C. D'.

Daly, William, violinst, born in Dublin, circa 1848. Settled in Edinburgh for many years, and teacher of the violin at Fettes' College there. Leader of the Edinburgh Quartet, which began giving ehamber coneerts in 1890. Author of a treatise on the violin, published in the " MIusical Edueator' (see Greig, John). His sou, Wrli mam, has eontributed a treatise on Musical History to the same publieation. JoHN DALY, violinist, bom in Dublin, August, 1851, is brother to Villiam Daly. Studied at R.A.M., Dublin, under Sir Robert Stewart and others. Resided for a tine at Glasgow; then in Manchester, where he was for some years in Halle's orchestra as a violin player; at present time in Glasgow as teacher and performer.

Dalyell, Sir John Graham, antiquary, was boru in 1776, and died June 7, 1851. He was edueated for the bar, and succeeded as sixth baronet of Bimus, Linlithgow, in 1841. In addition to a number of valuable historical and seientific works, he wrote "Musieal Memoirs of Seotland, with historieal ammotations, and uumerous illustrative plates," Edinburgh, 1849. This is now a scarce work, and is of some value as a eontribution to Scottish musical areheology.

Damian, Grace, contralto roealist, born at Brighton. Studied under Madame Sainton. Dolby. Made her debut at the Monday Popular Coneerts, January 12, 1880; and in the same year sang in "Elijah," and other works, at the Gloneester Festival. She also sang at the Leeds Festival, 1883, in Raff's "Find of the World"; and has been heard at the principal London and provineial concerts. 


\section{DAMION.}

In 1889, she was on tour with Madame Albani in the United States and Canada. She made her first appearance on the stage at Covent Garden, October 29, 1890, in "La Gio conda."

Damon, William, composer and organist, was born 1540 . Organist of Queen Elizabeth's Chapel. He died early in the seventeenth century.

Works.- The Psahmes of David in English Meter, with notes of foure parts set unto them by Gulielmo Damon, for John Bull, to the use of Christians for recreating themselves, instede of fond and unseemely ballades, 1579 [said to have been published by Bull, a goldsmith in London, without Damon's consent or knowledge]. The Former Booke of the Musicke of Mr. William Damon, late one of Her Majesties musitions; conteining all the Tunes of Dauids Psalmes as they are ordinarily soung in the church, most excellently by him composed into four parts, altus, cantus, tenor, bassus; in which sett the tenor singeth the church tume. Published for the recreation of such as delight in musicke, by W. Swayne, Gent. Printed by T. Este, 1591. The Second Booke of the Musicke of Mr. IVilliam Damon, containing all the Tunes of David's Psalmes, differing from the former in respect that the highest part singeth the Church tune, London, 1591. The tunes to which Damon gave harmonies are forty in number, and are the first psalms with harmonies published in England.

Danby, John, Englisl glee composer, was born in 1757 [1750]. He gained ten prizes from the Catch Club, for seven glees, two canons, and an ode, 1781-94. He was organist of the chapel of the Spanish Embassy, Nanchester Square, London, and died at London, May 16, 1798. Very little has been preserved concerning the biography of this musician.

Woriss. - Masses; Motets; Catches, canons and glees, for three, four, and five voices, in Score, four books, London, n.d. [c. 1785-98]; La Guida alla Musica Tocale: Op. 2, London [1787], n.d. Glees-When Sappho tuned (Smollett), three voices; When generous wine expands; When floods retire to the sea; The fairest flowers the vale prefer; Sweet thrush ; Shepherds, I have lost my love; Go to my Amna's breast; Fair Flora decks; Come, ye party jangling swains; Awake, Eolian lyre, four voices; Music has power; Soft pleasing pains unknown before; When beauty's soul; The nightingale; $O$ salutaris hostia, etc.

Dance, William, violinist, pianist, and composer, born 1755. He studied under Aylward, Baumgarten, and Giardini, and was a violinist at Drury Lane Theatre, 1771-74. He was leader at King's Theatre, 1775-93, and led the band of the Handel Commemo-

\section{DANIEL.}

rations in 1790 , etc. He was one of the founders of the Philharmonic Society, and acted as director and treasurer. He died at London, June 5, 1840.

Dance was a successful piano teacher in London, and composed sonatas, fantasias, variations, etc. His brother, George Dance (1741-London, January 14, 1825), was a painter and a Royal Academician. He was a singer and rocal composer.

Dando, Joseph Haydon Bourne, violinist, born in Somers Town, London, in 1806. Studied under his uncle, Gaetano Brandi, and then for seven years under Nicolas Mori, 1819-26. In 1831, he became a member of the Philharmonic Orchestra, and remained so till 1855 . He was also in all the leading orchestras, and in those of the Birmingham, Three Choirs, and other festivals. He anticipated the Concerti da Camera, started November 7,1835 , by giving a chamber concert of a similar type at the Horns Tavern, September 23 of that year. In 1836, he joined Blagrove, Gattie, and Lucas in chamber quartet concerts, at the Hanover Square Rooms, the first taking place March 17, Dando playing viola. Ilis claim to the introduction of public performances of the string quartet cannot be maintained, as they were played from the date of the first Philharmonic Concert, March 8,1813 ; and at the British Concerts, given in the ball-room of the Argyll Rooms in 1823. But Dando did good work in his day, up to his retirement in 1875 . His appointment as music master to the Charterlouse Schools he held from 1875 almost to the time of his death, at Godalming, in May, 1894.

Daniel, Albert Edward, composer and pianist, born in Birmingham, November 9, 1862. Studied privately under several masters, but owes much to his own unaided exertions. F.R.C.O. 1885. Has appeared as pianist and organist, giving recitals in the Birmingham Town Hall and other places. Increasing deafness lias put a stop to a promising public career, and his time is now chiefly devoted to teaching.

Works.-Two masses; a Harvest Cantata, performed 1888-9, but remaining in MIS., and other church music; Choral song, The Summer Rain, produced by the Birmingham Festival Choral Society, April, 1891 ; A comic operatta, MS; many songs, ete. Two concert overtures, orchestra; Quintet and trio, pf. and strings; Quartet, strings; Fantasia, Clarinet and pf.; Sonatas for organ and pianoforte, and various pieces in smaller forms

Daniel, John, musician, was boru at Aberdeen, in 1803. He studied music under John Ross, and was a music-teacher in Aberdeen for a number of years. He was also precentor of St. John's Church, Montrose, 


\section{DANIEL.}

about 1833, and in 1843 he settled in New York as a teacher. He died at New York, June 21, 1881. He edited "The National Psalmody of the Churcl of Scotland, a collection of the most esteemed psalm and hymn tunes ..." [1837], 2nd ed. [1843]. Composed, also, part-songs, songs, and pf. music. James Daniel (Aberdeen, July 24, 1810February 17, 1889), probably a brother of the foregeing, was a music-engraver and editor. He issued "A Collection of Reels, Strathspeys, slow airs, etc," Aberdeen [1840].

Daniel, Rev. Richard Blackburne, curate of Tickenhall, Derby, 1878, and formerly organist of the parish churches of St. Mary Bredin and St. Mary Bredman, Canterbury. Author of "Chapters on Church Music," London: Elliot Stock, 1894.

Danneley, John Feltham, writer, pianist, and composer, born at Oakingham, Berkshire, 1786. He studied under C. Knyvett, S. Webbe, Woelfl, and C. Neate. Resided in Hampshire as teacher till 1812. Organist of Church of St. Mary of the Tower, Ipswich, 1812. Visited Paris, and studied under Reicha and Pradher, 1816. He died at London, 1836.

Works.-A set of twelve Italian duets: Glees and songs; Pf. music. An Introduc. tion to the Elementary Principles of Thorough Bass and classical music, Ipswich, 1:20; An Encyclopedia, or Dictionary of Music, London, 1825; A Musical Grammar, comprehending the principles and rules of the science, London, 1826.

Danyl, or Daniel, John, composer, of the latter part of the 16th and beginning of the 17 th centuries. He is supposed to have been the brother of Daniel, the poet, and was a Bachelor of Music, Oxon., 1604. He published "Songs for the Lute, Viol, and Toyce," London, 1606, and others of his compositions are preserved in MS.

Darnton, Charles, organist and composer, born in London, October 10, 1836. Many years organist of Park Chapel, Canden Town. Composer of the sacred cantatas, "The Star of Bethleham" (1893); "The Song of Creation ;" "Abraliam " (1895); "Spring-time and Harvest" (1895). Pastoral cantata, "Village Life," performed, London, 1891. Anthems for Church and Home; various anthems, etc.; Sacred songs. Compiler of "Comprehensive Psalmody" (Londori, 1866).

Dart, Henry John Baker, organist, horn at Torquay, March 5, $185 \mathrm{t}$. Chorister at St. Luke's (hurch there, 1866-8; organist, St. Michael's Mission Chureh, 1868; and Christ Church, Ellacombe, 1873. In 1875 he removed to London, and later on studied at the London Academy of Music, under Dr. E. J. Hopkins, J. F. Barnett, and E. H. Tur'in, his earlier teachers having been Charles Fowler and T. Craddock. Conductor, 1877-80, of

\section{DAVENPORT.}

the North London Philharmonic Society, at the concerts of which more than one important work was given for the first time in London. In 1879 he was appointed organist of St. John's, Waterloo Road, where he organised the series of recitals and oratorio performances that became famous. In 1893 he resigned that post for the parish church (St. James's), of Paddington, where he is still in office. He is A.R.C.O. and Professor at the London Academy of Music. He has written a Sonata for organ and trombone, performed at St. Johu's, February, 1884; Concert allegro for organ. A setting of Psalm 84, for soli, chorus, and organ, was produced at the Church of St. John, March, 1893. A morning and evening Service in D is published.

Darwall, Rev. John, clergyman and composer, was born at Haughton, Staffordshire, in January, 1731. He was educated at Manchester and Oxford, where he graduated in 1756 . In 1769 he became vicar of Walsall, and died there December 18, 1789 . He composed the Psalm tune, "Darwall's" and many others not so well kuown.

Dauney, William, musician and antiquary, boru at Aberdeen, October 27, 1800. Educated at Dulwich and Edinburgh University. Called to the Scottish Bar, 1823. Solicitor-General for British Guiana, at Demerara, 1838. He died at Georgetown, Demerara, July 2s, 1843.

Work.-Ancient Scottish Melodies from a manuscript of the reigu of King James VI., with Iutroductory Inquiry (Skene Manuscript), Edinburgh, 183\%.

In the preface to this work, Dauney covers an amount of ground previously unattempted either by Tytler, Ritson, or Stenhouse, and displays much judgment and learning in the general handling of his subject.

Davenport, Francis William, composer, born at Wilderslow, near Derby, 1847. Educated at University College, Oxford. Pupil of Sir G. A. Macfarren, whose son-in-law he afterwards became. Appointed Professor of Harmony and Composition, R.A.M., 1879, and subsequently elected an Honorary Member of the same. He is also a Professor at the Guildhall Sehool of Music. IIis compositions number two Symplonies in D minor and $G$, the first wimning the prize in the Symphony Competition at the Alexandra Palace, 1876. Also an overture, "Twelfth Night," produced at the Viard-Lonis Concerts, St. James's Hall, February 18, 1879; and a prelude and fugue for orchestra, performed at the Crystal Palace, November 1, 1879. His other works include a trio in B flat, op. 5 , for pf. and strings (Monday Popular Concerts, January 31, 1881); six pieces for $p f$. and violoncello; French songs, for children; 


\section{DAVENPORT.}

songs and part-songs. Author of "Elements of Mlusic "(Longman, 188t); "Elements of Harmony and Counterpoint" (Jongman, 1886); "A Guide for Pianoforte Students" (jointly with Percy Baker), Longman, 1891.

Davenport, Uriah, composer and writer of the latter part of last century, and teacher in London, compiler of "The Psalm-Singer's Pocket Companion, containing a new introduction, with such directions for singing, as is proper and necessary for learners," London, $1755 ; 2$ nd ed. 1758 ; 3rd ed. 1785 .

Davey, Henry, pianist and writer on music, born at Brighton, November 29, 1853. $\mathrm{He}$ acquired the first rudiments of music through the Tonic Sol-fa method; and studied for three years at the Conservatorium, Leipzig. Resident in Brighton as teacher. $\mathrm{He}$ is a Scholar, and his work is not confined to music, as he is librarian of the Brighton and Sussex Natural History Society, and active in other ways. He is author of "The Students' Musical History, " Lond., Curwen [1891]; "History of English Music," 1895; and has contributed articles to the "Dictionary of National Biography," and to the musical press.

Davidson, Peter, Scottish violinist and writer, was born about 1834. Author of "The Violin: a concise exposition of the general principles of construction, theoretically and practically treated," Glasgow, 1871. Second edition, London, 1880 , with lives of the most eminent artists and dictionary of violin makers, and lists of violin sales. In 1886 Davidson went to America. He is reputed to have dabbled in occult science and to have made magic mirrors.

Davidson, Thomas, Scottish musician of the 17 th century, was appointed teacher in the Music (or Song) School, Aberdeen, in 1640. This position he must have held till far on in the century, as we find from the Burgh Records of Aberdeen, that on January 16, 1666, he received an angmentation of his salary, making it 250 merks. He is chiefly celebrated as the editor of "Cantus, Songs, and Fancies. To Thre, Foure, or Five partes, both apt for voices and viols. With a brief Introduction of Musick, as is taught by the Musick-Schole of Aberdene, by T. D., Mr. of Musick," Aber. deen, printed by Joln Forbes, 1662. Seeond edit., 1666. 'Third edit., 1682. Reprint, New Club Series, Paisley, 1879. The three cditions of the "Cantus" differ slightly in respect of several omissions and insertions It was the first secular music-book published in Scotland, and consists chiefly of English and foreign melodies, some by Gastoldi, or imitations of them, arranged. All these editions are extremely searce and valuable.

Davie, James, violinist, fute-player, and composer, born about 1783 . He resided in

\section{DAVIES.}

Aberdeen as a teacher, and member of the Aberdeen theatre orchestra. He was choir. master of St. Andrew's Church, Aberdeen, and conductor of Aberdeen Choral Society. He died at Aberdeen, November 19, 1857.

Works.-Music of the Chureh of scotland, being a numerous selection of Psalm and Hymm Tunes, Ancient and Modern, in Four Vocal Parts, with an Instrumental Accompaniment . . To which are prefixed Remarks on Church Music, etc., Aberdeen, 8vo., [1841]. The Chorister . . Psalm and hymn tunes . . arranged in four parts, Aberdeen, n.d. A Compendious Introduction to the Art of Singing, comprising the most useful scales and examples, Aberdeen, n.d. The Vocal Harmonist, a Collection of Duets, Trios, Glees, etc., n.d. Caledonian Repository of the most favourite Scottish slow airs, MIarches, Strathspeys, Reels, Jigs, Hornpipes, etc., expressly adapted for the Violin. Aberdeen and Ediuburgh, Svo., about 1829-30 [six books]. Scales for the Voice. Songs, etc.

Davies, Ben, tenor vocalist, bom at Pontardawe, near Swansea, in 1858. Craining a reputation locally, he decided upon his profession, and enrered the R.A.M., studying under Randegger. In 18so, he won the Evill prize for declamatory singing, and was elected an Associate. He joined the rarl Rosa Company, and made his operatie début at Her Majesty's Theatre, as Thaddeus, in "The Bohemian Girl;" sang for a long period in Cellier's "Dorothy ;" in the title part in sullivan's "Ivanhoe" on its production; and in Augustus Harris's Company, 1892. He first appeared at a Festival, at Cardiff, 1892, in Drorák's Stabat Mater; sang at the Norwich Festivals of 1893-96; Leeds, 1895 ; and Bristol, 1896. Sang with great suceess in Chicago, 1893, and Berlin, 1894; as well as at all important concerts in the United Kingdom, standing in the first rank of artists. In 1885, he married Miss Clara Perry, a soprano singer, who was for some time a member of the Carl Rosa Company. She sang in the provinces at first, and appeared in London as Arline, March 27, 1883, at Drury Lane.

Davies, Cecilia, vocalist, born in 1752 $[17+0]$. Travelled in France and Italy, and sang with success. Debut in Isondon, 1773, in Sacchini's "Lucio Vero." Sang in London and on Continent, till 1791. She died at London, July 3, 1836. Mer sister Marianne (born 1736, died 1792), was an harmonicaplayer, ana appeared with her sister in public. She was a skilful performer on her instrument.

Davies, Clara Novello, pianist, conductor and teacher, born at Cardiff, April 7, 1861. Daughter of Jacob Davies (noticed below), by whom she was principally taught. Began as accompanist and teacher of the pianoforte. About 1884 she formed a ladies' 


\section{DAVIES.}

choir, and gave concerts at Cardiff for some years. The reputation of the choir rising, tours were undertaken, and performances giveu in Loudon, from 1890; in Birmingham, 1892 ; and on tour with Madame Patti. In 1893 Madame Davies took her whoir to Chicago, and won the gold medal in the competition for ladies' voices. On her return she was, with her choir, commanded to sing before the Queen, at Osborne, February, 1894. She is the head of a Music Institute at Cardiff. In 1882, she married Mr. David Davies, of Cardiff.

Her father, JACOB Davies, born at St. Fagaus, in 1840 , is a well known musician and conductor. The Blue Ribbon Choir became famons under his direction, and won many prizes. He now conducts the Cardiff Glee Society, and is resichent in that town.

Davies, David Ffrangcon, baritone vocalist, born at Bethesda, Carnarvonshire, December 11, 1860. He reeeived his first musical instruction from his father, an ama. teur; but he was originally intended for another profession, and educated at Oxford, graduating B.A. and 11.A. Deciding to become a singer, he entered the Guildhall School of Music, and studied under Richard Latter, afterwards becoming a pupil of W. Shakespeare. He made his first appearance in January, 1890, at Mr. De Jong's coneerts, in Nanchester; saug in the title part, in "Elijah," at the IIovingham (Torks.) Festival the following October ; at the Monday Popular Concerts, November 3; and in the "Messiah," at Birningham, December 26. His Festival dibut was at IIanley, in October, 1893, where he was engaged again, 1896; and he sang at the Cardiff Festival of 1895 . In opera he has appeared at times from 1890, in "Faust," "Lohengrin," de., and created the part of Cedric in Sullivan's "Ivanhoe." In the Spring of 1896 he toured with great success in the United States; and as an oratorio singer, especially, now occupies a foremost position.

Davies, Fanny, pianist, though hom in Guernsey, June 27, 1R61, is connected with Bimingham by family aud early residence. Her first teachers were Miss Welchman, Charles E. Flavell, and A. R. Ganl (hamony), all of Birningham. Studied at Leipzig, 1882-3, under lieinecke, Oscar Panl, and Jadassohn; at Franlifort, 1859-5, with Madame Sehumann and Beruhard Scholz. She made her first appearance, on her leturn to Lngland, at the Crystal Palace Concerts, Octolver 17, 1885, playing the solo part in Beethoven's concerto in G; on Norember 16, she played at the Mouday Popular Concerts; at the Saturday Concerts, November 28. She then played at Manchester, Glasgow, aud other places, making her Birminghan début, March 30, 1\$80, since which time she has annually given a recital, or concert, with Joachim and Piatti, in that

\section{DAVIES.}

city. She played at the Philharmonic Concerts, April 15, 1866, choosing Bennett's concerto iu C minor; and has given recitals in London and many places. She has played in the old and new Gewandhaus, Leipzig, 1887-8; at Berlin, and Rome, 1890, and before several reigning Sovereigns; and has achieved a high position, being regarded as a specially fine interpreter of the music of Schuminn.

Davies, H. Walford, eomposer, studied at R.C.MI., and while there produced a number of important works. He has written a Symphony, produced at the Crystal Palace, October, 1895; an ovcrture, quartets, for strings, and pf. and strings; sonata, for pf. and violin. Also a choral ballad, "Hervè Riel," poem by Browning. In 1894, he won the Bristol Orpheus Suciety's prize with his glee, "The Sturdy Rock," and he has written other vocal music. In 1895 he was appointed a Professor at the R.C.MI

Davies, Hugh, organist and composer of early part of the 17th century. 11e was organist of Hereford Cathedral, and in 16:3 he graduated Mus. Bae., Oxford. He died about 164t. Composer of Church musie, none of which has been preserved.

Davies, Llewela, pianist and composer, born at Brecon, Sonth Wales. Gained admission to the R.A.M., 1887, by winning the John Thomas (Welsh) Scholarship. Pupil of Walter Macfarren for pf., and of Stewart Macpherson for harmony and composition. Her career at the Academy was distinguished, and she took, among other prizes, the Macfarren Scbularship, 1892 ; The Lncas Medal, 1894 , both for composition. In 1893 she was awarded the Medal of the Worshipful Company of Musicians. She appeared as solo pianist at the Hereford Festival chamber concerts in 1891, and 1894, and has played at concerts in St. James's Hall, Qneen's Hall, and the Covent Garden Promenade Concerts. Her compositions comprine Three sketches for orchestra; A quartet for strings ; Sonata, produced by the Musical Artists' Society, March, 1894, pf. and violin; and a number of songs.

Davies, Miss, see sub BattishiLL, JONATHAN.

Davies, Margaret, soprano vocalist, born at Dowlais, South Wales. Sang in public from ten years of age. In 18.66 gained a Scholarship at 12.C.M., and while a student there appeared with success at the Crystal Palace Concerts, April 5, 1890. She sang at the Cardiff Festival in 1892; luas been heard at many of the best concerts; and was chosen for the part of Kitty O'Toole at the production of stanford's Opera, "Shamus O'brien," March 2, 1896.

Davies, Mary, soprano vocalist, born in London, of Welsh parents, February 27, 1855. 


\section{DAVIES.}

Educated in the Home and Colouial Schools, Gray's Inu Road. Singing at Welsh concerts in London, she attracted the notice of Brinley Richards and Edith Wynne, both of whom gave her instruction. She won the Welsh Choral Union Scholarship in 1873, and studied at the R.A.MI., chiefly under Randegger, winning the Parepa-Rosa Gold Medal, 1876, and the Nilsson prize, 1877. In $187 \mathrm{~S}$ she appeared with success at the Worcester Festival; also sang at Gloueester, 1883, and at Norwich and Chester Festivals. She sang in the first complete performances in England of Berlioz' Faust, at the Halle concerts, MIauchester, Narch 11, 1880, and at St. Janies's Hall, May 21. As a ballad singer she is best known, and has sung at the principal concerts throughout the country. She has been eleeted, first an Associate, then a Fellow of R.A.M. In 1888 , she was married to Mr. W. Cadwaladr Davies, of the Inner Temple.

Davies, Rev. Owen, Eos Llechyd, composer, born at Jlanllechid, Bangor, September, 18.28. In years past a sueeessful Eisteddfodie eompetitor. Has devoted his attention ehiefly to Church music; and his anthems are held in mueh esteem. He has been a zealous worker in the cause of music in Wales, and is still living.

Davis, Gabriel, composer and vocalist, was a native of Bath, where he was born, about 1770. He was choirmaster of a Baptist Chapel at Portsea early in the present eentury. Composer of "Saered Music, two hymns on the nativity of Christ, and forty psalm tunes," London, 1800 ; Ode for Christmas Day, etc.

Davis, Mrs. Gabriel, bom Marianne Davis, composer of a large number of partsongs and songs. She died at Littlemore, Oxford, July 18, 1888. Among her eompositions may be named-By the river; Dama Trot; Dame Wiggins of Lee; King Carnival; Three Stars; Zingara; Four-part songs, ete.

Davis, Miss, an Irish composer of the present time, has written a large number of sacred and secular songs, anets, etc. Among her songs may he named-The arrow and the song; Better land; Old clock on the stairs; Ruth; Song of the bell, etc.

Davis, J. D., composer and pianist, born at Edgbaston, Birmingham, October 22, 1867. Was musieal from childhood, but in $18 \times 2$ was sent to Frankfort-on-the-Main to study German, with a view to business pursuits. While there he entered the Conservatorium, and had lessons from Hans ron Bülow. In 1883, he went to Brussels, and took up the study of musie in earnest, under Zarembski, Kufferath, and Arthur de Greef. Returning to Birmingham, in 18s, he gave himself up to composing and teaching. His works include an opera, " The Zaporogues," produeed by amateurs at the Theatre Royal, Birmingham, May T, 1895;

\section{DAWBER.}

Legend, "Hero and Leander," for bass solo and orchestra; songs and part songs. A suite, overture, and nocturne for orchestra - the last given at Mr. Stockley's eoncerts, January, 1892 ; Sonatas for pf. and violin, pf. and eello., and pf. solo; six pieees for pt. and violin (Novello's Album); two suites for same; pieces for pf., etc.

Davison, James William, composer and writer, bom at London, Octuber 5, 1813. He studied under W. H. Holmes and (Sir) G. A. Macfarren. Married Miss Arabella Goddard, 1860. Musical eritic of the Times and Musical Ilorld. He died at Margate, Nareh 24 , 1885.

Works. - An Essay on the Works of Frederic Chopin, London [1849?, 11 d. Sonys - Swifter far than summer's flight; The light canoe; Poor heart, be still ; Sweet village bells; The lover to his mistress ; False friends, wilt thou smile or weep? Piunoforte Music-Four Bagatelles à la valse, op. 4 ; First Sonata, op. 6; Tarantella, op. 7 ; Three Sketches, op. 8; Romance, op. 11. Dramatic Overture to the fairy tale of "Fortunatus," for pf. duet. Contributions to periodical literature. Contributions to Grove's "Lictionary of Music and Mnsicians."

Davison, (Mrs. J. W.), See GODDARD, Arabella.

Davy, John, composer, was born at UptonHelions, Exeter, Deeember 2:3, 1763 . Articled to Jacksun of Exeter, 17T7. Resided in Exeter as teaeher. He afterwards becane a violinist in the orchestra of Covent Garden Theatre, and a teacher and composer in London. $\mathrm{He}$ died in st. Martin's Lane, London, February 22,1824 , in extreme indigence, having outhived all his kindred.

Worrs.-Music to Plays, ete.-What a blunder! 1800; Perouse (with J. MInorhead), 1801 ; Brazen mask, ballet (with Mountain), 1802; Cabinet (with Braham), 1802 ; Caffres, 1802 ; Rob Roy, 1803 ; Miller's maid, 1s04; Harlequin Quicksilver, 1,04; Thirty thousand (with Reeve and Braham), 1803 ; Spanish dollars, 1805; Harlequin's magnet, 1805; Blind boy, 180s; Famer's wife, 1814; Rob Roy Macgregor (new version), 1818; Woman's will, a riddle, 1820. Overture to shakespere's Tempest. Six quartets for voices, in score, with figured basses for the pf., op. 1, n.d.; Six madrigals for four voiees, op. 13 [c. 1810]. Beauties of Handel, 6 vols., n.d. Songs-Bay of Biseay, O mighty Bacehus. Beggar boy, Brave marine, larling Sue, Harvest home, Milkmaid, Smuggler, Son of old Saturu, ete. Single and double chants, various. Anthem, Lord, who shall dwell, op. 9.

Davy, Richard, composer of the 16th eentury, sonle of whose works are in the British MIusem, among the Fayrax MSS.

Dawber, James, organist, born at Wigan, 


\section{DAWSON.}

September 18, 1851. Received his musical training at Henshaw's Blind Asylum, Manchester, 1864-9, and then studied under (Sir) Walter Parratt for two years. Graduated Mus. Bac., Cambridge, 1878. Settled in Wigan as teacher, organist, and choirmaster, St. Paul's Congregational Church. To Mr. Dawber is due the inception of the movement which resulted in the formation of what is now known as the Incorporated Society of Musicians, and he was its first Secretary, 1882. He has given chamber concerts, and has published songs and part-songs.

Dawson, Charles, author of "Analysis of Musical Composition, showing the construction of all Musical pieces, together with a concise and comprehensive system of Harmony," London, 1845. "Elements of Music, condensed for the use of students of the pianoforte," London, 1844.

Dawson, Frederick H., pianist, boru at Leeds, July 16, 1868. At the age of five he began his studies under his father, William Dawson, a pianist of repute; and when ten he was taken to (Sir) Charles Halle, who at once recognised his great ability. From Rubinstein, a few years later, he also received encouragement. As a juvenile prodigy, he played a great deal in public in the north; but his first important engagement was at Ed. Haddock's concer'ts, Harrogate, in October, 1885. He appeared at the Halle Concerts, Manchester, December, 1890, and made his London début April 18, 1891, at a chamber concert of Willy Hess. Gave recitals at St. James's Hall, 1891; appeared at the Monday Popular Concerts, January 8, 1893 ; at the Crystal L'alace, February 23, 189; ; and at the Philharmonic Concerts, March 20, of the same year. He is now recognised among the leading pianists of the day.

Dawson, W. H.C., musician, compiled "Psalm and liymn tunes, in score, for four voices," n.d.

Day, Alfred, physician and musician, born at London, in January, 1810, and died there February 11, 1849. Author of a "Treatise on Harmony," London [1815], n.d. His work on harmony advocates many alterations in theory, and a number of technical terms, most of which have been adopted by Macfarren and other's.

Day, Alfred H., organist, of present time. He held an appointment at Kimberley, Sonth Africa, and went thence to Graham's Town, where he was appointed to the Cathedral. There he estahlished a College of Music. In 1893 he was appointed borough organist, and conductor of the l'hitharmonic Society at Maritzlourg, Natal, where he remains.

Day, Captain C. R., writer on music. Son of the Rev. Russell Day, of Horstead, Norfolk; born in 1860. Educated at Eton,

\section{DAY.}

and studied music under the late Sir Joseph Barnby. Entered the Oxfordshire Light Infantry (the old 43rd) in 1882, and served in India until 1887. Was severely wounded in the operations against the Moplas in 1885. Married, in 1892, Katherine, daughter of Mr. Scott-Chad, of Thursford Hall, Norfolk. His principal works are: "The MIusic and Musical Instruments of Sonthern India and the Deccan," Londor, Novello, 1891; and "A Descriptive Catalogue of the Musical Instruments recently exhibited at the Royal Military Exhibition, London, 1890" (Eyre and Spottiswoode, 1891). These are both important and valuable books. He contributed an article on African Musical Tustruments to Ferryman's "Up the Niger," 1892. Author of several papers and brochures on National and Military Nusic, read at meetings of the Musical Association (1894), etc. I. was a Member of the English Committee of the Vienna International Musical and Dramatic Exhibition of 1892 .

Day, Ellen, pianist, born in London, March :3, 1828. Studied under her father, William Day $\left(q . \iota^{\circ}\right)$, Henry Westrop, and Fduard Schulz. Her first appearance was at Drury Lane Theatre, in 1836 , when she played a fantasia by Hïnten, with orchestra, Mori leading. In 1838 she played at a concert given by Thomas Baker, violinist, in Windsor Town Hall; and the next evening played, by command, before the Queen at Windsor Castle. The same year she played in London with Teresa Nilanollo, in June. Then, for some years, she appeared in conjunction with her brother John (q.v.) When Mendalssohn was in London, in 1844, she was invited to his house to play to him, and highly complimented by him. At the first concert the two young artists gave, June 16, 1846, Ellen Day played a pianoforte duet with Vincent Wallace. She continued to play in pablic for many years, in London and the provinces, and still retains lier powers of execution. For about thirty years the has been an organist, first at St. Mlattinew's, and to the present time at Christ Church, IVestminster. Balfe was her staunch friend, and she was instructor of his two daughters for some years.

Day, John, publisher and editor, was born in St. Peter's parish, Dunwich, Suffolk, in 1522. He was established at Holborn, London, in 1549, as printer and publisher. He died at Walden, Essex, July 23, 1584. He published Damon's Psalmes of Tavid, in English meter, 1579, and a work bearing the title "The Whole Booke of l'salmes, collected into English metre by T. Starnhold, I. Hopkins, and others; conferred with the Ebrue, with apt notes to synge therewithal, faithfully perused and alowed according to the ordre appointed in the Quene's maiesties injunctions,".... 
DAY.

London, 1562. In 1563 he issued the first English psalter with music in four parts, and in 1565 another edition was issued. The title is "The Whole Psalmes, in foure parts, whiche may be sung to al musical instrumentes, set forth for the encrease of vertue, and abolishying of other vague and triflying ballads," London, 1563.

Day, John, composer, who flourished at end of last, and beginning of the present century. Composer of "Harmonica Lyrica, selected from the poems of M. T. Scott, and adapted for organ or pianoforte," 1820.

Day, John, violinist, brother of Ellen Day (q.v.), was born in London, March 7, 1830. Studied under his father, and first appeared at the Hanover Square Rooms in 1838. With his sister, he was, early in the forties, engaged by M. Jullien, and they performed at the Lyceam, Covent Garden, and on his provincial tours. In 1843, the pair visited Brussels, and De Beriot took the young violinist to his home as a pupil, afterwards passing him into his class at the Conservatoire. On his retmm home he made his début at the Philharmonic Concerts, June 23, 1845, playing two movements of De Beriot's second concerto. He played at the Norwich Festival, in September, and at the second concert of the Bimingham Festival Choral Society, October 30, of the same year; and engagements followed at every important musical centre. He entered the Queen's private band in 1817, and is now the senior member. He was appointed organist of New Upton rhurch, Slough, in 1853; of Old Upton Church shortly afterwards, resigning in 1857. Two years later, he went to All Saints', Fulham, where he remained until 1869. For the last forty-five years his hobby has been the making of copies of violins by the old masters. 'These have been pronounced by competent judges to be equal to the originals. See "Violins, old and new," Reeves, reprinted from the Musical standard.

William DaY, father of the above, was a violinist of some reputation. He acted for many years as leader at Drury Lane Theatre. Died in London, IIarch 3, 1851.

Day, W, , musician, compiler of "Sacred Harmony," Madras, 1818.

Deacon, Harry Collings, vocalist, teacher, and writer, born london, 1822 . He studied pf. under Cip. Potter, and singing under Mazzucato the elder. He lost his voice while he was studying at Milan, and he afterwards resided in London as a teacher and pianist. He trained Anna Williams, Herbert Thorndike, etc. One of the contributors to Grove's "Dictionary of Music." He died in London, February 24, 1890. He composed "Anacreon's Grave," a four-part song; Contemplation; Ethel; Nay-time; Only once
DEAKIN.

more; Over the crisp white snow; Sing to me; and other songs. First set of 24 studies for the pf., London, 1864; Tarantella, for the pf., etc.

Deacon, Mary Ann, pianist, organist, and teacher, born at Leicester, June 26, 1821. Began the study of music at the age of six. and in 1838 began, at Leicester, her career as a teacher, which was successfully maintained until her retirement a year or two ago. Though not conspicuously public, Miss Deacon's life has been one of consistent usefulness to the cause of music in Leicester, and the locality. For twenty years she was organist a.t St. Mary's Church, and officiated for ten years at two Congregational Churches. From 1842 onwards she has appeared as vocalist or piauist at many concerts; assisting at Mr. Oldershaw's lectures; training choirs for oratorio performances; and being intimately associated with the musical work of that enthusiastic amateur, the late Villiam Gardiner. In May, 1896, a complimentary concert was given to her by all the musical societies in Leicester, on which occasion she played in a duet for $p f$. and flute, with $M r$. Henry Nicholson, a life-long friend and colleague in art. On October 28, 1896, she was publicly presented with a portrait of herself, and a sum of money; the latter she placed in trust for founding a "Deacon prize" for students resident in Leicester.

Deakin, Andrew, organist, and critical writer, born in Birmingham, April 13, 1822. Began to study music at a very early age, and, entirely self-tanght, became a creditable vocalist, organist, and violinist. Served a strict apprenticesbip to the printing trade, and printed, in 1845, the Birmingham Musical Excminer, edited by James Stimpson. After some years service as organist at different places of worship, he was appointed to the Church of the Saviour (founded by George Dawson, the great preacher and lectnrer), in 1847 , a post he held until 1878. As early as 1849 he began writing nusical criticisms for newpapers, and when the Birmingham Moming New's was started in 1871, he was appointed its musical critic. In 1876 he joined the Birmingham Daily Gazette in a similar capacity, resigning the office towards the close of 1894. A diligent student of everything appertaining to music, he is recognised as an authority, and his services are much in request as an annotator of concert programmes. He has composed hymn tunes, chants, and anthems, and among larger works a Stabat Nater for solo voices, chorus, and organ, and a "Miserere," have heen performed at the Church of the Saviour. In 1846 he compiled and published "Euphonia," one of the very earliest collections of music for nonconformist public worship; a work that exerted 


\section{DEAN.}

more than a local influence. A recent publication is a "Musical Bibliography, a catalogue of historical and theoretical works published in England, from the 15th to the 18th centuries," Birmingham, Stockley and Sabin, 1892; a companion work on a large seale, dealing with the music of the same periods, is in preparation. Mr. Deakin is also known as a landscape painter and etcher, and some forty years ago his name was often seen in the catalogues of London and proviucial exhibivions

Dean, J., author of "Guide and SelfInstructor for the Violin," London, 1853.

Deane, Thomas, composer and organist, who flourished during the end of the 17th and first half of the 18th centuries. He was organist at Warwick and Coventry, and lecame Mus. Bac. and Doc, Oxon, 1731. He composed music for Oldmixon's " Governor of Cyprus," contributed to the "Division Violin," and was the first to introduce Corelli's Sonatas to England.

Dearle, Edward, organist and composer, born at Cambridge, March 2, 1806 . As a boy he was a chorister in King's, Triuity, and St. John's Colleges, Cambridge, and having studied the organ, obtained his first appointment at St. Paul's Deptford, 1827. He was successively at Blackheath parish church, 1830; Wisbeach parish church, 1832; st. Mary's, Warwick, 1833; organist of the parish church and master of the song school, Newark, 1835-64. While at Newark he graduated Mus. Bac., 1836, and Mus. Doc., 1s42, Cambridge. In 1864 he removed to Camberwell, where he continued to reside. He was one of the founders of Trinity College, London, and took an active interest in the welfare of the musical profession. An occasional contributor to the press, he wrote iu 1850 , a series of letters on organisation, anticipating in a remarkable manner the formation of the Incorporated Society of Musicians. He died at Camberwell, London, March 20, 1891.

Wonks - Israel in the Wildemess, oratorio (published 1579); Morning and evening service in $\mathrm{F}$ (1882); Morning and evening service (1852?); A rolume of church music (1838). Anthem, Tum 'Thee again, Thon God of Hosts (Gresham ['rize, 1537); The desert shall rejoice; liend your hearts; Four anthems (1852), ete. Thirty-six chants (1852). Sungs - Tays of the heart (1so9), etc. Part-songs -

Sigh no more, ladies; Nountain Daisy, and others. Andante Cantabile, organ, etc.

Dearnaley, Irvine, organist and conductor, bom in the village of liroadbottom, Chester, September 29, I 439 . His father was a spinner in a cotton mill, and was devoted to musie, helping his son as far as he could. When seventeen, young Dearnaley obtained the post of organist at Staleybridge, and

\section{DEMPSTER.}

studied under J. J. Harris, afterwards taking pianoforte lessons from Halle, and working at harmony under H. Hiles. Then he became organist of Christ Church, and of the parish church, Ashton-under-Lyne, from 1864. He was conductor of the Grentlemen's Glee Club, and Philharmonic Society in that town; and in 1883, was made musical director of the Gentlemen's Glee Club, Manchester. Gave many organ recitals in the district. Compused some anthems and pieces for the organ. He died at Ashton, September 18, 1894.

Deering, or Dering, Richard, composer and organist, born in Fent, at the end of the 16th century. He was educated in Italy, and afterwards became organist at a monastery of English nuns in Brussels, 1617. Organist to Henrietta Maria, Consort of Charles I., 1625. Mus. Bae, Oxon., 1610. He died in 16930.

Wonks.-Cantiones Sacre quinque vocum, cum basso continno ad organum, Antwerp, 1597 ; Cantica Sacre ad melodiam madrigalium elaborata senis vocibus, Antwerp, 161s; Cantiones Sacre, 1619; Canzonctte, $16 \pm 0$. He also wrote motets, madrigals, etc., many of which are preserved in $11 \mathrm{~S}$. at $\mathrm{Ox}-$ ford and Lonton. Te died in the Roman Catholic faith. It is claimed for Dcering that his 1597 Cantiones wele the first works issued with a figmred loass.

De Fonblanque, Ellen, Sec sub. Campbell, Gilbert James.

De la Fond, John Francis, author and teacher of languages in London during the first half of last century. He issued, among other" works, a "New system of Musick, both theoretical and practical, and yot not mathematical, written in a manner entirely new, that is to say, in a style plain and intelligible," London, 1724.

Delany, J. A., organist and composer, loom in London, 1852. Went to Sydney, Anstralia, and beeame a pupil of W. I. Cordner, whom he succeoded as organist of St. Mary"s R. C. Cathedral, a post he held 1s71-6. Then he went as choms-master and pianist to the Opera Honse, Malbonme (then nuther the management of W. S. Lyster, who died in 1880), where he remained some years. In Intre he was appointed choir-master of $\mathrm{St}$. Mary's Cathedral, syduey, and three ycars later succeded Max Vogrich as comrluctor of the sydney Liedertafel, which positions he still holds. For tit. Mary's Catheriral he has componed Masses in F, and A flat: and has also composed a Cintata, "Captain Cook," and other works.

Dempster, William Richardson, (omposer, born at Keith, Banffshire, in 1Kos; dicd at London, March 7,1871 . He eonnged a number of palt-songs and pf. pieees; also Songs: Bird of the wildemess; Blind boy; Come o'er the mountain to me; Douluting 


\section{DENNIS.}

heart; May qreen; My love Amnie; Songs in the Idylls of the King, Tennyson [1864].

Dennis, John, writer and musician, born at London in 1657. He studied at Cambridge, and afterwards travelled in France and Italy. He died on January 6th, 1733. Author of "An Essay on the Italian Opera," London, 1706.

Derham, William, English writer, was born in 1657, and died in 1735. Author of, among other works, the following, "The Artificial Clock-maker. . shewing. . the way to alter clock-work, to make chimes and set them to musical notes," London, 1696 [other editions].

Dering, see Deering.

D'Este, John, musician and writer, author of "MIusic made easy, the liudiments of Musie," London, 1849; "The Tocalist's Vade Necum, or Poeket Companion, Practical Hints on Singing," etc., London, 1872.

Deval, Harry, writer and composer, author of "The Art of Toealization, with complete instrnctions for the Cultivation of the Toice," London, n.d. Composer of "The Rival Clans," Opera, Newcastle, 1846, and of musie to "A Midsummer night's dream," Nerreantle, 1846.

Dewar, Daniel, ścottish clergrman and author of the end of lant and leginning of the present eentury. He was profensor of nural philosopliy in Aleerdeen Lniversity. He wrote "Observations on the character, cuntoms, superstitions, music, poetry, and langurge of the Frish," London, 1812, 2 vols.

Dewar, James, composer, conductor, and violinist, born at Edinlurrgh, July 26, 1793. Deputy-leader in Theatre Ficral, Edinlnugh, 1807 , and afterwardsmusical dirtetor. Organist of St. George's Episcopal church, 1815-35. Conduetor of Edinburgh Insical Association. $\mathrm{He}$ died at Edinhmigh, Jannary 4, 1st6. Dewar is famons for his arrangements of Scottish airs for the orchestra, a pf. edition of which was publinhed about 1850. His work with the title, "I'opular National MIelodies adapted for the r'imoforte, "Edinlurgh, 18.6, had a large cirenlation. He conposed also a few part-song and other rocal pieces, and editerl "The Border" Garland, Poetry by Hogg," [c. 1829. His brother Johs was alio a compoer.

Dewberry, William Charles, organist and condnctur, born at Camlridge, Jannary 16, 1843. Churinter and solo boy at King's College, Cambridge, and afterwards assistant-organist. Pupil, later, of Sterndale Bennett, C. Lncas, and W. G. Cusins, and R.A.M. silver medalist and Associate. Organist of Clare College, and St. Edward's Church, Cambridge, where he is resident as performer and teacher. He grartnated MLus. Bac., Cambridge, 18at. He took an active part in establishing several of the college musical societies, and monder his

\section{DIBDIN.}

direction the Cambridge Musical society at talined a high position, producing such works as Macfarren's "St. John the Biaptist," ete. As a Freemason he is a P.M. of Lodge 4t1, and P.P.G.O. for the Grand Chapter and Province of Camloridgeshire. His compositions embrace a setting of Psalm 13; An Evening Service in E flat; Anthems, chants, and part-songs, ete.

Fuedertck LewberRr, his youmger lorother, was born at Cambridge in 1sts. Chorister at Trinity College, Cambidge, and articled pupil of the late J. L. Hopkins. In 1868, elected organist and choimaster of Gonville and Cains College, retiring in 1892. Organist of St. Michael's, Cambridge, 1s71; st. Andrew the Grent, 1873 , to the present time, with the exception of a year, 1s90-1, at st. Nary's, saffron Walden." Graduated Mus. Bac., Camlridge, 18s6; F.R.C.O., L.R.A.M. In 1882 he was given the appointment of organist at the Guildhall, Cambridge, and is also organist to Dr. A. H. Mann's festival choir. Has given many recitals. Like his brother, he is a prominent Froemason, holding innportant uffices in the Provincial Grand Chapter.

Dews, Elizabeth, contral to vocalint, horn at Wolverhampton. Received her early musical training from local teachers and masters in Birmingham. Appeared in that city in "Elijah," in Norember, 1s, wh, while still a young student Afterwards proceded to Lendon, and studied under IV. Shakenpeare, and signor Rundegger the made her debut in St. Jamen's Hall, Norember 25, 1891; sang at Pooser's ballad concerts, 1s:13; and at the Crrstal 'Plalace, in Berlioz' "Romeo et Juliette," December 15, 18!94. She went on a tom in Cremany with Madame Valleria, and is num a singer of established reputation, being engaged for such concerts as those of the Bimingham Festival Choral Society, the Liserpool Philhamonic, and societies at Leeds, Edinhmrgh, Glasgow, and Dublin. Madame Dews sang at the julilee performance of "Elijah," at the Royal Albert Hall, April 23, 1896. She is married to a scotmman, Mr. 1). A. Parlier.

Dibdin, Charles, composer and writer, was born at Dibden, near Southampton [haptized March 4, 1745. He studied at Winchester College, and was taught music by Kent and Fussell. Appeared as an actor at Richmond and Pirmingham. Went to London, and was employed by Rickerstaff as composer and singer, 1765. Renounced stage, and commenced giving medley monodramas in London, 1788. He died at London, July $25,1814$.

Works.-Masical Mramas etc.- Shepherd's Artifice, 1763; Love in the city, 1767; Thamon and Phillida, 1768; Lionel and Clarissa, 1768; Padlock, 1768; Maid the Mistress, 1769; Re- 


\section{DIBDIN.}

cruiting Sergeant, 1769; Ephesian Matron, 1769 ; Jubilee, 1769 ; Queen Mab, 1769 ; Captive, 1769; Pignny Revel, 1770; Wedding Ring ; Institution of the Garter, 1770 ; Ladle, 177.2; Mischance; Brickdust Man; Widow of Abingdon; Palaee of Mirth, 1772; Christmas Tale, 1773; Trip to Portsmouth; Deserter; Grenadier, 1773; IVateman, 1774 ; Cobbler, 1774; Quaker, 1775; Two Misers, 1775; Seraglio, 1776 ; Blackanoor ; Netamorphoses ; Razor grinder ; Yo, yea, or the friendly Tars; Old Woman of eighty; Mad Doetor; She is mad for a Hushand; England against Italy; Fortune Hunter: All's not gold that glitters, 1776; Poor Vulcan, 1778; Rose and Colin; Wives Revenged; Amette and Lubin; Mrilk. maid, 1778; Plymouth in an uproar, 1779; Chelsea Pensioners; Mirror; Touchstone, 1779; Shepherdess of the Alps, 1780; Harlequin Freemason; Islanders, 1780; Jupiter and Alcmena, 1781; None so blind as those who won't see, 1789; Barrier of Parnassus, 1783; Graees; Saloon; Mandarina; Land of simplieity; Passions; Statue; Clump and Cudden; lienevolent Tar; Regions of Ae. complishment; Lancashire Witehes, 1783; Cestus, 1781; Pandora ; Loug Odds ; Liberty hall, 1785; Harvest Home, 1787; Loyal effusion, 1797. Monodramas-Whim of the moment, 1788; Oddities, 1789; Wags; Private Theatricals, 1791 ; Quizzes, 1792 ; Castles in the air, 1793; Great news, 1794; Will of the wisp, 1795; Christmas gambols, 1795; General Flection, 1796; Sphinx, 1797 ; Valentine's day, 1797 ; King and Queen, 1798; Tour to the Land's End, 1799; Tom IVilkins, 1799 ; Cake house, 1800; Frisk, 1801; Most votes, 1802; New Year's Gifts ; Broken Gold : Briton's Strilse Home; Datchet Mead; Commodore Pemnant; Heads and Tails; Frolie, ete. Litrary Musical Works-The Harmonic Preeeptor, a Didactic poem in three parts, Loudon, 1804; The linglish Pythagoras, or every man his own music-master, London, 180;; Music epitomized, a sichool Book in which the whole science of music is clearly explained, I onclon, n.d. Hamnah Hewitt, or the female ('rusoe, novel, 1792; Younger brother, novel, 1793 ; MIusical tour, Sheffield, 1788 ; Iistory of the Stage, London, 5 vols., 1795; Olsservations on a 'T'our through almost the whole of England, and a considerable part of seotland . . Tondon, 2 vols., 1801 ; The professional life of $\mathrm{MI}$. Dilodin, written by himself, with the words of six hundred songs selected from his works, London, 1 vols., 1803. Songs, chronologically arranged, with notes, memoir, etc., by George Hogarth, 1842, 2 vols.

Dibdin, according to the hiography prefixed by his son Thomas to the 1875 edition of his songs, wrote over 1300 songs. In addition to these he wrote other music in his entertain-

\section{DICK.}

ments, ete., the gross amount of musie and words which he wrote being in number over 3000 pieces. Of these, very few are now used, "The Waterman" is the only large piece, and "Poor Jack" and "Tom Bowling" almost the only songs.

Dibdin, Charles, Jun., son of the above, poet and writer, born about 1769 . He was for some year's part-proprietor of Sadlers' Wells Theatre, London, and wrote, among other pieces, the "Farmer's wife," "MIy spouse and I," and a number of Burlettas, Pantomimes, Songs, etc. He died at London, January 13, 1833.

Dibdin, Henry Edward, musician and compiler, hom in London, September 8, 1813. Grandson of Charles Dibdin. He studied mder his sister, Mrs. Tomma, and Bochsa, the harpist. From 1833 he resided at Mormingside, Edinburgh, as a teacher; and he also was hom. orgunist of TrinityChapel, Edinburgh. He died at Edinhurgh, May 6, 1866.

Works.-The Standard Psalm-Tume Book, eontaining upwards of 600 specimens, compiled from the original editions.. London 1851]; Reid's Praise Book, 1868, harmonised; Collection of Chureh Music, consisting of chants, palm and hymm tmes, etc., 1843, edited with J. T. Sizreme.

Tis sols, litward Rimbaulat Vere (Fdinburgh, Augnst 25, 1853), and JAnes Ropent Wulliam (Fdinburgh, December 9, 1856), are both musicians. The former has composed some songs and part-songs, and the latter is perhaps best known by his "Ammats of the Fdiuburgh stage," 1888 . His wife, born Isaphlla Perkins Palmer, was horn at Sontliwold, Suffolk, Jannary 19, 1828. She was married in 1846. She composed a few hrmm tumes, and was a good soprano roealist. Hiis sister, MARY ANxE DIBDIN, born ahout 1800 , was a harpist, and studied moder Chalhoner and Bochsa. In $182 t$ she became assistant teacher of the harp at the R.A.MI. she married Mr. Tomma.

Dibdin, Thomas John, dramatist and musician, som of Charles, senr., horn, Lomdon, Murch 21, 1771. ILe was an actor and dramatic anthor, and appeared in the provinces and at Fadler's Wells Theatre, and Covent rarden Theatre, London. He was joint proprictor of sadler's Wells Theatre from 1802, and died at Clerkenwell, London, September 16, 1841 .

Worḱt-Numerols dranatic pieces, produced at sidler's Wells, and elsewhere. The Cabinet, an opera. Songs in the collection entitled "Lays of the last three Iniludins." Reminiscences of Thomas Dildin of Covent Garden," etc., London, 1827, 2 vols.

Dick, Charles George Cotsford, composer, horn in London, September 1, 1846. Edncated at oxford, and prepared for the 


\section{DICKONS.}

Bar, but obliged, from ill-health, to give it up. Works.-Operettas: Our doll's house (German Reed, 1876); Our new doll's house (the same, 1877); Back from India (1879); Doctor D, comic opera (Royalty Theatre, 1885); The Baroness (the same, 1892). A Children's Opera, A Fairy Weddiug, in six parts, for pf. The Waif (play, adapted from the French, Haymarket Theatre, May, 1892). Songs: Dolly Varden; Olivia; Golden wedding song; Three songs, etc. Pf. pieces: Fireside fancies, six pieces; Toecata; December and May; Belinda Gavotte; Deux Melodies; ete. Author of a volume of verse: The Way of the World (London, Redway, 1896).

Dickons, Maria, born Poole, soprano vocalist, born at London about 1770 . She studied under Ranzzini, at Bath, and first appeared at Vauxhall in 1783 . She appeared at Covent Garden in 1793, and sang regularly at the Ancient (from 1792) and Vocal concerts, and in the principal provincial towns. In 1800 she married MIr. Dickons, and retired for a time, but she resmmed public singing again in London in 1806, and afterwards appeared at Paris, 1816, Venice, etc. She was made a member of the Instituto Filarmonico, Venice. She appeared for a short time in London in 1819 , but retired soon afterwards, and died May 4, 1833 .

Dickson, Ellen, "Dolores," composer, daughter of Creneral Sir Alex. Dickson, was born at Woolwich, in 1819 . She resided during her life-time chiefly at Lyodhurst, in the New Forest, having been an invalid from youth. She became known in her district for many charitable actions. She died at Lynd hurst, July $4,1878$.

Works.-Songs: Clear and cool ; Destiny ; Goldilocks; The land of long ago; O my lost love; Pack clouds away; The racing river; She walked beside me; Tell her not when I am gone; Unchanged, ete.

These songs acquired a considerable amount of popularity in their day, and some of them are even now in vogue.

Dickson, Rev. William Edward, clergyman and writer, born at Richmond, Yorkshire, 1823. B.A., Cantab., 1846 ; M.A. 1851. Ordained 1846. Precentor of Ely Cathedral, 1858.

Wonks. - Singing in Parish Churches, 1858; Cathedral Choire, 1877 ; Practical Organ Building, London, 1.881; Fifty years of Church MIusie, Ely, 1895.

Diemer, Philip Henry, composer, pianist and organist, born at Bedford, July 18, 1839. Of German extraction, and cousin of the distinguished pianist, Louis Diemer, of Paris. Studied at R.A.M., pianoforte, under W. H. Holmes, and harmony with F. A. Macfarren. Elected Associate of the Philharmonic Society 1882. Has been organist and choirmaster of

\section{DISTIN.}

Holy Trinity, Bedford, for more than thirty years, and has directed musical services there when Bach's "Passion," and other oratorios have been given with orchestra. Director of Music at Bedford Grammar School for over thirty-five years In 1866, founded the Bedford Musical Society, which gives four concerts amnually; at the 100th concert he was publicly presented with a testimonial. For ten years he gave a short season of chamber concerts, at which he appeared as pianist

Works. - Cantatas: Thoughts of home, treble voices (1867); Bethany, Bedford, 1881, and, later, in London, many other places, and some of the Colonies; Alcestis (written for 25th annual concert of the Grammar School). Farewell, and a Jubilee Ode (both with orchestra). Collection of original hymn-tunes; anthems; Songs and part-songs; Pf. pieces, etc.

Dignum, Charles, tenor vocalist, was born at Rotherhithe, London, in 1765. Chorister in chapel of Sardinian ambansador, London. He studied music under Samuel Webbe, and worked for a time as carver and gilder. Articled to T. Linley for seven years. Début as Neadows in "Love in a Village," 1784. Sang afterwards at Vauxhall, Haymarket Theatre, etc. He died at London, March 29, 1827 .

Dignum, who was usually regarded as the successor of Beard, composed a number of songs, and published a collection of "Vocal MLusic, consisting of songs, dnets, and glees," London [c. 1810], with portrait. He was most successful as a singer of English ballads. Among his single songs may be named Maid of the rock; Neglected Tar; Poor Recruit; Soldier's consolation; Sweet Jane; William of Allerton Green, etc.

Ding, Lawrence, musician and publisher, who was engaged in business in Edinburgh, and died there in October, 1800 . He published "The Songster's Favourite, or a new collection containing 40 of the most celebrated songs, duets, trios, etc.," Edimburgh, n.d. "The Anacreontic Musenm," Edinburgl, n.d., ete.

Distin, Theodore, composer and singer, born at Brighton, in 1823. Son of John Jistin (1793-1863), a celebrated trumpetplayer and inventor of the keyed bugle, under whom he studied. His father having organized a band, composed of members of the family, Theodore played the French hom in it, and travelled with it from 1836 to 1844 . Afterwards he studied singing under T. Cooke and Negri and became a baritone singer in the Pyne and Harrison Opera Company. He was a singer in Rencher's Clapel, Lincoln's Inn, and an Associate of the R.A.M. He was latterly a teacher in London, and died on April 12, 1893. 


\section{DIXON.}

Works.-Services in C and G. Glees and part-songs. Two masses. Songs, etc. In 1890, he wrote a madrigalian ehorus entitled The Break of Day. Tutor for the Baliad Horn 1871]. His father issued A selection of Swedish Melodies arranged for comet, sax. horn, etc. [1847].

Dixon, Rev. E. S., writer, author of "The Piano Primer, and Instructor's Assistant," 11.d.

Dixon, George, eomposer and organist, born at Norwich, June 5, 1820. Chorister Norwich Cathedral, 1827-34. Musically trained as a private pupil of Dr. Buck to 1835. Pupil and assistant organist of Parish Church, Grantham, 1435-45. Organist of the Parish Church, Retford, Notts., 1845-59; Parish Church, Louth, 1859-65; Parish Chureh, Grantham, 1865, resigned, 1886. Mus. Bac., Oxon., 1852; Mus. Doc., 1858. An Hon. Examiner for Royal College of Music, at Grantham and Lincoln. He died at Finchley, June 8, 1887.

Works.-121st Psalm, for voices and orchestrit (MS.) Pope's Messiah, cantata for voices and orehestra (MIS.) Numerons anthems, hymms, hants, etc. Songs. He also contribut $d$ to various collections of psahms and chants.

Dixon, J., musician, anthor of "Canto Recitativo, or a system of English Chant ..." London $\lceil 1816\rceil$.

Dixon, William, writer, teacher, and music-engraver, born about 1760 ; died London, 1825. He resided chiefly in Liverpool and London.

Works.--Sacred music, consisting of a Te Deum . . anthems, psalm tunes, and bymus . . . [1790]. Euphonia . . 62 Psalm and hymn tunes in four parts

for the congregarion of All Saints' Church, Liverpool. Six glees for three voices. Moralities: six glees, Cambridge $[1800]$. Introduction to singing, containing rules for singing at sight .. 1795.

Dixon, William Hubert, organist and composer, born at Bishopstone, Wilts., August 1, 1846. Organist of High Church, Kilmarnoek, from 1869, and conductor of the Philharmonic Society there. His sacred eantata, "Jerusalem," was produced at Kilmarnock, December, 1887; he has also written some part songs and pf. pieces. He died at Kilmarnock, July 31, 1893.

Dobson, John, psalmody collector and composer, was born in 1814, died, Richmond, Surrey, May 1, 1888. He was an in collector of psahn and hymm books, and his library was sold in November, 1889, in 492 lots, cousisting mainly of collections of psalmody. He edited "Tunes new and old," 1861, and other editions till 1877, of which some were revised by Dr. Gauntlett.

\section{DONE.}

Docker, Frederick Arthur William, organist and conductor, born in London, August 14, 1852. Studied, R.A.M. Associate of the Academy. Organist and choirmaster, St. Andrew's, Wells Street, London, where he was first a chorister, then pupil of, and assistant to, the late Sir Joseph Barnby. When the Handel Society was formed, in 1882, he was appointed conductor; an office he held for ten years. He also conducts the concerts of the Kyrle Society. suceeeding $\mathbf{M a l c o l m}$ Lawson in 1886. He has published a setting of the Te Deum; O ye that love the Lord, and other chureh music; part-songs, etc.

Dodds, Tom William, organist and composer, son of Thomas Dodds, tenor vocalist (died 1892), was born at Leeds, September 22,1852 . At nine years of age became a chorister at Leeds Parish Church, and a year later organist of Headingley Chapel. Educated at Bury Grammar School. Organist sucessively of St. Matthew's, Leeds, 1863-6 ; St. Wilfred's Collegiate Chapel, 1866-72 ; and of Queen's Collegre, and St. Clement's Church, Oxford, since 1872. Graduated Mus. Bac., 1876 ; Mus. Doc., 1887, Oxford. Examiner for musical degrees in Oxford University, 1895. His compositions comprise an oratorio, "Hezekiah," a setting of Psalm 8; chants, hymm tunes and pf. pieces.

Dodwell, Rev. Henry, elergyman and writer, born at Dublin, 1641, died in 1711. In addition to many theological works, he wrote "A Treatise on the lawfulness of instrunental Musick in Holy Offices,"..London, $1700 ;$ 2nd edition, with large additions, 1700.

Dodworth, Harvey B., bandmaster and composer, born at Sheffield in 1822. Inventor of the rotary string-valve and bell-back instruments. Settled in the United States. He wrote and published several works on band instruments and military band justrumentation. The first military band in the U.S. was organised by Mr. Dodworth. He was a musician of sterling worth, and was much esteemed in the United States. He died at New York, in April, 1891.

Dolby, Charlotte, see SAINTON-DOLBY.

"Dolores." See Dicison (Ellen).

Donaldson, John, musician, theorist, and Professor of Music in Edinburgh University, 1845-65, was born about 1790, died at Cramond, near Edinburgh, August 12, 1865. He was for snme time previous to his appointment a teacher of music in Glasgow, and had been bred to the law. He did much to promote the interests of the Chair of Music in the University, and practically did everything to establish the efficiency of the Chair, by the erection of the music room and organ, and by getting the rights of the Music Chair estab. lished by process at Law in 1851-55.

Done, Joshua, organist and writer, was 


\section{DONE}

born in London. He studied at Paris under Cherubini, and was organist successively of S. John's, Lambeth; Chelsea Old Church; Knightsbridge Chapel ; and S. Augustine's, Liverpool. He died at King's Lymn, November 2, 1848, in extreme poverty. Author of "A Short Treatise on Harmony, Thorough Bass, and Modulation, including the compass and properties of Musical Instruments in general." London, Cocks, n.d. "Treatise on the Organ," London, 1837. "Tuner's Companion: a Treatise on the Construction of Pianofortes.. with various methods of Tuning them," London, n.d. "Selection of the most popular, with many original Psalm and Hymm Tunes, Chants, etc.," London [1830.]

Done, William, organist and conductor', born at Woreester, 1815. Entered the Cathedral choir in 1825, and sang in the chorus at the Worcester Festival of 1827. In 1839 he was apprenticed to Charles F. J. Clarke, the Cathedral Organist, and was elected his snccessor, June, 1844. He conducted the Worcester Festival of 1845 , and was associated with the meetings of the Three Choirs until 1890, when he resigned the briton, and trok upon himself the duty of orchestral steward. In 1s94, he celebrated his jublilee as organist of the Cathedral, when the Archbishop of Canterbury conferred on lim the honorary degree of Doctor of Music. He was for many years conductor of the Woreester Phithilrmonic Society, an oftice he resigned in 1884. He eomposed much Church musie, but will be more remenbered by the reforms he instituted in the Cathedral services, the introduction of great works on special occasions, and the formation of a large voluntary choir. He died at Worcester, Angust 17, 1895.

Donkin, W. F., writer and musician, M.A., F.R.S., ete. Savilian Professor of Astronomy, Oxford. Anthor of "Aconstics, Theoretical." Part I., Oxford, 1870. All pulbished of a work designed to cover the whole range of the science of sound.

Doorly, Martin Edward, organist and composer, born in Demerara, British Guiana, 1847. Wats for many year's organist of the Cathedral, Bridgetown, Barbadoes, and conductor of concerts; also music master at Queen's College, Barbadoes. In 1891, he graduated Mus. Bac., Durham, after examination held at Codrington College (affiliated to Durham University), Barbadoes. He composed an oratorio, "The Raising of Lazarus," produced at Marshall's Hall, Bridgetown, August 24, 1880 , and repeated on the $27 \mathrm{th}$, in St. Leonard's Church; this performance being conducted by the Lord Bishop of the diocese (Dr. Mitchinson). He also wrote an opera, "Equality ;" A burlesque; and published some organ pieces and songs. He died at Barbadoes, August 22, 1895.

\section{DORRELL.}

His brother, the Rev. IV. S. Doorly, was born at Upper Park Camp, Jamaica, in 1851. Studied music nuder F. Jackson, of Hull; J. Whomes, of Woolwich; with 1)r. Wylde, and others at the London Academy of Music; and Tonic Sol-fa with L. C. Venables. Was organist of St. Mary's, Bridgetown, Barbadoes, 1870-2 ; appointed organist and choirmaster of Holy Trinity Cathedral, Trinidad, in 1872. Took holy order's in 1877 , and was appointed Hon. Canon and Precentor of the Cathedral in 1894. At Port-of-Spain he has been very active as a conductor of choral and orchestral societies; and in addition to the Messiah, Elijah, Hym of Praisc, and such established compositions, has lrought forward "The Redemption" (Fonnod); "Lazarus" (MI. E. Doorly, 1883); "St. John the Evangelist" (Armes); "The lrodigal son" (Sullivan); "The Crucifixion" (Stainer); and many other important works for the first time in Trinidad.

Doran, Rev. John Wilberforce, clergyman and author, born London, 1834. B.A., Cantab, 1857 ; M.A., 1861; Ordained, 1857. Vicar of Fen Stanton, Huntingdonshire, 1883. He has compiled a large number of worls for the musical service of the Church of England, such as Choir Directory of Plain Song. The Psalter and Canticles arranged for Gregorian chanting. Ritnal Insic of the Altar. Choir Book of Ritual Arusic of the Altar. Hyfforddwr av y Gân Eghwysig (Welsh Plain-song Directory). Te Deums, Chants, etc.

Dorrell, William, pianist, born in London, September 5, 1810. Son of Edmund Dorrell, painter, and early nember of the old Water Colour Society. William Dorrell received his first lessons from his eldest sister, and afterwards entered the R.A.M., and studied under Dr. Crotch, Cipriani Potter, and Charles Lncas. In 1844 he went to Paris, and studied with Kalkbrenver and Stephen IIeller. Returning to London, he was made a Professor of the Pf. at the R.A.M., an office he retained for over forty years. Half a century ago Mr. Dorrell was known as a most skilful pianist, and he appeared occasionally in public. One noticeable concert he gave at the Hanover Square Rooms, June 2, 1842, when he played Bennett's Concerto in E flat. Mendelssohn was present at this concert. His time was afterwards mainly occupied in teaching, his pupils including members of many noble families. Of his compositions very little is known. At a Matinée d'invitation he gave at his residence, June 20, 1882, he introduced a movement from a Sonata for pf. and violin, which he played with M. Sainton. He was one of the founders of the Baeh Soeiety, in 1849; Member of the Royal Society of Musicians, and of the Philharmonie Society. He died in London, December 13, 1896. The sister, already mentioned, JANE 


\section{DORRINGTON.}

Dorrell, was a fine pianist, pupil of Mrs. Anderson, and Cipriani ['otter. In 1830, she played at the "Oratorios" at Covent Garden Theatre. She played Mendelssolnn's Rondo brilliant in B minor, at the concert of June 2, 1842; and once had the honour of playing to Queen Adelaide, at St. James's Palace. She died in London, July 19, 1883

Dorrington, Theoph., elergyman of the 18th century, author of "A Discourse on Singing in the Worship of God," London, 1704 .

Dougall, Neil, minor poet and composer, was born at Greenock, December 9, 1776. Apprenticed to mercantile marine service, 1791. He continued a seaman till accidentally wounded while discharging a cannon, in 1794. Became a teacher of music, 1799. Married Margaret Donaldson, 1806. Inn-keeper in Greenock, 1824. He died at Greenock, October 1, 1862.

Works.- Poems and Songs, Greenock, 1854. Psalm tunes: Naples, 1801; Kilmarnock, 1823; Patience; New East Church; etc. Also tunes contributed to Stevens' "Sacred Music," vol. 6.

His dalighter, Lilly Dougall, was at one time a well-known contralto vocalist.

Dow, Daniel, composer, teacher, and collector of last century, was born in Perthshire in 1732, and from 1765 he resided in Edinburgh as a teacher, etc. He died at Edinburgh, January 20, 1783.

Worrs.-Twenty Minuets and sixteen Reels, or Country Dances for the Violin, Harpsichord, or Germau Flute, Edinburgh [1775]. Collection of Ancient Scots Music [1778]. A Collection of Ancient Scots Music for the Violin, Harpsichord, or German Flute, never before printed, consisting of Ports, Salutations, Marches or Pibrochs, etc., Edinburgh, n.d. Thirty-seven New Reels and Strathspeys, for the Violin, Harpsichord, Pianoforte, or German Flute, Edinburgh (N. Stewart), n.d. Of his dances, "Monymusk," a strathspey, is probably best known.

Dowland, John, composer and lntenist, born at Westminster, in 1562. He resided on the Continent in 1581-84, but returned to England and became Mus. Bac., Oxon,, in 158s, and also Cantal), in 1592. Lutenist to Charles IV. of Demmark alout 1599 . Returned to Fnclind in 1605, and after another period of residence in Demmark he finally settled in Englind from 1609. Ile became lutenist to the King in 1625. He died in 1626.

Works. - The First booke of Songes or Ayres of foure parts, with tablature for the Lute, 1595. Second looklie, do., 1600 . Third looke, do., 1602. Lachrimat or seren teares figured in seaven passionate parans, with dirers other pavans, galiards, and almands, set forth for

\section{DOYLE.}

the lute, viols, or violins, in five parts, 1605. A Pilgrim's solace, wherein is contained musical harmony of three, four, and five parts, to be sung and plaid with lute and viols, 1612 . Translation of Ornithopareus, his Micrologus, or introduction : containing the art of singing and the perfect use of the monochord

London, 1609. Hammonies in Este's Psalms, etc.

The poetry and music both in Dowland's works are of an exceptionally high degree of excellence, and he is properly classed among the best musicians of his time. The poetry, indeed, is so good that Professor Arber has reprinted the three looks of songs, etc. (words only), in his valuable series of classical reprints, while the Musical Antiquarian Society have done a like service for the first book of the same set. His music has that quaint, delightful flayour common to compositions of the $16 \mathrm{th}$ and 17th centuries. Shakespeare has shown his preference for Dowland in the somet commencing

"If music and sweet poetry agree."

Dowland, Robert, composer, son of ahove, succeeded his father as lutenist to the King, in 1626 . He cdited several musical pulbications, and a " Varietie of Lessoms," ete.

Dowling, Thomas Barrow, orginist and conductor of the present time. Student aud Associate, R.A.M. Some time organist of St. Philip's, Regent Street, London. In 1888, appointed organist of St. George's Cathedral, Cape Town, and conductor of a choral union. After four scasons he amalgamated this with a suciety in Cape Town, and began produeing oratorios on a filler scale. In 1895 he was invited to conduct the Orehestral Society in Cape Town, which dated back to 1864. The chief works of the great masters, and those of the modern school, have been presented under his direction. He has also developed the Cathedral choir, which has given perfomances of Mendelssohn's "St. Panl," and other great works. A new organ was ereeted in the Cathedral, and Mr. Barrow opened it with a recital, Nor. 4, 1890, since when he has given many public performances mpon the instrmment; and is a bussy worker in the canse of music in Sorth Afriea.

Downes, Rev. James F., annateur composer, born in the West Riding of Forkshire, has written the cantatas, "The Paralle of the ten Virgins," Leeds, 188\%; and "The Prodigal Son," 1885; and some secular pieces. He is a priest of the Roman Catholie Church, and is at present at St. Patrick's, Bradford.

Doyle, c. W., viola player, horn at Scarlsorough. Educated at R.A.M., and elected a Fellow of that Institution. For many years Member of the Royal Italian Opera, and other orchestras. Priucipal viola, Birmingham Festival orchestra, 1861-82; 


\section{DRIFFIELD.}

Leeds Festival, 1874-92; Worcester Festival, 1893. Played in chamber concerts with the Carrodus Quartet, $\mathbf{1 8 7 7}$, etc. Professor in the Guildhall school of Music. ADA Doy Le, his daughter, contralto vocalist, was a pupil of Madame Dolby, and made her début at Buxton, in May, 1885.

Driffield, Edward Townshend, amateur organist and composer, born at Prescot, near Liverpool, December 10, 1851. Organist of Christ Church, Clanghton, Birkenhead, where he has given recitals, 1883-4. He is the composer of a Cautata, "My soul doth magnify the Lord" ; a Sonata in G, for organ; and some glees, one of which, "Come follow me" was sung by the Bristol Orpheus Society at its annual concert, February 9, 1893.

Druitt, Dr. Robert, writer, author of "A Popular Tract on Church MInsic, with remarks on its moral and political importance, and a practical scheme for its reformation," London, 1845; "Conversations on the Choral Service, being an examination of the popular prejadices against Church Music," London, 1853.

Drummond, George, organist and composer, was borm in 1798, died in 1839 . Blind from infancy. He studied under Crotch, and published "Parochial Psalmody, or 70 plain psalm tuues arranged for the organ or pianoforte," n.d. O give thauks minto the Lord, Anthem.

Drummond, James, musician, was born at Cambuslang, near (ilasgow, in October, 1811. He was choirmaster of St. George's Church, Glasgow, from 1852 to 1875 . Wellknown in Glasgow as a good musician. He died at Glasgow, November 18, 1883. His youngest son, Thomas Sirth Drumiond, born, Glasgow, June 1, 1854, is a pianist and conductor. He holds varions positions in Glasgow, and has composed some vocal music.

Dryden, Henry E. L., author of "On Churel IInsic, aud the Fittings of Churches for Music," London, 1854.

Drysdale, F. Learmont, composer, borm in Edinburgh, 1866 . Originally educated for an architect, he turned to music, and entered the R.A.M., winning, in 1890, the Lucas prize for composition. While a student he produced a ballad for orchestra, "The spirit of the Glen" (1889); Orchestral prelude, "Thomas the Rhymer" (1890); and a scena, forming part of a Cantata, "The Felpie," afterwards produced at Edinburgh (Paterson concerts), December 17, 1894. His overture, "Tam O'Shanter," was awarded a prize by the Glasgow Society of Musicians, 1891, and it was performed at the Crystal Palace, October 24, of that year. Another overture, "Herondian," was produced by the Stock Exchange Orchestral Society, April 24, 1894. $\mathrm{He}$ has been selected to compose the music to

\section{DUDENEY.}

the opera founded on Baring-Gould's novel, "The Red Spider." His mystic musical play, " The Plague," was produced at the Lyceum Theatre, Edinburgh, in October, 1896.

Dubourg, George, writer, grandson of Matthew, was born m 1799, died at Maidenhead, April 17, 1882. Author of "The Violiu; being an accomt of that leading Instrument, and its most Eminent Professors," London [1832]; 2nd edition, 1837; th edition, 1852; 5th edition, 1856.

Dubourg, Matthew, violinist and composer, was born at London in 1703 . He studied uuder Geminiani. A ppeared first at Brittol's concerts, 1715. Composer and master of state music in Ireland, 1728. Succeeded Festing as member of King's band, 1752. Leader of band on production of Handel's "Messiah." He died at London, July 3. 1767. He composed concertos, solos, and variations for the violin; odes, songs, and other vocal music. He was the leading English violinist of his day, and one of the greatest among his contemporaries.

Duchemin, Charles Jean Batiste, pianist, composer, and conductor, borm in Birmingham, May 12, 1827. His father was a French naval officer, who was taken prisoner during the war with Napoleon I. He married an English lady, and settled in Birmingham as a teacher of languages. The son was edueated at King Edward's Crammar School, and his musical talent leveloping, lie was sent to Brussels, where he stuclied at the Conservatoire under M. Fétis. On his return he devoted his attention to teaching, and concert work, and was for many years a foremost figure in musical life in the Midlands. He was organist successively at st. Peter's, R.C. Church, and the Oratory, Edigbaston, where he had the preseut Duke of Norfolk as a pupil. He conducted the German Liederkranz; founded the Edgbaston Amatenr Insical Union, an orchestral society of which he was for nearly tweuty years the conductor. With two other artists he originated chamber concerts in Birmingham, which he continued for some time, introducing many famous performers to the town. He was for many years local secretary for Trinity College, London. His compositions iuclude several operettas, and orchestral pieces, which remain in MS. Many of his pf. pieces have been published: Tarantella in $\mathrm{F}$ minor; Saltarello in D minor ; La Velocité Etude, in octaves; Caprice brilliante; Idyll in E flat, etc. He has also composed songs, trios, etc.

Dudeney, Thomas James, organist, composer, and conductor, born at Mayfield, Sussex, Norember :9, 1854. Studied nnder G. A. Macfarren. Organist Dunster parish church (1876); St. James's, Tamton; and now of St. Anne's, Eastboume. Established 


\section{DUFF.}

in 1875 the Tamuton Philhamonic Assoeiation, and a similar one at Danster, in 1877; and the Wanhwood Musical Society in 1880. I'rincipal of the Tamnton College of Musie, 1888. He has given many concerts, noticeable for the production of important works by British composers. He has written a cantata, "Song of joy," for soli, chorus, and orchestra; "Who is rivia," eight-part chorus, with orchestra; songs and part-songs. Also an overture, "Cassiluelan; an Elegy (1r Memoriam, Sterndale Bennett), for orchestra; String quartets in J) and Is minor; organ pieces, ete.

Duff, Charles, Scottish collector, was a teacher in l nundee about the begimning of the present century, and a partner in the music and bookselling firm of Inuff and Chatmers. His partner, James Chahmers, was the inventor of the adhesive postage stamp, which did so much to make the establishment of the penny post such a snecess. Duff published "A Cullection of Strathspeys, Reels, Jiggs, etc., with a bass for the violincello or harpsichord, etc." Edinlmrgh, [1790]. Duff died at Dundee, about $182 \%$.

Archibald Duff, brother of the abore, was a dancing-nitster and eomposer in Nontrose and Aberdeen, and published "A Collection of Strathspeys, Reels, etc., for the pianoforte, violin, and violoncello," Edinburgh, 1794. "The first part of a choice seleetion of Minnets, Dances, etc.," Aberdeen, 1812. Duff was a teacher of dancing in Aberdeen till 1820, and is said to have been conductor of the Philharmonic socisty before John Mackenzie, grandfather of Sir A. C. Mackenzie.

Dufferin, Helen Selina, Lady, was bom in 1807 . She was a daughter of 'Thomas Sheridan, and grand-daughter of R. B. Sheridan. Her sister was Caroline, the Hon. Mrs. Norton. In 1825 she married the fourth Baron Dufferin, and, in 1862, was married a second time, to the Earl of Crifford. She died on June 13, 1867. She was mother of the present Marquess of Infferin. Composer of "A set of ten Songs and two Duets, the words and musie by two sister's" [1833]. Ako rets of twetve and seven Songs [1833-39]. Ten Sonngs for contralto or nezzo-soprano voice, with $\mathrm{pt}$. accompaniment [1s61]. She also composed "Terence's farewell to Kathleen" ("So, my Kathleen! you're goin' to lave me"), and wrote many lyrics set ly barker, ete. See further, "Songs, Poems, and rerses, by IIelen, Lady Dofferin, edited by the Mariuess of Dufferin and Ava," 1 is94.

Duggan, Joseph Francis, composer and pianist, born at lonblin, July 10, 1817. He went early in life to the United States, and became aecompanist of the reeitatives in the Itatian Opera at New York. Afterwards he became musieal conductor of opera under Johm Wilson, and of a German opera com-
DUNCAN.

pany. He became a teacher in Philadelphia. Baltimore, and Washington, and was principal of the Philadelphia Musical Institute, 1841. He resided in Paris as a pianist and teacher, 1844-45, and afterwards in Fdinburgh. Afterwards he settled in London, and became musical director at the Mirylebone Theatre, 1854 , and later a protessor of singing at the Guildhall School of Music, ete.

Wonks.-Operas-I'icre, London, November, 1853; Leonie, London, Mareh, 1854; The Brides of Venice (MIs.); Alfred, Philadelphia (MS.); Le Nain Noir, Paris (MS.) Overture, etc., to As you like it, 1854. IIome and foreign lyries, a set of thirteen songs. Rhythmic tentatives, six songs, Op. 1 (1879). Two symphonies in $\mathrm{C}$ and $\mathrm{l}$ flat. Six string quartets. Numerous pianoforte pieces and songs. Author of the singing-master's assistant, a first series of vocal exercises, Lundon, [1878]; and translator of Albrechtsherger's "Science of Musie," Philadelphia, 1842; and Fétis" "Counterpoint and Fugne."

Dun, Finlay, composer and teacher, was born at Aberdeen, February 24, 1795. He studied under Baillot, and at Milan. $\mathrm{He}$ played first tenor in the theatre of San Carlo. Afterwards he studied singing under Crescentini, and settled in Edinburgh as violinist, composer, and teacher. He died, Edinburgh, November 28, 1853.

Works.- Two Symphonies for full oreh. (MS.); Solfeggi and Exereises upon Seales, Intervals, ete...to which is prefixed an Introduetory Discourse on Vocal Expression, London, 1829; Two prize glees; The Vocal Melodies of Seotland, edited with John Thomson (Paterson); Wood's Songs of Seotland, edited with G. F. Graham, etc.; Pf. music. Part-songs and Glees: June; The Parted Spirit (prize at Manchester Gentlemen's Glee Club), 1831; She is coming, trio, ete ; Anthems, psalms, hymms; Lays from Strathearn, by the Baroness Naime, Glasgow, n.d. [c. 1845-7]; The Musieal Serap Book, Edinburgh [1833], 2 vols. Orain na'h Albain, a Collection of Gaelic Songs, with English and Gaelic words, and an Appendix containing Traditionary Notes to many of the Songs . Edinburgh, 1848. Analysis of Scottish Nusie, ete.

Duncan, Alexander, music-teacher and vocalist, born about 1796 . He was preeentor of the outer High Chureh (now St. Paul's), Glasgow, from 1829 to 1836. Died at Springburn, Glasgow, Mareh 26, 1863. Compiler of "The Choir, a collection of psahm and hymn tunes, adapted to various measures.. with copious rudimental instruetions in the art of voeal musie," Glasgow, 1828. For this work the Rev. Dr. Wm. Anderson wrote a preface.

Duncan, Arthur, violinist, who resided in Dumfries. Published "A Collection of 


\section{DUNCAN.}

reels, strathspeys, quadrilles; waltzes, etc," Glasgow, 1852. Of this we have only seen one part.

Duncan, Gideon, author of the "True Presbyterian, or a brief account of the new singing, its author and progress in general." 1755.

Duncan, William Edmondstoune, composer, pianist, and organist, boln at Sale, Cheshire, in 1866. Showed musical talent very early, and becam A.R.C.O. at sixteen. At the opening of the R.C.M. in 1883, he won an open Scholarship for composition, studying under Hubert Parry, Villiers Stanford, E. Pauer, and G. C. Martin. He studied, after leaving R.C.M., with Sir G. A. Macfarren, and for ten year's pursued his profession in London, during which time several of his works were performed, notably a concert overture under the direction of Hamish McCum, at Hampstead, in June, 1888. He then returned to his native town, where he is chiefly occupied in composition; also holding a professorship at the Oldham c'ollege of Music. While in London he was musical critic to a provincial, and also to a Londun daily paper.

Works.-Ye Mariners of England, ode for chorus and orehestra, op. 4, produced by the Glasgow Choral Union, March 1, 1890 ; Mass in F minor, op. 13, compo ed, 1892; Perseus, opera in two acts (libretto by Professor Marshall Hall), 1892; Ode to Misic (Swinburne), soprano solo, chorus and orchestra, 1893; Sonnet to the Nightingale (Milton), soprano solo and orchestra, op. 32, 1895. Morning and Evening Service, together with the office for Holy Communion, set to music in the key of G, op. 21. Album of four Songs, op. 1; Three Songs; Four Sonnets of Shakespeare; Ye Mariners of England; Hymn to the Queen, 1897, and other songs; part-songs, ete. Orchestral: Concert Overture in D minor, op. 4, composed 1887, produced 1888; A Tone Poem. op. 7 ; Processional Narch ; In Memoriam, meditation in D minor, op. 17 ; Trio in F minor, pf. and strings, op. 28, produced at Oldham, December 18, 1895; Sonatas in C minor, op. 3, D minor, op. 8, and tit flat minor, op. 9 ; Six tone pictures; Six pieces for children, all for pf.; Six pieces for organ (Cecilia, Book 49); Meditation; Postlude; Processional March, organ, ete.

Dunkley, Ferdinand L., composer and organist, bom in London, 1869 , related to the family of smart. In 1881, he was in the practising schools of St. John's, Battersea, under Edward Mills, Miss. Bac. In 1886 he obtained the F.R.C.O., and the same year gained a scholarship at the R.C.M., where he remained four years, studying composition under Dr. Hubert Parry. He gained the prize of 50 guineas offered by the directors of

\section{DUNN.}

the Promenade Concerts at Her Majesty's Theatre, 1889 , for a Suite for orchestra. His setting of "The Wreck of the Hesperus," for chorus and orchestra, was produced at the Crystal Palace, April 7, 1894. He has also composed several songs. In 1893 he was appointed Professor of Music in St. Agnes' School, Albany, U.S.A., and holds the office of organist in the chief church in that place.

\section{Dunmore, Earl of, Charles Adolphus} Murray, amateur composer, born on Mareh 24, 1841. In 1866 he married the 3rd daughter of the Earl of Leicester. He was a captain in the Seots Guards: Lord Lientenant of Stirlingshire, etc. Composer of a Suite Symphonique, for orchestra, produced at the Brighton Festival, 1880; Pastorale, for violin and pf. (1878); Military mareh, for the pf.; Dance music. Songs: Fisher maid; For ever ; Spirit of my dream ; Years, years ago, duet, ete.

Dunn, John F., violinist, boln at Hull, February 10, 18f6. Began leaming the violin when eight rears old nuder his brother, the leader at a Hinll theatre. He was soon playing at concerts, and when barely eleven was engaged as assistant leader at the Theatre Royal, Hull. In 1878 he cntered the Conservatorim, Leipzig, studying under schradieck (violin), Jadasohn, and F. F. Richter. After distinguishing hinself at the Conservatorimm, and plaving the first movement of the Beethoven Concerto at the Hanptprïfung, in May, 1882, he gave some Chamber concorts in different towns in Saxony, and returned to England. He made his first appearance at Covent Garden Promenade Concerts, Octuber 1, 1882, playing the Concerto in E, of Vienxtemps. In 1885 he appeared at the Crystal Palace Concerts (Mr. Manns' bentefit), and also November 13,1886 , when he played Gade's Concerto in D nninor. Since then he has given concerts in many places, and gained a place among the finest violinists of the day. His repertory embraces all schools, from Paganini to spohr; and it was as the exponent of the Ninth Concerto of the last-manied that he made his first appearanee at the Philharmonic Society's Coneerts, Feloruary 27, 1896.

Dunn, Matthew Sinclair, tenor voealist, lyric author, and composer, bor'n at Glasgow, Alugust 3, 18t6. As a lad he played the conet in a Volunteer band, and later while engaged in business, kept up his musical studies as a Tonic Sol-faist. Was precentor in Ayrshire, and choimaster to the late Lady Elizabeth Pringle, in Berwickshirc, where he wrote and gare his popular entertaimments. In 1879 he won a scholarihip at the Tonic Sol-fa College, and went to London. He afterwards entered the R.A.M., studying singing under Ettore Fiori, W. H. Cummings, and J. B. Weleh, and harmony with Sir G. A. Macfarren. He 


\section{DUNNE.}

has sung at the Crystal Palace, the Promenade Concerts, and in most of the provincial towns. His concert lectures and entertainments, and chamber concerts of Scottish song, have been given in many places. In 1888 he was appointed conductor of the Choral class, and teacher of singing in Trinity College, London. $\mathrm{He}$ is author of The Solo Singer; The Solo Singer's vade mecum, Curwen; The Art of Singing; The Choir-boy's Mamual; and The Music Class, or Sight-singer. Editor of Auld Scotch Sangs, two collections, each of 96 Songs, Glasgow, Morison. Anthor of The Bride of Cambus (set by W. G. Wood), and other opera libretti; also many lyrics, set by himself and other composers. His compositions comprise twelve trios for ladies' voices; twelve two-part songs; Beautiful Snow, and other Services of Song; Stars of the Summer Night (with 'cello obligato); sweetheart, come baek, and many other songs. Six anthems. Matin Chimes, a collection of easy voluntaries for organ or harmonium, composed and arranged, 11 books; Fireside Fancies, pf. pieces for little players, etc.

Dunne, John, composer and organist, born at York in 1834. In 1850 he beeame a chorister in Worcester Cathedral, and in 1854 chorister in Cashel Cathedral, Ireland. He was a member of Christ Church, St. Patrick's Cathedral and Trinity College choirs, Dullin. In 1866 he gradnated MLus. Bac, and in 1870, Mus. Doc., Dublin. He was an examiner to the fovernment Intermediate Educational Board of Ireland. He died at Ashton, Killiney, near Dublin, June 7,1883 . Compuser of "Myra," and "The Hanging of the Crane" (Longfellow), cantatas; Chmreh services, anthems, glees, songs, ete.

Dunstable, John, composer and mathematician, was horn at Dumstable in Bedfordshire, early in the 15th century. Author of "De Mensurabilis Musice," a work quoted by Ravenscroft and others. Little is known of his hiography, but he died in 1453 .

He was erroneonsly attributed with the invention of counterpoint by Tinctor, lut is generally held up by suceeeding musicians as a composer of much ability and a musician of universal influence.

Dunstan, Ralph, organist, writer, and teacher, lorn at Carnom Downs, near Truro, in 1857. In music chiefly self-taught. Pupil teacher at St. Mary's Wesleyan Day School, Truro, 1871-6. In 1877, entered Westminster Training College, as a Queen's Seholar, and receired his first regnlar instruction in music from Mr. James Thomson, then music master there. In 1880 he was appointed organist at the College Chapel, and in 1889, music master. That year he gradnated Mus. Bice, and in 1892, Mus. Doc., Cambrickge. $\mathrm{He}$ is also a graduate and member of the Council of the

\section{DYCE.}

Tonic Sol-fa College. Since 1885 he has been music master at the Southlands Training College for Schoolmistresses; and from 1893, head of the music department at the Battersea Polytechnic Institution. Besides his degree exercises, Ps. 146, and "The Wreck of the Hesperus," cantata, he has composed services, anthems, hymn-tunes; a school cantata, "The Jester," school songs, etc. He is author of "The Teachers' Nanual of Music," 1886, fourteen editions; "Basses and Melodies" (Norello's primers), 1894, two editions; "First steps in harmony, and the harmonizing of melodies," London, Curwen, 1895.

Dupuis, Thomas Sanders, composer and organist, born at London, November 5, 1730. Son of John Dupuis, who was descended from a family of Huguenot refugees. Nember of the Chapel Royal. He studied under Gates and Travers, and became organist of Chapel Royal, in 1789. Organist of Charlotte Street Chapel, near Buckingham Palace, in 1773. IIus. Bac. and Doc., Oxon., 1790. He died at London, July 17, 1796.

Wonss.-Cathedral music, in score, composed for the use of His Majesty's Royal Chapel, by the late T. S. Dupuis, selected from the criginal manuseripts, and carefully revised, by John spencer, London, n.d., 3 rols. Twenty-four double and single chants $1780 \%$. Sixteen donlle and single chants, as performed at the Chapel Royal. Second set of Chants [1784]. Twenty-four donble and single Chant. . . [1791]. Five Concertos for organ, with accompaniments 1768]. Concertos, somatis and lessons for pif. Songs, six glees 1785 , etc.

D'Urfey, Thomas, minor poet, playwright, and musician, was born at Exeter, of French parents, in 1649. He lived in London as a writer for the playhouses and the court, and died there on February 26, 1723. He edited "Wit and mirth, or pills to purge melancholy, being a collection of the best merry ballads and songs, old and new, fitted to all humours, having each their proper tune for either voice or instrument.". .London, $1719-20,6$ vols., and also other editions and reprints. "Nusa et musica, or humour and musick, being an extraordinary collection of pleasant and merry humours, with Scotch and love songs," London, n.d. Many of the songs in "Wit and Mirth" were set to music by Purcell and other musicians of distinction.

Dussek, Olivia, see Buckley, Mrs.

Dyce, William, artist and musician, born at Aberdeen, in 1806, died at Streatham, London, February 14, 186t. The celebrated painter and Royal Academician, who did so much for art education in Britain. He was a cultured musician, and was one of the founders of the old Motett Society, for which he edited in 1814 the Book of Common Prayer, 


\section{DYER.}

with the ancient Canto Fermo set to it at the Reformation period, with an essay on that class of music." Also editor of The Urder of daily service, the Litany and order of the administration of the Holy Communion, with plain tune; according to the use of the United Church of England and Ireland, London, 1843; and author of Articles on Music in the "Encyclopedia Britannica," etc. He was an accomplished organist, and composed various pieces of music possessing merit

Dyer, Arthur Edwin, composer, organist and pianist, born at Frome, February 20,1843. Musical traiuing, private. Graduated Mus. Bac., 1873; Nus. Doc., 1880, Oxford. F.IR. C.O. Organist of the Parish Church, Westonsuper-Mare, 1865-75, and from that date has held the office of organist and director of the music at Cheltenham College. He was also, for some time, Conductor of the Cheltewham Musical Society. His compositions are: Sacred Cantata, "Salvator Mundi" (Degree Ex.; IIus. Doc., 1880) ; Cintata, "Harold," produced at Cheltenham, 1882; Music to Sophccles' “Electra," produced at Cheltenham College, June 28, 18s8, and two fullowing days. "I wish to tune my quivering lyre," chorus (Gloucester Festıval, 1883); Psalm 97, for soli, chorus, and orchestra; Anthem, " Except the Lord build the house," composed for the College Jubilee, 1891; An Evening Service; Songs, etc. Also an Opera, "The Lady of Bayonne," produced, Cheltenbam, Februaly, 1897. His brother, WuLIAM CHINNock I)YER, organist of St. Peter's, Norbiton, and Cunductor of the Norbiton Choral society, is the inventor of a patented attachment of pedals to the pianoforte.

Dyer. William Fear, organist and com poser, nut related to the foregoing. Has for some years held an appointment at st. Nicholas' Church, Bristul, and also that of conductor at the festivals of the Pristol Church Choral Lnion. He is the composer of a Cantata, "'The Second Advent of the Redeemer," performed at St. Nicholas Church, December 22,1889 , and several anthems.

Dygon, John, composer of the $15 \mathrm{th}$ century, who was supposed to be prior of the convent of S. Augustine, Canterbury in 197. He died in 1509. There is much doubt as regarls the identity of this musician, the authority hitherto followed having been Hawkins, who published a three-part motet by Dygon, entitled "Ad lapidis positionem " in his "History of Music." A Johu Dygon graduated as bachelor of music at Oxford, in 1512 He was a Benedictine monk, but it is dombtful if he is the same as the Dygon mentioned by Hawkins.

Dykes, Rev. John Bacchus, composer and clergyman, was born at Kingston-uponHull, Malch 10, 1823 . He was a soll of

\section{FAGER.}

William Hey Dykes, bank-manager at Hull. He was educated at a proprietary school at Wakefield, and entered St. Catherine's Hall, Cambridge, in 1843. While there he was a leading member of the University Musical Society. He had previously studied music under Skelton, the organist of St. John's Church. Hull, which had been built by his grandfather, the Rev. Thomas Dykes, LL.B. Afterwards, he studied music under Dr. Walmisley. In 1847, he graduated B.A. at Cambridge, anl in the same year he was appointed curate at Malton, Yorkshire. He became minor canon and precentor of Durham Cathedral, 1849 In 1850 he married Susan, daughter of George Kingston, of Malton, M.A., Cantab., 1851. Mus. Doc., Durham, 1861. Vicar of St. Oswald, Nurham, 1862. He died at St. Leonards-on-Sea, January 22. 1876.

Works.-Service in F; 'The Lord is my Shepherd, 23rd Psalm; These are they which came out of great tribulation, anthen. Partsongs. Psalms and hymms: Alford, St. Cross, Melita, Yox Dilecti, Horbury, Hollingside, St. Cuthbert, Dies Ira, Lux Benigna, Nicea, St. Agnes, Purliam, and a variety of others. Healso published Eucharistic truth aud ritual, a letter . . London, 1874, and varions sermons, etc.

The hymus of Dykes are among the finest examples of modem times. Melody and harmony are beautifully and agreeabiy combined in all. They are so well known, that little need be said beyond that their place in our collections will always be assured. His services and anthems are occasionally used, but their merits are not by any means so high as the genuine beauty of his hymrs would lead us to expect. His son, John St. Oswall Drkes, is a composer and pianist.

Dyne, John, composer and alto rocalist of the 18th century. He was a gentleman of the Chapel Royal in 1772; a Lay-Vicar of Westminster Abbey in 1779; and Principal at the Fandel Commemoration in 1784. He committed suicide on Octoler 30, 1788. He composed prize and other glees, songs, etc.

Eady, W. H., musician. Author of an "Introduction to the theory of Music," London [1878]. Composer of jif. music, ete.

Eager, John, composer, organist, violinist, etc., was born at Norwich, Angust 15, 1782. He removed with his parents to Farmouth early in life, and in 1794 was noticed by the Dulie of Dorset, who took him to Knowle, where he remained for some time. In 1800 he maried Misi Barubs, of Yarmouth, and in 1803 he became town organist of Yarmouth, and organist of St. Feorge's Chapel. He directed many concert enterprises in Sarmonth. Abont 1836 he settled in Edinburgh, and acted 


\section{EARNSHAW.}

for a time as teacher to the roral children at Balmoral, He was a violinist at the principal Edinburgh and (rlasgorv coneerts, and is remombered as an enthusiastic advocate and teacher of Logier's systemt. He died at Edinburgh, Jume 1, 1853. He had two daughters, one of whom married Joseph Lowe $\left(q \cdot v^{\circ}\right)$, the reel composer, and another Mr. Bridgman, a pianist, father of F. W. Hridgman $(q . \tau$.$) Hager$ wrote a tract, entitled "A brief aceount, with accompanying examples of what was actually dome at the socond exannination of Mr. Eager's pupils in musie, educated upon Mr. Logier's strtem." London, 1819.

Earnshaw, Robert Herry, organist and composer, born at Tudnorden, Lancashire, September 17, 1856. Musically educated in London under varions masters, retming to Lancashire in 1880. Graduated Mus. Bale., 1892, Mus. 1)oe., 1893, loublin. Orsanist and choimaster, J'arish Church, Morecambe, 1882-5; Sit. I'hiliy's, southport, 1890-1; Christ Chmeh, Preston, 18.)1, in which town he ocenpies a high position as an earnest worker for music. His compositions include "The Wreck of the Hesperms" (TTiversity Exercise), and a cantata, "Hail to the Lord's Anointed," for soli, eight-part chorus and orchestra (Exercise for Mus. Doc.) He has published anthems, part-songs, songs, and pf. pieces, some of which havo attained considerable popmlarity.

Earsden, John, composer of and of 16th and begiming of the 17th centuries. He composed songs, etc., and is mentioned in Hawkins" History.

Eastcott, Richard, witer and musician, born at lexeter in 1740. (hatplain of Livery Dale, levon. He died in 1ses.

Works. Sketches of the origin, progress, and effects of muske, with an aceount of the ancient bards and minstrels, illustrated with varions historical facts, anecdotes, etc., Bath, 1793 (2 editions). The harmony of the Muses (songs), n.d. Six sonatas for pf., ete.

Eastlake, Lady, English writer, born 1816 , died 1852, authoress of "Music and the Art of Iress," london, 1852. Wife of Sir Charles Eastlake the painter.

Eaton, Thomas Damant, wijer and musician, at one time President of the Norwieh Choral Society. Jie wrote Critical Notices of Bexfield's "Israel restored," and Pierson's "Jerusalen" (reprinted from the Norfolt: Neles), Norwich, 185\%. Musical Critieism and Biography from the published and monblished writings of T. D. Eaton, edited by his soĩ, I Jondon, 1872.

Eavestaff, William, writer and pinnoforte-maker. Author of "Instructions for the Pianoforte," London, 1830. A selection of Freneh Melodies, with symphonies and aecompaniments, the words by IV. II. Bellamy,

\section{ECCLES.}

six books, 1825-6.

Eayres, William Henry, violinist, born in Marylebone, London, 1846. As a child, he studied the violin under Henry Blagrove, and subsequently under Sainton and Henri Wieniawski, his pupilage with the latter ripening into close intimaey and fiendship. He has also made a study of the pf. and organ, and for abont four yuars was organist of limerick Cathedrat. He heads the second violins in the rehestras of the Philharmonic Soeiety, the Leeds and Three Choirs Festivals; was principal violiu, with T. Carrington, Bristol Festival, 1896; and holds important positions in London. Of his compositions, the music to Riclard Davey's classical conredy, "Lesbia," was performed at the I.ycenm 'Theatre. in September, 1888. He also wrote the music of one act of "Babil and bijou," and has composed various anthems, Church services, and songs-Beguiling eyes, Our sister May, liver thme, The chapel by the sca, etc. An overture, two strioig quartets, pieces for violin, pf , etc.

Ebdon, Thomas, composer and organist, born at Durliam, 1798. He was trained in Durlam Cathedral, as a chorister, and acted as organist in it from 1763 till 1811. He died at Durham, September 2:3, 1811.

Works.-Sacred music, composed for the use of the choir of Durham, 1780, two vols. Anthems. Collection of six glees, Op. 3, 1780. Songs. Two sonatas for the harpsichord, 1780 .

Ebers. John, impresario and theatre manager, born at London, in 1785, of German parentage. He managed King's Theatre, from 1821-28. Was ruined, and relinquished dircetion, 1828. He wrote "Seven Iears at the King's Theatre," London, 1828. The date of his death is unknown.

Ebsworth, Joseph, musician and dramatist, born at Islington, London, October 10, 1788. Afrer living for a time in Comwall and London, he settled in Edinburgh, in 1826 , and became a teacher of music there, and precentor of St. Stephen's Church. He wrote and translated a number of dramas, and was for fifteen years a bookseller. Besides being leader of pralmody of St. Stepher's, he was teacher of music in many of the principal schools and colloges in Edinburgh. Died at Edinburgh, Jume 22, 1868. Fe published two collections of psalm and hymm tunes, 1834 and [1845], and issued a General index to first hundred volumes of the music in library of the Edinburgh Harmonists' Society Edinburgh, 1844. Short introduction to Toeal Music, adapted either for private tuition or class singing, Edinburgh, n.d. Songs, hymus. and other compositions.

Eccles, Henry, violinist and composer, son of Solomon Eecles, was horn at the end of 


\section{ECCIES.}

the 17th century. Member of the King's Band, 1694 to 1710. He published in Paris "Twelve excellent Śolos for Violin," 1720 . He was a member of the King's Band in Paris, and died about 1742. His brother THounas was also a violinist.

Eccles, John, composer and violinist, born 1668. Son of Solomon Eccles. He studied under his father. Member of the Queen's band of music, 1700. Master of Qucen's Band, 1704. He died at Kingston, Surey, January 12, 1735.

Woris.-Acis and Galatea, masque, 1701 ; Ode for S.'. Cecilia's Day (Congreve), 1701 ; The Judgment of Paris (Cougleve), masque, 2nd prize in competition with Weldon, ete.; The IIad Lover, 1701; The City Lady; The Fair Ienitent, 1703; The Lancashire Witches, 1682; The Spanish Friar, 1681; Jnstice Busy, 1690; The Chances, 1682; The Way of the World, 1700; The Provuled Nife, 1697; The Richmond Heiress, 1693; Rinaldo and Amida (Demmis), 1699; Don Quixote; Love for Love, 1695. Collection of songs for one, two, and three voices, ett., London [1701]. Songs in Pills to purge Nehuncholy, ete. Eceles mas one of the most populal comprosers of his day, and some of his melodies are very fine, though not now in vogne.

Eccles, Solomon, compuner and violinist, was born in London, 1618. Father of IIenry and John Fecles. He beeime a quaker in 1660 , and was freepently arrested for disturhing congregations at worship, and hehaving with mach eccentriteity in the name of religion. He died at Lomblom, February 1 1, 16:5. He eontribnted to the "I Irision Violin," 169:3, and wrote a work entitled "A Musick-Lector, or the Art of Munick. aliseomised of, by way of dialogue, hetween there men of sereral judgements: the one a musician. the other a Baptist. . the other a (Muaker (wo-ealled), being formerly of that art, doth give his judgment and seistente against it, lunt vet approves of the musick that pleareth frud," Lomdon, 1667.

Edmonds, M., author of "Musical Catechism adapted to the first elass of performers on the Piansurte," ] bulin, 1807.

Edwardes, Richard, pret and composer, born in tomersetshire, 1523. Scholar of Corpus Cheisti College, oxford. Studied music mder treorge Ftheridge. M.A., Oxon., 1547. Master of Children, Cloapel Roval, and Gentleman, do. Member of Lincolin's Inn. He died on Oetoher 31.1566

Wokks. The Paradise of Tainty demises. The foul's linell, poen. 1).11non and Pythias, comedy. Jalermon and Aleite, comedy. "In going to my naked beel," madrigal. Many poens, trivets, ete.

Elwarden is not known now save hy his lovely madrigal, "In gining to my naked hed," which is one of the finest xamples of this

\section{EDWARDS.}

species of composition extant. The titles of his other poems are set ont at length in Ritson's and Hazlitt's works on Early English Poetry.

Edwards, C. A., anthor of "Organs and organ building, a treatise on the history and construction of the Organ, from its origin to the present day." . . London, 1881.

Edwards, Frederick George, organist and writer on music, born in London, Uctober 11, 1853. Studied at R.A.II. Hected A.R.A.M., 1896. Organist of Surrey Chapel, Blackfriars Road, 1873; Christ Church, Westminster Road, 1876; and of sit. Johu's Wood Presbyterian Church since 1881. Conductor of Lavender Hill Choral Siociety, 1883. Composer of anthems aud pieces for pf. Author of "United Praise: a practical handbook of Noneonfomist Church Mnsic," 18st; Romance of Psalter and Hymmal " (jointly with Rev. R. E. Welsh, M.A.), 1Rsy; "The Nusical Haunts of Loudon," J. ('newen and Sons, 1895 ; "History of Mendelsson's 'Elijal,,", Novello, 1896. Contributor to the Musical Times and other papers.

Edwards, Henry John, orgauist, pianist, and composer, hom at Barnstaple, Devon, February 24, 1854. Studied at fist moler his father (noticed below), and later in Loudon, under Stemalabe Benmett, G. A. Matofaren, H. C. Banister, and George Cooper. Graduated Mus. Bac., 1nT6; Mus. Doc., 1865, Oxford. lieturning to liamstaple, he succeded his father as organist of the parish chureh, and, in 18 s6, as conductor of the libster $\mathrm{Ml}$ nsieal Festival Society. In 1896 , he was appointed conductor of the Exeter Oritorio suciuty. As a pianist he has appeared at the most important concerts in his county.

Works.-. Psalm 145 (Exercise fo) Mus. Bac.), produced in barnstaple; Oratorio, The Ascersion (Exercise for Mus. Doc.), performed at the Western Counties Festiral, Fxeter, April 12, 1siss; Motet, Praise to the Holiest (from Cardinal Newman's Drean of Geron. tius), produced at the Hereford Festival, 1891 ; Cantata, the Epiphany, Bamstaple, 1891. Two oratorios in MLS. Church service; Anthems; Songs; Devoria, The Vigil, The beantiful City, and others; Part-songs, ete. Trimmphal Mareh, orchestra and military band, perforned at the promenade concerts, Covent Garden, 188:3; pieces for pf., etc.

His father, JOHN EDWARDs, was born at Crediton, Dewn, in 180s. Studied under Moxen, of Exeter, and alont 1833 removed to Barnstaple. He was comnected with the parish church for half a century, first as assistant to Huxtable the organist, then as organist and choirmaster; the latter office being held until about 1sisti. IIe fonnded the Choral Suciety, first kuown as the Bamutaple Philhamonic Society, and still in existence 


\section{EDIVARDS}

under the title in the preceding notice. He was also a violinist, and for years was the leading professor of music in the district. His compositions were mostly for the Church, consisting of services, anthems, hymn-tunes, and chants. He died at Barnstaple, in April, 1894.

Edwards, Henry Sutherland, author, bom at Hendon, September 5, 1829. Author of "llistory of the Opera in Italy, France, Gernany, liussia, and England, from Monteverde to Verdi," . . London, 1862, two vols. Life of Rossini, London, 1869. The life and artistic career of Sims Reeves, London, Tinsley, n.d. Rossini (great musicians series), London, 1881. The Lyric Drama, essays on subjects, composers, and executants of modern Opera, London, 1881, two vols. The Faust Legend, Remington, 1886; Famous first representations, Chapnran and Hall, 1886; The Prima IDonna, her history and surroundings, from the 17 th to the 19 th century, two vols., Remington, 1888. Mr. Edwards has written a large number of works about Russia, Poland, etc., as well as opera libretti, novels, etc.

Edwards, Rev. John David, clergyman and composer, born in 1806 . He was vicar of Rosymedre, Ruabon. He died at Llanddoget Rectory, Denbighshire, November 24, 1885, aged 79 .

Edwards, Julian, composer and conductor, born 185s. First came into notice througlı an overture, "Corinne," produced at Mr. ('owen's Concerts in St. James's Hall, November 13, 1siso. For some years afterwards, lie was engaged as conductor for the Royal English Opera Company, at Covent Garden, 1884, and also in the provinces. He is now resident in America. His compositions include the operas, "Corinne," “Victorian," produced at Sheftield, 1883; "Prian Boru," Broadway Theatre, New York, 1896 ; a cantata for female voices, "I) Montford's Danghter;" a sonata for pf., ete.

Edwards, Robert James, organist at Banliury, Uxfordshire, in 1825. Published "Sacred music, being a large and valuable selection of the best Psahm tunes, both ancient and modem, arranged for four voices, or a single voice, with an accompaniment for the organ or pianoforte," London. Preston, 1825.

Edwin, John, singer and actor, born in London, August 10, 1749. He is mentioned by O'liefe, and appeared in various musical pieces during the latter half of last century. Died in London, october 31, 1790 . His son JoIn was maried to Erizameti Rebecca Ricilaris, who was an actress and vocalist.

Egan, Charles, Irish writer and harpist, author of a "Harl' Primer, heing a familiar introcluetion to the situdy of the flarp," London, 1522, also, 1829. The Roval Harp Director...London, 1827.

\section{EIGAR}

Egan, F., Irish flute player. Author of "The single and donble Flageolet preceptor. . Dublin [1810], and arranger of numerous airs, ctc., for flageolet or thite.

Egerton, Hon. John Gray Seymour, son of the second Earl of Wilton (q.v.), amateur violinist and composer. He has written some good part-songs: Adien to tlic Woods; King Vinter; Spring's approach; 'The Rose and tlue Soul, etc. Also songs, and a cantata.

Eglinton, Hugh Montgomerie, Twelfth Earl of, composer, was born on November 29,1739 . He entered the army and became a colonel, and after his succession to the title, distinguished himself by initiating many public improvements in Ayrshire. He died on December 15, 1819. He was a patron of music, and composed "New stratlispey Reels, composed by a gentleman, and given with permission to be pulplished by Nathl. Gow," Edinburgh, 1796.

Egville, John Herve d', bass vocalist, hom at Worcester, 1857. Situdied at R.A.M.; Parepa-Rosa prizeholder, 1879. Joined the Carl Rosa Company in 1881; and sone years later toured with Joyly Carte Company in a round of the Gilbert-ifullivan uperas. Well known also as a concert singer of repute.

Ehrenberg, Alexandra, see WARWICK, GivLIA.

EIford, Richard, alto vocalist, was born about the middle of the 17th century. He was a comber-tenor in Lincoln and Durham Cathedrals. He afterwards sang on the stage in London; and becane a Gentleman of the Chapel Royal in 1702, and Lay-ricar of St. Panl's Cathedral, and Westminster. Hedied October 29, 1714. It was for him Croft is supposed to have written florid solos in his anchems.

Elgar, Edward William, composer, born at Broadheath, near Worcester, Jime 2, 1857. Son of W. H. Elgar, organist, of Worcester. Stndied the violin under Adolpho Pollitzer, and was well-known as soloist and orchestral leader in Worcester and district; was also for a time a member of $M l r$. Stockley's orchestra, Bimingham, and of the Nortl staffordshire Festival orchestra. Conductor of the Worcester Instrmmental Sincietr, 1882; and organist of St. Grolge's (Roman Catholic) Chureh, 1885, succeding his father who had held the post for 37 vears. lioth these positions he gave up in 1889, wheu he removed to Jondon. Ill-health compelled him to leave Jondon in 1891, since which time he has resided at Malveru, devoting himself exclnsively to composition.

Wonks.-Oratorio, The Tight of Jife (Lux Christi, book by Rev. F. Capel-Curt, produced at the Worcester Festival, September 7, 1896). rantatas: The Black Knight (Worcester, 1893), and Scenes from the Saga of King Olaf 


\section{ELLA.}

(North Staffordshire Festival, Octolyer, 1896); Choral Suite: Six scenes from the Bavarian Highlands, chorus and orchestra (Worcester, April, 1896); Spanish serenade, chorus and orchestra. Four Litanies, and other Catholic Church Music. Part-Songs: My love dwelt in a northem land, etc.; The snow; Fly, singing bird (for ladies' voices, with accompaniment for $p$ f. and two violins). Songs: Like to the damask rose; The wind at dawn; The Poet's life, and others. Orchestral: Concert overture, Froissart (composed for the Worcester Festival, 1890); Sevillana ; Liebesgruss; Serenade (strings only), and other pieces. Romance, violin and orchestra; pieces for violin and pf.; Itudes caracteristiques, violin solo. Sonata, for organ, composed for the visit of the American II sicians to Worcester, July, 1895. and played by Mr. Hugh Blair in Worcester Cathedral on that occasion. Cantatas and other works in MIS.

Ella, John, violinist, eritic, and lecturer, born at Thirsk, Yorks., December 19, 1802. Hestudied for the law, but became a violinist in the King's theatre in 182.; Concert of Ancient Nusic; Philharmonic Concerts, ete. He studied music under Attwood and Fétis, 1826-29. Established the "Musical Tnion," 1845-80. Established "Musical Winter Evenings," 1845-80. Lecturer on Music at London Institution, 1855. He died at London, October `2, 1888.

Works.-. Tectures on Dramatic Music and Musical Fducation abroad and at home, 1872. Insical sketches abroad and at home, 1861 (3 editions), 1869-78. Records of the Musical Union, 1845-78 (analytical programmes, notes, biographies). Personal memoir of Meverbeer, with an analysis of Les Huguenots, London, 1868. French Song and traditional Nelody, Anglice, The Harmonious Blacksmith, London, 1865 ; ete.

Ellerton, John Lodge, amateur composer and poet, born at Chester (?), January 11 , 1801. Son of Adam Lodge, of Liverpool. He assumed the name of Ellerton about 1845 . Educated at Rugby School, and at Oxford, graduating B.A., 1821, and M.A., 1828. In this last year was published a song, "And will thy spirit view," which was very favommably reviewed in the Harmonicon. He had hegun his musical studies early, and after leaving Oxford he went to Rome and studied mnder Pietro Terziani, maestro di capella at the Church of San Giovanni Laterano. While there he is said to have composed seven Italian operas. He resided a good deal in Gemany, his symphonies haring been composed at Wiesbaden, and other places. When in London he had quartet meetings at his honse with the best artists. He died in London, January 3 , 1873.

Works.-Oratorio: Paradise Lost,pulblished

\section{ETLICOTT.}

1857 ; Stabat Mater, female voices and orclrestra, op. 130 ; Mass in C, op. 53 (1843); in B flat, op. 106; in D, for two tenors and a bass, op. 103 ; Notets and anthems. Operas: Issiple; Berenice in Armenio; Annibale in Capua; Il Sacrifizio di Epito; Andromacea; Il Carnovale di Venezia; Il Marito a Vista (Italian): Carl Rosa; Lucinda (German) ; Dominica, prodnced Drury Lame, Jume $\bar{T}$, 1838; The Bridal of Triermain (English). Nineteen Italian duets, with orchestra; duets, songs, etc. Srmphony, No. 1, in F, op. 65, performed in London, December 11, 1849; No. 2, in D, op. 66, composed 1845 , performed London, 1847 ; No. 3, in D minor (Wald Symphonie), op. 120, published; No. 4, in E flat, op. 126; No. 5, in C, op. 123; No. 6, in E minor, op. 127, the last trro composed in 1858. Overtures, Ia Tarantella, and others; one performed in London, 1831. Three string quintets, Forty-four string quartets, op. 60, $62,70,76,101,102,124$, etc. Three string trios; eight trios, pf. and strings, etc. Thirteen sonatas, etc. Many glees, inchuding Catch Club prizes, 1836, and 1838. Bridal of Salemo, a romance in 6 cantos, with other poems, 1845; The Elixir of Youth, a legend in four parts, with other poems and notes, 1864.

Ellicott, Rosalind Frances, composer and pianist, born at Cambridge, November 14 , 1857. Daughter of the Right Rev. Charles John Ellicott, Bishop of Gloucester and Bristol. Mrs. Ellicott, her mother, is an accomplished musician and rocalist, for whom the late Rer. Sir F. A. G. Ouseley wrote the part of Hagar, in his oratorio so named. She established the Handel Society, London, in 1882. Miss Fllicott began to compose when only six vears of age, having a natural gift for hamony. When seventeen she entered the R.A.M., and afterwards studied form and orchestration for seven years with the late Thomas Wingham. Her compositions are numerons, and have secured ber an bonourable place among women composers.

Works.-Cantatas: Elysimm (Gloncester Festival, 1889); The birtli of Song (the same, 1892); Radiant sister of the dawn (Cheltenham Festival, 1887 ; Bristol and Gloncester, 1888); Henry of Navarre (men's voices, prod. Queen's College, Oxford, 1894): both for chorus and orchestra. Part-song, Bring the bright garlands, Bristol Madrigal Society, 1890, and others; Duets, songs-To the Immortals, Gloucester Festival, 1883, etc. Dramatie overture, Gloncester Festival, 1886, Crystal Palace, 1891, etc. Concert overture, Spring, St. James's Hall, 1886. Festival overture, Cheltenham Festival, 1893. Fantasia in A minor, pf. and orchestra, Gloncester Festival, 1895. Quartet in F; Trios in G, and D minor, pf. and strings; and other smaller works. A sonata for pf. and violoncello; one for pf. 


\section{ELLIOTT}

and riolin, with other works, remain in MS.

Elliott, Carlotta, soprano vocalist of the present time. First came into notice at Ganz's eoncerts, 1880-2. Sang at the Saturday Popular Concerts, Decemler, 1882; at the Philharmonic conterts, 1885 . Has given voeal reeitals, and appeared with suceess in many provincial towns.

Eiliott, J., anthor of "Philosophical Olsservations on the benses of Yision and Hearing; and a Treatise on Harmonic Sounds," London, 1780.

Elliott, James, composer and bass roeal. ist, was born in 17. $\mathrm{K}$, and died at London in 1856. Ife was a singer of reputation, and was one of the principals at the Birmingham Festival of 1802, and, it is supposed, sang some soprano solos at the Festifal of $17 y$. Writer of a large number of glees, some of which obtained prizen. Among them may be nanned: A choir of bright beanties; At her fair hands; The Boe, when varying flow'rs; Chamnt we the reguiem; Come, nuy Celia; Go, lovely rose; Invest my head with fragrant roses; Let those eomplain; Mrild is the air, ete.

Elliott, James William, organist and composer, born at Warwick, Febuary 13, 183:3. Chorister in Leamington parish Chmeh, 1846-4R. Studied under (6. A. Makefarren, etc. Organist of Leamington Chaped, 1847-52. Private organist to the Fatel of Wilton, Heaton Hall, 1859-60); of Partish Chureh, Banbury, 1s(a)-62; St. Mary, Boltmes, London, 1862-64; All Saints', St. John's Wood, 1s64-74; and from 1st5, organist and choimastere, st. Mark's, IBanilton Torrace, Londin. Composer of two operettas: "Romante and Reality," produced at chatring Cross Theatre, with F. Naccabe in the principal part; and "Dan'l's l)elight," ('erman Reed, Wister, 1893. Other works are: "Nittimal Nursery Rhymes" (Novello, 1s70, with sixty-five illastrations, "ngraved ly the brotleers 1)alziel); "The Ilarmoninm Treasury," g vols. (arrangenents); Six original pieces for hammonm. "The C'horas Servine

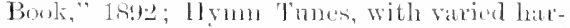
monise, l'hillips and L'age, 1895; Antlems, services, patrt-songs; song, IIybrias the Critan, ete.,

Ellis, Alexander bohn, musician and author, was born of parents named sharpe, at Hoxton, London, Jume 14, 1814. Fle was educated at slmewsbury, Eton, and Trinity College, Cambrilse, and graduated B.A. in 18.3. Afterwards, he became a Fellow of the Royal society, in 1s64, and a nembe of the Conncil in 1sise-81. He was atso president of the I'hilological Suciety, and member of many learned societies. He died at Kensington, London, Octoleer 2s, 1 sis.

To the proceedings of the Royal Soeicty he contributed various papers on musical theory
ELTEY.

and it.s physical basis, and published "Pronounciation for Singers, with especial reference to the English, German, Italian, and French languages, with exercises for teachers and for advanced students," London, 1877 "Speech in song," 1878 (music primer). $\mathrm{He}$ also translated, with considerable atditions, Helmboltr's "Die Lehre von den Tonempfindungen als physiologisehe gindlage fur die theorie der musik," as "On the sensations of tone as a physiological basis for the the ry of music," Lonton, 1875 , and with appendix and notes re-written, 1885.

Ellis, Rev. David Henry, composer and writer on music. (rraduated Mus. Bac., 1872; LL.D., 1880 ; B.1)., 1886, Trinity Cullege, Publin. Minor Canon, Bangor Cathedral, 1872-6 ; Precentor, sidney Cathedral, 1880-4; (foulburn Cathedral, and examining Chaplain to the Bishop of Goullum, 1845-9; vicar of St. Botolph, Lincoln, 1891. CompositionsPsalm 104, soli and chorus; Communion service; Evening service; Christmas anthems, etc. Author of "Essay on Cathedrals and Cathedral music."

Ellis, Henry Bramley, organist and conductor, born at Newark, Notts, February 3, 18t1. Studied under Dr. Dearle. F.L.C.O. Organist suecessively at it. Andrew's, Halsterad, 1863; St. John's, Leieester, 1sit; and St. Mary's, Leicester, from 187s. Conduetor of Leicester Orchestral soctety, Philharmonic suciety, etc. He has given a series of excellent concerts, and introduced many important works to the district.

Ellis, William, tompser anl organist of 17 th century. He was organist of Eton College, and of St. John's Collene, Oxford. On being expelled from sit. John's at the Rebellion, he estahlished music meetings at his house in Oxford, which wre attended by many of the most distinguishnel musicians of the time. At the liestoration it is beheved Ellis was remstated as organist at st. John's. In 1639, he graduated MLns. Bit"., Oxford, and in 1674 , he died them. 11 e composed rom ls and cansus in Hilton's esllection.

Elvey, Sir George Job, Kt., organist and composer, born at Uanterbury, Narch 27 , 1816. Chorister, and pupil of llighmore Skeats, at Canterbury Catheriral; he also studied under his brother. Stephen livey, and later at R.A.M., muler Cipriasi Potter and 1)r Croteh. In 1835, he sncceedef Hight. more Slieats, the younger, as organist and master of the boys at st. (ieoree's ('halpel, Windior, a post he held mont 1stie, when he retired. During his long perind of office he had the arrangement of tho music in comnection with many important events in the linyal Family - the marriage of the l'rince of Wales, in 1863 ; the l'rincess Lonise, 1871, and of the Dulie of Albany, in 1882. He graduated 


\section{ELVEY.}

Mus. Bac., 1838; Mus. Doc., 1840, Oxford. In 1871, he received the honour of knighthood. While at Windsor he was conductor of the Glee and Madrigal Society, and of the Windsor and Eton Choral Society. As late as October 18,1893 , he conducted some of his compositions at the annual concert of the St. George's Chapel Choir. His death took place at Windlesham, Surrey, December 9, 1893. He was four times married; his widow being a sister of Sir Josenh Savory, ex-Lord Mayor of London. In 1894, she published "The Life and Remiuscences of sir George Elvey, Lomdon, Sampson low.

Works.- Jratorios: 'The Resurrection aud Ascension (exerese for Mus. Bac.), 1838, performed by the sacred Harmonic sociey, Exeter Hall, December 2, 1840 ; Mount Carmel. A birthday vde; Victoria, an ode composed for opening of Royal Holloway College, June 30, 1886, words by Martin Holloway ; An ode to the north-east wind. Anthems: Bow down thine ear, Gresham prize, 1834 ; The ways of Zion do mourn (exercise for Mus. Doc.), 1st0; The Lord is King, composed for Gloucester Festival, 1853 ; Sing, $O$ Heavens, (for Worcester), 1857, and many others. MLoming and evening services; Thirty cathed ral chants; Fifteen double chants. Tunes contributed to Hymns ancient and modem, and other collections. Glees and part-songs. Festal March for orchestra, composed for th marriage of Princess Lonise; Introluction and gavotte, violin and pf.; Christm"s Bells, impromptu for organ or pf., ete.

Elvey, Stephen, composer and organist, brother ef above, born at Conterbury, in June, 1805. He studied, at Canterbury Cathedral, under slieats, and beeame organist of New College, Oxford, 1830. M11\%. Bac,, Oxon., 1831. Mus. Doe., Gxm1, 1s:3s. Choragus at ()xford, 1848-60. He died at Oxford, Oetober 6, 1860.

Works.-Services and Anthems. The Psalter, or Canticles and Palms, Pointed for Chanting, upon a New Principle, London (6 editions to 1s66). Hymms, etc.

Emanuel, Louis Alexander, composer, bor'n at Plymouth, in 1819. Student amd Associate, R.A.II. In $18 \pm 1$ was appointed bandmaster to the King's Roral Rifle Corps, and saw activi service in India. For many years lue has been choimaster of the Bayswater Syuagogne, London. Ammg his eompositionsare: The part-song, "Gentle winds"; the duet, "The Syren and the Friar"; and the descriptive song, "The Desert," which is still popular.

Emdin, John, amatenr mnsician, was born at Bristol in 1784, and died April 1:3, 1827. He composed the duets: Ever true; Hope, his Pilot whall be, etc.; Dearest Fillen, awake; Lady, tho' thy golden hair; and other songs, and vocal music.
ESTE.

Emerson, William, mathematical writer, author of, among other works, "Cyclomathesis, or an easy introduction to the several branches of the Mathematics," London, 14 vols., 176370. [Yol. 13 contains "Musie," ete].

Eos Llechyd, she l)aries (Rev. Owen).

Eos Morlais, spe liees (Robert).

Ennis, John Matthew, organist, pianist, and composer, born at 1)we'r, Angust 5, 1864. (iraduated MLus. Bac., 1892; Mns. Doc., 1895, london. Was organist and chommater of St. Philip's, C'lerkenwell, 1883-7: Holy Trinity, Lnightobridge, 1887-93; and st. Mary, Broolifield, London, 1s9:3. Has given concerts in Mreldelton Hall, Islington, ete. His works are: I'salm 46, for contralter wel , chorus, and orehestra; Magniticat, for soli, chorus, strings, and organ; songn: Beantiful maiclen, ete.

Esmond, Wilfred, tenur rocalint and comedian. Was for many years a memher of the Carl Rosa Opera Compiny, and also sang in comic opera, "Le's Cloches de Comerille," ete. In 1890, he appeared as Thadderis in the "Bohemian Girl," at C'apetown, South Africa. In 1895 , he acted as stage manager for the operatic performance of the fruildhall sichool students at Trury Lane Theatre.

Essex, Edward Charles, componer; of the firm of Hodge and Essex, instrument dealers. He has componed an Oratorio, "David," which was performed at Deal, in lecember, 1893; A trio, Ave Maria ; Songs, ete.

Essex, Timothy, comperer and organist, born at Coventry in 1764 . He was a teacher in Coventry, and alterward organint and choirmaster of st. Gerorge's Chapel, Albemarle street, London, near which be also had a munical academy. Mus. Bac., Oxon., 1806. Mus. Doe., Oxon., 1812. He died at London, September 27, 1847. Compused "simnets" of rarious kinds, be vallous anthor's, and wrote Rondos, six duets for 2 fluter, and uniscellaneons pf. mulic.

Essex, Countess of, see Stephexs (Catherine).

Este, Michael, composer, born in latter part of the 16tl century. Som of Thomas Erste. MIas. Bate, Camlin. 1606. He was mister of the choristers of Lichfield Cathedral, 161s. Died about 1638.

Works.-First set of Madrigals, London, 1604; Second set, London, 1606; Third set of Bookes, wherein are l'astorals, Anthens, Neapolitanes, Fancics, and Madrigals, to 5 and 6 parts, London, 1610; set of Madrigals, Anthems, etc., 1618; Anthems, 1624; Duos and Fancies for Viols, 1638; Hence, stars, you dazzle, 5 prert Nadrigal in the "Trimmph of Oriana," ete.

The name of this composer is varions sy spelt Est, East, and Easte. He is only supposed to be the son of Thomas Este. 


\section{ESTE.}

Este, Thomas, publisher and musician during latter half of 16 th and begimning of the 17 th centuries. He died about 1609 . He pulblished all of the more important works of his time, including anong others "The whole Booke of Psabmes: with their wonted tunes as they aresung in Churches, composed into foure parts," London, 1592; Byrd's Psalms; The Trimmphs of Oriana; and music by Campion, Dowland, Gibbons (Ortando), Weelkes, Kirbye, Wilbye, Mundy, etc.

Estwick, Rev. Sampson, clergyman and musician, born in 1657. One of children of the (hapel Royal. He studied at Oxford, and became Chaplain of Christ Chureh. Minor Canon of st. Paul's Cathedral, 1692. Vicar of St. Helen's, Bishopsgate, London, 1701. Do. of St. Michael's, Qucenhithe, 1712. He died in February, 1739.

Worrs.-The usefulness of Church Music; a sermon preached at Christ Church, November 27, 1696, Londcn, 1696. Odes, sermons, ete.

Etheridge, George, composer of the 16th century, was born at Thame, Oxfordshire. Wrote anthems, madrigals. and songs.

Euing, William, musician and collector, was horn at Partick, near Glasgow, May 20, 1788. Edneated at Glasgow Grammar School. Was an underwriter and insurance brcker. He died at Glasgow, May 12, 1874. He founded, in comnection with Anderson's College, Gilasgow, a music lectureship, by deod dated 1866, and the leetures have been delivered since 1869. Ho left also his valuable musical library to the same institution, together with $£ 1,000$ for its maintenance. This library has never been perfectly accessible to students and the public alike, by reason of some neglect in the administration of the provisions of the lequest. The library is one of the most valuable in Britain, and contains many rare and costly books on musical theory and history, together with valuable texts. The library of the late Dr. Rimbanlt is included in this collection. In 1876 , a very poor catalogue of this library was published, and in 1885 , a notice of its contents, by Jas. 1). Brown, appeared anonymously in Mason's "Public and private Libraries of rlasoow."

Evans, Charles, composer and organist. He was organist at Ludlow, shropshire, early in the present century. Composer of six sonatas for pf. or harpsichord, op. 3, London [1790]; March, for a military band, op. 7 [1807]: Epicedium on the death of Lord Viscount Nelson $[18067$.

Evans, Charles Smart, composer and organist, born at London, in 1778. Chorister at Chapel Roval, moder Arrtom. Gentleman of the Chapel Royal, 1808. Organist of St. Paul's, Covent Giaden. Gained prizes for glees in 1817, 1818, and 1821. He died at London, January 4, 1849.
EVANS.

Works.-Six Glees (Clementi), [1812]. Collection of Glees, ete., London, 1825. Music to Linler's Ode to the memory of Samuel Webbe, 1817 (prize from Catch Club). Two anthens, being the collects for the first Sinday after Easter... [1830]. I will love Thee, anthen, etc.

Evans, David Emlyn, composer, born near Newcastle Emlyn, Cardiganshire, September 21, 1843. Is musically self-taught, with the exception of a few pianoforte and organ lessons, whith he took while engaged in business in Cheltenham. More than twenty years of his life hav been spent in commereial pursuits, so that his musical activity has been something extraordinary. From 1865 to 1867 he competed at the leading Fisteddfodau in composition, the number of his prize works being nearly seventy. After the Wrexham Eisteddfod of 1876 , when all the prizes (four) in rocal compositions were awarded him, he retired from active competition; he has since acted, however, on many oceasions, as adjudicator. He hasedited rarious musical Journals, and is now joint-editor of $\mathrm{I}$ cerddor (The Musician); also edited The Biography of Welsh Dlusicians, for which a prize of $€ 30$ was awarded 11 . O. Jones $(q \cdot v)$ at the London National Eisteddfod (1887). Is author of a Manual on Accompaniment, and a series of papers on orchestration - the first ever published in Wales; and has contributed various papers on musical subjects to the Fondon Cymmrodorion, and other Welsh literary societies.

His published compositions include a sacred cantata, The Christian's Prayer (produced, Corwen, 1891): Songs of the Beatitudes, for Sunday School Choirs; a secular cantata, The Fairy tribe; twenty-six anthems and sacred chomses; thirty glees and part-songs; forty-eight hymm tunes; thirty-six songs; and he has a large number of works in MS., including a cantata, Mereh y Llyn (The Maid of the Lake). He has arranged a number of old Welsh tunes, authems, and airs,--amongst the last, The melodies of Wales, speciatly issued, and performed by a seleet choir before the Queen, at Palé, Merionethshire, during Her Majesty's visit there (1889). Chief musical editor of the Psalmist, a selection of tumes and hrmms, chants and anthems, for the use of the Welsh Congregationalists - a book since merged in a mueh larger collection, The Congregational Singer. Editor of a collection of music for Sunday Schools; and has arranged for pf. 5oo hitherto mpublished Welsh airs, Alawon Fy Nowlad, 2 vols., Newtown. Phillips, 1896. Scored for full orchestra, the first Wolsh oratorio, The Sea of T'iberias (Rev. E. stephen,. q.r.).

Evans, David Pughe, tenor vocalist and song composer, hom at Conwil-in-Elvet, Car- 


\section{EVANS.}

martheushire, 1866. Played the riolin, and sang in a choir in his early days. Won an open seholarship for singing at R.C.MI., 1887, studying under $G$. Henschel, and other's. On leaving, he joined the Rousbey Opera Company, and sang in several provincial towns, but ill-health obliged him to quit the stage. He afterwards resided in Swanseal as a teacher, and died there, February 3, 1897, of ehest disease. He eomposed songs, some of which have been popular; and won prizes at various Eisteddfodan.

Evans, Edwin, organist and composer, of the present time. Has given organ l'ecitals at the Bow and Bromley Institute, London, 1881-2; and conducted concerts at Richmond. Surrey, 1884, etc. His comprositions include a symphony; pianoforte concerto (performed at the Promenade Coneerts, November, 1882); suite de ballet, orchestra (the sime, October, 1888); sonata, pf. duet; a series of pieces for the organ, and some rocal music.

Evans, Evan, elergyman and musician, born 200 h April, 1795 ; died at Rhyl, January 21, 1855. He issued, among other works, "Y seraph, sef casgliad o donau crefyddol, ar amrrwiol fesurau": Caerleon, 1838. A collection of religious tunes: ("hester, 1838.

Evans, Fanny, see Frichexhats, Mladane

Evans, Hugh, Welsh musician, author of a catechisn of music entitled "Egwyddorion peroriaeth, ar ddull holwyddoreg ..." Llanrwst 1825$]$.

Evans, Robert Harding, writer, autlor of "An Essay on the Music of the Hebrews, intended as a preliminary discourse to the Hebrew Melodies of Braham and Nathan," London, 1816.

Ewing, Alexander, amateur composer, borm at Aberdeen, January 3, 1830 . Nephew of Bishop Ewing. He was educated at Marischal College, Aberdeen. After being trained for the law, he entered the army, in 1855, and became a st ff parmaster, with the honorary rank of lieut-colonel. In 1867 he married JuIiana Horatia Gatty ("Aunt Judy"), the authoress of many books for the young. He died at Taunton, July 14, 1895.

$\mathrm{He}$ is chiefly known as composer of the hymn-tune, "Ewing," usually sung to the verses beginning "Jerusalem the Golden." This has frequently been ascribed to his uncle, Bishop Ewing.

Eyre, Alfred James, organist, born at Lambeth, October 24, 1853 . Studied at R.A.M., under (Sir) G. A. Macfarren, F. Westlake, and others; and the organ with IV.S. Hoyte, and G. Cooper. Organist at St. Peter's, Vauxhall, 1867-72, and again, 1874-81; St. Ethelburga's, Bishopsgate Street, 1872-74; and St. John Evangelist, Upper Norwood, from 1881. In May, 1880, he was appointed organist of the Crystal Palace, a position he
FANING.

held until ill-health compelled him to retire in 1894. He has given recitals at the Bow and Bromley Institute; Birmingham Town Hall (October, 1890), and elsewhere. In 1885 , he was elected a nrember of the R.A.MI., and is now a Fellow. His compositions include Church Services (one written for the Salisbury Dioeesan Choral Association); Songs, partsongs, and pieces for pf. In MS. he has a setting of the 126!h Psalm; a scena for soprano solo and orchestra; String quartet; pf. trio, etc. He married Miss MARgaret BuckNall, an accomplished pianist, A.R.A.M. Who has played at various concerts with success.

Facer, Thomas, organist and composer of present time. Has held various organ appointments in Bimingham, and is teacher of singing at King Edward's Grammar Schools in that city. Conductor of a Choral Lnion, and gives concerts in the Birmingham Town Hall. He has composed the Cantatas, NoëlTide, 1892; The Crusaders, 1893; Maid of Lorn, produced at the Tonie Sol-fa Festival, Crystal Palace, July 11, 1896; Part-songs, school music, aetion songs, ete.

Fairbairn, James, writer, author of "Elements of Musie: Part I., Melody, containing an explanation of the simpler Principles of the Science. Part II., Harmony, with Appendix on the nature and causes of sound, and the consonance ard dissonance of intervals, as arising from one system of vibration," Edinburgh, 1932.

Fairfax, Robert, or Fayrfax, composer, born at Bayford, Herts, in Iatter part of the fifteeuth century $1470^{\circ}$. IIus. Doc, Cantab., 1501-2; Do., Oxford, 1511. About 1509 he was appointed one of the Gentlemen of the King'- Chapel. Organist of the Abbey Church of $\mathrm{St}$. Albans. He died at At. Albans in 152930. He con:posed sacred aud secular music, but is ehiefly known as the composer of a volume of songs in two, three, and four parts, now preserved in MS. in the British MIuseum. Other compositions of the same master are in the Music School of Oxford, at Cambridge, Lambeth Palace, ete.

Faning, Eaton, composer and conductor, born at Helston. Cornwall, Nay 20, 1850. Received his first lessons from his parents, and, in 1870 , entered the R.A.MI., studying under Sterndale Bennett, C. Steggall, and others. In 1873 he won the Mendelssohn Scholarship, and in 1876 the Lucas medal for composition. A.R.A.M., 1877; Professor, 1878 ; and later, a Fellow of the Institution. Graduated MIus. Bac., Cambridge, 1894. Held various posts at the National Training School, the Guildhall School of Music, and R.C.M., until 1885, when he was offered, and accepted, the position of Director of the 


\section{FANNING.}

Music at Harrow School, which he still holds. His compositions include a Magnificat and Nunc Dimittis, for voices and orchestra, performed at the Festival of the Sons of the Clergy, at St. Paul's Cathedral, 1878; Anthems, part-songs; Moonlight, Song of the Vikings; Choral ballad, The.Miller's IVooing; Chorus, Daybreak, with orchestra; Songs, etc. Operettas: 'The Two Majors, R.A. M., 1877; Mock Turtle, 1881; and The Head of the Poll, German Reed, 1882. Dramatic Cantata, Liberty, 1882; Cantata for female voices. Buttercups and Daisies. Symphony in C minor: Overture, The Holiday, Promenade Concerts, Covent Gardes, 1882; Qnartets ; Allegro, pf. and clarinet; Pf. pieces, etc.

Fanning, Charles, Irish harp-player and collector, born about 1736 . Assisted Bunting with his collections. Date of death unknown.

Farmer, Henry, violinist and composer. born at Nottiughisu, Iay 13, 1819, son of John Farmer, a vocalist. Chiefly self-taught in music, but had some lessons from J. Wade Thirlwall. A concert-giver from 1841, he led a busy life 10 the lasi in his native town. Was for many years leader of the Birmingham Festival Choral Society's concerts and member of the Festival orchestra in 1846 (but not leader), and for some time after. Organist of High Pavement Chapel, Nottingham, for over 40 years; and conductor of the Nottingham Sacred Harmonic Society up to 1880 . An active volunteer, he became Captain in the Robin Hood Rifles. Engaged in a music business for fifty years, he retired on a fortune just two days before his death, which took place June 25, 1891. His works comprised a Mass in B flat, published in 1844; a violin concerto, performed at Nottingham, Novem. ber 25, 1841; other concertos and violin pieces; Overture, "Calypso," Nottingham, 1845. Glees-Welcome joy and harmony, prize, Nottingham, 1845; The Wine Cnp, and others. "Singing Quadrilles," and various pf. pieces. New Violin School; The Violin Student; New Violin Tutor; Tutor for American Organ and Harmoninm; varions arlangements, etc. His daughter, EmLY Fardiley Farmer (Mrs. Arthur W. Lambert), is a composer, her works including a quartet for $p f$. and strings; an operetta for children, "Nell," prodnced at Nottingham, 1893 ; pieces for harp and pf., songs, etc. Other musical artists of the name were AnNa Maria Farmer, a vocalist, who died in London, April 11, 1846; and her sister, DinaH FARMmR, a pianist of distinetion (afterwards, Mrs. De Lisle Allen), who died in London, March $10,1884$.

Farmer, John, composer of the 16th century, harmonized Este's Psalms, and composed "Cantas, the first set of English Madrigals to foure Voyces, newly composed

\section{FARNIE.}

by Joln Farmer, practitioner in the art of musicque, Little Saint Helen's," 1599 ; “Fair Nymphs," six-part Madrigal in "Triumphs of Oriana;" Divers and Saundrie waies of two parts in one, to the number of fortie upon one playn-song," etc., London, 1591. His biography is unknown.

Farmer, John, organist and composer, born at Nottingham, August 16,1836. Nephew of Henry Farmer. Studied at Leipzig Conservatorium, and under Andreas Späth, at Coburg. Resident as music teacher for some years at Zurich. In 1862 was appointed music master at Harrow School, a position he held until 1885, when he became organist of Balliol College, Oxford. There he instituted a Musical Socicty, and has given much atten. tion to concerts of an educational character. His compositions include an oratorio, "Christ and his Soldiers," produced at Harrow, March, 1878 ; Requiem in memory of departed Harrow friends; "Cinderella," a fairy opera, composed 1882, performed, Harrow, November, 1883; Comic cantata, "Froggy would a wooing go," Oxford, 1887 ; Nursery rhymes quadrilles, for chorus and orchestra. Septets in $\mathrm{C}$ and $\mathrm{D}$, for pf., strings, and flute; Quintet, pf. and strings, Harrow, 1874. Editor of hymns and trmes for High Schools; Harrow glee book; Harrow School songs; Harrow marches; Dulce Domum ; Rhymes and songs, etc.

Farmer, Thomas, composer of the 17th century, was one of the waits of London, and Mus. Bac, Cantab., 1684. He died before 1695, and Purcell has included an elegy on him in "Orpheus Britamnicus."

WORKs. - A consort of musick in four parts, containing thirty-three lessons, beginning with an overture, 1686 . A second consort of musick in four parts, containing eleven Lessons, beginning with a ground, 1690. Songs in Playford's Choice Ayres, 1675, and in various collections of his time.

Farnaby, (iiles, composer and spinnet player, born at Truro, Cornwall, about middle of the 16th century [1560]. Mus. Bac., Oxon., July, 1592. Date of death unknown, but he lived mostly in London, and Sevenoaks, lient.

Works.-Canzonets to foure Voyces, with a Song of eight parts, London, 1598. Madrigals. Pieces contributed to Queen Elizabeth's Virginal Book (which also contains four pieces by Richard Farnaby, a son of Giles). Psalms in Ravenscroft's collection, etc.

Farnie, Henry Brougham, musician and librettist, was born in Fife about 1837. He was educated at St. Andrews and Cambridge Iniversities, and was for some time editor of the Fifeshive Joumal. In 1863 he settled in London, and was editor of the Orchestra, Sock and Bushin, and Paris Times. 


\section{FARNOL.}

He also was associated with Henderson in the opera bouffe productions at the Strand, Folly, Avenue, and Comedy Theatres. He compiled and wrote the librettos of a number of operettas, pantomimes, songs, etc.; and translated most of the more successful modern French comic operas. His talents as an adapter were of the highest order. Among his productions may be named "Sleeping Queen," “Rip Vau Winkle," “Cloches de Corneville," by Planquette. He also wrote words for Arditi's "Stirrup Cup," and translated Gounod's “ Romeo et Juliette," “La Reine de Saba," etc. He died at Paris, September 21, 1889. By his will he left $£ 23,072$ to his sister.

Farnol, Eleanor, see Morr, Mrs. F. L.

Farquharson, James, musician and teacher in Ediuburgh. Published a "Selection of Sacred Music, suitable for public and private devotion," Edinburgh, 18\%4.

Farrant, Daniel, composer, of the 16th and 17 th centuries; set lessons for the riol in what was known as lyra-way, in initation of the lute.

Farrant, John, composer, of the 16th century, was organist of Salisbury Catledral, about 1600 . Biography unknown.

Another John Farraxt, ol not mnlikely the same, was organist of Christ's Hospital, London, about the same time.

Farrant, Richard, composer and organist, was born about 1530 . He was one of the Gentlemen of the Chapel Royal to 1564 . Master of Choristers, St. George's Chapel, Windsor, 156t-69. Again Gentleman of the Chapel Royal, 1569-80. Organist and LayVicar, St. George's Chapel. He died at Windsor, November 30, 1580.

Works.-Services in G minor, D minor, and A minor. Anthems: Call to Remembrance; Hide not thou thy face; Lord for Thy tender mercies sake; O Lord, Amighty, etc.

The work by which Farrant is best known is "Lord for "Thy tender mercies salie," an anthem which is of disputed authorship, some attributing it to John Hilton. It has also been adapted as a psalm tune, in which form it appears in numerous collections.

Farrar, Joseph, writer and physician, who studied at Edimburoh, ete., and graduated MI.D. at St. Andrews, 1s8t. Now in practice in Gainsborongh. Anthor of "The Human Toice and connected parts. A practice book for orators, clergymen, voealists, and others." London, 1881, ete.

Farren, George, author of "The Mortalities of Celebrated Musicians," London, 1834.

Faulkes, William, organist, pianist, and composer, born in Liverpool, November 4, 1863. Studied under William Dawson, and the late Hemy Dillon-Newman. Organist of
FAIVCETT.

St. Margarct's, Anfield, Liverpool, since 1886. Resident there as teacher and performer.

Works.-Concerto in ( minor, pf. and orchestra, 1891; Concerto in A minor, violin and orchestra, composed 1892, performed, Art Club, Liverpool, May, 1s93; Suite in C minor, for flute, oboe, trmmpet, strings, and pf., 1892. Trios, for pf., viulin, and tello, D minor, compused 1s91, performed at C'unferences of Incorporated society of Musicians, London, January, 1893; G minor, and C minor. Twelve pieces for organ; Sonata in I) minor; Concert overture in E flat; and otler organ pieces. Pianoforte pieces; three pieces awarded the prize offered by the North-Western Section, I.S.M., 1893. 'Pieces for violin, violoncello, etc.

Faulkner, Thomas, musician. Author of "Organ Builders' Assistant," London, 1826. "Designs for Organs," London, 1838.

Fawcett, a remarkable Yorkshire family of musicians. JosEpH FAwcetr, the head was born about 1815 , and followed his vecupation as a weaver at Horsforth, and afterwards at Eccleshill, whither he was invited to assist in the choir of the New Commexion Chapel. He sang tenor, played the violin, and was choimaster. He has five sons, musicians, JoHx, JosepI, SAMUEL, trombone players; Tou, pianist and orgmist; and HAxDEL, contrabassist. John has two sons in the profession;-HARRY, a violinist; and MENDELssohn, a clarinettist. Joseph junior's son, Charles, is a violinist; and the three sons of siantel, named C'HARLEsworth, VERD1, and WeBer, play clarinet, violin, and oboe, respectively; while Fawcett MidgLey, the married sister's son, is a bassoonist. The nembers of this family are known all over the north of England; they have played regularly for the Carl Rosa Opera Company, and some have tomred the country through, while others are known as skilled players in Chamber Concerts.

Fawcett, John, composer and writer, was hom at Kendal, in 1789. He was a sloemaker for a timc, but afterwards became a teacher of music in Bolton, Lancasline. He died at Bolton, October 26, 1867 .

W'orks.- New set of sacred music, in three parts... hy John Fawcett, of Kendal [1830]. Mirian's timbrel, a new set of psalm and hymn tumes... London, n.d. Melodia divina, a collection of psam and hymm tunes, London [1841]. Harp of Zion, consisting of original tumes, and pieces $[1845]$. The cherub Lute ...hvmms, etc., London $[1845]$. Toice of Devotion, containing 400 psahm and hymm tumes, Glasgow [1862-63]. Musie for Thousands, or the vocalist's mamual [1845]. Lancashire Tocalist, a complete guide to singing at sight, London [1854]. Chanting made easy, London [1857]. Paradise, oratorio [1865]. 


\section{FAWCETT.}

The seraphic Choir, a Christmas piece, 1840. Juvenile Pianist's Companion, 1850 . Etude de salon, for lif., op. 1. Anthems, Temperance songis, etc.

Fawcett, John, composer and organist, son of alove, horn at Bolton, 1824. He studied under his father, and became organist of St. John's Church, Faruworth, 1835. Organist of Parish Church, Bolton, 1842. He studied at the R.A.M., London, wnder Bennett, from 1845. Organist of Curzon Street Chapel, London, 1845-46. Mus. Bac., Oxon., 1852. He died at Manchester, July 1, 1857.

He wrote a cantata, "Supplication and Thanksgiving," as a degree exurcise, 1852; anthens, glees, songs, and pf. music.

Fawcett. Rev. Joshua. musician, edited "Lyra Ecclesiastica, consisting of voluntarien, introits, thants, services, anthens." Bradford, 1845. Preface ly Rev. IV. H. Havergal.

Fayrfax. Robert; se' FaIRFAx.

Fearnside, Frederick, didactic writer, was a chorister at Norwich Cathedral in 1848, and afterwards articled to Inr. Buck. Tle died at Bradford, October, 18rs. Author of "The Systematic and Comprehensive singing Manual" [1887].

Fearon, see Crlossop.

Featherstone, Isabella, see PAUL (Mrs. HowARD).

Felton, Rev. William, organist and composer, born in 1715. Was Vicar-Choral at Hereford in 1741 , and afterwards Minor canon, He was Ticar of Norton Canon, 1751-69. He died on December 6, 1769. He wrote concertos for organ and harpsichord; and eight sets of easy lessons for the luapsichord, ops. 3 and 8 . He componet the well-known hymm tune, "Fabian." Ile was esteemed in his day a remarkable performer.

Fenton, Lavinia, bom Bestwick, soprano vocalist, who made her tébut at London in 1726. She was the original I'ully Puachem in "The Beggar's Opora," January 29, 1728. Retired from the stage as mistress of the third Duke of Bulton. Married to him at Aix, Provence, 1751. She died at Greenwich, Jannary, 1760.

This singer bas interest for the present time only in her connection with that ever-famous work, "The Begrar's Opera," in which she scored an enornuons success.

Fergus, John, composer, was horn at Huntly, Aberdeenhire, in 1767. He was organist of St. Andrew's Epiccopal ('hurel, Glasgow, for a number of fears. Iled at Glasgow, June 10, 18:5. He composed three glees, songs, and organ pieces.

Ferrabosco, a fanily of musicians. AlFox so, son of an Ftalian composer of the same nanse, who settled in England some timo before 1567 , was born at Creenwich, at a date unknown, probably about 1570 . Howas taken

\section{FIELD.}

to Italy by his father, and studied at Bologna. Mnsical instructor to Prince Henry, 1605. Published "Arres," 1609. Died in 1628. His works included lessons, and fancies, and he contributed to Sir William Leighton's " Lamentacions," 1614. His son, AlFoxso FERRABosco, succeeded his father in the King's hand in March, 1627-8. With his brother, IIENRr, he was appointed a musician-in-ordinary to the King. Some pieces for viols are to be found in the Addit. MSS., British Musemm. He died in 166I. John Ferrabosco, son either of Alfonso or Henry, was Mus. Bac., Cambridge, I671. Organist of Ely Cathedral from 1662 to 1682 , when he died. Anthems by him are in the Ely Cathedral library. The history of this family is olscure, but the best account will be found in the Dictionaly of National Biography, xviii., pp. 375-7.

Ferrey, George, organist of Christ Church Priury, Hampshire, from 1851, until his death, Fubruary 10, 1893. I1is predecessor, a Mr. Hiscock, wan appointed when the organ was built, in 1788 , the two holding office for more than a century.

Ffrangcon = Davies, see l) Aries, D. FFluAGCOx.

Field, Henry Ibbot, composer and pianist, born at Bath, December 6, 1797. He studied under Coombs, of Cheltenham, and tanght musie at Bath, where lie died, May 19, $18+8$. He wrote some numportant music for the pianoforte. He was one of the few provincial pianists thought worthy of a hearing in London. At the Phillamoune Concerts, February 25, 1822, lus played a concerto by Hummel (in A minor ?), for the first tine in England; and, June 22 , 1840, he played Hummel's Bminor concerto. II is father, Thumas Fiedd, Wats organist of Bath dbber.

Field, Joln, composti and pianist, botn at Dablin, July 26, 1762. Apprenticed to Clententi, London, under whom be afterwards studied. Taken byclenenti to P’aris, Gemany and Rusial. Teacher at st. Petershorg, 1804, and at Moscow, 1823. Appearecel at London Philharnonic Concert, 1832. He played in lielgimn, Switzerland, and Italy, and afterwards retumed to Rusisia with a family named Raemamn. He died at Moscuw, Jamuary 11, 1837.

Woris.-Op. 1. Three Sonatas for pf. in A, E flat, and C minor. Seven Concertos for pf. and orch., in $\mathrm{E}$ flat, I flat, E flat, E flat, C, C. C niner. Two Divertisisements for pf., with accomp. for 2 vis., flute, alto and biss. Quintet for pf., 2 vis., alto and bass. Rondo for pf. and quartet. Tariations on Russian air for pf. duet. Frand Valse for pf, duet. Three Sonatas for pf. in A, B, and C. Sonata for pt. in B. Exereise in Modulation for pf. Two Airs for pl. Fantasias for pf. Eighteen Nocturnes for pf. Rondo Ecossais for pf. 


\section{FIELD.}

Polonaises for pf. Two Songs for Voice and pf. Romances for pf. Romdos, and miscellaneous picces.

Field, John Thomas, orgmist and composer, born near Manchester, February 4 , 1850. First musical studies private. Later, pupil of sir John Stainer, and Dr. J. F. Bridge. In 1868, appointed organist and choirmaster, Parish Chureh, Holrwell, North Wates; 1870 , Christ C'hurch, Southport; 1872 , st. Creman's, Blacklieath; and, two years later, to Clnist Church, Lee Park, Kerit, where he is still in office. Assuciate of the Philhamonic Soeicty.

Works,-Monning, Conmmuion, and Evening Service in D; Benedictus and Agnus Du, in F; Magnificat and Nune bimitis in G; The Canticles of the C'lunch, Two sets; Chant Services. Anthems: send out Thy Light; Lord of onr life; Hail! gladdenimg light; and others; Carols. Songs: An uld story; Two children fair; Part-songs, ete. Oflerturéá la Sonate, in three movements, and other organ pieces; Nocturnte, pf.; L'iecen for pr. and violin; Ronnance in A, etc., ete.

Filby, William Charles, organist and composer, bom at Hammersmith, 15i6. Was organist of St. Peter, Hammersmith, in 1849 , afterwards spending sume tine in study in France. Organist and choinnater, Parish Church, Bromley, 1853 ; Sit. Pete'r's, Walworth; St. Matthew's, Bayswater; St. Luke's, Westbourne Park; Holy Trinity, Margate; Holy Trinity, stepney; and sines '18st, of sit. Paul's, West Creenwich. Conductor of C'horal Societies at Greenwich, Chelsea, etc. Has given organ reeitals in London, and in variont provineial towns. Was vne of the appointed organists at the International Exhibitions, 1882 and 1885. Lecturer on subjects connected with Church music, the upera, and musical education. His compositions are very numerous, and include sattings in Cantata form, of Psalms 13, 23, and 65; A Mass in E flat, op. 24; Mass in E, op. 28; Salve Regina, op. 67, and other music for the Roman Catholic Service. Anthems, settings of the Canticles. Operettas, Iour muney or your life; Alabama claims. A number of songs, choruses, and part-songs. Sonatas in E, op. 66, and $G$ minor, op. 76, with many other pieces for pf. Four organ voluntaries, op. 110; Three organ pieces, op. 124, etc. Revising editor of Lady T. Freke's tune-loook, song of Praise; and of J.B. Mead's, The Treasury. Contributor of hymm-tunes to Hymms Ancient and Modem; The Bristol Tume-book, etc. Author of Piccolo Tutor (London: Williams); Flute Tutor; How to write music; The Student's Copy Book (London, 1882).

His brother, STEPHEN Filbi (born 1831, died 1895), was organist of the Parish Chureh, Hammersmith, for over twenty years, and afterwards of Holy Trinity, Barnes, and the

\section{FISHER.}

Parish Church, Wealdstone, Harrow. He was an extemporaneous player of repute.

Filmer, Edward, composer of the 17th century. Hepublished "French Court Ayres of four and five parts," 1629 .

Finch, Hon. and Rev. Edward, composer and clergyman, fifth son of the 1 st Earl of Nottingham, born in 166t, died at York, February 14, 1738. He composed anthems, psiahns, ete. ; also a "Grammar for Thoroughbass, with examples." MS. of 66 pages in the Huing Library, (Hasgow.

Findlay, William, violinist and compser, born at Crofthead, Linlithgow, August 11, 1854. Resident at Broxburn, in the same county, as a music teacher. He his composed a number of reels, hornpipes, strathipeys, and other Seottish dance music,

Firth, R. A., composer, and organist of St. John's, Hampstead, compiled "Select p.rtiuns of the new version of Psalns, adapted to a thuice collection of Psalm tumes, for the llate of the Parish Clunch of st. John, Hampstead," London, 1819. "Congreyational and dmestic praise, consisting of select portions of prims and hymns adapted to appropriate trumen. . .," London, 1835. Six cinzonets [1.25]. Hymms, pf. music, ete.

Fish, William, violinist and composer, burn at Norwich, in 1775. Violinist in Norwich theatre. Teacher of music at Norwich. Was musical preceptor of Hdward Taylor and Grone Perry, and a composer of concertos; gratmi somatia for the pf., op. 1 ; glees, and surfos. He died at Norwich, March 15, 1866.

Fisher, Arthur E., is a profesinor of harmony, counterpoint, and composition, in the Tornitu College of Music. IJe is a MLus. Bac. (Turontu?) and A.R.C.O., England. He has comp wed a cantata for female voices, "The Wrati of the Hesperus." EDWARD Fisher, an ther Toronto musician, was musically edracited in Gemmany. He was musical direct $r$ of the Ottawa Ladies' College, and comductor of the Choral Society in that city. Organist of St. Andrev's Church, Toronto; conductor of the Toronto Choral Society for some rasis up to 1891. From its establishment, in 1887, he bas been principal of the Torunt, cumservatory of Music. Elected President ilse Canadian Society of MIusicians, 1888, and again in 1889.

Fislier, Henry, didactic writer, and teacher, born at Blackpool, December 21, 1845. Chiefly self-taught in music. Apprenticed to a firm of music-sellers in Manchester, he acquired a knowledge of the pianoforte, and gained further experience as assistant to a 1 rof nior of musie at Darlington. Graduated Ths. Bac., 1876; Mus. Doc., 1878, Canil we. For three years was organist of Chris Church, Blackpool, in which town he is settle 1 its a teacher of singing, pianoforte, 


\section{FISHER.}

and harmony. He is an earnest stud nt in every branch of kuowledge, and has been elected a Fellow of the Geological Society. His compositions are two eantatas, "Ruth, the Gleaner," and "The Call of Gideon;" a romance for viola and orchestra, and some minor works. liesides contributions to the musical press, and lectures, he is author of The Musical Profession, a handbook for profensors of the present and the future; The Candidate in Music, Part I., a text book of musical clements, and II., Harmony; editor and part author of E. Q. Norton's Construction, tuning, aud care of the pianoforte; and also of John Curwen's The Harmony Player, f $\sim$ the harmonium, all published by Curwen and Sons, for which firm he has arranged a number of operas for children's voices.

Fisher, J. Churchill, a composer, born in Australia. Has written a Cantata, "The Emigrants," produced at Parramata, February $22,1887$.

Fisher, John Abraham, composer and violinist, born at Dunstable, or London, 1744. He studied under Pinto, and appeared at King's Theatre as violinist, 1763. In 1764 he became a member of the Royal Society of Musicians. Married Miss Powell, 1770. Bac. and Doc. Mus., Oxon., 1777. Travelled in Russia and Germany. Married Anne Selina Storace, 1784 , but separated from her soon afterwards. He lived in Dublin as a teacher, and died in May, 1806.

Wonks.--Mnsic to The Monster of the Wood, 1772; The Sylphs, 1774; Prometheus, 1776; The Norwood Gypsies, 1777; Macbeth. Providence, oratorio (for degree), 1777. Symphonies; Concertos for pf., and for oboe; Violin and flute music; Canzonets. A comparative view of the English, French, and Italian Schools, consisting of Airs and Glees composed as examples of their several manner's, Londou, n.d.

Fisin, James, musician, born at Colchester, in 1755. 'He studied under Burney and Reinhold. Teacher in Chester. Wrote "The Seasons, or Vocal Year"; "The Judgment of Paris," a masque (Congreve) ; "Saered Scngs on the most Promment Incidents of our Saviontr's Life and Death," London, n.d. Sonatas, Glees, Canzonets, Ballads, etc. $\mathrm{He}$ died September 8, 1847.

Fitzball, Edward, or BALL, dramatist and writer, born at Burwell, near Newmarket, 1793. He died at Chatham, October 27, 1873. He wrote the librettos of some of the most popular of English operas, Wallace's " Naritana" being perhaps his most suceessful production. Although something more than a mere play-wright, his poetical powers were not of a high order. He published "Thirtyfive Years of a Dramatic Author's Life," London, 2 vols., 1859.
FLAVELL.

Fitzherbert WIlliam, elergyman and musician, born 1713 . He was a minor canon of St. Paul's Cathedral, London, 174t. He was successively rector of Hadlow, Kent, 1753; Hornedon-on-the-Hill, Essex, 1756-1771; and of St. Gregory by St. Panl. He died at St. Paul's College, Oetober 2, 1797. Composer of a donble chant in F, and other church music.

Fitzpatrick, W. A., musician, compiler of "Devotional Music; being a selection of nearly 100 melodies," London [1837], and composer of glees and songs.

Fitzwilliam, Edward Francis, composer and conductor, born at Deal, August 1, 1824. Music-director, Haynarket Theatre, London. Married Miss Ellen Chaplin, 1855. He died, London, January 20, 1857.

Vonrs.-Alusic for The Green Bushes (1845) ; Anything for a change (1846) ; Love's alarms (1854); and other dramatic pieces. Queen of a day, comic opera. Set of songs [1853] ; Songs for a winter night [1855]; Dramatic Songs, London [1856], 4 books; Four four-part songs, London, 1855: Glees, etc. Te Deum, hallads, pf. music.

His father, Fiward Franc1s (1785-1852), was an actor and singer, and his sister, KatrLEEN MARY (born 1826), who married Mr. C. Withall, was also a singer and actress.

Fitzwilliam, Richard, 7 th Viscount, English peer, and founder of the Fitzwilliam Museum, Cambridge, was born in Angust, 1745; and died February 5, 1816. The title is now extinct.

He bequeathed to the University of Cambridge, a collection of paintings, music, and books, the musical portion of which included a number of fine MS. compositions of early composers, prineipally Italian. These are housed in the fine Fitzwilliam Museum at Cambridge, The sacred music contained in this collection was edited and published by Vineent Novello, in 5 volumes, as "The Fitzwilliam Nusic, being a collection of sacred pieces from the MSS. of Italian composers in the Fitzwilliam Museum," n.d.

Flavell, Charles Edwin, pianist, born in Birmingham about 1817 . Studied under Robert Barnett, and later at Frankfort-onthe-Nain, under Aloys Schmitt. Settled in Bimingham, as teacher. About the year 1856, in conjunction with Mr. Duchemin (q.v.) he gave a series of chamber concerts, which were continued for some time, and then he started others on his own account. He removed to London abont 1873 to undertake the agency for this country of the Kaps pianos; and he died there, February 1, 1879.

Flavell, Edwin Mark, pianist and composer, of present time. Edncated at R.A.M. Sometime conductor of a choral society at West Hill, Wandsworth. He is the composer of a cantata, Babylon's Wave, produced at 


\section{FLEET.}

VVandsworth Town Hall, Oetober 18, 1883 ; cantata, "The Fairy Ring," 1883; Songs and duets; Pieces for pf. solo, and duet, etc.

Fleet, George R., see Barrington, RutLAND.

Fleming, Rev. Alexander. Scottish clergyman, born in 1770; died in Jume, 1845. He was minister at Neilston in Renfrewshire. Author of ". . . Letters . . on the subject of the organ which ... was introduced into St. St. Andrew's Church, Glasgow. To which are added remarks on the Rev. James Begg's Treatise on the use of Organs," Glasgow, 1808. "Answer to a statement of the proceedings of the Presbytery of Glasgow, relative to the use of an organ,'" Glasgow, 1808.

Another clergyman of the same name, Rev. JoHN Flening, was minister at Airdrie in Lanarkshire, and wrote "An inquiry into the compositions with which the praise of God should be celebrated in His public worship," Edinburgh, 1821.

Fleming, James $M$., writer and violinist, born at Glasgow in 1839. Studied for a time under the late Samuel D. Smythe, of Glasgow, and received some hints from Ole Bull. Contributor to various musical periodicals ; Composer of Easy legato studies for the riolin; and anthor of "Old Violins and their Makers," 1883; "The Practical Violin School," 1886; and "The Fiddle Fancicr's Guide," 1892.

Fletcher, Charles, violinist and conductor, born at Wincanton, Somerset, July 11, 1846. His father was a schoolmaster and a musical amatemr, and his mother was a cousin of Charles Lucas. At five years of age Charles Fletcher began his vocal studies, and at seven appeared in public as a singer and flute-player. When nine he was appointed soprano soloist and harmonium player at the Parish Church of Shepton Montague, at a salary of $\$ 50$ per annum. He had studied the violin from his seventh year, and now became prominent as a performer. He was engaged by the late Lord Arundel for the private chapel and chamber concerts at Wardour Castle, where he remained three years. His voice changing, he settled as a violinist at Southampton. Failing health necessitated sea voyages, and for some time he was in Egypt and Brazil. Ultimately he took up his residence at Bournemouth, where he has established a string orchestra of ladies', mostly his pupils. He has played as soloist, and in chamber concerts in London, and many prorincial towns, and at the conferences of the Incorporated Society of Musicians. He was principal professor of the violin at Winchester College for ten years. At the Boumemonth Festival of 1896 he was principal first violinist. He married, in 1869, a German lady, a pianist of repute. His daughter MAUD made her appearance as a violoncellist in Handel's Concerto

\section{FLORENCE.}

Grosso in $\mathrm{D}$ minor, at a concert given by the Rev. E. H. Moberly, with his ladies' orchestra, at Prince's Hal], London, December 4, 1894.

Fletcher, Thomas, double-bass player, in his day the leading professional musician in Bimingham. He was a nember of the Festival Orchestra from 1808, if not earlier; and was for years in the band of the Italian Opera under Weichsel. He died in Birmingham, in June, 1845, at the age of 60 . There were several other musicians of the same family. JANE FLETCHER, a contralto vocalist, was one of the principal singers at the Birmingham Festival of 1811.

FIinn, Kate, soprano vocalist. Studied under Ardellmann, and W. Shakespeare. She made her first appearance at a concert given by Mr. W. Ganz, July 1, 1884, and sang at the Ballad Concerts, St. James's Hall, the next rear. Made her debut at the Crystal Palace Concerts, March 17, 1886, and at the Saturday Popular Concerts, March 26, 1887, since which time she has sung at many important concerts in London and the provinces.

Flintoft, Rev. Luke, clergyman and musician of 18 th century, who was probably a native of Worcester. B.A. Cambridge, 1700 . Priest-ricar of Lincoln Cathedral, 1704-14. Gentleman of Chapel Royal, 1715. Reader in Chapel Royal, Whitehall, 1719. Minor canon, Westminster Abbey, 1719. He died at London, November 3, 1727, and is buried in Westminster Abbey. He invented the double chant, or rather adapted one of the earliest specimens yet discovered. It is in $\mathrm{G}$ minor, and will be found in any large collection.

Flood, Edwin, organist and composer, born early in the present century. He was organist of the Parish Church of Honiton, and died there in 1869. He compiled Psalmodia Britannica, a collection of psalms, anthems, chants, etc., London, 1847-54, 2 vols. issued in 12 books. Collection of chants for 4 voices [1846]. The Psalmodist, a collection of psahm and hymn tunes used in the Parish Church of Honiton, London, 1850. Gipsy's life is a joyous life, song. Sets of quadrilles, and other pf. music. Another Edwin Flood, possibly a son or other relative of the above, died at Honiton, April 29, 1848. We have been unable to disentangle the works of these two, both being contemporary composers.

Florence, Amy, soprano vocalist, born at Edgbaston, Birmingham. Studied singing locally, and under San Giovanni at Milan. Made her début in opera in Malta, afterwards singing at Como and Naples. Returning to England, she joined the Carl Rosa Opera Company, singing in "Carmen," and other works. In the season 1886-7, she sang at Covent Garden in "La Favorita," ete., and a year later under the management of Augustus 


\section{FLOWER.}

Harris. She took the stage name of Mlle. Firenze. She has given concerts at Steinway Hall, 1888, and elsewhere.

Flower, Eliza, soprano vocalist and composer. Sister of Sarah Flower (Mrs. Wn. Brydges Adams, died 1847, or August, 18t8), author of "Nearer my God to Thee," and other hymms. She was born at Harlow, Essex, April 19, 1803; and died December 12, 1846. Composer of "Hymns and Anthems," composed for the services at Finsbury Chapel, South Place, London; "Musical Illustrations of the Waverley Novels," London, 1831. "Now pray we for our comtry," and other part-songs; Songs of the Seasons, ete.

Flower, Sara, contralto vocalist, born February 22, 1805; died at Melbourne, August 16,1865 . A concert singer who sang in England and the Colonies. Her sister, ElizABETH, was a soprano vocalist and sang in public. These are frequently confounded with the two Flower sisters mentioned above.

Flowers, George French, composer, organist, and writcr, born at Boston, Lincoln, in 1811. He studied in Germany under Rinck and Schnyder ron Wartensee. He was organist of the Fnglish Chapel, Paris, and of St. Mark's, Myddelton Square, Clerkenwell, London. Mis. Bac,, Oxon., 1839. Mus. Doe., Oxon., 1865. Editor of Literary Gazette. Flowers was an unsuccessful candidate for the Music Trofessorship at Oxford in 18t8, and also for that of Gresham College in 1863. He was a successful teacher of singing, numbering Mrs. Howard Paul among his pupils, and established a 13ritish School of Vocalization. He died at London, June 14, 1872.

Works.-Anthems, songs, ete. Essay on the construction of Fugue.., London, 1846. Poem on Museular Vocalisation, with introduction," Barton-upon-Humber, 1861. Translation of Basler's I'ictorial representation of the science of harmony . . . n.d., etc.

Fludd, Robert, scholar and author, born at Milgate, learsted, licnt, 1574; died at London, September 8, 1637. Author of "Utriusque cosmin majoris scilieet et minoris metaphysica, physica atque technica historia," Oppenheim, 1617 (q.u.). He was educated at Oxford, and is best known as a philosophical writer.

Foley, Allan James (Signor FoLi), bass vocalist, born in Cahir, Tipperary, in 1842. His early years werespent in Anerica. Studied in Naples, under Bisaceia, and sang in opera at Catania, Turin, Milan, and Paris, 1862-4. He made his début at Her Majesty's Theatre, June 17, 1865, as St. Bris in the "Huguenots," and for some year's sang in many operas there, at Covent Garden, and Drury Lane. He has also appeared in opera in America, Russia, Austria, and elsewhere. His first performante in oratorio was in "Israel in Egypt," National
FORBES.

Choral Society's Concert, April 25, 1866, when he sang in the duet, "The Lord is a man of war," witl Mr. Santley. He sang at the Handel Festival, 1808 ; and in the provincial Festivals suceessively at Norwich, 1869 ; Birmingham, 1870; Gloucester, 1871; and Leeds, 1877. As a concert singer he has been heard in every important musical centre. In 1892, he toured in Australia; was in Sonth Africa, 1893; and singing in London again in 1896.

Folkestone, Viscountess, see RADNor, Countess of.

Foote, Frank Barrington, baritone vocalist, born at P'ynuouth, February 2, 1855. Was intended for the army, but his voice developing while he was at school in Gernany he was sent to Florence to study, his masters being Zuceardi, and Lamperti at Milan. As Signor Franceschi he made his début in opera at Pavia, and he sang, later, in Milan. In 1880 he was engaged at Fer Majesty's Theatre, singing in Verdi's "Aida," etc. Later he went to Anerica with Mapleson's troupe, and afterwards again visited Italy. In 1884 he was with the Carl Rosa Company, and sang in "Colomba," and "The Canterbury Pilgrims"; and in 1885 he took part in the Handel Bi-centennial Festival, at the Crystal Ialace. He now was busy with concert work, and studying oratorio with $\mathrm{Mr}$. Randegger. He appeared at the Norwich Festival, 1887; and those of Gloucester and Leeds in 1889. In the spring of 1889 , and again in 1891 , he visited Antrica, and has toured with Madame Albani, and Madame Patti. He was giving concelts in London in 1896 .

Forbes, George, pianist and composer, born at I'inulico, London, July 1, 1813. He studied under his brother Henry, and Sir G. Smart. Gave concerts with his brother in London, 1831-184t. Subsequently gave subscription concerts on his own aceount. Was organist of st. Mary's, Bryanston Square, for 45 years. He died at London, September $11,188.3$.

Wollis. Mianoforte: Sonata in C; March des Guides; Larghetto and Rondo Capriceioso in It : Rippelle toi ; La Caprera ; La Castellucia; Carnival de Florence; Marziale; La pluie des Perles; Forlues's Valse de Concert and Valse de Sylphes; Calliope Valse; Pluie de Printemps; La Rosamund, a noctmone; Louise, nocturne. Four operatic duets. Six teaching pieces for pf. Gavotte, Queen Flizabeth. March et Finale brillant, op. 7. Italian fantasia. Fspaniola. Billet-doux. Transeriptions, etc. Three books of easy Voluntaries for organ or harmonium. Offertoire for organ in $\mathbf{F}$.

Forbes, Henry, composer and pianist, brother of the above, born at London in 1804. A pupil of Sir G. Smart, Hummel, Moscheles, and Herz. Conductor of the Societa Armonica. 


\section{FORBES.}

Organist of Parish Church of S. Luke, Chelsea. Gave concerts with his brother George. He died at London, November 24, 1859.

Wonks-Fairy O.uk, opera, Drury Lane, October 18, 1845. Ruth, olitorio, 1847. Pf. music. Sungs. Psalms, etc. National Psalmody $[1843]$.

Forbes, John, Scottish printer and publisher, established in busintss at Aberdeen in middle of 17th century, where he died, in December, 1675. He is chiefly remarkable as having published the filst book of secular music in scothund see Davidson, Thomas]; and for the authorship of three inflated epistles dedicatory, prefixed to the "Gantus" of 1662 , and changed, to the edition of 1666 ; and again different, to the edition of 1682.

Ford, Ann, performer on the Hamonica, who flomrished during the 18th century. Married to the Hon. P. Thicknesse. Sat to Gainsborough for her portrait. Anthoress of "Iustructions for playing on the Musical Glasses, with a copperplate representing the order and manner of plaeing the glasses; with such directions for performing on them, that any person of a musical tum may leam in a few days, if not in a few hours," London, 1762.

Ford, David Everard, compuser and organist, who flourished during the first half of the present century. He was organist at Lymington, Hants. He wrote "The Rudiments of MIusic, etc." 11.d., and published "Original Psilm and Hymm Tunes," London, 7 books, 1827-36. "Progressive Exercises for" the Vuice..," 1829.

Ford, Ernest A. C., composer, born in London, February 17, 1858 . Studied at the R.A.AI. nuder Sir Arthur Sullivan (composition), and later at Paris with Fdonard Lalo. Was the fiest Sir John Goss Scholar at R.A.M. (1875), F.R.C.O. the same year, and A.R.A.M., 1883. Has acted as accompanist at the Saturday Popular Concerts, and is conductor at the impire Theatre. He was chosen by Sir Arthur Sullivan to conduct "Ivanhoe" on its production, in 1891.

Works.-Motet, Domine Deus (performed at 250 th Amnivelsary of Harvard Iniversity. U.S A.). Operas; Danicl O'Romrie (1884); Nydia (Duologue, 1889, libretto by Justin H. MeCarthy); Joan (R jbert Martin, 1890); Mr. Jericho (operetta, H. Greenbank, 1893); Jane Annie ropera, bok by J. M. Barrie and Conan I oyle, produced Saroy Theatre, May 13, 189:, and taken on tour in the provinces). Cantata, The Eve of the Festa, female voices. Music to the Ballets produced at the Empire Theatre, 1894-5. Album of six songs; Six two-part songs; Songs, various, ete.

Ford, Henry Edmund, organist, born at Warlingham, Surrey. Chorister in Rochester (athedral. Pupil of Ralph Banks, and later his assistanc organist. In 1842 appointed
FORSTER.

organist of Carlisle Cathedral, a position he still holds. The jubilee of his office as Cathedral organist was celebrated by the public presentation of a tentimonial at the County Hutel, Carlisle, April 23, 1892. In November, 1891, he received the degree of MIus. Doc. from the Archbishop of Canterbury.

Ford, Thomas, composer, who was born in the latter half of the 16 th century [1580]. Musician in suite of Prince Henry (son of James I.). Musician to Charles I., on his accession. He died in Norember, 1648.

Works.-Musicke of sundrie kindes set forth in two Bookes, the first whereof are Aires for foure Voyees to the lute, orpherion, or hasse viol, with a dialogue for two roices and two basse violls, in parts tunde the luteway. The second are Pavans, Galiards, Almaines Toies, Jiggs, Thumpes, and such like for two base viols the liera-way, so made as the greatest number may serve to play alone, very easy to be performed, 1607. Contributions in Leighton's "Teares." Canons, etc., in Hilton's "Catch that catch can." Ford is now chiefly remembered as the composer of the beantiful madrigal "Since first I saw your face."

Ford, Thomas, clersyman, autior of "singing of Psalmes the duty of Christians, in V sermons," Lundon, 1659.

Forde, William, musician, born 1796 , died 1850. Author of "An Essay on the Key in Music, fully illustrated by examples," London, 18\$1. Encyclopedia of Melody, 3050 Airs of all Comntries.., 6 vols., n.d. New Pianoforte Primer, London, n.d. New Method of Singing according to the Italian School, 87 exercises, Londor, 11.d. Art of singing at Sight, London 1840$]$. Principles of Singins, with practical examples, London [18:30], 7 editions. Master's Class Book on the sicales [1841]. 300 National Melodies of the British Isles, for pf., 3 vols. [1850]. frish national quadrilles, ctc.

Formby, Rev. Henry, writer, author of ... Duties and I'rivileges of Congregational Singing, Sermon, 1ร49. The Roman Ritual and its Canto Fermo compared with the w rks of modern music, Lumlon, 1849. The Catholic l'hristian's guide to the right use of Christian Psilmody and the Psalter, London, 1847. Collection of Cath lie hymms, 1853.

Forster, Simon Andrew, writer and violin maker, was born at London, Nay 13, 1501, died February 2, 1870. He was a violin and violoncello malier in London, and was a member of the celelnated Forster fimily of violin and double-basis plavers, of whom Wildia (Bramptom, Cumlicrland, May 4 , 1739-London, Iecember 14, 1808); his son Willial (London, Januarv 7, 1764; June 24, 18.4); and groudson, Williay (London, 


\section{FORTAY.}

December 14, 1788; October 8, 1824), were the principal members. S. A. Forster helped William siandys with his "History of the Violin,"' 1864.

Fortay, James Butler, organist and composer, bom in Liverpool, Oetober 26, 1856. Studied under 1). C. Browne, and G. W. kobner. Was an organist at an early age, subsequently holding appointments at Emmanuel Chireh, Everton (1879-91); and at St. Michael's-in-the-I Iamlet since 1891. Resident in Liverpool as teacher. Since 1891 he has lectured on musical topics ammually for the Liverpool Corporation Library and Arts Committee; and has also lectured in other distriets. He has published Hymms of the Church, a collection of original tmes; and contriluted to The Chant Book Companion; Church of Fngland Hymnal; Welsh Carvinistic Methodist Tune Book, etc.; and is the connposer of Night and Morning; Faithful unto death; Joy cometh in the moming, and other songs; pf. pieces, etc.

Fortey, Mary Comber, pianist and composer. Studied at R.A.MI. Married to sir Julius Benedict; and in 1886 to Mr. Frank Lawson. Author of "How to teach the pianoforte to young beginners," London, Hughes, 1883 ; and eomposer of Castles in Spain; Going to Sleep; Love, the Truant; and other songs.

Foster, James, amateur musieian, was boru at Bristol, September 12, 1807. He was a builder in Bristol. Ile aeted as honorary organist of the Bristol Tabernacle, and assisted Waite with his compilation called "H Illelujah." He died at Bristol, June 7, 1885. He eomposed a number of hymu tunes, among which "Claremont" is perhaps best known.

Foster, John, musician, of Sheffield, compiler of "Sacred Music, consisting of anthems, psalnus and hymms in full orchestral score, with organ or pf. adaptation,"York, n.d.

Foster, John, alto vocalist, organist, and composer, born at Staines, August, 1827. Pupil of Sir G. Elvey. Organist, St. Andrew's, Wells Street, London, 1817-56. Lay-Vicar of Westminster Abbey since 1856. His glee, "Sweet Queen of Autumn," men's voices, obtained a prize in 1852. In 1865 he published "Psalms and Hymns, adapted to the Chureh of England." He also issued "Tunes for the Psalms and Hymns," London, 1864. Choral Harmonist [1872]. ete.

Foster, Myles Birket, organist and composer, born in London, November 29, 1851. Eldest son of Birket Foster, the celebrated artist. Being of a Quaker family his early love of music was not enconraged, and he was placed in a stockbroker's office. This he left in 1871, and studied music under Hamilton Clarke, and at R.A.M. under Sullivan,
FOWLES.

Prout, and Westlake. He held the post of organist at l.ev. Il. R. llaweis' Church, $1873-4$, and was organist of the Foundling Hospital, 1880-1892. At the present time he is musical editor to Messrs. Boosey. He was elected an Associate of the Philharmonic Society in 1880 ; A.R.A.M. ; and 895, F.R.A.M. Travelling lexaminer for T.C., London, in which capacity he visited Australia and New Zealand in 1895.

Wonks.- Hve ing service in C (male voices); in A, Sons of the Clergy Festival, 1883; Communion service in $B$ flat; Anthems, ete. Cantatas for Children: Cinderella; Lamp. black; Beauty and the beast; The Angels of the bells; The bonnie finluwafe; The suow fairies; and The coming of the King. Songs : The clildren's Christmas; A day in a child's life; Six two-part songs; a second set; Songs and part-songs. Instrumental compositions in MSs.: Symphony in F shanp ninor, "Isle of Arran" ; Overtures ; String quartet, pf. trio, etc.

Foster, William Martin, eomposer and conductor, born in Londun abont 1834. He acted as bandmaster of the 9th regiment, and was afterwards in the orchestras of Drury Lane Theatre and the Crystal Palace. He beeame leader of the orehestra of the flasgow Theatre Royal alout 1870. He died at Newcastle-on-Tyne, 1)eember 18, 1872. He composed incidental music to varions plays, but is best linown for his overture to the play of "Rob Ruy," based on Seott's novel.

Fowle, Thomas Lloyd, organist, writer and editor, born at Amesbury, Wilts, Oetober 16,1827 . His father was a clergyman, a prebendary of Salisbury. Self-taught in music, he acted for some years as organist at his father's church, Amesbury, and later at Crawley, śussex. From 1856 to recent times he has been engaged as editor and publisher. He is l'h. Doe. of Giessen. He has published 4 vols. of anthems; 5 cantatas; 4 vols. of organ voluntaries; 12 marches for speeial seasons; The Chureh Tune Book; 2 Services, and numerous other musical works. Handel, a menoir; Charles Dickens, a memoir; Gentle Edith, a novel, and miseellaneous writings.

Fowler, Chas., pianist, studied under Sir W. Sterndale Bennett, at the Royal Academy of Musie, and was appointed a Professor there in 1885. At Torquay, where he resided, he was in high repute as a teacher, and gave frequent eoncerts. His compositions include a Sonata for pianoforte and violin, a Sonata Trio, for voice, violin, and pianoforte, and a Sonata Concertante for four violins. He was also the author of several humorous slietches, which were received with favour. He died at Torquay, in May, 1891.

Fowles, Ernest, pianist and composer, 


\section{FOVLLES.}

borm at Portsmouth, April 27, 1864. Gained the Chappell Seholarship at the National Training School for Music, in 1876 , and studied there for six years. In 1884 he entered the R.A.MI., studying composition under sir G. A. Macfarren, distinguishing himself at the Academy Concerts, producing several pf. compositions in the larger forms, and being elected an Associate. From 1887 ht has given ammual concerts in the Prince's Fall, and, October 29 , 1894, began a series of Concerts of British Chamber MIusic, introducing important works by Algemon Ashton, J. C. Ames, Walford Davies, and other young writers, besides works by Hubert Parry, Villiers Stanford, Swimnerton Heap, among more widely known composers. His own compusitions comprise a Quartet for strings: A Trio in D, for pf. and strings; Two Sonatas, and other picees for pf.

Fowles, Margaret F., pianist, organist, and conductor, burn at liyde, Isle-of-light, daughter of an artist. Studied pf. harmony and counterpoint under Chalmers Masters; organ under 1)r. Hopkins; and voice production and singing under Emil Behnlie, Alberto Randegger, and $W$. Shakespeare. At the age of fifteen she was appointed organist of sit. James's, Ryde; and in 1878, organist and choir director at st. Niehat and All Angels, which office she retains. In 1874 she fommed the Ryde Choral Lnion, the concerts of which she conducted for twenty vears, retiring in December, 1894. From the first concert, April 6,1875 , to the close of her official connection with the Society, Miss Fowles has produced many oratorios and rother important works, and has done great service in the eause of music. She is the componer of a number of anthens, and hymm tunes, also of several songs.

Fox, Albert H., pianist, compuser, and conductor, born at Dulwich. Studied at K.A.M., pf. under Walter Macfarren, composition under F. W. I)avenport. Hine Exhibitioner, 1883; Balfe Scholar, 1884; Stemdale Bennett Scholar, and Heathcote Long Prize wimner, 1886. A.R.A.M., 1890. He is musical director at the Royalty Theatre, London. His compositions include an opera, operettas; music to "Merry Monte Carlo," 1895 ; Romance for orchestra, 1893; March for baud of harps, 1888 ; pf. pieces, etc.

Fox, Arthur, pupil and Associate, R.A.MI., is choirmaster at Christ's Hospital, and a tenor vocalist. He has published an Album of eight songs.

Fox, George, composer and baritone vocaist. Sang at the Crystal Palace, March, 1876; on tour with Pyatt's operatic company in 1879; in Italian opera, at Her Majesty's, in October, 1880 ; and with the Royal English Opera Company, in the provinces, 1883. He is the composer of a number of comic can-
FREEMINTLE.

tatas and operettas, some of which have gained much popularity.

Works.-Cantatas: The jackdaw of liheins; The babes in the wood; The fair Inogene, 1880 ; Lord Lovel; Winifred Price, 1882; Gabriel Grub (adapted from "Pickwick"), 1882; John Gilpin; Hamilton Tighe, 1884; The messenger dove. Comedies and operas: The eaptain of the guard, 1882; Welcome home, 1885; Robert Macaire, 1887; The Corsican brothers, 1885; Nydia (from BulverLytton's "Last Days of Pompeii"), 1892. The last three were produced at the Crystal Palace. Songs: Grandmamma's jokes for little folks; Songs for little singers, etc.

Francis, Thomas, alto singer and composer, was born in 1s12. He was a vicalchoral of si. Paul's Cathedral, London. He died at Hackney, Loudon, september 2, 1887. Composer of glees and other rocal musie.

Fraser, John, author and musician, was born at Johnstone, Renfrewshire, abont 1794, and died there on Iarch 3, 1879. He was at one time well known in scotland for the series of lectures and concerts he gave in conjunction with various members of his family, chiefly illustrative of Seots national music. He edited for a time a clartist newspaper called "The True scotsman." His youngest son, JaAes RoY Fraskin, was boru at Jolnstone. September 21, 1892, and since 1865 has resided in Paisley as a music-seller and teacher. Since 1875 he has been organist of the Mid Church, Paisley. He vas one of the organisers and conductors of the Tammalill concerts ou Gleniffer Braes, which produced the funds which were applied to the erection of a statue of that poet at l'aisley. Mr. Fraser composed a cantata, "The rottar's Saturday Night," and several songs.

Fraser, Captain Simon, collector and violinist, born at Ardachic, Invernesin, in 1773; and died in 1852. Published "The Airs and Melodies peculiar to the Highlands of Sicot. land and the Fsles, with a plain hamnony for the pianoforte, harp, organ, or violoncello, acquired 1715-45," Edinlourgh, 1815. Another' edition, 1874; also 1884. A valuable and searce collection, containing a number of reels and strathspeys by Fraser himself. He also issued "Thirty $H$ ghland airs, strathspeys, etc. Selected and composed hy Mr. S. F . r."." n.d.

Fredericks, Charles Wigg, tenor vocalist, vicar-choral, Lichfield Cathedral, is a well-known concert singer in the Midlands and the North. He has sung at the Crystal Palace; at M. Gounod's Trocadero Concerts, Paris, 1884; and at St. James's Hall, London; also at the Hereford Festival of 1891, of which Cathedral choir he was formerly a member.

Freemantle, George, organist and musical 


\section{FRENCH.}

critic, born at Ely, April 23, 1833. His father, about 1838 , was appointed to the choir of Durham Cathedral, and in due time the son became a chorister there, and pupil of Dr. William Henshas, the Cathedral organist. In the antumm of 1853 , he gained the post of organist and teacher of music at the Blind Asylum, Manehester, and later held various positions in that city. He rave up music for a business life, but accepted the office of musical critic to the Manchester Guardian, which he held for thirty years. When the Carl Rosa Opera Company was re-organised he became one of the directors. He died at Ardwick, Manchester, May 31, 1894. His brother, William Thomas Frema \TLE, many years his junior, was assistant organist of Lincoln Cathedral, and in 1871 appointed organist of Sharrow Church, Sheffield. He published in 1876-7, "A Collection of Kyries, Glorias, Clıants, ete., by various Composers," in 8 books (Novello).

French, John, violinist and composer, of Ayr, in Seotland, who flourished in the latter part of last century. Composer of "A Collection of new strathspey reels, ete., dedicated to Mrs. Boswell of Auchinleck," Edinburgh, n.d.

Frere, Walter, composer of present time. He has published five songs for baritone; Three Italian songs; Six songs (Herrick's "Hesperides"), etc.

Frere, Rev. Walter Howard, amateur musician and author. Educated at Cambridge; graduated M.A.; ordained in 1887. Curate of St. Inmstan, Stepney, 1887-92. His works include the Order of the Holy Communion for men's voices; Memurials of Stepney Parish, 1891; The Marian Reaction in its relation to the English (lergy, S.P.C.K., 1897. Editor of "Fighteen well-known hymm tmes, as set in Ravenscroft's Psalter (1621)," London 18887. Graduale Sarisburiense, 1894. Bibliotheca Musico-Liturgica, a descriptive land-list of the musical and latin liturgieal MSS. of the middle ages, London. The Sarm Gindual and the Gregorian Antiphonale Missarun: a Dissertation and an Historical Index, London, Quaritch, 1896.

Frewer, Frank, organist of St. James', Garlick Hithe. Is author of a Collection of hymn tumes, chants, and kyries, London, Salter, 1886; also composer of songs, a scherzo for pf. and violin, ete.

Frewin, Tom Harrison, violinist and composer. Educated at R.A.11.; Balfe Scholar, 1885. He has composed a Mass, performed, 1896; Orchestral pieees: "The Battle of the Flowers," 1895 ; Ballad, Mazeppa, 1896, hoth performed at the Queen's Hall Concerts. Also pieces for violin and pf., etc.

Frickenhaus, Fanny, born Fraxs, pianist, born at Cheltenham, June 7,1849 . She

\section{FRITH.}

studied under George Mount, ind later at the Brussels Cons'rvatoire, under Auguste Dupont, also with Wm. Bohrer. She first came prominently before the public, January 11, 1879 , at one of the Saturday Evening Concerts, started in st. James's Hall, in November, 1878, Her snccess was immediatc, and she was engaged for the rest of the series. She gave a recital in the eoncert rom of the R.A.M., March 31,1880 ; appeared at the Crystal I'alace, November 20: and a week later played for the first time in London the pianoforte concerto of Guetz, at Cowen's Saturday Concerts. Her first appearance at the Popmlar Concerts was on Saturday, Janwary 27, 1883 , and at the Philharmonic, Mareh 4, 1886. From 1884, in conjunction with Joseph Ludwig, she has given chamber concerts at the Prince's Hall, introducing important novelties; and has been heard at the best concerts in Jimminglnam and other places, ranking among the leading pianists of the day.

Frias, Duchess de, see 13ALfi (VICTOIRE).

Fricker, Anne, or Mlogfori, songwriter and poetess, who was lxm about 1820 . Married Mr. Mogford. First song published, 1839.

Works.-Songs: A harvest hymm; Angel of peace; Antumm lreezes; Consolation; Dear voices of home; Dimma ye hear?; Distant bells; Fading awny ; the faney fair; Faithless swallow; Flow, gentle river; Footprints in the snow; Grutle Clare; Gentle Shepherd; Heart of hearts; Hesperus; I cried unto Thee; I stood bereath the chestmut trees; Marguerite; Mennry's tears; Nightingale; The old man's home; Oh, weary eyes; Phillis, fair; Rogret; Robin; Ruth's gleaning song; She is notmine; Softly at thy window; Sumbine; Sweet queen of hearts; Thirty vears ago; To The alone; Village bells; When Celia sings; When thon art nigh; You ask me for a song. l'f. music, etc.

Fripp, Edward Bowles, amateur organist and composer, born at Kingsdown, Bristol, January 29, 1787 . He lield the appointment of honorary urganist suecessively at St. James' Church, Bristol ; Westbury, Gloucestershire; and Hutton, near Westonsuper-Mare. He died at Tejgmmonth, Sept. 1, 1870. He edited "Selection of Psalms and Hymns, adapted in portions for every Sunday and Festival of the Church of Fingland " (1850); " ( hurch Psamody, a collection of tunes hamonised for four voices. "He also composed much music for the clurch service, including the hymm tune "Charmouth."

Frith, John, organist and composer of early part of the 17 th century. He was organist of St. John's College, Oxford, und graduated MIus. Bac. in 1626. He died in 


\section{FROST.}

1644. Composer of a degree exercise in seven parts and of other music.

Frost, Charles Joseph, organist and composer, born at Westbury-on-Trym, June 20,1848 . His father moved soon after to Tewkesbury, where he was schoolmaster and organist of Trinity Church. The son when quite a child played the pianoforte, organ, violin, and violoncello, and was soon actively engaged in coucert work. His first organ appointment was at St. James', Cheltenham, 1865 , from whence he returned to IVestbury, as organist of Holy Trinity. During this time he made periodic visits to London, studying under George Cooper, John Goss, and others. He was next appointed 10 Holy Trinity, Weston-super-Mare, 1869 ; Holy Trinity, Lee, 1873 ; St. Nary, Haggerstone, 1876 ; Christ Church, Newgate Street, London, 1880 ; and since 1884 has been organist at St. Peter's, Brockley. He started a choral society there in 1885 , and has given important concerts. In 1872 he was made F.C.O.; graduated Mus. B., 1877 ; Mus. D., 1882, Cambridge. He has been, since 1880 , a professor of the organ at the Guildhall School of Music; is head of the Music Section in the Goldsmith's Institute, New Cross; has given recitals at the Bow and Bromley Instute, and elsewhere. $\mathrm{He}$ is an examiner for the College of Organists, and I.S.MI., has lectured in many places, and contributed a number of articles to Musical Opinion, and other papers. Of his voluminous compositions only a selection can be named

Works.--Oratorios, Nathan's Parable, 1878; Harvest Cantata, 1880 (both in MS.); Psalms 92 and 137, for soli, chorus, and organ ; Fes. tival Te Deum; services, anthems, hymntunes, and chants. Secular choral works: Lollipop Dick; King John and the Abbot of Canterbury ; Sing a Song of Sixpence; The Gipsies; The Bell, and others. Songs: The Strawberry (rirl, Paradise, and others ; Dartsongs. Symphony for orchestra (MIS.). Organ: Collection of organ pieces; 55 hymn-tune voluntaries; Sonata in A; Forty preludes, $1880 ; 27$ original pieces, \&c. Two sets of six original pieces for harmonium; Bouquet of Flowers, 24 pieces; Seven sonatinas, \&c., for $\mathrm{pf}$.

Frost, Henry Frederick, organist and musical critic, born in London, March 15, 1848, son of Thomas Frost (a well-known bass vocalist, died 1884), and Eliza, his wife (contralto, born Redford). In 1856, he was appointed a chorister at St. George's Chapel, Windsor, where he soon became solo boy, and head of the school. He frequently sang in private before the Queen, and assisted at all the Royal functions there, to the wedding of the Prince of Wales, in 1863. In 1865, began the study of the organ under Sebastian llart, of St. Peter's, Great Windmill Street, Lon-
FRYE.

don; became his assistant three weeks later; and in December of the same year gained the post of organist, after competition, at the Chapel Royal, Savoy. Began his wnrk as a critic in 1874, on the Weekly Despatch, being among the earliest champions of Wagner. In 1877, was associated with E. Prout on The Academy, and later on The Athencum, taking the whole duty on this paper in 1888, and succeeding the last Desmoud L. Ryan on the Standard, the same year. Professor of harmony and sight-singing, Madame Dolby's Academy, and professor of pf. at Guildhall School of Music, 1880. Resigned these posts in 1888 , and his position at the Savoy Chapel Royal, 1891. Author of "Schubert," Great Musicians Series, Sampson Low, London, 1881. Lecturer on Wagner's Art works, at the Musical Association; London Wagner Society, etc. Composer of Saroy Hymm-tunes and Chants, London, Novello. His daughter, Beatrice Frost, soprano vocalist, studied under her father, and Hermann Klein, at the Guildhall School of Muic, gaining the prize for soprano, 1895. Nade her début at St. James' Hall, April 4, 1895 ; and gave her first concert at St.einway Hall, December 15, 1896. She has appeared at other concerts, and is gaining a good position.

Frost, William Alfred, alto vocalist, composer, and teacher, brother of the foregoing, born in London, November 7, 1850. Chorister at St. George's Chapel, Windsor, 1859-66. Returning to London in 1869, he was engaged as an alto in the choir of Archbishop Tenison's Chapel (afterwards consecrated as St. Thomas', Regent Street); in 1870 , at St. Andrew's, Wells Street; and in 1872 , at All Saints', Margaret Street. $\mathrm{He}$ was then elected assistant vicar-choral at St. Paul's Cathedral, entering rpon his duties, March, 1873. Appointed professor of pf. and assistant singing master in the Choir School, 1888 , and succeeding the late W. A. Barrett as vicar-choral in 1891. Became general secretary of the Choir Benevolent Fund, 1889. As a teacher he has been specially successful in training altos. His compositions embrace a complete morning, communion, and evening service, for men's voices, written for St. Paul's Cathedral at the request of the then organist, (Sir) John Stainer; an anthem, "I will go unto the Altar of God"; Songs, and partsongs. Author of an historical essay, "Good Friday and Easter Eve Communion, from the Days of the Apostles to the present time."

Frost, William Lane, organist and composer. He has written an opera, "Fred"; Cantatas, "Maldwyn the Crusader," produced Forest Hill, April, 1885, and "Lord of the Harvest." Pieces for pf., etc.

Frye, John Thomas, organist, was born in 1812. When only eight years old he was 


\section{FRYER.}

appointed organist of St. Mary's Church, Saffron Walden, a post he held for 64 years, from 1820 to 1884 , Ile died at Saffron Walden, October $23,1887$.

Fryer, (i., eompiler, issued "The poetry of various glees, songs, etc., as performed at the Harmonists," London, 1798.

Fulcher, John, musician and editor, born at I under Meyer Lutz and Alfred Mullen, and in 1855 settled in (ilasgow as a teacher, where he held the appointment of choimaster in Glasgow Cathedral, from 1868 to 1879 . He died at Glasgow, July 10, 18\%3. Editor of "Lays and Lyries of scotland," with a Historical Epitome of Scottish Song loy Jannes Ballantine, etc., London, n.d. [1870]. Somgs: Afton Water; Bomnie, bomie Bell; Hurrah for the Highlands; Where hath Scotland found her fante? Transcriptions, etc., for pf. Jart-songs (arrangenents); Beauties of Scottish Song (with T. S. Gleadhill and Thomson). The accompaniments and arrangements of the Scottish songs in his collections are much richer than those written by Surenne, 1)m, Mudie, and others, and are accordingly mote acceptable to modem taste. His som, Hexry Macleol Fulcher, hom at Glasgow, in Janlatry, 1856 , is an organist and composer of ability, who has written some effective pianoforte music.

Fuller=Maitland, see MaITLAND, J. A. Fithler-

Fussell, Peter, or Frsine, organist, hom about 1750. Siucceeded James kent as organist of Winchester Cathedral, in 177t, holding that appointment antil his death, July, 1802. Taught Charles Dibdin, the elder, his notes, and trained other musicians who alterwards attained gond positions.

Fyfe William, Wallace, Scottish writer, author of "Christmas, its custons and carols, with compresised rocal score of select choral ilhustrations," London 1860$]$; and various poeticat and other works.

Gabriel, Mary Ann Virginia, composer, was lown at bantead, Surrey, February 7 , 1825. She studied music under Pixis, Dohler, Thalberg, and Molique. Married to George E. March, November, 1s7t. She died at London, August 7,1877 , from the effects of a eariage accident.

Works.-C'antatas: Hrangeline (Longfellow); Ireamland; Graziella. Operettas: Widows Bewitched; (rrass Widows; Shepherd of Comomailles; Who's the Heir?; A Rainy Day. Songs: A farewell; Ariel; At her wheel the maiden sitting; Across the sea; Alone; At rest; A dead past; A fisher's wife; Alone in the twilight; A mother's song; Arden towers; Asleep; A song in the heather; At my feet; At the window; Beryl; beside

\section{GAFFE.}

the sea; Brighter hours; Bye and bye; Change upon change; Chattering; Calling the roll; Corra Isinn; Dawn; Dawn of Springtide; Day is dying; Inream, baby, dream; Echo; Eight fishers of Calais; Emerald; Fisheman's Widow; Golden wedding day; Happy days; His work is done; He will not come; Hopeless; In the gloaming; Lady Moon; Lost love; Little blossom; I Little flowers; Light in the window; Lady of Kienast Tower; Mountain echo; My love; Nightfall at sea; Only at home; Oh! spare my boy at sea; Only ; The Opal ring; Pearl; The Prodigal son; Prisoner and the himet; Ruby; Remenbered; Sweet seventeen; Shadow light; Somebody's darling; Sacred vows; Servian ballad; Skipper and his boy ; The surprise; Three roses; Tender and true; The ring; Tnder the palm; Wake my beloved; Work; Weep not for me; When the pale moon; Weary; When sparrows huitd. I'artsongs, pianoforte pieces, etc.

Gadsby, Henry Robert, composer, born at Hackney, London, Decemtier 15, 1842. Chorister at St. Paul's Cathedral, 1849-58, and self-tanght in misic beyoud the instruc. tion he then received from William Bayley, master of the boys. Ile was organist of St. Peter's, Brockley, Surrey, for some time up to 1884 , in which year he suceeeded John Hullah as professor of harmony at Queen's College, London, He is also a professor at the Guildhall Sehool of Music. Member of the Philharmonic Society, and hon. F.R.C'.O.

Works.-Psalm 130. Cantatas: Alice Brand, 1870; The Lord of the isles, Bighton Festival, 1879 ; Columbus (male voices), Crystal Palace, Mareh, 18si ; The Cyclops (male voices), Queen's College, Oxford, Nay, 1890 ; Music to Alcestis, 1876 ; to Andromache. Festival service in D, for eight voices: Service in $\mathcal{U}$, and others. Anthems: He is risen; Rejoice greatly; Sing, O danghter of Zion, ete. Part-songs. Orchestral: Symphonies in $A$, and $C$, movements from one performed at the Crystal Palace, February, 1871 ; Festal Symphony in D, Crystal Palace, November 3, 1888; Intermezzo and Scherzo, composed for the British Orchestral Society, produced, April 21, 1875. Orevtures: Andromeda; Golden Legend; Witches Frolic. Orchestral scene, The Forest of Arden, produeed by the Philharmonic Society, March 4, 1886 String quartet; Andante and rondo, flute and pf. Author of Supplemental Bonk of Exercises for the use of those learning to sing at sight Harmony, a treatise, and harmonisation of given melodies, London, 1884.

Gaffe, George, organist and conduetor, born at Cawston, Norfolk, July 27, 1849. Chorister, Norwich Cathedral, at the age of nine, afterwards articled to Dr. Buck for seven years. In 1874 he was appointed 


\section{GALE.}

organist of Oswestry Parish Church. While there he was associated with the late Henry Leslie in fouting a Music school, and establishing a Choral Society, which afterwards figured in the Musical Festivals of that town. In 1880 he was appointed to St. Albau's Cathedral. He has given performances of oratorios in the Cathedral, and been active in promoting the cause of music, founding, in 1887, u School of Music, which is suceessfully carried on. He is a Fellow and Mem. ber of the Council of the Royal College of Organists.

Gale, Robert, musician, was born at London, August 4,1769 . He was for a time a tuner 11 the service of Mlessrs. Broadwood, and afterwards he became a musi: teacher in Edinburgh. Finally he settled in Ayr, where he held the appointments of preceutor in the Relief Church, and afterwards in the Otd Established Church, till 1843. He died at Glasgow in May, 1815.

He compiled "Psalm and Hymm Tunes, selected from the most approved composers ... to which is prefixed a clear and easy method of initiating the scholar in the rudiments of Music," Edinburgh, 1824-1840, three editions. He also compored the sougs, "Scotland, I've no friend but thee," and "The Maid of Elderslie." He was an enthusiastic musician, and formed a small circle of equally earnest musicians, who all helped to improve psalmody in Ayrshire.

Gall, Rev. James, musician and clergyman, born at Edinburgh, September 27, 1808. He devoted much of his life to the Sunday School movement, and published a number of cheap musical works through the firm of James Gall \& Sons, afterwards Gall and Inglis, of which he was a member. These comprised "Children's Hymu Books," "Scottish Psalm Tune 13ook," "English Hymm Tune Book," etc. He invented a cheap process of music printing which greatly facilitated his work. He also composed some hymn tunes.

Gamble, John, violinist and composer of 17 th century. He studied under A. Beyland, and became a violinist in the private band of Charles II., etc. He died in 1657. He com. posed "Ayres and Dialogues," 1657. "Ayres and Dialogues for one, two, and three voyces," 1659.

Gandsey, John, a celebrated Irish piper, who was born in 1768, and died in 1857 .

Gardiner, William, musician and writer, born at Leicester, Narch 15, 1770. IJe travelled much on the Continent. Died at Leicester, November 16, 1853.

Works.--Sacred Melodies, from Haydn, Mozart, and Beethoven, 6 vols., London, 1812, etc. Judah, an oratorio, adapted from the works of Haydu, Mozart, and Beethoven.

\section{GARLAND.}

Popes "Universal Prayer" set to music by IIaydn, Mozart, and Beethoven. The Musie of Nature; or, an attempt to prove that what is passionate and pleasing in the art of singing, speaking, and performing upon Mnsical Instruments, is derived from the sounds of the animated world... London, 1832. Anerican reprint, Ditson, Boston, n d. Music and friends; or, pleasant recollections of a Dilettante. London, 3 vols., 1838-1853. Sights in Italy; with some accont of the present state of musle and the sister arts in that country. Londun, $18+7$.

Gardiner composed some songs under the pen nane of W. G. Leicester. He is chiefly $t$ ") be remembered as the author of "The Mrusic of Nature," a work which contains much useful inturmation and curious and occasionally eccentric speculations.

Gardner, Charles Graham, organist and pianist, born at Rotherhithe, Surrey, February 14, 1808 . Studied under J. B. Cramer, Moscheles, IW. Horsley, and Samuel Wesley. He was highly esteemed as a teacher, and numbered among his pupils H.R.H. Prince Arthur, The Duke of Connaught, who received lessons from him during the seven years he was stadying in Woolwich. He was org mist of St. MIargaret's Church, Lee, for 36 years, and after his death, which took place October 31,1869 , the parishioners, by whom he was held in great esteem, erected a monum nt to his menory.

Gardner, Charles, pianist and composer, son of above, was horn at Greenwich, April 1, 1836. He received his first instruction in music from his father, afterwards studying under Oliver Nay and Emest Paner (pianoforte), and J. MeIIurdie and G. A. Macfarren (composition). When the elmrel of St. Iichael and All Angels, Paddington, was consecrated, Charles Gardner was appointed organist and choirmaster, an office lie held for some years, but he has for a long time given up organ work. For many years his Insical Matinèes have been a feature of the London season. He is a member of the Philharmonic Society, and has since 1884 continuously held the office of a Director; also professor of the pianoforte at the Guildhall School of Music, and L.R.A.M.

Works.-Trio for pf. and strings; Sonata in A. Suite for pf., op. 40 ; Suite in five movements, op. 50., pf., and many smaller pieces. Educational publications: Technical Exercises for pf. students; Diatonic and Chromatic cales, with rules of fingering; Arpeggios of the Common Chord, and Dominant and Diminished Sevenths, \&c.

Garland, Thomas, organist of latter half of $18 \mathrm{th}$, and beginning of present centuries. $\mathrm{He}$ was organist of Norwich Cathedral till 1808 , the year of his death. Chiefly remark- 


\section{GARLAND.}

able as the teacher of several musicians who have attained fame.

Garland, William Henry, organist and conductor, born at York, in Jume, 1852. In his eighth year was placed as a chorister in the Minster, where he was distinguished as a solo boy. He was then articled to Tr. Monk. In 1878 he took the Mus. Bac, degree at Oxford, and 111882 passed the examination for F.C.O. ITis first organ appointment was at St. T'aul's Churel, Rome, whither he went on the expiration of his apticles. Here he remained for three years, when ill-health commelled his return to England. He next held the post of organist at Reading Parish Church for three years, and after a year's work as acting organist and choirmaster at Fork Minster (during Dr. Monk's alssence thromgh illuess), was appointed to Halifax Parish Church in 1884. In 1886 he was elected conductor of the IIalifax Choral Society, one famous in local musical history, established early in the century, and now flourishing. Six years later he received a similar appointment to the Bradford Festival Choral Society, and was divisional chorus master for the Leeds Musical Festival since 1892. He died at Halifax, February 13, 1897. His I egree Fxercise was a setting of Psalm 23, and he published some Church music. His brother, Charles T. Garland, was a chorister, and afterwards a bass singer in the choir of Tork Minster. In 1874 he was appointed to Magdalen College, Oxford, where he is now the senior lay-clerk. He is also music-master at the College School.

Garrett, George Mursell, composer and organist, born at Winchester, June 8, 1834. Son of William Garrett, master of the choristers, Winchester Cathedral. Chorister of New College, Oxford, and pupil of Tr. Stephen Elvey. Studied later under S S. Wesley. Assistant organist, Winchester Cathedral, 1851-4; organist of Madras Cathedral, 1854-6; of St. John's College, Cambridge, 1857; and organist to the University in 1873. Graduated Mus. Bac., 1857; Mus. Doc., 1867, Cambridge: and, by grace of the Senate, received the degree of M.A. propter merita, 1878. F.R.C.O. Cniversity lecturer in hamony and comnterpoint, 1883. Examiner in Music for the University of Cambridge, for the Irish Intermediate Education Board, and other institutions. Conductor of St. John's College Musical Society, and solo pianist at its concerts, 1876, etc. Member of the Phiiharmonic Society.

Works.-Oratorio, The Shunammite, produced by the Cambridge Tniversity Musical Society, Jume 13, 1882, and given at the Hereford Festival of 1882. Cantatas: The Deliverance of Sit. Peter; Prayer and praise; Harvest Cantata; The Two Adrents, com-

\section{GASKELL.}

posed for a choir festival, New York; Secular cantata, The Triumph of Love, produced by the Cambridge University Musical Society. Church Services in D, F, E flat, and E; Evening Service in B flat, written for St. James's Choir Festival, New Jork, and others. Anthems: Psalm 43; In humble faith and holy love; Praise ye the Lord (Harvest); Thy mercy, O Lord, written for the Festival of the Loidon Chureh Choir Association, St. I'aul's Cathedral, November 16, 1893, and various others. Chants, old and new, selected and arranged in order of daily use for one calendar month, with special chants for the Venite and Proper Psalms. Part-songs, songs, organ pieces, etc.

Garrow, Mrs., see sub abrans, Harriet.

Garth, John, organist and composer, born at Durham, 1722, He died in 1810. He published "The First Fifty Psalms, set to music by Benedetto Marcello," London, 8 vols., 1757. He also wrote much instrumental music, anong other works, "Six sonatas for th harpsichord, two violins, and violoncello," op. 2,1768 . Six organ voluntaries, op. 3 [1780]. Thirty collects set to music, London, 1794. Avison aide 1 Garth with the editing of Marcello's psalms.

Garth, Richard Machill, organist and composer, borm at Pudsey, near Leeds, October 15, 1860. Educated at Batley Grammar School, and chorister at the Parish Church. Pupil of the late James Broughton, Leeds, for pianoforte; also studied under J. H. Collinson, Gustav Schreck, and others. After holding several appointments he became assistant organist of St. Mary's Cathedral, Fdinburgh, 1882, later undertaking the duties of private organist to, among others, Sir Michael Shaw Stewart, of Ardgowan. Orgauist of Clark Memorial Church, Largs, 1893; Choirmasier St. Columba's Episcopal Chureh, Largs, at present time. Conductor of Unitrd Choir, Cumbrae, and, 1888, of the Greenock Choral Society. Elected a Fellow of the Educational Institute of Scotland, 1885. Has given organ recitals in London ("Inventions," 1885), Edinburgh, Glasgow, and Paris.

Worlis.-Ezekiel, dramatic oratorio, 1888; Choral ballads - Charge of the Light Brigade, 1889 ; Wild Huntsman, 1890. Full cathedral service in E flat; anthems, hymn-tunes, and chants, Songs: A message from the sea; Though years have lapsed; The heaving of the lead (prize), and others. Concerto in D, violin and orchestra; Six string quartets; Sonata in F, and other organ pieces; Six Lieder ohne worte. pf., \&c. A number of arrangements, and a text-book on arrangements, for military bands. In MS. an opera, The brigand (libretto by Fdward Oxenford).

Gaskell, James, org ${ }^{\prime}$ ist and composer, 


\section{GASKIN.}

born near Wigan, August 26, 18t1. Studied pianoforte with C. A. Seymour, harmony with Dr. J. M. Bentley, and organ under F. H. Burstall. Organist, Parish Church, Pemberton, near Wigan ; and from 1885, of St. Barnabas, Swindon, Wilts. Composer of a collection of anthems and hymu-tunes; songs, \&c.

Gaskin, James J., musician, born about 1820 ; died at Dublin in 1876 . Author of "Early History, etc., of Vocal Music." London, 1860.

Gason, Adam F., author of "A short Treatise in Defence of Cathedral Worship," Dublin, 1846.

Gater, William Henry, organist and composer, born in Dublin, August 8, 1849. Musical training private; studied organ under Sir R. P. Stewart. Graduated IIus. Bac., Trinity College, Dublin, 1876, and B.A., 1881, with honours in English and modern literature; Mus. Doe., 1886. He also passed through ihe Diviuity School, obtaining several prizes. Organist of Christ Church, Bray, 1871-3; to the Exhibition Palace, Dublin, 1872.3 ; St. Andrew's, Dubin, 1873 ; and since 1876, organist of St. Stephen's, Dublin. Choirmaster, for several years, to the East Meath Dioeesan Choral Assoeiation. His compositions include a setting of Ps. 66, for soli, ehorus, and organ; a cantata, "The Passions" (Collins), for soli, chorus, and orchesıra; two services, and other Chureh music; hymn tume, "From Greenland"s Icy MIountains," Wrexham Eisteddfod Prize, 1888 ; organ pieces, etc., the greater part remaining still in MS

Gates, Bernard, organist and composer, born in 1685. He was one of the ehildren uf the Chapel Royal, 1702; a Gentleman, 1708; and Naster of the children from 1740 to 17.58 . He died at North Aston, near Oxford, Nuvember 15,1773 ; in the Parish Chureh of whieh there is a memorial to him. His eompositions, including a service in $\mathrm{F}$, are mostly in MS.

Gattie, Henry, violinist. He was seeond violin in the Blagrove quartet, which commenced a series of chamber coneerts in the Hanover Square Rooms, March 17, 1836. For years he was associated with chamber music in connection with Joseph Banister, Dando, and others; and was in repute as a teacher. He died in London, early in 1853.

Gatty, Alfred Scott, composer and writer, born at Ecclesfield, Yorks., April 25, 1847. Second son of Rev. Alfred Gatty, D.D, vicar of Ecclesfield, Sub-dean of York Catledral, etc. Studied at Marlboruugh, and C'llrist,'s College, Cambridge. Rouge Dragon, Pursnivant of Arms, Herald's College, London, 1880. He has composed two operettas, "Sandford and Merton's Christmas Party," 1880 ; and "Not at Home," 1886. Is author
GAUNTLETT.

of "Little songs for little voices" (words and music), two books, published originally in Aunt Judy's Magazina'; other books for cuildren, illustrated by C.A. Doyle; and a large number of songs, True till death; U fair dove, O fond dove; Some future day; The open window; When luve was a little boy, etc. Pianoforte music, etc.

Gaudry, Richard Otto, organist and composer, born at Dublin. 1800 . He was elorister in the chapel of Dublin Castle, and organist of St. Anne's, Inoblin. He died at Dublin, August, 1825. Composer of anthems, ete.

Gaul, Alfred Robert, organist and composer, born at Norwieh, April 30,1837. Of a musieal family, he was entered as a chorister at Norwich Cathedral at the age of nine; afterwards articled pupil of Dr. Buck, and assistant or anist. When seventeen lie was appointed organist of Fakenham parish church, which he left in 1859, for St. Johu's, Lady Wood, Birmingham. He has been organist and choimastel at S. Augustine's, Edgbaston, since the clurch was built in 1868. He graduated Mus. Bac., 1863, Cambridge. In 1887 he suceeeded MIr. Stockley as conductor of Walsall Philharmonie Society, and for some year's he held that and other sinnilar offices in different places. He is now teacher of harmony and counterpoint, and conductor of the ladies singing class at the Biminglam and Midland Institute; teacher of harmony and singing at King Edward's lligh Sehool for Girls; and teacher at the Blind Asylum. He has condncted performanees of his works in many towns, and played at the Buw and Bromley Institute in 1888.

Works.-Hezekiah, oratorio, produced by the Amateur Harmonic Association, Town Ha!l, Kirmingham, Noventber 29, 1861 ; Psalm 1 (degree ex.), 1863. Cantatas: Ruth, 1881 ; The holy eity, produeed at the Birmingham Festival, 1882; Passion music, 188:3: Joan of Are, produced by the Birmingham Festival Choral Society, 1887; The ten virgms, 1890 ; Israel in the wildemess, Crystal Palace, July 9, 1892 ; and Una, composed for the Norwich Festival, 1893. P'salm 150, performed by the London Church Choir Astociation, St. Panl's, 1886; The Lort is my Shepherd; Psalm 96, for eight-part chorus, and others; hymn-tunes, chants, \&c. Ode, A song of life; The shipwreck, prize glee; T'he silent land, performed by Leslie Choir, Paris, 1878, and given at the Bimingham Festival, 1879; The singers; The day is done, and other part-songs, sehool cantatas, collection of trios, duets, \&c. The ferry maiden; Faithful yet; The sea's love, and other songs. Sonata in B flat minor, and various pieces for pf.

Gauntlett, Henry John, organist and composer, born at Wellington, Shropshire, July 


\section{GAWLER.}

9, 1805. Son of the Rev. Henry Gamntlett. Organist at Olney, Bucks., 1815. Articled for a time to a solicitor, 1826. Orgauist at St. Olave's, Southwark, 1827-47. Admitted as a solicitor, 1831. Commenced his labours in connection with the establishment of the $\mathrm{C}$ organ, 1836, which latterly took the place of the $\mathrm{F}$ and Ginstruments. Organist of Christ Church, Newgate Street, 1836. Gave up practice of the law, 1842. Mus. Doc., Lambeth, 1843. Organist of Union Chapel, Islington, 185.-61; Church of St. Bartholomew the Less, Smithfield, 1872. He died at Kensington, Loudon, February 21, 1876.

Works.-Hymnal for Matins and Evensong, 184t; The Church Hymnal and T'une Book, 1844-51; Cantus Melodici, 1845; The Comprehensive Tune Book, 1846-7; The Hallelujah, 1848.55; The Congregational Psalmist, 1851; Carlyle's Manual of Psalmody, 1861; Tunes, New and Old, 1868; Harland's Church Psalter and Hymmal, 1868; The Encyclopedia of the Chunt; St. Mark's Tune Book; The Choral use of the Book of Common Prayer, London, 1854. Anthems-..I will go unto the altar of God; This is the day the Lord hath made; Thou wilt keep him in perfect peace, in E flat. Hymms and Christmas carols; One Hundred and Fifty-six Questions on the art of Music-making and the science of Music, London, 1864. Songs, glees, organt-music, \&c. Revised, Jos. Willians' "Christmas minstrelsy, or carols, anthems," \&c.

Mr. Gauntlett was in his lifetime recognised as one of the foremost organists and authorities on psalmody. His hymnals, psalms, etc., are compilations of the highest merit, the hand of the musician being always observable where too often we find the work of the officious reviser. His anthems are in frequent use, and his hymus are favourites. Among the latter may be named Alexandria, Braylesford, Bredon, Croyland, Deubigh, Gauntlett, Houghton, and Lux Alma.

Gawler, William, organist and teacher, born in Lambeth, 1750. He was organist in the Asylum for Female Orphans. He died in March, 1809. He compiled " Harmonia Sacra, or a Collection of Psaln Tumes, with interludes, and with a thorongh-bass, forming a most complete work of Sacred Music," London, 1781. Dr. Watts's Divine Songs [1780]. Lessons for the harpsichord. Hymus and psalms used at the Asylmu or House of Refuge for Female Orphans, London [1785]. Voluntaries, interludes, etc., for organ. Miscellaneous collection of fugitive pieces for harpsichord or pf. [1780]. Sougs, etc.

Gawthorn, Nathaniel, English musician, was conductor of psalmody at the Friday lecture in Eastcheap, London, early in the 18tl century. Compiler of " Harmo-
GEAR.

nize Perfecta, a compleat collection of psalm tunes in four parts, fitted to all the various measures now in use, taken from the most eminent masters," Loudon, 1730.

Gawthrop, James, tenor vocalist, born in York. Studied singing under J. B. Welch. Appointed in 1877 vicar-choral of Wells Cathedral; in 1880, to St. George's Chapel, Wiudsor; and in 1-85 made a Gentleman of Her Majesty's Chapel Royal, St. James's. As a concert singer he has been heard at the Covent Garden Promenade Concerts, in the chief proviucial cities, etc.

Gay, George, stomemason and musician, born November 17, 1771, at Corsham (?), died there, July 26, 1833. Builder of Melksham Bridge, Wilts. Organ builder and verse writer. Organist of Corsham Iudependent Chapel, Wilts. Committed suicide by cutting through carotid artery with his own mallet and chisel. Composer of anthems and hymm tunes in 3, 5, and 8 parts. Compiler of "Sacred Music, consisting of 50 psalm and hymn tumes..to which are prefixed some original ideas calculated to improve the method of singing," London, 1827. In 1833 he revised T. Hawkes' "Collection of Tunes."

Gear, Henry Handel, tenor vocalist and composer, born at Lundon, October 28, 1805. Son of an artist, who held the appointment of painter to the Duke of Sussex. He was a choir boy in the Chapel Royal and St. Paul's Catheäral; but in 1822 he went to New York and became organist of Grace Church. In 1828 he proceeded to Italy, where he studied singing under Nozzari, etc., and afterwards he went to Frankfort and sang there, and in Paris. He finally settled in London as a professor of singing, and was for over 17 years organist of Quebec Chapel, Bryauston Street. Composer of church services, anthems, songs, etc. He died in London, October 16, 1884.

His third son, George Frederick Gear, composer and pianist, was boru at Loudon, May 21, 1857. He studied under Dr. Wylde, and J. F. Barnett, and in 1872 gained a scholarship at the London Academy of Music. He gained medals for harmony and pianoforte playing, and was elected an associate and professor of the London Academy of Music, and an associate of the Philharmonic Society. Musical director of the German Reed Company from 1876 to 1892 , and is a member of the Incorporated Society of Musicians, and the Musical Artists' Society. He has given many concerts, and has frequently appeared as a vocalist.

Works.--String quartet; Two pf. sonatas; Scena, for soprano voice and orchestra; "A water cure," and "Hobbies," 2 operettas. Songs: Day is done; My Lady sleeps; Sweet visious; The rose is dead; When night is gathering round; White rose, etc. 


\section{GEARY.}

Geary, E. M. Author of "Musical Education, with practical observations on the art of Pianoforte playing," London, 1841, 1848, and other editions.

Geary, Timothy, composer, born at Dublin, 1783; died in 1806. Composed glees, duets, and other vocal music. Known also as Thomas Augustine Geary.

Geaussent, George F., pianist and conductor, born in London, in 1852. Has held organ appointments at Hampstead Parish Church, and elsewhere. As a pianist he gave recitals at various times, and as conductor of a choir bearing his name, he gave high-class concerts, introducing, for the first time in London, important works, such as Dvorák's "Patriotic Hymn." Principal of the Hampstead Conservatoire of Mnsic, and member of the Governing Council since its re-organisation in 1896. Also director for some years of a Conservatoire at Croydon; and, 1896, Principal of Belfast Conservatoire of Music.

Gee, Samuel, organist, bom at Congleton, Cheshire, May 12,1834. Pnpil and Associate, R.A.M. Organist successively at the Parish Cburch, Chertsey; St. Peter and St. Paul, Wantage, 1861; Christ Church, Clapham, 1864; St. Mark's, Lewisham, 1870; and in his later years at Leek, Staffordshire. He read papers on various topies at meetings of the College of Organists, and was well-known as a teacher. He died suddenly of apoplexy, in his room at the Hanley Academy of Music, Staffordshire, November 15, 1892.

Geikie, James Stewart, composer and writer, born at Edinburgh, Jannary 12, 1811. For a number of years musical representative of the Scotsman. Conductor of the Edinburgh Sacred Harmonic Association, and other societies of a kindred nature at Newington. He was conductor of psalmody at St. Augustine Church, Edinburgh, from 1843 till 1880. He died at Ormiston, Haddington, Angust 14, 1883. He composed a number of secular vocal pieces: "How beautiful is night," partsong; "My heather hills," song, etc.: but his psalms and other sacred music will enjoy a more lasting popularity, $\mathrm{He}$ edited an edition of R. A. Smith's "Sacred Harmony," entitled, "Supplement to R. A. Smith's Sacred Harmony, adapted to the Psalms and Hymns used in the churches and chapels of Scotland," n.d. Also, "Songs of the Sanc. tuary, a collection of psalms, scripture hymms, etc.," 1863.

His sons, Sir Archibald Geikie, and James Geikie, are the well-known scientists, while his brother WALTER was the famous artist and etcher.

Geoghegan, Joseph, vocalist and teacher, born at Ballinasloe, Galway, in 1830 . $\mathrm{He}$ lived in Edinburgb, from about 1846, where he worked originally as a bookbinder. After-

\section{GIBBONS.}

wards he became choirmaster of Old Greyfriars Church, 1857-83, and teacher in various schools and colleges in Edinburgh. Ile died at Musselburgh, on January 27, 1892.

George, Miss, see Oldmixon, Lady.

German, J. Edward, composer, violinist and conductor, born at Whitehurch, Shropshire, February 17, 1862. Entered the R.A.MI. in 1880 as an organ student, int the next year took the violin as principal study. In 1885, he won the Charles Lucas medal for composition, his work being a setting of the Te Deum for chorus and organ. While at the Royal Academy he wrote many works of importance, some of which have bee, performed at concerts in various places. He left the Academy in 1887, and was made an Associate, and in 1895, a Fellow of that Institution. In 1889, he was appointed Musical Director at the Globe Theatre, London. He has conducted concerts at the Crystal Palace, 1893, and performances of his own music at the Leeds Festival, 1895, and elsewhere.

Works.-Dramatic: Operetta, The Rival Poets (R.A M., July, 1886), St. George's Hall, December 21, 1886; Incidental IInsic to Richard III, Globe Theatre, 1889; Henry VIII, Lyceum, 1892; 'The Tempter (H. A. Jones), Haymarket, 1893; Romeo and Juliet, Lyceum, 1895; and As you like it (for Mr. Alexander), 1896. Orchestral: Symphony in E minor (R.A.II , July, 1886), Crystal Palace, December 13, 1890; in A minor, Norwich Festival, 1893. Gipsy suite, Crystal Palace, 1892; Suite in D minor, Leeds Festival, 1895; Suites arranged from music to Henry VIII., and The Tempter; Funeral March in D minor, Henschel Concerts, January 15, 1891. Suites: Flute and pf., 1892; in E minor, pf. Pieces for violin and pf., oboe and pf., clarinet and pf., etc. Serenade for tenor voice, with accompaniment for pf. and wind instruments;

\section{Songs, etc.}

Ghilberti, Gilberto, see Campbeld, Gilbert Janes.

Gibb, Alexander, violinist, composer, and dancing-master, who lived in Haddington and Edinburgh in the last thirty years of the 18th century. He had a dancing sehool in Edinburgh from 1786 to 1809 , after which all trace of him disappears. He issued "A new collection of minuets, medlies, high dances, marches, strathspey and other reels, with entertaining tunes, etc., for the pianoforte, violin, and violoncello," Edinburgh, 1798.

Gibbons, Christopher, organist and composer, born in 1615. Baptised August 22. Son of Orlando Gibbons. He studied under Edward Gibbons at Exeter. Organist of Winchester Cathedral, 1638-61. Served for a time in Royalist army. Organist of Chapel Royal, 1660-76. Private organist to Charles 


\section{GIBBONS.}

II., 1660. Organist of Westminster Abbey, 1660-65. Mus. Doc., Oxon., July, 1664. Died Oetober 20, 1676. A few works by this musician exist in M\$., such as his "Act-song" (a degree exercise), music to Shirley's Cupid and Death, a masque; Compositions in Playford's "Cuntica sacra," ete , but it is as an organist that he was principally known.

Gibbons, Rev. Edward, organist and composer, born about 1570 . Mus. Bac., Oxford, 1592, incorporated from Cambridge. Organist of Bristol Cathedral, 1592-1611. Organist of Exeter Cathedral, 1611-44. He died about 1650. Works in MS., anth ms, ete.

Gibbons, Ellis, organist and composer, born at Cambridge about end of the 16th century. Brother of Edward. Organist of Salisbury Cathedral. He died about 1650. Composer of "Long live fair Oriana," madrigal for 5 voices; "Round about her chariot," for 6 voices ; both contained in the "Triumphs of Oriand."

Gibbons, Orlando, organist and composer, born at Cambridge in 1583. Brother of Edwark and Ellis Gibbons. Chorister in King's College, Cambridge, 1596. Organist of the Chapel Royal, March, 1604. Mus. Bac., Cantab., 1606; Bac. and Doe. Mus., Oxon., 162.2. Organist of Westminster Abbey, 1623 . He died at Canterbury, Jume 5, 1625. Buried in Canterisury Cathedral.

Works.-Homing and Evening Service, in $\mathrm{F}$; Te Ieum and Jubilate, in D minor; Venite exultemus, in F; Magnificat, Nunc Dimittis, in D minor and in F; Te Deum and Benedictus, in F. A collection of the sacred compositions of Orlando Gibbons fof which the scores are not contained in Boyce's collection) from the original MSS. and part books, together with a transposed organ-part to some of his publislied works. Edited by the Rev. Sir F. A. Gore Onseley, 1873 (contains two services, two sets of preces, seventeen anthems, six hymu-tunes). Single Anthems: Hosanna; Lift up your heads; O clap yonr liands; Amighty and Everlasting; God is gone up (Boyce); O Lord, in Thy wrath; $\mathrm{O}$ Lord, in Thee; Why art thou so heavy? Blessed be the Lord; O Lord increase my faith; Deliver us, O Lord; Behold, thou hast made; This is the record of John; Behold, I bring you; I fye he risen again (Ouseley); We praise Thee, O Father; Lord, grant grace; Glorious and powerful God See, see, the Word is incarnate; Sing unto the Lord; Blessed are all they; Great Lord of Lords; O Thou, the Central Orb. Hymms. Fantasies of III. Parts ..composed for viols; London, 4to, 1610. Reprinted, edited by E. F. Rimbault (Nusic. Antiq. Soc.), London, fo., 1843. Lessons in "Parthenia" (with Bull and Byrd), London, 1611. First set of madrigals
GIBSON.

and motets, for five voices, London, 4 to, 1612. Reprinted, edited by Sir G. Smart (Music. Antiq. Soc.), London, fo., 1841. Fancies and songs made at King James ye First's being in Scotland, London, n. d. Tunes for "Wither's Hymns" (Reprinted by the Spenser Society, 1881). Tunes in Leighton's "Teares," 1614. Madrigal titles-The silver swan; I weigh not fortune's frown; I tremble not; I feign not friendship; Dainty fine bird; Farewell all joys; Oh! dear heart; Ne'er let the Sun; Trust not too much; $O$ that the learned poets; Nay, let me weep; Yet if that age; I see ambition; Fair ladies that to love; What is our life? etc, Galiards, fantasias, preludium, pavans, ete.

Gibbs, Joseph, organist and composer, born in 1699. For forty years he was organist at Ipswich. He died December 12, 1788. Composer of " Eight siolos for a violin with a thorough bass for the harpsichord or violin" $[1740]$, ete. Some of his pieces have recently been re-published, and a sonata and other pieces performed by Mr. Otto Peiniger, 1885-7.

Gibson, Alfred, violinist, born at Nottingham, October 27, 1849. After some early lessons from his father, a good violin teacher, he studied for two years with Henry Fammer, after which time he was practically selftaught. He played with success, from the age of eleven, in differents parts of the conntry, and abont 1868 went to London, and was engaged as first violin in the opera at Inrury I ane. In 1871 he was appointed to the Royal Opera orchestra at Govent (iarden, remaining there twelve years. He appeared at the Nonday Popular Concerts, January 23, 1882, as a violinist in Svendsen's Octet, ultimately taking the position of principal viola, which he still retains. He succeeded Ludwig Straus as learler of the Queen's Private Pand; is professor of the violin at the R.A.M., and of the viola at the G.S.M. Among the fine instruments he possesses is a Stradivari viola formerly belonging to Charles lieade, the novelist.

Gibson, Edmund, bishop and writer, born at Brampton, Westmoreland, in 1669; died at Bath, in 1748. Wrote a number of antiquarian works, and a "Method or course of singing in Church; direction to the Clergy of the Diocese of London, 1727 ; etc."

Gibson, Francis, pianist and composer, born in Edindurgh, in 1861. After studying pianoforte and harmony five years with Mr. William Townsend, he entered Dr. Hoch's Conservatorimm, Frankfort - on - the-Main, studying composition under Joachim Raff, and the pianoforte with Carl Faelten. Settling in Edinburgh as a teacher, he succeeded Mr. G. L. Deas as a professor of the pianoforte and theory at the Edinburgh Ladies' College, which, with other appointments, he still holds. 
GIBSON.

He has played at various chamber concerts at Edimburgh, where some of his compositions have been performed. So far he has only published an Album of ten songs; a Serenade; and a $R$ verie for violin.

Gibson, Rev. James, D.D., clergyman and writer, was a professor in the Free Church College, Glasgow. Author of "The Public Worship of God: its anthority and modes, Hymms and Hymu Books," Glasgow, 1869.

Gibson, Louisa, teacher and writer, born in London, 18:33. For some years head professor of music, Plrmouth High school for Girls. Authoress of "A First Book on the Theory of Music, applied to the Pianoforte," Iundon, 6th edition, 1876 ; second and third books of same; key to exercises in third book. Songs, etc.

Gibson, Mrs. Patrick, bom Isabella MARY ScotT, vocalist and composer, born at Edinburgh, in 1786. She was a daughter of William Scott, teacher of elocution, Edimburgh, and married l'atrick Gibson, R.S.A., in 1818. She at one time kept a Boarding School for Young Ladies, in Inverleith Row, Edinburgb, and was an associate of many distinguished men of her time. Distantly related to Sir WValter Scott. She was consulted much by R. A. Smith in the composition of his songs and duets, and some of her psalm tumes are in Dr. Andrew Thomson's "Sacred Harmony," 1820 , and in vol. 6 of Steven's "Church Music," edited by Turnbull, 1833. Her song "Loch-1ra-gar" is contained in the 6 th vol. of R. A. Smith's "Scotish Minstrel." Mrs. Gibson was a skilful harp player. She died at Edinburgh, November 28, 1838.

Gibsone, Burford George Henry, composer of first half of present century. He is stated to have died about 1868. Composer of fantasias for the pf., songs, and glees. His "Table Book of Glees" [1810], contains original compositions.

Gibsone, Guillaume Ignace, composer and pianist, born in London, of Scottish parentage, about 1826 . Studied under Moscheles. Resident in Brussels, 1845, where he gave concerts. In $18 \pm 6$ he was made an honorary member of the Societé de Grand Harmonie, Brussels. Toured in Germany the same year. Returned to London in 1850, where he settled as teacher and composer. His works include three Cantatas: The Wood Nymphs, The Elfin Kuight, and The Three Sisters; an Opera and two Symphonies (in MS.) ; Sonata for violin and pf.; A large number of pf. pieces; Meditations, 24 pieces; Polonaise; Chansou à boire; Chanson d'amour: Four sketches, etc. Songs : My lady sleeps;

Her voice; Sweet hour of eventide, ete.

Gick, Thomas, alto vocalist and composer, born in Liverpool, February 22, 1837. Musical

\section{GILBERT.}

training private. Appointed lay-clerk, York Minster, 1859; and in 1864, vicar-choral, Christ Church, and St. Patrick's Catledral, Dublin; he is also a nember of the choir of Trinity College, Dublin. He graduated Mus. Bac., 1880; Mus. Doc., 1882, Dublin; and is Examiner in Iusic under the Intermediate Education Board for Ireland. His compositions comprise a cantata, The Bard, for soli, chorus, and orehestra, 1)ublin, 1882; a morning and erening service in $\mathrm{B}$ flat, and an evening service in $\mathrm{F}$. He has also published: O Come, let us worship; Hear, O thou shepherd ; Blesied is $\mathrm{Ht}$, and other anthems, ete.

Gilbert, Alfred, pianist and composer, second son of Francis and Jane Gilbert, was born at Salisbury, October 21, 1828. Commenced his musical studies at the age of six, then became a pupil of Dr. Charles Corfe, and later, of Alexander Lucas, whose asssistant organist he was at St. Thomas's Church. In 1845 he entered the R.A.M., and soon after was made assistant organist of Hanover Chanel, Regent Street. He then held organ appointments successively at St. Matthew's, Spring Gardens; Chepstow; Mitcham ; Kentish Town ; and St. Mark's, Hamilton Terrace, but deroted himself chiefly to pianoforte playing and composition. In 1651 he commenced a scries of classical chamber concerts with the sisters, Charlotte and Susanna Cole (q.v.), the former of whom he married in 1853 . Concerts were also given by the Arion Choir, the Polyhymnian Choir, and other societies under his direction; and he has lectured on music at varions institutions. A concert of his works was given in Rome in 188t, when he received the distinction of being elected socio onorario della Reale Accatemia S. Cecilia. $\mathrm{He}$ is director of the Musical Artists' Society; Society for the Encouragement of the Fine Arts; Nember, and a director of the Philharmonic Society, and in 1896 elected orehestral manager in succession to Mr. W. H. Cummings; Nember of the Court of Assistants of the Royal Society of Musicians; F.R.A.M. Mr. Alfred Gilbert, R.A., the distinguished sculptor, is his son.

Works.-Spectacular Cantatas: Abdallah; L'Amie du Drapeau. Operettas: The rival roses; Outwitted ; Blonde or brunette. Quintet in $\mathrm{E}$ flat, for pf., strings, and four voices, performed in Rome, January 24, 1881. Trios in $C, A$, and $B$ flat, pf. and strings; Sonata in F, pf. and violoncello. Suite for strings. Pieces for pf. and violin. A complete School for the pf. Classical Library, edited. Many smaller works.

Gilbert, Davies, writer and musician, compiled "Some Ancient Christmas Carols, with the tunes to which they were formerly sung in the West of England." London, $1823 ; 2 \mathrm{nd}$ ed. 


\section{GILBERT.}

Gilbert, (Ernest) Thomas Bennett, composer and vocal teacher, born at Salisbury, October s.2, 1833. Brother of Alfred Gilbert. He studied at the R.A.M. from $18+7$, and at Leipzig under Moscheles, Hauptmann, Richter, etc., in 1852. Organist successively of St. George's, Isle of Man, 1853; St. Barnabas, do., 1854 ; St. Paul, Newport, Mon., 1856 ; Parish Church, Abergavenny, 1857; St. Peter's, Walworth, 1861; S't. George's, Southwark, 1864 ; and St. Matthew's, Southwark, 1867. He was afterwards a vocal trainer in London. Died at Gipsy Hilt, London, May 11, 1885.

Works.-Operettas: Night in fairyland, 1861 ; Das Helldichein, Leipzig, 1851. Ramiro, cantata, 1879. Orchestral: Concert overture, 1853; Merry wives of Windsor, overture, 1854: String quartets in $\mathrm{E}$ flat and C; Trio for pf., violin, and 'cello, in F. l'iunoforte: Nocturnes, scherzos, ballads, impromptus, dances, ete. Numerous part-songs and songs. Tocal exercises, for daily use, in 2 books; School harmony, London, n.d., various editions; Practical and natural method for the pianoforte, 2 books; and other works.

Gilbert, Walter Bond, composer and organist, lorm at Exeter, April 21, 1829. Studied moder Alfred Angel, Dr. Wesley, and Sir H. Pishop. He was organist successively at Topsham, 1847; Bicteford, 1849; Tumbridge, 1854; Maidntone, 1859; Lee, líent, 1866 ; Boston, Lincolnshire, 1868; and in 1869 accepted a similar post at Trinity Episcopal Cbapel, New York, which he still holds. He graduated Mus. Bac., Oxford, in 1854; and while in England, in 1888, took the degree of Mus. Doc., Oxford, bis Exercise having been approved more than twenty-five years before. In $18 \times 6$ he was made a Mus. Doc. of Trinity College, Toronto. His talent as a composer was hlewn at an early age, and one of his most widely known works is a Cathedral Service written when he was serenteen. He is the composer of two oratorios: "The Restoration of Israel," and "St. John"; the last performed at Iraidstone, in 186t. Also of church services, many anthems, and organ piceses, ete. Editor of I Iymmal and Canticles of the Protestant Episcepal Church, New Fork (with Fier. A. 13. (roodrich, I).D).), 1875; The I'saltex, or Prahns of David, New York, 1882. The well-known hymm tune, "Maidstone," Wats first publisbed in the "Parish Tune Book" of Mr. (T. F. Chambers, in 1869. Author of The Antiquities of Maidstone, 1865: Memorials of All haints' ('hurch, Maidstone, 1864 ; and other historical works.

Gilbert, William Schwenck, dramatist, and opera librettist, bom in London, November 18, 1836. Ectucated for the Bar, and graduated B.A., London. Clerk in the Privy

\section{GHLMER.}

Comncil Office, 1857-62. Called to the I3ar of the Inner Temple, 1864. In 1891 his name was added to the Commission of the Peace for the County of Middlesex. His first dramatic piece, "Dulcamara," was produced, St. James's Theatre, 1866 ; but here it is only necessary to name his operas and operettas. These are: Princess Toto (Clay), 1875; The Mountebanks (Cellier), 1892; Thespis, 1871; Trial by Jury, 1875; The Sorcerer, 1877; H.M.S. Pinafore, 1878; Pirates of Penzance, 1880 ; Patience, 1881; Iolanthe, 1882 ; Princess Ida, 1884; Mikado, 1885; Ruddigore, 1887; The Yeomen of the Guard, 1888; Gondoliers, 1889: Ttopia, 1893; and The Grand Duke, 1\&96, all set by sullivan, (q.x.)

Gildon, John, composer and pianist, who flourished in the latter part of last, and early part of the present century. He composed a large quantity of pf. music, inclucling sonatas, as well as songs and other pieces.

Giles, Nathaniel, composer and organist, born near Worcester, about 1548-50. Bac. Mus., Oxon., 1585. Dore. Mus., Oxon., 1622. Organist of St. George's Chapel, Windsor, and master of choristers, do., 1595. Master of Children of Chapel Royal, 1597, and organist, 1625. He died on January 24, 1683. Buried in St. George's Chapel, Windsor. "His services and anthems announce his leaning and abilities, and, by the lovers and judges of church composition, ane regarded as masterly productions."-Busby. He composed a complete service in C, in Barnard's Collection, and other compositions by hin are in Leighton's "Teares," and varion. MIS. collections.

His father, Thomas filles, or fiyles, was an organist, and sneceeded John Redford as organist of St. Paul's Cathedral.

Gill, William Henry, composer and writer. Author of "The Minsical ladder; or Tonic sliding scale," London [1864]. Composer of "Easy Anthems for village choirs" [18s8-91]; "Voluntaries from Handel, Mendelssolnn, ete." I'art-songs: Before sweet nightingale: Three merry maids; When twilight dews, etc. Songs.

Gilmer, Alfred Walker, cornet player and conductor, was born in the parish of St. Margaret, Westminster, in 1838. As a child he played the violin, but was afterwards sent to Paris to study the cornet under Joseph Arban. His first important engagement was as first violin in a Manchester theatre, and about 1858 he joinerl the orehestra of the Theatre Royal, Birmingham, that town from henceforth being his home. His ability as a cornet player secured him engagements at the best orchestral concerts in the locality, and for some years he was a member of the Festival orchestra. In conjunction with Henry Synyer (q.v.) he formed a military band, which acquired a high reputation in the 


\section{GILMIORE.}

Midlands. He was also bandmaster of the Worcestershire Yeomanry Regiment, and his annual coneerts in Worcester were great events. Many of his pupils obtained good positions as comet players. He died at Birmingham, Nay 16, 1892 .

Gilmore, Patrick Sarsfield, bandmaster and composer, born near Dublin, December 25, 1829. Joined a military band at Athlone while a youth, and went to Boston, U.S.A., when nineteen, as a coruet player. He was for several years salesman in a $m$ sic store there. In 1858 he organised a band bearing his name, which gained a high reputation, and in 1563 he was appointed director of military bands in Louisiana. The musical arrangements in the Peace Jubilee at Boston in 1869 were under his direction. He toured in Europe with his band in 1878 . It is stated that his was the first military band to perform the Tannhäuser overture. He wrote a History of the National Peace Jubilee and great IInsical Festival in Boston, 1869; Diatonic and Chromatic Scales for the Cornet; much Military band musie; aud composed some songs that became very popular, asGood news from home: Building castles in the air; Freedom on the old plantation, etc. He died at St. Louic, September 2 ; 1892.

Gilmour, Robert, musician, who was a teacher in Paisley at the end of last century. He compiled "The Psalm Singer's Assistant, being a collection of the most approved psalm and hymn-tunes ... with a compendious introduction, for the use of Iearners ..." Paisley [1793]; second edition, frlasgow, n.d.

Gilson, Cornforth, teacher and writer. Was originally a chorister in Durham Cathedral, and latterly Master of Music in the Edinburgh city churches, 1756. He was made Mrusic-master of Heriot's Hospital, Edinburgh, in 1757-1764, and after a residence in London for a time, was re-appointed in in 1771. He died at Edinburgh after 177t. He wrote "Lessons on the practice of Singing, with an addition of the chureh tunes, in four parts, and a collection of hymns, canons, airs, and catches, for the improvement of beginners," Edinburgh, 4to, 1759. "Twelve songs for the voice and harpsichord," Edinburgh, 1769. Gilson did much to improve psahmody in the Edinburgh churches.

Girvin, John, musician and writer, who was born in Edinburgh in the first half of the 18th century. He was precentor of the Tron Kirk, Glasgow, 1761-62, and a teacher in Glasgow. He afterwards went to PortGlasgow as a teacher in 1762. Published "A New Collection of Church Tunes," Glasgow, 1761. Author of "The Voeal Musician, Part I., wherein the grounds of music are distinctly handled, the intervals explained, and their use in practice fully shown, etc.

\section{GLEADHILL.}

Illustrated with plates. For the use of Schools" (preface dated Port-Glasgow, 1763), Edinburgh, 1763.

Gladstanes, Frederick, composer, who flomrished during the first half of the present century. He composed "Six Glees for 3 and 4 voices," 1830, and other glees published separately. His other works consist chiefly of pf. music and songs.

J. C. Gladestanes, probably a relative of the above, composed "The Indian," and other glees, songs, etc.

Gladstone, Francis Edward, composer and organist, born at summertorn, near Oxford, March 2, 1845. Articled pupil of Dr. S. S. Wesley, 1859-64, then appointed organist of Holy Trinity, Weston-super-Mare. In 1866 he was chosen organist of Llandaff Cathedral, and in 1870 appointed to ('hichester Cathedral. This post he resigned in 1873 , and went to reside at Brighton, where he remained until 1876, when lie removed to London, and became organist of St. Mark's, Lewisham. He accepted the post of organist of Norwich Cathedral, Inecember, 1877 , and in 1881 returned to London, acting as organist of Christ Church, Lancaster Gate, until 1886. The next year he was received into the Roman Catholic Chuneh, and was director of the choir at St. Mary of the Angels, Bayswater, up to 1894. He graduated Mus. Bac., 1876; Mus. Doe., 1879, Cambridge. He is an Hon. R.A.M., F.R.C.O., and a Member of the Board of MInsical Studies at Cambridge. Professor of eounterpoint, ete., Trinity College, London, 1881; Professor of harmony and counterpoint, R.C.M., 1883; and examiner for various institutions.

Woris.-Cantatas: Nicodemus, produced by Highbury Philharmonie Societr, December 13, 1880; Philippi, Nemantle Cathedral, July 26,1883 ; and Constance of Calais, Highbury, May 18, 1885. MIorning and Evening Service in F; Anthems. Mass in E minor, written for the Brompton Oratory; Mass in E flat, fonr voices and organ, 1858. Church musie, rarions, in MS. A wet sheet and a flowing sea, chorus and orchestra, Highbury, 1880. Orerture, string quartet, Trio, pt. and strings, 1876, all in MS. Sonata in A minor; Twelve original pieces; Ten pieces; Three preludes, and other organ music. The Organ Students' Guide, several editions. Editor of Select Anthems from the works of English composers.

Glasgow, James, Irish clergyman and writer. Was professor of dirinity in the Irish Presbyterian Chureh. Author of "Heart and voice: instrumental music in christian worship not divinely authorised ". n.d.

Gleadhill, Thomas Swift, composer and teacher, born at Edinburgh, January 30, 1827. Son of Benjamin Gleadhili, a musician, who was born in Derbyshire, April, 1789; 


\section{GLEDHILI}

and died at Edinburgh, October 6, 1859. He resided in Glasgow and Edinburgh as a teacher, eompiler, and choirmaster. from 1857. In 1889 he was appointed organist of the Parish Church of Peterhead, and on September 21, 1890, he drowned himself in the sea. He wrote or compiled the following works:-Beauties of Scottish song (with Fulcher and Thomson), Glasgow, n.d. Harmonium Album (popular airs arranged). Harmonimm Repository (do.). Children's songs (with J. Thomson). Seottish airs arranged as part-songs, and for the pf. Lyrie Gems of Scotland, Glasgow, n.d. Songs of the British Isles, 2 vols. Original songs, among which may be named, "Be kind to auld Grannie" ; "Thorn-tree"; "Farewell to the land," etc.

Gledhill, John, pianist and composer, was one of the early students at the R.A.M., a fellow-pupil being Sterndale Bennett. $\mathrm{He}$ was made an Associate, and afterwards studied at Leipzig. For some years he was a professor at the R.A.M. From about 1876 he settled in Brighton as a teacher. He died there in 1891, having been disabled some three years previously by a stroke of paralysis. $\mathrm{He}$ composed a number of pf. piees, and several sets of songs, ete.

Glen, Alexander, bagpipe maker, was born at Inverkeithing, Fife, in 1801. He was established in business in Edinburgh, and died there in Mareh, 1873. He issued "The Caledonian Repository of MIusie for the Great Highland bagpipe . . " Edinburgh, 1870.

His son, DAvid (born at Edinburgh in 1850), who sueeeeded to the business, issued a "Collection of Highland bagpipe music . .." Edinburgh, 1876-1880, 2 parts ; and a "Highland Bagpipe tutor, with a selection of quieksteps, strathspeys, reels, etc.," Edinburgh, 1866. In 1896 this firm supplicd sets of bagpipes for use in the French army.

Glen, Annie, soprano vocalist and writer, of present time. Gave her first concert at Steinway Hall, London, January 25, 1883. Is known as the author of "Nusic in its Social Aspect," and an elaborate treatise, "How to Accompany," London, Cocks \& r'o.

Glen, Thomas Macbean, musical in. strument maker, brother of Alexander, was born at Inverkeithing, Fife, in May, 1804. He established a musieal instrument business in Edinburgh, in 1827, and made bagpipes, flutes, and other instruments. He invented a wooden Ophicleide, called a Serpentcleide; and the system of modern music-holders for military band instruments. He died in Edinburgh, July 12, 1873. Publisher of "A new and complete tutor for the great Ifighland bagpipe ... Edinburgh, n.d., 2 vols.

His son, JoHN (born at Edinburgh in 1833), succeeded to the business in company with his brother Robert in 1866. He compiled

\section{GLOVER.}

"The Glen Collection of Scottish Dance Music... arranged ... for the pianoforte. Containing an introduction on Scottish dance music, sketches of musieians, and musicsellers . . . and a ehronological list of works, ' Edinburgh, book 1, 1891 ; book 2, 1895. An accurate and valuable work. This he intends to follow up with a work on "Early Scottish Melodies," llesigned to clear up the misconceptions regarding their origin and history which have arisen. His brother, RoBerT (born at Edinburgh in 1835), is an artist and skilful mechanic, who has acquired a collection of musical instruments of some archcological value. The firm of J. \& R. Glen has issued some books of instructions for playing the Bagpipe, and various collections of bagpipe music, among which may be named "Collection for the great Highland bagpipe, contaning instructions and 52 marching, dancing and slow airs, etc." Edinburgh, n.d., 3 parts.

Glencorse, Peter, ehoir conductor and teacher, was born at Edinburgh, April 17, 1852. He studied under Janes sneddon, A. C. Mackenzie, G. C. Martin, ete. He sang in various Edinburgh choirs as a lyass, and in 1883 sueeeeded Joseph Geoghegan as choirmaster of Old Creyfriars Church. As conductor of a choral society in Edinburgh, Mr. Glencorse has produced many good works with much acceptance.

Glossop, Mrs., born Fearon, operatic vocalist, who sang at La Acala, Milan, in 1829-25, and appeared at the King's Theatre, Lond on, in 18:34. She married Joseph Glossop, the impresario, and was the grandmother of the late sir Augustus Harris the theatrical manager.

Glover, Charles William, composer and violinist, born, London, February, 1806. He studied under T. Cooke, and became violinist. at Drury Lane and Covent Garden Theatres. He afterwards acted as musical director of the Queen's Theatre from 1832. Died, London, March 23, 1863. He published a very large number of songs and pf. pieces, very few of which now survive.

Glover, J. H. L., composer and writer, author of a "Coneise Organ Tutor," London (Goddard), n.d. Te Deum, songs, pf. music.

Glover, John William, composer, organist, and teacher, born at Dublin, June 19, 1815. He studied in Dublin, and beeame a violinist in the Dublin orehestra in 1830. In succession to Haydn Corri he became director of the cathedral choir, and in 1848 was appointed professor of vocal musie in the Normal Training School of the Irish National Education Board. In 1851 he established the Choral Institute of Dublin, and was conneeted with the organisation of the musical commemorations of O'Connell, Moore, and 


\section{GLOVER.}

Grattan. He las lectured on Irish music in Dublin and London, and has been active in promoting the eultivation of choral musie in Ireland.

Wonks.-Operas: Deserted Village (Goldsmith, dramatized by Edmund Falconer) London, 1880; Two Italian Operas by Metastasio (MS.). Cantatas, etc.: St. Patrick at Tara (O'Comell eentenary), 1870; Erin's Matin Song, Patria, 1873; "One hundred years ago," Ode to Thomas Moore, 1879. Masses, hrmms, songs, etc. Concerto for violin and orchestra in A; Fantasias; Concertos and otber music for organ: Pf. music, etc. He also edited Moore's Irish Melodies, 1859 , and a large number of musical works for school use.

His daughter, Ermixia (Mr's. Mackey), was a harpist. She died at Dublin, in June, 1883.

Glover, Sarah Ann, musieian and teaeher, daughter of the Rev. MIr. Glover, of Norwich, was boru at Norwich, 1785. Died at Malvern, Oetober 20,1867 . She invented the Tonic S I-fa system of musical notation, which the Rev. John Curwen afterwards modified and changed till its present form was reached. To Niss Glover much credit is necessarily due for the commencemeut of the system now so universally used in Britain. She published "A manual of the Norwich Sol-fa System . . . . [1845]; "Manual containing a Development of the Tetrachordal system," Loudon [1850].

Glover, Stephen, eomposer, brother of C. W. Glover, was born at London, in 1812. He was a teacher and composer in London, and died there on Deeember $7,1870$.

IVorks.-Songs: Amnie on the banks o'Dee; Mary Astore; Oh! give me hack my childhood's dreams; The maiden's dream; Dreams of ehildhood; I dream of thee; The minstrel knight; The river of song: Woman's wiles ; Yes or no; Abide with me; Autumn eve; Bonnie Teviotdale; Beware; Break, break, break; Down the green lane; Ellen Vane; Fair ruse of Killarney; Flower of the sonth; Fond memory; Good words; I love him, yes; Ildegonda; King of the ocean wave; Lays of the London season; Merry mountain maid; May Queen: Oh far the bloom o' my ain native lieather; Ol ye mountain streams; Pearl of the east; Songs of other years; There onee was a knight; Underneath your window; Winter night; Would you remember me. Duets: The cuckoo; The dove; The fairies' serenade; The gleaners; Our bark is on the Rhine; Return of the swallows; Savoyard maids; The skylark; Hymn to the night; Stars of the summer night; The curfew bell ; The gipsy countess; 'To the woods! to the woods; Yoices of the night; What are the wild waves saying? Four-part songs, trios, etc. Pianoforte music, transeriptions, etc.

\section{GODDARD.}

Glover, William, organist and composer, was born at London, in 1822. He was a chorister in Trinity College, Cambridge, 1829-38, and studied under Walmisley. Organist successively of Christ Church, Cambridge, 1841-42; St. Matthew's, Manchester, 1842 ; St. Luke's, Cheetham, 1846.

He has composed two oratorios "Jerusalem," 1848, and "Emmauuel," 1851, both produced at Manchester; The "Corsair," cantata, 1849 (printed 1856) ; Chamber music, pf. music, songs, ete.

Glover, William Howard, composer and violinist, born at Kilburn, London, June 6, 1819. Son of Mrs. Glover, the actress. He studied musie under Wagstaff, and for a time travelle 1 in Europe. Member of the staff of the Moming Post. Resided in U.S.A. from 1968, and died at New York, October $28,1875$.

Wonks.-Operas and operettas: Ruy Blas, Covent Garden, London, October, 1861; Aminta, Haymarket, London; Once too often; The Coquette; Palomita, or the Veiled Songstress. Tam o' Shanter, cantata, London, July, 1855; Overture for orehestra, Manfred; Twelve Romances for pf., in 2 books: Voeal quartets, duets, ete. Miscellaneous pf.music ; Songs for voice and pf.

Goddard, Arabella (DAvisox), pianist, born at St. Servan, near St. Malo, Brittany, January 12, 1836. Daughter of Thonras Goddard (died at Boulogne, July 19, 1890), of a Salisbury family. When a little child of four she played in public in her native village, and two years later received instruction from Kalkbrenner, in Paris. At the age of eight she played before the Queen and Prince Consort at Buckingliam Palace, and at the same age (184t), published six Waltzes for pianoforte (D'Almaine). Her instructors at this time were Mrs. Anderson, and Thalberg. She made her debut at the Grand National Concerts at Her IIajesty's Theatre, October 30,1850 . For the next three year's she studied with J. W. Davison (q.r.), to whom she was married in 1860. She also studied harmony under G. A. Macfarren. Her reappearance took place at Willis's Rooms, April 14, 1853 , at a coneert of the Quartet Association, when she played Beethoven's Sonata in 13 flat, Op. 106. On May 11, she played at the New Philharmonic Concerts, Bennett's Concerto in C minor; and the same work at the Philharmonic, where she played for the first time, Jume 9, 1856. In 1854-5 she toured in Germany, and played at the Gewandhaus Concerts, Leipzig, Jannary 11, 1855, Mendelssohn's D minor Concerto. Returning to England she was reeognised as one of the greatest pianists of the time. She appeared at the Crystal Palace, Nareh 15, 1858; Leeds Festival, 1858; Birmingham, 1s61-70; Gloncester, 1865; and 


\section{GODDARD.}

at all the leading concerts throughout the country. She first appeared at the Popular Concerts, Mareh 9, 1\$59, at an extra Mozart Night, on a Wednesday; and was for many years associated with that undertaking In 1873 she left for a tour in Australia, Anerica, and all round the world, returning in 1876 . About 1880 she gave up public work, and devoted herself to teaching; but reappeared at Sims Reeves's Concert, Marel 21, 1882. Later, her liealth failing, she retired to Tunbridgre Wells, where she stıll resides. She published a ballad, and some pf. pieees, 1852-3. A concert was given for her luenefit in St. James's 1 Iall, Marel 9, 1890.

Goddard, Joseph, writer and composer, born in 1833. Author of " M ral Theory of Musie," 1 1 57; "Philosophy of Musie: a series of essays," London, 1862; "Musical Development, or remarks on the spirit of the principal Musical Forms," Louston, n.d. ; "New Graduated Method for the Pianoforte," n.d.; "Tine Exereises for the use of P'ianoforte Students," nd. ; "A study of Gounod's sacred Trilogy, 'The Redemption,', London [1883]. Contributions to Musiral Times, 1885, ete. Songs, pf. mnsic, ete.

Godding, James Henry, organist and composer, born alout 1820 . He wats organist for nincteen years of the Parish Church of Newbury, where he died, April 20, 1884. Compiler of "I'arochial I'salmodist, being a collection of pialm and hrmm tunes," London, 12.d., with appendix.

Godfrey, Charles, landmaster and composer, born at Kingston, Surrey. November 2.2 , 1790. At an early are becance a drommer in the First Royal sinerey Militia; nosted to the band of the Coldstrean fruads, corporal, April 10, 1820; Sergeant, Nlay 3, following; and Master of the loand, Februmy 5, 1825. Discharged form military engagement, July 8 , 1834, but continued as civilian bandmaster. until his death, Decemper 12, 1863. Was present with the band in Paris, 1815. Mnsieian in ordinary to the King, 1831. He arranged a good deal of music for military bands. Three of his sons becime distinguished bandmaster's:-

GODflare, DANIEL, the eldest som, born at Westminster, septemler 1,1831 , was educated at the 1R.A.M. of which institution he is a Fellow, and also professor of military music. Appointed landmaster of the Grenadier Guards, August 29, 1856. Gazetted Honorary Second lieutenant in the army, Jnne 21, 1887 , the first English hamdmaster to hold Her Iajesty's Commission; Travelled with his band in the rnited states of America, 1872. Hasalranged much musie for military hands, and is the composer of the "Mabel," "Hilda," and other waltzes, etc. In 1896 he retired from the army, and formed a bind of his own.

\section{GOMEZ.}

Received a testimonial from the officers of the Guards, March 8, 1897. His som, DANIEL Evers Godfrex, L.R.A.M., was appointed conductor of the London militaty band, 1890. He toured in South Africa, 1891-2, and since his retum has established lis reputation as a bandmaster at the Crystal Palace, Boumemouth, etc. He has published some pieces for pf.

Godfrex, ADolphes Frederick, second son of Charles Godfrey, was borm in 1837. I Ie was educated at the R.A.M., and made a Fellow. Inteved the Coldstream Regiment, September 2, 1856; served with his father as sergeant of the band, and snceceded him as bandmaster, beeember 14, 1863 . Was compelled to resign owing to ill-health, 1880 , and died, Augnst 28, 1882. He wrote a number of dance pieces, and other musie of a poptular chavacter.

Fodfrex, Charles, third som of Charles Godfery, was bon Jamuary 17, 1839. student and Fellow, R.A.M. Bandmaster of the Scots Fusilier Grands, 1859-68, and of the Roval Horse Guards from 1868 to the present time. He is professor of military music at the R.C.M., and at the roildhall sichoul. His compositions and arrangements are very numerous, ineluding the popular l'rincess Beatrice, Princess Lomist, Elush Rose waltzes, ete., and he is editor of The Orphows, a military music periodical. He has three sons who are musicians: Arrhur E. Cronfrer, student and associate, R.A.M., who was appointed musical director at the shafteshmy Theatre, I mondon, 1890 , and is the composer of a string quartet, songs, ete. Charles George, also astudent, R.A.Ml, and composer of some orchestral pieces and songs: and HEleEET A. GOHFREx, who was appointed bandmaster at Christ's Hospital.

Goldwin, John, or Goldixg, organist and composer, born in 1670 . He studied under Ir. W. Child. Organist St. George's Chapel, Windsor, 1697. Master of the Choristers, do., 1703. He died at Windsor, November 7, 1719. He eomposed a service in F; Anthems: Behold my servant; I will sing unto the Lord; O Love the Lord; O praise God in His Holiness, ete.

Gomez, Alice, vocalist (mezzo-soprano), was born at Calcutta, her father being of spanish and her mother of Portuguese descent. She studied muder Mr. T. Henry Webb, organist of the l'rotestant Cathedral, Calcutta, also learning the organ sufficiently well to be able to play a service. At first her voiee was a high soprano, and she studied such rolles as Leonora in "Trovatore." Ultimately, her voice settled into a mezzo-soprano of great compass, and remarkable evenness and purity of tone. She left Caleutta in 1885, and made her first appearance in England at a concert 
GOODBAN.

given by Mr. Webb, at the Kensington Town Hall, July 14, 1885. Her début at the Crystal Palace took place April 9, 1887, and she now holds a high position as a concert-singer, having appeared at the priucipal concerts in Loudon and the provinces. In 1891, she was married to $\mathrm{Mr}$. Webb, now resident at Torquay.

Goodban, Thomas, composer and writer, was born at Canterbur December, 1784. Chorister Cauterbury Cathedral. He studied music under S. Porter, and was afterwards articled to a solicitor. Resigned the Law in 1798. Lay-clerk Canterbury Cathedral, 1809. Leader of the Catch Club, Canterbury, 1810. He died at Canterbury, May 4, 1863.

Works.-Glees, sougs, pf. music. New and eomplete gulde to the irt of playing the violin, London, 1rio. Guide to the piano, 1811. liudiments of music, London, 1825; new edition, 1836. New and eomplete introduetion to singing, London, 1829.

His soll Charles (1-12-1881) was a Mns. Bac., Oxun., 1847, and composed some miscellaneous pieces, the "Vocal Album" (1850), etc. Henky Williai, A.R.A.M., another son, born 1816, is a rioloneello player and composer, having witten "Pidyham Abbey;" overture, Crystal I'alace, 1885 ; pf. music and songs. Thumas (roudbax, a thind som, bom

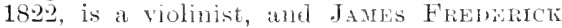
Goovbax, A.li.A.ll, a nephew, is an organist and eomposer.

Goodgroome, John, composer, born in 1630. He was a chorister of St. George's Chapel, Windsor, and becanne a gentleman of the Clapel Royal in 1660. Mnsician in ordinary to the King, lfift He died in June, 1704. Composer of coneerted sacred and secular vocal music, sougs, ete.

Goodhart, Arthur Murray, assistant classical master at Lton College, has composed a ballad for chorus and orchestra, "Earl Haldan's I)aughter," producel, London, Jannary 21, 1s91; A "Dorian song", (founded on W. Jackinon's Canzoners, by F. Corder), for suprano solo, chorus, and orchestra; "Arethura"; śchool sougs, ete. He graduated Mus. Bac., 18\%2, Cambridge; B A., 1888 ; M.A., $189 t$.

Goodson, Richard, eomposer and organist, burn about the midule of the 17 th century, Organist Christ Cluncel and New College, Oxford. Mus. Bice, Oxon., 1682, and Professor of Musie at Oxford, niversity, in suecession to Edward Lowe, July, 1682. He died, January 13, 1716. Composer of a few odes, songs, etc., mostly in MS.

His sols, Richalio, bom in latter part of 17 th eentury, wa- organist of Newbury till 1709. Mus. Bac, Uxon., 1716. He succeeded his father as organist of Christ Churoh and New College, Oxford, and in the Professorship
GOSS.

of Music, 1718. He died June 9, 1741. His eompositions, in MS., are preserved in the library of Christ Chulch, and in the Music School at Oxford.

Goodwin, Amina Beatrice, pinist, born at Manchester, danghter of John Lawrenee Goodwin, violinist and conductor (olied, May, 1883). Received her first lessons from her father, and appeared in pullic at the age of six. Studied at Leipzig Comservatorim nuder Reinecke and Jadtsiohn; and hater, under Delaborde, at Paris. (iave concerts in Manchester in 1si2; plaved at Covent ( tarden L'romenade Concerts, November, 18rio; and appeared at the Crystal Palaee, April 12, lint, playing Mondelssohn's Concerto in I) minor. previons to this she had enjoved the advantage of studying moler linzt, at Weimar. Later, she studied with Madame Shommann, making her rentree in Lomthn in 1s!2, and now ranking ammong the leading pianists of the day. lin 1s95 she fomnded a P'ianoforte College for latlies. She is monicd to Mr. IV. IngramAdams, an Anlican, whose new national anthem she has net to music. She has compused some preess for ph., and is auther of P'ractical Hints on the Technigne and Tonch of Piamorte Playing, Angenter, 18!2.

Goold, Rev. Ebenezer, witel sn munic. studied privately. Gladuated Mis. Bac.,

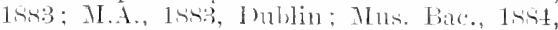

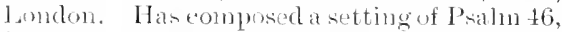
for solo, chorus, and orehentrit. Author of Sitory of the Mlesiah; 1 encriptive programme of the steat musical works.

Gordon, George, Roman c'atholik minister and muxicinu, was bone at Fochathers, Jigin, Marche 27, 1776. He wats a violinist and enmposer, atnd issited two collections of satered musie for the une of choirs. Hestudied at Yalladolid for the R nman Catholic priesthood. He died at Intfitomn, Maty 10, 1.856.

Gordon, John, mu-ician, horin at London, Marel 20,1702 . Educated at Wentminster selucol and Trinity College, Cambridge. He studied for the Law in 1718-2.2, and hecame l'rofessor of Music at freshan College, Tandary 16, 172.3. Called to Bar, 1725. Hedied at London, December 12, 17:39.

Gordon, William, musician and fluteplayer, was loom at the esd of the 1sth century. He studied nuder. Dronest, and became a Captain of the Swiss Gmards in Paris. Commenced improving thute mechanism, 1830 . He died insine, in consegnence of unsuccessful experiments, abont 1.939. His srstem of fingering was perfected by Buehnu, lut athorities differ both as regards the original invention and subsequent improvements.

Goss, John Jeremiah, vocalist, born at Salisbury iu 1770. He was choristel in Salisbury Cathedral, and lay-viear, do. Gentleman of Chapel Royal, 1s08. Viear-ehoral, 
GOSS.

St. Paul's Cathedral. Lay-viear of West. minster Abbey, Principal alto at meetings of the Three Choirs. He died in London, April 25, 1817 .

Goss, Sir John, Kt., composer and organist, born at Farelum, Hants., December 27, 1800. Son of Joseph Goss, organist, of that plaee. Chorister in Chapel lioyal, under J.S. Smith, 1811. Hestudied unde Attwood, and becanne organist of Sitockivell Chapel, 1821 ; organist of St. Luke's, Chelsea. 1824-38; organist, St. l'aul's Cathedral, 1838-72. Composer to Chaptl lioyal, 1856-7\%. Kinghted, 1872. Mus. Doc., Cantal,, 1876. He died at Brixton, London, May 10, 1880.

Works.-Chureh Serviee, in A; Burial Service, in E minor; Te 1)emm for H.M. Thanksgiving at St. Paul's Cathedral, for the restoration to health of H.R.H. the Prince of Wales. Benedictus. Te Perms in $\mathrm{C}, \mathrm{D}$, and $\mathrm{F}$; Cantate Domino and Dens misereatur, in C ; Magnifieat and Nune Dimittis, in E. Anthems: Almighty and mereiful rod; And the king said to all the people (dirse); Behold I bring you good tidings ; Blessed is the man ; Brother, thou art gone lefore us ; Christ, our Passover; Conne, and let us return unto the Lord; Fear not, o land; Have merey npou me; Hear, O Lord; I heard a voice from heaven; I will magnify Thee, O God; If we believe that Jesus died; In Christ dwelleth; Lift mp thine eyes round about; O give thanks; O Lord God, Thou strength of my health; $O$ praise the luord; $O$ praise the Lord of heaven; O haviour of the world; $\mathrm{O}$ taste and see; I'raise the 1,ord, O my soul; Stand up and bless the Lord your God; The glory of the Lord; The luod is my strength; These are they which follow the Lamb; The wilderness. Seven glees, and a madrigal, London, 185.; six glees, and a madrigal, 1826. Parochial Psalmody, a collection of ancient and modern tunes, l,ondon, 4 vols., 1897. Collection of Voluntaries by eminent composers, organ. The Organist's Companion, 4 vols. Collection of Voluntaries, varions composers. The sacred minstrel. . 1833, 3 vols. Ghurch Psalter and Hymm Book, for the use of congregations and families, by Rer. Wm. Mercer, II.A., Incumbent of St. George's, silneffield, London, 186\%. An introdnction to Hammony and Thorough-bass, Loudon, 1833. l'janoforte Students' Catechism of the lindiments of Musie, London, 1835. Collection of chants, ancient and modern, in score... 1841. Orertures for orchestra, in F, Philharmonic Socjety, 1825; also one in $\mathrm{E}$ flat, and miscellaneous orcluestral music. Songs, ete.

Cioss, Joseph, organist, youngest brother of Sir John Goss. Born at l'oole, Dorset, 1809. In 1822, went to his brother in London. Succeeded Henry Smirt, at St. Philip's, Regent Street, and was well-known in London
GOW.

and Brighton (w) were he resided) as a pianoforte teacher. In 1876, he retired from the profession, and went to reside at Surbiton, where he died February 13, 1892.

Gostick, Joseph, author of " A Manuel of Musie," Edinburgh, 1851 .

Gostling, Rev. John, bass vocalist, born in [1652], died in 1733. Was tlie possessor of a most powerful voice of great compass, for which it is said Purcell composed some sacred and other music.

Gould, Rev. Sabine Baring=, theological writer, novelist, and song eollector, born at Exeter, January 28, 1834. Fdncated at Clare College, Cambridge; M.A., 1856; Ordained 1864; Incumbent of Dalton, Thirsk, 1869 ; Reetor of East Mersea, Colchester, 1871-1881. On the death of his father in 1872, he succeeded to the family property, and in 1881, to the rectory of Lew-Trenehard, Devon, of which county he is justice of the peace. Author of "Lives of the Saints," 15 vols., and other theological works; " Mehalah," "John Herring," and many other novels. In conjunction with the Rev. H. Fleetwood Sheppard, he lias collected and arranged "Songs of the West," " A Garland of Country Song," both published by Methuen, London; and edited "English Minstrelsie," 8 vols, Edinburgh, Jack, 1895 ; and a "Book of Nursery S.ongs and Rhymes," Methuen, 1895. He has composed various hymms, "Eudoxia," and other pieces.

Gow, Niel, violinist and eomposer, born at Inver, Dunkeld, March 22, 1727. Taught violin by John Cameron, a retainer in the Grandtully family. He was twice married, and had large families. He played at the prineipal gatherings and balls of his time, in the large towns of Scotland. lle died at Inver, Mareh 1, 1807.

Works.-A collection of Strathspey Reels, with a hass for the violoncello or harpsichord, dedicated to Her Grace the Duchess of Athole, Fdinburgh (Corri), 1784]. Second eollection, dedieated to the nohlemen and gentlemen of the Caledonian Hunt, Edinburgh (Corri), 1788]. Whird collection, dedicated to the Marchioness of Tweeddale, Edinburgh, [1792]. A complete repository of original Scots slow strathspcys and dances (the dances arranged as medleys for the harp, pianoforte, violin, and violoncello), fdinburgh [1799], issued in four parts. Fifth and sixth eollections of strathspey reels, 1808 and 1892.

As personal recollections ean not now be brought to bear on the subject of Gow's character, we have transcribed the following passage, which, with a curions portrait, appears in T. Garnett's "Observations on a Tour through the Highlands, etc, of Scotland." Second edition, vol. 2, p. 73, London, 1811:- 
GOW.

". . We were favoured with a visit from Niel Gow, a singular and well-known character, and a celebrated performer on the violin. When I call him a celebrated performer, I do not mean that he can execute the sweet Italian airs with the touch of a Cramer. His only music is that of his native country, which he has acquired chiefly by the ear, being entirely self-taught; but he plays the Scotch airs with a spirit and enthusiaim peculiar to himself. . . . He excels most in the Strathspeys, which are jigs played with a peculiar spirit and life, but he exeeutes the laments, or funeral music, with a great deal of pathos.'

A great deal of nonsense has been written about the Gow family, and numerous fables of all sorts have been published regarding Niel and his alleged doings. In Glen's "Collection of Scottish Dance Music, book 2, 1895, there is a very fair and impartial examination of some of these stories, and a careful sifting of his compositions, whereby many of them are rightly assigned to other composers.

Gow, Nathaniel, viohinist and composer, born at Inver, near I munkeld, Nay 2s, 1763 . Fourth son of Niel Gow. He studied under his father, R. M'Intosh, M'Glashan, and J. Reinagle. Violinist at Edinburgh under his brother William. One of H.MI. trumpeters for scotland, 1782. Succeeded his brother William as leader of the Edinburgh concerts. 1791. Established in Nusic-pulblishing businesis with W. Shepherd at Edinburgh, 1796-1813. Gave mp bnsiness, but snbseqnenly resumed it in partnership with his son Niej. Continner the firm till ISQ7. He died at Edinburgh, January 19, 1831.

Works.- The Beanties of Niel Gow, being a Selection of the most favourite tunes from his first, second, and third collections of strathepey resels and jigs, chiefly comprising the empositions of Niel Gow and Sons (edited by Nathaniel). Edinburgh, 3 parts. The Foeal Melodies of scotland, arranged for the pianoforte, or harp, violin, and violoncello, by Nath. Gow. Edin., 3 parts, n.d. The Ancient curious Collection of Scotland, consisting of genuine scotch tmmes, with their original variations, with basses throughont, for the pianoforte, or harp, riolin and 'cello. Ded. to Sir Walter scott. Edin., 1823. A Select Collection of uriginal dances, waltzes, marches, mimuets, and airs..many of which are composed, and the whole arranged for the pf. and harp by Nath. Gow, Edin. A Collection of Strathipey Reels, with a bass for the rioloncello, or harpsichord, containing the most approved old and the most fashionable new reels, some of which are composed, and others with additions, by Nath. Gow. Edin. $\lceil 17977$. Complete Repository of Old and New Scotch Strathspers, Reels, and Dances. Edin., n.d.,

\section{GRAHAII.}

3 books. Nathaniel fow is best remembered as the composer of "Caller Herrin," and "Bothwell Castle," the former being very popular.

Gow, Niel, Jun., violinist and composer, born about 1795 . Son of Nathaniel Gow. He was a partner in the music-publishing business in Edinburgh with his father. He died at Edinburgh, November 7, 1823.

Works.-Edinburgh Collection of Glees, Catches, Dnetts, ete., Edin..n.d. A Collection of Airs, Reels, and Strathrpeys, being the posthumous compositions of the late Niel Gow, Jumr., arranged for pf., harp, violin, or 'cello, by Nathaniel Gow. Fdin., 1849.

This most promising young man died after giving convincing proofs of his capacity for musical composition. His melodies, "Bomie Prince Charlie" and "Flora Hacdonald's Lament," are well-known all over the world. He composed a nmmber of melodies to words lyy Hogg, etc., but the two songs named are those br which he is best known.

Other members of this family were AsDrEw [1760-1803], JoHN [1764; died, London, Norember 22, 18267, and William 175117917, all of whom were musicians of some fame in their day, the last being especially well known as a fresli and vigorous violinist. They all composed reels and strathspeys of merit.

Goward, Mary Anne, see lieeler, Mrs. Gower, John Henry, organist, pianist and composer, born at Kugby. May 25, 1855. Gradnated Mus. Bac., 1s66; Mus. Doc., 1883, Oxford. In 1876, he was appointed organist and music master at Trent College, Notts., where he remained until $18 \mathrm{~s}$, when he went to Denver, Colorado, U.S.A., as precentor and organist of the cathedral there. $\mathrm{He}$ gave organ recitals in various towns in England; was an early and enthusiastic member of the I.S.M. ; conductor of the Long Eaton Philharmonic Society; and a captain in the First Derbyshire Regiment, Volunteer Battalion. His compositions comprise a cantata, "The Good Shepherd"; part-songs, songs, etc. In 1897 , he read a paper, "The needs of the Musical Profession," at the amnual meeting of the Music Teachers' National Association of the U.S.A.

Graddon, Miss, soprano vocalist, born at Bishop's Lydiard, near Taunton, 1804. She studied under Tom Cooke; sang at Vauxhall in 1822, and at Dublin in 1823 . Afterwards she appeared at Liverpool, Nanchester, London, and throughout the English provinces. On November 10, 1824, she sang in "Der Freischutz, at London. Died?

Graeme, Elliot, Author of "Beethoven: a memoir," London, 1870, two editions. Novels, etc.

Graham, George Farquhar, composer 


\section{GRAHAM.}

and writer, born at Edinburgh, December 29, 1789. Son of Colonel Humphrey Graham. He was educated at the High school and University of Edinburgh, but was chiefly self-tausht in music. With George Hogarth he acted as joint-secretary to the Edinburgh Musical Festival, in 1815. For a time he resided in Italy. He was an unsuccessful candidate for the Music chair of Edinburgh University. Jied at Edinburgh, March 12, 1867.

Works. - Twelve pieces of roeal musie, with accompaniments for the pf.; composed, and as a sunall tribute of scottish respect, inseribed to the memory of Haydn, by a Dilettante, Edinburgh, 1811. The song of Seotland. adapted to their appropriate melodies... with listorical, bographical, and critical notices. . Ediuburgh, $14+8-49,3$ vols. Cilees, hymons, songs, ete. An account of the first Linburgl Nusical Festival, held ... 1815, Edinburgh, 1s16; 2nd edition, 18:35. Elements of singing... Edinburgh, $1 \$ 17$. Essay on the theory and practice of Musical Composition ... Eliuburgh, 1538. Being a reprut, with additions, of the article "Music " in the 7 th and 8th editions of the Encyclopiedia Britannica. (General observations npon Musie, and remarks upon Mr. Logier's system, Edinburgh, 1817. Notes and editurial work in comnection with the publication of the "skene MIs." (1)auney).

Graham, James Lascelles, organint and writer, horn at Eelinburnh, May 22, 1.85t. He is music-master of the High school of Sirling, and organist of Allan P'ark Church there. He is author of "Music made eany," London, n.d., a pianofore intor.

Graham, Maria, autlor of "A few words on the formation of the Major and Minor Scales, in a letter to her pupils, by M. (1," London, 1852.

Graham, Thomas, composer and organist, born in 1800 , died in 1867 . He was organist of the Larish Church, Wigan, and a composer of vocal music. His daughter, MARY ANN. is Madame Endersoma, the soprano singer, for ma y years a popular favourite.

Grain, Richard Corney, entertaimer. born at Tevershan, Cambridgeshire, October 26, 18t4. He was educated for the law, and called to the Bar in 1, sits Lis gitts for music and minnicry soon decilled his carteer, and he joined the German Reed Entertainment, Nay 16,1870 'There he continued foi th: rest of his life, performing in london and the provinces. He wrote an immense number of amusing sketcher, of which may be mentioned Small and early, Sipring's delights, Troubles of a tourist, Echoes of the opera, Buck in town, That fatal meun; as well as setting music to pieces by Arthur taw and others. His experiences he embodied in a little book, "Cor-

\section{GRAY.}

ney Grain, by hiniself," London, Murray, 1888. He died in London, March 16, is95, a year fatal to the whole German Reed combination.

Grant, Donald, teacher and composer, a native of Elgin, published "A collection of stratlispeys, reels, jigs, etc., for the pianoforte, violiu, and violoncello," Edinlsursh 1790].

Grant, Sir James Hope, musietan, born 1sos; died 1875. He entered the army in 1826 , al d served in China, etc. He retired from the army a Geweral. See "Life of General Hope cirant, by H. Knollys, London, 1894,2 vols. His portrart, representing him pl ying the violoncello, painted by his brother, sir Francis Grant, l'.R.A., is in the National Portrait (rallery, London He romposed 'Three sketches for pf. and 'cello; The sea and the lake, for pf. and 'cello; Notturno for pf. and 'cello; The three violonceilo makers, For pf. and 'cello; Elegie for pf : Voluntaries for the organ; Songs, etc.

Grant, John Campbell, musiciun and writer, was bom at Edinburgh, in 1s:39. He holds various teaching appointments in Edicburgle. Author of "Elements of music and siuging."

Grassinean, Jacques, musician, born, London, 1715; died there, 1769. Anthor of - Irusical Inictionary, being a collection of terms and characters. . London, 1740.

Gray, Alan, composer and organist, born at York, December 2:3, 1855. Educated at St. Peter's School, York, an I Trinity College, Cambridge, being intended $f x$ the legal profesion. Studed musie under Dr. E.G. Monk. Ciraluted L1..B., 1877; LL.M., 1843; Mus. Bace, 1s4ti; Mns. Woc., 1889, Cambridge. In 1843 , he wh appointed musical director at Wellington College, and in 1892 suceeded Professor Stunfud as orgauist of Trinty College, Cambrilge, and Conductur of the University Musical Society, positions he still holts.

Works. The IVidow of Zurephath (a reading, whth choral exp moton), protuced th York Minster, Mav, 18so Cantatas: Arethusa (Alielley). Leeds Festival, 1492: The Legend of the lioek Bnoy Bell, Hovingham Fentival, 1 1593; The Vision of lielshazzar, the same, 1s96. In Msi, Milton's version of P'salm 7

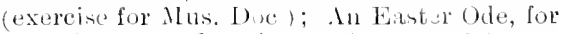
soli, chorras, and orehentra (composed 1842) ; and a Festival Te Demm, with orchestra (composed 1895). Chareh Services in F, and A ; Anthems, ete. Album of four songs; various sollgs. Overture for full orehestra; Quartet, pf. and strings; Quartet, striugs, all in IIS. Four sonatas (composed 18sis); Fantasia, and other pieces for organ. Sunata in G. pf and violin; Sonata, pf.; and various smaller works.

Gray, George, musician and vocalist, born at Eton, in June, 1815. He was a vicar- 


\section{GRAY.}

choral of St. Patrick's Cathedral, Dublin, and founder of the Choir Benevolent Fund. Isied at Dublin, May 8, 1888 .

His father, William Henry (iray, born at Eton in 1785, died November 7, 1824, was an organist and composer.

Gray, John Locke, organist, borm in 1843. He was the first pupil of Evenezer Prout when he entered the profession in 1859. $\mathrm{He}$ was appointed organist of Lee Cliapel, Kent, 1862; then, in succession, of St. Mark's, Lewisham; St. (ieorge the MIartyr, Holborn; Holy Trinity, Richmond, 187'; and of Christ Church, Keusington. In 1875 he was appoirted organist of Bombay Cathedral. He died at Bombay, from sunstroke, June, 1878.

Gray, Louisa, Mrs. Abixgix n Conptox, amateur composer of the day. Her operetta, "Between two stools," has been performed in several plices; and slie is the composer of a number of songs, What an angel heard; The thread of the story; Evening star, ete.

Greatheed, Rev. Samuel Stephenson, clergyman and composer, born near Westonsuper-Mare, Fehruary 22, 1813. B.A., Cantab. 1835. M.A., 1838. Ordained, 1838. Rector of Corringlam, Sussex.

Works.-Enoch's Prophecy, an oratorio, words by James Montyonery, 1852. English Gradual: a book of plain song for Holy Communion, from ancient English sources. Plain song for Holy Communion on ordinary days, so far as it differs from that for feasts; with offertory sentences, the Dies Ire (English), and the Order for the Burial of the Dead. Anthems: Blessed is the man; Ye that fear the Lord; Hail, gluddning liglit; O God, Thou art worthy to he praised: Let nyy soul bless frod; O liord Almighty, God of Israt: O Saviour of the world: The Son of mau, etc.

Greatorex, Thomas, organist, conductor, and composer, born at North Wingfield, near Chesterfield, Derby, October 5, 1759. He studied under Dr. P. Cooke, 1772. Adopted by the Earl of Sandwich. Chorister at Concert of Ancient Music, 1758. Organist of Carlisle Cathedral, 1780-84. Teaclier in Newcastle, 1784-85. Travelled in Holland and Italy, 1785-88; and was introduced to 1 rince Charles Edward Stuart. Teacher in London, 1789. Conductor of the Concert of Ancient Music, 1793. Revived the Vocal Concerts, 1801. Organist of Westminster Abbey, in succession to G. E. Williams, 1819. Con. ductor of Birmingham Musical Festival. Fellow of Royal and Linnean Societies. He died at Hampton, near London, July 18, 1831.

Wonks.-Twelve glees from favourite English, Irish, and Scotch melodies, London, n.d.[1832]. P'salms, chants, etc. A selection of Tunes...London, 18:9. Parochial Psalmody, a collection of approved tunes for four voices,

\section{GREEN.}

in score, with organ or pf. accompaniment, London, n.d.

Greaves, Thomas, lutenist and composer, of 16th and 17th centuries. Biography unknown.

Works.-Songs of sundrie kindes, 1604. Reprinted madrigals: Come away, love; Lauly, the melting crystal of your eye; Sweet nymphs, etc.

Green, James, organist and composer, was organist at Hull in first half of last century. He published "A Book of Psalmody, containing chanting tunes for the Canticles, etc. . . . the readng Psalms, with eighteen anthems and a variety of Psalm-tunes in four parts.," 1724 ; 8th edition, 1734; 11 th edition. 1751. He al $: 0$ composed hymns, etc.

Green, John, composer and teacher, of first half of the present century. Anthor of "Concise Iustructions for performance on the Royal Sermphine and Organ," London, 1833. The ser phine is described as "a new musical instrument having the power of a large organ, in the size and shape of a chiffionier." Green also issue "A bird's-eye view of the rudiments of music," London, $184 t$, and achapted airs, etc., for the pf.

Another JoHN (iREN published "Hints on the Spanish Gnitar. beng a peparatory tutor for that instrument," Loudon [1N30]. " Liıtle songs fur little singers," losued in parts, etc.

Green, Joseph N., writer, anthor of "The 'l'ritone: is method of hillmony and modulation adapted to the scales of keyed iustrments, with Appendix, Loldon [1471].

Green, Richard, haritone vocalint, born April 21, 1A66, in Kensington, London Wducated at Margare, and hegan life in a city Bank. Studying singing under Edwin 11olland, he was arvised to erter the R.A.M. After two ye rs' study there, he went to Nlilan, in 18sis, and studied with Giulio Moretti. Returning to Londom, in 1890, he was engaged for the Royal English Opera Honse, and made his début as Prince Juhn, in Sullivan's "Ivanhoe," January 31, 18!1, afterwards taking the part of the Templar. The next season he was engaged for the Savoy, where he created the part of Sir George Vernon, in "Haddon Hall," singing it more than 200 times. He next appeared at Covent Garden, in Italian Opera, creating the part of Silvio in "I Pagliacci," on its production, May 19, 1893. He had been engaged by Sir Augustus Harris for grand opera every season since, and has achieved success in a great number of works. He is also distinguished as a concert singer, and has appeared at the Saturday Popular Concerts, and other institutions in London and the provinces.

Green, William, musician, of 4 Cumberland Street, Shoreditch, compiler of "The 


\section{GREENE.}

Clerk's Companion, or the Christian's vademecum, containing 373 tunes of two and three parts," London [18\%0]. "The Ladder to Iusical learning," London, 1834. Pf. music, etc.

Greene, Harry Plunket, bass vocalist, born at Old Connaught House, County Wicklow, June 24, 1865. His mother is the authoress of "Cushions and Corners," and many other popular children's books, and sister of Mr. 1)avid Plunket, First Commissioner of Works. He was educated at Clifton College, and destined for the Bar; but, gifted with a fine voice, he ultimately decided upon entering the musical profession. In 1883 he went to Stuttgart, and later, to Florence, studying under Vannuceini. On his returu to London he had lessons from J. B. Weleh, and Alfred Blume. He made his début at the People's Palace, Stepney, January 21, 1888, in Handel's "Messiah." In March following he sang at Novello's Oratorio Concert., St. James's Hall, in Gounod's “ Redemption" ; at the Crystal Palace, March, 1889; and in Germany the same year, being everywhere successful. His operatic début, was at Covent Garden. June 2, 1890; and he first appeared at the Provincial Festivals at Worcester in 1890 . He has given song recitals all over the country, and has twice visited America, in 1893 (Chicago Exhibition), and 1896.

Greene, Maurice, organist and composer, born, London, 16961695 . Chorister in st. Paul's Cathedral. He studied nusic under R. Brind. Organist of $\mathrm{S}$. Pomstan in the West, Fleetstreet, 1716; $\rightarrow$. Andrew's, Holborn, 1717 ; $\therefore$ Paul's Cathedral, 1718; Chapel Royal, 1727. Professor of Mnsic, Cambridge, 1730. Doc. Mus., Cantab., 1730. Naster of the King's Band, 1735. He died at London, December $1,175 \%$.

Works.-.Oratorius: Jephthah, 1737; The Force of Truth, 174t. Florimel, or Love's Revenge, dramatic pastoral, 1737; The Judgment of Hercules, masque, 1740. Phrebe, opera, 1748. Spenser's Amoretti for voice, harpsichord, and violin. Ode on S. Cecilia's Day, Pope, 17:30; Odes for King's Birthday and New Year's Day, 1730; Catches and Canons, 3 and 4 voices; The Chaphet, collection of 12 English songs; Chureh Service in C, 1737; Te Deum in D, 1745; Forty select Anthems in Score for $, 2,3,4,5,6,7$ and $R$ voices, London, 2 vols., 1743 . Songs, organ and harpsichord music, etc.

Greenish, Arthur James, organist, born at Haverfordwest, Pembrokeshire, January 26, 1860. Mnsical edncation partly at R.A.M., partly private. Fraduated Mus. Bac., 1885; Mus. Doc., 1892, Cambridge. F.R.C.O., F.R.A.M. In 18so, appointed organist of St. Mary's, Battersea; and in 1889, organist and choirmaster of St. Saviour's, South

\section{GREGORY.}

Hampstead, which offices he still retains. Was conductor of the South Hampstead Musical Society for some time, and is an Examiner for Trinity College, London. In addition to the Degree Exercises (Sing; O ye heavens; The miracle at Bethany), he has composed songs, and pieces for violin; and has published an Evening Service, and some songs.

His brother, Frederick Robert Greenish, is organist of St. Mary's Church, Haverfordwest. He graduated MIus. Bac., 1883, and Mus. Doc., 1891, at Oxford. Composer of "The Church Triumphant" and "Adoration" cantatas; Church services, anthems, eüc.

Greenwood, James, organist, and teacher of singing, born of a Yorkshire family, in Laucashire, in 1837. At the age of nineteen he went from Tudmorden to Bristol, and gained a place as lay-clerk in the Cathedral, an office he resigned in 1877 . While there, he studied under s. S. Wesley. He was organist at St. Paul's, Bedminster' Wesiburyon-Trym; and lastly, at St. Matthew's, Kingsdown, Founder and Hon. See. of the Lay-clerk's Choir and Mutual Aid Society, and of a choir, 1870-79. Music-master at Colston School, and the Grammar School, Bristol. A great advocate of the Lancashire Sol-fa, of which he wrote a primer, and a Set of 396 Two-part Exercises for Choirs and Schools, Novello's Primers, Nos. 19 and 23. $\mathrm{He}$ also composed some Church Services, anthems, and organ pieces. This earnest and unassuming worker for music died at Clifton, June 14, 1894.

Greenwood, John, musician and teacher, of Leeds. Published "Selection of antient and modern Psalm tunes...," Leeds [1825]; "Modulus Sauctus, a collection of sacred music," Leeds, 1828; “Psalmody harmonised in score, with accompaniment for organ and pianoforte," Halifax, $18: 88$.

Greeting, Thomas, teacher of the flageolet, in London, at the end of the 17th century, Author of "The Pleasant Companion; or new lessons and instructions for the Flagelot," London, 1666, another edition, 1680.

Gregg, Annie Jessy, see sub., Curwen, JOLN SPENCEN.

Gregory of Bridlington, musician, of 13th century. He was a canon of the Order of St. Augustine, and precentor, and latterly Prior of Bridlington, abont 1217. Author of "De Arte Musices," in 3 books.

Gregory, George Herbert, organist, born at Clewer, near Windsor, Iecember 6 , 1.53. Studied under Samnel Reay. F.R.C.O., 1873, and Mus. Bac.. Oxford, 187t. Organist of Holy Trinity Episcopal Church, Metrose, 187.24; Tamworth Parish Church, 1874.5; and Boston Parish Church, 1875, to present time. Conductor of Boston Choral Society 


\section{GREGORY.}

for some years. He has a good tenor voice, and has occasionally sung in oratorio and concerts in Lincolnshire. Has composed services and other church music, songs, ete., and contributed to the "Church of Scotland Children's Hymnal," and the authorised "Hymmal of the Established Church of Scotland."-JAnES LIVELY GREgORY, brother of the preceding, was born at Old Windsor, March 27, 1860. F.R.C.O., 1883, and Mus. Bac., Durham, 1892. Received most of his musical training from his brother, whom he succeeded at Melrose, in 1875. From there he went to Welford Parish Chureh, in 1877, and to the Parish Church, Ware, in 1880. There he is actively engaged as a teacher; he is also conductor of the Ware and other Musical Societies. He has published ehurch services, songs, part-songs, organ and pf. pieces. A third brother, ALFRed EDWARD Gregory, was born at Clehonger, near Hereford, May 16,1862 . He also was chiefly educated in music by the eldest brotber. Graduated Mus. Bac., Oxford, 1895. Organist of the Parish Church, Lanark; conductor of the Lanark Select Choir, etc. This family presents the possibly unique circumstance of three brothers holding Degrees in Music.

Gregory, Rev. John Herbert, author of a "Letter to the Bishop of Melloume on Church Music," Melbourne, 1857.

Greig, Gavin, organist and composer, born in Aberdeenshire, February 10, 1856. $\mathrm{He}$ is a schoolmaster at New Deer. Composer of "Prince Charlie," a musical drama; "Mains's Wooin'," a musical drama; numerous songs, etc.

Greig, John, composer and organist, born in Edinburgh. Educated at Moray Training College, and appointed English Master in the High School, Leith. While holding this and similar appointments he pursued his musical studies, graduating Mus. Bac., 1878; Mus. Doc., 1889; Oxford; M.A, Edinburgh; and F.C.O., 1880. Organist and choimaster St. Cuthbert's Free Church, Edinburgh. Nominated during illness of Sir Herbert Oakeley, interim professor of music at Edinburgh University, during which time he gave many lectures and organ recitals. His compositions include an orat,orio, Zion (degree exercise); an opera, Holyrood, Glasgow, October 5, 1896; an orchestral suite, The Graces(Edinburgh, 1890). Part-songs; Herald of Spring; Month of May; Merrily row we, ete. Editor of Scots Minstrelsie, 6 vols., Edinburgh, Jack, 1892-5, and the Musical Educator, Edinburgh, Jack.

Gresham, William, composer, born at Dunstable, about the middle of the 18th century. He died early in the present century. Compiler of "Psalmody improved, containing portions of the Psalms of David

\section{GRIEVE.}

and 13 hymns . . ."London $[1780]$; and composer of songs by Sir IValter Scott, ete.

Grey, Annie, Irs. Wane, contralto singer, born at Edinburgh, July 4, 1860. She studied at the R.A.M. as a pupil of Randegger, and afterwards she appeared in Edinburgh. In 1890, she sang before the Queen at Balmoral, and since then she has appeared at many concerts in scotland and England.

Grey, Rev. John, compiler of "Manual of Psalm and hymn tumes," 1857, and "A Hymnal for use in the English Church, with accompanying tunes," London, 1866.

Grice, Robert, baritone vocalist, born at Leeds, 1859. Was for seven years a chorister in Durham Cathedral, and at the age of tiventy was appointed to Peterborough Cathedral as bass; a year later taking the position of principal bass at New College, Oxford. In 1885 he was elected assistant vicar-choral of St. Paul's Cathedral, from which choir he retired in 1893. He has sung at the principal concerts in London and the provinces; at Chester Festival; Hereford Festival, 1894, as the narrator in Parry's "Job"; and at the Crystal Palace in the same. He also took part in the quartets in the Jubilee performance of "Elijah" at the Crystal Palace, June 27, 1896.

Grier, William, writer. Author of "An Essay on the first principle of Music." Aberdeen, 1838. This originally appeared in "The Musical Cyclopredia, being a collection of the most approved English, Scottish, and Irish songs, ellited by J. W. Wilson," London, 1835 ; also 1852 .

Griesbach, John Henry, pianist and composer, was born at Windsor, of German parents, on June 20, 1798. Violoncellist in Queen's band, 1810. He studied under lialkbrenner, and afterwards became pianist in London, and director of Philharmonic Society. He died at London, January 9, 1875.

Worrs.-Belshazzar's feast, 1835; Daniel (reproduction), 1853; Music to the "Tempest" ; James the First, or the Royal Captive, operetta ; The Goldsmith of West Cheap, opera; Eblis, opera, unfinished; Raby Ruins, musical drama; Overtures for orchestra. Analysis of Musical Sounds, with illustrative figures of the ratios of vibrations of musical intervals and their compounds, harmonic vibration, temperament, etc., n.d. Elements of Musical notation, containing tables of the comparative value of the different kinds of Notes, Signatures of the different keys, etc., n.d. Pianoforte Students' Companion, containing all the Scales in four positions, etc., London [1825]. Anthems, songs, etc.

Grieve, John Charles, composer, conductor, and didactic writer, born in Edinburgh, August 29, 1842. Fellow of the Educational Institute of Scotland; lecturer on 


\section{GRIFFIN.}

musical theory, Heriot-Watt College, Edinburgh. Sonnetime choirmaster, Lady Yester's Church, and conductor of Phcenix Musical Association, Fdinburgh. Teacher of singing in various schools, and for some years editor of The Musical star.

Works.-Benjamin, an oratorio, Edinburgh, 1877 ; Christian songs of praise, 24 hymus, for 4 voices $(1873)$; The sower and the seed, scripture narable, for soli and chorus ; The good Samaritan, ditto. Cantata, Legend of St. Swithin (1891). Kinderspiels: The happy family; Playmates; The flowers o' the forest; Rip Van Winkle; Don Quixote; Hearts and Homes; Day of rest and gladness. Part-songs: Good-morrow to my lady bright ; Stars of the summer night, etc. Songs: The Assyrian; Comin' hame; Broken vows; Earth's partings, etc. Arrangements of Scotch songs, etc. Author of the Harmonium : how to nse it (Edinburgh, n.d.); Practical harmony.

Griffin, George, organist and composer, born at Winglave, Buckinghamshire. Aprit 1, 1816. Compiler of "New Siacred Music, consisting of Psalnu and Hymu-tumes, with one Christmas piece," London [1840]: "The Buckinghanshire Harmonist," conprising a new set of original Psain and Hymn-tunes London [1842].

Griffin, George Eugene, pianistand connposer, was born at London, January 8, 1781. Member of Philharmonic Society, teacher, etc. He died at London, May 28, 1863.

Works. - Two concertos for pf. and orchestra, op. 1 and 4 ; Ode to charity, 1820; Four sonatas for pf., op. 2, etc.; Three string quartets; Rondos, marches, variations, ete., for pf.; Songs, glees, Cynthia (1810), ete.

Griffith, Frederic, flutist, bon at Swansea, November 12, 1867 . His talent was displayed at an carly age, and from 1881, he won several prizes at Eisteddfodan at Mer. thyr, and otber places, playing both piccolo and flute. Attracting the notice of leading musicians, he was arvised to enter the R.A.M., where he studied under the late Olaf Svendsen. Here lie carried off all the Academical honours, and on leaving, in 1891, was elected an Associate. Furthor studies were pursued in Paris, nnder Taffanel. Returning to London an accomplished artist, he gave a number of recitals; and in 1893, appeared in the provinces, with the Melua touring party. His executive powers are very great, and his tone is pure and unforcos. He was appointed, in 1895, solo flute at the Royal Italian Opera, Covent Garden. Editor of Notable Welsh Musicians, I Jondon, Goodwen, 1896.

Ciriffiths, F. J., musician, compiler of "Psalm Tunes and Chants, original and sclected, arranged for four voices," London [1846].

\section{GRIMSON}

Griffiths. John, bass vocalist, born about the middle of the eighteenth century. He was origindly a parisli clerk of a village in the Vale of Clywd. Became a nember of the Worcester Cathedral Choir, and was one of the principal singers at the Three Choirs' Festivals, from that at Gloucester in 1784, to the year 1799. He remained in Worcester up the time of his death, under tragjcal circumstances, October 7, 1821. At the Worcester Festival he sang in the chorus, and during a solo by Vaughan, fell back in a fit, on October 5, and expired two days later. He also sang in the Covent Garden oratorios, London. His voice was of great power, and of deep compass.

Griffiths, Richard, organist and composer, born about 1789 ; died at London, July 18, 1850. Composer of instrumental music, and compiler of "Psalm tunes and chants, original and selected," London, 1846.

Griffiths, Lieutenant Samuel Charles, son of a colour-sergeant in the Royal Sicots (Lothim) Jeginest was born in 1847. As a boy he cutered the bind, and nltimately becanc landmaster, in 1874 , of the sceond battalion of that remiment. In Mat, 1850, he was made quarter-muster of Sandhurst College, and in December appointed after competition, to the directorship of Kneller Hall. He died suddenly, while out walking near the hall, Uctolser 31, 1895. Author of "The Military Band"; and "Hints on the Managenient of Arnuy Bands.'

Girigor, Alexander Lockhart, musician, born Glasgow, March 2s, 1853; died there, March 25, 18:1. Author of "Hints and Maxims to players on I'ianoforte, Harmonim, etc.," Glangow, 18n3. He was a teacher in Glasgow, and hold the position of harmonimm player at Oatlands Church there for some Year's.

Grimshaw, Arthur Edmund, composer and organist, lom 1864, in Leeds, where he received his musical training. Since 1883 he has been organist and choimaster of St. Anne's R. C. Cathedral, Leeds. He has composed a setting of l'salm 141, for soprano solo, and chorus, produced, Jannary, 1885, at Leeds, and some Church music. Also two operettas, "El Eseribano," and "Amaranthus," produced at Leeds in 1891, and 1892. Songs, and part-songs. Two Melodies for string orchestra, produced by the Leeds Symphony Society, December 11, 1893; a liomance for violin and orchestra, etc.

Grimslnaw, Jolnn, orgunist and composer, who died on February 18, 1819. Composer of "Twenty-four hymis, in four parts," London [1810]. Songs, ete.

Grimson, Samuel Dean, violinist of the present time, has published a book of "Technical Studies for the Violin." He is the 


\section{GROOMI.}

father of a remarkable family of musicians. Of his children, AxNIE is a pianist, scholar of the R.U.M. She has appeared with success at varions concerts since 1886 , and has composed a symplony, pieces for violoncello, etc. Anr, another danghter, pianist and rioloncellist, was also educated at the R.C.M. For some time she played in the Rev. E. H. MLberley's Ladies' Orchestra, and is favourably known as a soloist. Jessie Grimson is a violinist of repute, and other members of the family possess musical talent. A concert was given in the Queen's (small) Hall, January 21, 1896, by the Grimson family, numbering eight, when Mendelssohn's string Octet was played under possibly unique circumstances.

Groom, William, of Ivinghoe, composer, pnblished "Conglegational Melndies, consisting of a new set of psalm and hymm tunes... ," Ivinghoe, 18:38; Sinplement. 1839. London edition, edited by Thomas Jordan, 1841.

Groome, W., author of a "Concise treatise on Mnsic. Nusical Hamony and Thoronghbass," London, 1870.

Grossmith, George, vocalist and actor. who has b:come famous for his monolognes and sketches given in London and throughout the combry. From 1877 he was, for some time, associated with the Gillbert-sullivan operas, appearing in "The Sorcerer" wher produced at the Opera Comique, November 17, of that year. He was also oceasiomally with the German Reed party in the provinces. His official position was that of Bow street police-court reporter, a post held by his father before him. Among his sketches may be named, Cups and sancers, 1878; Uncle Simmel, operetta, 1881: Drama on crutches, 188:3, etc. Songs: Autocratic gardener ; Awful little scrub; Cockney's life for me; Gay photographer: Happy fatherland; Haste to the wedding; Muddle puddle porter; See me dance the polka; Spealier's eye, etc. He has also written various books, such as his own reminiscences in "A Societr Clown," and stories in conjunction with his brother, WEEDos, the popular actor. In 1rses he published the "Autobiography of a Society Clown," Bristol, Arrowsmith.

Grosvenor, Symeon, organist and composer, was born at Dudley, Jannary 11, 1816. He was a pupil of Mloscheles and Thomas Adams, and held the position of organist of St. Thomas' Parish Church, Dudley, from 1836 to 1854 . He gradnated Mus. Bac., Oxon. in 1852. He died at Dudley, July 8, 1866. Editor of "Hymns, Anthems, Chants, ete., as used in the services of St. Thomas's Church, Dudley," c. 1850 . He wrote some music for the church service.

Grove, Sir George, Kt., writer on music, born at Clapham, Surrey, Angust 13, 1820.

\section{GROVER.}

Educated as a civil engineer, but quitting that profession he became Secretary to the Society of Aıts, 1850 ; and in 1852, Secetary to the Crystal Palace Company, an office he held until 1873. It was here he began his long service to music, a service difficult to over-estimate. His analytical programmes gave a great impetus to musical study. In 1867, he visited Tienna, in company with Arthur Sullivan, and recovered Schubert's music to "liosamunde," lost since its performance in December, 1823. On leaving the Crystal Palace he was associated with the publishing firm of Macmillan and Co., and edited Macmillan's Magazine for more than 15 years. Other details of his long and active career are beyond the scope of this work. In 1882, he was appointed, by H.R.H. the Prince of Wales, Director of the Royal College of Music, the founding of which owed much to his strenuous efforts. In 1875, the University of lourham conferred on him the degree of D.C.L.; on the opening of the R.'.M., May, 1883, the Qneen honoured him with a knighthood; in 18.55 he was made L.L.D., Crlasgow; and in 1857 he was elected on the Committee of the Hach-Gesellschaft, Leipzig. He resigned his Inirectorship of the R.C.M., in November, 1894. His great work is the Dictionary of Music and Mnsicians, 4 vols., Macmillan, 1879-89, which he edited, and to which he contributed many important articles. He wrote an appendix to Hellborn's Life of Schubert, English edition, Iıngmans, 1869 ; published in 1896. Beethoven and his Nine Symphonies, Novello; and was a frequent contributor to the musical press.

Grover, George F., teacher of singing, born at Clapham, Angust 8, 1860. Chorister, st. Paul's Cathedral, from 1870, where he was mnsically edncated under Sir John Goss, Dr. Stainer, F. Walker, and D 1 . Martin. Organist successively at St. Michael's, Poplar; St. John's, Wapping; and, from 1881, St. Peterle-poor, Old Broad Street. Principally engaged as a teacher of singing, many of his pupils holding good positions. He has published a sacred cantata, "The Raising of Lazarus," produced at Tottenham, in 1852; and is author of "Musical Hints to Clergymen," London, IV. Reeves, 1894. He has contributed articles to varions musical periodicals, among them a series of biographical sketches of Old English Musicians, in Musical Opinion, Vols. VIII. and IX.

Grover, Haydn, composer and alto singer, is a native of London. He has sung in many chnrches and institutions in London; was organist of Godstone Parish Church, 1879-80; and is now a teacher and concert-giver in South London. Alto in the Temple Chureh, etc. Composer of a madrigal, "Come, nymphs and shepherds." Part-songs. Songs: "Sons 


\section{GRUNEISEN.}

of the lurave," "Soldier boys," "Fill the gleaming sail," "Lyrie of love," "In dreanland," ete.; numerous pieces for pf., ete. His brother, Heirbert Grover, is a wellknown tenor singer, who has appeared at coneerts in London and the provinees.

Gruneisen, Charles Lewis, musician and critic, born at London, November 2, 1806 ; died there November 1, 1879. Author of "The Opera and the Press," 1869. Memoir of Meyerbeer, London, 1848.

Guenett, Thomas Harbottle, pianist, born at Fleetwood, Lancashire, June 22, 1850. Pupil of Halle and Pront. Settled in Melboume, Anstralia. 1'rofessor of pianoforte; organist of Toorah Presbyterian Church, Iusical critic of the Melbourne Argus; lecturer on musical sulnjects. Founder of the Mellyorne Popular Concerts of Chamber Nusie, 1878.

Guernsey, Wellington, lyric poet and composer, born at Mullingar, Ireland, June 8, 1817, and died at London, November 13, 1885. Author of the words of a great quantity of songs, elicefly of a sentimental kind, of which "Mary Blane," and "Alice, where art thou?" are examples. His own productions consint chiefly of songs, such as "I'll hamg my harp on a willow tree," but he has written a Mass in B flat, and other musical worlis. He also issued "Old Songs of Old Ireland, with symphonies and accompaniments, by IV. Guernsey, and characteristic words by Jos. Fitzgerald," London [18t3].

Guest, George, organist and composer, bor'n at Bury St. Edmunds in 1771. Son of Ralph Guest. He studied under his father. Chorister in Chapel Royal. Organist at Eve, Suffolk, in 1787; and at Wisbeach in 1789. He died at Wisbeach, September 10, 1831. Wrote glees, hymus, songs, duets, organ music, etc.

Guest, Ralph, composer and organist, born at Basely, Shropshire, 1742. Chorister in Basely Church, and in Portland Chureh, London, 1763. He studied the organ under Ford of S. James' Church, Bury, and was choir-master of S. Mary's, Bury St. Edmunds, 1805-22. He died at Bury, Jume, 1830.

Works.-The Psahms of David, collection. Hymms and Psalms suited for the use of Parish Churehes, n.d. Glees, songs, etc.

Guildford, Lord, see North, Francis.

Guinneth, John, see Gwrnneth, John.

Guise, Riclıard, musician, lorn in 1740.

$\mathrm{He}$ was a Gentleman of the Chapel Royal, and a lay-vicar and master of chorister's, Westminster Abbey. He died on March 10, 1808. Composer of 3 single chantis, contained in Vandernan's " Divine Harmony," 1770.

Gunn, Barnabas, organist and composer, was born at the end of the 17 th century. He was organist of St. Philip's, Birmingham, till
GUTTERIDGE.

1730, when he became organist of Gloncester Cathedral, snceeding Hine. He wrote Two cantatas and six sollgs, Gloncester, 1736. Sonatas for harpsichord, etc. He died at Gloucester (?) in 1743.

Gunn, John, writer and violoneello player, was born in the Highlands of Scotland [Edinburgh, 1765?] 'Teacher of 'cello at Cambridge, and in London, from 1789 . He afterwards returned to Edinburgh, and married Miss Anne Young, in 1804. He died about 1824.

Works. - An Essay, with copious examples, towards a more easy and scientifie method of commencing and pursuing the study of the l'ianofurte, with the principles of thoroughbass and musical science, London, n.d. Forty favourite Scotch airs, adapted for violin, German thute, or violoncello, with the phrases mark'd . . supplement to the examples in the theorv alid practice of fingering the violoneello, London, n.d. The theory and practice of fingering the violoneelio, eontaining rules and progressive lessons for attaining the knowledge and command of the whole compass of the instrument, London, 1793; second edition, n.d. Art of playing the German flute on new principles, n.d. An essay, theoretical and practical, on the application of harmony, thorough-bass, and modulation, to the violoneello, Edinburgh, 1801. An historical enquiry respecting the performance on the harp in the Highlands of Scotland, from the earliest times until it was discontinued about the year 1731 ; to which is prefixed an aeeount of a very ancient Caledonian harp, and of the harp of Queen Mary. Edinburgh 1807. This work he proposed to supplement by An enquiry into the antiquity of the Harp, ete., but it never appeared. School for the German flute, n.d.

Gunn, Anne, born Young, pianist and writer, wife of John Gumn, wrote "An introduetion to music; in which the elementary parts of the soience, and the principles of thorough-bass and modulation, as illustrated by the musical games and apparatus, are fully and familiarly explained, with examples and complete directions for playing the several games," Edinburgh, 1803; second edition, 1820.

Gunn, William, compiler of "The Caledonian Repository of Music, adapted for the bagpipes, being a collection of strathspeys, reels, jigs, etc.," Glasgow; Four editions to 1867.

Gurney, Edmund, musician, who died at Brighton, in June, 1888. Author of "The Power of Sound," Londun, 1880, and several contributions to magazines on musical subjeets.

Guthrie, Mrs. T. A., see Austen, AuGUSTA A.

Gutteridge, William, organist, violinist, 
GUI.

and composer, born at Chelmsford, July 16, 1798. He travelled in Belgimm, etc., in 1815. Organist of Private Royal Chapel, Brighton Pavilion, under George IV. William IV., and Victoria; also organist of st. Peter's Church, Bright in, 1828-1872. Nember of private band of George IV. Leader of orchestra of Brighton Theatre, and conductor for many years of Brighton sacred Harmonic Rociety. He was music-master to the Duke of Cambidge. He died at Brighton, Septemler 23, 1872. Composer of nocturnes, galups, rondos, etc., for pf., numerolls songs, etc.

Guy, Henry, tenor vocalist and eomposer, born at Uxford, in 18+7. Student and Associate, R.A.M. In 1876 he was appointed a Gentleman of the Chapel Royal, St. James's. He sang at the Worcester Festival of 1878 ; at the Alexander Palace in 1876; and has been heard at the chief concerts in London and the provinces. He has written a trio, "Reflection"; a serenate, with violinobbligato; and some glees and songs.

Guylott, Robert, comluser, born in 1794, died at London, Decemller 18, 1876. He wrote songs chicfly, of which the following are among the principal: All remember thee [1848]; Beggar's petition: Bellis on the water; Broken row; Days that ale gone; Down the burn, Dary love; Hante to the woodlands; In the pretty spring time; Love on ; Maid of Llanwellyn ; Rose shall ceatse to blow; and a large number of comic and other songs. Glee, The orb of day, etc. I Le also issued a "Book of Melody, and drawing-room companion," 1847.

Gwilym, Gwent, see Willians, Wu. AUBREY.

Gwilt, Joseph, architect and musician, was born in Surrey, in 1784. Architect to the Grocers' Company, London. Te died at Henley-on-Thames, September 11, 1863. He published a "Collection of Madrigals and Motets, chiefly for 4 equal voices, by the most eminent compusers of the 16 th and 17 th centuries...," London, 1815; and wote the article "MInsie" in the "Encyclopedia Metropolitana." He also compiled a valuable "Encyclopedia of Alchitecture," ete.

Gwynneth, or Guinneth, John, musieian and priest of the 16th century. One of the eminent musicians nentioned in Morley's catalogue. He graduated Mus. Doc, Oxford, in 1531, and in 1533 he lecame rector of st. Peter, Westchepe. Composer of Masses, songs, etc.

Gyde, Margaret, pianist and composer, born in London. Studied pianoforte and composition under WT. C. and sir G. A. Macfarren; violin under F. Ralph. Sterudale Bennett Prizeholder, 1879; Potter Exhibitioner, 1880; Lady Goldsmid, and Thalberg Scholar, 1881. A.R.A.MI., 1884. Made her

\section{HADDEN.}

début at W. Macfarren's concert, St. James's Hall, February 25, 1882, when she played liis Concertstïli in fs minor. She lus played several times at the Crystal Palace eomeerts, including the Weher centenary, December 18 , 1886; and has given recitals at Steinway Hall, 1884-91. In 1895, she established the Kensington Mnsical Aeadeny. The late Richard Jefferies, novelist and naturalist, was her first cousin.

Wonks.-Pf. and riolin: Sonatas in G minor, and C minor ; Suite, Idylls of smmmer (two books); Scherzo; Romanza ; Rerevie, ete. Impromptus; Minuet; Tarantella, and other pf. pieces. Prelude and Frogue in G minor, organ. Stis apart; The lridge of tears; Love's greeting, and other songs, etc.

\section{Habyngton, see ABYNGDON.}

Hackett, Charles Danvers, composer. born in 1812. Mus. Bac., Oxon., 1850 Died London, 1859. He edited "The National Psalmist, consisting of original psaln and hymn tumes, ete., composed expressly for this work by the most eminent authors in England," London [1839]; various editions. "Zion," a saered cantata [1859]. Original music $[1840]$, ete.

Hackett, Maria, musician, born November 14, 1783; died Hackney, London, November 5, 1874. She interested herself greatly in the education of cathedral choir hoys, and to encourage the composition of church music founded the Gresham prize medal, in 1831. Author of "A brief account of Cathedral and Collegiate Schools, with an abstract of their statutes and endownents," London, 1827. "A memoir of Sir Thomas Gresham, with an abstract of his will," 1833, anm. "Corres. pondence and evidences respecting the ancient Collegiate School attached to St. Paul's Cathedral." "A popular account of St. Paul's Cathedral," London, 1816. Songs, ete.

Hadden, James Cuthbert, musician and writer, born at Banchory-Ternan, near Aberdeen, in 1861. He studied under private teachers in London, and in 1882 became organist of Mannofield Parish Church, Aberdeen. He was appointed organist of St. Michael's ''arish Church, Crieff, in 1884, and in 1859 went to Edinburgh as organist of St. John's Parish Church. He resides in Edinburgh, and is chiefly engaged in literary work.

Works.-Greorge Frederick Handel, London, 1888. Mendelssohn, London, 1888. Lays of Caledonia, a collection of Sicottish airs arranged for the harmonimm, Glasgow, 1883. Contributor of musical and otler articles to the Dictionary of National Piograplyy; Love's Scottish Church Music; Scottisli Review, Quiver, Cassell's Magazine, English Illustrated Magazine, ete. Editor of the Scottish 


\section{HADDOCK.}

Musical Montlıly. Fditor also of a selection from Hogg the Ettrick Shepherd, for Bryce of Glasgow; and author of a work on Violin Collecting, to be published in Redway's Collector Series.

Haddock, George, violinist and composer, born at Killingbeck, near Leeds. His father was musical, and at his house the great instrumentalists who visited Leeds often met for chamber music. The son began his studies at an early age, under Bywater, and in 1846 went to London. There he had lessons from Henri Tieuxtemps, and afterwards from Molique. Returning to the north he was, for many years, a foremost figure in musical life in Yorkshire. He was the first to give a performance of "Elijah" at Bradford; and as a teacher he has sent out many players, now occupying important orchestrai posts. He established a Music School at Bradford, and also the Leeds College of Music, opened in 1894. He is author of "A complete Practical School for the Violin," 3 vols., Schott and Co. "Major and Minor Scales in all positions, with exercises on double notes, octaves, and staccalo bowing," etc., Ashdown. Fantasias and arrangements for violin and pianoforte

Haddock, Edgar, son of the preceding, violinist and composer, was born at Leeds, in 1862. Studied under his father, and in 1884 started a series of "Musical Evenings" at Leeds, which have been continued annually. He appeared the same year at York, Halifax, and elsewhere. In 1891, he gave a series of concerts at the Steinway Hall, London; and at the Huddersfield Subscription Concerts of that year (March 3) was associated with Herr Joachim in the performance of Spoln's violin duo in A minor, op. 67 , No. 1 , a rare compliment to an English artist. In 1896, he gave a series of Historical Recitals at Leeds. At one of the daily concerts at the Crystal Palace, March, 1885, he introduced Gade's violin concerto, more than a year before it was placed in a Saturday concert programme. The composer sent Mr. Haddock an autograph score in acknowledgment. $\mathrm{He}$ is one of the directors of the Leeds College of Music. His works include a Practical School for the Violin; The Students' series of Violin Solos; Ballade Norvegienne; Sarabande and Tambourine, and other original compositions for violin. His brother, G. P'ERCY IIAnDock, violoncellist, was born at Leeds. 1le is associatcd with the management of the " Nusical Evenings;" is a Director of the Leeds College of Music; and is known as a pianist and organist. He has composed a number of songs, of which may be named "The Soul's awakening," with accompaniment for pf., violin, and organ; "A crown of thorms ;" and "The King of Kings." He has also written

\section{HAGUE.}

pieces for violin, violoncello, and an entr'acte for orchestra. A magnificent collection of violins and violoncellos is in the possession of this artist family. THomas HaDrock, violoncellist, borı at Leeds, in 1812, was another nember of the family. He settled in Liverpool, as teacher and performer, and was for many years principal violoncellist of the Liverpool Philhamonic Society. He died September 22, 1893.

Haden, Arthur C., conductor and violinist, born in London, in 1852. Pupil of Sir John Goss and Henry Holmes. Conductor of the I nundee Ladies' Orchestra. His compositions include several cantatas; Campsie (ilen; Bonnie Lassie; Two Reveries (with violin obbligato), and other songs ; Studies; Air and variations for clarinet and pf., etc.

Hadow, William Henry, composer and writer on nusic, born at Ebrington, (iloncestershire, December 27, 1859. Educated at Malvern College, and Worcester College, Oxford. Studied pf. at I armstadt (1882), and composition with I)r. U. H. Lloyd, Oxford (1884-5). Graduated B.A., 1882; M.A., 1885; and Mus. Bac., 1890, Oxford. Fellow and Tutor, Worcester College, Oxford, 1888 . Lecturer on Musical Form (for Sir John Stainer) 1890-2. Appointed, 1897, to edit for Clarendon Press, a fortheoming series of works on Iusical History.

Works.-1Hymn, Who are these? for soli, chorns, strings, and organ; Cantata, The Soul's Pigrimage (published 1886); Anthem (Prize, Curven) When I was in trouble (1885); Songs; Quartet in E flat, strings (1885); Trio in G minor, pf. and strings (composed, 1887 ; produced, Musical Artists' Society, 1890); Sonatas in A minor (1886), and F (1891), pf. and violin; Sonata in B minor, pf. and viola (1889); Andante and allegro in $\mathrm{F}$, violin and pf. Sonatas in $\mathrm{C}$ sharp minor (1884); and A flat (1890), for pf. Some of these remain in IS. Anthor of Studies in Modem Music, London, Seeley \& Co., 1892; Second series, 189t; being estays on Criticism, Method, Berlioz, Sclmmann, and Vagner; Chopin, Dvorák, Brahms, and Outlines of Musical Form. Sonata Form, Novello's Priners, No. 54 [1896]

Hafrenydd, see Willians, Tiromas.

Hague, Charles, composer and organist, born at Tadeaster, Nay 4, 1769. He studied the riolin at Cambridge moler Manini, 17791785. Removed to Lundon in 1785, and studied under Salomon and Dr. Cooke. Mus. Bac., Cantab., 1794. I'rofessor of Music, Cambridge Tniversity, in sncecsion to Randall, 1799. Mus. Doc., Cantab., 1801. He died at Cambridge, June 18, 1821.

Worrs.-Ode performed at Cambridge in June, 1811, at the installation of the Dulie of Gloucester as Chancellor of the University; 
HAIGH.

By the waters of Babylon, Psalm. Glees: Two Colleetions; Arrangements of Haydn's 12 symphonies as pf. duets; Plmmptre's Collection of Songs, moral, sentimental, instructive, and amusing, Cambridge, 1805. Pf.music, etc.

His daughter HaRliot (born 1793, died 1816) published in 1814 "six Songs," with pf. aceomp.

Haigh, Thomas, composer and pianist, born at London, 1769. He studied musie under Haydn, at London, 1791-92. Resided in Nanchester, 1793-1801. Returned to London in 1801, and died there, April, 1808.

Wonks.- Sonatas for pf. and riolin, op. 4, $6,8,9,10,12,15,16,24,33,34,36$; Three sonatas, pf. duet, op. 5 ; Easy sonatas for pf. duet, op. 7; Three divertmentos, op. 18; Three sonatas, pf, and flute, op. 19; Three sonatas, op. 20 ; Three capriecios, pf., op. 38 ; Three serenatas, do., op. 40; Twelve preludes: Twenty-eight familiar airs, etc., pf. : Twelve petites pieees for the pf., with introductory preludes to each, op. 32. Songs and glees.

Haite, John James, composer and writer, who died in Londun in October, 1874.

Works.- The Principles of Natural Harmony; being a perfect srstem founded upon the discovery of the tine semituric scale, London [1855]. Violoncello Tutor, London, n.d. Oratorio, operettas, symphonies. Glee Garland, varjons number's. Mrelodies arranged for flute and other instrmments. Songs.

Haking, Rev. Ranulf (Richard ?), composer, born about 1830. Ordained, 1861. Mns. Bac., 1855; Mus. I)oc., 1864, ()xford. Some time rector of Eaton Gray, Malmeshury; and of Congham, Norfolk, 1852. Composer of anthems: Doth not wisdom ery; Lord, let me know my end, etc. (rlees: Twine no more the cypress wreath: By the mossy fountain ; Song of the old bell; Welcome home; and others. Songs, etc.

Hale, Thomas, of Darnhall, Cheshire, musieian. Composed "Social Harmony. A collection of songs and catches, in two, three, four, and five parts. Also several choice songs on Masunry, all with the music," London, $1763 ;$ 3rd edition 1770

Hale, Mrs. William (Jeaxie M. Stevens), pimist and vocalist, born in Birmingham. Her father, Joseph Sterens, was an energetic member for years of the Festival Committee. Miss Stevens sang in the trio,"Lift thine eyes," from "Elijah," at the Birmingbam Festival of 1849, with Miss A. and Miss Williams. She was, for several years, solo pianist and principal vocalist at the Town Hall Monday Concerts. She played to Mendelssohn, who gave her a copy of Chopin's studies, upon which he wrote his name. For many years she had a large teaching connection in the locality, and was frequently heard at ehamber concerts, etc. Was heard as a pianist in Lon-

\section{HALL,}

don, in June, 1854; and sang at Boosey's Ballad Concerts, St. James's Hall, 1869 . She is now living in retirement in North Wales. William Machin, the lass singer, was her uncle.

Hales, William, writer on acoustics, author of "Sonorum doctrina rationalis et experimentalis, ex Newtoni opt. physicorum scriptes," Dublin, 1778.

Halford, George John, organist, pianist, and conchetor, born at Chilvers Coton, Warwickshire, February 13, 1858. His early musieal studies were under W. Chater (organist of Holy Trinity, Coventry; died, March 27 , 1880). In 1875 he went to Bimmingham, and studied pianoforte, eomposition, ete, under Dr. C. s. Heap. F.R.C.O.; Mns. Bae., 1892, Durbam. Has been organist snecessively of St. Jlary's and st. George's, Birmingham, 1876-80; St. John's, Wolverhampton, 1881; st. Michael's, Handsworth, 1886; and from 1891, of Handsworth Parish Church. Conductor of the Birmingham Musical Association from 1886, now fomed into a choir bearing his name; People's Concert society, Stourbridge, 1886-91 ; Philharmonic Society, Redditch, 1890-4; Bimningham Amatenr Orehestral Society; and the Midland Institute Madrigal Choir. He has introduced many important works to the local public, notably Schumamn's "Nanfred," produced in the Town Hall, April 16, 1896 ; and has probably conducted the first performance in this country of a symphony in a parish church, introducing at a special service at Handsworth Peethoven Ssmphony, No. 1, October 6, 1892 ; and Schumann's symphony in B flat, November 1, 1893. He has composed a cantata, "The Paraclete," produced, 1891; Anthems, part-songs, ete. A concert overture, 1896; organ pieees, etc.

Hall, Charles King, organist and composer, born in London, in 1845. Was organist of St. Paul's, Canden siquare; St. Luke's, Oseney Crescent; and up to the time of his death, at Christ Church, Brondesbury. He wrote an Evening service in E flat, performed at it. Paul's Cathedral by the London Church Choir Association in 1891, and other church music. The Verger: A Strange Host; The Foster Brothers, and other operettas produced at the German Reed Entertaimments; also a cantata, Beanty and the Beast; Songs, pf. pieces, etc. Author of "A sichool for the Harmonium, 1874; Estey Organ Tutor; and a primer on the harmonim, Novello. He died in London. September 1, 1895.

Hall, Rev. Edward Vine, composer and organist, born at Maidstone, Kent, June 11, 1837. Chorister of Magdalen College, Oxford, 1845-55, and assistant organist, 1858-9. Gradnated B.A., 1859; M.A., 1863, Oxford. Appointed Precentor of Worcester Cathedral, in 1877 , and held the office till 1890 , when he 


\section{HALL.}

beeame ricar of Bromsgrove. He has been Conductor of the Worcestershire IIusieal Union from 1879 . His roice at its best was a light tenor of sweet tone; and he has frequently sung at the coneerts of the "Magdalen Vagabonds." He has also given organ recitals, and lectures on music, at IVorcester, Birmingham, and other places. His compositions include a Cantata for Lent; Two settings of the Service for Holy Communion; Two of the Magnificat and Nume dimittis (one, in C, performed at the elosing service of the Worcester Festival, 1881); Praise the Lord, O Jerusalem, and other anthems; and a part-song, Waken, lords and ladies gay, sung at the Worcester Festival, 1878.

Hall, Elias, musician, compiled "The Pralm-singer's compleat Companion," London, 1708 .

Hall, G. W. L. Marshall = composer, borm in Edgeware Road, London, 1862, grandson of the famous physician, Dr. Narshall Hall. Edncated at King's College, London, and ac Oxford. Studied music at R.C.M., and in Switzerland and Germany. Was for some time master for foreign languages at Newton College, Newton Abbott. In 1888 he was conductor of the Choral and Orchestral Societies of the London Organ School, and in 1890, was eleeted Ommond Professor of Music, Melbourne University, Australia. $\mathrm{He}$ has founded a Conservatorimu of Music there, and gives an annual series of orchestral concerts. Papers bave been contributed ly him to the musical press. His eompositions are numerous, including three speras, of which he has written both libretti and music: Leonard; Dido and Eneas; and Harold. A study on Tennysun's "Mand"; an wrepture? in f $\mathrm{r}$ minox (Crystal Palace, 189:3); Idyll, for orchestra; Quartets for strings (one, in C, performed at (Yueen's Hall, London, December 20, 1895): smaller works, songs, etc., etc.

Hall, Henry, organist and composer, born at New Windsor in 165.5. Son of Capt. Henry Hall. He was a chorister in the C'hapel Royal under Capt. Henry Cooke, and he studied also under Dr. Blow. Organist of Exeter Cathedral, 1674, and organist and ricar-choral, Hereford Cathedral, 1698. 1Ie took holy orders in 1698, and died at Hereford. March 30,1707 , and is buried in the cathedral. He composed anthems. Te Dem in E flat, and other church music. He also wrote songs and prems.

His son, Hexry, was organist and vicarchoral of Hereford Cathedral, and William, another son (died 1700), was a member of the King's band and componser of songs.

Hall, H. Foley, composer and pianist, who Hourished alyout 1820 and 1866. He wrote a large number of sentimental songs, for many of which George Linley supplied the

\section{HAMERTON.}

words. Among them may be named "Ever of Thee" (1859); "Blame not the heart" (1860); "Far from those I love"; "O, yes, thou'rt remember'd "; When I am far away": "Still in my dreams," etc. He also wrote polkas for pf., etc.

Hall, John, violinist and composer, born at $\mathrm{Ayr}$, about the end of the 18 th century. He studied the violin at Edinburgh, and returned to $\mathrm{Ayr}$ as a teacher, and formed a land, consisting of himself, his brothers, and others, which performed at all the principal gatherings and balls in Ayrshire. In 1822 he played in Niel Crow's band when it performed before George IV. at Edinburgh. He died at Glasgow, December 4, 1862. He published "A collection of quadrilles and waltzes for pf. and violin," n.d., and "A selection of strathspeys, reels, waltzes and Irish jigs," Ayr, n.d.

His brother, JAmes (died, Ayr, 1860), played sccond riolin in his band, and was a teacher of dancing in Ayr and neighbourhood.

His youngest brother, Dovglas (died, Ayr, 1878), was a violoncellist, and resided in Ayr as a teacher and performer.

Hallewell, Frederick John, bass vocalist, born in Leeds, 1846. l'upil of "Joe" Wood, of IIndelersfield. Appointed solo bass at Leeds Parish Church, 1866; to York Minster, 1867; and, two years later, to New College, Oxford, where he remained until 1880 . He then went to Australia, and is now bass at st. Mary's Roman Catholic Cathedral, sydney, and engaged in teaching. Was considered the finest bakn singer in Australia.

Halley, T. Douglas, musician, was opganist of St. John's, Wapring, and of St. Panl's, Shadwell, London. lle published "Twelse hymos appropriate to charity sermons...." London, n.d.

Hambois, or Hanboys, John, musician and writer of the 15th century. Generally believed to have been the first Finglish musician on whom the degree of Doctor of Music was conferred. He is supposed to have received the degree in 1463 , but there is no evidence to prove that he graduated either at Oxford or Cambridge. He wrote two tracts in Latin: Summum Artis Musices and Cantionum Artificialium diversi Generis, ete.

Hamerton, William Henry, composer and writer, born at Nottinghan, in 1795. Chorister of Christ Chureh Cathedral, Dublin. He was taughtmusic under T. Vaughan, at London, 1812. Teacher in Dublin, 1814. Master of Choristers, Christ Church Cathedral, Dablin, 1815. Gentleman of Chapel Royal, Dublin, 1823. Teacher in Calcutta, 1829. He is supposed to have died at Calcutta.

Works - St. Alban, opera, Dublin, 1827. Vocal Instructions combined with the theory and practice of pianoforte aceompaniment, 1824. Anthems, chants, glees, songs, etc. 


\section{HAMILTON.}

Hamilton, Sir Edward Walter, Kt., composer, son of Rt. Rev. Walter Ker Hamilton, Bishop of Salisbury (1808-1869), borm July 7, 1847. Edueated at Kton and Christ Chureh, Oxford. Studied under Dr. Stainer, and graduated Mus. Bac. 1867. Appointed a clerk in the Treasury, 1870 ; served as private secretary to the Rt. Hon. R Lowe, 1872-3; to the R. Hon. IV. E. Gladstone, 1873-4; appointed prineipal elerk of Financial Division in Treasury, 1885; Assistant Financial Seeretary, 1892; and Assistant Secretary to Treasury in 1894. Created C.B. in 1885, and K.C.B. in 1894. Nember of the Comncil and Exeentive Committee of the R.C.M. His published works include a Sacred Cantata, Praise the Lord, O my sonl (degree ex.); sundry songs, singing quadrilles, pieces for pf., ete.

Hamilton, James Alexander, writer and eomposer, born at London, in 1785; died there, August 2, 1845.

Works. - Cathechism on the nature, invention, expusition, development, and eoneatenation of musieal ideas, with examples from the great masters, London, 1838 (varions editions): Cateclism on the art of writing for an orchestra, and on playing from seore, with sixty-seven examples, 18tt; second edition, 1846, other elitions; Dictionary, comprising an explanation of 3,500 Italian, French, German, English, and other musical terms, phrases, and abbreviations, also a copious list of musical characters, Loudon, $18+3$ (numerons other editions); The same, with appendix containing John Tinetor's Teminorum Musiea Diffinitorium, elited by John Bishop; Modern instructions for the pianoforte, London, 1290 editions said by publishers to have been issued; New musical grammar, in three parts (fonr editions); Catechism on double counterpoint and fugue; Practical introduction to the art of tuning the pianoforte, etc.; Catechism of the organ, with an historical introduction, and a list and description of the principal organs in Great Britain, Ireland, Germany, France, and Switzeriand (five editions); Modem instructions for singing, eontaining a eomplete compendium of the rudiments of music, etc.; Easy method for the violoncello; Catechism for the violin; Harmonium instruetion book; The pupil's new daily exercise, containing all the scales and chords in their respective positions; Method for the donble bass, . . London, 1833; Sacred hamony, a collection of three hundred and fifty standard psahm and hymm tunes, Loudon [1843]. Psahms and hymms, in the order they are appointed to be sung or chanted in cathedrals, churehes, chapels. etc., during the morning and evening service of the Chureh of England, with explanatory notes; An introduction to choral singing,

\section{HANCOCK.}

ete.; Order of chanting the morning and evening serviees, aecording to the Rubrie of the Church of England; Method of chanting the Psahns, as used in the service of the Chureh of England. Compositions, various, pf. pieces, glees, songs, ete.

Hamilton, David, organ-luilder and writer, lrom at Edinburgh, April 2, 1803. He was organist of St. John's Episcopal Church, Edinburgh, for many years. Died at Edinburgh, Ieeember 20, 1863. Inventor of the menmatic lew action for organs, and writer of musical articles in the old edition of "Chambers" Encrelopredia." He also contpused a few organ pieces, and edited a colleetion of chants. He edited, with J. M. Miiller, his partner, "Hamonia sancta, a collection of chants, psalm tmues, sanctuses, etc., adapted to the service of the Episeopal Church of Scotland.. 114:3s]; supplement 1858. His yomngest hrother ADA was born in Edinburgh and is an organist and composer, who was conductor of the Edinburgh Choral Tnion, 1866-83, and other soeieties. He studied in Germany under F. Achneider, and has composed several orehestral works. Also editor of "The scottish (rphens, a collection of the most admired scots songs arranged with svmphonies and accompaninents," Edin., n.d. His son carl Drechisler Hanlltox, born at Edinlmugh in 1846, is conductor of the Edinburgh Amatemr Orchestral Suciety, and a violoncellist of great merit. He is a memlerer of the Edinburgh String quartet, formed in 1890 .

Hamilton, John, musician and poet, was horn in 1761, and died at Edinhmrgh, Septensber 23,1814 . He was a music seller in Edinburgh, and wote several well-known Scots songs, wneh as " $[$ " in the morning early," etc. He also issued "A collection of 24 scots songs, chiefly pastoral," Edin., n.d. "A complete reporitory of old and new Scoteh strathspeys, reels, and jigs.." Edin., n.d. "The Caledonian Musemu, containing a farourite collection of ancient and modern Scots tmes adapted to the German flute or violin," Edin., n.d., 3 books.

Hamiltor, William, musician and publisler, was bom at Pajsley abmut 1812. He was established as a music publisher in Glasgow for a number of rears. 1)ied at Kirm, April 25, 1887. Amoug the publications issned by Hamilton may be named the "British Jinstrel and musical and literary miscellany," Glasgow, 18t2-4t, issned in parts. "The British Harmonist," 1847-th. "Select songs of Scotland," 1848 , etc. He was a musician and poet, and wrote songs and music moder the psendonym of Willian McGarin.

Hancock, Charles, musician, anthor of "Accordion Instrutetions," London [1545]. "Flute Preceptor," London|1846]. "Tiolin 


\section{HANCOCK.}

Preceptor," London [1846]; also "Improved" editions of these works in 1852 and 1853.

JAMES HANCOCK, a musicjan of the early part of this century, published Hym Tunes and sacred Odes for 3,4 , and 5 voices London [1800]. He also composed anthems, canons, ete.

Hancock, Charles, organist and conductor, born at Islington, London, January 4, 1852. Choir boy at st. Michael's, Combill, 1859, under IR. Limpus $(q r$.$) ; and in 1861$ elected to the choir of st. George's Chapel Royal, Windsor. Articled to Sir (r. Elvey, 1867 , at the same time being organist at Datchet, and at st. Andrew's, Uxbridge. Received pianoforte lessons from (I) r.) Keeton, and remained as assistant to Sir G. Elvey until 1875. F.C.O., 1872; Mus. Bac., 1474, Oxford. In July, 1875, he was appointed organist of St. Nartin's, Leicester, in which town he still resides He is conductor of the Leicester New Musical Socjety; and fom 1886, of the Derby Choral Cnion, and actively engaged as a teacher. His compositions comprise a setting of Psalm 18, for soli, chorus, and orchestra; Organ music, Andante in A flat, Wesley Prize, Cohlege of Organists, 1887; Songs, etc.

Hanforth, Thomas William, organist and composer, born at Hunslet, a suburb of Leeds, March 6, 1867. Chorister at Tork Minster. Articled pupil of WV. H. Garland, and studied later under I)r. Naylor. Gradwated Mus. Bac., 1892, Durham. Assistant organist, York Minster; Organist to the late Archbishop Thomson, 1885 ; St. Martins-leGrand. York, 1888; Deputy at York Minster, part of 1891 ; and in 189y sucereded $\mathrm{E}$. H. Lemare at the P'arish Church, sheftield. Conductor of Visconntess Inwne's Madrigal Society, 1891 ; Countess of Harewood's Ladies' Choir, 1892-3. I His compusitions are: P'ralm I for soli, chorus, and strings; Two evening services, anthems; Pieces for pf., and for organ; and musie for the Three Masonic Crift Ceremonies.

Hann, William Henry, viola player. Mnsician in ordinary to the Qucen. Nember of the 3'hilharmonic, and other orchestras; and for many years in the band of the Three Choirs Festivals. In 1895 he staceseded Mr. Doyle as principal viola in the Leeds Festival orchestra. Fince 1886 he has, with his sons, Lewis R. HAN, violinist, A.R.A.M.; Enward Hopkns, violgnist; SHDNey II., A.R.A.M., pianist; and Clement, A.R.A.M., violoncellist, given series of chamber concerts at Brixton, which have had considerable educational value. WiLLIA ('HARLis FLANe, violoncellist, pupil of Tratti, is a player of repute, and has appleared at London concert with success.

Hanway, Jonas, traveller and writer,

\section{HARDIMAN.}

born at Portsmonth, in 1712; and died in 1786. He was a traveller, and occupied much of his time in acts of benevolence. Author of "Thoughts on the importance of the Sabbath, also on the use and advantage of music," London, 1765.

Harcourt, James, organist and composer, born in Norwich, October 27, 1818. After some years as chorister in the cathedral, he was apprenticed to Alfred Pettet, organist of St. Peter, Nancroft; and to this church he was appointed in 1851, after holding office at some other churches. Failing health compelled him to resign in 1877. He was for thirly years organist and conductor of the Norwich Choral Society; for many years organist at the Triennial Musical Festivals, until 1872, when he became chorus master, which last office he held for about eight years. He was a fast frieud of the composer. $H$. Hugo Pierson. He died at Norwich, May 27, 1883. He composed a Rondo in D, for orchestra; Two string quartets (one, in C, afterwards published as a Sonata for pf. and violin); Thr e movements for the soft stops, organ, and some arrangements of chamber music for that instrument.

J. Artiun IIARCOURT, his son, was born at Norwich, January 2, 18,2. Received his musical edueation from his father. Organist and choirmaster of the Roman Catholic Church (cathedral), the nave of which was opened August 29, 1894, erected at the cost of the Inuke of Norfolk. He has written much, but his compositions remain in MS. They include an operetta "The science of love" (Clifford Harrison), performed, Norwich, Octoher, 1874; Canta a, "The return of Spring" (words by the same), Norwich, May, 1nst; Liturgical music; Twelve sungs ; Four duets, etc. A concert overture, for orchestra; organ and pianoforte pieces, and various arrangements. ERNEST HARCOURT, brother of the foregoing, was born at Norwich, January 25, 1860. Chorister and solo boy at St. Peter, Mancroft. Resident in Norwich, as composer, conductor, violinist, and violoncellist. In 1893, founded the Norwich Orchestral Union, which gives good concerts in St. Andrew's Hall every year. Among his compositions are an oratorio, "The Deluge," op. 32; Cantatas, "The Chapel bell," op. 19; "An Antumu legend " (composed, 1890); Anthem, "And in the sixth month," op 34; and a part-song, "A song of welcome," all with orchestral accompanimect. Arabesque, for orchestra; Quintet for wood-wind (Norwich, 1896); Chanson in F, violoncello and pf., performed by the Musical Artists' Society, Loudon, May, 1893; and pieces for violin and pf., ete.

Hardiman, James, Irisk writer and M. R. I. A., was a native of Galway. He 


\section{HARDING.}

became Librarian of Queen's College, Galway, and died there in 1855. Author of Irish Minstrelsy, or Bardic remains of lreland; with English poetical translations, collected and edited with notes and illustrations," London, 2 vols., 1831.

Harding, Henry Alfred, organist, born at Salisbury, July 25,1855 . Studied under Dr. Abram, Dr. Keeton, and Dr. C. W. Corfe. Graduated Mus. Bac. 1877; Mus. Doc. 1882, Oxford. F.R.C.O.; L.R.A.M. (organ), 1895. Examiner for the Incorporated society of Musicians. Organist of sidmouth Parish Church, and conductor of Sidmonth Choral Society for some years. Organist and director of the choir Bedford Parish Church, and Corporation organist. His compositions include Psaim 106, for soli, chorus, and orchestra and an oratorio, St. Thomas (University ex. Mus. Doc.); Morning service in D, etc. He has published some songs and pf. pieces, and is author of Analysis of Form, as displayed in Beethoven's thirty-two pianoforte sonatas, Novello, 1890 .

Hare, Amy, pianist, born at Taunton, Somerset. Studied at R.A.M., winning the extra Bennett Prize, 18s0; and the Potter exhibition, 1881. A.R.A.M. Appeared as solo pianist at the Gloncester Festival, 1883. Toured in Germany with success, 1856-7; and visited America in 1889. Gave recitals at Taunton and other places in 1893, and settled in Washington, U.A.A., in that year. She was again in England in 1895-7, and played at St. James's and the Queen's Hall.

Harford, Rev. Frederick K., amaten musician, born at Chifton, Bristol, in 1832. Educated at Rughy School, and at Oxford. Ordained 1856. Chaplain to the Bishop of Gibraltar; appointed a Minor Canon of Westminster Abley, $186^{\circ}$. He lias composed several settings of the T' $t^{\prime} t^{\prime} u m$ and Jubilat': an evening service, and a $n$ mmber of anthems. A cantata, "Harom al Raschid," proluced 1884; Marches and other pieces for orelestra. "Schlummerlied," and various songs. He was active in the attempt to popularize the National Anthem in I I dia, and prepared a version that was performed at the Albert Palace, on dime 20, 1857. He was the projector of the "Guild of st. Cecilia," an association having for its object the employment of music as an aid in ilhess. An experimental concert was given in Westminster Palace Hotel. September 14, 1891.

Hargitt, Charles, pianist and composer, born in York, in 1804. First studied under his uncle (Charles Hargitt, died 1865), and played in pulblie, a concerto, when eleven years of age, A few rear's later he studied pianoforte with Charles Kinsett, hamony with Dr. Crotch, and had vishin lessons from Spagnoletti. He played for three years in the
HARKER.

band at the Ancient Concertis. His London debut as a pianist was at C. Knyrett's concert at the Hanover Square Rooms, May 18, 1821, when he played Field'seoncerto, "The Storm," for the first time in England. Subsequently he studied under Moscheles. Cpon the advice of his intmate friend, J. B. Cramer, he settled in Edinburgh, where for nearly fifty years be occupied the leading position as professor. He was passionately fond of pietmes, and his collection was considered one of the sights of Edinburgh. His compositions were numerous, his arrangements and rariations being the best known. The Musical Beauties of scotland, and the songs "The last rose," and "MIy soul doth long," may be mentioned. After retiring from the profension he resided in Liverpool, where he died, in $18 \mathrm{~s} 0$.

Hargitt, Charles John, son of the preceding, was horn in Edinburgh, in 1s33. studied nnder his father, Charles flalle, (r. A. Maefarren, and Ferdinand Hiller. Was organist of st. Mary's Catholic C'hureh, Edin. burgh. Fomider, and up to 1862 , Conductor of the lidinburgh Choral Lnion. In 1862 he went to London, where he continnes to reside; and has conducted oratorio and other concert performances. IJe organised the Royal Albert Hall Choral hocietr, of which he was subconductor to Gounod.

Woris.-Opera, Curonet or Crown; Two operettas; Cantata, The ffarrest Guten; (Nertures, marehes, and incidental music to plays; (hureh music. Song, The Mithorlesis Bain; The Iant (rood-night; A Parting (rift, etce Melody for trombune and organ; Pf. piecen, cte. Sootch air's harmonind ; l'altsoligs, ete.

Hargreaves, George, musician and artist, son of Thomas Hargreate's, the famous miniature painter, horn at Liverpool, 1799. He died at Liscard, Cheshire, in 1469. Best known as the composer of numerons prize gle'es. He wrote masses, an opera, songs, The Battle of Muta; The Breathings of sung, eight songs; I Lomers of Beanty, glee, 5 voices, etc., and had some little renown as a miniature painter.

Harington Henry, M.D., composer and physician, born at Kelston, fonersetshire, September 29, 1727. Entercd Quesen's College, Oxford, 1745; B.A., 1748. MI.I) and M.A., Oxon. Member of Oxford Mnsieal Society. Thrsician at Wells and Biath. He established a IInsical society there, and at one time held office as Maryor of Bath. He died at Bath, Jannary $15,1816$.

Wonis.-Three Books of Glees, 1770, 17,55, and 1797; Single Glees: Songs; Anthems; The hrmm tune "Harington," or "]letirement," ete.

Harker, W., musician, author of "Practical Grammar of Music," London, 18:30-36. " Elements of Tocal Music," London, 1845. 


\section{HARLAND.}

Harland, Robert Holland, vocalist and writer, born in Yorkshire, alout 1822 . He settled in Glasgow as a teacher of musie, and died there, Octoher 7,1889 . He composed a number of songs, and wrote a "Treatise on Singing, in which the rules of sol-fa notation, or leming to sing loy notes, are explatined by examples calculated to render sight-singing simple and easy," Chitsonw, 1881.

Harmston, John William, composer and pianist, bom in lumclon, 1423 ; died luibeck, Augnst 26, 1881. Composer of an immense number of pianoforte piecer, such as" "Te jet deau," op. 193; La belle losiere," op. 195 "Dinlse des strphes," op. 196; Les Naiades," op. 211, etc, chicfly printed by foreign pub. lishers.

Harper, Clıarles Abraham, horn player, second soll of Thomas Harper, was born in London, in 1819. For many years he way the principal performer on his instrument in the ladking linglish orehestras, ocenpring the post of first hom at the Royal I talian Opera for thirty rears. He rutired from the profession in 1886, - his last appointment being in the orchestra of the Sivoy Theatre, receiving from his colleagues a handsome token of their estrem. Charles A. Harper died in Londom, Jinuary 5th, 1893.

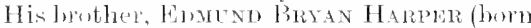
nbout 1817; died at Hillwbrongh, Iroland, May 1s, 1869), was also a noted horn phayer, and har some reputation as an orwmist the was organist to the Marguis of Downshime anrl composer of vocal music. Among lis songs may be named "A bandit's life is the lifelor me", 1868; "Love's whisprer" ; "Many years ago"; "Truth in alsence," cte. Jle also emmprsed pf. musie. He married Mariame Lincoln, the vocalist (q.r.).

Harper, Rev。Jolnn, clergyman, anthor of "The nature and effieney of Musick to prepare the mind for good impressions," a semon; London, 1si30.

Harper, Thomas, trumpet player, horn Worcester, May 3, 1787. Studied in London, under Flrey 1798. Nenber of the Fast India Volnnteer Band. Principal trumpetplayer at Drury Lame and English Opera Honse. Played at Birmingham Musical Festival, 1820. Inspector of musical instruments for the Fast ludia Company. Principal trumpet-player at Royal Italian Opra, and at Concert of Ancient Mnsic. He died at London, Jatnary 20, 1853.

Ho wote an Inatruction buok for the Trumpet: "Sichosol for the comet-á-piston," London 1son, and compitod a number of books of solections for that instrmment, the Kent bugle, ete. He alsir arranged airs for the bugle.

Jin som, Thomas Jomn, horm Lomdom, 1816 , entered the Ji.A.M. in 18\%0, studying violin

\section{IIARRIS.}

and pf., in addition to the trumpet. He was for a time violinist in the opera lyand at Her Majesty's Theatre. As a trumpet-player he was early in arriving at a high position. Associated with his father in the principal orehestras and festivals, he succeeded him as the first trumpet-player of the day. His last Festival appearance was at Hereford, 1885. He was for a long time a professor at the R.A.M., of which institution he is a Fellow.

Harper, William Henry, pianist and composer, born in London, Angust 26, 1845. He is accompanist to the South London Choral Association, and the composer of several songs and pt. pieces; "Hunters" chorus"; "Tis lone on the waters," and other part-songs, ete.

Marraden, R. Ethel, Mrs. Frank Glover, comproser of the present time. Her works comprise an uperetta, "His last chance"; A cantatal, "[earl," for treble volices; Chorus, "() (vell the sea our galleys wont," perforned by the Browning Society, Nurenber 28,1884 ; The lover's leap; Waking and dreaning; Gaydon Inn, and many other songs. Two mulides; (ravotte; Legende, for violin and pf, ete. Tler sister, Beatrice Hatranen, is a skilful performer on the violoncello, lont is hetes linww as the writer of "Ships that pass in the night," "In varying moods," and other works. Herbert HARRADEN is a composer, pianist, and lyric author. He wrote the book of the operetta nimmed ahove, and has published some songs, ete.

Harrington, Henry, see HaRington, HENRY,

Harris, George Frederick, RedolF Nomman, organist and composer, lorn at Lundon in 1796 . For 45 years he was organist of St. Lawrence, Jewry, London. He died at Lrmdon, Noventher 21, 1867. Truder the psendonym of Rudelf Nomann, he pulblished many arrangements for the pianoforte and orgait.

Harris, James, M.P., author and amateur composer, lorn at Salisbury, in 1709, dised, Decenlber 22, 1780. Author" of "Three Treatises-Music, Painting, and Poctry," etc., London, 174t. 5 editions issned to 1792.

Marris, Josepln John, organist and composer, born at Lmabn, in 17939. Chorister in Chapel Ioyal. Oranist of S. Olave's Chureh, Sonthwark, 1823; of I3lackburn Chureh, 1828; and rhoirmaster of Collegiate Church, Manchester. He becane rerganist of the Cathedral in 1848. He dicd at IImchester, February $10,1 \times 69$.

Works.-Selection of Psalm and Hymm Tunes, adapted to the pasturs and hymms used in the Church of s. (Bhve, Southwirk, 1827; Fonr glees [1837]; Mnthems; Songs, ete.; The Musical Exposition, a guide for parents 


\section{HARRIS.}

in their choice of qualified teachers of music, 8 vo, 1845 .

His son, Joseph Thorne Harris (18281869), was also a musician.

His brother JAMEs, born 1797, died at Lewisham, April 13, 1875. Graduated as Mus. Bac., Oxford, in 1833.

Harris, Joseph Macdonald, organist and composer, born at London, in 1789. He was a chorister in Westminster Abber, and a pupil of Robert Cooke. In 1843 he had to be confined in a lunatic asylum. He died in May [1860]. Wrote songs, duets, and pf. music. Published five vocal trios [1817]; Six glees [1812]. "Select portions of the Psalms, a collection of metrical versions, with sixty psalms and fifty hymns by the most approved authors. By Mlontague Burgoyne. The music newly harmonised and arranged for 1 , 2, or 3 vorices by J. M. Harris," London, 2 vols., 1827.

Harrison, Annie Fortescue, spe sub. HILL, LORD ARTHUR.

Harrison, John, watchmaker and writer, born at Foulby, Forkhire, 1693; died at London, March 24, 1776. Anthor of a work entitled "A description concerning such mechanism as will afford a nice or true mensuration of Time, with an account of the discovery of the scale of music." London, 1775. He invented an improved chronometer and was a celebrated mechanician.

Harrison, John, musician and organist, was born at canterbury, in 1808. He rwas a pupil of Goodban and Field, and was for eighteen years organist of St. Andrew's Church, Deal. He died at Deal, February 21, 1871. Compiler of "Sacred Music, a selection of Psalm tunes from the works of Bach, Handel, etc.," 1838. "Chants ar. ranged for four voices, or a single voice," ete.

Another JoHx Harrisos, of Malton, York. shire, issued "Original Sacred Melodies," Malton, 1865

Harrison, Rev. Ralph, clergrman and musician, born at Chinley, Derbyshire, September 10, 1748. He was minister of Cross Street Unitarian Chapel, Manchester, from 1777 till 1810. He died at Manchester, No. vember 4, 1810. Compiler of "Sacred Har. mony, a collection of Psalm tunes, ancient and modern, set in four parts . . ," $1784-91$, 2 vols. This contains the well-known psalintunes, "Warrington," "Ridley," and "Peterborjugh," all by Harrison.

Harrison, Samuel, tenor vocalist, borm at Belper, [Derby, September 8, 1760. Appeared as treble singer at the Concert of Ancient Music, 1776-78. Sang at Handel Commemoration, 1784. Tenor at Concert of Ancient Nusic. Married Miss Cantelo, 1790. Established (with Knyvett) the Vocal Con-

\section{HARTUP.}

certs, 1791-4. He died at London, June 25, 1812 .

Was one of the most popular tenor singers of his time, and was particularly successful in ballad singing.

Harrison, William, tenor vocalist and composer, horn at Marvlehone, London. June 15, 1813. He made his first public appearance in 1836 , and afterwards studied at the R.A.M., 1836-7. He sang at sacred Harmonic society concerts; début in opera, at c'ovent Garden Theatre, in Rooke's."Hemrique." Established, with Miss Louisa Pyne, "'The English Opera Company," 1856. Sang in tenor rôles in operas by Balfe, Wallace, Benedict, Mellon, etc. He died at London, November 9, 1868. He composed an operetta. "Les noces de Jeannette," and a number of songs, but is best remembered as an encomrager and promoter of national English opera. He produced Balfe"s "Bohemian Girl": "Rose of Castille," etc., and Wallace's "Mlaritana" and "Lunline."

Harrison, William, organist and composer, bom at Lichfield, in 1841. He ras a chorister in Lichfield Cathedral, and afterwards a music teacher at Trughy School, and at Liverpool. In 1867 he was appointed organist of sit. James's C'hurch, at Leith, and he was also conductor of the Dunfermline Choral society. He composed a Jubilee Ode, words by W. B. Haildon, 1887. He died at Fdinburgh, June 21, 1889.

Harriss, Charles Albert Edwin, organist and composer, born in London, December 15, 1862. Son of EnwI Hapriss, sometime organist of st. Mark's, Wrexham, where he was a chorister at the age of eight. Flected Onseley Scholar, st. Michael's College, Tenbury, 1875. Was assistant organist at St. Giles Parish Chureh, Reading, 1880; and in 1881, appointed to the Parish Church, Welshpool, and private organist to the Earl of Powis. In 1883, father and son settled in Montreal, Canada, and soon imprarted new vigour to the musical life of the place. Charles was appointed organist and rector. chori of Christ Church Cathedral, and later to the Chmreh of St. Jimes the Apostle, which became, by his exertions, famous for the excellence of its musical services. A glee and madrigal society was also established. His cantata, "Daniel before the King," produced by the Montreal I'hilhamonic Society in 1890 , was the first published work of the kind by a composer resident in Canada. He has also written an opera, "Torquil," produced Montreal, 1896; a large number of anthems, songs, pf. and organ pieces. As an extempore player on the organ he has a high repntation.

Harrop, Sarah, Mrs. JoAH BAtes, soprano vocalist, born in Lancashire, and ras originally employed in a factory at Halifax. She 


\section{HARROWAY.}

studied under Sacchini and Dr. Howard. Married to Jouh Bates, 1780. She sang at all the principal London concerts and festivals. Died in luondon, December 11, 1811.

Harroway, John, composer and conductor, horn ahout 1809; died, January 25, 1857. He composed music for numerons conic and other songs by San Cowell, J. E. Carpenter, ete., such as "Alunzo the brate"; "That's the way the money goes"; "Who's your hatter"? etc. He also publisbed much dance music.

Hart, Charles, composer and organist, born May 19, 1797. Studied at the Royal Academy of Music under C'rotch. Organist successively of st. 1)unstan's, stepney, 1 s.? 33; Tredegar Square Church, and St. George's, Beckenhan. He died at I ondon, Mareh 29 , 1859 .

Works. - Omnipotence, oratorio, 1839. Three anthems dedicated to I)r. Crotch. Te Deum and Jubilate in U (Gresham prize com. position, 1831). Glees, songs, etc.

Hart, George, violinist and writer, born in Iondon, Narch 28, 1839. He studied at the Royal Acadeny of Music under sir (i. A. Macfarren and M. Sainton. While a fine violinist, he was better known as a judge of the instrument and as a malier. Hesuceeded to his father's business, and became head of the firm of Ifart and Son, Wardour street, London. Author of two valuable works: The Violn, its famons m+kers, and heir imitators, London, Dulan, Int5; and The Vutin and its music, London, Novello, 1881. The first has passed throngl several editions, and was published in French, in $18 s 6$. He died in Isondon, Apris 25, 1891.

Hare, Joseph Binns, organist and compower, burn at London, in 1794. Chorister in St. Panl's Cathedral in 1so1. He studied under John Sale, s. Wesley, M. Cooke, J. B. Cramer, and Attwood. leputy organist to Attwood at st. Paul's. 1so5. Org nist at Walthamstow, and at Tottenham. Chorusmaster, English Opera House, I recm, 181s 20. Music-seller in Hustings, 1829. Organist St. Mary's Chapel. Hasting.. He died at Hastings, December 10, 1844 .

Woks - Inomatir Music: Amateurs and actors, 1818 ; A walk for a wager, 1819 ; The Bull's head, 1s19); The Vampire, 1s20. Sets of quadrilles, waltzes, luncers, etc.; An easy mode of teaching thorough-bass and composition. Songs, pf. music.

Hart is eredited with the invention of the dance form linown as the laucer's Quadrille. His mnsic is zut of much importance. With John Fawcelt, he edited "Melodia divina, a sacred companion for the pf.

Hart, Philip, composer and organist, was bom alout the middle of the 17 th century. He was a bass siuger at York Minster till

\section{HARVEY.}

1670 , when he became a Gentleman of the Chapel lioyal, 1670-1718. Lay-vicar Westminster, 1670-1718. Organist of St. Andrew Undershaft, Loudon; St. Michael's, Cornhill; St. Dionis, Blackheath, 1724. He died at London, 1749.

Wukls.-Ode in praise of musick (Hughes), 1703; Morning hymn from Paradise Lost, Milton, 1729 ; Anthems; Organ fugnes; Songs in various collections. Melodies proper to be sung to ally of ye versions of ye P'salms of David "[1713].

JAMES HART (1647-17Is), who was a Gentleman of the (hapel Royal and a chorister of Westminster Abbey, was probably a relative.

Hartland. A family of musicims, at West Bromwich, Staffordshire. The father, T1зотну Hartland, was borm in 1810. For some rears he was organist of the Purish Church, and afterwards, for 50 years, organist and choimaster of Ebenezer Ċurch, West Brom. wich. The first in the locality to adopt the Hullah srstem of teaching singing, he formed a large and smecessful class. Tle had a fine tenor voice, was a skilful flute player, and did much for the promotion of music in the dintrict. He wrote a good deal of chmrch music, and his anthems and hym tunes lave gained popularity in America and Australia. Hedied at West Bromwieh, Felnnary 16, 1891.

His youngest son, Willam Hartlaxin was boun at West Bromwich in 1850. Appeared in pullic as a pianist at a very early age. studier first under a local teracher, symeon Cirossenor, and later under ('. E. Flavell, and Franklin Taylor, with whom he resided in Iomion: stridied the organ with $\mathrm{F}$. Archer. Returning to West Bromusich, he beld office as organist at several churches, but his teaching comection extending, lo gare thene np. In 1857 he was eleeted Town Hall organist; and in 1875 he founded the West Jironwich Choral society the conductorship of which he still retains. In 1891 le started a series of sumday evening organ recitals in the Town Hall, and has lineprently appeared as pianist at coneerts. The choral society attaining its majority, a Mnsical Fentival - the first-..was held at West Bromwich, April 22, 1\$86, to colelurate the event, and occasion was taken to recognise the honorary work of the connductor. He is Professor of singing at the West Bromwich Institute. His sister, Inzzre Hanthane, was for some time aecompanist to the Choral society, hut is now ocempied in traching and composition. Her dramatic cantata, "Crenr de lion," was perfomed at West Bromwich in Februmy, 1ses. She has also written a cantata for female roices, "Queen of the roses"; many songs, flartsongs, and pf. pieces.

Harvey, Richard Frederick, composer. Has pulsished an immense munler of pf. 


\section{HARVEY.}

picces, fantasies, arrangements, and a few original compositions. Also "I love but thee alone; The golden days; Thady and I; Stomy petrel, and many other songs, partsongs, ete.

Harvey, William, musician, composer of "The Nelksham Harmony, eontaining 50 original tunes, ete," London $\lceil 1800$

Harwood, Basil, organist and composer, born at Woodhouse, Olveston. Gluncestershire, April 11, 1859. Educated at Charterhonse, and Trinity College, Oxford. Studied under J. L. Roeckel, G, Riseley, C. W. Corte; and at Leipzig Conservatorium under Reinecke and Jadassolnn. Mus. Bac., 1880; B.A., 1881; MI.A., 1884, Oxford. Organist of Trinity College, Oxford, 1878-81; st. Bamab.s, Pinlico, 1883-7; Ely Cathedral, 1887-92; and Whist Church Cathedral, Oxford, from 189.2. Conductor of Oxford Orchestral Astociation, 1892; Orpheus Society, 1s94. President of the University Musical (lub, 1895. His puhlished works comprise: Agnus Jei, and O Salutaris, chorus and organ, op. 2; Cathedral Service in A flat, op. 6: Six songs, op. 3; Trio, female voices, To Daffodik, Christmas Carols, etc. Sonata in C sharl minor, op. 5 ; and Drthrramb, op. 7 , for organ. Three pieces for pf., op. 1, etc.

Harwood, Edward, componer, hom at Hoddleson, near Blacklomm, 1707, died in 17s7. Comprosed "A Set of Hrmms and T'salm Tumes,".n.d.; "A second sict,". ('hester, 1786. Chants and anthems, a few of which are in nse at the present time. The first set of liymms contains the well-known setting of Pope's "Vital spark of heavenly flame." Harwood also wrote a number of once popular songs.

Haskins, James F., musician, compiled a Concertina I'receptor, London, 1852; P'ianoforte Preceptor, 1853; Singing Preceptor, n.d. : Modern Comopean Preceptor, 1853, and other works, for Tegg, the pullisher. He was a teacher in London, and celebrated the toth amniversary of his musical career at shoreditch, in 1888.

Hastings, David Henry, writer on musie, was borm ahont 1809 ; and died on Inecember 10,1890 . He was musical eritie to the Monning Herald, and for over forty years he contributed to the Musical World.

Hately, Thomas Legerwood, composer, editor, and teacher, born at Greenlaw, Berwickshire, Septemler 26, 1815. Apprenticed when a boy to Messp. Ballantyne \& Co., printers, with whom he remained 11 years. Entered employment of Thomas Constable. Self-taught in music. Preeentor of Nortl Leith Parish Church, 1836; do. St. Mary's Parish Church, Edinburgh. Appointed after disruption)preeen tor to Free Chureh Astrembly. Precentor in Free High Church. Established

\section{HATHERLY.}

"Ammual aggregate meetings of Congregational Classes," for practice of psahmody, $1 \$ 46$. Director of the Sicottish Vocal Music Association, founded 1856. He died at Ediuburgh, Narch 22, 1867.

Works. - The National Psalmody, a seleetion of tunes for the nse of churches, etc., Edinburgh [1847]; The Psalmody of the Free Church of scotland, with an accompaniment for the pianoforte. Prepared under the superintendence of George Hogarth, Ekq., Edinburgh, 1845 (other editions); The scottish Psalmody, 1852; Irish Presby terian Psalmody; Hymmals of the Chureh of Reotland: Historical lectures on Psahnody, with illustrations: Lecture on music of the seottinh Reformation (included in Tricentenary proceedings). 1860; Itarmonies of Zion. Psalm Tunes: Glencain. Huntingtower, Cnuningham, Lenchars, Submission, ILakerstem, Nenthorn, lilmany, Zuingle, Polwarth, Cons lation, ete. ; Sam Fhuim natn Sith Mar tha iad air an Simon amms A Ghaeltaled mu Thuath; or, the old raclic palm tmmes as smug in the congregations of the Free C'hurch of reotland in the North Highlands, Edinburgh, 1845. Neludies for the yenug, Edinburgls, $n$ d.

Hately, Walter, pimist and compuser,

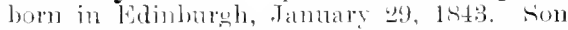
of the preseding. Edneated at the High

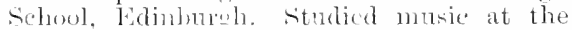
Conservatorim. Leiprig, nuter Plaidy, Mos. cheles, Reineclse, Hauptmann, R. F. Richter, and Ireysehock. 1,661-4. Later, lue studied for a short time with Schulholf at lresden. Resident since 1865 in Edinburgh. Teacher of pf. in the Ladiw' College: Me'reluant Company's Schools; ('hurch of Scothand Training College: and precentor of Frees st. (iterrge's charch. President of the Ediubrowh Free Chunch l'raje Tnion. 1ste. Mr. Hately has published: Heigh-ho, daisios and butterenpe; Ellorie; Kong winter; Row, lonnie row, and other songs, including two nettings flom Goethe. Noctume: Romanees; Barearolles, etc., for pf.; also a New Pf. Tutor. Fditre of Chureh of Scotland Psalter and Hymmal, 186s; and contributor of hymm tumes to varionseollections. Healsoaided the Psahnody Committee of the seottish (hureh in the preparation of their tune-bouk.

Hatherly, Very Rev. Stephen George= son, compuser and writer on music, born at Bristol, Felnuary 14, 1827. Studied music privately, and received instruction in composition from the Rev. W. II. Tarergal. Held appointments as organist at Darlaston, 184t; Solihull, 1847: st. James's, Wedneshury, 1855: Tettenhall, 1863-8. Nusical conduetor at the Greek ('hureh, Liverpoul, 1857. Graduated Mus. Pac., Oxford, 1856; and in 1893, received the degree of Mus. Loc., homor is 
HATTERSLEY.

causî, from the Iniversity of St. Andrews. Ordained deacon and priest of the Greek Church at Constantinople, 1871; and in 1875 became Protopresbyter of the Patriarchal Femmenical Throne of Constantinople. Was engaged on the Mission to Gleek and Slivonian Seamen at Bristol Chamel ports. He has published upwards of fifty works, nany of then relating t) Greek music, on which subject he is an ackuowledged authority. These include specinens of Ancient Byzantine Feclesiastical $\mathrm{N}$ lody, for 4 roices, Greek text, 1579; Hymms of the Eastern Church, translated by Ir. Neale, complete, with music from Greek and other sources, 18s:; A treatise on livantine Nhusic, Londun, Farduer, 1892, an elaborate and scholarly work. An oratoriette, Baptism, 1860; Te Demm and Jubilate, 1859; Benedictus and Apostles' Creed, 1856; Service of the Greek Clumeh in English, 1860 ; Common Praise, an ellarged edition the 5th) of Rer. W. H. Havergal's Old Church Psamody, 1s64; Appendix to 6th edition of same, 18f6. Imperial Risssian Air, and fod save the Oneen, set in canon, ete. He has lectured on Greek ('hurch MIusic (Liverpool, 1889), and contributed to Musical Crinion, and other papers.

Hattersley, Frederick Kilvington, pianist and composer, born at Wortley Grove, Leeds, Jume 11, 1861. Studied at 1.A.M. winning the Balfe Scholarship, 1881, and the Charles Lucas prize for composition, 1883. Studied laterat 1 unich Conservatorium under Theinberger. A.R.A.M.; Mus, Bac., Camhridge, 1887. Resident in Leeds as organist and choinmaster of St. John's Church, composer and teacher.

Works.-Cantata. Robert of Sicily, for soli, chorus, and orehestra (specially written for the Leeds Philharmonic Society, and produced March 14, 1894): Evening service in E flat; songs, etc. rymphony for orchestra (Bradford, 1885) ; Concert overture in E minor (composed for, and produced at the Leeds Festival, Octoher 15, 1586, and performed at the ('rystal I'alace, February 19, 1887); Trio in I) minor, pf. and strings (Leeds, 1865): Sonatas for pf. and violin, in Gr minor (Leeds, 1889), and $\mathrm{F}$ major (London, 1894); pieces for pf., etc.

Hatton, David, bag-pipe player, horn at Thornton, Yorkshire, 1769 ; died November 22,1847 . He invented an instrument something like the Irish bag-pipe, on which he performed with much skill.

Hatton, John Liptrot, composer and pianist, born at Liverpool, Ottober 12,1809 . He was ehiefly self-targht in music, and in 1832 lie settled in London, where he becane pianist at Lrury Lane Theatre, efc. Tle visited the Tnited States in 184s. Musical director of Princesses Theatre, London, under

\section{HATTON.}

management of Charles Kean. He was a teacher and pianist, and frequently travelled in the provinces as accompanist to concert parties. He died at Margate, September 20, 1.886.

Works.-Operettas-Queen of the Thames, 1844; Pascal Bruno, 1844. Music for Macbeth, 1853; Sardanapalus, 1853 ; Faust and Marguerite, 1854; King Henry VIII , 1855 ; The Tempest; Richard II., 1857 ; King Lear, 1858; Merchant of Venice, 1858; and Much ado about nothing, 1858. Rose, or Love's Ransom, opera, Covent Garden, London, 1864. The First printer. Robin Hood, cantata, 1856; Hezekial, sacred lrama, December 15, 1877. Concert overture in G. Two fantasias for pf. and orchestra. Morning and evering service in $\mathrm{E}$; Services in $\mathrm{C}$ and $\mathrm{E}$ flat. Anthems - Blessed be the Lord of Israel; Come Holy Ghost; I will extol Thee, my God; I will praise Thee with my whole heart; Out of the deep; Thou art gone up on high; Pastor Holy; Graduale; Mass for four voices and organ. Part-songs-Absence; All things love thee; A song of winter; Auburu village; A lover's song; Beware; Bird of the wilderness; Bonney blackbird ; Come, live with me; Good night, beloved; Hark! the convent bells are ringing; I loved a lass, a fair one; I met her in the quiet lane; King Witlaff's drinking horn; Lo! the peaceful shades of evening; Love me little, love me long; Now let us make the welkin ring; Over hill, over dale; Shall I wasting in despair ; Sleep, my sweet; cong of the gipsey maidens; Song to Pan; Stars of the summer night; Summer eve; Life boat; Pearl divers; livals; Village blacksmith; Venetian boatmen's evening song: When evening's twilight. SongsSongs for sailors, written by W. C. Bennett; 19 songs by Herrick, Jonson, and Sedley; Autmon; Aftermath; By the millstream; Bird of song; Cloris; Come back, Annie; Dream, baby, dream; Dick Turpin; Fair is my love; Fair daffodils; Fair and false; Friar of orders gres; Farmer at the banks; Garl nd, the; Gentle flower; Good-bye, sweetheart; Hope; If my mistress hide her face; I stood on the beach; I think on thee; Jack o' Lantern; King and the cobbler; King Christmas; Kitty Carew ; Jeather hottel ; Lass of Watertown; Lady Maud; Memory ; Maiden's rose : Maid I love; Ocean; Phobe dearest; Sweet as the moonlight; Simon the cellarer; Song should breathe of scents and flowers; Spring; Starbeams; Sailor's return; Sun to his rest; Sea song; Show-man; True to love and thee; The wisling well; The blind boy ; The goldsmith's daughter; The last fond look; The w11n a d the rose; The slave's dream; 'Tis midnight; Uncle Jack; Under the greenwood tree; Wexp no more; Winter; When 


\section{HAVERFIELD.}

far from thee in distant lands; Wilt think of me? Pianoforte Music-Six impromptus ; Prelude and fugue in G minor; Magic music; Presto; Arrangements; Dances. Singing Methods for various voices; Thirty Elementary Studies for pf.; and many other works.

His son, George Frederici Hatton, appeared at a Richter concert in London, June 13, 1881, in which year he was appointed pianist to the Duke of Saxe-Meiningen. He has played in many cities of Germany. Composer of "The Golden Rose," a cantata for treble voices; Two trios for pf. and strings; Organ music, songs, etc. Another of his family, a daughter, was a focalist, now married to MI.C. G. Moore, and resident in Canada.

Haverfield, Rev. Thomas Tunstall, clergyman and writer, anthor of "Ferice Sacre, or short notes on the great festivals of the church and the services appointed for their celeloration, with appropriate chants and hymus," London, 1847. Composed Collects, etc.

Havergal, Rev. William Henry, composer and divine, born it High Wycombe. Jannary 1s, 1793. Elucated at Oxford. B.A., 1815; M.A., 1819. Rector of Astley, Worcestershire, 1829-42. licctur of st. Nicholas, Worcester, and hon, canon Worcester Cathedral, 18t5. Rector of Slatenhill, near Wolverhampiton, 1866-68. He died at Leamingtors, April 19, 1870.

Worms. - A llistury of the Old Hundredth Psahm Tune, 185t. Old Church L'salmody, 1849. One Hundred Psalm and Hymn Tunc's. Ravenscroft's Psalter (1611), edited 1847. Anthems, psalms, hrmms, etc., to mumber of about 50. Among his best linown tunes may be named Havergal (1870), and Evan (1846), the latter being very popular in Britain and America, where it was introduced by Lowell Mason.

His daughter, Fraxces Ribles, born at Astley Rectory, Worcestershire, 1 recember 1t, 1836, was a pupil of Dr. W'ms. Marshall and Alberto Randegger. She died at Caswell Bay, Swansea, June 3, 1879. She was a poetess of some note, her hymms and other pieces having been very popular. She composed some hymm tunes, "Eirene," etc.

His eldest son, the Rey. Hexry East Havergal (born 1820, died January 12, 1875), was educated at Oxford. He was made rector of Cople, Bedfordshire, in 1847, and did much to promote the cultivation of good music in Bedford and Oxford. He composed much church musie, chants, hymms, etc., and edited Wither's "Hymms of the Church," 1816.

His youngest son, the Rer. Fraxcis T. Haveraal, I. D., was rical of Uton Bishop, Hereford. Died near Russ, in July, 1890.

\section{HAWES.}

Author of "Memorials of Sir F. A. G. Ouseley," 1889.

Hawdon, Matthias, organist and composer. A celehrated pertormer in his day, but of whom very few particulars are known. $\mathrm{He}$ was organist of Beverley Minster, and of St. Nicholas (now the Cathedral), Newcantle-onTyne. He was appointed to the latter in 1776 , and is said to have held the dual appointment for some time. He was buried, March 22, 1787 , according to his explesised wish, underneath the old Renatus Harris and suetzler. organ, in St. Nicholas' C'hurch. His works inchude Two Concertos in B flat, and F ; Sis Conversation sonatas for the harpsichord or pianoforte, with accompaniment for two violins and violoncello $[1785$; An Ode on the ling of Prussia, and six songs. First Sett of six somatas spirituale or voluntiry's, for the harpsichord, organ, ur pf., op.t. The opening of an urgan, a chajce set of foluntaries. The concerto in 1) flat is still played at organ reeitals, and his hymm tune, beverley (C.M.), has been in use at Newcastle ever since his time. He composed "Fancy," at sonlg, and other vocal music.

Haweis, Rev. Hugh Reginald, amateur violinist, and writer on music, horn at Egham, Surrey, April 3, 1839. Educated at Cambridge, graduating J.A., 1859; M.A., 1864. Incumbent of st. James's, Maryleivene, 1866. Editor of Cassell's Fumily Magazine, 1868. Has leetured on musical topies at the London Institution, and in many provincial towns; and in 1885 lectured in America. Itis contrihations to various periodieals have been numerous; and be is the anthor of two rolmus on music: Music and Morals, London (W. H. Allen), 1873; and My Musical Life, Lomdon, W. H. Allen, 1sirt. The firnt of these has reached it 16 th edition.

Hawes, William, composer and writer, born at London, June 21, 1755. Choristel in Chapel Royal, 1793-1801. Tiolinint in Covent Gaten orchestra, 180:. Deputy Lay-ricar, Westminster, 1802; afterwards full vicar, a post which he held till 1820. Gentleman of Chapel Royal, 1805. Master of Chorinters, Almoner, and Vicar Choral, St. Paut's Cathedral, 1812. Associate Philharmonic Society, 1813. Master of Children of Chapel Royal, 1817. Lay-ricar, Westminster Abbey, 1817-20. Established Farmonic Institution in the Argyle Rooms, strand, where Hawes was a munic-publisher for a time. Music directur, English opera, Lyceun, 1824-36. Produced Weber"s "Der Freyschiitz," July 21, 1824. He died at London, February 1s, $18 \pm 6$. Buried in Kensal Green Cemetery. Member' of Glee Club. Conductor of Madrigal Society, etc.

Wonks.-Music for Plays: Broken l'romises, 1825; The Sister of Charity, 1829 ; The Irish 


\section{HAIVKER.}

Girl, 1830; Comfortable Lodgings, 1832; The Dilsk gatherer, 1s32; The climbling boy, 1832; The Mnmmy, 1833; The Quartette, 1833; Yeoman's I Daughter, 1833; Convent Belles (with J.A. Wade), 1833; The Muleteer's Vow, 1835. Collection of five glees and a madrigal [1814]; Six glees for 3 and 4 voices [1815]; Six Scotch airs hammonized as glees [1817]; Prize glees. Adaptations of operas by Paër, Salieri, Winter, Mozart, Ries, Marschner, etc. Songs: The Beacon; Father William, etc. Edited an edition of "The Trimmphs of Oriana." Chants, sinctuses, and responses to the commandments, as used at St. Paul's Cathedral and Westminster Abbey. Selected from ancient and modem composers, London, 1830, 12 pts. Anthems, and other sacred music, as used at His Majesty's Chapel Royal, and the various Cathedrals throughout the kingdom, selected from ancient and modem composers, London. A collection of Spofforth's glees, and a Collection of madrigals for $3,4,5$ and 6 voices, from the works of the most eminent composers of the 16 th and 17 th centuries, carefully extracted from the original worlis as preserved in the Madrigal society. Service in G minor (MIS.). Crolt's services and anthems, 1840. Psalm and hymm tunes.. harmonised for 3 voices, edited by J. W. Hall, London [1836].

His daughter, Maria Billington Hawes, contralto vocalist, was born at London, April, 1816. She studied under her father, and others, and sang at the Bimingham Festival of 1846 . She corresponded with Mendelssohn. Married to Mr. J. D. Merest. Died at Ryde, Isle-of-Wight, April 24, 1886. She composed a large number of ballads.

Hawker, Peter, musician, Lient-colonel in the army, and a well-known writer on sport, etc. He died in 1853. Author of "Instructions to young performer's for acquiring, by means of patent hand moulds, the best position for strength and articulation on the Pianoforte," 1840,3 editions.

Hawker, Thomas Henry, musician, issued "Collection of Psalm and Hymn tumes, chants, etc., as sung at All Saints' Chureh, St. John's Wood, London [185t].

Hawker, Willian, musician, issued "Hanmonia Sacra Familie, containing psalms, hymms, cte.," Lomdon, 1841. Ind ed., Exeter" [18+5].

Hawkes, R. W., musician, compiler of "The Worcester Tune book . . ," London, 1865.

Hawkes, Thomas, land surveyor and musician, born at Wiveliscombe, Somerset, Norember 3, 1786; died at Williton, Somerset, July '), 1857. Author of "An Introduction to divine service, Watehet, 1831; and compiler of "Hawkes's Psalmody, a eollection of tunes comprising the most approved

\section{HAWKINS.}

standard, with a great variety of original compositions adapted to the lymms in use by the Wesleyan Methodist Societies," Watchet, Whitehouse, 1833. The original tumes were chiefly composed by local amateurs of Somerset and Wiltshire.

Hawkes, William, musician, author of "The Theory of Music simplified, and the principle of the temperament applied to the tuning of keyed instruments explained; also the best method of Tuning," Liondon, 1805. "A specific statement and view of the improved musical scale for organs and pianofortes," London, 1810.

Hawkins, James, composer and organist, born in latter part of the 17 th century. Chorister, St. John's College, Cambridge. Organist of Ely Cathedral, 1682-1729. Mus. Bac., Cantab., 1719, He died at Ely in 1729 . Composer of Services, Anthems, collection of Scotch songs. "As northern winds, song," etc. His son, JoHN, was organist of Peterborough Cathedi:1. 1714-1759, and composed a number of Anthems, preserved in Tudway's collection, etc.

Another JoHN Hawnins issued a "New Set of Psalm and Hym 'luues," Londun [1810].

Hawkins, Sir John, Kt., writer and lawyer, born at London, March 30, 1719. Became an Attorney. Nember of Madrigal Society, and of Academy of Antient Music. Married Miss S. Storace, 1753. Retired to Twickenhan. Chaimman of Middlesex Quarter Sessions. Knighted, 1772. He died at Spa, May $14,1789$.

Worlis.-Twelve Cantatas (words), 1742.43, masic by J. Stanley. An account of the institution and progress of the Academy of Antient Music, 1770. A General history of the Science and Practice of Music, London, 5 vols., 1776 (with portraits); new edition, Novello, 1853. Edition of Walton and Cotton's "Compleat Angler." 1760.

Hawkins was much esteened in his day, and was one of Dr. Johnson's literary executors. He did much by the publication of his "History" to enlighten the English musical public on the past state of the art, and though its ralue is less owing to the lapse of time, it is still a standard text-book to the history of music. Its merits, and superiority in some respects over the history of Burney, lie in its acknowledged greater accuracy and plaimness of detail. Its merits in this respect are indeed great, for, despite some few blemishes in the matter of mis-stated facts, it is a remarliably erudite and straightforward production. Hawkins was buried in Westminster Alhey. His danghter, Letrtia Matuda (1758, November 22, 1835), was a novelist, and biographical writer, and his son, JoHN SIDNEY, wrote amongother works " An inquiry 
HAY.

into the nature and principles of thoroughbass on a new plan," London [1818].

Hay, Walter Cecil, organist, composer, and conductor, born at shrewsbury, August 7, 1828. Studied, R.A.M. Has been bandmaster in the army, militia, yeomanry, and volunteers. F.R.A.ì. Organist and professor of music at Shrewsbury School; Conductor of New Choral Society, 1865, and of Shrewsbury Orchestral Society. Author of Prize Ode to the Victor in the Wenlock Olympian Games (1857). "The Valley of St. John," cantata (from the Bridal of Triermain, 1863) ; "May," cantata, Shrewsbury, 1866: "Etheldred," operetta, 1887 ; and incidental music to "Phyllis," a pastoral play, by J. P. Donglas, 1887.

Hayden, George, organist and composer of first half of the 18th century. He was organist of st. Mary Magdalen, Bermondsey, London. Composer of Harlequin Director, cantata $[1723]$; three cantatas [1723]. Songs: Careless Conplanion; Mad Tom; Welcone Damon. As I saw fair chloe, and other twopart songs. Plumstead's "Beauty's of Melody," 1827, contains some of Hayden's songs.

Haydock, Frederick W., organist and composer. Studied under Dr. Horton Allison and privately. Graduated Mus. Bac. 1880, Mus. Doc. 1891, Dublin. Was sometime organist of St. Gabriel's, Manchester; and since 1880, of Union Chapel in that eity. His compositions are two cantatas, "O mag. nify the Lord," and "Lazarus," for soli, chorus, and orchestra. Some songs, etc, of his have been published.

Haydon, Thomas, organist and musician, born in London, in 1787. He studied under C. Neate and Crotch, and became organist and Professor of Pianoforte at R.A.M. He died about 1845. He composed songs, and many romances, waltzes, and quadrilles for pianoforte.

Hayes, Catherine, soprano vocalist, born at Limerick, (1ct. 25, 1825. She studied singing under sapio and Garcia, and at Milan under Ronconi. Début at IIarseilles in "I Puritani," 1845, and afterwards sang in Vienna (1846), Venice, and elsewhere in Italy. Appeared in London, Covent Garden Theatre, April 10, 1849. Sang in Ireland, America (1851), India, Australia, etc. Narried to $\mathrm{Wm}$. Avery Bushnell of New York, October 8, 1857. Slre died at Sydenham, London, August 11, 1861.

Miss Hayes was a singer of remarkable porvers, and in her day was a most popular and favourite vocalist. Her chief power lay in the rendering of ballads. Her biography was issued under the title of "Miemoir of Miss Catherine Hayes, the 'Sivau of Erin.', 4 to, n.d., with portrait.

Hayes, William, organist and composer, born at Hanbury, Worcestershire, in Decem-

\section{HAYNE.}

ber, 1706. Chorister Gloucester Cathedral, under IV. Hine. Organist of St. Mary's Church, Shrewsbury, 1729-31; of Worcester Cathedral, 1731-34; Magdalen College, Oxford, 1734-77. Mus. Bac., Oxon., 1735. Drofessor of Music, Oxford University, 1741. Doc. Mus., Oxon., 1749. He condutted the Gloncester Musical Festival in 1763. Died at Oxford, July 27, 1777.

Works.-Collins' ode to the Passions, and other odes. Twelve ariettas or ballads, and t.wo catches, 1735 . Services and anthems. Circe, masque. Glees, catches, etc., first set, 1757 ; second set and supplement, 1763-65. Cathedral Music, in score, edited by lhilip Hayes, 1795. Instrumental music. Kemarks on Mr. Avison's essay on musical expression, Loudon, 1753. Anecdotes of the five music meetings, etc. Sixteen Psalms from Merrick's new version, set to music for the use of Magdelen College Chapel, Oxford . . . n.d.

Hayes, William, clergyman and writer, third son of the above, born at Oxford, 1742 . Chorister Magdalen College, 1749-51. R.A., 1761 ; M.A., 1764. Minor Camon, Worcester Cathedrat, 1765. Do. St, Paul's, London, 1766. Vicar of Tillingham, Essex. He died on Oct. 22, 1790. He wrote a paper entitled, "Rules necessary to be ob-erved by all Cathedral singers in the Kingdom," in Gentleman's Magazine, 1765. Sermons, hymn tunes, and other works.

Hayes, Philip, organist and composer, was born at Oxford, 1738. Second son of William Hayes, under whom he studied. Mus. Bac., Oxon., May, 1763. Gentleman of the Chapel Royal, 1767. Organist of New College, Oxford, 1776; Magdalen Colege, Oxford, and Professor of Music in the University, 1777. Mus. Doc., Oxon., 1777. Organist of St. John's College, 1790. He died at London, March 19, 1797.

Works.-Prophecy, oratorio, 1781 ; Ode for St. Cecilia's Day; Ode, Begin the song; Telemachus, a liasque. Authems, services, psalms, glees, and songs. Harmonia Wiccamica, London $[17 \leqslant 0]$. Six concertos for organ, harpsichord or pianoforte, 1769. Eight anthems, Oxford [1780].

Hayne, Rev. Leighton George, clergyman and composer, was born at St. David's Hall, Exeter, February 28, 1836. He was educated at Eton and Oxford. In 1856 he graduated Mus. Bac., and in 1860 proceeded to Doe. Mus., Oxford. In 1857 he was appointed organist, and in 1860 precentor, of Queen's College, Oxford. He was ordained in 1861. In 1863 he was made corypheus or precentor of Oxford University; and he held the livings of Helston, 1866, and Mistley-withBradfield in 1871. He became succentor of Eton College in 1867, and held it till 1871. He died at Bradfield, in Essex, March 3, 1883. 


\section{HAYNES.}

He edited, with the Rer. H. W. Sargeant, "The Merton Tune Book," 1863, and composed the following well-known hymn tumes: "Compline," "Hayne," "Mistley," "St. Cecilia," "sit. Margaret," "Chalvey," ete. While at Eton be had a huge organ of five manuals built in the music-room; it was ultimately divided between the organs of Bradfield and Mistley.

Haynes, Walter Battison, organist, pianist, and composer, born at liempsey, Worcester, in 1859. Studied at Leipzig Conservatorium, where some of his compositions (novements from a symphony, and songs), were performed in 1882. He was appointed organist of St. Philip's, Sydenham, in 1884; and in 1891 succeded H. F. Frost at the Chapel Royal, Saroy. In 1890 he was appointed profestior of harmony and composition at the R.A.MI.; and he is an Associate of the Philharmonic suciety. For the flandel Festival of 1891 he wrote additional accompaniments to Handel's Chandos anthem, "O come, let us sing." His compositions include two eantatio for female voices: The Fairies' Isle, and A Sea Dream; Three settings of the Magnificat and Nunc dimittis; I Communion Service, ete. Songs and duets. An Idyl for violin and orchestra; Preluele and Fugues for two pianos; Sonata in I) 1ninor, and other pieces for organ.

His uncle, Wiletam Harese, born at Worcester, september 19, 1829, was an articled pupil of Mr. W. Done, and in 1850 was appointed organist of Malvern Priory Church, a post he held for 43 years. He has composed chureh music, songs, and organ piecess. In 1858 he estallished a music business in $\mathrm{Mal}$ vern. His wife, lom Elzizabeth Broas, a soprano, freguently sang in public under the name of Mlle. Brétet. She was edneated at the R.A.M., and the Cunservatoire, Paris.

Hayter, Aaron Upjohn, urganist and comporer, born at (illingham, Dorset, Deeember 16, 1799. His father, SAMLEL Harter, was organist at Here, Wilts., and composer of services, anthems, etc. In 1805 Hayter became a chorister at Salisbury Cathedral, under Corfe. Afterwards he was organist at Hereford Cathedral, but in 1835 he went to New York as organjst of Grace Chutch. He remored to Boston, Mass., as organist of the Trinity Church soeiety; and in 1839 was slected organist and conductor of the Handel and Haydn Society, a position he held till 1848. He died at Boston, July 28, 1573. Hayter introduced many oratorios and eantatas to the Boston pullic which had never been heard in Annerica. He was sncceeded by his son, Gironge F. HAYTer, as conductor of the Handel and Haydn Society. Another son, Althur UpJohx HaYter, is organist of St. Mary's Church, Stratford-le-Bow.
HEALE.

Hayward, Henry, violinist and composer, born at Broseley, Salop, in 1814. Received his first lessons from his father, and played a solo in public when five year's old. His studies were continued under Spagnoletti, and his executive power's were so extraordinary that he became known as the Englislo l'aganini. After some years passed in the Midlands, he made his début in London, at one of $\mathrm{Mr}$. Carter's Soirées at the Hanover Square Rooms, June 19, 1839 . He appeared at the Philharmonic Concerts, Narch 23, 1840, playing his introduction and Polonaise. About tilis time he settled in Wolverhampton, where he established musical societies, and a music business. As an orchestral player he was for many years engaged at the principal festivals, and was much associated with music in Birmingham. Hiscompositions were numerous, but remained mostly in MS. For some years he was in poor health, and died at Wolverhampton, November $12,1884$.

Head, F. A., mumitim, compiler of " Choral Psalmody, a collection of tunes to be sung in 3 parts, without instruments, by all village choirs, with simple rudinests and instructions for teaching music on a short and easy plan," London [1810].

Heale, Helene, pianist and compuser, born in London, February 14, 1855. Educated at Queen's College, Harley Street, obtaining the Naturice Scholarship. Studied music under John Hullah. In 1876 she oltained a Scholarship at the National Training School, and the next year won one of the four livyal Scholatships there, which she held until 1 s81. Her teachers were Emest Paner, J. F. Barnett, E. Prout, and (Sir) A. Sullivan. In 1860 she played lefore the Queen at Windsor Castle. Resident in London as teacher and composer.

Wonks.-Madrigal, Mourn, oh rejoicing heart, Madrigal Socicty's I'rize, 1882; The Watersprites, cantata for fenale voices, 1885 ; Jubilee ode, chorus and orchestra. 18s7; Epithalamion (from Edmund Spenser), tenor solo, chorus and orchestra, 1893. Part-songs for female volces; thrce-part songs; twelve two-part songs; twenty-four rounds for female roices; eight Christmas tarols; Love wakes and weeps; Cradles song; Lament, and other songs. Six characteristic pieces, pf. duet; Polacca, three violins and pf,, etc. Compiler of Class Singing School, 4 books; editur and arranger of songs for female voices; songs for the young, etc.

Her sister, Alice Heale, contralto vocalist, was born in London, Decenluer 15, 1861. Educated at the Queen's College, and holder of the Queen's Scholarship for five rear's. Studied under J. Hullah. Lady Frealke Scholar at the National Training School, where she studied under J. B. Welch, and 
HEAP.

with him later at the Guildhall School. She made her debut at the Crystal Palace, May 9, 1885; sang at the Glasgow Choral Union, and other concerts, and before the Queen at Windsor, 1886. After further study under Mr. W. Shakespeare, she has devoted herself entirely to teaching voice production and singing.

Heap, Charles Swinnerton, composer, organist, pianist and conductor, born at Birmingham, April 10,1847. Sang in public as a child, and in 1858 was admitted to the choir of the Birmingham Festival as a soprano. Received lessons from Mr. Walter brouks (q.v.), and acted as organist at Queen's College, during his educational course at King Edward's Grammar School. He was articled to Dr. Monk, of York Minster, and in 1865, competed for, and won, the Mendelssohn Scholarship. Procecding to Leipzig he studied under Moscheles, Hauptmam, E. F. Richter, Reinecke, and others. There he produced several compositions, and occasionally deputised for Reineclie as accompanist at the Gewandhaus concerts. In 1867 , he returned to Birmingham, and $\mathrm{by}_{\mathrm{s}}$ arrangement with the Scholarship Committee plated himself under W. T. Best, for further study of the organ. He graduated Mus. Bac., 1sit ; Mus. Doc., 1872, Cambridge. In 1870, the Iirmingham Philharmonic Union was founded, and Dr. Heap appointed conductor, an office he held until 1856 , when the society was dissolved. Excellent eheap oratorio concerts were given. At various times he has been conductor of societies at Stone, Stafford, Walsalk, and Stoke. In 1881, he succeeded Mr. Stockley as conductor of the Wolverhannpton Festiva! Choral Society, and conducted the Festivals in that town in 1883, aud 1886. When the North Staffordshire Festival was established at Hanley, in 1888, he was appointed conductor, an office he has held since that time. In 1895 he was elected conductor of the Birmingham Festival Choral Societr, and in 1897, appointed chorus-master for the Birmingham Musical Festival. He has given chamber concerts in Birmingham, 1871-3, and 1884-6; given pianoforte and organ recitals in many places; whilst as a teacher his work and influence have been wide-spread. From 1869 to 1878 he held organ appointments in Bimingham and Wolverhampton. Was appointed examiner for Musical Degrees, Cambridge, 188t. He has received many tokens of appreciation of his work, the highest compliment paid him being the selection of his cantata, "The Maid of Astulat," for performance, mder his direction, on the occasion of the risit of the Prince of Wales to Hanley, Jannary $7,18.7$.

Works.-Psalm 3; Oratorio, The eaptivity, both in Ms. Cantatas: The Voice of Aspring
HEIGHINGTON.

(Hemans), chorus and orchestra, performed by the Liverpool Philharmonic Society, 1882; The Maid of Astolat, produced at the Wolverhampton Festival, 1886; Fair Rosamund, produced at Hanley Festival, 1890 (both librettos by the late D. L. Ryan). Benedictus, for soprano solo, chorns and orchestra; anthems, songs and part-songs, etc. Two concert overtures for orchestra, one, in F, composed for, and produced at the Birmingham Festival, 1879; Quintet, pf., and wind, 1882; Trio, pf. and strings; Sonatas, for pf. and clarinet, 1879 ; pf. and violin; and pf. solo. Pf. pieces, various; Organ music, etc.

Heather, or Heyther, William, musician, was born at Harmondsworth, Middlesex, in 1584. Lay-vicar, Westminster Abbey. Gentleman of the Chapel Royal, 1615. Doc. Mus., Oxon., 1622. He founded a music lecture at Oxford in 1626. Died, July, 1627, and is buried in Westminster Abbey. Chiefly famous as the founder of the music lectureship at Oxford, which ultimately became the present professorship.

Heather, William Edward, composer and pianist, born in 1784, son of STEPHEN Heather (choimaster at Eton College; borm 1748, died at Windsor Castle, November 14, 1831). He died after 1830. Composer of National airs as trios, with variations for harp, pf, and flute [1820]; Selection of German Hebrew melodies... poetry by J. Hogg, London [1816]; Serenade for pf. and thute. Songs: Brignall banks; Cypress wreath; Hygeia, and many others, by Sir Walter Scott, and others. Anthor of a "Treatise on Pianoforte Study," London [1820].

Hedgcock, Walter William, organist and composer, born at Brighton, Jannary 15, 1864. Studied the organ and composition under Dr. Alfred King, and was assistant organist to him at St. Michael's, Brighton, in 1876. Afterwards he was appointed organist of Patcham Church, near Brighton, and, in 1879, went to London as urganist of St. Agnes', Femington Park, taking, later on, also the duty of choimaster. He was now very busy with concert work, and acting as accompanist. In 1894 he succeeded Alfred J. Eyre as organist of the Crystal Palace, Sydendam, and in a little over a month after his appointment had the onerons duties of organist at the Handel Festival, which were snectsufully carried out. He has been solo organist at the Crystal Palace saturday Concerts. Of his compositions a Suite de Ballet, for orchestra, was performed at the Crystal Palace. May 16, 1892. He has, besides, written a number of songs, uf which "When bright eres whine," and others. have beome pupnhar; also sone pieces lor pf.

Meighington, Musgrave, cmmper and organist, loom in 1680 . He was an organist at Yarmouth, 1738, and Leicester, 1739. For 


\section{HELE}

some time he resided at Dublin. He was a Doc. Nlus., but it is not known at which university he graduated. He died at Dundee in 1774 .

Works.-Ode for the Spalding Gentlemeu's Society; The Enchantress, or Harlequin Merlin. Six select odes of Anacreon in Greek, and six of Horace in Latin, London [1760]. Songs: When I survey that matchless face; Song upon a lady being drowned taking pleasure on the sea with her lover, etc. Tunes in Alcock's "Harmony of Jerusalem," etc.

Hele, John, organist. Student, and associate, R.A.M. Mus. Bac., Oxford, 1871. In 1860 he was organist of Pennyeross Chureh, Plymouth; and has since held appointments there, and at Devonport, Christ Church, 1863; St. Mary's, 1864 ; St. Peter's, 1872; Compton Gifford, 1894. He was organist at Morden, Surrey, 1865-7; and of Bodmin Parish Church, 1868-72. He is conductor of the Plymouth Choral and Orchestral Association, Vocal Association, and other societies. In 1883 he was appointed borough organist, Plymouth, and he gave his $2000 t h$ recital in that town in Octolyer, 1896. He has published some church and organ music.

Helmore, Frederick, writer on "Church Choirs," London; and on "Speakers, Singers, and Stammerers," Londom, 1874.

Helmore, Rev. Thomas, writer and composer, born at Kidderminster, May 7, 1811 Edncated at Oxford. Cmrate of S. Michacl's, Lichfield, 1840. Priest-vicar, Lichfield Cathedral. Precentor of S. Mark's College, Chelsea, 1842. Master of Choristers, and Priest in ordinary, Chapel Royal, 18t6. Died at London, July 6,1890 .

Works.-Manual of Plain Song. 1850 (other editions, enlarged); l'rimer of Plain Song (Novello's Music Primers); The St. Mark's ('hant Book, 2 parts; A Hymnal Noted, or Translations of the Ancient Hymns of the Church, set to their proper melodies; Fuller Directury of the Plain Song of Holy Commnnion: Hamonies to P'salter, Canticles, ete. ; Aceompanying Harmonies to the Hymmal Noted..1852; Catechism of Mnsic, 1s67; Papers on Church Music read at the Church Congress at Woherhampton, 1867 ; Swansea, 1879; and London, 1868 and 1880. Christmas carols, hynms, ete. Trans. of "Treatise on Choir and chorus singing," F. J. Fétis.

Hempel, Charles Frederick, organist and composer, borm at Truro, September 7 , 1811. Son of (. W. Hempel (1777-1855), who was organist of St. Mary's Church, Truro, mider whom he studied. He sueceeded his father as organist of St. Mary's in 184t, and in 1857 he was appointed organist of St. John's Episcopal Church, Perth, where he died, on April 25, 1867. He was Mus. Bac., 1855, and

\section{HENDERSON.}

Mus. Doc., Oxon., 1862. He composed "The Seventh Seal," oratorio, 1862 (Degree excreise); Songs, and pianoforte music.

Hempson, Dennis A., or Denys a HAMPSY, Irish harp-player and composer, born in 1695; died November, 1807. Supposed to have been a skilful performer, and said to have composed some of the fine national airs of Ireland. He played at the Belfast Meeting of harpers in 1792 . His harp, dated 1707 , was preserved in the collection of the Rev. Sir H. Harvey Bruce, at his mansion at Downhill.

Hemsley, John, organist and composer, born at Arnold, Notts., in 1838. Chorister, Lichfield Cathedral. Organist, Merivale, Warwick, 1857. Lay-clerk, Ely Cathedral, 1860. Stipendiary Choirman, Christ Church and St. Patrick's Cathedral, Dublin, 1864. Composed anthems, songs, etc.

Hemstock, Arthur, organist and writer, born at Bingham, Notts., 1845. Author of "On Tuning the Organ," London [1876]; and composer of church music, organ and pf. musie, and a setting of Psalm 145 [1885]. He is organist at Diss, Norfolk.

Hemy, Henri Frederick, composer and organist, was born of Creman parents at Neweastle-on-Tyne, November 12,1818 . He was organist of St. Andrew's R. C. Church at Newcastle, and latterly a professor of Music at Tymemontl, and of singing and pianoforte at St. Cuthbert's College, Ushaw, Durham. Compiler of "Crown of Jesus Music," in four parts, 1864, ete. Best known by his "Royal Modern Tutor for the Pianoforte," 1858 , which has gone through numerous large editions. His son, C. Napier Hemy, is a well-known marine painter.

Henderson, A. G., author of "Philosophy of Music," 1856. (Appears also in Manchester Papers, a Series of Occasional Essays, v. 1, 1856.)

Henderson, Rev. Andrew, clergyman and musician, born at Kirkwall, Orkney, January 4, 1825. He was educated at St. Andrews, and ordained minister of Coldinghain, 1847, and of Abbey Close, U. P. Church, Paisley, 1855. He was secretary to the Hymnal Committee of the United Presbyterian Church. He edited "Church Melodies," 1858, 1860, and 1862; "The New Scottish Psalter," 1870, in which several of his own tunes appear.

Henderson, J. Dalgety, tenor vocalist, born at Montrose, Forfarshire, December 23, 1856. Brought up to a business career, he is now a well-known paper agent in London; but coming of a musical family, he inherited the gift, and studied singing at the Guildhall School of Music, under Mr. Richard Latter. His fine voice soon gained him notice, and he has sung with success in most parts of the 


\section{HENLEY.}

United Kingdom. He appeared at the MIonday Popular Concerts in January, 1883; at the Crystal Palace in May, 1885, and has gained an honourable position among the vocalists of the time.

Henley, Rev. Phocion, clergyman and composer, born at Wootton Abbots, Wits, 1728. Rector of St. Andrew's Wardrobe, with St. Anne, Blackfriars, 1759. He died at London, August 29, 1764. He composed "The Cure of Saul;" "Hear my pruyer," and other anthems, hymms, and chants. "Divine Harmony : being a collection of Psalm and hymn tunes in score," 1798, two vols., compiled in association with Thomas Sharp.

Henniker, Henry Faulkner, organist and composer, born at Chatham, in 1839. Entered the R.A.MI., and studied under Sterndale Bemmett, Sainton, n nt others. A.R.A.M.; Mus. Doc., Cantuar, 1889. Since 1864, he has been organist of Holy Trinity Chureh, Maidstone. He is conductor of a Choral Society there. His compositions include an oratorio, "St. Stephen :" several operas; "Who will come with me?" and other songs; choruses for use in public schools. A Manual for the violin, etc.

Henry, Chaplin, otherwise Henry Chas. STRoud, bass vocalist, was born in 1826 . He was originally a bookseller, but became principal bass at the Foundling Chapel. He died January 12, 1888. His daughter, Elizabeth (or Bessif Stroud) was also a vocalist. She married Mr. Nontem Smith.

Henry, John, composer, born in North Wales, has published a cantata, "Olga," for soli, chorus, and orchestra, produced, Liverpool, February 9, 1893. He has also composed a number of songs.

Henry, John Harold, violinist and composer, born at Lichfield, August 5, 1870. Appeared at concerts when thirteen, and later, entered the R.A.M., studying under A. Burnett and Prosper Sainton. Shortly after leaving the R.A.MI., he went to Leipzig for further study under Hans Sitt. On his return to England he renewed his concert engagements, and in 1892 settled in Derby. There he established an Orchestral Society, and has given some excellent concerts. He has published Scales and arpeggios for the violin; Wiegenlied; Cavatina; Six Feuillets d'album, for violin and pf., etc.

Henry, P. C., author of "Universal Singing Preceptor: exercises for the formation of the Voice, the production of a good tone," etc., n.d.

Henry VIII., King of England, born at Greenwich, 1491; died at Vestminster, 1547. $\mathrm{He}$ is accredited with the composition of the anthem, "O Lord, the maker of all things," and a Latin motet. He was a patron of
HERBERT.

music and the fine arts generally, and is frequently mentioned as having been a musician of some skill.

Henshaw, Grace Mary Williams, pianist. Studied at the R.A.MF, and was the first to obtain the Liszt Scholarship, 1887. Studied at Berlin, with extension of the scholarship, and made her début there in 1890 , as a pupil of Klindworth. Returned to London in 1892, and is established there as a concert-giver and teacher. She is an Associate of the R.A.MI.

Henshaw, Thomas W., organist and composer, born in 1780. Entered the Chapel Royal, St. James's, when eight, and afterwards acted as assistant organist there. Organist of St. Pancras Chureh, London; resigned in 1864. He died at London, October 17,1868 , accidentally burnt to death. He compiled "A Selection of the most approved Psalm and Hymn Tunes adapted to the Nanual of Parochial Psalmody of the Rev. T. H. Horne. ." London [1829], also [1843].

His brother, Wildiam Henshaw (born 1791, died September 30, 1877), was organist of Durham Cathedral from 1811 to 1862 , and brought the choir to a high state of efficiency, which made it celebrated throughout Britain. He was a Mus. Doc. (Durham?).

Henslowe, Rev. W. H., author of "The Phonarthron, or Natural System of the Sounds of Speech, including the Phonodion or Elements of Music," n.d.

Henstridge, Daniel, organist and composer of 17 th and 18th centuries, was orgauist of Canterbury Cathedral from 1700 to 1730 . He composed anthems and other church music. He died at Canterbury in 1736 .

Hepworth, George, urganist and com. poser, born at Almondbury, Yorkshire. studied at Hamburg, and was appointed organist of the Parish Church of Mecklenburg, and later, to the Cathedral at Schwerin. He has composed a Sinfonia in G minor (published in the Organists' Quarterly Journal); a Concertstiick for 4 hands, performed at Chemnitz, 1884; a Fantasia, and other pieces for organ.

Herbert, Edward, organist, composer and author, born in 1830. He was organist at Perth, and of sherborne Abbey Chureh, and Wimbome Ninster. Graduated Mus. Bac., Oxford, 1862. He died at Wimborne in 1872. Author of a "Manual of the Rudiments of Music," and composer of anthems, etc.

Herbert, Victor, violoncellist of the present day, bom in Ireland (?), about 1858. Grandson of Samuel Lover. Lived for some years in Vienna, where his Suite for violoncello was produced in 1885 . He married Fraulein Förster, soprano, of the Dresden Court Theatre, and with her went to the United States in 1886. 


\section{HERON.}

Heron, Henry, musician and organist. He was organist at Ewell. Author of "Parochial music corrected: plain and distinct rules for the more pleasing and correct performance of Psalmody, to which is added an easy introduction to singing," London, 1790. Composer of songs and ballads sung at Ranelagh Gardens [1765] ; ten voluntaries for the organ or harpsichord [1770], etc.

Heron=Allen, see Allen, E. Heron.

Hersee, Rose, soprano vocalist, born in London. Received her first instruction from her father, and studied later with Garcia, Madame Rudersdorff, and Arditi. Made her first appearance on the concert platform at the age of eleven. Her operatic debut was at Her Majesty's Theatre, when she sang as the Nermaid in "Oberon." Went to America in 1869 to join the Carl Rosa Company, where she met with great success. Sang in opera in Australia, New Zealand, and the Cape, 1878-80. In 1881, was prima donna at the Lyceum, and of the Royal English Opera in London and the provinces. Has sung at the Crystal Palace, Philharmonic, and other concerts. Married Arthur Howell, contrabassist (q.v.). A brilliant vocalist, she long enjoyed the favour of the public.

Her father, Henry Hersee, was a teacher of singing, librettist, and musical critic, retiring from the Observer in 1894. He was secretary of the Philharmonic Society for some years, from 1880. He died at Lewisham, May 21, 1896, in his seventy-seventh year. His chief works were English adaptations of "Carmen," "Aida," "The Nerry Wives of Windsor," and an original libretto, "Panline" (founded on "The Lady of Lyons"), for F H. Cowen, produced in 1876.

Hervey, Arthur, composer and writer on music, born in Paris, January 26, 1855. Only son of Charles J. V. Hervey, of Killiane Castle, Wexford, Ireland. Educated at the Oratory School, Edgbaston, Birmingham. Studied harmony under Berthold Tours, and instrumentation with Edonard Marlois. $\mathrm{He}$ was originally intended for the Diplomatic Service, but from 1880 has devoted himself entirely to music. For some time he acted as musical critic to lunity Fair; and on Jannary 1, 1892, he entered on a similar duty on the Morning Post, in succession to the late IV. A. Barrett. He married a daughter of the late Sir Edmund Harrison, a lady whose literary ability is shown in the words of many of the songs he has set. The translations of the three albums of songs named below are by Mr. Hervey's father, author of "The 'Theatres of l'aris," and numerous essays contributed to leading magazines and reviews.

Wonk - - Opera in one act, The Fairy's Post Box (Palgrave Simpson), Court Theatre, 1885; Opera (in MS.). Songs: Sechs Liebes-

\section{HEYTHER.}

lieder (Heine); Herzens Stimmen, six songs (Heine); Neue Liebeslieder, eight songs; Love of my life; May song; Once; Mine all, and many others. Dramatic overture, Iove and fate, for orchestra, produced at St. James's Hall, November 21, 1890, and at the Crystal Palaee, A pril, 1892; Suite for orchestra (MS.). Romance, violin and orchestra; Reverie, violin and pf.; Cantilene and Légende Espaguole, 'cello and pf. Six album leaves; Six esquisses en forme de valses, and other pf. pieces, ete. Literary: Masters of French Music (one of a series of works on eontemporary musicians), London, Osgood, 1894.

Heseltine, James, organist and composer, flourished during the first part of 18th century. Organist of St. Katherine's Hospital, London, in the beginning of the 18th century. Organist of Durham Cathedral, 1711-1763. He died at Durham, June 20, 1763. Composer of anthems, and other church music.

Heullan, see Roberts, John.

Hewett, James, author of "An Introduction to Singing; or, the rudiments of music, to which is added a complete set of practical lessons, together with a colleetion of the best and most useful psalm tunes, and several anthems by eminent masters, London, 1765.

Hewitt, Daniel Chandler, musician and writer, born in 1789; died at Jondon in 1869. Author of "New Analysis of Music, in which is developed a theory of melody, harmony, and modulation," London, 1828. "The True Science of Music, being a new exposition of the laws of melody and harmony," 186! and 1864.

Hewlett, Henry Gay, writer, died February 25, 1897. Author of "Autobiography, Memoir, and Letters of Henry Fothergill Chorley," London, 2 vols., 1873.

Hewlett, Thomas, organist and composer, was bom at Oxford, Narch 16, 1845, He studied music under the Kev. I. G. Hayne, at Oxford, and graduated as Mus. Bac. there in 1865 . In 1865 he became organist in the private chapel of the Duke of Buccleuch at Dalkeith, a post he retained till $1871 \mathrm{He}$ was also organist of St. Peter's Episcopal Church, Edinburgh, from 1868 to 1869; of St. Mary's R. C. Churelı; of the Edinburgh Choral Union; and of Newington Parish Church, Edinburgh, 1873-1874. He died at Edinburgh, April 10, 1874, and is buried in Newington Cemetery, where a monument, erected by the Choral Union, marks his grave. He composed some very meritorious musie for the organ and pianoforte; songs and partsonts, and wrote the two well-known hymns, Angelic songs ("Hark, hirk, my soul") and 1)alkeith.

Heyther, William, See Heatier, WiL- 
HEYWOOD.

Heywood, John, organist and writer on musie, born at Birmingham, 1841. Studied pf. and organ under John Chapnran (organist of St. Thomas's, Birmingham), and afterwards at R.A.M., nnder C. Steggall, Walter MIacfarren, and H. Regaldi. Has held appointmenits as organist and choirmaster at St. Jude's, Birmingham, 1863 ; St. Mary's, Aston Brook (and to Plain-Song Choir, Holy Trinity, Bordesley), 1864.5 ; St. Margaret's, Ward End, 1865; and St. Paul's, Balsall Heath, from 1866 to the present time. Organizing Choirmaster to Chureh Choral Association for Archdeaconry of Coventry, 1871-95; and choir inspector for the same, 1895 to present time. For some years on the staff of The Choir and Saturday Mnsical Review, and later of The Honthly Musical Record. Composer of Try me, O God; I am the Lord; and other an thems. Sundry Festal Chant settings, hymn tunes, sougs, etc. Editor of the Anglican Psalter Noted (1864) ; The Choral Office of Matins and Evensong (1876). Author of Our Church Hymnody, an essay and review (1881); The Versicles and Responses, a paper (1886); and The Art of Chanting, London, Clowes, 1893.

Hicks, Rev. Edward, B.A., author of "Church Music, a Popular Sketch; being a glance at its origin, development, and present use," Manchester, 1881.

Hickson, William Edward, composer and teacher, born early in the present century ; died, London, April, 1870. Compiler of "Singing Master: containing instructions for teaching singing in schools and families. ." London, 1836-42, 6 vols. "Musical gift from an old friend: containing 24 new songs for the young," London, 1859.

Higgins, Edward, composer and singer. Was a vicar-choral of Dublin Cathedrals. Died in August, 1769. A composer of chants.

Higgins, William Mullinger, F.G.S., author of "The Philosophy of Sound and Musical Composition, and History of Music," London, 1838.

Higgs, H. M., composer of the present day. He has composed a Suite de ballet, for orchestra, performed at Reading, May, 1891: Six pieces for violin and pf.; Sonata in C minor; Prelude and Fugue; Offertoire in D minor, and other pieces for organ.

Higgs, James, organist and writer, graduated II us. Bac., Oxford, 187t. F.R.C.O. Was organist of Eaton Chapel, Pimlico, 1843; St. Benet and St. Peter, Paul's Wharf, 184t; St. Mark's, Kennington, 1852 ; St. Michael's, Stockwell, 1864; and from 1867, organist and choirmaster of St. Andrew's, Holborn. An Examiner for College of Organists since 1867. Author of Primers on Fugue and Modulation (Novello); Editor of a Collection of Two-part Solfeggi; Joint editor (with Dr. J. F. Bridge)

\section{HILES.}

of Bach's organ works; and writer of a series of articles on "Organ arrangements," with brief sketches of authors (Musical Stundard, 1882). He has given organ recitals at the Bow and Bromley Institute, etc., and in 1883 was appointed professor of harmony, R.C.M.

Hiles, Henry, organist, composer, and didactıc writer, born at Shrewshury, December 31,1826 . Received his early instruction from his bruther John (q.v.), and held an organ appointment at thirteen. In 1846 he was appointed to a church at Bury, and the next year to Bishopwearmouth. From 1852 he was abroad for some time on account of ill-health. In 1859 he was appointed to St. Michael's, Wood Street, London; and later in the year to St. Thomas's, Old Trafiord, and organist and teacher to the Blind Asylum, Manchester; 1861, to Jowden Parish Church; 1864, to St. Paul's, Hulme, Manchester, which he resigned in 1867. Conductor of societies at Preston, Warrington, aud other places; and of the Manchester Athenreum Musical Society up to 1891. Graduated Mus. Bac., 1862 ; Mus. Doc., 1867, Oxford. Gained the first prize for an organ composition, College of Organists, 186t, and four other's consecutively for an thems and organ music. Elected a Fellow in 1865. Gained the prize for a serious glee, 1878, Manchester Gentlemen's Glee Club: and in 1882, won the Meadowcroft prize. Appointed, in 1876, lecturer on harmony, musical composition, and history, Owens College, Manchester, and in 1879 to the Victoria University. Inew up, in 1890, a sclieme for the establishment of a faculty of music in conformity with the Charter of the University, and in 1891 was appointed permanent Senior Examiner, and Lecturer, etc., as before. Professor of hamnony and composition, Royal Manchester College of Music. He took an active part in promoting what is now the Incorporated Society of Musicians, from 1882, and was one of the strongest workers for it, by pen and personal effort.

Works.-Oratorios, David, 1860; The Patriarchs, 1872. Cantatas; Fayre Pastoral; The Crusaders; Watchfuness, female voices and orchestra. Settings of Psalms 46, 90, 96 and 100, for voices and orchestra. Anthems, services, etc. Operetta, War in the Household, 1885; Historic opera, Harold (libretto by Marian Millar), composed, 1893 ; Installation Ode, Come, sacred learning, Tictoria University, 1892; Break, break ('Tennyson), chorus and orchestra, 1892; The W'reck of the Hesperus. Part-songs, various; Songs, ete. Concert overtures, Youth, and others. Sonata in G minor, Six Impromptus, and other work' for organ ; P'ieces for pf., etc. Educational works: Grammar of Music, 2 vols.; Harmony of sounds, three editions, 1871-2-8; Part Writing, or Modern Counterpoint ; Har- 


\section{HILES.}

mony, Chordal and Contrapuntal; Harmony versus Counterpoint, 1894. First lessons in Singing, 1881; Fingers and wrists, technieal exercises for pf. Wditor of, and contributor to, The Quarterly Musical Review, 4 vols., 1885-8. Contributions to Musical Opinion, and other journals; Papers read at meetings of the Musical Association, and Conferences of the Incorporated Society of Musicians, ete.

Hiles, John, writer and organist, brother of the above, was born at shrewshrury in 1810. He held various organ appointments in Shrewsbury, Portsmonth, Brighton, and London, and was organist at shrewsbury Festival, 1840-41. He died at London, February $4,1882$.

Works.-A progressive introduction to playing the organ, consisting of fifty-five Preludes, Fugnes, Airs, etc., in two, three, and four parts, from the works of the great composers; to which is added some accomnt of the instrument itself; a notice of its varions stops, and the manner of combining them; with directions and exercises for the use of the pedals (Novello), 1.d. Handbook for the Organ (selections). Short voluntaries (selected). A Catechism for the pianoforte student, etc. Cateehism for the organ, 187s. Catechism for barmony and thorough-bass, with key, 2 vols., n.d. Dictionary of 12,500 Musical Terms, 12mo, 1871. Cintechism for part-singing, n.d. Juvenile library of pianoforte mnsic. Voluntaries for organ, original and transcribed. Pianoforte pieces, songs, etc.

Hill, Alfred F., violinist and composer, resident at Wellington, New Zealand. Conductor of an orchestral society there, and a concert-giver. He has composed an opera, "The Whipping Boy"; and two cantatas, "Time's great monotonie." produced at a Festival, Wellington, in 1894; and "Hincmoa," performed at the opening of Wellington Industrial Exhibition, November, 1896. Also some conipositions for orchestra, etc.

Hill, Arthur George, architect, author of "Organ eases and organs of the middle ages and renaissance, a comprehensive essay on the art archeology of the organ ; containing an account of the most interesting specimens of ancient organs in the churches of Continental Enropes," etc., London, 1883.

Hill, Lord Arthur William, second son of the th Marquess of Downshire. Antatem composer; was born July 29, 1846. He was lieutenant in the 2nd Life Gruards, and comptroller of H.MI. Household, 1886-92. Married first to Annie, daughter of Lient.-Col. Cookes (she died in 1874); second, to Axvie ForTescue IIAlasos, third daughter of James Fortencue Harrison, late M.P. for Kilmarnock Burghs. He has composed some songs, ete. His second wife composed "The Ferry Girl," St. Ceorge's Hall, 1883; "The Lost Husband,"

\section{HILL.}

operetta, London, 1884. Holiday songs. Many single songs: In the gloaming [1877]; At noontide ; Sing to me; Yesteryear; and many patriotic songs. I'f. music. "In the gloaming " beeane very popular when first issued.

Hill, Frederick, organist and composer, born at Louth, Lincoln, in 1760 . He was organist at Loughborough, and York, and died early in the 19tl century. He composed pf. music, songs, and music for flute, clarinet, etc. His brothers, JosEPH, organist at Stockton, and Thomas, organist at Pontefract, were composers of glees, organ, pf., and harp musie, ete.

Hill, Horace, composer and conductor, lorn at Norwich. Graduated Mus. Bac., 1869 ; Mus. Doe., 1878, Cambridge. Conductor of the Norwich Festival Choir; East Dereham Choral Society; North Walsham Musieal Soeiety; and chorusmaster, Norwich Festival. some time conductor of Lymn Philharmonic Society. Composer of a cantata, "A song of Praise," produced at Norwich Festival, 1869 ; and an oratorio, "Nehemialn," produced, Norwich, 1885. Concert overture, Norwich Festival, 1880. Overtures, "May Morning," Norwich, 1886; "Yewbarrow," Norwich Festival, 1893 ; "Dawn to Sunset," Norwich Philharmonic Society, May, 1896, and others. Somnet, oloe and orebestra. Qnartet, Benedictus. Part-song, "The Calm," Norwich Festival, 1884, etc.

Hill, John, composer and conductor, born at Norwich, April 5, 1797. He founded, in conjunetion with Edward Taylor, the Norwich Choral Soeiety, and acted as chorus master of the musical festivals from 1826 till his death. For some years he was precentor of St. Mary's Chapel, Norwich. He died at Norwich, July : 8, 1846. In conjunction with his son, James Frederick, he edited the Norwich Tune Book, a collection of tuues by the most eminent composers . . . , 1844, to which he contributed several tunes.

JAMES Frederick HiLL, soll of above, was born in the parish of St. Michael at Thorn, Norwich, May 5, 1817. He was a chorister in Norwich Cathedral, and a pupil of Dr. Z. Buck. Succeeded to his father as conductor of the Norwich Choral Society. Conductor of the Madrigal Society, the Vocal Society, etc. Sang before the Queen at Windsor in 1850 and 1859. In conjunction with R. K. Bowley, Jos. Surman, etc., he aided in founding the Crystal Palace Handel Festivals. He died at Norwich, March 9, 1877.

Works.-Hypatia, a cantata, Norwieh. I saw fair Chloris, madrigal; Old friends met together, part-song. Songs-The pearly dewdrop, ete.

Theodore Shalders Hile, son of J. F., was born at Norwich, October 30, 1844. He is a professor of music at Birkenhead. 
HILL.

Conductor of Wallasey Musical Society ; Wirral Choral Society; Birkeuhead People's Concerts; Y. M.C.A. Orchestral Society ; Blackburu Orchestral Society, etc.

Hill, Thomas Henry Weist, violinist and conductor, born in London (Islington), Jauuary 3, 1828, Studied at R.A.1l., under Sainton; King's Scholar, 1845. F.R.A.M., and sometime professor of the violin at that institution. He soon became known as a concert performer, being taken up first by E. J. Loder, and then by Jullien. He toured in America under the management of $\mathrm{F}$. Burgess, and was the first to play Mendelssoln's violin concerto in that country. Later he visited the principal cities of Europe. On his return he was engaged in the orchestras of the Opera, Philharmonic, and Sacred Har. monic Societies. He was appointed conductor at the Alexandra Palace, which was opened in May, 1873. Conducted the orchestral concerts of Madame Viard-Lonis, in 1878, bringing forward many important compositions. At the Alexandra Palace he revived Handel's "Esther," November 6, 1875; and "Susamna," April 1, 1876. The Symphony Competition was instituted at the Palace in 1876 (vide Davenport and Stanford). He was appointed Principal of the Guildhall School of Music, 1880, an office he held till the time of his death, at South Kensington, December 26,1891 . He was a fine artist, and an able administrator. His compositions were not numerous; they inchuded a civic anthem, produced at the Guildhall, December 3, 1887; several pieces for violin, of which "The Pompadour Gavotte" became popular ; pieces for violoncello, etc.

His son, Ferdinand Veist lille, a violinist, studied at the Brussels Conservatoire, and appeared in London in 1892, and the next year played Vieuxtemps' Concerto, No. 4 , at a concert of the IVestminster Orchestral Society, December 20. He is now (1897) a member of the Queen's Hall string Quartet. The younger son, Thomas E. HiLl, obtained a violoncello scholarship at the R.C.M., 1889, and is now resident in London as a professor of the violoncello.

Hilton, John, composer and organist, was born at the end of the 16 th century. IIus. Bac., Cantab., 1626. Organist and clerk of St. Margaret's, Westminster, 1628. IJe died in March, 1657, and is buried in St. Margaret's, IVestminster.

Works.-Ayre-, or Fa-las for three voyces, London, 162\%, also edited by Warren for Musical Antiquarian Society, 18t4. Catch that catch can; or, a choice collection of catches, rounds, and canons, for three or four voyces, .. London, 1652. Service in G minor. Authems. Elegy on William Lawes, 1648. Fair Oriana, beauty's queen, madrigal for
HINE.

five voices, and Fair Orian, in the morn, for six voices, are in the Triumphs of Oriana. The authem, "Lord for thy tender mercies sake," usually ascribed to Richard Farrant, has also been attributed to Hiltou.

Hilton, Robert, bass vocalist, born at Preston, Lancashire, 18t0. Mis grandfather and father were both singers in the choir of Penwortham Church, near Preston, and he jimself sang bass for some years at Preston Parish Church, whilst holding a clerkship at the Railway Station. In 1869 he was appointed a lay clerk at Salisbury Cathedral, and succeeded William Machin (who died September, 1870) as Vicar Choral of Westminster Abbey, an office lie still holds. His voice is a true bass, of great depth and power, and he has been a successful singer in oratorio. He appeared at the Norwich Festival of 1878; the Bristol Festival of 1879; and the Chester Festival of 1882 . He has also sung for the Birmingham Festival Choral society, and at the principal Iuondon and Irovincial Concerts. Of late his chief public work has been in connection with the combination known as the I)ilettante Vocal Quartette.

Hime, Edward, Laurence composer and tenor rocalist, born in Liverpool, July ' 6 , 1823. Sang at the Princess' Theatre, London, and appeared as Tom Tug, in "The Waterman," at Manchester, in 1st6. He has written a large number of songs, "Light. house keepers," "Leaves from Longfellow," "Coming of Age," etc., and lf. pieces, of which "Parfait Amour," and "I)anse des Paysans," became popular. The latter was also arranged for orchestra. A morceau fantastique, "Phospho," for orchestra has been played in several places. He has also done much in arrangements, etc.

Hindle, John, composer, was born at Westminster in 1761. Mus. Bac., Oxon., 1791. Lay-vicar, Westminster Abbey, 1785. He died in 1796. He published a "Collection of Songs for 1 and 2 voices" $[1790]$, and a "Set of Glees for 3, 4, and 5 voices, op. 2" [1790].

Hindmarsh, John, violinist and composer, born about 1755, died in 1796. He was a pupil of Salomon. Composer of "Favorite Grand March, as performed by the Staffurdshire band," London [1795], etc.

Hine, Benjamin, music publisher and composer, born in 1796, died at Manchester, May 19, 1871. He composed songs, aud other vocal music.

Hine, William, composer and organist, born at Brightwell, Oxfordshire, in 1687. He was a Chorister of Magdalen College, Oxford, from 1694 to 1705 , and a Lay-clerk in 1705. He was dismissed in the same year and went to London, where he studied under Jeremiah Clark. Organist of Gloucester Cathedral, 


\section{HINGSTON.}

1712. He died at Gloncester, Angust 28, 1730. Buried in Gloncester Cathedral.

Works.-Harmonia Sacra Glocestriensis; or, Select Authems, in score, for 1, 2, and 3 voices, and a 'T'e Deum and Jubilate, together' with a voluntary for the organ, 11.d. $\lceil 1730\rceil$.

Hingston, John, organist and composer of 17 th century, who was a pupil of Orlando Gibbons. He was musician to Charles I., and afterwards organist to Cromwell (1654), and teacher of his daughters. He died December 17, 1683. Composer of "Fancies for the Viol."

Hinton, John William, organist and composer, horn at Edmonton, Niddlesex, April 26, 1849. Studied at the Paris Conser vatoire. Graduated at Dublin, Mus. Bac., 1871; B.A., 1872; Mus. Doc., 1874; and M.A., 1876. Organist of St. Nary's, Charingcross Road, 1876; St. Stephen's, and Holy Trinity, fuernsey, 1877-90; and of St. Michael's, Woolwich Dockyard, 1840, to present time. Resident Seeretary, 1876.8, and professor of organ and singing, Trinity College, London. He has composed an oratorio, "Pharaoh," an opera, "Mazeppa" (1880), both in MS.; Chureh music, anthems, organ music, ete. Editor of The International Organist, two series; Author of Facts abont organs; Guide to the purchase, ete., and of A Manual of Harmouies for the Gregorian Tones, 1884.

Hinton, Joseph Harold, organist and composer, born at Claydon, Bucks., January 1, 1862. Stuctied unter Jr. J. F'. Bridge, and others. In 1885 he was appointed organist of Hyndland Church, IIithead, Glasgow. He has composed a Setting of I'salm 130, Latin text, prockuced at Glasgow, April 26, 1887; a requiem, "Nan goeth forth," for voices and orchentra; a cantata, and other pieces.

Hipkins, Alfred James, F.S.A., writer on nusic and musical instrments, born at Westminster, Jume 17, 1826. (His father, James Hipkins, died April 25, 1882, was for many years a contributor to the Musical $\mathrm{J}^{\prime}(\mathrm{r} / \mathrm{l})$. In business connection with John Broadwood \& Sons, Emdon. Mr. Hipkins mado a special jommey to Berlin and Potsdam in 1881, under the pritronage of H.R.H. The Crown P'rincess of Prussia (now the freman Empress Frederick) to idrntify and examine the pianofortes made by Gottfried Silhermann, which had belonged to frederick the (rreat. In 1883 he was awarded the silver medal of the Society of Arts for a lecture on the technical history of the pianoforte. In 1884 , at the request of H.R.H. The Prince of Wales, he was eoneemed in fornding Jivision 11. (Alusic) of the Inventions Exhibition, Sonth Kensington, 1885, and became a member of the Music: Committee. He was also ehaiman of the committee of the IJistoric Loan Collee-

\section{HOARE.}

tion shown in the Royal Albert Hall in connection with that Exhibition, and for his services was awarded a gold medal. At the request of H.R.H. The Duke of Edinburgh, he became a member of the committee of the British Section of the Musical and Dramatic Exhibition held at Vienna in 1892, and acted as one of the honorary secretaries. He is, from 1895, honorary curator of the General Museum of the R.C.M.; and a Fellow of the Society of Antiquaries, from 1886. His lectures on the old keyboard instrmments, with his illustrations on the clavichord, spinet, and harpsichord, are well-known; they were given at intervals, from 1883 to 1893 . One vecasion was historic: at the Musical Association, Jume 7, 1886, when Rubinstein was present, and turned over the leaves for the accomplished player.

His writings include contributions to the Encyelopedia Britamica; Grove's Dictionary of Music and Musicians; the Musical Times; Musical Ricuiew (Novello, 1883); and the (now defunct) Musical World. Anthor of "Musical instrmments, historic, rare and unique" (A. and C. Black, 1888); The Cantor lectures on "Musical Instruments" (1891); "The standard of Nunical Pitch" (Society of Arts, Febrnary 26,1896$)$; and "A deseription and history of the Pianoforte, and the older keyboard stringed Instruments" (Novello, 1896 ).

Hird, Frederick William, organist and composer, born at Leeds, in 1826. Organist of All Souns' (1look Memorial) Church, Leeds. He was esteemed one of the fiment organists in Yorkshire, and an excellent musician and teacher, many of his pupils now ocenpying leading positions. He was also a good pianist, and gave chamber eoncerts with George Haddock, 1851-2. The splendid organ in his house was partly built, and wholly voiced by Schulze. He died at Leeds, November 9, 1887. He compused several anthems, including, "O God, onr Defender," performed in York Minster, Julilee Diay, 1887; a collection of introits, kyries, hymn-tumes and chants; Thene in A, and other pieces for organ ; Canzonctta, scherzo, ete., for pf.

Hirst, Thomas, author of "The Music of the church, in fonr parts; containing a general history of music, inchuding an account of Helrew music," London, 1841. "The Zephyr . . containing a set of original common tumes," ete. [1863]

Hitchin, Rev. Edward, Dissenting minister, anthor of "scripture pronf for singing of seripture Psalms, Hymms, and spiritual Songs," London, 1696.

Hoare, Margaret, soprano vocalist, studied under sims Reeves, and at the R.A.M. under W. Shakespeare, ohtaining the ParepaRosia l'rize in 1884. She made a sncecssful 


\section{HOBBS.}

appearance in London, December 19, 1882, in Gade's "Psyche," and a few months later in Gonnud's "Redemption." She was heard in many provincial towns in the next year or two. Sang at the Chester Festival, 1891; at the Royal Albert Hall, 1893; and at the Tonic Sol-fa Festival at the Crystal Palace, 1895, in "St. Paul"; and is established as a singer of reputation.

Hobbs, John William, composer, and tenor vocalist, was born at Henley-on-Thamnes, August 1, 1799. He was a Chorister in Canterbury Cathedral, and was articled to John Jeremiah Goss. He sang at Norwich Musical Festival in 1813. Tenor singer of Trinity, King's, and St. John's Colleges, Cambridge, and St. George's Chapel, Windsor. Gentleman of Chapel Royal, 1827. Lay-vicar Westminster Abbey, 1836. He died at Croydon, January 12, 1877.

Works.-Glees. Songs: Brave old Temeraire; Caliban [1861]; Crier, or lost heart; Dear father, take thy gentle child; England; Jack's alive; Music of the past; Nina; Philkis is my only joy [1848]; Soldier's departure; Then you have not forgotten; When Delia sings; Oh my own native land; Captive Greek Girl; Eulalia, and many others, amounting to over 100 .

Hobson, Frederick, see Lestie, Fred. Hoby, Charles, violoncellist and bandmaster, burn in London. Studied at R.C.M., violoncello, organ, and pianoforte; and instrumentation for military ban. under Charles Godfrey. IVent to India as bandmaster of the Punjab Frontier Force. His health failing, he returned to England, and became a candidate for the bandmastership of the Royal Engineers, but was disqualified on account of not having passed through Kneller Hall. He was then appointed organ ist to the Royal Military Asylum, Chelsea, and was engaged on the staff of the Orchcstral Iimes (now the British Musician), to which he contributed papers on the violoncello, and other subjects. In 1891 he went to South Africa with Mr. Daniel Godfrey, junior, as pianist to his opera company. After an extended tour, he settled in Natal as bandmaster of the Royal Rifles. He has composed a Suite for orchestra, "Scenes of childhood," produced, Durban, July, 1896 ; a number of pieces for violin and pf.; Songs, etc

Hodge, William, organist, born in London, in 1862. Scholar of the National Training Schoul for Music. Appointed organist of St. Marylebone Parish Church, 1886 ; Suborganist, St. Paul's Cathedral, and organist to the Royal Choral Society, Albert Hall, 1888. Gave recitals at the Bow and Bromley Institute, 1\$84, and elsewhere; and conducted performances of "Elijah" at St. Marylebone

\section{HOECK.}

Church in 1892. An organist of exceptional talent, his career was all too brief. He died in London, July 15, 1895 . His brother, Herbert Hodge, also an organist, studied at the R.C.M., and was made an Associate. He was appointed organist of Hornsey Parish Church in 1888, and is now holding a similar position at St. Peter's, South Kensington. He is Musical Director at the School for the Indigen $\mathrm{B}$ Blind, St. George's Fields, Southwark.

Hodges, Colonel C. L., published a "Collection of Peninsular melodies, with words by Mrs. Hemans, Mrs. Norton," etc., London [1830].

Hodges, Edward, organist and composer, born at Bristol, July 20, 1796 . Organist successively of Clifton Church; St. James Church, Bristol, 1819 ; St. Nicholas Church. Mus. Doc., Cantab., 1825. He went to America, 1838, and was appointed organist of Toronto Cathedral. In 1839 he became organist of St. John's Episcopal Chapel, New York. Organist of Trinity Church, New York, 1846. He returned to England in 1863, and died at Clifton, September 1, 1867.

Works.-Church Services. Anthens. Contributions to the Musical Journals. An Ap logy for Church Music and Musical Festivals, in answer to the animadversions of the Standard and the Record, London, 1834. An Essay on the Cultivation of Church Music, New York, 1841.

Hodson, George Alexander, song-writer, who flourished in the first half of this century, and died in 1863. He composed a number of fine melodies, among which may be named: Tell me, Mary, how to woo thee [1863]; My pretty gazelle; Bridal wreath ; Briton's home; Child's first prayer; O give me but my Arab steed [1828]; Poor Besiie; Six ballacts 1830].

His son GEORGE (born, Dublin, 1822, died, 1869), was a vocalist.

Hodson, Rev. Henry Edward, of Lichfield, Staffs., is the composer of a chramatic cantata, "The Golden Legend," performed in Londou, Nay 23, 1881; in Lichfield, Bimingliam, and other places, 1882-4.

Moeck, William Thomson, composer and conductor, born at Paisley, Jume 14, 1859. Studied under his father, Lonis Hoeck, music teacher in Paisley; also under Dr. A. L. Peace. Organist and choimmaster Renfrew Parish Church, 1874; Queen's Park U. P. Church, Glasgow, 1880. Conductor of Paisley Philharmonic Society, 1878-83; Hillside and Pollokshields Musical Associations; and Glasgow Amatenr Orchestral Society.

Works--Orchestral-Undine, characteristic piece, 1884; On the water, 1885; Overture, 1890 ; all produced in Glasgow. Romance, 'cello and pf., Op. 3; oboe and pf.; Legend, pf. and violin, 1890 (Prize, Glasgow Society of Musicians); pf. pieces, various. Te Deum, 


\section{HOFFMANN.}

op. 2; A love song; How I envy the ring, and others. Hymn tunes, etc.

Hoffmann, Richard, see Andrews, Richali) Hofmann.

Hogarth, George, writer and composer, born at Carfrae Mill, near Oxton, Berwickshire, in 1789. He was edneated at Edinburgh for the law. Member of Edinburgh Choral Union. Joint Secretary, with G. F. Graham, of Edinburgh Musical Festival, 1815. Contributed to the Mamonicon, 1830. Subeditor of the Morning C'hronicle, London, 18:3t; editor of the Musical Herald, 18t6-7, and musical critie of Daily Neus, 184666 . Secretary to Philharmonie Society, 1850-64. He married Hiss Thomson, daughter of George Thomson. Died at London, February $12,1850$.

Woris.-Musieal history, biography, and criticism, being a general survey of music from the earliest period to the present time. London, 1835; second edition, 1838, 2 vols. Nemoirs of the musieal drama, London, 1838, 2 vols, portraits. Memoirs of the opera in Italy, France, Germany, and Englaed, Lon. don, 1851. The Bimingham festival of 1852 , London, 1852. The l'hilharmonie Society of London, from its fomdation in 1813 to its fiftieth year, 1862, London, 1862. How's Book of British song, illustrated by several distinguished artists, with pianoforte accompaniments and biographieal and historical notes, London, 1845, 2 vols. Contributions to periodical literature. Glees and songs.

Hogartl was one of the few cultured men of letters who have written intelligibly about music. His works are all of standard value, and are still sought among musicians. One of his daughters, Catherint, married Charles Dickens the norelist, in 18:36; and another, Helen (Mrs. Roney), was a vocalist, and tanylht singing in London, and at the Iadies' College, Cheltenham.

Hogg, James, the "Fttrick Shepherd," poet, nusician, and general writer, was horn in Ettrick Forest, Selkirk, November, 1770. Engaged as farmer at Altrive, hut chiefly as contributor to Blackurod's Mugazine, and as a general writer. He died at Altrive, November 21,1835 .

Worrs. - The Nonntain Bard, 180?; Mador of the moor; The pilgrim of the sun: The Queen's wake; The Jacobite relies of Scotland, being the songs, airs, and legends of the adherents of the Honse of Stuart, Edinhurgh, 2 vols., 1819-21, with music; The Border garland, 1829 , with music; tales, fugitive pie es, ete. ; musical settings of his own verses.

Hohler, Tom, tenor vocalist, son of the Rev. F. W. Hohler, Reetor of Winstone and Coleshorne, Gloncestershire. Bom in 1839. Held an appointment in the Civil Service,

\section{HOLDEN.}

and was afterwards private secretary to the Earl of Dudley, upon whose advice he went to Italy, and studied under Romani. He sang in Italy, Switzerland, and Germany; and returning to London at the end of 1865, he was engaged for Italian Opera at Her Majesty's Theatre. He m ide his début, April, 1866, as Arturo, in "I Puritani," achieving great suecess. He sang in oratorio, "Elijah," Manchester, January, 1868, ete., and eoncerts in London and the provinces. In 1869, he studied further under P'ierre Wartel. He married, in 1880, Henrietta, widow of the sixth Duke of Newcastle, and retired from the stage; singing occasionally at concerts for eharitable purposes, and residing ehiefly in Paris. He died at Monte Carlo, May 2, 1892.

Holborne, Anthony and William, English musicians, who, in 1597, published in London, "The Cittlarne Schoole, by Antony Holborne, gentleman, and servant to her most exeellent Maiestie. Hereunto are added six short Aers Neapoliton like to three voyces withont the Instrument, done by his brother, William Hollorne."

Holcombe, Henry, composer and vocalist, born Salisbury, 1600. He was a chorister in Salisbury Cathedral, and afterwards a singer at Dpury Lane Theatre, London. He was a teacher of singing and the harpsichord in London, where he died in 1750 . lie published "The Musical Medley, or a collection of English somge and cantatas set to musie," 1745 ; "The Garland," a collection of wongs and cantatas [1740]; six solos for a violin and thorough-latss, with some pieces for the (reman flute and harpsichord," op. 1, Londom, 1745. Somgs: Dnke mpon dulie; (to, lapps paper; llappy man, ete.

Holden, George, composer and organist, was lum in 1s(0). He was organint of st. Feorge's Church, Liverpool, and teacher of music there. For many years he acted as conductor of the Apollo (ilee (tho of Liverpool. He dicd at liverpool, Decmuber 5, 1856. Composed Church Munic, comsisting of original anthems. . psalms, hymus, ete. [1840] : Sacred music by varions authors. Iance and organ music; in thems, songs, ete.

Holden, John, writer and composer, who lived in Glasgow during the latter half of the 18th century. He settled in Glangow as a potter, about 1757 , and was made a burgess in 1757. He acted as instructor to the band of the Glasgow College Chapel, and was in other ways comnceted with the musical affairs of the University. The statement in Fétis" " Biographie universelle des Mnsiciens," that he was a professor at the Eniversity is apparently based on Holden's comeetion with the music of the College chapel, or the statement on the title-page of the "Collection of Church 


\section{HOLDEN.}

Music." He issued "A Collection of Church Music, consisting of new setts of the common psalm tunes, with some other pieces... principally designed for the use of the Lnirersity of Giasgow," Glasgow, 1766. "An essay towards a rational system of music," Glasgow, 1770; Calcutta, 1799 ; Edinburgh, 1807. The psalm tune "Glasgow" is usually assigned to Holden.

Holden, S., Irish musician, issued " Collection of old-established Irish slow and quick tumes arranged for the harp, pf.," etc., [)ublin [1800], two books. "Selection of Masonic songs," Dublin [1812].

Holder, Joseph William, organist and composer, born in Clerkenwell, London, 1764. He was a chorister in the Chapel Royal, and studied music under Nares. Assistant to Reinhold, organist of St. George the Martyr, Queen Street. Organist snecessirely of st. Mary's Chureh, Bungay, and at Chelmsford. Bac. Mus., Oxon., 1792. He died in 1832.

WORFs. - Collection of catches, canons and glees, op. 6 [1787] : Collection of songs, duetts and glees, op. 1t [1800]. A mass. Anthems and Te Demms. Favourite collection of songs, op. $4[1786]$. Six sonatas for pf., op. 2 [17 45$]$; Sonatas for pf., opp. 20, 47. 56. Twentyeight preludes for pf. ... Lassie would ye love me (Oh! gin I were a baron's heir), Scots song, etc.

Holder, Rev. William, DD., clergrman and writer, born in Northamptonshire, in 1614. Fdncated at Cambridge. Rector of Blechindon, Oxford, 1642. II)., 1660. Canon of Ely. Canon of st. Paul's. suls-dean of Chapel Royal, 1674-89. He died at London, January 24, 1697.

Works.-A treatise of the natural grounds and principles of Harmony, London, 1694; another edition to which is added by way of appendix, Rules for playing a Thorow-bass, by the late M. Godfrey Keller, London, 1731; Evening service in C; Anthems, ste.

Holdroyd, Israel, “Philo-M[usicae," an English musician of the first half of the 18th century. He published “The Spiritual Man's Companion, or the Pious Christian's kecrea. tion, containing an historical accomut of music, etc.; grounds of music and composition in all branches. . . Psaln and hymu tunes," . . 3rd edition, 1733, 5th edition, 1753. Chants and anthems, 1733 , etc.

Holford, William, musician of the latter part of last and early part of the present century. He was a choir-master at Manchester. He compiled " Tocs di melodia, being a collection of congregational psalm and hymn tunes, from approved authors, arranged for four roices". n.d. [c. 1820 ].

Holland, Caroline, amateur composer. Daughter of Sir Henry Holland, and sister of Lord Knutsford. Miss Holland's Choir, under

\section{HOLLINS.}

her conductorship, has given concerts aunually, since 1883 , at which important works by Grieg, Rheinberger, Tinel ("Franciscus," 1.590), and others, liave been performed for the first time in England. Her compositions include a cantata, "Miss Killmansegg and her Golden Leg," produced 1883 ; ballad, "After the Skirmish" (Rohilcund, 1858), words by Sir Alfred C. Lyall, for chorus and orchestra, 1896 , etc.

Holland, Edwin, baritone vocalist and teacher of singing, boru in London, March 24, 1845. At first studied the violoncello under A. Guest, and played in the orchestra at Covent Garden, while Alfred Mellon was conductor. Later, he took up singing, and received instruction from Frank Romer, his incle. He then went to Italy and studied with Victor Maurel. For some years he sang in oratorio and concerts, but has chiefly devoted his attention to vocal training. He was appointed a professor of singing at the R.A.M., in 1880 , and resigned in 1892, on establishing an academy of his own. He has given anmual concerts by pupils, and operatic performances, since 1875. Author of Edwin Holland's Method of Voice Production, London, R. Cocks, in which exercises are written for each individual class of voice.

Hollingsworth, A. B., comic singer, who appeared in London music halls as the "Mau with the carpet hag," and in other eccentric sketches. He died at London, Octolser 10 , 186.5, and is buried at Finchley.

Hollins, Alfred, organist, pianist and composer, boln at Hull, september 11, 1865. Began his musical training at the age of six, at the Fork School for the Blind. From there he went to the Royal Nomal College for the Blind, Norwood, where he studied pianoforte playing with Fritz Hartvigson, and organ under Dr. E. J. Hopkins. He played, at a concert of the students, at the Crystal Palace, July 10, 1880 , and at later ones, showing remarkable powers as pianist and organist. His organ recitals in the provinces date from 1882, and he has been heard throughout the Lnited Kingdom and Ireland. He has twice visited America, in 1886, and 189. Appeared as a pianist at the Monday Popular Concerts, April 10, 1886; and at the Philharmonic, May 31, 18s8. He played in Berlin in 18\$5, and studied with Hans von Bulow, who called him "one of the rape true musicians amongst the piano rivtuosi." He is now a Professor at the Royal Normal College. He has composed a Concert Over. ture in C; Preludes, and sther organ music; pianoforte pieces, and songs.

Hollins, George, organist, born in Birmingham, March 16, 1809. Son of William Hollins, architect and sculptor. Pupil of Thomas Munden, whom he succeeded as 


\section{HOLLOWAY.}

organist of St. Paul's, Birmingham, and of the Town Hall (about 1837). He was a fine performer on the organ, and an excellent pianist; he was also a good singer, having a baritone voice of rich quality. He was frequently engaged in concert work, and was noted for his organ accompaniment to songs. Symptoms of phthisis (brought on by overwork) manifesting themselves, he was sent to the Isle-of-Wight; while away he ruptured a blood vessel, and was brought home, where he died, December 16, 1841. Very few of his compositions were published, but he wrote many hymn tunes and chants, and a setting of the Benedicite was very popular for mauy years, as was a song, "Sabbath Bell."

Holloway, Arthur Stephen, organist, pianist and composer of present time. Graduated IIus. Bac., 1875; Mus. Doc., 1894, Oxford. He has composed a church cantata, "The promised King," for Advent and Christmas; Songs, organ and pf. pieces, ete., and a Schiool Board Singing Tutor.

Holloway, H. R., author of a " Nanual of Chanting," London, 1850.

Holman=Andrews, see Ashton, GerTRU D.

Holmes, Alfred, violinist and composer, was born at London, November 9, 1837. He studied the violin under his father, Thomas Holmes, of Lincoln. Sopranist at the Oratory, King William Street, Strand. Début with Henry, his brother, at Haymarket Theatre, July, 1847. Appeared at Beethoven Rooms, London, 1853. Played in Germany, 1856; Austria, 1857; Sweden, 1857-9; Norway and Holland, 1860-1. Settled in Paris, 1864. Organised a quartet party, 1866. Travelled with it in Holland Prussia, and Germany, 1867. Ile died at Paris, March 4, 1876.

Works. -symmonies: Jeanne d'Are, st. Petersburg, 1867, London, February, 1875; The Yonth of Shakspere, Paris; The Siege of Paris, 1870; Charles XII.; Romeo and Juliet; The Cid, 1874; The Muses; Robin Hood, 1870. Inez de Castro, opera, 1869. Pf.music and songs.

Holmes, Edward, writer and musician, born near London, 1797. He studied music under V. Novello. Musical critic of Atlas newspaper. Marred grand-daughter of Samuel Webbe. He died in 1.S.A., Angust 28, 1859.

Works.-A ramble among the musicians of Germany, giving some account of the operas of Mnnich, Dresden, Berlin, etc., with remarks upon the church music, singers, performers, and composer's, and a sample of the pleasures and inconveniences that iwait the lover of art on a similar excursion; by a musical professor ; London, 1828; 2nd edit., 1830; $3 r d$ edit., 1838. Life of Mozart, including his correspondence, London, 1815; Life of Purcell; Analytical and thematic index of
HOLMES.

Mozart's pianoforte works; Contributions to periodical literature.

Holmes' "Life of Mozart" is recognised as the standard English work on that master, and is valued accordingly. His work on German musicians is now scarce, and is valued for its clever pictures of the German musical manners of his time.

Holmes, George, organist and composer, bom about the middle of the 17th century. He was organist of Lincoln Cathedral from 1704, and died in 1720. Composer of odes, anthems and songs.

Holmes, W. Gordon, physician and writer. Graduated M.D., Brussels, 1882; L.R.C.P., Edinburgh, 1871. Holds various appointments in London. Author of "Treatise on vocal physiology and bygiene, with especial reference to the cultivation and preservation of the voice," London, 1879; 2nd ed. 1880. Various works on the throat and its diseases.

Holmes, Henry, violinist and composer, brother of Alfred Holmes, born in London, November 7, 1839 . Studied under his father. Tonred with his brother on the Continent, from 1855, and played at the Gewandhaus concerts, Leipzig, December 4, 1856. Resided in Paris, Copenhagen, and Stockhohn, from 1864. Settled in London, and established the Musical Evenings, in 1868. Led quartets at the Mnnday Popular Concerts, February 12, 1883. Sometime professor of the violin at the R.C.AI.

Works.-Saered cantatas, Praise ye the Lord; and Christmas Day - the last produced at the Gloncester Festival of 1880; O may I join the Choir Invisible, for baritone solo, chorus and strings; songs, ete. Symphony in A, op. 32, Crystal Palace, February 24, 1872; No. 2; No. 3, in C; No. 4. Concert overture. Concerto in F, op. 39, violin and orchestra, Crystal Palace, Deeember 11, 1875. Octet, strings, 1886; Quintet, strings, and pf. and strings, op. 49; Octet, strings and two horns, 1889 ; Quartets, strings; and numerous pieces for violin and pf., ete.

Holmes, John, organist and composer of 17th century. Organist of Winchester Cathedral abont end of 16 th century, and of Salisbury Cathedral, 1602-10. He was the master of Adrian Batten and Edward Lowe. He composed services and anthens for the church, and madrigals, among which is "Thus Hommboots the lirthday celebrated," contained in the "Trimmphs of Oriana," 1601.

His soln, Thomas, who died at Salisbury, Nareh 25, 1638, was a composer.

Holmes, Mary, musician, authoress of "A few words about Musie, by M. H.," Imondon, 1851. Composer of "Songs with ut words, for pf." 1850$]$.

Holmes William Henry, pianisi and composer, born at Sudbury, January 8, 1812. 


\section{HOMES.}

He studied at the R.A.M., where he gained two medals. He afterwards became subprofessor of pf. at R.A.M. (1826), and later, principal professor. First appeared as pianist at Philharmonic Society Concert in 1851. He died in London, April 23, 1885. Among his pupils was W. Sterndale Bennett, J. W. Davison, George A. and Walter Macfarren, etc.

Works.--The Elfin of the lake, opera. Symphonies for orchestra. Concerto (The Jubilee) for pf. and orchestra; Sonata for pf. and violin; Numerous works for pf. solo; Songs, etc.

Homes, N., D.D., author of "Gospel Musick; or, the Singing of David's Psalms, etc., in the publick congregations, or private families asserted and vindicated," London, 1644.

Honeyman, William Crawford, violinist and author, born of Scottish parents at IVellington, New Zealand, January 30, 1845. In 1849 he was taken to Edinburgh, and he studied music and the violin. From an early age he contributed tales and sketches to various journals, and became connected with the "People's Journal" and "People's Friend," of Dundee. 'T'o these he contributed numerous detective tales, under the psendonym of James McGovan, and wrote various novels and articles. He also issued in the "People's Friend," a series of papers on "The Violin: how to master it," 1879, which has been reprinted in book form. He has also published "The Young Violini-t's Tutır and Duet Book," 1883; "Three easy Fantasias on Scottish Airs," 1884; "Hints to Violin Players," 1885; "The Secrets of Violin Playing."

Hook, James, composer and organist, was born at Norwich, June 3, 1746. He studied under Garland, organist of Norwich Cathedral. Settled in London, and became organist and composer at Marylebone Gardens, 1769-1773; and Vauxhall Gardens, 1774-1820. Organist of St. John's, Horsleydown. Gained Catch Club prizes, 177.2, 1780. Married to Miss Madden. He died at Boulogne, 1827.

Worns.-Mnsic for dramatic pieces: Dido, 1771; The Divorce, 1771; Trick upon Trick, 1772 ; Double Disguise, 1784; Jack of Newbury, libretto by Rev. Jas. Hook, 1795 ; Diamond cut Diamond, 1797; Music mad, 1807, etc. Songs: Hours of love; Hermit, op. 24; Adieu ma liberte; Along the birks; And where are you going?; Believe not youth; Blow cheerly, ye winds; Bonny sailor; Brown Bess; Can'st thou love me, Mary?; Come out, my love; Dear Mary, be mine; Death of Auld Robin Gray; Flitch of Bacon ; Gentle as the breath ; Gipsy girl ; Hail, lovely rose; Hook, or by crook; Hours of love; Hush every breeze; Lowland Kitty; $\mathrm{My}$ Nancy was the sweetest maid; Near Glasgow

\section{HOPEKIRK.}

city; Orphan Bess; Should fears alarm; Softly waft, ye southern breezes; Sweet lass of Richmond Hill (1789); Thro' the braes of Kirksaldy; What is love?; Within a mile o' Edinboro town; Ode for the opening of the New Exhibition Room, 1772. Petrarch's Somnets set to music, op. 60. The Hours of Love, or collection of sonnets, containing morning, noon, evening, and night. Pianoforte pieces, as sonatas, op. 16, 54, etc.; Rondos and transcriptions; Concertos, op. 11 ; Concertos for organ, op. 20, op. 55, etc.; Three sonatas for pf. and flute, op. 71; another set, op. 72 ; and another set, op. 77. Cantatas, canzonets, catches, glees (Christmas Box, 1795). The Ascension, oratorio, 1776. Guida di MIusica, being an easy introduction for beginners on the pianoforte, to which are added 24 progressive lessons, in the most useful keys, composed and fingered by the author, op. 37, London, 4 to, n.d.

His sons, Janes (1772-18\%6), dean of Worcester, and THEODORE (178\$-1841), novelist, achieved much distinction in their day. The latter was also a musician.

Hooper, Edmund, composer, borm at North Halberton, Devon [1553]. Chorister Westminster Abbey, 1582. Master of Choristers, IVestminster Abbey, 1588. Gentleman of the Chapel Royal, 1603. Organist of Westminster Abbey, 1606. He died at Westminster, July 19, 1621.

Woriss.-Harmonies in The whole Booke of Psalms, 1594. Anthems in Barnard's Collection. Contributions to Leighton's Teare's.

Hooper, Mrs. M., see Penna, Catherine.

Hooper, Rev. Richard, clergyman and musician, author of "Music and musicians (especially English) to the days of Henry Purcell . . "London, 1855.

Hope, Robert Charles, author of various works on dialect, holy wells, church plate, etc. In 1894, he issued a book entitled, "Mediaeval Music, an bistorical sketch with musical illustrations," London, Stock.

Hopekirk, Helen, piauist and composer, bor'u near Edinburgh, where her early studies were pursned under G. Lichtenstein and A. C. Mackenzie. These were followed by two years at the Leipzig Conservatorium, and study under Th. leschetitzki at Viemna. Her début was made at the Gewandhans Concerts, Leipzig, November 28, 1878, and she played, for the first time in England, at the Crystal Palace, March 15, 1879, the G minor Concerto of Saint-Saëns. Then followed recitals and concerts in England and Scotland, up to the year 1883, when Madame Hopekirk paid her first visit to Anerica. Her first appearance was at the Boston Symphony Concerts, December 8, 1883, and her first recital in New York took place December 27. She speedily became popular, and was 


\section{HOPKINS.}

engaged for the Philadelphia Festival of 1884 , and played in nearly every centre of musical culture. During her stay slo gave upwards of bwenty concerts in New York alone, her artistic performances attracting large audiences. In the spring of 1886 , she was back in Edinburgh again, but the next year she went again to Vienna, for further study with Leschetitzki. While there, she also studied composition, with Carl Nawratil, and orchestration with Richard Mandl. At the close of her stay she appeared at the Viemna Philharmonic, and on her return, at the Richter Concerts, London. Two more tours in America were undertaken, and since her returu to Europe, composition has chiefly occupied her time. Among her works may be named a Concertstück for pf. and orchestra, produced at Henschel's Concerts, Edinburgh, November 19, 1894, the composer taking the solo part ; a Concerto aud several orchestral works; a Sonata for pf. and violin (Boston Quartet Concerts and Chicago Exhibition, 1893); and upwards of a huudred Songs. Some sougs, aud a Serenade for yf. lave been published.

Hopkins, Edward, bandmaster, born about the year 1778 . Formed the first regular baud of the Scots Guards in 1815, after the return of the regiment from Paris. He was the first clarinet player of his day; aud, with a brother, was in the orchestra of Covent Garden Theatre, during its occupancy by Charles Kemble. He was also at one time conductor at Old Vauxhall Gardens. He retired from the army on a pension in 1838 , and died in 1860, aged 82. He was the father of a family of musicians. His son EDWARD became organist of Armagh Cathedral; and John Larisin (q.v.) of Rochester Cathedral. His daughter, LouIsA, entered the R.A.M., iu 1831; was King's Scholar, 1834; and afterwards an Associate. She married Richard Lloyd, a lay vicar of Westminster Abbey, and after his death settled as a teacher of music in Cheltenhan, where she died in 1880. The distinguished tenor singer, Ed. ward Lloyd, is her son.

Hopkins, Edward John, organist and composer, born at Westminster, London, June 30, 1818. Entered the choir of the Cliapel Royal, St. James's, in 1826, and studied under WWm. Hawes, in 1833 becoming a pupil of T. F. Walmisley. Obtained the post of organist at Mitcham Church, Surrey, iu 1834; St. Peter's, Islington, 1838; St. Luke's, Berwick Street, 1841 . He played his first probationary service at the Temple Church, May 7, 1843; and in the following October was elected organist to the "Honourable Societies of the Temple," a positiou he still retains. His Jubilee as an organist was marked by the presentation of a testimonial

\section{HOPKINS.}

in 1884; and on the completion of fifty years' service at the Temple Church, in May, 1893 , he was the recipient of a handsome testimonial from the two Honourable Societies of the Temple. In 1851, lie became a member of the Royal Society of MIusiciaus; Associate of the Philharmonic Society, 1852, Member, 1864; was one of the Founders of the College of Organists ; Hon. R.A.M., 1871; an original member of the Musical Association, 1874; and identified with Trinity College, Londou, as Examiner, etc. In 1882, he received the degree of Mus. Doc., from the Archbishop of Canterbury; and from Trinity College, Toronto, 1886 ; He is professor of the organ at the Royal Normal College for the Bliud, Norwood. His powers as an organist have been demoustrated not only in the services of his church, but in recitals all over the country, which he continued up to his 78th birthday, June 30, 1896; and modern rrgan building lias been greatly infleuced by his writings.

Worlis.-Anthems: Out of the deep; God is goue up (Gresham prize medals, 1838 and 1840) ; The King shall rejoice (in celebration of the marriage of the Prnce of Wales, 1863); (rod who tommandest the light to shine (Thanksgiving for the recovery of the Prince of Wales, 1872); Thou shalt cause the trumpet of the Jubilee to sound (composed for Her Majesty's Jubilee, 1887, and for which the Benchers of the Temple voted Dr. Hopkins fifty guineas); The Lord is full of compassion (composed for his own Jubilee), performed at the Temple Church, May 7, 1893; O, sing minto the Lold, and many others; Church services, hymn tunes, and chants. Organ: Select organ movements, from the scores of the great masters, 22 numbers ; Select movements, 15 numbers; Allegro moderato in A ; Adagio in D, and others. Chloe and Corinna, madrigal; songs, part-songs, ete. Author of The organ, its history and construction, London, 1855; second edition, 1870 ; third edition (with E. F. Rimbault) 1877 , etc. Editor of madrigals by Bennett and Weelkes, for the Musical Antiquariau Society; The Temple Psalter, pointed; Book of responses; Purcell's organ music (Novello). Lectures and papers, various, read before the Royal Archreological Institute, the Conferences of the Incorporated Society of MLusicians, etc. Contributions to the musical press. Senior editor of The $\mathrm{Or}$. ganist and Choimaster, his colleagues being Dr. C. IV. Pearce, and Dr. C. Vincent. Contributor of valuable articles on accompani. ment, organ, etc., to Grove's Dictionary of music and musicians.

Hopkins, John, organist and composer, brother of Edward J. Hopkins, born at Westminster, in 1822. Became a chorister at St. Paul's Cathedral in 1831, remaining there 


\section{HOPKINS.}

until 1838, but was allowed, some months previously to leaving, to take the organist's duty at Mitcham Church. He was appointed to St. Stephen's, Islington, 1839; I'rinity Church, Islington, 1843; St. Mark's, Jeriey, 1845 ; St. Michael's, Chester Square, London, 1846; and to Rochester Cathedral, May, 1856, a position he still holds. Many distinguished organists have been his pupils: Drs. J. F. and J. C. Bridge, E. J. Crow, and D. J. Wood: and Joseph Maas, the vocalist, etc. His compositions include Church services, anthems, a large number of hymn tuues (many written expressly for use at St. John's, Chatham), chants, etc, A set of twelve Sketches for pf.; a series of movements for the organ; a book of ten songs, etc. Geurge, and GLanvill Hopkins, his sons, are organists; the former at Gillingham Church, and the latter at Trinity Church, Old Brompton, and assistant orgauist at Rocbester Cathedral.

Hopkins, John Larkin, organist and composer, bom at Westminster, November 25, 1819. Cousin of E. J. Hopkins. Chorister in Westminster Abbey under James Turle. $\mathrm{He}$ was successively organist of Rochester Cathedral, 1841 ; Trinity College, Cambridge, 1856 ; and Cambridge University, 1856. Mins Bac., 1842, and Mus. Doc., Camb., 1867. He died at Ventnor, Isle of Wight, April 2\%, 1873.

Works. -Services in $\mathrm{C}$ and $\mathrm{E}$ flat; Te Denm in G; Twelve anthems dedicated to the Dean and Chapter of Rochester [1830]; numerous separate anthems. Five glees, and a madrigal, London, 1842. Part-songs, songs, etc.

Hopkins, Thomas, organist, brother of E. J. Hopkins, was, circa 1862, organist of the Edinburgh University Music Hall, in Park Place. He afterwards removed to York, and was for many years organist of St. Saviour's Church, and also had the care and tuning of the Cathedral organ. He had a rare gift as an extempore player. He died at York, March 22, 1893.

Hopkinson, Thomas, organist and writer on music, born in York, October 22, 1826. Quite early in life he had a strong predilection for drawing, and wished to become a painter, but his father decided for music, and at the age of eight he became a chorister in York Minster. There he remained for nine years, a pupil of Matthew C'amidge. Two days after leaving the choir, in 1843, he became organist of the two churches of Pontefract, posts be retained until 1856, when he removed to Hull. At that time there were only three music teachers in the town, and he soon found himself fully occupied with teaching in the district. He held several organ appointments. About 1886 he retired, and took up his favourite art of water-colour

\section{HORN.}

painting. For forty years' past he has contributed to the local Press, and the unusical Journals, letters on various topies, and has been a strenuous adrocate of the claims of native musicians, and our own national art.

Horan, John, organist, born at Drogheda, in 1831. Organist successively at Booterstown, Sandymount. St. Andrew's, Dublin, Adare, Tuam, and Derry. Sometime member of the Choir, Limerick Cathedral; Assistant organist and master of the choristers; then organist and choirmaster, Christ Church Cathedral, Dublin. He has composed some anthems, and organ music. His son, George Frederick, was appointed organist of Trinity Church, Rathmines, in 1886. He has written church music; "A voice in the gloaming," and many other songs, some of which are popular. John Horan, another son, is solo bass in Christ Church Cathedral Choir, Dublin.

Horn, Charles Edward, composer and conductor, born in London, Jume 21, 1786. Son of Carl Friedrich Horn (1762-1830), a German musician under whom he studied. He also studied under Fauzzini, in 180s, and sang at the English Opera House in 1809. He studied singing under Thomas Welsh in 1809 , and re-appeared as a voealist in 1814. Mnsical director at Lycemn, 1831-32. He went to America and introduced English opera, 1833, and was a music-publisher in America for a time. Returned to England in 1843, and became musical director of Princess's Theatre, London. He settled in America as director of the Händel and Haydn Suciety of Boston, in 1847, and died at Boston, ()etoher $21,1849$.

iVorks.-Oratorios: Remission of Sin ; Satan, 1845; Daniel's Prediction, Lundon, 184h. Operas, etc.: Magie Bride, 1810; Tricks upon Travellers (with Reeve), 1810; Bee-hive, 1811; Boarding-house, 1811; Rich and Pour', 1812; Devil's Bridge (with Braham), 1812; Godolphin, 1813; Ninth statue, 1814; Woodman's Hut, 1814: Charles the Bold, 1815; Persia Hunter, 1816; Election, 1817; Wizard, 1817; Circe, 1821; Actors al Fresco (with Cooke and Blewitt), 1823; Philandering, 1824; Peveril of the Peak, 1826; Honest Frauds, 1830; "M. P." Christmas Bells, cantata. Songs: Als, flattering man; Breaking of the day; Brian Boru; Chimes of Zurich; Cherry Ripe; Child of earth; Deep, deep sea: Desert isle; Early home; Fond heart; He loves and rides away; I've been where fresh flowers; Long time ago; Love's stolen kiss; My bomie barque; Mermaid's care; O never say I stole the heart; Old occan is calm; The sun is on the mountain; Trafalgar; When Mary is away ; Woman's heart is free. Duets and glees. Pianoforte music. Hindoo Melodies Harmonized, London, 1840. 


\section{HORNCASTLE.}

His wife, born MARia Horton, was born at Birmingham in 1811. She sang in opera in Americil and elsewhere. She devoted herself to teaching after $18 \pm 9$, and died at Morrisania, Jannary, 1887. She was a sister of Mrs. German Reed.

Horncastle, Frederick William, Irish composer and organist of the present century, who flourished about 1810-50. He was organist of Armagh Cathedral, 1816-23, and afterwards a Gentleman of the Chapel Royal. He composed a great number of pieces for the pf., with songs, glees, comic rounds, etc. He compiled "The Alusic of Ireland; as performed at Mr. Horncastle's Irish Entertainments," London, 184t, 3 parts, etc.

Horncastle, John Henry, author of "The Whole Art of Singing at Sight," London, 1829.

Horne, George, D.D., author of "The antiquity, use, and excellence of Church Music: a scrmon preached at the opening of a new organ in the Cathedral Chureh of Christ, Canterbury ..." Oxford, 1784.

Horne, Rev. Thomas Hartwell, scholar and biblical writer, born in London, in 1780. He was a clergyman in London, and in 182t he became an assistant in the British Museum, where he remained till 1860 . He died at London, January 27, 1862. Compiled "Manual of Parochial Psalmody," London, 1829; "Selection of Psalms and Hymns, arranged by Thomas Henshaw, 1829 ('l unes for No. 1)." "Historical Notices of Psalmody," London, 1847. "Introduction to the critical study and knowledge of the Holy Seriptures," 1813,3 vols" "Introduction to Bibliography," 2 vols., and other works.

Horner, Burnham W., organist, composer, and writer, born at Luton, Beds., in 1848. Studied under Dr E. J. Hopkins, Franklin Taylor, and Signor Ciabatta. In 1863, he was appointed organist of St. Mary's, Mortlake; and in 1867 became assistant organist of the Chapel lioyal, Hampton Court. Appointments followed at Holy Trinity, Richmond, 187t; St. Luke's, South Kensington, 1893. He has appeared with success as a pianist at various concerts. Of his compositions, a cantata, "Penelope," was proanced at Richnond, December, 1890; and he has published a Festival March for organ, besides arran:ements of the overtures to "st. Polycarp," and "Hagar" (Ouseley). Many papers on musical topics have been issued by the "Sette of Odd Volumes," and in other ways, including "Organ writers of the 18th and 19th centuries," "Musical London a Century ago," etc. He is author of "Organ Pedal Technique," Novello, 1 s95.

Horner, Ralph Joseph, conductor and composer, boru at Newport, Mommonthshire, April 28, 1848. Educated at Leipzig

\section{HORSLEY.}

Conservatorium, under Moscheles, Reinceke, Hauptmaun, and others. Graduated IIus. Bac., Durham. Some time conductor of opera at the Alexandra Palace, Muswell Hill; and for eleven years conductor of Sullivan and other opera companies in the provinces. Organist of Park Hill Church, Nottiugham, 1890-94. At the present time he is conductor of the Nottingham Amateur Orehesiral Society, and the Amateur Operatic Company; and lecturer in music at Nottingham University College. He has composed a dramatic cantata, "Confucius," produced at Albert. Hall, Nottingham, February 19, 1892 ; several operettas; and has published numerous pt. pieces, songs, etc.

Horrocks, Amy Elsie, pianist and composer, born, of British parents, at Rio-Grandedo-Sul, Brazil, February 23, 1867. Entered R.A.M., in 1882, studying pianoforte and composition under Ad. Schloesser, and F. W. Davenport. Won the Putter Exhibition, 1888, and the Bennett Prize, 1889. Elected Associate, 1890; Fellow, 1895. At the Academy Concerts, a Pf. Trio in B flat (1887); Sonata for 'cello and pf. (1889), and other compositions were perfomed. Resident in London, as tcacher. Has given Channber concerts in Princes' Hall, 1891.

Works.-Ineidental music to An Idyll of New Year's Eve, Chelsea, January, 1890 ; The wild Swan, op. 9; The winds, op. 21 ; A Spring morning, op. 22; dramatic cantatas for female voices; two Fairy songs (Elfin sleep-song, and The Fairy thrall), op. 13, for soprano solo, chorus of female voices, with strings, harp, and triangle; two songs, op. 3, with orchestra; album of twelve songs, op. 6 ; six songs, op. 10 ; fourteen songs, op. 20 ; eight rocal canons, op. 15 ; ten canons, op. 18 ; songs, varions. Sonata in G, pf. and violoncello, op. 7; variations for pf. and strings, op. 11; orchestral legend, Undine, op. 16, Queen's Hall, February 6, 1897. Tarious pieces $f \circ \mathrm{r} p \mathrm{f}$. solo, violin and pf., ete.

Horsley, Charles Edward, composer and organist, son of William llorsley, was born in London, December 16, 1822. He studied under his father, Moscheles, and at Leipzig under Hauptmann and Mendelssohn. Organist of St. John's, Notting Hill, London. He went to Australia in 1868; and alterwards settled in the United States. Hedied at New York, May 2, 1876.

Works.-Oratorios: David; Joseph ; Gideon; Glasgow, 1860. Comus, cantata for solo and chorus (Milton), 1874; Impromptu for pf., op. 12; Trio, No. 2, for pf., viola and 'cello, op. 13; Sonata for pf. and 'cello (1844); Quartet for pf. and strings, 1845; six Lieder for roice and pf., op. 21. Anthems. I'f. pieces, various. Songs, part-songs, ete. Textbook of Harmony for schools and students. 


\section{HORSLEY}

Horsley, William, composer, organist, and writer, born at London, November 15, 1774 . Articled to T. Smith, a pianist. He studied under J. W. Callcott and Pring. Organist of Ely Chapel, Holborn. Established Concentores Sodiles (society for propagating the study of concerted vocal music), 1798-1847. Assistant organist at Asylum for Female Orphans, 1798. Mus, Bac., Oxon., 1800. Chief organist of Orphan Asylum, 1802. Organist of Belgrave Chapel, Grosvenor Place, 1812 ; Charter-house, on death of Stevens, 1837. He married Élizabeth $H$. Calleott, daughter of J. W. Callcutt. He was one of the founders of the Philharmonic Society. He died at London, June 12, 1858.

Worrs.-Glees, canons, etc., published in five different collections, op. 1, 1801; op. 3, 1806 ; op. 4, [1808]; op. 6, 1811, and 1827. Forty canons of various species for $2,3,4$, and 6 voices in score, op. 9. Tocal harmony (edited) London, 7 vols. 1830]. Elegiac odes to memory of $\mathrm{S}$. Webbe and $\mathrm{S}$. Harrison. A collection of Psalms, with interludes, 1828. Twenty-four P'rahn tunes and eight ehants, 1844. Calleott's glees, edited with memoir, London, 2 vols., 1824. Airs of the Rhine, edited 182s Pf.music, miscellaneous. An explanation of musical intervals, and of the major aud minor scales, op. 8, London, 1825. An introduction to the study of practical harmony and modulation, London, 1847. Songs and canzurlets, ete.

Horton, George, oboist. Student and Associate, R.A.MI. Nlember of the orchestras of Her MIajesty's Opera; Bimingham Festi. val to 1888; Leeds Festival to 1889; Three Choirs Festival to 1894 , as performer on the oboe and cor Anglais. He has also played the oboe d'amore in Bach's l'assion NInsic, etc., in Westminster Abbey and elsewhere; and long held the leading position in his special department. He is a professor at the R.A.M. and R.C.MI., and a nember of the Queen's private baud.

Horton, Maria, see sub. Horn, Charles EDWARD.

Horton, Priscilla, see Reled, Il ras. German

Houghton, William, organist and composer, born in Dublin, 1844; died there in 1871. He was a chorister and leputy-organist in Christ Church Cathedral, Dubliu, and organist of St. Ann's, Dublin. Composer of anthems, songs, and organ music.

Houldsworth, John, organist, violinist, and composer, who was born in the latter part of the eighteenth century. He was appointed organist of the Parish Church of Halifax in 1819. He played first violin at the Forkshire Festivals of 1823 and 1825. Died after 1836 . Le edited an edition of Chetham's Psahmody, 1832, and composed several hymm-tunes, ehants, ete.
HOWELL.

Houseley, Henry, organist and composer, born at Ashfield, Nott.., September 20, 1851. F.C.O. From about 1875 resident in Derby, and organist and choimaster of st. Luke's church. Then, removing to Nottingham, he became organist of St. James' Church in 1882, and Lecturer in Musical Theory at Nottingham University College. In 1888 he left England for America, as sub-organist and choimaster of the Cathedral, Denver, Colorado. He has written an opera, "Native Silver," performed at Denver. 1892; a quartet for strings; a number of pieces for pf.; and some vocal music, among which is a part-song which gained a prize given by the Glasgow Select Choir.

Houston, Allan, Scottish musician, who lived in Glasgow as a teacher of music at the end of last and beginning of the present century. He published a "Collection of church Tunes, with a few anthems, canons, and catches," Glangow, 1799.

Howard, Samuel, organist and composer, born in London, 1710. He was a chorister in the Chapel Royal under Croft, and he also studied minder P'epusch. Organist of St. Bride's and St. Clement Danes Churches, London. Mus. Doe., Cantab., 1769. He died at London, July 13,1782 .

Wionks.-Amorons Goddess, opera, 1744. Musical Companion, a collection of English songs, London, n.d. Anthems, psalms, cantatas; large number of songs and instrmmental music.

Howard, William, conductor and violinist, born at Edinlumgh, March 18, 1831. He plaved the violin in the Theatre Royal, Edinlurgh, monder Alex. Markenzie, and in 1857 he leccame musical direter of the Edinlourgh and Clasgow assemblies. Conductor of the Edinburgh ('horal L'nion, 1s63-1865. He died at Dumfries, June 2, 1877.

Howe, W. F., anthor of "Lecture on French Horns, ancient and modern, both historical and practical," n.d.

Howell, Arthur, domble-hass player and vocalist, born in $18: 36$. Som of James Howell. He married Mliss Rose 1 lersee, the vocalist, in 1874, with whom he travelled in Australia, etc. For some time he was stage manager to the Carl Insa Opera Company. He died on April 26, 1845.

Howell, Edward, visloncellist, bom in London, February, 1846. F.R.A.M. Professor of the rioloncelio at R.A.II., and R.C.II. Mnsieian in ordinary to the Qneen. Nember of the Phitharmmic Society, and for many rears prineipal risuncellist in its orchestra; holds the wane puition in the Lends Fentival orchestra fr m 1 ses); and at the meetings of the Three ('h sils. Is widehy linum as soloist and quartet plaser. Appeared at the Crystal Palace $C$ neerts for the first time, 0 ctober 27 , 


\section{HOWVELL.}

1883 , as suloist in Goltemann's third violoncello Concerto. Author of a "First Book for the Violoncello" (from Romberg), ete.

Howell, Francis, composer, son of James Howell, lom in 1834; died, Octoher 28, 1882. He wa blind from 1s:1. Composer of "The Land of l'romise," oratorio; "Song of the Months," eantatar. Songs, etc.

Howell, James, double-bass player and teacher, borm at Plymonth, in 1811. He studied at the R.A.Mi., under T. MI. Mudie, and studied the donble-bass under Anfossi. Profesior of double-bass at the R.A.M. Member of R.A. II., etc. 1Ie died, London, August 5, 1879. His sun, ArThur, was also a bassplaver.

Howell, Thomas, conposer, writer, and pianist, was bron at Bristol in 1783. He was a teacher at liristol. Author of "Practical instructions for the Piunoforte" [1816]; "Lessons in all miljor and minor kevs, for the pf.," n.d.; "six progressive sonatinas for the pf." [1\$17]; "Uriginal instructions for the Violin," Bristol, 1825; " Practical elementary examples for the violin" [1829]; "six quartets, for 2 violins, and other instruments," ctc.

Howgate, John, musician, who issued "Sacred Music: eighten hymm and psalm tunes," etc. MIanchester 1810].

Howgill, William, ormist, born in the 18th century. Hewas orgunist at Whitehaven, in 1794, and afterwards in London. Componer of four Toluntaries. . . and six farourite Psalm tunes [1820; Pincell's, or, the Velsh gromud, with ome hundred variations for the grand pit., London [1810].

Howson, se'f Albertazzi, Emia.

Howson, George, earthenware manufactur'r a man whose work in the cause of masie discrves a word of record. Nith the late .T. W. Powell (q.v.), he was a pioncer in the work of elementary vocal teaching in North sitaffordshire, and in popularizing the sol-fa srutem. He gave up teaching many years ago, lut was always a warm smpporter of any movennent for providing good nusic for the people. lle was president of the 11 mley Gloe and Madrigal rocietr, and founded a seholarship in connection with the Tonic sul-fa College, for the benefit of North Staffordshire students. Ile died at silselton, Hanley, April 4, 1sog, aged serenty-eight.

Hoyland, John, orgmist and composer, born at siluefficld, 17\%3. He studied nuder Iather of shetfield, and becane organist of St. James' 'lmereh, Sheffirld, in $180 \mathrm{~s}$; orginist of Parish C'hurch, Touth, Lincoln, 1819. He died . Tannary 18, 18.7. Composer of anthems, songs, and oryan music.

His som, WiLldAM, was also an organist.

Hoyle, John, nusician, who flourished about the middle of the 18 th century, and
HUDSON.

died in 1797. Author of "Dictionarium Musicce, being a complete Dictionary or Treasury of Music," 1770. Other editions, 1790 and 1791 .

Hoyte, William Stevenson, organist and composer, born at sidmouth, Devon, September 22, 1844. Received instruction from Sir J. (ross, and George Cooper. Organist of St. Paul's, Hampstead; All Saints', Kings Lynn ; St. Pauls, Bow Common, 1862; St. Matthew's, City Road, 1864; Holy Trinity, Westminster, 1865; and All Saints', Margaret street, from 186s to the present. Has given organ recitals at the Alexandra Palace; the Royal Albert Hall; in (tlasgow, and other places; and has also apleared with success as a pianist. For some vears exaniner to College of Organists: [rofessor of organ at R.C.M., from 1888; at R.A.MI., 1893; and of pianoforte at Fuildhall school. Member of the Philharmonic Society. He has composed a "Book of Iitanies, metrical and prose, with an Evening service"; "The Choral office for the solemnization of Holy Matrimony" ; Church music, various. Minuet and Trio, orchestra, 1882 ; organ and pf, pieces, ete.

Hubi, Georgeanne, see Newcombi, (ieorGEANNE H.

Huckel, William, musician, author of " Practical instructions in the art of singing," London, 1845. "Practical instructions for the cultivation of the Voice, with a series of rules for its adaptation to the chamber, the concert room, and the stage." London, n.d.

Huddart, Fanny, contralto vocalist, was born in the first part of the present century. She sang in Italian and English opera, and in oratorio, in London and the Provinces, and had a high reputation in her day. She was married to Mr. John Russell, of Drury Lane Theatre. She died at London, June 28 , 1880 .

Hudson, Arthur, violinist and composer, boru at Hull. Studied at R.A.M. Resided for some time at Clifton, Bristol; now settled as professor of his instrmment at $\mathrm{Hull}$. He has composed a Sonata, a Ronnuce, and other pieces for violin and pf, which have been performed at Bristol, etc.

His brother, JoHN WILLIA HUDSON, boln at Hull, is organist of St. James's Church there, and is the composer of a string Quartet in A minor; a Trio for pf, and strings, produced at Hull, Bristol, ete.

Hudson, Robert, composer and vocalist, born February 25, 173z. He studied under Charles King, and was originally a tenor singer in Marylebone and Ranelagh Gardens, London, but in 1755 became assistant organist of St. Mildred, Bread Street, London. He next became vicar-choral of St. Panl's Cathedral, in 1756: Gentleman of the Chapel Royal, 1758; Almoner and master of the 
HUGHES.

children of St. Paul's, 1773-93; and musicmaster of Christ's Hospital. He died at Eton, December 19, 1815. He composed serviees, anthems, hymus, and glees, and edited "The Myrtle, a collection of new English Songs," in three books, 1767.

His daughter, MAlx, was organist of St. Olave, Hart Street; St. Gregory, Old Fish Street, 1790-1801. She died in London, March 28, 1801. Composer of a few hymns.

Hughes, David, baritone rocalist, born at Landore, Swansea, in 1863. After singing with success at local concerts, he entered the R.A.M., studying uuder Manuel Garcia, and winning the Parepa-Rosa (1887), Evill (1889), Leslie Crotty (1830), and other prizes. He made his lébut at the Monday Popular Concerts, Bristol, March 10, 1890, and speedily won for himself an honourable position. He has been heard at the primcipal oratorio eoncerts, etc.

Hughes, Mrs. F. J., authoress of "Harmonies of Tones and Colours developed by Evolution,' London, 1883, illustrated. Appendix, 1885.

Hughes, G. A., musician and teacher, author of Instruetion Book for the Pianoforte or Organ for the Blind, London, 1848. Congregational Psalmody, 1843.

Hughes, J., author of "Young Student's Musical Definitions, London, 1877.

Hughes, Joseph, halpist, born iu North Wales. In 1839, published a collection of Welsh airs, partly arranged, partly composed by himself. Soon afterwards, this promising yomng harpist and musieian went to America, and was accidently drowned in the Hudson.

Hughes, Richard Samuel, pianist and composer, born at Aberystwith, July 14, 1855 , Studied at R.A.M. Organist at the Independent Chapel, Bethesda, near Bangor. Published a Cantata, The shepluerds of Bethleham, anthems, part-songs, and a number of very popular songs. In this last respect he has been ealled "'lhe Sullivan of Wales." He was an al)le executant, and well known throughout the Principality. He died at Bethesda, Mareh 5, 189:.

Hullah, John Pyke, composer and teacher, boln at Worcester, June 27, 1s12. Hestudied under W. Horsley, 1829, and at the 1R.A.M., in 1832. Tisited Paris, and adopted Wilhen's method of roeal instruction. Musical instructor in Six James Kay Shuttleworth's (then Dr. Kay) Training College, Battersea, 1840. Taught inusic to schoohmasters in Exeter Hall, London, 18t1. Extablished classes in St. Martin's Hall, 1847-50. Professor of rocal music, King's College, London, 184t-7t; do. Queen's College, London, and Bedford College. Organist of Charterhouse, London, 1858. Conductor at R.A.M., 1870-73. Musical Enspector of Training Schools for
HUME.

United Kingdom, 1872-retired 1883. LL.T), Edinburgh, 1876. Nember of Society of st. Cecilia, home, 1877, and of Music Academy of Florence. He died at Lomdon, February 21, 1884.

Norks.-Operettas: The village coquettes (Dickens); The untpost; The barbers of Barsora. Singer's library of Concerted MusicSecolar and sacred series, 6 vols. Whole book of Psahms, with the cauticles and hymns of the Church, for morning and evening service ... Lomdon, 1s4t. Fifty-tight Finglish songs, by composers chiefly of the 17 th and 1sth centuries. Songs: C'one forth from thy bower ; Home of our youth; Gre look of love; Free conspanion; Joy coneth in the monning; Message from the hattlefield; The stom. Motets, anthems, concerted rocal music, etc. Method of teaching singing, by Wilhem, London, 1442; do., revised and reconstructed edition, 1850. Grammar of rocal music, founded on Wilhem's method, 18t3. Inity and advantages of learning to sing, London, 1846. Grammina of munical hammony, 1853; Exercises for do., 1873; new edit., 1873. Music in the parish church, a lecture, London, 1856 . Histury of modern music: a course of lectures delifered at the Royal nustitution of (rreat britain, 1862 (2 editions). Lectures on the thisd or transition period of musical history, Londun, 1865: 2nd edit., 1s76. The song looks, works and tmes from the best poets and musicians, 1866. Cultivation of the speaking ruice, Oxford, 1870 ; another edition, 1874. Grammar of eunterpoint. Rudiments of mmical grammar, n.d. Notation: Brief direction concerning the chojce, adjustment, etc., of the musical alphahet, 1876 . Time and tune in the elementary school; new method of teaching rocal music and exerciscs, $187 \%$. Husic in the homse (Art at Home series), 1877. Exercises for the cultivation of the voice, 2 parts, n.d. How can a sonnd knowledge of music be generally dissernimated? Lomion, Longinan, 16rs. Reportis to Government on progress of musical education in schools. Contributions to prodiodical literature. See "Life of John Hullah, by his wife," London, 1886.

Hulley, William Frederick, organist and composer. Conductor of Choral and Orchestral Sucieties, Swansea, and organist of st. David's, Roman Catholic C'hurch in that town. He is the composer of two tomic operas, "The Coastguard," produced, 1886; and "The Pustic," produced, 188s, at simansea.

Hume, Alexander, composer and minor poet, born at Edinburgh, Fehmary 7, 1811. Engaged in business and teaching in Fdinburgh and Glasgow. He died at Glasgow, Fehruary 4, 1859.

Works.-The English Hymm Tume Book, 


\section{HUME.}

containing two hundred and four of the most common hymms used in England: arranged for four voices, Edinburgh, n.d. Anthems and Sacred Songs, containing fifty-four pices, Edinburgh, 11.d. Gall's Psalm and Hymn Book, Edinburgh, 1842. Six sensible songs, Songs: Afton Water; My ain dear Nell; The Scottish emigrant's farewell, etc. Glees and ducts. Poens, various. Hume's version of "Afton Water" is now the one almost universally sung to Burns' song.

Hume, J. Ord, bandmaster and composer, born in Edinburgh, September 14, 1864. He joined the Duke of Bucclengh's Dalkeith Militia when eleven years old, and became solo cornet a year later, studying under Alexander Miller. When sixteen he went to the band of the Royal Scots Greys as solo cornet, and remained with the regiment until 1887. He was then appointed organist of the Military Presbyterian Church, Aldershot, and bandmaster of Aldershot Town, and Famham Institute bands. After holding various other appointments, he became bandmaster of the 3rd V.B., Durbam light Infantry, Sunderland. $\mathrm{He}$ is also professional teacher to many bands in the district; and in a contest held at Newcastle-on-Tyne, November 16, 1895, his bands carried off the 1st, 2 nd, 3rd, 5th, and divided the 6th and 7 th prizes. As an adjudicator, he has had much work, and headed the list in 1895. He has written upwards of 500 pieces, and is the principal writer for A. Haigh's Brass Band Journal, and The Cornet Band Journal. A book of sixteen marches by him is published by Rudall Carte \& (o).

Hume,'Tobias, English military officer and musician, was a performer on the viol-dagamba, and a colonel in the army. Died in the Charterhouse, London, 1645. He wrote "The First Part of Ayres, French, Pollish, and others together, some in Tabliture and some in Pricke," 1605; "Captain Hume's Poeticall Musicke, principally made for two Basse Violls, yet so constrned that it may be plaied eight several waies, mpon smindie instruments, with inuch facilitie," 1607.

Hume, William, composer and editor, son of Alexander. Hume, born at Edinburgh, September 25, 1830. Settled in Crlasgow as teacher of riolin and singing. Editor of musical publications of Mr. Hamilton, Glasgow; Grall and Inglis, Edinburgh ; and Parlane, Paisley. For some rears, from 1872 , musical critic of The Bailie, Crlasgon, and contrilutor to various musical jommals. His compositions incluce the cantatas: The call to battle; Blind Pintimens; and Psalm 67, for trelsle voices. A motet for soli and chorus, Answer me, huming stars of night (Hemans); Antherus, songs, and part-songs. Editor of Tnion sacred Tume-book; The Westminster Wesleyan Tune-book; Psalm and Hymu

\section{HUNT.}

tunes, with supplement of anthems; Harmonium Tune-book, etc.

Humphrey, Pelham, or Humfrex, composer, was born in 1647. Chorister in the Chapel Royal, under Henry Cook, 1660, and a pupil of Lulli, at Paris, in 1664. Gentleman of the Chapel Royal, 1667. Master of Choristers, do., 1672. He died at Windsor, July 14,1674 .

Wolks.-Anthems and Services in collections of Clifford, Boyce, Tudway, etc.; Haste Thee, O God; Have mercy upon me; Hear, $O$ heavens; Like as the hart; Lord, teach us; O Lord nry God; Rejoice in the Lord; Thou art my King, O God. Odes on the King's Birthday, and on New Year's Day. Songs in various collections, etc.

Humphries, John, composer and violinist of the 18 th century; died in 1730.

Works.-12 Concertos in seven parts, for 2 violins and violoncello obligato, etc., op. 2. 12 Concertos in seven parts, for the following instruments: one for 2 trumpets and kettledrums; two for 2 hautboys and violins, ete., op. 3.

Hunnis, William, musician and author of the 16th century. He was a Gentleman of the Chapel Royal in the time of Edward VI., but was dismissed by Mary for his part in plots against the Roman Catholics. On the accession of Elizabeth. he was reinstated at the Chapel Royal, and became custodian of gardens and orchards at (ireenw ch, 1562; and master of the children of the Chapel Royal, in succession to Edwardes, 1566. He died on June 6, 1597.

Works.-Certayne Psalms chosen out of the Psalter of David and drawen furth into English meter, Loudon, 1549. A hyve full hunnye, containing the first booke of Moses, called Genesis, tumed into Englishe meetre, London, 15i8. Seven solss of a sorrowfnil soule for sinne, . . whereunto are annexed his handfull of honisuckles, London, 1583; also $1585,1587,1621$, ete. Hunnies' recreations, containing foure Godlie and compendious discourses, Loudon, 1588. Music in MIS. preserved in the Music School of Oxford.

Hunt, Anna, see Thillon, Anna.

Hunt, Arabella, vocalist and lutenist of the 17 th century. She was attached to the family of Queen Mary, as a teacher, and was much estecmed as a performer. Blow, Purcell, and other musicians were among her friends, and poems on her were written by Congreve and $H$ ghes. She died on December 26,1705 . Kneller painted ler portrait.

Hunt, Rev. Henry George Bonavia, writer on music, born at Malta, June 30,1817 . Privately edncated in music. Graduated Mus. Bac, 1876, Oxford; Mus. Bac. and Mus, Doc., Dublin, 1887. F.R.S.E., L.T.C L. Choirmaster, South Hackney Parish Church, 
HUNT.

1872-5. Warden of Trinity College, London, 1872-92; Professor of Musical History, 187687 ; and Professor Emeritus, 1892. Appointed Curate and evening preacher, St. Jannes's, Piccadilly, 1884; Incumbent of St. Paul's, Kilburn, 1887. His compositions are, "The Angels' Song," and Psalm 133, for soli, chorus and orclsestra (degree exercises) ; an Evening Service, and anthems. Author of Concise History of Music for the use of Students, Cambridge, Deighton, Bell, and Co., 1878, now in its 13 th edition. Also, of many papers read at Trinity College, London; at the Social Science Congress, 1883, etc.

Hunt, John, organist and composer, born at Marnhull, Dorset, December 30, 1806. Chorister of Salisbury Cathedral from 1813, and afterwards articled to A. T. Corfe. He was educated at Salisbury Grammar School till 1827 , and in that year he became Iay-vicar of Lichfield Cahedral, where he remained till 1835 . Hc became organist of Hareford cathedral in succession to S. Wesley in 1835. Died at Hareford, November 17, 1842, from the results of an accident at an audit dimner.

A collection of his songs, with a memoir, was issued in 1843 .

Hunt, Thomas, composer of the 16th century, who wrote the madrigal, "Hark! did you ever heare so sweet a singing," for six voices, in the "Triumphs of Oriana." Beyond this there is nothing known about him, though it is stated he was a bachelor of music.

Hunt, T., musician, compiler of a "Selection of 40 Sacred Melodies, adapted to the Psalms. ... n.d.

Hunt, William Henry, composer and teacher of singing, born in London, in 1852. Educated at the Cooper's School, Ratcliffe, and was for years teacher of general suljects in different schools. About 1875 , he went to Birkenhead as school master, and gradually drifted into the profession of music, an art he had studied since his twelfth year. $\mathrm{He}$ was mostly self-taught. In 1880 , he graduated Mus. Bac, London, being with H. K. Moore (q.v.), the first recipient of that degree; and took the Mus. Doc. in 1886. He was a busy worker up to the spring of 1894 , when he was smitten with paralysis. He rallied for a time, but died at Birkenhead, December 6, 1894. His wcrks include a Stabat Mater for soli, eightpart chorus, and orchestra; Church services and anthems. Two comic Operas, "Rum tifoo, or wrecked on a Princess," and " Ltopia, or the finger of fate," produced, Birkeuhad, May 4,1891 ; a number of songs; studies and exercises for pf, etc.

Hunter, Thomas Munro, vocal teacher and tenor singer, was born at Alloa, N B., in 1820. He settled as a teacher and concert-
HUTCHESON.

giver in Ediuburgh, and became precentor of various churches. He was well-known in Edinburgh as a teacher of singing in schools, for which he wrote various elementary collections of exercises and songs. He died at Edinburgh, July 16, 1886, from the effects of a gig accident.

Huntley, George Frederic, organist and composer, born at Datchet, Bncks, May 31, 1859. Studied under Dr. Keeton, C. Hancock, "nd Sir G. Elvey, at St. George's Chapel, Windsor. Graduated Mus. Bac., Cambridge, 1887 ; Mus. Doc., 1894. Organist and Choirmaster successively at St. George's, Kensington, 1880 ; St. Andrew's, Westminster, 1890 ; Newcastle Cathedral, 1894; and St. Peter's, Eaton Square, Jondon, 1895. Conducted Anuual Festivals of Association of Kensington Church Choirs, and was also conductor of Staines Choral Society, Twickenham Symphony Society; holding at present the contuctorship of the Church Orchestral Society. While at Newcastle-on-Tyne he revived the orchestral services in the Cathedral, in 1894, and produced, for the first time there, Bach's Natthew Passion, in Holy WVeek, 1895. He is A.R.C.M., L.R.A.M., and F.R.C.O. His compositions comprise an Oratorio, Dies Domini ; Cantatas, "O J ord I will praise Thee," "Saint George for England" (produced, Crystal Palace). Festival Te Deum. Anthems, services, and hymns. Operettas"The white Cat," "The wild Swans." Cantata, "Victoria, or the Bard's Propheey, 1897.

Husband, Rev.Edward, amatenrorganist and composer, vicar of St. Michael's, Folkestone. He has given many organ recitals in his church; atso lectures on Clunreh music; and is the composer of an evening service, anthem, etc. Editor of "supplemental tunes to popular hymms," Novello [1882].

Husk, William Henry, musician and writer, was born at London, November 4, 1814, and died at Jondon, Angust 12, 1887. He was librarian to the late Sacred Harmonic Society. Anthor of "An account of the Musical Celebrations on St. Cecilia's Day, in the 16th, 17th, and 18th centuries, to which is appended a collcction of ()des on St. Cecilia's I)ay,"London, 1857; "Songs of the Nativity, being Christmas carols, ancient and modern, several of which appear for the first time in a collection, edited with notes," London, n.d. [1866] ; "Catalogues of the library of the Sacred Harmonic Society," 1853, 1862, and 1872: Contributions to sir G. Grove's "Dictionary of Musicians." Numerous prefaces to Word Books of oratorios, and other pieces, etc.,

Hutcheson, Charles, composer, born at Glasgow, 1792. He was a merchant in Glasgow, where he died in 1858. He published "Christian Tespers," Glasgow, 1832, containing hymm-tumes harmonized, in 3 and 4 


\section{HUTCHESON.}

parts, with an introductory essay on church music. II was one of the founders of the Glasgow l)illetanti Society.

Hutcheson, Francis, Fraxcls Irelind, composer, born at Glasgow, in 1720. Son of

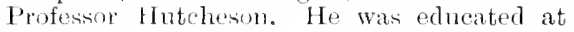
Glasgow and bublin, and graduated B.A., 1745 ; M.A., 1748, and M..1)., Dublin, 1762. He died in 1780. Composer of glees and catches, mudr the psendongm of Francis Ireland, of which a number appeared in Narren's "Tocal Harmony." He gained prizes from the Catch Club, in 1772 and 1773. His best remembered glees are "How sleep the brave," "Where weeping yews," "Jolly Bacehus," ete.

Hutchinson, Cecilia Mary, soprano Focalist, lom in Indial. Sitndied in Frances, and Itals, and muder Joseph Robinson, I nh)lin, and Alfred BInme, London. She made her debut at a special saturday Concert at the Crystal Palace, May 21 , 18si ; at the Monday Popmar Concerts, Jamuary 9, 1882; and appeared at the principal provincial concerts. Her Festival fébut was at Wureester, 18st; and she croted the soplano part in Cowen's "Silepping Peanty," at the Bimminghan Festival of 1885 ; and sang at the leeds Festival, 1sice. She has done much to popnlarise the delicate songs of Berlioz, "Les Nuits a'ité."

Hutchinson, Joseph T., baritone vocalist, born in London, July 12, 1st9. Began his mosical career as lay-vicar of Salisbory Catheral, to which he was appointed when twenty-ome years of age. At the end of a year he retimerito londm and antered the R.A.M., studfing singing moler Mammel rarcia, and elocuti in with Wilter Lary. Appointed snecesifely sub-professor, asisistant-pofesisor, and professor; and eleved A.R.A.M. Crave concerts, and sang in eantatas and oratorio in varions parts of the country, his most conij)icuons successes bejng in Barnett's Aneient Mariner, and Macfarren's Lary of the Iake, and cratsios. $H_{t}$ is co-tramslator, with Winderer Clark, of Cromod's Commentary on Mozat's "I Mom Giovann" (1R. Cocks, 1895).

Hutchinson, Thomas, orgmist and composer. Musically educated at lonrham Cathedral. (iradinated MLus. Pac., 1879; Mus. Doc., TS.t, Oxford. Organist at sillsworth Church, smolerland, np, to 18!6, when he was appointed to torlingtom Parish (horch. His compositions include cantatas, "The liedecmer," and, "The childien of the captivity"; Anthems; Te [ remm and Jnbilate in F flat; services, varions; Pieces for organ, amel pf. Smgs: Irvelight; silver shadows; Futters of guld, tete.

Hutchison, (i. B., anthor of "'Shorthand Music; an easy and rapid method of writing music," I mucton, n.r.

\section{HYDE.}

Hutchison, M. J., anthor of a "Treatise on Musie," London 「1847

Hutchison, William Marshall, composer, bol'n at Glasgow, May 28, [854. His workis include: "The story of litaine," and "Story of Naomi and Rnth," cantatas; "H.R.H.," and "Glamour," comic operas. Also songs: Dream faces: Ehren on the Rhine; Pierrot; Mine again; Little Mandarin ; Part-songis, pf, pieces, ete,

Hutt, William, organist and tacher, was a chorister at Westminster Abley, under J. Turle. Since 186.5, he has been organist of Winchester College, master of the choristers, and music master. In this retired sphere he has dome much valuable work in the cause of musical edncation.

Huxtable, Anthony, Christopher, and William, a family of English musicians who flourished about the middle of this century. Anthony, hom in 1818, was a violinist and teacher; Christopher, his som, an organist and violinist, composed much dance music; and William, a happist, pianist, ete.

Hyam, Lottie, pianist, born in sydney, New South. Wales, Is6t. At the Sychey International Exhilition, opened September 17,1879 , she was engaged by Messrs. Steinway to give a series of recitals upon their pianofortes. Hesident in Srdney, she has become known as one of the best pianists in that city.

Hyde. Four generations of musicians. The first of the name, JAMEs, was a trumpetplayer of some renown. Trumpeter to the Dulie of York, and anthor of works for the trumpet; and probaloly the Hyde who introdueed an improvement in the instrument by a small slide, sometime hefore 1812. His nane appeared in the limingham Festival orchestra several times from 1402. His son, JAmes Hrot, was also a clever perfomer on the trimpet, and a composer of popular ballads, one of which, "Edwy and sne," was sung by Braham. He settled in Manchuster, and his name fignred in the Pimningham Festival band list from 1811. His son, JAMEs Hroe, was a violinist and teacher of the pianoforte, for many rears resident in Birmingham. His son, James Hroe, born in Bimingham, 1849, is a violinist, conductor, and composer. Pupil of his father, and then of Henry Hayward, for riolin, and Andrew I Galin for organ and harmony. I'p to 1870 he was actively engaged as teacher, soloist, and musical director in his native town. In 1870 he removed to London, and was conductor at the Royalty Theatre. Ile went to Sonth Africa in 1875 as conduetor of the Turner Opera Company. For some time he resided at King Williant's Town, and is now settled at Johameslourg, where he is musical director of the Wanderer's Chub, which has a eoncert room and opera house. He has com- 
IEUAN.

posed cantatas, many songs (The Land of Good Hope, etc.), and pf. pieces, beside a rast number of arrangements. His wife, née Kate LEIPOLD, is an excellent pianist, and frequently assists at recitals, ete. Florexce Hrde, a sister, was drowned at Bath, in Jnne, 1879 , throngh the capsizing of a boat. She was a member of the Carl Rosa and In'(oyly Carte companies, and a rery promising young singer.

leuan, Glan Alarch, see Mills, Rev. JoHs.

Ieuan, Gwyllt, see Roperts, Rey. John. leuan, Dhu, see T'homas, Johx L.

lliffe, Frederick, composer, organist, and conductor, born at smeeton-Westerby, Leicester, February 21, 1847. Was privately edneated in music, and filled his first appointment as organist at st. Wilfred's, Kibworth. In 1883 he was appointed organist and ch ilsmaster of Sit. John's College, Oxford, an offies. he still holds. He was also, for some time, from 187s, urganist of St. Bamabar', Oxford. He graduated Mus. Bac., 1873; M 11 s. Doc., 1879, Oxford; also MI.A. Since 1863 he has been conductor of the Queen's College (Fglesfield) Invical Society. Fur this society important works have lieen expressly composed by 1)r. Bridge, Profesior Pront, Di. Mee, the subject of this notice, and other's; and it has a musical record, since 1871 , merpulted by any other college societs.

Works.-Oratorio, The Visions of st. John the Divine, composed 18T9, published 1sso ; Evening Service in D, for men's roices: Anglican chant settings $f_{1} r$ the whole of the Canticles; whort and easy anthems for parish choirs, ete. Lara, cantata for men's voices and orchestra, prodnced, Queen's College Musical Societr, Mav, 1st5; sweet Edho (Milton) for eight-part chorns and orchestra, Cheltenbam Festival, 1693; Moming, a Pastoral (Rer. Canon Belly for sopramo solo, chorus, and orchestra, the same, 1896. Concert orerture in E: Festal overture in I), Oxford, Mar, 1894, Bimingham (Stuckley), 1895: Terenade in G, strings, Queen's College, 1884. Prelude and fugne for organ; Sonata, and other pieces for pif., cte. Anthor of a Critical Analysis of Bach's Ins Wohltemperirte Clavier, in four part., Novello, 1896.

Immyns, John, attorney and lutenist, bom early in the 1sth century. Member of Academy of Ancient Mrusic. Amannensis to Dr. Pepuseh. Established the Madrigal Society, 1741. Lutenist to Chapel Roval, 175\%. He died at London, April 15. 1764. His son JoHx was organist of surrey Chapel, London, and died in 1794.

Incledon, Charles, tenor rocalist, born at St. Keverne, Cornwall, 1763; baptized Benjamin on February 5th. Sun of a physician.
IONS.

Articled pupil to W. Jackson, Exeter, under whom he was a Chorister in the Cathedral. Sailor on board H.ML.S. "Formidable," 177983. Recommended as singer to Colman by Lord Admiral Hervey, hut services declined. Nember of Collins' Iramatic Company at Southampton, 17st. Alpeared at Bath, its5. Pupil for a time of Rauzzini, at Bath. Sang in Tauxhall Gardens, 17ss. Debut in "lhe Poor soldier" at Corent Garden Theatre, London, 1790. Travelled much in the Prorinces. Retired from Covent Garden, 1815. Appeared in North America, 1s17. Resided at Brighton. He diel at Worcester, Feb. 11, 1826 , and is buried at Hampstead, London.

His son Charles (1791-1865) was also a tenor singer.

Ingham, James, musician, compiled "National Chant Pook," London, 18ts, also 1849 ; "Psalter, pointed for Chanting," Loudon, 1856, 3rd. ed.

Ingham, Richard, comproser and organist, was born in 1 riot. He was organist of Parish Chnch, Gateshead: Carlisle Cathedral, 1833; and died in June, 1841. Composer" of some rocal music; "Titania's Lullaby," round $\lceil 1840\rceil$, ete.

Inglott, William, orgunist and conposer, was born in 155. He was organist of Norwich Cathedral, 160s. Died in Inecember. 1621. Nentioned as one of the greatest of early English organists. Biography ubscure.

Ingram, Thomas, musician, who was org mist of Chapel Royal at lirighton. He flourished 1810-51. Anthor of "Choral Class Book, or singer's Mamual, containing easy and progressive exercines," 1_oudon, 1851; and compiler of "Twenty five Select Lsaln Tunes, ancient acd modem...., as used in krighton College, London, 1R18; "Select Chints arranged for funr voices," London, 1s.51.

Inverarity, Eliza, Mrs. MAнт's, soprano vocalist, born Eilinburgh, Nareh 2:3, 1813. Grand-niece of Rubert Fergusson, the poet. She studied under Mr. Thorne, of Eainburgh, then under Mr. Alex. Murray, at whose concert in 1829 she first appeared. On December 14, 1830, she saug in London in " "inderella," and in 1836 she married Charles Martyn, a bass singer and composer With him she appeared in opera in the United states and in England. In $18: 39$ she sang in New York in Beethoven's "Fidelio." she died at Newcastle-on-Tyne, December 27, 1816. Sle composed some ballads.

lons, Thomas, organint and composer, eldest son of James Ions, plate-glass mannfacturer, of Neweastle-on-Tyne, burn Angust 19, 1817. Displayed musical talent very early, and studied locally mder Mnnro, Nlarr, Ingham, and Thompson; and later, mider Moscheles. In 1833, was appointed Ingham's successor at St. Mary's Parish Church, Gates- 


\section{IONS.}

head, after competition. His youthful appearance, when presented to the judges, caused them to think a mistake had been made, and he was required to repeat a fugue hy Bach, and a Handel ehorus, while they looked un in admiration. The next vear he was eleeted, by the Mayor and Corporation, organist of sit. Nichola', Neweastle, on the death of his teacher, Thomas Thompson. This post he retained till his death. He was conduter of Newcastle and Gateshead Choral society; and in 1835 established the Amatenr Glce Club, and Subseription Concerts. Chorusmaster, and assistant conductor (under Sir Geo. Smart), Neweastle Festival, 1842. (traduated Mus. Bac., 1848; Mus. Doe., 1854, Oxford. Conductor of Newcastle Sacred Harmonic Society, founded 1848. Public testimonial, 1855. Died suddenly, while driving home after teaching at Gateshead, September 25,1857 . In 1860 , as a memorial to hin, the great east window of St. Nicholas' Church was restored, and filled with stained glass at a cost of $£ 1,000$, subseribed by his admiring townspeople.

Works.-Cantata, Prayer and thanksgiving, eight-part chorus and orchestra; l's. 137, six poices and or hestra; Services in C, $A$, and $E$ flat; anthems, motets, etc. A Christmas madrigal, Musical Times. Jannary, 1849 ; part-songs, songs, pf.music, ete. Editor of Cantica Eeclesiastica: a complete volnme of eongregutional music, 1849, to which lie contriluted many tunes, chants, ets.

lons, William Jamson, brother of the preceding, burn at Newcastle-ont.Tyne, November 3, 1833. Fntered the choir of sit. Nicholas' at age of nine; articled $t$, his brother in 184\%, and appointed assistant organist, 1850. Situdied in Germany, 1852-4, ineluding matters relating to the eonstruction and voicing of large organs. Returning to Newcastle, he devoted himse]f chicfly th the improvement of Church music and church organs. On the deatle of his brother, he was appointed organist of sit. Nichndas' ('hurch. He worked with liev. Dr. J. B. Trkes in compiling and improving the sorvice bros for use at the Festivals of ('hoirs in the Northem diocese; was made a Life crovemon of the Northern Counties' Orphanage, 1sfit, for his improvenents in themusic there. Was active in promoting the Festival held in sit. Nicholas' (now the Cathedral) ('hurcl, July, 1883, when Dr. (rladstome's oratorio, "'Plilippi," was produced. Designed the new organ. opened in 1891 ; was publicly presented with a Testimonial, 1893; and retired from active duty, 1894, after more than half-a-contury spent in the service of the Church. This step was caused by the affliction of deafness. Mr. Ions has composed anthems, services, and other Church numic.

\section{ISIDOR.}

Ireland, Edmund, musician, compiled "Tumes of the Psalms, in two parts," York, 1699 ; 2nd edition, issined as "The most useful "Tunes of the Psalms," York, 1713.

Ireland, Francis, see HuTCHESON, FrancIs.

Irons, Herbert Stephen, organist and composer, born at Canterbury, January 19, 1834. His father was a lay-vicar at the Cathedral; and Sir Feorge and Stephen Elvey were his uncles. Chorister in Canterbury Cathedral, 1844-49; Precentor and master of choristers, sit. Columba College, Ireland, 1856-57 ; organist of Sonthwell Minster, 185779. In 1872 he beeame assistant organist of Chester Cathedral. Now resident in Nottingham, and organist of Sit. Andrew's Church, since 1876. He has published a Te Deum and Jubilate; several anthems, an evening hymm, and edited a collection of chants.

Isaac, Benjamin Ralph, pianist, born at Liverpool (1818?) Pupil of a Mr. Molineux in that city, and in 1836, of Cipriani Potter, at 1R.A.M. A brilliant performer. He settled in his native place, and was shortly afterwards elected an Assoeiate, and then Fellow of the R.A.M. He died, sinddenly, at Southport, January 9, 1881.

Isaacs, Rebecca, actress and vocalist, born in Lo.don, 1828. She made her appearance 1834 Début in opera, at Olympie Theatre, - ondon, in December 1836. Married Thomas Roberts, acting manager. Sang with much success in London and the provinces. She died at London, April 21, 1877.

Isham, John, or Isum, organist aud composer, born in 1685. Deputy-organist to Dr. Croft. Organist of St. Anne's, Soho, in succession to Croft, in 1711. Mus. Bac., Oxon., 1713. Organist of St. Audrew's, Holboru, 1718 ; also St. MIargaret's, Westminster. He died in June, 1726.

Wonks. Church Services and Anthems; Songs, single and in collections; Catches ]1710]. etu.

Isherwood, James Wright, tenor vocalist and compuser, born at Manchester, March 2, 1812. He was organist of St. Anne's, Mauchester. Died at Manchester, October 30, 1854. He composed "The Soldier's Dream " and "A Violet Blossomed"; Glees, produced by the gentleman's glee club, Manchester. His father, JOHN IsHERWOOD, was a bass vocalist, and rang at the York Festival of 1823. He was a member of the Manchester Philharmonic Uoncerts, and frequently sang in oratorio. Died at Manchester, October 29, 1849

Isidor, Rosina, soprano vocalist, of Jewish family. Made her lébut at Her Majesty's Theatre, Octoher 23, 1880, in the title-part of "Iucia di Lammermoor." Gave concerts in 1892. Illness, resulting in loss of sight, com- 


\section{ITHURIEL.}

pelled her retirement for some time; but she returned to the stage in 1885, at Nodena. She gave a concert at St. James's Hall, in December, 1886 ; and appeard in Italian Opera at Covent Garden in 1887.

Ithuriel. See Coutts, W. G.

Ive, Simon, composer of the 17 th century, born 1600, died Loudon, 1662. Lay-vicar of St. Paul's Cathedral, and singing master in London. Composed "The Triumph of Peace," a masque by Shirley, 1633 (with $H$. and W. Lawes). "Lamentation and Mouruing, Elegy on the death of William Lawes." Various compositions in Hilton's Catches, Playford's Collection, etc.

Ivery, John, composer, born at Northam, Hertford, in the second part of the 18 th century. Published "The Hertfordshire Melody, or Psalm Singers Recreation, being a valuable collection of Psalms, Hymns, Antlrems, etc., on varions occasions, to which is prefixed a new, concise, and easy introduction to the art of singing, and a copious Dictionary of the terms made use of in Music." London, 1773.

Ives, Joshua, organjst and composer, born at $\mathrm{HI}_{\mathrm{y}} \mathrm{e}$, Cheshire, 185t. Studied under Dr. J. F. Bridge, and Dr. Chipp; graduated Mus. Bac., Cambridge, 1884. Organist, Auderston Parish Church Glasgow, and Lecturer on Iusic at the Glasgow Athenteum. In 1884, he was selected by Sir G. A. Macfarren and Dr. Stainer to be Professor of Music in the University of Adelaide, and was also appointed city organist. Before leaving to take up his duties in Australia, he was the recipient of a handsome testimonial from his pupils at the Glasgow Atheneum. He is the author of a work on Harmony, has given lecures on music, and composed church music, pieces for organ, etc.

Ivimey. A family of musicians. GEorGE Irimer, organist, born at Southampton, 1856. Studied privately. F.P.C.O. Organist and choirmaster, Holyrood Church, and Green. side Parish Church, Southampton. His daughter, Alice Irimex, born at Southampton, is a pianist, and was educated musically at the Conservatorium, Stuttgart. She made her début at Princes' Hall, London, 1894. John William Ivimey, cousin of George, was born at IVest Ham, Essex, September 12, 1868. Pupil of Henry Gadsby, and Corporation Exhibitioner, Guildhall School of MIusic. F.R.C.O. and A.R.C.M. (for composition). In 1888 was appointed Assistant Music Master at Wellington College, and in 1890 to a similar post at Harrow School, which he resigned in 1893. From 1891 he has been organist and choirmaster at St. Pauls, Onslow Square, Kensington; is head of the Music Section of the South-West London Polytechnic Institution; and conductor of the London County Council Musical Society, and South Kensing-

\section{JACKSON.}

ton Choral Society. His compositions comprise five comic operas: "Fairy Genesta" (produced, Surbiton, 1892); "Y'lang Y'lang", (Surbiton, 1893); "The Red Rider"' (MS., produced, St. George's Hall, London, 1894); and "Marie Tanner" (MS., Cardiff, December, 1895); "The Lady Lawyer," Garrick Theatre, London, March, 1897. He has also written a Trio for Pf. and Strings (1889); a Rondo Pastorale for Violoncello and Pf., and some Pf. pieces, etc. His brother, JosepH IrIMEY, is a violinist. He was boru at West Ham, 1867. Studied under Alfred Gibson, aud was also a Corporation Exhibitioner at the Guildhall School. In 1888 he founded the Surbiton Chamber Concerts, in counection witl which he has done valuable artistic work. He is also conductor of Weybridge Orchestral Society.

Jack, David, vocalist and publisher, was born at Edinburgh, February 16, 1824. He edited and published the "Syric Gems of Scotland" (185t-5S) and "The Casquet of Lvric Gens", (1857), both collections of rocal music. He gave many concerts in various parts of Scotland.

Jackson, Arthur Herbert, composer and pianist, born in 1852 . He studied at the R.A.I. ; Associate; Professor of Harmony and Composition at R.A.M. He died, Lon. don, September 27, 1881.

Works. - Choral ballad, Lord Ullin's danghter; Jason and the golden fleece, cantati (MS.); The bride of Abydos, overture; Intermezzo for orch.; Violin concerto; Ballet suite for orch.; Concerto for pf. and orch.; Magnificat for chorus and orch; Two masses for male voices; Pf. music; Songs and partsongs.

Jackson, Frederick J., author of "The Construction of the Musical Scale, as determined by the arithmetical evolution of its measures or ratios." London [1869].

Jackson, G. K., musician, anthor of "First principles, or a treatise on practical Thorough-bass, with general rutes for its composition and modulation," op. 5. London [1795]. Other musical works, as "Three songs and duets," op. 3 ; Sonatas for pf., etc.

Jackson, Jane, see sub. Roeckel, J. L.

Jackson, John, organist and composer, born early in the 17th century. He was choirmaster of Ely Cathedral in 1669, and organist of Wells Cathedral in 1676. He died after 1688 . Wrote services, anthems, etc.

Jackson, John P., musician and writer, anthor of "Album of the Passion Play at Ober-Ammergan . . . 1873," and other works on the same subject; Richard Wagner's "Ring of the Nibelmug," an illustrated handbook, London, 1882; and an Enolish version of "Die Meistersinger," 1892; "Parsifal," 1890 ; etc. 


\section{JACKSON}

Jackson, Miss, see Lacr, Mrs. Johx.

Jackson, Seymour, tenor vocalist, attracted attention hy his singing in Manchester and neighbourhood about 18s\%. Made his début on the stage, Nareh 18, 18s6, with the Carl Rosa. Opera Company, talsing the part of Thaldews in Balfe's" opera, "The Bohemian Gill." Tomed with the same company, and gave concerts in rarious towns. At present resident at Blackpoul as vocalist and eoncert agent.

Jackson, Thomas, psaim composer, horn about 1715. He was organist of the Parish Church of Newark, and master of the Song School there. He died at Newark-o-Trent, November 11, 1781. Composer of the psalmtune, "Jackson's," and of 'Twelve Psuhn tumes and eighteen double and single chants . . , composed for four voices, 1780 .

Jackson, William, author of "A Preliminary loscourse to a scheme demonstrating and shewing the perfection and hamony of Sounds," IVestminster, 1726.

Jackson, William, composer, organist, and writer, born at Exeter, May 28, 1730. He studied under sylyester, the organist of Exeter ('athedral, and under J. Travers. Teacher in Exeter. Organist and choil-master Exeter Cathedral, 1777. He died at Exuter, July 12, 1803 .

Works.-Operas - Lord of the Manor, Jon don, 1780; Metamorphoses, London, 1763 Odes Ode to fancy (Warton). op. 8; Lycidas, 1767; Hying Christian to his son! (Pope). Songs - Twelve songs, op. 1, 175.5; Twelve songs, op. 4; Third set of twelve songs, op. 7 ; Fourth set of twelve songs. Six elegies for three mate voices, op. $3\lceil 1767 \mid$ : Twelve canzonets for two voices, on. 9 ; Śsond set, op. 13; Twelve pastorals. Six vocal quartets, op. 11, 1780; Six Madrigals, op. 18, 178f; T'welve hymus, in thre parts, op. 6 . Six sonatas for harpsichord; Eiglit ditto. Six epigrams for 2, 3, and 4 voices and pf., Op. 17 [17s6]; Anthems and church services, lis the late William Jackson, of Fxeter, edited hy James l'adlon, 3 vols., London, n.t. Selection from his works, sacred and secular, London, 4 vols., n.d. Thirty letters on various subjects, London, 17s.j Observations on the present state of music in London, 179l. The four ages, together with essays on various subjects, I,ondon, 179s.

Jackson was a man of varied accomplish. ments; an essayist, musician, organist, and painter. "He was a friend of ('rainshop" had a good taste for art, and was known in his day by his clever landscapes. In 1771 he was an honorary exhibitor at the Academy. He copied Gaimslorongh's work and wrote a sketeh of his life." Redgrave.

Jackson, William, organist and composer, born at Masham, Yorkshire, January

\section{JACOX.}

9, 1815. Self-taught in music. Organist at Masham in 1832. He was for a time a tallow chandler in Masham. Gained Huddersfield Glee Club first prize in 1840. Nusic-seller in Bradford, with W. Winn, vocalist, 1852. Organist of St. Jolın's Church, Bradford; Horton Chapel, 1856. Conductor of Bradford Choral Union. Chorus-master at Bradford Festivals of 1853, '56, '59. He died at Bradford, April 15,1866 .

Worss.-Oratorios-Deliverance of Israel from Babylon, 1845; Isaial. Cantatas-The Year, 1859; The praise of music. 103rd Psam for solo voice, chorus, and orchestra, $18+1$. Church services, a mass and anthems. The Bradford tune book (with Samuel Smith). Congregutional Psalmody, 1863. A singing class manual, n.d. Glees, part-songs, and sones.

His soll, WhLlaM, born at Bradford in 1859 , was instructed by his father. He became organist of Nomingside Parish Church, Edimburgli, but falling into bad health, died at Ripon, September 10, 1siT, at the early age of 24. He published four part-songs, to words by Burns, in 1875 , and left a fow other works.

Jackson, William, composer and pianist, born in 1828; died at Girvan, August 19, 1876. He was a pianist in connection with various Glasgow music halls, but is now only remenbered as the composer of a ouce popular song called "The dear little shamrock."

Jacob, Benjamin, composer and organist, bom at London, in 17\%s. ITe studied muder his father, Ii. Willoughls, shrulsole, and Amold, 1796. Chorister in Portland C'hapel, 1746. Organint of Salem ('hapel, soluo sig.,

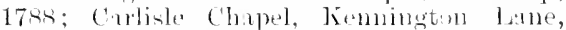
1790 ; Bentinck (hapel, Lisions Green, 1790-4; surrey Chapel (R'wland Hill's), 1794-1825; sit. John's, 182?. Treble singer, Wentminster Abber, at Festival, 1730-91. Nembaj Royal sociefy of Musicions, 1799. Conductor of a selies of oratorion, 1800. (tave organ recitals in empunction with S. Wesles, and W. Croteh, t, grat andinces, 180s-14. Comductor of the lenten orutoriss at Covent frarden Theatre, 1s1s, Associate, Philhomonic society, 1sis. One of Court of Assictants, Rosal Society of Musicians, 1s23. He died in lumdom, Aing. 24, 1829. Buried in Bmmhill Fields. In 1892, MIr. F. G. Fdwards, organist of surrey Chapel, restored the tomlistones of Jacob and Shrubsole, for which he obtained snbseriptions.

Works.-National P'sahodr, a collection of Tunes for every Sunday thronghont the vear, Londor [181!)]. Tuines for the use of Surper Chapel. In. Wattis divine and moral songs, as solos, duets and trios. (tlees, songs, and an arrangement of the "Macbeth " music.

Jacox, Rev. Francis, writer of present 


\section{JACQUES.}

time. Was curate of Wellingborongh, 184748. Anthor of "Biblemusic, being variations in many kers on musical themes from soripture," London, 1871 ; 2nd edition, 1874. Also writer of works on Bible history, "Traits of Character," "Aspects of Author'ship," etc.

Jacques, Edgar Frederick, musical eritic and lecturer, born in London, March 27. 1850, of French parentage. Edneated for a commereial career, but in 1869 decided upon musie as a profession. Had studied music from lis eleventh vear, and leaving Manchester, where he had been engaged in business, he returned to London, and began teaching. acting also as organist. In 1874 he beeame dircetor of the or hestral serrices at St. Andrew's, Tavistotk Place, an oftice he held for two vears. Began musical Journalism in 1885 , and in 1888 suceeeded I r. Hueffer as editor of the Musical W'orld. This jommat ceased in 1891, and the next year Mr. Jacoures was appointed editor of the Musical Times (retiring in 1897), and in 1894, musical critic of The Observer. He has lectured several times at the R.A.M., and read papers before the Musical Association; also viven explanatory discourses at Mr. [Bonawitz's Historical Recitals (1892), and on Kuhnam's "Bilslical Sonatas," at the R.A.M. (Fel,, 1896). He has composed an opera, an operetta, and partsongs, etc., which remain in MLs.

Jakobowski, see PrLtille, HIWAR1.

James 1., King of Scotland, puet and musieian, born in 1394; died in 1437. Noticed here as the alleged inventor of the Scottish strle of music. Fonnding on what has been regarded as a wrong reading of a passage in a work of Tassumi, the I calian poet (1565-1635), Willian Tythel has endeavoured to show in his " Fssay ou Seottish Music" that James I. not only invented the "plain. tive style of melody, called sicottislı," but likewise greatly influenced the strle of several Italian composers, among whom are fresualda and Palestrina. The researches of I baney, Graham, Burney, and others, bave proved this therery to be quite absurd.

James, John, organist and composer, of the 1sth century. He was organist of st. Olave, Sonthwark; and sit. Feorye's-in-theEast, 1738. He died in 1745. ('omposer of songs, organ voluntaries, and other pieces; "Celinda," a two-part song, ete.

James, W. N., Hute-player and writer, author of "A word or two on the Flute," Edinburgh, 1826. The Flutist's Catechism, in which are explained the First Principles in Mrsic, London, 1829. The German Flute Magazine, or plain practical instructions for the flute, London [1885].

Jameson, D. D., author of "ColourMusic," London, 1844.

Jamieson, Augustus Grant, organist

\section{JEBB.}

and composer, was born at Edinburgh, December 20, 1814. He studied under J. C. Kieser, J. T. Surenne, Professor [Domaldson, and at stuttgart. He held the position of organist to st. Paul's Episcopal Church, Edimburgh, from 1872 till 1898, and was eonduetor of the Orpheus Orehestral societr. He held other appointments. Died at Edinburgh, January „21, 188s. Composer of various hymn tmes, "Brierley," "st. Sulpice," etc. and a number of pianoforte pieces.

Janes, Robert, organist and conposer, was born Feb. 3, 1806. He was educated at Inlwich c'ollege, and in $182 \mathrm{t}$ was articled pupil to Dr. Z. Buck of Norwich Cathedral. In 1831 he was appointed organist of Fly Cathe. drai, and held the post for 35 rears. He died at Ely, Jume 10, 1866. He js said to have composed the "Ely ('omfession" (1864). Editor of a Psalter, and composer of rocal music. He was an anatemr printer, and patt-hooks, composed and worlied off at his wwn press, were in we up to 1866 .

Jarman, Thomas, nunician, of Chinton, Was born about 1788; died in . Jantary, 1862. compiled the" "Devotional Melodist, original set of psalms and hymn tunes, short anthems and set pieces, particalarly tesigned for public workhip," n.d. "The sacred Harmonicon: containing upward of 200 original tumes to all the motres now in nse," m.d. "The Northamptombire Harmony: containing a greater variety of tmes, anthems, and set pieces than has hitherto apreared in any other publication," n.rl.

Jarvis, John, musician, compiled "Zjon's Harmonist : comprising a new set of orininal psalm and hymu tunes. " Inndon $|1 \mathrm{~s} 44|$

Jarvis, Samuel, organist and emuloser of 18th centiry. He was lind. After receiving lestons from I r. Wirgan, he became organist of the Fomdling Hospital, and later, of st. Semlehros, London. He was master of Wm. Russell, organist of the Fonndling Hospital. He composed "An Ode in homom" of the Albion's Societr," Lomdon [17407; "Twel resongs, to which is added an epitaph" ; " six songs and a cantata," pte.

Jarvis, Stephen, conposer, horn in 1834; died at Lewisham, Londm, November 27, 1880. He composed a quintet for strings, songs, and music for the pianoforte.

Jay, John George Henry, pianist, violinist and composer, horn in lssex. Norember 27, 1770. He studied under Hindmarsh and Phillips, and on the continent. Setted in London, 18g0, as teacher. Mus. Bac., ()xon., 1809. Mrss. Doc., Cantal., 1811. Nember of the R.A.M. He died at London, september 17,1849 . Wrote pf. and voral music. His son Johs (horn 1612; died Mar 31, 18s9), was also a riolinist.

Jebb, Rev. John D. D., clergynan and 


\section{JEFFERSON.}

musician, was born at Dublin in 1805; died at Peterstow, January 8, 1886 . He was Canon of Hereford and Rector of Peterstow, Herefordshire. Author of Choral Service of the United Church of England and Ireland, being an Inquiry into the Liturgical System of the Cathedral and Collegiate Foundations of the Anglican Communion, London, 1843; Three lectures on the Cathedral Service of the United Church of England and Ireland, 18t1; 2nd edit., 1845; The Choral Responses and Litanies of the United Church of England and Ireland, collected from authentic sources, London, 2 vols., 1847-57.

Jefferson, Joseph, author of "Lyra Evangelica ; or an Essay on the use of instrumental music in Christian Worship," London, 1805.

Another musician of this name, WILLIAMI Arthur Jeffreys, organist of Leeds, issued "The National Book of hymn-tunes, chants, and kyries," 1885.

Jefferys, Charles, composer and music publisher, was born Jannary 11, 1807 . He carried on business in London, and died there June 9, 1865. He wrote the words of a number of popular songs, "Rose of Allandale," "Mary of Argyle," etc., and himself composed "Rose Atherton," "Oh Erin, my country," and other songs.

Jeffreys, George, org nist and composer of 17 th century. He was a son of MATTHн.w JeFFtreys, Mus. Bac., Oxon., 1593, who was vicar choral of Wells Cathedral. In 1643 George became organist to Charles I. at Oxford, and from 1648 he was steward to the Hatton's of Kirby, Northamptonshire. He died in July, 1685. He composed anthems and other sacred music mostly preserved in MS. His son. Christopher, who graduated M.A. at Oxfori in 1666 was also a musician. He died in 1693.

Jeffries, John Edward, orgauist and composer, born at Walsall, Staffordshire, October 18, 1863. Clorister, and afterwards assistant organist at St. Paul's Church. Walsall. where his father, an amateur, held the post of organist for many years. Studied at the R.C.M., under Drs G. C. Martin, J. F. Bridge, and F. E. Gladstone, for organ, counterpoint, and harmony, and $p f$. with Franklin Taylor, and is F.F.C.O. He was appointed organist of Walsall Parish Church when seventeen, and afterwards choimaster. At the Annual Dedication Services he introduced oratorios and cantatas, with full orchestral accompaniment, and gave frequent organ recitals, also appearing as solo pianist at concerts. He was several times conductor and choral inspector for the Lichfield Diocesan Festivals. In November, 1895, he was anpointed organist and choirmaster to the Cathedral, Newcastle-on-Tyne, and conducted special Advent services the next month. His

\section{JENKINS.}

first organ recital was given in the Cathedral, February 8, 1896. Conductor of Jarrow Philharmonic society. He is the composer of an oratorio, The Life and Death of Christ; the sections, "The Annunciation," and "The Redemption" were performed in the Cathedral, in Mlarch and April (Good Friday), 1896. He has also written several works for church use.

Jeffries, Stephen, organist and composer, was born in 1660 . He became a chorister in Salisbury Cathedral, under Wise, and organist of Gloucester Cathedral in 680 . He died in 1712.

Jekyll, Charles Sherwood, organist and composer, bom at Westminster, November 29, 1842. Chorister at Westminster Abbey. Studied under James Coward and G. A. Macfarren Organist of St. Paul's temporary church, Kensington, 1857 ; assistant organist Westminster Abbey, 1860-75; organist parish church, Acton, 1860 ; St. George's, Hanover Square, 1861-77; organist and composer to Her Majesty's Chapels Royal, St. Jamies's Palace and Whitehall, November, 1876 ; retired October, 1891. Grand organist to the United Grand Lodge of England (Freemasons) 1880-2 Mr. Jekyll was the recipient of the silver Jubilee medal, presented by Her Ma. jesty the Queen.

Works. - Services: Communion in C; Morning and evening in F (MS.); Morning and evening in $\mathrm{C}$, for male voices, composed for St. Paul's Cathedral (MS.); Benedictus and Agnus Dei. Anthems: O, send out Thy light (eight voices) ; Save me, O God; Arise, O Lord; Go forth, ye daughters of Zion (Jubilee anthem, 1887); The righteous live for evermore; and others; hymns, chants, etc. Twelve kyries. Purt-Songs: On the sea; When twilight dews; Night after the battle, etc. Songs: Pro Patria Mori; Now; Go, forget me; In memoriam, etc. Organ: Jubilee march, played by the composer, IVestminster Abbey, at the Qucen's Jubilee, June 21, 1887; Narche Niptiale, played by the composer at the wedding of H.R.H. the Duchess of Fife; Grand march ; Andante in A. Pieces for pf. Editor of Musical sunday at IInme, a series of twelve numbers.

Jenkins, David, composer, born at Trecastell. Brecon, January 1, 1849. Self-tanght at first, but afterwards studied under Dr. Joseph Parry, at the University College of Wales, Aberystwith. Graduated Mus. Bac., Cambridge, 1878. Often acts as conductor of Psalmody festivals, and adjudicator at the National and other Fisteddfodau. In 1885, went to America, where he conducted at several festivals, besides being adjudicator at competitions. Is joint-editor of The Musician; Professor of music at the University College of Wales; Nember of the Council and Examiner Tonic Sol-fa College, and Examiner 


\section{JENKINS.}

R.C.M. Invited to conduct his "Psalm of Life," and Welsh airs at the Tonic Sol-fa Festival, Crystal Palace, July 11, 1896.

Works.-Cantatas: The ark of the covenant (prize of $\$ 20$, Eisteddfod); David aud Goliath ; A Psalm of life (composed for, and produced at the Cardiff Festival, 1895). Oratorins: David and Saul; The Legend of St. Dıvid (Carnarvon Eisteddfod, 1894). Operetta, The village children. Anthems, partsongs, songs, etc. A eollection of tuues, chants, and anthems (English and Welsh texts); Gems of praise, etc.

Jenkins, George, composer and teacher of dancing in Edinburgh and London, in the latter part of the 18th century. He died at London about 1806. Composer of Eighteen airs for two violins and a bass, Edimburgh [1789] ; Jenkins' thirty Highland airs, London, 1791; New Scoteh musie, cousisting of slow airs, strathspeys, quick reels, country dances, and a medley on a new plan, with a bass for a violoncello or harpsiehord, London [1793].

Jenkins, John, composer, born at Maidstone, in 1592. Musieian to Charles I. and Charles II. lesided duriug the greater part of his life with H. L'Estrange of Norfolk. He died at Kimberley, Oetober 27, $167 \mathrm{~S}$.

Works.-Elegy on the death of William Lawes, 1648. Theophila, or love's saerifice, poem by E. Benlowes, 165:. Twelve sonatas for two violins and a bass, with a thoroughbass for the organ or theorbo, 1660. Fantasias in five or six parts for viols Anthems, rounds. Compendium of practical music, London, 1667 .

Jeremiah, John, author of "On Eisteddvodau: their antiquity and history," London, 1876. "Notes on Shakespeare and memorials of the Urban Club," London, 1876.

Jervis, St. Vincent, musician and composer, pupil of Molique. At a coneert of the Amateur Musical Society of London, March 27,1854 , an adagio and rondo for pf. and orchestra, of his composition, was produced. Five sonatas for pf., by this composer, have beeu published at different times up to 1887 , as well as other pieces.

Jeunesse, see La Jeunesse.

Jewell, E. Ellice, musieian of present time, author of "Cateehism of the rudiments of music and pianoforte-playing," London [1882]; "Elementary exereises" [1883] for the same book.

Jewson, Frederick Bowen, pianist and composer, born in Edinburgh, July 26, 1823. Studied at R.A.M., under Cipriani Potter, and was King's Scholar, 1837. In 1835, he give a concert at Edinburgh, and played a composition of his own. Elected in turn a member, professor, and director of the R.A.MI. He was appointed a life member of the Court

\section{JOHNSON.}

of Assistants of the Royal Society of Musicians in 1849 ; and in 1866 becamc one of Musicians in Ordinary to the Queen. Member of the Philharmonic Society. For half a century he occupied an important position as a teacher of the pianoforte; retired from professional life in 1889, and died in London, May 29, 1891.

Works.-Overture, Killicrankie, orchestra, R.A.M., May 16, 1840; Five overtures. Two concertos for pf. aud orchestra, No. 2, in E, op. 33, performed St. James's Hall (Miss Dinah Shapley), June 28, 1882 . Trio, pianoforte and strings. Six grand studies, op. 16; Douze Etudes, op. 23; Chanson d'Amour, and other pieces for pf. Songs, etc.

His wife, formerly Miss KIRKMAN, was a niece and pupil of Mrs. Anderson, and a pianist of recognised talent, who frequently took part in the musical matinées and concerts given at various times. She died in London, December 24, 1896 . Two sons are in the musical profession--Frederick AUGUatus Jewson, born in London, February 12, 1856, who is organist to the Strolling Players' Orehestral Sueiety, and conduetor of the Regent's Park Sacred Harmonic Society. He married Miss I) unbar Periñs, a violinist who is farourably known in musieal cireles. William A. Jewson is a violinist of repute, and eonduetor of musieal soeieties.

Johnson, Basil, B. A., was appointed director of the mulsic, and organist at Rughy School, in 1886. He is a son of the late Dean of Wells, and was musically educated at R.C.M. He has published Teehnical Exereises for $p$ f.

Johnson, Edmund Charles, physician and writer, vice-president of the sichool for the Indigent Plind, Sonthwark, London. Author of "An Inquiry into the Musical Instruction for the Blind in France, spain, and America," London, 1855, and other works on the Blind.

Johnson, Edward, cumposel of the 16th century. He gradnated Nus. Bac., Cantal)., 1594. Contributed to Este's Psalns. He composed the madrigal, "Come, Blessed Bird," in the "Trimmphs of Griana," 1601. His biography is unkinown.

Johnson, James, engraver and publisher, was a native of the Ettrick district of scotland. He was established in business in Edinburgh, and printed and engraved most of the collections of music published during his time. He was the first to print music from pewter plates. He dierd at Edinburgh. February 26, 1811. He is chietly moted for his comnection with Rolvert Burns, and the publication of "The Soots Musical Museum, with proper Basses for the pf..." Edinhurgh, 6 vols., 11.d. $\lceil 1787-1803\rceil$. This work was re-edited by Thavid Laing and Stenhouse, and 


\section{JOHNSON.}

reprinted by Messm. Blatelwood, Edinburgh, 4 vols., 1858 . The success of this venture was entirely due to the fine lyrics which Bums contributed, and which liave since become world-wide farourites. The arrangements of the melodies in Johnson's Collection were by Stephen Clatice.

Johnson, Robert, elergyman and conposer, who flowished about the middle of the 16th century. He compused part-songs, etc., one of which appears in the "History" of Sir John Fawkins, and others in contenporaty collections.

Johnson, Robert, composer and lutenist, was horm in the latter half of the 16th century. Mnsician in service of Sir T. Kytson of Hengrave Hall, Suffoll. Resided latterty in London as teacler, and musician in service of Prince Henry. He died after 1625.

Works.- Music to Dramas: "The Witeh" (Middleton); "The Tempest" (Shakerpere); "Masque of the (ipsies" Jonson); Contributions to Leighton's "Teales." fiongs, nad. rivals, pte.

Johnson, William, anatell organist and compostre b.m at Warringtom, september 23, 1853. Situdied of. moler the late T. Standish; organ under T. Mee Pattison;

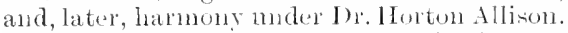
Appointed organist of St. Amme's, Warrington, 1868, and introduced the first Choral Communion service known in the distriet. Jlon. organist, 1885-7, to the Warrington Musical Society (comalucted by H. Iiles), which, in 1686 , produced lis cantata, Ecce Homo. Anotler' cantata, "May Mon at Magdalen College, Oxfort," remalins in MS. He has composed anthems and other pieces. His grandfather, Turomas kisgrox, was for thirtyfive vears organist of the Parish Church of Fingswond, filoucester, and was reputed to be an excellent ferformer on erery then known instrument. He died about the vear 1850 , aged seventy-six.

Jolunson, W. Noel, rioloncellint aud composer, Jorn at Reptom, Derly, May 22, 1869. Fducated at Emmanued College, C'ambridge. Atudiod violoncello at R.A.M. muder W. F. Whitehouse, and afterwats proceeded to Leiprig and studied with Alwin Sehröder, Oscar 1'aul, and Paul Klengel. Ile first appeared in $\mathbf{I}$ ondom, in $\mathbf{1 8 9} 3$, and is settled there as performer and composer. He has made serelal provincial toms, and met with much stecess. As a composer he has becu very alctive, his works comprising Three pieces for violoncello and pf.; Caprice, Nocturne, feremale, Idrlle, Reverie, for the same. Somgo: 1 lowe thee (prize, Incmporated suciety of Mnsicians, North-Midland Section, 1890); Four songs; Six Songs (lleines); If thou Wert blind; Cood-night, pretty stars; and many uthers. I'art-songs: Where shall the lover
JUNES.

rest; When Flora dects (male roices), etc, ete. He las also written the music to several plays, one of which, "The Tournament of love," was performed in Paris (Theatre d'Application, La Bodinière), in May, 1894, with success.

Johnston, Rev. David, authol of " Instrumental in the Church of scotland, by the Minister of the United Parishes of Harray and Birsay." 1872 (privately printed).

Jolly, John, composer and organist, uncle of the undernoted, bon at Knutsford, Cheshire, 1794. Was organist of St. Phillip's Chapel, London. Died at London, April, 1838. He composed "Glees, in score, for 3 and 4 roices," n.d.; Songs, ete.; and "Devotional Melodies, consisting of piahms, hymms, collects, and short anthenss," London, 1832.

Jolly, John Marks, nephew of above, conposer and conductor, was born in 1790. He was conductor at the surrey Theatre, London, and at the strand Theatre, in 1853. He died on July 1, Isict. Wrote a large number of somgs, part-somgs, eto., among which may lie named set of six songs of the wild flowers of spling [1834]; Mipsy sisters, duet; Love is still at little buy, song: Queen of the starry night, song; Polkas, galops, cote., for pef.

Jozas, Elizabeth G., pianist, bom at sonthwarl, London, about 1825. Began learning the pianoforte muder Mr. Platt when four years old; then muder. John Field, at whose concert, in 1832, she made her début. she also played at the Paganini concerts, and frecruently before royalty, in London and at Windsol; at the "(Matorios" at Drury Lane, etc. She then studied under Moscheles, and in 1836 won the King's schularship, R.A.M., and again in 1838 . In 1 ht 1 whe was made an Associate, and appointed Professor of pf. and latmony. Abont 1852 Miss Jonas retired from the loufession, her lealth not being sood; and enjoying an independency, she exercised her musieal gifts in privite circles.

Jones, Arthur Barclay, pianint and composer, born in London, December 16 , 1669. Entered the choir of the Brompton ()ratory when nine yeas old, and remained there as a singer nutil 1893, wher, 1 pon the death of his friend Thomas Wingham, he was appointed nusical director, an office he still holds. By the advice of Wingham, whose pupil he was, he entered the Guildhall school of Music when fifteen, and gained a Scholarship. In $18 x$ ) he was made Associate, with homonss, and became a Profestur of pf. there in 1892, and of hamouy in 1896. L.R.A.MT. (pf.), 1891. JIis other master was H. C. Bamister, who taught him harmony. His compositions include a symphony in C minor (dedicated to the nemory of Thomas Wingham, and produced by the Westminster 


\section{JONES.}

Orchestral Society, June 3. 1896); a Concert Overtule in L minor (Crystal Palace, October 22, 1892); Sonata, violin and pf.; Pieces for violoncello, for pf., and orgau. An Ave Maria, for soprano, and Hymus for children, ete.

Jones, Daniel C., organist, bor'n at Tamworth, Staffordshire, November 20, 1857. Received his musical education at Lichfield Cathedral, mder the late Thomas Bedsmore. Became F.R.C.O. at the age of nineteen, and took the degree of Mus. Bac., Trinity College, Toronto, in 1887, and Mus. Doc., of the same, 1891. In 1877 he was appointed organist and choimaster of Londonderry Cathedral, a post he still holds. He has composed several anthems, and other church music. "Thus saith the Lord concerning the King of Assyria," was specially written for and performed at the celebration of the Bi-centenary of the closing of the Gates of Derry, in the Cathedral, Jecember 18, 1858.

Jones, Edward, BARIY BRexix, witer and musician, bom at Llanderfe], Merionethshire, April 18, 1752. He studied the Welsh harp under his father. Appeared in London as harper, 1775. Weksh bard to Prince of Wales, 1783. He died at London, April 18. 1824.

Works. - Mnsical and poetical relicks of the Welsh hards, preserved by tradition andanthentic manuscripts from very remote antiquity. with a collection of the Pennillion and Eirglynion epigrammatic stanzas or native pastoral sonuets of Wales, a history of the bards from the enrliest period, and an acconnt of their mosic, poetry, and musical instruments, London, 17it, two parts. Musical and poetical relicks of the Welsh bards, preserved by tradition and anthentic manuscripts from very remote antiquity, with a select collection of the Pennillion and Englynion, with English translations, likewise a general history of the bards and druids, from the earliest period to the present time; with an account of their Music and poetry; to which is prefixed a dissertation on the musical instruments of the aboriginal Britons, London, 1794. The Bardic Musenm of Primitive British Literature and other admirable rarities, forming the second volume of the Musital, Poetical, and Histonical Relicks of the Welsh Bards and Druids . . 1802. Lrric Airs, comsisting of specimens of Greek, Albanian, Malachian, Turkish, Arabian, Persian, Chinese, and Moorish songs and melodies, with a short dissertation on the origin of ancient Greek music, London, 1804. Cheshire melodies: provincial airs of Cheshire, London [1803]. The musical miscellany, n.d. Terpsichore's Banquet (National airs), n.d. The minstrel's serenades, n.d. Collections from works of Handel, etc. The Minsical Bouquet, or popnlar songs and ballads. . London, 1799.

\section{JONES.}

Maltese Melodies, or national air's and dances usually performed by the Maltese musicians ... London, n.d.

Jones, Edward, composer and conductor. Was for some years a first violin in sir Michael Costa's opera orchestra; has been in Anerica with the Mapleson Opera Company; musical director at the Court, Adelphi, and Duke of York's Theatres, London: and is at present musical director at the Lyric Theatre, London. He is the composer of incidental music to "Clandian"; "Hoodman Blind," produced, Princess's Theatre, 1885; "The Fay O'Fire," Opera Comique, Norember, 1885 ; "Pharoah," Leeds, 1892 ; "A Near shave," farce, Court Theatre, 1895; "The Sign of the Cross," Liverpool, 1895, tet.

Jones, Edward Stanton, writel and bandmaster, author of " Eniveral Cornopean Tutor..., London, 1855; " Booser's Univerisal Cornet 'lutor," n.d.; Shilling Cornet Tutor. Songs, etc. He died in $18 \$ 6$.

Jones, George, author of " Histor' $\mathrm{y}^{+}$of the rise and progress of Mnsic, theorecical and practical," London, 1sis. German edition, Vienma, 18221 .

Jones, Griffith Rhys, or Caradog, a noted Wekh conductor, was born at Trecynon, 1)ecenber 21. 1834. His first study was the violin: but when quite a vouth he became conductor of a choil known by the name of "Côr Carodog," This choir being ricturiuns at a local Eisteddfod, the name was attached to the conductor. In 1872 he was appointed condnctor of the Welsh choir which compested at the Crystal Palace contests in $1872-3$, winning the challenge prize colp on each aetasion. Afterwards he conducted choirs in Carliganshire, at Cardiff, and now at I'ontrpudd, his male voice choin dividing the first prize at the Llandudno Eisteddfod of 1896.

Jones, Hannah, contrulto vocalist, born at Shewen, near Swansea. At the age of fourteen was first plize wimner at the National Fisteddfod. Entered the R.A.M., and studied muder Garcia, and others, winning Llewelvn Thomas Prize, 18st, and Siantom-I)olly Prize, 1Rs4: A.R.A.JI. Sang in "Elijah" "at the Roval Allert Hall, Felnuary, 188s, with sulcersis, and has since gained a good position among contralte vocalists of the day.

Jones, Henry Festing, anateur connposer. In conjunction with Samnel Butler, lorught ont, in 1884, a collection of original gavottes, minuets, etc, in the style of Handel; and some rears later, a dmatic calstata, "Naucissus." Mr. Jomes is also the composer of My silks and fine array; I pbraid me nut; Go, luvely rose; Six songs, op. 5; a secoud set of six songs, etc.

Jones, Hirwen, tenor vocalist, born near Cadigan, Narch 9, 1857. As a routh, attended Tonic Sol-fa classes, and was a 


\section{JONES.}

suceessful competitor at Eisteddfodau. In 1879 he entered the R.A.M., and studied under A. Randegger, and IV. Shakespeare. One of his earliest appearances in London was in Carter's "Placida," at Brixton Hall, March, 1882; he also sang at the Popular Concerts, and at the Crystal Palace, October 17, 1885, in the quintet from the Meistersinger. He made his festival début at Brighton, in 1882, and sang at the Worcester F'estival, 1890; Hereford, 1894; and Leeds, 1895. He was one of the artists in Madame Patey's farewell tour, 1894, and in the Patti tour, 1895. Is now well established as a concert singer. $\mathrm{He}$ has had some experience in light opera, having been principal tenor in the D'Oyly Carte Continental Opera Company, in "Patience," and other works, at Berlin, Hamburg, ete., 1887-8.

Jones, Rev. James, anthor of "A Manual of Instructions on I'lain-chant or Gregorian music, with the chants as used in Rome," London, 1845.

Jones, John, organist and composer, was born in 1728. He became organist of the Temple Church in 1749; Charterhouse, 1753; St. Patul's Cathedral in 1755. He acted as one of the directors of the Handel Commemoration in 1784. He died at London, February $17,1796$.

Works.--Sixty Chants, single and donble, 1785. Jessoms for the harpsichord, 1761 ; Eight setts of Lessons for the harpsichord, 175t. Songs, etc.

Jones, Joseph David, Welsh musician, born at Pryncrugog, Montgomery, in 1827. He was a teacher of singing at Ruthin, and tanght also in the British school there. He died at Ruthin, September 17, 1870. Compiler of "Y cerub yn eynwys toman, an theman, a darnan gosndedig cymbirs i'w harferyd yn y gwasanalth dwyfol," Llanidloes, 1855. "Caniadan Bethlehem," Ruthin, 1857 (We).h carols for Christmas). "Perganiedydd," Llanidloes, 1847. "Tonan ae Emynan," Wrexham, 1868. "Llys Arthur," cantata, 1864. Hvmms, ete,

Jones, Moses Owen, composer, conduetor, and adjudicator, horn in Carnarvonshire, Norember 13, 1842. One of the editors of "The Coungegational Singer" (sce 1). Em1yn Evans.) Was awarded the prize of $\$ 30$ at the London National Fisteddfod, 18s7, for a Pingraphy of Welsh Musicians, since published in Welsh (see D. E. Evans); also a prize of $\$ 20$ at the Carnarvon National Fisteddfod of 1894, for a Critical and Historical Essay on Wolsh National Melodies.

Jones, Richard, autbor of "The most New and Eatsy Method of singing the Pralms," London, 1705 .

Jones, Riclıard, musician. Issned "The Cormubian Tume Book; or Manual of hymn-

\section{JONES.}

tunes, carols, sanctuses, etc.," Penzance, 1870.

Jones, Robert, composer and lutenist, who flourished at the end of the 16th and beginning of the 17th centuries. Biography unknown, but he graduated Mus. Bac., Oxford, in 1597.

Works.-The First Booke of Ayres, 1601. The Second Booke of Ayres, set out to the Lute, the Base Violl the playne way, or the Base by tableture after the leero fashion. Ultimum Vale, or the 'J'hird Booke of Ayres of 1, 2, and 4 royces, 1608. A Musicall Dreame, or the Fourth Booke of Ayres, the first part for the lute, 2 voices, and the viol da gamba; the second part is for the lute, the viol, and four voices to sing; the third part is for one voice alone to the lute, the base-viol, or to both if you please, whereof two are Italian Ayres, London, fo., 1619. The Muse's Gardin for Delights, or the Fifth Booke of Arres, only for the Lute, the Bass Violl, and the Voyce, n.d. The First set of Madrigals of $3,4,5,6,7$, and 8 parts for viols and for voices alone, or as you please, 1607. "Fair Orisma, seeming to wink," madrigal for 6 voices, in Trimmphs of Oriana. Contributions in Leighton's 'Teares. Songs in simith's Musica Antiqua.

Jones, Sidney, composer, of present time. Has written the music to "An Artist's Model," produced, February, 1895 ; and the Japanese musical play, "The Geisha," produced, April 25,1896 , both at Daly's Theatre, London.

Jones, T. H., organist of the Congregational Church, Adelaide, South Australia [1884], is known as an ahle executant, and has given recitals in the Town 1 [all, Adclaide, etc. He was the first upon whom was conferred the Inegree of Mus. Bac. by the University of Adelaide, 1890 .

Jones, Thomas, of Grddesdon, musician. Composed "Ten new country dances for the Harp," 1788. "Music purposely composed for the Harp," London, 1800.

Jones, Thomas Evance, organist, born in 1805. In 1813 he entered Canterbury Cathe 3 ral as a chorister, and in 1822 became lay clerk. He was appointed singing-master to the choristers in 1830 , and in $18: 1$ he succeeded Skeats as organist. He died at Canterbury in December, 1873.

Jones, William, author of "A Discourse on the l'hilosophy of Musical Sounds," n.d.

Jones, Rev. William, of Nayland, composer and writer, born at Lowick, Northamptonshire, July 30, 1726. Educated at the Charterhouse, London, and at Oxford. He was sucessively vicar of Bethersden, Kent, 1764; Pluckley; Paston, Northampto', and rector of Hollingbourne, Kent, 1798. He died at Nayland, Suffolk, February 6, 1800, where he was perpetual enrate from 1776 .

Works.-Ten Church Pieces for the organ, 
JONES.

with four anthems in score, composed for the use of the church of Nayland, in Suffolk, op. 2, 1789. A treatise on the art of musick, in which the elements of harmony and air are practically considered and illustrated by 150 examples in notes . . the whole intended as a course of lectures preparatory to the practice of Thorough-Bass and Musical Composition, Colchester, 178t; Second edition, Sudbury, 1827. Church music, miscellaneous. Collected Works, published in 12 rols., 1802, and again in 6 vols., 1810.

Jones, Sir William, orientalist and scholar, born in London, 17 16 ; died at Calcutta, 1794. Author of "Commentaries on Asiatic Poetry," 1744; “"The Musical Modes of the Hindus," 1784 ; References to Oriental Music in Collected Works, etc.

Joran, Pauline, soprano vocalist and violinist, born in Australia. Appeared, with two sisters, as a party of jureuile artists at San Francisco in 1885. Joined the Carl Rosa Opera Company, and as Beppi, in "L'Amico Fritz," achiered much success, 1893. Sang in Gounod's " Faust," and other operas, at Drury Lane, 1894; at Govent Garden, 1895; and in various places in Italy, 1895-6. Played Mendelssohn's Violin Concerto at Liverpool, 1893, and alsu appeared as a rocalist. Gave a Concert at St. James's Hall, London, December 10, 1896, appearing as vocalist and violinist. Her sister, Elise Joran, is a pianist, and played Mendelssolnn's $F$ minor Concerto at Liverpool, 1893; and also appeared with success in London, in December, 1896. Slie was a pupil of $\mathrm{E}$. d'Albert.

Jordan, Charles Warwick, organist and composer, born at Clifton, Bristol, December 28, 1840. Chorister at Bristol Cathedral and St. Paul's Cathedral. Appointed organist of St. Paul's, Bumhill Row, 1857; St. Luke's, West Holloway, 1860 ; and St. Stephen's, Lewisham, 1866 to present time. Mus. Bac., Oxford, 1869; Mus. Doc., Cantuar, 1886. F.R.C.O. Honorary organist London Gregorian Choral Association. Examiner College of Organists and Trinity College, London; and Professor of organ and harmony Guildhall School of Music.

Works.-Cantata, Blow ye the trumpet in Zion, for soli, chorus, and orchestra; Festival Te Deum, voices, organ, trumpets, and drums, Crystal Palace, 4000 voices, June 19, 1895 ; Festival Jubilate in C, the same, February 20, 1897. Communion Service in E; anthems, etc. Overture, Pray and praise, for organ, trumpet, and three trombones, Lewisham Church, October 1, 1882; Duo concertante, organ and trumpet, Exeter Hall recitals, January 31, 1891, etc. Anthor of A short paper on the construction of the Gregorian tones, 1874; 150 harmonies for the same.

Jordan, Mrs., born Dora or Dorothea
JOWETT.

BLAND, actress, singer, and composer, born neal Waterford, in 1762. She was daughter of a Captain Bland. After being trained as a milliner she appeared on the stage at Dublin in 1777. She adopted the name of Mrs. Jordan in 1782, but was never married though mother of various children. She died at St. Cloud, near Paris, July 3, 1816. Her biography belongs more to theatrical than musical history, and her chief claim to notice here, apart from her sliglit merits as a singer, is as the composer of the "Blue Bells of Scotland." This was issued as the "B] Be Bells of scotland, a ballad as composed and sung by Mrs. Jordan," London [1800].

Jortin, Rev.John, clergyman and autlior, born in 1698; died in 1770 . Vical of Kensington. Author of "A Letter concerning the music of the Ancients," in 2nd edition of Avison's "Musical Expression."

Joseph, Kinsell, organist, born in Essequibo, British Guiana, December, 1845. For many year's organist of St. George's Cathedral, Georgetown, and master of St. George's Parish School. He died May 26, 1892, and left a legacy to the choir of the Cathedral; and this being invested, forms an endowment, probably the first of the kind in a West Indian Colony. Joseph was by race a negro, and a man of singular charm of character, wimming the esteem and respect of his Bishop (Dr. Austin), and all with whom he was associated.

Joule, Benjamin St. John Baptist, organist, composer, and editor, born at Salford, November S, 1817. Studied violin muder Richard Cudmore, and organ, etc., under J. J. Harris. He was honorary organist of Holy Trinity, Hulme, 1846-53 ; St. Margaret's, Whalley Range, Mauchester, 1849-5.'; and of St. Peter's, Manchester, from 1853. President of the Manchester Tocal Society; Fellow of the Genealogical Society of Creat Britain; F.C.O. ; and J.P. for the County of Lancaster. Contributor to various periodicals, and music critic, 1850-70, to the Manchester Courier. He died at Manchester, May 21, 1895.

Works.-The hymms and canticles, pointed for chanting, 1847. I)irectorium Chori AngJicanum, Loudon, 1849, which has passed through many editions. A collection of words of 2,270 Anthems, with 452 biographical notices, London, 1859. The Psalter, or Psalms of Tavid, after the translation of the great Bible, pointed as they are to be sung or said in Churehes, London, 1865. Collection of chants, London, 1860, 18 editions. The Order for Holy Communim, hannonized on a monotone; Organ and pf. music, etc.

Jowett, Rev. Joseph, clergyman and musician. was born in 1784, and died May 13, 1856. He was rector of Silk-Willoughby. Compiler of "Lyra Sacra, select extracts 
JOYCE.

from the Cathedial music of the Church of England, for 1, 2, 3, and 4 voices ...," London, 1825. "A manual of Parochial Psalmody, containing 142 Psalm and Hymn tunes, by varions authors, London, 1832 .

Joyce, Patrick Weston, LL.D., Irish writer, born at Ballyorgan, Limerick, in 1827. Compiler of "Ancient Irish M Insic, comprising one hundred airs hitherto umpublished, many of the old populat songs, and several new songs, ete., Dublin, 1873. Irish Names of Places, 2 rols., 1\$69-70. Old Celtic Romances, 1879. lrish music and song, a collection of songs in the lrish language set to musie, London, 1888.

Joze, Thomas Richard Gonzalvez, composer and organist, born at Inblin, September 26, 1853. Entered as chorister in Christ Church Cathedral, 1861; and was deputy organist, 1869. Organist of St. Paul's, Glengarry, 1870; at present time organist of Christ Church, Leeson Park, Dublin. Gradnated Mus. Doc., 1877, Dublin. Is professor of organ and harmony, R.I.A.M.; Fxaminer to Commissioners of Intermediate Education in Ireland, and to the Royal Tniversity of Ireland. Conductor of the Strollers' (innl, The Sackille Hall Choral Society, and Grand organist of the Grand Lodge of Freemasoms, Ireland. Ilis compositions include two cantatas, "The Prophecy of Capys," and "A Dream of the Fairies"; Prize Festival Hymn, "St.Patrick's Breastplate"; Hibernian Catch Club first prize (ilee, 1871, "The dead Soldier"; Part-songs, pf. pieces, cetc.

Jude, William Herbert, organist and composer, bom at Westleton, Suffolk, 1851. Sonnetime organist of the Bhue Coat Hospital, Liverpol; founder of the Purcell Society, Liverpool; Fditor of the "N[onthly Hymnal"; Organist, 1889, of Stretford Town Hall, near Manchester. He has given recitals in varions plices; fectured on musical subjects in Great Britain, and in Australia. An operetta, "Innocents Abroad," was produced at Liverpool in 1882; and he has written a number of songs, cte.

Karn, Frederick James, organist and composer, horn at Leatherhead, Angust 29, 1862. Organist at Cobham, Nurrey; now of St. John's, Downshire-hill, Hampstead. Graduated Mns. Bae., 1885, Cambridge. Has given concerts at St. John's College, Hurstpierpoint; and was appointed conductor, 1889, of the Acience and Art School Orchestral Society, Sonth Kensington. He has composed church musie, songs, ete.

Keach, Benjamin, clergyman and musician, was pastor of the Baptist Church in Goatyard Passage, Horsleydown, Southwark, in latter part of 17th century. Author of "The Breach repaired in God's worship, or
TEEELEY.

singing of psalms, hymms, and spiritual songs proved to be an holy ordinance of Jesus Christ," London, 1691. "Spiritual Mlelody," 1691 ; a collection of palms, etc., the publication of which, and of the pamphlet named, led to a secession in his congregation

Kearns, William Henry, Irish musician, born in 1794. He was an instrumentalist and teacher in London. Died in London, December 28, 1846. Composer of "Bachelors' Wives, or the British at Brussels," operetta, 1817 ; Songs of christmas for family choirs.. 1847; Songs, pf. musice, etc. With H.J. Gauntlett, he edited "The Comprehensive Tume Pook."

Kearton, Joseph Harper, tenor voealist and composer, born at Knaresborongh, October 25,1848 . At the age of seven he joined the choir of Trinity Church there, and was appointed, when fourteen, organist of the Congregational Church. Three real's later he became a tenor singer at York Minster. There he studied with Îr. Howard Herring, and had some assistance from Dr. E. (i. Monk. In 1867 he was oppointed a ricar choral at Wells Cathedral, and held other offices in the locality. He studied there with Edward Herbert, with a riew to the profession of organist and teacher, and passed his exercise for the degree of Mins. Bac. His singing attracting attention, he devoted himself to that art exchusively, and studied for a time at the R.A.MI, and in 1875 was made a vicar choral of Westminster Alluer. He sang at the Chester and Bristol Festivals, 1882, and Hereford, 1885; at the Crystal Palace, Monday Popular Concerts, and has taken part in many notable performances. He has composed anthems; Six orgm voluntaries; Songs and ducts; and contributed to the pastiecio, "Harold Glynde." His danghter, Annie Keartos, made her debut as a soprano vocalist, in London, June, 1893.

Keddie, Henrietta, SARAH Trther, Scottish novelist and writer, born at Cupar Fife, March 4, 1827. Authoress of "Musical Composers and their Works," London, 1875; 2nd ed., 1877. Also writer of other liographical works, and many novels.

Keeble, John, organist and composer, bom in Chichester, 1711. Chorister in Chiehester Cathedral, under Kelway. Hestudied music under Pepusch, and became organist of S. Feorge's, Hanwer square, London, in 1737. Organist of Ranelagh Gardens. He died at London, December 24, 1786.

Works. - Five Pooks of Organ Pieces. Songs, etc. The Theory of Harmonics, or an Ithstration of the Grecian Flarmonies, London, 1784.

Keeley, Mary Anne, born Goward, voealist and actress, bom at Ipswich, November 22, 1805 . Studied singing under Mrs. 


\section{KEETON.}

Henry smart (sister-in-law of Sir George Smart), and made her dibut in Dublin in 1824. She sang in "Rosina" at the Lyceum Theitre, London, July 2, 1825; and was the original Merinaid in the production of Weber's "Uberon," Covent Garden, April 12, 1826. After her marriage with Mr. Robert Keeley (died, 1860), she was seen only in comedy, in which she acquired a high reputation. When she retired from public life, her interest in the stage continued. The was present at the benefit to Ada Swamborough, Strand Theatre, December, 18st; and opened the new Theatre at Ipswich, Narch 28, 1891, with an address. Her 90 th lirthday wats celebrated br a grand reception at the Lycem Theatre, Norember $22,1895$.

Keeton, Haydn, organint and comproser, born at Mosborvugh, near C'hesterfield, ()etober 26,1847 . Received his musical training at St. George's Chapel Roval, Windsor. Graduated Mins. Bac., 1869; MIus. Doc. 187\%, Oxford. Was appointed organist of Hatelnet Parish Church, 1467; and of Peterlsoromgh Cathedral, 1870. Sionetine Examiner, College of Organists; Conduetor and organint, Peterborongh and Lincoln Cathedral Festivals; Conductor, I'eterburongh C'horal Lnion, etc. He has composed an Orchestral sirmphony; Give ear, Losd, unto my prayer (Meadowcroft Prize); 1 will alway give thanlis, and other anthems; Church Services; Offertory Sentences (College of Organint Prize); Pf. pieces, songs, ete. Anthor of Chureh and Cathedral Choristers Singing Method, London, Cocks, 1892.

His father, Euwix Keftox, has heen organist of Eckington Parish Church since 1848 , and has taken an active part in the Festivals of the Derby Archidiaconal Choral Association, ete.

Keith, Robert William, pianist and writer, was born at stepney, London, in 17st; died, London, Jine 19, 1846. Author of “A Musical Tade Necum, being a compendious introduction to the whole Art of Misic," London, 1820, 2 vols. "Instructions for the Pianoforte.." London 1833]. "Tutor for the German Flute"; "Britannia, mourn: elegiac verses on the death of Princess Charlotte," 1817 , etc.

Kellie, Lawrence, tenor rocalist and composer, of Scottish dencent, born in London, April 3, 1862. He was musical from childhood, but was articled to a solicitor, and did nct adopt the profesion of music mntil 1884. Studied for a time at R A.M., but chic Hy moler Mr. Randegger as a private pupil. Made his debut at the Covent Garden Promenade Concertis, in Novenber, 1896; and commenced giving rocal reeitals at Steinway Hall, May 23, 1887. He has sung in the provinces, and has made a reputation; but is

\section{KELLY.}

more widely known as a song composer. His works in this directron are already very numerous, and include: AlI for thee; My fairest child; This heart of mine; Donglas Gordon; A winter love song; The city of night, and many others. It is understood that Mr. Kellie has an opera in course of completion.

Kellie, Thomas Alexander Erskine, sixth Earl of, Scottish amateur musician, was born September 1, 1732. He studied music in Germany, mnder Stamitz. Succeeded his father, as sixth Earl of Kellie in 1756 , but afterwards sold most of the Kellie property. He died at Brussels (mmarried), October 9, 1781. He composed a number of overtures (The Maid of the Mill, 1761, etc.); Symphonies and other works, some of which were produced at Ranelagh and Tauxhall. A collection of some of his compositions was issued as "Minuets and Songs now for the first time published, with an introductory notice by C. K. Sharpe," Edinburgh, 1839. Songs, etc. He was reckoned among the most respectable amateur violinists of his time, and was a composer of some ability.

Kelly, Charles W., baritone vocalist, nember of the choirs of St. Patrick aud Christ Church Cathedral, Dublin, and professur of siuging in the R.I.A.MI. He has a reputation in the concert room, and ranks among the best singers in Ireland. His brother, Thomas Grattax Kelly, is a bass; vicar choral of St. Patrick's and Christ Church Cathedrals, Dublin, and nember of the choir of Trinity College. He is also recognised in the concert-room as an artist, both as regards voice and style.

Kelly, Michael, composer and vocalist, born in Dublin, 1762. He studied singing under Rauzzini, and also at Naples under Aprile, etc., 1779. Drbut as vocalist at Dublin, 1779. Travelled in Italy, and became acquainted with Mozart. Dibut at Drury Lane, as Lionel in "Lionel and Clarissa." Sang at Concerts of Ancient Music, Handel Commemoration, in English Provinces, Ireland, ete. Nanager of King's Theatre, 1793. He died at Margate, October 9, 1826.

Wonis.-Musical Dramas, for which the music was chiefly compiled, as-Adelmon the outlaw, M. G. Lewis, 1801; The Africans, 1808; Blind bargain, 1805 ; Blue beard, 1798; Bride of Abydos, 1818 ; Castle spectre, 1798; Cinderella, 1801; Conquest of Taranto, 1817 ; Counterfeit, 1804; False appearances, 1789 ; Friend in need, 1797 ; Hero of the north, 1803; Of age to-morrow; Pizarro, 1799; Wrood demon, 1807, ete. Six English airs and six Italian duetts, 1790 ; The woodpecker, ballad, and other songs and glees. Elegant extracts for the German Hute, 1805. Reminiscences, during a period of nearly half a century, with 


\section{KELIVAY.}

original anecdotes of many distinguished persons, London, 2 vols., 1826 ; 2nd edition, 1826.

His niece, Frances Maria Kelly, a singer and actress, was born at Brighton, October 15, 1790. First appeared in Blue Beard in 1798, and sang at Drury Lane and other Theatres. She died at Feltham, Middlesex, December 6,1882 , after a life partly spent in trying to elevate the stage in public estimation.

Kelway, Joseph, organist and composer, was bom alout the beginning of the 18th century $[1702]$. He studied under Geminiani, and was organist of St. Michael's, Cornhill, London, till 1736. Organist St. Martin-inthe-Fields, 1736. Instructor on harpsichord to Queen Charlotte. He died in 1782. He composed Six sonatas and lessons for the harpsichord, London [1764]. Songs, etc.

Kelway, Thomas, organist and composer, was born about the end of the 17th century. Brother of Joseph. Organist of Chichester Cathedral, 1720. He died at Cbichester May 21,1749 .

Works.-Evening services in B minor, A minor, G minor; Seven services and nine anthems in IIS. at Chichester Cathedral.

Kemble, Adelaide, Mrs. Sartoris, sin. ger and actress, born in 1814. [)aughter of Charles Kemble. Appeared first in London as singer. Sang at York Festival, 1835. Travelled in France and Germany. Sang in Italy, 1840. Married Mr. F. Sartoris, 1843. Author of "Past Hours." London, Bentley, 18:1. She died August 4, 1879.

Kemble, see also Alkwright, Mrs. R.

Kemble, Rev. Cliarles, compiler of "Church Psamody: a selection of Tunes and Chaunts in four parts," 1840 . Also of various works on duties of clergymen, sermons, ete.

Kemble, Giertrude, see sub. Santuey Chardes.

Kemp, Joseph, composer, horn at Exeter, in 177\%. He studied under IV. Jackson, and became organist of Bristol Cathedral, 1802. Mus. Bac., Cantab., 1808. Music teacher in London, 1sos!, Nus. Doc., Cantab., 1809. He died at London, May 22, 1824.

Works.-The Jubilee, 1809; The siege of Isca, 1810 ; The Crucifixion ; Musical illustrations of the Lady of the lake, 1810; Musical illustrations of the beauties of Shakespear; The vocal magazine, Edinburgh, 3 vols., 179s, 1800 [edited], also Bristol, 1807; Glees, 2 sets, London [1:00-1803] ; Twelve songs, op. 1,1799, and other's; chants, duets, anthems, ete. Upwards of one lumdred cards contain. ing more than 500 points in music [1810]. New system of twelve Psalmodical melodies, 1818; Sonatas or lessons for the pf. [1810]; Musical education, London [1819].

\section{KENNEDY.}

His son, John, born at Exeter, 1801 ; Died there, January 14, 1885; was lay vicar of Exeter Cathedral.

Kemp, R., author of "Directions for tuning the Alexandre Harmonium," Loudon, 1874.

Kemp, Stephen, pianist, born at Yarmouth, Norfolk, November 8, 1849. Educated at R.A.M. Fellow, and Professor of pf., R.A.M. Has given concerts in London, and is known as the composer of some tasteful pf. pieces; songs, "The Cavalier," etc ; trio for female voices, "O, lady, leave thy silken thread," ete. He is also professor of the pf. at R.C.M., and the Guildhall School.

Kempson, James, parish clerk of St. George's, Birmingham, was an active participator in musical doings in that town from the middle of the last century. He started, in 1766 , the Birmingham Choral Society that gave annual performaneas in St. Bartholomew's Chapel for the "Distressed Housekeepers' Charity" ; and his aid was sought for the First Musical Festival held in Birmingham, in 1768 . It is said that he was assistant conductor of those Festivals to the year 1817 . He was called the "Father of the Oratorio Choral Society." He died at a great age, Narch 10, 1822 .

Kempton, Thomas, organist and compuser, who died in 1762, was organist of Ely Cathedral from 1729 .

Kennedy, Arnold, pianist and teacher, born in London, in 1859. Edueated at Edinburgh High School, and Lniversity, where he graduated M.A. His musical studies began with the 'Tonic Sol-fa system when he was a boy. After leaving Edinburgh, he entered the Ti.A.M., and was elected an Associate. He took his 11 us. Bac. degree at Oxford, 1893. Resident in London as teacher and lecturer. He has published a few songs, and is part composer of children's operetta, "Prince Ferdinand."

Kennedy, David, tenor vocalist, was loom at Perth, on April 15, 1825 . He received no regular instruction in singing, but was a precentor and teacher for some time in Edinburgh. He was precentor of Nicolson Street U. P. Church, Edinburg], for a number of years. He first made himself known through popular concerts which he gave originally in Edinburgh, but afterwards in most of the larger towns in Scotland. Latterly Mr. Kennedy sung in Africa, New Zealand, America, and London, in all of which places he has met with extraordinary success, giving concerts of Scottinh song along with his family. He died at Stratford, Ontario, Canada, October $12,1886$.

He had a large family, most of whom were musicians. Darit (born at Perth, 1849; died, Pietermaritzburg, December 5, 1885), 


\section{KENNEDY.}

was a tenor singer anj journalist, and wrote "Singing round the WVorld," which is incorporated in his sister's book mentioned below. Jaxes (born 1856; died Nareh 23, 1881), was a baritone singer, and perished in the fire at the Opera House, Niee, where he had been studying under Lamperti along with his sisters, Kate (born 1861; died Marel 'ב3, 1881), who was a eontralto, and Lizzie (18631881), who was a soprano. Other members of the family are Ropert, a tenor singer, who studied at Milan, and gives Sicots eoneerts on lines similar to his father; now in Australia. Helen (Mrs. Campbell), a soprano; MarJory (Mrs. Fraser), a contralto, who wrote a book ealled "David Kennedy, the Seottish singer," Paisley, 1887; and MARGaret, who was, to 1890, sub-professor in the Royal Aeademy of Musie, London.

Kennedy, Rev. Rann, elergyman and musieian, bom in 1773. Ineumbent of St. Paul's Chapel, Birmingham. Lied at Birmingham, January 2, 1851. Author of "Thoughts on the musie and words of Psalmody as at present in use among the memlers of the Church of England," London, 1821. "Chureh of Fingland Psalm Book," 1821. Poems and other literary works.

Kenney, Charles Lamb, playwright and writer, born in 1423; died at London, August 25, 1881. Author of "Memoir of Miehael William Balfe," London, 1876. I Le was also a musieal critie and barrister-at-law.

Kenningham, Alfred, trus rocalist. A member of the choir of st. Andrew's, Wells Street, London. In 1872 he was elected assistant vical (Thoral; and in 188s, viear choral, sit. Paul's Cathedral. He has been heard in concerts in London and the provinces, and is the composer of "The hour of love." and other songts.

Kenningliam, Charles, tenur rocalist, is a native of Torkshire. In 18 so he was apprinted to the choir of Canterbury Cathedral, where he remained alont four sears. He made his stage dibut, Jannary 31, 1891, in sullivan's "Iranhoe," as lo Bracy, and afterwards sang in "La Basoche." He then went on tour with the D'Orly Carte Company in the "Natutch Girl," "Vicar of Brar," "Jane Amnie," and other light operas; and sang at the Saroy Theatre in "Haddon Hall," ete.

Kent, James, organist and composer, born at Winchester, Mareh 13, 1700. He was a chorister in Winchenter ('athedral under. Vangham Richardson 1711-171t, and in the Chapel Roral moler Dr. Croft. Snccensively organist of Parish ('hurch of Finedon, Northamptom, till 1731; Trinity College, ('ambridge, till 1737; and Winchester Cathedral, 1737-7t. He died at Winchester, May 6, 1776. He comprosed Services in ( and I), and ". Twelve

\section{KERR.}

Anthems "1773,vol. 1 ; and "Eight Anthems," vol. 2, edited by Corfe. Kent's Anthems, edited by T. (Fraham, London, 1841, 2 vols.; An edition edited by Vincent Novello; also many single anthems.

Kenward, William Daniel, composer and rocalist, born at Lewes, March 21, 1797. He studied under the Ashleys, and he was a chorister in Durham Cathedral under Dr. Camidge, and from there was appointed preEentor of the West Church, Aberdeen. 1824-28. In 1828 he lecanne precentor of the High Church, Edinhorgh, and he acted as singing master at Heriot's Hospital from 1837, and conductor of the Harmonists' Society from 1829 till 1860. He died at Edinburgh, May 1, 1860.

Works.-Sacred Harmony 1839 also [18t8]. The l'salmody of Sicotland, 1855. The Seottish Psalm and Tume Book, 1855. Collection of the sacred Music of the Chureh of Scotland . to which is prefixed the rudiments of Music, and scales and exercises for the voice, Ediulurgh, n.d.

Kenway, Helen, a teather of music at Bath, desirous of extending the means of aid. ing musiciaus disabled by ill-health, or other causes, and to provide a school for orphan girls, has devoted herself entirely to the realisation of these benevolent olnjeets. Beginning, about $1 \times 77$, by taking one girl into her sister's school at Bath, she gradnally extended her operations; and in 1843 tork a house in London. Since 18,4 the Orphan school has lreen located at 16. Norland square, Notting Hill, and there Mims Kenway gives her time and means entirely to thisinstitution, the only one of its kind commected with the musical profession, and dependent upon the voluntary pecmiary aid of those interested in her philanthropie work.

Kerfoot, Joseph, hind organist, was horn at the end of last century. For over 53 years he was organist of the Parish C'hurch, Leigh, Lancashire. He died at Leigh, in August, 1854.

His son, Joseph, was born in 1819, and was organist of Winwick Parish Church from 1837 to 1890 , when he retired. He died at Leigh, in Nay, 1's9t.

Thomas, lirother of the first named, was a mative of Chester, and for orer 50 years was organist of Warrington Parish church. He published a book entitled "I'atrochial I'salmody," 1838.

Kerr, Mrs. Alexander, bom Lours HAY, song-witer and authoresis of the present century she wrote a number of sentinental lotllads, and a few part-smgs, words and musie. Among the former may be nimed, "Melodies, the Words written and the Music composed by Mrs. Alexander kerr," London, L'Alnuane 1835; Evening hymm, ete. 


\section{KETTLE.}

Kettle, Charles Edward, organist and composer, bom at Bury St. Hdmunds, March 28, 18:33. Organist suceessively at St. Margaret's, Plhmstead; St. Nicholas, Plumstead; Holy Trinity, Woolwich; Hove Parish Church; Qneen's Siquare Congregational Church, Brighton. He died, March 2, 1895.

Wonks.-Sunday School Hymms, London, Weekes; Songs of the Church; Northern Psalter; Chants, ancient and modern; Rettle's Tune Book: containing 700 original tunes and chants; Hymm Tunes in various collections; Service of song. Three operas: Amelie; Hermina: The water cure (IIS.). In the dawning; The voice of music, and other songs. Postlude in C; Marche Solennelle; Offertuire, ete., for organ. Pf. pieces, various.

His danghter, Lrzzie lietTle, was educated at the London Academy of Music; and is now a teacher of pf., violin, etc., at Brighton.

Key, Joseph, of Nuneaton, church composer, who flourished in the first half of the present century. He wrote a numbre of marches for organ, ete., and Eleven Anthems on general and particular occasions, for four voices, n.d. Five anthems, four collects, twenty psalm tunes, ete., London [1790]. Collected anthems, in 4 books, ete.

Kiallmark, George, composer and violinist, bom at King's Lynn, February, 1781; baptized in March. He studied under Barthelemon, Spagnoletti, and Logier. Violinist in various orchestras, and teacher. Leader at Sadler's Wells, London. Died, Islington, Marcli, 1835.

Works.-Songs: All alone; Autumn noons; Banks of the Rhine; Bound where thou wilt; Cupid and Hymen; Fair Haidee; Fare thee well: Farewell, bright star; IJelen's Farewell; Him I love; Maid of Athens; Now each tie; O come, my love; etc., etc. Partsongs: An immense number of divertimentos, fantasias, marches, fanfares, etc., for pf.

His eldest son, George Frenerick, was born in Islington, London, November 7, 1804. He studied at home under his father, Logier, and Moscheles, and at Paris, under Kalkbrenner, and others. He resided in London as a teacher and concert-giver, and died December 13, 1887. Celebrated as a pianoforte player.

Kidd, William James Pasley, musician and editor of first half of the present century. He compiled "The Chorister's Text-book, containing nearly 200 psalm and hymn-tumes, preceded by a comprehensive Grammar of MLusic," 1856. One of the contributors to the "liritish Minstrel."

Kidson, Frank, musician, of Leeds, compiler of "Old English Country I)ances... with notes, and a bibliograpliy of English country dance music," London, 1890. “Traditional Tunes, a cullection of ballad airs,
KING.

chiefly obtained in Yorkshire and the South of Scotland...." Oxford, 1891.

Kilburn, Nicholas, composer and conductor, born at Bishop Auckland, February 7,1843 . Was privately educated in music. Graduated MIus. Bac., Cambridoe, 1880. Since 1875 he has been conductor of the Auckland Musical Society; from 1882 of the Middlesborough Musical Union; and of the Sunderland Philharmonic, from 1885. He has conducted concerts at Newcastle-on-Tyne; lectured on music; and as a zealous amateur, done much to promote musical culture in the north. His compositions include a sacred cantata, "Grant us Thy peace" ; an oratorio, "St. Thomas," both for soli, chorus, and orchestra, the latter produced at Bishop Auckland, December, 1886. Psalms 23, and 137, for chorus and orchestra; Anthems, and Church services. The Golden River; The Silver Star, cantatas for female voices. Suite for orchestra (1894); Songs and part-songs. Duologue for pf. and violin. Author of pamphlets: How to manage a Choral soniety; Notes and notions on Musie; Wagner, a sketch of his life and works; and Parsifal, a pilgrimage to Bayrenth.

Killen, Rev. William D., clergyman and writer. President of the Presbyterian College, Belfast, and profes or of ecclesiastical history. Author of "The Wes minster Divines and the use of instrumental music in the worship of God," Belfast. 1882. "A Catechism of the scriptural authority for the use of instrumental musie in the Christian Church," Belfast, 1885. "Ecclesiastical history of Ireland," London, 1876, 2 vols.

Killick, Thomas, musician of early part of present century, who resided at Gravesend as an organist ard teacher. Among other works he issued "Original set of Quadrilles and a waltz for the pf.," London [1829]. Also Handel's Overtures, arranged for the organ and pf., Clementi [18.23].

Kilner, Thomas, organist and author, who died at London, September 30, 1876. Author of "Manual of Psalmody and Chanting," 1850; "Pocket Chant liook," 1850; Jottings about choral and congregational services, organs and orgauists, Gregorians, benches, and chairs, etc.," London, 8vo, 1872 ; second ed., 1873. Numerous pieces of organ music, etc.

King, Alfred, organist and composer, born at Shelley, Essex, April 24, 1437. He studied for the Church, but was a pupil for organ of Dr. Steggall. Became F.C.O., 1868; graduated Nus. Bac., 1872; Mus. Doc., 1890, Oxford. Held organ appointments at Cuddestou Theological Cullege, 1856; Eastnor Castle (Earl Somers), 1857-64; St. Michael and All Angels, Brighton, 1865-77; Brightou Parish Church, 1877 87. Appointed organist 


\section{KING.}

to Brightou Corporation, 1878; and from that date to 1883 , was chorus-master and part conductor of the Brighton Musical Festivals. Principal of the Brighton School of Music. His works include a cantata, "Deliverance"; an oratorio, "The Epiphany," produced at Brighton, April 9, 1891 ; Mass in B flat; an Evening Service in B flat. Madrigal; Music, when sweet voices die, for six roices, Brighton, December, 1886; Part-songs, hymms, etc.

King, Charles, composer and organist, bornat Bury-St.-Edmunds, in 1687. Chorister in St. Paul's under I)r. Blow and Jeremiah Clark. Narried to sister of J. Clark. Almoner and Naster of Choristers, St. Paul's Cathedral, 1707. Mus. Bac., Oxford, 1707. Organist of St. Benet Fink, London, 1708. Vicar-choral of St. Paul's, 1730. He died at Loudon, March 17, 174s.

Works.-Services in F, C, D. and B flat. Anthems-Rejoice in the Lord; Hear, O Lord; O pray for the peace of Jerusalem; Unto Thee, O Lord; Wherewithal shall a young man learn.

King, Donald William, tenor vocalist, was born in 1812. Was appointed principal tenor, Foundling Hospital, 18t5. He sang in Opera at Drury Lane, and with the English Opera Company at the Strand Theatre, in 1848. He was a successful ballad singer. Died at Kilburn, London, August T, 1886 .

King, Frederick, haritone vocalist, born at Lichfield, January 3, 1853. Chorister at St. Mary's, Lichfield, and afterwards studied under John Pearce, Birmingham. Gained a Scholarship at the National Training School for Music, in 1876. Nade his debut at one of Harrison's Concerts, Birmingliam, January 30, 1879, and sang at the Birmingham Festival the same year. In 1580 he sang at the Gloucester Festival, and in succession at the other Three Choirs' IIvetings; also at Leeds, in 1880, in the title part in "Elijah ;" and again in 1883-86, creating the part of Lucifer iu Sullivan's "Golden Legend." He sang at the Handel Fes'ivals, 1880-8.2, and 1885; Chester Festival, 1852; and at the principal Metropolitan and provincial concerts. He was appointed a professor of singing at R.A.M. in 1890 ; and in 1895 made Hon. li.A.MI.

King, Henry John, organist and composer, born in Australia. Composed a cantata "Ceritennial Ode" (Rev. W. Allen). performed at the opening of the Melbourne Exhibition, August 1888. He has also written a choral ballad, "Trafalgar," for men's voices, withont accompaniment; a Morning and Evening Service, with the Communion Office in F, etc.

King, James, musician, born abont 1788. He was a singing master in London. Died, London, August 6, 1855. Author of " $\mathrm{An}$ Introduction to the theory and practice of Singing," London [1823]. "Collection of
KING.

Glees, Madrigals, etc." London [1839]. Psalms of David arranged to chants. London [1840]. Songs, etc.

King, James, composer and bandmastex of the 5th Dragoons, was born about 1809 . When only six years old be was present at the battle of Waterloo with his father, who was a trumpet major. He died at Derby, September 22,188. Composer of music for military bands.

King, Jessie, contralto vocalist. Studied in London, and appeared at the Crystal Palace June 22, 1859, taking part in the concerted music in "Elijal,," performed on Festival scale in the Handel Orehestra. She was engaged for the Glourester Festival of 1892, at Worcester the next year, and at Hereford in 1894; singing with much success. Since then she has gained a good position among vocalists of the day. She sang at the Crloucester Festival, 1895 ; at Tewkesbury Festival and at the Jubilee performance of "Elijah," Crystal Palace, June 27, 1896.

King, Matthew Peter, compos $r$, born at London, 1773. He studied music under C. F. Hom, and was a teacher and musical director in London. He died at London, January, 182:3.

Works. - Sonatas for pf., op. 1, 2, 5, 14; Rondos, op. 13, 22; Quintet for pf., flute, vu., tenor, and 'cello., op. 16; livertissement for pf., op. 24. The Intercession, oratorio, 1817. (This contains the celebrated song, Eve's Lamentation.) Music to DramasMatrimony, 1804; The invisible girl, 1806; False alarms (with Braham), 1807; One o'clock, or the wood demon (with kelly), 1807; Ella Rosenberg, 1807; Up all uight, or the smugglers' cave, 1409; P'lots, 1810; Oh, this love, 1s10; The Americans (with Braham), 1811; Timonr the Tartar, 1s11; The fisherman's but (with I)ary), 1819: The magicians (with Bralım). The Harmonist, a collection of glees and madrigais, from the classic poets [1814]. A general treatise on music, particularly on harmony or thoroughbass, and its application in composition, London, 1800. Introduction to the theory and practice of singing at first sight, 1806. Partsongs; duets, as The minute gun at sea; songs, etc.

His son, C. M. KING, composed songs and pf. music.

King, Oliver A., composer and pianist, horn in London, in 1855. Chorister at St. Andrew's, Wells street. Articled pupil of J. Barnby, and afterwards assistant organist at St. Anne's, Soho. Studied pf. under IT. H. Holmes; and at Leipzig Conservatorium under Reinecke, and other's, 1sit-7. Appointed pianist to H.R.H. the Princess Lonise, 1879 , and was in Canada in that capacity, 1880-3. While there, he gave recitals in 


\section{KING.}

rarlons towns, and visited New York. He has also given concerts on the eontinent of Europe. Sometime musical director of St. Marylebone Parish ('hurch; he is now a professire of pf. at R.A.M. His compositions are very mmerous, the principal being named below.

Works.-Pralm 137, for soli, chorus, and orehestra, produced, Chester Festival, 1888. Cantatas: The Romance of the Roses, op. 80; Proserpina, op. 93, female voices, both with orchestra; The Naiades, female voices; Morning and Exening Service in D: Te Deum and Jubilate in $D$, with free organ aceonmaniment. Album of duets; songs, and part. songs, Soldier, rest; The Curfew (6 voices), ete. Orchestral: Symphony, Night; Concert overture, Among the Pines (Prize, Philharmonie Soeiety, 1883); Concert overture in D minur, produes at Novello Concerts, 1888; Concertr, pf. (1885, Brinsmead Prize); ('oncerto in G minor, violin, Hensehel Concerts (Emil Mahr), Jamnary 20, 1887. Sonata in D minor; Twelve pieces, violin and pf. Legende; Miniatures, 3 books, and other pieces, pf. Twelve original voluntaries; Suite, op. 6 ; Fonata, op. 71, and other compositions for organs, ste.

King, Robert, composer, was born alout the midale of the 17 th century. Mnsician in band of William and Mary, and Qnesele Ame. Mus. Bar., Cambriclse, 1696. He died after 1711 .

Woriss.-Music in The banquet of Musick. 168s; ('hoire Avres, Songs, and Dialegues,

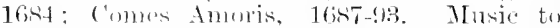
Shatwell's ode on st. Cercilia's Inas, 1690. "Oncenome tis born," Ode on Earl of Exeter, 1693. Simgs for 1, 2, and 3 voices, comporl to a Thuromgh lasse, for ye organ of harpischord," Lourlim, nid.

King, William, organist and composer, born in 1624. ('horister in Magdalen Collecon, Oxford, 16th. P.A., 1649. ('haplain of Magdalen colloge, 1650)-t. Problationer-fellow of All Soul's College, 1054. Organist of New College, Oxford, 1fift. the died at Oxford, Novemler 17, 1680. Ho wrote a Sorvice in 1 flat, Anthems, ste, and " Poemen of Mr. Cowley and others, compuned into fonge and Arres," Oxford 1668 .

His father, Centris Kror, was organist of Winclester Gathedial.

Kingsbury, Frederick, pianist, conductor, and teacher, borm at Tanntom, 1815 (?). Gave his first concerts in his native place, in Jannary, 1841, plaring pf. pieces ly Hönten and Thallerg, and alwo appearing as a vorilist. In 18 it he lreante a student at the R.A.MI. He conducted oratorio concerts at Holborn Theatre: was direretor of the Jondon Vocal Acarlemy ; and alout 18683, formed the West London Choral Thion, giving concerts in st.

\section{KINROSS.}

James's Hall, and assisting, with his choir, at the Crystal Palace concerts. In 1868 he condueted the Promenade Concerts at the Agricultural Hall; and up to 1882 was engaged in concert work. In that year he was appointed a professor of singing at the Blackheath Conservatoire, and was also a professor of pf. at the Fuildhall School. He died in London, February 26, 1892, at the age of seventyseven.

Author of "The Voice and the structure and management of the vocal organ"... London, 1858

Kingston, William Beatty=, journalist and writer on music, lown at London in 1837. He was in the Pullic Record office in 1852, and in 1856 , lecame attached to the Austrian Consular service. Has acted as special corresomitent to varions newpapers, and travelled much in varions parts of Europe. Anthor of "Music and Manners," London, 1887, Chapman and Hall, 2 vols.; "Monarchs I have met," 1887. 2 vols. " Wanderer'" Notes," 1888, 2 voli.; the English lihretto of "The Beggar Student," produced ly Corl Rosa, 1884; and contributions to The Lute, and other musical journals. In 18st, hr recuived the Order of the ('rown of Rommania, being the first Englishman so flecorated; and in 1885 , the Order of the Redeemer, from the King of Creece. He las also composed some pinces for pof.

I is daughter, Mhnif Axtornette RingsTox (uow liaroness von Zudlitz), has eomposed a number of songs: Tell her; sweethent, say?; For lack of thee: When leares are green, and others. Also some compositions for p. E. Elitor of Lnigi Arditi's " My Reminiscences," London, slieftington, 1896.

Kinloch, George R., Seottish ballad collector, published "Ancient Scottish Pallads recovered from trafition. and nexer before published, with notes anrl an appendix containing the airs," Eflinburgl, 1827. The flance tume "Kinloch of Kinlech," ustally adapted to Conolly's song, "Mary Macneil," and alio to Antrew lark's " Hurrah for the Highland " Was composed ly George Kinloch of Kinloch. 1t first apreared in Watlen's " ("ireus Thues," aftrwards in collectisus of (row.

Kinlock, Eliza, born Trafmen, soprano singer. born at Jondon, March 7,1796 . She appeared very carly as a ballad singer, and married Mr. lane, an actor. who died soon after. In 1827 she appeared in the United States, and in the sime rear married Mr. Kinlork, an actor. She olied at Long Branch, New Jersey, August 11, 1887.

Kinross, John, pianist and composer, lorn in Edindourgh, (Dotober 16, 1sts. Apprenticed to a music seller. and in eally routh mostly self-tamght. Was in a telegraph office in Jreland for a short time, and alyont 1865 


\section{KINSEY}

settled in Iomdee, studying moler G. A. Macfarren, and others, in London, during his holidays. settled in London, 1883. Died, Deceniber 30, 1890. He was a successful teacher, hut devoted most of his time to composition. His works consist of a Cantata, "Songs in a vinevard," for fenale voices: T'saln of life, part-song: Two-part song (Mery Songsters); Song, Bessie Bell and Mary" (iray: Feotch and Fuglish songs, etc. Twelve sicandinavian siketehes. op. 16: Snite, for small hands, op. 18; Three Rondolettos, and other pieces for pf. Twenty-four sketches, in two books, for harmonimus, etc.

Kinsey, Thomas Hague, pianist and composer, born at Liverpool, December 15, 1856. Pursued his early studies in private, and went to Leipzig in 1877. There he remained until 1880, studying under oscar Paul, E. F. Richter, and Jadassohn. Resident in Liverpool as professor of pf. ; organist of Sefton Park ('hurch, and conductor of Refton Park Musical society, ete. He luas composed several orchestral works; a trio in $\mathrm{A}$, for pf. and strings, produced, Livernool, Lrst'): pieces for pf.: songs, part-songs, and some churely music.

Kirbye, George, composer, who flourished in the latter half of the 16tl century. He was a native of Suffolk. He resided mostly in Bury st. Fdmunds, where he died in 1634 , and is buried in st. Mary's Church. One of the ten composers who hammonized Este's Psalms, 159\%, and he composed the madrigal for six voices in the "Trimmphs of Oriana," entitled " Bright Phopus," and published "The First Set of English Madrigalls, to 4 , 5, and 6 royces," London, Este, 1597. Of this a new edition, edited by (r. F. P. Arkwright, was published in 1-91-92.

Kirk, Helen Drysdale, Scottish contralto rocalist, was born about $184 t$. She sang in various parts of Scotland, particularly in Edinburgh and Glasgow, along with Mr. Tom Maclagan and others, and was well-known as a successful singer of Scotis songs. She died at Clasgow, January 30, 1871.

Kirkhope, John, amateur musicinn and conductor, born at Edinburgh, November, 1844. In 1881 he established a choir which bas performed works of a very high elass, chiefly in Edinburgh. The choir is one of the best in Scotland, both as regards the finish of its performances and the quality of the works performed.

Kirkman, Mrs.Joseph, musician and teacher, author of "A practical analysis of the Elementary principles of Hamony," London, 1845; "Pianoforte Instructor for the million...," London 1854 : "Three easy lessons for the Spanish guitar," London [1840]: L'f. exercises, etc.

Kitchin, George, organist and conductor,

\section{KLEIN.}

nephew of the Dean of Winchester. Was organist of Sit. Saviour's, Brockley, 1871; Holy Trinity, Sydenham, 1874. Has been conductor of the Stock Exchange Orchestral Society since its formation in 1885. In April, 1893 , he conducted a Festival held in Winchester Cathedral.

Kitchiner, William, physician and musician, born London, 1775. Educated at Eton, and graduated M.D, Glasgow. Having inherited his father's fortune, he never practised, but lived mostly in London, devoting his time to scientific and other pursuits. He died at London, February 27, 1527.

Works. - The cook's oracle (1817); Art of invigorating and prolonging life (1822); The economy of the eyes (1834); The traveller's oracle, 1827. Ivanhoe: or, the Knight Templars, musical drama. The loyal and national songs of England, for one, two, and three voices, selected from original manuscripts and early printed copies in the library of William Fitchiner, M.I)., London, 1823. The sea songs of Eugland, etc., London, 1823. Amatory and anacreontic songs set to music, London, n.d. The sea songs of Charles Dibdin, with a memoir of his life and writings, London, 1821. Observations on vocal music, London, 1821. Glees, songs, etc.

Kiver, Ernest, pianist and organist, born in London, September 2\%, 1864. Studied at R.A.M., under the late Thomas Wingham; A.R.A.M., and F.R.C.O. Some time organist of sit. Bride's, London, and later of The ()ratory, Brompton, which position he resigned in 1893. Has appeared as solo pianist, and, since 1886 , given high-class concerts at Princes' Hall and (Qneen's Hall. bringing forward, especially, important works by English composers. He introduced, for the first time in public, Sterudale Bennett's String Quartet in G (May 14, 1nsfi), Thomas Wingham's Quartet (Nay 8, 1si9), and worts by other composers. He is a professor of the pf. at the R.A.M.

Klein, Hermann, musical eritic, and teacher of singing, loom at Norwich, July 23, 1856. Stmited singing under Mamuel Garcia, 1574-7. Appointed professor of singing, Gaildhall School of Music, 1s\$7; and director of the opera class, after the death of $\mathrm{Mr}$. Weist Hill, December, 1891. He gave a performance of "Fra Diarolo," at the Lyric Theatre, March 19, 1892. He is the composer of "The Cavalier"s Farewell "; "The Empty Saddle" ; "The Toice," and other songs. Anong the undertakings successfully organized by him were the reception held in London in honom of the Juhilee of $1 \%$. Joachim, 1s!t, and the celebration of the Toth hirthday of Mr. Angust Mamms, 1895. In 1879-80, he was musical critic of The Eraminer: and has filled a similar post on the Sumuly Times, from 1881. 


\section{KLITZ.}

Compiler of "Musical Notes," 1886-7-8-9. Lectured on the "Progress of Opera during the Queen's Reign," 1s'yt.

Klitz, Philip, organist and eomposer, borm at Lymington, Hampshire, January 7 , 1805. He was the son of a German musieian, George P. Klitz, under whom he studied. Teacher and organist in Southampton, where he lield appointments at st. Lawrence and St. Joseph's Churches; afterwards at All Saints'. He died at Southamptor, Jamuary 12, 1854. Composer of "Songs of the Mid. Watch," 1838, and numerous single songs. Author of "Sketches of life. character and scenery in the New Forest," 1850.

His son, Georate, was also a composer, and his brothels Wrllam (died 1857), Charles (died 1864), Jamles Freinerick (died 1870), Ropent Juhn and John Henry (died 1880), were all musicians.

Klose, Francis Joseph, composer and writer, bom at London, in 1784. He was a member of the orehestra of King's Theatre, and of the Concert of Aneient Music. Teacher of, the pf in London. He died at Marylebone, London, Mareh 8, 1830.

Composer of a large quantity of pf. music, and author of "Practical hints für acquiring thorough-bass," London, 182. I Iis songs, "My native land," "The liose," ete., were popular in their day.

Knapp, William, composer, was born at Warehann. 1698. Was parish clerk of Poole. He died at Poole, Dorset, September, 1768. He publisluel "A Sett of New Psalms and Antlems, in four parts, and an Introduction to Psalmody," London, $173 \mathrm{~s}$; 2nd ed.17+1; th ed., 1750; t th ed.1762. "New Chureh Melody, being a set of Anthems, Psahus Hymns, ete., in four parts; with an Imploration wrote by Charles I., during his captivity in Carisbrook Castle," London, 1753, 5th ed., 1764.

Knapton, Philip, pianist and composer, born at York, in 1788. He studied under Hague, at Cambridge. Teacher in York. He died on June 20, 1833. He composed overtures for orchestra, concertos for pf. and orchestra, sonatas for pf., arrangements for pf., songs, part-songs ete. His song "There be none of beauty's daughter," issued about 1818, was well known. He also published a "Collection of Tunes for Psalms and hymms, selected as a supplement to those now used in several ehurches in York," Tork [1810].

Knight, Edward, musician and eomposer, son of Edward Knight, comic song-writer and vocalist (177t-1826), who composed the "Sajlor and soldier," a musical faree, 1805. Young Knight edited "Canadian airs, collected by Lient. Back, R.N., during the late Arctic Expedition under Captain Franklin, with symplonies and accompaniments," London, 1823. He also edited his father's "Comic

\section{KNOWLES.}

Songs and Recitations," London, 1827. His brother was J. Preseott Kuight, the painter.

Knight, Joseph Philip, song-writer, born at Bradford-on-Avon, July 26, 181\%. He studied under Corfe of Bristol Cathedral. Vicar of S. Agnes in the Scilly Isles. Retired latterly from the ministry. He died at Great Farmonth, on June 2, 1857.

Works. -Songs-A little bird told me; All on the summer sea; Beautiful Venice; Bells of Venice; Breathe not her name; Beautiful spirit; Come roam to the greenwood; Down beneath the waves; Days gone bye: Ellen and Patrick; Farewell to thee, sweet Venice; Farewell my native land; Gentle words; I would I were a child again; I love the bright and smiling Spring; Love that blooms for ever; Music, sweet music; Merry hearts; May time; My mother's song; Old green line; Pale rose the moon; Parting song; Rocked in the eradle of the deep; Say, what shall my song be: She would not know me; Spring's first violet; sleep and the past ; st. David's bells; she wore a wretth of roses; There was a time; Though thou art cold; Thou wert not there; Tree of the forest; The merry muleteer; The old songs we sang; The veterau; What pleasant sounds; World is a fairy ring; Why chime the bells? Duets, ete.

Knight, Thomas, musician and organist, born 1789; died November 21, 1811. He was organist of Peterborough Cathedral for a short time.

Knott, John, musician, son of a Laptist minister of Sevelloaks, Kent. He was a chorister in Durham Cathedral, and in 1811 became precentor in the West Church, Aberdeen. In $182 t$ he was appointed precentor of the New North Chureh, Edinburgh, and music-master at Heriot's Hospital, 1827-37. He died at Edinburgh in 18:37. Compiler of "Sacred harmony, bemng a collection of psalm and liymn tnues. . "Aberdeen, 1814; and edition 1815. "Selection of tunes, in four parts, alapted to the psahms and pardphases of the Church of Scotland," Ediulurgh, [1824]. Two of his sons, PHellu and Taterxor, attained some distinetion in Scrtland, the first as a poet and the other as a painter.

Know!es, George, mateur musician, was bom in 1749 . He was educated at Marischal College, Aberdeen, and was licensed to preach in 1771 . He beeame minister of lirse in Aberdeen, 1778-89. He died at Birse on March 29, 1789. Composer of "Birse," or "Balfonr," a psalm tune, which appears in Smith's "People's Tune look," ete, and other pieces of sacred music. There is a reference to Knowles in Peacoch"s "Travels in Scotland." He is perliaps best known as author of a descriptive poem on Ineeside, which originally appeared in the "Scots" Magazine," 1814. 


\section{KNYVETT}

Another George KNowles published "Sacred Music, consisting of thirty-two hymn tunes, etc.," London, Goulding [1815].

Knyvett, Charles, organist and vocalist, was born on February 22, 1752. He sang at the Handel Commemoration, in 1781, and at the Concerts of Ancient Mnsic. Gentleman of the Chapel Royal, 1786. Established, with S. Harrison, the Tocal Concerts, 1791-94. Organist of Chapel Royal, 1796. He died at London, January 19, 1822. Composed Collection of favourite glees, catches, and rounds, London, 1800. Six airs harmonized for three and four voices, London, 1815.

Knyvett, Charles, organist and composer, eldest son of above, was born in 1773. He studied under Parsons and Webbe. Revived the Vocal Concerts with IV. Inyvett, Greatorex, and Bartleman. Organist of St. (reorge's, Hanover Square, 1802. He died on November 2,1852 .

Wrote glees, etc., for "Re-Unions" of the Prince of Wales, London, 1870 . Selection of Psalm tunes sung at St. George's Hanover Square, 1823; 2nd ed., 1825; th ed., 1850. Epitaph in Brading Church Yard, set to music for three voices, September 2f, 1831. Collection of favourite glees, catches, rounds, etc.; Fight effusions for the pf., London $[1847]$.

Knyvett, Deborah, born Traris, singer, second wife of William Knyvett, was born at Shaw, near Oldham. She studied under Greatorex, and sang at the concerts of Ancient Music in 1813. Sang at principal Jondon concerts, 1815-43. Married IV. Kuyrett, 1826. She died on February 10, 1-76.

Knyvett, William, singer and composer, born April 21, 1779. Foungest son of Charles Inyvett, the elder. Sang at concerts of Ancient Music, 1788. Prineipal alto, ditto, 1795. Gentleman of Chapel Royal, 1797. Lay-Vicar of Westminster Abbey. Composer to the Chapel Royal. He sang at Londori and Provincial concerts, and was conductor of Concerts of Ancient Music, 1832-40. He died at Ryde, November 17, 18.56. He composed anthems, glees, songs, etc., but was best known in his day as a voealist.

Kollmann, George August, organist and composer, born in London, 1780. Son of Aug. F. C. Kollmann (1756-1829), musician and anthor. He succeeded his father as organist of the German Chapel Royal, sit. James's, 1829. Teacher in London, where he died March 19, 1845 Composer of Three Grand Sonatas for pf., op. 1, 1808: Six waltzes for the pf. . . , London 1814], etc. He also invented a railway carriage, which had the property of traversing the base of hills, so as to avoid the need for tumuels; and a new mode of stringing and tuming pianofortes, His sister, JoHanna Sophia

\section{LACY.}

(died, London, in May, 1849), succeeded him. as organist of the German Chapel Royal in $18 \pm 5$.

Kyte, Francis, anthor of "Memoir relating to the Portrait of Miandel . . ," 1829.

Lablache, Fanny Wyndham, born WiLTON, contralto vocalist, who studied at the R.A.M., 1836-7. Dibut at the Iycenm. Sang at H.MI. Theatre, etc. Married Frederic Lablache, son of Luigi, and retired from the stage. She died at Paris, September 23, 1877.

Lacy, Frederick St. John, composer and teacher of singing, boln at Blackrock, County Cork, Irelaud, March 27, 1862. Son of Lientenant John Franci: Lacy, J.P. Fducated at Dublin, and intended for the Bar. Deciding for music, le became a student at the Cork School of Music, 1880-3; then a private pupil of H. C. Swertz; finally entering the R.A.M., in 1886, and studying under Sir G. A. Macfarren, E. Prout, W. H. Cummings and others. A.R.A.M. 1858, and Associate of the Philharmonic Society. Has held various appointments, and was director of the choir at St. Angustine's Ramsgate, 1893-4. His lectures and recitals, "Notes on lrish music," and "Song and Ballad music," have been given in London and the country; and he has contributed to the "Musical Standard" and other papers.

Works. - Four songs, op. 1; Anuabel Lee, for tenor solo, chorus, and orcliestra, op. 2; Three songs, op. 3; Three songs, op. 5 ; Four songs, op. 6; Six fonr-part songs, op. 7 ; Chas elatr, a cycle of songs from the WhyteMelville Tableanx music, op. 8. Two sketches for violin and pf., op. 4; all published. In MS.: Bethlehem, sacred cantata; Mass in C: Benediction service, in B Hat; Palt-songs, etc. Incidental mnsic to A fairy fantasy (1889); Whyte-Melville Tableaux (1890); Comic opera, Matrimony (18.2); Musical farce, Cluas; The Iudian serenade, tenor solo, chorus, and orchestra (1nss). Overtures Celtic, in A minol (1891): Hernan and Dorothea. Orchestral serenade, in F; String quartet, in $\mathrm{E}$, etc., etc.

Lacy, John, bass vocalist, was born about the end of the 18th century He studied under Rauzzini at Bath. Appeared in Isondon, Italy, etc., at oratorios and concerts. Married Miss Jackson, vocalist, widow of $F$. Bianchi, 1812. Received appointment in Calcutta, 1818, but returned to England about 1826. Resided on the continent for some time. Died while on a visit to Devoushire, 1865?

Lacy, Mrs, born JAClison, wife of above, soprano vocalist. Appeared in London, April 25, 1798. She married F. Bianchi in 1800 , and after his death, in $1 \$ 10$, married Lacy, 1812. She went with her husband to Calcutta, where she probably died. 


\section{LAHEE.}

Lahee, Henry, composer and organist, bor'n at Chelsea, April 11, 1826. Studied under Sterndale Bennett, John Goss, and Cipriani Potter. Organist, from 1847 to 1874 . of Holy Trinity Chureh, Brompton. Resident in Croydon, as professor and composer. Mem. ber of the l'hilharmonic Society; and for years a successful pianist and concert-giver.

Worrs.-Cantatas-The building of the ship (produced, Finsbury Chapel, Moorfields, December 27, 1869, and publicly performed at the Hanover Square Rooms, May 30, 1870) ; The blessing of the children, (1870); The sleeping beauty, and The blind girl of Costel Cuille, both for female voices (the latter still in MS.); The jolly beggars (MS.) AnthemsGrant, we beseech Thee; Iraise the Lord, and others . . . Prize Glees - Now the bright morning star (1855); llark! how the birds (Bristol, 1869); Hence! loathed melancholy (Manchester, 1878) ; Away to the hunt (Glasgow, 1879); Love in my bosom (London, 1880); Ah! woe is me (London, 1884). These. with other glees and part-songs have enjoyed great popularity. Instrumental compositions inchude a suite for violoncello and pf. and pf. pieces.

Laidlaw, Anna Robena, Mrs. Thomson, pianist, lorn at Bretton, Yorkshire, April 30, 1819. I'upil of Robert Multer, Edinburgh. Taken to Gemmany in 1830 , where she pursued her studies; and took further lessons from Henri Herz in London, 1834. In 1836 she returned to Germany, and played at the Leipzig Gewanthaus concerts, July 2, 1837. While there she made the acrnaintance of Robert Schumann, who dedicated to her his Phan. tasiesticke, op. 12. She remained in Germany until 1540, and was appointed pianist to the Queen of llanover. Her eareer was continued with much suecess until the year 1852 , when she married Mr. Thomson, a Seotsman, and has since lived in retirement.

Laing, David, LL.D., antiquary and scholar, horn at Edinburgh, 1790; died at Portobello, (Oetober, 1STR.

Works. Select remains of the ancient poetry of Scotland, 1822. Farly metrical tales, 1826. An account of the Scottish Psalter of A.1). 1566, containing the psalms, cauticles, and hymms, set to music in four parts, in the Mrss. of Thomas Wode or Wood, Vicar of Sanct Androns, Edinburgh, 4to, 1871. See also Strinhorse, William.

La Jeunesse, Marie Louise Cecilia Emma, or Aluran, soprano rocalist, hort of French-Canadian parrntage, at Chambly, near Montreal, il: 1850 . leceeived her first instruction in music from her father, as accomplished happist, and studied at Albany, New York, whither the family removed, in 1n6t. While there she decided to adopt the profession of singing; and when she made

\section{LAMISERT'}

her dibut at Messina, in 1870, she appeared under the name of Albani. Previously she had studied at Paris, under Duprez, and at Milan under Lamperti. After singing in various places in Italy, she went to Londou, and made her first appearance at Covent Garden Opera House, April 2, 1872, as Amina, in "La Sonnambula," and, with few exceptions, has sung there every year since that time. Her repertory is rery extensive, embracing the principal soprano parts in Lucia di Lammermoor, Faust, Mignon, Rigoletto, Flying Dutchman, Lohengrin, Tamnhäuser, Tristan, and others, her latest addition being the part of Donna Anna in "Don Giovanni." July 23, 1896. She has sung in opera at Pur'is, Brussels, Berlin, ete. Her Festival dibut was made at Norwich, in 1879. The next year she sang at Bimingliam, and at every succeeding Festival; at the Three Choirs, since $187 \%$, at Gloncester (with two exceptions); at Bristol, from 1876; and at Leeds, 1877. She has been heard at all the principal concerts; has made several tours in Canada, and the United States, and alike in ol'atorio, opera, and ballad, has held a commanding position. From 1885 onward, she has frequently sung before the Queen, who has more than once visited her at Old Mar Lodge. In 1878, she married Mr. Emest Gye.

Lake, George Handy, composer and writer, lorn at Txbrilge, Jnne, 1827. Editor" of the Musical Gazette. He]d rarious London organ appointments. He died at London, Inecember 24, 1h65. Composer of "l hnicl," oratorio, 1852, and a number of part-songs, lallads, pieces of dance music, ete.

Lake, George Ernest, organist and composer, son of George Handy Lake, horn in Lomdon, Xay 29, 1\%5t. Organist and musicmaster, St. Freorge's School, lirmpiton, IJunts., 1876; St. John's Episcopal ('horch, Edinhmgh; Weylorige Chureh; All Saints', North liensington, from 18s5. (of repute as an organ plaser, he was also known as a scholir; and the papes's read before the College of Orgmists, and other bordies, were varied and able. lle was an Examiner for Trinity College, London, and a menber of the Mrrsical News Srndicate. Ile died in Imon, Wareh 15, 1853. Flis compositions consisted of anthems, hymm tmes, chants, ete.; some urgan pieces, and part-songs. Also a musical comedy, "swerepstalies," produced at Terry"s Theatre, May 21, $18: 1$.

Lamb, Benjamin, omganist and composer, who flomished alomt the begimning of the 1sth century. (Mrganist of Eton college. Composed organ and chureh music, songs, etc.

Lambert, (ieorge Jackson, organist and emmoser, born at bererley, Norember 16 , 1794. Hestndied muder his father, S. T. Lron, and l)e (rotch. (Organist of Beverley Minster, 


\section{LAMBERT,}

1818-1875. He died at Beverley, Jamnary 24, 1880. Wrote sonatas, trios, overtures, septet for strings, British concerts, 1823; Dance music for pf., ete.

His father, George Lambert, who died at Beverley on July 15, 1818, was organist of Beverley Minster for 41 vear's.

Lambert, James, musician and painter, was born at Jerington, Snsiex, in 1725. He resided at Lewes as a painter, music teacher and organist of st. Thomas-at-Cliffe. Died at Lewes, December 7,1788 . We have not fonnd any published works of this musician.

Lambert, Sir John, distinguished eivil servant, and first Pernanent secretary to the Local Govermment Board, demands mention here on account of his services to Roman Catholie Church music. He was born at Bridzor, Tisbury, Wilthire, Febmary 4, 1815, and died at Milford House, Clapham Common, January 27, 1892. He was a nember of the St. Cecilia Academy, Rome, and the recipient of a gold medal from Pius IX. for his arrangements of the Pralms and Antiphons of the Roman Liturgy. Hispullic and political life is dealt with in the memoir in rol. XXXII. of the Dictionary of National Biography (London: Smith, Elder \& (o., 1892).

Works.-Totum Antiphomarimu Vesperale Organistrum in Ecclesiis accommodatum, 1849; Hrmmarinm Vesperale, Hrmmos Vesperales totius amni connlectens; Ordinarium Missie e Graduale Romano in usinn organistrarum adaptatum, 1851; The true mode of accompanying the Gregorian ('hant, 18ts; Harnonising and singing the Ritnal sons; Grammar of Plain Chant; Nlusie of the Middle Ages, 1857 , ete. Ite also collaborated in the preparation of other workson litmrgical Nusic.

Lambeth, Henry Albert, organist and conductor, born at Harkway, near Gosport, January 16, 1822. Studied the organ under Thomas Adams and Henry Snart, upon whose recommendation he was appointed Glasgow City Organist in 1853. He was conductor of the Glasgow Choral Union, 1n5!)-80; of the new West of Scotland Choral Union, 1885. Formed a choir, which gave its first concert in 1874, and was then called by his name; afterwards known as the "Bahnoral Choir"; and now the famed Glasgow select Choir. This he left in 1s7s. He was organist at st. Mary's Episcopal Chmreh, Ctlasgow, and later, at Park Church. He died at Glasgow, Jume 27, 1895. His compositions were sottings of Psalms 86, and 137, both performed by the Glasgow Choral Union; varions songs and pf. pieces. He edited (with D. Baptie) The Scottish Book of Praise, 1876; and arranged a number of scotch songs for choral singing.

Lamond, Frederick A., pianist and composer, born at Glasgow, Jannary 29, 1868.

\section{LANCIA.}

Studied at first with his brother, David Lamond. In 1880 he was organist of Laurieston Parish Church, and gave organ recitals. He studied the violin, while in Glasgow, with $H$. C. Cooper, and with Heerman when he went to Frankfort, in 1882. While at the Raff Conservatorium in that town, his master for pf. was Max Schwarz, and for composition, Anton Lispruch. Later, he had lessons from Hans von Bälow, and Liszt. He made an appearance at a concert at Berlin, November 17, 1885, and achieved a great success; he also played at Viemma shortly after. He gave his first recital on his return to Glasgow, March 8, 1886, and was heard in London the same month, at the Princes' Hall; but he removed to St. James's Hall for the fourth recital, April 15, when he was honoured by the presence of the Abbe Liszt, then on his last visit to London. The next few vears he was chiefly in (iemmany; hut he played at the Crystal Palace (Saint-Siëns Concerto, No. t, in ('minor), April 5, 1s!o ; and at the Philharmonic (Brahns' concerto, No. 2, in B flat), Nay 14, 1891. Since then he has still further advanced his claim to be placer among the leading pianists of the day. He plays frequently in Germany, and was in Berlin in February, 1896, and visited Rnswia later in the year. His compositions are not ret very numerous, but thes include a srmphony in A, produced hy the Glasgow Choral Union, December 23, 18x!): An overture, "Aus dim Schottischen Hochlande," performed bx the Philharmonic Sociuty, Narch 7, 1895; A pf. tric; Sonata, pf. and violoncello, op. 2; Eight pieces for pr., op. 1, etc.

Lampe, Mrs., see Yotxg Imabella.

Lancaster, Joseph, wrganist and composer, editor" of the "Leeds 'Tune Book," London, 1868 ; I London, 1475, etc. Composer of ballads, dance music, etc.

Lancia, Florence, soprano vocalist, born in London, Jarch 20, 1sto. Of Trish descent on her father's sicle. In 1850 she was taken to Milan and recoiveri lensums for a few months from Antonio Sungiovanni; and, retuming to London, was instructed by Nignor Brizzi, throngh whose aid she seenred an engagement at Turin, making her ribut, early in 1858, as Rosina in "Il Barbiere." she then toured in opera and concerts in Freland and scotland, and sang in the first series of Monday Popular Concerts, Jannary 3, 185!). In 1861 she was articled for five vears to Frank Mori, but continued her pullic career. She first sang in oratorio at Exeter Hall, January 22, 186?, in Haydn's "Greation"; and from that time until isft was constantly before the pulblie, in opera and on the concert platform. She appeared as mima donma in at least thirty operas, including the chief works of Donizetti, Bellini, Verdi, Balfe, Wallace, Benedict, Anber, 


\section{LAND.}

ete., and also in "Don ('iovanni," " Der Freischïtz," and "L'Africaine." she toured in the provinces with her own opera company in 1867 , ete. ; sang in opera at the Crystal Palace, 1872 ; at the Gaiety Theatre, ete. One of her greatest trimuphs was at the Norwich Festival of 1872 , when, at shortest notice, she added to her own work, that allotted to Mlle. Titiens, in "Elijah," and Benedict's "St. Peter," the andience rising "n musse to cheer her. After her retirement in 1874, she sang for a few years at Mr. Samnel Brandram's Shaksperean recitals; and now teaches the art in which she had been so successful.

Land, Edward, pianist and eomposer, born at London, 1815. One of the children of the Chapel Royal. Accompranist to John Wilson, the Glee and Madrigal Union, etc. Secretary of the Noblemen and Centlemen's Catch Chub. He died at London, November 2!) 1876.

Works. Ficottish melodies arranged as songs without words, pf.; Lady Nairu's Lays from Strathearn, do. : Miscellaneous pf. works. Sonys: A loving heart; Birds of the Sea ; You hnow not low l've missed you; MIy Gentle Elodie; Mine, love? yes or no; Bird of beauty, wing your flight; Sighs that only love can share; So sweet is love's young spring; What can the heart want more; Angel's watch; Ireaming and waking: Italian flower girl's song; etc. Part-songs, arrangements, ete. Nine fonr-part Songs, harmonjzed, London, 1862.

Lane, E. Burritt, organist and composer, born at Christrhureh, Hants, in 1849. Studied at Trinity College, London; now Examiner there. Graduated Mns. Bac., Durham, 1 sig1. Organist of Promley Parish Chureh to 1846; then appointed to New Weighhouse Congregational Church, Duke street, Grosvenor Scpuare, London. Is professor of organ, ete., at Bromley Sichool of MLsic. Has published a Te Deum, and other Church monse; also songs. Contributed articles to C'assell's Magazine, Academe Gazotte, and Musical Ne's.

Lane, George William Brand, comductor, and choir-trainer, born in London, Angust 13, 1854, but from infanc $y$ to the age of twenty lived in Brighton. Tonie Sol-fa student, and choir-trainer, Brighton. In 1875 , removed to Manchester, where he conlducted large Tonic Sol-fa classes, and formed a "Temperance Choir," which took the first prize in competitions at the Crystal laalace, in 1884-6, and 1889. In 1880, he founded the Manchester l'hilhamonic Suciety, which has a great reputation for refined maccompanied singing. The Society also gave oratorios, entatas, and operas in connection with Mr. De Jong's concerts; and was invited by (Sir) charles Halle to co-operate with his choir in the opening and closing ceremonies of the

\section{LARA.}

Manchester Jubilee Exhibition of 1887. Mr. Lane has been very suecessful as a vojeetrainer, many of the leading local singers having been under his tnition.

Lane, Gerald $\mathbf{M}$., is the composer of a number of songs: Only dreaming; Dawn at last ; Lover's; Sleeping and waking; Love's vigil; Tatters, etc., some of which have become popular.

Lang, John, musician, loom at Paisley, October 17, 1829; died at Glasgow, April, 1892. Inventor of the "Union Notation." In this system the notes are indicated to Solfa musicians by having the initial letter of the various notes in the Sol-fa seale placed within the head of the ordinary musical characters, and so presenting a combination of both old and new notations. A considerable amomnt of music has been printed on this system.

Langdon, Richard, composer and organist, born at Exeter abont 1729. NIns. Bac., Oxon., 1761. Organist of Exeter Cathedral, 1753-77. Organist, Bristol Cathedral, 1777-81. Organist of Ely Cathedral for a few months in 1777. Organist, Amagh Cathedral, 1782-94. He died at Exeter, September S, 1803, aged 74.

Wonks. Twelve Songs and two Cantatas, op. 4, London, n.d. Divine Harmony, being a collection in score of P'salms and Anthems, 1774. Anthems. Twelve Glees for 3 and 4 voices, London. 1770 , etc.

Langran, James, organist, born in London, November 10, 1835. Pupil of J. B. Calkin. Graduated Nus. Bae., Oxford, 1884. Organist of St. Michael's, Wood Green, 1856; Holy Trinity, Tottenham, 1859; and from 1870 to the present time, organist of All Hallows (Parish ('hurch), Tottenham. MIusical Instructor, since 1878, at St. Katherine's Training College, Tottenham. He has published a Moming and Evening Service: contributed tunes to Hrmos Aneient and Modern; and is Musical Editor of the New Mitre Hymmal, 1s75. His hymms, "Deerhurst," and "St. Agnes," are well known.

Langshaw, John, organist and composer, born in 1718. Ile was urganist of the Parish Church of Lancaster, and died, 1798.

His son, JoHx, born, London, 1763, studied under Charles Weskey, and succeeded his father at Lancaster, in 1798. He composed hymus, chants, songs, pf. concertos, and organ music.

Lara, Adelina de, bom Preston, pianist, born at Carlisle, January 23, 1872 . Her parents were musical, and were her first instructor's. She played, as a juvenile prodigy, at Liverpol, Neweastle-on-Trne, and other places; and was afterwards placed moler the care of Miss Fammy Davies, who secured her the notice of Madane Schumann. She studied with that lady at Franlfort, 1885-90, and made her dibut at the Saturday Popular Con- 


\section{LARGE.}

certs, Narch 21, 1891, with success. She appeared at the Crystal Palace, April 25 , of the same year, taking the solo part in kubinstein's Concerto in D minor; and has since been heard at concerts in Bimingham, and other places. At the Queen's Hall, in 1895, she gave a series of concerts of Early, Medizval, and Modern Music.

Large, Eliza, Rebecca, Mrs. Henry CHATFIELd, rocalist, was born in 1815. She studied under sir G. Smart, and Sir Henry Bishop, and was well known as a singer at the Aneient and other London concerts. She died at Brixton, London, July 30, 1881.

Larkcom, Charlotte Ägnes, soprano vocalist, horn near Reading. Situdied at P.A.MI., winning the Westmorland Sicholarship, 1s7t. Awarded First Prize for sopranos at the National Musie Meetings, Crystal Palace, July 1, 1875; and sang at the Saturdar Concerts there, Tannary, 18r6. Hiected an Associate, R.A.M., she was afterwards alpointed a professor of singing. Sang at concerts in the provinces; tomred with success in Holland, 1Rse. In 18se she married Mr. Herbert Jacohs, barrister, but still pursues her professioual duties.

Larkin, Edmund, organist, born in 1785. For some time he was organist of Peterborongh Cathedral; afterwards he was organist of the Parish Church of Stamford, where he died, December 9, 1838.

Larrington, Rev. George, author of "The Intluence of Church Insic. Sermon preach'd in the Cathedral Church of Worcester," London, 1726.

Lates, Charles, composer, who flomrished about the end of the 18 th century. He studied mder P. Hayes; and was a candidate for an organist's apjointment at Whitchurch in 1805 . Composed sonatas, songs, etc. His father, JoH . JAmes, was a violinist of some local fame in ()xford, where he was a teacher. He wrote chamber music. He died in $177 \pi$.

Latham, Morton, writer on music, and composer. Edueated at Cambridge University, graduating B.A., 1865: M.A., and Mus. Bac., 1889. Has lectured hefore the College of Organists, 1sst-7, on Common Principles of Art; The effect of the Renaissance on Musical Art, etc. He has published a Te Demm, and a 11 mimber of songs.

Latrobe, Rev. Christian Ignatius, writer and composer, born at Fulneck, near Leeds, Febmary 12, 1758. He was educated at Niesky, and Barby, in Prussia. Secretary to the United (Moravian) Brethren in Fngland. He died at Fairfield, near Liverpool, May 6, 1836.

Works,-Original Anthems, with organ or pf. accompaniment, 2 vols., n.d. Jubilee Anthem for George IlI., October 25, 1809. "Dies Irae," for 4 voices, 1799. Hymns.
LEVALLEE.

Selection of Sacred IIusic from the worls of Eminent Composers of Gemany and taly, 6 vols., 1806-1825. Three sonatas for pf., op. 3 (dedicated to Mr. Haydn). Instrumental and miscellancous music. Hymm Tmes of the United Brethren [1814].

Latrobe, John Antes, M.A., writer and organist, son of the ahove, horn 1799. Vicar of St. Thomas's kendal. He died at Ciloncester, November 19, 1878.

Works.-Music of the Chureh considered in its various branches, Congregational and Choral, London, 1831. Instructions of Chenaniah: plain directions for accompanying the chant or the psalm tune, London, 1832.

His brother, the Rev. Peter Latrobe (born London, Fehmary 15. 1795; died at Bertheldorf, near Hernhut, Gemany, September 24, 1863), composed some hymm times and chants, and wrote an introduction to (. I. Latrobe's Hrmms.

Latter, Richard, bass voealist, born at Bromler, Kent, July 22, 1823. Received his first instruction from hic lorother William, and entered the R.A.M., in 1st1, intending to become a pianist; but his volce developing power, he took to singing, studying under Crivelli. A.I.A.M., 18t9. Hesang at various concerts in London and the provinces, and made his stage debut at the Princess's Theatre, as Malatesta in "Don Pasquale." He also plaved in opera at Bath. Birmingham, Nanchester, and other places 11, to 1851, when he settled in Aberdcen as teacher, remaining there till 1871. He is now a profestor of singing at the fruildhall School of MLusic, and F.R.A.M

Willian Latter, his elder brother, a pianist, entered the R.A.M., in 1831. His life was spent chictly in teaching, and he died at Lee, Kent, Norember 15, 18st, in his 69th year. He was also a Fellow of the R.A.M.

Lauder, W. Waugh, pianist, born in Canada. Studied at Lejpzig. and was also a pupil of Liszt. Toured in Europe, and alront 18s5 settled in Landon. ()ntiujo. In Canada and the United states he has a great reputation as an executant.

Lavallee, Calixa, pianist and composer, born at Tercheres, Canada, in 1842 . Stuclied in Paris under Marmontel, and Adrian Boieldien the rounger. Settled in Buston, Mass., where he was a profesior at the Petersilea Academy of Music. He was a foremost worker for the Nusic Teacher's' National Association, U.S.A. ; and as a delegate therefrom attended the Conference of what is now the Lncorporated Society of Musicians, held in London, Jannary, 188s. He died at Boston, in Jammary, 1891. He wrote a cantata for the reception of the Princess Lonise at Qnebec, in 1878; several operas; an oratorio: songs, ete.; also a s.mphony; string quartets, pf. pieces, etc. 


\section{LAVENU.}

Lavenu, Louis Henry, composer and violoncellist, was born at London, in 1818. He studied at the R.A.M., under l'otter and Bochsa. 'Cellist at the opera, London. Musicseller in partnership with $N$. MLori. MIusic director of Sydney Theatre. He died at Sydney, August 1, 1859 .

Works.-Loretta, a tale of Seville (Bumn), opera, November 9, 1846. Songs : Cottage rose; Deserted; Harrest queen; Memory's dreanl. Come, wander with me, duet. Pf. music, etc.

Lavington, Charles Williams, organist, born at Welfs, Sonnerset, February, 1819. Chorister, Wells Uathedral, and studied under Perkins, the Cathedrat organist, and later with James Turke at Westminster Abley. Returning to Wells, he beeame assistant organist at the Cathedral; in 1842 was appointed acting organist; and on the death of Perkins was made organist and master of the choristers, and organist of the Theological Coltege. At a special service in Wets Cathedrat, Angust 4, 1892, the Choir's of Bristol and Exeter Cathedrals assisted; indireetly marking Lavingtrm's Jubilee. He died at Weth, Uetober 27,1895 , and with him almost the last of the old schoot of or wan ptaying, and aceompanyings.

Lawes, Henry, cimposer, torn at linton, near Salistury, Wittshire, December, 1595. Son of Thonnas Lawes, died 1640, Vicar-chorit. He stmelied nuder John Cooper (Coperario). Epinttes and Gentleman of Chapel Royat, 1625. C'trik do. Nlenter of privilte band of Charles I. Nusic nuaster in fantily of the Earl of Bridgewater. Stripped of appointments during the Jrotectsiate, but reinstated at the liestoration, in 1660 . He died at London, Oetober 21, 16ifs, and is buried in the cloisters of Wentmininstrex Ablesy.

Works. The Trimuphs of Teace, masyue (with W. Lawes and s. lves), 1683. Coetum Britannicum, milsene (Carew), 16333. Comms, mastue (Milton), 1694. A Jaraphrase upon the P'salmes of l lavid, set to New Tumes for Private lexotion, and a thorow base, for voice or instrmment, 1637 (Sandys' version). Choice Psalnues put into Musick for Three Voyces, 16ts. Ayres and I) ialogues for one, two, and three vojees, 1653; Do., 2nd book, 1655; Ino., ard bouk, 165s. Nusie: to poetry by W. Cartwright, Ilerrek, Davenant, Milton, Wialler, ete. Somgs in Contemporary Collections, as The Treasury of Musick, 1669; Anthems in clifford's and other collections; Musie in sederet Ayren and Diakgnes.

Lawes, William, componer, brother of

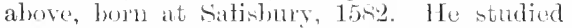
under coprerario. Atember of Chichester Cathedral choil tilt 160\%. Genteman of Chaterel Royal, 16it. Musiein in ordinary to Chartes I. Kitted at siege of Chester, during the Civit War, 1645.

\section{LAWRENCE.}

Wonks.-Music to shirley's "I'eace." The Royal Consort for Viols. Songs in various collections, ete. Fantasias for varions in. struments, ete.

Lawler, Thomas, latsis rocatist, born in 1818. Studied under Bianchi Tavtor. Established the City (ilee C'lub in 1853; and on his retirement in 1886 , wats presented with a testimonial. He was for many years a Gentleman of the chapet Royal, resigning on a pension early in 1887. He sang in oratorio in London and the provinces, and appeared on the stage; hut it was in glee-singing, and in old Engtish songs that he was nuost celebrated. He died in London, May 16, 1893.

Lawrance, Edward, organist and composer, born at Weymonth, 1836. Studied in that town under Ricardo Linter, and 1856-8, at Leipzig Conservatorium, under Moseheles, Plaidy, E. F. Richter, Hauptmam, and others. In 1859 he was appointed organist of sidmouth Parish Church, and a vear later to st. Darids, Merthyr Tydfil. This appointment be held until the begimning of 1891 , when he resigned in conserguence of the introduction of ritualism he could not conseientivensty assist in. since 18993 he has been organist at Christ C'hurch, Merthy Trafil. He is conductor of the Merthys Musical Linion. His eompositions comprise an oprera, "Consracline" ; a castatil, "The siege of Ilarlech" which gained the prize at the National Eistedafod, Swansea, 1863); anthems, services, chants, hrmm-tuness, somgs, ete. Also a Trio for pf. and strings: pieces for pf., ete.

Lawrence, Charles, organist and composer, grailuated MIan. Bac., Oxford, 1875. the has held organ appointments at Bearwood, Wokinghann, 1870; Sit. John's, East Duhwich, 1573: C'hrist C'hureh, Eastbourne, 1883; st. Athan's, streatham Park, 1884; st. Stephen's, sonth Duwich, 1894. Conduetor of Choral hociety, Easst Dutwich (1883). His compositions comprise Psaln 118, for soli, chorus, and orchestra; Quartet in A; Trio in C nninor, for tef. and strings, perferued by the Musienl Artists' Sucicty. l’f. Aucts. Three seoteh sollgs ; part-songs, ete.

Lawrence, Emily M., pianist and composer, born at Rughy, in 1854 . Studica under her" mother, and afterwards in Londun under Sterndale Jennett, Mannel Garcia, and Dr. Steggall. She subsequently entered the R.A.M. remaining there three years. Madame Lawrence is the conductor of a Latices Choral Society at Rughy, and a soeiety at Wenbley, near tarrow, and has viren performances in buth places, at the R.A.M., and elsewhore. the has been urganist of St. John's Chureh, Wenthey, since ts89. Iler compositions comprise two cantatas for ladics volces: Bomny Kilneny, Kensington, 1890 ; and The Ten Virgins, Wenbley, 1893; a Sonata in F 


\section{LAWRIE.}

sharp minor, violin and pf., produced by the Musical Artists' Soeiety, July, 1882; an Album of pf. pieces; Ronnance, op. 16, etc. The Book of Songs for Girlsand Boys; A number of songs; Part-songs; Duets, and some anthems.

Her nother, Mrs. Elizabetie S. Lawrexce, was organist of Rngby Parish Chureh, 1842-77. She compiled a book of psalmody, and com. posed some hymn tmnes and chants.

Lawrie, Álexander, composer and pianist, was born at Edinburgh, June 26, 1818. Organist of S. Jame'spiscopal Chapel, Edinburgh, and in the Rev. John Kirk's Chureh in the same city. He died at Edinburgh, December 9, 1880. A blind musieian of great local fame. He arranged some music for the pf., and composed some hymms and songs. He also wrote accompaniments for a few of the songs in Wood's "songs of scotland."

Lawson, Malcolm Leonard, composes. and conductor, born at Wellington, shropshire, in 1849. Studied nnder varions nasters in London, and in France, ltaly, and fermany. Was organist and choirnister of the Catholic Apostulic C'hurch, London, 1876; Conductor of the Gluck hoetest 1875; of the St. Cecilia Society; and for some time, from 1878, director of the musical branch of the Frrle Soeiety. Ender his direction, important works Iy Gluck, lergolesi, Leo, Purcell, and others, have been revivel.

Works.-Fentival services, op. 1, in $\mathrm{F}$; Op. 2, in I); Op. 16; all eomposed for the Catholic Apostolic C'hurch. Six anthenss, op. 24, for 4 volces. Music to the plar, Olivia, London, 1877: Opera, The Three Princesses; Airs and interludes to the plar, England, London, 1876. Six part-songs, op. 3; Three songs, op. 4; Seruteen People's songs, op. 8; Twelve love songs, op. 14; Six Motets for ladies' roices, witten for the St. Cecilia society, op. 1s; Twels ficotch songs, words by Buris, etc., op. 20; six songs, words by the old dramatists. op. 21; Three songs, with violin obligato, op, 22; Cupid's Curse, duet; Last words, song, etc. Symphonies in D, Pan, op. 12; in G minor, Mahomet, op. 19; Overture, Saronarola, op. 23: Andante, Scherzo, and Minuet, op. 6, pf., ete.

Lawson, R. E., musieal director, Theatre Royal, Manchester (1885), is the composer of the music to a comedy, "Silver Fortune," produced at Ramsigate, 1858 ; also of pantomime music for the Theatre Roval, Nanehester.

Lazarus, Henry, clarinet player, lom in London, Jannary 1, 1815 . Ftridied under Charles Godfrey, sen., and made his dibut as a solo player at Madame Dulcken's concert, Hanover Square Rooms, May 2, 1838. In that year he was appointed second to Willman at the sacred Hammonic concerts; and on the death of Villman, in 1840 , succeeded him as prineipal clarinet at the opera, and chief
LEE.

concerts and festivals. At the Birmingham Festivals, he was engaged from 1840 to 1885 ; and played for the last time at a Festival at Gloncester, 1886. He was the last surviving nember of the late Duke of Deronshile's private band. For many years, from 1854, a professor at R.A.M., he was nrade an Hon. Nember of that Institution; and was, from 1858, professor at Kneller Hall. He retired from the concert platform in 1891 ; was given a testimonial eoncert at St. James's Hall, May 31, 1892; and on March 6, 1895, he died in London. He wrote fantasias and other pieces for his instrument, but will be longer remembered as the greatest plaver of his day.

Leach, James, composer, was bom at Wardle, near Rochdale, in 1762. He received no musical instruction, and was employed as a hand-loom weaver in Rochdate. Mémber of the King's band, and tenor vocalist in London. Tenor singer and teacher in Rochdale, 1789, and latterly in Salfort, 1796. He died from the effects of injuries lecrived in a coach accident, Blackler, near Manchester, February 8, 1798, and is buried in Fochdale.

Works.-New sett of Hrmm and Psalm Tumes, adapted for the une of churches, chapels, and Sunday schools... London, 1789; Second Sett of Hrmn and Psalm Tnnes, London [1757]; Collection of Hymn Tumes and Anthems, composed and adapted for a full choir, London [179, ] Anthems, te. ; Psalmody, by James Leach . . Harmonised in eompressed score by John Butterworth, with a sketch of the composer's life and work hy Thonas Newbigging, London [18st]

Leaver, William John, organist and composer of present time. Situdied at R.A.M. Graduated Mus. Bac., 1884, Cambridge. Organist and choinnaster, St. John's, Blackheath, and eonductor of a choral societr there. Has eomposed a setting of Ps. 146 , for soli, chorus and orchestra; and published anthems, songs, part-songs, pf, pieces, etc.

Leburn, Alexander, violinist, who was born at Auchtermuchty, Fife, in 1767, and was a teacher of music thele. He was a selftanght mathenatician. He died at Anchtermuchty, in March, 18:6. He published "A Collection of New Strathsuey Re'els, ete., with a bass for the violoncello, or harpsichord," Edinburgh, 1798 .

Lee, David, organist. He held theappointment of Citr organist, Mulbonrne, Anstralia, for a number of rears; also conductor of Nellomrne I'hilharmonic societs, which has produced Handel's oraturios, among then "Jephtha" in 1sist, for the first time in Australia. In 1 sist he vinited Fnoland, and played at the C'rystal and Alexandra l'alaees, also in the porvinces. He was made an honorary memler of the college of Urganists that year. 


\section{LEE.}

Lee, Ernest Markham, conposer and organist, born at Cambridge, June, 1874 . Enterest the choir of clatre College at the age of nine, rectiving instruction from IV. C. Dewlerery, the college organist. Craduated Mus. Face and B..t., Gantoridge, 1894, and becanne F.R.C.O. the same year. In 1890, Was appointed organist of st. Matthew's, Cannlorige; in 1s!) organist of Emmanuel College, holding, 1st3, likew ise a similar post at All Gaints", Woorford Green. Began composition when fourtern, his first publication being a caml, Masicul IIprald Prize. This compositims comprise, Patho 98, for solmamo solo, chorns, strings, and organ; Cantatas: $A$ stmenty night at sea (prodnced, 16!rs); "Jael," an wle in homome of the lirth of

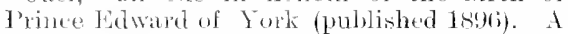
Conedy Opera, "Alicia" ; Songs, part-songs, ete.

Lee, $\mathbf{G}_{\text {o, }}$ anthor of "The Voice, its artistic morluetion, derelopment and preservation," 1870,2 editions.

Lee, George Alexander, composer and conductor, burn at London, 1802. Tenor singer in theatre at Dublin, 1825; Jaynarket Theatre, London, 1826. Insie-seller in London for a tine. Opend Tottenhan street Theatre for Fnglish opera (with Chapman and Melrose). Lesice of lowry Lane Theatre, 18:30. Manager of Ientern oratorios at Covent Garden and lmury Lane, 1831. Married Mrs. Waylett, the singer. Conductor of strand Theatre, 18.28; (Hympic Theatre, 1845. He dien at Londom, vetober 8, 1 s5s.

Workis.-Music to Drumas: Invincibles, 1824: Sullime and heantiful; Nrmple of the grotto, 1sz!); Witness, 152!); Legion of hononx, 1s31; Love in a cottage; Anla Robin Gray; Fuiry lake, and other operettas and musial dramas. Branties of Byron, 8 songs; lones of the butterflice (T. H. liayly), 8 songs. Songs and Bulluds: Away, away, to the monn-

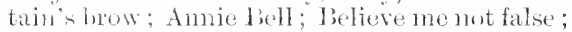
Ibells num the wind; liells at sunset; come, dwell with me; Come, merry fays; Cora; Come Flower of Lammermoor" "Fairest flower; Falryand; Garden of losese; (Hipsy's wild "hatut; Gondolier"'s lay; Goed night, love; He armes not; I'll not beginite thee; I sigh for the woors; I'll be a fairy; I lowe all that thom lovest; Kate Rearney; Lar who wears the plandy; Matenreger's gathering: Maid of Kildare; II native ixells; Mlomaids invitation; Mert ine in the wilkng glen; My cottage and my mill; Oda Irish ('ientleman; Rover's bride; Rose of Rillarney ; siveetly sound the Village bells; she watls in beanty; Thou art not false hnt fickle; The wild white rose; 'Tis love's hallowed honr ; When the moon is brightly beaming; Why shonld we sigh; Wild mandoline. A Tocal Tutor. Duets and partsongs, ete.

\section{LEEVES.}

His brother, Dafu, who died at London, in Novenuler, 1849, was a plianist and had studied muder loussek.

Lee, J., author of " Musical Education, a treatise on melody and hatrumony in conjunetion with pianoforte playing and singing.." 1850.

Lee, J. H., musician, pullished "Sightsinging made easy, a progrensive manual," London [1889)

Lee, J. So, eomposer and loandmaster, was born on Felumary 14, 1831. He was one of the oldest military landmasters in the British army, and for many years beld the post of bamdinaster of the 20th llushats. He composed chureb music for military choirs; a fantatia for the cornet; Prance music for military bands; Gavotter, marehes, arse songs.

Leechman, John, musicim, edited "The Choral Book: a selection of sacred music," Lundon 16557.

Lees, John, musician of ealy part of present century, conpiled "The 11,mm 't'mes of the church of the Erethren. . arranged for four voices, in seore," Jondom, 18yt.

Lees, John Kenyon, composer, teacher, and conductor, hom October 6, 1853. He studier nnder his father and T. S. Hill, of Norwich. He has beld various organ appointments in Edinlough, among them leing that of st. Natthew's Church, MFomingside, 188518\%. In 18:1 he instituted the Horningside Choral s ciety, whith hats performed a number of innortant works. Composer of some dance music, and entitor of "The somgs of Bums, with symphonies and acempaniments by John Kenyon Lees, and introduction and historical notes by 11. C. Shelley," Glangow, 1896. "The Finnoral lieel Bork," 1814, ete. He is also musical celitor of a collection of 100 Scotch songs, albont to be pullished.

Leeson, Joseph Frederick, composer and orgenist, was born at Armagh abont 1806. He was an organist and teacher in Arbroath, and afterwards in 1 mufmmline, where he died, on Jamary 1, 1862. I fe composed a number of steres, and some songs, among which is "Oh sing to me the and sonteh songs" [1850], a popular but sumewhat vulgar effusion.

Leete, Robert, bass singer and fouduetor, born in latter part of lant century. He was a celebrated glee singer, and sueceeded Sale as Secretary of the Catch Chuls. For many years he acted an conductur at the Glee Club. He died on Decumber 25, 1835.

Leeves, Rev. William, clergyman and composer, born on June 11, 1748. He was Reetor of Wrington, Smmerset, from 1779. He died at Wrington, May 25, 1828. Composer of "Anld Robin Gray," 1770, a song known thronghont the world. The words by Lady Anne Barnard (1750-1825) are so natural 


\section{LEFELER.}

and true to life that the musical aid afforded by Leeves' setting is not, as some suppose, the chief reasou for its popularity. Leeses wrote much church music, now completely forgotten, among it being "six sacred songs.. with a corrected copr in its orisinal simplicity of the well-known ballad, "Auld Rolnin Gray," London, 1812. See "In Memoriam, with a few notices of other members of his family, printed for private circulation," 1573 , ports.

Leffler, Adam, bass singer, was born in 1808. He was a ehorister in Westminster. Abber, and sang in opera and at concerts. He died in London, March 2s, 185.

Legge, Robin Humphrey, writer on music, and composer, born near Liverponl, Jume 28,1862 . Of a shropshire fanily, of Bishop's Castle, he was intended for the Bar, and entered at Trinity Hall, Cambridge; but giving that up for minic, he went to Leipzig in 1895, studring at the Conservatorium, atud privately, mder Gustay sichreck, ['aul Klengel, Richard Hofmann, and other's, and later, at Frankfort, under Anton Lrspereh. 1R:tmrning to England in 1s:10, he settled in London, and deroted himnelf chiefly to musical literature, eontributing artieles to varions papers. "An appreciation of sinetana," which appeared in the New Cinaterly Musical Firifle, seems to have lat some influence. While in Cremany he wrote a sreat deal of music, but his published wolks are lew: Two books of carols: A set of fire part-nong (poems by Charles Kingsley); sme pieces for violin and pf., ete. His most important works are: Articles in the Irictionary of National Biography (from Tol. XXXY., (i. A. Nacfarren); Trantatim of Wallaschelis '. libe Musik der Naturvolker (Primitive Musie, Longunass, 18931; History of the Norwich Musical Festivals, 1424-1893 with W. L. Hansell), London, Jarrold, 1s9t.

Lehmann, Liza, soprano rocalist and composer, born in Isondom. Studied singing with her mother (a daughter of Robert Chamber's, LL.D.), and afterwards moler Randegger: composition with Rammlilde (Rome), Frondenberg (Wiesbaden), and Hamish MacCnm. Her debut as a rocalist to k place at the Mondar Popnlar Concerts. November 23, 1985. She wang at the Norwich Festival, 1897; and has appeared at the principal concerts in the United Kingdom. also in Germany. A feature of her repertoly was the inclusion of many fine old and forgotten songs, to which her artistic singing gave a new life. She was also an interpreter of her own compositions. In Julv, 189t, she gave a farewell concert, retiring from the profession of vocalist on her marriage with Mr. Herbert Bedford (q.v.). Her compositions include Two Albums of German songs; Album of English songs; A Musical Duologue, The

\section{LEIIARE.}

Secrets of the Heart (MIS.); A song cycle for four voices, In a l'ersian Garden (from Omar Kharyany, l'opular Concerts, l)ecenber 14, 18.46; 'Songs. Mirage; Titanial's Cradle, etc. Allnmin of 'Ten siletches, and other" pieces for pt. Ronance for violin, etc.

Leicester, W. (i., see (HARLARR, IFILLIAM.

Leigh, Arthur George, organist and composer, born at Ashton-in-Malerfield, Lancashire, Algust 22, 1st6. Studied music, 1nio-f, minder the late Thomas ( ivatham, Wigan. In 1 s6gi he was appointed oryanist and choirmaster of the Parish c'hurch, Chorler, which post he resigned in 1stos. In $18 \pi$ the accepted a sinilar fusition at sit. (Feorge's, C'horley, which he held until 1sog. He was elected a Town Conneillor when Chorler was incorporated: and elected Alderman, and Masor of c'horley in 1nst-8-9. He has a fine library of early inusic and munical literature, valuable collection from which have been exhibited in Londom (1892-4-5), and elsewhere. 1Lis componitions are mainly for the church, and include Ten responses, Thirty-three chants, Thirty-three hrmm tmos, later, merged in a work, "Sacred Musice, and a portion contributed to the Chureh of England Hymmal, the sacred Melodist, and other collections. The Story of the C'russ. Pf. : Violet, snowlrop, Falder Rerel, and other pieces. He has alsu edited stepping stones to the Classics, 12 numbers.

Leighton, G. A., musician of first half of the prement century. Author of "New and Improved Preneptor for the Pianoforte," London 1845].

Leigliton, Sir William, musician, gentleman-pensionere, and linight, who flourished during the 16 th and 17 th centuries. He published ". The Teares or Lamentations of a Sorrowful Sonle; composed with Mrusicall Arres and Songs both for Toyess and Divers Instruments," 161t. ['salms, Hymms, ete.]. Burd, Bull, l)owland, Ford, O. Gibhons, Giles, Hooper, Willye, Weellies, and Milton, are among the contributors to this now extremely scarce and raluable pullication.

Le Jeune, Arthur, organist and pianist. With his brother Charles, gave organ performances from aloout 1866 , exciting much attention by their juvenile talent. Arthur Le Jeune is resident in London as pianist and composer. He has published a number of pieces for pf.; Liebeslied, for violin and pf., ete.

Lely, Durward, see Lrle, James.

Lemare, Edwin H., organist and $\mathrm{com}$ poser, born at Temtnor, Isle-of-Wight, September 9, 1865. He was elected Sir John Gows Scholar, R.A.M., in 1878; and on the completion of his sturies made an Associate, and later, a Fellow. F.R.C.O., 18st. Organ- 


\section{LEMARE.}

ist of St. John the Evangelist's, Brownswood Park; Sit. Andrew's, Cardiff ; l'arish Church, Sheftield, 1sito; Holy Trinity, Sloane Square, Pimlico; and now of St. Margaret's, Westminster. He has given organ recitals at the Bow and Brontey Lustitute, 18is6; St. George's Hall, Liverpool, ete., and ranks among the most brilliant of the younger organists of the day. Editor of The Recital Series of original organ compositions, R. Cocks, to which he has contributed several pieces.

Lemare, William, organist, conductor, and conmoser, hom at Godalming, Surrey, in 15:39. Studied under Dr. Gamtlett. Organist successively at St. Jude's, East London, 1860; St. Andrew's, Stockwell, 1865; Brixton Parish Chureh, 1א72; St. Saviour's, Hernehill, 1876 ; St. Nary's, Newington, 1880; St. Nary's, Longfleet, 188s; st. Nathamael, Westboume, 18.94. In 1888 he received the degree of Mus. 1)oc., Cantuar. For a number of years he gave important concerts at Greshan Hall, Brixton; and later, was conductor of choral socjeties at Bonmemouth and locality, and conductor of the Boumemouth Festivals. In 1896 loe was appointed conductor of the Nottinghan Sacred Harnonic Society, and is now resident in that town, He has composed two operettas: "A Cahn Sea," Brixton, 1882; and "Pride and Policy," Poole, 18s9. His compositions also include churel services, anthems, songs, ete.

Lemmens=Sherrington, see SHerrixcTON.

Lemmone, John, flutist and composer, born at Ballarat, Victoria, Anstralia, Jn11e 2:, 1862. His father is an Ionian, bom a Britiols subject, ant his nother is English. He had to depend munch npon his own efforts in the way of musiral edueation; but learnt much from artists visiting the eomontry. He has toured through Australia, New Zesalanel, India, China, and Jatran. Was assuciated with Mialame Anty sherwin, 1S89; with Madane Pater, 18:1, on their toms almost romed the world. He risited London in 1syt, and made a suceessful debut at the Frard liooms, ()etober 25 . Since then he has heen heard in the principal concerts in Iunfor and the provinces; bas tomed with Madame Patti, etc., and established himself ats an artist of the firnt rank. In Marels, 1s97, he returned to Australia. 1le has composed n1any pomantes, fantasias, ete., for his instrmmetit, and has some reputation ats a violonetellist.

Lemon, John, amatere compuser, born at Truro in 1754. He entered the army and became a lientenant-colonel, and also entered Parliament as nember for ('omish constituencies. Fe dird at I'olvellen, near Looe, April 5, 1sit. Comproser of chants ant other sacred music.

Leng, Robert, musician of first lialf of

\section{LESLIE.}

present century, who lived at Malton in Iorkshire, issued "Uriginal sacred Melodies, containing several psaln tunes of various metres, together with an antlem and Hallelujah chorus set to the words 'Behold what manner' of Love, etc.,'... The whole is arranged for four voices... The composer who labours under a great deprivation, namely, the loss of sight, is self-tanght," Leeds, ete, 4 parts, 1847-49. Title-pages vary.

Lenton, John, composer, who flowrished in the latter half of the 18th century. He was a nember of the private hands of Willian and Mary, and queen Amse. He died in 1719.

Works.-The Gentleman's I)iversion, or the Violin explained, 169:3; A Consort of Musick, in three parts, 1694 . Music for Venice preserved, 1685; The Ambitions stepmother, 1700; Tamburlain, 1702; The fair I'enitent, 170:3, etc. Songs in contenporary collections.

Leo, Rosa, vocalist, n1tzzo-soprano, bon'n in London, of English parents; studied singing at the London Acadeny of Music, and elocution under the late Mrs. Stirling. While yet a student, was engaged by Mrs. German Reed for her entertaimment at St. George's Hall. Then went to Florence, and studied for some tinne under Luigi Vamnuccini, and on her retum was engaged to create the titlerole in Lecocy's oprera, "Manola," at the sitrand Theatre, 1852. She mate her dibut in concerts at the covent farden Promenade Concerts, and apleared at the Ballad Concerts. in 1ort. Fince these she has lesen engaged for nuany concerts in Lonton and the prorinces, and latterly has been distinguished for her artistic vocal iecitals, making a speciality of the best nodern songin loy French and Fnglish composents, and heing supported by instrmuentalists of high standing.

Leonard, William A., atuthol of " MIusic in the Western C'hurch, a lecture on psahmody ... London, 1872: "The Christmas Fostival, witl a sulection of carols," London, n.d.

Leslie, Fred, professional name of FrenERrch Hopisox, haritone singer and burlesque actor, Was born at Woolwich, April 1, 1855. som of cluarles Hulson, military outfitter there. He was originally engaged in eommereial pusuits in Lomelon, but frequently took part in anatenr theatricals. In Felmory, 1876, he adopted the stage as a profesision, and obtained lisisfist emgagenent from Misis Kate Sintley, at the Rovilty Thestre, Landon. 1) afterwards appeared in operatic and burlesque pieces at the Alhambra, flobe, Comedy, and Gatedy Thetatres in Fomdon. In 1881, he appeared in America, and in 1858 went to Australia. He also played in the English provinces, and in Fentland. Among the pitces in which lie took a leadimg patt may be named:-Nefistofele II.; Rip Tan Winkle 


\section{LESLIE.}

(1882); Nadame Favart (1882); Manteaux Noirs (1882) ; Beggar student (1884); Little Jack sheppard (1ธr6-s8); Nonte Crinto (1\$88); Miss Exmeralda (1888); Cinder-Ellen (1891); Ruy Blas (1891), etc. For the text of some of these, Leslie was responsille. He died at London, Inecember T, 1892.

Besides writing some dramatic works he wrote a few songs and other pieces. See "Reminiscences of Fred Leslie, by W. T. Vincent," London, 2 vols., 1894.

Leslie, Henry David, conductor and composer, bom in London, June 18, 1.22. Studied under (harles Luteas, from 1838, and for some time played as an amaterur violoncellist in the band of the Sacred Harmonic Society. When the Amatemr Musical Society was formed, in 1817, he was appointed Hons. Sec., and from 1855 to $1 \$ 61$, when the Soe iety was dissolved, he was its conductor. The famous choir, with which his nante was so intimately associated, originated with Joseph Heming, who for many vears acted as chorusmaster. The first concert was given in the Hanover Square Rooms, May 22, 1856. Mr. Lesslic eontimned to conduet the enucerts up to July 12, 1880, when the chnir was dishanded. He went with the ehoir to laris, in $18 \pi \mathrm{s}$, and gained the first prize in the International competition. The choir was resuscitated in 1882, with $\mathrm{Ir}$. Randeguer as conduter, and Leslie as president. The latter aga in assumed the direction in 1885, and gave concerts to May, 1887. In 1863 he nudertork the conductorslop of the Hereford Phithitrmonic Societr, an office he retained nntil 18s?. He was also connected with the short-lised National College of Mnsic, 1s6t; and the crild of Amatem Mnsicians, 1sit. Retiring to an estate which he posisessed at l3ryn Tanat, near Oswestry, he did much to pomote musical culture in the locality and originated the Onwestry Festivals in 1879. He diecl, February 4, 1896.

Works.-Oratorios : Immannel, 1853; Judith, Birmingham Fentival, 185s. Cantatas: Holrrood, 1860 ; I anghter of the Isles, 1s61; Biblical Pastural, The First chrintian Morn, Brighton Festival, 1880). Fentival anthem, Let fod alise, for soli, chortus, and orchestra, 18t9; Morning servite in I), etc. Operas: Romance, or Fold Irick Turpin, 1657; Ida, 1s64. How sweet the moonlight mleeps; My sonl to God, my heart to the'e; The Pilgrims, and other part-songs. Editor of Choral Mruic, Novello; Little Songs for Little Follss, Cassell. Trio, Memorv. Mt darling. hush!; Flower girl; Mountain iIaid, and other songs. Simphony in F, Londom, Mareh 24,1848; Srmphony, Chivalry, Crystal Palace, December 17, 18si: Dramatic orertnre. The Templar, 1852. Quintet, pf. and wind; pieces for pf., ete.

\section{LEVEY.}

Leslie, James, Scottish musician, was an itinerating teacher of psalmody in Morayshire at the end of last and beginning of the present century. He compiled "A Collection of Psalm and Hymn Tunes selected from the best authors, by James Leslie, teacher of ehnrch mnsic, Fochabers," Elgin, 1810. Engraved by Johnson, Edinburgh, 42 pp.

Levenston, P. M., violinist, and musical director at the Queen's Theatre, Dublin, is the composer of a Burlesque Opera, "Doctor Faust," produced at that theatre, May, 1892.

Leveridge, Richard, bass vocalist and composer, was born in 1670. He sang in opera at Inrmy Lane and Gneen's Theatres, 1705-12; at Lincoln's Inn Fields and Covent Garden, 1713-30. He died at London, Mareh 22, 1758.

Works.- Music for the Island Princess, or the Generons F'ortuguese, 16999: P'rramus and Thisbe, 1716; Collection of fiongs, with the music, London, 1727, 2 vol.., with frontispiece engraved by Hogarth. New Book of songs, engraven, printed, and published for Richard Leveridge, London, n.d.

Leveridge is lnown only as a song-mriter, though he hits lexen credited with the composition of the mule-discusied "Macheth" music, on the anthority of a notice in Rowe's edition of shakespeare. The well-known songs "All in the downs" and the "Rvast Beef of old England "sery fairly illnstrate the strle of his worlis.

Levesque, P., musician, was organist of At. Andrew's, Enfield. Compiled "Sacred Hammony, a new collection of palmody in three parts. "Lomdon [1-10].

Levett, English writer' and composer, who flourished in Lomdon during the latter part of the 18th century. He wote "Introductory Lesions in singing, particularly on pialmody, to which are annexed several palm tnnes," London, n.d. Hymms for Easter, Christmas, etc.

Levey, William Charles, componer and condnetor, born in Inulsin, April 25, 1837. studied under bis father (unticed below), and from 1852, in Paris, muder Anber, Thalberg, and Prudent. While there he was elected a nember of the societé des Antenrs et Compositenrs. On his retum to London he held positions as condueter at Covent Garden; Drux Lane, 1sbis-74; and again, later: Haymarket, Princess's, and Adelplai, ete. He died in London, Augunt 18, 1s94.

Works. Operas, etc. : Fanchette, Corent Garden, Jammary 4, 1s6t; C'lande; Nazarille;

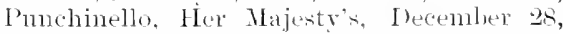
1864: Fanhion; Wanted a Parlune Maid; Musie to Antony and Clnopatra; Any Robsart; Rebecea : King o scots: Lady of the Lake; Esmeralela; Fack in the Bux, ete. Mnsic to varions pantomimes. Cantatas: 


\section{LEVY}

The Man of War; Robin Hood (for boys roiees); The Ride to Ware (humorons). Many songs: Esmeralda; Here stands a post; Ùnfading beaty ; ling and the beggar maid; Maritana, gay Citana; Lmllaby, ete. Pieces for pf., ete. Irish overture for orchestra.

His father, Ricilanu Nicifael Leyey, bom in Dublin, Oetoler 2, 1s11, violinist, was apprenticed to James Barton, leader at the Theatre Royal, Dublin, in 1s.6. In 1830 he succeeded to the post, and was afterwards musical director. On lis fiftieth amiversary of office he received a handsome testimonial. As a violinist he was well known at the Crystal Palace I Iandel Festivals, ete. He was also professor of the violin at the Royal Irish Academy of Mnsic, and is still living. The violinist known as "Paganini Redivivus" is his son, licharl, M. Levex. He first appeared in Paris, in 1850, and was for some time principal violin at Muzard's Concerts at the Hotel d' Osmond. Then he came to. London, and at the Roval Polvtechnic lnstitution, gave a weird impersonation entitled "Paganini"s Ghost." He has given recitals in the provinces and on the continent, but no particulars are available concerning his bio. graphy.

Levy, Isaac, cornet player, for many years a faromrite at the Promenade concerts at Covent (rarden and elsewhere. He has resided in America at different times. but reappeared at the Westminster Aquarium in 1887. 1 later it was stated that he had been natmalized as a citizen of the Cnited States of America. He is anthur of a l'opular cornet Tutor.

Lewis, Eric, vocalist and composer of present time. 17t has alpeared on the stage as the lonke in Osmond ('arr's musical farce, "1n Town," 1sy2, ete. His skrtches, "A Round of Tisits," podnces at Prightom Aquarimm, 1sk'; and "A Water l'ic-nice," Gernan Reod, 1884; with an operetta, are his principal works. He has also written a glee, etc.

Lewis, James Henry, organist and didactic writer, hom at freat Ialvern, February 23, 1856. Chorister, St. Peter's, Malvern; organist at st. Cuthluert's Episcopal C'hurch, Hawick, N.B.; Parish Chureh, West Hartlepool: St. Peter's, Staines, Niddlesex; and of Jarish Chureh, Twiekenham, from 1859. Conducter of Hartlepos Philharmonic; Staines Orchestral societr. Warden of the Church choir Graild, Lundon, the proceedings of which lie beyond the scope of this work. He is anthur of Elements of Music; Connterpoint in Catechetical Forns; Donble comnterpoint and Fugne, all published by Novello. He has mblished some Chmeh molsie, ete.

Lewis, Thomas, anthor uf "Organ building and bell fonmding," London, 1sits.

Lewis, Thomas C , musician, who floul-

\section{LIDDLF.}

ished about 1840-60. He edited “Lewis' Times," a periodical, from 185, and issned "The Cormopeanist," being a selection of airs ... London [1854], and on a sinilar plan, workis entitled "The Flautist," and "The Violinist."

Lewys, Dyved, tenor vocalist, born, March 28,1865 , at limerwys, Carmathen, of musieal parentage. His talent was manifest at an early age, and while ret at buy he carried off prizes for singing, and as concluctor, at local Eisteddfodan. When eighteen, as a nember of the Orphens Glee C'lnb, be sang before Adelina l'atti, at ('raig-y-nos, and, upon that distinguished artist." advice, decided npm adoptiog the profersion of music, and entered the R.A.Ml. He soon became one of the leading Welsh tenors, and besides wimning immomerable prizes at Eisteddfodau, sang in many important coneerts in London and the provinces. He conducted the Welsh Festivals at st. l'anl's ('athedral on reveral occasions; toured in the L.S.A., in 1893 , appearing at the Chicago Exhibition, where he was the recipient of many tokens of success.

Leybourne, George, comie singer, who was well-known in Loudon and provincial music-halls as a delineator of the heary swell viriety of eharacter. He called himself the "Lion Comique," anet introdnced or sang such songs as "Chanpagne Charlie," "Up in a balloon," "She danced like a fairy", and "Lancastire Lass," etc. He died in London, September 15, 1884.

Lichfield, Henry, composer of the 16th and 17th centuries, who published "The First set of Madrigals of Five Parts, apt both for viols and rovees." London, 1613.

An edition of his madrigal, "All ye that sleepe in pleannre," was issued in 1893, under the care of $W$. B. Sqnire.

Liddle, John Shepherd, organist and eonductor. Frachuated Inus. Bac, 1876, Cambridge. Urganist successively of Clewer Parish Chmrch, 1872; Halifax Parish Church, 1883; Newbury Parish Church, 1884, to present time, Conductor of Newbry Choral Society, and Orchestral Union; Aron Vale Mnsical Society; English Ladies' Orchestral Society : Wallingford Philhamonic. In 1896 he succeeded Angust Manns, as eonductor of the Handel Society, London. He has given many concerts, lut hitherto has not published any compositions.

John S. Linnes, was organist at Newcastleon-Tyne, first at St. Anrlrew's, for 8 years; then at St. Peter's, for 9 vears. From 1863 to 1884 he was organist of the Parish Church, St. Neots, Hunts, where he died, March 30, 1884 , aged 60 years.

Liddle, Robert William, organist, bern at Durbam, Narch 14, 1s6t. Cborister at St. Oswald's, Dumann; then at the Cathedral. 


\section{LIDDLF.}

Studied under Dr. Armes. Appointed organist of St. Baldred's, North Berwick, December, 1885; and organist and choimaster, Sonthwell Minster, 1s8s. He has composed some chureh music.

Liddle, William Henry, organist and composer. Gradnated Ilus. Bac., 1s91, Durham. Appointed organist to the chapel Royal, Windsor Great Park, 1876; Parish Chiuch, Basingstoke, 184:3. Organist to H.R.H. Prince Christian, 1975. Conductor of Basingstoke Harmonic Society. His compositions include Psalm 96, for soli, chorms, and orehestra ; a cantata, "Horsa," prodnced, Basingstoke, April 30, 1s.9, etc.

Lidgey, C. A., pianist and composter of present time. Has given concerts in London. His works include a setting of Browning's "Women and Romes," for churus and orchestra, produced at the crystal Palace, October 31, 1891; an orchestial ballade, "A Day Dream," the same. Octolyer 15, 1892; a number of songs (from sheller, Heine, ete.): and a ballade op. 3. for two pianofortes.

Light, Edward, musician of end of last and begiming of present centurs. Author of "The Art of plaring the Gnitar, to which is anmexed a selection of the most familiar lessons, divertissennents, songs, airs, ete," 1795. "Concise Instructims for playing on the English Lute," London. "Intruduction to the alt of playing on the Harp-lute, and Apollo lrre." "A First Book, wr master and scholar's asisistant, being a treatise on. Music, London 1755?. Tations collections of arrangements fur guital ; Songs, otc.

Lilley, G. Herbert, anthor of "The Therapentice of Music,' London, 1siso, and composer of hrmms, etr.

Lillycrop, Rev. Samuel, musician and writer, was originally a music touther in Exeter early in the present entury, but afterwards became a Baptist minister at Windwr, where he lived from about 1850 to 1570 . He died in 1870, and is buried in the spital cemetery at Windsor. Anthor of "Theoretical and practical Thorough-bass, exemplified in a plain and easy ma ner," London, n.d.

Limpus, Richard D., orgunist and musician, born on September 10, 18:4. Son of Richard Limpus, organist of Isleworth Old Chmeh, who died on Norember 1, 186 . Founded, with others, the (a)llewe of Organists, 1864. Secretary to College of Organists, 1864-75. Died on March 15, 1875. Composer of songs and pf. mnsic. His wife, who died, London, Jamnary 2!), 18R!), was a conerert vocalist. His hother, the Rer. F. Hexpr Lmpes, was some time minor canon of st. George's Chapel. Windsor, and composer of an oratorio, "The Prodigal son," London, Nay 10, 1870; Songs, etc. He died in 1898.

Lincoln, Henry John, lecturer on music,

\section{LINCOLN.}

critic, pianist and organist, born in London, October 15, 1814. Son of the organ-builder, H. C. Lincoln. Began his musical studies at an early age with the pianoforte, and was an organ pupil of Thomas Aclams, for whom he frequently acted as deputy at St. Dunstan's, Fleet Street. He was app inted to Christ Church, Woburn Śquare, and in 1817 , elected a member of the Royal Society of Musicians. He did not retain his post at Christ Chureh many years, owing to otler elaims upon his time. In 1846 he became associated with the Daily News, as secretary ; and on the retirement of Mr. George Hogarth, in 1s66, succeeded to the position of musical critic, retaining this office nutil 18 s6. The last Festival he attended was that held in Birmingham, in 1882, when (romod's "Redemption" was pridued. He began his career as a lecturer at Crosby 1 Iall, in 1843, where he gave an anmul series for some years. He also lectured at the London Institution; the Philsophical Institutiom, Edinburgh; (tasgow; Manchester; liverposl, ete. His subjects included Pach, Handel, Havdn, Mozart, Chermbini, Cimarosa, R mini, spohr. Weber, Mendelssohn; also Greman song; German and French opera ; the Operatic oferture, etc. Toeal and instrumental illustrations were given by the Misses Lincoln, Miss Orger, and many eminent artists. In the lecture on Mendelssohn, at the Wenteru literary Institution, Iecember 2.?, 1s45, his Tiolin Concerto was played, for thr first tine in Fngland, hy Herr Krentzer (a ratative of Rodolphe Krentzer), with Mr. Lincolls at the pianoforte. For the last few rear's he las lived in complete retirement. He edited "The Practieal Organist" (six numbers of organ munic, by Adolph Hesse) : and arranger ". The ()iganint's Anthology," a series of murements from classical compositions, in twelve numbers, publi-hed in 183:\%. He alse contributed a few articles to Grove's Dictionary of Music and Musicians.

His eldest sister, MArinxe Lixcolx, soprano vocalist, was born in London, in 1823. Her early progress in music led to her entering the R.A.M., in 1840, where she studied moder Crivelli, Benedict, and G. A. Macfarren. Immediately on leaving she made a tour in Germany, and sang at the Leipzig fewandhaus, December 12, 1844, and again the following month. On ler return she was make an Associate of the R A.M. She there continued her profession until her marriage with Mr. Edmund Harper (q.l.), when she removed to Hillsborough in Ireland. She took the leading parts in the private operatic performances organised ly the Iuchess of Downshire. She died at Sydenham, October 6,1885 . Her younger sister was married to Mr. H. C. Lunn (q.e.). 


\section{LIND.}

Lind, William, anthor of "A popular account of Ancient Musical Instruments," London, Clarke, 1897.

Lindley, Robert, violoncellist and composer, born at Rotheram, March 4, 1777. He stulied the violin and 'cello, and beeame 'cellist at Brighton Theatre. He was principal 'cellist at the Opera, London, 1794-1851. He played at all the princifral provincial and other festivals, generally in company with Dragonetti, the double-bass player. He died at 1.ondon, June 13, 1855 .

Works. - Three duetts for violin and violoncello, [1802]; another set, op. 12 [1806]. Five sets of duets, for 2 violoncellos, op. 11795 ; Op. 3; Op. 4; Op. 8, and Op. 14 . Trio for bassoon, tenor, and 'cello, op. 7. Six easy solos for a 'cello and bass, op. 9. Fantasia for violoneello, first string, op. 18. Handbook for the Violoncello, London [1855]. Songs, ete.

1 Iis son, William (born, 1802; died, Mlanchester, August 1:2,1869), was a violinist of some repute in his day, and his brother, Charles', who died in December, 18t2, was also a violoneellist, and played at the Phil harmonic and Ancient Coneerts.

Lindsay, Christopher, Seottish musieian and writer. Brother of Lady Anne Barnard, Nember of the Choir of St. Paul's Cathedral. Author of "A Scheme showing the Distance of Intervals," London, 1793.

Lindsay, Miss, sep Pisiss, Mrs. J. W.

Lindsay, Thomas, anthor of "Elements of Flute-playing, according to the most approved principles of Modern Fingering," Iundon, 162s. Nelanges for the flute and pf., and other arrangenents.

Ling, William, composer, pianist, and teacher, who flonrished abont the end of last and beginning of present century. Composer of op. 1, Three sonatas for harpsichord or pf. [1790]; (1). 2, Luets for two flutes; Inivertimentos for pf., opp. 6, 7,8 ; Sonatas for pf., opp. 12, 13; Serenade, op. 17, ete.

Lingard, Frederick, organist and composer, born at Manchester, in 1811. He studied musie under Harris, of Manchester, and beeame organist of st Gorge's Church, Hulme. In 1835 he was Iay-vicar of Durham Cathedral, a post he held till his death, at Durkann, on July $4,18+7$. He issned "Antiphonal Chants for the Psalter," 1843, and composed anthems, chants, etc.

Linley, Francis, composer and organist, was born at Doncaster in 1774. Blind from birth. IIe studied under Mather, of Doncaster, and became organist of Pentonville Chapel, London. Nlarried to a blind lady of fortune. Opened music-selling business. Becanne bankmpt, and was d serted by his wife. He went to America as an organist, but retumed to England in 1799, and died at Doncaster, September 15, 1800 .

\section{LINLEY.}

Works.-Sonatas for pf. and flute, op. 1 ; Practical Introduction to the Organ, in five parts, London [1800]. Collection of Interludes, fugues, ete., for organ, op. 6; Thirtytwo familiar airs for 2 flutes [1790], and other music for the flute; Sougs.

Linley, George, poet and composer, born at Leeds in 1798. Died at London, Sept. 10, 1865.

Works.-Operas and Operettas: La Poupée de Nuremberg, Covent Garden, 1861; Law versus Love, comedietta, 1862; The Toy Nlakers, 1861; Francesca Doria, 1849. The Jolly Beggars, caritata (Burns). Songs of the Camp, 12 pieces. Selection of Scottish Melodies (with C. G. Byrne), 1840. Songs of the Troubadours, London, 1830; Seleetion of original hymn tunes. Songs and Ballads: Alice; Bonnie New Moon; Bird of Beauty; Beantiful Brunette; Ballad singer; By the spangled starlight; Clara; Chide no more; Constance; Dream no more of that sweet time; Gipsy mother; Hetty; Hear me but once; Ianthe; I camnot mind my wheel; I'm the little flower girl; Jeanie; Love me little, love me long; My own happy home; Mariner's wife: Maid of the Rhine; Minnie; Queen of the fairy dance; Some one to love; Sweet village rose; Star and water-lily; Thou art gone from my gaze; Under the vine tree. Part-songs, trios, duets.

Linley also wrote the words of a large number of songs, and published two satirical poems, "The Musical Cynies of London," London, 1seg, an attack on Chorley, the musical critic, and "Modern IIudibras," London, 1864. His son GEORGE (died 1869), published some poetical works.

Linley, Thomas, composer, born at Bath, 1725. Hestudied under Chilcot and Paradies. Conductur of oratorios and concerts at Bath. Went to London and purchased Garrick's share in I)rury Lane Theatre, with Sheridan, 1776. He died at London, November 19, 1795. Buried in Wells Cathedral.

Works.-Operas and musical dramas: 1)uenna (Sheridan), 1775: Camp, 1776; Carnival of lenice, $17 \AA 1$; Gentle shepherd, 1781; Triumph of Mirth, 17R2; Spanish Iaid, 1783 ; Selima and Azor (from Grétry), 17Rt; Spanish Rivals, 17 45 ; Tom Jones, 1785; Strangers at lome, 1756; Love in the Fast, 1788 ; Robinson Crusoe; Leggar's opera (new aceompaniments, ete.): Songs in "The School for Scandal." Six Elegies for three voices and pf., London, 1770; Twelve Ballads; Canzonets. Numerous glees, single songs, and anthems. "The Posthumous Vocal Works of Thomas and T. Linley, junr," 1800 , 2 vols.

Linley, Thomas, composer, son of the above, born at Bath, 1756. Ile studied under Boyce and his father; also at Florence under 


\section{LINLEY.}

Nardini. He was acquainted with Mozart. Leader of Bath concerts, and at Drury Lane, London. Drowned at Grimsthorpe, Lincolnshire, August 7, 1778.

Woris.-Music to the Tempest; Ode on the Witches and Fairies of Shakespeare, 1776; The Song of Moses, oratorio; Accompaniments for wind instruments to "Macbeth" music; Anthems, glees, and songs. The popular setting of the song, "O bid your faithful Ariel fly," in the "Tempest," is by him. His brother, the Rev. Ozias Thurston Li $\backslash$ Ley (born 1765; died, London, Narch 6, 1831), was a composer of songs, and other vocal music.

Linley, William, composer, son of Thomas Linley, senior, born at Bath, 1767 (1771). Educated at Harrow. He studied under Abel and his father. Appointed to post in East India Company's Service, by Fox. Resided in India for a time. He died at London, May 6, 1835.

Works. - Shakespeare's Dramatic Songs, consisting of all the songs, duets, and choruses, in character, as introdnced in his Dramas.. with an Introduction, London, 2 vols., 1\$15-16. Two operas. Glees, ete. Ile also wrote novels and other literary works.

Linley, Eliza Ann, the "MI IID OF Bath," sopruno vocalist, daughter of Thomas Linley, senior, born at Bith, in 175t. She was trained by her father, and sang at the Bath concerts, and in London, Worcester, Hereford, and Gloncester Festivals. She eloped with and ntarried R. B. Sheridan in 1773. She died at Bristol, June 28, 1792.

Linley, Maria, soprano vocalist. third daughter of T. Linker, horn at Bath, abont 1764. Sang at Bath, ete. She died at Bath, September 5, 1784.

Linley, Mary, soprano vocalist, second danghter of T. Linley, horn at Bath, in 1756 , 1759 (?). Sang at Bath. Hereford Festival, 1751, etc. Married Richard Tickell in 1780. She died at Clifton, July 27, 1787.

Linter, Ricardo, jianist and composer, was born in Deronshire about 1815. In 1862 he went to Cheltenhan, and became a snecessful teacher and pianist. He held the position of organist of St. James' and St. Luke's Churches, Cheltenham. Ired at Cheltenham, February 6, 1886. Composer of a large number of polkas, quadrilles, variations on airs, and other works for pf. Songs, and other vocal music.

Linwood, Mary, composer, born in Birmingham in 1755 , died at Leicester. March 2 , 1845. Composed "David's First Victory," oratorio, London 18407. The Kellerin, and The White Wreath, IIS, operas. Songs, and other vocal music. She was celebrated for her fine needlework, of which she gave exhibitions in 1770,1778 , and 1798.

\section{LITOLFF.}

Lisley, John, composer, known only as the composer of a 6-part madrigal, "Faire Citharea presents hir doves," in the "Triumphs of Oriana," 1601.

Liston, Rev. Henry, writer and inventor, born in 1771. Minister of Ecclesmachan, Linlithgow, from 1793. He died at Merchistonhall, February 24, 1836. Author of "An Essay on Perfect Intonation," London, 1812.

He invented an Enharmonic Organ, which was performed on in Edinburgh, and his system was applied to several other instruments, though unsuccessfully, owing to the great number of pedals, and the difficulties consequently attending manipulation. His son, Robert, was the famous surgeon.

Lithgow, William Hume, composer, teacher, and conductor, was born at Leith, on February 15, 1806. He stndied in Edinburgh and London, and became precentor of St. Enoch's Parish Chureh, Glasgow, and music-master at the High School, in 1842. He died at Glasgow, August 22, 1874. Compiler of "I'arochial Sacred IIusic, being a selection of the best ancient and modem psalm and hymm-tunes, etc. . . Intended for the use of St. Enoch's Church, Hlasgow,"... Glasgow, n.d. [c. 1845]. "A Selection of Sacred Music, with accompaniments for the organ or pianoforte," Clasgow, n.d. He also composed a number of songs, "( )ld Scotland, I love thee," etc., and about 50 psalm and hymm-tmes.

Litolff, Henry Charles, composer and pianist, born in London, February 6, 1818. His father was a native of Alsace, taken primoner by the English in the Peninsular war, who settled in London as a viohinist. His mother was lrish. Litolff studied the pianoforte under Moscheles, and made his debut at his master's concert, Corent Garden Theatre, July 24, 1832. In 1835 he married, against his jarents' wish, and we nt to reside in France. He gave concerts in various places, tonred in Germany, 1845-6, gaining the title of "The Enghish Liszt." He played at the Leipzig Gewandhans several times from Novenber 28, 184t, to February 7, 1856. In 1851 he entered upon the music business of Mleyer, of Brunswick, which he transferred to his son, Theodor, in 1860 . From 1861 he resided chiefly in Paris; and died at Colombe, near that eity, August 5, 1891. In 1889, a Festival in his honour was held at Angers.

Works.-Operas : Der Braut rom Kynast, 1847; Rodrique de Tolède; Les Templiers, written abont 1865; produced, Brussels, January, 1886: The Flying sifuadron of the Queen, Paris, 1s8s; and King Lear, funished in 1890, and found among his papers after his death. Five Symphony-concertos, for pf. and orchestra. Orertures, Rubesperre: Les Girondins; Das Welfenlied; C'hant des Belges. 


\section{LITTLE.}

Quartet, strings; Three Trios, pf. and strings; and a number of pieces for pf. He was a man of genius, and his works abound with beatiful ideas; Int the workmanship is frequently faulty, and in value his compositions are very uneiual.

Little, Edgar E., tenor vocalist and composere, resident in loublin. Was for some time in the chapel Royal choir, Dublin Castle. He is the comproser of a comedy opera, "The Mallock," produced, Duthlin, February, 14trez; also "Vietoire," a military conedy (both books liy Alfred smythe), produced at Leinster Hall, Dublin, April 17. 1sy3, with much success. Nr. Jittle is an amaten of considelable attainments, and holds an appointment in the Pionk of Ireland.

Little, Henry Walmsley, organint and composer, born in London, September 1.2, 1853. Stndied at R.A.M., under (i. A. Macfarren, C. Steggall, H. C. Banister, and F. B. Jewson, 1ni2-s. F.C.O., 1875; Mus. Bac., 1877; Mus. Doe, 1sis5, Oxford; F.J.A.M., 18st. Organist of church of the Anmunciation, Chislehurst, 1st1; Christ Church, Woburn syluare, 1sit; st. Matthes's, Denmark Hill, 1sso; st. Giles-in-the-Fields, $1 \mathrm{~s} / \mathrm{1}$; and of tholy Trinity, Tulse Hill, from 1siso. Examiner for R.C.O.; Trinity College, London; and the Incorporated siciety of Musicians. Associate of the Philharmuic Sircietr. Ifas given concerts and organ recitals at Greshan Hall, ete. His compositions include cantatas, "The Rock of lwalel," produed, Fobuatry, 18st; and "Great is the Lord" (both in Ais.). C'hureh serviees, anthenus. P'ild-solngs, ete. Ilo has also eomposed somer pinces for orehestra (in Mis.): and published a suite de pieres, anel other workis for ple

Livingston, James R., writer and eomposer, native of Aherdeenshire. Thesidnd in Glangow from 1st4. Anthol of "The Organ Defented: leeing an exsay on the nee of that insteument in J'ublio Worship, with strietures on 'Phinehas Voeal's' attack on the (Organ and In. Anderson." (Hasgow, 11.t. c. 1857. Reply to a pamplotet entitled "Ine. Anderson as an Organist," by Phinchas Vocal, (Flatsow, n.d. Compuser of anthems, somgs, ctet.

Livingston, Rev. Neil, clergyman, wats Free Chureh moinister of Stair, in Avrshire, from 1844 to 1886 . Editor of a reprint of "The scottish Metrical Psalter, of A.1). I(i35, with "opions dissertations and Notes," Glasgow, 1 stit.

Llanover, Lady, ast patroness, danghter. of Benjamin Waddington, Esef, of Llanover, was born Mareh 21, 1802. Married, J exember

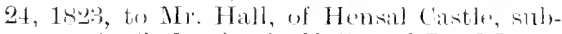
sequently sir lienjamin llall, and Lord Llanover (died April 27 , 1867). Lady Ltamover revived the ancient glory of the Finteddfod,

\section{LLOYD.}

and was a prize wimner herself, for an essay, at Cardiff, in 1834. In 1838, she brought out, in eonjunction with Miss Jane Willians, of Aberpergwym. a collection of Welsh Airs. Further, to promote the mational music, she invited a meeting of Welsh harpors in 1869, t) compete for a triple harp. She died at Llamover, Jammary 17, 18! 16 .

Llinos, see Willians, MARia liNe.

Liloyd, Charles Francis, com meser, born in Chester, October 7, 145\%. Son of John Anbrose Lloyd (q.v.). Ciliduated Nus, Bac., Oxford, 1s7s. Appointed organist of Parish Chareh, beammalis, at the age of sixteen, and four years later, organist and climeter of the choir of Tynemouth Parish Chureh, Conduetor of Tyremonth Philhammenic suciety, 1879 991, and sunth shiedds ('horal society, 1889-9). In the latter vear he resigned these aprointments, and häs since deroted himself to compositim. Adjudicator at Royal National Eistedelfod of Wales, and some time monsical critic ol the Yeweastle laily Cleronacle. Counproser of a Concert werture in F (National listeddfod, 1893); Orehostral suite in F (1894). ('hurch services, anthems, part-simgs. Prize Cyeling Song (18:1), and numerons songe, "Itarie"; "Vreve I the streanlet"; "The chord of Life," "te., matry of which have met with wide atecoptance.

Lloyd, Charles Harford, organit and compreser, born at Thormbury, (ilonembershire, October 36, 18t9. Edncated at 'Thorutury

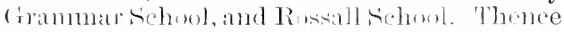
to Magdalen Hall (now llertford (callegee), oxford, where he held an open alasicieal scbolarubij). Graduated Mus. Bac. Isti;

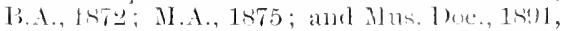
Gxfort. Ju 1876, he wals appointer organist of Gloncester Gathedral; in t485, of Chrint

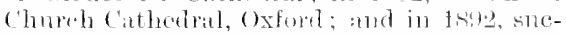

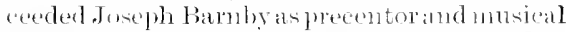
instructen at liton college. Ile was a fommder, and first presiclent of the oxford Lniversity Musicill chul, conductor of the ciloncester Festivals of 1877 and 1860() ; and is still comdueter of the (Oxford simminury concerts.

Wonks. C'entates: Ilero and Jombler, produced. Worcester Festival, fost: The siong of Balder. Hereford, 1k85; Andromedal, Gloncester, 1sisf: A homg of Indgum nt. Ilerefurd, 1891; sir Ogie and the lady Blsie, Hereford, 1ng4. MIusic to Aleestis, oxford, 1sist. The sleaner's Harrost, cantatit for female voiters. Full Gathedral servien in E that: antheme, ete. Pastoril, the Jiony Dawn, Leneds Festival, [889; N-part moms, Tr Morning. Wurcester, 1s90): part-songe, songs, ote. Somata in I) minor', organ ; pieces for elarinet and pf., ete.

Lloyd, Edward, tenor vocalist, horn in Londen, Narch 7, 18t5. Son of Richard Lloyd (noticed later), and Louisa, his wife, 


\section{LLOYD.}

born Hopkins (q.v.). Chorister at Westmiuster Abbey under James Turle, leaving at fifteen, and after a year passed at a school at Southwark, joined his mother at Cheltenham, where he remained until 1865. He then sang at a ehureh in Belsize Park, London, for a short time, obtaining an appointment at Trinity College, Cambriage in 1866 . A year later he went to St. Andrew's, Wells Street, London, and shortly afterwards was appointed a Gentleman of the Chapel lioyal, St James's, an office he resigned in a few years. He was now becoming known as a eoncert singer, taking part in the performance of Beethoven's Choral Fantasia at the Oratorio Concerts, Nareh 9, 1870. His first great opportunity came with the Gloncester Festival of 1871, wheu he distinguished himself in Baeh's Matthew Passion. He las sung at every meeting of the Three Choir since that time save the years 1875,6 , and 9, while his eonnection with the Norwich Festivals dates from 1872. He has been prineipal tenor at the Leeds Festivals since 187t; and has sung at every Birmingham Festival from 1876. At other Festivals and Coneerts he has been constantly heard, and has ereated the tenol lart in most of the great works of recent times. As a singer of Wagner's music he is unsurpassed. He has visited Ameriea on several oceasions, from the Cincinnati Festival of 1888, and has sung in Brussels and Paris.

His father, Richard Lloyd, born at Vauxhall, March 12, 1813, was a tenor singer of repute, and became a vicar choral of Westminster Abbey. He ched, Jume 28, 1853. Hanri Lloy', a younger brother of Edward, appeared as a tenor singer for a short time 1859-90; and $\mathrm{E}$. Turner Llosd, son of Edward Lluyd, studied pianoforte under Mad +11 e Schumann, and singing under F. Walker; appeared as a vocalist; toured in America, $1892-3$; and is now a professor of singing at the R.A.M.

Lloyd, George, musician, who published "Peninsular Melodies," London, 1830, 2 vols.

Lloyd, John Ambrose, composer, born at Mold, Flintshire, June 14, 1815. Father of Charles Francis Lloyd $(q, r)$. Though in the main self-tanght, he gained the reputation of being the most refined Welsh composer of his day. His eantata, "The Prayer of Habakkuk" (1851), was the first work of its elass produeed in Wales; his anthem, "The Kingdom of the Earth" (Eistedlfod Prize, 1852), is still the most popular anthem in Wales; and his part-song, "The Last Flower," is looked upon as a Welsh classie. In $18+3$ he published a eollection of Hymn. tumes; and a second, "The Praise Offering," in 1873. Several of his hymu-tunes were awarded prizes. He often acted as adjudicator at the National Eistedeffodau. Died at Liverpool, September 14, 187t.

\section{LOCKEY.}

Lloyd, John, Frederick, musician, compiler of "The Paroehial Psalmist, or a selection of Psalms and Hymms," Dublin [1845]; 2nd ed., 1848 ; 3rd ed., 1850.

Locke, Matthew, composer and writer, was boru at Exeter in 1632 or 1633 . He beeame a chorister in Exeter Cathedral, and studied musie uuder Edward Gibbons and W. Wake. Composer in Ordinary to Charles II., 1661. Afterwards he became a Roman Catholie, and was appointed organist to the Queen. He died at London, August, 1677.

Works.-Cupid and Death, masque (Shirley), with C. Gibbons, 1653. Little Cousort of three parts for viols, 1656. Music for The Stepmother (Stapylton), 1664; Davenant's alteration of "Macheth," 1672 ; Shadwell's "Psyche," 1673; and the "Tempest," 1673. Anthems, various, for Clrapel hoyal. Kyrie and Credo, 1666 (preface defencting the work against the opposition which its novel form raised, entitled, " Modern Church MIusic: Preaccused, censur'd, and obstructed in its performance before his IIajesty," A pril 1, 1666). Reply to Thomas Salmon's "Essay to the Adrancement of Music," entitled, "Olservations upon a late book entitled, An Essay to the Advancement of Musiek, by casting away the perplexity of different elifts and writing all sorts of musick in an [niversal character." London, 1672. Reply to Sithon's "Vindication," entitled, "T'he Present practice of Musick, vindicated against the exception and new way of attaining Musick, lately published by Thomas Salmon, London, 167\%. "Melothesia, or certain general liules for playing upon a continued hass, with a choice colleetion of Lessons for the Harpsiehord or Organ of all sorts," London, 1673 . Songs in contemporary collections, as the Theater of Musie; The Treasury of Mnsic; ete.

Lockett, William, organist and composer, Was born at Manchester in 1435. He has held the appointnent of deputy assistant organist of Manchester Cathedral; organist of St. John's, Higher I'rroughtom, 1855-61; St. Mark's, Cheetham; Urion Chapel, 1877; Cross Street Chapel, Manchester ; and conductor of Moston Choral Society. He has composed anthems; Evening, fonr part song; Merry monutain maid; Mother's prayer, and other songs.

Lockey, Charles, tenor voealist, borm at Newbury, Berks, 1820. Son of Angel Lockey. Chorister, Magdalen College, Ox ford, 1828-36, in whieh last year he went to Bath to study under Edmund Harris. In 1st2, became a pupil of Sir George Smart, and lay-clerk of St. George's, Wiudsor. Appointed vicarehoral of St. Paul's Cathedral, 1843, but in October, 1842, made his first appearance as an oratorio singer in liossini's "Stabat Mater," at Store Street liooms. Was en- 


\section{LOCKHART.}

gaged for the Ancient Concerts in 1846, and sang at the Birmingham Festival the same year, at the production of Mendelssohn's "Elijah." Also sang at the Three Choirs Festivals, 1846-56, and at the concerts of the Sacred Harmonic Society. In 1848 was made a Gentleman of the Chapel Royal. Narried Miss Martha Williams, contral to singer, May, 1853. An affection of the throat compelled his retirement in 1859. One of the most eminent and popular singers of his day, his early retirement was a public loss. $\mathrm{He}$ is now resident at Hastings, and retains, officially, his Cathedral and Chapel Royal appointments.

Lockhart, Charles, organist and com. poser, born in London, in 1745. He was blind from his infancy, but became organist of the Lock Chapel in 1772 ; St. Katharine Cree; St. Mary's, Lambeth; Orange Street Chapel; and Lock Chapel again in 1790-97. He died at London, February 9, 1815. Composer of "A set of hymn tunes and anthems for three roices," London [1810]; "An Epithalamium, or nuptial ode" $[1770]$; Seleet and original vocal piees; March, in honour of the Lambeth Loyal Association, London [1795]; Sonatas for harpsiehord. Female advice, Rural gift, and other songs. His hymn tune "Carlisle" is included in many modern collections.

Lockwood, Adolphus Raven, harpist, born in Lonclon, 18t0? Appeared, with his brother and sister, at a concert at the Hanover Square Rooms, February 18, 1848, the three then being pupils of Gerhard Taylor. $\mathrm{He}$ soon rose to a ligh position, but spent the later years of his life in Germany. He played at the Gewandhaus Concerts, Leipzig, December 11,1876 . In 1884 he was created a Lioyal Chamber Musician, Munich, in which place he died, January 23, 1885, aged 45 . His younger brother, ERnest Lockwood, harpist, was a member of the orchestras of the Philharmonic Society, the Royal Italian Opera, and the Crystal Palace. Ite played Handel's Concerto for harp at the Crystal Palace, November 28, 1885, and was known as one of the foremost professors of the harp in London. He died, April 21, 1897. Miss Lockwoon (the sister?) was for years harpist to the Carl Rosa Opera Company. She died suddenly at Hanley, Staffs., while on tour, February, 1897.

Loder, Edward James, composer, born at Bath, in 1813. Son of John l)avir Loder. Hestudied under his father, and at Frankfort, under F. Ries, 1896-28. Returned to ling. land, 1hes. Again went to Germany and studied under Ries. Conductor at Princess's Theatre, London; also at Manchester. He diesl at London, April 5, 1845.

Works.-Operas: Nourjalsed, July, 1834;

\section{LODER.}

Dice of Death (Oxenford), 1835; Night Dancers, Princess Theatre, 1846 ; Puck, a ballad opera; Sultan, dramatic piece; Young Guard, 1848; Island of Calypso, a masque, 1851; Raymond and Agnes, Manchester, 1855; Francis the First, 1838 (compilation); Foresters; or, Twen ty-five years since; Deer Stakkers, Scottish opera; Beggar's Opera, revised. Selection of Songs, in 3 books. Dr. Watt's Divine and Moral Songs. Sacred Songs and Ballads, Poetry by D. Ryan. Improved and Select Psalmody. Divine Harmony. Twelve Sacred Songs. Instructions and Exercises on the principles and practice of the art of Singing (Ashdown), n.d. Songs and Ballads: Afloat on the Ocean; Arnold the Armourer; Bare-footed Friar; Brave old oak; Come to the glen; Columbus; Come blushing May; Deep-sea Fisher ; Forester's Bride ; Hermit ; Ivy tree; I love these merry festive times; I'll weave a sweet garland; My harp is strung for thee; My own loved home; Martin, the man of arms; O here's to the holly; Oh, the merry days; Outlaw; O speed my bark; Philip the Faleoner; Rhine song; Sweet girls of Erin; Stars of the flowers; Thou art gone to the grave; The song of the water king; The village mill; Wake, my love; Where is my loved one? Part-songs, hymns, and pf. music.

Loder, George, cousin of E. J. Loder, composer and singer, born at Bath, in 1816; died at Adelaide, Anstralia, July 15, 1868. Compiled "The Old House at Home," musical entertainment; numerous songs ; symphonies; pf. music, ete.

Loder, John David, violinist and writer, horn 1788; died February 13, 1846. Author of the "The Modern Art of Bowing exemplified, with exercises in the major and minor reales," 1 London, n.d.; Violin School, n.d.; Works for Violin.

Loder's violin school is one of the most popular among recent productions of that nature.

Loder, John Fawcett, violinist and composer, son of above, born at Bath, 1812. Teacher and concert-director at Bath. Leader of orchestra and teacher in London. He died in London, April 16, 1853.

Loder, Kate Fanny, pianist and composer, born at Patb, August 21, 1826, only daughter of Feorge and Fanny Loder. Her musical talent was manifest at a very early age, and when six years old she was placed muder a Miss Batterbury. She was then placed with Henry Field, and in 1838 entered the R.A.M. Her teachers were Mrs. Anderson and Charles Lneas. Elected King's Scholar, 18:39; re-elected 1841. On leaving the Acadeny in 184t, she was eleeted Professor of Harmony. She appeared at concerts, Bath, in 1840; played at Mrs. Anderson's 


\section{LODGE.}

concert, at Her Majesty's Theatre, May 31, 1844, when Mendelssohn was present to hear her rendering of two movements from his first concerto. First appeared at the Philharmonic Concerts, Marel 15, 1847, as soloist in Weber's concerto in E flat; and played for the last time in public at the san1e, Mareh 6, 1854, Mendelssohn's concerto in D minor. On December 16, 1851, she was married to the eminent surgeon (Sir) Henry Thompson. She continued her connection with the R.A.M. for some years after her retirement from the concert platform. Her works include an opera, L'Elisir d'Amore; au overture; two string quartets; a trio for pf. and strings; sonatas for pf., and pf. and violin; pieces for violin; pf. pieces, etc.

Lodge, John, see ElLFrTox, Johy LOdGE.

Logan, Edmond, amateur musiciau and flute player, born about 1804; died Edinbargh January 24, 1865. He was a writer to the Signet in Edinburgh, and acted as musical critic to the Scotsman for many years.

Logan, William, amatent violinist and composer, was born in Ayrshire, about 1745. He was a major in the army, and is chiefly notable as a friend of Burns lle poet, who addressed an "Epistle" to him beginning "Hail, thairim - inspirin' rattlin' Willie." He composed various dances, etc., contained in John Hall's collection, and elsewhere.

Löhr, Frederick Nicholls, composer, pianist, and conductor, was born at Norwich, in January, 18t4. He vas a pupil of Dr. Z. Buck. He settled in Plymonth as a teacher and concert-giver, and became organist of Sherwell Chapel, and conductor of the Plymouth Vocal Association. He died at Plymouth, December 18th, 188. He composed Fairy Music, a cantata for treble voices; Country sougs for the children's hour ; School songs; Orchestral and pf. music, ete.

Löhr, Richard Harvey, composer, pi anist, and organist, born at Leicester, June 13, 1856. Son of (ieo. Aug. lühr, many years organist of St. Margaret's, Leicester. Fducated at home, and later at the R.A.MI., under Sullivan, Prout, and W. H. Holmes. Won the Lucas medal for composition twice1877-8. Potter Exhibitioner and Santley Prizelolder, 1879. A.R.A.MI. Associate Philharmonic Society and Member of the Royal Society of Musicians. Has acted as organist since the age of ten, and at present holds office at St. James's, Marylebone (Rev. H. R. Haweis). In 1882, began giving concerts in London, and chamber concerts in Leicester ; and is in great request as accompanist and as a teacher.

Works.-Oratorio, The Queen of Sheba, selection performed St. James', Marylebone, Dec. 13, 1896. Anthems: They that go down (for soprano solo, chorus, and orchestra, 1885);

\section{LONGHURST.}

God, who madest earth and heaven; Watching, praying, waiting, and others. Morning and evening service in C, op. 12; Communion service in A minor. A Border raid, chorus with orchestra (1883), and other part-songs. Album of ten solngs, op. 16, etc., etc. Quartet in E minor, op. 15, pf. and strings (produced at a concert given by the composer, June, 1882; published 1889); Ballade in G, op. 3, violoncello and pf. ; Duo concertanti, op. 13 , pf. and violoncello; Caprice in G, op. 11, Cavatina in $\mathrm{B}$ tlat, op. 14, violin and pf. The Window, twelve pieces, op. 7, and other compositions for pf. Scales and arpeggios, specially adapted for examinations. Author of Lohr's Primer, catechism of the Rudiments of music, London, Lacas, Weber, and Co., 1882 ; Principia of music, a complete explanation of the rudiments of music, etc., London, Forsyth, 1890. Editor of London chant Book, 1885.

Lomas, George, organist and composer, born at Birch Hull, Bolton, November 30 , 1831. He studied under Steggall, Sterndale Bemnett, and J. F. Bridge. He acted as voluntary organist of I idsbnry Parish Church, and at Emmannel Church, Barlow Noor. He graduated Mus. Bac. in 1876. He died October, 18, 1nst. Composer of music for the charch, the hymn tune "Submission," etc. Song, "Take me to thy heart, dear maiden " (Professor Blackie), composed expressly for Madame Marie Roze.

Long, Samuel, organist and composer of latter part of last century. Among other works he published "Four lessons and two voluntaries for the harpsichord or organ," London [1770]; "Where'er you tread," prize glee, 1764; "Hash the god of love," glee; Psalms in Riley's collection, etc.

Longbottom, T. K., composer, born at Burley, Yorkshire, 1h:3. He was a teacher and conductor. I)ied at Bradford, August 15, 188. Composer of a number of stories with music, such as Alfred the Great, Daniel, David, Elijah, St. Paul; and other vocal music.

Longhurst, John Alexander, vocalist, born in 1809. He studied under Joln WVatson, and first appeared in Bishop's opera, "Henri Quatre," in 1820. He sang at numerous concerts. Died in 1855.

Longhurst, William Henry, organist and composer, born at Lambeth, October 6 , 1819. When he was two year's old his parents went to reside at Canterbury, and in 15.8 he was admitted a chorister in the Cathedral. In 1836 he was appointed assistant organist, master of the choristers, and lay-clerk; and in 1873 succeeded T. E. Jones as cathedral organist. F.C.O., 1865; Mus. Doc., Cantuar, 1875; Toronto, 1886. Musical Lecturer at St. Augustine's College, Canterbury. 


\section{LOOSEMORE.}

Works.-Oratorio, I)avid and Absolom, produced, Canterbury, Jaunary 10, 1872 ; The Village Fair, an Alpine Iciyll (words by Jetty Vugel), Canterbury, February 6, 1882. Cathedral service in $\mathrm{E}$; Benedicite in E; chants, etc. Anthems: Blessed is he; Grant to us, Lord; Great is the Lord; The Lord is my strengih, and others. Editor of A Collection of Anthems, as performed at Canterbury Cathedral [1845]. Andante piacevole and Tarantella, violin and pf., songs, etc.

Loosemore, Gieorge, organist and composer, who flowrished in the 17 th century. Mus. Bac., Cantab. Chorister in King's College, Cambridge, 1660. Organist of Trinity College, 1660. Doc. Mus., Cantab., 1665. Composed Anthenrs, mostly preserved in MS.

Loosemore, Henry, organist and composer, father of the above, was a chorister at Cambridge. Organist of King's College, Cambridue. Mlus. Bae., Cantab., 1610. Organist of Exeter (athedral, 1660. He died ill 1670. Commoser of servire and anthems.

His brother, JoHN (1619-April \&, 16il), was an organ-bulder. and built the organ of Exeter ('atheriral, etc.

Lorimer, John, amateur composer and artist, was hom at Paisley, on June 9, 1812. He was an artist and poet, and resided chiefly in Paisley, where lie died, on October 13, 1878. He composed a number of psalnu tunes, "Crookstor," etc., and several humorous songs, the best known being "I'm ower auld to marry noo."

Lott, Edwin Matthew, organist and composer, born at St. Helier, Jersey, January 31,1836 . When ten years of age he was organist of St. Matthew's Chmrd, and lield in succession several similar appointments in Jersey. Studied under IV. T. Pest, 1851-2; F.C.O., 1865. Urganist of St. Ulement I)anes, and other churches in London, 1S60-4; retumed to Jersey in 1865, and was professor of music in Victoria College, and bandinaster of three regiments. Reappointed organist of St. Peter's, Bay'swater, 1870 ; organist of St. Eitlelburga, Bishopsgate, 1880 ; and of St. Sepnlchre's, Hobborn, $18 \times 3$ to the present time. Mr. Lott has been professor and examiner, Trinity College, London; principal of Musical International College; was made Mus. Doc., honoris causit, Trinity College, Toronto; examiner for the same; and in 1891 appointed to the chair of music. He lras written a cantata, "Thus saith the Lord, heaven is my throne" ; church services, anthems, ete. "Into the silent land"; "The Fairy wedding," and other songs. Sonata in F; Bonrée; Minuet; Fifty-five finger inventions in all keys, for pf., with about 300 picees for that instrument. Organ pieces in various styles. He is author of a Pianoforte Catechism ; Harmony Catechism; and a Iictionary of Musical Terms, all of which have passed througl several editions.

\section{LOWE.}

Lott, John Browning, organist and conductor, was a chorister at Canterbury Cathedral nuder Dr. Longhurst, and afterwards organist successively at the churches of St. Dumstan and St. Paul in that city. The last he left to become assistant organist at the cathedral. He went next to the parish Church, Margate, and while there graduated Mus. Bac., Oxford, 1876. In 18si he was appointed orgauist and nuaster of the choristers at Lichfield Cathedral. He conducts the Diocesan Choral Festivals, and is the founder and conductor of the Tichfield Musical Society, which has done important service to music in the locality.

Love, James, conductor, organist, and author, born at Dundee, Jannary 1, 1858. He has been organist of High Church, Falkirk since 1878 , and has for many years acted as conductor of the Falkirk and Vale of Leven Choral Societies. Anthor of "Scottish Chur.h Music, its composers and sources," Fdiubnrgh, 1891 , a work of much value and accuracy which is particularly strong in its biographical details.

Lover, Samuel, poet, painter, novelist, and composer, was born at Dublin, February 24, 1797; died at Jersey, July 6, 1868 .

Works.-Yarious Novels. Songs and Ballads, London, 1859. Music to the following plays: Rory O'More (based on his novel) 1837; White Horse of the Peppers, 1838; Happy man, 1839; Green Poy, 1840; Il Paddy Whack in Italia, 1841; MacCarthy More, 1861. Songs: A leaf that reminds me of thee; Angel's whisper; Birth of St. Patrick; Bowld Soger Boy; Fairy Boy; Fairy Tentpter; Fisherman; Forgive but don't forget; Four leaved Shamrock; Hour before day; I leave you to guess; Irish mule driver; Land of the west; Letter (the); Low backed car: Nay dew; Molly Rawu; Molly Carew; My Mother dear; Rory O'More; Saint Kevin; True love can ne'er forget; 'Twas the day of the feast; Can you ever forget; Dove song; Fisherman's daughter; I can ne'er forget thee; Kathleen and the Swallows; Lady mine; Macarthy's grave; $\mathrm{O}$ wateh you well; Rose, zephyr, and dewdrop; Sally; Say not my heart is cold; That rogne Riley; Yoice within; Whistling thief; Widow Machree.

Many of Lover's songs liave passed into the Irisl national repertory, the "Augel's Whisper," " The Letter," " What will you do love?" and "The Fairy Tempter," being among the best known.

Lowe, C. Egerton, pianist and writer of present time. Studied at Leipzig Conservatorium, Has published Six Album leaves for violin and pf., and is author of a Chronological Cyclopredia of Mlusicians and Musical Events, London, Weekes, 1896.

Lowe or Low, Edward, organist and composer, was born at Salisbury $[1615]$. He 


\section{LONE.}

was a chorister in falishury ('athedral, muter Holmes. Oreaniet of Chrint ('hurele, oxford, 1630. Organist of thapel Rowal, litio). ('horilgus and professon of munsic, Oxford, 16681-42. He died at oxford, July 11, 165:2.

Works.--A short direction fur the porformance of cathedrale service, etc., Oxford, 1661. Anthems, ete.

Lowe, Joseph, composer and dancingmaster, born at Marykirk, Kincardineshire, in 1797. Son of John Lowe, a dancing-master and componer there. He resided at Prechin, Inverness, etc., and finally settled in lindirburgh, where he died on July 12, 18fici. He jssued a "Collection of reels, strathisers, jigs, ctc.." Edinhmeh, n.d. c. 1845], and "Roval collection of reels, strathopers, ete.," Ediulurgh, и.d.

Lowe, Thomas, tenor singer, was lom early in the lsth contury. Irebut. Imory Lane Theatre, Siptember 11, 174s, Sang in Ame's " Is rom like it"; Handel's matolis, etc. Apleated at Vamxhall, 1745. Matmatere

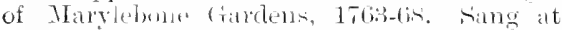
Sadter's Welis, 177.2. He died on Mareh l. 1783.

Lowthian, Caroline, Mlis. C'verL A. Prescort, in the composel of a mumber of

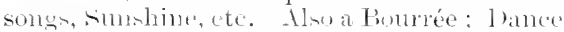
de billet, and other pieces for pit.

Luard = Selby, se' SELBX.

Lucas, Charles, componer, orgmist, and conductor, was bun at salishur, July 20, 180s. Chorintel in Sialishorv Cathodral, moder Corte, 1,15-23. I'mpil at R.A.M., under Limaley and Croteh. 1423-30. Memiser of Gneen Adeladide private band. Conducter

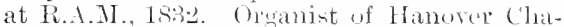
pel, Regent sitreet, 1839. He was oceasionally conductor of the Ancient Concerts in 1sio-4:3. Principal 'cello at opera, and provincial Fontivals, ete. Member of firm of Addison, Hollier', amd Lueas, music-pnblishors, 1856-65. Principal of R.A.M., 1559-60. He was married to Miss [Iten Tavlor, the soprano vocalist; who dien at Lomdon. March s, 1860 .

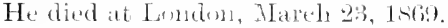

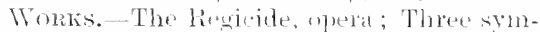
phonies: Overtures: Tioloncello anceletr, etc. Anthems: Blesed be the Lond: Sing, O hoavens; Homama; () Lord, open thour; O Grod, the stremgth; O thon that dwollest. Magnificat, forr vosces, in canom, Greshan prize, 1836. llai] to the new-burn spring, glee. Ah, fading joy, madrigal. Songs: Clonds from wht the shy are driven: Hone. ward thoughts: Poet's comsolation. String quartets, unfinished uperas, ete.

Lucas, Clarence, composer, born in Canada, 1866, studied at the Conservatoir', Paris, under Theorore Dubois. He has published a number of pieces for pf., and is the composer of the operas, "Anne Hathaway"
LUNN.

and "The Money Spider," the last produced at the Matinée Theatre, Easter Monday, 1897.

Lucome, Emma, seesub. Reevris, J. sins.

Ludwig, William, bass vocalist, born in Dubliu. For many years associated with English opera companies. Touled with Carl Rosa's company in the spring of $1 \mathrm{r} / \mathrm{f}$; with the Blanche Cole company in 1879; and took the part of Fanderdecten in the "Flying Drutchman" in Mr. J. WV. Turner's complny in Bimingham. He was in America for some time from 1s86, joining the American Opera Company in New York, Chicago, ete. He has sung in concerts and operatic recitals at the Crystal l'alace and elsewhere; and in 1896 rejoined the Carl Rosa company, creating the part of Hums Sachs in "The Nleister. singers," at Manchester, April 16. Also appearing at the Garrick Theatre, London, Jallury, 1897.

Lukis, Rev. William C., author of "An Accomnt of Clumeh Bells," Londun, 1857.

Lumley, Benjamin, witer and operatic manager, was born in 181\%. He was lrought 11) to law, and becane solicitor in 18.32. Marager of Inury Lane Theatre, $1841-52$ and $1856-5 \%$. He died at London, March 17, 1875. Lumley produced a number of operas ly Tonizetti, Terdi, Costa, Haléry, etc., and ainung the singers who appeared under his management may be named Lind, Cruvelli, Tohanna Wagner, Piccolomini, Tietjens, (riuglini, Ronconi, etc. He wrote a work entitled, "Reminiscences of the Onera," Lond., 1sfit, with portrait.

Lunn, Charles, writer and teacler of singing, born at Bimingham, January 5, 1835. Brother of Rev. J. R. Lunn (q.r.). Studied in Italy nuder Cattaneo, Saugiowanni and Tizone, from 1860. In 1864-5, sang, with success, at Worcester, Cheltenham, r.te. In 1867, gave up public singing and devoted himself to voice training, settling in birmingham. The result of his work was shown in the concerts given for many years in the Town Hall and other places, when large nnmbers of pupils sang. He hegan about this time a series of articles in The Orehestra; and, in 1873, contributed to The Medical l'ress ame circular. His principal work, "The Philosophy of Voice," appeared in $1 \leqslant \pi t$, and reached its sth edition in 1896. Iı 1840, he published a sequel to it, "Tox ['opuli." He has frequently lectured on the voice, in Bimningham. London, ete., and published a number of pamplilets-lioots of Musical Art; Tocal Expression; Conservation and Restoration; The Artistic Voice; The Voice and its Training; The Ascent of Parnassus: or the Teaching of the Future, etc. In $1895 \mathrm{Mr}$. Lumn removed to London, where he continnes his teaching. He is a frequent contributer to the musical press. 


\section{LUNN.}

Lunn, Henry Charles, critic, pianist and composer, boln in London, in 1817. Sor of Joseph Lunn, Assistant-Commissary of the Field Train Department of the Ordnance. He entered the R.A.M. in 1835, remaining until 1\$13, studying under Mudie, IV. S. Bemett, and Cipriani Potter. Elected Associate, then Fellow. Was also professor, member of the Committee of Management, and lirector, retiring in 1887. From 1863 to 1887 he was editor of the Musical Times, to which he contributed many articles, besides notices of the provincial festivals. He married, December 28, 1848, Mliss Mary Anme Lincoln, younger sister of Henry J. Lincoln (q.v.). From 1887 he lived in retirement, and died, January 23, 1894.

Wonks.- A deseriptive essay on the patent Clavicattachment, invented by liobert Brooks, junior, showing its importance in facilitating performance on the violin, 1845; Musings of a musician, a series of popular sketches (appeared in the Musical Horld, 1845), London, Simpkin, Marshall \& Co., 1846, several editions; The elements of Music systematically explained, Jefferys, 1849. Compositions for orchestra; songs, and pf. pieces.

Lunn, Rev. John Robert, clergyman and composer, born at Cleeve Prior, Worcester, March 8, 1831. His father removing to Birmingham in 1834, the son began receiving instruction in organ playing from G. Hollins in 1835 , and piano lessons from W. H. Sharman in 1836 . He opened an organ at Cleeve Prior in 18.39, and generally displayed remarkable musical talent. Educated at King Edward VI. (Grammar School; was organist of Edgbaston Parish Church, 1846-7. Heard first performance of "Elijall," and that given in April, 1847, when he wrote down the music of "Cast thy burden" as it was being sung, and received a letter of commendation from Mendelssoln, perhaps the last he penned in England. Entered Cambridge University, 1819, gaining various scholarships. Graduated P.A. (fourth wrangler) 18.53; M.A., 1856. Ordained Deacon, 1855; Priest, 1856. Was Fellow, and Sadlerian Lecturer, St. Joln's College; Sometime President of the University IIusical Society, and frequently appearing as pianist at the concerts, introducing Schumann's Concerto, March, 1862, its first performance by an Englishman. Appointed vicar of Marton-cum-Grafton, Yorks, 1863. At the consecration of the new church, January 11, 1876, Schubert's Mass in $\mathrm{F}$ was performed, probably for the first time in an Anglican church (vide Joseph Short). Has given lectures on nusical subjects in several places, and also pianoforte recitals, doing much to make known the works of J. S. Bach.

Works.-Oratorio, St. Paulinus of York

\section{LYLE,}

(1892, MS.) ; Two Motets, for two choirs and organ; Motet, Heaven is my throne, eightpart chorus (MS.) ; Service in E, for Holy Eucharist, King's Chapel, Cambridge, November 1, 1861, published. Te Denm and Benedictus in $\mathrm{E}$, for two choirs and organ, Cambridge, 1862. Priest's part for Aylward's Responses; Hymm tunes. ete. Arrangements for pf., 4 hands and hamonium, of Bennett's Woman of Samaria, and other works; Organ arrangements, etc. Contributions to Smith's Dictionary of Christian Antiquity, Church Times, etc. Nemoir of Caleb Farnliam, Rector of Ufford, Surtees Suciety, 1880.

Lunn, William Arthur Brown, musician, anthor of "The Sequential System of Musical Notation," London, 184t. Five editions to 1871. This was published under the psendonym of Arthur Wallbridge. He died in London, April 4, 1879.

Lupo, Thomas, violinist and composer, who flourished in the reign of James I. He composed masques, anthems, madrigals, songs in contemporary collections, and contributed to Leighton's "Teares." His father, Thonds Lupo, was a member of crueen Elizabetlı's Band, 1579 , and was also a composer.

Lupton, Rev. James, composer and tenor voealist, was born in York, 1799, and died at London, December 21, 1873. Chorister, York Minster. Ordained, 1524: and in 1829 appointed minor canon of St. P'aul's, and of Westminster Abbey. He did much to improve the status of the vicars-ehoral. He composed church and secular vocal music.

Lyall, Charles, temor vocalist, was a menber of the Carl Rosa Opera Company, from 1875, for a nmmber of years, taking light comedy parts. He also sang in the Royal English Opera Comprony, 1843, etc. The is, perhaps, better lsnown as a caricaturist, and his cartoons in the Musical IVorld, Musical Hevald, and other papers, have afforded much ammsement.

Lyle, George Edwin, organist of Sherbome Abbey, is the composer of the cantatas, "Nina," Slierlrome, 1884; "Enoch," Sherbome Albey, Norember, 18st; and "St. Philip," Sherborne Abber, May 10, 1888. Also of a Festival Te Demin, for choris, organ, and military band, performed at the reopening of the Albey organ, November 9, 1887. He is conduetor of the Abley Choral Society, and the sherbome Philhamonic society.

Lyle, James, Derwarn Letr, temor vocalist, born at Arluoath, Forfarshire, in 1857. As a boy he cutered a lawyer's office at Blairgowrie, and leant the Tonic Sol-fa method from a Mr. Robertson. Gaining some reputation as a singer, he was, l,y the aid of $\mathrm{Mr}$. Patrick Allan Fraser, of Hospitalfield, enabled 


\section{LYON.}

to study in Milan, under Sangiovanni, Lamperti, and otlers. On his return to England he sang much in opera. He was the original Don dose in "Carmen," when Miss Emily" Soldene produced the work in 1879, in English. He also sang at Her Majesty's, and elsewhere, with the Carl Rosa Company, 1879-90. A few rears later he started, with his wife, recitals of "Scottish song and Story," which met with great success in the United Kingdom, Canada, and the United States. In 1896 he was on tour with his own opera company, and produced Dr". (ireig's opera, "Holyrood," at cilangow, in Oeterber of that year".

Lyon, Thomas, organist and composer, who was a relative of Bernard Gates. He was organist of St. George's Church, Ratcliffe Highway, London, for more than 50 years. Died at London, in Janniry, 18:37, from the first known epidenric of virulent influenza. He composed "Six eanzonets, and a glee for 4 voices," London 1795.

Samere Thoust Lrox, probally a relative of the alove, composed sonc piantoforte music, about 1s0-1815.

Lysons, Rev。 Daniel, clergyman and writer, was horn about 1760 ; died Jannary 3 , 1834. Anthor of "Hintsry of the urigin and progress of the meeting of the Three Choirs of Cloncenter, Worcester, and Hereford," Gloucester, 1s1\%. Ferond edition continued by John Amott [see that nume], London, n.d. [1s64; continued to 1894 by (. Lee Williams (q.r.), and H. (roodwin Chance, M.A., Gloncester, Chance and Bland, 1895.

Maas, Joseph, tenor vocalist, born at Dartford, Kent, January 30, 1847. Of Dutch descent, his father, Joseph Maas, died Norember 6,1888 , being also a singer. Chorister in Rochester Cathedral from 1656, studying under J. L. Hopkins and later under IIadame Bodda-Pyne. When his voice broke he became a clerk at Chatham dockyard. In 1869 he went to Milan, and studied under San. giovanni. Made his détut at St. James's Hall, February 9, 1871, at one of Henry Leslie's concerts; sang in "Babil and Bijou" at Covent Garden, September, 1872. He then went to America and joined the Kellogg Opera Company. Joined the Carl Rosa Company in 1878 , remaining with it some years, and appearing in a variety of parts. First saug in Italian Opera at Her Majesty's, May 15, 1980, in "Faust"; and took the part of Lohengrin at Covent Garden, June 7,1883 . In the concert room he speedily became popular; and was engaged at the Birminghan Festivals, 1879 (Messiah), to 18.5 ; Gloncester and Leeds, 1880, etc. His last pablic appe rance was at Nottin ham, December 31, 1885, and he died in London, January 16, 1886. He was buried at West Hampstead Cemetery. A monument
ICBURNEY.

over his grave was unveiled February 20, 1887; and a "Maas Memorial Prize" was instituted the same year, for the encouragement of tenor vocalists.

M'Allister, Robert, musician and teacher' of singing, was born in Cilasgow, February, 1822. Author of "The Art of Singing at Sight Simplified," 1844; "The Art of Singing at Sight; or, a Complete Theoretical and Practical rocal Music Instruction Book," etc. Glasgow, 1848. "Easy Introduction to the Key Board of the Pianoforte or Harmonium." Iuventor of the Tonic Sliding Scale or Musical Ladder; Initial Note Notation ; Stave Sol-fa Notation, ete.

Macbeth, Allan, composer, pianist, and conductur, born at Greenock, March 13, 1856. Son of Norman Nacbeth, A.R.S.A. Educated in Germany. Studied music first under Robert Davidson, and Otto Schweitzer, Edinburgh; and later, at Leipzig Conservatorium, under E. F. Richter, Reinecke, and Jadassohn, 1875-6. Has held organ appointments at Albany Street Congregational C'lapel, Edinburgh, 1871; Woodside Established Church, 1882 ; and St. George's in the Fields, Glasgow, 1884. He was choimaster of the Glasgow Choral Lnion, 1880- 7 ; conductor of the Greenock Select Choir, 18s1; and the (ilasyow Kyrle Choir 18st. On the establinhment of a school of music at the Crlasgow Atheneum in 1890 , he was appointed Principal, an office he retains.

Works.-Operetta, The Duke's Doctor (MS.); Cantata, The Land of (ilory (Prize, Glasgow soeiety of MLusicians), produced Glasgow, May, 1890; Silver Bells, cantata; Jubilee Chorus, Glasgow Acadeny Choir, 1896. Three four-part songs, op. 26; The Steerman's song; Near thee, still near thee; Queen Dagmar's Crons; The Waif; My heart, its sorrows; and other songs. Arrangements of Scotch songs for four vulees, ete. In memoriam for orchestra; Forget me not, Gavotte, orchestra, Glasgow ('horal Lnion, 1883; Intermezzo, strings; Serenata; Danse Pizzicati; Ballet de la Cour, orchestra. Trios, pf. and strings; Suite, 'cello, and pf. Barcarolle, op. 25; Berceuse; Scherzino, and other pieces for pf. Overture and incidental music to a drama, not yet produced.

Macburney, Charles, se Bunet, Chas.

McBurney, $\mathcal{S}$., teacher of Tonie Sol-fa, was born at Glasgow. Son of the late Isaac IIcliurney, LL.D. Studier] at Glasgow Universitr, 1S64-6; opened a sehool at Bathgate, near Edinburgh; but, in 1870, for his health's sake, went to Australia, where he has made his home. For some years held rarious positions in schools; but, having stunled Tonic Sol-fa in his yonth with Juhn Melellau, he began to devote himself more to music. He spent sone months in Germany, and attended the summer session of the Tonic Sol-fa Col- 


\section{II $\backslash \mathrm{C}$ ABE.}

lege, London After his return to Australia lie foundect the Victorian Tonie Sol-fa Associrtion, and was its first president. In 1890 le graduate? Mus. Bace and Mins. Doe., Dubhu. He luhls the affice of Inspector of Musie to the IIellumme Wducational Department. He has comluresed l's. 103 for soprano solo, d ulitechorus, and orehestra; sehool eantatas, Christmas (iretung; Victoria; Children's Festival: Ode for Mtelbourne Sunday Sehool Union ete.

Maccabe, Frederick, tenor vocalist, ventriloquist and enterlainer, who has travelled all uver lirst 111 and the colonies with a monologne entertaimout, partly musieal, partly ventriloguial. He atso sang in eomic opera, and appeared on the stage. About 1860, his entertaimmut entitled "Begone dull eare," was produced at Inulin, London, and other towns. Ite lis composed the following songs -Cease thy rewing, Fluttering on the line, Lady rise, Oh-t, at man, Oh happy days of youth, latiant wals, Sailing of the ship, Whispering of lope, ete. Also author of "Art of V'sutriluruism, ineluding direetions to learners," I om lon, 1875. "Voiee produetion," Nolverhan1ptor, 1893.

MacCalla, James, ('omposer and teacher, was boln alumt the end of last century. He was a mnsician $n$ london, and a member of the Royal Sicuty of MI usieians. Died London, April 3, 1847. He eomposed "Life, a cantati," 1sto; Somss, pf. musie, ete., and edited "The Chun and Congresational Part Bonk. . ,' Lunion, [S44!.

MacCann, J. H., concertina player, in business as a conertina maker, at Plymouth. Has appeared at nany concerts in the lueality. Authol of "New method of instruetions for the new Chromatr. Inet English Coucertina

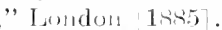

MacCunn, Mamish, composer, born at Gretnock, March 22, 1868. Som of James MacCum, shipurner, of Greenoek. Commenced the study of musie at an early age, and on the openung of the R.C.MI, in 1883, won a Scholarship for composition. His principal teacher was Inr. Hulsert Parry. The scholarship he rosigned in 1886. He beeane known as a composer the next year, throagh the instrumentality of Mr. Angust Manns, and in 1sist, received a commission to eompost a cantata for the (ilasgow Choral Union. In May, 1his. he gave a series of Orehestral Concerts in the studio of Mr. John Pettie, R.A., whose dausluter he married in June, 1889. He was alyrinted a Professor of Harmony at the R.A.M., in 1888, a post he held until 1894 In $1 \mathrm{k} / 2$, he was conductor of the Hampstead Conservatoire Orchestral Society. He has couducted performanees of his compositions in different plaees.

Works-Oprias: Jeanie Deans (Jos. Ben-

\section{MACDONALD.}

nett), produeed, Carl Rosa Company, Edinburgh, November 15, 1894; and Diarmid and Ghriné (Marquis of Lorne), composed 1 s96. (antatas, ete.: Bonny Kilneny, op. 2, 1888; Lord Ullin's T)arghter, op. 4, Crystal Palace, February 18, 1568; The Lay of the Last Mins. trel, Glasgow Choral Cnion, Deeember 18, 1888 ; The Cameronian's Dream, op. 10, Edinburgh, January 27, 1890 ; Psalm 8, composed for opening of Fdiuburgh Exhibition, May 1, 1890; Queen Hyude of Caledon, Glasgow, January 28, 1892; The deatl of Parry Reed, men's ehorus and orchestra. Orchestral: Overture, Cior Mhror, Greenoek, January 22,1887 ; Concert overture, Land of the mountain and the flood, Crystal Palace, November 5, 18x7; Orelrestral hallad, The S'luip 0 ' the fiend, Henschel Concerts, February 21, 1888; Ballad overtıre, The Dowie Dens o' Yarrow, Crystal Palace, Oetober 13, 1488; Highland menories, 3 pieces. Songs: To Julia, weeping; Pour forth the wine; Ave Maria (The Lady of the lake): Six love lyries; Six sougs (Lady Lindsay): Six songs (Robert Bridge); Album of seven songs (George Iacdonald); Part-songs, ete. I'ieces for 'eello and pf. Set of six Seotcly dances for pf., etc.

Macdonald, Alexander, musician of last half of 18 th and early part of present centu. ries. He was joint music-master of Heriot's ILospital, Fdinburgh, 1807-10, with Arehibald Macdonald, his father, or other relative; and held the post of preecntor of Old Greyfriar's Church, Edinburgh, from 1804 to 1 sit. He compiled "A new eollection of Vocal MIusie, containing Chureh tuues, anthems, and songs for the use of the several hospitals of this city," Edinburgh, 1-07. He is also, in all probability, the author of "The Notation of Insie simplified, or the development of a system in whieh the cliaracter's employed in the notation of langruage are applied to the notation of music," (ilasgow, 1826 .

Macdonald, Donald, musieian, who flourished at the end of last and beginning of the present century. Compiler of a " Collection of the ancient martial music of Caledonia, ealled Iobaireachd, as performed on the great Highlaud bagpipe, adapted to the pianoforte and violoneello, with some old Highland lilts, ete," Edinburgh. n.d. This work ineludes a tutor for the bagpipe. A eollection of Maedonald's quicksteps, stratlispeys, reels, and jigs was issued by Messrs. J. \& R. Glen, of Ediuburgh.

Macdonald, John Denis, M.D. and F.R.S. Held various public appointments, and was inspeetor-gencral of hospitals and fleets, 1880-6. Author of "Sound and colour, their relations, annlogies and hamonies," London, 1869. “Naval Hygiene," 1881, ete.

Macdonald, Lieutenant $=$ Col. John, musician and writer, born in 1759. Son of 


\section{MACDONALD.}

Flora Macdonald, the Scottish heroine, and Maedonald of Kingsburgh, skye. He entered the service of the East India Company, and held various other military and seicutifie appointments. Fellow of Royal Society in 1800. He died at Exeter, Angust 16, 1831. He published a number of works' on military taeties, telegraphy, and a "Treatise explanatory of the principles constituting the Practice and Theory of the Violoneello," 1s11. Also a "Treatise on the Harmonie Srstem, arising from the Vibrations of the aliquot division of strings," 1822.

Macdonald, Joseph, musician, horn Strathnaver, February 26, 1739; died in India, 1762. Anthor of " $\mathrm{A}$ Collection of Pagpipe Musie," Edinburgh, 1803. He assisted his brother Patrick in the compilation of his collection. His "Treatise on the theory of the Seots Highland hagpipe "is pullished in the collection of 1803 , which was edited by Patrick-see below.

Macdonald, Keith Norman, anateur musician and violinist, Was born in skre, Norember 23, 1834. He is a doctor loy profession. Editor of "The skye Collection of the best Reels, Strathopeys, ete, arranged for the violin and pianoforte," 1887 ; '2 editions in the same rear.

McDonald, Malcolm, emposer and violoncello player, who lived in the latter part of the 1Sth century. He resided at Inver, in Domkeld Parish, and played the violoncello in Niel Gow's band. He is said to have died at Inver. He published "A collection of Strathopey reels, with a lasis for the violoncello or harpsichord," Edinlurgh, 1788. He also issued three other collections of the same kind; 1789,1792 , ete.

Macdonald, Patrick, miscian and elergyman, was horn at Dumess in Strathuaver, April 22, 1729. He was educated at therdeen University, and licensed as minister in 1756. Presented to the living of Kilmore, in Argveshire, 1756. He died at Kilmore, September 25, 1824 . With the assistance of Joseph Macdonald, his brother, he compiled "A Colleetion of Highland Tocal Airs, never hitherto published, to which are added a few of the most lively Country Dances, or Reels, of the North Highlands and Western Isles; and some specimens of Bagpipe Musie," Edinburgh, 178 .

Macdonald, Robert Houston, organist. Educated at P.A.M. Won Henry smart Seholarship, 1890. In 1893 he was appointed organist and choirmaster, Presbyterian Chureh, Kimberley, S. Africa; and in 1895, Borough organist, Durban, Natal.

Mace, Thomas, writer and musician, born in 1619. Clerk of Trinity College, Cambridge. Married, 1636. He died in 1709, aged 90 .

\section{MACFARLANE.}

Works.-Musiek's Monument; or, a Remembrancer of the Best Practical Musick, both Divine and Civil, that has ever been known to have been in the World. Divided into Three Parts. The First Part shows a necessity of Singing I'salms well in Parochial Churehes, or not to sing at all. . . The Second Part treats of the Noble Lute (the Best of Instruments). In the Third Part, the generous Tiol in its Rightest use, is treated upon. Lond., 1676 [portrait]. Nace invented a Dyphone or Double Lute of 50 strings, and a table-organ.

M'Fadyen, John, musician and publisher in Wilson Street, Glasgow, in succession to Aird, in early part of the present century. He died at Glangow, March 8, 1837. Published collections entitled, The Repository of Seots and Irish Airs, Strathspeys, Reels, etc., Glasgow, n.d.; Miscellaneous Collection of the best English and Irish Songs, Glasgow, n.d.; Selection of Scotch, English, Irish, and Foreign Airs, alapted for the Fife, Violin, or German Flute, 6 vols. Dedieated to the Volunteers and defensive bands of Great Britain and Ireland (c., 1800); Collection of Highland Strathepey Reels. . Glas., n.d., ete. He kept a music eirculating library in Glasgow.

His son, Joskl'h TaYLoR M'Fadyex (1807 -Dec. 25, 1856) was also a publisher in Glasgow, and another son, JaMes (c. 18051850), a distinguished botanist, poet and musieian, was eurator of the Botanical Gardens, Kingston, Jamaica, and died there during the cholera epidemic of 1850 .

Macfarlane, George, hand-master and writer, was a member of the Duke of Deronshire's private band. Author of "Cornopecen Instructor, containing the elementary Principles of Musie, together with Exereises, Preludes, Airs, and Duetts in every key in which the Instrument is playable with effect," Lond., u.d.; Two Fintasias for eornet and pf. [1860]; Waltzes and other dance musie.

Macfarlane, John Reid, Scottish composer, was born in 1800 . Precentor in the Outer High Church, Glasgow, 1824-28. Afterwards settled in London as a teacher. $\mathrm{He}$ died in the Middlesex Hospital, London, June 10, 1841. Composed a number of glees, psalm tunes, ete. Erother of Thomas Maefarlane noted below. He edited "Harmonia Sacra, a Selection of Sacred Musie, Ancient and Modern, in four parts," Glasgow, n.d. [1835].

Macfarlane, Thomas, organist and composer, born at IIor'sham, sussex, about November, 1808. Son of Duncan Macfarlane, a fine bass singer, who played the French hom in the Ayrshire Militia. Pupil of Andrew Thomson, music-teacher, Glasgow, and afterwards under J. B. Cramer, Herz, Bergotti, 


\section{MACFARREN}

and M. Gareia. Organist of the Old Episcopal Chapel, Crlasgow, 1827, where he remained five or six years; of st. Mary's Episeopal Church till 1834; and of sit. Jude's Hpiscopal Church till about 1857. Precentor of Park Church, 1859-1866. He was conductor of the Glasgow Amateur Mlusical Soeiety, and it was muder him the first performance of Handel's "Messiah" Was given in (ilangow, on April 2, 184t. He removed to London about 1869-70, and was larmonimmist in Canden Road Preslytedian ('hurch, 1871-1882; and conductor of the Canden Road Choral Society for a tine. He retired from all professional worli in 18s:. He compiled Congregational Psahmody of Sit. Jude's Church, Cilasgow, n.d.; Selection of Sacred Mnsic, containing a selection of Psaln and Hymn Tumes, Channts, Te Deums, etc.; l'ark ('hurch Psabnody, Glasgow, 1860; The Clomale and Supplenentary Psalmodr, a Selection of Ancient German and other Chorales.. (ilasgow, n.d.; The Seripture Clhant Book.. Gilasgow, n.d. Songs in "Lyrie ( rems of chostland," tete

Macfarren, Sir George Alexander, composer, author, and professor, Jom in London, Nanch 2, 1s13. He studied under his father, (rovege Macfarmen (1788-1843), the dramatist, and under (harles Lneas in 1827, and Cipriani l'otter at the R.A.Nl., 1829. In 18.34 he lecante a professor at the R.A.M., and on Malch 16, 1875, was apprinted J'rofessor of 11 usic at Cambride Iniversity. He was Mus. Bace and lux. Mrs., Cantali., in April, 1876. He leecame lrincipal of R.A.M. in 1876 , and was knjglited in 1849. He died is London, ()etoluer 31, 1sist. For many years he was hlind.

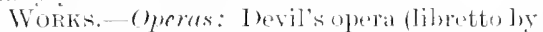
Geo. Macfatren), English opera Homse, Lom-

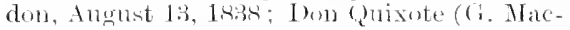

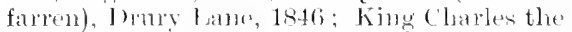
Second (I). Rivan), Princess' Theatre, () (cotoles

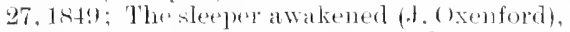
H.M. Theatere, 1850; Rohin Hood (J. ()xerlford, H.Ml. Theatre, 1sion; Jessy I tea (J. Oxtellford), Crallery of lllustration, 1869 ; She stomes

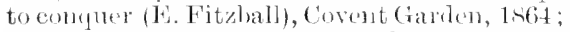
Soldier's Legacy (J. Oxenford), rallery of Illustration, 1stit; Helvellyn (J. (xenford),

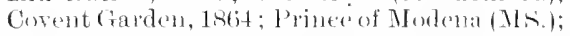
Caractarus (MS.); LI Malhechor (NL), Allası of Aherfeldy (Mn.). Masques: Fonhlematical trilute, on Her Ma jesty's marriago of. Mac-

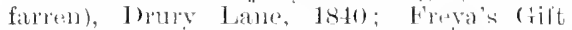
(J. (Xxenford), on mantiage of the Prince of IVales, Covent Garden, lisio. Farces and Metedramas: Mis. G., ()ueen's Theatre, 1s:31; Majd of switzerland, (green's Theatre, 18.32; Generiese, 18:34; I and my Imolble, 18:35; ()]d onk trees, 18,35 (Finglish opera Hotloc); If the cap fit ye, wear it, 18.36 ; Immeret sims, 1436; Love anmong the roses, 1839; Agnes

\section{MACFARREN.}

Bernduer, 1839. Oratorios: Nit. Joln the Baptist, Bristol Festival, Octolser 23, 1873; Resurrection, Bimingham Festival, 1876; Joseph, Leeds Festival, 1877; King ravid, Lexds Festival, 1883. Cantatas: Lenora (Bürger-Oxenford), Harmonic Unjom, 1853; May Day (Oxenford), Bradford Festival, 1856; Cloristmas (Oxenford), fundon, 1860; Songs in a cornfield (C'hristina lossetti), 3868 ; Outward Bound (Oxenford), Norwich Festival, 187\%; Lady of the Laki (scott adapted), Glasgow Fentival, November 15, 1877; St. George's Te I beunn, Crystal Palace, 1884. Church Music: Choral Siervice in $\mathrm{E}$ Hat; Unison Service in G; Fiftr-two lutroits or short antliems for holy days and seasons of the church; Two-part anthems for female and nale voices, and for female voices alone; Numerons single anthems; H lomms in Anglican Hymu frook, ete. ; Chants, ete. Secular Toral Music: Six convivial glees for 3 boices; Fiftren shakipere song for + voices (1860-64); Three fonm-part somgs for male voices; Six four-part songe (by Chas. Kingsley) ; Six fourpart songs (hy Herricls); Three madrigals; Nomerons detached fompopt somgs, trios, duets, etc. Songs and ballads: Fomr somgs from Jane's "Arabian Nights" ; 'Two songs with clarionet accomp.; 'Three somgs with

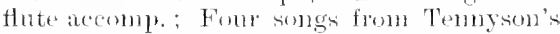
"Idylls"; Three songs from Heine; Six songe from lewis Morris" "Gwen" ; Numerous detached songs. Symplemirs: No. 1 in C

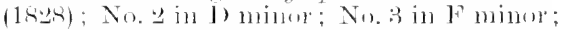
No. 4 in A minor (1834): No 5 in Bthat; No. 6 in ('sharle minor'; No. 7 in 1); No. 8

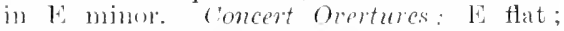
Nerchant of Veriee: Romeo and Juliet; (hery Chase (18:30); I)on Citrlos; Hamlet; Festival; Irlyll in memory of sir Stemdale Benuett; Concerto for pf. and orehestre, in C'minur; ('omerto for thate ame orehestra, in $1 ;$; Concerter for violin and onelestra, in $\mathrm{F}$ minor. Concerted Husic, Instrumental:

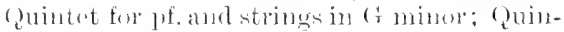
tet for oneretina and strings in A; six Quatets for strings in G miner, C, A, F, G minor and (; : Tris for pe, vinlin, and rello, in E; Trio for pf., flute, and ecelle, in A; Somatas lor violin and pf. in A and C; Śnata for Hute and pll. in li flat. Orgem: Somata in C. Pianoforte: Sindatais in $\mathrm{E}$ Hat, A, ('minor, 1), J mimor, B Hat, lit, and ('minor, ste. Tiolin: Five romances for violin and pif., ete. Literary and Theorstical Horks: Little Clarina's l ésson Pook, 145.3-5.5; Rudi-

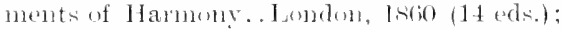
Six I ectures on Hammony. Londone, 1867, Srd ex., 1,80; On the Sitructure of a Sonata, bonden, 1st1; lighty mmsical semtences to illustrate cluomatie chords, Jorden, 1875; Comberpoint, a practical course of study, London, 1s79; Musical history lorefly narrated 


\section{MACFARREN.}

and technieally discussed, London, Ins5 (from the "Eneyclopaedia Britamica," 9th ed.); Analyses of orat rios, ete., for concert programs; Addresses and lectures at li.A.A. ; Musical l,iographies in "Imperial I)ictionary of Biography"; Grove's " l)ictionary of Iusie," etc. Collections, or Edited Works Old English Ditties, 2 rols. : Sings of Eugland (Chappell); Old Scottinh Ditties; Moore's Irish Melodies; British Vocal Allomm; Editions of Purcell's "I Dido and Eneas," Handel's "Belshazzar," "Judas IIacenbens," "Jephtha," and "Messiah." soe "reor"ge A. Matarten, his life, works, and inthence," by H. C. Banister, London, 1891.

Macfarren, Natalia, born ANDLEAE, rocalist and teacher, wife of the foregoing, was brom at Lüheck. Shle has translated a number of opera lihretti, and written a Vocal Schuol, and an "Elementar'y Conrse of Vocal. ising and Pronouneing the Einglish Langinge," London, n.d.

Macfarren, Mrs. John, born Exma Marte Bensett, pianint, compuner, and lecturer, born in London, Jume 19, 1set. Regan her musical studies at an early age her teachers being IV. II, Kenrms, and later, Madame Dulcken. Compmitim sles stodied under (sir) G. A. Macfarters. In 184 s she marred Mr. John Mataren, a lnother of Sir (remge, and the conplo went to Nex York, remaining in the United sitates threes vears. Her talent was duly recognised there, but home atsociations drew her hatek to londom. She gare her first concert at the New Peethoven Rowns, April 12, [851, playing in IV. H. Holmes's quartet for forr pianists "I ${ }^{+}$. R Rmance de Lenx Minntes," with the compors, Arahella frrddard, and William Dorrell. Cipriani Potter and sterndale Bemet also played at this coneert - a remarkables gathering of pianist.s. Musical nuatineses were then given anmully, and also enencerts in the saburls, up to the year 1849. In 1860 Mrs. Mucfarren filst appeared an a lecturer at St. Jam s's Hall. These lectures were virtually pinoforte recitals, with romalks on the works performed, written axpersely for her by $\mathrm{G}, \mathrm{A}$. Macfarren. They were wathed over many yedrs, and also given in the provinces. Under the nom-de-plume ol JuLes Brissic she produced a great mumber of pf. pieces, amongst the most popular leing "Bumie Scotland," and a "Valse de Bravoure." From 1s83 her time was deroted exclnsively to teaching and writing, and she died in London, after a lirief but painful illnesis, on Novemlier 9, 1895.

Macfarren, Walter Cecil, pianist and composer, brother of sir (tenger, was bom in Londom, Angust 2s, 1826. ('horister at Westminster Abley, 1836-4I, muder Jame's Turle; and pupil of R.A.MI., 1rt2-e, sturlying piano-

\section{MCGIBBON.}

forte under W. H. Hohnes, and composition monder his lrother, and Cipriani Potter. During lois student days he played a duet with W. H. Holmes at one of H. J. Banister's quartet eoncerti, Miarch 30, 1844; and on the 26th of April following was introduced as a composer by a Pf. trio, at the G. A. Macfarten and Davidson concerts. In 1845 other works were produced ly the soeiety of British Musicians. In 1si6, he was appointed a professor at the R.A.M., aud his 50th year in that office was marked, in 1896, by a presentation from past and present pupils. He e monded the Acadeny concerts, 1873-80. F.R.A.11. For many rears he was comnected with the Philharmonic sweiety as disector and treasurer, having been elected an Associate in 1849 . He gave a series of orehestral con. certs in 1842, conducting the whole from memory. His pianoforte recitals and lectures have been numerous, and have been given in London, Bristol, and other platees: and many of his pupils have attaned high positions.

Works. - Srmplony in Is flat, composed, 1879, prodned, brighton Festival, 18so. Orevtures: A Irintere's Tale (184t): 'Taming of the shrew (1545): Beplo (1-45): I'astoral (187s); Hero and Lemoler, componed, 18TR, produced, lirishtom Pentival, 1879, C'rystal Palace and I'hithammic, 18so; Henry V., Norwich Fentival, 1881; Othello, compused, 1895, perfomed, Queen's Hall, Febuary 16, and at Bristol Festival, (Oetober 1t, 1s!ge. Concertstück in E, pf and we hestra, lirightom Festival, 18s1. Throe trios, pf., violin and cello; Two sonatas, pf, and violin; sonata, pf. and "cello; fonl lommances, pr. and volin. Piunoforte: 24 studies in strle and Tech. nique: 40 P'reludes, in all kers, as studies in the art of Improrisation: two sets, 12 studies. Comprehensive Scale and Arpengio mamal, Asludown; I'f. Method, R. Corlis. Three Suiter de P'ieces, in D mimor, F, tlat, and C. Alegro appassiontero; Toceata in (' minor; and an immense mulber of piexes at Tarantellas. Mazurkas, Talses, Nouturmes, Impromptus, etc. local: Countata for female soices, The Somm of the sumbeam. Moming and Evening sorvice in A; Eventing service in C; anthem, Praine ye the Lord; Tumes in Hymms Ancient and Mendern, and other Collections. Darberals: An emigrant's somg; Antumn; Yon stole ny lose; bells across the sea; Who is srlvia?: and other part. songs. Six sacred songs; A widow hird nat mourning; Awake, (O hemet: Als! swet, thon little knowest: and other songs. Editor of Mozart's P'f. Works: becthosen's smatas; Popular Clasics; Morceanx Clasmiques, ete.

McGibbon, William, violinist and composer, was born alvont the leegiming of the 18th century. Sim of Natthew McGibbon, obre player, who performed at the st. Cecilia 


\section{MCGFLL.}

concert, Edinburgh, in 1695 . He studied the violin muder Corbet, of Fondon. Leader of Gentlemen's Concerts at Edinburgh, and teacher there. Ife died at Edinburgh, October $3,1756$.

Works.--Six Sonatos or solos for a German Flute or Violin, Edinhurgh, 1740; A Collection of Scots Tmes, some with variations for a violin, laautbois, or German flute, with a bass for a violoncello or harpsichord-Book 1 , 1742; Book 2, 1746; Book 3, 1755. Original dances, and some flute music.

McGill, John, composer, born in Ayrshire, in 1707. He was an associate of John Riddell, of Ayr, but is supposed to have been an itinerant musician in some of the towns of Ayrshire. He composed the tune now associated with the song called "Come under my plaidie,"

M'Glashan, Alexander, violinjst, who flourished in Edinburgh about the end of last century. He was the leader of a fathionable band, in Edinlsurgh, and gave concrerts. He was nicknomed" "King Xl'Glashian," on aceount of his fine personal appearance. He died at Edinburgh, in May, 1797. He pmblished "A Collection of Strathopey Reels, with a bass for the violoncello or harpichord," 1778 ; A Collection of Sicots Neasures, Hormpipes, Jigs, Allemands, Cotillons, and the fashionable Country [nances, with the bass for the violoncello or larpsichord, Fdinburgh [1778].

MacGlashan, John, a teacher of the piano, and collector, who flourished in Edinburgh, about $17919-1 \mathrm{~s} 12$, was probally a relative of the above. He published "A Collection of Stratheper Reels for the pianoforte, violin, or German flute," Edinhorgh, 1795.

M'Guckin, Barton, tenor wealist, born at Dullin, July 29.1853 . At the age of ten he becane a cheir boy at Armagh Cathedral, and Rolecet Turle tanght him singing, pianoforte, and organ. In 1s71, he gained the post of first tenor at St. Patrick's Cathedral, Dublin, and also at Trinty college. He then studied under Toseph Rolinson. After singing at coneest in Dublin, and at the Crystal Palace, 1874-5, he went to Milan, and studied under Tresulsi. On bis return he sang at the Crystal P'alate, October 28, 1876; and at the Anciunt Concert Room, Dublin, November 28. Then followed engagements in many places. His Festival work dates from 18r9, at Hereford; lae sang at liristol Festival the same rear: Norwich, 1881; Lecds, 1846, tete. Ife madr his début in opera, at the Theatre Roval, september 10, 1880 , as Thaddeus, in Balfe's "The Bohemian Girl," and since that time up to 1896 , as a member of the Carl Rosa Company, bas appeared in a variety of parts. He also sang in opera in New York,

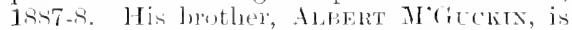
a baritone singer, and has been heard in opera and concerts. He married, in 1s92, Miss

\section{MACFNTYRE.}

Lucille Saund ass, an American mezzo-soprano; and in 1893, with his wife, went to America.

Machardy, James M. P., musician and teicher, is a native of Edinburgh. Brother of the undernoted. Author of "The Rudiments of Music, as it ought to be studied, rocal and instrumental," n.d.

Machardy, Robert, composer and teacher, born at Edinlurgh, September 10, 1848. Has composed "The Woodland Witch," a dramatic cantata; "Hymu of the Scasons," cantatina; some songs and pf. pieces; and edited for some time The Scottish Musical Times, now defunct. Author of "Progressive Pianoforte Playing," n.d.; "Progrensive SightSinging." n.d."

Machin, William, bass singer, born at Birminglam in 1798. He was a chorister in Lichfield Cathedral, and on the recommendation of Sir Robert Peel was appointed to the Chapel Rural, Lonton; and he afterwards sang at the Temple Church and St. Paul's Cathedral. He sang at the Birningham Fontivals from 1834 to 1849 . Died at Handsworth, in September, 1870.

Machray, Alexander, amatem musician, born at therdeen, June $7,18: 37$. He studied musie under Fichard Latter and IV. R. Broomfield. From 1855 to 1876 he was leader of pralmody in the East Church, Aherdeen, and was Secletary of the Aberdeen Choral Lnion, ete. He is an adrocate in Aberdeen. Compiler of "The Scottinls 1'samist, a manual of standard and choice psalm and hymm tumes for christian worship," Alerdeen, 1876

McIntyre, Duncan, mnsician and daneing master, born alwent 1765. He was a teacher of dancing in London in latter part of last century. $H_{c}$ died at London or Calentta abrut 1806-7. Compiled a "Colleetion of slow airs, Reels, and strathepers, ete.," London, 1795. Ho lived at 22, Great Mar. boroligh Street, London, as a teacher of Scoteh dancing. According to Mr. John Glen this Mecintyre went to Inelia, probably as master of ceremmies to the Gorernor-General's court at Calcutta.

Macintyre, Margaret, soprano vocalist, of Scottish descent, born in Indial. Danghter of General John Mackenzie Macintyre, R.A. Studied as an anatem at the Brightom lnanch of the Frondon Academy of Musie, and occasionally sang at the Academy concerts, notably when Liszt attended the performance of his oratorio, "St. Flizalueth," by the students, at St. James's Hall, April 7, 1886. She studied under Mannel Galrcial, and Madame Della Fille, and declamation with Miss Carlotta Leclerer. She made lier dibut at Covent Farden, May 14, 1888, as Micupla in "Carmen," and has since sung in a variety of parts there. She apleared with success at Milan, 1893; 


\section{MACIRONE.}

toured in Sonth Africa; and was engaged for the grand opera, St. Petersburg, 1896-7. Her first important concert appearance was at Edinburgh, December, 1888, since when she has been heard at all the chief concerts. She sang at the Leeds Festival, 18s9; Birmingham, 1891, in "Elijah"; at the Handel Festival, 1891, ete., and is recognised as an artist of high attainments.

Macirone, Clara Angela, compostel, pianist, and teacher, bom in London, in 1821 . Descended from an ancient and noble Roman family. Her grandfather, who settled in England, served in the American war of Independence. Her father was a skilled amateur tenor singer, and her mother a cultivated pianist, pupil of Charles Neate. Her musical talent developed early with such home surroundings, and her sister (who died in 1888 ) became a water-colom painter of note. Miss Macirome entered the R.A.MI. in 1839, studying under Cipriani Potter, WT. H. Holnes, Charles Lucas, and othel's. On leaving, in 1842, she received a testimonial from the committee, a circumstance quite unique. She was made a professur of the pf. there, and elected an Asisociate of the Philhamonic Soeietr, and F.R.A.M. Her first euncert was given in the Hanwer Square Rooms, June 26 , 18t6, when Pisches sang a lenedictus of her composition. Thin work, later, received praise from Mtendelsinoln. The conterts were continned until 186t, and then her chief work was in teaching and composing. She was head music mistress at Aske's School for Girls, Hateham, 1872-s; and at the Church of England High Sehunl for (rirls, Baker Street, Londun, she sristematiod the music teaching with the best results. The last few years liave heen passed in compralative retirement. In addition to compusition, she has contributed many articlen to the Girls Own Paper, the Argosy, and other periedicals.

Works.-Te fenm and Jubilate, sung at Hanover Chapel, the first service by a woman ever used in th" (hurth; Anthem, By the waters of Babylom, sung at Canterbury, Ely, and other cathedrals, ete. Silered songs, and duets. Songs: Cavalier"s nong; Henri de Lagardere; Mr child; Golden grain; Dreams; The Recall; Hesperus; Oh, hush thee my babie; Sweet and Low; The Balaclaracharge: There is ders for the fiow'ret; Montrone's Love Song, and many others. Lurt-songs: The Battle of the Baltic; Sir Jinight fsung at the composer's concert by four artists of repute, May 20, I862); Autolyeus' song; Jog on, jog on the fuotpath way; The Aron to the Sevem runs; Old Daddy Longlegs (in the programme of the Tonje sol-fa Festival, Exeter Hall, XIar [5, 1852, but the words were objectud to br the authoritien of the Hall, and another pieee had to be substituted);

\section{IACKFNZIE.}

Humptie Dumptie; Fohoes; When summer's come at last; A Chrintmas welcome; etc. Children's songs: I had a little castle; Little Boy Blue; Little grey pussy cat. Suite de pieces in E minor, riulin and pf, s Summer serenade; Cantilena; Nacht Reise Lied; Rondino in $G$, and other pieces for $p^{f}$. Several works in Ms.

Mackay, Alexander, riolinist and musician, was a native of Islay. He issued a "Collection of Reels, Stratlimpers, and slow tures," Glasgow, 11.cl. [1-05j.

Mackay, Angus, Scottinh collector, and piper, born about 1813. He was piper to Queen Victoria. Accidentally denteded in the river Nith, neal Dumfries, Narch 221, 1859. Compiler of "A Collection of Ancient P'iobaireachd, or Fighland Pipe Muric... To which are prefixed some sketches of the principal hereditary pipers and their establishnents," Edinlumgh, 1s:3, "The Piper's Assistant, a collection of marches, quicksteps, strathspeys, reels and jign. ." Edinburgh, 1t.d.

McKay, Iver, tenor vocalint, boln in Dublin. At the age of six he was a chorister at the Chapel Royal, Duislin C'astle, and in the chapel of Inblin Enirersity ; and also sang teror at St. l'atrick's Cathedral. After some vears spent in commercial pursuits, he went to Italy. Not gaining in-truction suitable for an English carecer, he returned to Lomdon, and placed himstelf mader T. A. Wallworth, and W. Shalespeare, to whose training he attributes much of him suceens. He hals been heard at the principal lumdon and provineial concerts; silng at the Lexed Festirals of 1856, and 1sis!); created the tenor part in Drorals's Requiem, at the Birminuham Fentivat, 1891, cote. [11 operat he atpleared ats Lenshi, in Tsehaïkm-ky"' " Engene Onugin," at the Ner Olvmpic, (letoler, 1syz. lle has toured with Mr. Sims Reeren (18st), and has gained an honomable ponition annong singers of the day.

Mackay, William, muician, published "The complete Tutor for the great llighland bagpipe," Halinbugh, IRto.

Mackenzie, John, reottish musician, born at Durban, in 1797. Son of a nuember of the Forfarshire nolitia hand. He was a violinist and teacher in therdeen, and header in the Theatre Royal there. At the request of James Dewar he removed to Edinburgh in IS31. He died at Elinburgh, Octuber 25, 1852.

His son, Alexanuen MICKExzit, was a violinist and composer, bor'n at Nontrose, in 1819. In 1831 he aceompanied his father to Edinburgh, and becantse a violinint in the Theatre Roval, under Dewar. Heafterwards studied under sainton, at Londons, and at Dresden, muder Lipinsli. He was leader of the orchestra of the Theatre Royal, Edin- 


\section{MACKENZIE.}

burgh, under the snccessive management of Murrav, (tlover and Wrndham. He died at Edinburgh, Oetober 2, 1857. He edited "National Dance Mnusie of Scotland," Edinburgh, n.d.; new edition, with additions, by A. C. Mackenzic, London, 1889, 3 books. "Six Scoter Airs for Violin." "One humdred Seoteh Airs for Violin." Songs: Grey hill plaid; Nameless lassie; Linton Lowrie, ete.

Mackenzie, Sir Alexander Campbell, Kt., son uf Alexander Nackenzie, composere, violinist, and conductor, lorn at Edinburgh, August 22, 18t7. Studied under his father, and at the age of ten was sent to (iermany, whore he stndied at Schwarzburg-Sondershansen, under W. Chlyich, violin, and Erluard Stein, enmpusition. In 1861 he was a nember of the Dincal orchestra. The next year he went to Lmdon, and entered the R.A.M. gaining the King's Seholarship that year. 1463. Ho studind under Sainton, Jevson, and Charles Lucas. L11 1865 he returued to Edinbmrgh, and was engaged in tuition and componition. He was a professor at Queen Street Ladies' Collene; Choimaster at St. George's ('hurch; and conductor' of the Seottish Focal Asuciation. Also member of the Festival orchestra, límingham, 1867-73; Concert-giver in Edinlomgh, and Quartetplayer. Abont this time his comprositions begim to attract attention, and in order to defote himself to this work, he went to dive at Flonence in 1479. He visiter England oceasiomally to enduct commesitions at the Worecenter Fentival, 1s81: Brintol Fentival,

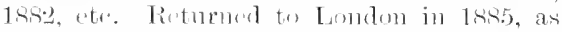
condecter of the Novello ()ratorio (onecerts; left Lmolon again in $184 \pi$, lut after the death of sir (x. A. Mircarren that rear, he becamer a cancliclate for the prest of Principal of the R.A.M., and was eleeted, Fetnuatry 22,

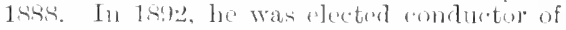
the Philhammic sweinty, the first comeert under his direstion tisking place, MEareh 9 , 1898. He has anducted comorets at the

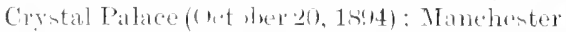
(1Ialle concert, Dorembler 5, 1895); Royal

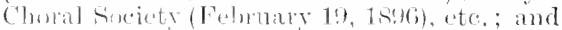
has girom addremes on mon in Monchester and wher plares ; Iextenter at the Royal Institution, 1848 , and $1 \times 15$, etc.; and tiken an action interest in the procostings of the Ineorporated suedoty of Mnsicians. IIe was elexter llom. Yjo-l'terident of the Edinburgh

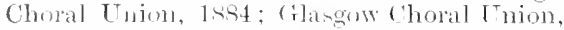
18ss: recerised the fould Modal for Art and Sicience, from the frand Duke of Henser, 1884;

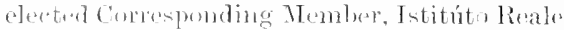
di Firenze [18s's]; received the homomiry degree

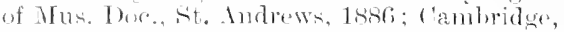
18s8; and Erlinlungh, 1896: and in 1895, the

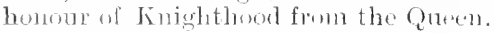

Woriss.--cuntelus and Oratorios.

\section{MACKENZIE.}

Bride, Worcester Festival, 1881 ; Jason, Bristol, 1882; The Rose of Sharon, Norwieh, 1884; The Story of Sayid, Leeds, 1886; Jubilee Ode, Crrstal Palace, Jume 22, 1887 ; The New Covenant, Glasgow, 18s8; The Dream of Jubal, composed for Jubilee of Liserpool Philharmonic Society, performed, February 5, 1889; The Cottar"s Saturday Night, Edinburgh, December, 1892; Veni, Creator Spiritus, Pirningham Festival, 1891; Bethlehem, composed, 18\%2, produeed, Royal Albert Hall, April 12, 1894. Operas: Colomba, produced, Drury Lane (Carl Rosa). April 9, 1883; The Trubladour, Drury Lane, Jume 8, 1886; His Majesty, emmic opera, Savoy, Felruary 20, 1897. Incidental musie to Ravenswond, Lycenm, 1890; Marmion, 1891 ; Choral od w for female voices for The bide of Lore (Bmonanan), Adelphi, 1890. Orehestrul: Scherzo, Glasgow, 1878; Scottish Rhapsodies, No. 1, op. 21: No. 2, op. 24 (Burns); La Rel] Dame sams Merci, Phil. hamonic suciets, 1883. Orertures: Cervantes; To a comedy; Tempo di Ballo; Twelfth Night, comprosed in Italy, 1587-88, prodnced, Richter cuncerts, Jnne 4, 1888; Pritamia, Quren's IIall, May 17, 1894. Concerto, op. 32, Birnungham Festival (Sarasate), 1885; Pilmoch, Leents (Sarasate), 1896, both for violin and orchutra. Seottish Concerto, pf. and onclentra. (Montet in F flat, op. 11, pf. and strings; six pieces for vinlin, op. 37 ; 1liglıland ballad, violin, op. 47; Larghetto and allegro. pf. and cello, op. 10; From the North, 9 vislin pieces. Rustic scenes, op. 9; Five pieces, op. 1?; Fix pieces, op. 20, and other eompusitions for pt. Thare short pieces, organ. Seren anthens. Song of Love and Deatl (Temyson). "p. 7 ; 'Two songs, op, 12; Thre songs (Christina Rosutti), op. 17; Fightern somgs, op). 31; Spring songs (7); Three shalsespeare somets, ete. The Empire Flag, solo and rhorres part-songe, varions. Voreal Melodies of thestland, arranged for pf.

Mackenzie, Marian, contralto vocalist, born at Plymouth. Studied there under Sammel Weèkes, and later at R.A.M. under A. Randegger. Wentmoreland, and Parepa-Rosa Scholar; A.R.A.M.; Associate of the Philharmonic Society. She made her debut at the Jondon Ball id Concerts; sang at the Crystal Palace; Nonday and Saturday Popular Concerts; and in the provinces. Her first Festival engagement was at Norwich, in 1890 ; then followed appearances at Leeds, 1852 ; Biminglram, 1894 , ete. She also sang at the Handel Festivals, 1891-94. For a short time she sang in comic opera, making her first appearance on the stase at the frand Theatre, Birmingham, Oct. 10, 18s7. In 18s5, she was married to Mr. Richard Smith Williams, a brother of Miss Amna Williams the soprano vocalist. In 1896 she made a successful tour in Australia, 


\section{MACKENZIE.}

singing at festivals at Sydney, Melbourne, Adelaide, etc.

Mackenzie, Sir Morell, surgeon and musician, born at Leytonstone, Essex, July 7, 1837; died at London, February 3, 1892. Author of "Treatment of hoarseness and loss of voice," London, 1863; new edits., $1 \mathrm{~s} 6 \mathrm{~s}$, 1871. "Use of the Laryngoscope in diseases of the throat," London, 1865, also 1871. "Hygiene of the voeal organs: a practical handbook for singers and speakers," London, $1886 ; 5$. l edit., 1888. "Fatal illness of Frederick the Noble," London, 1 s88.

$\boldsymbol{M}$ 'Kercher, Duncan, riolinist and composer, born at Inver, Dunkeld, N.I., in 1796. He resided chiefly in Edinlurgh, and died at Colinton, neat that city, on I necember 14 , 1873. He composed a number of strathspeys, most of which were published in two collections of dance music which were issued ahout 1830. Many of the dances in these collections were by Captain Daniel Menzies.

Mac Kerrell, John, musician and writer, author of "Familiar Introduction to the first principles of music"... Op. 2., I ondon, [1800; Fongs and other compositions.

Mackeson, Rev. Charles, clergyman, editor, and literary musician, born Miay 15, 1842. Compiler of "Guide to the Churches of London and its Nulurbs," published annually for some time. Editor of The Choir. new series, 1879 80; and of the (7urchman's Shilling Magazine. Contributor to Grove's Dictionary if Music and Iusicians. Anthor of biographical notices of living musicims, published in the choir, 187!-80. Lecturer on Church music; Hymn writers; Christmas carols, etc. Ordained by Bishop of I,ondon, 1855. Curate of Church of the (rood Shejherd, Hampstead, 1885-89; Minister, 1889-94.

Mackewan, Joseph, musician, compiled "Select I'salm Tunes, metrical hymus, chorales, chants, etce,' London [1857]. 'omposer of Songs, scenas, duets and other vocal music.

Mackinlay, Thomas, music publisher, compiled "A Catalogue of Original Letters and Manuscripts in the Autograph of Distinguished Insicians, Composers, Performers, and Vocalists," London, 1Rt6.

Mackintosh James, anthor of "The Musiemaster for Schools and Families," London, 1860.

Mackintosh, John, Scottish lasisoon player, born in 1767 . He played in the principal orehestras between 1821-1835. He dicd at London, Mareh 23, 184t. Famous at one of the fincest performers of his day, and celebrated all over Europe for the excellent tone and style of his playing.

Another Machintosi, Peorge, issned a "New and improved Bassom Tutor, etc.," London $\lceil 1$ sito

Mackintosh, Rohert, Scottish composer

\section{MCLACHLAN.}

and riolinist, was born about the middle of the 18th century [Tullymet, 1745]. He resided in Edinburgh as a teacher and performer till ahout 1803, when he removed to London. Teacher in London at Little Vine Street, Piccadilly. He died at London, February, 1807.

Works.-Op. I. Airs, Minuets, Gavotts, and Reels, mostly for two Violins, and a liass for the Violoncello or Harpsichord, 1783: op. 2. Sixty-eight new Reels, Stratlspeys, and Quick Steps; also some slow pieces, with variations for the Violin or Pianoforte, with a Pass for the Violoneello or Harpsichord, 1792; 2nd Book, 1793; 3rd Book, 1793; 4th Book of Reels, n.d.

This composer was well known in his time as Red Rob Mackintosh. He win a good performer, and wrote music for the song "A cogie of ale and a pickle ait-meal."

His son, ABraHam (hom, Edinburgh, June 15, 1769 ; died, Newcastle, ahout 1807), was also a violinist, and isinted a collection of dance music, entitled, "Thirty new Strathspey resels, etc., with a basis for the vinloncello or harpichord," Edinburgh, 179\%. A Collection of Strathspeys, Reels, jigs, ete... for the harp, pianoforte, violin, and violoncello, Neweastle [1\%05], 2 Nos.

McKorkell, Charles, organist and enmposer, was born in 1s0.). He studied at the R.A.M., London, and for fo years was organist of All Saints', Northampton. He died at Northampton, Januars 10, Ist9. ('ompiler of "The Sacred Masic Book, a selection of 100 standard trues with chants," n.d.; and composer of anthems, and of many pieces of minor importance for the pf.

McLaclilan, Jessie Niven, M Irs. Robert Picchasax, sopmono singer, form at Olsam, June 1s, 1sfic. (elebrated an a singer of Highland somgs in the original traelic. In 1892 she sang before the Queen at Balmoral, and she has froquently appeared at concerts in Glasgow, London, and other parts of the comntry. Her husbund, RoBert bechanan, was hom at Glasgow in December, 1858, and has held various posts as church organist and pianist.

M'Lachlan, John, musician, who was a teacher in Glasgow, and precentor of the North West Church from 175t. He died in Glasgow in 1791. Compiler of "The Precentor, or an easy introduction to chnreh music, with a choice collection of prahm tunes," Glasgow, 1776 (with Finlay); The Precentor, or an easy introduction to church music, Glasgow, 1779; another edition, flasgow, 1782.

McLachlan, John, musician and piper, compiler of "The I'iper's Assistant: a new collection of marches, quicksteps, strathspeys, reels and jigs. Edited by John 


\section{McLAREN.}

MeLachlan, late piper to Neill Malcolm, Esq., of Poltalloch," Edinburgh, n.d.

McLaren, Daniel, violinist and composer, who was born in Perthshire in the latter part of last century. He resided in Ediuburgh as a teacher and performer, and probably died there about 1820. He published "A collection of strathspey reels, etc., with a bass for violoncello or harpsichord," Edinburgh [1794].

Maclean, or Macklean, Charles, Scottish musician, who flourished in latter part of last century. He published "Twelve solus or sonatas for a violin, op. 1," Edinl,urgh, 1737 ; and a "Selection of favourite Scots Tuues, with variations for the violin...." Edimburgh $[1770$.

Maclean, Charles Donald, organist and coniloser, born at Cambridge, March 27 , 1843. Studied moler Ferd. Hiller at Cologne. Graduated Mfus. Bac., Oxon., 1862; MIus. Doc., 1865; M.A., Oxon., 1875. Organist of Exeter College, Oxfurd, 1862, and 1872-5, music direetor at Eton College. From this time he spent many years in India, and is now resident in London.

Worses.-Noaln, dranatic oratorio; Requiem Mass; Sulmala, cantata fron the Grelic. Orchestral: Symphony in G; Cynthia's Revels, concert overture; Concert overture in C; Ballet, withont dance; Trio in B, pf. and strings; Music for pf., songs, ete.

Maclean, Alick, composer, son of preceding, born at Eton, July 20, 1872. His works include an opera in three acts, " guentin Durwasd," and "Petruccio " (libretto by his sister), opera in one act, which won the Moody-Manners prize of tlok, and was produeed at Covent fiarden, June 2y, Is95. IIe has also written some songs.

Maclean, William, minor poet and amateur musician, bom at Glasgow, Narch 22,1805 . Elucated at Cilasgow University. He was a manufacturer and merchant in Glasgow; J.P. for Comnties of Renfrew and Lanark, cte. He died at (slasgow, November 28, 1892. I'ublished "Maclean's Sacred Music, atranged for four voices, with organ or pf. accompaniment," London, 2 parts, 1854.5. Also composer of a large volume of "sacred Melodies" in manuscript, now deposited in the Mitchell Library, Glasgow.

Maclennan, William, piper and daneer, was burn in Scotland in the first part of the present century. He was regarded as one of the best performers of Highland bagpipe music, and was four tim s commanded to pipe and dance before the Queen. He died at Montreal, Canada, in Octoler, 1892, while on a tonr with a company in Anerica.

Macleod, Captain Neil, Scottish collector, published a "Collection of Piobaireachd or I'ipe Tunes, as verbally tanght by the

\section{MCMURDIE.}

MI'Crummin Pipers in the Iste of Skye, to their Apprentices," Edinburgh, 1828. A reprint of this searce work was issued by Messrs. J. \& R. Glen, of Edinburgh. It is distinguished by the use of an extraordinary notation, consisting of syllables, which has not yet been deeiphered.

Macleod, Peter, anteur tomposer, son of James Macleud of Polbeth, West Calder, Midlothian, was born on May 8,1797 . Well known in Edinburgh musical and other circles during his lifetime. He associated with the leading men of the time, and was an early friend of $l$. A. Smith, the composer. With the profits of the work named second below he completed the Bums Monument at Edinburgh by enclosing it within an iron ruil. He was a Justice of the Peace for Midlothian, and succeeded to the property of Polbeth. He died at Bumington, near Edinburgh, February 10, 1859, and is buried at Roseliank Cemetery there.

Wonks.-Original melodies, consisting of songs, duets, and glees, the symphonies and accompaniments by $\mathrm{Mr}$. Nather, the poetry written expressly for this work, Edinburgh [18:8]; Original Scottish melodies, Edinhurgh, n.d., dedicated to the Duchess of Buccleuch; Original national meludies of Scotland, London and Ediuburgh [1838], dedicated to Queen Victoria; New national songs, the meludies never before published, Edinburgh, 11.d. Among Macleod's bestknown songs may be maned scotland yet; M $\%$ bomine wife; Oh, why left I my hame; Our's is the land o' gallant hearts: Ilowie dens o' Yarrow; Yellow locks o' Charlie; Land o' cakes; Emigrant's eomplaint; My Highland vale; I had a hame; Hore dear art thou to me; I have loved thee only; Flora's lament; and many others, chiefly to verses of good poets.

Macmeeken, J. W., elergyman and amaten musician, Wat minister of Lesmahatgow, in Lanarkshire. Author of a "History of the seottish Metrical Pralnos, with an acesunt of the paraphrases and hymms, and of the music of the old pralter. Illustrated with twelve plates of Mis. music of $1566, "$ (ilasyow, 1872, privately printed.

McMurdie, Joseph, composer and writer, was born at London in 1792 . Ile studied music under lh. Croteh. Mus. Ball, Oxon., 1814. Director of Thilharmonic Society. He died at Merton, Sumey, December 23:38. 18 s.

Worrs. Cilees. Canous, etc., London, 1828, 18:6, 1s40, etc.; Trios tor Fentale Vuices, 1859; Glees, etc., London [182t]; Arrangements for pf. ; Sacred Music, a collection of tumes adapted to the new rersion of Palmos, as sung at the Plilanthropic Society"s Chapel, Lomdon, 1827; The Elenents of Minsic, with the dit of Playing from a Figured lsass, and 


\section{M'NABB.}

an introduction to Composition, London [1845]; A Juvenile Preetptor for the Pianoforte, London, 1828; A Collection of Psalm and Hymm Tunes, London [185.3]; Te Profundis Clamavi, motet; Ode to Spring, glee. Handbook for Vocal Classes, Part-songs, ete., London [1859].

M'Nabb, Hugh, witer and eonductor, born in Ayrshire about 1842. He is conductor of the Ayr Choral Lnion, and of a rocal association in conneetion with the 1st Lanarkshire lifife Volunteers. From 1867 he has been choimaster of the Lnited Presbrterian Church, St. Tincent Street, Glasgow. Author of "Morley's New Singing Tutor," London, 1883 , ete.

McNaught, William Gray, teacher, conductor, and editor, horn of sicottish parentage, at Stepner, Londun, March 30 , 1849. Began his musical studies with the Tonic Sol-fa method, and eontinned them after he had entered a merchant's office. Was awarded the society of Arts prize for composition, 1871, and, yiving up business, entered the R.A.MI. that vear. Asisociate, 1878; Fellow, 1895; Mus. Doe, Cantual, 1896. In 1872, at the National Music Neetings, Crystal Palace, the Asheroft-lias Choir, under his direction, won the prize of $\$ 100$ in Class I1. This choir, in 1874 , was tranferred to Bow, and formed the nuclems of the excellent choir of the lustitute, condreted br him ever sinee. He was appointerl dxisistant Inspector of Music for the Educational Department in 1889, and Exanniner in Munic. to the Sineitety of Arts in 1893. Author of "Hints on elioir training for competitions," Novello, 1896; Editur of The shool Music Review from its eommencenent, in 1892: of Novello's School songs; and translat or of a number of works inte the Tonic siol-fal Notation. Adjudicator at schorel singing competitions, lecturer, etc.

Macphee, Donald, author and bagpipe maker, bom at Coathridge in 1841 , died near Glasgow, Deetmler 9, 18so. He worked in Glasgow at his trade. Author of A Selection of Music for the Highland Bagpipe, with a complete tutor, Glasgow, 1876. Marehes. quicksteps, reels, and itrathspers, and collections of Pilbuchs, 1879, for the lyogipes, ete.

Macpherson, Charles, organist and eom poser, born in Edinhurgh. In 1879 he entered the choir school of St. Paul's Catlretral, and was a chorister for about eight years, under Dr. G. C. Martin. Sometime choirmaster, St. Clement's, Easteheap. Private organint to Sir Robert Menzies, Veem, Perthinire, 1887 ; at Madame de Falla's chapel. Luton Hoo Park, Jeds., 1889. Entered R.A.M., 1890; Won the Charles Luean Prize, 1892; A.R.A.M., 1896. In 1895 he was appointed assistant organist at St. Paul's Cathedral.

\section{MCSWINEY.}

Works.-Ps. 137, chorns and orchestra, R.A.M., 1895; Three Gaelic melodies, with aecompaniment for strings and harl, Glee for 5 voices, There sits a bird (awarded the prize of 10 guineas offered by the Bristol Orphens Glee Society, for the best composition by a student of IR.A.M., 1893). Overture, Cridhe an Ghaidhil (The Heart of the Gael), Crystal Palace, March 2, 1895; Highland Suite in A, orchestra; Sextet, for wind instruments, ete.

Macpherson, Charles Stewart, composer and conductor, of seotch deseent, born at Lirempol, March 29, 1865. Fducated at the City of London sichool. In 1880 he won the Sterndale Bennett Seholarship, and entered the R.A.M. Studied pianoforte mider W. Nacfarren, and composition with Sir (r. A. Nacfarren. Balfe ścholar, 1842-3; Lucas Prize, 18s4; I'otter Exhibitioner, 1885. While a student he wrote a large mumler of workis, orchestral and chamber music, ete. Elected an Associate, 1887; Fellow, 1892. In 1889 he was appointed a profusor of harnony and composition at the Academy. He became organist and choimaster of hmmantel Church, Streathan Common, 1885; was appointed eonductor of the Westminster Urchestral society the same rearr and in 1siso, founded the Streathan Choral society. Has given ('hamber concerts, and pianoforte recitals, and contriluted occasionally to the musical press.

Works. - Orchestra?: Srumphony in C', 1885; Oxerture, The student of Salannance, 1897 ; Fental overture, 1s:91; Ballade, 1890; Nottumo in E flat, 1s!2 ; all protuced by the

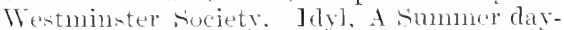

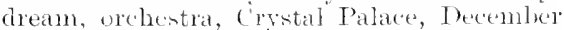
8, 1894. Concertotick, pf. and orchestra, 18:13; Ronnance in D, violin and orchentra,

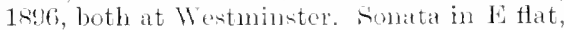
pf. and violin: Sulte de Valses, pf. Chunch music. Songs, duets, ete. Anthor of "I'ractical Harmony, a cuncise treatise, $189 \pm$; and Aplendix to tlie same.

Macpherson, D., authur of "Catechism of Music, adapted for leamers on the Piano, etc.," Edinburgh, n.d.

A D. Macphrmsox componed music for the pf., some of which was issed at Liverpoul about 1820 .

Macrory, Edmund, author of "A Few Notes on the Templo Organ," London 1859], anon.; recond cdit., 1861; 3rd edit., 1875.

McSwiney, Paul, conposer, bom at Cork, Ireland. In Cork, February 2:), 1881, was produced an opera, "Anergin," of which he wrote the libretto and music. IJe them went to the Enited States of Anerica, and became mmsical director of the New York branch of The Societr for the Ireservation of the Irish Language. He prodnced at Steinway 


\section{MADAN.}

Hall, New York, December 28, 1884, a Gaelic Idyll, "An bind 'gus an Fo" (The bard and the linight), for solo voices, chorus and orchestra, the book and music hisown. Both works were highly spoken of.

Madan, Rev. Martin, nusician and clergrman, born in 1726; died on May 2, 17)0. He founded the Lexcli llospital, in London, and acted as chaplain. He edited "Palms and hymms extracted from various authors," 1760; "Lock ILospital Tumes" [1769]; and composed the wall-known hymntune "IIuldersfield." Antlor" of "Thelyphthora: a treatice on female ruin," $3 \mathrm{v}$., etc.

Mahaffy, Rev. John Pentland, Professor of Ancient History, Trinity College, Dublin, was born at Chapponnaire, near Veviuy, on the Lake of Geneva, February 26, 1839. Fducated in Geminy, and Trinity College, 1)ublin. Received the degree of D.D., 1886; and is Mus. Doe., homoris causu, Trinity College, Dublin. He is an Examiner in Music for Dublin Lniversity; has arranged some Irish melorlies; and has contributed articles referring to music to Cosmopolis (September, 1896), and olher papers.

Mahon, John, clarinet blayer, was born in 175.5. He played in Dullin and at the Bimiughan Festivals, 1802-11. Died at Dublin in 18.34.

Mahon, Mary, see SECONn, Marr.

Mainwaring, Rev. Joln, dergyman and author, born 1735 ; died at Cambridge, April, 1807. He published anonymously, "Memoirs of the tife of the late George Frederick Handel, to which is added a catalogne of his works and olservations upon them." Londun, 1760.

Mainwating, Townshend, Welsh musician and anthor, born abont 1809 . He was N1.P. fol the l)enhigh horoughs from 1sit to 1847 , and again from 1857 to 1868 . He died at Galltfaenan, ntar [Denbigh, ju I)ecem] e'r, 18s.3, agel 74. Composer of Advent hymm, Emyn ail ddyfodid Crist; Dafydd and Myfanwry, Hanes Cymlateg, Lontion 1880); a Nelsh romance for treble roices; IJyms, etc.

Maitland, Jobn Alexander Fuller, writer on music, bon'n in London, April 7 . 1856. Gralmated at Trinity College, Cambridge, P.A., 1579; M. A., 188s. Becane F.S.A., 18s6. Wrote for the Pall Mall Gasotte, 1882.1; for the Guartiun, 1884-9; and, after the death of Dr. Hueffer, in 1889, was appointed musical critic of The Times. Contrilunted articles to the l)ictiouary of $\mathrm{Na}$ timal Biography; Grove's Tictionaly of Mnsic and Mnsicians (ant editor of the Appendix to that work); the Nineteentl Contury; National Review, ete. Lectured on The IIstory of English Music, two series, 1857 ; and on loncell, 1s,15. I Ias appeared as a pianist at concerts of the Bach Choir.
MAKER.

etc., and played the harpsichord at coneerts of ancient music.

Works, - Schumann ("Great Musicians" series, Sampson Low, 188t); Life of J. S. Bach (joint translator, with Clara Bell, of Spitta's work, Novello, 3 vols., 188t); Carols of the 15 th century, edited from a roll in Trinity College library, Cambridge, 1891; English county songs (joint editor, with Miss Lucy F. Broadwood), 1893; C.talogue of the music in the Fitzwilliam Museum, Cambridge, 1893 ; Masters of German Music (Osgood), 1894; Editor of Purcell's Twelve somatas of three parts (1683), and Ode on St. Cecilia's Day (1692), for Purcell's Socicty, 1893-6; and Fitzwilliam Virgina) book (with IV. Barclay Squire, B.A., F.S.A.), in course of publication.

Maitland, William, musician, was born abont 1796. He was originally a shoemaker, but was appointed precentol of the East Church, Aberdeen, in 1821, and held the appointment till 1827, when he emigrated to Canada and became a Congregational minister. Died in Canada, Decenber, 1873. Compiler of "The Aberdeen Psalmody, being a collection of tumes in four parts, adapted to the P'salms and I'haraplirases of the Church of Scotland..." Aberdeen, 1823. Has riew of St. Nicholas' Clinreh. "Supplement to the Aberdeen Psalmody, being a collection of hymn tunes adapted to particular metres used in the Congregational Chapels," Idinburgh, n.d.

Major, Joseph, musician of the first half of the present century, issued "A collection of psalm and hymn tunes," London [1825]; "A collection of sacred music, consisting of fifty-two psalm and liymm tunes for four voices.." Luondon [c. 1826]. He also composed songs, etc.

Major, S. D., musician and author, compiled "Tunes and chants for home and school," Batl, 1870 ; "Tunes for the family and congregation," Bristol [STTT]; "Tunes for supplement to new congregational tume book" [187.] ; "Notabilia of Bath," 1879, and other worlis.

Makepeace, William, basis rocalist, bun ahout 18:20. Chorister at Sit. Paul's Cathedral muder Hawes. Appointed lay-clerk, Rochester Cathedral, in 18t5. He was also choir schoolmaster and librarian. Many eminent musicians passed moler him as pupils. Je resigned the office of sehoolmater abont 1886 , and retired from the cluse an a pension a few months only before his death, which trok place at Rochester, septembur 11, 1896, in the feth rear of his age. IJe was an original momber of the ('loir Benerolent Fund.

Maker, Frederick Cluarles, mintist and compostr, born at liristol. Chorister in Brists Cathedral, and pupil of Alfued sit me. 


\section{MALCOLM.}

Organist of Milk Street Methodist Free Church; Clifton Downs Congregational Church; and from 1882 of Redland Park Congregational Church. Has composed a cantata "Moses in the bullushes" ; eontributed tunes to the Bristol Tume Book: Isined a collection of original tunes; Anthems, etc.

Malcolm, Alexander, musician and author, born at Edinisurgh in 1687. The particulars of his life and date of his death are unknown. Anthor of "A Treatise of Musie, Speculative, Practical, and Historical," Edimburgh, 1721; also Lundon, 1730. This work, from its scientific basis, achiered much suceess, and was reprinted in an alridged form by an "Eminent Musician," in 1776.

Mallandaine, John E., composer and pianist of present time. Composer of Comntess Rosa, opera (1865); The Two Orphans, opera (1874); Love's Limit, comic opera (1875); Ali Baba, eomic opera: [ncle Tum's Cabin, songs and choruses (1879). Six songs, the words by J. Ellison, Liverpos (1s71). Dance musicand arrangements for pf.; Single somgs, etc. In 1881 Mallandaine went to the Enited States.

Mallett, Louis Balfour, violinint and composer, died in London, I eerember 12, 1,91, at the early age of 24 . He was an able execntant, and howed much promise as a componer. His worlis were not numeroms, comsisting of a few pieces for the pianoforte, a carote in $\mathbf{F}$ for tiolin and pianoforte, and a set of seren pieces for the same justroments.

Mann, Arthur Henry, organist, oditor, and eomposer, borm at Norwich, May 16, 1850. Chorinter at Norwich Cathedral inder Ir. Buck. F.C.O., 1871; Mus. Bac., 1st4; Mlus. Doc., 1882, Oxford. Hon. R.A.M., 1896. Organist snceesively at st. Peter's, Wolrerhampton, 1sт0: Tettenhall I'arish Church, 1871; Bererley Minster, 1575; and from 1876 organist and director of the churr, King's College, Cambridge. He in known as a Handelian Scholar, and was the diseoverer, with E. Prout, of the original wind partis of "Mresiah," in 1894, at the Fommdling Hospital. A performance of the oratori;, with the re-constructed scorte, was given in King's College, Cambridge, June 13, 1894. He has composed "Eece Homo" for soli, chorus, and orchestra, 1882; an Erening service in E, for chorus, orchestra, and organ; one in $\mathrm{E}$ for double choir, unaccompanied: a Te Deum, for ehorus, orchestra, and organ, 1657. Anthems, organ pieces, part-somus, etc. Editor (with J.A. F. Maitland) of the Catalogne of Music in the Fitzwillian Museun, Cambridge; of Tallis's Motet for 40 voices, London, Weekes, 18ss; and Mnsical Hditor of the Church of Fngland Hymual, Hodder and Stoughton, 1-95.

Mann, John A., Scottish violinist and
MANSEIILD.

violin maker, born, Forfar, May 13, 1810. Lived in Glasgow as an artint, machinist, and violin maker. He died at Glasgow, April 30, 1889.

Mann, Richard, organist and composer, was born in 1837. He was organist and teacher at Chichester, where he died in 1869. He wrote "A Manual of Singing for the use of choir trainers and school masters," London, 1866 , and composed anthems, ete.

Mann, Thomas Edward, homist. When a boy he was in the Duke of York's School, Chelsea. He lrecame one of the finest hom player's of his day, and was also a performer on the cornet. For many years he was principal in the loading orchestras, and up to 1896 was in the band of the Philhamonic Societr, the Three (hoirs, and other provincial Festivals, playing at the Worester Festival of reptember, 1sug. He died at Killown, London, January 17, 1897. He was profesior of the horn at the Lineller Hall Military sehool of Musie; at the R.A.MI, and R.C.MI.

Manners, Charles, mupely sot'thCote Maxsemgh, bass voealist, bun in London. Fourth son of Culonel J. C' Manseroh, li.H.A., and J.P. for Cork and Tipperary. Hestudied at the Royal Irish Acadmuy of Mnsic, and obtained the Albert Schularinip. Later he went to the R.A.M., Lmedom, and afterward studied in Italy. In 1 sist, he joined the Carl Rosa Opera Company, tomring in the provinces for two rears. In Ision, he appeared at Cuvent Frarden, as Bertram, in "Robert le biable" ; and has smong there and at Drury Lame since that time. II made his first appearance in Amerien at the Seidl orehentral concerts, New Fork, Jammer 8, 1s.98. Toured in opera, Cape Tume, with great success, 1896-7. He married, July 5, 1890, Miss Famm Moody (q.x), with whom he has since been associated in artistic (nterprine's, forming a company for concerts and prepar recitals. In 1895 he offered a prize of $t y 00$ for all opera in one act. See sub. Mtaculat.

Mansfeldt, Edgar, see I'inzisox, Hexty HTro.

Mansfield, Orlando Augustus, organist and composer, hom at Iomingsham, Wilts., Norember 28, 186:- Sind of the Rev. James Pearse Mansfield. Studied music privately, and in $18 \times 3$ was aplesinted oreanint at the Manvers Street Wesleyan Chapel, Truwhidge. Thence he went in 18s.5 to Torynay, asolgandint of Holy Trinity Chnuch, an appointment he lesigned in 1835. F.R.C.O., 1485: Mns. Bat., 1887; Mus. Doc., 1890, Trinity College, Toronto, Nember of the Sinejety of Authors. Has given lectures on musital snlojects, and contributed a number of articles to the Musical Standard, and other papers. II compositions include a numler of anthems, 


\section{MANSON}

one of which obtained the prize offered in 1896 hy the Nonconformist Choir Uniom; hymu tmes, etc. Postlude in C: Finale Fugato, op. 23 (prize voluntary); Andante piacevole; and other organ pieces. Scherzino, pf.; Romance in B flat, op. 28, pf. and violin, ete. Anthor of The Student's Harmony, London, Weckes, 1896 ; The Student's Manual of Pedal Scales and Arpeggi.

In 1886, he maried Mlle. Lousse ChrisTINE JuTz, of Geneva. She is a pianist, medalist of the Crenera Conservatoire, and, in conjunction with her husband, has given Jecitals of mmsic for two pianos.

Manson, James, musician, and minor poet, was born at Kilwimning, in Arrshire, abont 1812. His fathor was a tailor, and for some time James followed the same ocenpation. He went to Glasgow and engaged in literary pursuits, but becane blind in 1858, He died at Glasgow, September 3,1863 . He edital the British Minstrel, 1842-4t, and issued a volume of poetry, and a collection of music, in three volumes.

Marbeck, John, or Merpecki, writer, composer, and nganist, boln in 1523. ('horistor in St, Georye's Chapel, Windsor, 1531. Embraced Protentant faith, and narrowly escaped being burned for heresy, 154t. Taken under the patronage of the Iishop of Winchester. MIns. Fac., Oxom., 1550. He died about 1585.

Works.-The Booli of Common Praier, Noted, London, 1550. A Concordance, that is to saie, a worke wherem by the ordre of the letters of A, B, C, ve mave redelye finde any worle contayned in the whole, so often as it is there explessed or mentioned, London, 1550; The Lrves of the Holy Sainctes, Prophets, Patriarchs, and others, contained in Holve Suripture, 1574; The Folje Historie of King David, etc., 1579; Book of Notes and Common Places, gathered out of divers writers, 1581 .

Iarbeck re-set the Fuglish Charch Service amost in its entiretr, and is said to have influenced later composers in the style of ecclesiastical composition. His setting continned in nse during the many fluctuations in musical taste, which have been witnessed since his time, and is still in nse, though not wholly.

March, Mrs., see GABRIEL, MARY ANN VIRGINIA.

Marchant, Arthur William, organist and composer, burn in London, October 18, 1850. He was privately educated in music, and took the diploma of F.C.O., 1878; and graduated Mus. Bac., Oxford, 1879. Organist of St. John's, N[ansfield, 1870; Streatham Parish Church, 1876; St. Luke's, Kentish Town, 1877. In 1880, lie went to America as organist and choimaster of St. John's

\section{MAliKS.}

Cathedral, Danver, Colorado. While there, a fine organ was built from his specification, and a large choir forned. He returned to England in 1882, and was appointed to the Parish Church, Sevenoaks; in 1889, to All Saints', Huntingdon; and in 1895, to St. John's Episcopal Church, Dumfries, where he is doing good work. He has composed a setting of Ps. 48, for soli, chorus and orchestra; a Morning Service; Evening Service; 'This is the Day; Hail to the Lord; I will magnify Thee; and other anthems. Album of six songs; Vocal trios and duets; vocal music for children; part songs, etc. Suite de pieces, violin and pf.; four duets, violin and $\mathrm{pf}$. Six pieces in old dance form; six Songs without words; and other pf. pieces. Preludes and Fugues; 18 original pieces in different styles; and organ pieces, varions. Anthor of Primer, 500 F'ugue Subjects and Answers, Ancient and Modern, Novello's Primers; Elitor of Twelve Trios for organ, by Albrechtsberger ; Pamphlet, Voice Culture, reprinted from Dumfrirs and Galloway stamiard, 1896.

Marchant, Charles G., organist and conductor, resident in Dublin. For a number of years he has been organist and choirmaster of St. Patrich's Cathedral ; conductor of St. Patrick's Choral Society, and director of Oratorio Services; conductor of Dublin Diocesan Cholal Association; and, since the death of Sir R. P. Stewart, conductor of the Duhlin University Musical Society. He has given many important oratorio and other concerts; and is Mus Bac., Trinity College, Dublin. Another musician of the name, T. Frenerick Marchant, was for some time a member of the St. Patrick's Cathedral Clioir; he is known as a bass rocalist of repute.

\section{Marks, Godfrey. See Swift, J. F.}

Marks, James Christopher, organist and composer, born at Armagh, Ireland, May 4, 1895. Chorister at Amagh Cathedral, under Robert Turle, 1842-51; deputy organist, 1852. Pupil of F. Hart for violin. Appointed organist and choirmaster, St. Finnbarre's Cathedral, Cork, in 1860, an office he still holds. Graduated Mus, Bac., 1863; Mus. Doc., 1868, Oxford. Conductor of Cork Musical Society, and has given many highclass concerts. He has composed an oratorio, "Gideon" ; an anthem, "If we believe," for soli, chorus and orchestra; and has published songs and pf. pieces, etc.

His son, JAmes Christopher Marks, born at Cork, July 29, 1869, is an organist and composer. He was a chorister at Cork Cathedral from 1871; and in 1883 was appointed organist and choirmaster of St. Luke's Church, Cork, where he remains. His compositions comprise anthems, The day is past and over; The souls of the righteous; and 


\section{MARKS.}

others; Evening Services in B flat, A and D. A number of songs, including $\mathrm{My}$ loved one, sleep secure, which won the prize offered by Methven \& Co., Edinburgh, 1893 ; part songs, Blow, ye gentle breezes; I'll think of thee, etc. Tocal duets; pf. pieces, etc.

Marks, Thomas Osborne, organist and composer, step-brother of the preceding, born at Armagh, February 6, 1845. Chorister at age of six in Armagh Cathedral, and deputy organist to Robert Turle when fifteen. Graduated Mus. Bac., Oxford, 1870 ; Mus. Iloc., Dublin, 1874. In 1872, he was appointed organist and choirmaster at the Cathedral in succession to R. Turle, a position he retains to the present time. He is conductor of the Armagh Philharmonic Society. His compositions are: Ps. 95, for soli, chorus and orchestra; cantata, St. John Baptist (MIS.) ; church music, and songs, etc.

Marlow, Isaac, clergyman and author, wrote the following tracts:- " Prelimited forms of praising God rocally sung by all the church together, proved to be no Crospel ordinance," London, 1691. " "T'ruth solemuly defended, in a reply to Benjamin Keacl, concening Psalm-singing," 1692, "The controversie of singing bronght to an end," ete., London, 1696.

Marriott, Annie Augusta, soprano vocalist, born at Nottingham, Мay 26, 1859. Studied under J. B. Welcl at the National Training School for MIusic, Kensington. In 1880 she sang at the Saturday Popular Concerts, January 17 ; in Haydn's "Creation," Sacred Harmonic, April 16; Promenade Concerts, Covent Girden, Angust 4, etc. She was engaged for the Worcester Festival, 1881; and Leeds, 1883. A proof of her good musicianship was given at Bimingham, November 26 , 1885, when at a moment's notice she sang the soprano solos in "The Spectre's Bride," withont a rehearsal, and without having ever heard the work. She sang at the Handel Festival, 1855; and at Buckingham Palace, before the Queen, in Stanford's "Jubilee Ode," May 11, 1887. She married, July 20, 1882, Pencr Palner, a tenor vocalist. He was born at Flaxton, Yorks, December 17, 1861. Studied under James Broughton, Leeds; and J. B. Welch on going to London. He was just entering upon a career of promise, when he died Angust 10, 1893.

Marriott, Charles Handel Rand, composer and violinist, born at Loudon, November 3,1831 . He was a violinist, and acted as musical director at Highbury Parn, London, from 1860 till 1865. Afterwards he held the same position at the Cremorne Gardens, and at the Pier Pavilion, Hastings. He was musical editor of the Foung Lallies' Joumal. He died at Hastings, December 3, 1889.

IVorks.-Songs:' England's trust; Land
IIARH.

ahead; Lily of the West; Lost friends; There grew in the forest a mighty uak. Song- for children. Nimeroms light pieces and arrangements for the pianoforte.

Marriott, Frederick, alto vocalist, layclerk in St. George's (hapel, Windsor, from about 1845, and also for some time in the choir of Eton College. He assisted at many of the Royal functions during the Queen's reign, and was the oldest lay-clert in the Chapel. He died at Windsor, March 19, 1895, aged 8.2.

Marsden, George, organist, composer, and conductor, loom at italyluridge, ('heshire, Apri] 11, 1843. Studied at the Conservatorimn, Cologne, moler Ferdinand Hiller, and others. Graduated Mus. Bar., 1876; Mus. Doc., 1882, Cambridge. Ho is resident in Manchester as a teacher, and is organist at St. Thomas', Werneth, near Oldham. He holds an appointment now probably unique in this comtry, that of conductor of a private orchestra, giving wokly concerts in the winter (see 2 . R. Platrit, and is Principal of the Oldham School of MInit. IIis compositions comprise settings of I'sitm 23, and Pralm 46, for soli, chorno, and orehestra, and other chureh music. Rimance for oboe and orchestra ; pieces for oloce and pf. borcthy, a rustic dance, and other pt. pieces; Partsongs, ete.

His brother, Jonn Marimen, born May 31, 1835, died at Manchester, Norember, 18s:), was an alle organist, and teacler of the pf. His pupils came out first in all Enslind at the local examinations of Oxford, 1sfie, and Cambridge, 1sit. The brothers were early and active workers for the Incorpurated Society of Mnsiciams.

Marsh, Alec, biritone rualist, born at Stratford, near Salishury, Nilts. Situdied moler Borton Smith. Articled to a solicitor, but deciding to loceme a sincer, entered the R.A.M. While a sudent he sing in Pandeggel's "The Rival beanties," at St. Creorge"s Hall, May, 1885. Was Erill prizeholder, 18n7. He made his fentival folut at Norrich in 1887, and sangr in light operat the same real. In 1890 he joined the Carl Rosa Company, and has appeated in a romed of charaters with success. He maried MIss AlfCE ExTr, the American soplano, and has appeared with her on the stage, and in the concert room. These artist had a sucesisful tom in Australia.

Marsh, Alphonso, composer, born in 1627 , died in April, 16is1. He was a Gentleman of the Chapel Royal in 1661, and composed songs and other rocal mmic in Playfurd's Collections.

His son, Alpiroxso, bom about 1618, was also a Fentleman of the Chapel Royal in 1676. He died April 5, 1692, and is buried in 


\section{MARSH.}

the west cloister of Westminster Ablesey. Composer of sorgs, which were published in variols collections.

Marslı, Jolnn, writer and conposer, born at Irorling, 175\%. Articled to a solicitor at Ronnser, 176x. Married, 1774. Leader of Sulmeription Concerts at Salisbury, 1780 . Resided at Chichester from 1787, and died there in $182 \mathrm{~s}$.

Works. fix Anthems, 1790; Favorite Symphory in 13 parts, for a grand orchestra; Orerture, and 8 somatinas for the pf.; Overture and six pieces for the organ [1791]; Quartette for solins, tenor and bass. T'wo sets of organ voluntaries. Gleess, songs, ete. A Short Introduction to the theory of harmonics, or the philosophy of musical sonnds, Chichester, 180\%. Rudiments of Thoroughbass, lumdon, 1805. Hints to Young (onnposires of instrunental music, London [1800]. Collectim of the mont popular and approsed Psalm T'mes, with a few Hymms and east Anthens, the whole in 3 parts. principally for the use of eountry choirs, to which is added a selection of 20 favourite tmess set for barrel organs, n.d. Cathedral Chant Pook, Londorm 1800

Marsh, J., musician of present time, publisherl "Intruduction and progresive lessons for the Tenor," London 18nL

Marsl, Narcissus, amatelu musician and arehlishop, was born in Wiltshire in 1638. In 170:3 he was consecrated Arohbishop of Arnath. He died at loublin in 1713. Now best remennbered as fonnder of Marsh's Liblary, St. J'atrick's Cathedral, I)ublin, 1707. He wrote an " Essay touching thes smpathy between hute of viol strings," 1677 , published in Plot's Nitural Flistory of Oxfordshire, and an Introductory essay to che doctrine of sounds, 1648 , retc.

Marsliall, Frederick, composer, and teacher of musice, born at Northamptom aloult 17!x. He Was suecessively organist at Rughy School; Christ Chureh, Istamington!; and Parinh chomeh of Bambuty, Oxford. Ife died near (O)ney, Bueks., July, 1557. He eomponed hrmm tines, ete.

Marsliall, Julian, ann tem musian, and collectur, hom at Headingly, Leeds, Jume 2t, 18:36. Anthor of the "Ammale of Temis.' Contriluator to the Musical T'imes, and other periodicals; and writer of a number of articles in (ifore's l)ietionary of Music and Mnsievins. He was a member of the committees of the first Leede festival, 185s. His larese and raluable musieal librar was dispersed by anction, Juls, 18st. His wife, born Florwacle A. Thomas, borm at Romes, March 30,1849 , is a comploner and writer on mmic. She studied at the R.A.MI. Comancts the concerts of the south Hampstead orehestra, and is the composere of "fatiry opeletta, "Prince Sprite" ; a Nucturue
MARSHALI.

for elarinet and orehestra. I Jas eontributed articles to Grove, and to varions periodicals. Author of "Handel," Great Musicians' Series, London, Sampson Low, 1883; Sulfeggi, Novello's Primers, 1885; Interval Exereises for Singing Classes, Novello. She is an Assuciate of the Philharmonic society.

Marshall, Oldfield Sherwin, rganist and pianist. In 1883 he was appointer to the Anglo-Ameriean Chureh, Rome; and in 1890 slleeeeded Dr. Mark J. Monk as organist of the Parish Church, Banlury. He has appeared as pianist at varions eoncerts; and an orchestral suite of his eomposition was perforned at Alingdon in 1849. In 1884 he was elected Associate of Merit of the Acarleny of St. Cecilia, Rome, the only Englishman thus distinguished.

Marshall, Willian, violinist and composer, lorn at Fuchabers, Deember $27,1748$. House stewad and inter to the puke of fiordon till 1790. In 1773 he narried Jane tiles, by whom he had a family of five soms and a daughter. Farnuel at Keithmore, and factor to the louke of (rodom, 1790-1517. He died at Newfield Cottage, 1)indaleith, Rotbes, Elginshire, May 29, 1s:3, and is hured in Bellit Churehyard.

Woms.-A Collection of Strathspey liecls, with a hase for the Tiolonetllo or l Iarpichord, Fdinburgh, Neil Fitewat $[1781]$. A seend collection atpreared later, Matrshall's Scottish firs, Melodies, stratlispers, Reels, ete., for the pianoforte, violin, and violonewlo, with appropriate lasses. Iredicated to the Matchimess of Huntly, Edin., 182.2 [eontaining 170 airs. Collection of sicottish Molodies, Reels, Strathopers, Jigs, Slow Airs, etc., for the pianoforte, violin, and rolonceles, leing the semeine and posthmmous worlis of William Marshall, Edinhmgh, 1847. Choice selection of Tiees and stratlispeys, Edinlowruls, n.d. (with (Tow).

Matshail is best linown as a eomposer by his melnties "Of a' the airts the wind can blaw "("Miss Admiral (jorden's strathspey"), "This is no noy ain house," "The wind lilew the hommie lassios plaidie awa," and several others, all of which were dance toumes which hatre been adapted to poetry.

Marsliall, William, cirganist and comm poser, was lorm in 1806. He becane a chorister in the Chapel Roval, nnder J. s. Sinith and W. Ilawes, and in Chrint Church, and St. John's College, Oxford, 1-23. Organist of All Saints', Oxford. Mus. Bac., Oxon., 1826, Mlis. I)oc, Oxun., Jamlaty, 1840. Organist of Kt. Mary's Church, Kickerminster, 1846. I1. died at Handsworth, Angust 17, 1875.

Wouks. Anthems used in the Cathedral and collegiate Churehen of Fngland and Wales, 1 sto. Art of Reading Chruch Music, and Exercises intended to atceonnpany the 


\section{MARSHALL.}

same. Oxford, 1842-13. Miscellaneous church music. Three canzonets $[1830]$. Cathedral Services, arranged for organ and pf., Oxford, 1847. Cathedral Chants, edited with Alfred W. Bennett [1829].

A Irs. William Marshall (wife of above?), composed a number of songs and ballads, about $1830-40$.

Marshall = Hall, see HALL, W. I. MarshaLL.

Marson, George, composer of the 16th century, who wrote anthems, and a 5 -part madrigal, "The Nimphes and Shepheards," in the "Trimmples of Oriana," 1601. He is said to have been a Bac. Mus., but it is not known at what university he graduated.

Martin, Amy Florence, contralto vocalist of present time. Was educated at the London Academy of Music, studying singing with Nannel Carcia; and distinguishing herself also in liamony. She won two scholarships while there, was made an Associate in 1885, reeciving her diplona from the hands of Madame Patti, and Was appointed a professor of singing. Her concert engagements included tours with $11 \mathrm{r}$. Sinns lieeves, appearances at the Crystal Palace and other concerts. She then turned her attention to opera, and assisted at the first production of several light operas, finally becoming a member of Mr. J. WV. Turner's company about 1892. In the tours of this complans she has appeared with success in a varicty of parts, ranging from Azucena, in "Il Trovatore," to Siebel, in "Faust."

Martin, George Clement, organist and composer, born at Lamboume, Berks, September 11, 1844. Studied under J. Pearson, and Dr. Stainer. Graduated Mus Bac., Oxford, 1868; F.C.O., 1875; and received the Canterbury degree of Mus. Moc., 1883. Private organist to the Duke of Buccleuch, Dalkeith, 1871; Master of Song at the Choir School, 1874, and deputy organist, St. Paul's Cathedral, 1876; and elected organist, on the retirement of Dr. Stainer, 1888. Professor of the Organ, at 12.C.ML., for a few years from 1883. His compositions are chiefly for the church, and comprise a Morning, Communion, and Fvening Service in C, for voices and orchestra; Evening Services for the same, and for military Band; setting of the Benedicite, and Offertory sentences. Te Deum for the Queen's I lamond Jubilee service, St. Paul's, June 22, 1897. Come my soul; Ho every one that thirsteth ; Rejoice in the Lord; Veni, Creator Spiritus; and other anthems. Editor of liesponses to the Commandments. Evoning; Cold blows the wind; Let maids bu false (men's voices), and other part-songs. Arrangements for the organ, of movements from St. Ludnila ; Redemption; and Mors et Tita. Elitor of

\section{MASON.}

Organ Arrangements, Novello. Author of The Art of 'Training Choir Boys, Novello's Primers, No. 39.

Martin, George William, composer and conductor, was born on March 8, 1828. He was a chorister in St. Paul's Cathedral under W. Hawes. Professor of music at the Normal College for Army Schoolmasters; Music master at St. John's Training College, Battersea, 1845-53; Organist of Christ Church, Battersea, 1849. He conducted the concerts of the National Choral Society, the Metropolitan Schools Choral Society, etc. Editor of the "Journal of Part Music," 1861-62, and of other musical journals. He died at Bolingbroke House Hospital, Wandsworth, April 16, 1881. Martin composed several prize glees, anthems, songs, the hymm tune, "Leominster," etc.

Martin, Henry Maclean, EnRICO CAMPOBELLo, baritone vocalist, born in 1839. Sang in opera in Colonel Mapleson's company, and toured in the provinces with the same in 1872 , etc. He is also well known as a concert singer. In 1874 he married the soprano vocalist, known as Madame sinico, whose maiden name was Clarice Marini.

Martin, Jonathan, organist and composer, born in 1715. Chorister in the Chapel lioyal under Croft. He studied the organ under Rosingrave, and became deputy of St. George's, Hanover Square, London, and organist of the Chapel Royal in 1736. He died at London, April 4, 1737.

Martyn, Mrs. See Inyerarity, Eliza.

Mason, Edward, composer and teaeher of singing, born at Newcastle-muder-Lyme, July 4,1864. Descended from an old Staffordshire family settled in that town from the sixteenth century. Received his musical training at St. John's College, Battersea, under Edward Mills, 184:-4; and at the Tonic SolFa College, under McNanght, Tenables, and others. Became a Fellow of the College in 1889, and graduated Mus. Bac., Durham, 1892. Is singing instructor to the Arbroath School Board; choimaster, St. Mary's Episcopal Church, and conductor of several choral societies. He has composed a Good Friday Service, "The Man of Sorrows" (1896); Wee Folks" Songs; and is author of Old Notation Reader (5 Nos.), and Standard Music Charts for Schools. He executed the Tonic Sol-fa translation of Sullivan's " Light of the World," and has contributed to the Scottish Musical Review, and other papers.

Mason, John, author of "All Essay on the power of mumbers and the principles of Harmony," Fondon, 1749; and composer of songs, "The Admiring Lover," ete.

Mason, John, clergyman and musician, of the early part of the loth century. One of the famous musicians mentioned by 


\section{MASON.}

Morley. In 1508, he was instructor of the choristers at Magdalen (ollege, Oxford, and in the same year he graduated Mus. Bac. He died in 1547-48.

Mason, William, poet, musician, and writer, bern at Hull in 1725 . Ordained minister, 1755. l'rehendary and Preceptor, York Cathedral, 1763. He died at Aston, April 5, 1797. Wrote various papers on ecclesiastical musice collected under the title of "Esisays, historical and critical, on English Church Music," York, 1795, and composer of "Lord of all power and might," anthem, and other vocal music. His works are chiefly literary, and he talies rank among the minor poets of Eng]and.

Massey, Richard, musician, bom in 1798, was organist at the Chapel Royal, Whitehall, for 40 years $1837-77]$. He died at London, April 21, 1883 .

Another lichand Massey, probably the father of the foregoing, issned a work entitled "Sacred Nusic: twenty-six psaln tunes and three anthens," Nanchester $[1810]$.

Masson, Elizabeth, contralto singer and composer, was born in scotland early in the present century. She was a pupil of Madame Pasta, and made her début at the Ancient Concerts on March 16, 1831. She founded the Royal Society of Female Musicians in 1838 along with MIAR SAFah Steete (who Was a professor of singing at the R.A.M., and died at London, March 26, 18\$1, aged 65). Died at London, in January, 1865.

Works.-Original Tacohite Songs, London [1 $13: 39$; Twe ve songs for the classical vocalist [1845-61], st parts; Twelve songs by Byron [1543; rocal sketches. Songs: Oh! love was never yet without the pang [1837]; Balmoral rant [1840]; Come off to the moors; Here's a health into Her Majesty; Is my lover on the sea? Mary, adien; Ceotland, ete. Focal Exercises, London [1855]. Numerons arrangements, etc.

Masters, William J. Chalmers, pianist and composer, born in London, 1818. Sometime musical director, st. Gerorge's Hall, London. For many years resident as a teacher at sonthsea. He was the composer of two operettas, "The Forester's Danghters," produced at st. Feorge's Hall, November 19, 1867 , and "The Rose of Salency" ; of songs, pi. pieces, ste. Ile died at Southsea, Norember $29,1898$.

Masterton, Allan, Scottish musician and writing-master in the High school of Edinburgh. An associate of Rohert Bums, the poet, to whose song, “ Willie lrew'd a preck o" mant," he wrote music. He died about 1799.

Mather, George, musician and teacher, compiled "The Calcutta Melodies, comprising thirty-six original psalm and hymn tunes, London [1844]. The Freehay Singing Class

\section{NATHEWS.}

Manual, London $[1883]$. Also composed songs, etc.

Mather, Samuel, organist and composer, son of Williasn Mather, was born at sheffield in 1783. Orgauist of st. James' Church, sheffield, 1799; St. ['aul's, sheftield, 1808. Bandmaster of the sheffield Volunter's, 1805. He died at Edinhurgh, Mlay 26, 1824. Compiled a Book of Psalm Tumes, and assisted Uotterill in the compilation of his "Christian Psamody." He also composed glees, songs, Te Deum, nmmerous hymm, etc.

Mather, William, urganist and composer, born in 1756. He was organist of St. Paul's, and St. James', sletfield, and died at sheffield, in 1808. Compiler of "Sacred Music, consisting of Twenty-six Psahn and Hymn Tunes..." London 1805$]$; and eomposer of the Psahm-tune "Sheffield," known also as "Attercliffe." His son, John Mathen, bom in sheffield, March 31, 1781, was organist of Sheffield Parish (hurch, 1805, but settled in Edinhurgh about 1810 . Ho was organist at the Musical Festival of 1815 , and from 1815 till 1818, was conductor of the Edinburgh Institution for the onconragenent of sacred Music. He was pianist at the (rla gonw Festival in 1821, and chorus-master at the Edinburgh Festival of 1843 . He also sang at varions musical fertivals. Died at Edinburgh, January 20, 1850. He compresed "Hail to the Chief," a glee; songs: and wrote accompaniments for Peter MLacleod's "()riginal Melodies."

Mathews, James, amateur flutist and composer, born at Stourlridge, June 2, 1827. His father was a talented amatenr both in music and painting, and gare his son such musical instruction as he received, but would not consent to his entering the musical profession. The son deroted all his spare time to the cultivation of the flute, and like his father, became a fine perfomer. He played his first solo in publie in 18.3 ; and up to 1879, was frequently heard in the district, and nearly every year playing in Birmingham, his services being given to every call of charity. On Octolee 7,1868 , he was pubhicly presented with a gold flute, in the Union IJall, Stourbridge, a gift from his friends and admiress. The instrument was designed from his own plan of fingering, and has 32 keys, and his execution on it conld not be excelled. His friendship with Mr. Walter Broadwood, an excellent amatenr flutist, bronght him into contact with many eminent musicians, and he has enjoyed the rare experience, in private circles, of plaving to the pianoforte accompaniment of Joseph Joachim. He has composed nearly 100 songs, a few of which are published; some pieces for flute; and has arranged many movements from the great masters for his instrument. 


\section{MATT.}

Retired from business, he still devotes limself to Music at lits lome, at Clent, in Worcestershire.

Matt, Albert E., trombonist, of the Philhamonic and other orehestras. He is the composer of an orchestral suite, "An Erening Ramble"; "Rural scentes," in three novements; "Angelus" ; Idyl, "Sunset," performed by the Strolling l'layer's' orchestrat, Queen's Hall, 1895; Norwegian Suite, 1897; Idyl, "Dawn," etc., all for orchestra.

Matthay, Tobias Augustus, componer, pianist, and teacher, born at Clapham, London, February 19, 1858. Entered the R.A.MI. in 1S71; studied comperition under sterndale Bennett, Sullivan, and I'ront; and pf. moter W. Dorrell, and WV. Macfarren. First Sterndale Bemnett Scholar, 1572 ; and awarded the first of the two Read l'rizes for a pf. quartet, 1879. Made a Professir, and Assuciate, of the R.A.MI., 1880; and elected a Fellow in 1895. While a student, an orerture and other compositions of his were performed at the Academy concerts. He gave his first concert in Clapham Hall, May 14, 1850, when his prize quartet was performed; and since 18 st has given ammal recitals at Prince's Hall, Queen's Hall, ete. IIe has eontributed articles on music generilly, and lif. toneproduetion particularly, to The Ocerture, The Keyboard, and other paper's. As a teacher he has done excellent work at the R.A. ll., several of the most promising recent students having been his pupils. His componitions are already very numerous, and are ontlined in the subjoined list.

Wonks.-Crehestral: Two Srmphonic movements; Fuur Concert urertures (one produced at Promenade Concerts, 1sig); Scherzi, ete. Concerto; Concert allegro in A minor, another in I minor, for pf. and orehestra. Scena, Hero and Leander, comtralto solo and orchestra. P'salm 126, for chorus. Fright be the place of thy sonl; There be none of Beantr's danghter"s; The gentle erentide; A Lamient (shelley), and other somgs. Fairien' serenade, part-song. String quartet (1872): Quartet in F, pf. and strings (Read prize); Trio, pf. and strings; Idyll, in D flat, violin and pf., Musical Artists' Society, 188t; Ballade, 'cello and pl., the sime, 18s6. About 70 pieces for pr., of which may be mentioned, Four Norelletten: 17 variations on an original Theme, in C; Moods of a moment, 10 mmbers; Sonata in $\mathrm{B}$ minor; 35 variations and evolvements on an original theme, in A minor; Scottish dances; Lyrics, etc.

In August, 1892, he mantied Miss Jessie KENAEDY, a danghter of David Kennedy (q.r.); an excellent rocalist, who has smo in scotland, 1885; London, 1892; and assisted at her husband's recitals, etc.

\section{MATTIEWS.}

Matthew, James E., writer, of present time. Author of "A popular History of Music, Mnsicil Instruments, ballet, and Opera, from st. Ambrose to Mozart," London, Grevel, 1sss; "Manual of Mnsical History," an enlargement of the preceding, 1892; "The Literature of Music," London, Stock, 1896.

Matthews, H., author of "Observations on Sonud: showing the caluses of its indistinctness in churches," etc. London, 1826.

Matthews, John, organist, violinist and composer, born at Liskeard, Connwall, Mareh 27,1856 . Studied at the Conservatorim, Dresden, under Merkel, and Draeseke. Has held organ appointments at St. James's, Swansea; I'arisls Chnurch, St. Austell, Cornwall; and, since 1889 , has been organist at St. Stephen's, Guernsey. There he is actively engaged as a teacleer and eoncert giver. His wife is a elever violoncellist, and takes part in the chamber concerts given by him. His compositions include an Evening Service in D, composed for the St. Austell Deanery Choir Festival, 1s88; Te Deum in F; antlem. Song of the Streamlet; The Nother to her Chilit; and other songs. Part-songs, How soft the shades, etc. Sonata in C minor; six pieces, organ; pieces for violin; and for pf., etc. Editor and translator of Carl Schroeder's Catechism of Violin playing, and of Violoncello playing, Augener. Other works in MS.

Matthews, John Alexander, organist and conductor, born at (iloncester, June 17, 1it1. Educated at King's College School, having entered the Cathedral Choir in 1850. Articled pupil of, and assistant organist to, John Amott, and after his death, 1865, acting organist at the Cathedral, until the appointment of Ir. S. S. Wesley. In 1866 he went to Cheltenham, and has been organist and ehoirmaster of the parish cliurch of St. Matthew since that time. He started a choral society which is now known as the Festival Society, and in 1887 organised a Insical Festival, which is celebrated triennially, and at which several works of importance have been produced. This is under his own management. In 1893 he founded the County of Gloucester Musical Festival Association, numbering more than 2,000 members. He was for 15 years connected with the Gloucester Choral Society, as choirmaster, organist, and cunductor. In 1876 he received a public testimonial from this society at the hands of the then Nayor of Gloncester, Anthony Jones, Esq., and in 1890, a similar token of regard through the Nayor of Cheltenham, Colonel Thoytes, at the close of the Festival. He has had a busy life as a teacher; is hon. local representative of R.A.M., and hon. examiner for R.C.MI. ; and 


\section{MATTHEWS.}

prominent in the work of the Incorporated Society of Musicians. Hon. life member of Triuity College, London. Of his compositions, the songs, The Language of the Heart; God is Iove; Church Bells; and The Merry May, are the best known.

Matthews, Julia, soprano vocalist and actress, born in Australia. She sang principally in opera bonffe, and appeared in the title - part of Offenbach's "La Grande Duchesse," on its first production in English, Corent Gardeu, November 16, 1867. She was also the original Madame Lange, in the English version of Lecocq's "La Fille de Madame Angot," produced at the Philharmonic Theatre, London, November? 1873. She died at New York, May, 1876, at the early age of 34 .

Matthews, Rev. Timothy Richard, clergyman and musician, born at Colmworth Rectory, near Bedford, November 4, 1826. Educated at Bedford Crammar School and graduated B.A., Cambridge, in 1853. He studied the organ under Sir George Elvey. Rector of North Coates, near Grimsby, from 1869 .

Works.-Tunes for holy worship, London, 1859, 2nd edit., 1860 . The village-church tune-book, London, 1859. Congregational melodies; a collection of tunes, chants and responses, London [1862]. liymn tumes, London [1867]. North Coates supplemental tune book, London, [1878], 1883, etc. Anglican chants (Hatchards). The village organist, London 1877]. His hymn tunes, Ludborough, Clenies, and Winthorpe, have been often printed.

Matthison, Arthur, vocalist, actor and author, born in Birmingham, January 31, 1826. He studied singing in Ttaly as a tenor, but his voice afterwards changed to a haritone of rich quality; and he had the rare experience of singing, at different periods, the tenor and the bass solos in the "Miessiah." On the stage he took singing parts, but acted in melodrama at Drury Lane and elsewhere. For several years he was at Booth's Theatre, New York. He was a man of versatile ability, his dramatic works, including "Harold," a five-act drama, and a most successful skit on the hysterical drama, "More than ever" (1882), exceeding twenty in number; and he also wrote the English versions of Balfe's "Talismano," Rossini's "Mosé in Egitto" (for the Sacred Harmonic production of the work as an oratorio, Nlay, 1878), "Mignon," and "La D)ame Blanche," for Carl liosa, the libretto of "Rebekah" for Joseph liarnly, and other pieces. His poem, "The little I Lero," was set liy Michael Maybrick. A volume of Sketches and Exsays was published by J. Camden Hotten, London, n.d. He died in London, Nay 21, 1883. His

\section{MAXWELT.}

younger brother, Henry MatThison, too much engaged in official life in Birmingham to enter the musical profession, was for many years in request as a concert singer, having a sweet tenor voice. He married the Welsh contralto, Kate Wyune (q.v.), sister of Edith Wyune.

Maunder, John Henry, organist and composer, born in Chelsea, London, 1858. Musically educated at the R.A.AI. Organist, St. Matthew's, Sydenham, 1876-7 ; St. Paul's, Forest Hill, 1878-9. Conductor of the Civil Service Vocal Union, from 1881. Has done much work as accompanist, and in that capacity has been especially connected with Mr. Sims Reeves, playing for him at his farewell concert, at the Albert Hall, May 11, 1891. He trained the choir for Henry Irving's original production of "Faust" at the Lyceum 'Theatre, December, 1887. His compositions include an operetta, "Daisy Dingle" (Forest Hill, 1885); a cantata for men's voices, "The Martyrs," composed for the Queen's College, Oxford, Concerts, and produced, May 25, 1894; he has also published several anthems, settings of the Te Deum, and Benedicite, two Evening Services, carols, a chorus, "Thor's War Song," songs, etc.

Maurice, Rev. Peter, D.D., writer and elergynan, born in 1804. Ticar of Yarnton, Woodstock, and Chaplain of New College, ()xford. He died at Yarnton vicarage, March 30, 187s. Author of "What shall we do with Music? a letter to the Earl of Derby," London, 1856. "Choral Harmony, a collection of tunes in short score for four voices," 1854. He composed an evening service, hymn tunes, etc.

Maxfield, William Henry, composer and organist, horn April 37, 1849, at North Somercotes, Lincolnshire. ('horister, it. Philip's, Hulme, Manchester, 1860-5, and pupil of F. Pugh and Dr. Hiles. F.R.C.(), 1ss8. Took the Toronto Mus. Bac, 1889. Has held appointments as organist and choirmaster at st. Peter's, Levenshulme, 1866; St. 'Thomas', Norlury, 1872 ; St George's, Altrincham, 1879; and has been, from 1sst, at St. John's, Altrincham. Conductor of Choral Sucieties at Altrincham, Bowden, and other places; and lecturer on subjects connected with music.

Works.-Cantatas: Jacob and Esau (18ss); Star of the East (1889); The Lord is risen (1890); and The ohl, old story (1892). Choral Ballad. Delphi, men's voices and orchestra; The Silver Lily, cantata for female voices. Anthems, and compositions for pf., organ, etc. Editcd Collection of Fifty Minstrel Songs; Fifty Farourite Songs, ete.

Maxwell, Francis Kelly, anthor of "An Essay upon Tume, being an attempt to 
MAY.

free the scale of Music and the tune of instruments from imperfection," Ediuburgh, 1781; London, 1794. Naxwell died in 1782.

May, Edward Collett, organist and composer, was born at Greenwich, October 29 , 1806. He studied music and the organ under Adams, Potter, and Crivelli. Organist of Greenwich Hospital, 1837-69. Professor of Vocal Music in Queen's College, London. He died at London, January 2, 18s7. Author of "Progressive Vocal Exercises for daily practice," London [1853], and composer of songs, etc. He was celebrated as an organist and teacher.

May, Florence, pianist and composer, daughter of the foregoing, born in London. Her musical talent showed itself very early, and was fostered by her father and uncle; but it was not until some years later, after receiving some lessons from Madame Schnmann, that the young pianist devoted herself to music as a profession. Through Madame Schumann's influence, Johannes brahms accepted Florence May as a pupil, and to that happy circumstance is due her great success as an interpreter of his music. After some years spent in Germany, she returned to London about 1873, and continuing her studies for a further period, she gave her first recital in the Beethoren Rooms, February 3, 1575 . At the Bennett Nemorial Concert, March 0, at St. James's Hall, she played the deceased Master's F' minor ('oncerto. Then followed engagements in London, Liverpool, and other places. Further study in harmony, etc., with her father and Sir G. A. Macfarren was followed by another visit to Germany, and she studied under Bargiel, in Brlin. Two compositions of hers, Benedictus and Osanna, were perormed in Berlin at that time. In 1855 she returned to London, but has since made several tours in Germany, giving recitals in Viemna, 1890-96, etc., and has t uken her place among the leading pianists of the time, giving annual recitals in London. Her published compositions include Three Mazurkas, Bourrée; Waltzes, op. 4 ; and other pf. pieces. Three choruses for female voices; Six sougs with German and English words (her own translation). She has also edited a collection of pieces by Old Masters, from works written for harpsichord, including some by Heury Symonds (q.r.).

May, John, musician, of early part of the present century, composed "A selection of songs, duetts, glees, waltzes, etc., arranged for 1,2 , or 3 German flutes or patent flageolets," Edinburgh, 1809. "The loyal Marine Quadrilles, for pf.," London [1825

May, Oliver, pianist, born at Greenwich, January 27, 181t. His first instruction in music was received from his brother, Edwat Collett, noticed above. At the R.A.M. he

\section{MAYBRICK.}

studied for over five years, under Cipriani Potter, and on leaving was appointed organist at a chapel on Blackheath. Later he ofticiated for some years at a church in Bermondsey, and was for a short time, previons to 1857 , organist at St. Martin-in-the-Fields. He was appointed a professor of the pf. at Queen's College, London, at its foundation. A member of the original committee of the Bach Soeiety, London, he was an actire worker while the society existed; and was for many years a member, and occasionally a director of the Philharmonic society; also a Fellow, R.A.M. His retiring disposition militated against a public life, but as a teacher he was in great request and highly valued. He died at st. Albans, April 12, 1894. A fellow student at the R.A.M. with Niterndale Bemnett, the closest intimacy existed between them. Many interesting mementos of bemnett and other's at his death cane into the possession of his niece, Florence May (q.e.). His published works were few ; an orerture, Ihon Selastian, op. 1, arranged for pf. duet; I seek the haunts; The Moon's pale beam, and other songs. In IIS. remain a quartet for pf. and strings; songs, madrigals, and pf. pieces.

Maybrick, Michael, STEPHEX AlAnIs, baritone rocalist and composer, born at Liverpool, 184t. Nitudied under W. T. Best, and was organist of st. Peter's Church. Liverpool, 1858. In 1866 he went to Leipzig, and studied at the Conservatorim under Moscheles, Plaidr, and Richter; but later turned his attention to singing, and studied with Gatano Nara. He sang at the Oratorio Concerts, London, February 25, 1869, and in the provinces that rear; at the New Philharmonic Concerts, 1970; at the Bristol Festival, 1876; at the principal London and provincial concerts; and in 18st, toured in the United States and Canada. As the interpreter of his own songs he has been a great farourite. Of these songs may le mentioned, A warrior bold; Nancy Lee; 'The Tar's farewell; Garomne; Crood Company; Blue Alsatian momtains; Star of Bethlehem; Children of the City; Valley by the Seat Generieve; Little Hero; Holy Citr; sweet Kildare; MIona; Romany Lass; Fiona, ete. Many of these, particularly "Nancy Lee," enjoyed extraordinary popularity.

Other musicians of the name, and presumably of the same fanily, were Willian Marbiack, born 1779; died, 1843 , a composer of whom nothing alluars to he known; and Michael Marbirick, his son, bom 1799; died at Liverpool, May, 18t6. He was a prpil of Richard Wainwright. ()rganist of st. Peter's, Liverponl, and organist and conductor' of the Liverpool Choral society. He published "Twelve Voluntaries for the Organ; composed in a free style, and founded on 


\section{MAYCOCK.}

Church melodies" (W. Blackman, 1844?), 2 books. Also two sets of original chants; arrangements for pf.; Mozart's favourite air, "Life let us eherish," with new rariations for pf., ete.

Maycock, John Henry, clarinet playcr. was for 35 yeats in the orchestra of the Royal Italian Opra, and of Drury Lane. Dnring his time many English operas were produced, and it was for him that Balfe wrote the eomo di bassetto introduction to "The heart bowed down," and the loass clarinet solo in "The Danghter of St. Mark." For over fifty vears Maycock occupied a high position as a performer. He retired from public life in 1892 , at the age of 75 .

Maynard, John, lute-player and composer, of the 16th and 17 th centuries, published "The xii. Wonders of the World, set and composed for the Violl de Gambo, the lute, and the vovee, to sing the verse, all three jointly, and uone severall ; also Lessons for the Lute and Basse violl to play alome; with some Lessons to play lyra-wayes alone, or if you will, to fill wp the parts with another violl sot lute-way," London, 1611.

Maynard, John, musician, of Ponder's End, Fssex, wrote "Forty-eight original hym tumes, and two pieces," Loudon 18,30

Maynard, Walter, see Beale, Thomas WILLERT.

Mayo, Charles, surgeon and amateur musieian, horu at Winchester in 1897; died on a voyage to Syduey in 1877. Author of a pamplilet on the "Drgan in New Collego Chapel" [Oxford, 1875.

Mayo, Rev. Charles Herbert, author and nusirian. Ticar of Long Burton witl Holnest, 1)orset, since 1872. He has published a number of antiquarian works, family histories, and has issued "Traditional Carols for Christmas Tide, sung at Long Burton, Dorset... . liarmonies arranged by E, C. Howarth," Sherborne 18937 . He also edited "Bibliotheca Dorsetiensis," 1885.

Mazzinghi, Joseph, composer, was born at Loudon, Deeember 25, 176.5 He helonged to a Corsican family, from whiels he derived the title of Count. Pupil of J C. Pach, Anfossi, and Saeclini. Musical director of King's Tluatre, 1784. Nusic teacher to Princess of Wales. He died at Bath, January 15, 1844.

Works.-Musical dramas: A day in Turkey, 1791; Paul and Virginia, 1800: Blind Girl, 1801 ; Exile, 1ی08; La belle Arsene; Sappho et Phaon; Magician no conjuron; Free Knights ; Ramah Droog (witl Reeve); Turupike Gate (Reeve); Chains of the Heart (with Reeve); Wife of two llusloands. Gles, trios, songs, etc.: And whither would you lead me; Ava Maria; O Trignal banks; The captive to lis bird; Cypress wreath; Each throbhing lieart; For tenderness formed; Had I a heart; Harril the

\section{MEEN.}

brave; Hart aud hind are in their lair; Haste, O haste, glorions light; Hope told a flattering tale; Huntsman rest; I seek my shepherd gone astray; If the treasured gold; John of Brent; Lady beware; Lillo Lee; Lochgyle; The MIinstrel's summons; Mirth and beauty; The negro's glee; Noeturnal besiegers; O young Loehinvar; Pastoral Rondo; Roderick Vich Alpine; Soldier rest; Wake maid of Lorn; When order in this land eommeneed; When Phobus rays no more appear; When tell-tale echoes; and, Where shall the lover rest. Songs, ballads, ete. He also composed Admiral Lord Nelson's vietory, a sonata in commemoration of the glorious 1st of August. Twelve airs for the pf., with accompaniments for a flute and tambourine. A large number of sonatas and other pf. picees. Selection of German national melodies.... Lon'on [1815].

Meadowcroft, John, organist and composer, was born in 1827, He was a chorister in IIanchester Cathedral, and for ten years honorary organist at the cathedral evening serviees. He died at Searborough, August 28, 1873. Composer of eluants and editor of a psalter.

Mee, Rev. John Henry, composer and writer on music, born at lididings Vicarage, Derbyshire, August 16, 1852. Sicholar and Taberdar, Guecn's College, Ox ford, 1871; firstclass in Classieal Moderations, 1873; firstelass in Literie Humaniores, 1875 ; P.A., and Fellow, Mertou's College, 1875; Succentor, Queen's College, 1876; M.A. and elassical lecturer, Worcester College, 1878; Mus. Bac., 1882; Mus. Doe. 18s, Oxford. Ordained Deacon, 1876; Priest, 1877, by Bislop of Oxford. Public Examiner in Cniversity of Ox ford three times: Hon. Fellow, St. Miclael's College, Tenbury, 18sf; Preeentor of Chichester Cathedral, 1889: Comnty Councillor for West Sussex, 1890 ; and Coryphasus of Oxford University, 1890. Dr. Mee has done mueh for chamber music in Oxford, and has lectured at the MIusical Association, etc. He luas also eontributed the articles Steibelt, Vogler, and others to Grove's Dictionary.

Works.-Dies Aseensionis for soli, clıorus, and orchestra; Nissa Solennis in 1; Hat, for soli, double-rborus, and orchestra, Oxford, November 9, 1888. Ballads for nen's ehorus and orchestra: Horatius, London, April 21, 1891 ; Delphi, Oxford, 1895. Christmas Carols set to musie; God who at sundry times, anthem. Madrigals, Chloris' singing, Madrigal Society's prize, 1,85; The lesson of Love. Motet. Quartet in G, strings; Fantasia, organ, etc.

Meen, Fountain, pianist and organist, born at Haekuer, London, Septenlber 14, 1846. Not being originally brought ap to the musical profession, his studies were private, and he is for the most part self-taught. Has 


\section{MEGONE.}

been organist suceessively at Clapton Wesleyan ('hapel; St. Mary's, Stuke Newington; and, since 1880 , at Unien ('hapel, Islington. Was organist to the Saered Harmonic Soeiety for the last seren vears of its existence, and has played organ solos at the Ammual Festivals of the Royal Society of Mnicians, of which he is a nember. In 1sisi he sueceeded the late Josiah Pittman as professor of the organ at the Guildhall school of Musie. He is atso Local Examiner for R.C.M., and an Associate of the Philharmonic suciety. As a pianist he is chiefly known as a skilful aecompanist.

Megone, Norfolk, conductor, born in London, March 15, 1860. Situdied as an amatenr under Otto Standke, at Bom ; and also Leipzig and Frankfort. On his reburn to London he became comnected with several musical soeieties, and founded the Belsize Amateur Orchestral Society. In 1site he organised the orchestra of the strolling Players' Anateur Dramatic ('lub, and gave a number of excellent concerts. He joined the profession in $18 \times 9$, and was appointed condue tor of the Deronshire l'arli Concerts, Eastbourne; also of the Privite Pinks Mnsical Soeiety in 1890. He has eomposed " CEnone," and other ralsen, for or'chestrit, etce.

Melba, Madame, sé AmMitrona, Helen Politer.

Mell, Davis, violinist, and clock-malier, born at Wiltom, near Salishury, Nov. 15, 1604. He wasesteened the finent violin player in England prior to the arrisal of Paltzar. Fonne of his eompositions are to he fom in Christopher" Simpson's "Hivision Violin," livt. The date of his death is muknown, but he was a musician in the service of ('harles 11.

Meller, Clara, pianist, burn at Clifton,

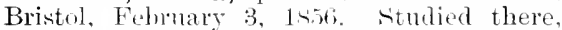
and in fondon, poceerling to Leipzig in 1871. There she entered the Conservatominn, studying nuder Oscar I'aul, and Reineclie. She returned to Ensland, and appeared in concerts in London and the provinces, but was ] te k again in (remany in 1876. In 1890 she wasmared to I)r. Herinam Kretzichmar. now Eniversity Musical I)irestor, Leipzig. Her profesional career was not almandoned, and she oceupies a high position as a pianist in Germany.

Mellon, Alfred, composet and violinist, born in London, April 7, 18:0). 1His earlier years were spent in Bimingham, of which place his parents were natives. He was a violinist at the Roval Italian Opera, London, and conductor at Haymarket Theatre; the Adelphi; and of Pyne and Harrism Opera Company; the Mlusieal society; l'romenade Concerts, Covent Garden: Liverponl Philharmonic Societr. 1805. Married to Miss Woolgar, the actress. He died at C'helsea, London, Nareh $27,1867$.

\section{MERRIOTT.}

Works.-Irish Dragonn, opera, 1845; Mysterious stranger, 1846; Victorine, opera, Covent Garden, 1859. Crown'd with clusters of the vine, glee (1850); Thou soft-flowing Aron; Good night; Let eoncord truse the strain, etc. Cupid's eyes, song, and numerons other songs and pf. pieces.

Mellor, Richard, organist, born at Huddersfield, Mareh 2:3, 1816. Was appointed organist at Zion Chapel, Lindley, when just eighteen; and later held similar posts at Linthraite Church; Honley Wesleyan Cliapel (where he played the arolophon, a preeursor of the harmonimm); rit. Patrick's Roman Catholie Church, Huddersfield; and Ransden Street Independent chapel, where he remained 33 years. He retired from aetive duty about 1sit, but played the organ at the Huddersfield Exhibition of 1A8:3. For some years he undertook eoneert arrangements, and introdueed Sims Reeres and other great artists to Huddersfield, and was a notable figure in the musical life of that town.

Melton, William, writer, Chancellor of the Duchy of York, fiourished during the early part of the 16th century. Author of a treatise entitled, "I Mlusice Feelesiasticit," preserved in MŚ.

Menzies, Archibald, violinist and famous reel player, was born at Ioull, Perthshire, in 1,of, and died at Edinburgh on July 16,1856 . Ihe was in the orchestra of the Theatre Royal, Ediuburgh, and took part in many eompetition concerts organised by Jullien and others.

Menzies, Daniel, amateur composer and violinist, was born alyout 1790, and died about 1828. He wai a captain in the army. He composed a number of good strathspeys, which are contained in the eollections of Duncan II Kercher.

Merbeck, John. Ser Marbecli, Johr.

Meredith, Edward, hass singer, horn near Wrexham in 1741. He was diseovered by sir W. Wym singing in a enoper's wortishop, and was by that baronet put with singing masters and properly trained. He luad a very fine voice and saug at thr Aneient Coneerts in London, but was ehiefly ilentified with Liverpool, where he sang at all the principal eoneerts. He died at Wrexham, 1)ecember $26,1<0$ ?.

Merriott, Edwin, composer, of first half of the present eentury. He compiled "Select portions of the Psalmis of David, with original melodies...sung at Farwham and Basingstoke" [1826]. Composer of a large number of marehes for military band or pf., among which may be mentioned a once popular one in imitation of a band in the distance [1835]. The suceess of this led to tho composition of many other marches Cireassian. Coronation, etc., issued between 1835 and 1840 . He also 


\section{MERRYLEES.}

published Drawing Room Melodies, London, [1838]; Progressive Exercises for the pf. [1838]; Progressive Lessons for the pf. [18261836]. Songs, etc.

Merrylees, James, amateur composer, born at Paisley, April 10, 1824. He studied music under John Curwen and Colin Brown, and gained the Fuing silver and gold medals for the best hymm tune and anthem, in competition, in 1871-72. He died at Dullatur, Dumbartonshire (detached), Oetober 31, 1891. Fditor of the accompaniments in "The Thistle," a collection of Scots music compiled by Colin Brown. He also arranged for four voices, Stewart's "Killin Collection of Gaelic Melodies." His compositions were chiefly part-songs, anthems, and hymm tunes, such as "Atlantic," "Formosa," eto.

Metcalfe, Rev. Joseph Powell, musician and clergyman, horn at Canterbury in 1824. He was educated at Cambridge, and graduated B.A., 1847; M.A., 1850. Ordained in 1847. Rector of Bilbrongh, Yorkshire, 1856.

Wonks.-School Round Book. Rules in Rhymes and Rounds. Netrical Anthems. Rounds, Gatches, and Canons of England (with F. F. Rimbantt), London, 1873. Contributions to Musieal Literature, ete.

Middleton, Edward Hulton, organist, born at Failsworth, near Manchester, Feloruary 26, 1854. Articled pupil of .T. Kendrick Prone; also studied under tames P'attinson, Fir. J1. Watsm, and Henry Wilson. F.R.C.O. Gradnated Mns. Pac., 18st; Mus. Doc., 1887, Cambridge. (Heanist of St. Mary's, Higher Cxmmpsall, Nanchester, 1ssid): Professor of Music, Wesley ('ollege, sheffield, 1883; and from 1889 organist and chomaster, Kelvinside Free Church, Glasgow. Has given organ recitals at Edinhurgh fexhibition, 1890, ete., and has composed a (antate l)omino, and $\mathrm{Te}^{\mathrm{x}}$ Demm, for soli, chorus, and mehestra.

Midgley, Samuel, piantist, hom at Bierlev, near biadford, Forkhire, Thecmler 2:2, 1849. His father played the violin, and was sometime choimaster at Pethel ('hapel, Bierley. The son hat his first organ appointment at this ehatel, and held the like at satem Chapel, and Tong Street Chureh. He studied for a time moder dames Proughtom, and afterwards procesered to Leipzig. where he studied muder lieinecke, l'apperitz, Oscar Panl, and others. At the public rxamination, Easter, 187.1, he distinguished himself in the performance of Bemett's F minor Concerto. On his return he settled at Bradfurd, and gave his first chamber encert, September $23,1874$. He has given anmul series of these ever since, and brought forward many important works by L'ary, Stanforel, Mackenzie, I'ront, Asliton, and others, lesides comprositions of Pemett, Westrop, ete. Ho is conductor of Cleckheaton

\section{MIILLAR.}

Philharmonic Society ; pianist at the Ilkley subseription concerts; and acconpanist at the Bradford sulsscription concerts, and writer of the analytical programmes for the same. Examiner for the Ineorporated Society of Musicians; and local representative, R.A.M., and R.C.M. In 1888 he married Henrietta Tombinson, a soprano voealist, who has sung in oratorio and lallad concerts throughout Yorkshire and adjoining counties, and has also been heard in London, with her sister, Marion Tomlinson, an excellent contralto.

Miles, P. Napier, amateur composer of present time. l'npil of Dr. Hubert Parry. His setting of Coleridge's "Hymm before sumrise," for baritone solo, chorus, and orehestra, was prodnced at the Bristol Festival, Octoleer 15,1896 , He has also composed a Symphonic suite for orchestra, produced at Riseley's concerts, Bristol; and a Sonata in B minor, for violin and pf., Bristol, 1892.

Miles, R. E., bass vocalist, born in Rochester, May 24, 1857. At the age of nime, entered the Cathofral as a chorister, remaining there five year's. Then for a time was tutor and musical instructor in the family of Captain Nalcolm, R.L. Afterwards entered R.A.M., as at pupil of Alberto Randegger. In 18R1, apprinted chormantex of St. Mark's, Lewisham; and in 18 s6, clected to the choir of St. Paul's (athedral, loth of which positions he still retains. Appuinted by sir (r. A. Macfarren, professor of singing, JR.A.Ml., 1884. Professor, (Hillihall schorl, 1896. Has sung in oratorio at the principal concerts; at the Crrstal Palace, and Royal Alloert Hall, ete., and is a successful tracher of singing. Of his commonitions, chureh services, and many songs are in MS., but he has published a few songs, The stars are with the voyager, The language of thr heart, etc.; also a leaflet, "How to sing a hong."

Milgrove, Benjamin, composer, born probably at Bath about 1731. Ile was precenter of the Comntess of Huntington's chapel, Bath, and died in 1sio). Composex of (hureh music, and of "sixteen hymms as they are sung at the Right Honomralile the Comtess of Huntinglom's Chapel in Bath" 1769$]$.

Millar, Marian, pianist and writer, born in Manchester. Sturlied muder Dr. Hiles, and gained First Class homours, with distinction, in ('ambridge Cniversity higher local examinations in musie, 1884; and the Professimal Diploma (in pf. playing) of the Incorporated siciety of Musicians, with First Class honours, 1886. Though not the first of her sex to pasis the Examination for a Degree in Nusic at an English Unisersity ride Elizabeth Stirling, 1856; Adelaide Thomas, and Emilie B. Grant, 1892,-Miks Nillar has the distinction of loing the first woman to ditain the degree of Mus. Bac., at Victoria 


\section{MILLAR.}

University, Manchester, June, 1894. She is professor of harmony and pf. at the Manchester High School for Girls, an appointment held from 188t. Her degree exercise was "A Song of Praise," for soli, chorus, and small orchestra. She wrote the libretto of "The Crusaders" (Dr. Hiles), and "The Armada" (G. J. Miller); and contributed many articles and translations to The Quarterly Musical Review (Manchester, Herwood, 18858), with some lyrical pieces.

Millar, Samuel, trombonist of present time. He has made a special feature of music for trombone and organ, and has frequently played at the recitals given by H.J. B. Dart (q.v.). He is also known as a trombone soloist at eoncerts, and he played Ferdinand David's Concerto for trombone at the College Hall, Richmond Green, November 20, 1884. $\mathrm{He}$ is professor of the trombone at the R.C.MI.

Millard, Rev. James Elwin, headmaster of Magdalene College Schrol, Oxford. Vicar of Basingstoke; Canon of Winchester. Author of "Historical Notices of the office of Choristers," London, 1ists. Account of Basingstoke and other works.

Millard, Mrs. Philip, rocal composer, of first part of the present century. She wrote a number of solggs, of which" "Alice Gray" (1835) was perhaps the most popular. Other songs were Ilinna forget; Forget thee my insie: Happy New Tear; Lament of the Scotch fisherman's widow: Soldier's return, etc.

Millard, William, musician, of early part of this century, issued "The Branch, comprising Forty i'salm and Hrmm tumes," London 1810

Miller, Agnes Elizabeth, pianist, born at Brierley Hill, Staffs., April 20, 1857. From the age of eleven she studied under Mrs. WT. P. Marshall, of Bimingham (a pupil of Noscheres). In 1873, she went to Mainz, studring under Berschlag: and in 1876, was admitted to the linyal High School for Musie, Berlin, where her teachers were Rudorff, Bargiel, Franz schutz, and, for history, spitta. She played at the semi-public concerts, and had the privilege of teaching two daughter's of Dr. Joachim. In 1879 she retumed to England, and established herself as a pf. teacher in London, giving some time to pupils in Birmingham. At the Saturday Popular Concerts, 1884, and in the provinces, she was assoeiated with Joachim. Made her début at the Crystal Palace, Narch 7, 1885, plaving Peethoven's C Minor Concerto. Gave ammal series of chamber concerts in Birmingham, 1883-91, and gained an honourable position among pianists of the day. Married Herr Schanenburg, a frerman engineer, and in 1891 went to reside at Berlin.

Miller, Alexander, military bandmaster,

\section{MIILLER.}

entered the service in 1833, in the First Battalion, Rifle Brigade. Served in Kaffir wars of 1846 and 1850 ; in the Crimea, 1854-5. Afterwards bugle-major and bandmaster, Edinburgh Queen's Light Infantry; appointed Queen's trumpeter, 1862; bandmaster First Midlothian Artillery Volnnteers, 1878. This band, under his skill and zealons labours became one of the foremost in Edinburgh. Owing to ill-health he resigned this appointment in April, 1891, and died early in the winter of 1892-3.

Miller, Edward, Scottish musician, of the early part of the 17 th century, who was a teacher at Edinburgh. He graduated M.A. at Edinburgh University in 1624 , and has been identified as a teacher who taught children in Blackfriars Wynd, Edinburgh. $\mathrm{He}$ is best remembered as editor of "The Pralmes of Darid, in prose and meter, with their whole tumes in fonle or mo parts, and some psalmes in reports...." Edinburgh: heirs of Andrew Hart, 1685. The preface to this work is signed "F.M.," and Miller has been proved to have been the editor.

Miller, Edward, composer and writer, was born at Norwich in 1735 . He was apprenticed to a pavionr, but absconded and studied musie under Burney at Lym. Organist of Church of Doncaster, 1756-1807. Mis. Doc., Cantab., 1786. He died at Doncaster, September 12, 1807.

Works.-Six solos for German flute; Six sonatas for the harpsichord, with an accompaniment to three of them for a violin or German flute; Elegies, songs, and an ode, with instrumental parts; Twelve songs, 1773; Psabms of David, for the use of Parish Churches, London [1790], edited by G. H. Drummond; Sacred music, containing 250 of the most favourite tunes. . the music selected and adapted for two, three, and four voices, and intended as an ampendix to Dr. Watts' Psalms and Hymus, 1802; Psalms and hymms set to new music, 1801. Institutes of Music or Easy Instrizetions for the Harpsichord, London, n.d. 1771]: Elements of Thoroughbass and Composition, London, op. 5, 1787; The Psahms of David set to music, and arranged for every Sunday in the year, 177t; Treatise of Thorough-bass and Composition, Dublin, n.d.; History of Doncaster, Doncaster, 1804 .

Miller, George John, bandmaster and composer, born at Pimlico, London, Novem. ber 26,1853 . He comes of a military family, his grandfather fonght at Salamanca, and his father was hardmaster of the 63rd (Manchester) Regiment. In this corps young Miller began his musical eareer. He afterwards became assistant in Alfred Mapleron's Music Library, and then enlisting in the 1fith Regiment, he was sent to Kneller Hall to ntudy. 


\section{MILLER,}

While there he trained the choir at St. Stephen's Mission Church, Hounslow, aud was organist at Whitton Parish Church, In 1875 he was appointed bandmaster of the $16 \mathrm{th}$ (Bedfordshire) Regiment, and went to India. Returning, he was made bandmaster and organst of the Ruyal Military College, Sandhurst, 1880 ; and in 1884 became bandmaster of the Portsmouth Division. Royal Marines. L.T.A.M., 1882; Mus. Bac., C'ambridge, 1892. His band is famed all over the Empire, a: d he frequently has to conduct at Usborne, ete. He also eonducts an anleur operatic society, and the Nimesingers glee club. His compositions comprise a cantata, The Armada; concert overture, Evangeline; Nautical fantasia, and many original pieces and arraugements for military and string bands; an oporetta, ete. He also composed the funeral mareh for the obsequies of Prince Henry of Battenberg, 1896. Editor (with Francois Cellier) of The Soldier's Sung l3ook, London, Clowes, 1897.

Miller, Henry Walter, composer, organist, and writer on music, born in London, June 15,1843, son of the late Rev. I)r. Miller, Viear of Greenwieh. Educated at Oxford, where he graduated Mus. Bac., 18665 ; B.A., 1\$6s; M.A., 1875. Musieal training private. Organist of Hobart Cathedral, and Examiner to the Govermment of Tasmania, 1885; Conductor to the Brisbane Musical Union, and Ipswieh (Queensland) Choral Society, 1887. Organist of the American Episeopal Church, Niee, 1894. In 1874 he initiated the Tallis Menum. rial Fund, for placing a Brass in Greenwich Parish Church, which was accomplished in 1876.

Wokks. - The Seasons, for soli, chorus, and orehestra; Cantata, Paridise and the L'eri; Jubilee P'rize Ode (Qneensland), for soli, chorns, and orehestra. Dno Concertante, organ and trombone. Anthems, songs, organ, and $\mathrm{pf}$. pieces. Author of "Notes on Old English Music," London, 1875, and magazine artieles; Editor of the "Gregorian Quarterly Magazine," 18\%:3.

Miller, James, friend of Bums the pet, and reputed composer of the air usually sumg to "Te Banks and liraes o" Bonnie Doun." He was a writer in Edinburgh, and a friend of Stephen Clarke ( $\left(1 . x^{\circ}\right)$, who put the tune into shape. Burns account of the origin of the air will be found in his correspondence with George Thomas. See also Chappell's "Popular Nusie of the olden time," and Glen's "Scottish Dance Musie," 1891. The tune was first published in Gow's second collection as "The Caledonian Hunt's delight." in 1788 .

Miller, William, organist and anthor, was horn in 180!\%. Ile was the first organist of the Sacred Harmonic Society, London, and held the post for 14 years. From 1832

\section{MILLS.}

till 1873 he was organist of St. Giles', Cripplegate, London, in which he took much interest and was active in raising funds for its restoration. He died at London, June 25, 1873. Author of a history of St. Giles' Chureh; a little brochure, entitled, "Juttings in Kent," etc.

Miller, William Mackie, teacher and conductor, was bom at Glasguw, October 2I, 1831. Conductor of Tonic Sol-fa Society, and late prineipal of a College of Music. He was Precentor of Free St. Matthew's Church, Glasgow, and superintendent of music in the Glasgow Board Schools from 1873. He died at Glasgow, February 3, 1894. He edited a few works by Handel, in the tonic sol-fa notation, and wrote a "Tonic Sol-fa Flute Instructor," Edinburgh, n.d., and other works clesigned for instruction in the tonic sol-fa notation.

Mills, Edward, organist and teacher, was a choir boy at Portman Chapel, Marylebone, and played the organ at the afternoon services at St. James's, Marylebone. Student, teacher, and eventually organist and music master, St. John's College, Pattersea; Whiteland's College, Chelsea; and Home and Colonial College, Gray's Inm Road. Graduated Mus. Bae., Oxford, 1881 his exercise being a setting of Psalm 32. He has published a Course of Sight Singing

Mills, Rev。John, IECan Gitan Alarch, musician and clergyman, born at Llanidloes, December 12, 1812; died July 28, 1873. Anthor of " (iramadeg cerddoriaeth yn nghyda geirlyfr enwedigaethol yn cynwys eghrhad ar y geirian ambhynefin a arferir yn y Gwaith," Llandoes, 18 is.

Rrcharis MnLLs, bom near fianidloes in Narch, 1809; died in September, 184t, wrote - Caniadan Seion, sef casgliad a donau addas i'w cann yu yr addoliad dwyfol. ." Jlanidloes, $1840-42,2$ parts.

Mills, John Henry, musician, puhisled "A Selection of Sacred Poetry, set to music," London, 1R60. "A selection of saered I'oetry for private and congregational use, set to musie," I ondon, $186 \%$.

Mills, Robert Watkin, baritone vocalist, born at Painswick, Gloncestershire, March 4 , 1856. Sang in the chureh ehoir there as a boy. A baritone voice developing, he was in request at local concerts. He then went to London, and studied under Edwin Holland, afterwards proceeding to Milan, he studied with S. Blasco ; and on his return to London had some lessons from Alfred Blume. He made a successful dibut at the Crystal Jalace, May 17, 1884, and a still greater impression in the "Messial,," at the Royal Albert Hall, January 1, 1885. He then sang at the Monday and Saturday Popular Concerts, and made his first Festival appearance 


\section{MILLS.}

at Birmingham, in August of the same year. In 1886 he was heard at the Gloneester and Leeds Festivals, and took his plaee among the first singers of the day, singing at every important eentre in the Kingdom. From 1894, he has made annual tours in Canada and the United States, singing at Festivals, and giving vocal recitals. He made one appearance in opera, at Birmingham Theatre Royal, as Buldassare, in "La Favorita," May 21, 1884, but declined Mr. Carl Rosa's offer of an extended engagement, deroting himself to concert work, and oratorio singing.

Mills, Sebastian Bach, pianist, eomposer, and teacher, born at Cirencester, March 13, 1839. He studied music at Leipzig, and settled in New York, 1858. He played in London as an infant prodigy in 1815, and at the Gew undhans Concerts, Leipzig, December 2, 1858. Teaeher and composer in New York. He has published numerous pieees for the pf., and is regarded as one of the leadng pianists in America.

Milne, Peter, violinist and composer, was born at Kincardine O'Neil, Aherdeenshire, September 30, 1824. He was a violinist in Aberdeen and Edinhurgh. Cmmpler of a "Sielection of strathspeys, reels, etc....," Keith, n.d. This work has reached at least 5 editions.

Milner, Abraham, musician of the 1 sth century. Compiler of "The Psitm singer's Companion, being a collection of psalm tunes, hymns, canoms, and anthems. with an introduction to psalmody..." 1751. " The Psalm Singer's Pocket Anninement, being a collection of pralm tunes..," London [1750]. A Colleetion, Revival and Refining (from the more gross and obscene songs) of the old catch books, together with a variety of two and three-part songs from the most eminent masters," London [1750]. Sacred Melody, being a ehoice collection of anthems....,", London 1780].

Milnes, George, alto vocalist, born at York (?) about 1815. Sang in the chorus at the York Festivals of 1823-5-5, and 1835, in the last year removing to Fuddersfield. Menber of several chunch choirs in that town; one of the founders of the Huddersfieid Choral Society : and principal alto at the George Glee Cluts in its best days. He died at Hnddersffeld, Nosember 25, 1883.

Milton, John, musician, who was born about the end of the 16th century. Scrivener in Bread street, Cheapside, London, where he died in 1646. Composed "Fayre Oriana in the Mone," madrigal, and numerons songs and motets in the principal collections of the period. His merits as a musician are celebrated in a short poem, "Ad patrem," by his son, the great poet, whose works have been set by numerous composers, like Handel, Lawes, King, Nelson, and others.

\section{MITCHISON.}

Minns, George, tenor rocalist, lay-clerk of Ely Cathedral, won the Molineux Prize of t10 offered by the Madrigal Society, in 1882, for the best madrigal. He has pulblished a Rustic Dance; Tarantella; and other pieces for pf.

Minshall, Ebenezer, organist and conductor, born at Oswestry, Salop, in 1845. Intended for the law, but, adopting music, became organist, when 16, at Leatherhead Congregational Church; then took a similar appointment in Oswestry; and remoring to London in 187t, was organist at Txloridge Road Chapel. In 1876 he was appointed organist and director of the mumic at the City Temple, where he remained mitil 1893. In 1881 he started the Thursday Popular Coneerts in that building. He is Chaiman of the Nonconformist Choir Lnion, formed in 1888, and eonductor of its ammual festivals at the Cristal Palace; has lectured on musical sulijects; and is the componer of anthems, hymm tunes, etc. Editor of The Nonconformist Musicul Joumal; Organists' Magazine of Volnntaries; and Modem Orman Music. Anthor of "Organs, Organists, and Choirs," London, Curwen.

Mitchell, C. H., anthor of "How to hold a fiolin and bow," 1, she.

Mitchell, Helen Porter, see trustrosa, Helex P'ORTER.

Mitchell, James, anthor and inventor, born at Kilmanock, April 19, 1831. Resident at Coatbridge. Inventor of an innproved metronome, and author of a work on Musical Theory, illustrated by diagrams, 1878.

Mitchell, John, hass vocalist. Entered the choir at St. Feorge's ('hapel, Windsor, in 1815 , when six years of age. Sang at the Coronation of feorge IV., William IV., and Queen Vietoria: also sang at the Jubilee Service, Westminster Alihey, Jume 21, 1887. In that year Her Majesty presented him with an engraved portrait of hernelf in recognition of his long musical serviee. He completea his 75 th year with the chapel choir, May 1890; and died in the Horseshoe Cloisters, Windsor Castle. January 6, 1892, aged 82. He was organist of Eton College for about 40 years.

Mitchison: William, musician and publisher, was born about 1809 . He was a music publisher in Glasgow till about 1854 , when he went to America. He died at Brooklyn, July 1, 1s67. He issued The Psalmist's Companion, a eollection of devotional harmony for the use of Preslyterian Churches, seleeted from the works of Steven, Robertson, R. A. smitl, ete., flasgow, n.d. [c. 1813]. A few Remarks on the Pianoforte, giving details of the meclanical construction of that instrument, ete., Glasgow, 1545. Selection of Sacred Music, n.d. R. A. 


\section{MOBERLY.}

Smith's anthems, edited Glasgow, n.d. The Garland of Scotia, 1841. Handbook of the Songs of Scotland, with music and descriptive historical notes ... to which is added a biographical sketch of the life of the late John Wilson, the celebrated Scottish vocalist, Glasgow, n.d.

Moberly, Rev. E. H., amateur conductor, born at Winchester, October 20, 1849. Son of the late Bishop of Salisbury. Selfeducated in music. Bronght up for the church, and took orders; but gave up clerical work about 1887 . aud devoted himself entirely to music. In 1885, he formed a musical society in Hampshire, the Test Valley; and later a similar one in North Wilts. From about 1885 he has given concerts for charitable purposes with a Ladies' String Orchestra, which has now attained a high reputation. He visited London with the orchestra in 1892, and gave a concert in Princes' Hall, May 19; and again at St. James's Hall, in 1893, and later. The orchestra has been heard in Oxford, Birmingham, and other places.

Moffat, Alfred Edward, composer, born in Ediuburgh, I)ecember 4, 1866. From 1852 to 1898 studied composition with Ludwig Bussler in Berlin. Since 1889 , he has resided partly in Germany and partly in Britain, deroting himself entirely to composttion and arrangements of various kinds, many of his works being published in (iermany.

Works.-Cantatas: The Passing Year; The I)ressing of the Well; The Children of Samuel; A Christmas Dream; all for female or children's voices. Album of ten trios for female roices; Pastoral album, two books, duets; Twelve duets; Six duettinos; Three duets, witl female chorus; Twelve sacred rounds; Fight books of scliool songs, ete. Two songs, with violoncello obligato; Four songs, etc., etc. Arrangements: The Minstrelsie of Ricotland (200 Scottich songs, Augener); Twelve Sicottish songs, in three parts; Folksongs of England, eight books (Paterson); Songs of the British Empire, etc., etc. Instrumental: Quartet, pf. and strings (Berlin, 1886); Twenty-fonr pieces (Simrock); Abbum of twelve pieces (Angener); Album of six pieces, etc., all for violin and pf. Twelve salon pieces, Twelve pieces, Sonata, for violoncello and pf., etc. Arrangements for pf. and strings: (rolden Sonata, P'urcell; Thirty-two classical pieces (Schott); Nine pieces (Preitkopf and Härtel), ete. For pf. and violin: Three sonatas (oboe and figured bass), Handel; Album of twelve picces, etc. For pf. and violoncelln: T'wo albums, twenty four pieces; I yricche stiicke, ten pieces; and a large number of pieces by Hanclel and Narcello. Thirty Highland reels and stratlispeys, arranged for pf., etc.

\section{MOLINEUX.}

\section{Mogford, Mrs. See Fricker, Anne.}

Moir, Frank Lewis, composer, born at Market Harborough, April 22, 1852. Originally intended to follow his father's art, that of painting, but began composing music while an art student at South Kensington. He gained a scloolarship when the National Training School for Music was opened in 1876, and soon acquired a reputation as a song composer. His works include a comic opera, "The Royal Watchman," Exeter, 1877 ; Church Services, etc. One Summer night; The wish of my heart; The story of years; The Golden Meadow; Only once more; Best of all; and an immense number of other songs; Duets, Over the Heather; Love shall never die; and others. Madrigal Society's Prize, 1881, When at Chloe's eyes I gaze; Melody in A, violin and pf., etc. He married, April 5, 1886, Miss Eleanor Farnol, of Birmingham. She is a soprano vocalist, and studied under W. C. Stockley, and at the National Training School. She has sung in London and the provinces, and has taken part in the vocal recitals given by her husband.

Moir=Clark, see CLAliK, J. MIOIR.

Molesworth, Lady, born Carstairs, a soprano singer who was born about 1810 . Her father was Bruce Carstairs. She studied at the R.A.M., and first appeard at a singer under the professional name of Miss Grant. In 1831 she married Mr. Temple West, the virtuoso, who died in 1839 . She next married Sir William Molesworth in 184t, and retired from public life. She died on May 16, 1888.

Molineux, John, musician and author, of latter part of last and first-half of present century, who resided for a time in Liverpool, where he had a music academy at Newington Bridge. Author of "The Singer's Systematic cruide to the hicience of Music," London, 18:31; "Concise Cullection of the rudiments of Tocal Mnsic, intended to assist persons who practice glees or chunrch music, in the art of singing at sight," London [1830]. "English P'salmody, domestic, choral, and congregational, being a collection of sacred music," [1829]. "The Yenite, Te Deum, Benedicite, etc., properly accented and adapted to favourite chants," Liverpool An Essay towards an elucidation of the principles of musical liarmony, London 1841. Principles of the notation and the science of music.... London [184t]. Songs, ete.

Molineux, Thomas, horn in Manchester, September 16, 1802. liefore he became known as a pf. maker, was a practical musician. While a yonth he studied the flute, and later acquired skill on the violin, 'cello, and doublebass. Ile was still more accomplishea as a performer on the bassoon, and played at the Gentleman's, Professional, and other concerts in Manchester up to about 1850. He was 


\section{MOLLESON.}

offieially connected with St. James's Hall, and the Polyteehnic Institution, London; and will be remembered for his munifieent gifts to the Royal Society of Musiciars. $\mathrm{He}$ died in London, January, 31, 1891.

Molleson, Alexander, Scottish minor poet, was a bookseller in Glasgow at the end of last and beginning of the present eentury. Author of "Melody the soul of Music, an essay towards the improrement of the Musical Art," Glasgow, 1795 ; reprinted in his "Miscellanies in Prose and Verse," Glasgow, 1806.

Molloy, James Lyman, amateur composer and writer, horn in 1837. Eldest son of Kedo Molloy, Esq., of Cornolore, King's Comnty, Ireland. M.A., of the Roman Catholic University of Ireland. Called to the English bar, 186t. Married Florenee, youngest daughter of Henry Baskerville, Esq., of Crowsley Park, Lord of the Manor of Shiplake, and deputy-lientenant for the County of Oxford. Secretary to the late Sir Johm Holker, attorney-general. Nember of the Sunth-Eastern Cirenit, and Brighton Sessions, and of the IIiddle Temple, ete.

Wonks.-Operettils: Student's frolic; $\mathrm{My}$ Aunt's secret ; Very catching. Songs: Blue eves; Because 1 do; By the river; Bird and the cross; Child's vision; Clang of the wooden shoon: Love's old sweet song; 1)arby and Joan; I Iome, dearie, home; Rosenaris; old Sailor wife; Irish piper; Thady O'Flim ; The carnival; lierry dance; A race for life; Vagahond; and many others. Six Song Stories for children. lrish melodes (Bmosey), edited with new accompaniments. Prose work: Our Antumm Holiday on French Rivers.

Monk, Edwin George, manist and composer, born at Frome, Somerset, December 13, 1819. Pupil of Henry and (reorge Field: later, in London, joined Hullah's classes, and studied singing with Henry Phillips. Held organ appointments at Midsomer Norton; Christ Church, Frome: and, 18t4-46, at st. Columba's College, Rathfarnham, near Dublin, Then studied composition under G. A. Macfarren. In 1847 he was in Oxford; and the next year was appointed organist and music master at St. Peter's ('ollege, Radley. Graduated Mus. Bac., 1848; Mus. Doc, 1856, Oxford. In 1859 he was appointed organist of York Minster, in sucession to John Camidge, an office he resigned in 1883. Examiner for musical degrees, Oxford, 1871-83. Now resident at Radley, near Abingdon.

Works.-Milton's Ode to the Natirity; Ode, The Bard. Enison service in A : Evening service; God so loved the world, and other anthems; hymm-tunes, ete. Boating song; Football song; The jolly cricket lall; and other part-songs. Editor of the Anglican

\section{MONK.}

Chant Book; Anglican Choral Service Book; with Rer. R. Corbett Singleton, Anglican Hymm Book; and, with Rev Sir F. A. G. Ouseley, The Psalter and Canticles pointed for chanting; and Anglican Pralter Chants. Compiler of the libretti of G. A. Macfarren's oratorios, St. John the Baptist; The Resurrection; and Joseph.

His youngest brother, IIENRY TheophiLt's Monk, born at Frome, March 6, 18:31, studied under his brother, and afterwards under C. W. Lavington and (Sir) G. A. Macfarren. He was successively organist at Wells; Radley, Berlis.; and st. Philip's Chureh, Sheffield. Music master and organist at Forest Schools, Walthamstow. He was minfortunately drowned while bathing in North Wales, July 23,1857 , at the outset of a promising career. He composed some chants and other vocal music.

Monk, James Jonathan, organist, composer, and teacher, born at Bolton-le-Noors, February 20, 1846. Studied under James Thomson, and 1). Westlorook. Has held rarious organ appointments in the neighbourhood of Liverpool, where he resides as teacher. Gave organ recitals at the Liverpool Exhibition, 1887 ; and annual concerts of his pujils. Has acted as musical eritic for the Liverpool Courier, and Liverpool Eiening Express; has been for many years the local correspondent for the Musical standard; and has contributed to The choir articles on the St. George's Hall organ, and other local matters. His compositions include a Te Deum; Festival antlem, O be josful in God. Ah! thou pale moon; True for ave; Primose lane; Oh, give me back those kisses; and other songs. I met my love, part-song. The Water Mill, pf piece, etc. A paper read at Liverpool, in 1853 , led to the Compilation of a Mnsieal Directory on more distinctly professional lines, in 1884 ; but the experinent was not repeated.

Monk, Mark James, organist and composer, born at Hummanhy, Forkshire, March 16, 1858. Musically educated at York Minster, 1867-78, mader D)r. E. G. MIonk. Organist of varions churehes in York; st. John's, Ladywood, Birningham, 1879 : Parish Church, Ashby-de-la-Zouch, 1880 ; Banbury, 1883; and of Truro Cathedral from 1890. Diocesan choimaster, and conductor, Choral festivals: Precentor of Deaners of Pinder Choral Ansociation; conductor' of Truro Philharmonic, 1890. Graduated Mus. Bac., 18тs; Mus. Doc., 1888, Oxford. F.R.('). Composer of an Elegiac Ode (Coplas di Manrifue), for suli, five-part chorus, strings and urgan: Festival Te Dewm; Quintet for wind; Madrigal for fire roices; pf. and organ pieces, ete.

Monk, William Henry, composer and organist, loom in London, Warch 16, 1823. He studied under T. Adams, J. A. Hamilton, 
MUNRO.

and ( $r$. A. Crieshach. Organist of Eaton Chapel, I'indico, I womon, 1811-43; St. George's Chapel, Albemarle street, 1843-45; Portman Chapel, Natrybome, 18+5-47. Choir-master, 1847; organist, 1849 ; and Professor of rocal music in King's College, London, 1874. Professor of nutsic at School for Indigent Blind, 1851. Organist of St. Mattlias, Stoke Newington, 1852. Professor in National Training College for Mnusie, 1876; Professor in Bedford College, Lundon, 1n78; Mns. Doc., Durham, homoris cansî, 188:. He died at Stoke Newington, London, March 18, 1889.

Works.-Te Demms, Kyries, and other worlis for the church service. Anthems: And the angel Gabriel; Blessod are they that alway keep judgment; If ye love me keep my commandments; In God's word will I rejoice; Like as the hart; The Lord is my strength; They shall cone and sing, cte. Hymms, psalins, ete. Hymns of the Chureh, Lundon, n.d.: The Holy Year, or hymms for Simdays. holidars, and other necasions thronghout the year. .with applopriate tunes, Lomdon, 1865; Fifty-two simple chants: The Canticles arraiger for chanting to the ecelesiastical tones; The Book of Pralms in Metre (Church of Scothand); Senttish Hymmal (edited); The Psalter (C'hurch of Scotland); Book of Anthems (Church of Scotland), etc.

Dr. Momk composed many popular hymm tumes, of which "Eventide" is perhaps best known. He also acted as musical editor of "Hvmms, Aneient and Modern." His danghter FLORExCE is a soprano vocalist of repute.

Monro, George, composer and organist, was lum ahont the end of the 17th century. He competed musuccessfully against T. Rosingrave for the post of orgaisist of St. Feorge, Hanover Square, London, 1725. Afterwards he becane organist of st. Peter, Combill, and harpsichord player at Goodman's Fields Theatre. He dited at London in 1731.

Worlis.-Trmple Buan, an opera. Songs : Amorons swain's complaint; Charm of wine; Complaining maid; Gold, a recespt for love; Happy Dick: Passionate lover; Song in praise of Polly, ete songs in the "Mnsical Miscellany," 1731.

Monro, Henry, composer and organist, was bom at Lincoln in 1774. He was a chorister in Lincoln Catheriral, and studied afterwards under Dussek, D. Corri, and others. In 1796 he became organist of St. Andrew, Newcastle-on-Tyne. Composer of songs, sonatas, and other pf. music.

Monro, John, composer and pianist, was born at Edinburgh in 1786 . He was a misicseller and musician in London, where he died, on March 3, 1851.

Works.- Selection of English Melodies, the words by J. W. Lake, London [1825]; Border Ballads, a set of six songs, the poetry by

\section{MOODY.}

J. E. Carpenter. Sungs: Barefooted Friar [1840]; Come now we are met; Ellen Aureen [1s17]; Mary, the maid of the green; My nother's grave; My Nora; Sir Hubert's bride; Wert thon like me [1847], ete. Selection of Country Dances, issucd annually, 1817 1834. The Gleaner, or select flute miscellany, 2 vols., n.d. Flute Music, 3 vols. A New and Complete Introduction to the art of plaving on the Pianoforte [1819]. Also various pf. pieces.

Montgomery, R., author of "The Voice and vocalisation," London, 1879.

Montgomery, William Henry, musician, born aliont 1811; died at London, September 13, 1886. He produced an immense number of teaching pieces for the pianoforte, and wrote "The Royal Standard Tutor for the Hamonimm," London, n.d. Composer of songs and other rocal music, and editor of an edition of Moore's Irish Melodies.

Moodie, William, musician and conductor, horm at Bonhill, Dumbarton, April 19, 1833. ITe was successively conductor of the psalmody in Dumbarton Episcopal Church; Lausdowne Lnited Preslyterian Church, Glasgow, 1864-77; Baromy Church, 1877-s9; East Pollokshields Free Church, 1889.92 , He also acted as conductor of the I) nmbarton Choral Union; and of the St. George's Choral Union, Glasgow, 1873-81, a society which he founded. He has composed various anthems, songs and part songs, of which last " Willie Wastle" is best known, as well as music for the $p \mathrm{f}$. and various cantatas, etc., in MS.

Moody, Fanny, soprano vocalist, born at Redruth, Comwall; daughter of Mr. J. Hawke Moody, of that town. Studied under Madame Sainton-Dolby, and sang at the concerts of her rocal academy; and at the In Memoriam concert, April 25, 1885. Made her lebut in opera at Liverpool, in February, 1887, as Arline, in "The Bohomian Girl," with the Carl Rosa company. Sang in London and the provinces for some time with that company, appearing in a variety of characters. From 1890 she has sung in Italian opera at Covent Garden, and Drury Lane with much success. With her own concert party has given costume recitals of operas at Crystal Palace (1894), and other places; and has sung at the principal concerts in Great Britain; also in Canada, and in South Africa, 1896-7. In 1890, she was married to Mr. Charles Manners (q.v.). The artist pair offered, in 1895 , a prize of $£ 100$ for the best ont-act opera, without chorus. This was won by a young composer, Alick Maclean $(q . *)$, and the opera was produced at Covent Garden, Jume 29, 1895.

Moody, Marie, composer of present time. Her pulblished vorks comprise over- 


\section{MOONIE.}

tures, Fing Lear; Hamlet; Othello; Der Sterbende Krieger; Concert overtnres in E minor, and C major. Adagio and allegretto in D; allegro moderato in $D$ minor, for string quartet. Studies for pf. Anthem, Great Isord of Lords, ete.

Moonie, James Anderson, conductor and composer, was born at Edinburgh in 1853. He studied nnder liandegger, Welch and Cottell, and has held various ehureh appointments in Edinburgh. Conduetor of the Hope Park Mnsieal Association, and of a male voice choir which have performed with great success in Edinburgh. Mr. Moonie holds various appointments in the large public schools of Edinburgh as a teacher of singing Composer of a short cantata, Jerusalem, my Happy Home.

Moore, Bertha, soprano voealist, born at Brighton, January 19, 1s62. Studied at the R.A.N. under WV. H. Cummings, then took lessons from Madame Florence I aneia. Sang at Dublin and other places, lnt made her first great suecess in " WIijah," at St. Tames's Hall, London, May 25, 185.5. The next year she sang at the Crystal Palace Concerts: has also appeared at Kuhe's Brighton Festival, 1888, and at the Monday Popular Concerts, 1891 ; and is now a popular and admired singer. Fond of acting, she has oceasionally sung in operetta performances.

Moore, Graham Ponsonby, composer and pianist, born at Ballarat, Australia, April 14, 1859. Studied at Rerlin Conservatorium under Theodor Kullak, and later with Seharwenka and Moszkowski. Making his home in London, he was appointed a professor of pf. at the R.C.MI., and is an examiner under the Associated Board of the R.A.MI., and R.C.NI. His compositions are chiefly for the pf., and many of them have been played by the leading pianists in this comntry and in Germany. The principal are: Coneertstïcke (after Longfellow's poem, "seaweed "); Hochzeit im Dorfe, six pieces; Fünf Klavierstiicke, op. 22; Chromatische Ftïden; Lyrische Tonbilder, op. 25 (10 pieees); Tén short and melodions studies, op. 30 ; Twelvo poetical studies, op. 31 ; Three noeturnes, op. 32; Three archaie dances, op. 33, etc. Anthor of The Candidates' Iractical Scale and Arpeggio Handhooks, London, 1R. Coeks.

Moore, Henry Keatley, dirtatic writer, born at London, In 1846 . Studied nnder Dr. Westbronk. Graduated B.A., 1871; Mus. Bae., 1880, London, being, with the late Dr. W. H. Hunt (q.x), the first to receive a musical degree at London University. Has been honorary choirmaster of South Place Chapel, Finsbury, and of the Free Christian Church, Croydon; also trainer, since 18!1, of a choir for maceompanied part-singing. Hon. Treasurer of the Froebel society, and sone-

\section{NIOORE.}

time Examiner in Insie to the same. Cotransiator and editor of Frocbel's Antobiography, and Letters. Author of The Child's Pianoforte Book; 'The (hild's Song and Game Book, in four parts, Iondon, Swan Somnenschein. He has composed some pieces and studies for pf.; Songs, ete.

Moore, Reginald Bowerman, organist and conductor, born, Octoher, 1850, at Lyme Rogis, Dorsetshire, where his father, an excellent musician, was for many years organist of the Parish Church. After receiving some pianoforte lessons from a lady (pupil of Dr. Wesley), Mnore was sent at the age of ten to I)r. Mark, of Manchester, where he remained a year. When fomrteen, he became organist of the Parish ('hurch, Uplyme, Devon. In 1870 he was apprinted to the Congregational Chureh, Fxeter, and three vears later to St. Mary Major in that eity. During this time he studied with Mr. P. J. Wood, the ('athedral organist, and Dr. H. A. Harding. Became F.C.(1). 1879, and graduated Mus. Bae, Oxford, 1845. Was conductur of the Historic Madrigal Soejety, 1-ist-7, and from 1886 to the present time has eonducted the concerts of the Exeter Orehestral Six ietr. Music-master to the Grammar School, and is honorary local Examinel for R.A.M., and R.C.NI. IIis compomitions comprise I'saln 145, for soli, chorus, and orchestra. Duets, and pieces for pf., oroan, ete.

Moore, Thomas, musie teacher, who resided in Mamchester abont 1740-50. He became resident in Glasgow in latter half of the 18th century, and in Jume, 1755, became precentur of Plackfriars ('hureh. (on November 22, 1756, he was appointed hy the magistrates teacher of the free music classes in Hutcheson's Hospital. He was also a bookseller in Princes street and Stockwell street, and died in Glasgow about 1792. He compiled "The Psalm-Singer's Tivine Companion," Manchester, 1750, 22 rols, of which another edition was issued in the same year as "PsalmSinger's Compleat Tntor and I)ivine Companion," Nanchester, 2 rols. "The PsalmSinger's Pocket Companion, containing great variety of the best English Psalm-Tunes, suited to the different metres in the Scotch Version of the Psalms of I arid, set in three and fonr parts; likewise all the tunes that are usually sung in most parts of Seotland; with a plain and easy introduction to MIusiek..."Ctasgow, 1756. "The Psalm-Singer's Delightful Pocket Companion. Containing a Plain and Easy Introdnction to Psalmody, and an Introduction explaining more at large the gromds of Music in general. Illustrated with great variety of Tables, Scales, and Initial Lessons..,"' Glasgow, n.d. [1762]. The Toeal Concert Glasgow, 1761.

Moore, Thomas, poet and musician, 


\section{MOORE.}

born at Dublin, May 28, 1779; died at Sloperton Cottage, near Devizes, Felurnary 25, 1852. Best known as anthor of "Lalla Rookh," and other poem, and by his. "Irish Nelodies," which were issued in 1807-34, with accompaniments by Sir John Stevenson. Of this collection many editions have appeared, among which may be mentioned those edited by Balfe, Bishop, Glover, Macfarren, Montgomery, Rimbault, Romer, and Shrivall. Moore composed a "Collection of Toeal Music," London [1820」, annong which is the Canadian boat-song "Row, brothers, row," originally published in 1805 . He wrote the words of "A Selection of Popular National Airs," 1818, 6 parts, and compiled "Evenings in Greece," Lundon, 1831, 2 vols. ; a work of poetry and musie. See his "Memoirs and Correspondence," by Lord John Rnssell.

Moore, William H., cornet player, composer, and cond uetor, horn in Birmingham, May 7, 1852. Sometime solo comet in the band of the Theatre Roval, Birmingham. Conductor of the orchestra at the Museley Botanieal Gardens, 1892-5; and engaget in principal local orchestral concerts. He has composed an opera, "Rudolph"; cantatas, "Torfrida," prodnced, Birmingham, Jannary, 1885; "Daniel," 1886. Also a Suite, and Romance for orchestra; Fair Marguerite; Queen of my dream; and other songs, etc.

Moorehead, John, Irish riolinist and composer, who was born alont the miclde of the 18th century. He was a violinist at the Worcester Festival of 1794, and afterwards plaved the viola in the orelestra of Sadler's Wells Theatre, Londom. In 1798 he was violinist at cosent Garden Theatre, and com posed munic for Sadler's Wells, Covent frarden, and other theatres. Abont 1802 he beame insane, and was confined in Northoumptoin House, Clerkenwell. Afterwards be was in the navy for a short time, hut in Narch, 1804, he hanged himself near Deal in a fit of insanity.

Works.-Music to Plays: philosophers stone, 1795; Birds of a feather, 1796 ; Naval Pillar, 1799: Voleano, 1799; speed the plongh, 1799); 11 Bomdoxani (with Attwood), 1801; Peronse (with Invy), 1801; Cabinet (with Dary), 1802; Family quarrels, 1802; HarJeruin Haheas, 1802. Songs: Absence; Ben and Nary; Gallant Forty-second ; Traveller's joys: Troubadonr, etce Duo concertante for violin $(1800)$, ete.

llis brother, Alexanier, was a riolinist, and for a time acted as leader at sadler's Wells Theatre. He died in a lunstic asslum at Liverpool, in 1803.

Moran, Charles, organist, lorn Inecenlere 10, 1805. IIis professional life was spent at Holyhat, where he held oftice as arganist, first at the ('hureh of st. Cybi ; and then, for

\section{MORGAN.}

nearly 60 years, at the Church of St. Seiriol. On his retirement in Deeember, 1891, he was publiely presented with an address.

Moreton, John, musician and composer, was born at Birmingham in 1764; died in 1804. Compiler of "Sacred Melody, being 50 psalm and hymn tunes in four parts," London [1796].

Another MIoreton, James, issued a "Selection of Sacred Mnsic," Longport [1856].

Morgan, Edward, musician and writer, anthor of "New and improved instructor for the German or Anglo-German Concertina," London [1858]; "Nethod of learning the Accordion," London [1852]; "Instructor for the Flutina or Accordion," London [1860].

Morgan George Washbourne, organist, born at Gloncester, April 9. 1823. He was a chorus singer in the Gloncester Philharnonic Society in 1834. Articled pupil of John Amott. Held organ appointments in Cheltenham, 1s4t; at Christ Church, and st. James's, Crloncester; at S'outh Hackner, 1851; and St. Olare's, sonthwark. Was an nusnecessful cindidate for the Worcester Cathedral appointment, in 1845 , albout which time he wis conductor of the Gloneester Philharmonic. In 1853 be settled in America, and was organist successively of St. Thomas's Episcopal church, New York; Grace Chureh; St. Stephen"s; and Brooklyn 'Tabernacle (Dr. Talmage's ('hurch). The last office he held about twelve years. He died at Tacoma, Washington, July, 1892. His compositions included chnreh music, rocal music, muiscellaneous pieces for $p^{f .}$ and orchestra, etc.

Morgan, J.Wilford, tenor vocalist and composer. He has smig in opera in London and the provinces; in the "Old Guard," and other comic operas, at varions times from 1872 to 1857. In 1888 he was appointed a professor of singing at the Grildhall Schrool of Music. He is the composer of a cantata, "Christian the Pilgrim"; and of a number of songs, some of which, as "MIy sweetheart when a lioy," lrave been very popular.

Morgan, Lady, boral SYDNEY OWENSON, was born in I)ublin about 1783. Best known as a novelist, but was distinguishel in her day as a harp player and musician. In 1802 she published a number of Irish airs to which she had written words, and this was the forerunner of Moore's better known lrish melodies. Apart from her novels she wrote "The Hirst Attempt," an opera, Dublin, 1807 , and "The Lay of the Irish IIarp," poems, 1809. In 1812 she married Sir Thomas Charles Morgan, and on April 14, 18.59, she died at London.

Morgan, Robert Orlando, pianist and composer, born at Manchester, Narch 16 , 1865. Studied at the Guildhall school of IIusic, where he gained the Merelhant Taylors' 


\section{MORGAN}

Seholarship, for pf. playing and composition, 1883; and was awarded the Webster Prize, 188t, for a sonata for violin and pf. Appointed professor of liarmony, composition and pf. at the scliool in 1887. In 1893 he won the prize, valued at 65 guineas, offered by the proprietors of The Lutt', for the best anthem. At the Grand Concours International de Composition Musicale, held at Brussels in 1894, he was awarded the first prize and medal, and two diplomas of honour, for a sonata for pf., and a ehorus for mixed voices, with organ aceompaniment. He has also eomposed two cantatas for female voices, "Zitella," performed at the Guildhall Sehool, July, 1889 ; and "The Legend of Eloïsa," both extensively popular; a ehurch eantata, "The Crown of Thorns." Pieces for orchestra; Sonatas for violin and pf.; many pf. pieces; songs, palt-songs, ete.

Morgan, Tom Westlake, orgasist and writer, born at Congnesbury, Somersetshire, August 6, 1869. Chorister, King's College, Cambridge, 1879 ; then pupil of Boyton Smith, at Dorehester. In 1856, organist of St. Catherine's College, Cambridge, and pupil-assistant of I)r. A. H. Mamn, at King's College. Organist for a time at St. George's Angliean Chureh, Paris. Studied at R.C.M. under Sir Walter Parratt, and Dr. F. E. Gladstone, 1890. (Irganist at St. David's, Merthyr Tydvil, 1891 ; founder and eonductor of Philharmonie Society there. In 1892 he was appointed organist and master of the choristers, Bangor Cathedral. He has given recitals at St. George's Hall, Liverpool; at the Bow and Bromley Institute, ete. Has composed some Welsh anthems, ete.; is a contributer to periodical literature, and musical editor of st. David's Heckly. Has acted as adjudicator at Eisteddfodau; aud is Provineial Grand Organist for North Wales in Royal Areh Freemasomry.

Mori, Nicholas, violinist and composer, born at London, Jauuary 24, 1796. Son of an Italian wig maker in the New Road, London. Pupil of Viotti. Prineipal violinist in London orchestras. Music publisher in Bond Street, London. He died on June 14, 1839.

Mori, Frank, composer, son of the above, born at London, Mareh 21, 1820. Studied under Forbes and Sterndale Bennett, and in 1836 under Zimmerman at Paris. He died at Chaumont, Franee, August 2, 1873.

Works. - Fridolin, eantata, Worcester Festival, 1851. The River Sprite, operetta, words by G. Linley, Covent Garden, February 9, 1865. Sougs: Twelve songs, by Mackay, Longfellow, Oxenford, ete.; Six songs, by Moore, Shelley, Tennyson, Hunt, ete.; Breathe, oh! breathe that simple strain; I love my love in the springtime; Whither art thou roaming. Tocal exereises, etc.
MORLEY.

Mori, Nicholas, the secont son, was horn Jamuary 14, 1822. Studied under lis father, and Charles Lueas, and also in Paris. Played in public from 1s:ss. Composer of descriptive musie to Gilbert's "The Wiclied World"; a setting of Pmalm 187, and other workis.

Morine, Charles Harland, composer and organist, was lrorn in 182s; died at Elgin, February 19, 1879. He edited the collections of Scottish and Irish Melodies published by Maver, 1877, and composed pialloforte music. He also issued " Beanties of Scotland, airs for pian oforte," 1869. Songs : Burd Ailie; Golden davs, ete.

Morison, Christina W., burn BogtE, composer, lorn in Dublin, 1840. She studied under Glover and John Blockley. Composer of "The Thlans," opera, in 3 acts, Dublin, 1884, and Frlasgow, 1885. Songs, and pianoforte music.

Morison, John, "musician and copier of music," Jyorn in 1772; died at Peterhead in 1848. He lived in Rose street, Peterhead, and was precentor in St. Peter's ('hurch there. Editor of a "Collection of New Strathspey Reels, with a few favomrite marches....,", Edinburgh 1801]. A Select Collection of Favomrite Tunes adapted for the pianoforte, German flute, violin, and violoncello, dedieated, by permision, to General Gordon Cnming skene," n.d.

Morison, Roderick, or RORY DALL O'CAHEN, poet, harper, and composer, was born in the Island of Lewis in 1646. He was the son of an episcopal elergyman, and was educated at Inverness. He lost his sight after an attack of small-pox, and became harper to the family of Macleod, of Lewis. $\mathrm{He}$ died near Stomioway early in the 18th century. He eomposed some Gaelic airs, but is best known as a poet.

Morley, Felix Wilson, organist and composer, born at Bassingboume, Cambridge, Norember 20, 1855. From 1868 to 1873, he acted as honorary organist at the Parish Church, and in the latter year was elected Organ Scholar of Pembroke College, Cambridge, an office he was allowed to hold for a year before entering as an undergraduate. After taking the B.A. degree, he remained in residence as organist, and proceeded to M.A., 1883 ; and Mus. Bae., 1885. Since 1878 he has aeted as hon. inspeetor of Choir's for the Ely Dioeesan Church Music Soeiety (now the Commeil of Church Music); and from 1891 has been anmully eleeted hom. see. In 1892, and 1895, appointed Diocesan inspector of the Choirs taking part in the Triemial Festivals at Ely Cathedral. Conductor of Royston Amateur. Musical Soeiety, 1888-94. Of his compositions there are, in MS., a setting of Psalm 150, for solo, ehorus, orchestra, and organ; a Magnificat and Nmne Dimittis in 


\section{MORLEY.}

E flat, for ehsrus, orehestra, and organ; his published works include church services; songs, and part-songis; pieces for violoncello, and pf.

Morley, Thomas, composer and writer, was born abont 1557 . He studied under Byrd, and was a chorister in St. Paul's Cathedral. MIus. Bac., Oxon., 1588; organist of St. Paul's Cathedral, London, 1591; Gentleman of the Chapel Royal, 1592-1602. Obtained patent for exelusive right to print music books, 1598. He died in 1604.

Works. - Canzonets, or little short songs to three rovees, 1593 ; Madrigalls to foure voyces, 1594; First booke of ballets to five voyces, 1595; First booke of Canzonets to two royces, 1595 ; Canzonets, or little short aers to five and sixe voyces, 1597; The first booke of Consort Lessons, made by divers exquisite Authors for sixe instruments to play together, ete., 1599 ; The Trimmplis of Oriana, to five and six voices, eomposed by diver: several author', newly pullished by "Thomas Morley, London, Este, 1601 contains madrigals by NI. Este, J. Bennet, J. Hilton, J. Holmes, Wilbye, Morley, E. Johmson, T. Weelkes, Kirbye, Carlton, Cavendish, Lisley, Famer, Milton, Jones, Croce, Iunt, Bateson, Mundy, E. Gilsbons, R. Nicholson, Tomkins, Marson, F. Pilkington, Norcome, and Colblold]; Services in $\mathrm{D}$ minor; Evening service in $\mathrm{G}$ minor (in Barnard's collection); Burial service (in Boyee); A Preces, Psalns, etc., in Barnard's MIS. collection; Five sets of Lessons in Queen Elizabeth's Virginal Book; A plaine and easie introduction to Praeticall Musicke, set downe in forme of a dialogue. Divided into three partes. The first teacheth to sing with all things necessary for the knowledge of prickt song. The second treateth of descante and to sing two parts in one upon a plain song or ground, with other things necessary for a descanter. The third and last part entreateth of composition of three, foure, five or more parts, with many profitable rules to that effect, with new songs of $2,3,4$, and 5 parts, London, 1597 , varions editions. This was translated into German.

Morley, William, composer of the 18th century. MIus. Bac., 1713. Gentleman of the Chapel Royal, 1715. He died on October 29, 1731. Supposed to be the composer of the oldest donble chant known, published in Boyce's Collection in D minor.

Mornington, Garrett Colley Welles= ley, Earl of, Irish peer and composer, born at Dangan, Ireland, July 19, 1735. Father of the Duke of Wellington, and of the Marquis of Wellesley. Mus. Doc., Dublin, 1764, where he was the first Professor of Music in the University from $176 t$ to $177 t$. He succeeded to the title in 1758. Created Viseount Wellesley, 1760. Gained prizes from Catch Club
MORRON.

in $1776,1777,1779$. He died at Kensington, London, May 22, 1781.

Works - Glees and Nadrigals composed by the Earl of Mornington, edited by Sir H. R. Bishop, London, 18t6. Among them the following are famous:-As it fell upon a day; Beneath this rural shade; By greenwood tree; Come, fairest nymplu; Gently hear me, charming maid; Go, happy shade; Hail, hallowed fane; Here in cool grot; O bird of eve; Rest, warrior, rest ; and, Soft sleep profoundly. To these may be added the cateh, "Twas you sir." The collection of glees, ete., made by Bishop, is the only complete one extant; though all the glees, madrigals, and cateles can be had as originally published in single parts. He also composed chants and other church music.

Morris, Margaret, Mrs. Alflied Morris, soprano vocalist, organist, and conductor, born at Caerleon, Mommouthshire. Showed musical talent from childhood, lnt her desire to adopt the art as a profession was not gratified until after her marriage, when monetary reverses turned her talent to practical account. She is to a great extent selftaught, but studied harmony with Dr. Bradford, and voice production with Emil Behule. As a rocalist she is favourably known, and the Gwent Ladies' Choir, muder her leadership, has a good reputation. She has conducted many concerts, including a performance of Gounod's, Mor's et Tita, with full chorus and orchestra. She is organist of Christ Chureh, Caerleon, principal of a music school in that town, and has given lectures on nunsical topics at Newport, and other places.

Morrison, James, musician, author of "A New System of IInsie, applicable to all musical instruments," London [1852].

Morrison, William, composer and violinist, compiler of "A Collection of Highland music, consisting of strathispeys, reels, marches, waltzes, and airs, with variations original and selected, for the pf., violin, and violoncello," Inverness, n.d. [1813].

Morrow, Walter, trumpet player, born in Liverpool, June 15, 1850. Studied his instrument under Dan Godfrey, and at the R.A.M. He obtained high repute by his playing of the rarious parts for trumpet obligato in Handel's works, and did much to restore the Trumpet to its legitimate place in the orchestra. He developed a special trmupet for the performance of Bach's high trumpet parts, so long considered mplayable. This instrument he employed for the first time in Bach's "Ein feste Burg," at a concert of the Cambridge University Insical Soeiety, Jume 11, 1895; and at the Leeds Festival of 1886 the same straight trumpet was introdnced in Bach's High Mass in B Minor. Mr. Morrow is teacher of the trumpet at the R.C.MI., and 
MORTEN.

Guildhall school, and is now prineipal trmpet in the orchestras of the Philharmonic Society, Royal Choral Society, the Srmphony Concerts, Handel Festival, and at most of the provincial festivals.

Morten, A., author of "Hints on the purchase of an organ," London, 1877.

Moseley, Caroline Carr, composer, danghter of the late MIr. Moseley, of Leighton Hall, staffordshire. Studied at R.A.M. under Sir C. A. Macfarren. A.R.C.M. Composer of a number of part-songs for ladies' voices; The Child of the South; The Carol of Hope, and other songs; "Ten minutes in the country," two pieces for pf., riolin, 'cello, and toy instruments, performed in London, 18821883 , etc.

Moseley, Rev. W. Willis, anthor of "The quantity and Musie of the Greek chorus discovered," Oxford, 1847.

Moss, Edwin, composer and tenor vocalist, born in London, Jannary 4, 1838. He was for many years a teacher at Cardilf and Wantage. In 1866-75 he was precentor of Poultry Chapel, and from 1877 tenor in the Foundling c'hapel. Editor of "The London "Tume Book," 1sit, and composer of a number of hymn tmes, ete.

Moss, Sydney, pianist, violinist, and conductor, born at Sydney, New South Wales, January 9, 1854. Studied at Leipzig, under Reinecke, Inavid, and E. F. Richter, 1865-7t. Retumed to Sydney in 187 , and was conductor of the Musical Union in that city to the year 1881. Mrr. Moss has been most disinterested in his service to music in Australia, and in many ways has done much for the adrance. ment of the art.

Motley, Richard, composer of the early part of the 1sth century. He composed a number of songs, "Draw, Cupid, draw" [1705], and issned a collection of "Avres" in 1701 .

Moul, Alfred, joumalist and musician, has been resident in England and Amstralia. He is the composer of several songs, one of which, "Nid Rapture" (Rosivetti), was sung at the first Melbourne Festival, December, 1882. On leaving Melbomme, in 1883, he was publicly presented with an address. He has also written some pf. music. In 1888 he was appointed representative for the British Empire of the copyright interest of the Societé des Auteurs, Compositeurs et Editeurs de Musique.

Moulds, John, composer of latter part of the 18th century. He was a composer to Ranelagh Gardens, London, and to the theatres he contributed The Phisiognomist, 1795, and The Sultan, 1796, operas. Among his other works may be mamed Collection of Favourite Songs sung at Ranelagh, 17s7; The Retrospector: a collection of somets [1790]. His
MOUNT.AIN.

single songs include Caledonian maid [1790]; Cowslips of the valley; Destription of London [1796; Edwin and Emma (by Mallet); Deserted village (Goldsmith); Eleanor of Exeter (ly G. S. Carey); Link boy; Nutbrom maid, ete.

Mounsey, Ann S., see Bartholonew, Mrs.

Mounsey, Elizabeth, organist and composer, born in London, October 8, 1819. Sister of Mrs. W. Bartholomew (q.v.). As a pianist she had a good reputation, and frequently took part in the chamber concerts given at Crosly Hall by Mr. Dando (q.r.). It was chiefly as an organist that Miss MLomsey was known. She was appointed to st. Peter's, Cornhill, in 1834, and retained the oftice of organist until 1882, when she retired. In that church the first CC organ in England was erected. under the superintendence of Dr. Cramntlett. That was in 1810, in which rear, and again in 1842, Mendelssolm performed mpon it. Miss Mounsey possessed many interesting menertos of Nendelssohn, and greatly aided Mr. F. G. Edwards (q.v.) in his history of the oratorio "Elijah." she has published some rocal music, and pieces for guitar, organ, pf, etc. Since 1842 Miss Nounsey has been an Associate of the Philharmonic Society.

Mount, George, composer, contrabassist, and conductor. On the formation of the British Orchestral Society, in 1872, Mr. Mount was appointed conductor, an office he held till the dissolution of the Society a few vears later. The first concert was given in St. James's Hall, Decemler 5, 1872. He was deputy conductor, Sir Arthur Sullivan being chief, and afterwards conductor of the Roval Amatenr Orchestral Society, from 1871 to the present time. Appointed assistant conductor at the Royal Aquarium. Westminster, 1876; condnctor, Alexandra Palace, in 1885; and occasional conduetor of the Philharmonic Concerts, 1884-7. His compositions include an overture, composed in celelration of the twentr-fifth amniversary of the Royal Amateur Orchestral Society; a "Pizzicato," for strings, 1894 ; and various smaller works. Mr. Mommt is a professor at Trinity College, London.

Mount Edgcumbe, Richard Edgcumbe, 2ND EARL, amateur composer and writer, was born September 13, 176t. Married Lady Sophia Hohart, daughter of the 2nd Earl of Buckinghamshire. He died at Richmond, Surrey, September 26, 1839. Composer of "Zenobia," an opera, King's Theatre, London, 1800. Author of "IIusical Reminiseences of an Amateur, chiefly respecting the Italian Opera in England, for fifty vears, 1773 to 1823, London, 1823; 2nd edition, 1827; 3rd edition, 1828; 4th edition, 1834.

Mountain, Sarah or Sophia, born 


\section{MUTALIYAR.}

WhLAnses, soplano voealist, was horn in 1768. She mate an appearance in 1782, but afterwards sang with Tate Wilkinson's Company, at Hull, and there nuade her debut in 1786. In the sante rear she sang in Leed and in Liverpoul. She married Mr. Momutain, a violinist, in 1786. She afterwards sang at Covent Garden, and also in Toublin. In 1814 she retired, and died at Hammersmith, London, July 1, $18+1$.

Mudaliyar, A. M. Chinnaswami, editor of a treatise on Indian music, "Oriental Music in Enropean Notation." Ave Maria Press, Pudupet, Madras, 189:3.

Mudie, Thomas Molleson, composer and organist, born at Chelinea, London, Norember 30, 1809. He studied music under Croteh, Potter, ete, at R.A.MI., 1823-32. I'rofessor of Pf. at R.A.M., 1832-4t. Organist at Galton, Surrey, 1834-44. Teacher in Edinburgh for a time, but returned to London in 1863. He died at London, July 21, 1876.

Works. Svmphonies in (, B flat, F, I); Quintets, quartets, trios, etc., for strings, ete.; Pf. music, consisting of duets, solos, fantasias, nocturnes, etc.; Antlems and sacred songs; Songs: Dying Gladiator; Evening song; Fisheman: To Nenory; Six songs and two duets; Sacred songs [1840]; Three sacred duets [1842]. Aecompaniments in Wood's "Songs of Scotland," edited by Graham.

Mullhollan, John Macpherson, Irish musician, who flomished in Treland and Edinburgh about the end of last and the beginning of the present century. He issued a volume of Irish Melodies about 1800 , with titles in Irish and English, hased on a collection begun by his father, who died in 1770. He also issued "A Selection of lrish and Scots tunes, consisting of airs, malches, strathspeys, country dances, etc., adapted for the pianoforte, Edinburgh, n.d. [1s04].

Mullen, Adelaide, soprano vocalist, born in Dublin. Daughter of Benjanin MIullen, Lay-vicar of St. Patrick's Cathedral. Studied at the Alexandra College, Dublin, and with J. B. Welch. Was first introduced to publie notice by the late Sir Robert Stewart, at a concert of the University Choral Soejety. In March, 1882, whe sang at a State Concert, and at the musical inauguation of the National Exhibition, Dublin, in August, being then an amateur. In IIay, 1883, she gave her first concert in Dublin, and since then has pursued a successful career, appearing in Edinburgh, 1885; (Hasgow, 1886; and at the Crystal Palace Concerts, Narch 19, 1887. In 1888 she was engaged by $\mathrm{Mr}$. William Ludwig for his concerts of Irish music in the United States, and has since twice risited America. Tomred with the Bums-Crotty Company in 1891-2. Married, April 26, 1888, Henry Beaumont, the tenor vocalist (q.v.).

\section{MUNDEN.}

Mullen, Alfred Frederick, musician, who died in 1sis. Anthor of "Hammonimm Tutor, with a series of easy lessons progressively arranged," London, n.d.; Fasy and Complete Instructions for the P'ianoforte, London, n.d.; Catechism of MInsic, n.d. Composer of numerons transcriptions for pf., and songs.

Mullen, Joseph, composer and organist, born at I ublin in 1826. C'horister in C'hrist Chuch Cathedral, I)ul, lin. Organist at Tuam Cathedral; Succentor of Limerick Cathedial; Organist of St. Mary's Chnreh, st. Catherine's Church, and of Chint ('hureh, Leeson P'irk, Dublin.

Mullineux, William, organist, born at Worsley, Lancuster, April t, 1854. Studied meler his father, I)r. J. F. Bridge, and I)r. Hiles. Was organist of Worstey Wesleyan Chapel at the age of ten, and in 1876 was appointed organist of Bolton Town Hall, an office he still holds. F.R.C.O. He is the composer of a cantata, "Harvest Home," produced at Bolton, 1887.

Mullinger=Higgins, William, see HIGGINs, WM. MLLLNGER.

Mullinex, Henry, composer and rocalist, born ahout 1793. He was a Gentleman of the Chapel Royal. Died at London, Deeember 15, 1838. He composed waltzes, marches, etc., for the pf., and some rocal mulic.

Munday, Eliza, see SAlnox, ElizA.

Mundella, Emma, pianist, teacher, and composer, born at Nottingham in 1858. Innghter of the late John Mundella, of Leicester, and niece of the Right Hon. A. J. Mundella. Received her first musical instruction at home, and studied under Arthur Page, 1873-6. Won the Nottingham Scholarship on the opening of the National Training School for MIusic in 1876, and afterwards took the diploma, A.R.C.M. Was director of the music at St. Elphin's Clergy Daughters" School, Warrington; and from 1880 at Wimbledon High School. A career of much nefulness was cut short by death, February 20, 1896. Of her compositions the principal was "The Victory of Sing" (Lewis Morris), for female chorus, three violins, pf. and harp. She also published two anthems; Twelve elementary duets; Three sketches; and other pieces for pf. Editor of The Day School Hymn Book, Novello, the enlarged edition of which was in the press at the time of her death.

Munden, Thomas, organist and conductor, was a chorister of Westminster Abbey, and pupil of Greatorex. He was one of the conductors of the Bimingham Festivals from 1826 to 1846 , and first organist of the Town Hall. He was also organist of Christ Chmrch and St. Paul's, Bimingham. He died in North Wales about 1879. 


\section{MUNDY.}

Mundy, John, organist and compuner, was bown in latter half of the 16th century. He studied under lis father, and became organist of Eton (ollege. Olganist, sit. George's Chapel, Windsor, 3585. MIus. Wate., Oxon., 15s6; Mus. Doe., do., 162t. Ile died in 1630 .

Wouks.-Songinand Palms, composed into three, four, and five parts, for the ane and delight of all such as either love or learne musicke, 1594; Anthems, and other sacred music; "Lightly she tripled," madrigal for 5 roices, in "Trimmphs of Oriana."

Mundy, William, compeser of the 16th century, father of the above. Yicall-choral, St. Pain's. Gontleman of the Chapel Foral, 1563. Ile died in 1591. Composer of anthems in Cliffort's collection, ete.

Murby, Thomas, compuser, vislinist, and writer, born at Leicenter, Mareh 27, 1834 . Educated at the Hill Street British Sichool there, and in 1849 heconne amountersis to William Gardiner (q.x.). In 1.5: he Hutered

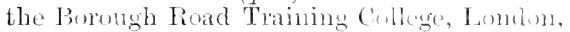
and the next rear was alporinted it munical professur, a post he held for tem ge: res. Beyoud

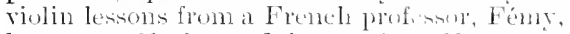
he was self-educated in masic. Hle was a nember of the Phithamonic orehestra for ejght rears; and of the Reyal Amateme seiety for aliunt wixteen years; and is now the llead of an educational publishing homess.

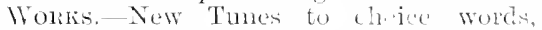
2 boulis: Merry-go-round, a collection of rhymes, jingles, and songs 1854 ; 'The Golken Wreath, a collection of somgs, miginal and adapted: The Invonshire Melodist, original settings of 12 sougs by Fawad (atperis, the

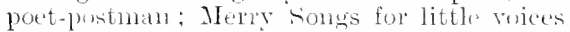
(in enjunction with Thomas lloud the younger, and his sister, Mrs. Irodurip), Lomdon, iriftith \& Farran. Children's cantatas. Five oble clitea, 1StT: Elsa, or the impeisond fairy, ksto; Shaliespeare's merrie nuesting: and Lost Dimplechin, 18s.9, all perfomned at Gresham Ilall, Prixton. Author of The Musical Student's Manual, London, 1862, now in its sth edition.

Murdoch, Alexander Gregor, minor poet and author, born at Chasgow, April, 1843; died there, February 13, 1891. He published sereral volumes of potry, and wrote a series of papers on Scots riolin jetsand violin malsers, which originally apleared in the Glasgou Weekly Mial, and were afterwards issued as "The Fiddle in sic stand: "om. prising scoteh Fiddlers and Fiddle makers," Londm, 1888. Hisson, Weldaw, is a violinist of much promise.

Muris, John, English witer and mmicrian, who flourished during the 14th centry. Doctor and Canon of the conhonne, or a Chanter in the Church of Notre I lame of
NARES.

Paris. Anthor of a number of musical works, preserved in MS.; anoug which ale treatises on comnterpoint, and metices, the earliest of the lind of the time talble. II s nationality has been varjously stated as Nomman, or Flemeh, bet a concensis of opinion seems to fix bis nationality as English.

Murphy, John, musician and piper, published "I collection of Irish airs and jiggs with rariations, by John Murphr, perfomes on the mion pipes at Eglinton Castle," London, n.d. $[1-20]$

Murray, James Robertson, composer and organist, loom in 1ri36. Organist of St. Botolphis, Alderserate, Lundon. Fonnder of the London chereh (hoir Astueiation, and conducted the anmual serriecs at sit. Paul's Cathedral, 1sso, ete. He died at London, September 3, $18+5$.

Musgrave, Frank, componel and conductor. Hewain musical director of the strand Theatre, London. In List le was an immate of Bethmal Green Lunatic Arrlum, and in Mar, 1stis, he died. Compuner" of " Mindsor

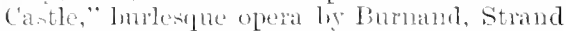
Thatie, 1s65; and a horlesple on "LAfricaine," aliso loy Fomand, in 1465. Sungs: Eary lowe; l'll forgive ther: Nellie Lee; the hiunte me like a happy deams. A large momber of pollias, valies, galope, cte, for pf.

Rluthow, Villiam, organist, Was born in 1761. He becanue orsmist of (ilonecinter Cathedral in $17 \times 2$, and held the ap pintment till 1832, when he was sueceeded hy John Amott. He diod at Cilonecster in 1sise. He conducted the Gloncenter Festivals frem 1790 to 1n39. Composer of " Cunto Thee, U God," anthem, ete.

Napier, Milliam, musician and publisher, bom in seotland in 17t0. He entablinhed himself in London as at music-sellel, and in this capacity served the lowal fanuily. Memlex of the King's band till he was foreed to retire beeause of gont in his hands. He also played the riolin at the Profexional concerts. Fe died in Somers Town, London, June, 1812. He pulblished A selection of the most favourite Scots Sonsis, chiefly l'astmal, adaleded for the harpsichord, with an aceonnpaniment for the violin, by eninent Masters, Londom 1790; A Selection of Original Sicots somgs, in three lints, the hamony by H. ydn, L milom [17:42]; Napiel"s belection of Dances and strathepers, with new and appropliate basises, adapted fol the pianoforte, harp, etc.,n.t. The "eminent maters" mentioned in the first work wele s. Anold, W. Shiele, Carter, and barthelemon. This wolk alio contains a "I liscertation on Scottinh Music," ly William Tytle (q.u.)

Nares, James, "(mmporiel" and organist, bom at Stanwoll, Midrlencx, ahont April, 1715. He was a chorister in the Chapel 


\section{NASH.}

Roval, under Gates, and also studied under Pepmsch. beputy-organist of St. George's Chapel, Windwor. Organist of York Cathedral, 1734. Organist and composer to the Chapel Royal, 1756. Mus. Juc., Cantab., 1757. Master of children of Chapel Royal in 1757-80. He died at London, February 10, 1783.

Works.-Fight Setts of Lessons for the harpsichold, 1717; Five harpsichord lessons, 1758; Three easy do.; The Royal Pastoral, a dramatic ode; Collection of catches, canons, and gles, London [1772]; Twenty Anthems in score, for the use of H.M. Chapel Roral, London, 1778; Morning and Evening Service, with six anthems in score, 178s; Six organ fugues. A Treatise on Singing, n.d. Il Principio, or, a regular introduction to playing on the harpsichord or organ, n.d.; Concise and easy treatise on Singing. . with a set of Fnglish duets for beginners; Songs, and miscellancons instrumental music; six grand thoruses from Handel's oratorios, adapted for the organ or harpsichord, n.d.

Nash, or Naish, F., bass vocalist, known as Sirror Fraxco Nopara, born in the West of Englanel. Made his dibut at Her Majesty"s Theatre, MaY 2A, 1881, as Mephistopheles, in "Fanit." He sang with the Carl Rosa Compans in 1883; at Covent Garden, 1889, etc. Ile has been on tour with Madane Patti, and has sung in many parts of the kingdon. In 1896 he was appointed a professor of singing at the R.A.M. He has composed some sougs: Earl Douglas; The bold, bad Baron; Tieni con me, ete.; The plighting kiss, duet.

Nathan, Isaac, composer and writer, was born at (anterlury of Jewish parents, 1792. He was educated at Cambridge, and studied masic moler I). Corri. Tle sang at Covent Garden Theatre, and afterwards emigrated to Melbonme, Anstralia, in Feloruary, 1841. He was killed in Sydney, January 15, 1864.

Works.-Operas: Sweethearts and Wives, 1829; The Alcaid, opera, 1824; The Illustrious Stranger, musical farce, 1827; Merry freaks in tronblous times, Sydney, 1851; NusmriaVocalis, an Fssay on the Iistory and Theory of Mnsic, and on the qualities, capabilities, and management of the hmman voice [182:3], illnstrated; 2nd edition, 1836; Life of Madame Malibran de Beriot, interspersed with original anecdotes, and critical remarks on her musical powers, I ondon, 1836. The King's Fool, drama. The Southern Euphrosyne and Australian Miscellany, containing Oriental moral tales, original anecdotes, poetry and music; an historical slsetch, with examples, of the native ahoriginal melodies, otc., Sydney [1846]. Holnew II lodies (from Byron), with Hraham, 1s2.); alio 18fil. Let's bow to Solumu, glee, Bristol [1819]. Songs: Beautr"s bower; Conne kiss me, said Colin; Fair

\section{NAYLOR.}

Haidée; Lady-bird; Long live on monarch (with chorus); When I roved a young Highlander, etc. Six new danees [1812".

Naylor, John, organist and eomposer, bom at Stamingley, near Leeds, June 8, 1838. Chorister at Leeds Parish Church, pupil of R. S. Burton, and afterwards his assistant organist. Gradnated Mus. Bae., 1863; Mus. Moc., 1872, Oxford. In 1856 he was appointed organist of St. Mary's, Scarborough; and in 1873 to St. Michael's Church in the same town. There, in conjunction with the Rev. R. Brown-Borthwick (q.x.), he raised the musical services to a high degree of excellence, and gave frequent organ recitals. On the retirement of Dr. Monk from York Minster, in 1883, Dr. Naylor gained the post of organist there. A special feature at the eathedral, since 1885, has been the anmual Military service, for which he has composed anthenis for choir and military land. He was conduetor of the lork Mnsical Society, retiring in June, 1896. His chief works are four cantatas: Joremiah; The Brazen Serpent; Merinah, and Manna: produced at Festivals in Tork Ninster in 1884-87-90, and 1893. He has also composed a service in G; anthens, "O ve that love the Lord," ete. Siongs and part-songs. Owing to ill-health he resigned his organ appointment in April, 1897, and died while on the voyage to Auntralia, May, 15,1897 .

His som, Fiward Woothle Naylor, was educated at the R.C.M., and at Emanuel College, Cambridge, graduating Mus. Bac., and M.A., 1891. He has composed a scena, "Merlin and the Gleam," for baritone solo and orchestra. Author of "Shakespeare and Mnsic," London, Dent, 1896.

Naylor, Sidney, pianist and organist, born at Kensington, Jondon, July 24, 1841 . Chorister at the Temple Chureh, and pupil of Dr. E. J. Hopkins. He was organist suecessively at St. George's, Bloomsbury; St. Michael's, Bassishaw ; St. Mary's, Newington; and St. Michael's, North Kensington. But he was more widely known as an able aceompanist, officiating for many rear's at Boosey's Ballad Concerts; occasionily at the Monday Popular Concerts; and for many toming parties, particularly those of Mr. Sims Reeres. He was Carl Rosa's partner in the English Opera Season of 1874 . He died at shepherd's 13nsh, March 4, 1893. In 1868 he married Miss lilaxche Cole, the soprano vocalist. She was born at Portsmouth, in 1851, and logan her stage career very early. From 1871, she sang for a few years in concerts; but was nostly heard in opera. At various times, up to 1887 , she was a member of the Carl Rosa Company; in 1879 , tomed with a company of her own; and in 1882 sang in the Royal English Opera Company. She appeared in a 


\section{NEALE.}

roumd of characters, and was very popnlar. Her death occurred in London, Angust 31, 1888.

Neale, Rev. John Mason, hymm writer, amateur musician, and elergyman, was born at London, Jamnary 24, 1818. Educated at Cambridge. Curate of St. Michael's, Guildford, 1841. Warclen of Sackille College, East Grinstead. He died at East Frinstead, Angust 6, 1866. He composed "An Easter Carol" [1849, and some Church music, but is chicfly remembered by his works on the Eastern Church, and varions popular hymms, published in such collections as Hrmms for the Sick, 18t3; Hymns for Children, 1843; Hymnschiefly medieval, 1865 ; Hymmal noted, 1851-54, 2 vols. ('arols for Christmas-tide, 1853; Carols for Easter-tide, 1854, both edited by Hehmore.

Neale, Richard, conpiler of "A Poeket Companion for gentlemen and ladies: being a collection of the finent operin songs and airs in English and Italian. . . fignred for ye organ, harpsiehord, and spinet," London, 1725.

Neate, Charles, composer and pianist, born at London, March 24, 178t. He studied the P'f. muder J. Field, and Woelfl. Appeared as planist, at Corent fraten, 1800. Member of Philharmonic Societs, 1813; afterwards a director and conductor. i felecame acquainted with Beethoven in 1815. He took lessons from Winter, and plaved in England at the principal encerts. He died at Brighton, Mareh $30,1877$.

Wokks. - iranel Sumata for pf., op. 1, 1808 ; Sonata for pf., in I) minor, op. 2, 1822: Les Caractères, a set of original quadrilles, op. 19; Fantasias, op. 4, 35; A Hundred impromptus, or short prehdes: Serenade, op. 15; Toceatas, op. 5; Kinloch, a Scoted air arranged for pf. 1R27] : l'f. rondos, and other instrmmental works. Fantasia for pf. and 'cello, op. 9; Quintet, pf., wind, and double bass; Trios for pf., viulin, and 'cello, op. 21 and op. 22 [1831. Estay on fingering, chiefly as connected with expresion, together with some general obserration on I'ianoforte Playing, London, n.d. [1.5.5]. Songs, etc.

Needham, Mrs., see Claytor, Eleaxor Creathorsi:.

Needler, Henry, muician and violinist, born, London, 16S5; died, August, 1760. One of the original fonnders of the Academy of Ancient Mnsic, and a performer of merit.

Neilson, L. C., see Nielsox, L. C.

Nelson, Sidney, composer and witer, born in 1800 . He was a teacher in London, and died there on Aprit $\tau, 1862$.

Works.-IIiddle Temple, operetta [1829]. Cadi's Daughter, opera [1,551]. Songs of the Gipsies, London, 1832; Mountain Lay, six sacred sones; Six rocal trios $\lceil 1852\rceil$. Songs: Away to the momtains [1858]; Better land

\section{NEWELL.}

[1840]; Gipsy fortme teller; Highland widow; Hunter's horn; Life is a river; Mary of Argyle $[1860]$; Oh! Steer my lark to Frin's Isle [1840]; Pilot [1835]; Rose of Allandale [1836]; By the gentle Gnadalyuiver, and other vocal duets. Instructions in the art of Singing, London 1835]. Vocalist's daily practice, London, 1852. Tocal school, a series of scales, exereises, ete., London, n.d., also 1879.

Nesbitt, A. Mr, heid-master of Toowom ba Grammar Schoul, Queensland, Australia, was awarded the prize of fifty gumeas, offered by the Brisbane Musical L'nion, in 1887, for a "Jubilee Ode," for chorus and orchestra.

Newark, William, composer of the 15 th and $16 \mathrm{th}$ centuries, who contributed to the Farrfax IIS. A madrigal of his, entitled, "Thus musing," was printed by Novello in 1894.

Newbury, Philip, tenor rocalist, horn in Jersey. Most of his carly life was spent in Australia, where be studied moder the best available teachers. In 1888 he came to England, and sang at various concerts in sheffield, Birmingham, Londun, ete. He appeared in opera at the Shaftenbury Theatre, Oetober, 1891, as the ['ilot in "The Flying

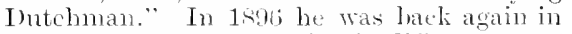
Anstralia, and after tourng in different parts was reported as settling in Tammania as a teacher of singing.

Newcombe, Georgeanne $\mathrm{Hubi}=$ bom HLBI, soprano vocalist, composer, and lyrie anthor, born in London, Decemler 1s, 1843. Studied under R. Glemn Wesley and Dr. Hiles. Organist for some rears at Latchford Parish Chmrch. Now resident at Warrington. llas written many lvrics set by Gerard Cobb, Denza, Pontet (Trhisuer and I sall hear'), Wellings, and others. Her own compositions include snch popular" songsas "Ever faithful," "The miner and bis boy" (Orchestra, prize song), "Irish Potheen," and many uther's. Her pf. piece, "Ye Fancre Fayre March," has met with great popularity. Her danghter, Ethel Hori-Newcomse, goh medallist (Llerelyn Thomas), R.A.MI, is a soprano vocalist of much promise.

Newell, Joseph Edward, compuser and organist, born at Hunslet, near Leeds, October 11, 18t3. Studied under F. W. Hird, and when about sixteen wis appointed organist of St. Philip's, Leeds. In 1866 he went to St. Miehael's, Headingly, where he remained until 1885, when he took over the duties of organist and singing-master at Leeds Grammar School, and its Collegiate Chapel, St. Wilfred. He renosed to London in 1892, where he is chiefly engaged in composition, and arranging, etc., for some of the leading publishing firms. Of the large nmmber of his publications the most important are: The 


\section{NEIVIAN.}

Christian lilgrim, sacere entata, produced at Trinity Chureh, Teeds, Mareh 24, 1889; Spring, eantatat for fernale volees: Stella, operettat for the same. The roug-Pirel slbum. Six fonr-part souge: Twelve two-part songs: Anthems, ite. Six Diversions, for two violins anrl pef : Six musical poems, pf.; I'f. Shchool in threse grades, 1s95: T'utor for harmonium and American organ; Rondinents of Music, with listorical notes, 1805. He has atso pulblished much muse for Nandoline and Gritar molder the noms ale plame of Carlo Murretti and Nicola Podesta.

Newman, R. A., musician and author, published "] peseription and use of the Far. monimetre," Wrinonth, 1845.

Newson, George Lincoln, violinist, lorn at liss, Norfulk. His talent was exhilited very early, and while yet a sehoolboy he was ongaged in the land at the festivatis of bury st. Fidmunds and Nompieh. Situdied at R.A.M., muder Mori, and was in the orchestra of the beyal Italian opera, and played at the prineipal Tondon encerts, and porincial festivals. The appears to haw retired from the prolession since 1890, $\mathbf{H}_{\mathrm{H}}$ is an A.R.A.M.

Newth, Robert Boulcott, tem.. vocalist, born at Worester. ('horistel at the Gathedral. Studied monder IV. Deme. Was appuinted orgunist of St. Paul's, Worester ;

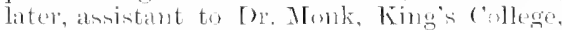
Lomelom; then to St Johnte, Angell Town. Brixtm, 1ss1. Ahout that time, his singing attrarted attention, and he alpeared at

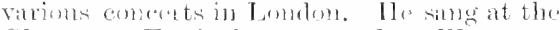
Gloncenter Festival, 18s? ; and it Worcester Festival. 18st. He is a mofessor at the Guildball school of Nunie.

Newton, Mrs. Alexander, born AneLAIDE WTARI, singer and commorer, bom at Lomdon, 1821, sister of J. C. Ward. She Was one of Tome lind is concert party during

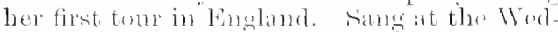
nesday Concerte, bxiter Hall, 1st?. She died

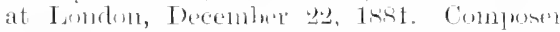
of smlge and pif. mmeis: and wats at hravura singer of exceptional ability

Newton, James Widiam, mician of end of last and firnt half of the present eentury. Compiler of "I'sahnudy impored. in at collection of Poilnn tumes and an-

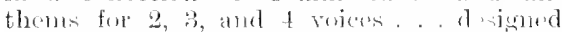

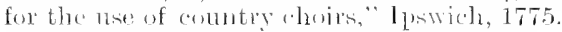
"Companion to the l'ilgrim, containing 30 psalm thrnes, ete," Lumdin [1839].

Nichol, Henry Ernest, “mupuser, pianist

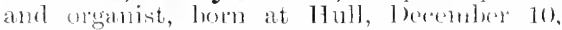
186. Alpmenticed to civil engincering in 1875, but almondones that for the serions study of music in 1,845. Musical training

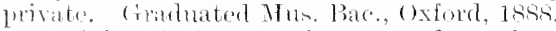
settled in llull as proformex and teacher.

\section{NICHOLSUN.}

Music master, llull Grammar school; Organist, St. Andrew's, Kirk Ella; Condnctor, North Cave Choml Society, and Newport Hamonic society.

Works,- Cantatas: Day and Night (Hull, 1892); Ode to Mnsic, for choms and orchestra (compused, 1894; prodncen at Crystal lalace, July 13, 1895, at the Tonic Sol-fa Festival); Will o' the Wisp (1 tog). An Frening service in F, anthems, carols, liymms, ete. Partsongs. Somata in A minor pe. (MIS.): pieees for pf., songs, cte. Anthor of a book on Choral Tecbuies (curwen), for choir-training, and a primer on Tramspositim at sight.

Nicholds, Joseph, comproser and conductor, was born at hedgley. For some time he acted as direetor of Wrombwell's band, but was afterwinds a teather of music. He died a pauper in Indey Inion, Funary 18, 1860. Composer of balsyom, aratorio; The Trimmph of Zion, oratoris, Wol werhampton, september 17. 184t. Sacres 1lu-ic, a selection of psalm and hymn tumes, London $1 \mathrm{~s} 20$, somgs, ete.

Nicholl, Horace Wadham, composer, born at West Bromwioh, Staffordshire, Mareh 17, 18tr. Som of a musician of some local repute. 1Ie has lecen for many verats resident in Now York. of his works, a "Romanee Antisur" for orchestra was podnced at New Yonk in 18s.5; and " ('loister secene, "for soli, chorus, and orehestra, at the l'ittulourgh

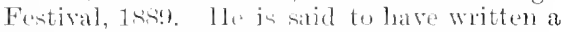
Tetralegy, "The Fall of Man; Abraham; Tsatac: and Jacell,",

Nicholl, William, tmor realist and tereher, was born at Chlasgow, Tume 30, 1851, and originally worked as an engineer in Crlasgew and india. He studied at the Royal Acatemy of Mnsic, meler Fioni, from Jamuiry, 1Rst, tri July, 1stri, and ganed the ParepaRosa gold nedal, and the Acadenty lowene medal. 1h. afterwards stratied at Florence

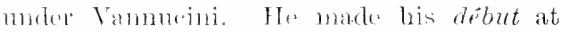
Glasgow, in Nox(molner, 1sist, with Madame Grorgina Burms' party. Since 1806 he has given an ammat serits of classical concerts in London, and has smg at ('hester (1888),

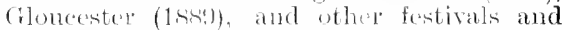
concerts thromghont the kingdom, such as the London Ballar concerts, Crystal lalace, Richter comerts, ete. IJe las appeared

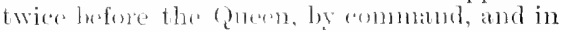
16!) he accompanied Ilr. Gladstone in the "Tantallom Castle" when sir Donald Currie was cmising in the North Sen. He is A.R.A.MT. and has leen at pofresor of singing at the

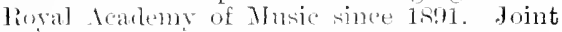
anthor with George Thorpe of "Text-Book on the natural nese of the Vuice," lomdon, 1805, and has lectured on "Voice l'roduetion" at the suciety of Arts, Jammay $27,1897$.

Nicholson, Alfred, ohoist, lxom at Leicester, June 30, 1822, for mamy years in 


\section{NICHOLSON.}

the band of the Royal Italian Opera, and also in the different festival orehestras. Appeared as soloist at the Wednesday Concerts, Exeter Hall, 1849, etc. Was in the orchestra at production of "Elijah," Birminghans, 1846. He died, August 29, 1870. 1Lis brother, Hexry Nicholson, flutist, was hom at Leicester. He has played at the principal coneerts in the provinees, in thamber music, ete. Was for vearly 80 years a member of the Bimingham Festival orchestra. In 1859 he started Concerts for the People, at Leicester, and has done much for music in that town. In May, 1896, thee testimonial concerts were given in his honom Iry a number of artiste, and a cheque for Exon, the result, publicly presented to bim hy the Mayor of Leicester. He is still actively engaged in his profession, and took part in the complimentary concert given to Miss Deacon (q.x.) in May, 1896. Author of "Instrnctions for the Flute," and arranger of musie $f$, that instrument.

Nicholson Charles, flutepliarer and composer, bom at liverpool in 1795 . Fluteplaver at Covent Garden, Inrury Lane, Philharmonic Soeiety, ete. He died at London, Mareh 26. 1837. Wrote "Irreceptive Lensons for the Flute," with Portrait and Appendix, London (10 numbers). 1821; "Complete l'reseeptol for the German Flute, in a style perfectly simple andeasy," Lomdon, 2 parts [1816]: "studins in the sharp and that lieys, eomposed with marks of expression and articulation for the Flnte "; "Le Bonguet, or Fluwers of Melodr, a choice collection of airs. for 1 or 2 flutes. ." ; School for the Flute, I new edition by Rardeliff, London [1873]; Polero [1825]; Collection of waltzes for the flute; Four concertinos for the flute and pf.; Admired Tyrolese melodies sming by the Rainer family (rvith Bochsa), 1830. Numerons fantasias, relections, ete., for flute and pf.

Nicholson, Rev, Henry D., M.A., author of "The Organ : its mechanim, stops, etc, explained, London, n.d. (2 sditions). Boston edition publinhed under the title of "Organ Manual."

Nicholson, James, musician, anthor of "A Concise Treatise on Thorough-bass, with practical lessons selected from the most eminent composers," London [17!96]. Another" James Nicholsox, probahly the same, was a performer on the pipe and tabor at York, and died on August 30, 1807.

Nicholson, or Nicolson, Richard, organist and composer, was born in the seeond half of the 16th century. Organist and chorus-master, Jagdalen College, Oxford, 1595. Mus. Bac., Oxon., 1596. He was the first choragus or professor of music in Oxford Cniversity on Heather's Fonndation, in 1626. He died at Oxford, 1639. Composer of madrigals in the "Trimmphs of Oriana," ete.

\section{NIELSON.}

Nicks, George, viola player and composer, was hom alout 1775 . He was viola player in the orehestras of the Italian (1)peri and Covent Garden, and at the Ancient and Philharmonic enncerts. For many years he acted as manager of the Sulnscription Concerts in the Inusic Rooms at Oxford. He died at London, January 8, 18+1. Composer of much roeal music, anong which may be named the following songs:-Adien, Ben Cable, Kaleidoscope (1828), O Memory (1810), Pleasures of lovers (1797), Poor Harry (1806). The Robin (1825), Since truth has left the shepherd's tongue, The Tear, ete.

Nicolson, Ludovick, composer and violinist, who was a weaver to trade. He was born in Paisley alont 1770 , and died there Angust 3, 1852. He was an associate of $R$. A. Smith, Tamnahill the poet, and other worthies of his time. Compiler of "A collection of pralm and hrom tunes in four prits, adapted to various metres and may lo used in the principal ehurches, chapels, and diswenting congregations in Sontland," Paisley (Glasgow engraved), alout 1852. The tumes "Paisley" and "Low Church" are hy him.

Nield, Jonathan, tenor rocalist, lom in 1769. In 1795 he was appointed a gentleman of the chapel Royal in succesion to J. Suaper. He was alio in the rheirs of Westminster Abley and St. Taul's. For many years he was principal tenor at the Ancient Concerts, and a membre of the Nolslemen and Gentlemen's (rlee ('hul); Royal society of Musicians, ete. He also sing at the Crloucester Musical Festival in 1793, and afterwards at other fostivals. IJe died at London on Narch 6, 18t?.

William Ashtox Nefeb, probably a relative of the formong. composed "The Juvenile IInsieal Libraer..." London, 1854, illustrated by (reorge "ruilishank, and now very scarce. "Collection of l'salms and Hyimns as sung at Al] Souls' ('hurch, St. Mary-le-Bow..." Lomkm 1827]. Songs: Davs of sore, Harbent of prace. Rounds; Pf. music, etc.

Nielson, Lawrence Cornelius, composer, organist and pianist, was horn at London in 1760 . He was talien to America in 1767 , lut afterwards returned and beeame organist at Dudley and Chesterfield. $\mathrm{He}$ died at Chesterfield alont 1830.

Woris.-Sonatas, duets, divertinwements, ete., for pif.: Twolve fasomite airn for two German Flutes [ J 800 ; Marches for pf. [1810]. Songs: Palmy pledge of love, Halpy the youth, When absent, ete.

His son, Fnwe Johx Nielsox, borm in 1812, was one of the foundation stadents of the R.A.Mr. He composed a 11 mmlere of songs between 1839-1840, of which may he named Better land, liaply home, I hate naebody 


\section{NIGHTINGALE.}

now, Mary, Queen of Scots' adien, Norwegian love song, Romember me, otc. He was a harpist and composed some music for harp and pf. The surname of these musieians is spelt variously Neilson and Nielson.

Nightingale, John Charles, composer and organist, was born about 1785 . Organist of the Foundling Hospital, London. He died alont 1837. He issued a "Collection of psalm and hymm tmos, odes, ete., in 3 and 4 parts," Lundon [1824], and composed rondos, waltzes, and arrangements for the pf. Also arranged "The celelrated choruses from Handel's oratorios for the organ "; "A selection of overtures from Handel's most celebrated oratorios, arranged for the organ and pf." He wrote some Familiar voluntaries for the organ, whieh were issned in a collected form as a Series of voluntaries, about 1855; and composed Battle songs; Indian lover's song; Man to man, and other songs and vocal music.

Joseph C. Nightivgale, born 1822, was an organist in Liverpool.

Nimmo, Robert Hamilton, teror vocalist, born at Catrine, September 10, 1836. The Was a music seller and gave concerts, thiefly of scot's music, in various parts of scotland. He died at (Hlasgow, March 20, 1893. He wrote the song, "Creep before ye gang," and others of a like mature.

Nisbet, James, tenor vocalist and writer, born 1817; died at Liverpool, Felnuary 29, 1884. Author of a "Vocal I'rimer, or" student's singing mannal," Glasguw [1860], and other workis.

Nixon, Henry George, composer and organist, was born at Winchester, February 20,1796 . He was organist of St. George's Chapel, London Road, from 1817 to 18.0); next of Warwiek Street Chapel, 1820-36; then of St. Andrew's Roman Catholic C'hapel, Glassow, 18:36-39; and finally of st. George's Roman Catholie Cathedral, London, 1839-49. He died in London of elulera, in 1849.

Woriss.-Five Masses and other munic for the Roman Catholic Chureh service. Nomerous airs arranged for the pif. There came to the lady's gate a linight, and other songs, etc.

He was a nephew of IImAn Nixox, born at Liverpool, 1787; died July 25, 1834, who was a writer on musie and inventor of a musical instrmment called the Eolina. Il. G. Nixon was married, in 1818, to CArolixe Melissa Danis (died 1857), a daughter of Danlyy the glee composer. They had a large family, anoug whon may be nomed James Cansaxa (1828-42), a viclinint, and Hemry Cotter, noticed below.

Nixon, Henry Cotter, fourth son of H. (i. Nixon, was born in London in 1842. Studied under H. Deval, Henry smart, Lre

\section{NODES.}

Steggall, and G. A. Macfarren. Became F.C.O., 1867 ; graduated Mus. Bac., 1876, Cambridue. Organist of St. ['eter's, Woolwich, 1864-8; St. James's, Spanish Place, 1870 ; st. Mary Magdalene's, st. Leonard'son-Sea, 1872-7. Conductor of an orehestral society there. Now resident in London. $\mathrm{He}$ won the Trinity College, Londun, prize, 18s0, for I'f. trio; 1881 , for sonata, pe and 'cello; alio prizes for six-part matrigal, Brighton Sacred Harmonic, 1889 , and that of $£ 25$ offered by Mtethen, Simpson, Edinburgh, 1893 , for the best set of two-part somgs. His other worlss include Psalm 95, for soli, chor'us and orchestra; Overture, "Titinia" ; Symphonic pocm, "Palamon and Areite," both for orehestra; pf. pieces; songs, etc.

Noble, Charles, organist, borm at Southwell, Nott, september 17, 1812. He was organist of St. Nartin's, Stanford; of St. Mary's Nottingham, for 38 years; and lastly of Sonthwell Minster. He died at Southwell, September 10, 1885. As a teacher he was very snecesuful, and highly est rened.

Sancen, John Noble, orgunist and pianist, was ling's Sicholar, R.A.MI., 1439). Pupil of W. H. Holnes. He played at the Wednesday Concerts, Exeter Hall, London, 184!); and was organist of Spitalisfeld Parinh Church; and of st. Mary-at-Hill, 1s61. Another Samule Noble, an alto singer, is a Gentleman of the Chapel Roval, St. James's.

Noble, Thomas Tertius, organist and compuser, burn at Bath, Mlay 5, 1867. Educated at R.C.M., where he was exhibitioner and scholar, under Waiter Parratt, Villiers Stanford, and J. F. Bridge. A.R.C.ML. When fourteen was organist of All siantis, Colehester ; and after leaving the R.C.M., Was appointed successively to st. John's, Wiltom Road, S.W., 18s9; Assistant organist, Trinity College, Cambridge, 1s9o; and organist and choimaster, Ely Cathedral, 1892. There he has becn active in promoting special services, introducing I Iaydu's "l'assion," and other works of importance. Ile has a mumber of compusitions, iutluding an organ somata, in Ms. Of his published worlsis the principal is a setting of the Commmnion Oftlee, scored for voices, organ, horns, trumpets, trombones, and drums (1891). A Solemn Marels, and other piees for organ, are alor published. He has also composed music to the A.D.C. burlerque, Jupiter, at Cambridue.

Nodes, O., musician of early part of present century, edited with J. Bowcher "A selection of Psalm and Hymn Tunes adapted to the farions metres now in use in all churches, chapels, and dissonting congregation throughont Creat Britain," London [1803]. Ho also issued "A selection of Pralm and Hymn Tunes," London [1806], pulblished in numbers. 


\section{NORBURY.}

Norbury, John, author of "The Box of Whistles, an illustrated book on organ cases ; with notes on organs at home and abroad," London, 1877.

Norcome, Daniel, musician and composer, was born at Windsor in 1576 . He was a son of one of the lay-clerks at Windsor, and was probably a singer in the Chapel Royal there. He jis stated to have left England on acconnt of his religion, and he became a member of the band in the Arch-ducal Chapel at Brussels, where he was in 1647 . He composed "With angel's face and brightness," a madrigal in the "Trimmphs of Oriana," 1601 .

Norledge, Annie E., soprano vocalist, born at Newark, Nottingham. At first she studied the riolin, being a scholar of R.C.MI., and later, a student at the Leipzig Conservatorium. She played the viola in the first Ladies' Quartet in Leipzig. After her return she studied singing under W. Shakespeare. For some short time she played viclin at various concerts, but is now farumably lnown as an aceomplished vocalist, having appeared with success in many parts of the United Kingdom.

Norman, Melen S., see sub., Staxdixi, F. H.

Normann, Rudolf, see Harris, George Frenerick.

Norris, Thomas, composer, and tenor rocalist, born at Mere, near Salishry, abont Allgnst, 17t1. He became a cluorister in Salisbury Cathedral under Stephens. Fang at Worcester and Hereford Festivals, 1761-62; and at Drury Lane Theatre, 1762. Organist of Christ Chureh, Oxford, 1765. Mus. Bae., Oxon., 1765. Organist of St. John's C'ollege, Oxford, 1765. Lay-clerk of Magdalen Cullege, Oxford, 1771. Sang at Handel Commenoration, 1784. He died at Himley Hall, near Stourbridge, September 3, 1790.

Works. Six Srmphonies for 2 violins, 2 hantbors, 2 French horns, a tenor and lass, op. 1, London $[1770]$. Fight solo songs for voice and happichord, oxford [1775]. Fongs in "Amusement for Ladies," Four glees. Anthens, ete.

North, Francis, Lons GeILnForn, writer, born in 16:37, died in 1685. Held several important legal appointments, but has interest in a musieal sense only as the author of "A Philosophical Essay on MIusic," 167t. His brother lioger (1650-1733), was a misedlaneous writer, who left in MIS. "Memoirs of Musicl,... now first printed from the original MIS. and edited, with copions notes, by E. F. Rimbault," London, 1846. This is an interesting work, containing a fund of information on events in the musical history of the author's period.

North, James M., vocal teacher and

\section{NOVELIO.}

composer, born at Hnddersfield in 1835. He was taken to the United States in 1842, and was a pupil of Lowell Mason, (. . F. Root, and G. J. Webb. He was suecussirely a teacher in St. Lonis, and in the New Tork State Nommal Sehool, Albany, from 1859 to 1860. Afterwards director of music in the public schools. Fditor of Toeal exercines and rarious collections of music for church and choral soeiety une

North, John, conductor, and tercher of singing, born at Huddersfield in 1852. In 1862 he entered the business of Wood and Marshall, Huddersfield, andafterwards became a partner. Learnt to play pf. and violin; was in the theatre orchestrat, and ultimately leader. Conductor of the lluddersfield Glee and Madrigal Society; Philhamonic Soeiety; and Festival Choml Society, the last one of the finest in existence; also conducted other societies in the district. Was for some years organist of New North Road Paptist Chapel, but resigned in 18s7. Te died at Huddersfield, Oetober 12, 1,9!1.

North, Robert Augustus, Examiner in Music to the New Zealand Government, published in London, 1s96, a work, thitled, "Voxometric Revelation."

Norton, Hon. Mrs., born CARolixe Elizabeth sarah SHblinax, danghter of Thomas Sheridan, grand-danghter of R. B. Sheridan, and sister of Ilelen Lady Dufferin (q.e.). She was lom in 1809. Pest known as a novelist and pertess. In February, 1877, she was married for the second time to Sir William stirling-Maxwell, That. She died at hondon, Jnnt 15, 1877. Joint composer of "A Set of Ten Rongs, ete., ly two sisters" [1833]. Componel of set of Seren Songs and a duet, 3 sets [c. 1s40]; Songs of affection; Avenge the wrong of Adan Leslie; Blind girls'lament; Lore of Helen l rouglas; Mother's lament, and other songs. Health to the ontward bound, glee. Words of a number of popular songs, like Blockley's "Love not," "Arab's farewell to his stend," ete.

Novello, Clara Anastasia, soprano vocalist, hom at London, June 10, 1818. Daughter of Vincent Novello. She studied at Paris Conservatory, and nnder John Robinson, of Fork. Oin January 7, 1839, she sang at the first coneert of the Tocal Society, Hanover Square Romms, London, and appeared at Windsor in the sanne year. Sang at Ancient and Philharmonic Concerts, and at all the important Provincial Festivals, and at the Gewandhaus Concerts, Leipris, in Italy, tetc. whe married Connt (iglincei, 1s43, and retired iil 1800 .

Novello, Joseph Alfred, pullisher and musician, born at London in 1810. Eldest son of Vincent Novello. Choir-master of Lincoln's Inn Chapel. Bass rocalist at 


\section{NOVELLO.}

varions concerts. Pulsisher morer title of Norello \& Co. in snccession to the buminess founded by his father. Retiled to Genoa in 1856, and dixed there, July 16, 18tad. He wrote "Analysis of Vocal Rondiments ly Qnestion and Answer," London, n,d, " Concise Explanations of the Fregorian Note," I Jondon, 18t", etc. Wrote Englinh rersion of Mondelscohn's "Lobgesang." He invented a form of resisel that was claimed to prevent seasickiness.

Novello, Mary Sabilla, witer, and soprano vocalist, deughter of Fincent Novello. Apleared as singer at varions places, hut now knownonlyaswiter of a "Voual Schoul, ete. .," London, is.d. " Toice, and Tocal Art," n.d.

Novello, Vincent, organist, composer, and publisher, born, London, september 6, 17si. Chorinter in the sirdinian (havel, Inulse Street, moder S. Wablie. Deputy omanist to Weble and Inuly. Organist of the l'ortugurst (hape], 17!6-1820. Fomnded the firm of Novellod Co., in 1811. I'ianist to Italian Opora. Tumalon, 1812. (Jrganist of Poman Catholic Chapel, in Mourfictds, 1840-43. Member of l'hillummonic Siectrat and foumder of the ('lasical Harmonists Society. He

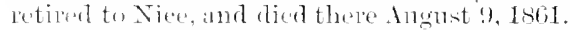

Works. Collections of chuleh muse, consisting of relections from the writings of complosers of all times. Anthems, listies, hrmms, and othere chm h music Catledral volumtarios for orgun, right looks of stections. S'hort melodies for urgan, in wix looks. Seleet mrgan pieces, in 1 is honke containing nomerons original pieces. Rusallat, cantata. Masses, varions. Collection of motets for the offertory. Convent music, collection of sietrer preces. Stonries in vocal connterpoint, ennistims of romuds, ote. Surrey Chapel music. Clees, solngs, ete. The works of Juredl (sacred). The Fitzwillian misie.

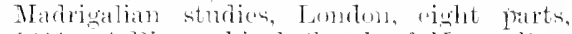

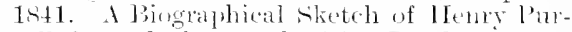
cell, from the best anthorities, Londom [1-9:2].

Non 1 , Edward Cuthbert, eompuser and pianist, ef petsent time. Stndied at R.A.Al. Wou the Lucar Modal for ('omposition, 1847;

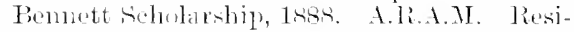
dent at Leytomistome, Esisex. He has given pf. recitals, ]net is leetter known by his commpositions. The chief are: l'salin 100 , for learitone solo and chorns, performed, Leytonstone, 1491; Cantiotas and operettas, Nilliam Tell, or A n(arrow) escape; sir lilluert the Fear"sos; Prince Kamal-al-Zammon, 1s!4;

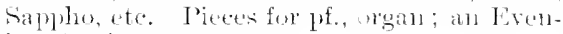
ing śerrice, solngs, etc.

Numn, Elizabeth Annie, comporer, died at Fall wfield, Manchester, Jammary 7, 14:14. at the age of 83. She publi hed a Mass in C', for orli, choms and mohestra, op. $t$; and other linugical music.
OAKELEY.

Nunn, John Hopkins, organist and conductor, born at Bury St. Erhmunds, Norenber 10, 1827. Studied at R.A.MI., of which Institution he is a Fellow. Organist at Sherborne in 1852, renoving to Penzance in 1854, where he has been organist of sit. Mary's Chureh since 1859. Conduetor of Penzance Choral Society, which has given many good concerts. He hat composed a Te Demm, anthems, etc. His dangters, Gentrine and HexrietTa, have been houd as vacalists in the Western counties, and in Mareh, 1885, sang at the Monday I'opnlar Concerts. The first-named is a violoncellist of some distinction. JoHN Noxx, posilbly related, was at one time living at Buty st. Fomund; and for many vears was organist of St. Panl's Church, Budford. From abont 1840 to 1860 , he trok an active part in encert giving, and was principal violin of the Bedfoid Sacred Harmonic Society.

Nunn, Robert Lindley, organist and pianist, born at Burs Sit. Fommonfs. July 15, 1526. Brother of Tolm H. Num. Sturlent, Assuciate, and Fellow, R.A.M. Girulnated Mus. Bac., Cambridge, 1s67. Organist of St. Iary-le-Tower, I pwich, 1856-81; and sometime organist of Queen Elizabeth Sehool. llas been a concert giver and jerformer at lpwich. Colchester, and other places, from 1.553. Resident at Ipswich as teacher, etc. Te has two danghters, talented musicians, the one a violinist, the other a pianist, pupil of the raris comservatoire. Euwrs Nexs, F.C.O., of Ipswich, is the musical extitor of "Hrmms and chants for female voices," Novellis, 18st, compiled for the nse of the Jpwich High fichool. He aliso gave eoncerts at Ipswich, Inso-t.

Nusem, Gi., was, 189t, organist of the Roman Catholic Cathedal, Jemerara, British Friana, and accompanist to the Demerara Mncical Socjety. Ju 14y2, G. W. Nusmm was appointed crainiat of the New Catbedral, I emerara, and opened the new organ therein, March 2.2, Ing:, witl a recital.

Oakeley, Sir Herbert Stanley, Kt., composer, orgmist, and conductor, born at Ealing, Middlesex, July 22, Is:30. Second son of sir Hombent Oalicler, Bart., and of Athole Mnrras, niece of the fourth Ionke of thole. Hencated at Rugly School, and christ Chureh, Oxford, gradnating B.A., 1853, and M.A., 1556. He bad at an eariy age shown recided taste and talent for music, and at ()xford intied hamony nuder Stephen Elvey. ()n leaving the Iniversity he went to Leipzig and studied with Plaidy, Moscheles, and Palpreritz: then moner Toham schueider, D)erden; and firally with Irofessor H. Karl breidenstein, at Bonin. Thomph intended for another profesion, he now determined to 


\section{OAKELEY.}

devote himself to music: and in 1805 berame a candidate for the Reid Chair at Fdinburgl. He wits elected, and the position of the Professorship, so much improvet by his preflecessor, John Donaldson ( $4 . v^{\circ}$ ), wats much enhanced by his work. The ammal "Reit Concert" became a three-lars' Festival, and the fine performances of the Halle orehestra gave a great impulse to the stury and appreciation of orchestral musje in Scotland. His organ recitalin, and the concerts of the Edinburgh Lniversity Mrasical society helped forward the cause of musical education in the district. In 1s6t he was elected member of a soeity called "Quirites," at Rome, ant after his Elinburgh appointments many distinetions were awarded him: Mus. Doe., Cantuar, 1871 ; Mus. Doc., ('anhluidge, honor is causri, 1871; the same, Oxford, 1s79; LL.1)., Aberdeen, 1881; I).C.L., Toronto, 1886; Mns. Doc, Dulblin, 1887; St. Andrew's, 18si; Adelaide, 1895; LI.D., Edinlmugh, 1891; and on his resignation of the Chair of Music in May of that vear, he was made Emeritus Professor, 1892. He was also elected an Hon. Nember of Institutions at Bologna, and Rome.

In 1876, at the inanguration of the sicottish National IIonmment to the late Prince Consort, the music was directed and composed by the Professor, who received the homour of knighthood from the Queen, at Holyrood. He was appointed composer to the Queen, in Scodand; President of the choltenham Musical Festival, from 1887. Besides his professional work, he has lectured and given organ performances in varions places: and was for some years musieal correspondent of The Guardian, and contributor to othes journals.

Works.-Tocal: Jubilee Lrrie, a short cantata, Cheltenham Festival, 18st; Who is this that eometh from Edom? Six short anthems; The Glory of Lebanon, composed for 800th anniversary of consecration of Winchester Cathedral, and perfomed there, April 9, 1893; Behold, now praise the Lord; Seel Him that maketh the seven stars; and other anthems. Servee in E flat; Psalms and Hymns for men's voices; Six hymms, with orchestra; Hymn tunes in Hymns Ancient and Modern, and other colleetions; Bible Psalter; Prayer Book Psalter, edited. Twenty songs; Album of 26 songs, dedicated to Her Majesty; Six songs, op. 2; Tears, idle tears, with orchestra, sung by Mlle. Titiens at the Birmingham Festival, 1873; To MFary; and many other songs. Three duets, German words, op. 8. Quartets, op. 7, 8; Students' songs; Six part-songs for men's voices, op. 17 ; Four memorial choruses; Choral songs, op. 25. National melodies (Scottish), op. 18. Forty choruses, with orehestral accompaniment, for Edinburgh University Musical Society,

\section{O'CAROLAN.}

etc. Instounental: Suite in (1) den Strle, Cheltenham Festival, 18.9:3; Edinhurgh Festal Mareh, Liverpool, 187t; Fnnelal March, op. 29: Minuet, Chester Festival, 1885; Pastorale, Manchester, 1891, all for orchestra. Sonata in A, op. 20; Rondo ('aprieciono; Rimance, ol, 21; Thlee romances, pf. farotte and musette, organ. Arrangements, etc

Oakey, George, composer, writer, and teachere, horn at sit. I'aneras, Lmdon, October 14, 1841. Sulf taught in music. Gained first prizen in Sireiety of Arts Examination under Hullal, 1869, and nnder Macfarren, 1873. (iratlated Mus. Bate, Cambridge, 1s7T. Examiner in hamony and eomposition, Tonie Soldta College; pofessor of the same, City of Lundon College. He has composed Psaln 100, for soli, chorms and orchestral. Anthems: Bleswed be the Lord; Praje the Lord of 1 lonts. Part-songs: The Ialisies peep; Pack elouds away; The Beacon Light, ete. Hymms, chants, and arrangements of national airs, madrigals, slees, ete, for mixed and for equal voje's, published in varions eollections. Author of Construction Exercises in Harmony, 157T; Text Fouk of Counterpoint, 187s, eight editions, rewritten and enlarged, 1890: Text Book of Harmony, 1894, seven editions; Text Book of Musical Elements, 1886, five editions; Compendim of Harmony, 1889; Fignred Batss, 1891, two editions; and New ( trabled Fxercises in Harmony, 189t. All published by Curwen,

\section{London.}

\section{O'Cahen, Rory Dall. See Morisox,}

\section{RONERICK}

O'Carolan, or Carolan, Turlough, composer and harp-player, born at Baile-Nusah, or Newton, West Meath, in 1670. He became blind when about 16 years old, but married and settled on a farn at Mosshill, I eitrim, where his extravagant mamer of living eaused his min and he was forced to beeome an itimerent havper. He travelled much about the country, and lecane widely known as a minstrel and boon companion. He died at Alderford Honse, March 25, 1738. He was a poet and composed a large number of popular Irish tunes, such as "Bumper Squire Jones," "Bridget Cruise," "Liquor of Life," and "Savourna Deelish." His musical works were published in 1747 , and again about 1785 as "A Favonrite Colleetion of the so mueh admired old Irish tunes, the original and genuine compositions of Carolan, the cele. brated Irish bard. Set for the harpsichord, viohn and German flute," Dublin, John Lee, n.d.; but it is understood that only a very small number of his tumes have been preserved or identified. Specimens of his works will be found in Hardiman, Bunting, and Walker. 
()'CATROLL.

O'Carroll, Patrick, author of "A Royal Poad to P'ianoforte Playing, 1889.

O'Daly, Gerald, Irish harpist and composer, of last century. The supposed composer of "Wilcen a Roon," now adapted to the song, "Rolin Adair."

Odier, Ludovic, author of "Epistola Physiologica Inanguralis de Flementariis Mnsice Sensationibus," Edinlurgh, 1770. Treatise on the connection between Music and Medicine.

O'Donnely, T. J., Abbe, anthor of " The deademy of elementary music, containing a lucid exposition of the theory and basis of the practice from its primary notions to those of composition," ete., London, 1841; Paris, 1842.

O'Kelly, Joseph, violinist and composer, born at Boulogne-sur-Mer in 1829. He studied under () shorne, Kalkhemner, etc., and resided at Paris as a musician. He died at Paris, Jantury, 1885.

Workn.--Piraguassii, Poem Lyrique in 3 parts, 1855; Ruse contre Ruse, operetta. Cantata for centenary of o'Commell, Dublin, 1878. Luten de Galway, opera, 1878; La Zingarella, opera, 1879. Songs. Pf. music.

okeover, John, organist and composer of the 17th century. He was organist and vicar-choral of Wells Cathedral. In 1633 he graduated Mns. Bac., Oxford.

Okey, Maggie, pianist, studied at the London Academy of MInsic, and appeared with snecess at the Promenade Concerts, Covent Garden, Angust, 1882. She gave concerts from that year, and has played at Viemna, in 1889; Perlin, 1887; Paris, 1889; in America, 1890-1, etc. She has alio played at the Mouday and Saturday Popular Concerts; the Crystal l'alace; and the Philharmonic, 1891. In $188+$ she was marricd to Vtadinir de Pachmamn, and was divorced some rears later. She has composed a sonata for pf. and violin; Romance in E, do.; Theme, with variations, pf., etc.

Old, John, composer and conductor, horn at Totness, Sonth Devon, Nay 28, 1827. Descended from an ancient family that oectr. pied Ruswon Hall for more than four centuries. He stndied first muder John and Fdwin Loder, 1842; then at R.A.M. under Bemnett and Goss; and later with Thalherg and Molique. Resident for some time at Torquay as teacher and conductor of a choral society. He afterwards settled at Reading, founding the Layston College of Music. He composed a sacred drama, "The Seventh Seal"; an opera, "Herne the J Inter," performed in Reading Town Hall, December 14, 1857 ; and an overtime, "lenth of March" (on the marriage of the Prince of Wales). He also wrote a number of pieces for pf. : Etude de Concert; Reveries; Impromptus, ete.; Part-songs; Songs: I have
O'LEARY.

a home in fairyland; Neet me at morn; My native vale, etc. He died at Reading, February 4, 1892; and at his request a copy of his opera, Herne the Hunter, and two other compositions, were buried with him.

Oldham, S. Emily, composer, of present time. Has given concerts in London, and is the composer of a number of songs, among which may be mentioned His ship; Her voice; Fair is the dawn; Guardami ; Loyal and true, etc. Minuet for pf.

Another Miss E. Otdnas is an Associate of R.C.M., and professor of the pianoforte at the Royal Irish Academy of MInsic, Dublin.

Oldmixon, Lady, bom George, soprano vocalist, was born in 1768 . She sang in opposition to Mrs. Billington at Dublin, 1789, and appeared at Drury Lane Theatre, the Oratorio, and other London concerts. Biography mnknown.

O'Leary, Arthur, composer and pianist, horn at Tralee, Comnty lierry, Ireland, March 15,1834 . He came of a musical family, his grandfather having been a teacher of inusic, his father (died, 1846), organist of the parish chnreh, Tralce, and his uncle (died, 1893, aged 100 or 102), organist of Killamey Cathedral. When quite a child, Arthur O'Leary's plaring attracted the attention of Mr. Wrndinam Goold, and through his friendship the boy was sent to the Conservatorinm, Leipzig, in 1847, and studied under Plaidy, MLscheles, Richter, etc. Returning to England, he entered the R.A.M., 1852, and stndied under Potter and Penmett. Several compositions from his pen date from his student days. In 1856, he was appointed a professor at the R.A.M., and, later, elected a Fellow. Commenced concert giving about 1858 . He has lectured on music, and contributed to the musical press; and held appointments at the National Training School for Nusic, 1876; Guildhall School, from its opening: and at the Crystal Palace School of Science and Art, 1886 , ete. Nember of the Philharmonic Society. Edited Stemdale Bennett's Pf. worls. In 1860 he marricd Miss Roscital Viming, noticed helow.

Works.-Oyerture and incidental music to Longfellow's Spanish Student (1.85t) ; Symphony in C; Suite, orchestra. Concerto, pf. and orchestra. Theme in $\mathrm{C}$, with variations; Toccata in F, performed at the Monday Popular Concerts, December 14, 1885; Wayside sketches; and many other pieces for pf. Six songs: Ask not why I love; and others. Mass of St. John (mison); Ode to the Victor, part-song. Edited Masses by Hummel, Sechter, and schubert.

Mrs. O'Leary, danghter of W. S. Tinuing, of Newton Abbott, Devon, showed remarkable talent as a child, singing and playing at concerts when seven. Entered the R.A.ML., 


\section{OLIPHANT.}

and won a King's Scholarship, Decemler, 1851, and again in 1853. Studied under John Thomas, harp; IV. H. Holnes, pf. ; and Steggall and G. A. Macfarren, conp sition. She is a Fellow of the R.A.MI., and Associate of the Phitharmonic Society. She now devotes chiefly to voice training, and for some years condueted the South Kensington Ladies' Choir. Her compositions include, I am the Angel; My Song is Love; How faithful are thy branches; My Angel Lassie; and other songs.

Oliphant, Thomas, writer and musician, born at Condie, Perthshire, December 25, 1799. Nember of London Madrigal Society, 1830, and acted as its hon. secretary for nearly 40 years. President of the Madrigal Society. He died at London, March 9, 1873.

Wonks.-A brief account of the Madrigal Society.... London, 1835. Short account of Madrigals from their commeneement to the present time, London, 1836. La Mnsa Madrigalesea, or a collection of madrigals, ballets, roundelays, etc., chiefly of the Elizalecthan age; with remarks and annotations, London, 1837. Catalugue of MS. Music in the British MIusenm, London, 1842. T'en Fasonrite Madrigals, arranged from the original part books, with an aceompaniment for the pf., London [1836]. Collection of Glees, Madrigals, ete. (Norello), n.d. Catehes and Romds, by old composer's, London [1835]. Ditties of the olden 'Time, London [1.835]. Arrangement of Songs, etc. Tallis' Song of forty parts; Responses (adited). Stay one moment, gentle river, madrigal. Poetry for various pieces of roeal music. Swedish part-songs (1860) ; German songs....London, 1838-49, issned in numbers. Sir ancient part-songs for five voices, London, [1845]. Songs.

Olive, Joseph, organist and composer, who was organist of st. Botolph's, Aldersgate Street, London, about the middle of last century. He died at London, October 8, 1786.

Wonks.-All for Searlet, an interlude, 1785; India Hoa, interlude [1770]. Six songs for a roice and harpsichord. Bacehus, god of joys divine, duet [1775]. Songs: Farewell, Fox hunter's, Lover's declaration, ete.

Another OLIVE, Emicxid was probably the son or other relative of the above. He was organist of the parish church of Warrington, and is said to have held a similar office at Bangor Cathedral. Died at Warrington, November 18, 1824. He compiled "Sixteen Psalm 'Tunes, adapted for three voices.....as sung in the parish church of Warrington," Warrington, Booth $[1820]$, 2nd. edit.

Oliver, Frederick, bandmaster, born abont 1812. He was bandmaster of the 20th Regiment for 31 years, and served in India, Burmah, and in the Crimean War ; was also

\section{ONSLOW.}

bandmaster in the Donegal Militia, and the 3rd Battalion of the 60th Rifles. In 14693 he went to Kelso as bandmaster to the seventh Duke of Roxburgh, whose band he brought to a high state of effieiency. He conducted a performance before the Queen on the occasion of her visit to Floors Castle in 1867. Up to his eightieth year he played solos on the saxophone. He died at Croydon, Surrey, in February, 1892, aged 82.

o'Mara, Joseph, tenor voealist, born in Limerick, July 16, 1866, son of James O'Mara, J.P., late High Sherriff for Limeriek City. Educated at the Jesuit College there, and was trained in the Tonic Sol-fa method of singing. For some time was manager of his father's business, and, for two year's, sang in the choir of Limerick Cathedral. In 1889 he gave up business, and went to Milan to study singing under Perini, and Moretti. At the end of 1890 he returned to England, and was at once engaged for the Royal English Opera Honse, where he appeared, Ftmary 4, 1891, in the title-part of "Ivanhoe." "He then took lessons from Edwin Holland. In 1892, he rang at the Monday Popular Concerts, and has since appeared at the prineipal London and provincial coneerts. Has been in Sir Angustus Harris's Grand Opera at Drury Lane, and Covent Garden, since 1893, in a variety of chameters, and created the part of Nike Murphy in Stanford's "Shamus O'Brien," prodnced Mareh 2, 1896. He is now in the front rank of opera singers.

O'Neil, Henry John, bandmaster and comet player, lon'n, Dublin, March 25, 1841. He studied under H. König, and acted as bandmaster in the Nary, 1859-62. He settled in Edinburgh, and became a member of the leading orchestras, and about 1879 was appointed Queen's trmmpeter. Bandmaster of the Royal Scots Fusilicrs, and of the 3rd battalion of the Volunteer Highland Light Infantry.

O'Neill, Arthur, Irish harper and collector, born in 1726; dicd near Armagh, in October, 1816. He was possessed of great stores of traditional melodies, ete., and was referred to by Bunting when preparing the first portion of his Irish Melodies.

Onslow, George, composer, bom at Clermont-Ferrand, France, July 27, 1784. Grandson of the first Lord Onslow. He studied under Hüllmandel, Dussek, Cramer, and Reicha. Resided for a time in Vienna, 1802, but returned to Paris, and reeeised the Cross of the Legion of Honour. Nember of the Institut (in succession to Cherubini), 1842. He died at Clermont-Ferrand, October 3, 1853.

Works.-L'Aleade de la Vega, opera, 1824 ; Le Colportenr, opera, 18.7; Le Due de Guise, opera, 18:37. Symphonies for orchestra, op. 


\section{ORCHARD}

41, 42. Quintets for 2 violins, viola, and 2 "eellus, of 'cello and bass, opl. 17, 18, 19, 23, $24,25,32,39,34,35,37,35,39,40,49,44,45$, $51,57,54,51,61,67,68,72,73,74,78,80,82$. Quitrets for strings, ople. 4, 8, 9, 21, 36, 44 , $46,47,44,41,50,52,53,54,55,56,62,63,64$, 65, 66, 6. Trios for pf., violin, and cello, opp. 3, 14, 20, 24, 26, 27. Duets for pf. and volin, (s). 11, 15, 21, 29, 31. Sextet, up. 30. Somata for pif. and 'cello, op. 16. Sonatas for pf. solo, op. 1, 2. Sonatas for pf. duet, op. 7, 2.2.

Orchard, W. Arundel, pianist and composer, of present time. Went to Anstralia, $18 \% 2$ (?), and then to Tasmania, where he was appointed organist and choirmaster of sit. David's Cathedral, Hobart, 1897. He has written an oratorio, "Easter Morn," produced at Bloomslury Hall, April 19, 1892; also an Andante and scherzo for pf. and string orchestra, 1891, ete.

Orger, Caroline, pianist and eomposer, danghter of Mary Ann Orger, actress and dramatic anthor (London, 1788, Briglton, 184!). Bom in London, 1818. Apleared at various concerti from the year 1sto. Gave her first concert at the Hanover Sunare Rooms, May 3, 1849, when she introducat her Concerto for the pf.; and prodneed a Pf. Trio the next yoar at a concert given in conjunctions with Miss Dolby. The society of British Mnsicians brought forward her I'f. Quartet, in 184t; in F flat, 1847; and a Sonata in ( $\mathrm{t}$, for 'cello and pf., 18t6. In 1846, she married Alexander $R$. Reinagle $\left(q \cdot r^{2}\right)$, and under that name afterwards published a pamphlet, "A few words on Pianoforte playing, with rules for fingering passages of frequent oecurrence [1855], Novello. She published Tarantellas and other works for the I'f.; Sonata for the Pf., op. 6 . Three songs by R. Browning (1868), etc. Died at Tiverton, Devon, Marth 11, 1892, aged 74 .

Orridge, Ellen Amelia, contralto vocal. ist, born at London, August 14, 1856. She studied at the R.A.M. under Garcia, and gained the Thomas (1877), Nilsson (1878), and Parepa-Rosia (1878), prizes. She was wellknown at most of the London and provincial coneerts, and was a special favourite in oratorio music. She died at Guernsey, September $16,1883$.

Osborne, George Alexander, pianist and composer, born at Limerick (where his father was lay-vicar and organist of the Cathedral). September 24, 1806. He was intended for the church, but having a strong bias toward music, he taught himself pianoforte playing, assisted his father at the organ, and finally decided upon music as a profession. In 1825 he went to Brussels, finding a hone with the Prince de Chimay. There he studied and gave eoneerts, and was musical instructor
OSTLFRE.

to the Printe of Orange (the late king of Holland). After the revolntion of 1890 he went tor Paris (Fétis says in 182li), where he studicd under P'ixis, Fetis, and Kalkbenuer. He remained there until 1843 , occupving a prominent position as perforner, tenteles, ind composer. In 1843 he is salid to have sottled in London, lnt lie kept np his houne in Paris to the end of $18+7$. 1le was in London in 1844, 1845, and also plaved at a conetert in $18 t 8$, in which year he seemsis to have made London his honie. Flon 1ot9 his concerts were important features of the musical seasom.

He was a Member, ant sometime Tirector, of the Philharmonic suciety; also birector, R.A.M., and assoeiated with other institutions. He retired from active life abont 1880 , ] nut played occasionally in performances of his chanher music mp to Novenuler, 1r89. I'ersonally acquainted witl the greatest musicians of the century, he has penned his memories of them in patpers reat lefore the Mnsieal Assuciation, 1878-83. He died at London, Novenber 16, 189:?.

His compositions comprise two oreras; sereral rocal scenas; Three orertures: The Forest Maiden, performed at Alexandra Palace, Februarr, 1876 , cte. ; and Narches for orehestra. A septet, Sestet (performed, Lomdon, 1849), and Qnintet for pf., wind, and donble bass; Three Trios in A (1844), $\mathrm{A}$, and E (1845), for pf. and strings; Sonata, pf. and "cello; pieces for violin, ete. A large number of pieces for pf.: La Pluie des Perles; Romance sans paroles; La Tenerezza; Talses, ete, many of them exceedingly poprular. With De Beriot he wrote a number of duets for violin and pf.

Osman, Fanny Wilson, soprano vocalist, born at Reading. Studied at the R.A.MI, and later under Vanmuccini. She has sung in oratorio and ballad concerts in London and the provinces with suceess, and is favourably known as an accomplished artist.

Osmond, Harold Bartrum, organist and composer, born at Southampton, Jannary 19, 1869. Studied at the Guildhall School of Music mader D. Beardwell, Henry Gadsby, and other Masters. F.R.C.O., 1888. He was appointed organist of St. Peter's, Bethnal Green, 1884 ; St. Barnabas, Honerton, 1886 ; and, since 1889 , has been organist and direetor of the choir of St. Peter's, Thanet. He is conductor of the Broadstairs and St. Peter's Choral Societies, and of the St. Peter's Church Oratorio Society. His ehief eompositions are a Sacred Cantata, The Aseension (1886); Psalm 23, for baritone solo, chorus, and orchestra (1886); Commmion Service in E; Anthems, ete. Symphonic Suite for small orehestra, Margate Philharmonie, 1896, etc.

Ostlere, May, eomposer of dance music of present time. Her pieces include waltzes: 


\section{OSWALD.}

Hypitia, Clytic, Ariadne, Idalia, Isis, Only once more, Spirit of the star's, ete. I'olkas: Genesta. Thistledown, Intch Doll, ete. Marches and songs.

Oswald, Arthur Louis, baritone vocalist, born at lirighton, July 1.t, 1858. At first studied as a pianist, at I'uis, Ist1-2, and at Mayenee, with Berschlas, INT3. Entered R.A.M., 1573, studied with Manuel Garcia until IsT7, when le went to Milan for two years. Made bis debut in opera at Vavese, appearing in Figaro, Il Babiere, Fanst, ete. In 1879 retnmed to London. Sang at the Monday Popular Concerti, Crystal Palace, and Philharmonic Concerts in 1riso, achieving a high'position at once. He has also sung in oratorio. In 1sist he was aplouinted a professor of singing at the IR.A.M., and elected a Fellow in 1891. He was appointed a professor of the Guildhall Sichool of $\mathrm{Mh}$ sice in 1896.

Oswald, James, mulicim and editor, born in ficotland ahont 1710-1711. He wats at dancing-manter in Innfermline, and afterwards a teacher of nutsic and dancing in Edinburgh. Fie settled in London in 1742 , and was engaged in lusiness as a musie-sellel at the Parenent, St. Martin's Churchyard. He became chambler compuner to George III. in 1761. He died at linehworth, Herts., in 1769 , aged 58.

Womks. A Curions Collection of Seots tumes for a violin, bisis viol, or Freman tlute, with a thorough-bass for the harpsichord, Ediuburgh, n.d. ¿c. ITto). Cullection of curions scots tmes for a violin, German flute, or harpsichord, Londun, 1r.d. [c. 1742]. The Caledonian Pocliet Companion, containing a farourite collection of Scotch tunes, with variations for the German flute or violin, London [c. 1740-1759], issued in 1.2 books, forming 2 volumes of 6 books each. Six pastoral solos for a riolin and violoncello, with a thorough-bass for the organ or harpsichord, London, n.d. Six Songs compos'd in the Scoteh taste, for a person of distinetion. Humbly inseribed to Her Grace the Dutchcss of Hamilton, London, n.d. [1750]. Airs for the Spring, Summer, Autumn, and Vinter, London, n.d., issued in 4 parts. Collection of Scots tunes, with variations... London, n.d. Ten Faronrite Songs, smong his Miss Formantel, at Ranelagh, London, n.d. Fifty-five marches for the Militia... London, n.d. Collection of the best old Seotch and English songs set for the voice, with accompaniments and thorough bass for the harpsichord, London, n.d.

Ould, Charles, violoncellist, born at Romford, Essex, July 19, 1835. Has played in the principal orchestras in London and the provincial festivals, and appeared ats soloist in Birmingham, at the Harrison and stockley concerts, ete. He has played at the Monday Popular Concerts, and is a member of the
OLSELEL.

Gompertz string quartet, giving conterts in the Queen's Hah, Londun, and in the provinces. Member of Her Majesty's P'rivate Band. His soll, Charles Hoplixis Orld, is an excellent pianint, and has atced atsalcennlanist at the Monday Popular Concerts (1565), etc.; and his daughter, KATE OLLU, is a violoncellist who has appeared with suceens at varions chanber concerts in London.

Ould, Edwin, contrabatsint, a nember of the l'hilharmonite and other orchestras, is the composer of a concert orerture. probluced, LSA5; "L'Esperance," for violin and orehestra, ete. His son, P'Ericy OcLI, violinist, Wals

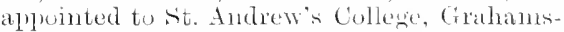
Town, fouth Africa, in 189:3, and in doing good worlin in cape Colony

Ouseley, Rev. Sir Frederick Arthur Gore, Bart., comluntr, organint and witer, was born at London, Alunint 12, I-25. Sun of Sin Willian Ouseles, Hant., whom he sueceded in 18t4. He wase educated at Uxford, and graduated B.A., ISt6; M.A., Irt?. ()rained 1849. Curate of st. Paul's, linightshidge, 1819-50. Mur. Bac., Oxom., 1850. Mus. Ince, Uxon., 185t. Frofensor of Music in Oxford University (in succession to sir l lenry bishop), 1855. Precentor of Herelord Cathedral, I855. M.A. and Mus. I)oc., I)urham, 1856. Warden of sit. Mlichatel's College, and Vicar of St. Michael, Tenbury, 1856. Mus. Doc., Cantab., 186. Hon.. LL̈.I), C'antab., 1853. Hon. LI.D., Edinburgh, 1885. He died at Hereford, April 6, 18s?.

Morks. - The Martyrdom of st. Polycarp, oratorio, 1855; Hagar, oraturio, IJereford Festival, 1879. Church services in D, Bminor, A, G, E, E Hat, and D, etc. Anthems: And there was a pure river; Awalie, thon that sleepest; Behold now praist the Lord; Christ is risen from the dead; Great is the Lold; I will give thanks; I waited patiently for the Lord; I will magnify Thee, O Lord; It came even to pass; In Gud's Word will I rejuice; Love not the world; 0 love the Lond; O sing unto God; Sing unto the Lord; The Lord is King; The Lord is my shepherd; Thus saith the Lord; Unto Thee will I cry ; Why standest Thou so far off? etc. The Psalter, arranged for chanting, with appropriate English chants (with E. (. Monk), London, varions editions and dates. Anglican Psalter Chants, London [1872]. Eighteen l'reludes and Fugnes for oryan; Sonati for the opening of the new organ in the sheldonian Theatre, Oxford; Three Andantes for organ; Preludes and Fugnes, various. Cathedral Services by English masters [Farrant, ('reyghton, Kemptom, Child, Kelway, Aldrich, ete.], London, n.d. [185:]; Collection of Anthems for certain seasuns and festivals (edited), 2 vols., 1.861-60; Glees; Six songs, etc. Treative on Harmony, Oxford, 1868; 2nd uditiun, 1876; 3rd edition, 


\section{OTFREND.}

1883. Treatise on Comnterpoint, Canon, and Fugue, based upon that of Cherubini, Oxford, 1h6s: Lnd edition, 148t. Treatise on Musical Form and (ieneral Composition, Oxford, 1875 ; snd edition, 18R6. Nammann's History of Mnsic, trans. ly F. Praeger (edited). Sermons, ete. Sie Memorials of Sir Frederick A. (i. Ouseley. Bart., by Francis T. Havergal, 1889. By his will he left his musical library to St. Michacl's College, Testury. 'The valize of his personal sitate exceeded $\$ 51,000$.

Overend, Marmaduke, organist and writer, who was born in the first half of the 18th contury. He studied nnder Boyce, and was organist of Isleworth, Middlesex. $\mathrm{Hc}$ died in 1790.

Wokks.-A linef account of, and an introduction to, eight lectures on the science of music, Loudon, 1781 ; Twelve sonatas for two violins and viuloncello, 1779; The Epithalamium made on the marriage of King George III. and Queen Charlotte [London, 1761]. Vocal music, etc.

Owen, Alexander, bandmaster and cornet player, born in 1851. He has been comnected for many years with brass bands in Lancashire, and has won many prizes in contests. He was conductor of the Stalybridge Band; solo comet player in the Meltham Mills Tand, 1875; conductor of the Poarhurst Band, 1877-84; of the Black Iylie, 1879-88; and of the Pesses o' th' Barn Band, 1884 to the present time. With these fine bands he has given concerts in many places, and has aranged much mnsie for their use.

Owen, David, sumamed DArYDD Y Garku - Wen, harpist and composer, who flomished in Wales about $1722-1751$. He is said to have composed the "Rising of the Lark," and other Welsh airs.

Owen, David, bandmaster and conductor. He was handmaster of a Highland regiment for some time, and in 1835 succeded his father as bandmaster of the 2nd Dragoon (ruards (Scots Greys). He died in 1867.

His yomiger brother, JAMEs ARTHUR OWEN, was a pianist and clarionet player. He was born in 1829, and died at Brighton, November 5, Lori. Composer of a Ponnance for cornet and pf. (1855), and a large number of polkas, ralsc's, marches, galops, etc., for $p$ f. and orchestra. He also composed some songs.

Owen, John, Owate Alaw, composer, teacher, and laritone singer, bom at Chester of IVelsh parents, November 14, 1821. He was bronght mo to trade till 184t, when he adopted the musical profession. Organist of various churches in Chester, and a prominent advocate of musical education. He died at Chenter, Jannary 30, 1883.

Worlis.-Jeremiah, oratorio, 1878. Habakkuk's T'rayer, prize cantata (with Ambrose Lloyd), 1851 ; Irince of Wales, cantata, Cal-
PAGE.

narvon listeddfod, 1862. This was the first Welsh secular cantata. Gwalia's Holiday, cantata, Chester, 1866. Anthems, glees, songs, etc. He also edited Crems of Welsh melody, a selection of popmlar Welsh songs, Ruthin, 1860. The Welsh Harp, airs arranged for four voices; a collection of tunes for Sunday sehools; a collection of English airs, ete.

His son, WILLAM Haxky, was born at Chester in 1845. He was an organist in Dublin, and was killed in a railway accident at Abergele, on Angust 20, 1868, when returning to his post. Some of his anthems were published in Welsh by his father, and a Magnificat by him is in Novello's list.

Packer, Charles Sandys, organist and composer, born in 1s10; died at Reading in September, 1883. Student, Associate, and Hon. Member, R.A.M. In 18:9 he was tried and condemned for forgery. While a student he wrote an Italian sacred drama, " La Morte d'Abele," and some rueal seenas. He was a composer of much ahility, and his lamentable fall put an end to a career of more than ordinary promise.

Packwood, Charles, musician, composed "Original saered Music, consisting of psalm and hymn tunes, etc," London, 1845.

Paddon, James, organist and composer, was horn at Exeter alout $176 \mathrm{~s}$. Fducated in the Cathedral there, and was organist of the Cathedral from 1803. Died at Fxeter, June 14, 18:35. He composed some sacred music.

JoHn PaDinon, probally the son of the foregoing, composed "Sacred Music, tused at Quebec Chapol," London [1810] ; Ballads, dance music, etc. Author of "System of Mnsical Education," London, 1818.

Page, Arthur James, organist and composer, Jorn at Ipswich, March 3, 1846. Enteled Norwich Cathedral as a chorister at the age of seren, and when fourteen was articled for seven years to Dr. Buck. He was taught hamony and counterpoint by Dr. Bumnett. At the end of his time he was offered a partnership hy ${ }^{2}$. Buck. This he did not accept, but ohtained the appointment of organist and choimaster at sit. Mary's, Nottingham, in 1867, where he still holds office. He started and maintains a sirpliced choir of some 80 voices at that ehurch? F.C.O., 1875. Sometime music master at Trent College. An active worker from the early days of the Incorporated Society of Iusicians, he has been Hon. Gen. Treasurer since 1885. At the Cardiff Conference, 1897, he was presented with a testimonial. Has contributed to the musical press, and is the composer of the following works:-Cantatas and operettas for treble voices: Red Riding 


\section{PAGE.}

Hood; Meadowsweet; Nymphs and Goblins; Sea King's Drughter ; Snow Queen; Spirit of the Year; Amabel; The Three Bears. Anthems and Services. Three-part, and twopart songs; Album of six songs, ete. 100 original rounds, composed and eolleeted, Forsyth. Pieces for organ or harmonimm, four books; organ pieces, variuns. Spring song, Bercense, etc., for pf. Madrigal, I dare not ask, performed by Nottinghan Philharmonic Society, 1891, ete. His son, Arther BenxARD PAge, is a music teacher in Nottingham, aud a lyrie author of ability, having supplied the books for most of the cantatas named above.

Page, Edward Osmund, organist and composer, who resided in Manchester as an organist and teacher. He died Iecember 2:3, 1883. Composer of a Mass and other vocal music.

Page, John, editor and tenor singer, was born about the middle of the 18 th century. Lay-clerk, st. George's, Windsor, 1790. Gentleman of Chapel Ruval. Vicar-ehoral, St. Patul's, 1801. He died at L mdon, August, 1812.

Works.-Harmonia Sacra: a collection of anthems in score, selected for cathedral and parochial churches from the most eminert master's of the 16th, 17th, and 18th centuries, London, 3 rols., 1800 ; 2nd edit., ly E. F. Rimbault. Festive lIarmony : a collection of the most favourite madrigals, glees, and elegies, seleeted from the works of the most eminent composers, London, 4 rols., 1sot. Collection of Hymms, London, 1804. Divine Harmony... by I'. Heuley, to which are added four psalm tmes, by T. Sharp, London, 1798. Burial Service, Evening Service, Anthems, etc., performed at the Funeral of Lord Nelson, Jannary 9, 1806. Four anthems (festival), etc. Anthems and 1'salms, as performed at St. Paul's Cathedral on the day of the Amiversary Meeting of the Charity Children, London 1785$]$.

Page, William, musician, insued "The Golden Lyre, containing 130 original psalm and hymn tunes...." London 1s56].

Paige, Kate, authoress of "Exercises on General Elementary Nusic." Part I., 1880; Part II., 1881, London. Daily Exereises for the Pf. [1883].

Paine, Robert Parker, composer, botn at Sandgate, Kent, Norember 15, 1823. Mrusical from chitdhood, he had to pursue his studies mder difficulties, and is practically self taught in composition. His friend, $\mathrm{C}$. H. Purday (q.x.), then of Sandgate, was one of the first to encourage his talent, and Paine contributed to his collection of 100 rounds. When he went to Windsor he was enconraged in his work by Sir George Elvey. His principal compositions are a cantata, "The

\section{PALMIER.}

Prodigal Son," perfomed at Eton, January, 1884; a Te Deum, bronght ont at the same time; and a setting of Pralm 9:3, for bass solo, chorus and orchestrit, produced at Windsor, May 23, 1887. He has also composed, When the soft light, The wind and the waves, The Fisherman, and other songs; and has in MIS. anthems, hymn-tunes, chants, songs, ete.

Palmer, Edward Davidson, organist and writer. Graduated Ins. Bac., Oxford, 1578. Organist of Upper Holloway Baptist Chapel, from 1845; profesisor of hamllony, comnterpoint and sulo singing, Metropolitan College of Music. He has conposed a setting of Pralm 1.46, for soli, chorus and orchestra; and pablished some pieces for organ, and arrangenents for viotin and pf. Author of "A Manmal of Voice Training," London, Jos. Williams, 1s91; and contributor of papers to the Ninetenth Centwy magazine, and the musical press.

Palmer, Isabella Perkins. See sub. Dibun, Hexti E.

Palmer, James, musician and editor, lorn at Southwold, Suffolk, December 7, 1796. He was a teacher of music in Edinburgh, and was precentor in Bronghton l'lace Cnited I'resbyterian Church, from $18: 30$ till 1851. Te died at Edinburgh on July 23, 1s61. Compiler of "Sacred Hammen original and selected, in four vocal parts, sulted to the psahms, paraphrases, and hrmms used in all the congregations in scotland," Edinburgh, n.d. "Christian Harmony, a collection of sacred music, adapted to the various metres in general use..." Edinburgh, n.d., issued in parts. "The sacred Minstrel, a collection of original church tunes and anthems, containing also several celebrated pieces by eminent composers," Edinlunrgh, n.d. "Collection of P'salm and Hymn Tunes used at the Relief Church, Broughiton Street, Edinburgh, 1828."

Palmer, Lucas Shelton, writer and organist, author of "First Studies in Sightsinging, for the use of schools, choirs, and chural societies," London, Novello [1875]. "A Short Catechism on Singing," London. Part-songs, Sunset; The white rose sighed; Phyllis.

Palmer, Percy. See sab. Mariott, Axvie.

Palmer, Thomas, organist and composer, graduated Mus. Bac, Oxford, 1579. Organist of All Saints', Londonderry, 1873; parish church, Alton, Hants, 1876: Omagh, Comnty Trrone, 1877; and st. Natthew's, Ipswich, from 1880. Conductor ef Felixstowe Choral Soeiety. Composer of Psahm 108, for soli, chorus and orchestra; Erening Service in F; $O$ sing unto the Lord, anthem; part-songs, songs, pf. pieces, etc. 


\section{PALTONI.}

Paltoni=Corri. Sier sub. Corri, Faxxy.

Panchari Baneriea, author of a "History of Hindn Mrasic," a lecture delivered at the Hooghly Institute, Bhowamipore, 1s80. It contains a notice of nomy native musieians of Southern India, and valualle information eoncerning the musical systems of that country.

Parepa $=$ Rosa, Euphrosyne Parepa de Boyesku, soprano focalist, hom at Edinburgh, May 7, 18:36. Danghter of a native of Wallachia. Educated by her mother, Elizabeth Seguin. Debut at Malta, 1852. Sang at Naples, (remor, Rome, Flortnee, Madrid, Lisbon, ete. Appeared in London, May, 1857. Married Captain de Wolfe Carvell. Sang at Handel Festival, London, 1862-65. Married Carl Rosa (after death of her first husband, 1865), 1867. Tisited America, 1867-1871. Re-risited Americat, antumn of 1sr1. She died at London, Jannary 21, 1874. She appeared in operas ly Bellini, Mellon, Macfarren, Balfe, Meyerlseer, Anber, and Mozart, and did much to establish the carl Rosil Opera Company.

Parish=Alvars, Elias, harpist and composer, born at Teignmouth, February 2s, 1810. Jewish br parentage. He studied under Dizi, Labarre, and Bochsa. Played in Germany, 1831; Italy, 1834. Appeared in London, 1836-7. Travelled in the Fast, 1838-42. Appeared in ( iemany and Italy again, 1842-44. Settled in Vienna, 1st7. Chamber harpist to Emperor. He died at Viemna, Jannary 25, 1849.

Works. - Toyage d'un Harpiste en Orient, Pecueils d airs et de melouties populaires en Turquie et dans l'Asie Mineure, Harp solo, op. 62: Concerto for harp and orelestra, in G minor, op. 81; Concerto for 2 harps and orchestril, ; Concerto for harp and orchestra in E flat, op. 9s; March for harp, op. 67; Fantasias, transeriptions, romances, and melodies, for harp and orchestra, and harp and pif., etc.

Park, Rev. John, D.D., poet, composer, and clergrman, born at (reenoel in 1804. Edneated at freenock and Paisley, and at Glasgow and Aberdeen Universities, and was lieensed to preach. Assistant to Dr. Steele, West Chureh. Greenock, and afterwards to Dr. Grigor of Bonhill. Minister at Liverpool. Minister at Glentairu, in I umfriesshire, and afterwards of Collegiate Parish Church of St. Andrews, first charge. He died at st. Andrews, April 8, 1865. His compositions were issued as "Songs composed and, in part, written by the late Rev. John P'ark, D.D., St. Andrews, with introductory notice by Principal shairp," Leeds, 1876, with portrait.

Parke, John, oboe player and composer, was born in 1745. He studied under Simpson and Banmgarten. Oboist at the opera, 1768.

\section{PARKER.}

Concerto player at Vanxhall, 1771. Principal olooist at Dimry Lime, 1771. Nember of King's Private IBand. Chamber Inusician to I'rince of Wales, 1783. Principal oboe at the Concerts of Ancient Music, etc. He died at London, Augnst 2, 1829.

Parke, Maria Hester, Beardmore, pianist, composer, and singer, bom in 1775. Danghter of John Parke. She studied under her father, and made her début as a voealist at Gloncester Festisal in 1790. Sang afterwards at London, and provincial concerts. Narried Mr. Beardmore. She died on Angust $15,1829$.

Works.-Three grand Sonatas for pf., op. 1; Two do., op. 2; Two Sonatas for pf.; op. 4; Sonata for pf., op. 7 . Concerto for pf. or harpsichord, op. $6[1800]$. Two sonatas for pf. and violin, op. 13. Set of Glees, London [17!) . Songs, etc.

Parke, William Thomas, writer, oboe player, and composer, born at London in 1762 . He studied moler Dance, Baumgarten, and his brother, John. Chorister at Inury Lane Theatre, 1775. Oboist at Vauxhall, 1776. Principal oboist at Covent Garden, 1783. Employed at principal concerts, Vauxball, ete., as ohoist, after 1800. He died at London, Angust 26, 1847 .

Works.-Overtures to "Netley Abbey," 1794; "Lock aud Ker," 1796. Cincertos for oboe. Three duetts for two German fiutes [1793]; Second set, op. 8 [1794]. Tutor for the hantloy : being a familiar introduction to the art of "playing this instrument. With sixteen duet for two hautboys, n.d. Songs : Plue bonnets; Cupid is a wanton boy: Inonald Macleod; Lad of the moor; Maid of the village; Merry tambourine. He also adapted Ialayrac"s "Nina" for the English stage. Musical Memoirs: comprising an account of the general state of Music in Fngland from the first Commemoration of Handel in 1784 to the year 1830 , interspersed with numerous anecdotes, musical, histrionie, etc., London, 2 vols., 1830.

Parke is now best remembered br his useful "Musical Memoirs," or amals of musie from 1784 to 1830 . It contains, among much gossippy matter and anecdotes, a very considerable proportion of historical and biographical data.

Parker, Henry, composer, eonductor, and teacher of singing, born in London, August 4, 1845. Studied at Leipzig nnder Moscheles, Richter, and Plaidy; and at Paris under Lefort. Has given concerts in St. James's Hall, Londou, ete. Composer of a romantic comic opera, "Nignonette," Royalty Theatre, Nay, 1889; "Jerusalem," for bass solo and chorus, Allert Hall, 1884; and other songs that have become popular. Gavottes, and other short pices for orchestra; pf. pieces, 


\section{PARKER.}

etc. Author of "The Voice: its Production and Inprosement, with Fractical Exelcisen." Loudon, various editions.

Parker, Louis Napoleon, composer and dranatiot, born in the Imparturent of Calvados, France, $U$ (ctoles 21,1852 Educated on the continent. Studied it R.A.M., 1870, under Stemdale Bemnett, Banister, Steggitl, and others. A.R.A.M., 187t. Nember of committee of the United Wagner Society, and English representative of the lisue Jingnerienne, 1885 . In 1877 he was appointed organist and nunsic master at Sherborne school, I brsetshire, and he made the school concerts fanous, also conducting varions soeteties in the locality. In 1892 he left sherlorine for London, to derote himself to dramatic anthosship. He was for a long tine a contributor to the musical press, principally upon Wagnerian topics. His eompositions comprise the cantatas, The Wreck of the Hesperus, Silvia, Tomng Tamerlane: Psaln sa, for equal voices; Orchestral orertures (MS.), violin and pf. pieces; Sings, and part-songs, ete. I rimnatic works: A loured talent; The love knot: Love in a mist; The sequel; and other's witten in conjunction with MLuray Carson, etc.

Parker, Robert, organist and conductor, studied under IV. S. Horte, Scotson Clark, and $\mathrm{G}$. Cooper; also violin and prf. nuder Lehnerer, and singing nurder F. Wallier. Was for sme time assistant to W. H. Momk at King's Corlege, Loudon. Al, int the end of 1878 he was appointed organist at the Cathedral, Wellington, New Zealind. There he established orchentral concerts, and conducted the first Mnsical Fentiral given in New Zealand, November, 1888. He has introduced many important comprositions, and has exercised great influence in the musical development of the country. He is singing instructor to the Board of Edincation, and represents the R.A.M., and other London institutions.

Parker, Septimus, composer and organist, loorn at London, June 10, 1824. He Was successively organist of Ashtead Parish Chureh, 184t-59; Epsom, 1859-61; Godalming, 1864-7t; Ashtead, 1874-77; St. Paul's Episcopal church, Alerdeen, 1877-79; St. John's, Longside : St. Paul's, Aberdeen, again, 1880-82; and St. Mary's, Aberdeen, 1855-86. He died at Aberdeen, April 27, 1886. He composed church services, at thems, bymmtunes, part-songs, etc. Edited a "Selection of Church Tumes and Cathedral Chant: arranged in 4 parts," Novello 18507.

Parker, William Frye, violinist, born at Dummow, Essex, in 1855. Entered the R.A.MI. in 1867, studying under the late MI. Sainton. At the age of sixteen he was engaged by Costa as a first violinist in the orchestra of Her Majesty's Theatre. Irofessor of the violin, R.A.AI and Guildhall School of Music,

\section{PARRATT.}

18s1. F.R.A.AI. Irincipal riolin at the Promenade Concerts at Her Majestry"s Theatre, 1887, and at the Queen's Hall, 1,45. After the death of $M I r$. Cirrodus, MIr. I'arker was appointe d pincipal violin at the Leeds Festival of 1 hsis, and of the l'hilhamonic society, 1896.

Parkinson, William, musicion of the latter pirrt of the 1sth century. Anthor of "Now look of Instructions for begimners on the P'imofurte," Londin 1790

Parkinson, William Wignall, muxician and writer, lonrm at Catterall, Garstang, Lancashire, 1s12. Author of "The natural and miversal l'rinciples of Harmony and Modulation, with illustrative and andyed extracts from the Works of Classical Composers," London, 1873. He died at ('atterall, June 3, 1878.

Parkyns, Beatrice, Mrs., bom CrawFond, conposer, born at Ponbay, India. Her works include: A Pois of l'roverbs, six songs; A Posy of Flowers, words of $]_{x}$ th by May (rillington; Slephertis lose nong, ete. A romante for violin, "songe d'antrefois"; Pf. pieces, ete.

Parr, Rev. Henry, elergrman and musician, burn at Lythwoud I Lall, shrophire, Angust 16, 1815. He was educated at Oxford, and ordatined in 1845. Vicar of Tituntom, 18t9-185s; Corate of Thubridge, 1859-1461; Perpetual curate of $A-h$ Church, cilnacenterhire, 1861-62; Curate-in-Clatrge of Yoxford, suffolk, 1867; and viear at Yoxford, suffolk, 14.2. Compiler of "Church of England P'salnody: Psalm tmes, Chants, with responses, ete., with memoirs of the composers and histories of the pieces," London, 8 editions to $18 \mathrm{se}$; and composer of chants.

Parratt, Sir Walter, Kt., Grinist and composer, born at Huddersfield, Felmury 10, 181. Studied under his father (noticed below), and when seven took a service at Amitage Bridge, near Huddersfield, succeeding his elder brother as organist there in 1852. Two years later he was appointed to st. Paul's, Hnddersfield; in 1861 to Witley Contrt, as organist to Lord Indley; I'arish Church, Wigan, 1s6s; Magdalen College, Oxford, 1872; and in 1842 succeeded sir George Elvey at St. George's Chapel, Windnor. Crraduated Ins. Bac, Oxford, 18,3. Appointed professor of the organ at R.C.MI., 1853; in 1832 received the honom of Knighthond; and in 1893 was appointed Master of the Music in Ordinary to the Queen. He is a remarkalle performer on the crgan, and has given recitals in many places, and also lectured and witten on the organ and kindred topics. Contrilntor to Grove's Dictionary. He has composed music "Agamemnon," Oxforr, 1880; set the Elegy to Patroclus, in the "Tale of Troy," London, 1883 ; Music to "Story of Orestes," London, 


\section{PARRY.}

18s6. Anthems, songs, organ and pf. pieces. Also a Mareh for the Royal Wedding at Windsor, July $6,1891$.

His father, Thomas Parnat, born Jannary 30, 179:, was an articled pupil of Braikford, the then organist of Ioncaster Parish Church. In 1812 Gray built a new organ in Huddersfield Parish Church, and Parratt was appointed organist. His first service was played on Christmat I ay, 1812, and he never missed playing on the amniversary of that day till his death, Warch 27, 1862. He was the first organist and resident professor in Huddersficld; a fine player of the old school, and celebrated for his aceompaniments.

The elder son, Henry L. Parratt, trained by his father, was organist first at Armitage Bridge Church; in 1852, of St. Paul's, Huddersfield; then, after some time spent in London, succeeded his father at Huddersficld Parish Church in 18fi2. For 85 Christmas Days in succession father and son have presided at the organ.

Parry, Charles Hubert Hastings, composer and writer, horn at Bommemonth, Febrnary 27, 1848, second som of the late Gambier Parry, of Higham Court, Gloucester. Went to Fon in 1861 , and while there lat lessons from I)r. (4. Flver, composed a Church Service in I), and passert the examination for Mns. Bac. Proceeded to Oxford in 1866 , graduated Mus. Bac., 1867; B.A., 1870; and II.A., 187t. While at Oxford he worlied at mnsic with Sir WT. S. Bemmett, and (Sir) $\mathrm{G}$. A. Macfaren; and, making it his profession, studied further with H. H. Pierson at situttgart, and with E. Damnrenther. It was not until 1s80 that he was generally known as a composer, though an orchestral Intermezzo Religioso from his pen was produced at the Gloncester Festival of 186s. In February, 1880, Mr. Dannreuther, at Ome sifuare, bronght ont some of his chamber mnsic; and his "Prometheus Unbound" was prodnced at Gloncester Festival that vear. Since then he has contributed more works to the provincial festivals than any other composer. He was appointed Choragus of the University of Oxford, in 1883; and professor of composition and musical history in the R.C.M., on its opening the same year. Fxaminer for Degrees in Musie, London University, 1891; and on the retirement of Sir George Grove in 1894, he was elected Direetor of R.C.M. He was creater Nus. loc. by l)ecree of Convocation, Oxford, 18st; and received the same degree, honoris causi, at Cambridge, 1883, and Dublin, 18.1. He has jectured on music at the Royal Institution, 18.91-3; at the Midland Institute, Binmingham, 1884, etc., and in other places; and has contributed to the Acalemy, 1<76, and writton man elahorate articles for (irove's " pictionary of IIusic."

\section{PARRY.}

Works.-Cantutas, oratorios, ctc.: Scenes from Prometheus Unbound (Shelley), Gluncester Festival, 1880; The Glories of our Blood and State, the same, 1883; Choral Ode, Blest Pair of Syrens (Milton), Bach Choir, May 17, 1887 ; Judith, Bimingham, 1888 ; St. Cecilia's Day, Leeds, 1889 ; L'Allegro ed il T'ensieroso, Norwich, 1890; Psalm 130, for soprano solo, three choirs, and orchestra, Hereford, 1891 ; Choric song, The Lotos Eaters, Cambridge, May week, 1892; Oratorio, Jol, (Honcester, 1892 , and repeated at Worcester and Hereford, 1893-4; King Sanl, Birmingham, 1894; Ode, Invocation to Music, Leeds, 1895. Ode for 450 th anniversary of Eton; Music to Aristophanes' Birds (Cambridge, November, 1883); Frogs (Oxford, Felmuary 17, 1892); and to Hypatia, Haymarket, January, 1893. Anthems and Selvices. English Lvrics, 4 sets; Three Odes of Anacreon; Six Shakesperean and other songs, etc. Orchestral: Srmphony No. 1, in (r, Bimingham Festival, 1882; No. 2, in F, Cambridge Cniversity Musical Society, Jume 12, 1883; No. 3, in Ci, Philharmonic, Nay 23, 1889; No. 4, in F minor, Richter, July 1, 18s!. Suite Modeme, in A minor, Gloucester, 1886; Orerture, Guillem de Caluestanh, Crystal Palace, March 15, 1879 ; Symphonieoverture, On an unwritten Tragedy, Worcester, 1893; sinite for strings, 1894. Concerto, in E sharp minor, pf. and orchestra, Crystal l'alace (Ianneuther), April 3, 1880. Chamber Music: Nonet in P flat, Wind; Quintet in E flat; Quartet in G, strings; in A Hat, pf. and strings; Trios in $\mathrm{E}$ minor (18s0), B minor, and $\mathrm{r}_{\mathrm{r}}$, $\mathrm{p} f$. and strings; Sonata in A, pf. and 'cello; Fantaisie-Sonata in 13 ; sonata in D; Partita in D minor; 12 short pieces for violin and pf. Ino in $\mathrm{E}$ minor, two pf.; sonatas in B flat and D minor; Variations; Miniatures; Somnets and songs withont words, ete., for pf. Charaeteristic popular tmos of the british Isles, pf. duet. Fantasia and Fugue, organ. Literary: Studies of (treat Composers, Routledge, 18s6; The Ait of Intic, 1893, enlarged as The Evolution of the Art of Music, 1896, Kegan Panl; Summary of Musical History, Novello's Primers, 1898.

Parry, John, Welsh harper and collector, of Ruabon, North Wales. He was bard or harper t, sir W. W. Wyme, of Wrmustay, during the middle of the 18 th eentury. He apeared in London as a player. 11e died at. Ruabon, Octoher $7,1782$.

Works.-Antient British Musje: or a collection of tunce never before published, which are retained by the Cambro Britons, more particularly in North Walos. An historical aceomnt of the rise and progress of Music among the Antient 13ritons, Lond m, 1742 [with Williams]; only 1 part published. British Harmony; being a collection of Antient 


\section{PARRY.}

Welsh airs, the traditional remains of those originally sung by the bards of Wales.... London, 1781. Music for the harpsichord.

Parry, John, "Barid Alaw," composer and writer, born at Dembigh, February 18, 1776. Member of band of Ienligh Militia, 1795. Bandmaster of same, $1797-1807$. Teacher of flageolet in London, 1807. ('omposer for tauxhall from 1809. Conducted an Eisteddfod in Wales. Received degree of Master of Song (Bard Alaw), 1821. Musieal critic of Morning Post, 1834-48. Treasurer of Royal society of Musicians, 1831-49. He died at London, April 8, 1851.

Works.-Incidental Musie to "Harlequin Hoax," 1814; Oberon's Oatl, 1816; High Notions, 1817; Ivanhoe, 1820; Fair Cheating, 1814; Helplesis Animals, 1818; Two Wives, 1821; My Uncle Gabriel; Caswallon, ete. The Welsh Harper, being an extensive collection of Welsh musie, to which are prefixed observations on the character and antiquity of the Welsh Music, London [1839-46], 2 vols.; An aecount of the Royal Musical Festival held in Westminster ibley, 1834, drawn np from official docments, n.d.; Beauties of Caledonia, or flower's of seottish Song... with symplonies and accompaniments for the I'f., Londun, 4 rols. [1840]; Selection of six Brazillian melodies; Cambrian Harmons, being a collection of antient Welsh airs [1810], 2 books; Collection of Welsh airs... for the hary [1825]; The Vocal Companion; British Minstrelsy [1830]. Flowers of Song: London collection of Glees, ete.; Sonatas for the harp; Complete scales for Wheatstone's Patent symphonium [1850]; Glees, part-songs, etce. Simgs: Jemny Jones; Apolio and the Muses; Oh, merry row the bonny bark; Naid of Toro, ete.

Parry, John Orlando, composer, pianist, and baritone vocalist, son of above, was born at London, Jamuary 3, 1810. He studied under Buchsa and his father. Dibut as harpint in 1825. Appeared as a ballad vocalist in 18:31. Sang in operettas and entertainments by himself and others. Organist of St. Jude's, Sonthea, 1853. Reapperared at the German Reed Entertainments, 1860-69. Retired, I877. He died at East Molesey, February 20,1879 .

Wonks.-Songs, of which the following is a selection :-Bridal Bells; Blue Beard; Cinderella; Country Commissions; Crotchet; Norah, the pride of Kildare; Take a bumper and try; A leart to let; Wanted a wife; Fayre Rosammole. The A B C duet, and numerons comic and sentimental pieces. Ridiculous things, or scraps and oddities, London. 1851. Series of humerous sketches in various colours of ink.

Parry, Joseph, composer, horn at Merthyr Tydvil, May 21,1841. Piclied up some know-

\section{PARSONS.}

ledge of music when a child, lut had, when ten years old, to work at a puddling furnace. In 1854 the family fullowed the father to America. Joseph Parry paid one visit to Wales before he finally returned home. $\mathrm{He}$ still continued his studies, and won Eisteddfodic prizes in 1 1862-3. Through the influence of Brinley Richards he entered the R.A.M. in 1868, and studied under Bemett, Garcia, and Steggall. Graduated Mus. Bat., 1871; Mus. Doc, 1878, Cambridgc. F.R.A.M. Appointed Professor of Music, University College, Aberystwith, 1871; and in 184s to the Musical Lectureship of University College of South Wales, Cardifi. He has lectureel on Music, and contributed articles on Welsh musicians, ete., to the press. At the National Eisteddfod, Llandudno, July 1, 1896, he was publicly presented with a cheque for $\$ 600$ for services rendered to Welsh music.

Works.-Oratorios: Emmanuel, London, 1880; Saul of Tarsus, produced at Rhyl, September 8 , and Cardiff Festival, september 23 , 1892. Cantates: The P'rodigal son (prize); Nebuchadnezzar; and Cambria, Llandudno, 1896. Operas: 'Blodwen, Aberdare, 1878; Virginia, completed in 1ss3; Arianwen, produced at Cardiff, June 5, 1n90; Sylvia, Cardiff, August 12, 1895; and King Arthiur, completed 1897. The Inruids' chorus. Nany anthems, hymn tmes, songs, etc. Orchestral Ballad, Cardiff, 1892; Orertures; Sitring quartet. Sonatas, and other pieces for pf. Editor of Cambrian Minstrelsie, 6 vols., Edinl,urgh, Jack.

His som, Josern Harme I'ARri, bom at Pennsylvania, L.s.A., in 1864, studied under him, and at Aherystwith. In $185 t$ he won a prize for a pf. sonata. His comic opera, "Cigarette," was produced with suceces at Cardiff in 1892; and another, "Miami," in London, October 16, 1893. He finished a third, "Marigold Fam," the sante year, and was the composer of a cantata for female voices, "Gwen." He was appointed a professor at the Guildhall sehool in 1890 . Died at Hampstead, March 29, 1894.

Another son, I). Mexidelsohx Parry, is a pianist, and was for a time at the Harrow Insic School. He is now a concert and operatic agent.

Parsons, Alfred William, organist, born at Salisbury, December 31, 1853. Chorister at Salisbury Cathedral. Organist of St. John's, Leicester, 1878; Parish Chnleh, Alerystwith, 1889. Mus. Bac., I Jurham, 1891 ; F.R.C.O. Lecturer in music, st. David's College, Lampeter. Composer of a setting of Psalm 18; Two settings of the Te Item ; Sacred songs, ete.

Parsons, John, musician, edited "The Hindustani Choral Book, or Swar Sangrah: containing the tunes of those hymms in the Gít Sangrah which are in native metres," Benares, 1861. 


\section{PARSONS.}

Another John P'assoxs, who lived at the end of last and leginning of this century, composed an "Ode to biberty, composed for" the centemary jubilee of the Revolution Chub," Edinlumb, 178s. Anthor also of "Elements of NInsic, with progressive practical lessons," Londion 1:ix)

Parsons, Robert, eomposer, was born at Fxeter in the first half of the Irth centurs. composed services, anthems, and madrigals. Drowned in the Trent at Newark, January 25, 1570 (1569?). His son Jors (?) was organist of sit. Margaret's, Westminster, in 1616. Organist, etc., of Westminster Abbey, 1621. He riad in 1629 .

Parsons, Sir William, musician, born in 1740. Chorister mider Dr. Cooke, Westminster Abbey. He strdied in Italy, I769, and became Naster of the King's MInsic, 17s6. Mus. Bac, and Mus. Doc. Oxon, 1790 (?). Kuighted, 1795. Teaeher of the Royal Princesses, 1796. Magistrate of Midilesex He died at London July, 1!), 1817, aged 71. Composer of Six English Ballads dedicated to the Prineess Mary. Songs: Dear is my little native vale; Dear to my Delin's peaceful heart; Fair Daphue; A scholar first my love implored, etc. The Court Minuets for His Majesty's Birthday, 1794. It was the kuighthood bestowed on Parsons which gave rise to the remark that he was knighted more on the score of his merits than because of the merits of his scores.

Partridge, James, pianist and teacher, born in Sitaffordshire in 1950. Like many other musicians he was originally intended for the scholastic profession, and passed two year's in training at Saltey College, near Birmingham. During that time he aeted as organist, an unusual position for a student. After holding various organ appointments in the conntry, he went to London, and entered the R.A.MI. in 1875, studying under I)r. Steggall and Brinley Richaris. Elected A.R.A.II. Brinley Richards acd he became warm friends, and on the death of the former in 188.5. Partridge was appointed to his class at the Cruildhall School of Music, having acted as his deputy for some years. That position he still holds, and he is also reader to one of the largest publishing houses in London. He was for sone time organist at St. Andrew's, Hammersmith. His compositions consist chiefly o: songs and church musie; and he has published various organ arrangements. He edited 2 vols. of Brinley lijchards's original works for pf., published by R. Cocks.

Pascal, Florian, See Willians, Jospri.

Paterson, Robert Roy, composer and music publisher, a member of the Edinburgh firm of Paterson, Sons, \& Co., which was founded in 1827 as Paterson \& Roy. Under

\section{PATON.}

the psendonym of "Alfred Stella" he has written a number of songs and pf. pieces.

Patey, C. A., author of "An Elementary Treatise on the Art of Playing the Violin, with Scales, Fxercises, etc.," London, n.d.

Patey, Janet Monach, bm Wнутоск, eontralto vocalist, horn in London, May 1, 1842, her father being a native of (ilasgow. Studied singing first with Joln Wass, and on August 20, 1860, made her first public appearanee at James Stimpion's Nonday Evening Concerts, Town Hall, Bimingham, as Miss Ellen Andrews. Became a nember of Henry Leslie's Choir, and studied under Mrs. Sims Reeves and Pinsuti. In IN65 she tonred with the Iemmens' Concert Party, and in 1866 married Mr. Patey (noticed below). That year she made her Festival dihut at Worcester, and sang at the Birminghan Festival, 1867; Norwich, IR69; and Leeds, 1874. On the letirement of Madame Sainton-Jolby, in 1870 , she succeeded to the position of first English contralto. Toured in America, singing in "Elijah," New York, Octoler 31, 1871. Sang in Paris, in 1875, in performance of the " Messiah," and at the Conservatoire, being presented with a medal by the Tirectors in commemoration of the event. Sang at all the important concerts in the United Kingdom, and was identified with the greavest compositions produced at the different festivals, etc. In 1890 she undertook a long tour in Australia, commencing with a concert at Sydney. Pe-appeared at the Crystal Palace, October 11,1891 . Decided to retire in 1893 , an l began a farewell tour in the winter, hut it was brought to a tra ic close by her sudden death, February 28, 18:4. She had sung at a coneert at the Albert Hall, Sheffield, the previons evening, and after singing "The Banks of Allan Water" in response to the encore, fainted as she left the platform, and died at her hotel early next morning, without regaining consciousness.

Patey, John George, husband of the above, bass vocalist, bom at Stonehouse, Devonshire, in 1835. Intended for the medical profession, but gave it up for musie. Stndied at Paris and Milan, and made his début at Drury Lane, as Plunlet, in Flotow's opera "Martha," 1858. Sang for several seasons in English opera at Covent Garden, etc., and visited New York in 1871, taking part in a performance of " Elijah," Octoher 31. Toured in the English protinces up to 1876. Was for some time a member of the choir at Lincoln's Inn Chapel. From 1888 a musie publisher in London

Paton, James Crooks, organist, composer, and rioloncellist, was horn at Edinburgh, March 28, 1855. He was oryasist of St. Leonard's Parish Church, and of Dalkeith Parish Church, and from 1881 was eonductor 


\section{PATON.}

of the St. Andrew's Anatem Orchestral Society: Nember of Waddel's (enartet Party. He died at Ediulumbh, Angmat 27, 1866. Composer of an orerture, "The Prusuit of Pleasme" (1s86); a quartet, for strings, in (i minor" Marches, gavottes, numznrlsas; "Lena" (1886), atc., for orehestra ; all of which ale in mamlscript.

Paton, Mary Ann, born Woon, soprano vocalist, was horn at Fdinhurgh, in Octolere, 1802. Datighter of George l'aton, writingmaster at lidinburgh High sehool. She sang at the Fuinburgh Concerts in 1810. studied the harp and pf. mnder.s. Weble, Jun., and sang in London in 1811; and [sath, 18:0-1. Sang at Covent Garden Thatre, London, as Sinsannah in Nozart's "Figaro," 18.2. Appeared in Weber's" "Der Frieschntz," Tuly, 18:4. Narried Lord William Pitt lemorix, 1824. Created part of Reiza in Weler's "Oberom," April 12, 1s26. llirorced from her bustrand (Lemox), 1890. Married Mr. Josenh Wood, tenor vocalist, 1881. liesided chiefly at Woolley Moor, Jorkis., 1433-5t. Tisited L tnited States, 1434-36. Appeared in London again in 1837-1844. Enulmaced Roman Catholic Religion, 1843, and retired from the stage in 184t. Lived almad, 1854-6.2. whe died at Bulcliffe Hall, near Chapelthorje, Wakufield, July 21, 1 sfit.

Patten, William, organist and compriser, was boln at Faveham in 1 sot. He wasurganist at Winchester. Iried in 1sfis. Compliter of "Congregational Melodies, original and selected..." 6 parts. "Six Anthems for large or small choirs," Fareham [IsGo]. Collection of sacred Dnsic... London [1850]; second collection. Six original hymms 1845]. Three sancturs for four volees. single anthems, songs, etc.

Patterson, Ada, soprano roealist, horn at Plvmouth. Situdied at R.A.MI. under Mannel Garcia. She has a roice of extratdinary compass in the high register, and has smig with success at the ('rystal I'alace (1891, etc.), and in many parts of the conntry.

Patterson (Alexander), composer and baritome rocalist, was born at Glasgor, December 26, 1847. He holds varions appointments as a teacher of vocal music in schools and since 1897 has been conductor of the Catheart Musical Association. He has composed "Hohenlinden," and "Semnacherib," cantatas: numerons original part-songs and songs; but is perhaps best known as the arranger of various scots song for mixed voices, which have been sung all over the country by the Glasgow Select Choir, in which Mr. Patterson sings and acts as deputy conductor. He

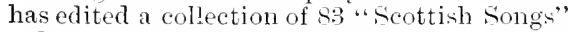
n.d.

Patterson, Annie Wilson, pianist, organist, and composer, born at Lurgan,

\section{PALL.}

County Amagh, Ireland, October 27, 1868. of French Hugnenot descent. Fidncated at Alexandra College, and husal lijsh Academy of Music, Dublin. Gradnated Mns. Bac, and B.A., 1867, Mns. Doc., 1869, Royal Lriversity of Ireland. Fxaminer in music for the same, 1892-5. Conductor of Dullin Choral Lnion, 1s91-3. Has lectured on Irish Music in Dublin, Cork, London (November 30, 1895 and $1897)$, ete. She has written the hibretti of her own compositions, and has some name as a painter. Her compositions ar': "Finola," Lrish cantata, for suli, chorms and orchestra,

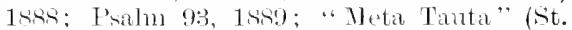
John's Tision of Heaven), for soli chorns and orchestra, podnced, l)ublin. February 25, 1,98: cantata, "The haising of Lazarus," 1)ublin, April 10, 18\%1. Six uriginal Gaelic songs; Uladh, or the Northern Star, patriotic song, with chorus and orchestra; it Parting, etc.

Pattinson (James), ('mmperser, organist, pianist and couductor, ]xom, (k.tuley 30. 1847, at Carlisle. Studied mnder thahan Young, and Hr. Ford, of C'arlisle Catbedral. Mus. Bae. Cambridge, 157!). Suttled in Paisley, in 1574. an firstorganint of the Abler. Aplointed to St. silas' Fpiscopal 'Thuroh, (ilasgow, 18so; Maxwell Parish Church, riasgow, 196:3;

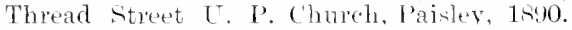
sinceeted G. Tagrate as conductor of Lildington society, Glasgow, 18s6. Comductor of Paisler Philhamonic (owhestral), and other Societies. Organ recitalist, and ratorio accompanist, at Clasgow, Edinlmugh, Paisley, Carlisle, etc.

Norks.-The Magnificat, for soli, chorus, strings and organ ; Cantata, The Ton Virgins. songs: Becathed; A last Rose; Kitty of Carlisle, and others; part-sungs. Suftly, oh softry glide, ete. Arrangements of sicotch and other songs. Mimmet for strings: Fantasia, and other pieces for organ. The major, minor and chromatic scales, in single and double notes, and arpeggios of common, dominant and diminished chords, in all keys, pf.

Pattison, Thomas Mee, composer and organist, born at Warringtom, January 27, 1845. Organist of Paul's Church, Warrington, 1869 ; and conductor of a choral society. Ahout 1886 he removed to London.

Works.-Cuntatas: The Ancient Mariner; Lay of the Last Minstrel, 1885; Sherwood's Queen: John Bull and his Trades, 1sso; May Das, 1887; Les Francs Chasseuns female roices. Sacred: A Day with onv Lord; The Mother of Jesus. Anthems: There wet shepherds; Truly God is loving; () praise the Lord; and others. Organ and pf. music. The Happs Valley, eomic opera. Author of Rudiments of Tocal Music, with Preparatory Exercises.

Paul, Mrs. Howard, born IsABELLA 


\section{PAXTON.}

FeATHerstone, actress and contralto vocalist, born at Dartford, Kent, in 1833. She appeared in the Beggar"s Opera, in 185.3, and in many musical and dramatic pieces. Married Mr. Henry Howard Paul, and in 1854 appeared with him in a large number of different entertaimments. She had a roice of much beatuty, but as she turned her attention chiefly to conedy, she never attained a great position as a rocalist. She died at London, June 6, 1879 .

Paxton, Stephen, glee composer and lass singer, was born in 1735. He was a pupil of W. Savage and gajned prizes from the (ateh Clul in $1779,1781,1783,1784$, and 1785 . $\mathrm{He}$ died at London, Angust 18, 1787. Composer of ntmmerons glees and catches, some of which were republished in "Collection of Glees, Catches, etc., for 3 or 4 voices," op. 5. London $[1780]$, and in other collections. He also composed six solos for the violoncello, op. 1 ; Eight duetts for a violin or violoncello, op. 2; Six cass selos for a violoncello or bassoon, op. 3; Twelve easr lesions for a violoncello or bass, op. 6. Masses, Lyries, songs, etc. Hisbrother W1Llian (born 1737, died 1781), was a violoncellist, and composed "Breathe soft, ve winds," a well-known glese for 3 voices, besides other pieces contained in the collections above noted.

Payne, Miss, tee sub. Coul, Aynsley.

Payne, Richard, amateur organist and conductor, born at Bimingliam in 1843 . He had great talent for music, but adopted a business career, which led him to reside in London for some years. In 1874, lie was appointed organist and conductor of the Psalmody class at Union Chapel, Islington, and was also conductor of the Borough of Hackney Choral society, which gave the first performance in England of Bacls's "Magnificat," May 19, 1874 . Returning to Birmiligham, he became organist of St. Luke's Chureh, 1876, and later of the Church of the Redemer, Edghaston. He was hon. conductor of the Birmingham Kyrle Choir from its formation until his death, at Birmirgham, July 10,1884 . He was self-taught in music, and composed a Pf. Trio and some vocal music; also contributed articles to the Musical lincord (1874) and Musical Standard (1882). He was succeded in his organ appointment by his son, a clever amateur.

Peace, Albert Lister, organist and composer, born at 11 uddersfield, January : 6, 1844. Showed musical talent at a very early age, and was placed under Henry Horn and Henry Parratt, and in 1653 receired his first oruan appointment, at Holmfirth Parish Chnreh. After beiug organist at Dewsbury, Huddersfield, and Cleckheaton (1858-65), he went to Glasgow as organist of Trinity Congregational Clumeh. In 1570 he was appointed organist

\section{PEARCE.}

to the University of Glasgow; St. John's Episcopal Church, 1873; Maxwell Parish Church, 1875; Hillhead Parish Church, 1876; St. Andrew's Hall, 1877 ; and in 1879 to the Cathedral. Graduated Mus. Bac., 1870; Mus. Doc., 1875, Oxford. F.C.O., 1886, honoris caust. He his given recitals in all parts of the kingdom, and opencd the organ at Canterbury Catliedral (1886), Victoria Hall, Hanley (1888), and represented Scotland in the gathering of great players at the opening of the organ in Newcastle Cathedral (St. Nicholas'), 1891. In January, 1897, he was elected organist of St. George's Hall, Liverpool, in succession to W. T. Bust, and now occupies the foremost position in the country.

Works.-Tsalm 138, for soli, chorus, and orchestra; Cantata, St. Joln the Baptist, 1875. Morning, Evening, and Communion Services. Awake up, my glory; The uight is far spent (eight voices); God be merciful; and other anthens. Souata da Canera, No. 1, in I minor; No. 2, in C minor ; No. 3, in Gminor; Concert Fantasia on Scottish melodies; Fantasia in B flat; two Andantes-all for organ; and organ arrangements of Overtures, William Tell, Oberon, etc. Musical editor of Scottish Hymmal, 1885; Psalms and Paraphrases; Psalter; and Anthem Book, for Psahmody Committee of the Church of Scotland.

Peacock, Francis, musician and miniature painter, born at Aberdeen, in 1723. He was a dancing-master in Aberdeen, and a violinist who frequently led the weekly subscription concerts given by the Musicul Society. He taught dancing, muder the patronage of the Town Conncil, in a hall in Drum's Lane. He died at Aberdeen, June 26, 1807. Editor of "Fifty Favourite Scoteh Airs, for a violin, German flute, and violoncello, with a thorough-bass for the harpsichord," London, n.d. [1762]. Author of "Sketches relative to the History and theory, but more especially to the practice of Danring," Aberdeen, 1805. The publication of this called forth a satirical poem, entitled, "On the Magistrates of the city luaving purchased twenty copies of 'Peacock on Dancing.'",

Peacock, Matthew, musician of first half of the present century, who was a native of Chesham, issued "A Set of Psalm and Hymn Tunes, composed in a familiar style," London [1837].

Pearce, Charles William, organist and composer, born at Salisbury, I ecember 5, 1856. Studied the organ moder Theodore E. Aylward, W. S. Hoyte, and Dr. E. J. Hopkins ; pianoforte, luarmony, and composition with C. J. Read, Dr. Hopkins, and (Professor) E. Prout. Graduated Mus. Bac., 1881; Mus. 


\section{PEARCE.}

Doe., 1884, Cambridge. Was organist of St. Martin's, Salisbury, 1871-3, and aceompanist to Sarum Choral Society, 1872-3. In 1874 he was appointed to St. Luke's, Old Street, Joudon, accepting, in 1885, the office of organist aud ehoirmaster of St. Clement's, Easteheap, whieh he still holds. Professor of Organ, Hamony, Counterpoint and Connposition, Trinity College, London, 1882 ; Dean of the College, 1892. Examiner for degree of Mus. Bac., Cambridge, 1885-91; and for Mus. Doc., 1895. Co-editor of The Orgarist and Choirmaster, and hou. treasurer of London Section of the Ineorporated Soeiety of Musieians from 1892. Has lectured on Plain Song Melodies; The Compositions of Samuel Wesley; Organists in relation to the Clergy (Dublin, 1895), and kindred subjects.

Woris.-Church Cantatas: All Saints (1880), The Man of Sorrows (1893), Our Risen and Aseended Lord (1895). Oratorio (Lniv. Ex. Mus. Doe.) Lux benigna (1st4), Eneeladus, choral seena, men's roiees, op. 43, produeed at Bristol, 1889. Serviees, Anthems, Hymns, in Anglican Choir Series; Songs, etc.; Quartet in C, for organ, pf., violin, and violoncello; Trio, "Noete Surgentes," for pf., violin, and violoncello; Three Idylls for violin and pf. Organ musie: Symphonie poen, "Corde natus;" two Sonatas (all, 1885): Preludes and fugues, fantasias, postludes, and introduetory voluntaries. Educational works: Voice Training Exercises (with Behnke, 1884); Toice Training situdies (1892) ; Voiee Training Primer (1893); Three Text-books of Musieal Knowledge, Junior, Intermediate, and Senior (Hammond and Co., 1889-91) ; Complete Pedal Seales, orgau (1892) ; Three books of Organ Studies (1893-4) ; Organ School (1895).

Pearce, Joseph, author of "Violins, and Violin-makers: biographical dictionary of the great Italian artistes, their followers and imitators to the present time. With essays on important subjeets eomected with the Tiolin," London, 1866.

Pearce, Stephen Austen, organist and composer, born near London. Pupil of $\mathrm{Dr}$. J. L. Hopkins. Graduated Mus. Bac., 1859 ; Mus. Doe., 1864, Oxford. Held organ appointments at St. John's, Oxford Square, London; St. Saviour's, Paddington; St. Panl's, Onslow Square, and elsewhele. Visited the United States and Canada; returned to London, and gave reeitals at Hanover Square Rooms, ete. Again went to America, and was appointed Instructor in rocal music at Columlia College. Organist successively at St Marl's, Philadelphia; St. Andrew's; St. George's; New Cathedral, 5th Arenue; and sit. Stephen's R. C. Chureh in New York. His latest appointments were, Lecturer, and professor of harmony and eomposition at New York

\section{PEARSALL.}

College of Musie. He has given eoneerts and lectures in many parts of the United States, and contributed to the press of Chicago, Boston, etc., and to the principal musical journals. His eompositions comprise a comedy-opera, "La Belle Amerieaine" ; orchestral musie, perfomed by the Thomas orchestra, etc.; many pf. pieces, songs, ete., as well as arrangements. His Degree lixereises were The Psalm of Praise, cantata; and Celestial Visions, a dramatic oratorio. Anthor of A Musical Dictionary; and editor and translator of various elaborate worlis for American publishers.

Pearman, William, tenor vocalist, was born at Manchester in 1792. He went to sea as a cabin-boy, and was engaged at the Battle of Copenhagen, and rounded. Appeared unsuccessfully as an actor, and sang at Siadler's Wells Theatre, London. Afterwards he studied for a short time under Addison. Sang at Newcastle, Bath, Bristol, etc. Dibut as operatic rocalist at English Opera House, July 7, 1817, in "The Calinet." Sang at Drury Lane, Covent Garden, and principal concerts. Died (?).

Pearman, James, probably a relative of the above, was lom at Winchester about 1818 . He studied mnder I)r. ('hard, and was an organist and teacher of music in Dundee, where he died, on April 3, 1nRo. Composer of a Mass, some pf. music, somgs, etc.

Pearsall, Robert Lucas de, composer, born at Cliftom, Narch 14, 1795. Educated for Law. Called to the Bar, 1821, and practised till 1825. He then studied music moder Pamny, at Mayence. Re-risited Fngland, 1829. Settled at Carlsruhe, 1830. Lived at Wartensee Castle on Lake of Constance from 1832. He died at Wartensee, August 5, 1856.

Works.-Madrigals for $4,5,6$ and 8 voices, London $1840^{\circ}$. Eight (ilese and Madrigals, London [1863]. Trenty-four Choral Songs, ete, edited br.J.Hullah [1R6:3]. Ballet Opera Choruses [1578]. Sacred Compositions, edited hy Trimmell, n.d. Fdited a C'atholic Hrmm Book, 1863, and emmposed parlmsand anthems. Part-songs: A king there was in Thule; Let us all a-Maying go; $O$ who will o'er the downs so free; Purple glow the forest mountains; Sing we and channt it; Sir Patrick Spens (10 parts); Bishop of Mentz; Hardy Norseman's house of rore; Red wine flows; Watchman's song; Winter song; Who whall win my lady fair? ete. Essay on Conscentive Fifths and Octaves in Comnterpoint, London, n.d., ete.

Pearsall, Samuel, tenor vocalist, who sang at the Gloncester Festival of 1832, and at Worcester and Hereford at times up to 1845 , and was a tonor in the choir of Lichfield Cathedral for many rears. He sang at nost of the provincial festivals, and gave lectures 


\section{I'EARSON.}

on musical subjects, illustrated by the members of Lichfield Cathedral choir. Inied at Lichficld in July, 1848 , at an aldranced age.

Pearson Arthur, organist and composer, hom at Stanningley, near I,eeds, April 22 , 1866. He is organist at St. Paul's Church, Huddersfield; and also Borough organist. His cantati, "The Tromised Land," was produced at New Wortley, Novemher $29,1885$. He has composed other vocal music, and was editor of The Forlishive Musician.

Pearson, Henry Hugo. See Pierson, Henry IIugo.

Pearson, Martin, composer, was loon in the latter half of the 16 th century. Naster of the child'en of St. Paul's Cathedral, 1604. Mus. Bac., Oxon., 1613. He lied in 1650, and left $\& 100$ to the poor of March, in the Isle of Ely.

Vorks.-Private Musicke, or the first Booke of Ayres and l)ialogues, containing Songs of 4,5 , and 6 parts of sererall sorts, ete., 1604. "Mottects, or grave chamber musicke, for voices and vials, with an organ part which may be performed on virginals, bass-lute, bandora, or Irish harp," 1630. Compositions in Leighton's “ 'Teares," etc.

Pearson, William Webster, composer and n'ganist, born at Pisliop Auckland, September 27, 1839. Chorister at York Minster, under Dr. Camidge. For many years he has been rrganist of the Parish Church of Ehmham, Norfolk, and teacher of the violin at the Norfolk County School, Dereham; also conductor of Dereham Orchestral suciety. IJe has composed church music, olgan and pf. pieces, songs, etc., a cantata, "Voices of the Flowers," for ladies" voices, and a great number of part-songs, among which nuy be named, Blow, Nestem Wind, Star's of the Night, The Lake, 'Tis Morn, Coral Grove, Woods in Winter, Tlie Anglers, and Aitumn; also a set with oreliestrai accompaniment: The Iron Horse, Off to Sea, Lifelrat, Ocean, Ironfomnders, etc. IImmoroms: A Ryghte Merrie Geste, Ben Bowley, Carrion Crow, etc. Songs for the Little Ones, Nursery Rlsymes; many contributions to Novello's School Somgs. Author of Notation of Tocal Music on the principle of the subst tution of l'itch; and the National Method of Tocal Mnsic for Elenentary Schools, Manchester, 1874 .

Peattie, William, musician, compiler of "Selection of Psalm and Hymn Tunes, adapted to the various metres used in the principal churches, chapels, and dissenting congregations in Scotland; to which is prefixf a compendious introduction, with some useful seales and examples, calculated to promote the improvement of -acred Music." Edinburgl, Oliver \& Boyd, 1824, 6th edit.

Peck, James, music publisher and
F'LNNA.

engraver, established in Iondon. He edited "Two Hundred and Fifty l'salm Tumes in Three Tarts," 1798; collection of Lymu Tunes, Fugues, and Odes, 1799, 3 books; Miscellaneous Collection of Sacred Music, 1809 ; Beanties of sacred Harmony, 1s24; and composed glees, etc. He was suceeded in business by his son JoHN, organist of St. Faith's, who isped in conjunction with his brother JAMEs, jun. (bom at London, 1773). "Peck's Pocket Arrangement or general collection of Psalm and Hymn Tunes," London, 1893,3 vols. The Union Tune Book being a collection of psalm and hymm tumes adapted for use in Sunday schools and congregations; to which is prefixed a short introduction to singing. London, 1837.

Pede, 01' Peed, 'Thomas Thorpe, composer, pianist, and singer, lom about 182.5 . Was a lectmer and teacher. loded at Margate, November 9, 1885, aged 68. Composed Waltzes for uf., op. $2[1846]$; Qlladrilles, ete. Songs : Faith is over ; I have not gold; Last rexpest; Loving for aye; Old Hall clock.

Peel, Rev. Frederick. (raduated Mus. Bac., Oxford, 1872. He was organist and music master at Reading School, Berks., 1871-5; and is now vicul of I Ieslington, near Tork. Composer of Psith 145, for soli, chorms and orchestra; Anthems, services, hymn tunes; songs; organ and pf. pieces.

Pegler, Daniel, amatem composer and pianist, was well-known in the cally part of the present century as a prerformer of ability. The died at (olchester, Decumler 2?, 1876. Thallorg considered Pegler one of the finest semi-professional pianists in England. He had a very wonderful memory.

Penna, Frederic, bariture vocalist and writer, born in Landon, July 15, 1831. Pupil of Sir Georese Simart. He was solo baritone at the Oratory, Brompton, for ten years; faronrably known in the concert room ; and appeared in opera for one season at Her Majesty is Theatre. Tfe is professor of singing at the London Academy of MIusie, and widely known as a teacher and lecturer on voice training, ete. Author of an Fssay on singing, London, 1878; Vocal Fxereises, to illustrate his method, 1898; Lecture, Mendelssoln's portrait of "Elijah," munically painted: his noral qualities, ete. His wife, CATHerine Louns Suxte (died, London, Tecember 27, 1880), was an excellent soprano rocaljst, who with her sister JcLIs, gained much reputation for duet singing. These ladies were nieces of Catherine stephens. His daughter, CATHERINe (MIs. M. Hooper), was also a soprano. the sang at the Saturday Popular and I'hilbarmon e Concerts, 1876; the Nurwich Festival, etc, and was in much favom as a rocalist, Composed some songs, and organ music. She died June 6, 1894. Villiax 


\section{PERCIVAL.}

Pexwa, his son, baritone, tomed with success in the Tnited States, in 1885 . He died, Jannary, 1889.

Percival, Samuel, organist, flute-player,

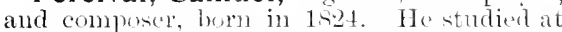
the R.A.M., London, and beeame organint at the School for the Blinel, Liverpool. Organint of Wallasey Parish Church, and teacher in Liverpool. He died at Iiverpons, Norember T, 1876. He composed a Magnificat and Nume Dinittis; a cantata, entitleel "The Lree," op. 7; Sonata for pof and flute, op. 2 : original melodies for flute and pf.; Pf. musice, somgs, ete.

Percy, John, compenerr, organist, and tenor voealist, was born in 174\%. Ho died at London, Jannary 24, 1797. little is known of this musician, and be is only remembered as the composer of the lallat, "Wapping ()d Stairs." He also componed some ot lie' wirlis, many of them possencing merit, antorles which may be nomed :- Eight songs, with an atecompaniment for the vishin, op. 1 [1Tis : frarden Scene from "Ronneo and Juliet," "luct, op). 2 [17-5) : Six Arietts, op. 5 [17sti. Sumgs: Bonny Seaman; Captise; (rafter Cray ; Hark the horn calls away; soft as yon silver ray; Sophrosme; sweet smells the brier; When Cloe tried her virgin firen: and c.thers.

Perkins, Charles William, organist, born at Birmingham, ().t, loce 4. 1,45.5. Situdied the organ under Andrew Deakin; and pianoforte and composition mder lyr. Heap. Held the appointment of organist at Wrothan Road Chureh, Handsworth, until 1sst, when he went to London as assistant to I)r. Bridge, at Westminster Abber. He studied with Pr. Bridge for some time, and held appointment successively at Immannel Church, Streatham Common, and st. Michatel's, Paddington. In Jume, 1889, he was eleeted organist of Birmingham Town Hall, an office he still holds. He is widely known as an organ player, and and has given recitals at the C'rrstal Palace, St. George's Hall, Liverpool, etc.; while his serviees are in great request at organ openings. He gives weekly froe recitals in the Bimingham Town Hall, and has introduced many famous organists to the Bimingham public. He has officiated as organist at the Birmingham Festivals since 18s?

Perkins, Dodd, organist and eomposer, was born about 1750 . For many years he was organist of Wells Cathedral, and numbered among his pupils James Turle. He died on April 9, 1820. Composer of "Ten Songs, written by the Hon. F. Seymour" [1797]. "Musie, the soul of melody," glee, ete.

Another Perixiss (a son?), was organist of Wells Cathedral, as late as $18+9$, but partieulars concerning him are wanting.

Perren, George, tenor voealist, born at

\section{PETERTON.}

Camberwell, 1827. Sang in concerts in London and the provinces, afterwards going to Milan to study nuder Lamperti. On his return he made his dibut at the surrey Theatre, May 28, 1855, in the "Faust" of Neyer Lutz. He appeared at the Sacred Harmonic Society, January 30, 1856, in "Elijab;" and was heard at various concerts in the prineipal musical centres, being very popular as a ballad singer. He took part in the first performance of Macfarren's "she Stoops to Conquer," at Drury Lane, February 11, 1s6t; and at times, up to 1878 , sang in Italian ()pera, at Her Majesty's Theatre. It is now some time since he retired from the concert platform. He eomposed a number of songs and ballads.

Perry, Clara, see sul. Diries, Pen.

Perronet, Rev. Edward, liymu-writer and composer, wats born in 172. He was a eolleague of John Wesley, anl afterwards preached to the C'ountess of Huntingdon's congregation at Canterbny Ined at Canterbury, danuary s, 179\%. Nuthor of "All hail the power of Jewn's name," the well-known hymn, and composer of various hymn tunes.

Perrot, Robert, see Porret.

Perry, George, orginist and eomposer, was born at Norwich, in 1793. Chorister in Norwieh Cathedral under Peckwith. Settled in London, 1422. Director of music in Haymarket Theatre, 18.2. Organist of Quebec Chapel. Leader of band of Sacred Harmonic Society, 1832-47, and conductor in 1848 . Or. ganist of Trinity Church, Gray's Inn Road, 1846, He died at London, Mareh 4, 1862.

Works.-Overture to the Persian Hunters, 1817; Family Quarels, opera 18307; Morning, Noon, and Niglit, opera, 1822; Elijah and the Priests of Paal, oratorio, 1s1s; The Fall of Jerusalem, oratorio, 18:30; The Death of Abel, oratorio [1846; Belshazzar's Feast, eantata, 18:36; Hezekialı, oratorio, 1847; Anthems, etc. Songs: I will remember thee; Spirit of the storm. Rondos and other works for pf.

Peterborough, Countess of, sef RobinSON, ANASTASIA

Peterson, Franklin Sievewright, oroanist and writer on music, born in Edinburgh, February 24, 1861. Studied at Dresden and Edinburgh; organ pupil of Carl Aug. Fischer, Dresden, 188t. Graduated Ins. Bac., Oxford, 1892 Organist and choirmaster, Palmerston Place Clurch, Edinburgh, from 1884. Nusic master, Edinhurgh Ladies' College, 1893, and Fettes College, 1894. Lecturer on Musical History at Dun. dee University College, and in Elinburgh and St. Andrews University Extension centres. Appointed, 1896, to act with Professor Niecks as additional examiner for Music Scholarships at Edinburgh University, founded by 


\section{P'STRIE.}

the late Signor Theophile Bucher, whose legacy is now at the disposal of the Senatus Mr. Peterson is author of the articles on musical matters in the new edition of Chambers's Encyclopredia, and has contributed important paper's to the Musical Times, The Monthly Musical Record, and the Magazine of Music, etc. His "Elements of Music" (Augener, 1896) reached a second edition in less than three months. He has also published An Introduetion to the Study of Theory (Augener, 1897), some anthems, songs, and part-songs, etc.

Petrie, George, antiquary and author, born at Dublin in 1789. He was a painter in Ireland, and was librarian to the Hibernian Academy. Attached to the Irish Ordnance Survey, and held other appointments. Died at Dublin, January 17, 1866. Compiler of the Petrie Collection of the ancient music of Ireland, Dublin, 1855, vol. 1 and pp. 1-48 of vol. 2 all published; and author of an "Essay on Music" in the llubin Ex tminer of 1816. His collection of Irish music is very valuable.

Petrie, Robert, musician and violiuist, born at Kirkmichael, Perth, February, 1767. He was a teacher, and played at many concerts, halls, etc. I)rowned when returning home from a party, in August, 1830. He composed four "Collections of Strathspey Reels and country dances, with a bass for the violoncello," etc., London and Edinburgh [1790]. The other collections differ but slightly in the titles. Some of these colloctions had a large circulation, being issued in editions of over 1,000 to subscribers. In his third collection the well-known air "Comin" through the Rye" appears in its original form as the "Miller's daughter," Strathspey, and as altered by John Watlen now forms the melody usually sung with Purns's song.

Pettet, Alfred, English musician, born about 1785; died about 1845. Compiler of Original Sacred Music, consisting of psalms, hymns, and anthems composed expressly for this work by Attwood, Bishop, Cramer, Crotch, Goss, Horsley, Shield, Wesley, etc..." London [1815]. Duettinos and Trios, selected [1840]. Waltzes, etc., for pf.; songs and other vocal music.

Pettit, Walter, violoncello player, born at London, March 14,1835. He studied at the R.A.M., and was principal 'cello at P'hilharmonic Society, H.MI. Theatre, etc. He died at London, Dec. 11, 1882. His son, William H. I'Eтtiт, is a violoncellist of repute.

Pettman, Edgar, organist and composer, born at Dunkirk, near Faversham, April 20, 1866. Educated at R.A.MI. Orgauist of St. Natthew's, New lient Road, London; St. James's, Piccadilly. He has composed a cantata, "The Nativity," produced, 1885, at St. Matthew's Cliurch, and some ehurch music.

\section{PHILI,IPS.}

Pew, John, violinist and conductor, was bom in the first half of the present century. Appeared as violinist at concers, Leeds, 1854, etc. He was for many years associated with the Carl Rosa Opera Company as chorus master and assistant conductor, and he aeted as conductor of the English Opera Company, 1877; Valentine smith's Opera Company, 1890 , etc. He died at Manchester, February 22, 1890. Composer of dance music and songs.

Phasey, Alfred James, euphonium player. He was originally an ophicleide and bass trombone player in the band of the Coldstream Guards, and afterwards a member of the Queen's private band. For nearly 25 years he was a member of the Crystal Palace orchestra. He was also bandmaster of the St. Creorge's Rifle Tolunteers. He died at Chester, August 17, 1888. He introduced many improvements on, and was practically inventor of, the euphonium. Author of Instruction Bonls for the Enphonium [1858]; I'opular Instruction Book for the Trombone [1860]; and composer of fantasias on operas for emphonimm, cornet, etc. His son ALFRED is also a good euphonimm player.

Philipps, Arthur, organist and composer, born in 1605. Clerk of New College, Oxford, 1622. Organist of Bristol Cathedral, 1638; Magdalen College, Oxford, 1639. Choragus ol Profesisor of Music in Oxford University, 1639. MIıs. Bac., Oxon., 1640. Organist to Queen Henrietta Maria of France, and, after his retmen to Fugland, organist to Mr. Caryll, an Essex gentleman. Composed "The Requiem, or liberty of an imprisoned Royalist," $16+1$; "The Resurrection," 1649 ; etc.

Plicipps, Peter, Petrus Philfppus, composer, who was born in England about $[1560]$. Canon of Bethme in Flanders. () rganist of viceregal chapel of the Governor of the Low Comntries. Canon of Collegiate Church of St. Vincent, Soignies. He died in April, 1625.

Wortis.-Melodia Olympica di diversi eccullentissimi Musici a $4,5,6$, e 8 roci, 1591 (and other editions). Il Primo libro de' Madrigali a sei voci, 1596. Nadrigali a otto roci, 1598. Il Secondo libro di Madrigali a sei voci, 1604. Cantiones sacre, 5 roenm, 1612. Gemmule Sacrat, 2 e 3 voci, 1613. Cantiones Sacke octi vocum, 1613. Litanice, 1623.

Phillips, Adelaide, contralto vocalist, horn at stratford-on-Avon in 1833. She sang in Boston and Philadelphia, and studied in London moler. Garcia and W. C. Masters, 1852; also in Italy. Appeared in London, Paris, and in United States of America. She died at Carlsbad, October 3, 1882.

Phillips, Anna Maria, sec Crover, AxNa Maria.

Plillips, Henry, baritone vocalist and 


\section{PHILLIPS.}

writer, born at Bristol, August 13, 1801. He sang in chorus at Inrury Lane Theatre, and studied under Broadhurst, and Fir (r. Snart. Sang at the English Opera Honse; at the Lenten Oratorios; in Arne's "Artaxerxes," 1824; "Der Freisehutz," 1824 ; at the Provincial Festivals, ete. He appeared in Ameriea, in 1844. Retired, in 1863. He died at Dalston, London, November 8, 1876. His daughter's Alice and Florence were vocalists.

Works.--Adventures in America, an entertaimment [1845]. The True Enjovment of Angling, 1843. Hints on Musical Declamation. London, 1848; Birningham edit., n.d. Musical and Personal Recollections during Half-a-Century. Iondon, 1864,2 vols. Songs: Best of all good company; Emigrant ship : Farmer's daughter of Berkshire; Terence Maearthy; Vovage through life; Noman, ete. He also issued an edition of Dibdin's songs, 1859 .

Phillips, Louisa, soprano vocalist, born at Bath. Studied at the Conservatoine, Paris, under Eugéne Crosti and Jules Barbut. Made her debut at Colston Hall, Bristol, at Mr. Riseley's Concerts, Decemler 4, 1852; sung at the Monday Popnlar Concerts, London, 1884; and has given concelts at Princes' Hall. and appeared with suecess at the principal concerts up to the present time.

Phillips, Thomas, tenor rocalist, lecturer and composer, born in lundon, 1774. Nember of a Nommonthshire family. Leetured and sang at concerts during his lifetinue. Made his debut at Covent Grarden, as I'hilip in the "Castle of Andalusia," 1796. Author of "Flementary Principles and Practices for Singing," London [1830]. Composer of a few songs, part-songs and glees, Crows in a comfield; Faded wreath; Why tarries my love, ete. He also compiled "The Mentor's Harp," moral ballads by T. H. Bayly; "Improved Psalmody for the Chureh and the Chamber." Also an arangement of Linley's "Duemna." He was accidentally killed at Hartford, Cheshire, while leaving or entering a train in motion, Oetolser 27, 1841 .

Phillips, William Lovell, composer and pianist, horn at Bristol, December 26, 1816. Chorister in Bristol Cathedral. He studied muder C. Potter at R.A.M., and became Professor of composition there. He studied the violoncello under Lindley. NLember of orchestra of H. MI. Theatre, Philharmonic Societr, and Sacred Hammonic Society. Conductor at Olympie Theatre; Princess' Theatre. Organist of St. Catherine's Chureh, Regent Park, etc. He died at London, March 19, 1860.

Works.-Borrowing a husband, farce [1844]. Offertory Sentences set to music. Symphony in F minor; Cantata. Songs: Lady mine; Iry green; The sleeping beauty: Longings; The old ballad; Pearls of the

\section{PHIIPPS.}

ocean; Voice of songs; Christmas rose; England's hope and pride; One word; Sientry; What must I sing yon? ; Songs of smmmer. New and complete instructions for the rioloncello. London, n.d

Phillipson, Wentworth, author of "Guide to Foung Pianoforte teachers and students, with analysis of examples, etc., London [1872, 2 editions.

Philp, Elizabeth, rocal composer, born at Falmonth, in 1827. She studied music miler Garcia, Marchesi, and F. Hiller. She died at London, November 26, 1885. Composer of a number of meritorious songs, etc., of which the following is a select list:-

Works.-Songs: Bye and Bye; Dolly; Fisherma'r's story; Forgiven; Golden past; Hop-pickers; I love him more than I can say; Love that's never told; My head is like to rend; Oh! why not be happy; Poacher's Widow; River ran between them; 'Tis all that I can say; 'Tis wine; Violets of the Spring; Wrecked hope. Part-songs, various. How to sing an English Ballad, London, 1883 [Reprint], etc.

Philpot, John, domble-bass player, was born in 1759. He was for more than fifty years a menber of the orehestra of Fatl, and as a double-bass player was considered second only to Dragonetti. He died at Bath, January $26,18+3$. lle was the father of Mrs. Anderson, the pianist.

Philpot, Lucy, See Anjerson, Lucy.

Plilpot Stephen, musician and author, wrote "An Introduction to the art of playing on the violin on an entirely new plan." London, [1767]; "Six capital lessons for the Harpsichord or Pianoforte." [17\$4].

Philpot, Stephen Rowland, composer. Studied at R A.M., under Sir G. A. Macfarren. His works include the operas, "Dante and Beatrice," produced November 25, 1889 ; "Zelica," December 17, 1890, in concert form, both at Gresham Hall, Brixton; Also "Ia Gitana," one act opera, 1896. He has also written pieces for pf. and strings; sougs, etc.

Phipps, Alexander James, composer and condnctor, of Liverpool. Situdied under W. H. Holmes and C. Steggall, at R.A.MI. Has given chamber concerts in that city, and is conductor of Opera and Oratorio Societies. Organist of St. James', Swansea, 1866; now of St. John's, Bootle, in which Chureh was produced his " Meditation on the Passion," for chorus and organ, 1893 . He has composed an oratorio, "The Ten Virgins"; an opera, "'Thea, or Solomon's Treasure ' ; songs, and other worlis. Author of "Comprehensive Guide to the study of Minsic," London [187t].

Phipps, Thomas Blomer, musician and author, born Loudon, January 30, 1796; died London, February 17, 1849. Son of one of the partvers of the firm of Goulding, Phipps, 
PHILSON.

and D'Almaine. He wrote "Guida de Chitarra, or complete book of instructions for the Spanish (ruital .. London, n.d. ; Strakenpeare musical wreath[18to); F'feasures of Harnony, airs for lf. : Six Royal Seoteh Polkas; numerons "recoflections," at rangements, ete., for pf.; Songs, and uther rocal music.

Phipson, T。L., anatenr musician and physician in Iondun, anthor of "Siographical slitches ank anecedutes of celebrated Vivinists," London, 187t. "Belfini and the Opera of La tommannhula," London, 1880. "Famons Violinists and fine Viofins: historical notes, anerdoter and reminiscences," London, 1896. Jr. Phipon was at one time president and solo violinist of the Bohemian Orchestral Society. He tramslated De Beriot's " Méthode de Virim," and wote "Some mysteries of natume." Londen, 1sto; The storm and its portents, 1sis; Meteors, aerolites and falling stars, 1 serit; and other works.

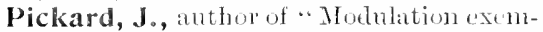
plified hy a grand taholar view of the preparations of all the notes of the octives," London [1835]. Composer of "Thirty approved and fashomate ats's for the violoncello," Lomdon 1825, 2 books.

Pickering, John, pianist and composer, boln at londem, May 23,1792 . He studied with I)onenico (orri, and in 1812 settled as a teacher in Preston. Afterwards, in 1817, he settled in Manchenter, where he attained a ligh pusition as a teacher and pianist. He died at Nanchester, November 6,1843 . Composer of anuch pianoforte mnsic and of music for the church.

Pickering, Thomas, musician and anthor, born at Londen, July 4, 1796. He was an associate of the Norellos, Horslers, and other musical familien, and a man of rematrable literary and musical attaimments. One of the fombders of the Royston Mechanics' Institute, where Charles Coivden Clarke defivered his firnt lec ure. He formed elasses for the study of munic, and was president and condnetor of the Ruyston Chomal society. He died at Royston, May 1, 1876.

Piercy, Henry Ralph, tenor vocalist. born at Bimingham. Came into notice locally about 14r9. Went to London and stndied nuder J. B. Welch, and from 1882 attracted favomable notice. He sang at the Bristel Festival, 1885; Wofverhampton Festival, 1ns6; Bimmingham, 18s8, in Drorak's Stabut Mater, ete; and Leeds, 1ss9. He hats been heard at the principal concerts in the United Kingdom, and has won an honourable position numong singers of the day. He is a member of the Temple Church Choir.

Piercy, Rosetta, violinist and soprano voca tist, born at Biruingham, November 9!, 1538. Received her first lessons on the violin from James Hyde, a local professor, and was

\section{PIERSON.}

afterwards for some years a pupil of Ilenry Hayward, of Wolvertampton, at one of whose concerts she made her dibut. As solo vinfinist and vocatist she was frequently heard at concerts in the principal Midland towns; and was a regular contributor to the Mtonday t'opular Concerts given in the Tuwn llall by the late James Stimpson, and was one of the party engaged when Madame Patey made her dibut. She retired from the profession on her marriage, in 1s61, with Mr. Alfred Feeny, a joumatist, formerty of Lomelon; for some time musieal critic, and later an assistant editor of the Birmingham I lail!l Post.

Pierpoint, Bantock, taritone vocalist, born at Funcorn, Cheshire, Angunt 8, 1856. Sang in Preseot Parish Chrurch when a log. Was srganist for some time at the Intepend"nt ('hajpel, limncourn, and sang at concerts as an anatem temor, being oceupied in bmsiness. Ilis first vocal instruetur wan Mr. W. I. Argent, of Lirerpool, and he afterwads stncticed at the

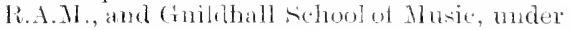
II. Viretti, eventually becoming a private fmpil of Mr. W. Shakespeare, his roice settling to a barritone of exceptional complats. He sang at farious concerts in Loudon, lanminghamb, and other places, but hin first great opportunity was at a concert of the sacred Iarmonic society, Decemfer 8, 18s' when (owing to the ilhess of Mr. Watkin Milfs) he twok the part of Lucifer in the " (rolden Legend" at a few hom's" notice. He first samy at the Bristol Festival in 18jo, in I'arry's "Judith," and hats fulfilled engagements at the Norwich, Chester, and Cheltenhan Festivats. He is a member of the Royal Soeiety of Musicians, and an Associate of the Philhatmonic society.

Jonkfh l'Inporent, no relation, was a tenor singer, and a nember of several Enghish Opera Cumpranies. He died at Preston, June 17, 1887, aged forty.

Pierson, Henry, Hugo, or l'earsox, composer, born at Oxford, April 12, 1816. Educated at Harrow and Trinity Conlege, Cambridge. Hestndied musie under Attrood and Corfe, in England; Rink, Tomaschek, and Reisiger in (rermany. Professor of Music in Edinfurgh University, 18.4. Married to Caroline Leonhardt. Resided mostly in Germany. He died at Leipzig, Jamuary 28, 1873, and is buried at the famify burying place at Somning, Bertss.

Works.-Oratorios: Jerusalem, Norwich Festival, 1852; London, 1853. Hezekiah, Norwith. 1869. Musie to Second Part of Goethe's "Faust," Hamburg, 1854. Operas: Conturini, Hamburg, 1872, Leila, Hamburg, 1848; symphony, Macheth, op. 54. Orertures: "As you like it "; " Romeo and Jufict," op. 86; "Julius Casar"; Romantique. Salve Eternum, a Roman dirge, op. 30, 1853; Der 
PIGGOTT.

Elfensieg. Six romantes for foice and pf.; Six somgs for voice and pt.; Elegies, do.; Lieder, various; Ie Mariners of England, part-song; Hurrah for Merry England; Now the bright morning star. Blesied are the dead, anthem: Ave Iraria. Office of the Holy Communion set to music $[1870]$. Thirty Hymn Tunes, 1870; 2nd series, 1872. Te Deums, etc.

Piggott, Francis, organist and composer, born about the middle of the 17 th century. $\mathrm{He}$ was organist of Magdalen College, Oxford, 1686-87; of Temple Church, London, 1698; and of Chapel Roval in 1697. In 1695 he was appointed Gentleman of the Chapel Royal, and in 169 he was Mus. Bac., Cantab. He died in May, 1704. Composer of anthems; "Choice Collection of Arres for the harpsichord, by blow, F. Piggott, etc.," 1700.

Pilkington, Francis, composer and lutenist of the 1 fith and 17 th centuries. He was a chorister in Chester Cathedral, and Mus. Bac., Oxon., 1595. He published First Booke of Songs or Ayres of 4 Parts, with tablature for the lute or orpharion, with the violl da gamba, 1605; First set of Madrigals and Pastorals of 3,4, and 5 Parts, 1613; Second Set of Madrigals and Pastorals of $3,4,5$, and 6 Parts, apt for Violl and Voyce, 1624.

Pilling, Samuel Wilkinson, amateur organist and anthority on organ construetion, born at Boltou-le-Moor's, 1856. Edueated at Victoria College, Manchester; received his musical training under $\$$. B. Whiteley, alid J. Dobson, of Southport, and later under J. Kendrick Pyne, of Manchester. Has given many organ recitals in different parts of the country, and appeared at the Bow and Bromley Institute, December 2, 1882, and is also known as an oceasional lecturer upon matters referring to the organ. Many improvements in organ construction have been initiated by him, and he has designed and opened uptwards of one hundred-and-thirty organs in various localities. He has an exceptionally fine fourmanual organ in the music-room of his residence, The Hagg, Mirfield, which was opened by Jules Grison, of Rheims, November 30, 1887, and upon which many distinguished organists have given recitals. Mr. Pilling is by profession a Ciril Engineer and Railway Contractor, succeeding to the business of his father, Abraham Pilling, J.P., late of Bolton.

Pillow, John William Davis, conduetor and organist, born at Chichester, in 1851. Chorister at Chichester Cathedral, ard organist of St. Pancras, Chichester, when 13. Artieled pupıl of E. H. Thorne. In 1869 he was appointed to All Saints', Portsmouth, and in 1880 founded the Portsmouth Philharmonic Society, which has given many excellent concerts. In 1889 he accepted the post of organist at the new Parish Chureh of

\section{PITTAIN}

St. Mary, Portsea $\mathrm{He}$ is a leading nember of the local Masonic brotherhood.

Pinto, George Frederick, or SATNDERS, violinist and composer, born in Lambeth, London, September, 25, 17*6. Grandson of Thomas I'into. He studied mier Salomon, and performed at the principal Loudon and provineial eoncerts; and appeared in Seotland with great suceess, $180 \%$. He died at Chelsea, London, Mareh 23, 1806.

Works.- Six Canzonets for voice and pf., Birmingham 1805]; Four Canzonets and a sonata, edited, witl preface, by S. Wesley, Edinburgh [1807]; Canzonets, edited by T. Oliphant [1546]; Three Duets for two violins obligato, op. 5 ; Three Sonatas for pf., op. 4 ; Three Sonatas for pf. and violin [1805]; other vocal and instrumental works.

Pinto, Thomas, violinist, born in England, of Italian parents, early in the eighteenth century. He performed at provincial festivals, and at King's Theatre, London. Resided suceessively in Jdinburgh and Ireland. Married to Miss Brent, the rocalist. He died in Ireland, in 1773.

His second wife, Miss Charlotte Brent, whom he married in 1766 , was a famous soprano voealist, and appeared as a concert voealist for many years in London and elsewhere, from 1758. She died in London, April $10,1802$.

Pitman, Ambrose, musieian and minor poet, born 1763. Musician in London. Died, London, in 1817.

Works.-Three favourite Amorosos for voice and pf., op. 6 [1795]; Laura, a somnet from Petrarch (? Metastasio), 1795. Songs : Gaffer Gray; Io! Trimmphe; Marian's complainu; The Robin, ete. Beauties of D. Searlatti, selceted by Ambrose Pitman [1780]; Eugenio, or the man of sorrow, by a young gentleman of seventeen, London, 1780; The IIiseries of Musick Masters, a serio-comick dramatick poem, London, 1815.

Pitt, Percy, composer, of present time. Studied in Germany under Reineeke, Jadassohn, and Rheinberger. Composer of a Coronation March ; Sujte, "Fètes Galante," both performed at the Queen's Hall, 1896; and other pieces for orchestra. Three Romantic pieees, op. 18, 'cello and pf.; Bagatelle, violin and pf.; Modern suite, pf. Songs, ete.

Pitt, Thomas, musician, of latter part of 18th century, who was appointed organist of Woreester Cathedral in 1793. Composer of "Chureh Music, consisting of Te Deum and jubilate, ete." Worcester, 1788-89, 2 vols.

Pittman, Josiah, organist and composer, born in London, September 3, 1816. $\mathrm{He}$ studied under s. S. Wesloy, Moscheles and Schnyder ron Wartensee. Organist successively at sydenham, 1831; spitalfields, 1835-47; Lineoln's Inn, 1852-64. He was 
I'ITTS.

accompanist at Her Majestr's Theatre from 1865 to 1468 , and at the Roval Italian Opera, Covent Farden, 1868-1880. He died at London, April 2:3, 1880.

Works. The People in the church, their Rights and louties in emmection with the Poetry and MLasic of the Book of Common Praver, London, 1858. The People in the Cathedral; a letter to the very Rev. Henry Hart Nilnuan, D.1)., London, 1857. Songs of Scotland, edited (with Golin Brown). Songs from the Operas, 2 vols. (edited). Royal Edition of Operas, edited with Sir A. Sullivan (Booser). Calleott's Grammar of Music (edited), Iondon, n.d.

Pitts, William John, organist, born at Tansor, near Oundle, April 17, 1829. Organist at Elton, Huntingdonshire when fourteen; and when the Oratory at Kensington, London, was founded he was appointed organist, and has been actively engaged in his duties for 55 years. Composer of the hymm tume known as "Princethorpe," and some other vocal music. His father was an organ lnilder, and he had two brothers organists, JAmes PITTs, formerly of the R. C. Church at Frook Green, Hammersmith; and JoHN PrTTs, formerly organist to the Duke of Norfolk, Arundel. Both are now deceased. JoHN and FRNEST PITTS, sons of the last nanted, ale pianists, and have gained some reputation on the concert platform, from 1887 onwards.

Place, Gertrude, author of "A Catechism of Music for the use of young children," Lomdon, 1856.

Plaisted, Philip, organist, born at Muswell Hill, Middlesex, 1837. Went with his parents to Australia in 1857 . Returned to London and became a pupil of George Cooper, E. J. Hopkins, and WV. H. Nonk, 1863-5. Held the post of organist at St. Stephen's, Richmond, and other churches in Melbourne. Was organist of the Melboume Philhamonic Society, and gave Saturday Evening Concerts. In May, 1889, he became insane, and is living still in that unhappy condition. A MIss GraCe P'LAisted sang in English opera, in Melbourue, 1883-4.

Plant, Arthur Blurton, organist and composer, born at Lichfield, May 12, 1853. TTas a chorister at the Cathedral for seven years, and then articled pupil of the organist, Thomas Pedsmore. Passed examination for F.R.C.O., 1875; graduated Mus. Bac., 1882 ; Mus. Doc., 1896, Oxford. In 1874, he was appointed organist and choirmaster of St. Paul's, Burton-on-Trent, and, in 1895, Borough organist, both of which positions he still holds. An able executant, he has given organ recitals at the Bow and Bromley Institute, and elsewhere. His compositions include a setting of Pralm 13, for soli, chorus, and orchestra; Sonata in C ; six Sonatinas;
PLAYFORD.

Concert Fugue; and other pieces for the organ, etc., etc.

Platt, Edward, composer and hornplayer, was born on June 11, 1793; died at Stirling, June 27, 1861. For many years a member of the Philharmonic, Opera, and other orchestras; and played at the Three Choirs' Festivals for twenty years. Retired from the profession in 1849 , owing to loss of teeth. The late Sir Michael Costa considered him without an equal for tone and "singing" on the horn. Author of an Instruction Eook for the Pianoforte, and composer of songs, "My Bonnie, Blythesome Mary," etc., and pf. music.

Platt, Robert, musician. Author of a “ New, Easy, and Correct System of Tocal Music: a Practical Manual of Singing at Sight." London, 1847.

Platt, Samuel Radcliffe, a wealthy and distinguished amateur musician, of Werneth Park, near Oldham. He maintains a complete orchestra of 45 performers, he himself playing first oboe. Concerts are given under the direction of Dr. Marsden (q.x.), and a choir has at times been employed. His library of classical and modern orchestral music, numbers over 1,000 works. The organ in St. Thomas' Church, Werı eth, was his gift. It has four manuals, and cost $£ 3,000$. He is a member and trustee of the Manchester Royal College of Music; and founder and President of the Oldham School of Music. Deputy Lieutenant, J.P. for the County, and High Sheriff, 1897.

Platts, James, composer, of latter part of last and early part of present century. He composed a large number of country dances, cotillons, stratlispeys, reels, quadrilles, medleys, waltzes, etc., for pf. or harp, between 1785 and 1815; also six Rondos for the harp or pf., with accompaniment for the tamborino; songs, etc.

Playford, John, composer and musicpublisher, was born in London, in 1623. Established a music-selling and publishing business, in the Inner Temple, London. Clerk of the Temple Church, 1653. He died at London, in 1693.

WORKs.-An Introduction to the Skill of Musick, in two books. To which is added the Art of Descant, by Dr. Thomas Campion, and Annotations thereon by Mr. Chr. Simpson (? 2nd edit.), London, 1655. (An earlier edition $[1654]$ is noted in Grove's "Dictionary of Music," as having been in the possession of Dr. Rimbault, and the only known copy). 3rd edit., 1660; an unnumbered edit., 1662 ; 4th edit., with portrait, 1664 ; nnnumbered editions in 1667,1670 ; 6th edit., portrait, 1672 ; 7th edit., with the Order of Performing the Divine Service in Cathedrals and Collegeate Chapels, portrait, 1674; 8th 


\section{PLAYFORD.}

edit., portrait, 1679 ; 9th edit. (?) ; 10th edit. (to which is added as a third book in place of Campion's treatise, "A brief Introduction to the Art of Descant, or Composing Music in Parts," ascribed in future editions to Henry Purcell), portrait, 1683; 11th edit., port, 1687 ; 12 th edit., port, 1694 ; 13 th edit., port, 1697 ; 14 th edit., port, 1700 ; 15 th edit., port, 1703 ; 16th edit., port, 1713 ; 17 th edit., port, 1718 ; 1Sth edit., port, 1724 ; 19 th edit., port, 1730. Psalms and hymms in Solemm Mnsick of foure parts on the Common Tures to the Psalms in Metre . . . London, 1671. The Whole Book of Psalms, with the usual Hymms and Spiritual Sougs, etc., composed in three $p$ rts, London (?); other editions, 2nd, 1695, 1697; 6th, 1700; 7th, 1701;8th, 1702 ; 9th, 1707; 10th, 1709; 13th, 1715; 19th, 1738; 20th, 1757. A Paraphrase upon the Psalms of David, by George Sandys. Set to new tunes, for private devotion, by Henry Lawes. Revised and corrected by John Playford, London, 1676. The Musical Companion, in two books. The first book containing catches and rounds for three voyces, the secoud containing dialogues, glees, ayres, and songs for two, three, and four voyces, London, 1673. A Booke of New Lesisons, for the Cythern and Gittern, London, 165\%. Musick's Recreation on the Viol, Lyra-way; being a choice collection of Lessons

etc., London, 2nd edit., 1682. In Locke's "Present Practice of Musick Vindicated," 1673 , is " A Letter from John Playford to Mr. T. Sulmon," in which he espouses Locke's cause to the disadvantage of Salmon. Publications, verious: Hilton's Catch that catch can; or a choice collection of eatches, rounds, and canons for three and four royces, 1652; Select Musical Ayres and Dialogues, in three books, for one, two, and three voyces

by sundry composers (composed by Wilson, Colman, Lawes, etc.), 1653; another edition, 1659; Choice Ayres, Songs, and dialogues to be sung to the theorbo . . . 5 books, 1676-84; The English Dancing Master: or Plaine aud Easie Rules for the Dancing of Country Dauces, London, 1651; 2nd edit., 1657; 3rd edit., 1665; and numerous other editions to 1728; Musick's delight on the Cithern, 1666; also published works of Lawes; Court Ayres; and most of the inportant music books of the period.

Playford, Henry, publisher, second son of the foregoing, born in London, May 5, 1657. Succeeded to his father's business in 1685 , which he carried on for a time in company with Robert Carr, but afterwards alone at the Temple Change, Fleet Street. $\mathrm{He}$ died at London [1710]. His principal publications consist of the Theater of Music; or a choice collection of the newest and best songs sung at the Court, etc. The words composed
PLUNISTEAD.

by the most ingenious wits of the age, and set to music by the greatest masters... Lond., 4 books, 1685-87. Banquet of Musick: a collection of the newest aud best songs sung at Court, 6 books, 1688-92. Pleasant Musical Companion, being a choice collection of catches for three and four voices; published chiefly for the encouragement of the Musical Societies, which will be speedily set up in all the chief cities and towns in England, 1701; 5 th edit., 1709. A Collection of Original Scotch Tunes (full of the Highland Humours) for the Violin: being the first of this kind yet printed: most of them being in the compass of the Fli te, Isondon, 1700. He also published Purcell's "Ten Souatas," in four parts." \& vols., 1697; Purcell's "Orpheus Britanuicus," 1698-1702; Blow's "Amphion Auglicus," 1700 , etc. He also published a work which went through a number of editions, viz., "Harmonia Sacra; or Divine Hymns and Dialogues, with a Thorow-bass, etc.," London, 1687-93; 3rd edit., with "four excellent hymns of the late Mr. Henry Purcell, never before printed," 1726.

His younger brother, Jонs (b. 1665, d. 1686), carried on the business of music printer, and reprinted some of his father's works. For some years he was in partner. ship with the widow of William Godbid, a wellknowu London music-printer, who executed numch work for John Playford, senior.

Pleasants, Thomas, organist and composer of the 17th century. In 1676 he became organist of Norwich Cathedral. $\mathrm{He}$ composed some sacred and secular vocal music.

Plumridge, Henry, organist and composer, graduated Mus. 13ac., 1871 ; Mus. Doc., 18ss, Oxford. He is organist of University College, and the City Church, Oxford; and the composer of an oratorio, "Daniel," 1888 ; "God came from Teman," soli, chorus, and orchestra; anthems, etc.

Plumpton, Alfred, composer and conductor of present time. About 1875 he was conducting an opera company in India, and afterwards went to Australia. He was some time director of the choir at the Roman Catholic Cathedral, Melbourne, and produced a Mass in G there, 1881 (?) His cantata, "Endymion," was composed for the first Musical Festival at Melbourne, and performed December 26, 1882. "The Apotheosis of Hercules," for men's voices, was produced at Melbourne, September 17, 1883. In 1892 he was in London, conducting at the Prince of Wales' Theatre. For some time he was musical critic for the Melbourne Age, and Leader. He has composed some songs, etc.

Plumstead, WV. H., published " Beauties of Melody, a collection of popular airs ... also Irish and Scotch melodies," London, 1827. 


\section{POLE.}

"Chureh of England Music," London, $18+6$. "Nursery Recreations for the Young," 185t-56, etce

Pole, William, civil engineer, writer on science, and amateur musician, horn at Birmingham, April 22, 1814. Professor of Civil Engineering at University College, London, 1859-76, and also held appointments in Iudia, and has done much scientific work for Government. F.R.s. of I Jondon, 18is1, and Hdinburgh, 1877. Cultivated his early taste for music, and graduated at Oxford, Mus. Bac., 1860 ; Mus. 1)oc, 1867. Was organist of St. Mark's, North Audley Street, London, 1836 66; Examiner in Music, London University, 1878-90. Hon. F.C.O., 1889. His contributions to musical literature date from 1836 , when he contributed his first papers to the Musical World, on the Construction of Organ pipes; on the Horn, etc. He wrote on the Musical Instruments in the International Exhibition of 1851; and the Official Report of the Jury, on the same subject, in 1862; on the Nusic at the Crystal Palace-Report to the Shareholders, 1875 ; on the proposed Regulations for Musical Degrees, University of London, 1877; and many papers for the Musical Times, Athenueum, Nature, ete.; also for the programmes of the New Philharmonic Concerts; and articles in Grove's I)ictionary of Music. His "Philosophy of Music," 1879, was reprinted by $k$. Paul, 1895; and "The Story of Mozart's Requiem," which appeared in the Musical Times in 1469, was issued by Novello in 1879 , as a pamphlet. These are two extremely valuable works. Dr. Pole's musical compositions include a setting of Psalm 100 in cantata form, which was given at a Festival at Tenbury by Sir F, A. G. Ouseley, October 3, 1861; and the 8-part motet from it, performed at the Chester Festival, 1882. He has also done some fourhanded pf. accompaniments to classical songs, and composed some organ music.

Poole, Clement William, amatem mmsician, born at Ealing, June 7, 182s. Studied music under Jos. 'T'. Cooper, and has acted its homorary organist at the Parish Church, Kingston-on-Thames; and Christ Church, Ealing. Composer of rocal music, among which is the hrmm tme "Westenhanger," etc.

Poole, Elizabeth, mezzo-soprano vocalist, born in London, April 5, 1820. Made her debut in opera at Drury Lanle, 1834. Sang in the United States, 1839. Was with the English Opera Company at the strand Theatre, 1848; and, until 1870, was prominent both as a billad singer and an actress. She married a $\mathrm{Mr}$. Bacon.

Poole, Fanny Kemble, boru BarnetT, contralto vocalist, born, 1845 , in London. She did not begin her public career until after her marriage; but from abont 1870 until 1891 she sang in concerts, chiefly in oratorio,

\section{PORTER.}

in all the large towns in Fngland, Scotland, and Wales. After the death of Mr. Poole, in 1891, she retired from the platform, and gave herself up to teaching, having a large comnection in the neighbourloood of surbiton.

Her sister, Alick Barnetrt (Mrs. Dickens), sang for some years at the Savoy Theatre, creating the contralto parts in mimy of the (iilbert-sullisun operas; also sang in the Carl liosa, and other companies. Toured in Australia, 1886. The sisters are connections of the celebrated Kemble family.

Poole, Maria, see I ickons, Mrs.

Poole, Reginald Lane=, amatent musician and anthor, was educated at Oxford, where he graduated, in 1878. Lecturer on modem history at Jesus College, Oxford, since 1866. Author of "Bach" (Great Musicians), Lonton, Low, 1882.

Pope, Henry, lass vocalist, born at Bristol. Sang at the Bristol Festival of 1876 , in Spoln"s "Fall of Babylon." Was a menber of the Carl Rosa Company for about ten years, from 1878; and sang at the principal London and provincial concerts. Now living in London as a teacher of singing.

Porret, or Perrot, Robert, organist and composer of the 16th eentury. He was born at Hackness, in Yorkshire, and in 1507 graduated Mus. Bace, Cambridge, and in 1515 became Mus. Hoc, Oxford. He was organist and instruetor of the choristers in Nagdalen College, Oxford, 1519, and was also for a time principal of Trinity Hall, Oxford. He died in 15.50 ).

Porteous, James, violinist and composer, was born in the latter half of the 18th century. He lived at Meinfoot, near Heclefeehan, ])umfriesshire, and was a miller on the Hoddom Estate. He died at Amman, July 17, 1847. He issued a "collection of stathispeys, Reels and Jigs; respectfully dedicated to Lady Jardine of Applegarth. Arranged for the pianoforte, violin and violoncello," Edinlurgh [1820]; 2nd edition, 1821, in parts.

Porteous, Richard, anthor of the "Bandmaster's Atlas, displaying at one view the scale compass and notation of every wind instrument employed in military and brass bands.." London, [1854]. "Composer's Mnsical Atlas, displaying the scale, compass, etc., of every instrument employed in orchestral bands.." London, 1854.

Porter, John, organist of the 17 th century. Was organist at Eton College and teacher of Johu Weldon.

Porter, Prince Walsh, amatenr composer and social leader. Composed a "Collection of melodies, ducts and glees," London [1827].

Porter, Richard, author of a small tract entitled, "Rndiments of Music, abridged for the use of Choirs," Oxford [1868], 2 editions. "Rudiments of rocal music," Oxford, 1879. 


\section{PORTER.}

Porter, Samuel, ormanist and conposer', bolll at Norwich, in 1733. He studied under Manrice Greene, and was urganist of ('anterebury Cathedrat, 1757-1503. He died at Canter. burv, Iecember 11, 1810. He cemposed Fom Anthems and Two Psalm Tumes," London [1800]. "Cathedral Music in sicore," edited by Rer. W. Tas. Porter, London 1815]. Twenty-five Odes, hymm tmues, ete. in foms parts, London, 1800." Songs, glees, marches, etc. His service in I) has been reprinted by Novello.

Whllay James Portel his son, was vicar of Himbletom, and composed a "Selection of 15 l'sahns from the new rersion.." I sondon [840 ; as well as anthems, ete. NisteL Portar, probilily another son, who died on July 14, 1523, held the position of organint of Faversham l'arish ('hurch for 37 vears, and was a nember of the King's band for the same period.

Porter, Thomas, author of "How t, choose a violin," London 1st.t

Another Thomas Politer, pullinhed aluont 1839, a "Fantasia for the oryan wr pianoforte, modulating twice through all the nuajur and minor keys," of. 1.

Porter, Walter, composer, was born about the end of the 17 th century. Son of Henry I'orter, who was MIus. Buc., Oxford, 1600, and musician to Jannes I. in 1603 . Gentleman of the Clapel Roval, 1616. Master of Choristers, Westminster Ables, 1639, but was dismissed at the Rebelloun. He died at London. Octolver, 1659.

Works. Malrigales and Ayres of two, thr e, fonre, and five royces. . . 1682. dyres and Madrigales for two, three, four, and fire voices, with a thorough-bass hase for the Organ or Theorho lute in the Italian way, 1639. Motetts of two Voices-treble, tenor and bass, with continued hass or score, to be performed on an organ, harpsychor, lute, or bass viol, 3 parts, London, 1657. I)ivine Hymns (1664), Psalms of Mr. Feorge Sandys composed into Music for two Voyces, with a Thorough-bass for the Organ [1670.]

Porter, Walter, organist and composer, born at Boston, Lincolnshire, MLay, 1856. Entered the choir of the Parish Church when eight, and in 1868 took lessons from WV. B. Gilbert, and later became a pupil of I). J. Wood. Passed examination for F.C.O Appointed organist and choirmanter of Bourne Abbey Church, 1874; and to St. Mary's Parish Church, Hull, 1875, a position lie retains. Conductor of Grimsby Philharmonic Society, 1884, and a similar society in Hull, since 1885. Honorary Local Examiner for R.C.M[. Scholarships. Composer of a string quartet (performed at hearlorough Conference of I.S.MI., 18.94); a setting of the Otfice of Holy Communion, Te Deum, etc.,
POULTER.

fugue, two andantes, and other organ music; a number of pieces for pf.

Postans, Mary, see Sinaw, Mrs. Alfred.

Potter, John, writer and composer of last century, anthor of "Observations on the present state of music and musicians, with general rules for studying Music, to which is added a scheme for erecting and supporting a musical academy in this kingdom," London, 1762. He also composed for Vauxhall Gardens, and published a collection entitled, "Collection of New Songs and Ballads sung at Vauxhall Gardens," London, 1767, 17711772 , etc.

Potter, Philip Cipriani Hambly, pianist and composer, bor'u at London, October 2, 1792. He studied nuder his father, Callcott, Attwood, Croteh, and Woelt. Lébut as pianist at Philharmonic Society Concert, in 1816. He afterwards studied at Yienna under Firster, and while there came in contact with Peethoven, 1817-1s. Protessor of pf. at R.A.M., l.ondon, 182. I runcipal of R.A.M. in succession to Cret $\mathrm{h}, 1832-59$. He dued at London, September 26,187

Works.-Nedora e Corrabo, cantata 1828; Op. 1, Sonata for pf. [1S.7]; Op. 2, Sonata for pf. in I); Op. 3, Sonata in E minor; Op. 6. Grand luo for two pfs. : ()p. T, Thet for two pfs.; Introduction and rondo, pf., four hands; Op. 11, Sextet for pf., flute, violin, vola, 'cello and bass: Op. 12, Ihree trios for pf, violin, and 'cello, or clarinet and bassoon [1835; Op. 13, Sonata ai hravura for pf. and hom or bassoon; Op. 19, Studies for the pf. in all the major and minor keys, London [1827]; Op. 20, Introduction and rondo for pf.; Op. 21, Second Rondeau brilliant for pf.; Nine Symplinies for orchestra in A, G minor, etc. ; four overtures for orchestra; Three concertos fur pf. and orchestra; Several string quatets; The Fnigma, variations in the style of five eminent masters, pf. [1826]; Octave lessons; Allegro brilliant in E; Toccattas, rondos, etc., for pf.; Canzonets and songs. A musician and teacher of great influence in his time, who directed the studies of a large number of the best modern Fnghish musicians. His father and grandfather were both musicians.

Potter, S., musjeian and autlıor, who was in the band of the Collstream Gruards. He published "Art of playing the Fife, with cump, garrison, and street dnty," n.d.; "Art of leating the Drum, with camp, garrison, and street duty," n.d.

Poulter, George Thomas, composer and organist, born at London, in September, 18:38. Studied under J. W. Elliott, ete, and himself acted as one of the teacher's of Hamish MacCumn (1. $\iota^{\circ}$ ). Successively organist at Warpertor, Warwickshire, 1854; 
POUNISS.

Ardgowan House (Nir M. R. Shaw Stewart), private, 1857; Town Hall, Greenock, 1861; Mid Parish Church, 1868; and St. Paul's Church, Greenock, 1886. Conductor for a time of the Greenock Choral Society, ete. Composer of songs; "The Bridge of Duty," a cantata; pf. music, etc.

Pounds, Charles Courtice, rocalist and actor, was born in London, MIay 30, 1869. For some years he was a treble singer in church choirs, but he afterwards studied at the R.A.M. Travelled in the English provinces with concert parties, and saug in oratorio, but was most suceessful in the Gilbert and Sullivan operas. He sang in Australia in 1895, with the Williamson and Musgrove Opera Company.

Povey, Miss, soprano rocalist, was born in Birmingham in 180t. She made her dibut on Jume 3, 1817. Pupil of T. Cooke and Bartleman. She sang at Drury Lane, 1819; English Opera House, etc. She was married to a Mr. F. Knight.

Powell, Josiah W., town-clerk of Burslem, Staffordshire. He and the late George Howson $(y . x$.$) were the fathers of elementary$ vocal nnllic in the Potteries. Half a centriry ago there was scarcely a singer in the district who could read music, and if an oratorio was to be performed singers had to be importu from Birmingham. Now, throngh the efforts of thene two men, the Potteries are vocal with song. Powell translated Mendelsiohn's "Elijah " into the Tonic Sol-fa Notation, one of the first great oratorios so treated. He formed the Burslem Choir, which soon achieved a great reputation. His memory will long be affectionately cherished in North Staffordwhire. He died at Wolstanton, May 22, 1891, in his $72 n d$ year.

Powell, Thomas, violinist and composer, born in London in 1776 . He studied the harp, violin, and pf. Menber of the Royal Society of Mlusicians. He was married in 1811 , and resided in 1)ullin as a teacher. Performed a violin concerto in IIaymarket Theatre, London. He died after 1860 . Composed 15 concortos for violin and orehestra; Three duets for violin and 'cello, op. 1; Three duet for 2 'cellos, op. 2; Capriccio for 'cello, op. 24; Introduction and Fugne for organ; Three grand Sonatas tor pf, and violin [1825]; Overtures for orchestra, pf. arrangements, ete.

Powell, Walter, tenor votalist, was born at Oxford in 1697. Chorister and clerk to Magdalen College, Oxford. Sang in Handel's oratorios. He died at Oxford, Novenuler 6, 1744 .

Power, Lionel, composer and writer, of the 15 th century, was author of various works on Misical theory, of which "Lionel Power of the Cordis of Musike" is contained in the Lansdowne MS. in the British Museum. He

\section{PRENDERGAST.}

also composed some church music, which is preserved in MIS. at Bologna, the British Miseum, etc.

Prat, Daniel, clergyman of 18th century, was rector of Harrixham, in Kent, and chaplain to George III. IIe wrote "An Ode to. Mr. Haudel, on his playing on the organ," London, 1722 ; reprinted as "An Ode on the late celebrated Handel, on his playing on the organ," Cambridge, 1791.

Pratt, John, organist and composer, born at Cambridge, 1772 1779]; son of Jonas Pratt, music-seller, $\mathrm{He}$ was chorister in King's College, Cambridge, and studied under Dr. Randall, whom he succeeded as organist of King's Colloge, 1799. Organist of Cambridge University, 1800; organist of St. Peter's College, 1813. He died at Cambridge, March 9,1855 .

Works. Collection of Anthems in seore, selected from the works of Handel, Haydn, Mozart, Clari, Leo, and Carissimi, with organ or pianoforte accompaniment, 2 rols. [1825]. Selection of Ancient and Modem Psalm Tunes, arranged and adapted for two trebles, or tenors, and a bass, for the use of parish churches [1810]. Psalmodia Cantabrigiensis; a selection of ancient and modern psalm tunes. . for the use of the University church, 1805 ; also, 1817 , with an appendix of later date. Four double Chants, and the Responses to the Commandments, as performed at the King's College, Cambridge, n.d.

Pratten, Robert Sidney, flute player and composer, born at Bristol, January 23, 1824. Performed when a loy at eoncerts in Bath, Bristol, ete. First flute in orehestra of Theatre Royal, 1)ublin; at lioyal Italian Opera, London, 184f; saered Harmonic Socicty ; I'hilharmonic Society, etc. He studied for a time in Gemany. He died at. Ramsgate, February 10, 1 -68.

Works. - Fantasias, arrangements, studies, solos, etc. for flute, in combination with other instrunents. Complete Series of Exercises for the Siccama Flute. Complete Suries of Scales and Exercises, carefully fingered for Pratten's Perfected Flute, n.d. Flute Tutors cone published by Boosey \& Co., and another by Edwin Ashdown).

His wife, Manam Sinxey Prattex, is a well-known guitar-player, and writer for that instrument. She has issued solos for the Gnitar, a series of alyout 250 original and selected pieces; Numerous Divertimentos on original and seleeted themes: Gritar school, leing complete Instructions for Modem Guitar Playing in the common key; Leaming the Guitar Simplified.. Also a look of Instruetions for the Gigliera (wood and straw instrument).

Prendergast, Arthur Hugh Dalrymple, composer and conductor, born in London, 


\section{PRENTICE.}

June 28, 1833. Studied under James Turle. Conductor of Lombard Amateur Musical Society, and of the Bar Musical Society's Choir. Sometime Secretary of the Bach Choir. Has lectured to the College of Organ. ists, ete.

Wonks.-The Second Advent, sacred Cantata: Festival Te Deum, Chureh Choir Association prize, 1882; Communion Service in C; Cantata and Deus in F, etc. Anthems: O Lord our Gavernour; Show me Thy ways (male voices); O God, thon hast east us out. Hymu tumes. Mnusic to The Maske of Flowers (with Birch Reynardson), performed at (iray"s Inn Hall, Julv, 1887, in celebration of the Queen's Jubilee. Madrigal, When as she smiles, Madrigal Suciety's prize and medal, 1889 ; Sweet western wind Sumshine; Hark! how the cheerful birds, Madrigal Society's prize, 18s0, and other part-songs. For men's voices: When for the world's repose; $O$ mistress mine, madrigal; Song of the Silent land; Imbuta; The Robin; The Pixies' welcome, madrigal; In this fair rale, ete, Songs: A birdies life; A shady nook; Sleep, wake, live; and others.

Prentice, Thomas Ridley, pianint and composer, born at Paslow Hall, Ongar, Essex, July 6, 18t2. Stondied at R.A.M. under G. A. and Walter IIacfarren. I'otter Exhibitioner, 1863, and elected Asrociate on leaving. In 1869 he began a series of Monthly Popular Concerts at Brixton, which he carried on for some years; also gave occasional concerts at the Hanover Siquare Rooms, St. (ieorge's Hall, and played at the Crystal I'alace. In 1872 he was appointed organist of Christ Church, Lee, but this, as well as concert work, ill-health compelled him to resign. He gast a set of twelve "Twopenny (oncerts" in Fensington Tumn Hall, 1880-1. In 1890 he was appointed a profentor at the Guildhall School of IIusic, and was I'rincipal of the Beckemham school of Music, established in 1883. As a teacher he was most successful and esteemed. He died at Hampstead, July 15,1895 .

Worrs.-Linda, cantata, ladies' voices; The Nermaid's Invitation, and other trios for the same. Christmas; Ye little birds, partsongs. Break forth into joy; I love the Lorel, anthems. The God of love my shepherd is; Evensung; Echoes, and other songs. Gavottes; Elegie; Reverie; Br the sea; Sunday musings, ete., for the pf. Editor of Six Cantatas by Carissimi. Author of The Musician, a guide for pianoforte students, in 6 grades, London, Somnenschein, 1883-6. Hand Gymmastics, Novello's Primers, No. 36.

Prescott, Mrs. Cyril A., see Lowthiax, Caroline.

Prescott, Oliveria Louisa, composer and writer, born in London, September 3,
PRESTON.

1842. Studied under Lindsay Sloper, and then for seven year's at R.A.M., under (Sir) G. A. Macfarren, Jewron, Folkes, and Ralph. A.R.A.MI. Teacher of harmony at the ('hurch of England High School for Girls, [pper Baker street, London, 1879-933, and lecturer in harmony and composition, for albont the same period, to the correspondence system in comnection with Newnham College, Cambridge. Sonnetime musical amannensis to Professor Sir G. A. Macfarren.

Works. - Psalm 13, for suprano solo, chorus and orchestra; Psalm 126, for voices alone (sumg in St. Paul's Cathedral.) Onr conversation is in hearen; The righterns live for evermore, anthems. Lord Ullin's Daughter, chorms and orchestra. Ballad of Young John; Donglas Raid; Crrer; Borter ballad; and other part-songs. The Fisherwife; Queen of my heart; songs. Crchestral: Two srmphonies, in B flat, and I) minor; Oserture (R.A.M., 1876); Concert Finale, D minor; Concert piece, Bright ()etuler: Concert overtures: Tithonus; Golden supler; Edipus and Antignne; Woodland. Concerto in A, pf. and orchestra. Hern watehing for Leander; Love and langhter: for sopraso solo and orchastra. Bohemian song, for 4 voices and strings. Quartets in A minur and $\mathrm{C}$ minor, strings; in $G$, pf. and strings, etce. Author of Form or Design in Music: I'art I., Instrumental; Part Il., rocal, London, 1852. Enlarged edition, prepares with the assistance of Professor Macfarren, 1594. Contributions to Musical IIorld, ete. Nix Lectmes about Musice and what it is mate of, Church of England High sichool, lialier street, 1n:3.

Preston, James $M$., organist and conductor, born at Gateshead-on-Tyne, July 14 , 1860. At an early age he studied violin and pf. under his fatlier, stephen E. Preston, a musician of repute, and when thirteen was placed under Lindsay Sloper, in London. In 1875 , he was appointed organist of St. Josepli's Roman Catholic Churcli, (iateshead, where he remained six years, diligently working at the organ. Entered the Guildhall School of Musie in 1881. and studied under I)r. Stainer. In 1883, succeded the late Mr. Robert Potts, as organist of St. 'Thomas', Neweastle-onTyne, and in 1888 was appointed to St. George's, Jesmond, a post he still holds. In 1891 he began to give organ reeitals there, on Sunday evenings: he has also played at St. George's Hall, Liverpoul, and elsewhere, and ranks among the foremost organists of the dav. He is also a pianist, and has been commected with the Newcast le Chamber Music Society for years. $\mathrm{He}$ is conductor of the Newcastle and Gateshead Choral Cnion, which has more than a local reputation, and has given many important concerts. Of his compositions, but few are yet published. A 


\section{PRICF}

Festival Chorus was performed in Newcastle Town Hall, October, 1895.

Price, Daniel, baritone vocalist, born at Dowlais, (tamorgan, 1s63. Was one of the first fifty scholars of the R.C.M when it opened in 1s:3. Studied singing under Albert Visetti; Counterpoint, under In. J. F. Briclge; and composition with IM. Stanford I)istinguished himself, especially in the operatic performances given by the stmdents. A.K.C.M., 1ses, and in the same year appointed a member of the choir, Westminster Abley. Is a professor of singing at Ii.C.M., and has appeared with suceess at concerts in Lomdon, Bimingham, and other places; and on the occasion of the Jubilee celebrations in 185i, liad the honour of singing before Her Majesty the ()ueen, at IVindsor. While at the R.C.MI. he composed some pf. pieces, which were performed at the College concerts.

Price, Tom, componer, born at Rhymney, Monmonthishe, in 1857. Worked as a boy in the coal mines. Self-tanght in music, and learned much by joining different Welsl choirs. ITon a lize offered by Wrexhan Festival Committee, 1886 , for a part-song, "Hands all romd" (Tennyson); other prizes in America, etc. He has composed a dramatic cantata, anthems, part-somg, songs, ete.

Pridham, John, pianist and composer, born at l'ophim, Devon, Octoher 1, 1818. lle stmdirrl at the R.A.M., and when still al yomig man, played frequently heforo the Yaeen and Prince Comst. He died at Tannton, in Angust, 1sor, He wote a "Method for the Pinno," Inomdon, Brewer,

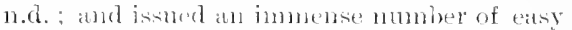
pieces for the uf. Composer also of a few songs and duets.

Pring. Jacob Cabitt, organist and connposer, Was borns at Lewisham, near Lomolon, in 1771. Olognjist of it. Botolph, Aldgate, London, Hus, Bate, ()xon., 1797. He died in 1799.

Works. - First look of Glees, Canoms, ete. [1730; Wight Gleses, Catehes, ete., London [c. 1795 ; Fight anthems, as performed in st. Panl's Cathedrai, Iondun [179s]; Magnificat, in two pats ; Dying Christian to his som, ode 17941. Wast pouressive losinss, with the fingering marked for romug begimuers on the pf. or harpsichord, Lomdon [1800]. Six progresicive somatimas for the harpachord or lif. Somgs, sommets, etc.

Pring, Josepl1, organist and composer, brother of alove, born at Kensington. London, Jamnary 15, 1776. Orinant of Pangor Cathedral, 1793. Mas. Bac. and Doc., Oxon., 180\%. Ite died at Bangor, February 13, 184:2.

Works.-Twenty Anthems, in score, for 1 , $2,3,4$, and 5 voives, London, 1805. MIagnificats, and other church musie.

Pring, Isaac, urganist and composer,

\section{PRINGTE.}

brother of above, born at Kensington, London, in 1777. Assistant to Dr. Thitip Hayes, at New College, Oxford, and his snceressor in 1797. Mus, Bae., Oxon., 1799. He died at Uxford, October 18, 1799. Composer of chants, anthens, ete.

Pringle, George Robert Grant, wganist and eonductor, born in Lumdon, May 26 , 1833. Chorister, St. l'anl's Cathed ral, 1841-51, and pupil of John Goss and Feorge Cooper, Went to Victoria. Australia, in 1s58. Appointed organist and conduetor of Melbourne l'hilhapmonic society. Founded and conducted the Musical Union, which brought forward many promising ingers, and produced, for the first time in Australia, Mendelssohn's Psahm 42; Spohr's "God, Thou art ('reat" ; Lestie's. Jullith," and other works. As organist of St. Peter's, Melbourne, Pringle, in isfis, traned and introduced the first smpliced choir in the colonies. He died, Jannary, 1873, when on a visit to Leipzig.

Pringle, Godfrey, compuser, of Scoteh descent on his father's side, his mother being Hungarian, was born November 30, 1867, while his parents were travelling on the Continent. Much of lis early life was passed in Italy, and in 1ine he was at Bayreuth when "l'arsifal" was protuced, and had the happiness of personal acpmaintance with Wagner. The influence of thit time derided him to make musie his prof ssion, and he studied at the R.C.M. under Villiers Stanford, produeing part of an Italian opera, " Messalina," in 18\%0, which he finished after leaving the Colege in 1sy1. His orchestral loallad, "Lurand" (based on Lhland), was produced at the Crystal Palace, Uctober 14, 1493; and a rhapsody, "Lo Zingaro," fur baritone solo and orchestra, Norember 10, 1894. He has also written an orchestral suite, "Bella Milano," and is engaged on an English opera. llis other works include a Romance, for violin and orchestra; Fantasia, cello and pf. ; pieces for pf., songs, ete.

Pringle, John, musician, resided in Edinburgh at the end of last and begimning of present century. I'ublished " A Collection of lieels, Strathspeys, and Jigs, with a Bass for the Violoncello or Pianoforte," Edinburgh, n.d.

Pringle, Lempriere, bass voealist, born at Hobart, Tasmania, 1869. At the age of is lie came to England, and was admitted a student at the R.C.MI. He sang in the operatic performance given in July, $\mathbf{1 8 8 9}$, and later in that year went to Frankfort and stndied singing under Stockhansen, and harmony and counterpoint under Humperdinek. Returning to Fingland in 1891, he was engaged by the directors of the Carl Rosa Company, and made his first appearance in the following autumn tour. His success was 
PRINGUER.

such that on the death of Arnsley Cook, in February, 1894, he was called upon to under. take the most important parts filled by that artist. His repertory is large, and embraces such widely different assumptions as that of Caspur in "Der Frieschutz" and the Lrondgrace in "Tambüuser." Mr. Pringle is understood to be a clever composer, but he has not yet published any thing.

Pringuer, Henry Thomas, composer and condnetor, of present time. Privately educated in music. F.R.C.O., 1876; Mus. Bac., 1877; Mus. Doc., 1885, Oxford. Organist of St. Matthew's, Redhill, 1870; St. Mary's, Stoke Newington, 1881. Conductor of Insurance Musical Society ; and of Trinity College Choir, London. Has given organ recitals at the Bow and Bromley Institute, 1884 , ete. Composer of I'salm 107 and P'salm 48, for soli, cliorus, and orehestra; a comedy opera, "Guinevere," 1890; pf, pieces, songs, ete.

Pritchard, Rev. Rowland Hugh, musician and minister, was born at Bala, about 1813. He was a minister, and acted as precentor at the annual riasiwns y Bala Died at Hulywell, Jannary 25, 3887 , aged 74 . Composer of Welsh hymn tumes, "Hyfryctol," "Elizabetl,," "Hiraeth y Cristion," ete.

Pritchard, Thomas, sumamed TwsBacH, celebrated Welsh lasper of the time of Qneen Elizabeth. He died at London in 1597 , and is buried in St. Sepulchre's Chureh.

Probin. The name of a notable liminingham family of hom players. Moses Probin, born about 1782 , was the first to acquile a reputation, though his father was a hom player before him. He took part in all the principal concerts in the Midlands, from Shrewsbury to Cheltenham, and was a virtuoso on the hand horn. With two of his sons he would, commencing at five in the morning, diligently practice trios for horns. He was a man of devout mind, and regular in attendance at ehurch. On one occasion his rector, with whom he was very intimate, expressed a wish that he would give up horn-playing and earn an honest living. He died August 8, 1857, in his 75 th year. His son, Henry Probin, was born June 10, 1812. He became famous as a hor'n player, and to the last used the old hand hom, as he could never reconcile himself to the valve horn. He played in the Birmingham festival orchestra for a long time, including the "Elijah" year, 1846. He was the intimate friend and companion of Alfred Nellon, and during lis conductorship played in the Theatre Royal band. He retired from the profession in 1879, and died June 30, 1885. His brother SAMUEL was also a horn player, but in no way remarkable. Alfred Probis, son of Henry, was born April 29, 1852, and at the age of eight began his study of the instru-

\section{PROUT.}

ment. Mr. Stockley gave him his first opportunity, and when sixteen he was first lorn in an opera company. His first festival engagement was at Nottingham in 1873, under Costa. He was first horn at the revived Chester Festival, 185\%, and since then has been in the orchestras of the Three Choirs, and Birmingham Festivals, and the principal coucerts in the country, As a solo player he has been heard in chamber concerts in Birmingham, and he played Mozart's Third Concerto for hor'n at Leicester, February, 1887. A young son is preparing to continue the artistic career of the family.

Proudman, Joseph, conductor and teaclier of singing, born in London, November 10,1833 . He sang in choirs as a boy; was a nember of the Sacred Harmonic Society in 1457 ; Conductor of the City Choral Union, $1,6,2$, and a year later applied himself to the Tonie Sol-fa method. He conducted concerts at the Crystal Palace from 1864, and won a prize at Paris in 1867. Some thousands of singers passed mider lis hands. For years lie had acted as precentor at several ehurches, and he was teaclier of singing to the children in Inr. Parnardo's Homes for more than twenty years, and was an indefatigable worker in the cause of popular music. He published Musical Lectures and Shetches, 1s69: and Musical Jottings, 1872; and was a specialist on the staff of the Musical Heruld. He died in Isondon, April 21, 1891. J.Frani Prouduan, his son, conductor, and sometime organist of St. Michael's, Stoke Newington, took up the work of his father in 1891, and made a reputation as a conductor and teacher. Delicate health decided him to leave Fugland for South Africa, and in February, 1897, he sailed for the Cape, having obtained an appointment at Maritzburg.

Prout, Ebenezer, composer and didactic writer, born at Oundle, Northamptonshire, March 1, 1835. The son of a Congregational Minister, he was intencied for another profession than music; and after learing Denmark Hill Grammar School he was engaged as a teacher in private schools in London, and Leatherhead, and when nineteen graduated B.A., London University. Musical from childhood, he had a few pianoforte lessons when a boy, and afterwards a course from Charles Salaman; for the rest he is self-educated. It was in 1859 that he gave himself up entirely to music, and his first pupil was Joln Locke Gray (q.e.). After acting as organist at St. Thomas's Square Chapel, Hackney, and other places, he accepted the appointment at Union Chapel, Islington, which he held for 12 years, 1861-73. During the Royal Wedding Musical Fetes at the Crystal Palace, March, 1863, he on one occasion gave an organ performance in lieu of 


\section{PROUT}

James Coward. In 1861 he was appointed a professor of the pf. at the Crystal Palace School of Art, resigning iu 1885; professor of hamony and composition at the National Training School for Music from its opening in 1876; succeeded to Sir Arthur Sullivan's class at R.A.M., 1879; and in 1884 professor of pf. at Guildhall School of Music. Conductor of Hackuey Choral Astociation, 1876-90, during which time a high reputation was gained by the Society, and many important works produced, some for the first time in Fngland. As a composer he was brought into notice by gaining the first prize of the Society of British Musicians in 1862, and again in 1865 ; and the performance of his first Organ Concerto by (Sir) Joln Stainer at the Crystal Palace, 1872, increased his reputation. His literary career has been equally striking. He was editor of the Monthly M/usical Recomd, 1871-4; musical critic of the Academy, 1874-9; and of the Atheneum, 1879-89. On retiring from the last, he devoted himself to writing those educational works which will rank among the most masterly and comprehensive examples Euglish musical literature cau boast of. He has lectured in London and the provinces; contributed valuable papers to the Musical Association, the Confercnces of the Incorporated Society of Musicians, Grove's Dictionary of Music, Monthly Musical Recont, etc.; and has conducted performances of his works at the Crysta] Palace, Bimingham and Bristol Festivals, and elsewhere. In 1894 he was elected Professor of Music in Dublin University, the degree of MIns. Doc., honoris causi, being conferred upon him at the beginning of 1895 , and later in the same year he was honoured by being the first to receive the degree of Mus. Doc. from the University of Edinburgh.

Wonks. Choral: Magnificat in C, op. 7 , for soli, chorus, and orchestra, composed 1573, produced, Crystal Palace, January 15, 1876 ; Chorus, Hail to the Chief, op. 10, composed for re-opening of Alexandra l'alace, $187 \%$; Cantata, llereward, op. 12, Hackney Choral Association, 1878; Cantata, Alfred, op. 16, the same, May 1, 1882 ; Ode, Freedom, of3. 20, the same, April 20, 1885; Psalm 100, op. 23, for soprano solo, chorus, and orchestra, 1886 ; Red Cross Knight, Cantata, op. 24, composed for the Jubilee of the Huddersfield Cloral Society, produced October 7, 1887; Hamon and Phintias (male voices), op. 25, (1xford, May 31, 1889; Queen Aimée (female voices), op. 21, 1885; Psaln 126, for soli, chorus, and orchestra, St. Paul's Cathedral, May 28. 1891; Church services and anthems, We give: Thee thanks (8 voices), and others. Scrna, contralto voice and orchestra, Norwich, 1887. Orchestral: Symphony No. 1, in C, Crystal Palace, Felmuary 28, 1874; No. 2, in Grinor,

\section{PURCELL.}

the same, December, 1877; No. 3, in F, op. 23, Bimningham Festival, 1885; No. 4, in D, Oxford, June, 1886; Minuet and Trio, St. James's Hall, March 5, 1878. Overtures: Twelfth Niglit, Bristol, February 14, 1881 ; Rokeby, Crystal Palace, March 23, 1889; Suite de Ballet, op. 28, 1891. Organ Coucerto in E minor, Crystal Palace (Stainer), October 19, 1872; in E flat, Bristol (Riseley), April 6, 1885. Quartets: Op. 1, strings (prize), 1862 ; Op. 3, pf. and strings (prize), 1865; Op. 15, in $\mathrm{B}$ flat, strings; Op. 18, in F, pf. and strings. $Q$ intet, $\mathrm{Op}_{\mathrm{p}}$. 3, pf. and strings. Sonata in D, op. 26, pf. and clarinet; Sonata, op. 4, organ; Duo Concertante, op. 6, pf. and harmonium. Organ arrangements, 44 Nos. Pf. pieces. Editor, with J. Curwen, of the Harmonium and Organ Book. Author of a primer on Instrumentation, Novello, 1876; Harmony, its Theory and Practice (with key, additional exercises and key) nine editions to 1896; Counterpoint, Strict and Free (with additional exercises), 5 editions; I louble Comterpoint and Canon, 2 editions; Fugue, 3 editions; Fugal Analysis, 2 editions; Iusical Form, 2 editions; and Applied Forms, 2 editions, all published by Augener. It is understood that Professor Prout lias two comic operas in MS. His sun, Lous BEEThover Proct, born in London, September 14,1864 , is a pianist and teacher. In 1888 he was appointed professor of harmony at the Crystal Palace School. He has set Psalm 93 for voices and organ, and is author of a work on Harmonic Analysis, London, Angener, and a pamphlet, Time, Rhythm, and Expression, London, Cocks.

Prys, Edmund, clergyman and musician, who was born in 1541 . He was educated at Cambridge and became rector of Festiniog in 1572 , and canon of St. Asapl's in 1602. He died in 1624. Editor of "Llyfr y Psalman w. di eu cyfiethu, ai cyfansodi ar fesur cerdd yu gymraeg," 161 , a collection of psalms in Welsh.

Pullen, H. W., author of "Our Choral Services," ILondon, 1865; and "The real work of a Cathedral," London, 1869.

Purcell, Daniel, organist and composer, born in London, 1660. Younger son of Henry Pureell, the elder. He was the organist of Magdalen College, Oxford, 1689-95. Settled in London, 1695. Composer for various theatres. Organist of St. Andrew's Church, Holborn, 1713-17. He died at London, December 12, 178.

Woris.-Wusic to Dramas: Love's Last Shift (Cibber), 1696; Indian (jueen, 1696; Biutus of Alba, or Augusta's Triumph, 1697 ; Cynthia and Endymion (D'L 'rey), 1697; Pliaeton, or, the Fatal Divorce, 1698; The Island Princess (Notteaux), with Clark and Leveridge, 1699; The Grove, or Love's 


\section{PURCELL.}

Paradise, 1700; The Unhappy Penitent, 1701 ; The Incoustant (Farquhar), 1702 ; The Judgement of Paris, a Pastoral (Congreve). [This masque gained the third prize in competition with Weldon, Eccles, etc.], 1700. Odes, numerous; iucluding several for "St. Cecilia's Day," by Addison and others; Songs in contemporary collections; the Psalms, set full for the organ or harpsichord, as they are plaid in churches and chappels in the maver given out; as also with their interludes in great variety, London, n.d.; Instrumental music, church music, etc.

Purcell, Edward, organist, youngest son of Henry Purcell, the younger, was born at London, in 1689. Organist of St. Clement, Eastcheap, London; and of St. Margaret's, Westminster, 1726 . He died at London, in 1740.

Purcell, Henry, the eller, musician, father of the celehrated Henry Purcell of musical history, was born in the first half of the 17 th century. He was a Geatleman of the Chapel Royal, in 1660, and Naster of the Choristers in Westminster Abbey. Mem. ber of Royal Band of Music, 1663. He died at London, August 11, 1664. Composed a three-part song in Playford's Musical Comparion, 1667 , etc.

Purcell, Henry, organist and composer, was born in St. Anu's Lane, Old Pye Street, Westminster, London, in 1658. Second son of Henry Purcell, the elder. He studied as a chorister in the Chapel Royal, under Cooke and Humphrey, 1664, and under Blow. Copyist in Westminster Abbey, 1676-7R; Organist of Westminster Abbey, 1680 . Organist of Chapel Royal, 1642. Composer in Ordinary to the King, 1683. He died at Wesminster. London, November 21, 1695, and is buried in Westminster Abbey. In 1895 various com. memorative concerts, etc., were given in London on the centenary of his death.

Works.-Dramatic music: Epson Wells (Shadwell), 1676; Aurenge-Zebe (Dryden), 1676; The Libertine (Shadwell), 1676 ; Abdelazor (Behn), 1677; Timon of Athens (Shakspere), 1678; The virtuous wife (D'Urfey), 1680; Theodosius (Lee), 1680; Dido and Eneas (Tate), 1680 [published by the 2Iusical Antiquarian Society, 1840] ; Circe, 1685; Tyranmic love (Dryden), 1686; A fool's preferment (D'Urfey), 168s; The Tempest (Shakspere), 1690; Dioclesian, 1690; IIassacre of Paris (Lee), 1690; Anıphitryon, 1690; Di -tressed innocence (Settle), 1691; King Arthur (Dryden), 1691 [published by the Musical An. tiquarian Society, 1S437; The Gordian knot untyed, 1691; Sir Anthony Low (Southerne), 1691 ; The fairy queen (Shakspere's Midsummer Night's Dream), 1692; The wife's excuse (Southerne), 1692; The Indian queen (Dryden), 1692; The Indian Emperour (Dry-

\section{PURCELL.}

den), 1692; CEdipus, 1692 ; Cleomenes, 1692; The marriage-hater mateh'd (D'T'rfey), 1682; The old bachelor (Congreve), 1693; The kichmond heiress (D'Urfey), 1693; The maid's last prayer (Southerne), 1693; Henry the Second (Bancroft), 1693: I'on Quixote (D' ' $\mathrm{Cr}^{\mathrm{r}}$ fey), 1694-95; The married bean (Crowne), 1694; The Double dealer (Congreve), 1694; The fatal marriage (Sontherne), 1694; Love triumphant (Dryden), 1694; The Canterbury guests (Ravenseroft), 1695; The mock marriage (Scott), 1695; The rival sisters (Gould), 1695; Oroonolo (Southerne), 1695; The knight of Malta (Beaumont and Fletcher), 1695; Bonduca (Beaumont and Fletcher), 1695. Odes and lurge local Wrork's: Elegy ou death of Matthew Locke, 1677; A Welcome Song for His Royal Highness' return from Scotland, 1680 ; A song to welcome His Majesty home from Windsor, 1680; Swifter, Isis, swifter flow (de), 1681; Ode for the King on his return from Newmarket, 1682; Three odes.for St. Cecilia's Day, 1683; From Hardy climes and dangerous toils of War, ode on marriage of Prince George of Denmark with Princess Amne. 1683; Welcome to all the Pleasures, ode, published, 168t: Why are all the II uses mute? ode for James I.: Ye tumeful IIuses. ode, 1686; Sound the trumpet, beat the drum, oxle, 16s7; Celestial Itusic, 1689; The Yorkshire feast song, D'Urfery, 1689 |reprinted by the Purcell society, edited by W. H. Cummings, 1.97א; Arise, my Muse, ode for the (uneen's birthday, 1689; Sound the trumpet, ode, 1689: Welcome, glorious mom, Birthday ode, 1691; Love's Goddess sure was blind. ode, 1692; Hail! great Cecilia, ode 1692 ; Celebrate this festival, 1693; Come, come, ye sons of art, ode, 1694; Who can from joy refrain, ode, 1695. Church Music: Purcell's Sacred Music, edited by Vincent Novello, London, 6 vols. [1899-32], contains most of the master's church music, with portrait and biography, including the Te Deum and Jubilate in i) (1694). Other collections in which his chureh music will be found are Borce's; Tudway's : Smith's Harmonica Sacra: Page's Harmonia Sacra ; and in nearly every other important general selection. The names of the anthems in current use in our churches and cathedrals will be found in Novello's catalogue of sacred music. Instrumental music: Three sonatas, for two violins, violoncello, and basso-continuo, London, 4 vols., 1693. Lessons for the harpsichord or spinuet, London, 1696. Ten sonatas, in four parts, 1 st and 2 nd violins, bassus and organ, London, \& vols., 1697. Collection of Ayres compos'd for the Theatre, and on other occasions, London, 1697. Orpheus Britannicus : a collection of the choicest songs, for 1, 2, and 3 roices, with such Symphonies for violins or flutes as were by 


\section{I'U'RCLLL.}

him designed for any of them, and a thoronghbass to each song figured for the organ, harpsichord, or theorbo-lute. book I., London, 1698, with portrait engraved by White. Book II., 17( :2; second edition (enlarged), '2 vols., 1706-1711, thind elition, 1721. The Gateh Club, or Merry Companion. By Purcell, Blow, etc., 2 books, n.d. "The art of Deseant," contributed to the loth edition of I'layford's "Introduction to the skill of Musick," 1683. Sulections from Purcell'sworks: The beanties of l'ureell: a selection of the favourite songs, duets, trios and choruses from his different works, arranged with pf. accompaniments by Ir. John Clarke, 2 vols., n.d. Beanties of Purcell...edited by Joseph Corfe, n.d. The words of Henry Purcell's Vocal Music, n.d. (privately printed). A selection of his Harpsichord pieces has been edited by Herr Emst Paner (Augener, London).

Purcell, Thomas, composer, uncle of meceding, was born in the first half of the 17th century. He was a gentleman of the Chapel Roral in 1660 , and Lay-vicar and copyist, liestminster Abuer, 16ti1. Composer in ordinary to the King, with Humplurey, in $166^{\circ}$; and master of the royal band of music (also with 11 mmllrey), 1672. He died at Lon. don, July 31, 162. He composed some chants, some of which are now in common nse.

Purcluas, Arthur (iuyon, musician and eomposer, author of "First Lessons for Singing Ulasses," London, 1rit!. Compiler of "The New Zealand Hymnal . . . with tunes," I undon, 1nT1.

Purday, Charles Henry, composer and writer, born at Folkestone, January 11, 1799. He was a publisher of musie in London, and lecturer on musical topics in Lundon and the English povinces, and at one time a vocalist of some repute. Chiefly celelrated as a reformer of the laws relating to musical eopyright. He acted for some years as conductor of Psalmody to the Scotch Church, in Crown Conit, Covent Garden, London. He died at London, April 28, 1885.

Works.-The Sacred Musical Offering, London, 18:33. Copyright, a sketch of its rise and progress. . . 1. 1.nd 11, 1875; Crown Court Psalnody, one hundred Psalm tumes and chants..., 1h5t: ('hureh and Home Tune liook. . . Lomdon 1857]. Songs of Peace and Joy, 1879 (F. R. Havergal). Writer and composer of a considerable number of songsDown among the barley, Home of my fathers, Maid of Llanwellyn, old Yew tree, Real ould Irish Gintleman, etc. Joint editor with John Thomas of a large volume of Welsh airs. Trios for female voices: two volumes of children's songs, etc. He composed "Sandon," "Notting Ilill," and other well-known hymns; Elementary exercises in the art of Singing, Joudon 1851].

\section{PYNE.}

Purdie, Robert, Sicots musieian, who flourished in Edinburgh as a music-seller early in the present eentury. He issued "A Complete Repository of Strathspeys, reels, jius, fuvourite airs and waltzes for the flute or violin," Edinburgh, n.d. The firm existed in Edninuglı till about 1887.

Purkis, John, organist and composer, boru, London, 1781; died there in 1849 . When twelve months old he became blind. IIe was a performer on the apollonicon and an organist. He composed some organ music. Fantasias for pf. on popular airs, marehes, etc. Songs: Magpie and the maid, Pale the moonlseam shone, 'The Reprieve, Song for' British Volunteers [1805].

Pye, Kellow John, pianist and composer, born at Fxeter, February 9, 1812. Entered R.A.M. 1823, receving from Cipriani Potter the first pianoforte lesson given there. Studied composition under Dr. Crotch. Won the Gresham Prize, 1832, with his anthem for five voiees, "Turn Thee again, O Lord." Graduated IIus. Bac., Oxford, 1842; elected F.R.A.M. Resided in Exeter after leaving the R.A.M. in 1839; but later entered into business in London, where he also conneeted himself with the management of the R.A.M., and other institutions. He is now living in retirement at Exmouth. His eompositions include a five-part authem (l)egree Exereise), O Lord, Thon art my (rod: Three Short Full Anthems; Children of Fancy, and other glees, songs, and pf. pieces. His latest publications were a Mclody and Farewell, for elarinet and pf., 1889.

Pyne, James Kendrick, organist and eomposer, born in London, August 21, 1810. His father, JAMEs KENIRICK PYNe-born, 1785 ; died, 1857 - was a noted tenor singer in his day. Jyne was one of the early pupils of the Royal Acadeny of Music, studying under Ir. Crotch. In 1 hus he was appointed organist of St. Mark's, Clerkenwell; and in 1839 was chosen organist of Bath thbey, an office he held for half-n-century. He was awarded the Gresham Prize in 1840, and his compositions included Church Serviees, anthems, part-songs, etc. In Felmuary, 1890, he was publicly presented with testimonials from his professional friends, and from the Abhey eongregation and eitizens of Bath, in eommemoration of his Jubilee as organist. He died while on a visit to his son, J. K. Pyne (notice below), Mareh 2. 1893. His sister, Louisa Aublrt Prne (Mrs. Willmore), was organist at St John's District Church, in the parish of St. Pancras, circa 1857. She eomposed songs and pf. pieees.

Pyne, James Kendrick, organist and composer, son of the preceding, born at Bath, Ferbuary 5, 182 . Studied under his father and Dr. S. S. Wesley. Was organist of All 


\section{PINE.}

Saints', Bath, when eleven; and assistant to Dr. Wesley at Winchester and Gloncester Cathedrals. After holding appointments at Cheltenham and other places, he was made organist of Chichester Cathedral, in 1sit; and in 1875 , he went to America, where he remained about a year. He was then appointed to Manchester Carhedral, and later, organist of the Town Hall. Professor of Manchester Royal College of Music, 1893. F.R.A M. He has given recitals in all parts of the Kingdom, and is one of the most brilliant organ players of the day. His lectures on music, and on antique musical instruments, of which he has a fine collection, have been of educational value. He has also contributed occasional articles to the musical press. He is the composer of a Festival Communion Service, with orchestra; Morning and Evening Services; songs; pf. pieces; etc. Minton Prne, his brother, was sometime assistaut-organist at Manchester Cathedral, and, in 18s1, appointed to St. Mark's, Philadelphia, U.S.A. He also was a pupil of Dr. S.S. Wesley. His recitals in America gained him a high reputation. In 1858, he was in England, and gave a recital at Bath Abley Church. Miss ZoE PYNr, a sister, is a volinist, and studied at R.C.M. She has given successful concerts at Bath (1984), and London, etc.

Pyne, Louisa Fanny, or Bovda, soprano vocalist, was born on August 27, 1832, daughter of Georue Pyne (1790-187T), an alto singer. Studied under Sir George Smart. First appeared in public, with her sinter (Mrs. F. H. Standing), 1842. Sang in Paris, 1847. Appeared at Boulogne iu "La Somambula," 1849. Debut on Lindon stage as Zerlina in "Don Juan," October, 1849 Sang afterwards at the principal theatres and concerts in London. Appeared in America, with her sister and $\mathrm{W}$. Harris ${ }^{2}$, 1854-56. Established, with Wm. Harrison, the "Harrison-Pyne" English opera company, which performed with much success in Britain, and produced a number of famous English operas, 1856-62. Married Frank Bodda, a baritcue vocalist, 1868 , and retired from the stage. Teacher of singing in London. Her voice was a clear soprano of great compass, and possessed of much expressive power. She excelled in such works as Wallace's "Maritana" and "Lurline"; Balfe's "Bohemian Girl" and "Rose of Castile" ; and it is due to her no less than to Harrison, that the English opera flourished so successfully under their management. In 1896 , she received an allowance from the Civil List. Her husband, Frank Bodda, born about 1823, was a pupil of the R.A.M. Sang in opera in London and Boulogne, 1848-9; and was also heard in the concert-room. He died Narch 14, 1892, aged 69 .

\section{RADIGEIR.}

Quarles, Charles, organist and composer of the early part of the 1,ith century. He was organist of Trinity College, Cambridge, and in 1698 he graduated Mus. Bac., Cambridge. In 1722 he was made organist of Fork Minster. He died at York, in 1727. He composed lessons for the harpsichord, ete.

Quatremayne, Frank, or simles, bass vocalist, hom at levonport, November 19, 18t4. Studied pianoforte and theory under Charles Noble; and singing, first with the late H. C. Deacon, then with Campana and Caravoglia. After singing in public for about three years, from 1880, he went to Milan, aud studied under Antonio Sangiovanui. since then he has sung at the principal concerts in luondon and the morinces, devoting hinself, the last few years, chiefly to teaching, and numbers among his pupils several successful singers of the day. He is the author of a treatise, "Correct voice production" (Weekes), etc. His father is William similes, C.B.. and he is nephew of samuel smiles, LL.I ., author of "Self-1[elp," etc.

Quin, Francis Stainstreet, organist of Monkstown Church, Dublin. Was a prominent Freemason, having risen to the 32nd degree. He died, June 14, 18s:-, aged 54.

Quinton, Mrs. H. A., see Rosse, J kasie.

Radcliff, John, flutist, horn in Liverpool. Studied under S. Percival, Liverpool, and at R.A.M., of which institution he is a Fellow. Became principal flutist in the orchestra of the Royal Italian Opera, after the death of Pratten; also in the orchest as of the Three Choirs Festivals; Leeds Festivals, 1874, 1880, and 1883; Handel Festivals, 1868 , etc Lectured on the Flute, Ancient and Modern, at the London Institution, 1882. Toured in Australia, 1883-4, and was presented by the Melbourne Liedertafel with their frolden Lyre, only conferred on artists of the highest distinction. Re-appeared at the Promenade Concerts, Lundon, in 1886; and began a concert-lecture entertainment, entitled “ From Pan to Pinafore," in 1888. In 1896-7 he was on tour in South Africa with Madame Famny Moody's party. His wife is the esteemed rocalist known as Madame PA Line Rita, who has appeared at the London and Provincial concerts.

Radiger, Anton, composer and organist, born at Chatham in 1749, of German parents. He died in 1817. Composer of a number of psalm tunes, such as "Praise," "Compassion," "Denton's Green," etc. "Four setts of new Psalm and Hymn Tunes in 3 and 4 parts," London, n.d. Four new Hymn Tunes, London [1810]. Three duetts for 2 violins, op. $4[1796]$. Two favourite sonatas for $\mathrm{pf}$. or harpsichord, op. 5. Miscellaneous music for pf., songs, etc. 


\section{RADNOR.}

Radnor, Countess of, formerly Viscountess Folkestone, amateur musician. Assisted the establishment of the R.C.M., by organizing concerts with an orchestra of ladies. One, given at Stafford House, under her conductorship, Jume 29, 1882, realizing more than £850 towards the funds of the College. She has conducted concerts in the country, at St. James' Hall, etc., from that time onwards; also appeared as vocalist at the People's Entertainment Sociely's Concerts, etc. Some songs of hers have been published, and she is the musical editor of "An Order of Service for Children," Novello.

Rafftor, Catherine, see Clive, Catherine.

Rainforth, Elizabeth, soprano vocalist, born November 23, 1814 . She studied under T. Cooke, and George Perry. Appeared in Arne's "Artaxerxes," at St. James's Theatre, 1836. Afterwards she studied under Crivelli, and sang at the Phitharmonic Concerts, Concert of Ancient Music, provincial concerts, etc. She was the original Arline in Balfe's "Bohemian Girl," 1843 , and sang in drama tic pieces in Dublin, etc. She resided in Edinburgh, 1852-56. Retired, and lived as a teacher at Old Windsor, from about 1858. After 1871, resided at Bristol. She died at Redland, Bristol, September 22, 1877.

Ralph, Francis, violinist, was born in 1847. He studied at the R.A.M., and was a professor of the violin there. He gave many good and interesting chamber concerts, in which, latterly, he was assisted by his wife, Kate Roberts, a pianist. He died at London, September 8,1887 . His wife, daughter of Ellis Roberts $(q \cdot v)$, was born in London, and studied at the London Academy of Music, where she was presented with a Scholarship by Madame Schumann. Played at a National Eisteddfod when sixteen, and received the bardic name of Morfida. Appeared with suecess at the New Phithanmonic, Crystal Palace, and other concerts, and has continned to give chamber concerts at the Queen's Hall, ete. Her compositions are numerous, but only a few pieces for violin and pf. have been published.

Ramage, Adam, music teacher and compiler, was born at Edinburgh, October 10. 1788. He was precentor of St. Andrew's Parish Chureh, Edinburgh, from 1838, and in 1846 he became singing-master at Heriot's Hospital Schools. He died in Edinburgh, April 5, 1863. He edited "The Sacred Harmony of St. Andrew's Clusreh, Edinburgh, in four vocal parts, with accompaniment for the organ or pianoforte," Edinburgh, 1843.

Ramsay, Dugald Carmichael, musician who was born at Rothesay in 1818, and died at Glasgow, August 12, 1891. He was author of "Four Diagrams illustrative of
RANSFORD.

intervals, scales, and chords." Glasgow, 1860.

Ramsay, Edward Bannerman Bur= nett, Scottish Episcopal elergyman and writer, born at Aberdeen, January 31, 1793. Dean of Diocese of Edinburgh, 1846. He died at Edinburgh, December 27, 1872. Author of "Two Lectures on the Genius of IIandel, and the distinctive character of his sacred compositions," Edinburgh, 1862; "Proposals for providing a peal of bells for Edinburgh," 186:3; "The Use of Organs in Christian Worship," Edinburgh, 1865, etc. Ramsay is best known by his "Reminiscences of Scottish lif and character," an interesting and valuable collection of anecdotes.

Ramsay, James, musician, born at Kilwimning, in 1812, died September 10, 1888. He composed tunes in the "Universal Tune Book," songs, ete.

Ramsey, Robert, organist and composer, of latter part of the 16th and begiming of 17th centuries. He graduated Mus. Bac., Cambridge, in 1616, aul was organist of Trinity College. He composed a Service in $F$, and various anthems.

Randall, John, organist and composer, was born in 1715 . Chorister in Chapel Royal under B. Grates. Mus. Bac., Cantab., 1744. Organist of Trinity College, St. John's College, King's College, 1775, and Pembroke Hall, Cambridge. Professor of Music Cambridge University, in succession to M. Greene, 1755. Mus. Doc., Cantab., 1756. He died at Cambridge, March 18, 1799, aged 83. Composer of odes, anthems, psalms, and chants, and a "Collection of Psalm and Hymn Tunes, some of which are new, others by permission of the authors." Cambridge, 1794. Songs : Happy Swain, Hopeless Love, Shepherd's Wedding.

Randall, Richard, tenor vocalist, was born on September 1, 1736. He studied under $B$. Gates, and s.ung principally in the works of Handel. He died on April 15, 1828.

Randles, Elizabeth, pianist, born at Wrexham, August 1, 1800. Known as the "little Cambrian prodigy." Gave very early indications of a talent for music, which was encouraged by her father [1760-1823], a blind harper and organist in Wrexham. She studied under Joln Parry, and appeared in London and the English provinces. She was a teacher for a time in Liverpool, and died in 1829.

Ransford, Edwin, baritone vocalist and composer, bom at Bourton-on-the-Water, (iloucester, March 13, 1805. He sang in London theatres in opera, and also as a concert vocalist. Latterly he engaged in music publishing. He died at London, July 11, 1876. Composer of a number of ballads, many of which were issued under the 


\section{RATCLIFEE.}

pseudonym of "Aquila." Among them may be named-1 eantiful Sea, Friar Tuck's channt, Harvest Home, Oak and the Iry, Winter Night, etc.; Gipsy life and character [1845], a collection of songs written in conjunction with Glover. His son, WILLIAM EDwin, was also a publisher, pianist, and tenor singer, who composed some vocal music. He died at London, September 21, 1890, aged 64 .

Ratcliffe, James, composer, born in 1751. He was a lay-ricar in Durham Cathedral, and died in 1818. Composer of church music, including anthems, psalms, and chants.

Ravenscroft, John, violinist and composer, was one of the Waits of the Tower Hamlets, and a violinist in Goodman's Fields Theatre. He died in 1745 . Ile published a collection of horupipes, also sonatas for stringed instruments; also songs, such as Foolish woman, fly men's charms [1740], etc.

Ravenscroft, Thomas, composer and editor, was born in 1592 15827. He became a chorister in St. Paul's Cathedral, London, under Edward Pearce. Mus. Bac., Cantab., 1607 He died at London in 1635.

Works.-Pammelia, Mnsicke's Miscellanie, or Mixed varietie of pleasant Roudelayes and delightful Catches of $3,4,5,6,7,8,9,10$ parts in one. London, 1609. 2nd edition, 1618. Deuteromelia: or the Second part of Musicks Melodie, or melodions Musicke of pleasant Roundelais, K. H. mirth, or Freemen's Songs, and such delightful Catches. London, 1609. Melismata; mmsical Plıansies, fitting the Court, Citie, and Country lumours, to three, four, and five vorces. London, 1611. The Whole Booke of the Psalmes, with Hymmes Evangelicall and Songs Spiritual, composed into 4 parts by sundry authors, to such severall tunes as have been and are usually sung in England, Scotland, Wales, Germany, Italy, France, and the Netherlands. London, 1621. 2nd edition, 1633. Selections from the works of Thomas Ravenscroft, a musical composer in the time of King James 1. (Roxburghe Club). London, n.d. A briefe Discourse of the True but neglected use of Charact'ring the Degrees by their Perfection, Imperfection, and Diminution in Mensurable Musicke, against the common practise and custome of these times. London, 1614.

Ravenseroft is best known by his "Booke of Psalmes," a work of much importance, containing contributions by Tallis, Dowland, Morley, Farnaby, Tomkins, Pearson, Parsons, Hooper, Kirbye, Allison, Farmer, Bemet, Milton, Cranford, Harrison, and the editor. It has been drawn upon by nearly every succeeding compiler of psalmody, and is now a somewhat rare work. It is worthy of notice that his "Pammelia" is the earliest collection of rounds and canons published in Britain.

Rawlings, Thomas, violinist, horn about

\section{RAIMIOND.}

1703. He studied under Pepusch, and performed at Handel's oratorios when they were originally produced. Organist of Chelsea Hompital, 1753. He died in 1767.

Rawlings, Robert, violinist, son of above, was born in London, in 1742. He studied under his father and Barsanti. Organist of Chelsea College, 1759. Mrnsical page to the Duke of York, till 1767. Member of private band of George III. He died in 1814.

Rawlings, Thomas A., composer and violinist, son of Robert, above-noted, was born at Lundon, in 1775. He studied minder R. Rawlings and Dittenhofer, and became a violinist at the Opera, the Ancient, Yocal, and Professional Concerts, etc. Teacher in London. He died about middle of present century.

Works.-Concerti di Camera, for pf., flute, violins, viola, and 'cello. Instrumental: Three somatas for happichord and riolin, op. 1 [1793]; Six new waltzes for pf., op. 2 [1794]; Inet for harp and pf.; and a large number of divertimentos, marches, arlangements, ete. Songs: Bee's wing; Evergrem leat; Hither, love, hithel: I Iome of routh; Lila's a lady; O 'twas wid; Oh come to me; Oh what a pity ; Sabbath betls; Strike the gnitar ; Weep not, thou lovely one; When spring time was gay. Also in collected form, "Selection of Foreigu Melodies" [1825], and "songs to Rosa" [1826], with endless contributions to the musical amnals. Rawlings is nsually identified with the well-known song, " Isle of Beauty, "which, however, was only arranged, not composed, by him, but it Major C. S. Whitmore (q.l.) 1830$]$.

Rawlins, Rev. John, clergyman, was rector of Leigh. Author of "The Power of Musick, and the particular influence of Church Musick: a sermon preached in the Cathedral Chmrch of Worcester . ," 1773.

Rayleigh, Lord, John William Strutt, D.C.L., LL.D., F.R.S., Third Baron, born November 12,1842 , and succeeded to the title on the death of his father in 1873. Educated at Trinity College, Cambridge. Senior Wrangler, 1865 . Author of a work on "The Theory of Sound," 2 vols. Second edition, 1896. Papers read before the Musical Association, etc.

Raymond, Fanny, Mrs. RAYIOND-RITTER, English poetess and musician, who married Frederick Louis Ritter (born 1834; died 1891). French-American author and musician. She has written "Woman as a musician, an art historical study," London, 1877; "Some Famous Songs, an art historical sketch," London, 1878; "Songs and Ballads," New York, 1888, etc. Translator of Ehlert's Letters on MInsic to a Lady, 1877, and Schumamn's Music and Musicians, 1877-80, 2 vols. According to a statement on page 49 of her "Songs and Ballads," she is a native of 
REA.

England, having been born "By Avon water and Arden woud."

Rea, William, organist, conductor, and composer, born in London, March 25, 1827. Articled pupil of Josiah Pittmian, and later studied pf. under Stermale Bennett, and in 1849 for a short time was at Leipzig and Prague, studying under Mloscheles, Richter, and Dreyschock. Deputised as organist for Pittman; was appointed to Christ Church, Watling Street, 1843 ; st. Andrew's Undershaft to 1858 , when he went to St. Michael's, Stockwell. Played at concerts of the Society of British NI usiclans; gave chamber concerts; acted as accompanist for the Harmonic Union; established and conducted the Polhymnia ('hoir of Men's Voices, 1856, and was brought into contact with Mlendelssohn and other eminent composers. In 1860 he was appointed organist to the Corporation of Vewcastle-on-Tyne. His church appointments were at St. Thomas's, St. Andrew's, St. Mary's, North Shiel 1s, 1864-7s; and St. Hilda's, South Shelas, to present time. He has been a hard worker for musical culture in the North; besides giving his recitals, he formed several societies, giving many important concerts, and introducing great works to the locality. His orchestral concerts, started in 1867, were carried on for nine years. He still conducts the Newcastle Amateur Vocal Society. His Corporation appointment he resigned in 1888 . He was elected an Hon. Fellow of the College of Organists, and in 1886 the honorary degree of Mns. Doc. was conferred upon him by the University of Durham. His compositions include "Sing, O daughter of Zion," "O, give thanks," and other anthems; a Jubilee Ode, composed for the Newcastle Exhibition, 1887 ; various songs, and pieces for organ and pf. EMma MARY Rea, his wife, was a daughter of W. S. B. Woolhouse $(q \cdot x \cdot)$, and an accomplished pianist, L.R.A.MI. and A.R.C.M. She was closely identified with the musical life of Newcastle for over thirty years. She died suddenty, of apoplexy, May 6, 1893.

Read, Charles John, organist and composer. Compiled "I'arochial Psalmist: a manual of psatm and hymm tunes for congregational singing, for four voices," Salisbury, 1854; "The Te Deum, the Jubilate, etc., of the Catholic Church, performed at Stratford and at Hanover Chapel, Regent Street . . ." London, 185.5; songs, pf. music, etc.

Read, Frederick John, organist ani composer, born at Faversham, Kent. Studied under Drs. Sloman, C. W. Corfe, and J. F. Bridge. Appointed organist of Christ Church, Reading, 1876, where he remained ten years, during which time he founded the Reading Orpheus Society (1882), and gave concerts.
READ.

Graduated Mus. Bac., 1876; Mus. Doc., 1891, Oxford. In 1887 he took up his dnties as organist of Chichester Cathedral, where he is still in office. Conductor of Chichester Musical Society.

Works.-C'untatas: Sigurd, men's voices, produced Oxford, 1892; The Song of Flannah, produced Cardifi, 1895. Scena, The Eve of the Battle, baritone solo and men's chorus, Reading, 1889. Meadowcroft prize anthem, "Let my complaint," 1879 ; anthems, services, etc. Madrigals: Love wakes and weeps (six voices); My dearest love (seven voices); Daffodils (eight voices); part songs, etc.; organ pieces.

Read, John Francis Holcombe, musical amateur and composer, born at Port Royal, Kingston, Jamaica, October 29, 1821. Sent to his grandparents at Woolwich when four months old. Began to learn the violin when about twelve from a nember of the Royal Artillery Band, sulsequently studying composition with (r. A. Macfarren. Was appointed to the War Office, afterwards entering the Stock Exchange. Resided at IValthamstow for nearly forty years; now resident in London. Was County Magistrate for Essex, and for some years a Vice-President, and member of the Committee of Management of R.A.M. In 1867 the Walthamstew Musical Society was formed, and Mr. Read was elected President and Conductor. For twenty-five years he gave his time to it, and wrote for it many of his choral works, besides. producing the standard compositions of all masters. He raised Valthamstow to an important musical centre, and to him the town is indebted for the Victoria Hall, and the Festival which inaugurated it in 1887. Mr. Real was also Presilent of the Stock Exchange Orchestral Society for some years from its foundation in 1885.

Works.-Cantatas, etc.: Homeward Bound, produced, Walthamstow, 1868; Consecration of the Banner; I'syche, 1873; Carastacus, 1882; Bartimeus, 1885; Harold, composed for the Walthamstow Festival, November 24 , 1887; In the Forest, 1890; The Death of Young Romilly, 1891; both for men's voices, and produced by the Stock Exchange Society at St. James's Hall. The Hesperus, cantata, 1896. Orchestral: Concert Overture, composed for the first concert of the Stock Exchange Society, December 18, 1885; Symphony, Evangeline, the same, February 20, 1889; Funeral March (In Memoriam, the late Duke of Clarence) 1892 . Chamber music, operettas, and orchestral works in MS Woodland Waltzes, for voices and pf. duet; a large number of songs and part-songs, etc. Of these works many have enjoyed much popularity, and have been given in various. parts of the kingdom, and in America. 


\section{READE.}

Reade, Charles, novelist, was born in 1814; died, London, April 11, 1854. Author of "Cremona Violins, four letters descriptive of those Exhibited in 1873 at the South Kensington Museum, also giving the data for producing the 'True varnishes used by the great Cremona makers, reprinted from the Pall Mall Gazette by George H. M. Muntz," Gloucester, 1873; also reprinted in Reacle's miscellaneous works cntitled "Readiana." Reade is best known by his novels "Hard Cash," "It is never too late to mend," etc.

Reading, John, organist and composer, born probably some time before the midale of the 17th century. Lay-vicar of Lincoln Cathedral, 166\%, and Master of the chorister's there, 1670. Organist of Winchester Cathedral, 1675-81; and of Winchester College, 1681. He died at Wincherter in 1692. Composed an "Election Grace" for the scholars of Winchester College; "Dulce Domum," a hymn, printed in Harmonia Wiccamica; and is stated to have composed the well-known hymn, "Adeste Fideles," otherwise the Portuguese Hymn."

Reading, John, organist and composer, son of alrove, was born in 1677. Chorister in Chapel Royal, where the studied mader Dr. Blow. Organist of I ulwieh College, Loudun, 1700-1702. I ay-vicar. 1702, and Master of choristers, Lincoln Catledral, 1703. Organist of St. John's, Hackney, London; St. Nary, Woolnoth; St. Oanstan in the West; St. Mary, Woolehurchhaw. He died at London, Septemlser 2, 1764 .

He composed "A Book of New Anthems, containing a hundred plates fairly engraved with a thorough-bass figur'd for the Organ or Harpsichord, with proper Ritornels," London [1715]; "A liook of New Songs (after the Italian manner), with symphonies, a thorough. bass fitted to the harpsichord, etc., all within ye compass of the flute.". London [1720]. Sold by the anthor at his houne in Arunde] Street, Strand. To him has also been attributed the composition of "Adeste Fideles." Another JoHN READING was organist of Chichester Cathedral from $167 \pm$ to 1720 .

Reading, Rev. John, clergyman, was prebendary of Canterbury Cathedral. Anthor of "A Sermon lately delivered in the Cathedral Church of Canterbury, concerning church musick." London, 1663.

Reakes, Albert, bass vocalist and conductor. Studied at the London Academy of Music; also a R.C.M. Conductor of West Loudon Male Voice Union, and was assistantconductor of the Bath Philharmonic Society, 1887 ; conductor of New Swindon Choral and Orchestral Union. Composer of glees: To the Rose; Love's a thing as I do hear (men's voices), etc.

Reay, Samuel, organist and composer,

\section{REDDIE.}

born at Hexham, March 17, 1822. Son of GEORGE AGNew ReAY, olganist of Hexham Abbey Church. Showed early aptitude for music, and when eight years of age, hip father having removed to Byton-on-Tyne, he was admitted a chorister at Durham Cathedral. Studied under IV. Henshaw, the Cathedral organist, and received valuable instruction from the Rev. Peter Penson, then precenter. On leaving Durham, he was placed under James Stimpson, organist of St. Andrew's, Newcastle, whom he succeeded in 1841, after holding alpointments at North Shields and Houghton-le-spring. In 1845, he became organist of St Thomas', Barras 1irjdge, Newcastle ; St. Peter's, Tiverton, 1847; while there, giving lectures on the History of Keyed Instruments. Appointed to St. John's, Hampstead, 1854; St. Saviour's, Warwick Road, 1856; St. Stephen's, Paddington; and, in 1859, succeeding Dr. E. G. Monk as organist and precentor of St. Peter's College, Radley. In 1861, he was appointed to the I'arish Church, Bury, Lancashire, famous for its choir; and in 186t, suceeded Dr. Dearle in the ancient and important office of Song Schoolmaster of the Parish Church, Newark, which he still retains. Gradnated Mus. Bac, Oxford, 1871. Has given organ recitals at the Bow and Bromley Institute, at the Royal Albert Hall, and at other places. On October 27, 1879, he produced, at the Institute just named, Bach's "Coffee" and "Peasint" cantatas, for the first time in England; the English text prepared by himself and Mrs. Newton. In 1891, he was invited to take part in the inauguration of the new organ in Newcastle Cathedral. $\mathrm{He}$ is conductor of the Newark Philharmonic Society.

Works.-Psalm 102, for solo, chorus, and strings; Morning, Evening, and Commumion Service in F. Anthems: I will go to the Altar; O Lord, why sleepest Thou? O sing unto the Lord; Rejoice in the Lord; and others. Hymn tumes contributed to the Hymnary, Bristol Tune Book, and other collections; chants, etc. Joint editor, with Drs. Gauntlett and Bridge, of Dobson's Tunes Nerv and Old. Part-songs: As it fell upon a day; Fairest danghter of the day, composed for the Jubilee of the Bristol Madrigal Society, 1887 ; Dawn of Day ; Hele let's join in hammony; Huntsman, rest; English hunting song; I lov'c a lass; In an arbour green; Sweet is the breath of early morn; The clouds that wrap the setting sun; and many others, all of which have been extensively popular. Edited and arranged Songs and Ballads of Northern England (collect d by John Stoke), London, Scott, 1892.

Reddie, a family of musicians. JosidH Ferumand Reduie, of Scotcl extraction, 


\section{REDFORD.}

was born in London, in 1797. He was apprenticed to John Purkis, and afterwards to S. S. Wesley, who pronounced him, while a youth of eighteen, to be the best extempore player in London. Years afterwards he presented himself in rustic guise to James Turle at Westminster Abbey, and gaining his permission to touch the organ, so surprised him with his performance that the two became close frinds. Reddie also studied under Thomas Adams. When sixteen, he was appointed organist of Denmark Hill Chapel; three years later to Rotherhithe Cliurch; to St. Botolph, Boston, Lincolnshire, 1822; St. Margaret's, King's Lynn, 1826, a post he held until his death, on February 20, 1860. His reputation as an executant was very great.

Josiah Henri Redde, son of the preceding, was born at Boston, Lincolnshire, April 2, 1822. Studied under his father, and was organist for some years at All Saints', Lyun, and succeeded his father at St. Margaret's Church, resiguing about 1893 . He is still living at Lynn.

Charras F. Rednie, son of the preceding, is a pianist, and made his first appearance at King's Lymn at the age of ten. Studied at R.A.M. under F. Westlake and E. Prout, receiving the certificate of merit in 1884. Played at a concert of the St. George's Glee Union, October, 1885 , with great success. On leaving R.A.M., 1886, was elected an Associate. Has given recitals and concerts in London and the provinces. In 1896 he was appointed a professor of pf. at the R.A.M.

Redford, John, organist and composer of the 16th century. He was organist and almoner, and master of choristers, St. Panl's Cathedral, in 1543. He died about 1516-7. Composed the well-kuown anthen, " Rejoice in the Lord," as well as sereral similar pieces in various collections.

Redliead, the name of two composers of the present time. Alfred RemHEAD was appointed organist of St. Augustine's, Kilburn, 1878. He is the composer of two cantatas for female voices, "The Flower Pilgrims"; and "Twelfth Night"; also of Christmas carols for children; two-part songs for children; songs, various, ete.

EDWARD ReDhEAD, graduated Mus. Bac., Oxford, 1845. He has published "Short Toluntaries for the organ, four books; picces for pf., etc.

Redhead, Richard, organist and composer, born at Harrow, March 1, 1820. Chorister at Magdalene College, Oxford, and pupil of the organist, Walter Vicary. He was appointed organist at Margaret Chapel (now All Saints' Church), Margaret Street, London, in 1839, an office he held until 1864. He officiated for a short time as organist at St. Andrew's, Wells Street, in 1847. From
REED.

1864 he has been organist at St. Mary Magdalene's, Paddington.

Works.-Church Music: a selection of chants, sanctuses, aud respouses, London, 1840; Laudes Diurnse, the Psalter and Can. ticles in the Morning and Evening Service, 1843; The Order for Morning and Evening Prayer, with Litany and proper Psalms; Proper Psalms, together with the Gospel Canticles, set to ancient psalm tunes; Metrical Litanies, 2 parts; Hymms for Holy Seasons ; The Celebrant's Office Book ; Parish Tume Book, compiled by G. F. Chambers London, 1868; Ancient Hymn Melodies and other Church tunes, as used at All Saints', Margaret Sitreet; Canticles at Matins and Evensong, adapted to the ancient Psalm chants; Music to the Divine Liturgy; The Cathedral and Church Choir Book, chiefly adaptations from the Latin works of the great masters; Parochial Chureh Tune Book and Appendix: Universal Organist, 5 books; Masses, Te Deum in D, antlems, etc.

Ree, Louis, English pianist and composer, pupil of the Stuttgart Conservatorium, and of Leschetitzky at Vienna, in which city he resides. Played at concerts, Stuttgart, 18-6, and in February, 1888, gave what was claimed to be the first concert of English music in Vienna. His compositions embrace a suite, Fête Cliampêtre, for pf.; variations and fugue, for two pianos; picces for violin and pf., ete.

Reed, Thomas German, composer and actor, born at Iiristol, June 27, 1817. Organist of Catholic Chapel, Sloane street, London. Musical director of Haymarket Theatre, 1838.51, and of the Olympic Theatre, 1853 . Clapel-master of Royal Bavarian Chapel, 1838. Married Miss Priscilla Horton, 1844. Established "Mr. and Mrs. German Reed's Entertaimments," 1855, and produced pieces by Brough, Parry, Gilbert and Sullivan, Bumand, Clay, Cellier, Reed, and Macfarren. He died at ${ }^{\top}$ pper East Sheen, Surrey, March 21,1888 .

Works.-Drama at home (Planché), 1845 ; Golden Fleece; Match for a king (C. Matthews); Who's the composer? (J. M. Morton); Miss P. Hortou's Illustrative Gatherings (1856), and other entertainments. Songs: Jock o' the mill; I would be a violet; Love makes the lome; Sweet Erin; Vixen: Young man from the country; adaptations from Auber's “ La Part du I liable," etc.

His wife, born Priscilla Hortoy (born at Birmingluam, January 1, 1818) a contralto singer and actress of great repute, who appeared in Macready's revivals of Shakespere's plays, and afterwards in Planché's pieces at the Haymarket Theatre, and in her husband's entertainments. She retired in 1879 . Died at Bexley Heath, March 18, 1895. 


\section{REES.}

Their son, Alfred German Reed, who continued the entertaimments, died at London, March 10, 1895.

Rees, David, author of "Reasons for and agaiust singing of Psalms in private or public worship," London, 1737.

Rees, Eleanor, contralto vocalist, born at Neath, Glamorganshire. Studied at R.A.M. under W. Shakespeare; Westmorlaud Scholar, 1883. Was assoeiated with Mr. Sinclair Dunn in his reeitals of Scottish songs, 1882. Toured in the provinces, 1885 , with the Valleria-Foli party. Nade her festival dibut at Woreester, 1887, singing in the first part of Mlendelisoln's "Elijah" with much success. She sang at the Philharmonie Concerts, March 22, 1s8,, and is known as a refined exponent of the better class of English songs, etc.

Rees, Robert, Eos Morrats, tenor voealist, born at Dowlais, Glamorganshire, April 5, $18+1$ Originally a working man, his great natural ability led him to follow music as a profession. His fine voice and artistic feeling soon won for lim an extended fame and great popularity, and he was a speeial favourite at the Eisteddfodau. He sang at the Crystal Palace, the Promenade Concerts at Covent Garden, in many provincial towns, and also toured in America. He died at Swansea, June 5, 1892 .

Rees, William Thomas, ALAW Div, composer, born near Bridgend, Glamorganshire, September 29, 1838. Self-taught. Has won a number of prizes at the Eisteddfodau, and also acted as adjudicator. Conductor of Psalmody Festivals. Editor of The MIusical school, and The Mrusician of Wales, the latter started in 1895, but neither now jn existence. Published a small eollection of tunes, anthems, etc.; composer of some cantatas, anthems, ehoruses, glees, part-songs, and songs; also of an opera for elildreu, Llewelyn Ein Llyw Olaf, performed at Treherbert, 1891.

Reeve, cotton, violinist and composer, who was born about 1777 . He was a theatrical mauager, and died at London about October, 1815. Composer of some instrumental musie.

Reeve, Percy, composer, of present time. His works eomprise a sketch "A condensed opera," produced at Steinway Hall, Mlay 4, 1882; "A private wire," vaudeville, Savoy Theatre, April, 1883; Operetta, "The Crusader and the Craven," Globe Theatre, Oetober, 1890. He has also composed a Symphony and Suite for orchestra; Songs, ete.

Reeve, William, composer and organist, born in 1757. He studied under Richardson, and beeame organist of Totness, Devon, 17811783. Composer to Astley's Cireus, London, and to Covent Garden Theatre, 1791. Organist of Chureh of St. Martin, Ludgate Hill, 1792. Joint-proprietor of Sadler's Wells Theatre. He died at London, June 22, 1815.

\section{REEVES.}

Wonks.-Alusic to Plays, etc. : Oscar and Malvina, 1791; Orpheus and Eurydice, 1792; Apparition, 1794; British Fortitude, 1794; Hereules and Omphale, 1794; The Purse, 1794; Merry Sherwood, 1795; Charity Boy, 1796; Harlequin and Oberon, 1796; Bantry Bay, 1797; Raymond and Agnes, 1797; Harlequin Quixote, 1797; 3Round Tower, 1797 ; Joan of Are, 1798; Ramah Droog (with Mazzinghi), 1798; Turnpike Gate (do.), 1799; Embarkation, 1799; Thomas and Susan 1799; Paul and Virginia (with Mazzinghi), 1800; Harlequin's Almanac, 1801; Blind Girl (with Mazzinghi), 1801; Cabinet (with Braham, Moorhead, and Dary), 1802; Family Quarrels (with Braham), 1802; Caravan, 1803; Dash, 1804 ; Thirty Thousand (with Davy and Braham), 1s04; Out of Place, or the Lake of Lausanne (with Braham), 1805; Corsair 1805; White Plume, 1806; Rokeby Castle, 1806; An Brataeh, 1806; Kais, or Love in the Deserts (with Braliam), 1808; Trieks upon Travellers, 1810; Outside Passenger, 1811; Chains of the Heart (with Mazzinghi); Jamie and Anna. Scots pastoral, 1800. Glees. Songs: Cherry-cheeked Patty; Bird in the hand; Enamoured shepherdess; Little haymaker; Live and be jolly; Nargery Grinder; Rose of the valley; Tippetywitchet, clown's songs for Grimaldi; etc. The Jurenile lreceptor, or Entertaining Instructor: a eomplete and concise ]ntroduction to the Pianoforte, witb 24 lessons and 4 easy duets, London, n.d. The well-known song "I am a friar of orders grey" appears in "Merry Sherwood," 1795. By this Reeve is best known.

Reeves, Daniel M. G. S., amateur musieian, author of "A Treatise on the Scienee of Musie," London, 1853; 2nd edition, 1861.

Reeves, John Sims, tenor vocalist, born at the Artillery Barracks, Woolwich, September 26,1818 ; baptized in Woolwich Chureh, October 25, 1818. His father, John ReEves, was born at West Bromwich, Staffordshire. He enlisted first in the Marines, and then in the Royal Artillery. His superior musieal attainments brought him into notice, and he beeame a corporal in the band. He is said to have been a splendid bass siuger, and a good instrumentalist. He was discharged in 1843 , and died at Foots Cray, Kient, November 30, 1860. From his father young Reeves received his first instruction, and when fourteen was made organist of North Cray Chureh. During the next few years he became a performer on the violin, 'cello, oboe, and bassoon; studied harmony with IV. H. Calleott, and pf. with J. B. Cramer. His adult voice developing, he decided on becoming a singer, and as a baritone, made his clébut as Count Rodolpho in "La Sonnambula," at the Newcastle-ouTyne Theatre, June, 1839. The same year he sang at the Greeian Theatre, London, as Mr. 
REEVES.

Johmson. He then studied as a tenor, under Holbs, and 'T. Cooke, and appeared in minor parts in "King Arthur," "Der Freischïtz," and other operas, at Drury Lane, 1849-3. For further study he went to Paris, and liad lessons from Burdogni, and at Milan, from Mazzucato. At La Scala, Milan, he appeared in 1846, as Edgardo in "Lucia di Lammermoor," with Catherine Hayes in the titlepart. Leappeared at Drury Lane, Decenber 6, 1847, in the same part, and achieved the greatest success witnessed for many years. Then for the first time called Mr, Sims Reeves. On the 20th of the same month he appeared in his first original part, as Lyunnel in Balfe's " Maid of Honour," also at Inrury Lane. On May 20, 1848, lie made his first appearance in Italian opera, at Her Majesty's, taking the part of Carlo in "Linda." His operatic career extended over many years, and he was equally great in works of all kinds, down to the simple ballad-opera. He sang iu "Rob Roy," at Edinburgl, so late as July, 1887. In oratorio he achieved a great success at the Worcester and Norwich Festivals of 1sts, and at the Sacred Harmonic Society's performanee of the "Messiah," November 24 , of that year lle was engaged for the Birminglam Festivals from 1849 to 1873 , and it was for him that Costa wrote the tenor parts in "Eli," and "Naaman." lle sang at the Crystal Palace Handel Festivals, 1857-74, his last fentival performance being in "Israel in Egypt," June 26, 1s7t. In the concert room he reigned supreme, and was matchless in his rendering of the artistic song, and the Dibdin ballad. From 1ss1 his public appearances were less frequent; and in 1890 he commenced a farewell tour at Sonthsea, in August; and gave his final concert at the Albert Hall, May 11, 1891. He commenced teaching ahout this time, and was on the staff of the Guildhall school of Music. Reverses and misfortume compelled a return to public life, and after singing at Covent Garden Promenacle Concerts, Queen's Hall, and other places, 1893-5, he appeared at the fmpire Theatre, November 4, 1895, and made a round of the provincial Tariety theatres during the winter following. Sailed for South ifriea, July 25, 1\$96, and had a most successful tour, returuing in Oetober. In 1888 he published his "Life and Recollections," London, Simpkin, Marshall.

$\mathrm{His}$ wife, bom Enma Licomm, was the daughter of Thomas Lucombe, a clever amateur actor, who died February 13, 1855. She was a pupil of Mrs. Blane Hunt, and first appeared at a concert of the Sacred Harmonic Society, in Fandel's "Joshua," June 19, 1839; and sang in London and the provinces up to 1815 , when she went to study in Italy; saug in opera in Milan, and made her dibut
REID.

on the English stage at Covent Garden, Nowember 4,1848 , in the titular part of Auber's "Hajdée." Appeared at the l'hilhamonic concerts, April 16, 1849, singing a duet with Sims Reeves, to whom she was married, at North Cray Church, November 3, 1850. For some time she continued to sing in publie, and then gave her attention to teaching. She died at Upper Norwood, June 10, 1895, in lier 75 th year. Henbent Sins ReEves, their son, educated by his father, and at Milan, made his dibut at WV. Ganz's concert, St. James's 1 fall, Jume 12, 1880; sang with suceess at the Crystal Palace, February 12, 1881, and in the provinees. Male his first appearauce on the stage at Brighton, in "Guy Mannering," February 13, 1884. Has sung in "The Waterman," and taken other parts made famous by his father. He has also sung in comic opera, "Falka," ete. He has pulnlished one or two songs. His sister, Coxstance Sins Renves, made her dibut on the stage in "Guy Aamnering," with her brother, singing under the name of Miss. Lester. She appenred at the Strand Theatre in July, 1881; sang in "The Waterman" at the Crystal l'alace, 1892; and lias been heard at various concerts. Mr. Sims Reeves married again in 1895, his second wife, Miss Mhon liexw, having been his pupil. She sang with him at the (Qneen's Hall, Christmas. Day, 1895; accompanied him on his provincial tour, 1895-6; and also on lis visit to Africa. EImin Ristres, a brotler, was a member of the Seguin troupe in their American tour, 1848-9; and sometime professor of singing at the Viceregal ('ourt, I)ublin. He died a Liverpool, in May, 1882.

Reid, Alan Stewart Bell, composer and editor, born at Arbroath, Forfarshire, February 6, 1653. Prought up at Forfar, and originally apprenticed to a calinet-maker. His talent for music showed itself early, and he is entirely self-taught. Elected choirmaster in the Barelay Church, Edinburgh, in 1 1875 , which appointment he still holds; also instructor in singing in three Board Sehools in that city. He has composed many educational works for sehools, operettas, eantatas (Round the Clock; The School Holiday ; Red, White, and lilue, etc.), and action songs; Ruth, a sacled cantata (1882); Friendship's Circle, a Scotish cantata; and lyrics and melodies in "Scots Minstrelsie." A rolume entitled "Music for Pupil Teachers" was recently eompleted, and he has a poetical anthology, "The Bards of Angus and the Mearns," in course of preparation. He is, further, editor of the Nutional chour, a monthly publication of glees and harmonised songs, and anthor of various poetical works.

Reid, General John (horn lionertson), musician, and founder of the Edinburgh 


\section{REINAGLE.}

Professorship of music, was born at Straloch, Perthshire, February 13, $1721[17: 0]$. Son of Alexander Robertson of Straloch. He studied at Edinburgh University. Lieutenant in the Earl of Loudon's Regiment, 1745; afterwards became a General in the Army. He died at London, February 6, 1807 .

WorKs. -A Set of Minuets and Marches, inscribed to the Right Hon. Lady Catherine Nurray, by J-R-, Esq., London [1770]. (Bremuer). [Contains the well-known air, "The Garb of Old Gaul," to verses of Sir H. Erstine, of Alva.] Six Solos for a German Flute or Violin, with a Thorough-bass for the Harpsichord, by $J-R-$, Esq., a Member of the Temple of Apollo, London, n.d. (Ossvald). There have also been eseribed to him "Three Grand Narches, and Three Quicksteps for a Full Military Band, by an Eminent Master," London, n.d.

General Reid directed in his will that, subjeet to the life-rent of lis daughter, the sum of $£ 52,000$ should he applied to frumding a Chair of MInsic in Edinburgh Iniversity, and that an annual coneert (to include a full military band) should be given un his birthday, at which was to be performed some specimens of his own composition, to slow the style of music that prevailed ahout the middle of last century. The chair was in. stituted in 1839 , when a sum of between $£ 70,000$ and $£ 80,000$ beeame irailalile. The snceession of Professors has heen John Thomson, 1839; Sir Jenry Bishop, 1sł2; Henry Hugo I'ierson, 1844; Jolm Donaldson, 18t5; Sir Herbert Stanley llakeley, 1865; Friedrieh Nieeks, 1889.

Reinagle, Caroline, Sic Orger, Caroline.

Reinagle, Joseph, violoncellist, comp, ser, and writer, born at Portsmonth, of Austrian parents, in 1762. Intended for the navy, but afterwards apprenticed to an Edinburgh jeweller. He studied the 'cello under Schetkey, who married his sister, and the violin minder Aragoni and Finto, and became leader at the Edinburgh Theatre. Performed as a violoncellist in London, etc. Resided in Dublin, 1784.6. Played at Salomon's Concerts in London, and in Oxford, where he latterly resided. He died at Oxford, 1836.

Wonk--Twenty-four Progressive Lessous for the I'ianoforte, London, 1796. Twetse Duets for the violoncello, op. 2; 3 sets of six do., op., 3, 4, 5. Six Quartets for strings. Slow March for orchestra [1800]. Concertos for violin and violoneel lo, with accompaniment. Concise Introduetion to the Art of Playing on the Violoncello, London, 1830. This work has reached $t$ editions.

His son, Alexander Robert, born at Brighton, August 21, 1799, was organist of St. Peter's-iu-the-East, Oxford, 1622-53.

\section{RELFF.}

died at Kidlington, near Oxford, April 6, 1877. Composed Preparatory Exercises for the Violin; Selection of Popular Airs, varied, for Violin; A Coilection of the most favourite Scoteh Tunes....London, n.d.; Yiolinist's Portfolio, for Amateurs; Allegro Maestoso, for Violin; Twelve Strdies for the Violin [1851]; Seven Easy Studies for Violoneello; First Lessons for Begimners on Violoneello, to which are added a Selection of Psam Tunes and Chants [1841]; Ten Airs for Organ or Harmonium; Ten original Melodies, and a Fugue for the Organ; Four Introits for Organ; Iroeessional March, du; Twelve songs without words, pf.; Two Sets of Bagatelles, 1f.; Psalm tunes for the voice and pf. [1830]; Collection of Psalm and Hymn tunes, ehants, and other music, London [1839]. The well-known I'salm tune, "St. l'eter," is by A. R. Reinagle.

Reinhold, Charles Frederick, bass singer and organist, born in Lendon, of German parents, in 1737. He was a chorister in St. Paul's Cathedral and the Chapel Roral. In 1755 he appeared at Drury Lane Theatre in J. C. Smith's "Fairies." ITe was organist of St. George the Nartyr, Bloomblury, and sang at Marylebone fiardens, 11 the provinces, and at the Handel Commenoration in 1784. He died in London, September 29, 1815. Composer of galops, valses, ant other music for the $\mathrm{pf}$.

Relfe, John, composer and writer, born at Greenwich in 1763. Son of Lupton Relfe, who was organist of Greenwich Hospital, under whom he studied. He also studied under Keeble. Member of King's land of IIusie, 1810. Teacher of harmony and pf. in Lonion, where he died, abont 1837.

Wonrs. - Select set of airs for harpsiehord [1787; Progressive sonatas for the harpsichord or pf.; Lessons, songs, and duetts for pf.; six divertimentos for pf., op. 8. Songs: Come thou laughter-loving power; Edwin and Angelina; Gardener; Laplander's song ; Nary's dream. Editor of M. Sharp's collection of original melodies $[1 \$ 27]$. Guida Amonica, or introduction to the general knowledge of musie, theoretical and practical, Iondon, 3 parts $[1798]$; reprinted as "The Prineiples of Harmony, containing a complete and compendious illustration of the theory of music," London, 1817. A Nuschedule, or music scroll, exhibiting an epitome of the whole scienee of music," Camberwell $[1,800$. Remarks on the present state of musical instruction, with a prospeetus of a new order of thorough bass designation, and a demonstrative view of the defective nature of the cnstomary mode.., London, 1819. Lucidus ordo: comprising an analytical course of studies on the several branches of musical science.., London, 1821. 


\section{RENDALL.}

Relfe's " Guida Armonica" anticipated in a large measure the method of Logier in regard to instruction by exercises.

His father issued "Hymms for the use of the Chapel of the Royal Hospital, Green wich," London, 1789; and "Greenwich Hospital hymns and music," 1796.

Rendall, Edward Davey, composer, educated at the Hoch Schule, Berlin. Graduated M.A., 1887; Mus. Bac., 1894, Cambridge. Music master, Dulwich College. His compositions are: Psalm 137, for soli, strings, and organ; "The Compleat Angler," Idyl for soli, chorus, and orchestra, Princes' Hall, May 5, 1894; Quintet for pf. and wind, 1890; Five vocal duets; Songs, part-songs, etc.

Reynolds, Charles, oboe player, born at Stockport, Cheshire, May 30, 1850. His father, Thomas Reynolds, was bandmaster of the 52nd Light Infantry (now 2nd Oxfordshire), and afterwards of the 6th Lancashire Militia. Charles Reynolds passed his boyhood in India, and while there the great mutiny broke out. On his return to England he studier the oboe under Lavigne, and joined the Hallé orchestra in 1871 as second oboe. becoming principal in 1890 . Was connected with the (ientlemen's Concerts, Manchester, from 1870; Liverpool Ihilharmonic, 1sit; joined the orchestra of the Royal Italian Opera, 1876; and the New Philharmonic Concerts, London, same year. Has played at the Bristol Festivals since 1873; Birmingham, 1885; Hanley, 1885; Handel, 1888; and at the Reid Festival, Edinburgh, 1893, he played for the first time in Great Britain Bach's Suite for oboe d'amore; and is also known as a fine performer on the Cor Anglais. He has conducted orchestras at Derby Castle, Douglas, Isle-of-Man, 1886-7; Falcon Cliff, 1889; and Rhyl, 1893. Is professor of the oboe, Royal Manchester College of Music.

Reynolds, Charles Tom, organist, composer, and conductor, born at Ross, Herefordshire, October 1, 1865. Chorister at Hereford Cathedral. Graduated Mus. Bac., 1890 ; Mus. Doc., 1895, Oxford. F.R.C.O. Appointed organist of Denstone College, 1883; of Oswestry Parish Church, 1885, an office he retains. Conductor of Oswestry Choral Society, which has given good concerts; of the Claughton and Oxton Choral Society; and, in 1896, appointed conductor of the Birkonhead Cambrian Choral Society. His compositions include a cantata, "The Childhond of Samuel," produced at Birkenhead, 1896; a setting of Psalm 130; and he has published church services, anthems, and part-songs.

Reynolds, John, composer of the 18th centurv. IVas Gentleman of Chapel Royal, 1765-1770. He died at Lambeth, London, 1770 [November, 1778?]. Composed the well-

\section{RICHARDSON.}

known anthem, "My God, my God, look upore me."

Reynolds, Williamson John, organist. and composer, born in London, October 22, 1861. Graduated Mus. Bac., 1886 ; Mus. Doc., 1889, London. Organist of Parish Church, Barnet; St. Michael's, Comhill, London, from 1891. He has lectured on. "Music and Evolution," in Birmingham, 1895, etc. His works are a Magnificat for soli, chorus, strings and organ; Festival Te Deum, for soli, eight-part chorus and orchestra, produced at Highbury Athenæum, April 19, 1891; "Crossing the Bar," four voices, etc.

Rhodes, Alfred, organist of Brixton Independent Church, is author of a work on "Curiosities of the Key-board and the Staff; or the Staff-notation shown to be unon a scientific basis .," London, Augener, 1896.

Richards, Henry Brinley, composer, pianist, and teacher, born at Carmarthen, November 13, 1817. Son of H. Richards, organist of St. Peter's, Carmarthen. Intended for medical profession, but abandoned it in favour of music. Entered R.A.MI. as student, with assistance of the Duke of Newcastle. Gained King's Scholarship, 1835 and 1837. Nember of R.A.M. Resided in I.ondon as teacher and pianist. He died at London, Nay $1,1885$.

Worrs.-Orchestral: Symphony ; Overtures in F minor, Paris, 1840, London, 1841, and another; Concerto for pf, and orchestra; The "Albert Edward" march (military band), 1862 ; The Carmarthen march. Pianoforte: Andante Pastorale; The angel's song; Picciola Estelle; Fête de la Reine (1819); La Reine Blanche, scherzo; Recollections of Wales (1852); Warblings at eve (1856); Narie, nocturne (1857); Book of Octave Studies; Andante cantabile (1858); Fantasias on Welsh airs (1861); Tarantelle (1864); Evening, nocturne (1877); Autrefois (1880). Part-songs: Up, quit thy bower, trio (1846); In the hour of my distress, solo and choir (1856) ; There's not a heath (1857); The boat song; Ye little birds, madrigal (1863); Sun of my soul (1868); The Cambrian plume (1869); Let the hills resound (1873); The men of Wales (18T7); Nobody cares for thee (1878). Duets: How beautiful is night; The old church chimes; Home, etc. Songs: In the hour of my distress; Cambrian war-song (1859); The harp of Wales (1862); God bless the Prince of Wales (December, 1862); As o'er the past (1868); The harper's grave (1869); The Black Watch (1874); Men of Wales (1877), etc. Songs of Wales, edited, London, 1873 (other editions).

Richardson, Alfred Madeley, organist, studied under William Haynes, of Malvern, and at R.C.M. Organ Scholar, Keble Col- 


\section{RICHARDSON.}

lege, Oxford, 1885-9. Graduated Mus. Bac., and B.A., 1888 ; M.A., 1892 , Oxford. F.R.C.O. Obtained diploma of A.C.O. when sixteen, and was then organist of Emmanuel Chureh, Malvem. Gave reeitals in the Priory Church there, 1884. Organist of Hindlip Chureh, Worcester, 1889; Holy Trinity, Sloane Street, London; St. Jude's, Gray's Inn Road; All Saints', Searborongh, 1892; St. Saviomr's Cathedral, Southwark, 1897. He has pul)lished church services, part-songs, etc.

Richardson, John, eomposer and organist, born at Preston, Deeember 14, 1816. He was appointed organist of st. Mary's Catholic Church, Liverpool, in 1835, and from 1837 to 1857 was organist of St. Nicholas Church in the same city. He was celebrated as a teacher, and was the instructor, in counterpoint, of W. T. Best. He died at Preston, April 13, 1879. He composed musie for Collins' "Ode to the Passions," masses, glees, hymu-tumes, ete.

Richardson, John Elliott, organist and composer, born at salisbury. Studied at Salisbury Cathedral, under A. T. Corfe, whose assistant organist he was for eighteen years. Appointed organist and master of the choristers, in 1863, after the death of A. T. Corfe. Conductor of Sarum Choral Society, 1849-69. Resigned Cathedral appointment, 1881, owing to ill-health. He composed a service in F; I will give thanks; Turn Thee, $O$ Lord; and other anthems. Author of "Salisbury Chant Book," Salislury, 1859; "The Tour of a Cathedral Organist," Salisbury, 1870. Editor of anthems by Greene, ete.

His brother, Thonas Bextrack Rrchardsox, chorister, and assistant organist at Salisbury Cathedral, was organist, for nearly thirty years, of St. Nary's Church, Bury St. Edmunds. He was a good musieian, and exerted great influence in his locality. He died at Bury St. Edmunds, April, 1893, aged 62 .

Richardson, Joseph, flute player and composer, born in 1814. Member of Jullien's orchestra, and latterly principal flutist in Queen's private band. He died at London, March 2.2, 1862. Composer of fantasias, variations, original pieees and arrangements for flute; Set of studies for the flute, exemplifying the different modes of fingering particular notes and passages, London [1844]; Waltzes for pf., songs, and other music.

Richardson, Vaughan, organist and composer, was born in the latter half of the 17th century. He studied under Blow in the Chapel Royal. Organist of Winchester Cathedral, 1695. He died in 1729.

Wolks.-A Collection of new Sougs for 1 , 2 , and 3 roices, accompany'd with Instruments, London, 1701. Odes, eantatas, ete. Anthems and songs. The well-known anthem
RICKARE.

"O how aniable are Thy dwellings" is by this composer.

Richardson, WVilliam, organist and eomposer, was a ehorister in the Chapel Royal, and organist of St. Nicholas' Church, Deptford, London, 1697. He died abont 1731-39. He composed "Lessons for the harpsichord or spinet," London, 1708; and "The Pious Recreation, containing a new sett of psahm tunes..," London, 1729. This contains "Greenwieh," a popular psalm tune.

His brother, Pellain Richardson, was also an organist.

Richmond, Rev. Legh, elergyman and musician, born at Liverpool, January 29, 1772. He was chaplain of the Lock Hospital, and afterwards rector of 'Turvey, Bedfordshire. Died at Turvey, May 8, 1827. Author of "The Dairyman's Daughter" in the "Annals of the Poor," and other religious works. Known to musicians by some good glees, contained in Hague's eollections. He also wrote songs, among which may be named Christian's rest [1825]; Gypsies petition; Happy cottager; Negro's prayer. Riehmond founded, abont 1820 , the Legh Richmond Library at Iona, in Argrleshire.

Richmond, William Henry, organist and composer. Studied mater Janes Rhodes and T. A. Marsh. Organist of Holy Trinity, Knalesborough; appointed to St. Paul's ProCathedral, Dundee, 1870; and later to st. Michael's, Exeter, which he resigned through ilhess in 1886 . He eomposed chmrch services, anthens, organ music, pf. music and songs.

Rickard, Richard Henry, pianist and composer, born at Birningham, November 12, 1858. When a child he showed much talent for music, and as a juvenile pianist frequently played at concerts. At eight rears of age he was placed muder Dr. C. S. Heap, with whom he studied for some years. He gave his first recital in Birmingham, Narch 30, 1876, and afterwards went to study at the Leipzig Conservatorimm, where his teachers were Reinecke, Louis Maas, and E. F. Richter. After completing his course, he played at the Gewandhans eoncerts, December 12, 1878, Reinecke's Coneerto in $\mathrm{F}$ minor, and was favourably noticed by the press. He reappeared at Birmingham in April, 1879 , and gave recitals at different times. Residing in London, he took a good position as a teacher there, and at Brighton. Played at the Crystal Palace concerts, for the first time, April 7, 1883; gave a series of recitals there, 1884 ; at the "Inventions" Exhibition, South Kensington, 1885; and played at concerts in various plaees. He also has played, with marked steeess, at Paris, and Dresden and other places in Germany. Visited Liszt at Weimar, and played to Rubinstein, to whom he dedicated a Ballade 


\section{RIDDELL.}

and ravotte. For upwards of ten years he has beem princilat plofesisol of pf. at the Sydenlam and Folest Hill Academy of Music. Ifis (onupositions include a Concerto in B Hat, for bf. and orchestrar; six duets, six characteristic pieces, and a mumber of other worlis for pl.; Twilight Mnsice, The Lotus Flower, and other somgs, ete.

Richan1, Richard, his father, was mathenratical master at King Filward's School, Pirmingham, from 1854. He was an excellent anatene flute player, and fir much to popularion music: in the Midlands. In 1set bo started a pomny singing elass at the lirmingham and Midland Institute, and in 1852 he began a penmy vinlin class. On the thire night 525 students provented themselves? Many soon dropped off, hut from these clasises the Institute Sehoul of Musite was devioped. Mr. lickard fied at Birmingluan, June 4, 1890 .

Riddell, John, munician, hom at Ayr, September 2, 1718. He was a mosic teacher, and is belined to have lreen hlind from infaney. He died at Ayr, Apria 5, 1795. Compromel of at "Collection of Scots Rects or country dances and minnets, with two par. ticular slow tunes, with a basis for the violin, violincetto or hartsichord . . " Edinburgh $[1766]$. "Collection of Sicots Reels, minuets, che, for the violin, harpsichord, or Germatu flute. The second edition greatly improved," Gilasgow, J. Aird [1782]. Rididull compened the air of "Jenny's Bawbee" and sereral well-knewn daness.

Riddell, Captain Robert, "f Ctenriddelt, I) mufriesshipe, sicottisli antiquary and musician, fest known as the friend of Bums the poet. He publisherd "A Collection of Seoteh, Gatwegian, and Border Twus, for the Violin and l'iduoforte, with a basis for the Violoncelle or llarusiclorel," Edintrurgh, 1794. "New Music for the P'ianoforte or Harpsi-

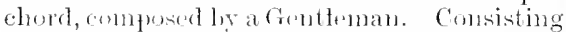
of a collection of Reess, Minnets, Hornpipess, Marches, and two Songs in the nid Seoteh taste, with valiations to five lavonrite tunes," Ediuburgh, n.d. Also music to some of burns' somgs. Ife died at Friar's Carse, lear Thumfries, April $21,1794$.

Ridding, John A., buitone vocalist, born in Pirmingham, December 5, 1862 . Interded for a solhoolnaster, he servodasa pupil

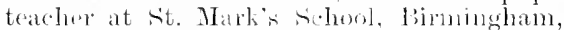
afterwards stadring at St. I'aul's Training School, Cheltenham. Having a voice that promised well, he lecame a candidate for admision to the Royal College of Music, and was wne of the fifty scholars elected in Amit, 1883. He distinguished himself at the coltege concerts, and in March, 1896, joined Mr. J. W. Trmers opera Company, of which he still remains a member. His repertoryinchudes

\section{RIJ)SDALE.}

upwards of thirty oferas, and the versatility of his talent is di-played in such widely differing impersonations as those of Mephistopheles, (Fanst), Lord Alleash (Fra Diavolo), and Alfio (Cimalteria Rusticana). Mr. Ridding is occasionally leard in oratorio, and genteral concert work in Bimmingham and elsewhere.

Rideout, Percy Rodney, pianist and composer. Studici at R.C.M., and privately. A.R.C.M. Graduated Mus. Bac., London, 1895. Teacher of pf. at London ()rgan School, etc. Composer of a setting of Pratm 115; an wrehestrat Symphonic poem (on shelley's Epipstadion), produced at Herunchel conecrts, January 29, 1891 ; an Evening Service in A, etc.

Rider, Charles, compler of "Psilmodia Intamnica, or a collection of psaln tunes seltered from rarjous componers, and adapted to the differont metres used in English palmody," London [1800, 2 vols. "Set of original l'satm T'Tmes," 1821-23.

Ridley, William, organist, loorn at Newark, Nottiuglam, 1820. Articied pupil of Tr. Inarte. F.C.O. Organist of Swaffham I'arish C'bureh; Kington Parish Church; and, 1850-78, of West 1) erly Parish Church, tiverpon. In 1878 he suceecled his son, $\therefore$ Clande Ridley (y.m), at sit. John the baptiste', The brook. He was for some time private regamist to the Earl of Oxford, and condictor of the Kington Choral society. I nring his thirty-three ratrs residence in Liverpool, he did monch to maise the standard of ehmeh services. His rontpilation of 301 rhants, ancient and modern, went through right editions; and he was the composer of matny hymu tunes. He died at Liverpool, ()ctulue 5, 1886. Ifis son,

Ridley, Sebastian Claude, organist, pianist, and conmposer, was born at West 1)elis, near Liverpoes, I)eemlex :31, 1853. sturfied under lis father. Was anistant organist at West 1)erby Parish Clumeh from 1865 to 1870 , in which last year he was appeinted organist of Sit. John's, Tue Brook; in 1878 to the Liverpool tieaman's Orphanage; in 1892 to Renshaw Street Lnitarian Chapel; and in $189+$ to Groat George Street Congregational ('hapet. Has atso acted as choirmaster at Sit. Couthbert's (1849), and sit. ('had's (1887). conductor of Banner's Oratorio Choir, 1883. As all orgat player he is well known, having given recitats at the Roval Albert Hall, Kensington, st. Genrge's Hall, Liverpool, and at valious provinciat exhilitions. His compositions include a Church service in G (unison); Prize hymm tunes, etc.; many songs, of which "The Wrecker" is a favomrable example; Pf. pieces, "Clymene," "Fairy wings," etc.

Ridsdale, Rev. C. J., B.A., Inembent 


\section{RIGBY.}

of Sit. Peter's, Folliestone, is the composer of a Communion Service, with orchestra, entitled "Cantio Dominica," produeed at Grostenor Hall, London, March 17, 1882. He is also the composer of three Magnificats it faux bourdons, in the 1st and 2nd Foclesiastical Tones, with raried organ accompaniments: a Benedicite, ommia opera, with Antiphon; Te Deum, for festal use; a second Communion Service, ete.

Rigby, George Vernon, temer rucalint. born at lirmingham, Jannary 21, 1810 . Chorister at St ('had's R.C. Catherdal when wine. When his roice changed to a tenor, he decided mpon his profesion, and having made a local reputation in 1,601 he went to London. singing first at the Alhambra, Leicester Square, and appearing at the Cosent Garden Promenade Concerts (Alfred Mellom, condurtor), september 18. In 1865 he tomed in opera with H. Corri's company. He then went to Milan, sturlying with siangiovanui, and apreared in opera there: also at Perlin in 1867, and later in I enmark. On retuming to Fugland he at once tok a high position, singing at the Festivals of the Three choirs, 1868-72: Norwich Festival, 1869; liming ham, 1s70-79. He sang at the ('rytal l'alace. Sacred Harmonic, and other London concerts, and at the chief provincial oratorio conederts. Of late rears he has beon seldom heard, one of his most lecent performances heing in Custa's "Isli," at Prighton, in Nowemler, $18 \times 7$.

Riley, William, musician and witry, was "principal teacher of prahmody to the ('harity Schools in London. Westminister, and part's adjarent," and singing master, St. John's, Bedford Row, London. Anthor of "Paruchial Musick Corrected, containing Remarks on Psalmody in Comntry (hurehes; on the ridiculons and profane manner of singing by Methodists; on the bad perfolmance of Psalmody in London and Westminster, with hints for'its Inplovement. . To which is added a scarce and valuable collection of Psalnu Tunes,.." London, 1762. Compiler of Psalnes and Hrmms for the use of the chapel of the Asrlum or Honse of Refuge for Female Orphans. London $[1750]$. "l'arochial Harmony, consisting of a collectim of Tsalm Tunes in three and four parts, by some of the most eminent Ancient and Modern Composers, and others." London, 176,. Divine Har. monist's Assistant, being a collection of Pialm Tunes. London [1790]. Also tumes in Aleoels's "Hamony of Jerualem," 1801.

Rimbault, Stephen Francis, organist, pianist, and composer, lom at London, in 1773. He studied under Dittemhofer, Honk, and Posin. Organist of St. Giles-jn-theFields. He died at London, Angust, 1837. Published numeroms adaptations for pf. from Haydn, Mozart, Beethoven, Rossini, Winter,

\author{
RIMBAULT.
}

etc. Composed three grand sonatas for pf., with flute accompaniment, ete.

Rimbault, Edward Francis, writer and composer, son of preceding. was born in Soho, London, June 1:3, 1816. 1 Ie studied muder his father, Sanuel Wesley, and Dr. Crotch. Organist of the Swiss Chureh, Soho, 1832, and subsequently of several other London churehes. Lectured at the Royal Institution and elsewhere on Fnglish inusical lisistory. One of the fomders of the Percy and Minsical Antiquarian Societies. Editor to Motett Society, 1841. F.S.A., 1842; Menbey of Academy of Music, and Ph. I)., Stockholm, 1842. Hon. degree of LL.T)., Harvard Tniversity, U.S.A., 1848. He died, London, September $26,1876$.

W'orks. - Who was Jack Wilson, the singer of Shakespeare's stage? an attempt to prove the identity of this person with John Wilson, 1) retor of IInsic in the Eniversity of Oxford, A.v. 1644, London, 18t6. Bilolintheca Madrigaliana; a hiloliographical accomnt of Musical and Poetical works published in England during the reigns of Elizaboth and James I... London, 1847. The first look of the pianoforte, being a plain and asy introdnction to the study of Music. Londom, 1s4s. The Organ: its listory and construction (with E. J. Hopkins), Londun, 1655 (variuns editions). The P'ianoforte: its origin, propers, and construction; with some accomit of instruments of the same class which preceded it, viz.: the clarichord, the virginals, the -pinet, the harpschord, ete., Londom, 1860. The early Fnglish Organ-luilders and their works, from the fifteenth century to the period of the great Rehellion.....London [1864'. J. S. Bach: his life and writings, onmpiled from Hilgenfeldt and Forkel. Lomdom, 1869. A Gruide to the use of the new Alexandre Church Harmonimu, with two rows of kers.... Londom, n.d. The Harmonimm: its uses and capalilities for the drawing-room as well as the church, 1857. Rimbault's Hammonium Tutor, a concine and easy busk of instruetion, London, n.d. Rimlianlt's New Singing Tutor, adapted from the valuable work of Lablache, London, n.d. Erlited, secular: Little book of Songs and Ballads, gathered from ancient musick bonks, MS. and printed ....London, 1840 (2nd edition, 1851). The Ancient Tocal Minsic of Fngland, London, 2 vols. [1846-49]. Little lavs for little leamers, set to easy songs, London, n.d. Nursery Rhymes, with the tunes to which they are sung in the Nursery of England, obtained principally from oral tradition, lomdon, 1847 ; Dnd edit., 1863; 3id edit., 1857 (other edits.). IInsical illustrations of Pishop Perey's Reliques of Ancient English Poetry, a collection of old ballad tmmes, ete..... London, 1850. The rounds, catches, and canons of 


\section{RIMBAULT.}

England...16th, 17th, and 18th centuries (with the Rer. J. Powell Mletcalfe), London, n.d. The Old Cheque-book, or Book of Remembrance of the Chapel Royal, from 1561 to 174t, London (Canden Society), 1872. Memoirs of Musick by the Hon. Roger North, Attorn:y-feneral to James IH.....Edited, with copinus notes, London, 1846. Thomas Morley's First book of Ballets for 5 voiecs (Mnsieal Antiquarian Soeiety). Thomas Bateson's First set of Madrigals (Musical Antiquarian Society). Orlando Gibbons' Fantasias of 3 parts for viols (Musical Antiquarian society). Purcell's Bonduca, a tragedy.. to which is added a history of the rise and progress of Imanlatic Music in England (Musical Antiquarian Society). Byrd, Bull and Gibbons" "Parthenia" (ALusical Antiquarian Society). Purcell's ode for St. Cecilia's Day (Musical Antiquarian Society). Edited, sacred: Cathedral Chants of the 16th, 17 th, and 1 sth centuries....Biographical notices of the composers, London, 1844. The Order of Daily service.. as used in the Abbey Church of tiant Peter, Westminster. . Londoni, 1844. A collection of anthens by composers of the Madrigatian era, Londun (Musical Antiguarian Society), 1845. Cathedral music, consisting of services and anthems. Iondon, n.d. Vol. 1., all published?. Collection of services and anthems, chiefly adapted from the works of Palestrina, Orlando di Lasso, Vittoria, Coloma, etc., London (Notett society), 3 rols. The Hand-book for the Parish Choir, a collection of Psahn-tunes, services, anthems, chants, ete., London, n.d. The Order of Morning and Hvening I'rayer, with the hamony in 1 parts.. London, n.d. Tocal Part Musie, sacred and secular, a collection of anthems, motetti, madrigals, part-iongs, etc., London, n.d. A little book of Christmas Carols, with the ancient melodies to which they are sung in various parts of the country . London $[1847]$. Old English Carols, and two hymms, London, 1865. The full Cathe. dral fervice, composed by Thomas Tallis.. with an historical preface, and a biography of the composer, London, n.d. The Order of Daily Service with the musical notation as adapted and composed by Thomas Tallis, London, 11.d. Edward Lowe's Order of Chanting the Cathedral Service, London, n.d. The Whole Trook of Pralmu, with the tunes in four parts, as printed by Thoman Este, 1592 . historical and hiographical notice, London (Musical Antiquarian Society), n.d. The Booke of Common Praver with musical notes, as used in the Chapel Tryal of Edward VI., 1550. Compiled by John Merbecke.. reprinted in facsinnile, London, n.d. Tocal: Comitry life, cantata; Fair maid of Islington, operetta, 1838. I'art-songin and numerous single songs. Organ: Organist's Handbook,

\section{RISELEY.}

a collection of voluntaries..arranged from composer's of the German school, London, n.d. The Organist's P'ortfolio, a series of voluntaries from the works of ancient and modern composers, London, 1866 (Boston edition, 1867). Some original pieces. P'iano. forte: An ellormons quantity of albums, arrangements, selections, transcriptions, and other pieces for solo and dnet, with a few original pieces. In addition to all the furegoing it should be mentioned that Rimbanlt edited many works for the Perey Society; an edition of Sir Thomas Overbury's works; several of Handel's oratorios; Operas by varions composers; and contributed many articles, biographical, and otherwise, to the " Imperial Dictionary of Biography," Grove's "Dictionary of MLusic," and to periodical literature.

Ring, John, amateur musician, surgeon and poet, born at Wincanton, finerset, Angust 21, 1752. Distinguished as an adroate of vaccination. He died at London, December 7,1821 . In addition to some poetry and professional books, he published "The Conmemoration of Handel: a poem," London, 1786; 2nd edition, 1819. This was issued anonymously.

Rippon, John, clergyman and musician, bon at Tiverton, April 29, 1751; died London, Iecensber 17, 1836. Conrpiler of "Selection of P'sahn and Hymm tunes, in three or four parts," London 1795」; "Selection of I'sahn and Hrmm Tunes from the best authors, in three and four parts London, and edition, 1806; 13th edition, 1820. "Selection of Tunes in miniature," London, 1806-8. A "Companion" to this was issued in 1820, edited by Walker. About 1837 an oratorio by Rippon, entitled the "Crucifixion," was published. A selection from his tune book was issued as "sacred Nusic," ete, by J. Tomlins, in 1810.

Riseley, George, organist and conductor, born at Bristol, Angust 28, 1845. Chorister in Bristol Cathedral when seven, and in 1862 articled to J. D. Corfe, the Cathedral organist. After holding sereral organ appointments he officiated at All saints', Clifton, until 1876, when he succeeded Mr. Corfe at the Cathedral. In 1870 he was appointed organist of Colston Hall, and his recitals gained a high reputation. As a performer on the organ he has also been heard at the Royal Alhert Hall, where he gave a series of recitals in 1885. In 1877 he started the Bristol Monday Popular Concerts of orchestral musie, which have had a wide edneational influence in the West of England. These he has carried on at great personal sacrifice, and has introduced the most important works of all schools, inching upwards of a hundred examples, orchestral and 
RITSON,

choral, by British composers. From 1878 he has been conductor of the Bristol Orpheus Society, the fame of which he has extended. The society, under his direction, has given concerts in London, 1894 and 1896; has sung at the Gloncester Festival, 1895; and before the Queen, at Windsor Castle, 1895, when Her Majesty authorised the choir to use the prefix "Royal," and presented Mrr. Riseley with an inscribed bâton. He is also conductor of the Bristol Society of Instrumentalists, and a busy teacher. Many tokens of the appreciation of his fellow eitizens have been bestowed upon him. He was eleeted conductor of the Bristol Festival in 1896, gaining further distinction in that important office. In 1893 he was appointed a professior of the organ at the R.A.M., of which Institntion he is an honorary nember. Of his compositions mention may be made of a Jubilee Ode, performed at Bristol, 1887; a Jubilee March for organ : Where'er my footsteps stray, and The Old Church Bells, part songs for men's voices; a Christmas Carol, ete.

Ritson, Joseph, antiquary and writer. born at Stockton in 1752, died at London in 180:3. Compiled, among other valuable and interesting works, "Aneient Songs, from the time of King Henry the Third to the Revolution. Prefixed are observations on the Ancient English Minstrels, and IDissertation on Ancient Songs and Music," London, 1790. "Scottish Songs, with the Munsic, and Historieal Essay .. ." I Reprinted, Glasgow, 2 vols., 1469. Also an English Anthology, Ballad Collections, and a Bibliographia Poetica, etc.

Riviere, Anna, see Bishop, Axsa.

Roberts, Arthur, voealist and comedian of the present time, who was born on September 21,1852 . He was a legal elerk in a financial office, and first began singing as an amateur. Made his mark in the Music Halls, and then appeared in pantomime at Oxford in 1878. Quitted the Music Halls and sang in "The Grand Mogul" at the Comedy Theatre, London, 1884. Toured in the provinces in comic opera, ete. Latterly has been giving entertainments with a party of his own. Among his best recent impersonations may be named "Gentleman Joe," which had a long and suceessful rum at the prince of Wales' Theatre, London. A memoir is pub. lished by Arrowsmith, Bristol, as "Adventures of Arthur Roberts, by rail, road, and river, told by himself, and chronieled by Richard Morton." [1895]. He has composed a few songs, "If I were to do such a thing;" "Keeping up the old girl's birthday," etc.

Roberts, David Alawydd, musician, was born in Carnarvonshire, June 16, 1820. He was self-taught in musie, and for three years

\section{ROBERTS.}

in succession, 1851-53, won the chief prize for anthem at the Bethesda Eisteddfodau. He also condueted performances of the "Messiah," "Israel in Egypt," "Samson," ete., at Bethesda. He died on May 26, 1s72. Anthor of a grammar of music, "Gramadeg cerddoriaeth, mewn tair rhan, sef nodiant," etc. Gwrecsam, 18ts; 2nd edition, Wrexham, 1862, a small bat coneise work which has proved very raluable to monoglot Welsh musieians. In 1867 he issued a Psam Tune book, also in Welsh.

Roberts, Eleazar, musician, published "Hymmau a Thonau. " Wrexham, 1870, Llawlyfr Caniadaeth," Wrexhan, and other works.

Roberts, Ellis, harpist and composer, born Dolgelly in 1819. He was harpist to the Prince of Wales. Ilied, London, Iecember 6, 1873. His son, fillis Ronerts, born in London, 1850, was a ehorister at St. Paul's Cathedral. Studied at R.A.M. as a violinist, and is a member of the l'hilhammonic orchestra, and prineipal second riolin, Royal Italian Opera, since 1895.

Roberts, Frederic Egbert, lass vocalist, born at Newtown, Nontgomery, September 26,1847 . Was lirought up to the printing and bookselling business, lut having a fine bass voice, stndied singing afterwards under Chevalier Lemmens, F. Kingsbury, J. C. Beuthen, and Alfred Blunne. Has sung at the principal concerts in hondon and the provinees. Made his début at the Crystal Palace Concerti, April 21, 1883. Was for some time a member of the Carl Rosa Opera Company, and sang at Irury Lane, as well as on tour in the prorinces. Principal lass at the Italian (hurch, Hatton Gatden, and, since 1894, musical director there.

Roberts, John, Hwt LAX, musician, born at Heullan, Mareh 30, 1807; died, April 4, 1876. Published "Caniadan y crssegr, neu gassglaid o donan ben a diveddar gan mwyaf o grfansoddiad Grommreig," 1A39. Selection of 55 Psalm Tunes in Welsh. "Casgliad o donau y diweddar," London, 1876.

Roberts, John Henry, composer and eonduetor, born at Bethescla, near Bangor, Nareh 31, 1848. Had lessons from a local teacher, and became an organist at twelve. Removing to Towyn he started a choral society. Entered R.A.M. in 1870, and studied under Sterndale Bemnett and C. Steggall. A.R.A.AI. Graduated Mus. Bac., Cambridge, 1882. He is also a Fellow of the Tonic sol Fa College. Resident at Carnarvon as urganist of Castle Square Church, and teacher and composer. In 1885, at the Aberdare Eistedd. fod, he wom prizes for an anthem, six-part madrigal, and tenor song. He has composed an overture, "Caractacus," a cantata, and other pieces. Author of handbools on Ele- 


\section{LOBERT'S}

ments of Nusic and Harmony ; and editor of Anthern Pook for the me of Welsh Chroches (Novello): musical editor of Jandbonk of J'atise, and Congregational Tune Book.

Roberts, John Varley, organist and comprorpl, loru at Stammingler, near Lueds, Septemles 25, 18+f. Jis musical talent was develoned at an uly age, and when twelve he was appointed urganist of sit. Juhn's, Farsley, nrar Leeds: in 1862 he was organist at Sit. Partholonew's, Armley, and in 1868 organist and choimaster of Halifax Jarish C'hmeh. Giaduated Mus. liac. 187I, Mus. I) e.e. 1876, (oxford; F.C.O., 1876. 1:1 1882 he was appointed to Magdalen College, Uxforl, as organist and magister choristarm, also holding office, $1885-9 \%$, at St. Giles' Church, Oxford. Condnctur of the Oxford Choral and Philhamonic Socicty, 1885-98; Madrigal Society of Magdalon College; and of the Magdalen Vagaluonds. Lecturer in harmony and comntorpoint for the oxford T'rofessor of Jusic; lexaminer for Musical Tegrees, 1h83-s6-8!-80. He has given many high-class enecerts at ()xforel.

Woris, Jonah, wacrud cantata, 1876, performer at Oxford and many uther places; Psaln 10?, for chorus and rrohestra; A full Morning, Commmion, and Frening Service in I); Full Commmnion Surver in D; Masnificat and None Dimittix in (: composed for the Festival of the Jonden Chureh ('hoir Association, st. Panl's Cathedral, 18:4t; Evening services in F, $\mathrm{F}$, and $\mathrm{C}$; Fonr settings of the Benedietus; The luord's Praper and Apostley Creed in hamonisod momotone; Benedicite, Ommia Opera, ete. Anthems: Inod, we pray Thee; seck yo the Lord: Ist, who shall dwoll; leace I leave with ron; I will sing moto the I ord, connposerl for the Jubilec Service in Magdalen chapel, 1857; The whole wath is at rest; and others. Prot Somps: Cupid onex npon a bed of roses; Come, my deate one: The shades of light: A red, led rose. Sings: The old Parish C'mmoh; The Far-off I and ; Hapres Moments; My Wrerle; Maiden with the mery cre; A Jinewell, etc. Andante in $\mathrm{F}$, Postinde in F, Larghetto and Allegro in $\mathrm{F}$, and wher pieces for orean. Selitor of The Pariol Chureh Chant Ponk, Novello: Sinplement to Cheetham's Psalmody: The Tictoria Book of Hymus.

Roberts, Kate, see sub. Ratuh, Francts.

Roberts, Richard, harpist, knowu as the "hlinet Minstrel of Camarvon," ],uln 1796; died Jump, 1855. He was a preformer of great skill, and played hofere Princess Victoria at Jemonnaris" in 1892. lle rompiled "Combrian Iarmony, hring a collections of Wals airs," Inllblin [1840

Roberts, Mrs. T., ser Isatcs, Renicca.

Roberts, W. Jarrett, componel and

\section{ROJBERTSON}

teacher, Was lorn at Liverpool in 1846. He studied at the R.A.M., and ifterwards becime principal of the North Wales Academy of Mnsic. He died at Bangor in Novenber, 1hise. Composer of "The Inundation of Contril Gwalod," a dramatic cantata, Merthyr, 1881; Musie for pf. and violin, soligs, ete.

Robertson, a Seottish family of violinists, who flomrished early in the present century. It consisted of HeNRY, JAMES, and WILLIAM, who mostly resided at Alloa, and perfomed at gatherings in the smrounding eountry.

Robertson, Alexander, musician and teacher of first part of present century. He tanght the pf. on the Logierian system, and was, in company with l'enson, a violinist, as musicseller in Edinburgh. He afterwards earried on a music-publishing husiness in partnership with his brother John. Robertson pulished Marshall's Reres and Strathspeys, and many other Seottish mutsical works.

Robertson, Daniel, musician, who was born in the latter part of the 18 th century, and died about 1857 . He isisued "a collection of new reels, strathepeys, jigs, waltres, ete." Fdinburglı, 1r.d. 1602]. "A selection of Seots, fuglish, and Irish songs with accompaniments for the piano." Fdinlonrgh, n.d., 2 vols. "A collection of Psalm and Hymn Tunes in miniature, arranged in three parts for voice and pf." Fdinlunigh, 1800.

Robertson, James Siewart, of Jidradynate. ('ollector, was horn May 15, 1823. He published "The Athol" Collection of the Tance Mnsic of Scotland," . . Itindingugh, 1sat, 9 vols.

Robertson, John, musician and publisher, borts aloont 1777. He was precentor of the Bupony ('hurch in filasgow, and had a musieselling business in the same city. He died at Glasgow, March 11, 1827. C'mpiler of "a selection of the lest Tsalm and Hymm Tunes, some of which are miginal, in fonr parts.." Glasgow, 1414. "l'he Seraph: a sulection of Pralm and Hymm Tunes.." [1827]; also Glasgow [Isto]. These collections were afterwards jostled in oblomg volumes as "Brown's Rolnertson's Sielection of Sacred Music."

Robertson, John, organist and composer, born in Jdinlongh, February 16, 18:38. While attending the University Insic Classes he gained one of the scholarihips offered by the U. P. denomination, hut deciding to malie music his profession, he resigned it. After studring with Professor Ilonaldson, he went to lierlin, and worked with Franz Schnlz. T11 1894, he graduated Mus. I)oe., Cambridge, the first seotsman to talse the deglee at that University. F.E.I.s. () rentist and director of the choir, New Greyfriss' ('hureh, 18761895: St. Audrew's Ejpismol Chureh, 1872 


\section{ROBERTSON.}

to present time. Conductor of Carubbers Close Choir. Has composed a setting of l'salm 122, for soli, chorus, orehestra, and organ; antlems, Pray for the Peace of Jelunilem, and others; Te Deum in F. Part sougs: Jull ye my Lose asleep (prize); Awake! ye mid. night mariners (sung at (rrstal Palate); Victoria Jiean, cte. Is anthol of a Treatise on Harmony and Comberpoint, in "The Musical Edizeat. ", edited by John (ireig. $\left(q \cdot x^{\circ} \cdot\right)$

Robertson, Sophis Maria, silumo rocalist, born at Valparaiso, Chili, July 31 , 1854. Jer father was a merchant who had settled there, and her mother a diaghter of Lieutemant Worthington whu forght monder Nelson at Trafalgar. In 186t the furily retmened to England, the fathere dying the same vear. As a child Misi livilertson's singing attracted attention, and later she was placed muler Randegger, and Benedict. She first appeared at the eoncerts of the lingal Anateur Orebestral siocietf, 1875-6; was heard in the provinces, 187\%, and the extraordinary range of her vice contributed much

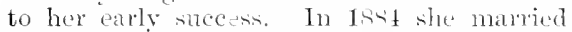
Mr. Stanley Stubbs, and retired from the platform; but mp to 1885 oreataionally sang at the R.yal Albert Hall, and in the conntry. Her sister, Farse Robrutsos, is a contralto rocalist, who has appeared at the ('rystal Palace and other ecncerts. The duet singing of the two sisters was very artintic, recalling the similar performanees of the Misies Williams, and other singers.

Robertson, Rev。Thomas, D.D., clergyman and witer, was minister at I)almeny, Linlithgushline, and died, Edinhmols, November 15, 1799. Anthor of "An Inquiry into the Fine Arts .." vol. 1, London, 1784. This volume, all that was publisher of the work, contains the "History and Theory of Ancient and Modern Music."

Robinson, Anastasia, Corxtess of Peterborocih, contralt) vocalint, bon at London about end of 17th centurs [1698]. Danghter of a portmit painter. Sint studied monder Croft and Sandoni. Ihlut in "Creso," 1714. Apperad afterwads in operas by Handel, Scarlatti, and Buonmoini. l'rivately married to the Farl of Peterhoromgh, 1724, at which time she quitted the stage. She is supposed to have lived with him, and to have been comsidered as his "mistress" till 1735, when, a short time previons to his death in that year, the Earl acknowledged the marriage. She died at Beris Momt, Sonthampton, 1750.

Robinson, Daniel, musician, author of "An Essay upon vocal musick," Nottingham, 1715.

Robinson, George Herbert, organist and teaclier. Graduated Mus. Bac., Cambridge, 18s5. Organist of St. Mary's, Abchureh,

\section{ROIBNSON.}

London, 1858; st. Bartholonew's Hospital, $186 \pm$; "rganist and choirmaster, Charterhouse School, Godalning, from 1872. Mtrmber, and sometime Director, of the Pluilhanmonic sxietr. Composer of a cantata, "Traise the Lord"; C'hurch services, pf. picees, ete.

Rodinson, Hamilton, linuist, organist, and composer, horm at brighton, December 6 , 1861. situdied at Ri.A. II. Mns, Bac., I)rham, 1891; F.R.('.). In 1879 : plpointed organist and choinuanter, Brumsicli ('hapel, Hyde l'ark, I. ndon; and in 145.5 to st. Fitephen's,

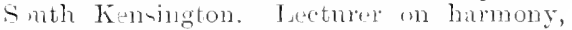
King's C'Alege, London, and sone tinne condactor of Burington Choral Asnotiation. His wife, a contrallo rocalist, was edueated at the R.A.M., and in 1895 Wian appointed a profesisor of singing at King's College, ladies' department.

Works. - Sacred Cantatal Cantata for ladies roices; Orcrture orchestra, and Postlude for orehtstra and organ, in MLs. Morving,

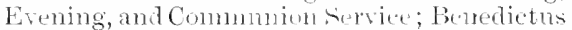
and Agmos Ine in F flat; Three Christmas Carols. The Fisherman; In thence; Love's Challenge; and other sollgs. Phantaniescenen; Impromptu; Valse Caprice; Tarantella; Gavote and Mnsette; Three Slietches, etc, for pf.; andante, ongan, etc.

Robinson, John, organint and eomposer, born in 1682. Te studind in the Chapel lioyal mater Dr. Hlow. ()rourist of St. Lawrence Jewry, 1710, and st. Magnus, 1713. Organist of Westminster Albey, 1727. He

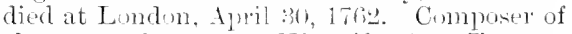
chants, psalms, tete. Jis wife, Axx T'urxer Ropertsos, whom be married in 1716, was a vocalist of some famte in hor day, and sang in the works of Jandel. Whe died on Jannaty $5,17 \pm 1$

Robinson, Joseph, the mont distinguished of a rematlatble fambly of musicians.s. The

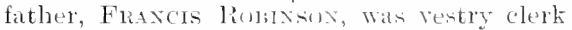
at sit. Peter's Parish Chureh, lonblin; a profesisur of music, and laritare singer. He fornded, in 1810, a society wlled the "Sons of Handel." of his serwi childerl, six-four sons and two dangletris lexame profrssional musicians. Fraxcls, the aldest son, born in Dublin, 1799 (?), was a chorister in Christ Chuch Cathedral; organist, st. Patrick's, 1829-30; Tiear-choral, tenon, C'lnint C'hurch, 1833, till his death, ()etoles 31, 1872. He was a Mus. D.e, honoris consti, Dublin, and Was the componer of some chunch musie and songs. He also edited Irish Melodies, with an introduction on Irish Music, by George Farqubar Grabam. Dullin, Buscell 1868]. Willy the seeond son, latd a hasis voice of exceptional quality and lange. He was a member of the St. Patrick's choir as late as 1845, and also of the elonirs of Christ Church and Trinity College. JuHx, the third son, 


\section{ROIBINSON.}

bom, 1812 (?). was also in the Cathedral Choirs. He had a turnor voice ranging to the high I). He was organist of St. Patrick's, 18.8; Trinity College, 1834; and of Christ Church, 1841. He died in 1844. JosEPH, the youngest som, was born in Dublin, August 20, 1816. Fntered the choir of Sit. Patrick's, 1824 , and when his voice loroke became olganist of Sandford Church. When a youth, visited Paris and London, gaining valuahle experisuce, and becoming acquainted with leading musicians. In 1894 cstablished in I) blin, the "Antient Socicty," which he conducted for nearly thirty rears, introducing many important works for the first time to Dubin. Became eorductor of the University Choral soeicty in 1837. Conducted at the opening of the Exhibitions at Cork, 1852 and 1883; 1)ublin, 1853. Professor of singing at Royal Irish Academy of Music from 1856, into which institution be infused new life; and in 1876 established the Dublin Musical suciety, which gave its last concert, I lecembes 6,1888, but was afterwards revived under Dr. Jossph smith (q.r.) In Angust, 1896, on attaining his eighticth rear, Mr. Robinson retired trom active work. As a laritone vocalist he long held a foremost position; while as a conduetor and teacher he was in the frout rank. His compositions include anthens, services, and songs: and he wrote a March for the oprening of the Duhlin Exhibition, 1882. It was for Joseph Rolnisson that Mendelssohn scoled for orchestra his setting of "Hear my Prayer," originally written with an acoompminent for organ alone. He married, in 1849, Miss FANNy Anthl'R, a pianist and composer, born, September, 1831. Studied at first at Southamptom, and later under sterndale Pennett and Thalberg. She played at Dublin in Felsuary, 1849; appeared at the matinees of the Mnsical [nion, London, June 26, 1855; and at the New l'hilhamonic Concerts, Jine 18, 1850. That year she became a professor at the R.I.A.M. She composed a sucred cantata, " (rod is Love," still occasionally performed; a number of pf. pieces, and some songs. She died at Dullin, Octolue 31, 1879.

Robinson, Thomas, musician of latter part of 16th and logginning of 17 th centuries. Author of "The Schoole of Nlusicke; wherein is tanght the perfect method of true fingering of the lute, pandora, orpharion, and viol-degamba, with most infallible general rules both atsie and delightful: also a method how you may be your own instructor for prick-song, etc.." London, 1603. New Citharen Lexsons, with perfect tunings of the same, London, 1609.

Robinson, Sir William Cleaver F., amateur composer, horn in 1839. Fourth son of the late Adniral Sir H. Robinsom, of

\section{ROCKSTRO.}

Rosmead, County Meath, and hrother of Lord Rosmead (sir Hercules Robinson). Private Secretary to his brother; Goremor of West Australia, 1880; South Australia, 1882; Victoria, 1889: and West Australia, 1890-5, when he retired, and settled in London. He died thele, May 2, 1897. He composed the operas, "The Handsome Ransom, or the Brigand's Bride," produced at Perth, Western Australia, and at Mellowne, 1893; and "The Nut-lorown Maid," completed 1896. His "Unfurl the Flag" was the first national song the Australians possessed. Other of his songs are: Remember me no more; Imperfectus; Severed; I love thee so; Thou art my soml, ete. He was also an accomplished violinist.

Robinson, Winifred, riolinist, born at Boston, Lincolnshire. Situdied at R.A.MI. under Sainton. Felsall prize holder, 1885. A.R.A.M. As a youthful performer was heard at the Bimningham Saturday Concerts in Felruary, 1880, and in other provineial towns. In 1 sst she made a successful appearance at Brunswick; and since 18s, has given concerts in Isondon. In 1895 she orwanised a ladies' string quartet, which has atyuired a good reputation in chamber music.

Roby, Arthur, organist and composer. Organist and choimmater at Stamford Hill Church, London. He has composed a sacred cantata, "Blind Fartimaus," prodnced, Octoher 13,1892 ; and two operettas, "1990," and "Won by wit," perfolned at Myddleton Hall, London, October 16, 1895.

Rock, Michael, composer and organist, horn in latter part of 18 th century. He studied under Ior. B. Cooke, and in 1802 became srganist of St. Margaret's, Westminster. He died in London, March, 1809. Composer of glees, "Beneath a churchyard yew," "Let the sparkling wine go round" (prize, 1794), etc.

Another mmsician mamed WrLtin Rock, a relative of the foregoing, was organist of st. Margaret's Westminster, from 1774 to 1802. He composed glees, "Alone thro" unfrequented wilds" [1790], ete.; songs and instrumental music.

Rockstro, William Smyth, originally Rackstraw, organist, composer, and writer, borm at North Cheam, Surrey, January 5, 1823. Studied under John Prikis, and later with Sterndale Bemutt. At the farewell concert of Francois Cramer, Hanorer Square Rooms, June 27, 1844, Staudigl sang a song, "Soon shall chilling fear," composed by Rackstraw. An overture for orchestra,, "Twelfth Night," was rehearsed by the Society of British Musicians, September 21 following; and a duet from an opera, "Die Weldon," was given at a concert of that society, March 27,1845 . After that time to the middle of 


\section{RODIDIE.}

1846 he studied at Leipzig Conservatorimm, and was one of the few who enjoyed the direct tuition of Mendelssohn. On his return he became known as Mr. Rockstrn, this being an older form of the family nane. He appeared at tines as a pianjst, and was accompanist at the British, and "Wednesday Concerts" at Fxeter Hall, ete. In 1847, in conjumetion with J. Wrey Mould, he began to edit, for Boosey and Co., a series of operas in vocal score, with menoirs, and indications of the instrumentation. Ther were the first operas published in monthly parts, at a cheap rate. Lived for many years at Torquay, and was, from 1867 , organist and honorary precentor at All Saints', Babbicombe. In 1876 he was received into the Church of Ronnc. He conducted concerts of Italian and wnglish sacred music of $16 \mathrm{th}$ and $17 \mathrm{th}$ centuries at the "Inventions" Exhilition, 1885, and, returning to London in 1891. give lectures at the R.A.M. and R.C.M., at the latter taking a class for plain song. In ancient ecclesiastical music he was a high anthority. He died in London, July 2, 1895.

Works. sacred cantata, The (rood siherpherd, produced at (iloncenter Festival, 1886; $O$, too eruel fair, madrigal, five roices, Bach Choir, 1894; ballet, Flora's l'ath, Bristol Madrigal Society, 1891; Queen and Huntress, A Jewel for my Lady's Far, and other songs; overture, Nieser, orchestra, 18t8; nuncrons light pieces for pf.; Festival 1'salter, adapted to the Gregorian Tones; Accomprnying Harmonies to the Ferial Psalter: Harmonies for Additional Chants and the Ambrosial Te Deum. Literary: A History of Music for Young Students, 1879; Practical Hamony, 1881; The Rules of Comnterpoint, 1882; Life of George Frederic Handel, London, Macmillan, 1883: Mendelssohn (Great Musicians Series). 1884; A General History of Music, Sampson Low, 1886; Jenny Lind, the Artist (with Canon Scott Holland). Nurrar, 1891; Jemny Lind, her Vocal Art and C'ulture (with Otto Foldsclmidt), Novello, 1ry4; a long series of ralnable papers in Grove's Dictionary; contributions to the Musical Times, Musical society, and other jouruals.

Richard Shepherd Rockstro, his hrother, is a professor of the flute at the (ruildhall School of Music. He was for rears in olchestras under Costa, and principal flute in British Orchestral Society, 1s72. Anthor of a Treatise on the Construction, History, and Practice of the Flute, London, Rudall, 1891? Also of the section relating to flutes in the descriptive catalogue of instruments at the Military Exhibition, London, 1890, compiled by Captain Day (q.e.)

Roddie, William Stewart, composer and teacher, bom in Glasgow, September 11, 18+5. Prought up to the business of an
RODIVFLL.

engraver; after some years abandoned it for music, for which he had a strong predilection. Received most of his musical training at the Andersonian University, Glasgow, and began his professional career at Perth, in 1871. In 1873, he removed to lnverness, where he is now settled. He is choirmanter in the Free High Chureh, conductor of the Choral $\mathrm{L}^{\top}$ nion, and superintendent singing-master to the sichool Board. He is also professor, Art of Teaching, in the Tonic Sol-Fa College, London.

Works.-Uperctas for Children: Queen of the Seasons; Hormit's Cell; The little old Woman; Sir Christus the (rood; Little Folks at Play; Norseman and Saxon. School Gantras: The sipring-tide Holiday; The Forest Rovers; The Nleeping Beauty; The House that Jack Built; Valentine and Orson; Aladdin; Ali Babu, and others. school song books, action songs, part songs, ete. Translator of The Bohemian (irl and Naritana into Tonic Sol-fa notation.

Rodney, Paul, composer, of present time. He has pmblisherl a number of songs, anong which may be named A l ream of Bethlehem; A Dream of golden days; As once in May; Alone on the raft; Emmannel; Thy King; On Carmel's Hill; Galvary; Fisher's Goodlye: In a garden of roses: Time and Tide; Tienezia, etc.

Rodwell, Anne, authoress of "The Jurenile l'ianist, or a mirror of music for infant minds," London, 18.35; 2nd edition, 1843.

Rodwell, George Herbert Bonaparte, composer and dramatist, was born at London, November 15, 1800 . Sion of Thomas Rodwell, part-proprietor of the Adelphi Theatre, on whose death, in March, 1-2y, he suceeded to his share in the theatre. Mnsic-director of Govent Garden, 1836. Married to Miss Liston, daughter of John Liston, the comedian. He died at Pimlico, London, Jammary 22, 1852.

Works.-Operettas, etc.: Bottl Imp, 1828; Nason of Buda, 1828; Nipring Lock, 1829; Earthquake, 1829; Tevil's Elixir, 1829; My own lover, 1832; Hvil eve, 183\%; Lord of the Isles, 1834; Panl Clifford, 1835; Sexton of Cologne, 1836; Jack Shelpard, 1839; Grace Darling; Die Hexen am linin; Sathanus; Don Quixote; Bronze Horse; Quasimodo (from NTeber's "Preciosa"); Last days of Pompeii. Songs of the Sablath Eve, poetry b. F. Fitzball. Siongs of the Birds, hy Fitzball; Six rounds, 2 looks, London, n.d. Royal Serenades, 3 part-songs. Songs : A cup of nectar; Awake, ye gallant sons of Greece; Banks of the blue Noselle; Beantiful blue violets; Blind Huwer-girl's song: Flower of Ellerslie; Hurrah! for the road; Here's a health to thee, Mary; Land of the free; Muleteer; Nix, my dolly, pals falie away; 


\section{ROE.}

Poor Louine; Song of night; Up, brothers, up; Who cares, etc. The First Rudiments of Harmony, with an account of all instruments employed in an orehestra, London, 1830. A catichism on Harmony, London, n.d. The Guitar, London, n.d. Edited Whittaker's hand-books of musical instruction [1845. A Letter to the Nusicians of Great Britain, Lomdon, 1833. Also a few novels, of which "old London Bridge" ran through several editions, and was reprinted in America. "The Memoirs of in Unibrella," and "Woman's Lofe," are two others. He also wrote farces and dramatic pieces.

Roe, John W., bass singer, who wrote a number of songs for John L'arry and others, and did mueb to foster the cultivation of Glees. He died at Howe, Brighton, Mareh 2, 1853.

Roe, Richard, clergyman, focalist, and writer, who died at London, April, 1859. Ile wrote "The I'rinciples of lihythm, both in Speech and Ilusic, enpecially an cxbibited

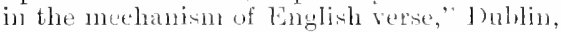
1823.

Roe, Samuel, musician, issted " ledfordshire IJasmony, a set of original tunes," London, 1.425.

Roebuck, Alfred, compiler of "old Methodist Tumes, intended to illuntrate a lecture entitled "Stories of uld Mcthodist hrmns," Manehester, Herwoud, 1sint.

Roeckel, Joseph Leopold, pimint and? composer, born in London, April 11, 1835. Foungest son of Profesisur Joskpa Accicstes Roferel, vocalist and operatie director (1783-1870), who, in 1832, produced for the first time in England, (ierman opera in the original languare, Becthoven's "Fidelic," May 1s, ete. J. L. Roeekel studied under his father; at Wiirglourg, with Eisenhofer ; and with Johamn (iötze, at Weimar. Settled at Chiftort, as teacher and composer. Itas bee'n often heard as a pimist; platyed at the first of Mr. Riseley's Popular Concerts, Oetober $6,187 \pi$; in Jimningham the wane year, on tour with Pyatt's concert party, ete. " $\mathrm{H}_{\mathrm{e}}$ has eomposed a great number of voeal and instrumental pieces, ontlined in the subjoined list:-C'entat is: F'air Rosamund, produced at the Crystal lalace, 1871: Westwird Ho!; The Ten Virmins; Ruth; Father Christmas; The Sea Naidens; Heather Bells; Mary Stuart; [a fitana; The Minstre] Prince; Jubilee Cantata, The Tictorian Age, I8s7; Nirium ; Yule-tide chimes; A summer sundar morning; The erystal slipper; The woodland sylphs; the angel's gift: Morrio old Fngland: Mountain rose; William Tell (for boys). The Christian's Apmonr, serrice of song. The hour's; 'The silver pentry, operettats for children. Gile's: Twilighe; Airs of stmmmer; Nadeline; In Memoriam (MIle. Tiet-

\section{ROGERS.}

jeus), ete. Dramatic scena, "Siddartha," for baritone solo and oreluestra, Bristol Festival, 1896. Songs of Nature, 12 two-part songs; Two sets of five songs, ol. 12, 13; Lieder-album, six songs; The stent of the lines; Can you forget; Angus Maedonald; Won by a rose; storm fiend; Sun djat ; and many other songs. Sute for orchestra; pieces for violin and pf.; Ahend-Traum; Air dı Dauphin; Fête liummaine; Impromptı eaprices, 22 books; Three Musical Sketehes, ete., for $p f$.

In 1864 he married Miss Jane JaCkson, pianist and comprosur, born at Clifton. Her father-the late S. Jaclison, of the old Water Colour Soeicty, and an excellent anatent musician was her first teacher; and she studied later under l'aner, Halle, Madame Schmmann, Bluntenthal, and Nolique. Appeared at solo pianist at eoncerts given hy Emst Paner in I, mdun; and from 1862 gave concerts at clifton, playing eoncertus by Ilummel, etce, with orehestral aecompiniments. Later, deroted herself chiefly to teaching and compuition, but playing oecasionally in pulblic. (Mn April 4, 18s5, she gave a concert of comprositions ly women. I'nder the name of Jules ne Sirkat, she has pultlished Balmoral, Reverie Maznoka, Prentiere Tarantella, Dinne Rusise, and other pieces for pf., several of whieh have been played by Arabellar froddard. She has also composed A Village Story, Drifting on, and mmmerons other songs; and is the invert or of the "P'anphonia," an ippliance for learning the stave and elefs. She founded, in 18s9, the Teachers' Provident Association, an excellent local inctitution.

Roffe, Alfred Thomas, anthor of " The Handbuls of Shakespeare Musie, being an aceouni of three lumdred and fifty piees of music set to words talien from the plays and poen of shakespeare, the compositions ranging from the Elizabuthan Age to the present time," London, 1sts. "Ghost Belief of Shakerpeare," London, 1851, privately printed, ete. "A musical trial from shaliespeare... to which is artded old English singers, and Mr. Bowman, aetor, singer, etc.," London, 1873.

Rogers, Benjamin, composer and organist, born at Windsor in 1614. Son of Peter Rogers, lay-clerk of St. George's Chapet. C'horister under Dr. Giles, and hay-elerk, st. ('reorge's Chapel, Windsor. Organist, Christ ('hurth Cathedral, Dollin, 1639. Gentleman of st. George's Chapel, Windsor, 16t1. Musicteacher in Windsor. Mas. Bac., Cantal., 165s. Organist of Eton College, circa 1602. Reappointed lay-elerk, Windsor, 1662. Organist of Magdalen College, Oxford, 1664-85. Inus. Doe., Oxon., 1669. He died at Oxford, Jume, 1698. 


\section{ROGEISS.}

Works. - A set of airs in foul parts, for violins, 1653. Hymmus Eucharisticus, 1660. Evening Service in G. Services in D, A minor, E minor, and F. Anthems: Behold now, praise the Lord; Lord, who shall dwell; O pray for the peace of Jerusalem; Teach me, O Lord ; etc., contained in the collections of Boyce, Page, Museley, and Rimbault. IIymms, songs, and instrumental pieces.

Rogers, Edmund, organist and composer, born at Salishury, October 9, 1851. Chorister, Salisbury Cathedral, 1860-5. Appointed organint of Holy Trinity, Windsor, 1869 ; st. Allutrs, Holborn, London, 1870; St. Thomas', Portman Square, 1871 ; and St. Michatel's, Paddington, 18s8, tu present time. Conductor of Merchant Tarloss School Choral Society since 1sif. His componitions are well known in Ameriea and Austratia as well as in this conntry.

Works.-C'antatus: Sacled: The Pilgrim's Progress, 1ss3: Footprints of the siaviour, 1886; The Lord of Crold, 1s90; (iathered Grain, 1890; From Croms to Crown, 1891; A Song of Praise, 1894: The King of Love, 1896. Steular: The Bridal Iay, 1871; Jack and the Beanstalk, 1s79: Blue Beard, 1881; Beauty and the Beast, 1842; John Gilpin, 1883; Forty Thieves, 1s.4; Pells of Elsinore, female voices, 18r8; Golden Fleece, 1890 ; Golden Flower, 1s92; Erangeline, equal voices, 1895. Opercttas: Elinome, or the Border Bride, 1sst; Daisy Dell, 1ss8: Princess Tiny Tut, 1489; The Florikins, 1892; and Woodland Fairies, 1896. Mass in D; Offertory sentences; Hym trmes. Anthoms, songs, and part-songs. 'Chorus, The Crusader, written for a clul, at Philadelphia, 1887. Organ and pf. pieces, ete.

Rogers, Frederick F., organist and composer, born at Cheltenham in $18+6$. Organist and choimaster, Highworth Parish Church, 1863; Assistant organist, Parish Church, Great Malvern; and organist at the College Chapel, 1865; St. Petex's, Malvern Wells, 1869. Appointed manager of Steinway Hall, London, 1893.

Works.-Deborah, sacred cantata, for soli, chorus, and orehestra; Psalm 69; Festival Te Dem in F; Offertory Sentences, and other church music. Cantatas for female voices: The Fairy Flower, 1884; Silver Sails, 1885; Elfin Chimes, 1886; Beantiful Land, 1887; In the hayfields, 1889; The Elfin IVell, 1889. The Old Albbey; Old Church Tower; Pardon; At set of sun; Old England's Flag ; For ever; and other songs. Pf. pieces: Minuet in A; Six Morceaux de Salon; Garland of favourites, 6 Nos., for young players ; Albumblatt, etc.

Rogers, Jeremiah, organist and author, born about 1818 . He was appointed organist of Doncaster Parish Church in 1835, and held
ROMLAIN].

that office until his death at Doncaster, Jamuary 22, 1879, aged 60. Author of a History of 1 oncaster.

Rogers, Sir John Leman, Bart., amateur composer, burn April 18, 1780. Succeded to the loronetry, 1797. Member of the Madrigal Suciety, 1819. President of Madrigal Society, 1520-41. He died December 10,1847 .

Works.-Sixteen glees, for three, four, five, and six roices (edited by T. Ohiphant), London [1842] Chmech service in $\mathrm{F}$; anthems, chants, and other sacred music.

Rogers, Roland, organist, conductor, and composer, bonn at West Bromwich, Staffordshine, Nosember 17, 18t7. Studied under his father, a good violinist, aud a local teacher. In 1858 he was organist of St. Peter's, West Bromwich, and when only fiftcen secured a similar appointment at st. John's, Wolverhampton. IFe moved to Tettenhall Parish Church, in 186s, and in 1871 was appointed to Bangor Cathedral. There he raised the musical services to a high position. He resigned at the end of 1891 . Graduated Mur. Bac. 1870, Mus. Doc. 1875, Oxford. I fine extutant, he has given recitals at St. Geurge's Hall, Liferpool (a series in 1890), and in other places, besides anmal series in Bangor Cathedral. Condueted the l'enrlyon anel Arvonic Choirs, wimning many Eistedalfodic prizes. Is now chieffy devoted to teaching, holding a leading position in Wales. His compositions comprise Psaln 130, for soli, chomis, and strings; Prayer and Praise, cantata, soli, eight-part chorus and orchestra; anthems and selvices; prize cantata, The Garden, produced at Llandudno, Jume 30, 18:16; Flotabel, cantata for female voices: school songs, palt-songs, and songs; symphony for orchestra; string quintet; organ pieces, ete.

Rogers, Rev. Thomas, clergyman and author. Was Choral Scholar, New College, Oxford, 1859-63. Graduated M.A., Oxford, 1861; M.A., Durham, 1882; Mus. Doe., honoris causci, Durham, 1882. Minor Canon, 1864-S4; Precentol', 1872-84, Durham Cathedra?. Occasionally conducted concerts at Durham, to 1884. Precentor, Chehmsford Association of Church Choirs, 1884. Vicas: of Roxwell, Essex. Has published church music, hymn tunes, introits, ete. ; also songs and part songs. Author of "Musical Art: its Influence on Religions Life and Thought, 1883 ; "Church music in rural districts," 1856 .

Rollinson, Matthew, violinist, teacher and conductor, borm about 1806. He was well known in Yorkshire as a performer, and in Huddursfield as a teacher. He died October 6,1874 , aged 68.

Romaine, Rev. William, clergyman 


\section{ROMANZINI.}

and writer, 1714-1795. Author of "An Essay on Psalmody, by WV. R.," London, 1775.

\section{Romanzini, Maria T., see Bland,} MIARIA T.

Romer, Emma, soprano vocalist, born in 1814. She studied under sir George Smart, and made her dibut at Covent Garden Theatre, London, in 1830. Sang in English Opera House, ete. Appeared chiefly in English operas, which she produced at the Surrey Theatre, London. She was married to a Mr. Almond. She died at Margate, April 11, 1868.

Romer, Francis, writer and composer, born in London, August 5, 1810. Member of the music-publishing firm of Hutchings and Romer. He died at Nalvern, July 1, 1889. Father of Mr. Justice Romer. Composed Fridolin, opera, 1840; The Pacha's Bridal, opera, 1836; Monntain maidens, cantata; Musical Readings of H. IV. Longfellow's Poetry, 1852-61, issued in parts. Songs : Six songs [1853]; Day dreams, Fair Chloris, F joyfully carol, F've watched with thee, Maiden of the sumny clime, Now smiling comes the joyous spring, $\mathrm{O}$, mother, hear thy poor blind child, The lay of the chimes; I'art-mnsic for three and four voices, ete. "The Physiology of the Human Voice," London, 1845 and 1850. School of Singing, London [1861].

Romer, Thomas, tenor singer, who sang nncter the name of $T$. R. Travers, was born at Liverpool in 1817; died at London, May 20,1855 , aged 38 .

His sister Axvie (Mrs. William Brough) was a soprano singer. She was born in 1829 , and died at London, February 1, 1852, aged 23. Nade her stage dibut at the Adelphi Theatre, Liverpool, September 30, 1846.

CharLes Rourer (a relative?) was singing in London at concerts in 1844, and was well spoken of.

Ronald, Landon, pianist and composer, born in London, June 7,1873 . When a child studied pianoforte under Ad. Schloesser and Carlo Albanesi. Scholar, R.C.M1., studying under Franklin Tavlor, Tr. Hulsert Parry, R. Gompertz, and 1). Bridge. Shewed extraordinary talent as a pianist, and appeared in public in 1887; but tumed later to composition and conducting. Was pianist on tour with "LiEnfant Prodigue" company, 1891. Engaged as conductor at Drury Lane, in opera, April, 1896. He has composed an operetta, "Did you ring?" produced by the Grosvenor Club, November 29, 1892, and is understood to have in hand an opera on a large scale. His published songs include: The Future (composed at the age of eight); I love Thee; When the Lamp is shattered; Love in absence; and others. Pf. pieces: Une Idée; Pallade, ete. Part composer of music to "The Little Genius," Shaftesbury Theatre, 1896.

\section{ROOTSEY.}

Rooke, William Michael, or liovrke, composer, born at Dublin, September 29, 1794. He was self-tanght in music, with the exception of a few lessous from Dr. Cogan. Chorns-master and deputy-leader at Crow Street Theatre, Dublin, 1817. He settled in England, and became chorus-master at Drury Lane Theatre, London; leader at Vauxhall, under Bishop, and teachex of singing. $\mathrm{He}$ died at London, October 14, 1847.

Wonks.-Operas: Amilie, or the Love Test, London, 1837; Hemrique, or the Love Pilgrim, London, 1839; Cagliostro, opera (MS.); The Valkyrie, opera (IIS.); Overture for orchestra; Polonaise for violin; Farewell merry maids (chorus). Songs: Little Cupid once tapped at a maiden's heart; Hark the echo. Pf. music, etc.

\section{Rookford, Rudolph, see CRAWFORD,} WiLLIANI.

Rootham, Daniel Wilberforce, baritone vocalist and conductor, born at Cambridge, August 15, 1837. Hisfather, Daxied Roothan, was a bass singer in the choir of Trinity College, Cambridge, from 1815, wntil his death in 1852. At eight years of age the son was admitted a chorister at Trinity and St. John's Colleges. Studied under his father, and for five years with Ir. T. A. Walmisley. On the death of his father he removed to Bristol, and was appointed a lay-clerk at the Cathedral. After this time he studied singing under Schira. In 1865 he succeeded J. D. Corfe, the cathedral organist, as conductor of the celebrated Bristol Madrigal Society, and in 1878 was appointed conductor of the Bristol Festival Choir, retaining these positions to the present time, with that of chorus-master at the Bristol Festivals. Was engaged in concert singing to about 1870: and was organist at St. Peter's, Clifton Wood, 1866, giving up his cathedral appointment in 1877. His time is now ehiefly devoted to voice training; and being an accomplished linguist and elocutionist, he has heen engaged for lectures on voice management at Wells Theological College, and elsewhere.

His daughter, Mabel MLargaret Roothay, was the first Bristol Scholar at the R.C.MI., where she studied pf. under Franklin Taylor, and violin with R. Gompertz. She made a snccessful début at Victoria Rooms, Clifton, October 9, 1891, and is now pianist of the Popular Chamber Concert Society, Bristol, and engaged in teaching pf. and violin.

Sanuel Roothan, brother of D. F., tenor rocalist, was in the choir of Bristol Cathedral for many years from 1851. He is musical instructor at the Blind Arylum, Bristol, and conductor of the Redland Park Hall Band. In a quiet unobtrusive way he has done much good work.

Rootsey, S., author of "An attempt to 
ROSA.

simplify the Notation of Music, together with an account of that now in use....," London, 1811.

\section{Rosa, see Parepa-Rosa.}

Rose, Algernon S., writer on music, and composer, born in London, January 27, 1859. Educated at Broadstairs, Kent, and at Stuttgart and Yverdon, Switzerland. Studied pf. under Buttschardt, and Carl Hause, and violin under Kettenns. In business connection with the house of Broadwood \& Sons, he has twice travelled round the world. F.R.G.S.; Fellow of the Philharmonic Society; and Liversman of the Musicians' Company. Hon. Sec., Vestminster Orchestral Society. Author of "Talks with Bandsmen: a popular handbook for brass instrumentalists," Londun, Rider : "Crreater Britain, musically considered," a paper read at the Inblin Conference (1895) of the Incorporated Society of Insicians; Contributions to the musical press. Composer of the "Queen's March Past," the regimental march of the Queen's Westminster Tolmuteers; Waltzes, "C"est Moi," and "Climes," for pf., and also for orchestra.

Rose, Henry Robert, organist, born at Bedford, May 6,1855 . Son of Robert Rose, many years organist of st. Panls, Bedford, Studied at R.A.M., under G. A. Macfarmen, Dr. Steggall, and others, from 1872. Second Read Prizeholdcr, 1879, for a quartet for pf. and strings. In 1880 he was appointed organist of St. Pancras Church, in succession to Henry Smart, a position he still holds. He has given organ recitals at Bow and Bromley Institute, from 1883, etc. Is a Fellow of R.A.M., and professor of the organ at that Institution. In 1880 he married MIiss C'LARA SArrelel, the soprano vocalist. She was born at Manchester, August 29,1857 . Studied in that city under Henry Wilson; later at Milan; and in 1876 gained the Parepa-Rosa Scholarship at R.A.M., and the Parepa-Rosa Prize in 1880. Elected an Associate, 1881. She has sung at the principal London and provincial concerts; at the Crrstal Palace; and is an Associate of the Philhammic Society.

Rosen, Lina, see sub., Balfe, Michaed W.

Rosingrave, Daniel, or Roseingrave, organist, who was a chorister in the Chapel Royal, and a pupil of Purcell, and Blow. He was successively organist of Winchester Cathedral, 1681; Salisbury Cathedral, 1693-98; organist and ricar-chural, St. Patrick's Cathedral, Dublin, June 9, 1698-1727; organist and stipendiary of Christ Church, Dublin, Norember 11, 169s. He died at Dublin, in May, 1727. His son, RALPH, became ricarchoral of St. Patrick's Cathedral, 1719; organist there, and of Christ Church, 1727, which post he held till his death at Dublin,

\section{ROSS.}

in October, 1747 . Thoms, another son, was born at Dublin, and was educated by his father. He studied at Rome, at the expense of the Dean and Chapter of St. Patrick's Cathedral, 1710. Composer at the King's Theatre, London, 1720. Organist of St. George's, Hanover Square, 1725-37. He died insane, at London $[1750]$. He published "Voluntarys and Fugues, made on purpose for the organ or harpsichord," London [1730]. "Twelve solos for the German flute, with a thorough-lass for the harpsichord," n.d.; "Eight suites of lessons for the harpsichord or sprinmet in most of the keys," London [1720] : Concerto for harpsichord; Six double Fugnes for organ or harpsichord [1750]; Twelve solos for a German flute $[1730]$; Six Cantatas, with accompaniments.... London, n.d.; "Narcisslis," opera by D. Scarlatti, adapted for the English stage, with additional songs, 1720 ; A collection of forty-two suites of Lessons, by D. Scarlatti, with an introduetion. Also some anthems, Italian songs, etc.

Ross, John, organist and composer, born at Newcastle-upon-Tyne, October 12, 1763. He studied music under Hawdon. In 1783 he became organist of st. Paul's Church, Aberdeen. He died at Craigie Park, Aberdeen, July 28, 1837.

Worrs.- Six concertos, for pf. and orchestra; Seven sets of 3 sonatas, for pf., op. 5 , 31,45 , etc.; Three sonatas, for pf. and flute or violin, op. 16; Four sets of six waltzes, for pf., op. 9, etc.; Duets for pf., op. 26, etc. Ode to Charity, for solo, chorus, and organ; Six hrmms, for 3 voices and organ; Two books of 6 canzonets, for voice and pf., op. 18, etc.; A select collection of ancient and modern Scottish airs, adapted for the roice, with introductory and concluding srmphonies and accompaniments for the pianoforte, Edinburgh, 1792, 3 rols. Fifteen songs, witten by Burns and Ramnie, composed with accompaniments for the pf., violin or German flute, op. 11, 1,ondon, n.d. Sacred Nusie, consisting of chants, psalms, and hymms, London, ni.d. A complete Book of Instructions for beginners on the harpsichord or pianoforte, to which is added a select set of airs, Scots songs, and lessons, London, 1820. Songs: Aberdeen volunteers (Ewen); Ance I was as blythe; Braes of Ballochmyle; Come, Cynthia; The Coronach; Ellen of the Dee; Maid of Seaton Vale; Valley of Clyde, etc.

Ross, Roger Rowson, amateur musician, born at NIontrose, August 25, 1817. Resident in Manchester, and has taken an active interest in music by founding two scholarships at the Roral Academy of Iusic, one for the study of sacred rocal music, and the other for performers on wind instruments. Composer and adapter of varions hymns, etc., for the Church service. 
ROSS.

Ross, Robert, musician, bom in 174 s. He was a music-seller in Edinhurgh, and carried on business at the back of the Fountain Well, and afterwards at the head of Carrubbers' Close. He gave pulplic concerts in Edinburgh, and retired about 1805. He died at Edinburgh in 1808, aged 60. Con1piler of "A Choice Collection of Scots Reels, or country dances and strathepeys, with a bass for the violincello or harpsichord," Edinlumgh, 1780.

Ross, William, piper, was born in Rossshire, abont 1815 , and died at Windsor, in August, 1891. In 1839 he joined the fond Highland Regiment, and remained in it till 1854, when he was appointed piper to the Queer. He issued a "Collection of Pipe Music," 1869, and another edition, "with an essay on the Bagpipes and its music, lyy the Rev. Dr. Nomuan Macleod" [1876]; 3rd edition, 188.5.

Rosse, Jeanie, Mrs. H. A. Qumton, contralto voealist, loon at Notting Hill, London, July 29, 1860. Received her. first munical training at Madane Sainton-Dollyy's Academy, afterwards studying morer Randegger and W. Shakespeare; also studied opera under Trantezzani, of the Naples Conservatoire, and declamation and acting under Fdmmed Russell. While still a pupil of Madame Dolly, she made here debut at the Crystal Palace Concerts, and later had many engagementis in London and the chief provincial citien. In June, 1898, she made loer first appearance on the stage at St. Feorge's Hall, London, as Nancy, in "Martha." The next year she joined the Carl Rosa Opera Company, but remained only a short time; on her inariage settling in Intslin, where, 1891, she was appointed a professor of the Royal lrish deadrmy of Mnsic. There she successfully conducts a declamation class, and also holls appointments at Loretto Ahbey and other inntitutions.

Rossetor, Philip, lute-player and composer of the first part of the 17 th century. Published "A Booke of Ayres, set foorth to be song to the Lute, Orpherian, and Base Violl," London, 1601; "Lessons for" Consort, made by sundry excellent authors, and ret to sixe several instrments, namely the Treble lute, Tredele violl, Bass violl, Bandora, Citterne, and the Flute," Lomdon, 1609.

Rothwell, Alexander, flute player and writer, of latter part of the 17 th centrirv. Author of "The Compleat Instructor for" the Flute, containing very plain and easie directions for beginner's, with variety of newest tunes. . and fourishes in every key." London, [1698].

Rousbey, Arthur, baritone rocalist, studied in Italy under Sangiovanni, and in London under T. A. Wallworth. First sang

\section{ROYILAND.}

in opera in Charles Dnrand's Company, then from 1578 apperared in a round of characters in the Gilbert-Sullivan operas, in London, the provinces, and America. In 1884 he sang in Nessler's " Pipes" of Hamelin," at Covent Garden; and subsequently in Italian opera, in "Rigoletto," ete. He has also been heard in concerts in varions places. About 1888 he organised an opera company of his own, which has appeared in every important town in the United Kingdom, and has had several successful seasons in London. He produced, for the first time on any stage, Daniele Pellegrini's opera, "Mercedes," at Dublin, Jamuary 11, 18:6; and has given, with excellent ensemble, a large number of standard works.

Rowbotham, John Frederick, anthor and composer, liom in Edinburgh, April 18, 18.54. Only son of the late Rev. Frederick

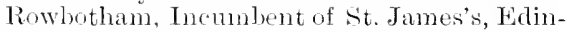
burgh. Edncated at Edinburgh Academy, and Rosisall Sehool. Proceeding to Oxford, he gaincd the Balljol scholarship when eighteen, and also took a first class in classics, and the Taylorian Scholarship for Italian. Travelled on the continent to collect materials for his History of Music. Studied music while at Oxford, and afterwards at Berlin, at the Stem Conservatorium for three years, with further study at Paris. Dresden, and Vienna. Ho has composed a Mass for double-chorus and orclestra; three songs to words by Alfred Mnsset; songs, valious, ete. Author of "A History of Music," 3 vols. Lendon, Trübner, $1885-7$; "How to write Nusic corlectly." Londin, Epeott Gill, 1889; "Private Life of Creat Compueri," Isbister, 1892; "The Trombadoms, and the Conrts of Love," Swan Sonnenschein, 1895. Contributed the musical articles to ('hambers's Encyclopitedia, and many papers to the Nineteenth Century, National Review, Blackwool's Magazine, and others, and also to the musical press. Author of poetical wolks, "The Death of Roland," 18s6; and "The Human Epic," 1890, both pulilished by Trülmer.

Rowden, George Croke, amateur musician and clergrman, born in 1820. He was hon. Precentor of Chichester Cathedral from 1859. Died, April 17, 1863. Founder of Chichester Choir Association. Composer of a magnificat and nnuc dimittis, and other church muxic; "Return of May," "Sweet evening loom,", and various other glees, songs, ete.

Rowland, Alexander Campbell, doublebass player, violinist, and composer, born at Trinidad, Jannary 1, 1820. His father was a fine clarinet player, and a band-master who served throngh the Peninsular campaign. The son, while an infant, was brought to Bath, and, when about six years old, received 


\section{ROWLEY.}

violin lessons from John Loder. Before he was seven, he entered the orehestra of the Queen's Theatre, London; and also played the side-drum at the Promenade and other concerts. He learnt scoring from Waetzig, bandmaster of the Life Guards, and in 1846, began the study of the double-bass under Casolani, becoming one of the most remark. able performers on that instrument. Played cornet, arum, or viola in Jullien's band, 1842-6. Joined the Phillarmonic olchestra in 1849, and was also in Royal Italian Opera, Sacred Harmonic, and principal Festival bauds. In 1854, he went to reside at Sontlhampton as music teacher, but continued his work in the Philharmonic Society mutil 1866, when Sterndale Bennett resigned the conductorship. At the Philharmonic concert, April 29, 1861, he played Mayseder's Tioliu Concerto, op. 40, on the double-bass. At Southampton, he conducted choral and orchestral societies, and did much valuable work. When sixty years old, he entered the examination for A.R.C.M., and passed with horours in seven subjects. He retired from active work in 1893, and died at Southampton, August, 1896.

Wonks.-Ps. 70, for voices and orchestra; Overture, orchestra; Set of Waltzes, for pf. and orchestra; original air in $C$, double-bass and pf. Various works in MIS. Blessed be the Lord: Moonrise; Morning thonghts; and other songs. Course of Exercises in partsinging, Stanley Incas. Author of a Method for the Double-Bass, in Two Parts, originally published by Lamborn Cock.

Rowley, Christopher Edward, com poser and organist, born in Manchester, January 5, 1840. Studied pf. and organ under George Grundy, of Manchester"; harmony and counterpoint with H. C. Banister. Appointed, when nineteen, organist and choirmaster, Christ Church, Harpurhey; since 1885, has held a similar post at St. Augustine's, Pendlebury. Has formed and trained many of the voluntary choirs in Nanchester and district, and in 1879, founded the Musical Union bearing his name, a Society that has produced many operas, with stage accessories, as well as the principal oratorios and cantatas. Is now chiefly engaged as a voice trainer,

Wokks.- Operas: The Drage? of Wantley (1881); Eulatie (1887); The Early English Ring, now called Robinson's Craze (1890, produced, MIanchester, 1891); Tilburina, or, The Spanish Armada (1894). Cantata, Doldrum, the Manager (1885). Anthems, Communion Service in F, Twelve Fongs (1891), songs, duets, glees, and part-songs. Romance and Scherzo, wind quintet. Contributions on musical topics to the local press; now engaged on an important work on voice-training.

\section{RUSSELL.}

Rowton, Rev. Samuel James, clergyman and musician, born in London, July 3 , 1844. Musical training private. MI.A., 1874, University College, Durham; Mus. Bac., 1889 ; Mus. Doc., 1890, Dublin ; Mus. Doc., 1891, ad eundem, Durbam. Organist and director of the music at Royal Medical College, Epsom, from 1872. He has set Cardinal Newman's "Dream of Gerontius," for soli, eight and twelve-part chorus, and orchestra; and lias published some hymus, songs, and pf. pieces.

Rudd, HenryWilliam Kingston, pianist and organist, born at Norwich, May 27, 1850. Began his studies at the age of six, under his father, HENRY RUDD, a musician of repute in the Eastern Comnties. Later he received instruction from Charles Halle. When ten years old he was appointed organist of Intwood Church, near Norwich; then of Thorpe Parish Church; and in 1870 , organist and director of the choir of St. Andrew's, Norwich, offices he still holds. As a pianist he appeared with great success at the Norwich Festivals of 1872 , and 1878 , playing in each portious of concertos by Benedict. In 1582 he was heard at the Wednesday Concerts at the Crystal Palace. He has conducted the Norwich Gate House Choir, since 1872, and given important concerts, the first artists leing associated with him in classical works.

Rush, George, composer of last half of the 18th century. He composed music for The capricious lovers [176t]; and the Royal Shepherd. Also, Concertos for the harpsichord [1785]; Six easy lessons for the harpsichord, calculated for the improvement of young practicioners, London [1770]; Sonatas for pf. or liarpsichord; Concertos for p.f., violin, and 'cello; Sonatas for the guitar.

Russell, George, pianist, who was a man of mark and promise in his earlier years. When eight years old he appeared at a concert with Iiszt, at H.MI. Theatre, London, and afterwards appeared at a concert of Alfred Mellon's, in the Floral Hall. He died at Croydon, November 12, 1889.

Russell, Henry, vocalist and composer, born at Sheerness, Kent, December 24, 1812. Began his musical studies hefore he was six, and was then placed under M. (. King. Sing at the Surrey Theatre in "The Nightinrale and the Raven," and "The Swiss Fanily," when eight reats old, in a children's opera company formed by Flliston. Went to Italy in 1825, becoming an out-door student at the Conservatorio, 13ologna, and aftervards studied for four months with Rossini at Naples. Was Maestro de piano in opera at Taresi, with Balfe in the company. Returning to Fngland, lit was for a time chorus master at Her Majesty"s Theatre. In 1833 


\section{RTESELL.}

went to Canada, and also toured through the United States. While there he composed his first solug, Mackay's "Wind of the Winter Night." On his return to England in 1841 he first went on a tour with Beale for six months, and Mirch 8, 1842, commenced his own vocal entertainment at the Hanorer Square Rooms. The Gambler's Wife, The Ship on Fire, The Maniac, and other of his songs soon beame as familiar as household words. Then followed provincial tours, the suceess of whieh was mprecedented. Later, with Dr. Mackay, he formulated the enter. tainment, "The Far West; or, the Fmigrant's Progress from the Old World to the New," with scenery painted loy Mills. This was also universally popular. He retired from public life albout 1865. Fis sungs reached the number of about 800 , and Longfellow, Dickens, liza Cook, and Charles Mackay were the principal writers whose lyries he set. A few may be named: Wreck of the Hesperus; Chieftain's Jaughter; Canadian Song: Iyy (reen: Old Sexton; Old arm chair; Cheer, boys, cheer; To the West; Far, far upom the Sea; Song of the Raft; Signal fim; Woodmin, spale that trec. To these may be added A Series of Songs from sicott's "Lady of the Lake;" Seripture Melodies; Dranatic Soenes: Cantatas, ete, with a Memoir, London, 1846; Copyright Songs, 2 vols., 1860; LiAmico dei Cantanti; The finger's Friend, a Treatise on the art of singing. His last composition was a Jubilee song, "Our Lumpress (gueen," for 1887. In 1889, ly anthority of the Admiralty, "A I ife on the Ocean Wave" was to be used by the Royal Marines as their regimental march. A "Henry Rusitell" night took place at Covent Garden Theatre, October 12, 1891, under the late Sir Augustus Harris's management. His songs were sumg, and the venerable composer was called upon for a speech. "Truly a remarliable occusion, and one not unworthy of a remarkable man." In 1895 Mr. Russell published Cheer, boys, cheer; Memories of IIen and Music, London, Maequeen.

Wrldial Clark Russell, hom at New York, Febrtary 24, 184t, whose novels of the sea lave olstained great popularity, is his som. "The Wrock of the Grosvenor," "Mr shipmate Louise," "Marooned," and "Conrict Ship" are among some of his most popular tales. Ho has composed and pulplished a few songs.

Russell, Mrs. J., see Huddart, Fandy.

Russell, William, organist and eom. poser, born at London, Octoler 6, 1777. Sion of an organ-builder. He studied under Shrubsole, Arnold, ete. Deputy organist of St. Mare, Aldermanloury, 1789-93; Chapel of Great Gneen Sitret, Iincoln's Inn Fields,

\section{SAFFERY.}

1793-98; St. Ann's, Limehonse, 1798 ; Fonndling Hospital, 1801. I'ianist at Sadler's W'ells Theatre, 1800 , and he held a similar post at Covent Grarden, 1801. Mus. Bac., Oxon., 1808. He died at London, November 21, 1813.

Wonks.-Oratorios: Job, with organ aceompaniments, by S. Wesley (1826); The Deliverance of Israel; The Redemption. Mass in C minor, for four voices. Operus: Adrian and Orilla, 1806; False Friend, 1809 ; Harlequin and Time; Highland Camp; Loa; Rugantino; St. George; Wild Islanders, 1807; Wizard's Wake, 1801. Odes: To music; Genius of Handel; St. Cecilia's Day (Smart); To Harmony. Glees and Songs. Psalms, Ilymus, and Anthens for the Foundling Chapel, London, 1809. Six Anthems, adapted from the works of Haydn, etc.,.... and a moming and evening service composed by the late William Rassell,.... arranged by Villiam Patten. Services and anthems. March, composed for the Guildford Volunteers $[1795]$ : Twelve voluntaries for the organ or pf. [1810.] He arranged Bingley's Welsh Airs, 1810, ete.

Rutherford, David, musician of the 18th ecntury. Author of "Art of Playing on the Violin, showing how to stop every note exactly.." Tondon, n.d.; "Gentleman's Pocket. Guide for the German Flute, with some agreeahle Lessons. ." "Ladies' Pocket Guide for the Guitar.." "Compleat eollection of 112 of the most caltrated minuets with their basses. proper for German flute, violin, or harpsichord." London [1775-80], 2 vols. Compleat collection of 200 country dances." Londom, 1765,2 vols.

Ryan, Michael Desmond, dramatic and mmsicul writer, born at Kilkenny, March 3, 181f. Edueated at Edinlurgh University. Engaged as musical and dramatic critic on staff of The Moming Post, Monning Herald, and Standard. Sub-editor of Musical Worlal. He died at London, December 8, 1868. Author of the libretto of Nacfaren's "Charles II.," and words for rarions musical works by Cronch, Loder, Mori, ete. His son, Desmond LCMLEY RYAN, born at London in 1851, was for a time musical critic of the Standard; editor of The Gem, until 1885, etc. He died at London, November 29, 1888 . Composed a toy symphomy for pf. strings and 15 toy instruments, 1885; pf. music and songs. Librettist of Heap's "Maid of Astolat" [1886], "Fair Rosamond," ete.

Saffery, Eliza, Mrs. Henry Shelton, composer of early part of the present century. Composer of Reminiseences of a Minstrel, ten songs by $\mathrm{F}$, Ryan [1832]; Hours of melody, songs [1836]. Songs: Broker vow; I love thee, native land; Old yew tree; 


\section{SAHASRABADHE.}

Rover's return ; Sailor's grave. Arraugements and other works for pf.

OsMOND SAFFERT, probably a brother or other relative of the above, issued "An introduction to MIusic, with a variety of progressive lessons.. on the pf.," London [1800]. "A select collection of Psalms, as sung at Ramsgate Chapel," London, 1836. College hornpipe for pf.: Reels, dance music, etc.

Sahasrabadhe, B. T., author of "Hindu Music and the Gayan Samaj," containing notes on the recent revival of Indian music, Poona, 188 .

St. George, C., musician, editor of "Mona Melodies, a collection of ancient and original airs of the Isle of Man, arranged for the voice with a pianoforte accompaniment by an Amateur, the words by Mr. J. Barrow. edited by C. St. George," London, 1820.

Saint=George, George, violinist, composer, and performer on the viola d'amore, born at Leipzig, of English parents, November 6, 1841. Studied at Dresden, and under Moritz Mildner, at Prague. He finally settled in London, and devoted himself to teaching and composition. Taking a great interest in antique stringed instruments, he has, with his son (noticed below), given concerts, the two performing on the viola d'amore and viola da gamba, not only ancient music, but modern works as showing the true capacity of those instruments. At a concert given in Steinway Hall, London, November 1 1, 1895, Bach's Concerto for two riolas, with strings and pf. (No. 6, of the Brandenburg Concerti Grossi), was performed for the first time in England. Mr'. Saint-George is an enthusiastic violin maker, and devotes his leisure to that art with great suceess. In 1896 he finished a Viola da Gamba, with dolphin head and inlaid finger board and tail-piece, probably the first made in this century. His compositions include an overture, "Spring's Awakening "; Suite in I), op. 20; Suite in B flat, "Rose, Shamrock and Thistle," in which British National dance forms are employed; and other works for orehestra. A large number of pieces for violin; Romanesca, dedicated to Joachim; L'Ancien liegime, petite suite; Elegy; Pieces, op. 24, 25, 26, etc. Also songs.

Henry Saint-George, son of the pre. ceding, was born in London, September 26, 1866. He was chiefly educated in music by his father, and is a violinist and performer on the viola da gamba, showing equal skill on both instruments. He has composed an opera, a pf. concerto, sonatas for violin and pf., songs, etc., but nearly all are as yet in IIS. An artist of culture he has contributed many articles to The Strad, and other journals.

Saint=John, Florence, the stage name

\section{SALANIAN.}

of Miss Maggie Greig, vocalist and actress, born at Kirkcaldy. Taught by her father, she began by singing suitable songs at dioramic entertainments. Appeared as a vocalist and pianist at a concert at Plymouth. Toured with the "Cloches de Comerille" company, 1878; made her first London appearance in "Madame Farart," Strand Theatre, 1879; sang in a roma of Offenbach, and other operas. Has risited America several times. Joined the Gaiets, 1888, in "Fanst up to date." Has also sung in concerts. Her latest character is that of Paolo in "The Little Genius."

Sainton $=$ Dolby, Charlotte Helen, born DoLbr, composer and contralto vocalist, born at London, May 17, 1821. She studied at the R.A.II. from 1832 miter J. Bennett, Elliott, and Crivelli, and gained the King's Scholarship in 1837. Member of R.A.II. She first appeared as a pullic singer about 1840 , and sang at a Philharmonic Concert in 1841. She also sang in oratorio and ballad music till 1846, when she appeared at a Gewandhans concert in Leipzig, in Mendelssohn's "Elijah," the contralto part of which was specially written for her voice. She afterwards made concert tours in France and Holland. In 1860 she married M. Prosper Sainton. From thence onwards to 1870 , when she retired, she appeared at all the most important concerts in Britain, and became one of the most popular and successful contraltos of her period. She estalblished in London a Vocal Acadeny, 1872, in which many promising rocalists hase been trained. Her last public appearance as a rocalist was made at her hushand's falewell concert, in June, 1883. She died at London, February 18,1885 .

Works.-Cantates: Leegend of St. I Porothea, London, 1876; Story of the Faithful Soul, 1879 ; Florimel, female roices, 1885 . Songs: A stream of golden sunshine; A-sailing we will go; Bonnie Dundee; Coming home; Charlie yet; Come forth, my love; Drummer's song; The G.L.U.V.E.; Heigho! Janet; In August; Is it for ever?; 1 love her; Lady's yes; My Donald; Marjorie's almanack: My love he stands upon the quay; Never again; Watehing and waiting; While I listen to thy voice. Tutor for English singers, a complete course of practical instructions in singing, London, i.d.

Saintwix, Thomas, mnsician of the $15 \mathrm{th}$ century, who was one of the earliest doctors of musie. In 1463 he wals made Master of King's Hall, Cambridge, ly Edward IV. He had been previously made Mus. Doc., Cambridge, and he also held the appointment of chaplain to the king. Saintwix tied in 1467.

Salaman, Charles Kensington, pianist, composer, lecturer, and writer, bom in London, 


\section{SALAMAN.}

Narch 3,181 . Showed musical talent very early, and began to learn the violin when seven, lut after a rear left it for the pianoforte. His first lessons were from his mother, an excellent amatem pianist, and hy her he was placed under S. F. Rimbant. In 182 the was elected a student of the R.A.M., but returning to school he lost the ehances therehy afforded. Studied under Charles Neate, 1826-31. Made his first appearanee in pullie at r. Lanze's concert, Blickheath, in the summer of 18\%8, when his song "Oh, come, dear Lonisa," his first published work, was sung. The same year he went to Paris, had lestons from Henri Herz, and played his kondean lrilliant in I). with orchestra, for the first time in London, March 10, 1830. Produced an Ode at Stratford-on-Aron, April 23, 1890, at the Jubiles Festival in memory of Shakespeare. In 1891 began his mofessional caleer as teacher; gave annual orchestral concerts at the Hanover Squnare Rooms, 14:33-7, introduring, among other artists, Mardame Frisi, 1834, to concert andiences. Instituted, with H. Blagrove, C. Lneas, and others, the Concerti da Camera, the first taking place Nosemuler 7, 1835 . Elected a member of thr horal society of Musicians, and an Associate of the Philharmonic Societr, 1837, withdrawing from the latter in 1855. Vicited the continent in 1836 . playing at Memich, Viemna, and other places, and heeoning acrpuainter with Schumam, Czemy, Mozart's som, Thallerg, and other artisti. Resided in Rome, 1 $446-8$, and in 1847 was made an Hon. Nember of the Academ of St. Cerilia, and of the Plithamonic Society of Rome. Fonnded an Amateur Choral Soeiety in London, 1849 ; played at the Philharmonic Concert, Nareh 18, 1850 , Buethosen's Concerto in (' minor. Commenced a series of lectures on mosical subjects in 1855 , which were continned for some vears in London and the comutry. In 1858 he helped to estahlish the Musical Society of London, and was Honn. Secretary until 1865. Assmed the name Kensington on the death of his father in 1867 . (His father was bom at Kensington in 170 ?). Was one of the founders of the Musieal Association in 1874, and aeted as Hom. See. till 1877 , when he retired, and was elected a vicepresident. All this time he was busy as a teacher and composer, produeing a large number of works (simmmarised below), besides contributing papers to varions musical jourmals, Concordire. The Musical Tims, ete. He was musical ritic to the Circle while it lasted. He played the accompaniments to his songs at Miss C. Penna's concert, June 10, 1886: and his last compositions, two songs, "The resigned lover," and "Concealed love," were issued on the emmletion of his send year, Narch 3, 1896.

Wonks.-Jubilee ode to Shakespeare, 1830.

\section{SALE.}

Psalm 84; Psalm 29, for donlle choir; Have merey upon me; Prenerve me, $\mathrm{O}$ God; and other anthems. A roiceless sigh; Fair is the swan; April, part-songs. Nearly 100 Hebrew choral works for the service of the symagogue. Songs: I atise from dreams of thee, 1836; A leave-taking; Al salir (Spanish); Are other eyes; A toi, toujonrs at toi (Hugo); Du Siisses matchen; Farewell! if ever fondent prayer; My sweetheart; No, I never was in love; Nimmured musie; My star; St. Patrick's Parlianent; The roice of my luve (March 3, 1893); Can'st thou be true? and many others, ineluding settings of odes, ete., by Horace, Catnllus, and Anacreon. Orchestral: Overture in $\mathrm{D}$; Fantasia in $\mathrm{F}$ minor: Grand Funeral March, in homonr of Victor Hugo, 1885. Parade Mareh, for military hand. Rondo al capriceio, pf and orchestra. Twelve voluntaries for organ or hamonimm; Six original pieces in Morley's rohntaries. Pianoforte: Atalanta; Birthilay valse; La vivacita, op. 13; La Nutta serena, op. 17; Il Mulino, op. 18; Syrian mareh; Toceata, op. 44; Zephyrus, op. 54: Tranguility, op. 62; Spring, duet, ete. Lectures: History of the Pianoforte, and the ancient kered instrmments, 1855-6; Handel; Beethoven; Weber; Mrasic in connection with the dance; Hintory of Italian, Geman, and Fnglish opera. Papers in Proceedings of Nusical Association, 18751877-80. Author of Jews as they are, London, Simpkin, Marshall, 18s.2.

llis kon, Malcolm Charles, lyric poet and dramatist, was born in London, September 6, 1855. He is anthor of Ivan's lose-quest, and other poems. London, 1879; and the verses of many of his futher's hest songs; also of words for compositions by sir G. A. Nacfarren, F. A. O-borne, otc. As a dramatic anthor and librettist he has prornced Deceivcrs ever, a farcical comedy, Strand Theatre, November 26, 1883; Boycotted, one act comedictta, with music by Engene Bamett; Dimity's dilemma, farce, Caicty Theatre; Both sides of the question, conedictta; A modem Ere, three-act drama. Haymarket Theatre. Known as a eritic of the drama and of painting; Editor of the published plays of A. W. Pinero; and anthor of the popular book. Woman-throngh a man's eyeglass.

Sale, John, bass rocalist and composer, born at Loncton in 1758. Sion of John Sale (borm at Gainsborongh, 1734; died at Windsor in 1802), who was a lay-elerk of St. George's Chapel, Windsor. He was a chorister of St. George's Chapel, Windsor, and at Eton College from 1767 to 1775 . unter. W. Webh, and lay-vicar from 1777 to 1796 . In 1788 he became a gentleman of the Chapel Royal, London; vicar-choral, St. Paul's Cathedral, 1794; Lay-ricar, Westminster Abhey, 1796; and almoner and master of choristers of St. 


\section{SALE.}

Paul's Cathedral, 1800-12. He became secretary of the Catch Club in 1812, and acted as conductor of the Glee Club, and bass at the Concert of Ancient Music, the Ladies' comcerts, and at London and provincial musical festivals. He died at London, Norember 11 , 1827, and is buried in the crvpt of St. Paul's.

Works. A Collection of New Flees, composed by John Sale..London [1800]. Also some others issued in a collection, with others composed by Lord MIornington, Calleott, ete.

Sale, John Bernard, composer and bass vocalist, brother of the ahove, born at I'indsor in 1779 . He was a chorister in st. George's Chapel, Windsor, and in Eton College, 1785. Lay-viear, Westminster Abber, 1800. (ientheman of Chapel Royal, 1803. Organist of St. Margaret's, Westninster, 1809. Mnsical instruetor to Queen Tictoria. Organist of the Chapel Roval, 1838. He died at London, September $16,1856$.

Works.-Psalms and Hymns for the Service of the Church. Lourdm, 1837. S. Webles's Solfegios as Exercising Inetts, newly arranged by J. B. Sale, London, n.c. Glies: O listen to the voice of love; Yon ask the reason why I love; The Butterfly; Little Piggy, and other duets. Songs: The Rolin, etc. IIarches for pf.

His daughters, Mary Axxe, and Sopula (died May 3, 1869), were also musieians. Another daughter, LAurA, married W. J. Thoms, the author. His brother, Georse Charles, borm at Windsor in 1796 , was a chorister in St. Panl's ('athedral, 1803. ()rganist, St. Mary's, Newington, in snecession to Dr. T. Busby, 1S17; and St. Feorge's, Hanover Square, 1826. He died at London, Jannary 23, 1869.

Salmon, Eliza, born Muxdy, soprano vocalist, was born at Oxford about 1787. She studied under John Ashley, and made her debut at the Lenten Oratorio Concerts, Covent Garden, London, in 1803. In 1805 she married James Sahmon, a singer, and sang at the principal London and provincial concerts till 1824, when her roice was lost, through a break down of her nervous system, caused by intemperance; she married the Rev. MIr. Hinde, after Salmon's death. On the death of her second husband she beeame destitute, and after varions ineffectual attempts to regain a position she died at Chelsea, Jume 5, 1849. Her husband, Janes SaLmon, was organist of St. Peter's, Liverpool, 1805 . He was latterly in very embarrassed circumstances, and went to the West Indies as a soldicr, where he died. His brother Willias (born, 1789; died, Windsor, January 26, 1858), was a singer and teacher.

Salmon, Rev. Thomas, clergyman and author, was bom in 1648. He was educated at Oxford University, of which he was MI.A.,

\section{SAMPSON.}

and became Rector of Mepsall, Bedfordshire. He died in 1677. He wrote "An Ersay to the Advancement of Murick ly casting away the perplexity of different cleffs, and miting all sorts of Musick, lute, riol, violins, organ, harpsichord, voice, ete. in one universal "haracter." London, 1672. "Tindication of an Frisay to the advancement of Munick, from Mr. Matthew Loels's Ohservations.. " London, 1673. "Proposal to perform Nusic in perfect and mathematical proportions" London, 1688. "Theory of Music reduced to arithmetical and geometrieal proportions" (In l'hilosophical Trunsactions, 1705).

Salmond, Norman, bass rocalist, horn at Bradford, Forkshire, August 27, 1858. Studied locally, and first came into notice abont 1886. He sung in the "Messiah" at Leeds Philharmonic Concert, December 19, 1siss: and made a still more important appearance at the Saturday Popular Concerts, London, Jamuary 18, 1490, his sncess being immediate. He was engaged for the part of Richard coenr de Lion in Sullivan's "Iranhoe," February, 1891; made his festival debut in "Elijah," at Leeds, 1892, and has loeen heard at Norwich and Hande] Festivals. Sang at the Philbarmonic Concerts, Mareh 23, 1893; Crytal Palace, December 15, 1894; and in the chicf prorincial centres. Toured in Sonth Afriea, 1895, and in America, 1896; and is now established as an artist of rank. He married an American lady, who in concerts in London and the provinces hals gained a reputation as pianist.

Salter, Humphrey, composer and instrumentalist of the last half of the 17 th century. Wrote "The fienteel companiom, leing exact directions for the Recorder, with a collection of the best and newest tmes and grounds extant." London, 1683.

Sampson, Brook, organist, born in Leeds, Jamuary 5, 1848. Choristor, as a hoy, at St. saviour's Episcopal Chureh, Bridge of Allan. Pupil of Dr. Spark. F.R.C.O. 1870; Mus. Bac. Oxford, 1875. After a short residence at Bradford, he was appointed, in 1s6s, organist and chorister of Jicttering Parish Church; removing to Northampton, he held similar oftices at St. Catherine's, St. Edmund's, and since 1891. All Saints' Church. Conductor of Church Choir Festrvalis, and of Northampton Choral Society. Has composed church music, and is author of a Harmony Primer, and "Notes, Staves, Clefs." a method of learning the rudiments of Musie.

Sampson, George, organist and composer, bom at Clifton, 1861. Organist at St. James's, Bristol, 1879; F.R.C.O., 1882. In 1884, he was appointed organist and director of the music at St. Allan's, Hollorm, London; and in 1888, music master and precentor, Brighton College, which offices he retains. 


\section{SAMUELL.}

He has composed a setting of Commmion Service in D for men's voices; an Evening Service in I): O Salutaris in E flat; Ave Verum in I) flat, for baritone solo, and men's chorus. Part-songs: sichool songs for Brighton College. Author of A Text Book of the Elements of Music; and a Text Book of the Pianoforte, for use in Schools, London, Swan and $\mathrm{Co}$.

Samuell, Clara, see sub. Rose, H. R.

Sanders, Alma, composer and pianist of present time. Studied at Trinity College, London; sometime professor of pf. there. She appeared as pianist at concerts, London, 1880, ete. Gained the Sir Michael Costa Prize, Trinity College, 1880 , for Trio, pf. and strings ; and 1883, for Quartet, pf. and strings. She has also written a Sonata for pf. and violin; foul pieces, violin and pf.; pieces for pf. solo, ete.

Sanders, James, conductor and teacher, was a clariuet player at Portsmoutl. About 1844, he went to Liverpool, where he was a double-bass player, music teacher, and sometime organist at St. Mar'y's, and St. Franeis Navier's churches. Trained the chorns at the Theatre Royal; was conductor of the Liverpool Nusical Society; chorusmaster, Liverpool Festival, 1874; and filled a like office to the Liverpool Philharmonic Society, 1870-80. He died at Liverpool, October 20 . 1891, aged 75. ELLEN SANDERS, his wife, was associated with him in the direction of a private choir, which did exeellent work; and was a teacher of repute. She died at Liver. pool, Mlay 10, 1891, at the age of 65.

Sanders, George Frederick, see PINio George Frederiek.

Sanderson, Edgar, composer and teachel, published "Harmonia Sacra, for private and congregational use," London, 1538-39, two series; and wrote part-songs aud other voeal music.

Sanderson, James, violinist and com poser, born at Workington, Cmmberland, in 1769. Self-taught in musie and on the violin. Tiolinist in Sunderland Theatre. Teacher in South Shields, 1784-87. Leader of theatre orchestra, Neweastle-on-Tyne, 1787. Violinist in the orehestra of Astley's Amphitheatre, 1788. Music-director at the Surrey Theatre. He was a violinist in the Philhamonie Orchestra, and composer for Vauxhall Giar. dens. He died at London, in 1841.

Works.-Music to Operas, Pantomimes, aml Dramas: Algerine eorsair, 1800; Almoran and Hamet, 1800; Blackbeard, 1797; Brave Cossack; Cora, 1799; Don Giovanni, 1820; Fair Slave; Friar Bacon; Harlequin Mariner, 1796 ; Halper's Son; Jew and the Gentile; John Bull and Buonaparte; Iron Tower, 1801; Laugh, and lay down, 1803; London Apprentice, 1804; Louisa of Lombardy,

\section{SANT.}

1805 ; Magic Pipe; The Mine; Niobe, 1798 ; Seasons, 1799; Sir Francis Drake, 1800; Successful Cruise, 1815; Talisman, 1810; Vicar of Wakefield, 1812; and many others. Collins' Ode on the P'assions, 1789. Three duetts for 2 violins, op. 6; Six original German waltzes for pf.; Airs arranged for violin; Broadside lornp pe, for pf.; many songs, among which "Bound 'Preutice to a Waterman," is best known. It first appeared in "Sir Francis Drake," 1800. He wrote music to burlettas, pantomines, and plays, to the number of over 150 .

Sandys, William, writer, was born in 1792. He was a member of the legal profession in London; an F.S.A., etc. He died at London, Februaly 18, 1874.

Works.-Christmas Carols, ancient and modem, including the most popular in the. West of England, and the airs to which they are sung, also speeimens of French Provineial Carols, with an introduction and notes, London, 1833. Christmas-tide, its history, festivities, and carols, with their music, London, 1852 (various editions); History of the Violin and other instruments played on with the bow, from the remotest times to the present. Also an account of the principal makers, English and foreign," London, 1 R6t.

Sangster, Walter Hay, organist and composer, born in London, September 17, 1835. Edueated at City of London School. Chorister, Temple Chureh. Studied under E. J. Hopkins and W. R a ; also at Berlin, 1855. Graduated Mus. Bae., 1870; Mus. Doc., 1877, Oxford. F.C.O. Organist of Christ Church, Ealing ; English Ambassador's Chapel, Berlin, 1855; St. Michael's, Chester Square, London; All Saints', St. Johu's Wood; St. James's, Wevbridge; St. Michael's, Paddington, 1872 ; St. Saviour's, Lastbourne. Conduetor of Eastbourne Musical Society, which has done excellent work. Composer of Cantatas: The Lord is my Light; The Knight of Elli; Elysium, produeed, Eastbourne, May 31, 1892; Dramatic eantata, The Seottish Chief, the same. Nay 11, 1897 . Anthems, part-songs, etc. ()verture, prelude and fugue, and other organ music; pf. pieces, etc.

Sant Angelo, Pauline, pianist, born in Manchester, of Italian descent. Played in public when ten years of age, and at thirteen was appointed by Sir Charles Ilalle pianist to the Beethoven Society, Manchester. She made her drbut at the Cryst I Palace, June 1, 1892, playing Weber's Concertstüek, and some solo pieces. This was at a Wednesday Concert, the pianist being about fourteen years of age. In 1893 she was heard at Edgar Haddoek's concerts in London and Leeds; and gave her first recital at St. James's Hall, May 21, 1895. Since then she has played at 


\section{SANTLEY.}

important concerts in Birmingham, and many other places.

Santley, Charles, baritone vocalist, and composer, son of William Santley (teacher of pianoforte and singing at Liverpool; died, October 22, 1891), born at Liverpool, February 28,1834 . Was a chorister at several churches in Liverpool, and sang as an anlateur. Deciding upon his profession, he gave a farewell concert at Liverpool, September 15,1855 , and the next month started for Italy. He studied at Milan under (inetano Nava, and returned to England in October, 1857. Had further lessons from Namnel Garcia, and made his debut at St. Martin's Hall, London, November 16,1857 , as Adam, in Haydn's "Creation." His success was immense, and every one was struck with his magnificent voice. He sang in the "Mt ssiah" at the same place, Deceniber 16. The next year he sang for the Sacred Harmonic Society. His first festival appearance was at Leeds in 1858 , and he saug there until 18,6 , with the exception of the festival of 1880 . With the Norwich Festival he was identified from 1860 ; and he sang in "Elijal " at the Birmingham Festivals from 1861 to 1891,1867 excepted, when Weiss took the part of the Prophet. He sang at the festivals of the Three Choirs, from 1863 to 1894 , with few intermissions. In concerts throughont the country he has long held the foremost position as a baritone singer. He toured in America in 1871 and 1891 ; and was in Australia, 1889-90. At the Handel Festivals, Crystal Palace, he las been frequently heard from 1862 ; and he took part in the Jubilee performance there of MIendelssolnu "s "Elijah," June 27, 1896. His career in opera has been almost as remarkable as in oratorio. He was first heard on the English stage at Covent Garden, October 1, 1859, as Hocl, in Dinorah; san' at the same house in Italian opera, April 15, 1862, as the Count in "Il Trovatore," and took the same part at Her Majesty's, May 31. Sang as Ford, at the production of Nicolai's "Merry Wives of Windsor," then entitled "Falstaff," at Her Majesty's, May 3, 1864; appeared in a round of characters at the same house. Sang in "Zampa," at the Gaiety, 1870; and joined the Carl Rosa Com any in 1875, taking the title part in Mozart's "Figaro," at the opening performance it the Princess' Theatre, September 11, and also toured with the Company, remaining with it for some years. Mr. Santley has also gained some fame as a composer. His principal work is a Mass in A flat, for soli, chorus and orchestra (he joined the Roman Chnreh about 1880), produced at the Pro-Cathedral, Kensington, December 25, 1892. He has also composed an Offertorium, Ave Maria, and other church

\section{SAVAGE.}

music; a berceuse for orchestra, performed at Sydney, Australia, 1890 ; a madrigal, and songs, some of which have been published under the name of Ralph Betterton. He is an Hon. R.A.MI, and in 1887 was created by Pope Leo XIII., a Knight Commander of St. Gregory the Great. In 1859, he married Miss Gertrude Kenble, a granddaughter of Charles Kemble. She made her first appearance as a soprano vocalist in the "Messiah," at St. Martin's Hall, December 16, 1857. After her marriage she retired from public life. She died, September 1, 1882 . Énith SANTLEY, their daughter, a soprano, made her stage début when very young in Chernlini's "Water Carrier," at the Theatre Royal, Birningham, May 19, 1s76. She sang at the Philharmonic Concerts, May 11, 1882, and in Birmingham, ete. She married, July 14 , 1884, the Hon. R. H. Lyttelton, and now resides in Warwickshire, but sings occasionally at concerts for charitable purposes.

Santley, Kate, actress and singer, appeared at the Strand Theatre, 1870, in "st. reorge and the Pragon." Sang in London and the provinces in connic opera, from alont 1476. Began a series of entertaimments, with drawing-room sketches, at Ipswich, in Oetober", 1890. Wats at Perlin, 1891, in "Faust up to Date, and has now for some years been lessee of the Royalty Theatre, Lmdon.

Sapio, Antonio, tenor vocalist, was bom at London, in 179. He was a son of an Italian rocalist (horn 1751, died London, Jume 30, 1827), under whom he studied singing. For a time he lield a commission in the army, hut afterward became a public singer, and first appeared in the "Messiah," in 182. He sang at York, Edinburgh, and other provineial concerts, and in 1824 he appeared on the stage. He died in London, Norember 27, 1851, completely destitute, haring occupied a garret in Qineen street, Fdgeware Road, nnder conditions of great distress, some time previons to his deatl.

Sartoris, Mrs., see Kindele, Anelande.

Saunders, Joseph Gordon, pianist and compnser, graduated Mus. Bac., 1872, Mns. Doc. 1878 , Oxford. Some time conductor of Clapton Philharmonic society, from 1884. Professor of harmony and pf., Trinity College, London. Associate of the Philhamnonic Societs.

Works.-Domine, Dominus noster; Benedie, anima mea, for soli, chorus, and orehestra; anthem, The Lord in His holy temple; Evening Service, chants, ete.; vocal trio in canon, Like the gale that sighs; pf. pieces, ete. Author of a primer, Examples in Striet Comnterpoint, old and new, Novello: A Practical Treatise on the Art of Phrasing. Hammond.

Savage, William, organist, composer, and bass vocalist, was bom about 1720. He 


\section{SAYILE.}

studied mader I)r. T'eprisch, and heeame a Gentleman of the Chapel Royal, 1744. Almoner, vicar-choral, and master of choristers, Sit. Paul's Cathedral, 17ts. He lied at London, July 27, 1789. He composed chants and other church music.

Jaxe SArain, probably a danghter or other relative of the alove, composed six rondos for harpsichord or pl., of. 33; Thett for pf. or harpichord, (T) 6 6490$]$; Two dnetts for roices, "p. 7 17!)17; Strephon and Flavia, cantata, "p). 4; liall the woodman, song, up. 5.

Savile, Jeremy ol Jeremiah, composer of the 17th exutuly. Now known chiefly as composer of "The Waits," a four-part song sumg at the meetings of rilee societies. "Here"s a luealth muto his majesty," "O by rivers," and other songs and part-songs contained in l'ayford's "Select musicall Ayles," 16.53 , and otlier contemporary collections.

Sawyer, Frank Joseph, organist, composel and conductor, l woln at Brighton, June 14, 1557. Studied at Leiprig Conservatorimm under F. F. liehter, and others; pupil of, and assistant organist to Tr. I. F. Pridge. F.R.C.O.; Mus. Pac., 1s77; Mus. Doe., 1884, Oxford. Organist and cluoimanter, sit. Patriek's, IHore, lirighton; conductor of Brighton and Hove ('horal and Orehestral Association up to 18m, when he resigned. Plofessor of sight singing, Ri.C.M. ITe has given many inlportant concerts; and organ recitals at Buw and liromley Institue, atc. Jectured on uresm music; the history of the dance; and wther topics, at the College of Organists, Musical Asrociation, London Institution, and elseswhere.

Works, ()roborio, Mary the Virgin, 188t; recast as Star of the East, and produced Brightun, I)ermber 12, 1869: Sacred cantatas, Jerusalem, 1880; The Soul's Forgiveness, Chester Festival, 1s!4t Widew of Nain (female voice). Iranatic cantata, Orplens. Nethuen prize of $\mathbf{1} 100,1893$; Cantata, The Pageant (female voiee). Two kelavish Itances, orchestra; Concertstick in I), organ and orchestra, 1sto ; Romance, violin and pif.; Technical exelcises, and pieces rarions, pf. Anthems, part somgs; Songs of a Simmoneday, four vocal duets, etc. Anthor of a primer on Extemporisation, Noxello.

Scarisbrick, Thomas, organist and composer, Jurn at l'pescot, Lancashire, March 24, 1805; died at liendal, Felmury 26, 1869, where he was organist. Composed anthems and other church music. His wife, forn Whitnale (born, 1829); died, 1874 , was a contralto singere.

Scates, Linda, Mis. Imtтox Conk, pianist, secund daughtar of Joseple Seates. Borus at Dublin, Nowember 16, 1855. Pupil of sir le. 1'. Sitewart and of R.A.MI. ; alected Associate,

\section{SCOTT.}

R.A.M. An accomplished pianist, she retired from public life on her marriage with $\mathrm{Mr}$. E. Dutton Couk, dramatic critic, Angust 20, 187t. After his death (September 11, 1883), she resimed her profession in 1884 , and was appointed a professor at the Guildhall School, and the sime year was granted an anmual pension of 150 from the Ciril List. She gave eoncerts at the Princes' Hall, and elsewhere. On Janmary 6,1885 , she maried Charles Dickens, second son of Edmund Yates.

Schirmacher, Dora, pianist, born at Liverpool, September 1, 1857. Fanghter of a professor of music in that city, who was her first instructor. Sindied at Leipzig Conservaturium under Frust F. Wenzel and Reincelse. Played at the Grewandhaus Concerts, February 1, 1877, and made her début at the Crystal Palace Mareli 31 following, her selection being the I) minor concerto of Mendelssohn. She appeared at the Monday Popular Concerts Incember 3 of the same year, and has played at concerts in Liverpool, Mancluester, and other places, and also in many towns in Fermany. She has published a sonata, suite, and some other pieces for pf.

Scholefield, Rev. Clement Cotterill, clempman and anateur musician, born at Edghatston, Bimninghan, June 22, 1839. Gradmated at Cambidge. Held livings of Parjsh Church, Hove, Brighton, in 1867-69; and St. P'eter's Sonth Kensington, 1869-77. Chaplain of Eton College, Windsor, since 1880. Composer of "A Wedding Hymm" [1889]; Hrmm tumes, "Fides," "Irene," “St. Clement," "St. Nicholas," cte.

Schultz, Madame, see Bishor, AxNa.

Scott, Lady John Douglas, born Alicia ANx SEOTTinoone, amateur composer. Edest daughter of John spottiswoode, of Spottiswoode, Berwickshire. She was narried on March 16, 1836, to John Donglas Scott, thind son of the fourth Inke of Bucclench, who died on January 2, 1860. In 1870 she succeeded to the estate of Spottiswoode, and, under tems of her father's will, resumed lier maiden name. Composer of a nmmber of Scots songs, among which may be named Maxwelton braes are bommy. . . Animie Lanrie, London [1847]; Douglas; Dmrisdeer (alranged Jỵ Eliz. Masson); Ettrick; Foul fords; Laminermoor; Nother, oh, sing me to rest; Shame on ye, gallants, ete. The first-named is by far the lest known, and is, indeed, one of the most popular of modem Scottish melodies. It was first pullished anonymously about $1846-47$, and appeared soon "after in Wood's "siongs of seotland," edited by (r. F. Graham. The words used are the nore modern of two sets. The wellknown song, "By yon bonnie banks," or the 


\section{SCOT'T}

“Bomnie banks o' Loch Lomond," was noted by Lady Seott from the singing of a lxy in the streets of Edinburgh, and was first printed by Paterson and Sons ahout 1844, with an accompaniment by Finlay Dun.

Scott, Walter, piinist, violinist, and conductor, born at Long sutton, Lincolnshire, Uctober 10,1842. Studied pf. under Benedict, and violin with H. Holmes. Resident in Cardiff; hon. local examiner for R.C.O. ; organist of St. Margaret's Church. Has played organ solos at Fisteddfodau, Cardiff, and trained the Cardiff contingent of the chrins of the Gloucester and Worcester Festivals up to 1890 , when those counties drew more from their own resources. With this Cardiff choir Mr. Seott has given some fint concerts; he has also acted as chorus-naster for the Cardiff Mnsical Festivals. He has written a Communion Service, Te Deun and Benedictus, songs, violin and pf. pieces, otc.

Searelle, Luscombe, theatrical hanatgel and componser. In 184t, he was conducting opera in London and the provinces; afterwards, up to 1890 , he was manger of the Queen's Theatre, Kimberler, and the Theatre Royal, Johannesburg, sonth Africa. Sinco then he has again been in England. He has compossed the operas " Estrella" (Walter Parke), produced at the Gaicty Theatre, Iondon, Nay 21, 1889; and "The Black Rover" (his owil libretto), produced at the riobe Theatre, September 28, 1 490 . Also a cantata, "Australia," produced at Lyttletorr, New Zealand, April 16,1891. Author of a series of humorous slietches, "Tales of the Tiansval," London, Fisher Unwin, 1896.

Second, Mary, bom MAHox, soprano vocalist. Was born at Oxford, abont 1771. She was a daughter of Mahom, a celebrated clarinet player. Dobut in "The Wroodnann," Covent Garden, Londun, Septemler 17, 1796. Married to a Mr. Second, 1800. Afterwards retired from the stage. She appeared at the principal concerts of her time.

Sedding, Edmund, architect and amatem musician, was born in 18:35. Pupil of the eminent architect, Mr. Street. He Was sometime organist at St. Mary the Virgin, Crown Street, Soho, London. Cantor, St. Ralph, Bristol. Edited and composed a "Collection of English Carols, French Nöels, etc." ; "Collection of Ancient Christmas Carols, arranged for 1 roices." London, 1860. Third Collection of Nine Ancient and Goodly Carols for Christmas-tide, Novello. "Dives and Lazarlis, a christmas carol " [1867]. Hrmms of ye Holy Eastern Church, set to Musicke for 4 voices. London, 1864. He was learned in all that appertained to Ecelesiastical Plain-Song. His last years were spent at Penzance, where he died of consumption, June 11, 1868, aged 33.
SELBY.

His brother, Johx 1). Senura, architect, was also an organist and church musician. He assisted for years at the services at St. Iary's, both in the choir and at the organ; and was sometime organist at Beddington, Sinrer. He died, April 7, 1891, in London.

Sedgwick, Alfred B., musician and writer, author of the following works: Conplete System of instruction for the Concertina, London [185t : Complete Method for the French Aceordeon; Complete Method for the German Aecordeon; also for German Concertina, Boston [1,65]; Complete Method for the Cormet, ete. He published a lirge number of arrangenents of popmlar airs for the Concertina.

Seeley, L. B., compiler of "Derotional Harmony, contajuing Psalms and Hymns from various authors, adapted to favourite tumes. the whole for 3 and 1 voices." London, 1806,2 vols., $3 r$ d edition, 1,830.

Seguin, Arthur Edward Shelden, hass singer, was boru at Ioudon, April 7, 1809. He was a pupil of the P.A.MI., and in 1829, he sang at a musical festival at Exeter; and in 1831, he appeared in opera in London. Afterwalds he saug chiefly in opera, and at the Concert of Ancient Music (first appearance there, March 28, 183\%), till 1838, when he went to the United States. He gave linoke's "Amilie" in New York, in Octolyer, 1s3s, and travelled in the States with an operatic company called after himself. He died at New York, December 9, 1452. His wife, born ANe ChtLde, was a soprano vocalist, and appeared with her hushand in all his principal concerts and operatic nroductions. She died at New York, in 188R. Elizabeth Shguts, his sister (loon Londan, 1815; died there, $1870)$, also a singer, was the mother of Martame Parepa-Rosa; and WrLlan Hevri Seguin (born 181t; died December 29, 1850), was a well-known hass singer in London.

Selby, Bertram LHard, composel and organist, born in Kent, February 12, 185. Was organist of Salisbury Cathedral, 1881-3; now organist of St. Iranabas, Pimlico, London. Gave concerts in London, 1880, ete.

Works.-Operas: The Ring (18.86); and Adela, produced at Nottiugham, February, 1888. Music to Helena in Troas, London, May 17, 1886. Weather or No, musical duologue, Savoy, August 10, 1896. School cantata, The Waits of Bremen. Songs and part-songs. Morning and Evening Service, with Com. munion office, in C. Idyl for orchestra, Henschel concerts, March 11, 1897. Two quintets, pf. and strings. Sonata and suite, violin and pf. Sonata in I), Sonata on Dies Irie, and other pieces for organ. Suite for pf., ete.

Selby, Thomas Leeson, violinist and composer, was born near Nottingham in 


\section{SEMPLE.}

1827. Studied under Henry Farmer. Conductor and teacher in Nottingham. Composer of some glees, songs, etc.

Semple, Charles Edward Armand, physician and writer, who was educated at Cambridge and London; B.A., 1867; M.B., 1872 , etc. Holds a number of appointments, such as physician to Royal Society of Musicians, and examiner in vocal and aural physiology and elementary acoustics to Trinity College, London. Author of "The Voice musically and medically considered," London, 1884; other editions, 1886, etc., and a large number of professional works, ehiefly on diseases of children and pharmacy.

Senior, John Edwin Ryder, organist, born at Batley, Yorkshire, Miarch 2:3, 1856. Studied under Dr. I'eace, James Broughton, and Hans ron Bülow, F.C.O., L.R.A.M. Organist of Govan Parish Church, 1881; st. George's in the Fields, Glasgow, to present time. Has a high reputation as a performer, and has given recilals at Exeter Hall, I ondon: Bow and Bromley Institute; Crystal Palace; East End Exhibition, Glasgow, 18:1; St. George's Hall, Liverpool, November, 1895, etc. He has published some piees for the organ.

Severn, Charles, organist, contrabassist and violoncellist, born in London, 1805. He was a Court musician at the Queen's accession, and played at her coronation. For many years a member of the principal orehestras in London, and of the provincial Festivals. He was in the orchestra at Limingham on the production of "Flijah," 1846. He was also organist for forty-six years of Islington Parish Church. A fire broke ont at his residence, Liverpool Road, Islington, April 1.1, 1885, in which his wife was burnt to death. He was then still organist at the church. He died at the end of December, 1894, having almost attained his ninctieth year. He wrote a glee, The Sunset, and a few other part-songs, motets, songs, ete., and edited "Psahm and Hymm Tunes, Chants, etc., for the use of the Parish Church of St. Mary, Islington." London $\lceil 1853]$.

Severn, Thomas Henry, composer and rocalist, elder brother of above, was horm at London, November 5, 1801. Son of a music master at Hoxton, and brother of Joseph Severn, the painter. He was a teacher in London, and died at Wandsworth, April 15, 1881.

Works.-Te Deum, rocal duets. The Lay, a collection of songs by C. T. Incledon [1845]. Songs of the Days of Chivally, by T. II. Bayly, 1831. Single Songs: 1)ear scenes of my home; Fill the goblet; Friendship; Groe, happy rose; ller eyes the glow-worme lend thee; Jamie; Ruse of Ellesmere, ete. If. music.

\section{SEYMOUR.}

Sewell, John, organist and composer. Has been organist for many years at St. Leonard's Church, Bridgenorth, Shropshire, where he is a music-seller. Composer of anthems, Break forth into joy; Blessed are the undefiled; This is the day; ete. The Order of Service, with choral responses, London, Skeffington, 1892.

AnotherJohn SEwELL graduated Mus. Bac., 1848; Nus. Doc., 1856, Oxford, Of him no particular's can be gleaned.

William SEWELL, son of the first-named, was born at Bridgenorth. Educated at R.A.MI. Balfe Scholar, 1876; Novello Scholar. 1879, A.R.A.M. Olganist of Christ Church, Clapham, 1882; the Oratory, Edgbaston, 1886 to present time. Has given organ recitals, Bridgenorth, $1882+5$, etc. He has composed a Mass of St. Philip Neri ; Magnificat; O Salutaris Hostia; Tintum Ergo, performed at the Brompton Oratory: Ave Maria, and other church music. Eelogue, orchestra; Quartet and trio, pf. and strings; Sonata, pf. and violoncello; pieces for pf., etc.

Sexton, William, composer and organist, born in 1764. ('horister in st. Cieorge's Chapel, Windsor, and Eton College, 1773. He studied under Edward Webb. Organist, sub-precentor, and master of choristers, St. Creorge's Chapel, W'indsor, 1801. He died about 1824. Composer of anthems, glees, and songs; and edited Handel's Chandos Anthem, 1808 .

Sexton, William, alto rocalist, born at Norwich. Chorister, Norwich Cathedral, and pupil of lor. Buck. Sometime member of the choirs of York Ninster, and St. George's Chapel, Windsor. Apponited vicar choral of Westminster Abbey, 1875 . Sometime conduetor of Brixton Choral and other societies. The Meister Glee Singers, consisting of Messrs. Sexton, G. Hast, IV. G. Torington, and W. Norcross, have gained a high reputation for finished part-singing. They have been heard at many concerts in London and the provinces from $18 \%$.

Seymour, Charles A., violinist, born at Edinburgh in 1810 . He studied at the R.A.M., and in 1830 became prineipal riolinist in Queen Adelaide's prisate band. Leader of Manchester Concert.Hall orchestra, 1838; and leader of Halle's band from 1858. For some years he gave annual series of chamber concerts in Manchester. He died at Manchester, November 1, 1875 .

Seymour, Joseph, organist, composer and writer, born at Cork, Maly 14, 1854. Studied at Nalines under Lemmens, and at Ratisbon under Dr. Haberl. Succeeded his father as organist at St. Peter and St. Paul's Chureh, Cork, 187s; and has been organist at St. Andrew's, Westland Row, Dublin, from 1881 to present time. Graduated IIus. Bac., 


\section{SHAKESPEARE.}

Trinity College, Dublin, 1892. Professor of Music in Board of Education Training College, Drumeondra; Examiner, Royal Irish Aeademy of Music, ete. Editor of Lyra Ecclesiastica, Dublin, 1884-91; correspondent to several musical jonrnals.

Works.-Mass Adeste Fideles, 1886; Mass in A flat (prize), 1888; Missa Trinitatis; Te Deum (prize), 1895; Six Motets (Archbishop of Dublin prize), 1889; other church compositions. An Irish May-Day, ehildren's operetta on Irish Airs; Seven Irish Airs, arranged. Part-song, Bells of Shandon; Lodore (prize), ete. Editor of Curwen's Latin Series of chureh compositions; and other collections.

Shakespeare, William, tenor vocalist and composer, born at Croydon, June 16, 1849. After singing in a choir he became an organist at thirteen, and pupil of Molique. In 1866 gained a King's Scholarship, R.A.M. Won the Mendelssohn Scholarship, 1871, and studied at Leipzig. A tenor voice of promise developing, he was sent to Milan to stndy singing under Lamperti. Returning to England in 1875, he sang at the Monday Popular, Crystal Palace, and other metropolitan concerts for some years, as also in the provinces, and at the Leeds Festival, 1877. He was appointed a professor of singing at the R.A.M. in 1878; and Conductor of the Coneerts in 1880, resigning this office in 1886. F.R.A.M. He is now chiefly known as a teacher, but sings occasionally at concerts. His chief compositions are a Dramatic Overture, 1874; Pf. Concerto, Brighton Festival, 1879 ; with a Symphony, overtures, and string quartets in Mis. Also songs, and pf. pieces, ete.

Sharman, Percy Victor, violinist, hom at Norwood, Surrer, in 1870. In his thirteenth year he gained a Scholarship at the R.C.MI, for three vears, which was extended for two years more, as he showed conspicuous talent. He also obtained the Exhibition of $£ 60$ per annmm, for four years, the gift of the Worshipful Company of Skinners. This was for the purpose of enabling him to continue his studies abroad. Accordingly he entered the Royal High School of Music, at Berlin, as a pupil of Dr. Joachim. Sinee 1887 he has appeared with success on the eoncert platform, and was the violinist of Mr. Sims Reeves' touring party, 1890-1; but he is chiefly devoted to tuition, and sinee 1890 , has been professor of the violin at the Charterhouse School, Godalming. Of his eompositions only a Romance for Violin, and one or two songs, have been published.

Sharp, Edward, pianist and composer, born at Aeton, Mliddlesex, December 27, 1831. Studied at R.A.M. under Cipriani Potter, and subsequently eame under the notice of Thalberg from whom he obtained valuable instrue-

\section{SHARPE.}

tions and advice. He was organist at All Souls, St. John's Wood, for some time from 1875 , but has devoted his time chiefly to composition. As a painter he has also acquired some repute. His compositions comprise a Trio for pf. and strings; Two Sonatas for pf. and 'eello; Sonata, pf. and violin; Sonata in E minor; Six Songs withont words; Rondo grazioso in G, op. 19; Twenty-four Characteristic Pieces, etc., for pf.; Various Songs.

Sharp, Francis, composer and pianist, of last half of the 18th eentury. Author of "New Guida di Musica, being a complete book of instruetions for beginners on the Pianoforte," op. 6, London [1790]. Composer of Six Sonatas for the Harpsichord [1785]; Poor Mary, a ballad.

RichaRd SHaRP, probably a relative of the foregoing, composed a number of arrangements for the pf., and songs.

MARy and L. Sharr, harp-players who played at the Birmingham Festival of 1811, are probably members of the same family. Mary Sharp issued a " collection of original melodies, edited by J. Relfe," London [1827]. A Thomas Sharp, who lived alont the same time, contributed to Henley's "Divine Harmony," 1798, and to the publications of John Page.

Sharp, Granville, writer, lorn at Durham in 1734; died London, July 6, 1813. Author of "A Short Introduction to Vocal Mnsic, London, 1767; another edition, 1777. Chiefly noted for his philanthropic efforts, and his work on behalf of freeing negroes from slavery. His memoirs were written by P'rince Hoare. His brothers WILLIAM and JAMEs, with whom he ehiefly lived, were musical, and gave concerts. The brothers apparently possessed a large musical library, as a hook-plate exists, showing a view of an organ in a ehurch, with part of a choirscreen, designed by Granville sharp, and inscribed, "Mressrs. Sharp, London." The horder of this plate is surrounded by Scripture texts.

Sharp, Simeon, author of "Music, a Satire,"London, 1824.

Sharp, Mrs. William, anthoress, wife of Wiltiam Sharp (born Glasgow, 1855), the poet and author, wrote "Creat Composers," London, 1887, in the Camelot Classies series; "Sea MLusic, an anthology of poems and passages descriptive of the sea," London, 1887; " Women's voices. poems by English, Seotch, and lrish women," London, 1887.

Sharpe, Charles Kirkpatrick, amateur musician, poet, etc., born at Hoddom Castle, Dumfriesshire, May 15, 1781 ; died at Edinburgh, Narch 18, 1851. He composed musie, and contributed to Stenhonse's Lyrie Poetry of Scotland. He also edited and published the Earl of Kellie's "Minuets and Songs," 1839. 


\section{SHARI'E}

Sharpe, Ethel, piasist, born in Dublin, 187\%. Pupil of the R.I.A.M., playing at a concert, June 10, 1884, when twelse, with great suceess. Seholar at R.C.M., studying under Franklin Taylor, distinguishing helself at the students' concerts. WVas presented with the silver medal of the Musicians' Comnpany, 1891, in which year she gave her first chamber eoncert, November 12, at the Princes' Hall. She played at the Crystal Palace, March 26, 1852' ; and receiving a grant from the R.C.M., proceeded to the continent for travel and study. Gave a recital at Vienua early in 1s94, creating an excellent inpression. Resimed her chamber concerts, London, 1595 , and played at the Crystal Palace, April 13, Eugene d'Albert's Concerto in E, op. 12. She is married to Mr. Alfred Hobday, a violinist.

Sharpe, Herbert Francis, pianist and composcr, born at Halifax, Yorkshire, Mareh 1, 1s61. Grained a Pianoforte Seholarship at the opening of the National Training School for Music at Sonth Kensington, and suceeeded Eugene d'Albert as Queen's Scholar at the same institution. From 188.2 he played frequently at concerts in London, Bradford, and throighout the North, as well as in other places, with much suceess. He was appointed a professor at the R.C.M. in 1884; and an Examiner under the Associated Buard of R.A.M.and R.C.M. in 1990. His compositions ale already very numerous, the principal being indivated in the subjoined list.

Works.-Comic opera in three acts (MS.); Three four-part songs, with orchestra, op. 52, also for female voiees with pf. Songs of the Year, 12 two-part songs, op. 16; 12 two-part songs, op. 1s; Songs of Hoor and Mountain, 12 two-part songs, ol\% 19 ; Songs by the Sea, 12 trios, op. 25; sungs and duets, varions. Concert overture, orchestra; liomance for two pianos (both in MIS.); Tariations, op. 46, for two pianos; Suite, op. 62 , Hute and pf.; Suite, op. 65, violin and pf.; Four duets, op. 29 , two violins and pf.; Idylle, op. 38, flute and pf. Pf. duet; Five clumacter pieces, op. 24; Threestmphonic pieces, op. 59. Pf. solo: Op. 1-10, pieces varions; Five pieces, op. 23; Two numical sketches, op. 28; Suite, op. 58; Pantomime snite, op. 61; Six Fnglish fantasias, op. 71, ete. Pianoforte School, op. 60, Stanley Lucas. Arrangements of Grieg's Norwegian songs and dances, ete., for pf. duct.

Shaw, Mrs. Alfred, bom MIARY Postaxs, contralto vocalist, born at Lee, Kent, in 1814. She studied at R.A.M., and under Sir Creorge Smart, and appeared in $1834-5$ at the Concert of Ancient Music, and at York Festival. She married Afred Shaw, artist, in 1835. Sang afterwards at all the principal festivals, and sang the contralto part in Mendelssohn's "St. Paul," on its first production in England. Sang at Leipzig, 1838; in Italy, 1839, and
SHAIV.

afterwards in England. She was married a second time to J. F. Robinson. Her voice failed owing to the shock caused by the appearance of insanity in her first husband, who died in a private asylum, Hoxton, Ncvember 29,1847 , and she retiled from public life soon after. she died at Hadleigh Hall, Sutfolk, September 9, 1576.

Shaw, George Bernard, journalist, musical critic, and dramatic author, born at Dublin, $26 \mathrm{July}$, 1856. Acted as musical critic for The Star, and succeeded Louis Engel on The ll orld, 1891-94. Lately he has devoted himself chiefly to dramatic authorship. Well-known as an active socialist and leading nember of the Fabian Society. Author of " Widower's' Houses " (Independent Theatre), 1892 ; "Arns and the Man" (Avenue Theatre), 1894 ; aud other plays. Several novels, essays on Socialism, and a series of articles on the drama in the Saturday Reriew, ete.

Shaw, James, urganist and composer, born at Leeds in 1842. Studied under R. S. Bunton. Orgauist of Sit. John's Episcopal Chapel, Edinlourgh ; St. Paul's, Edinburgn. Conductor of Edinburgh Choral Union, 1862186i. Organist. Flanpstead Parish Church, London; Collegiate Chapel of St. John, Clapham. Gave concerts, St. James' Hall, 1891-2. Formed the Midulesex Choral Union, 189. Compositions: "A Thanksgiving Oäe," for soli, chorus, and orchestra, 1850 ; Evening Service, composed for London Church Choir Association, 1874; Services and anthems. Songs: Break, break; Angel's Welcome; Morning Greeting, etc. Part-songs. Three Sketches; Introduction and Fugue; Two grand Studies; and other pf. pieces. Minuet; March; Meditation, ete., organ.

Shaw, Sidney, composer, born at Farnworth, Lancashire. Begin his musicial studies with the violin, and then placed himself under Dr. W. Rohner, of Isiverpool, for five year's, for composition. During that time he composed and produced, at Liverpool, an operetta, "Love's Trial," 1882 , and another work of the same kind. He went to Leipzig, and studied at the Conservatorium, and there wrote the oratorio, "Gethsemane," which was produced at St. James' Hall, London, November 26,1886 . His other vorks include a Romance for violin ; a Bolero, and other pf. pieces. Songs: Suspense; The Angel and the Child; Three songs (Byron), ete. In 1892-3, he was conductor of the Georgina Burus "Cinderella" company.

Shaw, Thomas, violinist and composer, of latter part of the 18th and early part of the 19 th centuries. Composer of The Stranger (opera), 1798; The Island of Marguerite (opera), 1789; anthem on the death of Princess Charlotte [1817]; Trio for 2 violins and 'cello; four sets of Sonatas for pf., op. 9, 
SHAW.

etc. [1795-98]; Concertos for violin and pf.; Solo for thute, op. 8 ; Songs, ete.

Shaw, William Maxwell, musician and editor, born at Aberdeen about the middle of last century. He studied under Urbani, and was precentor successively of the High Church, Inverness, and Test Church, Aberdeen, 1797. 1805. He was a successful teacher of rocal music, and sang at concelts in Edinburgh. In 1805 he went to Boston, U.S., where he died in July of the same year. He compiled "A Collection of C'hurch T'mnes, compiled and composed for the improvement of those who may not have the opportmity of teachers to instruct them, with the simple graees the author rises in singing. " Aberdeen, n.d.

Shedlock, John South, pianist, critic, and author, born at Reading, 1s43. (iraduated B.A., London University, 186t. Studied pf. under E. Litheck, and composition moler Ed. Lalo, at Paris. On his return to London he was principally engaged in teaching, occalsionally giving some excellent chanler concerts, up to 1879 , when he became munical critic of the Acalemy, and from that time he devoted himself chiefly to mmical literature. In 1875, however, he had contributed articles on Raff's Sirmplionies to the Monthly Musical Record. Other paper's followed: and is 1892 he began an eliborate series of articles on Beethoven's sketch Boolio in the Musical Times. In 1s:13 he discorered, at Berlin, a copy of Cramer"s Studien, with comments by Beethoren. An aceoment of this he pmblished with a preface, and explanatory notes. He edited Kuhnau's "Biblical sonatas," 1895 ; and played them at the R.A.MI., 1896, to illustrative leetures by E. F. Jaeques ; atso edited a Selection of Harpsichord pieces ly Bes'nato Pasquini. He has lectured at the li.d.M., and been a busy worker for music in many ways. Author of "The Pianoforte Sonatia, its origin and development, London, Nethuen, 1895. His most important composition is a Quartet for pf. and strings, 1850 ; he has also written a Romance and scherzino, etc., for pf.

Shelmerdine, William, organist and conductor, born at Salford, Manchester. Chorister in the Collegiate Chureh (now the Cathedral). Studied in London, under Pobert Barnett, and sterndale Bennett. Settled in Melton Mowloray as a teacher. About 1850 he obtained the post of organist at the Mechanies' lnstitute, Nottingham, and formed a large vocal class in connection with it. This afterwards became the Nottingham siacred Hamonic Society, shelmerdine being at first organist, and then conduetor. He wats also organist at the Baptist Chapel, Derby Road, soon after taking $m$ p his abode at Nottingham. He was active as a teacher, and exerted great influence in the town. In 1878 he retired, and went to reside at Pwllheli, North Wales,
SHEPLEY.

where he died, Feloruary 20, 1893. He edited a Collection of Psalns and Cluants from the old masters, London [1857]; "180 Chants, ancient and modern," London, Virtue, 1861, also 1864; The Amateur l'edalist, an introduction to the use of the pedal organ [1853]; and composed sone church music: and songs.

Shenton, Rev. Robert, clergyman and musician, was B.A., Oxford, 1750 ; M.A., Cantab., 1757. He became vicar-choral, Hereford Cathedral; Dean's vicar at Christ Church, 1757, and vicar of sit. Patrick's Cathedral, Inblin, 1758. Dean's vicar at St. Patrick's, 1783. He died at Dublin in 1798. Composer of anthems and other church music.

Shepherd, Charles Henry, organist and composer, was bom in 1847. Student and Associate, R.A.M. After holding appointments in London, he became organist of St. Thomas's Church, Newcastle-on-Tyne, 1876, and died there, April 29, 1886. He composed a Te Deum, anthems; The lass I left ashore; Do or die; The moon shines o'er the lalie, love; and other sougs; pf pieces, etc. His wife was a soprano vocalist, favourably known in the North.

Shepherd, William, violinist and composer, was born at Ediuburgh about 1760 . He was a partuer witl Natlaniel Gow in the firm of Gow and Sliepherd, 16, Princes Street, Edinburgh, and he performed at concerts. He died at Edinburgh, Jannary 19, 1812. He edited two collections of Strathspey reels: "A collection of stratlispey reels .. with a bass for the violoncello or harpsichord," Edinburgh, n.d.; "A second collection of Strathspey reels..for the pianoforte, violin and violoncello," Edinburgh, n.d.

Shepherdson, William, organist and author, born 1817; died, October 12, 1881. Wrote "The Organ, hints on its construction, purchase, and preservation," Loudon, 1873.

Shepley, Daniel Sutton, hass rocalist, born at Macclesfield, 1853. As a boy he had no singing voice, but played several instruments. In 1866 his parents removed to Halifax, and he was apprenticed to a firm of engineers. His voice developing, he took lessons from Mr. W. R. Fekersley, of Halifax, and soon becanne a popular oratorio singer in the North. Later on he studied under Dr. Varley Roberts, Alfred Bimme, and the late J. B. Welch. In 1879 came an offer to join the Carl Rosa Opera Company; but a vacancy occuring in the choir of Lincoln Cathedral at the same time, Mr. Shepley, by the advice of friends, chose the latter, and obtained the post. A vear later he was promoted to St. Creorge"s Chapel, Windsor, taking up his duties Jannary, 18s1. While there he was a member of Her Majesty's private choir. In 1887 he was appointed a 


\section{SHIEIPARD.}

Gentleman of the Chapel Royal, St. James's. He has done much nseful work as a concert singer, and also as a teneher. His wife was a contralto pocalist, and, as Miss SARAH Rifer, was widely known in the North as a concelt singer. She died at Brixton, July 12, 1894, at the early age of thirty-three.

Sheppard, Elizabeth Sara, novelist, horn at Piackboath, London, in 18:30; died at Brixton. London, Mareh 13, 1862. She wrote a $110 \mathrm{mber}$ of nowels, of which "Charles Auchester," 1853, 3 rols., and "Rumour," 1858,3 vols., deal with music and musicians. The character of sioraphel in "Charles Auchaster" is intended for Mendelssohn.

Sheppard, Rev. Henry Fleetwood, clergyman and musician. Ninor canon of Gloncuster and Windsor; sub-dean, Chapel Royal, Savoy, 1884. Composer of anthems, O Lord, the viry heavens; If the Lord Himself; and arringer of settings of Te Demm, Benedictus, Magnificat, and Nunc lomittis to ancient melodies, (iregorian Tones; Sories of Church Songs, 1884, 2 sots, ete. Collaborator with Rev. S. Baring-Gould (q.x.) in collecting and arranging "Songs and ballads of the West" [1s:)1]; "A Crapland of Comntry Song," Methnen, 1895; Fnglish Minstrelsie, Edinlurgh, Jack, 1895-06.

Sheppard, or Shepherd, John, organist and composer of the 16th century. He was a chorister in st. Paul's Cathedrat, London, and afterwads became jnstruetor of choristers and organist of Magdalen College, Oxford, 1542-47. He gracluated Mins. Ioc., Oxford, in 1554. He composed, masses, motets, and other Church music, mostly preserved in MS.

Sheringham, J. W., clergyman, and anthor" of "Ont" Cheir Festivals: can they be reformed without abolition?" (iloncester, 1874.

Sherrington, Hellen, Matamir Lmants SHerringtox, soplino voralist, horm at l'res. tom, Hancashire, octoler 4, 1834. The family migrated to Rotterdan in 1838. There the daughter studied muder Terhulst; in 1852 entred the Frossis Conservatoire, taking first prize lor singing and derelamation. Made her first appearanee in London, April 7, 1856 , at the Amatem. Musical Socicty's Concert, Hamorer Siguare Pooms. She soon obtained a leading position, and was heard at the Bimingham Festivals from 1s61; the Three (hoirs, Worcester, 1803-72. In 1880 she was nominater a professor of singing at the Bumsols Comservatoire, ]ut molertook a tour in the provinees, 188:-1. She made a special visit to London in 1889, to sing in Benoit's "Isucifer" at the Albert Hall, April 3. In 1.5)1 she resigned ber professorship at biuscels, and areepted one at the li.A.M., London, the same year, which she still retains, and was

\section{SHIELD.}

elected an Hon. Member of the Institution. In opera she made her début at Her Majesty's Theatre, October 10, 1860, as Maid Marim, in Nacfarren's " Robin Hood," and "took the audience by storm." She tirst sang in Italian Opera at the same theatre in May, 1866, as Adalgisa in "Nomm," appearing later in many operas, Fnglish, French, and Italian. she married, in 1457, Nicolas Lemmens, the minent belgian organist and composer, who died Jamuary 30, 18s1. 'Two danghters, MARy and Wula, nade succesiful first appearances at the Royal Acarlemy of Mnsic, Lomvain, November 6, 18R1; and both have been heard in London and the provinces, at times from 1882. Madane sherrington is the composer of some songs.

Sherrington, Jose, soprano rocalist, younger sister of Madame Lemmens-Sherrington, was hom at Rotterdam, October $27,1850$. Studied at Brusisels nnder Matane MeverBoulard, and Signor (hiriamonte. Made her appearance in Fngland in 1871, and sung at her sister's concerts in London, 1872, and in the provinces. Toured in Holland in 1873, but has resided chiefly in Hngland since.

Sherwin, Amy, soprano vocalist, born in Tasmania. Received her first instruction from her mother, then joined an Italian operatic troupe, and made her rlebut at Melbomme in "Lneia di Lammermoor." In 1879 went to America; sang in New York; at the Cincimuti Festival, and principal concerts, 18x(o-1. Studied muder Theodore Thomas, J). Dammoseb and others: and retuming to Furope, studied at Frankfort with Stockhansen; Nadane Ilustache at Paris; and also Tanmecini and Ronconi. Made her début at Inury Lime, April 7, 1883, in the title part of "Maritana," with Carl Rosa Company; sang at the l'romentade, Richter, Crystal Palace, and provincial concerts, 1881-5. Again went to Anerica; and in 1885 undertrok a tour through Australia, India, China, cte. , singing once nore in Eondon, July, 1890. In 1896 she took her own opera eompany to South Africa.

Sherwood, Percy, pianist and composer, bon May 23, 1866. Nephew of Edward Lawrance (q.2.). Educated at Dresden Conservatorim, 1885-8. In 189? he won the Mendelssolon Femman state Prize, for a Frand Requien for soli, chorus and orchestra. He was appointid a professor at the Hresden Conservatorimm in 1893. His works comprise a Concerto for pf. and orchestra; a Srmphony; Oyerture to Goethe's "Gritz von Berliehingen"; Sonata for pf.: chorus and somgs, ete. Also chamber muic, organ pieces, ete. As a pianist he has been hrard at many concerts in Gemmoy, and he has a high repitation.

Shield, W'illiam, composer and writer, bort at Whickham, I) 


\section{SHIELD,}

He studied under his father, a singing-master, and practised the violin and harpsichord. Apprenticed to a boat-builder at North Shieids, on the death of his father, but afterwards leeame leader of the Neweastle Subscription Concerts, and studied music under Avison, who befriended him. He went to Searborongh as leader of the theatre orchestra, and the subseription concerts. Violin-player in orehestra of the opera, London, 1772 ; and in 1773 he was made prineipal viola-plaver. Composer to Covent Garden 'Theatre, 1778-91 and 1792-97. Visited France and Italy with Ritson, the antiquary, 1791. Master of the Royal Nusie on death of Parsous, 1sit. Original member of the Philharmonic Soeiety. He died at 31, Berners Street, London, Jannary 25, 1829. Buried, February 4, in south cloister of Westminster Abbey. A new stone was placed over his grave in 1892. On October 19, 1891, a memorial eross was mneiled by Dr. Hodgkin in Whickham churchyard.

Works.-Music to Dramas, Operas, ete: Flitch of Bacon, 1778; Lord Mayor's Inay, 1782 ; Rosina, 1783 ; Poor soldier, 1763; Harlequin Friar Bacon, 1783: Robin Hood, 17st; Nolle peasant, 1784; Fontainllean, 17itt; Magic caven, 1784; Numery, 1785; Love in a camp, 1785; Choleric fathers, 1785; Omai, 1785; Richard C'cenr de Lion, 1786; Enchanted eastle, 17ite; Narian, 1788 ; Prophet, 17ss; Highland reel, 1788 ; Aladdin, 1788 ; Crusade, 1790 ; Pieture of Paris, 1790 ; Oscar and Malvina (with Reeve), 1791 ; Woodman, 1792; llartford bridge, 1792; Har. lequin's Niusenm, 1793; Deaf lover, 1793; Midnight wanderers, 1793 ; Sprigs of lanrel, 1793; 'Travellers in Switzerland, 1794; Arrived at Portsmouth, 1794; Netley Abbey, 1794: Mysteries of the Castle, 1795: Lock and key, 1796; Abroad and at home, 1796; Italian villagers, 1797; The farmer, 1798; Two faees under a hood, 1807; Wicklow mountains. A Cento, consisting of ballads, rounds, glees, and a roundelay; Cavatinas, eanzonettas, etc., London [1509]. Collection of six eanzonets and an elegy, London, n.d. Collection of favourite songs, etc., London, n.d. Six trios for violin, tenor, and violoncello, Lomdon, n.d., 3 vols. Six duos for two wiolins. Six quartettos, 5 for 2 violins, tenor and 'cello, and 1 for flute, violin, tenor, and 'cello, op. 3. An introduction to Harmony, London, 1800 ; 2nd edition, 1817, Rudiments of thorough-bass for young harmonists, londom, 1815. Numerous songs, of whieh the best known are, The wolf; The thorn; Old Twwler; The heaving of the lead; The Post Captain; The plongh-boy: Tleath of Tom Moody; The Arethusa; Last whistle; Lovely Jane; My own native village; The bud of the rose; Sailor's epitaph; On by the spur of valour goaded; and Violet nurs'd in woodlands wild.

\section{SHIRREEF.}

Shinn, George, organist and composer. born at Clerienwell, London, March 6, 1837, Privately trained in musie. (rraduated Mus. Bac., Cambridge, 18so. Appointed organist of St. Peter's, Hackney Ruad, December, 1858; St. Jude's. Whitechapel, June, 1863; st. I'anl's, Canonbury, 1866 ; st. Matthew's, Brixton, 1872; and Christ Chureh, Upper Norwood, 1887, a position he still holds. Published eompositions-Oratorios: The Captives of Babylon (1885); Lazarus of Bethany (Is)2). Cantatas, with rendings: The Reformation (1880); The Victories of Judah (1881): The Life of samuel (1884). Harvest Thanlisgiving Cantata (1s95). School Cantatas: The Four heasons; The Bell Tower; The Queen of Merry May. Morning and Evening Services; Anthens; Kyries, and Hymm Tumes. Twelve school songs; songs and part-songs. Original Compositions for the Organ ; Six bools's of 'Trumseriptions. Six riolin and pf. dnets; pf. pieces, cte.

His son, Frenerick George, organist, was horn in London in 1s67. He was educated at the R.C.MI. Gradiated MIus. Hac., I Hurham, 1892. F.R.C.0.; A.R.C.M. Organist and choimaster, All Saint's, Clapham Park, 18881892; St. James's, Marylehone, 1892-3; Parish Chureh, Sydenham, 189:3. Conductor of Reigate Rnial Ineanery Choral Union, 1893; Svdenham Choral suciety. Has given organ recitals in various places. Anthor of a brochure; "Forty Reasons of Caturday Concerts at the Crystal "Palalee" (1896).

Shinner, Emily, violinist, horn at Cheltentam, July 7,1862 . Began the violin at an early age, and in 1 sit went to Berlin and studied under Jacolwen. When female violinints were admitted to the lligh sichool in 1st6. Miss shimner entered as a pupil of Joachim. l'layed in sereral towns in (remany, returning to England in 1sist. She made a successful debut, Jume : 3,1 s.82, at Mr. H. R. Bird:s Concert, Kensington Town Hail ; was heard in the provinces som after: at the Monday Popular Concerts, Felumary 9, 1884; Crystal Palaee, March $s$, mpidly attaining a high position. In 18 s she organised a string fuartet of ladies, the first coneert taking place at King"s College, Lomdon, April 2 of that year. The shinner ( ) nartet have played in London and the provine's each year since, with increasing success. In Jamnary, 1889, Mism shinner married Captain A. L. Liddell, of the Artillery, the Queen kending a diamond bracelet to the hride.

Shirreff, Jane, soprano vocalist, born 1811 She studied under Thomas Welsh. Dibut at Corent Garden Theatre, London, in Ame's "Artaxerxes," 1831. She sang at the Philharmonie ('oncerts, the Concerts of Aneient Music, and at the Provineial Festivals; also at Drury Laue Theatre, and in 1838 , 


\section{SHIRREFS.}

she appeared in America with Seguin's company. Married Mr. J. Walcott, secretary of the Army and Navy Club, and retired. She died at Kensington, London, December 23, 1883.

Shirrefs, Andrew, poet and musician, was born at Aberdeen in 1762. He was educated at the Grammar School and Marischal College, Aberdeen, and graduated M.A. in 1783. Ile was a stationer and publisher in Aberdeen and Edinburgh, and edited the Aberdeen Chronicle and the caledonian Magazine. In 1798, he went to london and seems to have died there about 1801. His only known contributions to music were, " Horty Pieces of original music, inscribed to the Earl of Buchan," Aberdeen, n.d. [1788], and "The overture, airs, songs, and duetts in the Scots pastoral comedy of 'Jamie and Bess," "Edinburgh, n.d. He is best remem. bered as the author of "Jamie and Bess."

Shoel, Thomas, composer, born at Montacute, Somerset, in 1759; died 182:3. Compiler of Thirty Psalm Tumes, first sett; Twenty-four Psaln Tunes, 2 hymms and 3 easy anthems, London [1801]; Book of I'salm Tunes, Hymus, and Anthems, London, 18006, 6 vols.; The Chearful Psalmodist, a new set of tunes, London [1809]; Ode for Christmas Day, 1804; Peace, a two-part song; Shipwrecked Boy, duet; and songs.

Shore, John, trumpeter, was born in the latter part of the 17 th century. Hesucceeded his brother WiLlian in office of sergeant trumpeter. Trumpeter in the Queen's band. He died Novemler 20,1750 . He is credited with the invention of the tumirg-fork. The most celebrated trmmpet-player of his time. He was succeeded in lis office by Valentine Snow. His sister Caturline, born in 1668 , was a pepil of 11. Purcell. Married Colley Cij)ber in 1693. Appeared as a singer in operas by Purcell and others. She died in 1730, The founder of the shore family was Matrhias (died 1700), who was King's trumpeter in 1685 , and was succeeded by his son William (died 1707).

Shore, William, amateur commoser, horn at Nanchester, November 21, 1791. Was fomnder and musical director of the Manchester Madrigal society, and hon. secretary of the Gentlemen's Glee Chuls. He dited at Buxton, January 16; 1877. He edited "Sacred Music, selected and arranged from the works of the most eminent composers...." London 1835], and composed glees, and the well-known trio, "O Willie brew'd a peck o" maut" [1840]; anthems, songs, and pf. music.

Short, Joseph, composer and organist, born at Caldnore, Walsall, Staffordshire, May 22, 1831. Received his early training in the local Roman Catholic Chwirch choir,

\section{SHIRU1BSOLE.}

and became acquainted with much of the finest ecclesiastical musie. Self-instructed in harmony and composition. Appointed organist of the IRoman Catholic Church at Wednesbury in 1853, and later of St. Mary's, Walsall, where he began to produce the masses of the great composer's with full orchestra. He went to Bimingham in 1861, and, having a goud bass voice, was appointed cantor of St. Chad's Roman Catholic Cathedral, moving in 1867 to st. Joseph's, Nechells. About this time he published a "salve Regina," which lecame pronlar. In October, 1872 , he accepted the office of choir-master at St. Micharl's, Moor Street, Bimningham, which he still holds, and has made famous by the production of great works. He condiucted a performance in this church of Schuluert's Mass in F, in 1873 , and gave the same at a concert in the Masonic Hall, Birminghan, Septculber 7, 1875, with full orchestra, heing the first performances of the mass in Fnuland. For some years he gave concerts in the Biminghan Town Hall. He Was thosen as the English representative to give infomation to the sacred Congregation of Rites in the revision of the Liturgical rules for the guidance of composers of Roman Catholic Church music, a great mark of distinction. His derotion to music has been his recreation, he bejng ocempied in business as a merchant.

Wonks. Masses: St. Juseph (dedicated to Cardinal Newnass, produced Birningham Town llall, I tecember 9, 1880; sit. Greorge, 1rse, looth for soli, chorus, organ and orehestra. Offrotoriums: Ave Mlaria; Beata es Viron Maria; Penedic Anina Mlea Lomino; Bentedicite I onsinmm; Dels Isracl, quartet and chorus; De I'rofundis, baritone solo, with strings; Adoramus Te, for strings. Marche Cardinale, for orchestra. In Ms. two masses; a cantata, The Nativity ; motets, ete.

Shoubridge, James, musician and tenor singre, lom at Canterbury, in 1804 . He was a teacher there for a time, but died in London, Ilecember, 1872. He was appointed conductor of the Ceciliun Society, London, 1852. Composer of "Twenty-four original Psalm and Hrmn tunes, for 4 voices," 11.d.

Shrubsole, William, organist and composer, born at Canterbury in 1760. He was a chorister in Canterbury Cathedral from 1770 till 1777. In Septemiber, 1782, he was appointed organist of Bangor Cathedral at a salary of forty guineas a year. In December, 1783, he was dismissed for heing too closely cumnected "with one Abbott late of thisplace," and for "frequenting conventicles." $\mathrm{He}$ therefore next became organist of Spa Fields Chapel, Clerkenwell, in 1784, and held the post till his death, at London, January 18 . 


\section{SHUTTLEWORTH.}

1806. He was buried in Bunhill Fields, London, where a monument marlis his grave. This was restored by public subseriptions collected by Mr. F. G. Edwards, in 1s92. Benjamin Jacols and William Rusisell were among his pupils. Shrubsole is now chiefly remembered as the composer of the once popular hymn tune called "Miles Lane," or sometimes "Scarborough."

Shuttleworth, Obadiah, organist, violinist, and composer, boln at spitalfields, London, 1675. Tiolinist at the Swan Taven Concerts, Comhill, 1728. Organist sucetssively of St. Michael's, Combili, and of the Temple Church. Composer of concertos and sonatas for violin. He died in 1735.

Sibbald, James, publisher and bookscller in Edinburgh, who was born about 1717 , and died at Edimburgh, April s, 1809 . Fle tited “The Tocal Magazine, containing a selettion of the most esteemed English, Scots, and Irish Songs, ancient and modern, arlapted for the harpsichord and violin," Edinburgh, 1797-99. 3 rols., isinued in 19 parts. A second series only reached a few parts. "Collection of catches, canons, glees, ete., in score, from the worlis of the nost eminent composers, ancient and nodem," Edinlumeh, 3 vols., nd.

Sibly, Stephen, organist, born in 1766. He was organist of St. Thomas', Poltsmonth, and of st. John's ('hapel, Jortera, for 52 years. He died at Portsmouth, September 23, 1842.

Sime, David, musician and teacher, born about the middle of last century. He wits a teacher in Edinburgh, where he died on July 7, 1807. He edited "The Edinburgh Musical Miscellany, a collection of the most approved Scotel, Euglish, aud Trish songs, set to music," Edinburgh, 1792-3, 2 vols ; 2nd edition, 1808,2 rols.

Simms. A remarkable family of organists. JoHn Simas, the founder, was born in Staffordshire about the middle of the eighteenth century. He was brought up to the countinghouse, lut continued in his father's business, the iron trade, for some years. Cultivating his passion for music, he became a fair player on the organ and violin. Afterwards he devoted himself to the construction of instruments, aud made, among others, an upright harpsichord, which was publicly exhibited. The date of his death is not known. He had a family of eight sons and two daughters, who were all musical, as was his wife. Of his sons, Bishop Simms succeeded Joseph Harris, Mus. Bac., as organist of St. Philip's, Birmingham, aud was also organist of St. Mary's Chapel in that town. He was a violinist, and one of the orchestra at the Birmingham Festivals from 1805. Date of death unknown. JAMES SIMIs was organist of Bromsgrove Parish Chureh, and also at Chaddesley, Worcester, but nothing is known
SIMIMS.

of him after 1826. SAluel Simis, was esteemed one of the finest players of his time, In 1805 he was a candidate for the post of organist at Whitchurch, Salop, but the couditions were so unsatisfactory that only three of those assembled would compete. A curious letter on the subject appeared in Aris's Gazctte, Birmingham, April 15, 1805. He was organist of St. 'Thomas's, Stourbridge, for half a century, and died sometime before 1860. EDwaRD Simas was organist of Asburn and Oakover, Staffs, but no details can be obtained about him. HENRY Srums was an organist at Stourbridge, and auother son, JESSE, was a musician.

Simms, Edward, son of Edward Simms named in the preceding article, was born at Oldswinford, Worestershire, February 10 , 1s00. At the age of six he commenced his studies under his uncles at Stourbridge; and when ten axisisted his mele James at Bromsgrove He was appointed organist at Wombourne, near Wolverhampton, in 1813 . Went to London in 1816, and studied muder Thomas Adams, and Kalkhremner. In 1sish he removed to Corentry, and was orgnuist successively of Holy Trinity, 1N21; Nt. John's, 1825 (having meantime held an appointment for three years in Birmingham); and St. Michael's, 1828, holding this last office for the periud of 58 Fears, lesigning in 18s6. Established the Coventry Chonal Soejety about 1s:36, and did much to disseminate a taste for music in the district. He had nuny pupils of distinction, including the novelist freorge Eliut, and it is to him that reference is made in "Middlemiarch." He composed numerous pieces, but published very little. Hin death touk place at Coreutry, January 15, 1893.

Simms, Henry, organist and pianist, born in 1804. Son of Jente simms. He was a prupil of MLoscheles for pf., to whom he dedicated a Polacca. Appointed organist of Holy Trinity, Bordesley, in 1825, he held that office until 1875; whilst he was alıo organint at St. Philip's, Bimningham, 1829-71. He was famous as an extempore player, and widely known as a teacher of pf, and singing. His compositions were chithy teaching pieces for pf. and songs; but he also wrote a Communion Service which remained in MS. He died, IIay $1,1872$.

Ronent Hexry, his eldest som, was boln at Highgate, Bimingham, in 1s.9. Pupil of his father, and later of R.A.M. In 1851 he was appointed Music Master at Chester College; and organist at Wrexhan Parish Church in 185. ' ${ }^{\top} p$ to June 29, 1856, he oceupied his usual post at the organ, but the next Sumday he expired as the bells were ringing for morning service. His brother arrived from Bimingham the mevions evening, to take his place, but on the Sunday, by 


\section{SIMIIS.}

the Viear's desire, the organ remained silent as a mark of respect to the artist so suddenly passed away.

EDWARv Brshop Srmas, the second son of Henry Simms, was also the pupil of his father. He studied pf. under Cipriani Potter. Sueceeded his brother as organist of Wrexham Parish Chureh, August, 1856; and resigned in December, 1894. He was Music Master at Chester Úollege, 1856-86; and is still resident at Wrexham as at teacher.

Simms, Samuel, organist and composer, born at stourhridge in 1836. Fldest son and pupil of Samuel Simms, previously noticed. He succeded his tather as organist of sit. Thomas's Church, stoulbridge, and remained there for some years. Afterwilds he tork an appointment at St. John's, Ladywood, Birmingham; and was lastly reganist of St. Cyprian's, Hay Mills, Birninghan, a chunch distimsuished for its onate musical services. (His brother, tle hev. (x. Jlandel Simms, became vicar of that church). He was conkluctor of the brieller llill Choral society from its formation; Was a silful organist and pianist. His:onpositions included services, anthens, and organ pieess. Ho died at stombridge, Felruary 2.2, 1685. His eldest son, SAmre, sneceeded him as organist of st. Cyprian's, and retains that position to the present time.

Simms, Arthur, organist and composer, born at Bimningham, June 11, 1839. Son of the first-named Sammel Simms. T'upil of his mele, Henry Simms. IVas assistant organist of St. Philip's and Holy Trinity, Birminghan, 1856-65. Appointed organist of Shifnall Parish ('hurch, 1860; Wilmolow, Cheshire, 1кT0; St. Mary's Episeopal Church, (rlasgow, 1875 ; Organist and music master, Folest School, Walthamstow, 1840; Hythe Parish ('hureh, 169\%, to present time. Ciradmated Mus. Bac., Oxford, 1874. At Shifnall he was conductor of the Philharmonic Society; and while at Glassow he directed a performance of Bach's Passion Music, in 1877. He is correspondence tutor of (nueen Malgaret College, Grasgow. His compositions are: Lazarus, an oritorio; P'salm 33, for voices and orchestria, both in MS. Anthems prolished for Christmas, Faster, Ascension, Amnunciation, and ILarvest. Selrice for Holy Communion. Tnmproniptu for organ, etc.

Simper, Calleb, organist and composer, born at Barfurd St. Martin, Wilts., September 12, 185ti. Fourteen years organist at St. Mary MLasdalene, Worcester, and manager to E. J. Spark. Now resident at Barnstaple, devoting himself exclusively to composition. He has composed a large number of simple anthems-1 will feed my flock; He is risen; Fear not, o land; Break forth into joy, ete. ; also prize hymn tunes, Manchester Sunday School Urion, ete.

\section{SIMIPSON}

Simpson, Christopher, or SYMPson, violinist and writer, born [about 1610]. He tvas originally a soldier in the army raised by the Duke of Newcastle for service of Charles I. Being a Roman Catholic, he was patronlzed by Sir Robert Bolles of Leicestershire, whose son he taught the viol. He died at Tumstile, Holborn, London, about 1677.

Works.- The Division-Violist, or an Introduction to the playing upon a Ground, divided in two parts, the first directing the hand, with other preparative instructions; the second laying open the method and manner of playing, or composing divisions to a ground, London, 1659; 2nd edition as "Chelys Minuritionum artificio exornata, sive Minuritiones ad Basin, etiam extempore modulandi ratio.. or the Division Viol, etc., London, 1667 ; 3rd edition, with portrait, 1712. The Principles of Practical Musick, London, 1665; $2 \mathrm{nd}$ edition, A Compendium of Practical MI usic, in 5 parts: 1. The Rudiments of Song; 2. The Principles of Composition; 3. The $\mathrm{L}^{*}$ se of Discords : 4. The form of Figurate Descant; 5. The Contrivance of Canon .. London, 1667. Of this work there are many editions dated and undated to about 1760. Art of Discant, or Composing Musick in Parts, by Dr. Thomas Campion, with Amotations thereon by Mr. C'hristoplyer Simpson, London, 1655. Also contained in Playford's "Introduction."

Simpson, Frederick James, composer, born at Portolello, near linburgh, December 12, 1850. Fducated at the Edimburgh Academy, and later in England and Switzerland. Fintered the Leipzig Conservatorimu, 1887, studring under Alfred lichter; in $1879-80$ stridied at the National Training School for Nusic. London, under E. Pront, F. Taylor, and .J. F. Bridge. Graduated Mus. Bac., ()xford, 1ssf; and further studied composition with Latwig Bussler, Berlin, 1687-8. He has given concerts at ledinlurgh and elsewhore. His compositions inchude a Symplony in C; overture "Robert Bruce" (produced at the Crystal Palace, Norember $2,1889)$ : which, with a somata for pf. and violin, and two pf. sonatas, remain in MS. He hats also composed a cantata, "The Departure of Summer," for soli, chorus, and orchestra ; "Coromach" (from Scott's "Lady of the Lake," produeed at Fdinburgh, April 8, 1s91); "Come to the Woods," somg, with violin obligato; A Message to Phyllis, and wther somgs, duets, part-songs, ete. Four sketches; Tone pictures for the young; and other pf. pitecs; Cavatina in F, violin; Allegro giocoso, two violins, etc.

Simpson, James F., composer and pianist, horn in 18.5; died in London, Uctober 11, 188. In addition to a large number of album sketches, galops, and transcriptions for the pf. he composed incidental 


\section{SIMPSON.}

music to The Niller and his man, 1875, and wrote "Nursery rhymes and children's songs" London [1881]; "Six Scottish songs, the poetry selected from R. Burns" [1872]; partsongs, songs, and other works.

Simpson, John, musician of first half of the 18 th century, wrote "Delightful pocket companion for the German flute," London [1740]. Another Jons Simpsos, who flonrished later in the century, composed "Twelve voluntaries. for the organ or pf. to which are prefixed some remarlis on stringed musical instruments." London 1800$]$.

Simpson, John, member of a music publishing firm in Lendon, wrote " Easy method of learning the Coneertina," London [1855]; "Easy method of playing the Accordion, German Accordion, or Flutina, London 1 1s76]; Complete book of Instructions for the Flute; Arrangement for the Accordion, etc. These instruction books are istued in rarious editions.

Simpson, Palgrave, amatenr musician and writer, horn about 1815 . Solicitor practising in Liverpool, where he died, Jannary 22,1891 , at the age of 75 . Author of "The Bandmaster"s Guide," 2 rols., London, Boosey, 18.85.

Simpson, Robert, eomposer, was born at Glasgow, November 4, 1794. He was a weaver by trade, and led the singing in Dr. Wardlaw's church, Glasgow, for a time. Afterwards he was precentor and session elerk of the East Parish Cliurch, Greenock, from 18.3. He died at Greenock, in July or Auguet, 1832. He composed or adapted the tune well known in scotland as "Pallerma," which was first published in Turnbull's "Selection of Original racred Mnsic" (forming vol. 6 of Steven's Colleetion), 1833, from a IIS. found after Simpon's death. On the strength of a by no means close resemblance, the tune "Ballerma" has been assumed to be a eopy or adaptation of a melody composed or arranged by Barthélémon (17+1-1808), a Frenel violinist and composer.

Simpson, Thomas, English composer and violinist, who in 1615 was violinist in the ehapel of the Prince of Holstein-Sichaumberg. Composer of "Opuseulum never I'avanen, Galliarden, Couranten, und Volten..." Frankfort, 1610; "Pavanen, Yolten und Galliarden," Frankfort, 1611; "Tafel-Consort, allerliand lustige Lieder von 4 Instrmmenten und Generalbass," Hamburg, 1621.

Simpson, T., anthor of " The Norma Virium, or Musical Accentuator, a disquisitory essay on the obstructions stndents meet with in becoming good timeists...," London, 11.d.

Simpson, Thomas, organist and composer, was born April 25, 1839. Compiler of the Burnley Tune Book; Part-songs; Dance music for pf., etc.

Sims, Thomas, composer and organist,

\section{SINCLAFR.}

issued "Fifty original psalm and hymm tunes, figured for the organ," London [1816].

Sinclair, George Robertson, organist and eonductor, horn at Croydon, Oetober 28 , 1863. Son of the late IR. S. Sinclair, LL.D., of Dublin. When eight he began his studies at the R.I.A.M., I ublin, and a vear later entered St. Michael's College. Tenlnury, where he remained six years. In 1879 he became a pupil of Dr. Harford Lloyd, of Gloncester Cathedral, and was his assistant organist, as well as offieiating at St. Mary de Crypt Church. At the elose of 1 sist he was appointed by the Chapter organist of Truro Cathedral, where he worked up the choir to a high efficiency, and presided over a gathering of 700 performers at the consecration service in November, 1887. He originated, and was Diocesan Choimnaster of, the Heanery of Powder Choir Association, and conductor of other societies. In $18 \mathrm{~s}$ lie suceeeded the late Dr. Colborne as organist and master of the choristers at Hereford. Condneted the Hereford Festivals of 1891 and 1894 with conspicuons ability. He is a brilliant organ player, and has gisen many recitals. He condacts societies at Hereford and Ross. Elected Hon. R.A.M., 1 s.5.

Sinclair, John, tenor rocalist, was born near Edinburgl, in 1790. He became a clarinet player in the land of camplell of shawfield's Reginent, and afterwards a teacher of masic in therdeen. First appearance as a singer in Lomelon at Havnarket Theatre, as Cherly in "Luck and Key," 1880. He studied singing for it time unrter" Thomas Welsh. Engaged for ('went Garden Theatre, and appeared in Linley"s "Inemna," 1811. Married Mism Norton, danghter of Captain Norton, 1816. Appeared in London, and in English Provinces till 1,19; when he visited Paris, and studied for a tine under Pellegrini, and under Banderali at Milan. Visited Rosuni at Naples, 1s21. Sany in Pisa, Bologna (where he was made a nuember of the Philhamonie Academy), Modena, Florence, Tenice (where Rosinis wrote for him the part of Flreno in "Semiramide"), and (Fenoa, 1822-23. Re-appeared in London, Covent Garden, November 19, 182:3, and at other theatres till 1830. Sang in America, and appeared in opera, 1830, and retired soon after. He died at Margate, Septemleer 23, 1857. Sinclair was one of the most popular singers of his day, and was the ereator of the tenor roles in Bishop's "Gny Mannering," "The Slave," "Nolle Uutlaw," and Dary's "Roy Roy." He componed the well-known songs "Beneatl the wave," "Betty Sands," "Dimbarton"s bonnie dell," "Hey the bonnie breast-knots" [1828], "The Mountain Maid" [1830], "Come sit thee down," "Johnnie Sands" [1830], and other's in the Scots style. 


\section{SINKINS.}

Sinkins, Farley, bass vocalist, sometime lay-vicar of lixeter Cathedral. Gave subscription concerts at Hxeter up to 1888; and orchestral concerts at St. James' IIall, London, 1891, introducing eminent artists for the first time in Fondon.

Sivewright, John, musician, who was well-known in the north-east of Scotland as an itinerating teacher of psalmody. He held the office of precentor in the Parish Church of Old Meldrum till 1835, and died there about 1846 , a very old man. He travelled all over the counties of Aberdeen, Banff, and Fincardine as a teacher of church choirs. He published "A Collection of Psam Tunes, Hymns and Anthems, in three parts, by John Sivewright, teacher of music, Old Deer. The 4th edition ... Edinhurgh, printed for the author..." n.d. In the 5th edition, Edinburgh about 1815, he describes himself as "teacher of music, Turriff"; and in yet another he figures as "teacher of music, Fordomn." It is therefore probable he had an edition printed for each of his centres of operations. They are all little oblong books of about 64 to 70 pages, and are exceedingly rare.

Sivrai, Jules de, see Roeckel, Mrs. J. L.

Skeaf, Joseph, composer and pianist, born at Livernool, November 10, 1836. Stndied under George Holden, and was a teacher in liverpool, and conducted the Apollo frlee Club there. He was also (irand Organist to the Freemasons of West Lancashire. He died at Liverpool, November 1, 1884. Composer of "Harlech," a cantata, Liverpool, Novemler 15, 1888, published by his widow; some glees. Pf. pieces: Battle of Trafalgar, The Cimp, Fantasias, Sabbath evening chimes. Songs, etc.

Skeats, Mighmore, organist and composer, was organist of Canterbury Cathedral. He died at (anterbury in 1831. Compiler of "A Collection of Songs," London, 17st, and edited Stephens' Cathedral Music, 1805. Also composed All gracious freedom, glee [1790]; Cease thy carols, and Vietory of Fishguard, songs.

His son, HifHnone ShEats, eomposer and organist, was born at Canterbury, in 1785 . He became organist of Ely Cathedral, and afterwards of St. ( ieorge's Chapel, Windsor, in 1830, and died at Windsor, February 2t, 1835.

Skeffington, Hon, and Rev. T. C., author of a "Handy-Book of musical art, with some practical hints to students," London, 1858; "The Flute in its transition state, a review of its changes during the past fifty years," Tondon, 1862; "Oh! fair and bright is the Irish girl," and other songs.

Skene, John, of Halyards, a Scottish collector of the 1 fith and 17 th centuries, who died in 164t. He is supposed to have compiled the "Skene Manuscript," 1614-1620, a
SLATTER.

collection of vocal and dance music which was edited and published by Damey and Graliam for the Bannatyne Club, in 1838. It contains, among other melodies, the fine old setting of the tume usually sung to Jane Elliott's version of the "Flowers of the Forest."

Skinner, Florence Marian, Mrs. Stuart STRESA, composer, daughter of Alan Skinner, late Recorder of Windsor. Resident for many year's in Italy. Her opera, "Suocera," was produced at Naples, April 15, 1877; and a second, "Maria Regina di Scozia," at San Remo in 1883, and also at Turin and London the same year.

Skinner, James Scott, violinist and composer, born at Bancliory, Aberdeenshire, August 5, 1843. Son of IVilliam Skinner, who was known in the district as a good amateur violinist. He studied the violin under Dr. Mark (died 1868), a German musician of Manchester, and has performed much in Scotland, Canada, and the United States. Composer of a large number of reels, strathspeys, and songs, most of which have been issued in "The Miller O'Hirn"; "The Logie Collection of original music for voice, violin, and pf., comprising songs, slow airs, etc.," London, 1888, and other collections. Reputed one of the best players of scottish dance music.

Slater, Ernest, organist and composer, born at Taunton, 1860. Son of Rev. W. P. Slater, formerly Governor and Chaplain of Queen's College, Tamuton. Educated there, and entered R.A.M., studying under Dr. Steggall, T. A. Matthay, and Harold Thomas. Also pupil of Sir Julius Benediet, and Dr. D. J. Wood. Assistant organist of Exeter Cathedral, 1881. F.R.C.O., 1884. Organist of Lambeth Parish Church, 1893, also officiating occasionally at the Archbishop of Canterbury's private chapel. Selected by Nir John Stainer for the post of organist and choirmaster at St. John's Cathedral, Calcutta, 1885. Gave his first concert at Calcutta, September 7, 1886. Professor of Music at La Martiniere College, and his private practice has included the families of three Viceroys of India. Of his compositions a festival overture for orchestra was performed at Taunton, 1885; and his Jubilee Anthem was sung at the State Service in Calcutta Cathedral, 1887, a copy being accepted by Her Majesty the Queen.

Slatter, Rev. George Maximilian, clergyman and composer, born in 1790. He was rector of IVest Anstey, Devon. Died on April 27,1868 . Composer of "Three an thems, a Te Deum, etc., three psalm tunes and eight chants," London [1854]; "Ten Collects, a set of chants, etc." [1.835]: "Six canzonets, a trio, and a glee" [1815]. The Watcher, and other songs. 


\section{SLATYER.}

Slatyer, William, musician of 17 th century, issued the Psalms of David in four languages, and in four parts, set to ye Tunes of our church..16 13.

Slaughter, A. Walter, composer and conductor, boru in London. Educated at City of London School. Chorister, St. Andrew's, Wells Street. Studied under Alfred Cellier and Jacobi. Wrote some ballet music, etc., for the Sonth London Palace of Varieties; afterwards appointed conductor at Royalty Theatre; later at the Olympic; Drury Lane; and St. James's Theatre. His works include An Adamless Eden, 1882; Marie's Honeymoon; The Casting Vote, 1885; Music to lyric drama, Sappho, Olympic, 1886; Comic opera, Marjorie, Prince of Trales' Theatre, July 18 , 1889; The Rose and the Ring (Thackeray), the same, December, 1890. Incidental music to various pieces. MIusical comedy, The French Mlaid, Terry's Theatre, April 24, 1897.

Sloman, Charles, composer and comic singer, born about 1808; died, London, July 21, 1870. Composed "Sacred Strains, hymns, etc." London $\lceil 18607$. Songs: Charming Sue, Daughter of Israel, Danghters of Salem, Maiden of sunny Cachmere, Maid of Judah, Pilgrim of Erin, Promised land, Social bricks: a number of comic songs, etc.

Sloman, Robert, organist and composer, born at Gloncester (1830?). Studied under Amott, S. S. Wesley, and C. Lucas. Was private organist to Farl Powis, 1852; of the Parish Church, Welshpool; St. Martin's, Scarborough, 1869; Parish Church, Lower Norwood, 1877. Graduated Mus. Bac., 1861; Mus. Doc., 1867, Oxfort. He composed a Cantata, "Supplication and Praise," which has been performed several times; and a second, "Constantin," not produced until February, 1896, some months after his death. $\mathrm{He}$ also composert songs, part-songs, pf. pieces, ete. For some years he contributed to the Musical standurd notices of the Crystal Palace Concerts. He died at West Norwood, July 2, 1895, aged 65.

Sloper, Edward Hugh Lindsay, pianist and composer, born at London, June 14, 1826. He studied under Moscheles; at Frankfort under A. Schmitt; at Heidelberg under Vollweiler; and at Paris under Rousselot, 1841-46. Appeared in London at Musical Union, 18t6. Played at a Philharmonic Concert, May 6, 1850. Lectured on Music in England, at Alexandra Palace, in May, 1876. Teacher and pianist in London. He died at London, July 3, 1887.

Works.-Op. 1, Czartoryska, 3 mazurkas, pf. [1846] ; Op. 2, Henriette, valse, pf. ; Op. 3, 24 studies, pf.; Op 4, caprice, pf.; Op. 6, capriccio, pf.; Op. 7, serenade, pf.: Op. 8, six songs; Op. 9, grand duet; Op. 11, Tarantella;

\section{SIIART.}

Op. 12, serenade and canzonette, pf.; Op. 13, twelve studies, pf.; Sonata for pf. and violin; Op. 15, Pensée fugitive, pf.; Op. 39, hallad fantasia [1867]; Op. 42, By the lake, pf.; Transeriptions and arrangements for pf.; Suite for orchestra, Brighton Festival, 1879; Duo, for two pfs., in E minor [1847]. Scena, Joan of Arc in prison (by Chorley), 1853. Songs: Fairy's reproach; John O'Grady ; Nedora; Prentice lad; Rover's adieu ; Siesta; Violet, etc. Pianoforte instructions, exercises and lessons, London [1854] ; Technical guide to touch, fingering, and execution, London, 1877. Tutor and technical guide for the pf. Editions of pf. works of eninent composers.

Smallwood, William, pianist, organist, and composer, born at Kendal. December 31, 1831. Studiel under Dr. Camidge and Henry Phillips, and has been organist of Kendal Parish Church from 1847. Composer of an immense number of pf. pieces, chiefly for use in teaching, snch as Home Treasures: Flowers of Melody; Youthful Pleasures, ete.; also of anthems, hymms, and songs. Anthor of a Pianoforte Tutor that has had a large circulation. Another musician of the name, F. W. SmaLtwood, was appointed organist to the Earl of Breadalbane, Taymonth Castle, in 1885; and in 1890, organist of the Town Hall, Alloa, N.B.

Smart, Christopher, writer, who died on Mlay 18, 1770. He published a "Collection of Melodies for the Psalms of David, aceording to the version of Christopher Smart, A.M. By the most eminent composers of church music," London, Walsh, 1765.

Smart, Sir George Thomas, conductor and teacher, born at London, May 10, 1776. He was a chorister in the Chapel Royal under Arrton, and studied the organ under Dupuis, and composition under Arnold. Organist of St. James' Chapel, Hampstead Load, London. Knighter at Dublin by Lord Lieutenant, after conducting a successful series of concerts. 1811. Original member of the Philharmonic Society, 1813. Conductor of concerts of Philharmonic Society, 1813-44. Conductor of the Lenten oratorios. One of the organists of the Chapel Royal, 1822. Connected with Weber, who died at his house in 1826. Conducted Mendelssohn's"St. Paul," at Liverpool in 1836. Composer to the Chapel Royal, 1838. Conducted all the principal provincial festivals of his time, and arranged and conducted the music at the coronations of William IV. and Victoria. He died at Bedford Square, London, February 23, 1867. One of the greatest English conductors. He was a successful vocal teacher, and gave instruction to Jenny Lind and Sontag.

Works.-A collection of glees and canons, London [1863]: Collection of sacred music, 2 vols.; Three sonatinas for pf. [1800]: An acrostic 


\section{SMART.}

elegy on...Viscount Horatio Nelson [1805]; The Eolus Frigate, a favourite dance as performed at Weymouth, 1804. Glees: Merry Gypsies, Peace at home, Sighs, Siquirrel, Butterfly's Ball (cauzomnettina), Garland, The Wreck (on the loss of the Forfarshire), 1839, etc. He edited Gibbons" "First set of Madrigals," for the Musical Antiquarian Society, 1841; works by Beethoven, etc.

Smart, Henry, violinist, was born at London in 1778. Brother of Sir George Smart. IIe studied under W. Cramer, and became leader in various theatre orchestras, the Philharmonic Society, English Opera House, etc. He became part-proprietor of a brewery, which did not succecd, and afterwards established a pianoforte manufactory. He died at Dublin, November 2:3, 1823.

Smart, Henry, organist and composer, son of absve, born at London, October 26, 1813. He studied under his father and W. H. Kearns, lut was partly self-taught. Articled to a solicitor. Organist of Parish Church of Blackburn, 1831-36. Organist of St. Philip's, Regent street, London, 1836. Married, July, 18to. Organist, St. Luke's, Old Street, London, 184t-64; of St. Pincras, Euston Road, 186t. His sight failed him in 1s64. Franted pension of $\$ 100$ per ammum by the Crovernment, in 1879. He died at London, July $4 ;, 1879$, and is buried in Hampstead cemetery, Finchley Road, London.

Works.- Orevas: Bertha, or the Gnome of Hartzleerg, Harmarket Theatre, London, 1855 ; Endine (mutinished); surrender of Calais, by Planehe (unfinished). Cuntutas: The Brida of Donkerm, Birmingham Festival, 186t; King René's Inangliter (by F. Enoch), 1sit; The Fishermadens, 1st1; Jatel, sacred, Glasgow (boral Union, November 10, 1873. Full Alorning and Evening services in $\mathrm{F}$ and G, 1871. Anthems: () God, the King of (ilory; Sing to the Lond; The Angel Gabriel; Be glad, $O$ ye righteous; The Lord is $m \mathrm{y}$ strength; The Lord hath done great things; Lord thon hatst been onr refuge ; Part-Songs : Ave Maria (1859); Behold where langling Spring (1859); Cradle Song; Fvening Hrmm; Queen of the night: The shepherd's farewell; The waves' reproof; Stars of the summer night; Lady, rise, sweet Mom's awalsing: six 4-part songs (1869); t-part songs composed for Lesliess chorr. Tries for female volues. and many vocal duets. songs: The Lady of the Lea; Soft and bright the gems of night; The Spiming Wheel: Near thee, still near theer ; Vineta; The Lady Isoline; Antumm song; Come again spring; I dream of thee at morn; Rose of May; The gleaner matidens The midnight ride; The talisman; The fariry" whisper; Blue eyes; Go, whispering breeze; Wake, Mary, wake; Echo of the lake; Sir Roland; The bird's love song; The lark's

\section{SMIETON.}

song; ete. Organ: Fifty Preludes and Interludes (1862); Andantes in (,$A$, and E minor; Eighteen short easy pieces; Postludes in C, I), E Hat, etc.; Twelve short interhudes; Grand solemm march; March in (r; Festive march in $\mathrm{D}$; Hinuct in $\mathrm{C}$; Choral, with variations: The Organ Student, 12 pieces. Chamber [)uets and Trios, by G. F. Handel, edited loy smart for the English Handel Society, 1852. The Preslyterian Hymmal, 1877 (edited). Report on Organ of Christ Church Cathedral, Dublin, 18тs.

smart wasm anthorityon the organ, and the very large and beautiful instruments at Leeds Tuwn Hall, and in St. Andrew's Hall, Glasgow, were erected from his specifications. Some books on him are "Henry smate: His Life and Works," l,y Wm. spark, London, 1881, Sio, with portrait. "Henry Smart," by W. D. Sermour Leeds, 1881. "Henry smart's Compositions for the Organ, analysed by John Broadhouse," Iondon, 1880.

His sister, Harriet ANNe simart, Mrs. Callow, Was born at London, October 20,1817 ; died, London, June 30, 1883. She married William Callow, water painter, and was an amateur composer of hymms and other rocal music.

Smart, Thomas, organist and composer of the 1sth century, who was organist of st. Clement Danes, London, in 1Tri3. He compused "Five new songs and a cantata;" The Air lalloon $178+7$; Camps, or the royal review [1780]; Cupid's kisses: Squire's christening; Time and eare, and many other songs; also some pf. music, and a glee, "Happy fellow."

Smethergell, William, organist and composer, who flourished in the latter half of last century. He was organist of St. Margaret-on-the-Hill, Sonthwark, and of All Hallows, Barking. He composed"A Treatise on Thoroughliass," London, 1794, and "Rules for Thoromghhass, to which are annexed three sonatas for the harpsichord and violin," op. $7[1795 \mid$; Six concertos for harpsichord or pf., two violins and 'cello [1785]; Six duetts for two violins, op. 12 [1800]; six easy solos for a violin [1790]; Six lessuns for the harpsiehord or pf., op. 1; Six overtures in eight parts, and a second sett, op. 5. He also issued various adaptations from Jommelli and other composers, and a few songs.

Smieton, John More, composer, borm at Dundee, 1857. Pupil of Sir H. S. Oakeley, I)r. J. F. Bridge, and others. Some time cngaged in musical work at Broughty Ferry, near Dundee. His compositions comprise Psalm 121, for tenor solo, chorus and orchestra. C'rntatas: Pearl; Ariadne, Dundee, 1883 ; King Arthur, Broughty Ferry, December, 1889; The Song of the Sower, chorus and orchestra, prize, National Co-operative 


\section{SMILES.}

Festival, London, 1891; The Jolly Beggars (Burns), prize, Glasgow Select Choir, 1s93; Belinda (composed with Basil Hood), 1896; Corinla, cantata; school music, ete.; orchestral overture; The Princess of Thule, sketch for orchestra; string quartet, etc.

Smiles, Frank, see Quatramaine, Franik.

Smith, Alexander, musician of early part of the present century, issued "A Collection of Church tunes, hymms, and canons, in two, three, and four parts," Edinburgh, J. Johnson, sculpt., n.d. Dedicated to the ladies and gentlemen of Borrowstowness or Bo'ness, where Smith was a teacher of music.

Smith, Alexander William, teacher of singing, was born at Edinburgh on November 29, 1829. He studied under Bucher, Ran. degger, Schira, and under Promano at Florence. He was confuctor of psalmody at Broughton Place L'nited Presbyterian Church, Edinburgh from 1849 10 1864. He has chiefly devoted himself to the teaching of singing, and as a voice trainer has been one of the most successful in Scotland.

Smith, Alfred Montem, tenor vocalist, boru at Windsor, May 13, 1828, the old "Montem" day at Eton College, hence his second name Brother of George Townshend and Sammel Suith. Chorister at St. George's Chapel, Windsor, and Eton College. Abont 1850 was, for a time, tenor in the Choir of St. Andrew's, Wells Street, London. Succeeded.J.W. Hobbs as lay-vicar at Westminster Abbey; and was a Gentleman of the Chapel Royal, St. James's, from 1858 to the time of his death. Sang at the Concerts of the Sacred Harmonic Society; for nrany years at the Three Cloirs Festivals, from Hereford, 1855 ; in the quartets in "Elijah," Birmingham, 1858-fil, etc. Nember of the London Glee and Madrigal Tnion; a fine ballad singer, and popular lecturer. Professor of singing at R.A.M., and Guildhall sehool of Music. He died in London, May 2, 1891. His compositions consisted of songs and glees; one of the latter, "At the dawn of Life's day," was awarded the prize of the Noblemen's Catch Club, 1881. He married Miss Elizabeth Stroud, daughter of Henry Chaplin $\left(q \cdot v^{\circ}\right)$, a soprano vocalist, now a professor at the Guildhall Sehool of Music.

Smith, Alice Mary, Mrs. Headows White, composer, born at London, Nay 19, 1839. She was a pupil of Sir W. Sterndale Bemnett and Sir G. A. Nacfarren. In 1867 she was married to Mr. Frederick Meadows White, Q.C., now a judge of the County of Middlesex, and in the same year she was elected an associate of the Phitharmonic Society. She died at London, December 4 , 1884.

Works.-Cantatas: Rüdesheim, Cambridge, 1865; Ode to the North-east wind,

\section{SNITH.}

London, 1880; The Passions, ode by Collins, Hereford, 1882; Song of the Little Baltung (Kingsley), 1883; The Red King (Kingsley). Symphony in C minor, 1863. Endymion, overture, 1864 (re-written for Crystal Palace, 1871); Lalla Rookh, overtmre, 1865; Masque of Pandora, overture, 1878; Jason, or the Argonauts and Sirens, overture, 1879. Quartets for pf. and strings: B flat, 1861; D 1864. Quartets for strings in D, 1862 and 1870 , Concerto for clarinet and orchestra, 1872. Introduction and allegro, for pf. and orchestra, 1865. Two intermezzi from "The Masque of Pandora, 1879. Part-songs, songs, etc.

Smith, Arthur Francis, organist, pianist, and conductor. Articled pupil of Fdward Chadfield (q.v.), he was joint founder and director of the Derby School of Music, work in connection with which he still carries on. F.C.O., 1874; Mus. Bac., Cambridge, 1883. Organist at Tickenhall, 1869 ; St. Werburgh's, Derby, 1872 to present time. Conductor, Derby Archidiaconal Choral Association; and Derby Orpheus and Madrigal hociety. An early nember of the Incorporated Society of Musicians, he has done valuable work for it, and is editor of its Monthly Joumal. Examiner for that Society, and local representative of R.A.M. and R.C.M. He has composed a setting of Ps. 103; and has published songs and pf. pieces.

Smith, B., musician of early part of last century, published the Psalm Singer's Magazine, 1729; Harmonious Companion, or the psalm singer's magazine," 1739.

Smith, Boyton, pianist and comporer, born at Porchester, February 23, 1837. Brother of E. Sydney Smith. Educsted at Hereford and Winchester Cathedrals, under Dr. S. S. Wesley. Organist of Dorchester Parish Church. He has composed Church Services in D, E flat, F, and G; Anthems, songs, etc. Organ pieces for church use, six set3; Allegretto grazioso in A; Andante con moto, etc. Also many pf. pieces of a popular kind, such as Echo of the waves; Nightingale and Zephyr; Dew pearls; Woorland echoes; Song of the sylph: La fée coquette, op. 64; Sur le lac; and numerous transcriptions.

Smith, Charles, composer and bass vocalist, bom at London in 1786 . He was a chorister in the Chapel Royal under Ayrton, and studied also under Costellow and John Ashley. From 1799 he sang as a soprano at Ranelagh and in Scotland, till his voice broke in 1803 . He then became organist of Croydon Church, and afterwards of Welbeck Chapel in 1807 . In 1813 he sang in oratorio as a bass. He was married to a Miss Both, of Norwich, and resided in Liverpool from 1816. He died at Crediton, Devon, November 22, 1856.

Woris.- Music to Dramas: Yes or No, 


\section{SMITH.}

1809; Hit or niss, 1810; Anything new; Knapschou, or the forest fiend, Lyceum, 1830. Glees; Sougs and canzonets: Battle of Hohenlinden ; Far o'er the sea ; Sea boy's drean. Fantasias for harpsichord or pf. Ancient Psalmody from the publications of T. Est, liavenscroft, Morley, etc., arranged for 2,3 , and 4 voices, London [1844].

Smith, Clement, organist and composer, was born at Richnond, Surrey, in 1760 . He graduated Mus. Bac., 1791, and Mus. Doc., Oxford, in 1800. Teacher at Tichmond, where he died, November 16,1826 . He composed church nusie, glees, and songs. Sonata cappriciosa for pf. or harpsichord [1790]. Duets for pf., etc.

Smith, David, musician and teacher in Staffordshire. Compiler of "The Sacred Harmonist, or leader's guide, lueing a new selection of psahn and hymm tunes.." London, 1833,2 vols. He also edited the 1811 edition of Thomas Walker's Companion to Rippon's Tune Book.

Smith, Edward Sydney, pianist and conposer (bruther of Boyton Smith), born at Dorchester, July 14, 1839. He studied at Leipzig Conservatorium, under Mosclieles, Plaily, Hauptmann, Richter, Papperitz, and Reitz, from 1855. Settled in London as pianist and composer, 1859. He died at London, March :3, 1889.

Wonks.--l'iamoforte: Arcadia; Tarcarolle; Bolero; Chant des oiseaux; Chant der savoyard ; Coquetterie; Danse Napolitaine; Etudes de concert; Fventide; Fairy realms; Fairy whispers: Fandango; Fute champêtre; Fête Hongroise; Fète militaire; Gavotte; La harpe Eolienne; le jet d'eau ; Les trompettes de la guerre; Narche Hongroise; Maypole dance; Pas desabots; Rêveaugélique; Rliapsodie; Saltarcllo; Tarantelles; The spinning wheel; Titania; Tyrolienne; Fantasias on operas, and transeriptions, numerous.

Smith, Rev. Gieorge, author of "Church Music, two lectures," London, 1860.

Smith, George Montague, organist and composer, born at Norwich, July, 1843. Organist, Gilasgow University, and conductor of the University Choral Society. Organist of St. Silas' Episcopal Church; Coats' Memorial Church, P'aisley. Local examiner in music, Glasgow Luiversity; Professor of harmony, Queen Margaret's College, Glasgow. Composer of cantatas, Blessed is the man; and Psaln 137; an opera, The Killabag Shootings; Festival setting of Te Ieum; Songs, part-songs, etc. Also Concert overture in E flat, Gloucester Festival, 1877; Bourrée, orchestra, Glasgow, 1887, etc.

Smith, Gieorge Townshend, organist and composer (brother of Alfred Montem and Sannel Smith), born at Windsor, November 14, 1813. Son of Eaward Woodley Smith,

\section{SMITH.}

lay-clerk of St. George's Chapel, Windsor. He was a chorister in St. George's Chapel, Windsor, under Highmore Skeats, and he also studied music under S. Wesley. Organist successively of the old Parish Chureh, Eastbourne; of St. Margaret's, Lynn ; of Hereford Cathedral, 1843. He acted as conductor and honorary secretary of the Three Choirs Fes. tivals. Died at Hereford, August 3, 1877. He composed anthems, songs, and other vocal music, also quadrilles and other light music for the pf.

Smith, Isaac, composer, was born about the middle of the 1sth century. He was clerk of Alie Street Meeting House, London. He died at London, about 1800. Published "A Collection of Psalm Tunes in Three Parts, adapted to each measure as now sung in several churches, chapels, and meeting-houses in and about London"...London $[1770] ; 5$ th edition, by S. Maj r, 1788. The well-known tune "Irish" appears in this collection, and lias been attributed to Smith.

Smith, J. Whitehead, organist, pianist, and violinist, born at Wells, Somersetshire, 1827 ? Took lessons of a Mr. Dix, and of Mr. Angel. Entered the R.A.M., 1843, and dis. tinguished himself as a pianist at the Academy concerts, and played the violin in the students' orchestra. A.R.A.MI, and F.R.A.MI. Assistant organist, St. Mary's, Paddington Green ; librarian and organist, Marlborough College; and for more than thirty years organist of Wimborne Minster. Local examiner for R.C.MI.

Smith, John, orgauist and composer, horn at Cambridge in 1795. Stipendiary choirman of Christ Chureli Cathedral, Dublin, 1815. Vicar-choral of St. Patrick's Cathedral, 1816. Organist of the Cliapel, Dublin Castle, 183335. Professor of Music in the University of Dublin. Mus. Doc., Dublin. He died near Dublin, November 12, 1861.

Works.-The Revelation, oratorio ; Cathedral Music, in vocal score, with organ or pf. accompaniment [1837]; Lyra Masonica, collection of masonic songs, London, 1847; Selection of Mr. Kelly's Hymns on various passages of Scripture, Dublin [1850]; Seventy of the Psalms of David..the music by the best composers.. Dublin [1835]. He also edited Weyman's Melodia Sacra. Glees: Christmas Morning, Isles of Greece, King Alfred's hymm, etc. Songs: Absent, Fairy gold, Remenb'rest thou, Volunteer's song, etc. Treatise on the tlicory and practice of Music, with the principles of harmony and composition, Dublin, 1853, 2 vols.; Irish Minstrelsy, a selection of original melodies of Erin, with characteristic words by Edward Fitzsimons; symphonies by J. Smith, Dublin 1814. His son, J. S. Snith, succeedel him as organist of the Cliapel Royal, Dublin Castle, in 1835. 


\section{SNITH.}

Smith, John Stafford, organist and composer, born at Gloucester about March, 1750. He was the son of Martin Smith, organist of Gloucester Cathedral from 1743 to 1782. He studied music under his father and Dr. Boyce, and became a gentleman of the Chapel Royal in 1784. In 1795, he was made lay-vicar of Westminster Abbey, and in 1802, he succeeded Dr. Arnold as organist of the Chapel Royal. From 1805 to 1817 , he held the position of master of the children of the Chapel Royal. He died at Loudon, September 21, 1836.

Works.- Anthems, composed for the choir service of the Church of England, London, n.d. Twelve chants, composed for the use of the choirs of the Church of England, London, n.d. Collection of songs of various kinds for different voices, London, 1785. Collection of glees for $3,4,5$, and 6 voices, London, n.d. With some of these he gained prizes between 1773 and 1780. Enited: Musica Antiqua, a selection of music of this and other countries, from the commencement of the tivelfth to the beginning of the eighteenth century, comprising some of the earliest and most curions motettes, madrigals, etc., London, 1812, 2 vols.; Collection of English sungs, in score, for 3 and $t$ roices, composed about the year 1500, taken from 11SS. of the same age, London, 1779. Smith aided Hawkins with his "History of Musie."

Smith, Joseph, organist, composer, and conductor, born at Dudley, Worcestershire, 1856, of Irish parents. Educated on the Continent, and chiefly self-taught in music. Graduated Mus. Bic. 1880, Mus. Doc. 1881, Dublin. Began his career at seventeen as organist of a chureh at Galway. In 1877 appointed to Limerick Cathedral, where he remained till 1882 , founding a chcral society and giving concerts. Went to Dublin in 1882 as organist of the chureh of the Three Patrons, Ratligar, and professor of music at the Convent school of the Sacré Cour at Mount Annville, holding both appointments to present time. In 1883 he was appointed, in conjunction with Sir R. P. Stewart, professor of music in the Royal University of Ireland. Musical director, Dublin Artizans' Exbibition, 1885; conductor of Dublin Musical Society from 1889. His works include three masses; a cantata, "St. Kevin," produced at Hereford Festival, 1885; an Inaugural Ode, for the Dublin exhibition just named; motet, God be merciful, prize, National Welsh Eisteddfod, 1880; anthems, part-songs, ete ; Triumphal march, orchestra, 1855. Editor of Catholic Choir Music, Pohlmann, Dublin, 1891. Compiler of a Catholic Hymn-book, with tunes.

Smith, Laura Alexandrine, author of "Music of the Waters, a collection of the

\section{SMITH.}

Sailors' Chanties, or working songs of the sea of all maritime nations, Poatmen's, Fishermen's, and Rowing Sortgs and WVater Legends," London, Kegan Paul, 18s8. She is also the composer of some songs, My Castle in Spain, etc.

Smith, Robert, writer, was born at Cambridge, in 1689. He was Plumian Professor of Astronomy at Cambridge, and became Master of Trinity College in 1742. He died at Cambridge in 1768. He wrote "Harmonies, or the philosophy of musical sounds," Cambridge, 1749 ; zud edition, enlarged, London, 1759. A Postscript upon the changeable harpsichord, a perfect instrument, London, 1762.

Smith, Robert Archibald, composer, born at Reading, Berks., November 16, 1780. Son of Robert Smith, silk weaver, a native of East Kilbride, who settled at Reading in 1774 , during a heavy depression of trade in Paisley. He very early gave indications of his possession of musical ability, but was apprenticed to the weaving trade, which he followed in Reading, and in Paisley, from 1800, where he became intimate with Tannahill, Motherwell, etc. He married Mary MacNicol in 1802 Teacher of music, and precentor in the Abley Church, Paisley, 1807. Musical director of S. Feorge's, Edinburgh, August, 1823. He died at Edinburgh, January 3, 1829, and is buried in S. Cuthbert's churchyard.

Works.-The Scotish Minstrel, a selec. tion from the rocal melodies of Scotland, ancient and modern, arranged for the pianoforte, Edinburgh [c. 1821-24], 6 vols. The Irish minstrel, a selection from the vocal melodies of Ireland, ancient and modem, Edinburgh, n.d. [1825]. Flowers of Seottish Song, Glangow, n.d. Select Melodies, with appropriate woris, chiefly original, collected and arranged with symphonies and accompaniments for the pianoforte, Edinburgh, n.d. [1827.] Devotional Music, original and selected, arranged mostly in four parts, with a Thorough bass for the Organ or Pianoforte, 1810 ; New edition by John Turubull, Glasgow, n.d. Anthems in four vocal parts, with an accompaniment for the Organ or Pianoforte.....1819. Sacred Harmony, for the use of S. George's Church, Edinburgh, being a collection of Psalm and Hymn tunes..... Edinburgh [1820] (with Rev. A. Thomson); other editions, and a modem one edited by Jas. S. Geikie, Edinburgh, n.d. Sacred Music, consisting of the tunes, sanctuses, doxologies, thanksgivings, etc., sung in St. George's, Church, Edimburgh, Edinburgh, 1825. Edinburgh Sacred Harmony for the use of churches and families, arranged for four voices, Edinburgh, 1829, 2 vols. The Sacred Harmony of the Church of Scotland, 


\section{SMITH.}

n.d. [1828]. Songs: Jessie, the Flow'r o' Dumblane (1808); Pomnie Mary Hay; O wha's at the window?; The lass o' Arran. tenie; The IIarper of Mull; Loudon's bonnie wools and braes; On wi' the tartan; Naid of the sea; Highlander's farewell; The willow. Duets: Row weel, my boatie, row weel; ete. I'salm tunes: Morven, St. Mirren, Invocation, St. Lawrence, Kelburn, Selma, Paisley Abbey, and many others, all published in his colleetions. Anthems: How beautiful upon the mountains; The earth is the Lord's; etc. An Introduetion to Singing, comprising various examples, with seales, exercises, and songs, etc., Edinburgh [1826].

Smith was one of the best musicians whom Seotland produced in the first part of thi century. His works are now as mueh used as ever they were, and his songs and psahms are in constant use in Seotland. Ile eomposed many fine Scottish melodies, and did not seruple oceasionally to pass a number of them off as antirfues. He performed on the riola and violoneello, and played the former instrument at the Glaigow Musical Festival of $18 \% 1$. His violoncello, together with some manuscripts, is preserved in the I'ublie Museum of Paisley.

Smith, Samuel, musician and promoter of the 'J'onic sol-fa, was born in 1 ro6. He was a pioneer in the movement for promoting the ehanting of pahms in nonconformist ehurches. Ife identified himself with musical affairs in Bradford, and was the chief founder of St. Cieorge's I Iall and the Bradford Festival Choral Soeicty. He died at braciford, Juby 5 , 1 isis.

Smith, Samuel, organist and eomposer, was born at Eton, August 29, 1821. Son of Edward Woodley Smith, and brother of Alfred Monten and George Townshend Smith. Studied in Chapel Royal under Hawes, and also under Sir Geo. J. klvey. Organist successively at Hayes, Eton, and Egham; Trinity Chureh, Windsor, 1858-61; Parish Chureh, Windsor, 1\$61. Composer of Psahms and chants," Loudon $[1860]$; "Selection of ehants and responses used at the Parish Chureln. Windsor," Windsor 1865], privately printed. Psalms, hymns, and anthems [1870]. Songs, ete.

Smith, T. G., musician, issued "Original Naltese melodies, seleeted and purehased at Malta," London [1812]; also [1825]

Smith, T. R., anthor of "The Violoncello Preceptor, eontaining the rudiments of music, with seales," London, n.d.

Smith, Theodore, composer and pianist of latter half of the 1 sth and early part of 19th centuries. Composer of Six Sonatas for harpsichord, op. $5+1770$; Six Sonatas, op. 0 [17s0)]: Three Sonatas and a favorite march, for pi. or harpsichord [1790]; Three Sonatas

\section{SMIT'H.}

and an overture; Three Sonatas, pf., op. 36; Sacro Divertimento. . Londun [1810]. Songs, Welsh harper, ete.

Smith, Thomas, organist composer, and didactie vriter, born at Armold, Nottingham, February 20, 1832. Studied pf. under Henry Farmer, and organ under Charles Noble. At the age of fifteen he was organist of St. Stephen's, Snenton, Nottinghann, of sit. John's, Bury st. Edmunds, 1873, and since 1880 at Hozzinger, the seat of the Marquis of Bristol. Composer of $O$ worship the Lord; Thou crownest the year"; and other popular antheans. Author of "I Concise and practical explanation of the rules of simple IIarmony and Thorongh Bass," London, n.d.; Short praetical method for teaching singing, ete., London, n.d.

Smith, Thomas Roylands, Ilocesan choirmaster and organist, lom at Highgate, Middlesex, October 28,1847 . Studied under Joseph Thomas Cooper, and Scotsom Clark. Held the appointment of Music Master at Aloingdon (rrammar Sellool, but has now been for many years resident in Torguay. He was organist of St. John's, and st. Mary's, Torquay, resigning the former in 1876 , and the latter in 1602 . His principal work has been the promotion and improvement of Church musie. since 1855 he has been conductor of the Plympton Deinery Choral Union, and Exeter I) iocesan ('hoimuister, from 1886. In these capacities he has conducted as many as twelve choral festivals in the year, in which about 3,000 singers take part, including one in Exeter Cathedral. As a teacher he has been very successlul, and in ehoral music his societies at Chadleigh, Teignmonth, and Torquay, have done gond work. Ile bas published a Te Jemm, Pater Noster, and fire Frening Services to various forms of the Gregorian and Ambrosian melodies; and has contributed many articles on church and ehoral music to different papers.

Smith, Thomas Sydney, composer and organist of the present time. Ieputy organist and choimaste'r, St. George's Cathedral, Southwark, and organist of St. Mary's South Kensington, London. Author of "Tade Necum, a practical hand-book for the pf.," London 18T9: New sale Practice for the pf. [1882]; Lanthe and Haidee, two melodies for pf., op. 1 [188t]. Sacred music, songs, and pf. music.

Smith, Valentine, tenor vocalist, borm at Bamard Castle, Durhann. Sang for some tinte mater the name of Signor Fabrini. Joined the Carl Rosa Opera Company in 1885 , after a successful operatic career in Americat. In 1 ss! he organized an opera company, which opened in London. The next reatl the company mote with strecess at Hambirg and other places. lle bought out an English version of Idulphe Adaun's "si j'étais Roi," for the 


\section{SIITH.}

first time, at Newcaste-on-Tyne, February 22,1893 .

Smith, Rev. William, scottish clergyman and amateur musician, was born in 1754 . He settled in New York in 1783, and died there, April 6, 1821. He published "Chants for publick worship," 1814; and "The Reasonablness of setting forth the praises of God according to the use of the primitive clurch, with historical views of metre psalmody, "New Iork, 1814.

Smith, William, amateur musician, born at Chapel of Garioch, Aberdeenshire, where his father was minister, December 6, 1803. He was a merchant in Aberdeen, and died at Newtyle, Forfarshire, August 31, 1878. He issued "The People's Tune Book: a manual of Psalmody for Scotland. Selected by express permission fro:n the copyright arrangements of Novello, Horsley, Greatorex, Havergal, Jacoh, and other eninent professors." Aberleen, 1844.

Smith, William, musician, of Chesham, issued "M[usical Devotions, consisting of 20 P'salm and Hymn tunes." Chesham [1830].

Another Wromian SuITH edited "Sacred Harmony, containing an easy introduction to the art of ringing" Dublin, 1810.

Smitl, William Braxton, tenor vocalist. Educated as an architect, but gave that up for singing. Studied at the Guildhall School under F. Walker. Made his debut at the Crystal Palace Concerts, October 20, 1888, with success. Sang at the I'opular Concerts in 1891; and has been heard in many parts of the country, and at the Bristol Festiral, 1896. Toured with Madame Albani in Canada, 1896-7. Married, in October, 1896, Miss Maber Berrer, soprano vocalist, who has sung with acceptance at the Popular Concerts (1895), Crystal T'alace (1836), and in various provincial towns.

Smith, William Seymour, composer, baritone rocalist, and organist, born at Marlow, Bucks., August 20, 1836. Studied singing under Balfe, and orgau, pf., and composition with C. E. Horsley. Was organist of Hampstead Parish Church, some time from 1862; Musical lecturer at the Royal Polytechnic, London. At present time Professor of Singing, R.C.M. His entertainment, "Musical Sketches," was given in London and the provinces with much success.

Works. - Cantatas: Joshua, 1887; The Fairies' Festival, and May Time, female voices. The Noon, ode for female voices. Songs: The Rovers; Loving Hands; I an thine, etc. Caratina, violin and pf. Three Illustrations of Shakespeare; Six pieces in classic form; Dorothy; and other pieces for pf.; Andante for organ, etc.

Smyth, Ethel M., composer, born in London. Daughter of General J. H. Smyth,
SOAPER.

late of the Royal Artillery. Studied a short time at the Iseipzig Conservatorium; then with $H$. von Herzogenberg. First came into notice with a quintet for strings, perforned at Leipzig, about January, 1884. Then came a Sonata in A minor, op. 7, for pf. and violin, 1887. In 1890 two of her compositions were performed at the Crystal Palace; Serenade in D, for orcliestra, April 26; and overture "Antony and Cleopatra," October 18. Her most important work, a Solemm Mass in D, was performed by the Royal Choral Society at the Albert Hall, January 18, 1893. She has also published sets of songs, op. 3 , and 4 .

Snazelle, George Harry, bass vocalist. Was a member of the Carl Rosa Opera Company at the first season in London, Princess's Theatre, 1875; on tour with the same, 1876 , etc. Also sang in concerts in the provinces. Began, as a single-handed entertainer, in Liverpool, Oetuber, 1855, aud later visited other places, extending the scope of his work by engaging the assistance of other voralists. In $18 \times T$ he was selected to give his entertainment, "Music, Song, and Story," in Australia and New Zealand.

Sneddon, James, composer and teacher, born near Dunfermline. Studied under J. Fulcher, and others. Licentiate, Tonic Sol-fa College: Mus. Bac., Cambridge, 1845. Precentor of Tauriston Place Linited Preslyterian Clurch, Edinburgh, 1870-86. Teacher of singing under Edinburgh Schoul Board. Compositions: Psalm 130, for soli, chorus, and strings: Bright feet of May, and other part-songs. Author of The Musical SelfInstructor; Mnsieal Training; Series of School Song-books, and articles in the "Musical Fducator," edited by John Greig.

JANET C. SNEDION, contralto vocalist, has sung with acceptance in London, 1885 ; Glasguw, and Edinburgh, etc., from 1897.

Snow, J., organist and composer, was orgauist at St. John's College, Oxford. Composer of "Variations for the harpsichord to a minuet of Corelli's, etc.," London 1790.

Snow, Valentine, trumpet-player, who was born about the beginning of the 18th century. He succeeded Jolm Shore as serjeant-trumpeter to the King, in 1753. He played the trumpet parts in Handel's oratorios, which were specially written for him. He died in December, 1770 .

Mosms SNow, father of above, was a Gentleman of the Chapel Royal, and lay-vicar of Westminster Abbey. He gradnated Mus. Bac., Cambridge, in 1696, and died in 1700.

Snowdon, J., musician, edited "The Enterpean, being a collection of glees, catches, eanons, ete." Iuondon [1825].

Soaper, John, composer, born in 1743. ILe was a lay-vicar of Westminster Abbey, Gentleman of the Chapel Royal, and vicar- 


\section{SOLLENE.}

choral of St. Paul's Cathedral. He died at London, June 5, 1794, aged 51, and is buried in the erypt of St. Paul's. Composer of psalms and chants.

Soldene, Emily, soprano vocalist and actress, born at Islington, London. Articied to Howard Glover. Made her début at a coneert, St. James's Hall, in 186t; and in January, 1865 , sang for the first time on any stage at a morning eoneert given by Howard Glover at Drury Lane Theatre, when she took the part of Azucence in the seeond act of "Il Trovatore." Afterwards sang at the Oxford Music Hall as Miss Fitz-Henry, also at concerts of the Sacred Harmonie Soeiety, ete., and in the provinces. First appeared in comic opera at the standard Theatre in 1869 , in the "Graude Duchesse de Gérolstein." Visited the United States of America, 1874, and 1876-7; also Australia and New Zealand. Reappeared in London at the Alhambra, September, 1878. Securing the provincial rights of "Carmen," she produced it at Leicester, May, 1879. From 1880, again chiefly in America and Australia. Author of "My Theatrical and Musical Recollections," London, Downey, 1897; also of "Toung Mrs. Staples," 1896, and other stories. At preseut time she is understood to be preparing, while living at San Franciseo, another book of reminiscences.

Solomon, Edward, composer and conductor, born in 1855, of Jewish race. Chietly self-taught in music. Conducted comic opera touring eompanies, 1878 , ete. Composer of a number of comic operas: Billee Taylor, produced at Imperial Theatre, London, October 30, 1880; Claude Iuval, Olympic, August 20, 1851; Vicar of Bray, Globe, July 22, 1852 ; Virginia, New York, Jamuny 9, 1883; Poeahontas, Empire, December 26, 18rt; Maid and Moonshiner, New York, 1886; Piekwick, Comedy, February 7, 1889 ; The Red Hussar, Lyric, November 23, 1889; Nautch Girl, Sayoy, June 30, 1891. Killierumper, and other pieees for German Reed, ete. Also some pieces for pf. He died January 25, 1895.

His brother, Frem Solomon, sang in Billee Taylor, in the provinces, 1883; and is the composer of the comic opera, Captain Kidd, or the bold buccaneer, produced at the Prince of Wales Theatre, Liverpool, September 10, 1883.

Somerset, Lord Henry Richard Charles, annatem musician, second son of 8th Duke of Beaufort, was born December 7, 1819. He was M.P. for Mommonthshire, 1871-80, and comptroller of Her Majesty's Household, 1874-79. In 1872 he married Isalella Caroline, daughter of Charles, 3rd Earl Somers, who has distinguished herself in the cause of temperance. Lord Henry Sonnerset has composed anthems, pf. music, polkas

\section{SOUTHGATE.}

for orchestra, and the following among other Songs: Across the sea, All through the night, Along the sands, Dawn, Fal away, First Spring. day, Guod-bye, Love's flight, Once more, song of night, Song of sleep, Wher'e'er you go, ete.

Somervell, Arthur, composer, born at Windermere. Fiducated at Uppingham Sehool, and Cambridge. Studied music at Berlin High school, and at R.C.M. with Drs. Stauford and Parry.

Wopks. - Mass in C, for soli, ehorus and orchestra, produced by Bach Choir, March 10, 1891; A song of praise, Exhibition, Rendal, 1891; The forsaken merman (Matthew A mold), Leeds Festival, 1895; The Power of sound, Kendal, 1895; Elegy (Robert Pridges), alto solo, choms and orchestra, Hovingham Festival, 1896; Charge of the Light Brigade, chorus and orchestra; Ode to the sea, soprano solo, chorus and orchestra, accepted for Birminghim Festival, 1897. The enchanted palace, operetta for schools. Orchestral ballad, Helen of linkcomel, l'hilhamonic Gociety, Mareh 23, 1893; Bristul Festival, 1896; In Aready, snite for small orchestra, Brighton, March 23, 1897. Albmm of seven songs; Six songs; songs, various; arrangements of old seotch songs. Studies in pf. technique; By the sea, six slictches; On the river, five slictches; pf. pieces, valions.

South, Charles Frederick, organist born in Londun, February 6, 1850. Received his first lessons on the organ from his brother, Henry J. Sonth, afterwards studying under George Conper. When sixtem years of age he obtained his first organ appointment at Aslie's Hospital, Hoxton. In 1868 he was appointed to St. Augustine and st. Faith's, Watling street, City. II re he remained until 1853, his alsility as a choin-trainer being shown in the high reputation the choral services acquired. While there the organ was enlarged, in 1881. Cpon leasing for Silisbury Cathedral, where he was appointed in 1883, the parishioners and choir of his ehureh presented him with handsome testimonials. He was for some time conductor of the Sarm Choral Suciety. His compositions are not numerous, and are confined to chureh music, services, and introits, etc.

Southgate, Rev. Frederic, elergyman and composer, born at Gravesend, Octuber 7 , 1824. He was educated at Ramsgate and Cambridge, where he graduated B.A. in 1848. Curate at Castle Headingham, Suffolk; and afterwards minister of St. Mark's, Rosherville, and Northfieet, 1858. He died at Northfleet, Jannary 30, 1885. He issmed "Favourite hymm tunes. . . unsed at St. Botolph's Chureh, Northfleet." London, 1873, and eomposed other chureh musie.

Southgate, Thomas Lea, organist, musical scientist, and writer, born at Highgate, 


\section{SOUTHGATE}

London, August 22, 1836. Son of Thomas Bishop Southgate, noticed below. Foundation scholar of the old Grammar School, Highgate; and musically educated under his father, John Hullah, G. IV. Martin, and James Coward. Organist successively at Christ Church, Hornsey, 1862 ; St. Saviour's, Fitzroy Square, Loudon, 1865 ; St. Saviour's, Clapham, 1867; St. Margaret's, Dulwich, 1873 ; and Emmanuel Church, Dulwich, 1875. In 1862, he joined WV. Hammond in starting the Musical Standard, and became editor in 1871 , carrying on the paper himself for several years. Lp to 1891, he kept up his commection with that journal, writing many articles on different subjects. In 1891, a syndicate was formed to found the paper, Musicul Nows, and Mr. Southgate was joint-editor with I)r. Turpin until 1895. Besides his work on these papers, he has written articles for the Musical Times, Orchestra, Musical liecord, Choir, etc., and for Grove's "I)ictionaly." He has lectured before the College of Organists, Musical Association, R.A.M., and Fine Arts Society on variou subjects. lle took an active part in the protest against the Degrees in absentin of Trinity College, Toronto, and was publicly presented with a testimonial in recognition of his services, July 29, 1891. For the I nion of Graluates in Music, he has done valuable work, and his "History of Degrees in Music," for the Roll and Kalendar, was the first essay of its kind. From the formation of the Union, 1893, he has acted as Hon. Secretary. He is a nember of the Council of the Musical Association, and of the Plain-Song and Mediceval Music Society; and in 1s91, was made an Hon. Member of the Royal College of Organists. His researches into the subject of Egyptian Music, as exemplified in his description of the double flutes discovered by Professur Flinder's, Petrie, are of high historic and scientific value. It is understood that he has more to say on this subject. He has composed some vocal, instrumental, and orchestral music, but little has been published. Author of "Rudiments of Music for Choir-boys" ; and, in conjunction with F. T. Piggott, of a portion of the work on The Music and Musical Instruments of Japan.

His father, Thomas Bisirop SotthaAte, was born at Hornsey, Jume 8, 1n14. Chorister at the Chapel Royal, St. James', and, when twelve, occasionally acted as deputy-organist for Sir George Smart. Studied harmony under Attwood and Goss, and organ under Samuel Wesley. Was organist of Leyton Church, Essex; Hornsey Parish Chureh for nineteen rears; and of St. Amne's, Highgate Rise. An excellent violinist, he played first violin with $F$. Cramer for some time at the Opera House, He died at Highgate,
SPARK

November 3, 1868. Composer of Exercises and Scales intended to facilitate the study of the pf., London [1858]; The Seasons, 4 romances for 'oello and pf. [1861]; anthens, pf. music, sougs, and the hymns Nearer to Thee, Thy will be done, and others, in many collections.

Spark, William, organist and composer, the most prominent member of a family of musicians, was bor'n at Exeter, October 29, 1823. Chorister at Exeter Cathedral, and articled pupil of Dr. S. S. Wesley. Organist of St. Tawrence's, Fxeter, 1840. Removing to Leeds witl Dr. Wesley, in 1842 , he became deputy-organist at Leeds Parish C'hurch, and organist at Chapeltown and St. Paul's, Leeds, successively. Aftervards lie was appointed to Tiverton Parish Church, and Daventry, returning to Leeds, 1850 , as organist to St. George's, an appointment he lreld for thirty years. Founded the Leeds Madrigal Society, 1851 ; and, later, the l'eople's Concerts. Was associated with Henry simart in designing the organ in the Lecds Town IIall; and, in 1860 , was elected organist. Played his organ sonata at the Leeds Festival, 1858; and solos in 1874-7; and gave two afternoon recitals during the Festival of 1880 . Has given organ recitals in many parts of the country, and lias lectured on various musical topics. Contributed many articles to the Torkshire Post, 1883, and the musical press. He gradnated MIus. Doc., Dublin. 1sbi. Died at Leeds, June 16, 1897.

Works.-Oratorio, Immanuel, Leeds, May 17, 1887; cantata, Trust and Trimmph, Dublin, 1861 ; Ode to Labour ; The Birthday Festival. Magnificat and Nunc Dimittis in D) All we like sheep; O God, have mercy; Christ being raised from the dead; O Lord our Governour ; and otlier anthens. Church music, various. Glees, songs, etc. Grand Sonata, op. 21. Ten original compositions. Patriotic March, composed for the visit of the Duke and Duchess of York to Leeds, 1894. Tarious urgan pieces, Author of Lecture on Church Music, 1551; Choirs and Organs, 1852; A few words to Musical Conductors, 1853; Memoir of Dr. S. S. Wesley; Musical Tour in North Germany, 1871; Handy Book of Choral Singing Henry Smart, his life and works, London, Reeres, 1881; Musical Memories, 1888; Musical Reminisences, 1892, both published by Reeves. Editor of the Organist's Quarterly Journal, commenced in 1869, and still in progress; The Practical Choirmaster, twelve parts, contributing original compositions to each work; Sacred Harmony, selected and arranged; Batiste's organ compositions, adapted to English instruments, etc.

His father, Wildial SPArk, born in 1797 , was a chorister and lay vitar, comnected with Exeter Cathedral for nearly 60 years. He 


\section{SPEECHLEY.}

was a good mnsician, and had sung with Cataluni. He died at Exeter, September (?), 1865, at the age of 68. lowarn J. SipARK, the second som, was born at Exeter, August 7, 1829. He was organist of St. Lawrence's, Exetur, and after holding other appointments, becanne, in 1852, organist of Bury Parish Chureh. He then entered the railway service, and eventually settled at IVorcestex, where, in 1870, he established a music business. He was organist of Holy rrinity Chureh, Worcester, for 15 years, and resumed the appointment in 1888, after officiating for some time at Sit. Martin's Church. Conductor' for many rear's of the Worcester Amatemr Vocal Union. Ho has given many coneerts, and done much for music in Worcester. Frenerick R. SPAlis, the volmgest of the three brothers, is settled in lonsiness in Leeds. He is the proprietor of the Leeds E.xpress; has been hon. secretary of the Leeds Festival from 1877: and, in conjunction with Joseph Bennett, wrote a "History of the leeds Mucical Festivals, 1858-1889." Leeds: F. R. spark and Son, 1892.

Speechley, John, organist, was born at Peterborongh in 1811. He was organist of the Cathedral there, and at the church of St. John, for 38 years, and died in Angust, 1869. He was considered a skilful player, and a successful teacher.

Speer, Charlton Templeman, pianist and composer, born at Cheltenham, November 21,1859 . Wntered the R.A.M., 187.3, and obtained the Sterndale Bennett Scholarship, 1874. A.R.A.M., and Professor of Pf., 18851893. Associate, Philharmonic Society. Appointed orgmist, All Soul's, South Hampstead, 1876 ; St. Panl's, Bow Common, 1880. Has appeared in public as a pianist, and given recitals witl success. His compositions include two cantatas, "The Arsenal," and "The Day Drean" (Temnyson), to the latter" being awardel the Jubilee Gold Medal of the Bath Philharmonic Society. The work was produced at Bath, June 20, 1887, and at the Crystal Palace, February 18, 1888. He has also written songs, ete. His instrum 'ntal works consist of a concert overture for orchestra; an organ Sonata in D flat (Bow and Promley Institute, April, 1883); many pieces for pf., songs, etc. Editor (with J. R. C. (riale) of an English series of original songs, Weekes, 1897 .

Speer, William Henry, composer and conductor, cousin of the preceding, born in London, 1863. Studied under IV. Haynes, Malvern, Dr. C. FT. Lloyd ; and at Cambridge, under Drs. Stanford and Garrett; also for three years at R.C.MI. Graduated MIs. Bac., 1890 ; M. A., 1890, Cambridge. F.R.C.O. Hon. conductor, since 1893, of St. Albans Oratorio Society, and occasional organ recitalist. He

\section{SPINNEY.}

has published "The Jackdaw of Rheims," for chorus and small orchestra, op. 8; Album of six songs, op. 1; Three Elizabethan Jove Songs, op. 7; Vocal quartet (Ladies' roices) "To Music," op. 3; Part-songs, op. 5. String quartet, in 3 flat, op. 6; Sonata in B flat, pf., and violin, op. 4; Sonata in D, op. 2, pf. Some of these have been performed by the Musical Artists' Society, 1885-7. In MS. he has songs, pieces for violin, etc.

Spence, Mrs. Sarah, authoress of "An Introduction to the Science of Harmony," London, 1810.

Spencer, Charles Child, writel and composer, born at London, in 1797. He was organist and chrirmaster of St. James' Chapel, Clapton, London. He died at London, June 4, 1869. Author of "Elements of practical music," London, 1829 ; “ Elements of musical composition," London, 1840; “The Pianoforte, the rudiments of the art of playing," London, n.d ; "Rudimentary and practical treatise on Music," London, 1850, 2 vols.; "A concise explanation of the church modes, with remarks on the mutations they have uncergone since the inventions of the hexachord and the modem tonal system of Music ..," London, 1846. Some of the foregoing works have gone through several editions. He composed many glees: Beanteons rosebud; Ol, merry goes the time; Now April (madrigal) ; Sweet flowers; When the shadows of evening fall. Songs. Short anthems or introits, London, $18 \pm 7$.

Spencer, John, composer and organist, who was a pupil of Dr. Dupuis, and afterwards his son-in-law. He composed "Again the balmy zephyr" ; "O turn to Hebe," and other glees. Songs, carols, pf. music, etc. Edited the "Cathedral Music" of Dr. T. S. Dupuis, 3 vols.

Spinney-a family of musicians. THomas EDWARD SPINNEY, organist and composer, born, June 24, 182t, was a pupil of Sir Henry Bishop. Was for many years organist of Wilton Parish Church, and is now organist aut choirmaster of St. Edmund's, Salisbury, and conductor of the Salisbury Orpheus Society. A successful teacher; he was some time musical tutor to H.R.H. the late Duke of Albany. He has composed a cantata, Village Belles; Church music, and songs; "The Organist's Assistant"; nine new organ Toluntaries; three Musical Sketches (two sets); Novelette; Melodies Gracienses, and other pieces for pf, etc. MATTIE SPINNEY (Mrs. Beesley), daughter of the above, studied under Benedict, and Sterndale Bemnett, and later with Hans von Biilow. Held an organ appointment at st. Paul's, Salisbury, and was afterwards for a time organist of the Parish Church, Banbury. She made her debut as a pianist at a concert of the New Philharmonic 


\section{SPINNEY.}

Society, London, May \&, 1875, taking part, with Dr. von Bülow, in Bach's Concerto in C minor, for two pianos and orchestra. In 1876, she appeared at the Crystal Palace Concerts (November 25); and has sinee then given many performances at which she has been assisted by lier pupils. Fugfane SPINNer, the eldest son, was born in 1815 . When seventeen he was appointed organist of banbury Parish Chureh (1862), and in 1865, graduated Mrus. Bac., Oxford. He gave good eoncerts, and improved the ehureh choir; but his artistie career was short, as he was removed by death, December 4, 1s67, at the early age of twenty-two. A stained glass window was placed in the Parish Church as a tribute of affection from pupils and friends. Frank Sprnater, brother of the preceding, was born March 20, 1 \$50. He was artieled to the Rer. Dr. Hayne, (Ixford, and becime F l.C.O. His first organ appointment was to St. Denys, Warminster, 1869 ; from there he went to All Saints', Emscote, Warwick, 1s73; and in 1878 was appointed to Leamington Parish Church. The present organ and organ gallery were built during his period of office, and largely the result of his exertions. From 1842 a number of exeellent oreliestral, choral, and eliamber concerts were given by the Leamington Musieal Society, under his direction; and he gave frequent organ recitals, being a fine executant. He worked with great zeal for the canse of the best in musieal art, but overtaxed his strength; his death taking place, June 5, 1854 . He wrote a number of liymo-tunes, an anthem for harvest, and some organ music. His memory is perpetuated by a stained glass window in the vestry of Leamington Parish Church. WaLTeR Spriner, the next brother, was born March 26, 1952. He was articled to J. E. Richardson, the cathedral organist, whose assistant he afterwards became. Then followed appointments to St. Edmund's, Salisbury; Dudley Parish Chureh; Christ Church, Doneaster; and finally, in 18ss, on the death of lis brother Frank, to Leamington Parish Chureh. In this town he laboured as performer, teacher, eomposer, and editor, until his death, June 21, 1894. He composed some ehurch services, a number of anthems, and other voeal works; edited the "Organ library" ; and the "Vesper" bell" series of organ pieces, his own contributions to which enjoy wide popularity. Rev. T. Hereert Spinner, youmgest of the fom brothers, was born January 13, 1857. Studied under Dr's. G. B. Armold, and J. F. Bridge. Harmony Prizeman, Trinity College, London, 1876. F.R.C.O. From the age of sixteen was organist at Salisbury; later, organist, and assistant ehaplin, Exeter College, Oxford, having been ordained Deaeon in 1881, and Priest, 1882, by the Bishop of Oxford. M.A.,

\section{SPRAY}

Oxford, 18st. Curate of Soutl Hinksey, Berks., 1881-2; of IVallasey, Cheshire, 1883-5; vicar of Newborough, Burton-on-Trent, to present time. Composer of Clurist the first fruits: Now thank we all our God, and otler anthems: Church services: Christmas earols (three series) ; six hymms for a flower service; organ pieces, etc, etc. He was formerly known as an able pianist, and still gives oecasional organ recitals.

Spofforth, Reginald, eomposer, born at Southwell, Nottingham, in 1770 . He studied under his unele, Thomas Spofforth, organist of Southwell Collegiate Chureh, and under 1)r. B. Cooke. He gained two prizes given by Nob eman's Catch Club. He died at Ken. sington, London, September 8, 1827, aged 57, and is buried in Rensington Parish Church, where a monument bearing the following inseription is placed: "In Memoriam. Cinder this church are deposited the remains of Reginald Spofforth, professor of music, borm at Southwell, Nottinghamshire. He died at Brompton, on the sth September, 1827, aged 57 years. Laus Deo."

Works. - Set of six glees, London [1799]; A Colleetion of frees, eompiled from the unpublished manuscripts of the late MIr. Spofforth, carefully collated with the originals, by IV. Hawes, London, n.d.; The Christmas Box, a variety of Bagatelles for 1, 2, and 3 voices, with pf. accompaniment, 2 books, London, n.el. Single Glees: Hail, smiling morn (in No. 1), 1799; Come bounteous May; Ifow calm the erening; Fill high the grape's exulting stream (prize), 1810 ; Health to my dear; IIy dear mistress; The Spring, the pleasant spring; While the madly raging nations; Where are those hours; See, smiling from the rosy east; Lightly o'er the village green. Canzonets.

A composer whose name is kept in remembrance by his ever fresh glee, "l Iail, smiliug morn." His brother, Sineter, born in 1780 , studied under his uncle, and in 1798 became organist of Peterborongh Cathedral, and in 1807 organist of Lichfield Cathedral. He died at Lichfield, June 6, 1864 . Composer of chants and other elurch music.

Sporle, Nathan James, who was born B inNetT, tenor voealist and composer, borm at Ipswich, 1812. He studied under Thomas Welsh. Died ILarch 2, 1853. Some of the best of his many songs are: 1 calm is o'er the sea; Draw ronnd the fire; Country life; Heart that's true; In the days when we went gipsying [1840]; I dwell anong the beautiful; Lugger; Merrie England; Old winter [1853]; The place where I was borm; Sweet is the vale, etc.

Spottiswoode, Alicia Ann, see Scott, LADY JoHN D.

Spray, John, eomposer and singer, was 
SQLIRE.

a chorister in Southwell Minster. Afterwards vicar-choral of St. ]'atrick's Cathedral, Inublin Doc. Mus., Dublin. He died in Dublin, in January, 1827. Composer of some unimportant vocal pieces.

Squire, Emily, soprano vocalist of present time. Studied at R.C.M. and IR.A.M. Sang at Bath early in the year 1888, but made a more important cébut at Exeter in April, at the festival of the Western Counties" Musical Association. Made her first appearance at the Crystal Palace, March 21, 1891 ; and at the Monday I'opular Concerts, January 15, 1894. Has sung at the Bimingham Festival Choral Society's Concerts, and in the principal musical centres, attaining a good position among vocalists of the time.

Squire, William Barclay, musician and author, who is one of the staff of the British Museum, and a contributor of biographies of musicians to the Dictionary of National Biography, Grove's Dictionary of Music, etc. With J. A. Fuller Maitland he edited "The Fitzwillian Virginal Book," 1894 , and has edited a number of important works by Byrd, Gibbons, Famaby, Wcelkes, and other old English and foreign composers. He has also composed sone pieces for the pf.

Squire, William Henry, violoncellist and composer, born at lioss, Herefordshire, August 8, 1871. Studied at first under his father, a cultivated amateur violinist, and played in public when seven years old. Gained a scholarship at R.C.M., 1883, which was extended for a seconct period of three years. Studied under Ldward Howell, and was occasionally heard by Piatti, also receiving lessons in composition from $\mathrm{I} \mathrm{r}_{\mathrm{r}}$. Hubert Parry. Made lis drbut at the Alleniz concerts, St. James's Hall, February 32, 1891. Since then has been heard at various concerts in Lonkton and the provinces. Was associated with the concerts of British Chamber Music, Queen's Hall, 1894; made his first appearance at the Crystal Palace, April 20, 1895, playing the Concerto in $A$ of Saint-Saëns, and in the same year was appointed principal 'cello at the Royal Italian Opera, Covent Garden. He was elected an Associate of R.C.M., 1859. His compositions inelude a concerto for violoncello, performed T.C.M. Concert; serenade; pastorale; gavotte; tarantelle, op. 23; four sets of pieces; twelve easy extreises; and other pieces for violoncello; reverie, ete, for violin; pieces for pf. solo and dnet; songs, etc.; also music for mandoline. He has two operettas in MS.

Sreeve, John, musician and organist of first lalf of the 18th century. Compiled "The Divine Musick Scholar"s Guide, being a...collection of psaln tunes, hymms and anthems," London, 1740. "The Oxford
STAINER.

shire Harmony, containing a select number of hymns, anthems, and chants, etc.," London, 1741,3 vols.

Stafford, William cooke, musician and anthor, born at York in 1793. He died at Norwich, December 23, 1876. Author of "A History of Music," Edinburgl, 1830 (Constable's Miscellany, vol. 52). Translated into French, Paris, 1832, and into German, Weimar, 1835.

Staggins, Nicholas, composer, was made master of the Royal music in 1682, and gratuated Mus. Doc., Cantah., in the same year. He was the first professor of music in Cambridge University, 1684. He died in 1705. Composer of Odes for the birthdays of William III. and Queen Anne; Songs in Choice"Ayres, Songs, and Dialogues," 1763; music for Dryden's "Conquest of Granada," etc.

Stainer, Sir John, Kt., composer, organist, and writer, born in London, June 6, 1840. Chorister, st. Paul's Cathedral, $1 \$ 47-56$, during the later years often acting as organist. Studied under W. Bayley, Dr. Steggall, and George Cooper. Organist of St. Benedict and St. Peter, Paul's Wharf, 1854; and in 1856 was appointed, by Sir F. Ouseley, organist of St. Michael's College, Tenbury. In 1859 he matriculated at Christ Church, Oxford, and was appointed organist of Magdalen College the same year, and organist to the University of Oxford, 1860. Graduated Mus. Bac., 1859; B.A., 1863; Mus. Doc., 1 S65 ; and M.A., 1866, Oxford Conductor of College Insical Societies. In 1872 he was appointed organist of St. Paul's Cathedral, in succession to (Sir) John Goss, resigning in 1RSG owing to failing sight. In 1876 he was appointed professor of the organ at the National Training School for Music, and in 1881 succeeded (Sir) Arthur Sullivan as Principal. Organist to the loyal Choral Society, 1873-88; Juror at the Piris Exhibition, 1878; Government Inspeetor of Music in Training Schools, in succession to Mr. Hullah, 1882; and has held other important positions, his last appointment being to the Professorship of Music at Oxford University, 18.9. He is an Honorary Member of R.A.M.; l'resident of the Musical Association; Menber of Council, R.C.MI.; Honorary Fellow of Magdalen College, Oxford; and member of the Plilharnonic Society. In 1878 he was created Chevalier of the Legion of Honour of France; received the hon. degree of Mus. 1)oc., Durham, 1885; 1Ion. D.C.L., Durham, 1895; and in 1888 was Knighted by Her Majesty tlie Queen.

Works.-Oratorio, Gideon; Cantatas, The Danghter of Jairus, Woreester Festival, 1878; St. Mary Magdalene, Gloncester, 1883; The Crucifixion, London, 1887. Chureh Services in E flat, A, D, and B flat; Canticles, various. 


\section{STAINS.}

Awake, put on thy strength; Deliver me, $\mathrm{O}$ Lord; And all the people saw the thmolerings, London Chureh Choir Association, St. Paul's Cathedral, November 8,1883 ; Te shall dwell in the land; and many other anthems. Nadrigal, The Trimmph of Victoria, 1887; Album of Seven Songs, with English and German words; Loyal Death; My little Pet; Slumber Song (with violoneello ad lib.); and other songs. Arrangements for the organ, 5 Nos. Editnr of St. Paul's Cathedral Cliant Book; The Cathedral Psalter; Choir-book of the Holy Communion; Narbeeke's Offiee of the Burial of the Dead. Joint editor (with Dr. Martin) of the Ferial Responses; with W. A. Barrett, of A Dictionary of Mfusical Terms, Novello, 1876; with Rev. H. R. Bramley, of Carols, Old and New; with Rev. W. Russell, The Cathedral Prayer Book, Novello, 1891; and with Dr. Hubert Parry, of Novello's Music Primers. Author of Primers on The Organ; Harmony; Composition; Choral Soeiety Vocalisation; A Treatise on Harmony (which has gone throuph several editions), Novello; The Insic of the lible, 1879. A Few Words to Candidates for the Degree of Mus. Bac., Oxon., Novello, 1897. Lectures and addresses, Musical Association; Conferences of 1.S.M., ete. His son, C. StaINER, is author of a work on Violin Makers, Novello, 1896.

Stains, V. D. de, author of "Phonography, or the writing of resunds, in two parts, viz., logograplyy and musicography." London, 1842 .

Standing, Frank $\mathbf{H}$, laritone vocalist, known as F. H. CELlit. He was a member of the Carl Rosa Operal Company from 1875, and was also known as a concert singer, $1878-82$. One of his most recent assmmptions was that of the Toreador in Bizet's "Camen," at Covent farden, April 9, 1891. He married Susan (or Susanna), wister of Lonisa Prne (she died, 1886).

His sister, Madane Helen S. Norman, known as HELEX STANDISH, was a contralto realist. She sang in English and Italian opera compranies mder Carl Rosa and ILapleson, and had ako been heard in concerts. She ried snddenly, in .Jannary, 1 s.91.

Standish, Orlando, anthor of "Elementi di Contrappunto," Florence, 1836, with folding tables and plates of examples.

Stanford, Charles Villiers, composer and conductor, born at Dublin, Sepitember 30 , 1852. Sion of the late John Stanford, Exid., Examiner in the Court of Chancery, Lnblin, and an accomplished amateur. "He was edneated in musie under Arthur ()'Leary and Sir R. P. Stewart; and afterwards studied, 1874-76, at Leipzig, with Reineclie, and at Berlin with F. Kiel. Matrienlated at Cambridge as a eloral scholar, graduating with

\section{STANFORI.}

Classical Honours, B.A., 1874; MLA., 1877. In 1873 he sneceeded Ir. J. L. Hopkins as organist of Trinity College, Cambridge, an appointment he held until 1892. He was conductor of the Cambridge Amateur Vocal Guild, and directed the first perfomanee in England of Sir R. P. Stewart's cantata "The Eve of st. John," Novemler 19, 1872. The Cambridge University Mfusical Society, of whieh he was conductor for twenty years from 1873 , attained a high position, nany important compositions being heard at its coneerts for the first time in England, such as Schumann's "Paradise and the Peri," the First Symphony of Brahms, etc. It was at a coneert of this society that MLr. Stanford first appeared as a pianist, November 30, 1870. A few compositions date from the Cambridge period to 1875 , lut he came into greater prominenee by wiming the second prize at the symphony eompetition at the Alexandra Palace, 1876. From that time to the present he has been actively engaged in composition. At the opening of the R.C.MI, in 18s., he was appointed professor of composition and orelestral playing, and has given distinction to the College coneerts and operatic performances by lis enterpise in lninging forward new or neglected works. In 1885 he became conduetor of the Pach Choir and in 1887 was appointed Professor of Dusie at Cambridge Eniversity. He is a member of the Philharmonic society ; in 1883 received the Hon. degree of MLuis. Doe, Oxford; in 18ss, ]y Grace of the senate, the same degree was conferred npon him at Cambridge; and in 1892 was elected Corresponding Member of the Société dés Componitenr's de Masique, Paris. He has conducted concerts at the Crystal Palace (1883), Jhilharmonie Society (1884, etc.); at berlin, Dresden, ete. ; performances of his worls at the chief prosincial festivals, and of his operas at Hanover and Hamburg. In June, 1897, he was appointed Conductor of the Leeds Philharmonie Society.

Works.-Oratorios aml cantutas: The Resurrection (klopstock), op. 5, for tenor solo, chorus and orchestra, Cambridge, May, 1875; Pralm 46, op. 8, Cimbloidge, 187t: Elegiac Ode (Walt Whitman), op. 21, Norwich Festi. val, 1884; The Three Holy Children, oratorio, Bumingham Festival, 1885; The Revenge, choral ballad (Tennyson), op. 24, Leeds, 1886; Camen Sieculare, Julilee Ode, op. 26 (Temysom), performed at a state Concert, 1847; The Voyage of Maeldume (Temnyson), Leeds Festival, 1889; The Battle of the Baltic (Camplell), Hereford, 1891; Eden, dramatic oratorio (Rolert Bridges), Birmingham, 1891; Installation Ode, Comlridge, May week, 18y2 ; Ode, Want to West (Swinlmme), London, 1893; The Bard, cantata, Cardiff Festival, 1N95; l'haudrig Crohoore, 


\section{STANHOPE.}

choral ballad, Norwich, 1896 . Operas: The Veiled Prophet of Khorassan, composed, 1877, produeed at Hanoser, Febuary 6, 1881 (libretto by W. Birrelay squire); Savonarola, produced, Hamburg, April 18, 1884; The Canterbury Pilgrims, produced, Corent Garden Carl Rosa), April 28, 1884 (libretto by G. A. A'Beckett); and Shamus O'Brien, Opera Comique, London, March 2, 1896 (text by G. H. Jessop, from Le Fanu). Incidental music to Temnson's Qneen Mary, Lyeem, April 18, 1876; Temnyon's Beeket, Lyceum, February 6, 1893; Esschylus' Eumenides, Cambridge, 1885; Sophocles' Edipus, Cambridge, 1887. Mass in G, op. 46 (in memoriam, Thomas Wingham), Brompton Oratory, May 26, 1893; Pralm 150, Manchester, 1885; Awake, my heart (Klopstock), choral hymm, op. 16, st. Paul's Cathedral, November $3,18 \mathrm{~s} 1$; Moming, Evening, and Communion services in B flat, F, and A; Anthems, etc. Elizahethan Pastorals, 4 roices; Three Cavalier songs, op. 1s; Daty is dring; To the rose; Wiglnt songs (George Elliot), op. 1; two sets of 6 somgs (Heine), op. 4, 7 ; and other songs. Editor of fifty lrish melodies, 1893; Song book for schools, 1884; Irish songsand ballads, Norello, 1893 (?): The lrish melodies of Thomas Hoore, Buosey, 1896. Orchestral: symphony No. 1. in 1) flat (prize), 1876 ; No. 2, in I) minus (Elegiac), Cambridge, March 7,1882 ; No. 3, in F minor (1rish), Richter, June 27, 1887; No. 4, in F (Thm' ronth to strife; thro' death to life), Berlin Pliiharmonic Society, Jamuary 14, 1889; No. b, in I) (L'Allegro ed il Pensierosol, op. 56, Philhammonic Society, J undon, March 20, 1895. Serenade, op. 17, Bimingham Festival, 1882. Overtures, Fostival, in $B$ flat, Gloucester Festival, 1877; Queen of the Seas (Armada Tercentenary), 1Rst. Concerto. 'cello and orehestra (MS.); Concerto in (r, op. 59, pf. and orchestra, Richter', May 27, 1895; Suite in D, riolin and orchestra, Berlin, Jannary 14, 1889. Chamber Music: Sonata in A, op. 9, pf. and 'eello; in 1), op. 11, pf. and violin; 'Three intermezzi, pf, and clarinet, op. 13; Quartet in F, op, 15, pf. and strings; Quartet in D minor, op. 25 (Dammenther), 1886; Trio in E flat, op. 35; Sonata in I) minor, op. 39, pf. and 'cello, Popular Concerts, Norember 1s, 1s49); String Quartet in (;, op. 4t; A minor, op. 54; D nimor, op. 64. Four Irish pieces, violin and pf. Sonata in D flat, op. 20; Three pieces, op. 42; Toecata in C', etc., for pf. Prolude and Fugue, organ, Tro. fessor stanford's latest work is a Requiem Mass, accepted for performance at the Birmingham Festival of 1897 .

Stanhope, Charles, Third Earl of, peer and scientist, born $175 \%$, sueceeded 1786, died 1s16. Autbor of "Principles of the selence of tming instrments with fixed tones," Loncton, 1806.

\section{STANLEI}

Stanislaus, Frederick, composer and conductor, horn at Kidderminster, December 27,1844 . Studied the riolin at an early age, and was one of the "Little men" taken on tour by Dr. Mark, of Manchester. Organist of Kidderminster Parish Church, and at Hartlebury. Conductor of several opera companies in London and the provinces. Went to America, and on his retum was musical director at the P'rince's Theatre, and later at the Theatre Royal, Manchester. He then went to the Prince of IVales' Theatre, London, and subseruently spent some time in Australia. He conducted the touring companies with the Gilbert-Sullivan operas, and was much in request as an accompanist, acting in that capacity for Sims Reeves and others. He died at Hammersmitl, November 22, 1891. His compositions include an opera, "The Lancashire Witches," produced at the Theatre Roval, Nlanchester; music to several pantominues ; part of the music to "The Palace of Pèarl," Empire Theatre, London, 1886; songs, part-songs, ete, His wife, as Miss Faxxy RoBINa, sang with much suecess in comic opera.

Stanistreet, Henry Dawson, organist and composer, was a chorister in Fork Cathedral. Muss. Bac., Oxon., 1862. Mus. Doe., Dublin, 1878. Organist at Bandon, Cork, 1862, of Tamm Cathedral, 1864, and of Trinity College, Dublin. Composer of Psahns 16 and 69, anthems, and other Church music. He died at Dublin, August $1,1883$.

Stanley, Charles John, organist and composer, born at London, January 17, 1713. He was accidentally made blind when about two years of age. Studied music under J. Reading and NI. Greene, and hecame organist of All Hallows' Chmeh, Bread street, 1724; St. Andrew's, Holloom, 1726; and of the Temple Church, 1739. He graduated IIns. Bac., Oxford, 1729. In 1779 he was made master of the Royal band of music, in succession to Boyce." He died at London, May $19,1786$.

Works.-Oratorios: Jephthah, 1757; Zimri, 1760; Fall of Egypt, 1774; Arcadia, or the shepherd's wedding, 1761 damatic pastoral to eelebrate marriage of George III.) Six cantatas for a voice and instruments, London 1742]; Second set $[1750]$. Songs: Dull unanimated wretch; Heigh, ho!; I feel new passions rise; Leave me shepherd; Power of mrusick and beauty; The red breast. Instrumental: Op.1, eight solos for a German flute, violin, or harpsichord $[1745]$, ete.; Op. 2 , six concertos in seren parts for four violins, a tenor violin, and violoncello, with a thoronghlass for the har'pichord; Op. 4 , six solne for a frerman flute, violin, or harpsichord [1770]; Opp, 5, 6, 7, ten roluntaries for the organ or pf. : Six coneertos set for the harpsichord or organ $[1760]$. 


\section{STANLEY.}

Stanley, Samuel, composer, born at Birmingham in 1767. He was Precentor in Carr's Lane Congregational Chapel Eirming. ham, and afterwards in comnection with the same congregation on its removal to a new chapel in steelhonse Lane, in 1818. He played the violoncello in the Birningham Theatre urchestra, and in the Festival Choral Society, 1802-181s. He died at Bimingham in Oetober, 1822. Now best rementuered by his hrmn tumes "Doversdale "and " Warwick." He issued "Twenty-four tunes in four part.," Bimingham, n.d. ; Two psalm tunes in four parts, Birminghan, n.d.; Nineteen psalm, hymn, and charity hymn tuxes, Bimingham [1800]; Sacred nusic, comprising two new psalm and hrmn tumes [1825; Pralm and hymn tumes, 3 books [1830], collected.

Stansbury, George Frederick, composer, tenor singer, and flutist, was boru at Bristol in 1 1800 . He was trained by his father, Joseph Stansbury, and in 1819, travelled as accompanist with Catalani during a concert tour. For some time be acted as conductor at the Theatre Royal, I ublin, but in $182 \mathrm{~s}$ he sang at the Haymarket Theatre, London, in the "Beggar's Opera," afterwards appearing at the Londou theatres. He was conductor at St. James' Theatre, Surrey Theatre, and other places in London. Died at Lambeth, Loudon, Jume 3, 1845.

Works.-Operas or musicol dramas: Waverley (with Lee); Puss in Boots, 1832; Elfin Sprite, 18:33, ete. The Passions, being six songs, London [1839-, containing also songs by Cooke, etc. Oak aud the Rose, song, and others.

Stapleton, Mrs., born Anva Isabelta Matthews, is notable as having been the first professional teacher of the Tonic Sol-fa system. She died at London, March 23, 1885.

Stark, Humphrey John, orgauist and composer, born May 22. 185t. Craduated Mus. Bac., Oxford, 1875. One of the founders of Trinity College, London. Organist of Holy Trinity, Tulse Hill, 1575. Composer of an Evening service, with orchestra; Church services, anthems, ete. Cantata, The Rival Seasons, performed, Trinity College, London, 1885. Twelve pices for organ, ete. Author of various papers read before the College of Organists, and other institutions.

Statham, Francis Reginald, composer and author, settled in Sonth Africa. He was at one time minister of a scotch congregation. His cantata, "Prosperity and I'raice," was composed for the exhibition at Kimberley, 1892; and he has also composed a cantata, "Vasco de Gama," for" soli, chorus, and orchestra. Author of various volumes of poems; "Blacks, Boers, and British," 1881; "Mr. Magnus," and other novels.

\section{STEELE.}

Statham, H. Heathcote, architect, author, and amateur musician. $\mathrm{He}$ is a Fellow of the Institute of British Architects, and editor of The Builder. Author of "Form and design in MIusic: ientluetie condition of the Art," London, Chapman and Hall, 1s93; "Architecture for general readers..," London, Chapman, 1895 ; 2nd edition, 1896.

Statham, Rev. William, clergyman and musician, born at Tarporley Rectory, Cheshire, September 26 , 1832. Educated at Marlborough College, and Lniversity College, Durham. B.A., 1s56; Mns. Doc., 1876, Durham. Vicar of Ellesmere-Port from 1s66, and organist of the parish church. Organising choimaster, Fordsham Deaneries Choral Association, 1869-79. Composer of an oratorio, "The Beauty of Holiness," Liverpool, 1nss; Church Service in F (1869), songs, etc. Contributed to Hymms Ancient and Moderu; Hymmal Companion; I'rimitive Methodist Hymnal; and Chants Aweient and Modem. Organ arrangements, etc.

Stead, J. H., comic singer, who appeared in London and other music halls with an eccentric song, called the "Perfect Cure," which was once widely known and popular. He lost his savings in a bank failure, and died in London of consumption, January 24 , 1856 .

Steane, Bruce Harry Dennis, composer and organist, born at Champion Hill, Camberwell, London, June 22, 1866 . Chorister at the age of eight at sit. Augustine's, Forest Hill, and assistant-organist when twelve. Insical training private. Has held the posts of organist and choirmaster snecessively at St. Bartholomew's, Swanley; Seal Parish Chureh, Sevenoaks; and I'arish Church, Whitechapel ; and is also organist and choir trainer for the Rural Deanery of Spitalfields. His compositions, chiefly in the smaller forms, are very numerous, reaching to op. 89 , and iuclude a sacred cantata, "The Ascension," op. 18 (published 1895); church services; many anthems, published in Norello's octavo series; songs, part-songs, etc. Organ pieces, including two Albums for Imerican organ; pianoforte pieces, etc., etc.

Steed, Albert Orlando, composer and author, born in 1839. Studied nnder Sterndale Bennett. Professor of music, Totteridge Park School, Herts., abont 1 1 60-2. Organist of Parish Church, Long Melford, Suffolk, 186.5 ; and at Holy Trinity, Penge, for some years up to the time of his death, October 25 , 1881. Author of "Nusic in play and music in earnest," London, 1873; Favourite lessons for the pf. [1858; Fonr songs from the "Idylls of the King" [1 661$]$; Seven tunes to popular hymms, and two kyries, London [1878]; duets, songs, ete.

Steele, Joshua, musician and writer, 
STEFLE.

author of "A short treatise on harmony," London, 1730. "Prosodia Rationalis, or an essay towards establishing the melody and measures of speeeh to be expressed and perpetnated by symbols," London, 1775. "Two papers on musical instruments brought from the Soutly Pacific Islands.

Steele, Mary Sarah, see sub. Masson, Elizabeth.

Steggall, Charles, organist and composer, born in London, June 3, 1826. After a yeal's private tuition on the organ, he entered the R.A.M., 1847, and studied under Sterndale Bennett, afterwards his life-long friend. In 1851 he accumulated the degrees of Mus. Bae. and MIns. Doc., Cambridge, and was appointed professor of harnony and organ at the P.A.MI., of which Institution he is a Fellow. In 1848 he was appointed organist of Christ Chapel, Maida Tale; in 1855 of Christ Chureh, Paddington; and in 1864 the organistship of Lincoln's Im Chapel was conferred upon him, which position he still retains. While a student at the R.A.M., in 1849, he was consulted by Bennett on the subject of the Bach Society, and from its formation, Oetober 27,1849 , to its dissolution, 1870, he held the office of Hon. See. At Crosby Hall, in 1852, he gave two lectures on "Music as applied to Religion"; and Oetober 18, 1864 , delivered the inangural lecture of the College of Organists, of which institution he was one of the founders. He has occasionally lectured at other places, but his life's work is at the R.A.MI.

Works. - Psalm 105, O give thanks, soli, eight-part chorus, and orchestra; Psalm 33, Rejoice in the Iord (performed at R.A.NI., and, 1864, Cambridge); Magnificat and Nunc dimittis in C, and Cantate Domino and Deus misereatur in $\mathrm{C}$, for voices and orchestra; Morning and Evening Service in F, and various service settings. Harvest anthem, Praised be the Lurd; He was as the morning star; Hear ye, and give ear; and others. Instruction book, and various eompositions for the organ. Editor of Church Psalmody (1848); Six motets of J. S. Bach; Musical Editor (18s9) of Hymms, Ancient and MIoderu; Contributor to various eollections.

His youngest son, Regixald Steggall, " born in Tondon, April 17, 1867, was educated at the R.A.MI., of which he is an Associate, and, since 1895, professor of the organ. In 1886 he was appointed to St. Anne's, Soho, but he now aets as his father's assistant at Lincoln's Im Chapel. He has composed a Festival Evening Service for voiees and orchestra; various anthems; Dramatic Scena, "Alcestis" ; Songs, etc.; a symphony; Two overtures; a concert pieee for organ and orchestra; various organ pieces; a Mass for voices, orehestra, and urgan, etc.
STEPHENS.

Steil, William Henry, harpist and composer, was born about 1787; died at Poole, Dorset, February 3, 1851. Author of "An Elementary Treatise for the Harp," London, 1830. Composer of rondos, fantasias, diverti. mentos, duets, etc., for harp and pf., and arranger of a large number of celebrated compositions for the harp.

Stein, Grace, see Wallace, Lady MaxWELL.

Stella, Alfred, see Palerson, Robert Ror.

Stenhouse, William, writer and collector, born in Roxburghshire in 1773. $\mathrm{He}$ was by profession an accountant in Edinburgh. He diea at Edinburgh, November 10, 1827. Published "Illustrations of the Lyric Poetry and Music of Scotland.." Edinburgh, 1839. Second edition by David Laing, LL,D., Edinburgh, 185?. This was intended as a series of amnotations for Jolnson's "Scots Musieal Museum," and has proved a quarry for all subsequent students of Scots music. Many of Stenhouse's alleged inaccuracies, which Chappell and others have mentioned in contemptuous terms, turn ont, on investigation by later and more painstaking students, to be perfectly eorrect statements. The work generally is not commendable on the score of correctness.

Stephen, Rev. Edward, suruamed TANYMARIAN, composer, was born near Festiniog in 1822; died at Tanymarian, near Bangor, May 10, 1885. Composed the first Welsh oratorio, "The Sea of Tiberius"; Llyfr Tonau ae Emynau [1870; and various colleetions of Welsh music issued principally from Wrexham.

Stephens, Catherine, Countess of Essex, soprano vecalist, born at London, December 18, 1791. She studied muder Lanza and Thos. Welsh, and appreared in I talian opera in 1812, and in Ame's "Artaxerxes," 1s13. From then till 1835 she appeared at all the principal concerts in London, and at the provineial concerts. She also appeared in English opera at Covent Garden and Drury Lane Theatres. In 18935 she retired, and in 1838 was married to the Earl of Essex. She died at London, Febmary 22, 1882 . Well-lnown in her day as "Kitty stephens," and was famed as an admirable exponent of English latlad music.

Stephens, Charles Edward, eomposer, pianist, and organist, horn in London, March 18, 1821. Nephew of the preceding. Began his studies at an early age, his masters being Cipriani l'otter for pf., J. A. ITamilton for harmony, etc., and Jlenry Blagrove for violin. He first came into notice as a member of the Society of British Monitians, an orerture of his being rehentsed in Jammary, 1842. He played second riolin in the cruatets, and had string quartets of his own produced, one in 


\section{STEPHENS.}

$\mathrm{G}$, in 1843, and one in $\mathrm{F}, 1844$. He leeame a member of the Royal Society of Musicians in 1843 , and the same year was appointed organist of St. Mark's, Mydidelton Square. In 1846 he was elected organist of Holy Trinity, Paddington; St. Marks, Hamilton Terrace, 1862; St. Clement Danes, Strand, 1864 ; St. Sariour's, Paddington, 1872, resigning in 1875. He occasionally played in public as a pianist, hut was chiefly ocenpied in teaching. Flected an Associate, 1850, and Member, 1857, of the Philhamonic Society; and afterwards frequently ehosen as a Director; and from 1880 acted as Treasurer. F.C.O., 1865; Hon. R.A.TI., 1870. An original member of the Musical Association (187t), he read sereral papers at its meetings. In 1895 he was appointed one of the Examiners for musical degrees at Cambridge Iniversity. He took an active interest in the I.S.MI, plaved in his pf. duos at the Conferences of 18 sis and 1890 ; and conducted a performance of his Srmphons in (i minor, at Mr. Stockley's Bimingham Concerts, April 24,1890 , and at the Philhamonic concerts, Warch 19, 1891, He dieet in Londom, July 13, 1892.

Works.-Orehestral: Two smphonies; Five overtires-A Drean of Happiness, No, 4, performed at the Roral Albert Hall, October, 1873; A Peeollection of the Past, Phillralmonie, April 2S, 1890. Other orchestral pieces in MS. String quarteti in ( $\mathrm{r}, 0 \mathrm{l}) .21$; in F, op. 22 (Trinity College, Londom, Prize Com. positions), 1879: (Quartet in B minor, o]). 2: Trio in F, op. 1, pf. and strings; Allegro and andante varié, for flute, oboe, clarinet, horn, and bassoon, 1892; Somata piacevole, o1). 25, pf. and flute. Pianoforte: Dro brillant in F, op. 19; Duo concertante in $\mathrm{r}, 0 \mathrm{p} .4$, and in C, op. 26, two pianos. Sonata in A flat, op.s, Musical Artists' Society, 1882; Romance; Impromptu, etc. Transcriptions, varions. Grgan: Two morements, op. 3; a second set, op. 7 ; a third set, op. 15; Fantasia, Offertoile. ete. Church services and anthems. Partsong, men's voices, Come, fill ve right merily, Prize, Leslie's Choir, 1858; Glees, songs, etc. Author of article, Philharmonie Society, in Grove's Dictionary. Editor of The Choir Chant Book, containing 513 chants, with Biographical Notices of the Composers, London, Bemrose, 1882.

Sayer Johy Stephexs, his brother, horn in London, Septemlser 4, 1819, studied under Potter, Hamilton, and H. Blagrove. Appeared as pianist with $\mathrm{C}$. J. Sitephens at concerts in 1845. Associate, 1859; Temler, 1898, 1'bilhamonie Society. Fngaged in teaching, and esteemed as an excellent pianist. Died at Hammersmith, June 29, 18s9.

Stephens, John, organist and composer, was born probably at Giloucester about 1720 . He was a chorister in Ctucester Cathedral,

\section{STEVEN.}

and in 1746 he succeeded Fdward Thomson as organist there. In 1763 he sraduated MIus. Doe., Cambridge, and in 1766 he conducted the Gloncester Festival. He died at Salisbury, December 15, 1780. A volume of his compositions for the church was issued at London in 1805, as Cathedral music, eorrected and published by Highmore Sheats. One of his pieces called the Chimes of Floncenter Gathedral, was edited hy $($. L. Williams.

Stephenson, Joseph, musician of the 18th century, who resided at Puole, in Dorset. He published "Church Harmony saced to derotion, being a choite set of new anthems and palm tunes on varions subjects, having the energy of onr Fnglish words particularly expressed, with an air to each different subject," London [1770]. "The Mrsical Companion, containing te demm, jubilate in 4 parts....also 2 anthems for a club feast dar...the whole for the use of country chiris..." London, n.d. Songs: The Pipe, etc., and other voeal music.

Stephenson, R. J., author of " Elementary elucidations of the major and minor of Music, exemplifving the diatonic stale..."

\section{London 1817 .}

Stephenson OI Stevenson, Robert, musician of the 1 ith century, who maduated Mus. Bac., Oxford, in 15s7, and Mus. Doc., Oxford, in 15 (1)6.

Stern, Leo, violoncellist, bum at Brighton. His father, Leopold Stern, was born at Disseldorf, lut is a naturalised Englishman, and a well-known professor of the riolin and conductor, at Brighton. His mother, as Miss Amie Iaurence, was regarded as one of the lost amatem pianists in the district. He has appeared with success at concerts in London and the provinces since alont 1886. At the Philharmonic Soeiety's concert, March 19, 1896, he played, for the first time, Dropák's concerto for the violoncello, op. 104, and with such suceess that he was inrited by the composer to play it at Prague, which he did on April 9. In the early part of 1897 he was in New York. He has two sisters in the musieal profession. His compositions are chiefly for his special instrument, and consist of a Mazurka Fantastique, Melodie Romantique, gavotte, serenade, etc.; a]so songs.

Steven, James, music pulblisher and collector, who lived in Glasyow as a musicseller. He was leader of palmody at the University Hall. He died previons to 1833. Compiler of "A Selection of pralm and hrmm tumes in four parts... to which is added a compendious introduction...." Glasgow, 1\&01, vol. 1 ; Selection of Sacred music.... vols. $2,3,4$, and 5 . The sixth rolume of this collection was edited by John Turnbull as a "Śelection of original sacred music," 


\section{STEVENS.}

Glasgow, 1833 ; 2nd edition, 1840. "Harmonia Sacra, a selection of the most approved psalm and hymm tunes," Glasgow, n.d., 2 vols. He also published some music for the flute, etc.

Stevens, Alfred Peck, known as AlfFred Glenville Taxce, or even letter as the "Great Tance," a eomic singer, who was born in London, in 18to. He first appeared on the stage and made his dibut as a comic singer at the Snu Musie Hall, Knightsbridge. He also organised an ammual concert party, and introduced the music-liall strle to the higher classes of society. While singing "Are you Guilty" at the Sum Music Hall, Knightsbridge, on the night of Decenber 26, 1888, he fell at the wings after the third verse. He was conveyed to St. George's Hospital, but died before the cab leached the institution.

Stevens, Rev. Arthur Henry, organist, graduated Mus. Bac., Oxford, 1883. B.A., 1881; M.A., 1884. Organist, choir-master, and conductor, Worcester College, Oxford; Holy Trinity, Roehampton ; St. John's, Iammer'suith; director of the music, organist, and precentor, Dover College, Kent. Has given organ recitals in Canterbury Catledral (1897), ete. Compositions: Sacled cantata, "The Song of Tobit" (MIS.); authens, carols, erening service; seherzo for organ, etc.

Stevens, Charles Isaac, author of "An Essay on the Theory of Mlusic," Gottingen, 1863.

Stevens, Jeannie M., see HaLle, Mrs. WiLliaM.

Stevens, Richard John Samuel, composer and organist, lyorn at London, 1757. He was trained as a chorister in St. Paul's Cathedral under Savage, and beeanze organist of the Temple Church in 1786; and of the Charter House, 1796. Gained prizes from Catch Club, 1782 and 1786. Professor of Music, Gresham College, 1801. He died at Peckham, London, September 2:3, 1837.

Works.-Eight Glees for 4 and 5 voices, op. 3, London [1790] ; Eight Glees, op. 4, London [1792]; Ten Glees for $3,4,5$ and 6 voices, op. 5, London 1800]; Seven Glees, op 6, London [1 ${ }^{\circ} 0 \mathrm{~s}$. Iight (ilees, expressly composed for Ladies. Sacred Music for 1, 2, 3 and 4 voices, consisting of selections from the works of the most esteemed composers, Italian and English, London, n.d., 3 vols. Ten songs, with an accompaniment for two violins, London, n.d.

One of the most popular of English glee composers. Some of his works are in eonstant use at the present time. Annong his best known glees are "From Oberon in Fairy Land," "Sigh no more, Ladies," " Ye spotted snakes," "The cloud-capt towers," "Crabbed
STEWART.

age and Youth," etc. Many of his glees still remain in manuseript.

Stevens, William Seaman, pianist and composer, born at Westminster in 1778. He studied under R. J. S. Stevens, Dr. Cooke, and T. Smart. Author of "Treatise on Pianoforte Expression, containing the Principles of Fine Playing on that Instrument,". Lond m, 1811. Composer of Lyric recitation of the garden scene in Romeo and Juliet [1815]; Ladies eanzonets, 1795. Songs: Mary, or the beauty of Buttermere, The Naiad, etc.

Stevenson, Sir John Andrew, composer, born at Dublin, 1761-62, son of John Stevenson, a Scottish violinist from Glasgow, who settled in Dublin. He studied under Dr. Murphy, and was a Chorister in St. Patrick's Cathedral, 1775-80, and Viearchoral, 1783. Mus. Doe., Dublin, 1791. Vicar-choral, Christ Chureh Cathedral, Dublin, 1800; and Chorister in Trinity College, Dublin. Narried to daughter of Mr. Morton, of the Custom House, Dublin. Knighted, 1803. His daughter was married to the Earl of Headfort. He died at his daughter's house in Meath, September 14, 1833.

Wonks.-Music to The Son-in-Law; The Patriot; Border Feuds; Bedouins; Spanish Patriots; Agreeable surprise; Contract, 1783; and Love in a blaze, 1800, etc. Thanksgiving, an oratorio. Morning and Evening Services and Anthems for the use of the chureh of England,..London, 2 vols. [165]. Glees: See our oars with feathered spray; Welcome friends of harmouy; To thy lover, dear, discover; Hail! to the mighty pow'r of song; Dublin Cries (round), ete. ('anons, catches, and glees (eollected), London. Duets and songs. Moore's Irish Melodies, with symphonies and accompaniments by Sir John Stevenson and Henry R. Bishop 10 parts and supplement, 1\$07-34; re-issued, harmonized, 1858. A series of sacred songs, duets, and trios, the words by Thomas Moore. London, n.d. A selection of Popular National Airs, with symphonies and accompaniments by Sir John Stevenson,... London, 1818, 2 vols., illustrated.

Stewart, Charles, composer and violinist, who flourished in the latter part of last and early in the present century. He was a musieian and teacher of dancing in Leith and Edinburgh, and died in June, 1818. He issued two collections of Reels, Strathspeys, etc., entitled "Collection of Stratlispey, reels, giggs, etc., with a lass for the violoncello or harpsichord." Edinburyh, 1799. "First Book of Minuets, higl dances, ete." [1805]. His soll, Robert Barclay Stewart, violinist, was born on October 19, 1804. In 1858 he was leader at the Theatre Royal, Edinburgh, and was mostly engaged as a 


\section{STEWART.}

performer at concerts, balls, etc., in Edinburgh and its neighbourhood. He died at Edinburgh, May 16, 1885. Compiler of "A new set of military quadrilles arranged for the pianoforte," 1826 ; and a large collection of Scots dance music, also composer of the Jolly volunteer, song; Scott centenary quadrille, etc.

Stewart, Charles, collector, born at Glenlyon House, Fortingall, December 24, 182:3, $\mathrm{He}$ is a lient.-colonel in the army. Published "The Killin Collection of Gaelic Songs, with music aud translations," Edinburgh, 1884.

Stewart, Mrs.Colonel, see WainWright, HaRriet.

Stewart, Neil, Scottish music-seller, publisher, and editor, flourished in Edinburgh in latter half of last and beginuing of present century. He carried on husiness between 1759-1805, at the sign of the Violin and German Flute, and Violin and Guitar, in various parts of Edinburgh, and in partnership with his son Malcolm. In 1805 the whole stock of the firm was sold by auction. Published, A new collection of Scots and English tunes, adapted to the guitar . Edinburgh $[1760]$. A collection of the newest and best reels or country dances, adapted for the violin or German flute, with a bass for the violoncello or harpsichord, Edinburgh 1761 . 62], issued in 9 parts. A collection of the newest and best Iinuets.. 1770]. A second collection of airs and marches for two violins, German flutes, and hautboys, all of which have basses for the violoneello or harpsichord, Edinburgh. A collection of Scots songs adapted for a roice or harpsichord, Edinburgh $[1790]$. A collection of catches, canons, glees, duettos, etc., selected from the works of the most eminent composers, ancient and modern, Edinburgh [1780].

Stewart, Nellie, soprano vocalist, born in Australia. Created on the Australian stage the heroines in the later Gilbert-Sullivan operas, being particularly successful in the "Mikado." Organised and directed a company with success, and being advised to visit England, took her farewell at Melbourne, in "Paul Jones," January 22, 1891. Made her first appearance at the Prince of Wales' Theatre, London, F'ebruary 6, 1892, in " Blueeyed Susan," with much succes..

Stewart, Sir Robert Prescott, Kt, organist, composer, and writer, born at Dub. lin, December 16,1825 . Son of Charles F. Stewart, librarian of the King's Imms, Dublin. Received his musical education in the school of Christ Church Cathedral, Dublin, and was appointed catledral organist in 1844 , as well as at St. Patrick's, and Trinity College. In 1846 he became conductor of the University Choral Society; graduated Mus. Bac., aud

\section{STIDOLPH.}

Mus. Doc., Dublin, 1851; and in 1861 was appoiuted professor of music in Dublin Lniversity. There was no fund from which to pay an organist at st. Patriek's Cathedral, so in 1852 he was made a vicar-choral, with the understanding that he would continue to play the organ as he had previously done. In 1872 he was invited to represent Ireland at the Peace Festival held at Boston, L.S.A.; he did not go, but sent an (Ide, in which Irish and American airs were worked up. Alhout that time he began his connection with the Royal Irish Academy of Music, as professor of harmony, organ, etc. In 1873 he was appointed eonductor of the Dublin Philharmonic. He was a remarkably fine organ player, and gave performances in many parts of Englaud, his extemporisations being masterly. He travelled it good deal, and had great literary powers, as shown in his numerous lectures; and he was an authority on bagpipes of all kinds. In 1872 he was knighted by Earl spencer, and received many public tokens of admiration at the same time. He died at Dublin, March 25, 1894.

Wors.s.-Ode tu Industry, Cork Exhibition, 1852; A Winter night's wake (1858), and The eve of St. John, cantatas; Ode to Shakespeare, Bimingham Festival, 1870; "Committee " cantata, Lniversity Choral society, 1889; Ode for Tercentenary Festival of Trinity College, Dublin, July 5, 1s92. Ten other cantatas and odes in MS. Chureh service in $\mathrm{E}$ Hat, for double choir; Serrices, varions ; Motets and anthems, twelve published, other's in IIS. Musical editor of Church Hymnal. Gilee, O Nightingale (Milton), Hibernian Catch Club Prize, 1848; five other prize glees The bells of St. Michael's tower; Fairest flower: The dream; Haymaker's' song; and other partsongs. Song, The Reefer, Orchestra prize, 1865; many songs, published and in MS. Suite in G, violins, Dublin, 1891. Orchestral music, MS. Concert fantasia in D minor, and other pieces for organ. Lectures : Ancient Irish music; Irish composers; Bagpipes; Eastern music: Mrusical epochs, ete. Essays in Casiell's Biographical Dictionary; and articles in Grove's Dictionary.

Stidolph, Harold Edward, Organist, boru at Tumbridge, Kent, 1s45. Articled pupil of Walter Bond Gilbert. When eight years old, played the services in Tunbridge Parish Church, and acted as orgauist at the Chapel of the Grammar School, while a pupil there. In 1863 he was appointed organist and choirmaster of Speen Parish Church, Berkshire, and, a year later, to the Parish Church, Chelmsford; and also choirmaster of the Diocesan Music Association. There he founded a Vocal and Instrumental Association. In 1876 he was chosen, after competition, organist of Ealing Parish Chureh, and, 


\section{STILLIE.}

in 1880 of christ chureh, Ealing. In this place he started a series of popular concerts. In 1 - 84 he went to Cape Town, and after holding various appointments, settled in Johannesburgh, where he was organist of St. Augustine's, Doonfontein. Now resident at Wynberg, Cape Town. In 1887, he toured Cape Colony with Remenyi, and has eondueted performances of opera. He composed a national part-song, "Alound the Throne of England"; also chureh music, and songs. He has contributed to the local press, and is known as a writ $r$ of verse. A colonial national anthem, and lyric tributes to visiting artists, being suceessful efforts of his muse.

Stillie, Thomas Logan, amateur musician and writer, born at Maybole in 1832. He was engaged in business in Glasgow, and acted for many years as musical critic for the Glasgon Herald. He died at CHasgow, June 6,1883 . He left a valuable Jibrary to the University of Glasgow.

Stillingfleet, Beniamin, poet, musician, and naturalist, was born in 1702 , and died in 1771. Author of the words of five oratorios, and of a "Treatise on the principles and power of harmony," London, 1771, a commentary on Tartini's "Trattato di II sica."

Stillingfleet, Rev. Henry Anthony, author of "The antiruity and advantages of church music, a semon," 1803.

Stimpson, James, organist and composer, born at Lincoln, February 29, 1820 . His father was a lay-vicar of Lineoln Cathedral, but removed to Durham in 1822. He was a ehorister in Durham Cathedral in 1827, and in 1834 , he was articled to Mr. Inghan, the organist of Carlisle Cathedral. In 1836, he became organist of St. Andrew's, Neweastle; and in 1841, he sueceeded as organist of Carlisle Cathedral. He was appointed organist of the Town Hall, Bimingham in 1842, and in the same year took a similar appointment at St. Paul's Church; organist of st. Nartin's Chureh, 1852; Franeis Road Chapel, Edgbaston, from 1869. He founded the Birmingham Festival Choral Society in 184?, and was its conductor till 1855. Professor of Music at the Birmingham Institution for the plind. He gave many important organ recitals in Birmingham, and superintended the production of NIendelssohn's "Elijah." He died at Biminglam, October 4, 1886. Editor of "Services of the Chureh: being those portions of the liook of Common Prayer, which are appointed to be chanted, arranged for the use of congregations and choirs," Neweastle, Richardson, 1840; "The Organist's Standard Library," ete.; and composed songs and pf. music. Author of a "Manual of the theory of IInsie."

Stimpson, Orlando John, organist and teacher, lorm at Inrlnam, June 21, 1835,
STOCKLEY.

brother of the preceding. Received his musical training at Durhan Cathedral. Graduated Nus. Bac., Oxford, 1871; Mus. Bac. ad sundem, Durham, 1871. Musie master, Durhan Dioeesan Training College, 1871. Now resident at Tunleridge Wells. Author of "Singing Class Book for use in Elementary Schools, Glasgow, 1877.

Stirling, Elizabeth, Mls. F. A. BrIdge, organist and composer, born at Greenwich, Felmuary 26, 1819. Studied under IV. B. Wilson, Edward Holmes, J. A. Hamilton, and (i. A. Macfarren. In 1839, she was appointed organist of All Saint's, Poplar, an office she retained nutil 1858 . In 1856 , she presented an Exercise, Psalm 130, for 5 voices, and orchestra, for the degree of Nus. Bac. at Oxford; but thongh it passed the examiners, there was no power to confer the degree. She was organist of St. Andrew's, Tndershaft, from 1sts to 1880 , when she resigned. An expert organist, she was one of the earliest to play Bach's fugnes, and gave performances at the Apollomicon, in different London Churches, and at the International Exhilition of 1862 . As a composer she will be known hy her Six Pedal fugues, and slow mosements for the organ, but more for her part-songs of which "All among the barley " achieved remarkable popnlarity, Her marrage with Mr. F. A. Bridge took place Nay 16, 1803 . She died in London, March 25, 1895.

Stockley, William Cole, mromist and conductor, born at Farningham, Kent, February 1, 18:o). Studied locally, and appeared at encerts. In 1849 went to Pimningham, and entered the house of Sahin, music-sellers, ete. Pecame organist of St. Stephen's; St. Mary's; and St. Luke's churches; and up to 1899, was organist at Carr's Lane Chapel. He formed a Choral society while at St. stephen's; and in 185.5 was invited to become conductor of the Fentival ('horal society. He gave up husiness in accepting the offer; and his first work was to conduct a performance of the "Messiah," on Pinxing Night, 1855. On December 26,1894 , he conducted the toth consecutive annual performance of the samne. He serered his comnection with the societr in 1895. He was also conductor of Sincieties at Wolverhampton, conducting the Festivals there to 1880 ; and at Walsall and elseswere. Gave his first Orehestral Concert in Birmingham Town Hall, Hecember 11, 1873, and his last, March 11, 1897. During this period he introduced many works and composers to the city, and made the nearest approach to a permanent ofchestra that Jirmingham has witnessed. As choimaster to the Bimbingham Festival, 185.9-94, his work and experience have ben mique. In 1873 he resumed business, and resigned his teaching comneetion and many appointments. 


\section{STOCLS.}

He has received many tokens of the appleciation in which his public work has been held.

Stocks, William Henry, organist born at Chatteris, lsle of Ely, August 13, 1860. Received his earliest musical training from his father, and at the age of thirteen was appointed music-reater at the Roval Normal College for the Blind, Norwood. Anong those he arsisted in this capacity was Prince Alexander, now Landgrave of Hesse. He also accompanied the pupils of the College to Windsor, when performances were given befort $\mathrm{Her}$ Majesty. While at the College he studied pf. with (Ancar Beringer, and Fritz Hartrigson, and organ playing and choir-training under In'. E. J. Hopkins. Hamony and composition was studied with H. C. Banister, and further pf. study pursued with Dr. ron Bulow, at Berlin. A.R.C.O., 1845, and L.R.A.M. (organ), 1887. In 1879 , was appointed private organist to Sir Robert Menzies. Aftel holding other positions, was aypointed assistant musitemaster at Inlwich College, in 1855, and organist of the College Chape], 1857. Author of A short Hint ry of the Organ, Organists, and Services of the ('hapel of Alleyn's College of God's (rift at Inlwich (W. Reeres, 1891), a most interesting look.

Stokes, Charhes, oryanist and comploser, born in 17it. C'horister s. Paul's Cathexial, London. Organint at Croyden, ete. He died at Lontion, April 14, 18:39. Componer of anthens, glees, songs, and olgan music. Also "The Bancuet, a selection from the musit performed at the Caledonian Asylum," 1817.

Stokes, Walter, eomposer, "born at shipston-upon-Stour, Woreester, June 28, 1547. His parents were parochial school teathers, and his father, a good baritome singer, acted as choirmaster, and his mother as oryanist, of the parish chutch. The son was intencled for the seholastic profesion, and after being a pupil teacher, he olstained a Scholarship at Saltley College, Birmingham, and held ponitions in schools in London and Biminghan. From his childhood he was devoted to music. He received his first lessoms from Mr, J. Bourne, of Stourbridge; then had organ lessons from I)r. Roland Rogers; and litter studied under Dr. Beleher, and composition under Dr. C. S. Heap. Graduated Mlus. Bac., 1878 ; Mus. Doc., 1882, Cambridge. Now resident in Worcester. His compositions include a Cantata, "The Idol Bel," for soli, eight-part chorus and orchestra (in MS.) ; and he has published a large number of songs and part-songs. Also a sonata for riolin and pf., prize composition, performed at the 1.S.M. Conferente at Bristol, January, 1890; Sonata for pf. ; pieces and studies for pf. ; pieces for violin, organ, ete.

Stonard, William, organist and composer. He was organist of Christ Church,

\section{STURACE.}

Oxford, and graduated Mus, Bac., Oxon., in 1608. He died in 1630. Composer of anthems in Clifford's Collection, and in Mis. in the Musie Sichool of Oxforch.

Stone, Alfred, musician, born at Bristol in 1s+1; died thele Jimuary 3, 1sts. Organist suceessively of St. Paul's, Clifton; Arley Chapel and Highbury Chapel, Bristol. He was conductor of the Orplueum Glee society, teacher of music in several Bristol schools, and organised ant was chortssmaster of the Bristol musical festivals of 187\% and 1876 . He elited "The Bristol Tume Book," revised edition, 1876. Stone did muel to popularize nusic in Bristol.

Stone, William Henry, physician, and amatew musician, born July 8, 1830. Only son of the late Rev. William Stome, sometine canon of Canterbury Cathedral. Educated at Balliol College, Oxford, graduating B.A. 1852 ; M.A. Entered the medical profession, taking degree of M.B, 1sigti. Among his appointmentin was that of consulting physician and leeturer on Phrsies at st. Thonnass Hompital, London. 1n lisi he accepted the oftice of lecturer on musical acoustics at Trinity College, London. An enthusiantic amateur, he played the double-basiovon, and also the oboe di carceia, the latter in Bach's Christmats (Oratorio in Wentuninster Ablyer, and at the llereford Fentival of 1879 . He was an authority on wind instruments, especially those of ancient tiote, and had a fine collection of then. His articles in Grove's" Inictionary" dinplay his knowledge in this direction. Authol of siound as Music, 1s76; Elenentary Lessons on sound, 1579; and The Secientific Batsis of Music, Novello.

Stonex, Henry, organint and conductor, burn at Norwich, 14.23. Stutied first under' James Harcourt, and afterwalis was applenticel to Dr. Buek. 1n June, 1850, he was appointed organist of freat Yamouth Parish Church, an office he hele till the elose of 1894, when he resigned through ill-health. He gave the firnt recital on the fine new organ in the church, Jannary 22, 1889. The Fammouth Mlusical society was under his direction for many vears up to 1894 . A pulslic presentation was made him in May, 1899 , for his services to music in Yammonth. He died in that town, January 10, 1897 , aged 73 .

Storace, Anna Selina, suprano rocalist, born at London in 1766 . She was the daughter of Stefano Storace, an Italian double-bass player, and sister of Stephen storace. She studied under her father and Rauzzini, and appeared as a concert vocalist in London, 1774-1778. Afterwards she studied at Venice under Sacchini, and sang at Florence, 1780; Parma, 1781; Milan, 1782; and Viemna, 


\section{STORALE.}

178t. Married to J. A. Fisher, 1784, lnt separated from him soon afterwards. She appereed in Nozart's "Figaro," at Viema, 1746. Retmined to bondon and appeared in Fnglish and Ttalian opera from 1787. Sang at Handel Festival, 17!)1. Retired in 1808, and died at Dulwich, London, August 24, 1817.

Storace, Stephen, composer, born at London in 1763. Son of Stefano Storace, an Italian double-bass player. Hestudied under his father, and at Naples in the Conservatorio of St. Onofrio. Resided in London as composer to the principal theatres. He died at London, Mareh 19, 1796.

Woris. IItsical Imomas: Gli sposi malenutenti, 1785; Gli Equivoci, Vienna, 1786; Doctor and Apothecary, London, 1788; Hamnted Tower, 1789 ; La Cameriera astuta, 17!0; No song no supper, by Prince Hoare, 1790 ; Siege of Petgrade, 1791 ; Cave of Trophonins, 17.91 ; Lirates, 1792; Dido, 17.2; The Plize, 1793; My Grandmother, 179:3; Venus and Adonis, 17!4; Glorions First of June, entertaimment for the benefit of tho widows, ete., of the nuen who fell in the late engagement under Lurd Howe. 1794; lodoiska, 1791; (herukee, 1794; Le Nozze di Dorina, 1795; Iron Chest (Coman), 1796; Mahnour, 1796: Three and the Dence, 1795. Lamentation of Marie Antoinette; Captivity, a hallad (179:3); Shepherds, I have lost my love, song. Collection of original harpsichord music, Iondon, 17!10, y vols. Six easy and progressive somatimas for pf. or harpsichord. 'Three sonatas for hatpsiehord or pf. 1785'.

Storer, John, composer, organist, and critic, hon at Hulland, near Derby, May 1s, 185s. Choirboy, Ashbourlie L'arish Churel, to 1869 , when his parents remored to Scarborough. He then entered the choir of $\mathrm{All}$ Saints', Searborongh; was solo hoy, and afterwards articled pupil of Dr. John Naytor. Graduated Mus. Jac., Oxford, 1878; and in 18,86 took the Mus. Hoe. degree, Trinity College, Toronto. Organist and choimater, St. Tiehael's, Whitby, 185!-81, when he left to study composition in London. Returned to Hearborongh, 1882, as organist of the parish chureh, and conductor of the Scarborongh Ihilnamonie Soeiety. Organist of the Parish Chureh, Folkestone, 1885-T, when he joined the loman Communion. He then undertook similar duties at the Church of the Redemptorist Fathers, Clapham, London. liesigued in 1891 to devote more time to composition, for which he was attracting notice. Has been musical direetor at the (ilobe, Royalty, Strand, Olympic, and other theatres at different times. Musical critic to Thr Moming, 1894, St. Punl's, and Court Givcular, and contributor to other papers. At present time he is direetor of the inusical studies at St. Cregory's College,

\section{STRATTUN.}

Iownside, Path, and takes Sumday duty as organist at the new Benedictine Church attached to Downside Monastery.

Works.-Festival Mass in F, 1888; Mass of Our Lady of Ransom, for soli, chorus, and orchestra, op. 50, 1891 ; Grand Solemn Mass in F minor, 1895. Anthems, ete. Comic opera, The Punchbowl, Novelty Theatre 1887 ; Comedy opera, Grotna Green, Comedy Theatre, 1890 ; Operettas, various. Part-songs. Six rocal impromptus, songs, ete Dramatie eantata, The Toumament, 1885; Concert overture, composed for the opening of the Folkestone Fine Irt Treasures Exhibition, May 22, 1886. Organ and pf. pieees, etc.

Strachan, James Kelt, organist, born at Errol, Perthshire, October 1, 1860 . Choirboy at St. Paul's Fpiseopal Church, loundee, and pupil of W. H. Richmona and John Kinross. At sixteen he was appointed organist at St. Fuoch's, Dundee; and two years later at Rolvingrove Lnited Presbyterian church, Glasgow. At this time he studied under Inr. Armes. and went to Paris for some months, studying under Alexandre Guilmant, the two hericeforth lecoming fast friends. Returuing to (ilasgow, he was appointed organist of Claremont United Presbyterian Church; and in 18:2, of the Free College church, where he still offieiates. It is as a concert organist that he is most widely known; and his recitals at St. Andrew's Hall, Crlasgow; the Royal Alhert Hall, Kensington; the Bow and Bromley Institute, etc., have established lis reputation as one of the finest executants of the day.

Strang, Walter, composer and teacher, was born at Fdinburgh on December 26,1825 . He was choimmater of Eree sit. Creorge's Glumch. Fdinhmoh, from 1848 till 1885 , and fiom 1867 to 1889 he was preecutor to the General Assembly of the Free Chmph. He Was music master" at the Free Chnrch Nornal and other selools in Fdimburgh for many vears. His compositions include hym tunes and school songs, some of which hatter appear in his "School Mrusic," Fdinburgh, 1859.

Stratton, Alexander, musician of the early part of the present centuly, who was a teacher of music in Banti. He published a "Collection of Waltzes, Opera Dances, Strathspers and Reels, arranged for the pf., violin, and Ferman flute," n.d.

Stratton, Stephen Samuel, composer, writer, and lectmer, hom at London, December 19,1840 . He first studied the pf. under Miss Elizabeth Chamberlaine (Mrs. H. von Hoiff), and subsequently the organ under Charles Gardner, and composition under Charles Lneas. Assistant organist, St. Michael's, Paddington, 1862; organist, St. Nary the Virgin, Crown Street, Soho, 1863. From 1864 to 1866 he was professor of music 


\section{STREATFEILD.}

at Totteridge Park School, Herts., and organist of St. James's, Friern Barnet. W'as an original member of the College of Organists, 1864 , resigning in 1894. In 1866 he settled in Birmingham as a teacher, and was orymist of st. Bumabas Church, 1866-7; Edgbaston Parish Church, 1867-75; St. John's, Harborne, 1876-7; and Chureh of the Saviour, Birmingham, 1878-89. He is an Associate of the Philharmonic Society, 1882; and musical critic of the Birmingham Daily Post. He has published some church music, songs, and part-songs, and pf. pieces.

Streatfeild, R. A., is the author of "Masters of Italian Music," London, Osgood, 1895; and "The Opera: a history of the development of opera, with full descriptions of all works in the modern repertory," London, Nimmo, 1896. The firstnamed work treat in only of modern composers like I'erdi, Boito, Mascagni, ete.

Street, Josiah, musician of the list: century, compiler of " A Book containing great variety of Anthems in $2,3,4$, and 6 parts, likewise a set of P'salm-tunes in 4 parti,..." London, n.d. [17.29]; 2nd edition, 1746 ; 3rd edition, 1785.

Strelezki, Anton. The nom de mlume of an Fnglish composer, whose real name is understood to be BurNand. Bom at Croydon, December 5, 1859 (1'auer's Dictionary of Pianists). Pupil of the Leipzig Conservatorium, and later of Nadame Schumanm. Has given recitals in Anerica. He is a most voluminous writer for the pianoforte, his principal compositions being Eight pieces, op. 47; Three pieces, op. 146; Three boolis of pieces, op. 191, 197, 204; Leichte Klarierstücke, op. 220 ; hesides Polonaises, a grand Tarantella, Barcarolle, and many detached pieces. Also a Minuet for p. and violin, and some songs.

Stretton, A. J., bandmaster. Received his early education in the Roval Artillery Band Is an :xcellent riolinist, and has a general linowledge of every instrument. Appointed handnaster, and Battalion Cheshire Regiment, 1s93; Musical Director, Kneller Hall, February, 1896, with honorary rank of Lientenint.

Strong, David, tenor vocalist, born in London, March 9, 1852. He has given concerts, and has appeared with success as a vocalist; and is well known as a teacher. In 1886 , he was appointed a Gentleman of Her Majesty's Chapel Royal, St. James', and also a Professor at the Guildhall School of HIusic.

Stroud, Charles, composer, who was born in 1710 . He was a pupil of Dr. Blow. Died at London, April 26,1726 , in his 16 th year. He composed anthems which possessed merit, and was a musician of promise.

Stroud, Henry Charles, see HExRY, Chaplin.

\section{$S \mathrm{LCH}^{\top} \mathrm{CH}$}

Stuart, Ralph, pianist, born at Dartmonth, Devon. His father was an army staff-surgeon. He studied at Leipzig and Heidelberg, and in 1880 , went to New Kealand for the benefit of his health. He was heard in concerts at the principal towns there, and in Australia; and was the pianist of the Melba Concert Party. In July, 188s, he gave a Chopin recital at the Princes' Hall, London; and has since given recitals at various times, making a speciality of his interpretation of the music of Chopin.

Stubley, Simon, was organist of St. John's Church, Clerkenwell, from about 1740 to 1754 . He died at London in 175t. He composed some vocal music, chiefly songs, a few of which appear in the " Cicntleman's Magazine " for $1744,1746,1749,1753$, etc. He was sncceeded at St. John's, by PHiLIP Markifar, elected July, 175t-died 176t; and he in his turn was sncceeded by JoHs BAcus, appointed April 10, 176t-died May 16,1416 , who held the post for the long period of 52 years.

Sturges, Edward, organist and composer, born at I ondon, Fulntary 25, 1sos. (O)ganist of the Fonndling lospital. He died at London, Febmary 15, 1sts. Composer of "I know their solrows," anthem: Selection of chormes loy Handel, IR16; Organ gems, 18t5; Arangenents of Boyce's anthems, Haydn's "Creation," cte.

Sturges, Richard Yates, flutist, violinist, and poet, born at Biminghan, April 10 , 18t3. Studied under W. Tilly and Vobbe. loal teachers. Nade his dibut at Mr. James ritimpson's Monday Pupular Concerts, Town Hall, Bimingham. September, ls6n. In 1864 he plased at MIr. Rea's Concerts, Town Hall, Newcastle-on-Tyre; was for some months in the orchestra at the Theatre Roval there: and has tompod in the provinces m sereral oceasions. He visited Ttaly, 1hst, and took up the study of the violin. As a flute player he las given much attrution to the works of Adolph Terschals, and has been complimented by hasing a piece written expessly for him"The File IVorshiphers of the Caspian Sea." This he played at Sonthport, December 9, 1895. He has published "The Solitary, and other Poems," Edinhroh, Nichol, 1868; "The Angel of Love, and ather Poems," London, Provost, 1875; Summer-day Siecrets; "The Black P'hilosopher', or Scipio Africanus;" and other pootical workis.

Such, Edwin Charles, composer and teacher, born in J.ondon, August 11, 1840. Educated at Merchant Taylor' School, and London Univerity College, griduating B.A. Studied music under Hiller and Molique at Cologne Conservatorinm, 1861. Conductor of the Barnet and Ibis Choral Society, 188t-93; professor of harmony at Portman Academy. 


\section{SUIDLW.}

His compositions include Ps. 46 , for solo, chorns, and orchestra; Dramatic cantata, "Narcissus and bcho," produced at a concert at R.A.MI, July 6, 1881; Cantata, The Watersprite; Anthems, part-songs, songs, pf. pieces, ete. His som, Hexns Sich, violinist, pupil of Joachim and Wilhehnj, made his first appearance at a Berlin Philhamonic concert in 1sys. After a tonr in Germany he retumed to London, and gave his first recital at St. James' Hall, October 24, 1896. PEncr Such, another som, is a viobmeellist, propil of Rolvert Hansmann, and of the Jigh school, Berlin.

Sudlow, William, eomposer, organist, and violoncellist, born in 1772. He Was an organist in Nanchester, and died there in 18ts, Conposer of anthems, songs, and other vocal music. Jis brother, Emitid, born 1786 , died at Manchester, September 16, 1sit5, was a viola player.

Suett, Richard, componer, actor, and singer, born at Chelsea, London in 1755 . He was a singer and actor chiefly in London. Died at London, July 6, 1805. Componere of Corin and Joan, pastoral [1800]; Six canzonets, with an accompaniment for a haresichord or pf., London, 1803. Six glees [17!) ]. Songs: Kiss; Oh crllel absence; Signs of faithful love; Soft music; Sylvia again is true, ete.

Sullivan, Sir Arthur Seymour, Kt., composer and conductor, borli in Londom, May 13, 1842. His father, Thomas StoldVax, was comnected with Kneller Hahl alnowst from the commencement of that institution, as professor of bass brass instruments, and was also a clarinet player. He hat a ligh reputation throughout the army as an instructor. He died suddenly, of heart diveratse, September, 23, 1866. The son entered the Chapel Royal in 1854 as a chorister, under the Rev. Thonlas Helmore. He nade rapid progress in music, and hin first somg was published in 1855. In July, 1856, he wath elected the first Mendelswohn Scholar, but did not leave the Chapel Royal until 1857. He studied at the R.A.M., nuder. Goss and Stemdale Bemmett, and in 1854 proceeded to Leipzig Conservatorium, where his teachers were Plaidy, llauptnamn, E. F. Richter, Moscheles, and others. At the Hauptprifung, May 26, 1860, he conducted a performance of his overture, "Lalla liookh;" and while there he also wrote some string dultrtets, and the "Tempest" music, which he brought with him to London in April, 1stil. This was produced at the Crytal Palace, April 5, 18fie. For a time he wain organist of St. Michael's, Chester Square; and St. Peter's, Onslow Gardens, 1867-72. He soon ruse inte notice as a composer ; and from the production of his cantata, "Kenilworth," at the
SLLLIVAN.

Bimingham Festival, 1864, his career has been one of continued snceess. His light operas have attained a popularity without a parallel. He was appointed musical director of the Royal Aquarimen, Westminster, and conducted a concert of English music at its opening, January 23, 1876 ; Principal of National Training School for MInsic, and professor of composition, 1876, resigning in 18s1. Conducted the orchestral concerts of the Glasgow Choral I'nion, 1875-7; Promenade coneert, Corent Garden, 1578-9. British Commissioner for Nusic, I'aris Exhibition, 1Ars. Apluinted conduetor of Leeds Festivals, 1880, to present time; Philharmonic Society, 1885-7. Visited America in 1.85, and conducted "The Mikado" in New Furk. Condneted concerts at Crystal Palace, Manchester, Buckingham Palice, etc. F.R.A.M.; Nus. Doc, Cambridge, 1sit6, Oxford, 1sig, both honoris cantế; Chevalier, Legion of Honour of France, 1sis; corresponding member of the Royal Musical Institute, Florence, 188s; instituted grand organist of the Freematsons, April 27, 1887; eleeted president of the Pimningham and Nidland Institute, 1888, on Gctoler 19, giving his andress in the Town Hall; receised the homone of knighthosd from the Qneen, 1883; kinight of the Order of the Houne of Colurg, and recipient of the Order of the IIedjidieh from the sultan of Turkey, 1898.

Works.-Gratorios and cuntatas: KenilWorth, Bimingham Festival, 1864; The I'rodigal Son, Worcester, 1869; On shore and rea, composet for the opening of Royal Albert IIanl, Kensington, May 1, 1871; Festival Te I emm. Crystal Palace, 1872, to eommemorate the recorery of H.R.H. the Prince of Walen; The Light of the World, oratorio, Birmingham Fentival, 1873; The Martsr of Antioch, Leeds Fentival, 1880; The Gulden Legend, the rame, 1886; ode, I wish to tune my quiv'ring lyre, laritone solo and orehestra, Gloncester Fentival, 1880. Operas and Plays: Cox and Box, Adelphi, Nay 11, 1s67; The Cantrabandista, st. George's Hall, December 18, 1667 ; Thespis, Giacty, Irecember 26, 1871; Trial hy Jury, Ruyalty, Mareh 25, 1875; The Zoo, St. James's, Jume 5, 1875; The Surcerer, Opera Conique, Norember 17, 1877; H.M.S. Pinafore, the same, May 25, 1s7s; Pirates of Penzance, the same, April 3, 1sso; Patience, the same, April 25, 1881. And at the Saroy Thatre, Iolanthe, Nosember 25, 1882 ; Princens Ida, Jannary 5, 1884; The Miliado, Mareh 14, 1885; Ruddigore, Jannary 22, 1887; Feomen of the Guard, Octolver 3, 18s8; Gondoliers, December 7, 1889; lladdon Hall (Sydney Crmaly), September 24, 18s2; Utopia, Octoler T, 1893; and The Grand Duke, May T, 1896. Grand opera, Itanhoe 


\section{SUMMERS.}

(Julian Sturgis), produced Royal English Opera House, January 31, 1891. These works have also, for the most part, been performed in Germany, America, etc. Incidental music to The Tempest, op. 1, Crystal Palace, 1862; Merchant of Venice, Manchester, September 18, 1871; Merry Wives of Windsor, Gaiety, December 19, 1874; Henry VIII., Manchester, Angust 29, 1877 ; Macbeth, Lyceum, December 29, 1888; King Arthur, completed 1894. Orchestral: Procession march, composed in celebration of the marriage of the Prince of Wales, and performed Crystal Palace, Narch 14, 1863; symphony in E, Crystal Palace, Narch, 1866; overture, In Memoriam (his father), Norwich Festival, 1886; Marmion, Philharmonic Society, June 3, 1867; Di Ballo, Birmingham Festival, 1870. Concerto, 'cello and orchestra, Crystal Palace (Piatti), 1866. Ballets, L'Isle Enchantée, 1864; Victorian and Merrie England, Alhambra, Nay 25, 1897. Six Day Dreams, and other pieces for pf. Te Deum, Jubilate, and Kyrie in D; Hearken unto Ne; O, love the Lord; Who is like unto Thee? and other anthems. Hymm tunes in various collections. Musical editor of Church Hymus with tunes, S.P.C.K., 1874. The last night of the year; $O$, hush thee, my labie; Joy to the victors; and other part-songs, 1871. Sonus: The Window, or the loves of the wrens (Temmson), 1871; Bride from the North; Arabian love song; Orphens with his lute; $O$, mistress mine; Sweethearts; Will he come? The lost chord; Edward Gray; Thou'rt passing hence; Snow lies white; Let me dream again; $O$ fair dove, $O$ fond dove; A weary lot is thine; Looking back; St. Agnes' Ere; The Sisters, dnet; and many others.

His brother, Frederick Sullivan, whose talent for humour was so conspicuous, was by profession an architect. He turned to the stage, and his impersonation of The Judge in "Trial by Jury" had much to do with the success of the piece. Thile on a provincial tour he canght cold from damp sheets at Newcastle, and died, January 18, 1878 , at the age of 39 .

Summers, James Lea, composer and pianist, born at London, 1837. Sou of William Summers, a musician. He was blind from his birth, but became a pupil of Miss Kate Loder and of (Sir) G. A. Macfarren. $\mathrm{He}$ appeared as a pianist at the Crystal Palace about 1850-60. Died at London, July 8, 1881.

Works.--Quintet for strings; Quartet in E flat for strings; Quartet in A, pf. and strings; Andaute and rondo brillante, pf.; Two musical sketches, pf.; Valses. etc., pf. Anthems, duets, and songs.

Summers, Joseph, organist and com-

\section{SURENNE.}

poser, born in Somerset, 1843. Received his early training at Wells Cathedral, under C. W. Lavington, afterwards studying with Sterndale Bennett, and Dr. Gauntlett. Took degree of MIus. Bac. at Oxford, 1887, and in 1890 was made Mus. Doc., Cantuar. Has been organist successively at St. Andrew's College, Bradfield, 1861; Holy Trinity, Westonsuper-Mare, 1864; St. Peter's, Notting Hill, 1865. On going to Australia in 1865 he was appointed to St. Peter's, Melbourne, and now holds a similar position at All Saints', St. Kilda, near Mlelboume. Is Government inspector of music for public schools, Victoria, and holds other appointments of a similar nature.

Works.-Oratorios: Deborah; St. Sebastian. Cantata, A Song of Triumph. Odes: "Galatea Secunda;" "Thanksgiving;" Psalm 31, soli, chorus, and orchestra; Anthems, Services, etc. The Australian Natioual Anthem, "Maker of Earth and Sea." Hymn Tunes contributed to The Bristol Tune Book; Psalmody, British Empire; Parish Tune Book. "In Memoriam," for orchestra; marches; songs, part-songs, etc.

Sunderland, Susan, born Sykes, soprano vocalist, born at Brighouse, Yorkshire, April 30, 1819. Was instructed chiefly by local teachers, and first sang in concerts at Deighton, near Huddersfield, about 1834. She married Mr. Henry Sunderland, June 7 , 1838. Nade her début at the Sacred Harmonic Concerts, London, April 1, 1846, siuging as Achsah in Handel's "Joshua." Sang at the Birmingham Festival Choral Concert on the 10th of the same mouth; and at intervals up to 1859 ; at the Free Trade Hall, Manchester, 1849. So famous in the North as to receive the title of the "Yorkshire Queen of Song," she was a special favourite at the Bradford Festivals; she also sang at the first Leeds Festival in 1858. Her last public appearance was at Huddersfield, June 2 and 3,1864 , in the "Messiah," and a miscellaneous concert. Her golden wedding was celebrated by a "Jubilee" concert, June 7,1888 , the proceeds of which went to founding the Sunderland Vocal Prize, for natives of the West Riding of Yorkshire. At the meeting in December, 1888, when the Jubilee committee completed the work, Mrs. Sunderland sang "Home, sweet home," greatly delighting and affecting her old friends and admirers.

Surenne, John Thomas, organist and composer, borm at London, Mareh 4, 1814. His father, Gabriel Surenne, was a French musician and teacher, who settled in London, and afterwards in Edinburgh, about 1817, where he taught French and edited a well. known French-English dictionary. In 1831, J. T. Surenne, who studied under his father 


\section{SURMIAN.}

and Henri Herz, became organist of St. Mark's Episcopal Church, Portobello, and he also held, for many years, the appointment of organist of St. George's Episcopal Chapel, Edinburgh. He dicd at Edinburgh, February 3,1878 . Composer of an Overture for orchestra in D; a Rondo de concert for pf. and strings; many other pf. pieces, and some part-songs and songs. He compiled "The Dance Music of Scotland, a Collection of all the best Reels and Stratlispeys, both of the Highlands and Jowlands, for the Pianoforte." Edinburgh [1851], 5 editions. "Songs of Scotland without Words," 1852 and 1854. "Songs of Ireland," 1855. A Collection of Church Music, consisting of chants, psalms, and hymn-tunes, principally original (with $\mathrm{H}$. E. Dibdin), 1843-44, 2 vols. The Scottish Episcopal Church Music Book, Edinburgh, n.d. Students' Manual of Classical Extracts for Pf., and other instrumental compositions. Surenne wrote most of the accompaniments for the original edition of Graham and Wood's "Songs of Scotland."

Surman, Joseph, conductor and writer, born at ('hesham, November 14, 1804. He was conductor of the Sacred Harmonic Society, 1832-48. First conductor of the London Hamonic Society, which he started in November, 1848, with the "Messiah." Music publisher in London. Conductor of the Worcester Festival. He died at Loudon, January 20, 1871. He wrote "Statement submitted to the consideration of the mem. bers of the Society, in reply to charges preferred against the Conductor of the Society,' London, 1848; also a supplement. He had been removed from the couductorship of the Sacred Harmonic Society on certain charges against his management being made. Editor of "The London Psalmist. Psalms and Hymms adapted to the services of the Church of England," London [1850 .

Sutcliffe, Alfred Lister, organist and composer, born at Leckhampstead, Bucks. November 13, 1859. Studied music under the Rev. L. (G. Hayne, and was by him appointed organist of Bradfield, 1875; and of Mistley with Bradfield, 1878. Composer of a few hymn tunes.

Sutcliffe, Charles Thomas, organist, born at Manchester, April 12, 1853. Chorister at Manchester Cathedral, and assistant-organist there later. Organist successively at Salford; Longsight; Parish Church, Eccles; and now of St. Catherine's, Barton, near Manchester. He is the composer of some pf. pieces, songs, etc.

Sutcliffe, Jasper, violinist. Seholar R.C.M. Made a successful appearance at Mr. De Jong's Manchester concerts, February 2, 1889, when he played Max Bruch's concerto in $G$ minor. He has been associated with

\section{SWEPSTONE.}

the British Chamber Nusic concerts, 1894, and other artistic undertakings.

Sutherland, G., musician and composer, author of "A Manual of the theory of Music," London, 2 editions to 1871 ; and composer of a few songs.

Sutherland, John, musician. Published "The Ndinburgh Repository of Music: containing the most select Inglish, Scottish, and Irish airs, reels, strathspeys, etc," Edinburgh, n.d., 3 vols.

Sutton, Alfred James, organist, composer, and conductor, horn at Droitwich, May 1, 1827, Resident in Birmingham, where he was appointed conductor of the Amateur Harmonic Association, on its formation in 1855 , an office he held until 1877. Was chorusmaster, with W. C. Stockley, at the Birmingham Festival, 1858-76; and has held other appointments. Sometime organist of St. Thomas's, Birmingham ; St. Mary's, Warwick, and other churches. Composer of an oratorio, "Ruth"; and an opera, "Put to the test," both in MS. His ptoblished works inchude a Serenade for soli, chorus, and orchestra, composed in celebration of the marriage of the Prince of Wales; a cantata, "Sage Advice," composed for Madame SaintonDolly's Choir ; songs, part-songs, and pieces for organ. Mrs, Sutron, his wife, is a soprano vocalist, and for many year's held a prominent position in the Midlands as an oratorio singer. She also took part in concerted pieces at the Birmingham Festivals, 1861-73, and has been heard with favonr in London.

Sutton, Rev. Frederick Heathcote, author of "Some accomt of the mediæval organ case still existing at Old Radnor, South Wales," London, 1866 ; "Church Organs, their" position and construction," London, 1872 ; also 1883. The Appendix to this contains the Old Radnor tract.

Sutton, Richard, nusician, compiled " Book of musical varieties," London [1835].

Sutton, Robert, musician, author of "Flements of the theory of music," London, Cocks [1870] ; Brd cdition, 1874.

Sutton, William Walter, composer, pianist, and teacher, born at Dover, 1793; died there, in March, 1874. He published a number of arrangements for the Pf., ote.

Swaine, N., author of "The Young Musician, or the seience of music familiarly explaincd, with a glossary of musical terms," Stomport, 1818.

Swan, William David, pianist and composer, born Glasgow, November 30, 1856; died Burslem, May 27, 1889. He composed a few pieces for the piano and was a good pianist, acting in this capacity for a time as accompanist to the Glasgow Select Choir.

Swepstone, Edith, composer. Studied at the Cruildhall School of Music. One of her 


\section{SWIFT.}

earliest works to be performed was a symphony, part of which was given under her direction at Leyton, March 10, 1887. Other compositions are: Elegiac Overture, "Les Ténèbres," performed in the Queen's Hall, February 9, 1897; Quintet in F minor, pf. and strings; Quartet in G minor, strings; pieces for 'cello and pf.; and for pf. solo. Two cantatas for female voices-The Ice Queen ; and Idylls of the Mom ; songs, etc. Miss Swepstone has lectured on music at the City of London School, 1895, etc.

Swift, George Henry, organist and composer, born at Lamboum, Berlishire, 1856. Organist of Lambourn Church, and conductor of a choral society there till 1884, when he went to Hungerford. He has composed an Evening Service in E; O sing unto the Lord; Show us Thy mercy; and other anthems. Part-songs. A Sonata in C, for pf., etc.

Swift, James Frederick, composer and bass vocalist. For many years resident at Liverpool, and now at Liscard. Lnder the name of Godfrey Maris, he has published a number of songs, Sailing; A brave heart, etc., some of which have enjoyed great popularity. $\mathrm{He}$ has condueted various musical societies at Liverpool, and given concerts.

Sydenham, Edwin Augustus, organist and composer, was a choirboy at the Parish Church, Stratford-on-Avon. Studied at Leipzig Conservatorium, and became organist of St. Martin's, Dorking ; St. Andrew's, Farnham, 1873 ; St. James's, Bury St. Edmund's, 1879; and All Saints', Scarborough, 1882. There he worthily maintained the musical reputation of the church. He gave concerts, was busy as a teacher and composer, and was the inventor of a patent tonch regulator for the pianoforte. He died suddenly at Scarborough, February 18, 1891. His compositions embraced a number of anthems: Christ is risen; O give thanks; Great is the Lord; Sing unto God; and others. An Evening Service. A battle song; The maiden of the Fleur-de-Lys; The parting kiss; and other part-songs. Duet, pf. and harmonium; pieces for violin and pf.; 'Cello and pf.; and various compositions for pf. solo.

Symmers, James, amateur musician, who was rector of Alloa Academy. He wrote "Outlines of the Sol-fa method of singing," Glasgow, 1849. "The Sol-fa method of singing at sight from the common musical notation," Glasgow, 1858-59, 2 parts.

Symmes, Thomas, amateur musician and clergyman, born in 1678 , died in 1725 . He wrote "Utile dulci, or a joco-serious dialogue concerning regular singing," Boston, 1723.

Symonds, Henry, composer and organist. $\mathrm{He}$ was one of the King's Band of Music. Organist of St. Nartin's, Ludgate, and of the

\section{TAGORE.}

Church of St. John, London. He died in 1730. Composer of Six sets of lessons for the harpsichord, etc.

Synge, Mary Helena, pianist, born at Parsonstown, Ireland. Daughter of the late Sir Edward Synge, Bart., and descended from Archbishop Synge, of the 17th century. After some private study, she went to Brussels for further instruction in pf, playing and singing. On her retum she gave a recital in London, July 10, 1883, which brought her into favourable notice. She played at the exhibition in Cork the same year, and has since been heard at concerts in many places in England and Ireland. As a composer she is known by a vocal trio, "Spring" ; Songs, Time and Eternity; Fate, and others; and a number of pf. pieces. Of the same family was the Rev. EDWARD Srxge, born at Lockeen Glebe, Parsonstown, June 30, 1829. He graduated Mus. Bac., Oxford, 1865, and Mus. Doc., Dublin, 1869. His compositions included an mfinished oratorio, "Hezeliah" ; settings of Psalm 127, and I'salm 150, for soli, chorus, and organ; Milton's Ode to May, soli and chorus; and some songs. He published a Te Deum, and other church music; Morning song; Evening song; Spring song; Winter song, etc. Died, 1895.

Synyer, Henry, violinist and conductor, born at Nottingham, June 7, 1818; died at King's Heath, near Birmingham, July 17, 1892. He went to Birmingham as a young man, and as the junior in the firm of Harvey and Synyex; was well-known in the Midlands as an entrepreneur. For thirty years he was a nember of the Bimingham Festival orchestra, and for a long period was bandmaster of the 1st Warwickshire Rifle Volunteers. In conjunction with Alfred W. Gilmer, Henry Srnyer furmed a military band which had a high reputation, and was in great request in many parts of the comintry.

Sympson, see Srmpson, C.

Taas, William, musician of latter part of last century. He was an itinerating teacher of psalmody in Banffshire, etc. Alathor of the "Elements of Iusic, wherein the fundamental principles of that science are explained and illustrated. To which is annexed a collection of the best church tunes generally in use, and fitted to various measures of poetry. With several anthems, chants, and canons. The whole selected from the best authors with a view to the improvement of chureh music in Scotland," Aberdeen, 1787.

Tagore, Rajah Sourindro Mohun, Hindu amateur musiclan, was president of the Calcutta Music School, Compiler of "Hindu music, from various authors,". . Calcatta, privately printed, 1875. This contains all the treatises on the subject of any import- 
TAILOUR.

ance, by Willard, Sir Wm. Jones, Sir W. Ouseley, Nathan, ete. Six original Râgas; The Musical Scates of the Hindus. Some speeimens of Indian Songs.

Tailour, Robert, musician of the latter part of $16 \mathrm{th}$ and early part of 17 th centuries. He issued "Sacred Hymms consisting of fifte seleet Psahms of David and others, paraphrastieally turned into English verse, and by R. Tailour set to be sung in five parts, as also to the vicle and lute, or orpharion. Published for the use of such as delight in the exercise of music in her original honour," London, 1615.

Tait, Andrew, musician of the first half of the 18th century, issued "A New and correct Sec of Chureh Tunes," Aberdeen, 1753, 3rd edition. We have not been able to trace an earlier edition.

Tait, Annie, pianist and composer, who studied at R.A.M. under Sir G. A. Macfarren. She died at Eastbourne, Febuary 24, 1896, at an early age, after a eareer of much promise. Among her works are a Trio for pf. and strings; Sonata in $\mathrm{F}$ for pf.: and cther pieces for pf. and songs.

Tait, Patrick Macnaghten, F.S.S., F.R.G.S., son of the late William Tait, Esq., was bom in Edinburgh. In 1851 proceeded to India, and was there through the Mutiny, when he raised the Rifle Company of the Calcutta Volunteer Guards. Contributor to various maxazines, chiefly on subjects of Mortality and Insurance. The work claiming notice bere is "Vital and other Statistics applicalle to Musicians," 1880.

Tallis or Tallys, Thomas, composer and organist, born about 1520-1529. He is supposed to have been a elorister in the Chapel Royal. Organist of Waltham Abbey till 1540. Gentleman of the Chapel Royal during reigns of Henry VIII., Edward VI., Mary, aud Elizabetll. Joint organist with Byrd, of the Chapel Royal, and joint patentee with him in the exclusive right to print music. $\mathrm{He}$ died on November 23, 1585, and was buried in Parish Church of Greenwich.

Works. - Cantiones que ab argumento Sacre vocantur, quinque et sex partium, London, 1575. The Preces, Chants, Te Deum, Benedictus, Responses, Litany, Kyrie, Creed, Sanctus, Gloria, Maguificat, and Nune Dimittis (Church of England Serviee), first printed in Barnard's Collection, 1641, and since reprinted many times by Novello, limbault, Jebb, etc. Song of Forty Parts, for eight choirs of five voices each, "Spem in alium non habui." The Order of the Daily Service of the United Church of England and Ireland, edited by John Bishop, London, 1843. Anthems: All people that on earth do dwell; Come, Holy Ghost; Hear the voice and prayer; I eall and ery; If ye love Ne; Hear my prayer;
TATE.

Blessed are those: Salvator Mundi (motet); and many others in MIS. contained in the British Mruseum, Music School of Oxford, Fitzwilliam Inseum, Cambridge, and elsewhere.

In 1876 a brass memorial tablet was placed in Greenwich Parish Chureh, which was provided by subseriptions gathered on the suggestion of Henry Walter Miller (q.v.).

Tamplin, Augustus Lechmere, organist and composer, born in London, 1837; died Futham, London, Nay 8, 1889. He was. organist of St. James' Church, Narylebone, and was a performer of great albility. In 1883 he lectured in London on the history, construction and teehnicalites of the pianoforte. He introduced the donble tonch in harmonium playing. Composer of an operetta, "Fleurette," performed, Crystal Palace, 1874; Pf. music; Songs: Daybreak; Love, and other pieces.

Tans'ur, William, composerand collector, bor'n at Dunchurch, Warwickshire, in 1699 or 1700. He was a teacher of music at different times in Barnes (Surry), Ewell near Epsom, Cambridge, Stanford, Boston, Leicester, and other parts of England where be worked along with his son, but lately he settled in St. Neots as a bookseller and teacher of music, and died there, October 7, 1783 .

Wonks.-A Compleat Melody, or the Harmony of Sion. . London [17.4?], other editions $1730,1736,1739,1764-66$, etc. The titles and contents of the various editions of this work vary greatly]. Heaven on earth or the beauty of holiness. . London, 1738. Sacred mirth or the pions sonl's daily delight...1739. The Universal harmony containing the whole book of psalms.. 1743, 1746, etc. The Psalmsinger's jewel, or useful companion to the book of Pralms. London, 1760, 1766, ete. Melodia Sacra, or the devout psalmist's new musical companion, a choice selection of psalm tunes in 4 parti.. 1771, 177\%. A new musical grammar, or the harmonical speetator..Leicester, 1746; 2nd edition, London, 1753; 3rd edition, 1756; 7th edition, 1829. The elements of musick displayed. . London, 1772. I'vetical meditations..1740.

Tanymarian, see STEPHEN, EDWARD.

Tapley, Joseph, tenor vocalist, was a seholar of the National Training Sehool, South kiensington, to 1889 . Sang at Mr. De Jong's concerts, Nanchester, 1888 ; toured in the "Old Guard," and other comic opera companies, 1887; and sang in comic opera for three vears in Australia, his Rex. Henry Sandford, in "The Vicar of Bray," heing a pronounced success. IIeappeared in a round of characters in the (iilhert-Sullivan operas. Returned to England in 1896.

Tate, Nahum, poet and musician, bom at Dublin in 1652. He succeded Shadwell as poet laureate in 1692 . Died at London in 1715. Author of "An Essay for promoting. 


\section{TATTET.}

psalmody," London, 1710, lut is best lnown for his metrical version of the psalms, which he exe nted along with Nicholas Brady.

Tattet, J. A., organist and composer of first half of the present century. He edited MacMurdie's "Sacred Music," 1827, and composed a large mumber of songs and hallads, such as "The Blind boy" [1825], "Forget me not when beauty smiles," "May Day," etc.

Tattersall, Rev. William DeChair, clergyman and musician, was born in 1752 . Rector of Westlourne, Sussex, 1778, and of Wootten-under-Edge, 1779, where he died on May 26, 1829. Compiler of "Psalms selected from Merrick's version, the music new and partly chosen from the works of the most eminent composers," London, 1791. "Improved Psalmody, with new music," London, 1794; also 1795, 3 vols., and "Improved Psalmody, the words selected from a poetical version of the Pralms by $J$. Merrick, the music adapted from the sacred compositions of Handel," London, 1802.

Taverner, John, organist and composer of the 16th century. IIe was organist of Boston, Lincohnshire, and of Christ Church, Oxford. He was involved in the Reformation struggle, and narrowly escaped martyrdom. He composed masses, motets, and anthems, now existing in MS.

Taverner, John, musician, born 1584. Professor of music at Gresham College, 1610. Was vicar of Stoke Newington. Died there, 1638.

Taylor, Amram, musician of first part of present century. Composer of "The Sacred Harp, a new set of original psalm and hymn tunes, composed and hamonized for four voices," London [1842].

Taylor, Brook, mathematician and musician, born at Edmonton in 1685. He distinguished himself at Cambridge, and became Secretary of the Royal Society in 1714. He died in 1731. Celebrated for his theorem, which Lagrange adopted as the basis of the differential calculus. He was the first to publish analytical researches into the vibrations of strings, and contributed to the Philosophical Trannactious of 1713 a paper on the "Motion of a tense string."

Taylor, Ebenezer Willam, organist and composer, born at Stafford, Noremler 26, 1851. Began to study music when six years old, afterwards articled to $\mathrm{G}$. Townshend Smith, of Fereford Cathedral, and subsequently studied with Dr. C. W. Corfe, at Oxford. Graduated Mus. Bac., 1876: IIus. Doc., 18\$3, Oxford: F.R.C.O., 1879. Appointed organist of St. Thomas', Stafford, 1872; and of st. Mary's, 1880. Hon. local examiner for R.C.M. His compositions comprise an oratorio, "St. Stephen" ; a cantata,

\section{TAYLOR.}

"God our Refuge"; service for Holy Communion; songs, pf. pieces, etc. Author of Tocal score reading exercises; Figured bass and melody exercises; Pedal and manual scales, arpeggios, etc., for organ. Contributor to National Book of Hymn tunes, etc.

Taylor, Edward, writer and musician, born at Norwich, January 22, 1784. Son of John Taylor, a Unitarian preacher there. He studied imusic under Charles Smyth and Dr. Beekwith. Bass singer at the Norwich Concerts. Established, with others, the Norwich Musical Festival, 1824. Settled in London, 1825, and became bass singer, teacher, and musical critic of the spectutor, and a writer in the IIarmonicon. Professor of music, Gresham College, in succession to Sterens, 1837. Conducted Norwich Festivals of 1839 and 1842. Founded the Purcell Club, and with Rimbault and Chappell, the Musieal Antiquarian Society. Secretary of the Tocal Society. He died at Brentwoud, Nareh 12, 1863.

Works. - Three inaugural lectnres (Gresham (ollege), London, 1838 ; An address from the Gresham Professor of Music to the patrons and lovers of art,.. London, 183s; The Vocal Sehool of Italy in the sixteenth century, madrigals, full antliems, motets, and villanellas, actapted to English words, London [1839], A collection of Pralm tumes in various metres. . London, 1812; The People's Music Book (with J. Turle), London, 18t4; The English Cathedral Service: its glory, its decline, and its destined extinction, London, 1845 (reprinted from the Britishand Foreign Revieu'); The art of singing at sight (with Turle), London, 1846, 2nd edition, 1855; Airs of the Rhine, edited. Edited Purcell's " King Arthur" for the Musical Antiquarian Society. Translated librettos of Mozart's Requiem, Haydn's Seasons, Gramn's Death of Jesus, Spohr's Last Judgment and Fall of Babylon. Sungs: Guarda che bianca luna; I'll be a fairy; Ruver's farewell, etc. He also edited IIajor's collection of Sacred Music $[1820]$.

Taylor, Franklin, pianist and teacher, borm at Birminghan, February 5, 1843. Studied under C. Flavell, pf., and T. Bedsmore, organ, taking the services for the latter at Lichfield Cathedral when eleven. Went to Leipzig in 1859, and studied at the Connervatorium under Plaidy, Moscheles, Hauptmann, and others. Left for 1 aris in 1861, asd studied further with Madame Schumann. In 1862 he returned to London, and was eugaged in teaching. He played at the Crystal Palace, February 18, 1865, Hiller's Concerto in F sharp ninor; and made his first appearance at the Monday Popular Concerts, June 15, 1866, in a Beethoven programme. He has also played in Liverpool (Philharmonic), Bimingham-where he was a great favourite-aud other places. Of 


\section{TAYLOR.}

late years he has devoted himself chiefly to teacling, writing, and editing. $\mathrm{He}$ was sometime organist of Twickenham Parish Church, and St. Michael's, Chester Square. Was professor at the National Training School, 1876-82; at the R.C.MI., 1883; now Member of the Board of Professors, and Nember of the Associated Board. Examiner for South Africa, 1894. Member, and sometime Director, Philharmonic Society; and President of the Academy for the higher development of pf. playing. Author of Primer of Pianoforte Playing, Macmillan, 1877 ; Technique and Expression in Pianoforte Playing, Novello, 1897. Translator of Richter's Harmony, Cramer, 1864; Counterpoint, 1874 ; Canon and Fugue, 1878. Compiler of a Pianoforte Tutor, London, Enoch. Editor of Beethoven's Sonatas, 1-12, Boosey; Progressive Studies for pf. 52 books, Novello; Scales and Arpeggios, Novello's Primers, No. 53. Arrangement of Sullivan's Tempest Music, pf., four hands, ete. Contributor of some valuable articles to Grove's Dictionary of Music and Musicians.

Taylor, Harry James, organist and composer, born at CheItenliam, August 1, 1866. Articled pupil of J. A. Matthews. Gained National Prize, Trinity College, London, 1881. F.R.C.O., 1888. For several years organist to the Cheltenham Festival Society; in 1886 appointed organist and choirmaster, Parish Church, Cullompton, Devon; and from 1888 has held a similar position at Christ Church, Dover, and is also conductor of the Dover Choral Lnion. Hon. local examiner, R.C.M. His works inchude Twoovertures, orchestra; Serenade, for strings and harps, Cheltenham Festival, 1s96; String quartet: Trio in D minor, pf, and strings; Serenata; Gavctte, pf. and two violins. Pianoforte sonatas; Organ pieces, etc. Author of The Clooralists' Handbook, and Historical facts relating to music (London, Weekes, 1894), which has gone through several editions.

Taylor, James, musician and writer, born at Norwich, October 7,1781 ; died there June 7, 1855. Aurhor of "A Course of Preceptive Lessons for the Spanish Guitar, designed for the assistance of master and pupil," London [1827]; and composer of Twelve easy preludes for the harp [1820]. He contributed essays on music to the Quarterly Magazine and Review of Music, 1818-29.

Taylor, James, Scottish musician of present century, issued "A Collcction of Psalms, etc., with a familiar introduction to the theory and practice of rocal music," Alerdeen; Cornwall, n.d.

Another James 'TAÝlon, who was a violinist at Elgin, issued "A Collection of Strathspeys and Reels, dedicated to Lady Dunbar, of Northfield," EIgin, n.d.
TAYLOR.

Taylor, John organist and writer, organist to the Queen at Kensington Palace; Professor of Sight Singing, G.S.MI., 1897. Author of "A Manual of Vocal Music," London, 1872; "Music and the Sol-fa Systems in Elementary Schools," London, 1873; Mutation Singing Method, London, 1873. "A few words on the Anglican Chant," London, n.d.; "Student's Text Book on the Science of Music," London, 1876; Music sleet Stave Modulator [1882]. The Stave Sight-Singing Method for use in army schools. How to sing at sight from the Staff, London, Philip \& Son, 1897.

Taylor, Rev. John, clergyman and writer, born at Lancaster in 1694 ; died at Warring. ton in 1761. Author of "The Mlusic Speech at the Public Commencement at Cambridge," London, 1730; "A Collection of Tunes in varions Airs, with a scheme for supporting the spirit and practice of Psalmody in congregations," London, 1750 .

Taylor, John Bianchi, composer and conductor, born at Bath in 1801. He was a distingnished teacher of singing. Died at Bith, April, 1876. Composed "A set of seven glees," Bath [1840]. Duets; Green leaves, part-song. Songs: Convent hell, Flowers, I ask thee not, I never can forget, Mariner's life, Moonlight, Oh peaceful lake, Slave wife, When I leave thee, etc.

Taylor, Richard, composer and writer, born at Chester in 1758 . He died at Chester, Felmary, 1813. Anthor of "The principles of music at one yiew," London, 1791; "Beauties of sacred rerse," London, 1795,3 vols. National songs. Composer of IBuxom Joan, a burletta, 1778; A collection of favourite songs. and an overture, London $[1780]$. Glees: Now Winter with her hoary train; The gloomy season's past; Summer now upholds her scenes; Clad in her brown vesture; Gently as the breathing galc. Songs, etc. His son, Thomas, born at Chester in 1787 , was organist of St. John's, Liverpool. He published "A Book of Original Chants," songs, etc.

Taylor, Robert, conductor and organist. While a child was organist at Badsey, Worcester, and ChiId's Wickham, Glonester. Thence he entered Worcester Cathedral as a chorister, and was afterwards acticled to W. Done, and lecame his assistant organist. Alpointed organist of St. Patrick's, Hove, Brighton, he established the Brighton Sacred Harmonic Suciety, of which be has been condurtor since 1870 , doing excellent work in the cause of music. In 1869 he was appointed organist of Brighton College, an office he held for ninetcen years. With Dr. Alfred King he established the Brighton School of Mncic. He is choirmaster at the Church of st. Michael and All Angels, Brighton.

Taylor, Samuel Priestley, organist, 


\section{TAYLOR.}

borm in London in 1779. Son of Rev. James Taylor, Rector of Cumberland Street Chapel. When seven the boy played the organ for the choir of that Chapel, having previonsly sung in the choir of Surrey Chapel. He was taught music by John Whittaker, and Dr. Russell of Oxford. Went to New York in 1806, and was organist of Christ Chureh, when he introduced chanting. Played the clarinet and liettledrums in the band of the American garrison, New York, in the war of 1812, and received a pension up to his death. Was president, 1812, of a musical organisation, now become the New York Philharmonic Soeiety. His last public appearance was at Holy Trinity, Brooklyn, in 1865, when he played Luther's "Judgement Hymm" for a chorus of 100 . In 1874 the Handel and Haydu society of Brooklyn gave him a testimonial concert. Known as the oldest organist in the world, ho died at New York, in the summer of 1875 , at the age of 96.

Taylor, Sedley, M.A., author of "Sound and Mnsic," a non-mathematical Treatise on the physical constitution of musical sounds and harmony. " London, 1873, 2nd edition, Macmillan, 1883.

He has lectured at the Birmingham and Midland Institute, on the "I'hysieal basis of sound"; at the Musical Association on "Improved Notation": on Bach's Church Cantatas, Cambridge, 1893; and elsewhere. Conposer of part-songs, songs, and anthor of contributions to musieal journals.

Taylor, Silas, composer, born at Harley, Shropshire, July 16, 1624; died November 4, 1678. Published "Uourt Arres, or Parins, Almaines, Corants, and Sarabands," London, 1655.

His brother, Srupares, who died at Dublin in 1672, was a violinist.

Taylor, Mrs. Tom, born LALRA W. BARker. Third daughter' of the Rev. Thomas Barker, vicar of Thirklelsy, lorks. Narried Mr. Tom Taylor, the dramatist, in June, 1855. Composed Sonata for pf. and violin, the Country Walk, 1860. "Ballads and Song's of Brittany..Translated ly Tom Taylor, with some of the Original Melodies harmonized by Mrs. Tom Taylor," London, 1865. "Enone," cantata, 1850 ; Glees; Six Songs, London [1847]; Six Songs for voice and pf. [1852]; Musie to "As Jom Like It," London, April 14, 1880 ; Songs of Youth, 1883, etc.

Taylor, William, organist and composer, born at Kidderminster, December 8, 1832. Studied under Dr. William Marshall. Graduated Mus. Bac., Oxford, 1854. Organist and choirmaster, St. John the Baptist, Kidderminster, 1849.68; and of the T'arish Church from 1868. Honorary Borongh organist. Compositions: Psalm 104, for soli, chorus, and orchestra; oratorio, St. John the Baptist

\section{TEMI'LETON.}

(composed 1862 ; published 1879) ; Te Deum, Benedicite, Evening Service in F. Songs, etc.

Taylor, William Frederick, pianist and composer, born at Bristol in 1835; died in February, 1887. Composer of Diana, operetta, 188t; quartet for pf. and strings. Fantasias, galops, marehes, gavottes, and numerous transeriptions for pf. Part-songs and sougs. He gave concerts at which five of his orv family took part.

Temple, Hope, composer, born in Dublin, of English parents. At the age of thirteen came to England to complete her education. Studied under J. F. Barnett and E. Silas; and in Paris with André Mlessager. Gave concerts, Steinway Hall, 1890, etc. Composer of an operetta, "The Woodem Spoon," and of a number of songs, amoug which may be named 'Tis all that I can say, Au Old Garden, Were we lovers then? Mary Grey, A Mother's love, Queen of Roses, etc.

Temple, Richard, see Совв, Richard Barker.

Templeton, John, tenor vocalist, born at Ricearton, near Kilmarnoek, July 30, 180. One of a family of which other members were singers. He was precentor in Dr. Brown's Secession Church, Edinburgh, about 1822, but went to London, and studied under Blewitt, Welsh, and T. Cooke. Début on stage at Worthing, 182s First appeared in London as Belville in Shield's " Rosina," October 13,1831 . Became assoeiated with Malibran in 1833 , and sang with her in opera in London with great success. Sang in Scotland, 1836. Appeared in the United States as lecturer and voealist, $1845-6$, and published his leeture as "A Musical Entertainment," Boston, $18+5$. He retired from public life in 1852 . He sang in operas of Meyerbeer, Spohr, Mozart, Auber, Barnett, Balfe, Benedict, and Rossini, and was one of the most popular and refined ballad vocalists of his time. Ile died at New Hampton, near London, July 1, 1886. See Templeton and Malibran, reminiscences of these renowned singers, with original letters and anecdotes, by W. 1I. H., London, 1880, 3 portraits. He composed a few songs, "Put off! put off!" (Queen Mary's escape from Lochleven), ete.

His brother Janes (born in 1784; died January 4, 1868), was an alto singer, and acted as precentor of St. Andrew's Parish Chureh, Edinburgh, for many years. RoBerT (born in 1790; died 1853), was a tenor, and held a precentor's appointment in a chnrch in Kilmamock. MAтTHEW (born in 1792 ; died April 16, 1870), was a bass singer and a teacher of music. ANDREW (born in 1796 ; died in June, 1841), was a precentor in Kirkwood's Relief Church at Edinburgh, and possessed a fine alto voice. 
TENCH.

Tench, Mrs. Albert, see Cullex, Rose. Thicknesse, Mrs. Philip, see Ford, Amm. Thackeray, Duncan, organist, tenor vocalist and composer. Graduated Mus. Bae., Oxford, 1870; Mus. Doe., Dublin, 1871. Sometime organist of St. John's Chureh, Perth; later it Southgate, Niddlesex. Since 1860 tenor in choir of Armagh Cathedral. He has composed two sacred cantatas for soli, chorus (s part), and orehestra; Chureh Service; Songs, ete.

Thillon, Anna, born Hunt, soprano vocalist, born in London in 1819. Left England at the age of ten, and studied at Havre, marrying, when fifteen, M. Thilion, who was at one time principal first violin in Jullien's band. She made her debut at the Théatre de la Renaissance, Paris, November 17, 1838, in Grisar's "Lady Melvil"; and after singing in opera in Paris for some years, returned to England, and appeared first at the Princess's Thratre, May 2, 1844 , as the Qucen in Auber's "Crown liamonds." She sang at the Philharmonic Concert on June 24 following, and later, in the provinees. Tisited the Continent, and was in Ameriea, 1850-4. Returning to Furgland, sang at Jullien's Concerts, 1854 . Made her last appearance in opera at the Lyeenm Theatre, May, 1855, in the "Crowu Diamonds," and retiling from public life some years later, went to reside at Torquay.

Thirlwall, John Wade, eomposer and violinist, born at Shilluttle, Northumberland, Jamuary 11, 1809: died at London, June 15, 1876 He was leader of the band at Covent Garden Theatse, etc. Composer of a "Book of Ballads," 1843; Songs, violin musie, etc.

His daughter Axirs (boru 1830; died, London, October 19, 1881), who married E. Doussel Corri ( $q . \%$ ), was a soprano vocalist.

Thom, Rev. Robert Riach, clergyman, poet, and nusician, bon at Nontrose, lecember 16, 1831. Educated at Edinburgh University, ete. Minister of Free St. David's, Glasgow, and afterwards of the Free High Chureh, Kilmarnock. He has composed a number of hymus and other music for the church, and in 18 sis he edited a "Manual of Praise," containing music for the service of the church.

Thomas, see also Aptomis.

Thomas, Adelaide Louisa, pianist, bom at Clapham, London. Seholat of the National Traning School, Kencingtom; A.R.C.AI. Gave pf. recitals in Jondon, 1849, ote. In 1892 passed the examination for Mus. Bac., Oxford, but was not allowed to take the degree. Alithor of "A Roval Road to P'ianoforte Playing," Williams; and composer of Festival Sutting of Magnificat and Nunc Dimittis. Trincipal of the Seientific Training School for Music, 1894.

\section{THONAS.}

Thomas, Arthur Goring, composer, born at Rillton Iark, near Eastboume, Sussex, Novcmber 21, 1851. Intended for another profession, he did not enter upon the serious study of music motil he was over twenty years of age. Studied at Paris, under Emile Durand, 1874-6; and subsequently at R.A.M., London, mder Sullivan and Prout. Lueas Prizeholder, 1879-80. F.R.A.11. He resided in London, and devoted limself entirely to eomposition. His death was melancholy. Suffering from mental depression, he threw himeelf in front of a train at West Hampstead Station, March 20, 1892, and was instantly killed. A Goring Thomas Seholarship was fomderd, 1892 , at the R.A.M.

Wroks.-Operas: The light of the Harem (R.A.Ml. compusition, 1880); Esmeralda, produced hy Carl Rosa, Imury Lane, Mareh 26, 1883; Nadesthrla (Jubian Sturvis), the same, April 16, 1895; The Golden Wel) (left mufinished, seoring completed by S. I'. Waddington), produced, count Theatre, Liverpool, Felnuary 15, 1893. Choral ode, The Sunworshiperes, Norwich Fentival, 1881; Cintata, The Swan and the Skvlark (orchestral score by C. I. Stanford), Birninghan Fextival, 1894. Four vocal scenas, Hero and Leander (Lueas Prize), 1880, etc. P'salm for soprano solo, choms and orchestra, R.A.M. concert, St. James's Hall, Jume 19, 1878 . Songs: Twelve Lrries; Inllaby; Brese from shore; Song of Sinain; ('hanson de Mai; Know'st thou the land; A smmmer land; 'The Kiss; Altum of ten song (solected from a number found anomg his MLSi.), six are settings of French words ly Victor Hutgo, and other's. Dnet, The I)awn, Birmingham Festival, 1491; Duet, Simset. Suite de liallet, orchestra, composed for Cambridge Tuiversity Mrasianl society, aud profuced, Jume 9, 1887; Somata, pf. and violin, ete.

Thomas, C. No, amateur organist. For twenty-five years he was organist of St. George's Cathedral, Cape Town, recigning in 1888. A goud laritone vocalist, he has taken an active part in musical doings in the colony, by his work at concerts as well as in the elinch.

Thomas, Cadwallader, handnaster, born on November 15, 18:38. Joined the band of the coldstram Guards in 1853 , and became serjeant in 1866, at that time being solo clarinet player. Bandmaster to the lonke of York's sichool, 1870-80; and on the retirement of Frederick Godfrey, 1880, wasappointed bandulaster of the Coldstream (inards. This he held nutil early in 1896, when he retired.

Thomas, Dudley, tenor voealist. Won the prize for tenors at the Crrstal Palace Competitions, June 27, 1872. Was a member of Sirluey Lestie's Royal English Opera Company, 1885 ; and also sang in Italian opera at 


\section{THOMLS.}

Covent Garden in 1887. Later details are wanting.

Thomas, Evan William, violinist and composer, pupil of Spagnoletti. Ht played in the orchestra at the production of Weber's "Oberon," 1826. Most of his professional life was passed in Liverpool, where he was appointed leader of the Philharmonic band, 1850. He gave successful shilling Saturday Concerts in Liverpool, 1854; also classical chamber concerts in Manchester, 1853 , etc. He conrposed a cuncerto in A minor, for violin and crehestra, 1863 , and other picces. Retired many years ago, and resided at Dinas Dinlle, North Wales, where he died October 4,1892 , in his 79 th rear.

Thomas, Florence A., see sub. MARSHALL, JULIAN.

Thomas, Frances, clarinet player of present time. She has been heard at concerts in London, Bimingham, etc., from 1878, and has gained a reputation for tone and execntion.

Thomas, John, PExCEIDD GWALiA, harpist and composer, born at Bridgend, (rlamorganshire, Nareh 1 (St. David's Day), 1826. When a child he played the piccolo, and then the harp, winning the prize of a triple harp at Abergavenny Eisteddfod when eleven years old. Through the influence of the Countess of Lovelace he was placed in the R.A.M. in 1840, where he studied the harp under J. B. Chatterton, and composition under Charles Lucas and Cipriani Potter. Many compositions, including an opera, "Alfred the (i reat," were written during his student days, and produced at the R.A.II. concerts. In succession he was elected Associate, Fellow, and Professor, R.A.M. In 1851 he was harpist at the Royal Italian Opera; and 1852-62, undertook annual tours on the continent, playing at Vienna, Perlin, Moscow, St. Petersburg, etc. Played at the Leipzig Gewandhaus Concerts, October 3, 1852, and again in January, 1861. In 1861 the title of Pencerdd Gualia (Chief Bard of Wales), was conferred upon him at the Aberdare Eisteddfod. He gave his first concert of Welsh music at St. James's Hall, July 4, 1862, with a chorus of four-hundred voices, and a band of twenty harps, creating a great sensation. Some of his harp compositions were introduced. These concerts have been continued annually. In 1871 he was appointed Harpist to the Queen, in succession to the late J. B. Chatterton. That year he also was conductor of the Welsh Choral Union. By his efforts a Welsh Scholarship was founded at the R.A.M. in 1883 , and which bears his name. He acted as adjudicator at the Eisteddfod at Chicago Exhibition, 1893: his cantata, "Llewelyn," was perfomed September 6, and gave a harp concert there, September 18. Public recog-
THOMAS.

nition of his services to music has not been wanting, and he has been elected Member of the Academy of St. Cecilia, and Philharmonic, Rome; Plilharmonic, and Royal Musical Academy, Florence; Philhamonic Society, London. He is professor of the harp at R.C.M., and a Member of the Royal Society of Musicians, and of the I.S.M. At the Cardiff Conference, 1896- 7 , he gave a lecture on the Music of Wales.

Wonks.-Llevelyn, dramatic cantata, produced, Swansea Eisteddfod, 1863: The Bride of Neath Talley, a Welsh scene, Chester, 1866. The memory of love; The Minstrel; There be none of Beauty's daughters; and many other songs. Welsh patriotic songs, arranged for chorus and harp. Fdited and arranged a Collection of Welsh Melodies, for voice, with harp or pf. accompaniment, 2 vols., 1862 ; later, 4 vols. Harp: Concerto in $\mathrm{E}$ flat, produced, Philharmonic Concert, May 3, 1852; Concerto in B flat. Duets for two harps; for harp and pf.; Two sets of six studies, and many pieces for harp solo. Romance and rondo piacevole, liarp and violin. Transcription of Mendelssohn's Lieder ohne Worte, 8 books; Schubert's songs; Welsh melodies; Beethoven's Sonata, op. 27, No. 2; Handel's rariations in $\mathrm{E}$, etc.

Thomas, John. Born at Phananerch, Cardiganshire, December 11, 1839. Composer of many anthems, glees, and part-songs, of a popular trpe. Adjudicator and conductor of Psalmody Festivals.

Thomias, John L., IEUAN DDU, musician and editor, born near Carmarthen in 1795; died at Treforest, Glamorgan, June 30, 1871. He compiled "Y Caniedydd Crmreig: the Cambrian! minstrel, being a collection of the melodies of Cambria, with original words in Fnglish and Welsh," Merthyl Trdvill, 1845. Thumas was a schoolmaster ly profession.

'Thomas, John Rogers, composer, and baritone rocalist, born at Newport, Monmonth, Narch 26, 1830. Ile went to the United States, and became a teacher and editol. He published "Church MIusic, a selection of Gems from the best masters," New Yort, 186.3; Thomas' Sacred Music, a collection of psalm and hymn tunes, New York, 1863. Composed "The Pic-nic" cantata ; "Diamond cut Diamond," operetta, 1876. Songs: After long years; Benutiful isle of the sea (1865), Bomnie Eloise; Cottage by the sea; Evangeline; Pretty Nelly; Thine alone; 'Tis but a little faded flower.

Thomas, Lewis William, bass rocalist, born at Bath. of Welsh parentage, April, 1826 He was brought up as a wood-carver, but developing a fine bass voice, lie studicd singing under Bianchi Taylor. In 1850 he was appointed lay-clerk in Worcester Cathedral, and, in 1852, master of the choristers. 


\section{THOMIAS.}

For some years he assisted at the Three Choirs' and Birmingham Festivals. He was a great favourite in Birmingham, and sang at the Festival Choral and other concerts for many years. He first appeared in London at St. Martin's Hall, December 20, 1854, in "The Messiah," at MIr. Hullah's concerts, and sang at the Sacred Harmonic concerts for the first time, November 23, 1855. The next year he settled in London, and was in the choir of St. Paul's Cathedral. This appointment he left in 1857 for the Temple Church, and about the same time was appointed a Gentleman of the Chapel Royal. He sang at the Temple Church until 1885 , and resigned his position at the Chapel Royal in 1887. For a short time, about 1857, he sang in opera. During Mr. Joseph Bennett's visit to America, 1884-5, Lewis Thomas undertook his musical duties on the Daily Telegraph, and later was placed on the staff of that paper. From 1886 lie edited The Lute for some time. He died, after a lingering illness, in London, June 13, 1896.

Thomas, Llewelyn, physician, born in 1848. M.D., Brussels. He was surgeon to the Central London Throat and Ear Hospital; Hon. physician to the R.A.M. and G.S.M. ; lecturer on Vocal Physiology, T.C.L., resigning in 1882. A Llewelyn Thomas Prize was instituted at the IR.A.MI., 187T, and continued in memory of him. It is a Gold Medal for declamatory English singing. Dr. Thomas died in Londun, November 26, 1884.

Thomas, Robert Harold, pianist and composer, born at Cheltenham, July 8, 1834 . He studied at the R.A.M. under Bennett, Potter, and 13lagrove, and played at concerts in London from about 1850 . He was a professor of the pf. at the R.A.M. and the Guildhall school of Music. He died at London, July 29, 1885 .

Works--Oeertures: Mountain, lake, and moorland, Philharmonic Society, February 19,1880; "As you like it". .1864. Noctumes, fantasias, and numerous transcriptions for the pf. Songs, etc.

Thomas, T. D., musician, compiled "Sacred Hamony: a selection of church music...f for the use of country choirs...." Winchester 1815$]$.

Thomas, Thomas, see Aptomis.

Thomas, William Edwin, organist and composer, born at Oxford in 1867. Chorister at Christ Church at age of seven, and pupil of Dr. Corfe; at the same time playing (Gregorian) services at St. Nicholas' Chapel, Oxford. Graduated Mus. Bac., 1888; Mus. Doc., 1894, Oxford. While still a chorister he was selected four successive years by Sir F. Ouseley to sing at lis Festivals, St. Michael's, Tenbury. After acting as deputy at St. Paul's, Uxford, for some time, he was

\section{THOMAS.}

appointed to a church at Ellesboro', near Tring; but in a few months he returned to Oxford as organist and choirmaster of St. Mary and St. John, under Father Benson. In 1886 he was appointed organist and music master at All Saints', Bloxham, Banbury. There he founded a Choral Society which did good work. In 1894 he went to Bournemouth, obtaining the conductorship of the Boscombe Philharmonic Society there, and in 1895 was appointed to St. Clement's Church, which posts he still holds. Ilis compositions comprise Psalm 71, for eight-part chorus and orchestra (1893); Communion Service in F; Magnificat and Nune Dimittis in D; $A$ prize madrigal (Brighton Philharmonic), "And wilt thou weep?"; The School Song of All Saints', Bloxham (words by J. H. T. Goodwin, B.A.) ; serenade; song, "The Holy Chila," ete.

Thomas, William Henry, pianist, organist, and conductor, born at Bath, May 8, 184s. Son of Lcwis W. Thomas. Removed with the family to Worcester, 1850, and frequently sang with the choir boys in the Cathedral, though not an enrolled member of the choir. Went to London in 1856. His studies were continued under his father for singing, J. B. Zerbini for pf., J. H. B. Dando violin, and E. J. Hopkins organ and liarmony. Has been organist successively at St. Andrew's, Lambeth; St. Martin's, Ludgate 1 Hill ; St. George's, Tufnell Park from 1871 to present time. Has deputised at Crystal Palace for Jas. Coward, and at Chapel Royal for G. Cooper; was formerly much engaged as accompanist at the Novello Concerts at the Albert Hall, etc. Conductor of Tufnell Park Choral Society from 1879; Popular Ballad Concerts; Oratorios at the People's Palace; and an earnest worker in the cause of musical education. Professor of singing at the Guildhall School from its foundation; also at 12.A.M. Examiner for Associated Board, K.A.M. and R.C.MI. Editor of "Major and Ninor Scales in various forms and rhythms." His younger brother, Frank Lewis Thomas, studied at R.A.M. under W. G. Cusins and E. Ralph, and, after leaving there, studied with A. H. Thouless and C. S. Jekyll. His first appointment was as organist of Christ Church, Lancaster Gate, while the late W. H. Monk was ehoirmaster. From 1880 to present time he has becn organist and C.M. of St. Mary's, Bromley, kient. He founded the Iromley Musical Society, in 1880 , and has condueted many important concerts each year since; and has been frequently engaged as accompanist at the Covent Garden Promenade and Queen's Hall Concerts. He has composed a number of pieces for pf., and "I saw thee weep," "The impress of the Creator," "Love's wherefore," and other songs. 
THOMPSON.

Thompson, Lady Henry, see Loder, Kate.

Thompson, General Thos. Perronet, political writer and musician, born at Hull, in 1783; died at London, September 6, 1869. Author of "Instructions to my Daughter for playing on the enharmonic guitar, being an attempt to effect the execution of correct harmony, on principles analogous to those of the ancient euharmonic," London, 1829. “Enharmonic theory of MIusic," London, 1829; Second edition issued as "Theory and practice of just intonation," London, 1850 ; Third ed.: "Principles and practice of just intonation, with a view of embodying the results of the Sol-fa Associations, as illustrated on the enharmonic organ . . " London, 1859. Exercises . . , London, 1842,6 vols. ; containing Enharmonic of the ancients, Harmonics of the violin, Musical periodicals, Jews harps, etc.

Thomson, Alexandra, composer of present time. Daughter of the Most Rev. W. Thomson, Archbishop of York (1819-1890). Studied under Dr. Naylor. Her setting of Campbell's "Battle of the Baltic," for chorus and orchestra, was produced Octoler, 1890 , at the Festival at Horingham, Yorkshire. She has also composed some madrigals, "The shepherd's elegy," "Holiday in Arcadia," op. 12 , etc.

Thomson, Rev. Andrew Mitchell, clergyman and musician, born at Sanquhar, Dumfriesshire, in June, 177R, baptized July 11,1778 . He was successively minister of Sprouston, Roxburgh, 1805-08; East Church, Perth, 1808-10; New Greyfriars' C'hurch, Edinburgh, 1810-14; and St. George's Church, Edinburgh, 1814-31. He died at Edinburgh, February 9, 1831. Famous for his patronage of R. A. Smith, and for his efforts to promote good psalmody in the Church of Scotland. Edited "Sacred hamony for the use of sit. George's Church, Edinburgh," 1820. He composed "St. George's, Edinburgh," "Redemption," and other well-known psalm tunes and some other pieces for the musical service of the church.

Thomson, Andrew, musician and violinist, was born about 1792 . Teacher and violinist in Glasgow, where he died May 24. 1860. Author of a "New and improved Violin iustructor," London, 18t0. Compiler of "Evenings in Scotland, a collection of Scottish melodies," Glasgow [1845] ; "Selections from the melodies of Scotland, with characteristic words by W. H. Bellamy," Loudon, 1851, 2 vols.

Another Andrew Thomson has published the "Dance Music of Scotland, arranged as sets, for dancing," Glasgow [1883], and dance music for flute, pf. music, etc.

Thomson, Andrew D., composer and

\section{THOMSON.}

teacher, who resided in Glasgow, and was teacher in the Free Church Normal School, 1846 till 185t. He held other appointments. Author of "Training-School Song Book," Glasgow, 1848-49, compiled with W. Sugden ; "Union Sacred MIusic Chap-Book," Glasgow [1853] ; Contributions to Mitehison's Psalm books, etc.

Thomson, George, collector and editor, born at Limekilns, Fife, March 4, 1757. Secretary to the Board of Trustees for the Encouragement of Arts and Manufactures in Scotland, 1780. He died at leith, Felmuary 18, 18;1. Published "A Select Collection of original scottish airs for the voice, to each of which are added introductory and concluding Symphonies and accompanyments for the pianoforte, violin, and violoncello [by Pleyel, Kozeluch, Haydn, and Beethoven, vol. titles differ], with select and characteristic verses by the most admired Scottish Poets..." London [1793-1841] , 6 vols: v. 1, 1793; 2, $1798 ; 3,1799 ; 4,1802 ; 5,1818-1826 ; 6$, 1841. Collection of the Songs of Burns, Sir Walter Scott, and other eminent lyric poets, ancient and modern, united to the select melodies of Scotland, and of 1reland and Wales, with symphonies and accompaniments for the pianoforte, hy Pleyel, Haydn, and Beethoven, ete.....London, 1822, 6 vols. Select Collection of original Welsh airs, adapted for the voice, united to characteristic English poetry, with introductory and concluding symphonies by Haydn, Beethoven, etc.7, London, 1809,3 vols. Select collection of original frish airs, united to characteristic English poetry, with symphonies and accompaniments for the pianoforte, violin, and violoncello, composed by Beetloven, London, 1814-16, 22 vols. Twenty scottish melodies, added in 1838-39 to G. Thomson's new edition of the Melodies, Edinburgh, 1839.

Thomson was an enthusiastic musician, and frequently gave musical parties and "ances in his house His neighbours objected to the noise, and under cover of a new police act, Thomson was proceeded against and an injunction was obtained against him in the police courts. This case gave rise to a controversy to which Thomson contributed two pamphlets-." Statement and review of the recent decision of the judge of police in Edinhurgh, authorizing his officers to make domiciliary visits in private families, and to stop dancing," Edinburgl, 1807 ; and a fourpage "Postcript" on the same subject.

Thomson, James, musician, was precentor of Lady Yester's Church, lidinburgh, from 1800 to 1830 . He was also a teacher of music at Leith. Author of "Rudiments of MIusic, to which is added a Collection of the hest church tunes, hymns, canons, and anthems." Edinburgh, 177s, 3rd edition, 1793. 


\section{THOMSON.}

Thomson, James, organist, composer and teacher, born at Kendal, November 15, 1832. Studied at R.A.M. under Sterndale Bemett and others. F.R.A.M. Has held organ appointments at King's Lymn, Torquay, Liverpool, and Belfast. President at Saffron Walden, and Professor at the Training College there, and at Cavendish College, Cambridge. Of his compositions a symphony in A was heard at Liverpool in 1869; and an Ode to Hope (1880), and a cantata " The Lady of the Lake, have been performed in public.

Thomson, John, composer, conductor, and professor, born at spronston, Roxburgh, October 28, 1805. Son of the Rev. Andrew M. Thomson. Pecame acquainted with Mendelssohn in Edinhmoh, and renewed his acquaintance at Leipzig, where he studied under Schnyder yon Wartensee. Returned to Edinburgh, and in 1839 became first Reid Professor of Music at the University. Conducted the first Reid Concert, February 12, 1841 , at which for the first time analytical programmes were used. He died at Edinburgh, May 6, $18+1$.

Wouks.--Operas: Hermann, or the Broken Spear, London, 1834; The House of Aspen, London, 1834; The shadow on the Wall, London, 1835. Vucal Nelodies of Scotland, with symphonies and accompaniments by John Thomson and Finlay Dun, Edinburgh [1836], n.d.; New Edition, 1880. Minuetto for pf. and flute; Capriccio for pf. and violin. Bagatelle, 1831; Divertimento (duet); Polonaise's; and waltzes for pf. Songs: Arab to his steed; lilow light, thou balmy air; Cleveland's farewell to Mimna; Die tanti mei tormenti; Farewell, my love; If here still I linger; Lady! awalie; Love, art thou waling or sleeping?; Love wakes and weeps; The merry moonlight hour; Midnight Dream: O, eanld to ne; 0 ! sweet be your slumbers; The pirate's serenade; Poor Camille; Song of Harold Harfager; Song of the lihenish peasant: Song of the Spanish maid; The Savoyard's retum; Where art thou?; Zara! art thou sleeping?; etc.

Thomson, Mrs., see Laidlaw, AnNa RoBENa.

Thomson, William, Scottish mnsician, son of Traniel Thomson, King's Trumpeter in Edinburgh. He went to London, and became known as a singer. Pullished "Orpheus Caledonius, or a collection of the best scoteh songs set to Musick ly W. Thomson," London [1725]; Second edition, London, 1733, 2 volk. This is the earliest printed collection of Scots songs with musie and contains 50 melodies. The selection iswned by John Playford in 1700 as "Collection of original sicotch tmnes," is without the lyries, which in Thomson's case, were pilfered from hamsay"s "Tea table miscellany" without acknowledgment.

\section{THORNE.}

'Thorley, Thomas, English composer and vocalist, who flourished at the end of the 18 th and begimning of the present centuries. $\mathrm{He}$ composed a large amount of vocal and instrumental music, among which may be mentioned an extraordinary piece of discriptive music called "The Siege of Algiers, a characteristic divertimento for the pf."..1820, containing passages respecting rockets and bombs lumsting; ships on fire. Briton's triamph, ehristian slavery aholished for ever! etc. Flis other works inchnde, "Ten volnutaries for the organ or harpsichord [1775]; Epitaph hymn on the death of the I'rincess Charlotte of Wales [1817]; Sacred cabinet, or divine repository, entainingoriginal hymms, ete., London [1818].

Thorndike, Herbert Elliot, haritone vocalist, born at Liverpool, April 7, 1851. Edncated at Cambridge University, and while an undergraduate won the prize for Iyaritone at the National Music Meetings, Crystal Pal. ace, July 5, 1873 . Studied at Milan under Francesco Lamperti, and on his return to Fungland continued his studies with H. C. Deacon and Alberto Randegger. Sang at varions concerts in London, and appeared at the Norwich Festival, and the Monday 1'opular Concerts in 1884; Crystal Palace, ete. In July, 1886, he sang at Drury Lane Theatre in Hervés " Frivoli."

Thorne, Edward Henry, organist, pianist, and composer, born at Cranbome, 1horset, May 9, 1834. IInsically educated at it. George's Chapel, Windsor, under (Sir) Creorge infey. Organist snceessively at Henley-on-Thames, 1853; Chjehester Cathedral, 1803; St. Patrick's, Brighton, 1870; St. Peter's, Cranley Gardens, London, 1s73; St. Michael's, Cormhill, 1875; and st. Amme's, Soho, 1891 to present time. He has given concerts and pf. recitals in London, Brighton, and wher plaees, for a number of years; recitals at Queen's Hall, 1895-6; and is conductor of St. Ame's Choral and orchestral Society; and societies at Clapham and Worthing.

Woris.- Psalm 57, for tenor solo, chorus, and orelrestra, St. James's Hall (Willing's (hoir), Febmary 26, 1884; Psalm 125; Magnificat and Nrunc Dimittis, for soli, chorus, orchestra, and organ, composed for the Festival of the Sions of the Clergy; Church services. Anthems: All Thy worki praise Thee; Behold, the Lord, the Ruler, is come; In sweet consent; Let us now praise famous men (menls voices); The Lord that brought 1rs; and others. Sacred Nhrsic for the home (aircle, 1859. Edited A Selection of single and donble chants (1860?), London, Hamilton. Songs, varions. Overture, Peveril of the Peak (prize), Promenade Concerti, Covent Garden, Octoher 29, 1885. Two trios, pf. and strings; Sonatas for $\mathrm{pf}$, and violin, and pf. 


\section{THORNE.}

and 'cello; Sonata Elegia, pf. Romance, pf. and 'cello; Suite, pf. and clarinet, ete. Original compositions for organ, seven books; Organ pieces, various.

His son, Herbert Euward, born at Henley-on-Thames, October 11, 1861, is a pianist and organist. Appointed to All Sonls', South Hanıstead; St. Sariour's, Brixton, 1854; and to Clapham Parish Church, 1891. He has appeared as pianist at his father's coneerts at Brighton, 1882 , etc. His dimghter Beatrice, born in London, April 14, 187s, made her dibut as a pianist at Princes' Hall in 1888; played at Jersey the same year; Brighton, 1890 ; and at her father's recitals, Queen's Hall, November, 1895; and 1896. She has eomposed some pieces for pf., of which a garotte is published.

Thorne, George, comedian, son of the late Richard sammel Thorne, drantic manager. He has been associated with the D'Orly Carte travelling eompunies for many years; and his impersonations of the characters of ho ho, Jacl: Point, the Chancellor, and others in the Gilbert-sullivan operas, have been extremely popular.

Thouless, A. H., pianist and emposer. Studied moler James Harcourt at Norwich, and at R.A.M. Was appointed a professor of pf. at R.A.M. in 1867, and was also an Associate. He produced his pf. concerto in E flat, at the concerts of the International Exhilition, Kensington, 1873, himeelf plaving the solo part. As accompanist to varions coneert parties, he tonred in the provinces, 1s77-80, etc. He composed a Tantuin Ergo, and $O$ Salutaris, that were performed at sit. John's (R.C.) Chureh, Norwich, 1883; and a "Hymm to Diana," for soprano solo, and choms, 1884. He died about the year 1893 . H. Thoc less, tenor rocalist, was for rears a member of Norwich Catherlral Choir.

Thudichum, Charlotte, soprano vocialist, bom at Kensington, London. Her father, German by birth, is a physician of repute. F.R.C.O., and her mother is descended from a Freneh Hugnenot family. Miss Thudichum studied under Manuel Garcia at the R.A.M., and won the Parepa-Rosa sicholarship, 1880, and the Westmorland, 1882. In Paris she studied opera with Madame Viardot. Sang at the Monday Popular and Crystal Palace Concerts in 1883; for the Birmingham Festival Choral Society, November 1884; and elsewhere, early arriving at snceess. Took the part (with Miss Macintyre) of Rebecca in Sullivan's “Ivanhoe," 1891. Undertook a long tour, with success, in Australia, 1896-7.

Thumoth, Burk, Irish musieian and flute player, of the latter part of last century. He issued "Six Solos for a German flute, violin, or harpsichord" $[1740]$; "Twelve Scotch and tweke Irish airs," London [1775]; " Forty-

\section{TINNEY.}

eight English, Irish, and Scotch airs with variations," London [1785].

Thunder, Henry G., pianist and composer, born near Dullin, February 10, 18:32. He studied under Thalberg, and settled as a teacher and pianist in New Jork, where he also held appointments as organist of st. Augustine's, st. Clement's, and St. Stephen's Roman Catholic Churches. He died at New York, December 14,1881. Composer of church misic, songs, ete.

Thurnam, Edward, organist and composer, born at Warwick, September 24, 1825. Organist of Reigate Parish Church, 1s49-1880; and conductor of Reigate (horal Society. He dicd at Reigate, November 25,1880 . Composer of musie for the church. Songs, and pf. music.

Tiagya Raj, composer, born at Trivadi, Tanjore, in the Presidency of Madras, India. He was the composer of many sacred songs, called Kruthis, and other pieces. He flourished from alront 1820-1840.

Tiley, Joseph Crispin, composer, was born in 1843. He graduated Ins. Pac., Oxford, in 1866, and Mus. Doe., in 1874. Organist of Christ Church, Rotherhithe; st. Matthew's Episcopal Chapel, Westminster, 1862; St. Michael, Bassishar, 1n64. Gave recitals, 1866. Being possessed of private means he deroted himself chiefly to musical composition, but only a few of his pieces were published, and these "ehiefly in the Organists' Quarterly Jonmal, 1852-81. He died at London, July 1, 1879.

Tilleard, James, editor and composer, bom in 1827; died, January 17, 1876. He edited "Collection of sacred music, for the ase of schools," Londur, 1849; "Secular music for schools," 1851; "The People's Chant Book," 1853; "Patriotic Part-songs," London [1.864], 19 Nos. Composer of Te Deums, anthems, part-songs and songs.

Timbrell, Francis, musician of the 18th century, issued “. The Dirine Mnsick Scholar's Guide, with the famous Mr. Tho: Ravenscroft's Psalm tunes in four parts, corrected and revised. To which is added a ehoice collection of new psalm tmes, hymms and anthems. Also rules and directions for playing on the spimnet, harpsichord, or organ," London $[1715]$.

Tinney, Charles Ernest, bass rocalist, born at Pimlico, l.ondon, March 15, 1851. Chorister at Westminster Abbey, under J. Turle. Sang at Alexandra Palace, April 1, 1876 , in reviral of Handel's "susama," and at various concerts. In 1877 he was appointed to the choir of St. Panl's Cathedral, and professor at the Guildhall School, 1883. These he gave up for a professorship at the New England Conservatory, Boston, U.S.A., remaining in America fonr year's. Returning to England in 1890, he was appointed professor. 


\section{TINBUTT.}

of singing at the Roral Nomal College for the Blind, Trinity College, London, and other institutions. He is choimaster of AII Saints', Blackheath; and conductor of the Blackheath Glee and Nadrigal Club. He is the composer of an Evening Service in D, several anthems, songs, ete.

Tirbutt, John Charles Brettel, organist and conductor, horn at Bromsgrove, Worcestershire, March 30, 1857. Studied under private teachers. Graduated Mus. Bac., Dniham, 1891. Has been organist of All Saints', Reading, from 1879; organist to the Reading Philharmonic, 1884; Conductor of Berkshire Amateur Musical Society, and lecturer in music University Extension College, Reading, 1892. His compositions are P'sahm 130, for soli, chorus and strings; "The Phantom Ship," for chorus and orchestra, produced, lieading, May 8, 1890 ; "The Vale of Peark," cantata for fenale voices; anthems, songs, palt-solngs, ete.

Tofts, Catherine, linglish soprano vocalist, of the 18th century. She was the first English rocalist who attempted ] talian opera, and appeared in "Arsinoe," "Camilla," "Rosanond," and "Love's Trimmph." sihe is said to have been very avaricious, and was continnally mixed up in the broils and rivalry which early best the ltalian opera in Fingland. Latterly she married Mr. Joseph Smith, British Consul at Venice. She was living in Venice in 1735, and is supposed to have become insame, but is said to have died in 1760 .

Tolhurst, George, composer and organist, was borll in 1827 . He was a teacher in London, and for some time acted as organist of Nelbourne Cathedral. He died at Bamstaple, Janualy 18, 1877.

Works.-Ruth, oratorio, Melbourne, 1867 . Christmas, song and chorus, 1846. Songs: England the land of the free; Fear thon not, for 1 an with thee; Little brown jug; Pray withont ceasing; There's sunshine in the sky; Where there's a will. His father, Wilman Hwnty Tolmbrat, who was bom on October. 23,1798 , conducted the first performance of "Ruth" in Mellourne. He died there in 1873. HFART TOLHUlist, brother of W. H. and uncle of Feorge, was born on April 19, 1778. Died after 1820. Composer of "Six Anthems and six Psalms, for use of country choirs"; Chart Sutton [1810]; Glee, "As I saw fair Clora," ete.

Henix ToLHunt, violinist and composer, born London, September 24, 1854, son of Henry Tolmerst, brother of George bom September 6, 1825; died at Maidstone, May $28,1864]$ is conductor of the Lee (Kent) Philharmonic Society. Author of Cramer's Rudimentary Tutor for the violin [1891]; Gavottes, Bercense, Andante, Alkegretto, etc. for violin; also songs, ete.

\section{TONS.}

Tollet, Thomas, author of "Directions to play the French Flageolet"; and composer, with John Lenton, of "A Consort of Musick in three parts," 1694; also of "Tollet's Ground " $[1720]$.

Tomkins, Thomas, organist and composer, was born at Gloucester in 1586 . He became a chorister in Glowecster Cathedral. Educated at Magdalen College, Oxford. Mus. Bac., Oxon,, 1607. He studied under Byrd, and became a Gentleman of the Chapel Royal in 1621, and organist in 1621. Organist of Worcester Cathedral. He died at Worcester, in June, 1656. He composed "Songs of 3, 4, 5 and 6 parts," 1622 ; "Musica Deo Sacra et Ecclesix Anglicane, or Musick dedicated to the Honor and fiervice of God..," London, $166 t$ (issued in 10 parts).

His father, the Rev. THonas, who was a minor canon in Gloucester Cathedral, composed "The Fannes and Satirs tripping," madrigal in the "Triumphs of Oriana."

His brother JoHn (died, London, September 27, 1638), was organist of King's College, ('anbridge, 1606, and afterwards of St. Paul's Cathedral, London.

Another brother, Giles, was organist successively of King's College, Cambridge, and Salislurr Cathedral, till his death in 1668.

Tomlins, William Lawrence, conductor and teather of singing, born in London, February 4, 18t4. Studied under (7. A. Macfarren and E. Silas. Settled in America, 1869. Conductor of Apollo Glee Club, Chicago, from 1875; Cboral 1)irector, Chicago Exhibition, 1893. Nember of Anerican College of Atusicians. Author of a work on lelementary rocal tuition, "Children's Songs, and how to sing them," Boston, Ditson, 1885 (?) A paper on "Music and Education," delivered at Indianapolis, Febrnary, 1897, ete.

Tomlinson, Henrietta, see MIDGLEY, SAMELEL.

Tomlinson, Richard, composer and conductor, born at sheffield, August 22, 1822. Self-taught in music. Choimaster since about 1860 of the l'rimitive Methodist Chapel, Hecley, near Sheftield. Composel' of "Original Tunes, Anthems, etc.," 1879, etc., and of various hymms, ete.

Toms, Charles James, pianist, born at Devomport, July, 1824. Son of Jankes Toms, professor of music at Plymouth. Entered R.A.M. about 1839, studying harp and pf. nuder J. B. Clatterton, F. B. Jewson, and Cipriani Potter. King's Scholar, $18 \pm 1$. Settled in Liverpool, 1844, on leaving the Academy, when he was made an Associate, and later, elected a Fellow. WVas pianist to the Liverpool Philhamonic Society, and a successful teacher. 1)ied about 1880.

John R. Toms, orgarist of St. John's, Wellington, Somerset, has been many years 


\section{TONKING.}

engaged in that town as teacher and concert giver. His son, EDWARD JOHN KELwaY TONs, bore January 25, 1863, studied at R.A.M. He was a skilful organist; gave recitals at the Fisheries Exhibition, Kensington, 1883; concerts at Wellington, etc. A promising career was cut slort by his death, of typhoid fever, August 24, 1890, at the age of 27 .

Tonking, Henry Charles, violinist, organist, and composer, boru at Camborue, Cornwall, January 17, 1863. He was taught the violin by his father, a very clever amateur, and when quite a child appeared at concerts in different parts of Cornwall. He then studied under J. H. Namn, of Penzance, and in 1876 was appointed organist of Illogan Parish Church, Cornwall. In 1881 he entered the R.A.MI., studying under Sainton, Steggall, Prout, G. A. Macfarren, and others. He was organist of Westminster Chapel, 1883; the Royal Aquarium, 1886; Covent Garden Opera, 1888; and at different churches, the last being St. Jawrence, Jewry. As a recitalist he has been heard at the different exhibitions at South Kensington; and has played at the Earl's Court Fxhibitions, 1892-5; Edinburgh, Glasgow, and St. George's Hall, Liverpool; and was one of those selected to compete for the Birmingham Town Hall appointment in 1888. He has been violinist in the orchestras of the Royal Italian Opera; Leeds and Norwich Festivals; and, with Bermard Carrodus, has given organ and violin recitals in various parts with much success. He is now devoting himself to composition, and has published All the world to me; Do you love me? and other songs; organ pieces, etc.

Topliff, Robert, organist and composer, was born in 1793. He was organist of Holy Trinity, Southwark, London. Died at London in 1868. He was blind. Editor of "Selection of the most popul ir melodies of the Tyne and Wear, harmonised, with appropriate words, symphonies. etc.," Loudon [1820]; "Scripture Melodies, the words from Holy Writ," London, 2 vols, n.d. ; Six Sabbath Melodies, 184t; Original Sabbath Melodies, issued in parts. Songs: Consider the lilies, Heaven our home, How blest were I in yonder cot, Let the night darken in, Look from thy lattice, Spirit's call, etc.

Torrance, Rev. George William, composer, born at Rathmines, Dublin, 1835. Chorister, Christ Church Cathedral, and later, organist of St. Andrew's and St. Amne's, Dublin. In $\mathbf{1} 856$ visited Leipzig for further study in music. Graduated B.A., 1S64; M.A., 1867, Dublin. Ordained Deacon, 1865; Priest, 1866. In 1869 he emigrated to Australia, settling in Melbourne. Ten years later the degrees of Mus. Bac. and Mus. Doc. were conferred upon him by Trinity College, Dublin, on the recommendation of Sir

\section{TORRINGTON.}

Robert P. Stewart, professor of music at the University. Nember of the Board of Examiners in Music under the Education Department of Victoria; Mus. Doc., ad eundem, Melbourne University; Incumbent of Holy Trinity, Balaclava until 1895, when he was preferred to St. John's, Melbourne. Author of several papers on music.

Works.-Oratorios: Abraham, produced in Dublin, 1855; The Captivity, Dublin, 1864; The Revelation, Melbourne, June, 1882. Te Deum and Jubilate. Anthems and services. Opera, William of Normaudy. Part-songs. Songs: Angel of Light, with 'cello obligato; The Land beyond the Sea, etc.

Torrington, Frederick Herbert, conductor, organist, violinist, and pianist, born at I udley, Worcestershire, October 20, 1837. His early studies were under local teachers, and he was afterwards articled to Mr. James Fitzgerald, of Kidderminster. In 1853, he was appointed organist and cloirmaster at St. Anne's, Bewdley; and in 1856 he left England for Montreal, Canada, where he became organist of Great St. James's Church, an office he held for twelve years. While there he was solo violiuist, leader of orchestras, couductor, and for a time bandmaster of the 25th Regiment, King's Own Borderers, organ recitalist, etc. He was invited to furnish au orchestral contingent to represent Cauada at the Peace Jubilee, Boston, in 1872; and was offered and accepted tlie position of organist and music director at King's Chapel, Boston, remaining there four years, teaching at the New Fingland Conservatory of MIusic, and being one of the first violins in the Harvard Symphony, Handel and Haydn, and other societies. (rave recitals at Plymouth Church, Brooklyn (WVard Beecher's). In 1873 he accepted the post of organist and choir-master at the Netropolitan Church, Toronto, Canada, and conductor of the Toronto Philharmonic Society, holding both appointments to the present time. By his energy and skill the musical resources of the district weredeveloped and in 1886 the first Toronto Festival was held under his direction. Since that time he has introduced many important compositions. He founded the Toronto College of Music in 1888, of which he has been musical director to the present time, doing much for the cause of musical education. In 1891, he made a tour of Europe, visiting the great music schools and studying their organizations. He conducted the festival at the inauguration of the new Massey Music Hall, Toronto, Juue, 1894 ; the Jubilee performance of “Elijah," Massey Hall, November 28, 1896 , and is actively engaged in promoting the cause of music in Canada. He has composed church services, hymn-tunes, choruses and songs; organ voluntaries, etc. 
TOSH.

Tosh, James Westwood, teacher and conductor, born at Dundee, Jannary 16, 1849, Has been chiefly engaged in music teaching in comnection with the School Boards of Jarrow, Sunderland, and London. Anthor of "The Musical Inspection, and how to prepare for it," London (Curwen), 1888; "Sightsinging, voice and ear training for Schools," 1889 , etc.

Towers, John, organist and writer on music, born at Salford, Lancashire, February 18, 1836. Chorister in Manchester Cathedral and afterwards stndied at R.A.M., 1856, and with Adolph Marx, Berlin, 1857. Organist of Wilmslow Parish Church, 1863 ; St. Stephen's Conell, Manchester, and conductor of glee societies at Rochdale and neighbourhood for some years. Went to America, and in 1890 was appointed director of the vocal department in the School of Music, Indianapolis; and in 1892, to Utica Conservatorium. Anthor of "Beethoven, a Centenary Memoir ;" "The Mortality of Musicians;" a lecture; "Some Lancashire-born Musical Worthies" (1888), ete.

Towerson, Rev. Gabriel, D.D., clergyman and writer, born in 1635. Rector of St. Andrew Undershaft. He died in 1697. Author of "A Sermon concerning Vocal and Instru. mental Musick in the Church," London, 1696.

Townsend, Horace, anthor of "An Account of the visit of Handel to Dublin." Dublin, 1852. "The moral uses of music, a lecture." Dublin, 1862.

Townsend, John, flute player and author, born in Yorkshire about 1795. He studied under Müller and Ware, and was a teacher and performer in Manchester. He died at Lytham on April 2, 1864. Anthor of "New and complete Flute preceptor." London, n.d.

Townsend, Mrs., author of a "Floral music book for young learners." London, 1862.

Townsend, Pauline D., anthor of "Haydn." London, 188t. Published in the Great Musicians Series, and translator of Otto Jahn's "Mozart," 3 vols. London, Novello, 1882.

Townsend, William, pianist and teacher. was born at Edinburgh, November 26, 1849, He studied at the Royal Academy of Music, London (1865-68), under Bennett, Goss, Holmes, ete., and afterwards at Leipzig (1871-72), under E. F. Richter and Reineclie. In 1870 he became an Associate of the R.A.M., and has acted as an examiner for the Royal College of Music since 1883. He has given many recitals of high-class music in Edinburgh.

Towsey, Arthur, conductor and organist, was musically educated at St. Nlichael's College, Tenlunry. He went to New Zealand, and is now conductor of the Auckland Orchestral Union. He has given some excellent

\section{TRAVERS.}

concerts, and done good work. At the Wellington lndustrial Exhibition, 1896-7, he gave a series of organ recitals.

Tozer, Augustus Edmonds, organist and composer, born at Sutton, Cheshire, January 13, 1857. Studied at R.A.M., and was City of London Scloolar, National Training School, Kensington. F.R.C.O., 1876; L.R.A.MI. (pf. performer), 1882; A.R.C.MI. (theory and composition), 1887. Mus. Bac., Durham, 1893; Mus. Bac., Oxford, 1895, and qualified for Mus. Doe., Norember of the same year. Appointed organist and choirmaster, St. Mary Magdalene, St. Leonardson-Sea, and choirmaster, Holy Trinity, Hastings, 1876 ; Hon, organist, St. Mary, Star-ofthe-Sea, Hastings, 1884; St. Gregory's Priory Chureh, Cheltenham, 1885; Church of the Sacred Heart, West Brighton, 1888. In 1890 he received from Pope Leo XIII., the order of Cheralier of the Pontifical Order of St. Sylvester, for his services to Roman Catholic Chureh Music. He has composed six Masses; Te Denm; Motets; Magnificats; Antiphons, ete. Editor of Catholic hymns, with accompanying tunes; Complete Benediction Manual; and Modern Church Musie for Catholic Choirs.

Tozer, Ferris, organist, tenor vocalist, and composer, born at Exeter, November 8, 1857. Chorister, Exeter Cathedral, and pupil of Alfred Angel and D. J. Wood. Craduated MLus. Bac., 1891 ; Mus. Doc., 1896, Oxford. At eighteen he was appointed organist of st. David's, Exeter ; and in 1882, of st. Michael's, Heavitree, Exeter. Well-known in the Western and Southern Comnties as a tenor vocalist. He holds a position in the Devon and Comwall Bank, Exeter.

Works.-Psaln 3, for soli, chorus, and strings; oratorio, Baalam and Barak, produced at the Western Comties' Musical Association Festival, Exeter, April 22, 1897; cantata, King Neptune's Daughter, female voices. Moming and evening service in $\mathrm{F}$; Benedicite; Kyries, etc. Postlnde in D minor, organ. Songs, of which Lead Kindly Light has acquired uuch popularity. I'ieces for pf., etc. The flight of summer, prize, Exeter Madrigal Society. Edited and arranged a book of Sailor's' songs or chanties (collected by Capt. F. J. Daris, of the P.\& O. Service), London, Boosey, 1887.

Traubner, Eliza, see Kinlock, Eliza.

Travers, John, composer and organist, bor'm about 1703. Chorister in St. George's Chapel, Windsor. He studied under Greene and Pepasch, and became organist of St. Paul's, Covent Garden, 1725, and afterwards organist at Fulham. Organist of Chapel Royal May 10, 1737. He died in 1758. Published "The Whole Book of Psalms for one, two, three, four, and five voices, with a Thorough Bass for the Harpsichord," London, 1746, 2 


\section{TRAVIS.}

vols. "Eighteen Canzonets for two and three Voices, the words chiefly by Matthew Prior," London [1745]. "Twelve Canzonets for two and three Voices." Anthems: Ascribe unto the Lord: Ponder my words; Keep, we beseech Thee, O Lord. XII. Toluntaries for the organ or harpsichord [1760]. Songs: Bibs, Bright author of $m y$ present flame; Haste $m y$ Nanette: When vernal airs, ete.

Travis, Deborah, see Kximet, Deвorah.

Tree, Anna Maria, mezzo-soprano vocalist and actress, born at London in 180. Sister. of Mrs. Charles Kean. She studied under Lanza and Tom Cooke, making her first appearance at Bath, as Polly, in the Beggar's Opera, 181s. Afterwards she appeared at Covent Garden as Rosina, in the Barlyer of Seville, 1819, and from that time till her marriage in 18.5 to Mr. Jitmes Bradshatw, a rieh tea merchant and member of parliament, she was a popular singer and actress. In May, 1823, she sang in Pavme and Bishop's "Clari, the Maid of Milan," being the first to sing "Home, sweet home," and her other parts were ehiefly in minor English opera. She died at London, Felnuary 17, 1s62. Her sister, Ellex Tree (1s05-18-ion), was the celebrated actress who was married to Charles Kean. She also had a voice of some sweetness and power. - This cancels the notice under Bradshaw on page 57.

Tregarthen, William Coulson, organist, bom at P'enzance, Septenber 17, 1856. Artieled pupil of George Riseley, and pupil of Dr. S. s. Wesley. Mus. Bac., Trinity College, Toronto, 1892. Went to South Africa, where he has held organ appointments at the Collegiate Church of St. Nary's, Port Elizabeth ; Queenstown, and other places; and is now organist of st. George's Church, Johamnes. burg. He has given organ recitals and concerts, and done good work in the cause of musieal education in the country where he has made his home.

Treherne, Georgina, see Weldon GeorGINA.

Tremain, T., organist and eomposer of latter part of the 18th eentury. Composed "Thirteen Canzonets for two voices, op, 5 " [1786] ; Brown Jugg, eanzonet for two voices [1780]; Do not ask me, ehaming Phyllis (3 voices) 1780 ; Six Somatas for the Harpsichord or Pf., op. 4 ; Six Coneertos for strings, oboes, and horns [1790].

Trembath, Henry Gough, organist and composer, born at Penzanee, Cornwall, July 29, 1844. Studied at R.A.MI. Graduated Mus. Bae., Oxford, 1869; hon. fellow, College of Organists, 1875 ; organist at Truro: and from 1874 at St. John Baptist, Woodlands, Isleworth. Composer of a Sonata in D minor, Impromptu, and other pf. pieees; Songs, One Day, The Miner and his boy, etc.;
TROMAN.

also an anthem, Let not your hearts be troubled.

Trew, Charles A., pianist and eomposer of present time. Sometime organist of St. Paul's, Rusthall, Tunbridge W'ells. Resident in London, where for some time he has given amnual eoneerts. His compositions embrace a trio for $\mathrm{pf}$, and strings, Mnsical Artists' Society, 1884; Sonata in D minor; Romance; and other piees for violin and pf. Author of Harmony Lessons, arlapted for classes, London, Sehott, 18.8. His wife, Sustn Trew, is also a pianist and eomposer, and among her works a sonata for violin and pf. was produced by the Musical Artists' Society, June $26,1893$.

Trickett, Arthur, organist, pianist, and composer, born at Coventry. F.R.C.O. Held organ appointments at Coventry; Holy Trinity, Birmingham; and Hackney Parish Church. Conductor of Coventry Musical Society to 1853; societies in Birmingham and London. Appeared as pianist at eoncerts in Bimingham, ete. Composer of musical sketehes for pf. and orehestra; Notturno, Capriccietto, and other pieces for pf., Songs, ete.

Trimnell, -.., the oldest lay clerk of Bristol Cathedral. Died at Clifton, Jamuary 23,1865 , having retired on a pension several years previously. He was a sound and enthusiastic musician, and much respeeted.

Thomas Taldis Trinneld, his son, was born at Bristol, and at the age of eight became a ehorister in the eathedral, afterwards being articled to J. D. Corfe, eathedral organist. Graduated Mus. Bae., Oxford, 1\$75. He held organ appointments at Clifton, Chesterfield, Sheffield Parish Chureh, 1875-86. Direetor of Derby Choral Union, 185.2 In 1886 he went to New Zealand, and was organist at St. Nary's, Parnell, Auckland; and later of St. Peter's, Wellington. He was well known as an executant, giving reeitals at the Bow and Bromley Institute, Albert Hall, Sheffield, etc. In New Zealand he has given reeitals in different places. He has composed ehureh services and anthems, "The Earth is the Lord's" was performed at the opening of the Wellington Exhibition, November 18, 1896. His brother, Wildian Frederick, was also a ehorister in Bristol Cathedral. Organist and Musical Direetor, Clifton College, to 1896, when he resigned.

Trinks, C., organist of St. John's Chureh, Calcutta, edited "Hindoostanee Songs," Caleutta, 11.d.

Troman, Thomas, organist and composer, born at Old Hill, Cradley, Worcester, Mareh 21, 1839. Studied under local teachers, and was organist of Cradley Parish Chureh in 1848. Then appointed to Rowley Regis, 1855 ; Halesowen, 1862; Smethwiek Old Chureh, 


\section{TROTTER.}

1869 ; St. John's, Ladywood, Birmingham, 1880; Hanrivorth Parish Chureh, 1882. Graduated IIus. Bac., Oxford, 1875. Conlducted the first Festival of Choirs of Handsworth Rural Deanery, 1885. Invested as Grand Organist, Frand Lodge of Mark Masons, 1s89. Went to Boulogne, 1889, as organist of St. John's Church; and in 1892 was appointed to St. George the Martyr, Deal. Conductor of Deal and IValmer Choral Society. His compositions include Psalm 137, for soli, chorus, and orchestra; services, authems, ete. Pieces for organ, Melodie for pf. organ, viola, 'cello, and bassoon; Romance, 'cello, and pf., ete.

Trotter $"$ Trotère, Henry, composer, born in London, I lecember 24, 1855. Composer of a number of songs: Once for all; Toreador, Hola! Léonore; Tlie Deathless Army; Asthore; Ever dear; Love can wait, ete.

Trotter, Thomas Henry Yorke, organist and composer, was born at Great Stainton, Dorham, November 6, 1854. Educated at Durham Sehool, and at Oxford. Graduated B.A., 1878; M.A., 1887; Mus. Bac., 1887 ; Mus. Doc., 1892, Oxford. He is Director of Studies at the London Organ School, and is the composer of a ummber of works, which mostly remain in MS.

Troup, Emily Josephine, composer of present time. Of her songs may be named Spring showers; On a faded violet; Portuguese bre song, otc. She has also written Song by the river; Hark! the latk; Trios for ladies' voices: Two sketches, violin and pf., ete.

Troutbeck, Rev. John, dergyman and musician, born at Blencowe, Cumberland, November 12, 1832. He was educated at Oxford, and gradiuted 13.A., 1856; M.A., 1858. From 1865 to 1869 he was precentor of Manchester Cathedral, and in 1869) he becante canom of Westminster. He has published "The Manchester I'salter," 1868; Manchester Chant Book, 1871; "The Cathedral Paragraph Psalter," Novello, n.d. : "Hrmm Book for use in Westminster Abber"; "Mrsic Primer for Schools," London, 1873 with Reginald F. Dale), other editions; "Chureh Choir Training," London [1879]. English words for Beethoven's "Mount of Olives," Gade's "Crusaders," Wagner's "Flying Dutchman," etc.

Trowbridge, Leslie, soprano voealist, studicd at R.A.M. Gave her first concert in the R.A.M. coneert room, May 16, 1883; and has given concerts at the Portland Rooms, etc. She is the composer of a Mass in D; My rose; Our love; and other songs.

Troyte, Arthur Henry Dyke, $b \mathrm{~m}^{\prime} n$ ACLAND, amateur musician, was bor'n at Killerton, near Exeter, May 3, 1811. He was
TETWAY.

second son of Sir Thomas I yke Acland of Killertorr, and was edneated at Harrow and Oxford. He studied for the bar, and also was much engagor in scientific pursnits. In 1852 he changed his name to Troyte. He died at Inidehad, near lorebester, Dorset, June 19, 1857. He composed the well-known chants buang his nante which were composed at the request of Bishop Hamilton of Salisbury, and first appeared in the "sialisbury Hymm Book," 1857. He also composed a number of hymms, aud wrote "Liturgia I omestica," a book of family prayers: "The Hours"; "T)aily steps tervardis heaven" ; and "I Jetter's on Minsical Notation," Londom, 1841.

Trust, Helen Mary, born Stark, soprano Focalist, born at Norwich. (ireat-nicce of the artist James Stark. Educated at Norwieh and Paris. Sany for some time as an amateur. Studied chiefly in London mnder signor Tranezzani, if Naples. One of her earliest professional appearances was in the Town Hall, Birminglam, in Oetoler, 1887. In the seatson 1891-2, she frequently sang at the Nonday Popular Concerts; at the Leeds Festival, 1892; and at the produetion of Barnett's "Wishing Bell," and Gaul's "Una," at the Norwich Festival, 189:. Whe formed one of the party in Nadame Patey's farewell torr, and was with that artist when she died. Mrs. Trust now holds a high position among vocalists of the time.

Trydell, Rev. John, anthor of "Two Fssays on the theor'y and practice of Musie," Donblim, 1760 .

Tubbs, Mrs. F. Cecilia, translator of Dr. Joseph sichlüter's "Creneral History of Misic," London, 1865.

Tucker, Isaac, composer, of Westbury Leigh, IVilts; born in 1761; died in 1825. Composer of "Sacred Music, consisting of melodies composed for three and four voices," London [1800]: "Sacred NI Isie, consisting of Isilm and Hymn tmnes," London [1810].

Tucker, Rev. William, composer of the 17 th century. He was a gentleman of the Chapel Royal, and a minor canon and precentor of Westminster Abbey, 1660. He died at London, February 28, 1678, and was buried in Westminster Abbey. Composer of anthems and other Church music.

Tudway, Thomas, composer and organist of the $17 \mathrm{th}$ century, was born about 1650. Ife was a chorister in the Chapel Royal under Dr. Blow, from 1660. Layvicar St. George's Chapel, Windsor, 1664. Organist of King's College, Cambridge, 1670. Instructor of ehoristers, King's College, 167980. Organist of Pembroke College. Mus. Bac., Cantab., 1681. Professor of music in Cambridge University, 1704. MIus. Doe., Cantab, 1705. Suspended from his University offices, 1706-7. Resigned his organ at 


\section{TULLY.}

King's College in 1726, and retired to London, where he employed himself in forming a collection of music for Edward (Lord Harley) Earl of Oxford. He died in 1730.

Works. - A Collection of the most celebrated Services and Anthems used in the Church of Fngland, from the Reformation to the Restoration of K. Charles II, composed by the best masters and collected by Thomas Tudway..," 6 vols [1715-1720], now preserved in MS. in the British Museum, London. Of this collection a list will be found in the British Museum Catalogue of MS. Music. From it a number of services and anthems have been printed at various times. Tudway composed various anthems, motets, services, and songs.

Tully, James Howard, composer and conductor, born in 1814. He was conductor of the opera at Drury Lane Theatre and elsewhere. He died at London, January 28, 1868.

Works.-Operas: The Desert, 1847; Forest maiden, 1847; Island Jewels, 1850; King Charming, 1851; Loan of a Lover, 1834; liape of the Lock, 18:37; William and Susan, 1859. Songs: Happy innleteer, I'm a light bright water sprite, Kattv Moyle, Lovely May, Noreen, Summer hours, etc. Dance music for pf., etc.

Tunsted, Simon, English Franciscan monk and Doctor of Theology, born at Norwich early in the 14 th century. He died at Bruzard, Suffolk, 1369. Author of "De Musica Continua et Disereta cum Diagram. matibus," and "De Quatuor Principalihus in quibus totius Musice Radices Consistunt," two works preserved in MIS. in the Bodleian Library, Oxford.

Turges, Edmund, musician and composer of the 15th century. One of the eontributors to the Fayrfax MISS. in the British museum. An anthem: "Fnforce yourself as God's own knight," was published by Novello in 1894.

Turle, James, organist, composer, and writer, Hom at Somerton, Somerset, March 5 , 1802. Chorister in Wells Cathedral, 1810-13. Organist of Christ Church, Southwark, 1819 . 1829, and of St. James', Bermondsey, 18:9-31. Assistant organist to Greatorex at Westminster. Abbey till 18:31, and succeeded him as organist and master of the choristers, 18:31. Musicmaster at the School for the Indigent Blind, 1829-56. He died at London, June 28, 1882.

Works. - Art of singing at sight (with F. Taylor), London, 1846. Psalms and Hyms, 1855. Psalms and Hymns for public wornhip, with appropriate tunes, London, 1869, 1864, 1869. Hrmms for public worship, revised, 1863. Psalter and Canticles, with Cluants, London, 1865. Child's own Tune Book, 1865. The People's Music Book (with IE. Taylor),
TURNER,

London, n.d. Frlited Wilbye's First Set of Madrigals, for the Musical Antiquarian Society, 1841. Single and Double Chants, composed for the use of the Choral service of Westminster Abbey. The Westminster Abbey Chant Book, with Dr. J. F. Bridge, n.d. Church Services in 1), E flat, etc. Anthems: Almighty and most mereiful God; Hear ny erying, $O$ Crod; The Lord that made heaven and earth; This is the day which the Lord hath made; Arise and help, etc. Hymm tumes and chants.

His cousin, Willan Terle, born at Taunton in 1795, was organist of St. Mary's, Tamnton, and composed glees, a number of dances for pf., and isined arrangements from Beethoven. Ronent TrRLE, brother of James, born at Tamuton, March 19, 1804, was organist of Armagh Cathedral from 1823 to 1872 . He died at Salisbury, Mareh 26, 1877. Hexry Frentrick Turite, som of James, was bom in Lambeth, London, July 23, 18:35; died, London, Jume 28, 1883. He was a journalist and writer.

Turnbull, Jolın, composer and writer, horn at Paisley, January 12, 1804. He was precentor of Xew Chureh, Ayr, 1827, and afterwards precentor of St. George $\mathrm{Cl}$ Church, Glasgow, 1833. He died at Glasgow, November 1, 1st4. Inblished "A selection of original sacred Nusic, in vocal parts..adapted to the varions metres used in Preshyterian churches and chapels.. Cilasgow, 1833 (forming vol. 6 of steven's sacred Music). "The Sacred Harp, a selection of the most approved sacred melodies, ancient and modern...by Robert Burns. Fdited with a complete course of initiatory lessons and practical examples in the art of Singing, by Juhn Tumbull," Glasgow 1840 , 2 editions. The Garland of Scotia, a musical wreath of Scottish Songs, with descriptive and historical notes, Glasgow, 1841 (with Patrick Buchan). Easy and progressive exercises in singing and in reading immsic, Glasgow, n.d. Six Glees, for three and four voices, Glangow, n.d. He issued an edition of R. A. Funith's Inevotional Music, and composed a number of anthems, psalms, and songs, of which "Jeannie Lee" and "Thistle and the Briar" are the best.

Turnbull, Thomas, musician of early part of the present century. Compiler of The British Musical Miscellany, being a collection of Scotel, English, and Irish songs, set to music with proper keys for the voice, violin, German flute, and military fife," Edinburgh, 1805.

Turner, Austin 'T., organist, composer', and conductor, born at Bristol, 1823. Was a chorister there, and for some time a vicar choral at Lincoln Cathedral. In 1854 he went to Australia, and settled at Ballarat, which has since been his home. As singing master 


\section{TURNER.}

to the Govermment Sehool, and conductor of the Philhamonic Society, he did much to promote the study of musie. He conducted the Harmonic society, formed in 1864, and apparently the successor to the Philharmonie, which in sone seasons gave as many as six eoncerts. At the last concert we find any record of, Good Friday, 1875, he conducted a performance of hiseantata, "Adoration," produced at Melbonme, in November, 1874. His eompositions inclnde two Masses (performed in Melloume); two Marches for orchestra (Ballarat, 1868); choral pieces, cte. He has held the office of orgmist at Christ Church, Ballatat, for many years.

Turner, Rev. J. Egbert, O.S.B., organist and composer, horn at Preston, Lancashire, 1853. Sometime organist and chormuster, St. Ann's R.C. Church, Edge Hill, Liverpool. Composer of Masses, St. Tolm the Baptist, St. Cecilia, and St. Mary Magdalene; Ascendit, Dens, for basis solo, aid orchestra, cte.

Turner, James Villiam, tenor vocalist, born at Sutton Ashfivd, Nottingham, June 5, 1845. Sang as a treble at local concerts. Tonred in china, India, ete., with a concert party, 1864, and mate his dibut at Fon Choo, China; and his first stage appearance at MIe]bourne the same reur, as Elvino, in "Isa Somnanbula." Some time later he sang in an opera company at San Franciseo. Retruning to England he studied with Selirat at the London Academy of Mnsic; appeared in opera at the Crystal I'alace, 1872: with the Carl Rosa Company, london, 187t; and in 1875 took an opera company to Sonth Africa. In 1876 he rejoined the Carl Josa Company. Formed a company of his own in 1885 , opened at Nottinghan in Fumary. He has tonred the provinces every ycar since; given seasons of opera at the Princess's, Stanklard, and other London Theatres; and leseane proprictor of the Grand Theatre, Birmingham, 1898. His Fra Diavolo, anel Dom Cresar te Pazan, are among the most popmlar of his assumptions. He has revived opras of Balfe and Maefarren.

Turner, John, anthor of "Manual of Instruction in Voeal Music, chicfly with a view to Psalmody.." London, 18:33, 2nd edition 1835, Boston edition 1836; "Class Singing Book for Schools," 1844, 2 parts. Te Demm, songs, and other vocal music.

Turner, Jolin Bradbury, pianist, composer, and teacher, horn at stockport. Was taught the violoncello loy Lient.-Col. S. WV. Wilkinson, an amateur of repute, and played in local orchestras as a lad. Entered R.A. II., 1852, as a resident pupil, and studied under Sterndale Bennett, C. A. Macfarren, C. Steggall, and others, remaining there till 1861. F.R.A.M. Graduated Mns. Bac., Cambridge, 1865. He was one of the founders of

\section{TURPIN.}

Trinity College, London, and has for years been Director of Studies there. In his younger days he composed a great deal of music, but his oneroms duties at the College have precluded his engaging of late in that pursuit. His compositions include a cantata, "Thy Kingdom come" ; Ps. 13, for soli, chorus, and orchestra. An Overture and a Symphony for orchestra; Trioin C minor, pf. and strings; various pieces for pf.; songs, ete. Teelnical studies for pif.

Turner, Robert Henry, organist, born at Scarborongh, in 1859. Received his first training from his father (who was for twentyfive vears organist of Christ Church, Searborough), and afterwards studied moler Dr. Creser, and while a student at Cambridge, with Dr. Garrett. Graduated M.A., 1886; Mus. Bac., 1891, Cambridge. 1Jis first appointment, organist and ehoirmaster, st. Panl's Cathedral C'hurch, Dundec, he still retains. Conducted for some yeurs the Inndee and Kingskettle Choral Societies. Among his compositions is an Frening Serviee, composed for the eighth Festival of Associated Choirs, Dundee, 1883. I Te has publislyed "Abide with nte," and other anthens, hymns, etc.

Turner, William, composer, was born at Oxford in 165I. He became a chorister of Christ Church, Oxford, mder Lowe, and afterwards chorister in Chapel Royal under Cooke. Chorister in Lincoln Cathedral, and Gentleman of the Chapel Royal, 1669. Tiear'ehoral of St. Panl's, and lay-vicar Westminster Albey. Nus. Doc., Cantab., 1696. Ile died at Westminster, Tannary 13, 1739-40.

Works.-Operas: Presumptious Lover, 1716; Woman's a riddle, 1717; Generous choice, 1720; Tirgin Sacrifice, 1725. Twenty new songs of hmmont, London [1716]. Two catclies for three voices. Anthems in the collections of Boyee and Tudway. Seleet Lessons...extracted from the works of Tumer, ete. [1740]. Songs: Betty's panegyrick, Fair Su an, On doeanting a flask of Florence, Wanton Cupid, When Thobus did the skies adom, ete. Edited Ravenseroft's Psalm Tumes, 1728 .

Turner, William, musician aud anthor, published "A I'hilosophical Fssay on Musick, directed to a friend," I London [1677]; 3rd edition. 1740; afterwards issued as "Sound Anatomiz'd in a philosoplieal essay on musick, to wlych is added a discourse coneerning the abuse of musick," London, 1724.

Turpin, Edmund Hart, organist, composer, and writer, born at Nottingham, May 4, 1835. Son of James Turpin, a laee manufacturer and enthnsiastic musical amateur. Studied nnder C. Noble, and local teachers, and later in London under Hullah and Paner. Was appointed organist of St. Barnabas Chureh, Nottingham, 1850; and in 1851 gave 


\section{TURPIN.}

his first recital at the Great Exhibition, Hyde Park. He settled in London in 1857, but retained some appointments in Nottingham. In 1869 he became organist of St. George's, Bloomsbury: and from 1888 las held a similar appointment at St. Bride's, Fleet Street, Since 1875 he has been Hon. Sec. of the College of Organists; was presented hy the Council with the diploma of Fellowship, 1869 ; and he has frequently acted as Examiner for the College. Licentiate, Trinity College, London, 187t; and Warden from 1892. He was elected an Hon. NTember of the Tonic Sol-fa College, 1885; and of the R.A.II., 1890. In 1889 the Archlishop of Canterbury conferred upon him the degree of Mus. Doc. He edited the Musical Stamaril at different periods; was joint editor, 1891, of Musical News; and has contriluted many articles to periodical literature, besides lectures at R.C.O., Musical Association, and other societies. He is widely known as a concert organist, and has opened organs in all parts of the kingitom; he is also a pianist, and plays nearly every instrmment in the orehestra.

Wonks.-Mass in A flat, voices alone; Mass in I), for soli, chorus, lrass, drums, and organ; Notet, Jubilate Deo, for the same, except drums; Stahat Mater, voices alone. Oratorios, St. John the Baptist, and Hezekiah (MS.); Cantatas, A Song of Faith, and Jerusalem. Services and anthens. Symphony for orchestra, The Monastery; (Osertures, As you like it; Talisman; Richard 1I.; Concert overture in C. Quartet for strings; for pf. and strings; pf. Trio; pieces for pf. Orertura Pastorale; Nusette; Andante, and other orsan pieces. Editor of Students' Edition of Classical Compositions for pf.; Collection of Hymn T'unes, 1872.

Turpin, James, organist, brother of the foregoing, born at Nottingham, lecember 15, 18t0. F.R.C.O.; Mus. Bate, Cambridge, 1880. Organist of Rman Catholic Cathedral, Nottingham: Londunderry Cathedral: Parish Chureh, St. Leonards; Parish Chnreh, Berkhampstead; St. Andrew's, Watford. Music master at Berkbampatead School; Proferior of hamony and comnterpoint, Trinity College, London. As an organ plaper he was weel known, and he gave recitils at the Royal Allert Ifall (Inventions Exhihition, 1ssis), and in many proxincial towns. He was also a good pianist. II gave lectures before the College of Organists, the Musical Assuciation, ete. He composed a churcls service, songs, a sonata, and othe'r pieces for pf. He suffered from paralysis for some year's, and died, July 29, 1896.

Turton, Rev. Thomas, BIsHOP of ELY, was born in Yorkshire in 1760 . He was educated at Cambridge, and after holding varions ecclesiastical offices, became, in 1830,
TYE.

dean of Peterborough, and of Westminster in 184\%. In 1845 he was consecrated Bishop of Ely. He died January 7, 186t. Bishop Turton was a composer of rome ability, and wrote the hymu tmes, "Ely," "St. Ethelreda," and other music for the ehmreh.

Tutt, William Henry, organist, conductor, and composer of present time. Gradmated Mus. Pate, Cambridge, 1882 ; L.R.A.M. (composer), 1883. Organist of Okeorer Church, Staffordshire, and conductor of Ashborne (1)erby) Amatem Orehestral Society, and Choral Society. Has given mauy excellent concerts, and conducted a performance of Handel's "Messiah" in Bentley Church, Staffordshire, the first Festival of the Fenny Bentley Chureh Choral society, December 1, 1893. Has composed a setting of Psahm 104, for voices and orchestra ; Pieces for orehestra, etc.

Tutton, James Rufus, bandmaster and composer, was one of the fonnders of the suciety of British Mnsicians, 1834. Composed at dramatic orertme (1934), and has published a large amome of dance music for pf. and land; Overtmes arranged for pf.: IIarch of the Men of Kent, pf. 1450. Songs, ete.

Twining, Rev. Thomas, clergyman and musician, born at Londun, in 1794. Rector of Sit. Mary, Colcheste' 1770 . He died at Colchester, Anguat 6, 1804. Published "Aristotle's Treatise on I'oetry, translated with Notes. and Two Dissertations on poetical and musical innitation," (xford, 1789; London, 1812, 2 vols., znel edition. In 1882, was published a selection from his correspondence, entitled "Recreations and stndies of a Comntry Clergyman of the Eighteenth Century," London, Murray.

Tye, Christopher, organint, composer, and rerse-rwiter, born at Westminster, early in the 16tls century. If was a chorister and (rentleman of the Chapel Royal, 1545. Mus, liac., Cantah., 1536. Organist of Ely Cathedrat, 1541-1561. MIus. Doc., Carntab., 1545, and Oxon. (acl enulem), 15tr. 17e was a clergynan, and was snceessively minister of Little Wilbralam, 1564; Newton, 1567-70; and I oddington-cum-March, 1570-72, all in Cambidgeshire. He died in March, 1572.

Works.-The Acte's of the Apostles, translated into Englyshe neter, and dedicated to the Kynge's moste excellamite Matientye. . with notes to eche (hapter, to srmge and also to play npon the lnte.... London, 1553; A notable historye of Nastagio and Traversari, 110 less pitiefull than plexant, ont of Italian, London, 1569; Service in Gminor. Anthems: I will exilt Thee; Sing unto the Lord; This is the day which the Lord hath made; Arise, and help us. Masses, anthems, and other works in MS. A nmmber of palnn tmest have been adapted from Tye's compusitions. 


\section{TJLEF.}

Tylee, Henry Dixon, musician, published "Eight Indian Airs. adapted for the pf. or harpsichord," Lomdon [1805].

Tyndall, John, scientific anthor, born at Leighlin Pridge, near Carlow, in 1820; died, December" 4, 1893. Author of "Sound: a eonrse of eight lectures delivered at the Royal Institution of Great 13ritain." London, 1867, varions later editions.

Tyson, A. G., nuthor of "An Essay on the poetic and musical customs of the Aneients, ete.," 1852 .

Tyler, Sarah, see Keddic, Henrietta.

Tyler, William, of Woodhonselee, antiquary and author, was horn at Edinburgh, Octuber 12, 1711. He was educated for the law and became a writer to the signet in Edinburah. He died at Woodhonsclee, near Edinburgh, September 12, 1792. Anthor of "A I)issertation on the Scottish music," which was printed in Arnot's "History of Edinburgh," 1779, and also in Napier's "Selection of favonrite seoteh songs," and in "The Poetical remains of James I. of Seotlanu." He also mbrished in the "Transactions of the Socjety of Antiquaries of Scotland." "An account of fashionulble anusementsand entertainments of Edinlmugh in the last century, with the plan of a Grand concert of music performed there on St. Cecilia's Day, 1605." His other works were "A flistorical and Critical lnquiry into the evidence ponduced against Mary Queen of Scots," 1750, etc.

Uglow, John, organist, violinist, and conductor, horn at Gloucester, 1814? When six vears old was admitted a chorister at Gloncester Cathedral, by Mr. Mutlow, then organist. In 18.4 he sang at the Assembly Rooms, Cheltoulam, at a concert given by Mr. 'Thomas Woodward, organist of the parish church, to whom be was afterwards articled. Later he studied under Crotch and Nenkomm; violin with N. Mori; and violoncello with IVilliam Lindley. He was organist, at different times, of Trinity, st. James's, and St. John's churches, ('heltemham. In 1842 he went to Ireland, but the climate compelled his return to Cheltunham. He was the founder of the first Choral Society in Cheltenliam, and hand a high reputation as an organist, violinist, and violoncellist. In his later years he was a great invalid. In NIay, 1893, a grand concert was given for lis benefit, a number of minent artists assisting, with Mr. J. A. Mattluews as conductor Uglow died May 6, 1894, and was huried in Cheltenham Cemetery.

Upton, Emily, pianist, born in London, September 5, 186it. Showed musical ability at a very early age, and was placed under some of the best masters. She afterwards went to Dresden, as a pupil of J. L. Nicodé.
VALENTINE.

Returning to England in 1890, she made her début as a pianist, and has given a series of recitals and concerts at Steinway Hall since that time. In 1892 she succeeded to the principalship of the Anglo-German School of Music at Norwood, which she successfully directs at the present time.

Urich, John, amateur composer, born, of German parentage, at Trinidad, West Indies, in 1850. Studied at Stuttgart and Paris. Composer of several operas: Flora Macdonald, produced at Bologna, December? 1882; Le Serment, one act opera, Brussels, 1883; Le Pilotte, Monte Carlo, 1890; cantata, Nourmahal, London, 1882; song, The Angel and the Sunshine, etc.

Valentine, John, musician of 1 stli century. Resided at Leicester, where he died in 1791. Composer of "Thirty Psalm tunes in four parts with symphonies, interludes and instrumental bass, being set part to the old and part to the new version, op. 7," london [1787]. Ode on the birthday of the Narquess of Granby [1768]. Eiglit easy Symphonies for two violins, 2 luautboys, 2 horns a tenor and hass, op. 6 [1785]; Sixteen marches and minuetts, op. 8.

Ann Valentine, probably a relative of the above, composed "Teu Sonatas for harpsichord and violin," op. 1 [1798]; waltzes, marches, etc., for pf.

Valentine, John, composer and pianist, author of "Elements of Practical Hamony, or what is generally called thorough base." London [1834]. Songs: All round my hat, Medical student, Soldier's last drean. Pf. music, etc.

Valentine, Robert, composer and violinist, who flourished during the first part of the 18 th century.

Worrs. - Six setts of aires and a chacoon for 2 flutes and a bass, London [1720]. Op. 2, Twelve Sonatas or solos for a flute; (O). 3, Twelve Sonatas for a flute [1701]; (1). 4, Six sonatas for 2 violins, 2 hoboys, or Crerman flutes $[1720]$; (1). 6 , Nix sonatas for 2 violins and a bass: Op. 7 , Six sonatas of 2 parts for 2 violins; (op. 13, Sonatas for flute and harpsichord 17007 .

Valentine, Thomas, composer and writer, born in 1790. He was a teacher, and at one time popular as a composer. He resided for many years at King's Heath, near Birmingham, and died there. Felmuary 11, 1is. As a tribute to his memory, a road at King's Heath has been named Valentine Road.

Works.-Rondos for yf. ; Flowers of English melody for pf.; Ficoteh and Irish Cuadrilles [1845]; Early lessons for the ]f.; Numerous arrangements for pf.; songs, etc. Instructions for the pianoforte, to which is added a. selection of favourite airs.. London [1826]; 


\section{VANCE.}

Dietionary of terms used in musie, London, 1833 , various editious. He edited choruses from Handel, etc.

Vance, Alfred Glenville, sce Stevens, Alfred Peck.

Vandernan, Thomas, musician, of 18 th eentury, was a Gentleman of the Chapel Royal, and died October 2, 1778. He compiled "Divine Harmony, being a collection of two hundred and seren double and single chauts in seore... sung at His Majesty's Chapels Royal.." 1770.

Vaughan, Thomas, tenor rocalist, was born at Norwich in 1782. Chorister in Norwich Cathedral under Beekwith. Lay-clerk St. George's Chapel, Windsor, 1799. Gentleman of the Chapel Royal, 1803. Vicar-choral St. Paul's London, and lay-vicar IVestmiuster Abbey. Married Miss Temnant, a soprano singer. He sang at the Concert of Ancient Musie, and at the prineipal London and provineial concerts. He died at Bimingham, January 9, 1843.

Vautor, Thomas, composer of late $16 \mathrm{th}$ and early 17th eenturies He issued "The first Set: being songs of divers ayres and natures, of five and six parts; apt for vyols and voyces," London, 1619.

Venables, George I., choir trainer, bom at St. John's Wood, London, May 16, 1845. Studied musie through the elasses of the Tonic Sol-fa College. Was deputy conductor of the Sonth London Choral Association, of which he wis also hon. sec. from its fonudation in 1869. He was founder of the south Loudon Fustitute of MInsic, an outcome of the society previously named, which begin its educational work in 1580 , and of which he was the hon. sec. A tenor rocalist of repute, he was a zealous worker for popular musical education; but in the midst of his varied avocations he was seized with congestion of the lungs, and died on December 23, 1887 .

Venables, Leonard Charles, brother of the preceding, conductur and bass vocalist, born at St. Johm's Wroul, Lonton, November 5,1847 . He was a choir hoy at St. Stephen's, Avenue Road, St. John's Wood, aud studied under varions masters. Is a Graduate and Professor of the Tonic Sol-fa College. Has conducted the Sonth London Choral Association since its formation in 1869 , raising it from small beginnings to alr important pesition among metropolitan organisations, its concerts being of high excellence. The Upper Choir sang in the "Romeo and Juliet" of Berlioz, at the Philharmonic Society's Concert, Mareh 10, 1881. Mr. Venables conducted the concert by eertificated adult singers at the Tonie Sol-fa Festival, Crystal l'alace, July $13,1895$. He has been principal of the South London Institute of Musie sinee its

\section{VERTUE.}

commencement in 1880. Author of "The Choral Society, practical hints and experiences," London, Curwen ; also, of several vocal instruction books; and has composed part-songs, etc. The work of the two brothers and their eolleagues is told in the History of the South London Choral Association, and Institute of Music, by Eben. Lock, London, 1892.

Verne, see sub. Wiru, Marie.

Vernham, John Edward, organist, born at Lewes, Sussex, April 17, 1 1 56. Studied under Dr. Steggall and George Cooper. Appointed organist of All Saints', Lambeth, when fifteen; All Saints', Surrey Square, London, 1872; and at the present time is organist of St. Paul's Knightsbridge. Sueceeded the late W. 1I. Monk as Professor of Music at King's College, Lundon, 1889. Author of fifty three-part studies, Novello's Primers (1896). His wife is the composer of "Twilight," "Sleep," and other songs.

Vernon, Joseph, tenor vocalist, born at Coventry [1735]. He studied under W. Savage, and appeared at Drury Lane Theatre, London, 1751, and from 1756 sang at Tauxhall and other London concerts, and appeared on the stage in varion musical dramas. He died at Lambeth, London, March 19, 1782. Composer of an epilogne to the Irish Widow, 1780 ; music for The Witches, a pantonime, 1771 ; Strawberry Hill, a song, and other rocal works.

Vernon, M., author of "Analogy of the laws of musical temperament to the natural dissonance of creation," Loudon, 1867.

Verrinder, Charles Garland, organist and composer, born at blakeney, filoncestershire. Studied muder Sir G. J Elvey. Graduated Mus. Bac., Oxford, 1862; Mus. Iuc., Cantuar, 1873; F.R.C.O. Urganist successively at Holy Trinity, Windsur; st. (tiles' in the Fields, London; Christ Cliurch, Lancaster Gate: St. Michael's, Chester Square; and St. Mary's, West hensington. Also organist of the Reformed synagngue, London. Conductor of the Hebrew Choral Association, and of St. Mary's and Ealing Choral Societies. Composer of a cantata, "Israel"; Church Service in L; Seek ye the Lord; The Light liath shined upon us; Hear my ery, O God (Jubilee); and other anthems, kyries, etc. Ilebrew music and psalms, 7 vols. Ont of the deep, ancient Hebrew melody, " liol Nidrai." songs and part-songs, organ music, ete. Assisted Lady Elvey in the preparation of the memoir of the late Sir George J. Elvey.

Vertue, Matthew, organist and composer, born abont 1770 . He was an urganist at Weymouth, where he dicd, Octuher s, 1849. Composer of a Colleetion of l'salms (R. liooke), 1845; Bards have sung; How blest is the 


\section{VWSTRIS.}

friendship; If thou canst live on humble fare; dnets, somgs, and other vocal music.

Vestris, Lucia Elizabeth, bom BARToLozzi, eontralto voulist and actress, born in London, of Italian parents, in 1797. She studied mudra Corri, and in 1813 married Armand Vestris, a lallet-master. Appeared in opera in 18t5. Appeared in Paris, 1816 , and again sang in lundon from 1820, appearing in "peras and numerous theatrical pieces. She became manager successively of the Olympic, Corent Crarden, and Lycem Theatres, and produced a large succession of dramatic pieces, in many of which she appeared. Harried to Charles Mathews the younger, 183s. She died at Fulham, Loudon, August 8, 1856. Fumous for her beauty, and her charming style of acting and singing. See Madane Vestris: Memoirs of her public and private life and alventures, with anecdotes of celebrated characters of the fashimable world, with amorous confessions of Madame Testris, from a series of letters written to Handsome Jack. Tundous, 1839.

Vicary, Walter, organist and composer, was bon in 1770. He was organist of Magdalen College, Oxford, from 1797 to 1845 ; in 1805 he graduated Mus. Bace, Oxford; and he atso held the appointments of Lay-chaplinin of New Collew, Oxford, 1812.14; Singing man of St. John's College, Oxford, 1816-28; and organint of kit. Natry Ghureh, Oxford, 1830. He died at ()xfori, Jantuary 5, 1845. Composer of Chrreh music, somgs, ete.

Vincent, Charles John, organist and composer, burn at llomghton-le-spring, Inuham, Septonler 1!), 1852. His father, Charles Juhr Tinchist, was organist of it. Michael's Chmeh in that place, a geod mu-

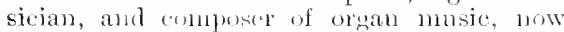
head of a $1 m$ mic business at Sunderland. The son entered Imrham Cathedral as a chorinter in 186t, sturying moler Dr. Armes, having received his first lessons from his parents. In 1869 he wats appointed organist of Monkwearmonth Parish Church. Studied at Teip. zig Conservatorinn, 1876-8; graduated NIus. Bac., 1878; Mıs. Гoc., 1885, Oxford. Organist of Tavisteck I'arish Chur'h, and Kelly Collegt, 1878; and of (Horint Chmoh, Hampstend, Londom, 188:-9t. Hom. See of the Lomdon Section of the I.S.M., and Thivisional (Oxford) Hon. Sec. Tuim of Craduates in Nusic. Examiner for 'Trinity Coflege, in which capacity he has luen to South Africa, 1893, and Anstralia, 18y7. He is a voluminous composer, and in joint editor of the Organist and cherimaster.

Works. (Matropio, lauth, produced, Hamp-

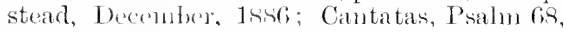
and The disy of rest (troth in MS.): The Crowning of the wheit, havest cantata; Church serviees and anthems. Cantatas lor
TINEN.

treble voices: Tillage Quecn; Tittle mermaid; A night in farryland; Spanish gipsies; Persian princess; The two queens. Operetta, Comot (into. Honour and Praise to Music, choral fugue in s parts. Two-part songs; upwards of a humdred songs. The Storm overture, orchestra, produced, Bradford, February 24, 1894. Other orchestral pieces in MIS. P'ieres for 'cello and ph.; violin and pf.; and $f(r$ pf. solo. Organ pieces, various. Author of A Year's Stury at the I'jano; First Principles of Music: Choral lustructor for treble volecs; ()n scoring for an orchestra (British Musiciun, 1897). Editor (with Sir John Situiner and Dr. 1).J. Weod) of IJymnal (ompanion to the Bonk of Common Prayer (1890) ertition); Chant Bonk Conspanion; Anglican organist; Anglican choir; Bach's 48 Fugues in seore; and Barh'sorgan Fugues, miniature edition.

Vincent, George Frederick, organist and composel, lmother of the preceding, born at Houghtw-le-Sprimg, March 27. 1855. Fereived private instruction in music to 1874 ; studied at 1 fepzis Comservatorinm, 1874-6. Organist amd ehoimaster, Smolerland Parish Clumels, $1872-4$; sit. Nary's, Whithmus, Durham, 1RT5; and from 18se to present time of Sit. Thomas's, Smuderland. Couductor of Choral Suciety, ladies' Orchestral Soeiety, aud Amatemi Opera society, sunderland. Examiner in practical musie, I.S.M., from 18se. Mas givon organ recitals in Sunderland, etr., and orrhestral concerts at Noweastle lixhilition, 18R7. He has emmposed several nperettas: l'eter's pledge, 1sis: Romany Lore, St. Feorge's Hall, Londen, 18s9; Tederliah the Scarecrow, Nottinghan, 1895. Cantata, Sij Humphrey Gil]ert, for Jaritome solo, chorns, and ofehestra, 18:5. Two choral fantasias on national airs. Tolume of 20 songs: Somps, rarions. Anthenes. Two Fantasias and Fugnes for two pianos; pf. pieces, varions. Offertoire and Fugne, etc., for organ, Original organ compositions, 2 vols. Oritures, galop, valse, for orehestra. Piceses for viotin and pf., ete.

Vincent, Rev. William, D.D., author of "Comsiderations on Parochial Music," London, 1790.

Vinen, Ernest Edward, organist and composer, born in London, Oetoler 12, 1865. Pupil of the Fuildhall School of Music. F.R.C.O., 1490. Was appointed organist and choimaster, St. John's, Horsteydown, 1881 (when sixteen years old); St. Augustine's, Bermondsey, 1886 ; and, in 18sis, to his present position at St. Augustine's, Honor Oak Park. Works. Cantata, The Legend of the Faithful Sonl, for soli, chorus, and or'hestra (Honor Oak, 1890) ; "Into tlıe Silent Isand," chorus and oreliestra (1894); Festival Te Deum, soli, double chorus, and orchestra; 


\section{VINER.}

Evening Serrice in C; bymn-tunes, chants, ete.; Songs. Two concert overtures, in E minor, and A minor; Romance in $\mathrm{E}$ flat, orchestra, etc.

Viner, William Letton, organist and composer, born at Bath, May 14, 1790 . He studied under Charles Wesley, and in 1820 became organist of st. Michdel's, Bath. In 1834 he was appointed organist of St. Mary's, Penzance, and remained there till 1859, when he wert to the Cnited states. He died at Westfield, Mass. U.S., July 24, 1867. Editor of "A useful selection from the most approved psaluns," London 1\$467. "One hundred psalm and hymn-tumes in score," London, 1838. "The Chanter's companion" 1857 . He composed church music, organ music and songs, and wrote the well-known hymn-tune, "Helston" or " Fingston," sometimes described as an ancient Comish melody.

Vinning, Louisa, soprano vocalist, horm at Kingsbridge, levon, November 10, 1836. Her father, Jom Vinnisg, was a musician, and at twelve years of age was organist of Torquay Chapel, and held other similar appointments later, leing also a composer. Lonisa Tinning showed an extraordinary passi n for nusic even in infancy. She savg at the Plymouth Theatre when only two-anda-half year's old, and a year later was taken by the Inke of Wellington to sing to the Gueen, who gave her a diamond ring. As the "Infant Sapplo," she sang in various country towns, and at the Adelaide Callery, London, 1s+o-2; gave concerts up to 1817 . Then studied under F. Mori, and others. Sang in 1856, on tour with Alfred Mellon; in the "Messiah," siacred Hamonic Society, December 12; at the Worcester Festival, and Crystal Palace, 1857; Hereford, 1858; and gave aunual matinées in London up to 1860 , on July 5 of that year introducing the pianist, Mlle. Remaury, to an English andience. Sang at the Monday Popular Concerts, Jan. uary 21, 1s61. On her marriage with Mr. J. S. C. Herwood soon after that time, she retired from the concert platform. She had many offers to go to America, and elsewhere, but declined them all.

Vinning, Rosetta, see O'Leary, Mrs. ARTHLR.

Vinning, William Skinner, organist and composer, is a native of levonshire. Pupil of Charles Fowler, Torquay, in which town he held organ appointments at the Parish Church, and st. Luke's. Organist of St. Peter's, Rayswater, London, since 1s8t. Mus. Pac., Cambridge, 18-0. Composer of two saered cantatas, "Song of the Passion," and "Song of the Nativity"; a setting of Psalm 8t, for soli, chorus, and strings; church services, etc. Alsoan operetta ."Equality Jack," produced at Ladbroke Hall, Feb-

\section{WADDELL.}

ruary 28, 1891. Author of Papers on Choir Management, and other subjects.

Vitton, Arthur, see Crowest, F. J.

Vokes, Henry, musician, compiler of "Psalms and hymus, with select sentences of seripture, sung at the Parinh Church of St. Botolph, Aldersgate," London [1820].

Von Hoff, Henry, tenor voe.list and teacher, was educated ilt R.A.MI, singing at the Academy concerts in 1842, and in public, 1.it6. Studied under Mazzucato, in Milan, 1851, and sang there. Retuming to London, he acquired an excellent teaching connection. He wrote many songs: Could $I$ hut call a leart my own; Sing me a song, love, etc., most of them of high quality. He died in Iondon, December, 1sig. His wife, bom Elizapeth Chamberlative, a pianist, was also a pupil of the R.A. II., where she studied under W. S. Pennett, and others, aud was a King's scholar, 1843. From 1857 she was, for a number of years, organist of the Rectory Church, Marylebone. She publishect a few pieces for pf., but was better known as a teacher. She died some time before 1890 .

Waddel, William, violinist and condnctor. born at Edinburgh in 18t2. Studied nuder Carnichael and Howard, and in London under Henry Blagrove. When twenty he went to Leipzig and studied under Ferdinand Invid. Returning to Edinburgh he became organist of Dublin Street Paptist 'hurch, an office he held for many vears. From the choir of this church surarg the organisation known an "MIr. Waddel's Choir," which he condncted for twenty-five vears, introducing all 'schmmann's choril work's, and many other compositions to the city of Edinburgh. He fornded a Violin School, and fomned a Ladies' Orchestra chiefly of lis pupils: established chamber concerts, and gave Frce MIusical Erenings for the People. Has been choirmaster for some vear's at it. cuthlert's Established Church. He married the daughter of the late Sir Dariel McNee, president of the Roval scottish Acartemy, and is himself a painter of reputation, for many years an exhilitor at the Royal Scottish Academy and other places.

Waddell, James, bandmaster, born at Banff, January 20, 1797. He was appointed bandmaster of the soth reginent in 1817 , but was compelled to resign on recount of ill health. He settled in Perthinire as a teacher of music, but in 1832 was asked to re-organise the band of the 1st Life Gunds, and remained as bandmaster in that regiment for 27 vears, resigning in 1863. Ife died at kensington, London, April 10, 1879. Composer of "Fair" Maid of Perth," overture: Pollias. Galops, Quadrilles, and arrangement for band, between 1843 and 1860. 


\section{IVADIINGTON.}

Waddington, Sidney P., composer of present itime. Studied at R.C.M., and was elected Mendeksoln scholar in 1891. Resident in London, and conductor of an amatemr opera society which gavo its first performance, "Dorothy," at st. (ieurge's Hall, May 27 , 1896. To him was allotted the task of completing the seore of the late froring Thomas's opera, "The folden Web." His eompositions consist of " Ballad, "John Gilpin," for chorus and orchestra, produced at R.C.M. concert, Norrmber 14, 1894; a concerto for pf. and orehestra: Trio, pf. and strings, Qneen's Halk, lecember 11, 1894; Sonata, pt. and 'cello, ste.

Wade, James Clifft, organist and composer, was horn at Coven, Staffordshire, on Jaunary 26, 1847. He stulied music under Drs. Wimn and Pradford, and lecame organist at Coven, 1860-65. Afterwards he studied in Birmingham during 1865-66, and then held the appointments of organist at the Parish Chmeh, Iver, near Cxbriage, 1s67-69; private organist to IT. S. Mugdale, Esq., Merevale, Warwickshire; and organist of St. Mary's Church, Maidentsead, from 1850. Conductor of the Maidenhead Orchestral Society, and composer of rhureh music, hymms, action songs for children, and other vocal music.

Wade, Joseph Augustine, composer and writer, born in I) lolhu, [1796]. He married a Miss Relly of Garnavilla. For a time he was \& surgeon, but afterwards he went to Isondon, and worked for the theatres and publishers. He died at London, July 15 , 1845.

Womks. -Two Housen of Granada, opera, 1826; Pupil of l)a Vinci, operetta; P'rophecy, oratorio, 1824. I'olish Meloxies, London, 1831. Songs of the Flowers [1827-24], 2 books. Many dnets, "l 've wandered in dreans," ete. Songs: The Bridge; Neet me by moonlight alone; Love was onee it little hoy; A Woodland life; and others. Fantasias for pf. and a large number of arrangements. Child's first Quadrilles, Waltzes, ete, for pf. IIs son, Josmin degrstine Wabe, has composed a very large number of pieces for pf. and other instrmments, songs, etc.

Wade, Mrs, srecilicy, Annis.

Wade, Richard, pinnist and writer, who flourished in lendon about the midale of the 1sth century. Author of "The Harpsichord illustrated and improsed, wherein is shewn the Italian manner of Fingering..." London, n.d., anois.

Wade, W. J., musieian, author of "Complete Instructions for the cornopean and saxhorm." Londun 1s(0) , 1stit, etc.

Wadham, Walter $T_{0}$, a native of Tasmania, is the composer of a number of songs, among which may lee mentioned: Who will be my love:" and My heart's Queen.

\section{WAINWRIGHT.}

Wadmore, John Lofting, baritone vocalist, born in 1849 . $\mathrm{He}$ studied at the R.A.M., gaining the Parepa-Rosa prize in 1875. A.R.A.M. He sang at concerts of the Philharmonic Society in London, and at important concerts in the provinces, and aclieved a high reputation, particularly in oratorio. IIe died at London, November 4, 1878 , from the effects of a cold, aged 29.

Wadsworth, Joseph, musician, compiled "Selection of Psahm and Iymm tunes, adapted to the most useful measures," Halifax, 1852 .

Wagstaff, William, organist and composer; born 1784; died in London, March 11, 1852. He was organist at Battersea Church for about 30 years. Compiled "Sacred Music, a hymm and chorus for Easter day and Kyrie Eleison, as sung at. st. Mary's Church, Battersea," London [1827]. Composer of pf. rondos and other music.

Wainwright, Harriet, afterwards Mrs. Colonel Stewalt, composer, who was probably related to the Wainwrights noted below. She flourished between $17 \pi()$ and 1sto. Composer" of "Collection of Stongs, dnetts, trios, and choruses," London [18I0]; "Comàla, a dramatic poem from Ossian," 1803 ; Merrily, merrily passes the day, glee; songs, etc. Author of "Critical remarks on the art of Singing," london, $18: 36$.

Wainwrighe, John, composer and organist, born at stockport aboat 1723 . He becanne organist of MInIclester cathedral in 1767. He died in Jantary, 1768 , and is buried at stockport. Hecomposed anthems, lymms, etce, and istued a "Collection of prahn tures, anthems, hrmms, and chants, for $1,2,3$ and

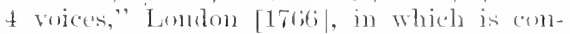
tained the well-known lymm or calpol distally smer to Brrom's words, "Christians, atwalie, salnte the haply morm."

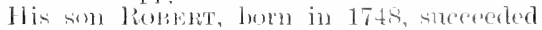
him as organist of Manchester collowiate ('hurch in 176rs. In 1774 he acemmulated the degrees of Bate. and thoce. Mris., Oxford, and in 1755 he became organist of st. b'eter's,

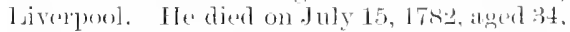
He eomposed an oratorin entitled "The Fall of legrlte"; a Te Itemm (degree excreise),

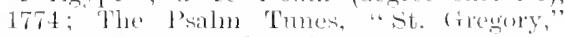
"Manchester," and "Fiverenol," ete.

Anothere som, Richafis, was bom in 1758. He was ongentist of the Collegiate Chomeh, and sit. Amn's, Manchester, and succederl his lerother in 17ine as organist of st. l'eter's, liverpool. Ha also held the apprimtment of organist of St. James', Toxteth Parls, Liverpool, for a time, but retmmed again to st. I'eter"s. He died at Liverpool, Angnist 20, 18:5. He composed "Life's a hmures'," a well-known glee [1800]; the hymn tone, 


\section{WAINWRIGHT.}

"Wainwright," and other" pieces of voeal music. Also editor of "A Collection of Hymns with appropriate symphonies," Liverpool 1809 . The Rev. J. J. Waite edited "Hallelnjah, a selection of tmess from Wainwright." Both brothers were celebrated as organists.

WiLliay WAIXWRIGHT, another brother (died at Mauchester, 1797), was a vocalist.

Wainwright, Rev.Jonathan Mayhew, compose', bom at Liverpool in 1792 , and died at New York, September 21,1854 . Composer of chants, prahns, and other chureh musie in collections such as "Music of the chureh, in collection of palm, hymm, and chant tunes," Boston [1852].

Wait, William M. organist and com. poser, born at chester, December t, 1851. His parents were churcls singers in that eity, and his uncle, William Wait (died Norember 10, 18s8), was for 83 years tenor lay-clerk at the cathedral. As a chorister at chester Cathedral lie received pianoforte lessons from the late John AIumms, sub-organist ; lue afterwards stmeled at Liverpool, and later, had organ lessons from .J. F. Bridge, and J. Kendrick Prne, at Manchenter, and studied harmony and comberpunt with le. H. Wilson. From 1870 he held varions organ appointments in Manchester and Londom, being from 1895 organist and choirmaster $\left.\left(f_{1}\right)\right)^{\circ}$ the second time) at St. MI argaret Pattens. He has given organ resituls at the Bow and Fromley Institute, the Agricultural Hall, Farl's Court Exhibitim, ate. ete. His compositions eonsist of the "antatas, "Sit. Andrew" (1Rag); "The Grod samaritan" (1892); "God with us," Christmas cantata (1893); an Evening Service in (': Part-songs, ete.

Waite, Rev。J。Jo, matem musician and clergyman, was a husy worlser, thongh blind, in the canse of musical edneation in Gloncenter and Ifereford. Ho died at I Iereford in Octuler, 186s. Among other works he edited "Halletujah....heing a relection of tmes from the works of Wainwright."

Wakefield, Augusta Mary, matem contralte roealist and composer, born at Kendal, Alng17st 19, 1853. situdied singing under Randergerer, Henchel, and Blumenthal, also at Rome, Has sung in rurisens parts of the conntry, and tow prat in the filoneester Festival if 1880. Establinhed an ammal series of rocal competitions alwont 1855, which have cuminated in the Walefield Festivals, held at fondal exory sping, and which are intended to encoulage the stndy of musie. Niss Walsefield conduct the perfomances, and appears as rocalist. She is the composer of sereral songs, No, sir: Yes sir!: Bunch of Cowslips; Mlar time in mirlwinter; Noreand more, ete. Her chorum, Queen of sixty vears, was sung at Kendal, Ipril 29, 1897. She has

\section{WALENN.}

given lectures on music, and has edited Ruskin on Mnsic, 1894, and contributed to various periodicals.

Walch, James, organist and composer, was horn at Egerton, near Bolton, June 21, 1837. His father was a musician, and he studied under him, and afterwards under Henry smart. Organist snceessively of Duke's Alley Congregational Church, Bolton, 1851; Walmsley Church, 1857; Bridge Street Weslesan clurch, 1858; ct. (Feorge's Parish Chureh, Bolton, 1863. He was conductor of Bolton Philharmonic Society in 1870, and in $187 t$ he retired. Composer of hrmm tumes and other chureh music, of which the best known is "Sawley," a popular bymu, composed in 1857 , and printed for private cir. culation in 1860.

Walenn. Fanily of musicians. Janes Farochansox Walexx, the edest, was borm in Loncton, January, 1860. A chorister, AH Saints', Margaret Street, and a fterwands pupil of W. S. Horte. In December, 1877, be won the Novello Seholarship at the National Training school for Music, and two rears later was appointed organist and chuimaster of sit. Allans's, Helloorn, and was also conAluctor of the st. Alhan's Chomal society. He composed some bureh musie; two pf. trios; many somgs, and left an opera mfinished. lle died at Hormey, February 10, 184t, a loss to the art he gave such promine to adorn. Artirto Wallis, his brotber, born in Lomdom, waseducated at All Sainte' Choir School, and at the R.A II. He legan as a vila player, and was som engared in the orehestras of the opera and concert rooms. With his sister and two founger brothers he formed the Walentu qualtet of strings's, and gave conrerts; but an excellent baritone voice defeloping, he, by the advice of Sir A. C. Mackenzie, devoted limwelf to singing, and the combination was lowken ny. After a comse of study under G. Henschel, he made his debut at the moming concerts at the gneen's Hall, in Norember, 1895, afterwarrs heing engaged for the London Sirmphony Concerts. lle has since been heard in many provincial centres, and has fairly established a repritation. Charles Walfixis, the next bother, born in London, 1869 , is also a baritone siuger, and has for some vears lreen a member of the I) Oyly Carte No. F company. Herpente WaLEXX, voluncellint, lwon in Eondon, June 25, 1870, studied under Hugn Heclier, at Franlsfont, and has appeatred with-nceess in Germany, and at the Qneen's 17all, 1897. GeleAli WALExx, the voungest hother, born in fondon, 1872, stndicd the riolin at the R.A.M., nuder śanton and samet. At the ange of fourteen he played before the gueen, at Windsor, and soon afterwards was heard at various concerts. He was in Germany, 1896, 


\section{IVALEY.}

where he was very snceessuful, and has since played at chamber concerts, Qneen's Hall. DoRothe WALEx, born in London, is also a violinist: pupil of sainton, simret, and Hugo Heepmann. Ifter' playing in the quartet mentioned, she deroted herattention to teaching, in Londin.

Waley, Simon Waley, pianist and amateur compuser, hrou at fundon, in 1827 . He wals rngaged in commerejal life in London. being a member of the Stock lexchange, and he was also an alctive member of the Jewish community in lsmdon, lie studied music, the pif. mind Mascheles, Bennett, and (i. A. Osborne, and throry under IV. Horster, and Molique. As a pianist he displayed alibity, and performed at the encerts of the Amatem Munsieal sicicity. He died at London, Jecember 30, 1875.

Works--Mnsie for the services of the Jewish Church: Duets. Songs: Angel's roices; l)ream of home; l'll rest; fort chond: Sing un, sing on, ye little birds. Fairies somg, we. comerto for pf. and atchestra: Romance for oloes, or violin and pef. (1s(i1): Romanee for violin and lif. (1sts); Marches. "iprices, and sther works for pf.

Walkeley, Antony, wrgmist and composer, was born in 167:z. He was trained as a chorister in Wells Gathedral, where he afterwards hecante ricatr-eboral. Organist of Salisbury (Gathedral, in successiom to 1 ). Rosingrave, 1698. lied at Salisbury, Jamuary 16, 1717. Composer of a Moming service in $\mathrm{k}$ flat, in 'Tndway's collection, and of anthems in MS.

Walker, Alexander, violinist and composer, of latter part of the $18 t h$ century. Composer of " $\mathrm{A}$ Colfection of Strathspeys, reek, marches, etc... dedirated to . Sir ('lrarles Forhes, Part., of Newe." Alberdeen, n.d.

Walker, Augustus Hayter, teacher of composition and musical seience, born in

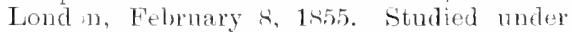
Dr. F. J. Sawyer. Fraduated Mus. Bac., 1853; Mus. Hoc, 188, l ondon, heing with Ir. IV. H. IJunt $(q \cdot x)$, the first to receive the degree of Mins. Poce, at London $T^{\top}$ niversity. Sometime resident in Brighton, and professor of hirmony and composition at Brighton College, and Conservatoire of Musie. Lectnrer in musical aconstics, T.C.I.., and tutor in music, University Correspondence College. His compositions are; Psatm 95, for soli, chorus, and strings; Regniem, for soli, eight-part chorus and orchestra, performed, London, Febru ry 20, 1886; songs, part-songs, and organ pieces, ete.

Walker, Bettina, pianist and writer, born at lublin. Not originally intended for the musical profession. Studied nuder Adolphe Henselt chicfly, ard settled in I,ondon abont 1890 as an exponant of his method

\section{WALKER.}

of teaching. Author of "My Musical Experiences," London, Bentley, 1890. She died at Fulham, February 4, 1893.

Walker, Francis, baritone vocalist of present time. Sang at various concerts in London up to 1885 , when he went to Italy for further study. On his return he gave a concert at B rlington Hall, London, April 7, 1sse. His experiences he embodied in a book, "Letters of a Paritone," London, Heinemant1, 1895.

Walker, Frederick Edward, tenor vocalist, born at Marylehone, London, Jaminary 17, 1835. Entered the choir of the Chapel Royal, St. James's, when nine. Studied under private teachers, and lrecame a vicar-choral of St. Paul's Catledral in 1858. In tist he succeeded Henry Buckland as Master of the Boys. Sang in the quartets in "Elijah," Sacred Ilamonic Concerts, Fnne 15, 1855, and in the same work at Madam Crokdschmidt's farewell performance, December 17, at Exeter Hall. Fur many years a familiar figure on the eoncert platform. Conductor of the London Tocal Lnion, which assisted at the first performance in Fugland of lirahms' "Rinaldo," Crystal Palace, April 15, 1,76. He was also appointed conductor of the Brixton Inhihatrmonic society, 148:3. Professor of singing, and Hon. memher (1887), of R.A.MI. ; professor, ('.S.MI. He is an organist, pianist, violinist, and performer on the oplicleide; and accompanied the recitatives on the pf. at the performance of Bach's "Matthew Pussion," it. L'aul's, April 8,1878

Walker, James, violinist and composer, was horn at I'ysart, Fife, in the latter half of last century, and died there on April s, 18t0. He publisher "A Collection of new Scots reels, strathspers, jigs, etc., with a bass for the violoncello or harpsichord," Dysart, n.ג. [1797]. "Second eollection of reels, strathopeys, jigs, etc., with bass for the violincello or harpsichord, atso defferent marehes for volunteer corps," Dysart, n.d. 18007.

Walker, James, amateur musieian, born at Aherdeen, July 6,1827 . A tea merchant in Aherdeen, and prominent $i n$ city and town conncil affairs. Anthor of "On .Just Intonation in Song and Speech," Aherdeen, 1876, privately printed. "Some notes rea raing the proposed IIunicipal Band," Aherdeen, 1878. He collected a valuahle musical library, which he presented to the Public library of Aberdeen in 1\$31. For some years he was president of the Aberdeen Musical Association.

Walker, Joseph, tenor vocalist and writer. Sion of Thomas Walker (y.e.) $\mathrm{He}$ was one of the foumlers of the Facred Harmonic society. Author of "Walker's Chro- 


\section{WALKER.}

matic Solmization," London [1825] ; “Pocket Memorial for the musical tyro," London, 1835.

Walker, Joseph Cooper, writer and musician, born at Dublin, November, 1760; died at St. Talery, near Bray, April 12, 1810. Author of Historical Memoirs of the Irish Bards, interspersed with anecdotes and occasional observations on the Music of Ireland...." 1)ublin, 1786. "An Historical account and critical essay on the Opera, and on the revival of the drama in Italy," Edinburgh, 1805. " Memoirs of Alessandro Tassoni, edited by S. Walker," 1815. Other works, chiefly on Irish antiquities.

Walker, Lawrence, organist and pianist. Studied at Armigh Cathedral, and at the Raff Conservatorium, at Frankfort, and gained high praise for a pf. trio performed at a concert there, July 9, 18s9. Graduated Mus. Bac. Cambridge, 1891 ; is also B.A., Dublin. Organist of St. James's Cluurch, Belfast, in which place he is resident as a teacher. He has composed a setting of I'salm 137, for solichorus, strings, and organ.

Walker, Reginald, H., musician, was born in 1839. He was the yomgest son of J. H. Walker, music master of Rugby School. Died at Kingstown, Ireland, in October, 1876. Composer of "Jerusalem," a cantata, and other vocal music.

Walker, Thomas, composer and alto vocalist, was born at London in 1764 . Teacher in London. Inicd at Queenhithe, July 5, 1827. Composer of "Anthems and set pieces for 2 $2,3,4$, and 5, voices," London [1808]; "Walker's Companion to Dr. Rippon's Tune Pook," London, 1811, 2 vols.; also 1815. Sougs and other vocal music.

Wallace, Frank M., violinist, son of Paul Wallace, was a pupil of A. C. Mackenzie, and studied later at Leipzig Conservatorium under F. David and others. For some years he was a nember of the principal London orchestras; but failing health caused him to leave England in 1886, and take up his abode in New Zealand. He has given concerts at Christchurch; is the conductor of a musical socicty there; and holds a good position as a violinist.

Wallace, Lady Maxwell, born GRAcE STE1N, born at Edinburgh about 1815. Married in 1836 to Sir James Maxwell Vallace. She died in 1878. Translated "Letters from Italy and Switzerland, by Felix Mendelssoln-Bartholdy," London, 1862 ( 2 editions); "Letters of Felix MendelssolnBartholdy, from 1833 to 1847 ..."1863; "Letter of Wolfgang Amadeus Mozart, 1769$1791 . . . "$ London, 1865; “Beethoven's Letters, 1790-1826," London, 1866, 2 vols.; "Letters of Distinguished Musicians, Gluck, Haydn, P. E. Bach, Weber, Mendelssohn,"

\section{WALLACE.}

London, 1867; "Reminiscences of Felix Mendelssohn-Bartholdy, by Elise Pollio," London, 1869.

Wallace, William, eomposer, born at Greenock in 1860. Educated at Fettes College, Edinburgh, and afterwards entered upon a course of medical study, which was continued at Vienna. He had already commenced to compose music, and on going to London he entered the R.A.M., and decided his career. In 1890 a seena of his was performed at the Academy concerts.

Works.-Orchestral: Suite in A based on Ibsen's The Lady of the Sta), produced by the Stock Exchange Orchestral Fociety, February 18, 1s92; Symphonic Poem, The Passing of Beatrice, Crystal Palace, November 26, 189:; Prelude to the Eumenides of Eschylus, the same, October 21, 1893; Concert overture, In Praise of Scottis Poesie, the same, November 17, 1s.44; Symphonie prelude, Amboss oder Hammer (on Goethe's liophtisches Lied), the same, October 17, 1890. Trio in A, pf. and strings: suite in Olden Style, pf. The Rhapsody of Mary Magdelene, Quecn's Hall, December 15, 1896 ; Lyric from Prometleus Cnbound, with accompaniment for violin and pf. ; Six Songs (Heine); Cycle of Spanish Šongs for 4 voices; Madrigal, In a glorious garden green, etc.

Wallace, William Vincent, composer, pianist, and violinist, was born at Waterford, June 1, 1811. Son of Scottisly parents, his father being an army bandmaster and bassoon player. On the removal of the family to Duhlin, young Wrallace frequently appeared at concerts as a violinist from 1829, and in 1834 he played a concerto of his own composition at a concert. He nuaried, first, Miss Kelly, from whom he soon separated, and about 1836 went to Australia, and travelled about there, in New Zealand, India, and South America. He appeared in London in 1845 , and produced his operas, but soun after resumed his wanderings, this time visiting the United States as well as South America. In 1850 he married Helène stuepel, who had some vogne as a pianist. He died at the Chateau de Bagen, Haute Garomne, France, October 12, 1865.

Works.-Operas: Maritana, London (Drury Lane), November 15, 1845; Matilda of Hungary, London, 1847 ; Lurline, London (Covent Garden), February, 1860 ; The Amber Witch, London, Febrnary, 1861; Love's Triumph, London, November, 1862; The Desert Flower, London, October, 1st3 ; The Maid of Zurich (never performed); Estrella (unfinished); Gulnare, operetta; Olga, operetta. Cantata: May Pole (E. Oxenford). Four Hymns by J. Keble. Corin for Cleora dying, four-part song. Pianoforte: Air Russe; Barcarolle; Caprice heroïque; Chant d'Amour, 


\section{WALLBRIIGE.}

op. 26; Chant des Pelerines, op. 19; Danse Cossaque; Fairy march; Goudellied [1859]; La Gondola, op. 18; Mazurka-étude; Grand mazurka guerrier; Premier noeturue [1856]; Three nocturnes, op. 20 ; Noeturnes, op. 32; Polka de coneert; Le Rêve, romanee, op. 21 ; Romances. op. 25, 36; Six valses; Tarantellas; Village Festival; Woodland mumurs; Le Zephyr, op. 47 ; numerous transeriptions of popular airs and arrangements from operas. Songs: Alice; Autumn (1853); If doughty deeds; Hope in absence; Katie Strang; Winds that waft my sighs to thee; Silent love; liellringer (1860); Coming of the flowers; Gipsy maid; Star of love; IVood-nymph; ete. His life, which was full of adventure and somewhat romantic, was written by Arthur Pougin moler the title of "WVilliam Tineent Wallace, étude biographique et eritique," Paris, 1866. In 1896 a concert was given in Lond m for the benefit of Wallace's soll.

His sister Eurza was a distinguished violinist and voealist; who toured in Europe and America as a concert giver. She was maried to Johu Bushelle. Settled latterly in Anstralia as a teacher, and died at Sydney in August, 1878.

Wallbridge, Arthur, see LunN, Wm. A. B.

Wallis, Ebenezer John, amateur composer, born in London, Mlay 9, 1831 ; diect at Sutton-at-llone, Kent, Octolser 26, 1879. Composer of "Barossa," a popular hymn tune, which was issued in "Anthems, eanticles, and hymus," 1869.

Wallis, John, mathematieian and writer, born at Ashford, Kent, November 23, 1616; died at London, October 2s, 1703. Anthor of "Observations concerniug the swiftuess of sound," London, 1672; "Claudii Ptolemi Harmonicormm. " Oxford, 1680. Also $111 \mathrm{~m}$ erous papers on musical subjects in the Philosophical Transactions.

Wallworth, Thomas Adlington, composer, teacher, and witer', born at Liverpool, Jamuary 18, 18:31. The family removed to Huddersfield when he was two years old. He was taught the Lancashire sol-fa by Jackman. of Huddersfield; sang as a baritone at Liverpool. Entered the R.A.NI. in 1848, studying thiefly under ('rivelli. Sang in the first performance of Bach's Passion (St. Matthew), given by the Bach Socjety at the Hanover Square Rooms, April 6, 1854 . Toured with the Pyne and Harrison opera company, and for many years was actively engaged in concert work. Ile was appointed professor of singing at the G.S.AI. from its opening; also professor, R.A.M., to 1890, and F.R.A.M., and Associate of the Philharmonic Society. His health failing he left England in October, 1856, to reside at Cape Town. Among his
WALSH.

pupils were Nadame Valleria, IIr. Iser Mekay, and other's who have made a reputation. He composed an operetta, "Kevin's 'hoice," produced at the Adelphi Theatre, March 25, 1882; a prize glee, Up, Sailor boy $(1865)$; and other voeal pieces. Author of $\mathrm{A}$ Course of Stndy and Practice for the Voice; Art of Voice Training and Tocalisation.

Walmisley, Thomas Forbes, composer and organist, born at London in 17.83. He wis a chorister in Westminster Abbey, and studied under Attwood. Married eldest danghter of Wm. Capon, 1810. Organist of St. Martin-in-the-Fields, London, 1812. He dierd at London, July 23, 1866.

Wonis.-. Six Glees for $3,4,5$, and 6 voiees, London, 1814; A Collection of Glees, Trios, Roumds, and Cimons, London, 1826; Six Glese, dedicated to the Cateh Chub, London, 1830; Six Glees for 4 roices, 3rd collection, London, 1830,; Six Flees, th (w)llection, foudon; many single glees, including prize gleses, ete. Six Anthems and a short llorning and Exening Service, Londun, n.d. Saered Songt, London, 1st1. Songs.

Walmisley, Thomas Attwood, organist and composer, born at London, Jammary 21, 1814. Sion of above. He stmdied under Attword, who was his godfather, Organist of Groydon Chutel, 18:30, and of Trinity and St. John's Colleges, Cambridge, 1833. Mins. Bate. Cantal., 1833. Professor of Munic at Cam. bridge, 1836. B.A., 1838; M.A., 18+1. Mus. Doe. Cintal, 1848. He died at Hastings, January $17,1856$.

Forks.-Cathedral Nusic, a collection of services and anthems, London, 1857, edited by T. F. Walmisley. Odes on installation of Inlie of Northmiluerland (18t2) and Prinee Albert (1849) as chancellors of Cambridge Iniversity. Collection of Chants with the lesponses in use at the chapels of Fing's, Trinity, and St. John's Colleges, Cambridge, London [1845]. Choral hymm in fonr parts. Cambria, trio. Fon songs ly Mrs. Eilliott (1854); Chatelar to Mary, Queen of seots, and other songs.

Walond, IVilliam, organist and composer of the 18th eentury, was a member of christ Chureh, ()xford, and in or abont 1757 graduated as Mus. Bae. TIe composed an ode "St. Ceeilia's 1)ay" (1790), by Pope, and other works. Another Williai WALOND, mobably the son of the above, was born abont 1750 . Ho was organist of Chichester Cathedral, and disd at chichester, February 9, 1836. He compused some music for the church.

Walsl, George, organist, who snceeded Rosinglate at Christ Chureh Cathedral, Dolblin. IIe died in 1765.

Walsh, Thomas, teacher of singing, was born in the latter part of the 1sth century. He was proprictor of the Argyle Rooms, Lon- 


\section{IVALSH,}

don, when the Philharmonic Society gave its concert there. Best known as a suceessful voice trainer. Kitty Stephens was one of many distingnished vocalists trained by him. He died at Brighton, January 24, 1848.

Walsh, William J., musician, issued "Gramnar of Gregorian Misic, with numerous exereises and examples," Dublin, 1885.

Walshe, Walter Hayle, physician and writer, born at Dublin in 1816. Author of "Dramatic Singing Physiologically estimated" London, 1881.

Walter, Ida, composer of the present time. Niece of chief pruprietor of the Times. Studied at R.A.M. Composer of an opera, "Florian," produced, Novelty Theatre, July 14, 1886; also of The sea hath its pearls; O let the solid gromend and other songs.

Walter, John, composer and urganist, of latter part of 17 th and beginning of the 19th centuries. He was organist of Eton College early in the 18th century. Composer of music for the church. Was teacher of John Tieldon.

Walters, Dr. Allan, conductor of the Musieal Union, Brimbanc, Quesmsland, Australia, is the composer of a Julbilee Ode, for chorus and orchestra, prodneed, Brisbane, June, 1887. Ho is said to be doing good service to music in his district.

Walthew, Richard H., pianist and composer. Pupil of Dr. Hubert Parry, at R.C.MI. First came into notice by playing a pf. concerto of his own at a concert of the strolling Players, Queen's IIall, May 3, 1494. An orehestral suite, and a Festival overture, have been performed ly the Stock Exchange soejety, 1895-6; and the Highbury Philharmonic Society produced his setting of Browning's Pied Piper of Hamelin (for soli, chorus, and orchestra), in 1893. He has also composed a Festival March for orehestra; Trio, pf. and strings; pieces for clarinet and pf.; snuwdrops, eantata for female voices; songs, cte.

Walton, Rev. C. B., amateur musician. Sometime vicar (or eurate?) of St. James's, Ogley Hay, compriled "A sulection of original chants, hymm tmes, kyries, etc.," Bimingham, Harrison [1880].

Walton, Emanuel, composer and organist, of first half of present century. Composer of "An original set of psalnu and hymm tunes, arranged for fonr voices," Leeds [1 1810]: "Church lwalmody, selected and arranged for four voices," Londun [1830]; Walton's psalmody, and edition [1835]. Songs: How sloep the brave; Radiant queen; When the smm is fast declining, and other rocal music.

Wanless, Thomas, organist and composer of the latter part of the 17th and early part of the $18 \mathrm{th}$ centuries. He gradnated Mus. Bae. Cambridge in 1698, and afterwards
WARD.

became organist of York Minster. He died in 1721. Composer of the "Yurk Litany" and some anthems.

Ward, Adelaide, see Newton, Mrs. Alex. Ward, Cornelius, orginist, comploser, and writer, born at speen, Pnekinghanshire, June 29, 1814. Organist and teacher at iseen.

Woris. - Prodigal Son, oratorio; Nativity, cantata; Seraphic tidings, ode. Puckinghamshire Melodist, a new set of palm and hymm tunes, London, 184t. Westeyan Minstrel, comprising a set of tmes adapted to all the varieties of metre in the Rer. J. Wesley's hymm book [1854]. The Choristor, 5 vols.; Choral Beauties, 2 vols. The Flute explained being an examination of the prineiples of its structure and action, London, 1s44. Anthems, songs, ete. He also editer a reprint of Nieholds' oratorio, "Babylon."

Ward, Francis Marshall, hass vocalist, organist, and concluetor, burn at Lincoln, Derember 26,1830 . Edreated as a chorister at Lincoln Cathedral, and in 1 sit5 was appointed organist of st. Peter in Eastgate, Lincoln. Was elected principal lass at Hereford Cathedral, 1851, and during the next twenty years sang a good deal in oratricio and general concert work. Organist and choimaster Alergavemuy Parish Chureh, 1856; St. Mary's, Lincoln, 1857. Was handmaster of the 1st Lincolnshire Volunteers when the movement started, and won several prizes at brass band contests. Removed to Nottingham about 1867, and was organist of Lenton Parish Church, and after holding similar appointments at other churebes, was appointed in 1894 to Broad Street Wesley chapel, where an orchestra is employed on Sinday Evenings. Was organist and music master at the Blind Institutinn, Nottinghom, for ten years; and has conducted societies at Lincrin and other plates. The Nottingham I'hilharmonic Society, under his direction, won the prize of $£ 100$ at the Liverpool Exhibition, 1.856. He is also musical director of the Nottingham Glee Club. His compositions include a Iinnet for or chestra, church services, anthems, songs, and part-songs, mly a few of which are published. His daughters, Linr, a soprano, and Jessie a contralto vocalist, have sung in the Midlands and the North with success since 1885.

Ward, Frederick, violinist and composer, born in Birminghan, December 26, 1845. Principal violinist in orchentral concerts, Birmingham, and in great request in the Midlands as a soloist. Nember of the Birmingham Festival Orchestra. J Tas composed a concert overture for orchestra; two concertos for clarinet and orchestra; a rextet, and ten quartets for strings; pieces for violin; songs, part-songs, etc.

Ward, John, composer of the 16th and 


\section{WARI.}

17th eenturies. I le died about $16 \pm 0$. Composed "The First sut of English Madrigals, to $3,4,5$, and 6 parts, apt both for viols and voyces; with a Mourning Song in memory of Prinee Henry.." London, 1613. Songs in Leighton's "Tuares," and service and anthem in Bannated's collection.

Ward, John, English writer, author of " Lives of the l'pofesisols of Gresham College, to which is purfixed the life of the founder, Sir Thomas Gresham, with an appendix eonsisting of orations, ctc..." Loudon, 1740. Contains lives of Bull, Clayton, Taverner, and other profussors of music.

Ward, John Charles, organist and conposer, born at U per Clapton, London, Mareh 27, 1835. Entered the choir of the Temple Church with his brother, R. J. Ward (notieed below), in 1842, remaining there until $18+8$. Studied pf. under his father, violin under Howard Glover, and concertina with George Case. Played a eoncertina solo at Crosby Hall, December 2, 1st6, and for a long time was known as a virtuose on the instrument. He has been oryanist successively at Bridewell Hospital Chipel, 1852 ; St. John's Chapel, Hampsteacl, 1\$53; Eaton Chapel, Eaton Square, 1856; Christ Church, Hanmpstead, 18ti3; Quebec Chapel, 1868; Holy Trinity, Haverstock Hill, 1884; Christ Church, Streatham Hill, 1886; and St. Mary the Virgin, Primrose llill, from 1890. Member of the Leslie Choir from its foundation in 1855, and organist and assistant-conductor from 1856 to 1865.5 . For his services as or' ganist when the choir visited Paris in 1878, he was awarded a medal. He has given organ recitals in various places.

Works. - Motet, Thy Word is a Lantern, double choir ; Sinetus, doul)le ehoir (sung by Iseslie's Choir); Cantata, The Wood; Testimonial Ode; A Psalm of Life, men's chorus and orchestra; Church services; anthem, I am the Resurrection, In Memoriam, Henry Leslie. Collection of hymn tunes and chants. Lives of great men; Rove not to the Rhine; and other part-songs. Trios, Faith, Hope, for soprano, mezzo-soprano, and tenor. Cantata, The Swedish Singers, female voices. Fugue on the Sailor's Hormpipe, orchestra, written for the Bradford Permanent Orchestra. Organ: Nautical Symplony in four movements; rrelude and Fugue, Westminster Chimes; Prcludeand Mareh, Wedding Chimes; Fugue on London New, etc. Fugues and other pieces for pf. Trio, for Eola, 'cello, and bass concertina; Minuct for 3 concertinas; Polonaise in E flat, pf. and concertina, ete. Mr. Ward invented a now form of piano, and the Harmonic Angehite.

His two sisters and brother were musicians. The elder sister Enm (Mr's. Alexander Newton) is separately noticed. The second, Eliza

\section{WARE.}

A. WARD, is a pianist and vocalist. Wats the pianist of the concert party on ton with Jenuy Lind, when Sims Reeves, Mrs. A. Newton, F. Labliche, and other singers were ineluded; and was one of the original numbers of Leslie's Choir. Resident in London as teacher. His brother, R. J. Wart, bern in 1813 , was a chorister at the Temple Church, 1842-6. Afterwalds he studied the slidetrumpet, and becane eminent as a performer. He belonged to the Royal Italian Opera, and other leading orehestras. While offieiating at a concert at Brighton he had an apoplectie strolie which closed his professiona! career; but he survived for fifteen years, and so far recovered as to be able to walk from ten to fourteen miles a day without fatigne. His lemaining yeals were devoted to the anseliolidtion of the sufferings of others, by remedial appliances so sutecessful in his own case. He died at lyat Lulwich, Jantaty 22, 184t, aged 59. C'Lenentine, dalughter of J. C. Mard, is resident organist of St. Saviour's Hospital, Osnaburg street, London. She has sung at her father's organ reeitals, and is the (onnposer of a Mareh, Gawotte, and "Dickens Reries" of little pieces, ete., for pf. Everix, another daughter, born at Hampstead, January 9, 1865 , is a soprano rocalist. She studied under her father, and took leading parts in various comic operas in England and the United States of America, from $188+$ to 1893 , when she retired from the stage. She maried Mr. Hamilton Tetley.

Ware, Alfred, musician, isstued "Sacled Meloties, containing Psalm, Hymn, and Anthems, atranged for the Tiolin," London [1852].

Ware, George, composer and writer, was born in 1762; died at Liverpool in 1850. Son of Gicorge Wate (172:): London, Wareh T, 1814), a teateher and composer of rocal music. George, the youmger, composed glees, songs, and rondos, and other music for the pf., and wrote "A Dictionary of musical chords, arranged so as to find any modulation by various nethods, through the twelve halftones," London, n.d.

Ware, William Henry, composer and violinist, was another son of George IVare, the elder. For some year's he was leader at Covent Garden Theatre, but no further trace of his career seems to have been preserved.

Worns.-Music to Plays, Pantomimes, etc. Aladdin, 1819; Bonifacio and Bridgetina, 1808; Cariolanus, 1806; Cymbeline, 1806; Don John, 1821; Grand tour, 1820; Harlequin and Mother Bunch, 1821; Harlequin and Mother Groose, 1806; Harlequin and the sylph of the oak, 1816; Maebeth, 1806; MLntrose, 1822; Ogre, 1807 ; Two galley slaves, 1822; Undine, 1821; Vision of the sun, 1823; Zumbuca, 1815. Six ballads and songs, [1835]. 


\section{WVAREHAM.}

Three duets for two violins, op. 2; Trio for two violins and 'cello, ete.

Wareham, Edwin James, tenor vocalist and organist, born at Wimborne, Dorset, September 16, 1864. Having a good soprano voice he wils a successful eoncert singer at eight rears of age, and when twelve was appointed at one of the churehes in Wimborne. In 1881, he was appointed organist of Woodbridge Parish Church, and conductor of the East Suffolk Church Choir Lnion; moving, in 1881, to Glasgow, as organist of Claremont Church. A year later he succeeded the late Channon Cornwall, as organist and accompanist to the Glasgow Choral Union. He also frequently conducted the rehearsals: and played the organ at thr great Jubilee service in the Cathedral, $18 \mathrm{~s}$, and at the opening of the Exhibition, 1858. His next appointment was to St. George's, Albemarle Street, London, 1890, where he greatly improved the musical services. He now restmed the study of singing at the Grildhall school, under T. A. Wallworth, and at the R.A.M., under W. H. Cnmmings. Made his debut in opera at the Olympic Theatre, Octoher, 1892, as the pret in "Eugene Onegin"; created the part of reoffrey Norreys in Thomas's "Golden Web," produced at Liverpool, February, 1s.9. Appeared in cirand Opera, Covent Garden, 1895; at Richter Concerts, 1893: Crrstal Palace, 1894, ete. Sang in South Africa, 1896- 7 , and at firt Festival in Johamnesburg, 1897.

Wareing, Herbert Walter, composer and organist, horn in Birmingham, tpril 5, 1857. Stndied under Dr. C. Swinnerton Heap, and at Leipzig Conservatorium, under Reinecle, Jadassohn, E. F. Richter, and others. Graduated MLus. Bac., Cambridge, 1882; Mns. Doe., 1ns6. Has held organ appointments at St. John's, Wolverhampton, 1876-9; Edgbaston Parish Church, 18-1-8; and since 1891, at King's Nortom Parish Church. Resident at King's Norton, engaged in composition, and teaching. He is professor of the pf. at Malvern College, and has other important engagements.

Works-Cantatas, Praver and Praise (Mus. Bac. Exercise); New Year's live (Exercise for Mus. Doc.): The Wreck of the Hesperus, for tenor and hass soli, chorus and orchestra, 1895. Chnrch service in (; ; Anthems, part-songs, songs, fte. Concert werture in $\mathrm{F}$ (Birmingham, 1879); String quartet in $\mathrm{F}$ (performed at the Hauptprifung, Leipzig. 1876); Ten cuncert pieces for vislin ant pf.; Two pieces for violoncello and p. : I'ieces for organ and pf.

Waring, William, molieian of latter part of 1sth century. Tramslator of Romsseau's "Dictionmaire of Musique" as complete Dictionary of Music, consisting of a

\section{WARNER.}

copious explanation of all words necessary to a true knowledge and understanding of music, translated from the original French of J.J. Ronssean," London, 1770 ; 2nd edition [1779].

Warman, John Watson, organist and writer, born at Canterbury, Angust 12, 1842. Son of a private schoolmaster, and descended from a fanily of French Hugnenot refugees. Received a few lessons from Dr. Longhurst, and E. H. Thorne, otherwise self-educated in music. Articled to organ lutilding about 1858. Was assistant organist at Ashford Chureh, Kent, 1862; organist at Hunton Bridge, near Watford, 1865; afterwards at Faringdon, Berks, and Hove, Sussex. Went to Quebec in 1872 as organist of the Anglican Cathedral there, but returned at the end of a year. He then, for the purpose of acquiring practical knowledge, worked for some months as an ordinary journeyman at Hill's organ factory, London. Returned to Cauterbury in 1877 , and was sometime local examiner for R.C.M. In 1887 he removed to Thornton Heath. Croydon, where he is giving himself up entirely to literary work. Author of a series of papers on Counterpoint, published in Musical Opinion, vols. $r$ and vi., and other contributions to varions periodicals. The Organ, its compass, ptc., London, Wm. Reeves, 1854. Now engaged on a large bibliography of organ, structural, musical, and mechanical works allied. He has composed a few hymn tumes, chants, etc.

Warne, George, composer and organist, was boln in 1792. He was blind, but for a number of years held the appointment of organist at the Temple Church, London. Died at Bath, October 29, 1868.

Toriss. - Set of pralm tmes, as sung at the Temple Church, Lumdon [1638]. Songs: Broken gold; Come away to the grot; Erening song; O bring me my harp; We meet again in heaven. Quadrilles, galops, and other music for the pf.

Warner, Daniel, musician, who was a singing master at the end of the 17th and begiming of the 1sth centuries. Compiler of the "I "Tevout Singer's (Anide, containing all the common tune's now in use, with select portions of the pailms arlapted to each tmme," London, 1711. "Singing Master's Guide," 1719. The "I beront singer's Gnicle" is recommended ly Warner, so he may not have actnally compiled it.

Warner, Harry Ernest, organist, pianist and compuser, born at Isleworth, Middlesex, July 1, 1859. Receiver his first leswon from the organist of the larish chomeh, whose deputy he became at the age of fomrteen. Later, he studied with the Lev. Ir. Hayden, M.A., and when eightern was appointed organist and choimnaster of Brentford Parish Church, which he left seven year's later for the 


\section{WARREN.}

Royal Church, Kew, where he is still in office. Honorary local examiner for R.C.M. Though busily engaged in eoncerts and teaching, he has found time for composition, and his works inelude two Cantatas for female voices, "Merry May" (1891), and "The Golden Valley" (1893). Also anthems, O God have mercy; If ye love me; hymn tunes, partsongs, seventeen part-songs for female voices, etc.-"La Felicite," orchestra; Air de ballet, string quartet; Romance in D, pf. and strings; Royal Bridal Narch, military band; Reverie, for violin, harp, pf., and organ; pieces for violin and pf., and pf. solo, etc., etc.

Warren, Ambrose, author of "The Tonometer, explaining and demonstrating by an easy method in numbers and proportions, all the 32 distinct and different notes, adjunets, or supplements contained in each of four octives inclusive of the gamut.." London, 1725.

Warren, Edmund Thomas, music-publisher and collector, was born about 1730 . He was engaged in business in London and acted as Secretary of the Catch Club. $\mathrm{He}$ died in 1794. Editor of "Reliques of ancient music," and "Vocal Harmony," a collection of catches and glees, issued in parts.

Warren, Joseph, organist and composer, born at London, March 20, 1804. He studied music under J. Stone, and from 1843 was organist and choirmaster of St. Mary's Roman Catholic Chapel, Chelsea. He died at Bexley, Kent, March 8, 1881.

Works.-Selection of Cathedral Chants [1840]. Seleetion of one hundred chants, London, 1845. Repertorium Musicæ Antiquæ, London, 1848 (with John Bishop). Collection of psalm and hymm tunes, 1850-54, 4 vols. Hymns and canticles, 1852. The burial serviee as performed at the funeral of the Duke of Wellington. . London, 1853. Hymms of Joh. Sebastian Bach, London, n.d. Theoretical, etc. : Hints to young organists, London, 1844. Biographical dictionary of deeeased musicians, London, 1845 and later editions. Chanter's hand-guide, London, 1845. Hints to young composers, London, 1846. Writing for the orchestra, 1846. Instruction lrook for the organ, London, n.d. Instructions for the hammonimm, London, 1852. Completeinstruetions for the concertina [1855]. Introduction and observations on the mode of singing catches, rounds, canons, glees, and madrigals, London, n.d. Nost of these works were published in various editions, chiefly by R. Coclis and Co.

Warren, Samuel P., organist and pianist, born at Montreal, Canada, February 18, 1841. Son of S. R. Warren, organ builder (died, Toronto, 1882). Studied loeally, and was organist at a church in Montreal, 1853-61. Then went to Berlin and studied under

\section{WARWICK.}

Haupt, G. Schumann, Wieprecht, and others, 1861-4. Returned to America in 1861, and the next year beeame organist of All Souls' Church, New lork, From 1874 he was organist of Holy Trinity, New York, for two years, his latest appointment being at Grace Chureh in that city. For a number of years he has given a series of organ recitals, embracing the entire literature for the instrument. He is also known as an excellent pianist. His compositions consist of ehurch serviees, anthems, and songs.

Warren, William, organist and composer, was born in the latter part of the $18 \mathrm{th}$ century. He was arganist of Christ Church Cathedral, Dublin, 1814, and graduated Mus. Doc., Dublin. Died at Dublin in July, 1841. Composer of a prize glee, "Shepherds, hither come," 1802, and others.

Warriner, John, organist, pianist, and writer, born at Bourton, Shropshire, May 12, 1858. Pupil of Chevalier de Val (Brussels), and G. Riseley. Organist of Dunster Parish Church, 1880, and concurrently, 1884-7, of St. Andrew's, and the Parish Church, Minehead. Conductor of Dunster Philharmonic Society, which gave some excellent concerts with orchestra; and organ recitalist. Graduated Mus. Bac., 1887; Mus. Doc., 1892, Dublin. In 1887 he was appointed to St. Matthew's, Denmark Hill, London, where he introduced oratorio serivces as he had done at Dunster. Conductor of Walthamstow Musieal Socicty, 1893. Professor of pf., T.C.L., 1890 , and examiner there, 1894. His compositions are, Psalm 30, for soli, five-part chorus, organ, and strings; Pralm 13, for soli, eight-part chorus and orchestra; and orchestral works in MS. He has published some church music, and pieces for organ, pf., ete. Author of a primer on Transposition, Novello; Editor ef National I'ortrait Gallery of British Musieians, Sampson Low, 1896. "Editor for two vears of the 1 inim.

Warrington, Frederick, bass vocalist, of Toronto, Canada, has sung at the leading concerts in the Dominion. He took part in the first festival held at Toronto, in June, 1886; sang in the Jubilee performance of "Elijah," Toronto, November 28, 1896; and has a good reputation as a vocalist, and choir trainer.

Warwick, Giulia, soprano vocalist, pupil of Madame Sainton-Dolly. Sang at concerts in London, and on tour with Wilhemj, in 1877. Was a member of the Carl Rosa Opera Company, 1879-82; and later, sang in comic opera. Formed a company of her own, and produced, for the first time, an English version of Vasseur's "Madame Cartouehe," at Leicester, September, 18:91. In 1894 she was appointed professor of deportment, etc., at the Guildhall School of Nusic; and in 1896, 


\section{WARWICK.}

professor of singing, succeeding her sister, Alexandra Fhrenberg, who died september 2,1596 . Whe was a contralto singer, educated at the R.A.M., of which she was an Associate. For some years she sang in oratorio and other concerts in London, and the provinces, appearing at the Crystal Palace in 1883. In 1891 she was appointed a professor of singing at the fuikhall school. She died at the early age of thirty-three.

Warwick, Thomas, organist and composer of $17 \mathrm{th}$ century. In 1625 he was lutenist to Charles I., and in the same year sueceeded Orbundo Gibbons as organist of the Chapel Roval. He died sometime after 1641. His son, Sir Philip Warwick, was secretary to the Treasury in the time of Charles II. Composer' of a song in 40 parts, said to have been performed in 1635 .

Wass, John, composer, born in 1800 ; died at London, in July, 1865. He was a teacher of singing in London. Composer of "The Foresters' Roundelay," a cantata, 1s6i3; Part-songs. Songs: Flower spirit; rood night to thee, ete. Pf. music. British Nary quadrilles, ete. Finger exercises for the pf., 1843. Author of “Boosey's Universal Singing Method," London 1855 ].

Waterhouse, George, organist and composer of the latter half of the 16th century. He was organist of Lincoln Cathedral, and afterwards of Queen Elizabeth's private chapel. In 1592 he graduated MLus. Bac., Oxford. He died in 1601. Composer of canons, etc., none of which are known to be cxtant.

Waterson, James, bandmaster, was a pupil of James Waddell, and succeeded him as bandmaster of the 1st Life Guards in 1866. After his retirement from that post he was appointed conductor of the hand of the Viceroy of India. He arranged a great deal of music for military bands; was the composer of a dramatic overture, founded upon the "Tale of 'Two Cities," by Charles Dickens, produced, Alexandra Palace, Feburury 19, 1876; a quintet for wind instrmments, etc. He was one of the joint editors of the British Bandsman when it started, October, 1887 . He died, Oetoher, 1893, and was buried in Windsor. Cemetery on the 13 th.

Waterworth, Robert, musician, who published "Original selection of Psalm and Hymn tunes, chants, and responses," Halifax [1852].

Watlen, John, musician of the latter part of last and early part of the present century. He seems to have been originally in the narr, but afterwards became an assistant to Corri and Co., music-sellers, Edinburgh, previous to 1788 . He next eommenced business as a tuner, teacher, and music-seller, on his own account in the North Bridge, Edin-
WATSON.

burgh, but failed in 1798, and subsequently went to London and started business in Leicester Place, Leicester square. He was the first secretary of the Edinburgh Musical Fund, established in 1790. Compiler of "Celebrated circus tumes, performed at Edinburgh. . with the addition of some new reels and strathspevs, set for the pianoforte or riolin and bass," Edinburgh, n.d. [1791]. He also issued a "Collection of old ścots songs," 1793, published in 12 parts; "Watlen's Complete collection of Sicots songs, plain and simple, without being Italianized in the least ..," 1796 . Watlen altered a reel of Robert Petrie's to form the melody usually sumg to Burns" song, "Comin' thro' the Rye." His compositions include Lord's Prayer, anthem; Amma, song; Sonata for pf. or harpsichord and violin, Edinhturgh [1798] ; Graud sonata for pf. and violin, op. 9, London [1800]; Edinburgh, grand naxeh for pf.; Glorious battle of Trafalgar, pf. (1805), etc.

Watson, Alfred Reuben, viohinist, composer, and conductor, lorn at Nottingham, July 22, 1845. Studied under T. Leeson selby, and the late Henry Famer. Joined the orchestra of the Theatre Ruyal, Nottingham, in 1871, and in 1876 succeded Mr. Leverton as musical director, a position he retained until 18ss. Inring that period he composed and arranged the whole of the music for the pantomimes produced there. He conducted the first fortuight's performances of Byron's "Sardanapalus," when it was produced at the old Dulie's Theatre, London, 1878, and eondneted the concerts at Woodhall Spa, Lincolnshire, 1891-2-3. His principal composition is a comie opera, "Geraldine" (libretto by Edyar Wyatt), which was produced at Nottingham, September 5,1897 , and which met with much success at Brighton, Bimingham, Dublin, and elsewhere during the following year. He has also written music to varous plars; for the Manchester Theatre Royal Pantomime, 1889; a great number of pieces for riolin and pf., and some church music.

Watson, Menry, organist, pianist, composer, and conduetor, horn at Bumley, Lancashire, April 30, 1846. Studied music privately. Graduated Mus. Bac., 1852; Mus. Doc., 18s7, Cambridge. Has held several organ appoincments, the last being at the Congregational Church, Withington, Manchester. Fstablished in 1867 (with Henry Wilson), the Manchester Tocal Lnion, and on the death of $\mathrm{Mr}$. Wilson in 1885 , became conductor. He is also conductor of the Manchester Athencum IIusical Society; Gentlemen's Glee Club; and societies at Stretford and Stockport; and conductor of the Choral class at the Manchester Royal College of Music. 


\section{WATSON.}

His works include Psalm 103, for soli, chorus, and strings; cantata, The deliverance of Israel, for soli, chorus, and orchestra. Also an opera, Fair Rosine, Manchester, 1882; A Shakesperian cantata, 1890 ; Music to Antony and Cleopatra (for Lonis Calvert, Manchester, 1897); Part-songs, songs, ete.

Watson, James, amateur composer, born at Glasgow, June 10, 1816. He identified himself with the Free Church movement in Scotland, and in 1845 he entered the fim of Nisbet and Co., publishers, London, as a partner. He died at London, September 1, 18s0. He aided in the compilation of "P'salms and Hymns for Divine Worship," 1867; and composed the hymn tume "Holyrood," generally included in scottish collections.

Watson, John, composer and pianist of latter part of 1 sth and beginning of 19th centuries. He was composer to Covent Garden Theatre, London.

Woriss.-P'ide shall have a fall, nutusical comedy by (i. Croly, Covent Garden, 182t. Musical IIoralist, containing a collection of songs and hymns. London [1805'. Royal ['salmist, or siucred melodies. . London [1825]. Six farontite dances, pf. Songs and instrumental music.

Watson, Thomas, poet and musician of the 16th centuly. Hedied in 1592. Composer of "The first sett of Italian madrigals Fuglished, not to the sense of the original dittie, but after the affection of the noate," London, 1590 .

Watson, Winiam Michael, componer and poet, form at Neweastle-on-Tyne, July 31, 1840. He originally studed painting it Leigh's School, Jourlsin, along with Fred. Wallire, II. S. Marks, and others, but in 1860 he adepted numsic as his profension. In 18483 he established the West Find Schmol of Music at London. He died at Last Dulwieh, London, Octoleer:?, 1869.

Works.-Maddin, cantata, 1855. Songs: Atfoat; Anchored; Blunh rune; My eomentry calls ne; Powder monliey (1s-4); "Qualker"s danghter: Somclody's pride; Talimman; Winter story, ete. Part-songs and lf. music. He composerl under the piendonym of Jules Farre.

Watts, John, organist and composer, was bor: in f7ro. Teather and arranger of mmise in London. 1)ied in Lanuleth, London, October 16,1 s.5t. He arranged Handel's 18 orertures for pf. or organ 18y4 ; Mozart's fuartets for pf., and edited much instrmmental musie of various linds.

Watts, Joseph Virgo, orgmist and composer, born at Wotton-mader-Hidge, (iloncester, June 27, 1822. He studied music under. Hullah, Mainzer, aud (r. W. Martin. Subseruently he lecame organist at Chromball, lyduey, and Berkeley, all in Gloncestershire; then hele
WEBP.

appointments successively at Midsomernorton (Somerset); Box Parish Church (Wilts.); All Saints' Chapel, Path; Kensington, etc. Afterwards he beeame choir-master of the Abley Church, Bath, from which he retired in 1885. He composed some church music, and published "Original IIymm-Tunes, chants, kyries, and chant services," 1876.

Watts, Thomas Isaac, organist and composer. Studied at R.A.M. Graduated Mus. Bac., 1886; B.A., 1887; М.A., 1891, Cianbridge. F.Ii.C.O. He was Choral Scholar of Queen's College, Cambridge, 1884-7; and in 1887 was appointed organist, choir-minster, and assistant master, Trinity College, Glenalmond, N.B., where he still remains. His compositions are: Ps. 19, for tenor solo, chorus, and strings; Ode, The Ages of Amond, written for the 5oth anniversary of the foundation of Trinity College, Glenamond, 1892; an evening service, hymn tunes, ete.

Waud, John Haydn, contrabassist and violoncellist, born in London, March 9, 1848; Principal donble-bass at the Alexandra Palace, 1876; of the Glasgow Choral Union orchestra for many vears; and member of the Philharmonic and Provincial Festival orchestras; prineipal double-bass, Bimingham Festival, from 1891. Musical director at the Garrick Theatre, and professor at G.S.M. Anthor of a Progresive Tutor for the Fonble-Bissi, London, Angerner, 1 s! 5.

Waylett, Mrs. Harriett, bom Cooke, soplanu vocalist, was lourn at Bath, February 7. 1s00. She studied nuder Loder, and first alperaped at Bath in 1s16. In 1819 she married a $2 \mathrm{H}$. Warlett, but separated from him in 1820. She afterwards married Geo. Alex. Lee, the enmposer. She first appeared in London in 1820; at Irululin in 1826; and she afterwards sang at all the principal London and provincial eoneerts. She died at Londom, A pril $26,1851$.

Weale, William, or Wheall, organist and componre, wals organlist of st. Paul's, bedford, fron about 1715. Mus. Bac. Cantah., 1719. He died at Bedford in Angnst or September, 1727. Composer of the palm tune "Bedford," etc.

Weatherly, Frederic E., poet and com-

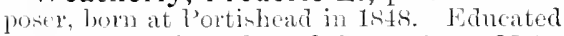
at Oxford and graduated I,.A., 1871; M.A., 1874. Trutor in ()xford. Best known as anthor of many of the most popular songs, cantatas, ete. of the present day. He has lrinself composed a mmmber of songs, chiefly to his own words.

Webb, Daniel, atuthor and musician, born at Taunton in 1735. Died at Bath, August 2, 1815. Author of "Observations on the Correspondence between I'oetry and Musie," Loudon, 1769 (Anon). Peprinted in his "Niscellanies," 1802. 
WEBB.

Webb, F. Gilbert, organist, composer, and eritic. Studied under H. F. Frost. Has been for some rears organist of st. Lulse's, Brompton, London. Is chiefly devoted to musical literature, and has read papers before the Musical Association, etc., contributed to the Musical Horld and other periodicals; and is much associated with musical criticism. He has composed chmreh music, songs, pieces for violin and pf., ete.

Webb, Francis, anthor of "Panharmonicon, an illustration of an engraved plate, in which is attempted to be prosed that the principles of Harmony more or less prevail thronghont the whole system of nature, but more especially in the himan frame," London [1815]

Webb, George James, organist and composer, born at Rushmore Lodge, near Salisbury, June 24, 1803. He was tanght music by Alex. Lncas, of Salisbury, and afterward. became organist at Falmouth, but resigned in 1830, when he went to the Cnited States. He was appointed olganist of the old south Church, Boston, Mass., and took an active part in the musical life of that city, being president of the Handel and Haydn Society in 1840. In 1870 , he went to Orange, New Jersey, and from 1876 , resided in New York as a tercher. He returned to ()range in 1885 , and died there, October $7,18 \mathrm{~s}$ T. Author of "Voeal Technics," Boston, n.d., and "Voice Culture," with C. (r. Allen; and editor of "Yonng Ladies' Tocal Class Book," Boston, 1853; "Glee Hive" (with L. Mason); "The Odeon,"1840; "New Odeon" (with I. MLason); "Cantica Laudis" (with Mason), New York, 1850. He composed a number of anthems, the well-known hrmm, " IIorning Light," etc.

Webb, Rev, Richard, M.A., clergrman and musician, was a minor eanon of St. Panl's, London. He died near Windsor. April 13, 1829. Pullished "A Collection of Madrigals for $8,4,5$, and 6 roices, selected from the works of the most eminent composers of the 15th and 16th centuries," London, 1808. Collection of Madrigals for 3,4 , and 5 voices, London, 1814. Composer of a Set of four (ilees for 3 voices, London, n. d.

Webb, William, organist and composer of 1 sth century, who was choirmaster and organist of St. George's Chapel, Windsor. He died in 1788 , from loss of blood, atter modergoing an operation for removal of a wen in the nostril. He was nearly seventy years of age.

Webbe, Samuel, composer and organist, was born at Minorea, in the Balearic Istands, in 1740 . His father was a government official there. He was principally self-taught in music, but he had some lessons frum Charles Barlondt. He married in 1763 . Chapelmaster in Portuguese Chapel, London, 1776.
WEBSTER.

Secretary to Noblemen and Crentlemen's Catch Chub, 1794. He died in London, May 25, 1816, and is buried in the Roman Catholic part of old St. Pancras chnrehyard.

Works. A Collection of sacred Musie, as used in the Chapel of the King of Sardinia in London, London, 1r.d. A Collection of Masses; with an accompaniment for the organ.... London, 1792. A Collection of Notetts or Antiphons, for $1,2,3$, and 4 voices, London, 179.. Fight Anthems hy Samuel Weble, the organ parts by V. Tovello, London, n.d. A Collection of original Pralm Tumes for 3 and 4 voices, by s. Webbe, Senior and Junior, London. Glees: A relection of Glees, Duets, Canzonets, ete., published at different periods from the vear 1761 , to which are added many new glees and canzonets never before published, London, 3 vols. A Collection of Catches, Canons, and (ilees, London, 9 vols. six original Glees, London, 1840. Single Glees: Breathe soft, ye winds; Cecilia, more than all the muses skilled; Cone live with me; Come, rosy health; Iniseord, dire sister, 1771: Glorions Apollo; Great Apollo, strike the lvre; Great Pacchms, 1 ) aid us; Hence, all ve vain delights; Hail, stal of brumswick; Mighty conqueror of hearts, 1775; Swiftly from the monntain's brow, 1788 ; Thy voice, $O$ hamons; When winds breathe soft. Those dated are prize glees. Dnets, songs. Concerto for harpsichord. Pf. music, ind other works. The well-known hymn tmes, "Melcombe," and "Benerento," are by him.

Webbe, Samuel, Junr., composer, writer, and organist, som of the above, horn at London in 1770. He studied under his father and Clementi. Organist successively of the Unitarian Church, Paradise Street, Liverpool; Spanish Ambassador's Chapel, London; St. Xicholas' Church, and st. Patrick's R. C. Chapel, Liverpool. He died at Hammersmith, London, Nurember 25, 1843.

Works. Collection of Palm Tunes, intermixed with airs adapted as such, fir fom roices, London, 1808. (tlees, duets, ete. Convito Amonico, a collection of madrigals, elegies, glees, canons, (atches, and dnets, selected from the works of the most eminent composers, London, 4 rols., n.d. L'Amico del Principiante, being os short sol-faing exercises for a single roike, London, n.d.; 'und edition rdited by J. B. Sale. 42 Vocal Exercises..n.d. Short exercises for young singers ..n.d. Harmony epritonined, or elements of the thoronghbass, London, n.d.

His som, Egertox Webbe (born Liverpool, 1810; died there June 24, 1840 , wrote many valuahle papers on musie for the early number's of the Mrisical Horld.

Vebster, Clarinda Augusta, pianist, born in London. l bughter of the late Robert Thomson, M.R.C.S., L.1).s., of London. She 


\section{WEBSTER.}

was musically educated in London, and went to reside in Scotland after her marriage. In 1860 she established the Aberdeen Mnsic School, and gave herself up to the work of musical education. As the onteome of her theoretical teaching she published the "Groundwork of Music," two looks; and the "Child's Irimer of the Theory of MIusic," Norello. Anthor of "Handel: an outline of his Life," and lecturer on I'jano Technic. Mrs. Webster is now resident in London, but is still Principal of the Aberdeen School, which she frequently visits. She is a Licentiate of the R.A.M. for pf., as professor and teacher.

Webster, Richard, composer and teacher, was born at Huntley, Gloucestershire, in 1783. He was a teacher and pianist in Glasgow, where he died, on December 26, 1849. Composer of varions glees, songs, etc., some of which are contained in "Lyric gems of Scotland." His best known song is "Pomnio Jeanie Gray." "Oh, not upon so cold a shrine," another song, is contained in "The Westem Garland," 18:32. He composed some instrumental music. Introduction and polonaise rondo, for pf., op. 1, etc.

Weekes, Samuel, organist, pianist, and teacher. sindied at R.A.M., and cleeted an Associate. Graduated Mus. Bac., Cambridge, 1873; Mus. Doe., Dublin, 1896. F.1R.C.O. Organist of St. Peter's, Hammersmith, 1861-2; Baptist Church, Plymouth, 1876, to present time. Conductor of Plymouth Choral and Orchestral society ; l'rincipal of Music School, Stoke, Devmport. Author of a Choral primer, and Questions on Acoustics. Compositions: Cantata, Bless the Lord, for soli, chorus, and orchestra; Hymm tmmes, songs, pf. pieces, ete.

Weelkes, Thomas, organist and composer of latter part of the 16ith and early part of the 17th centuries. Yery little is known abont his biography. In 1600 he was organist of Winchester College; in 1602 he graduated Mus. Bace at Oxford, and in 160 s he was organist of Chichester Cathedral. Neither his birth or death dates seem to have been preserved.

Works.-Madrigals to $3,4,5$, and 6 voyces, London, 1597; also edited by J. J. Hopkins for the Musical Antiguarian Society, London, 1843. Ballets and nuadrigals to five voyees, with one to six voyces, 1598 . Madrigals of five and six parts, apt for viols and voices, 1600. Madrigals of six parts, apt for the viols and voleces, London, 1600. Ayres or phantasticle spirites for 3 voices, with a song, a rememlinance of my friend $\mathrm{Mr}$. Thomas Morley, for 6 voices, Londom, $160 \mathrm{~s}$, 3 parts. Contributions in Lejghton's "Teares"; Anthems, etc., in thr collections of c'lifford and Rimbalt; MS. Music in British Musenm, etc.

\section{WELDON.}

\section{Weichsell, Elizabeth, see Billingtor,} Elizabeth.

Weir, John, musician of first part of present century, who was a teacher of music in Glasgow. Compiler of "A Collection of Psalm tumes and Anthems," Glasgow, n.d.

Weiss, Willoughby Hunter, bass singer and composer, born at Liverpool, April 2, 1820. He gave his first concert at Liverpool, May 5, 1842. His first stage appearance was as Count Rodolfo, in "La Somnambula," at the Princess" Theatre, 1843; and he was for year's a member of the Pyne and Harrison company. He was heard in the title part, in "Elijah," at the Bimingham Festival, 1867. As a vocalist he had a great reputation. He died at London, Octoher 24, 1867. Composer of many songs, among which may be named:-Autumn leaves; Bowmen of old England; Crimes of England; Crossing the moor; Fisherman's cottige; Gleaner; The ice, the ice!; Kniglut's vigil; Let me be near thee; Mid watch; Mower; O salutaris hostia; Tiolling home across the sea; Shipwreck; Twenty years ago; Village blacksmith (Longfellow) [1858]; IVatcher by the sea; Wreck of the Hesperus; Vreck of the homeward bound, etc. He was married to Georgina Ansell Barrett, a soprano vocalist, who was born at Gloncester in 1826, and died at Brighton, November 6, 1880 .

Welch, John Bacon, teacher of singing, born at Pattishill Vicarage, Northampton, December 26, 1839. Studied in London, and in 1861 went to Milan, where lie placed himself under Gaetano Nava. His voice was a baritone, and he sang in public for a short time. It was as a teacher, however, that he excelled. He was a professor at the G.S.M., and had many private pupils, among the most distinguised being Miss Anna Williams, Miss Annie Marriott, Messrs. Bridson, Brereton, and others. He gave concerts at Princes' Hall, 1887, etc. He died in London, July 1, 1887 , and was buried in Highgate Cemetery.

Weldon, Georgina, bom Treherne, soprano vocalist and writer, born in London, May 21, 1837. She studied under her mother and Jules de frlimes, and gave concerts in Canada, and afterwards in London. She organized a training school for vocalists in 1871, and lectured and sang in Bimningham and elsewhere, 1882-1886; but for a number of years past she has not been professionally connected with music. Author of "Musical reform," London, 1872: "Hints for pronunciation in singing, with proposals for a self-supporting academy." London, 1872. "Antobiographie de Ch. Gourod.." London, n.d.

Weldon, John, composer and organist, boru at Chichester, January 19, 1676. He studied under John Walton, of Eton C'ollege, 


\section{WELLINGS.}

and H. Purcell. Organist of New College, Oxford, 1694. Gentleman extraordinary of Chapel Royal, June 6, 1701. Organist of Chapel Royal, 1708. Second composer to Chapel Royal, 1715. Organist of St. Bride's, Fleet Street, and St. Martin-in-the-Fields, London, 1726. He died at London, May 7, 1736.

Works-Cperas: Agreeable disappointment, 1715; Fair Unfortunate, 1710; Judgment of Paris (masque), 1702; Orpheus and Eurydice, 1710; she would and She would not, 1703. Divine Harmony, six select anthems for a voice alone, with a thorowbass for the organ, harpsiehord, or arch lute.... performed by the late famous Mr. Richard Elford, London, n.d. Hear my erying; In Thee, O Lord; O God, Thou hast east us out; Who can tell how oft he offendeth, anthems. Collection of New Songs performed at his eoneert in York Buildings; Collection of new Songs [1707]; Collection of Aires for 2 flutes and a bass, London, 1710. Somys: Au amorous swain to Juno pray'd; As the snow in valley lying; Clarinda; Let ambition fire thy mind; Wakeful nightingale.

Wellings, Joseph Milton, composer, born at Handsworth, near Birmingham, December 4, 1850. Of his larger works, a sketel, "The Dancing Master," was produeed at the Criterion Theatre, London, February, 1894. His songs inelude Golken Love, At the ferry, I wait no more, Some day, My bonnie boy, Only a rose, You sang to me, Be mine again, Iou know best, old fashions, and many others, most of which have had a wide cireulation.

Wells, Alfred, flutist, pupil of William Card, made lis debut at a concert of the Soeieta Armonica, June 3, 184t, he then being eleven years old. For many years he was a member of the Crystal Palace orchestra, and distinguished as a soloist, especially in the coneertas and suites of J. S. Bach. His death, January 1, 1892, was the result of a fall down stairs, at his house, in London.

Wells, Benjamin, flutist, born at Cambridge in 1826. Studied at R.A.M., under Richardson and Clinton, and appeared with great suceess at an academy eoncert in April, 1845. He was eleeted A.R.A.M, and was for years a professor at the Aeademy. In later year's be has heen more widely known as a lecturer on musie.

Wells, Madame Thaddeus, eontraito voealist, born early in the present centary. She sang at many important concerts in her time, lut lattery had dropped ont of notice. She died at London in Marcly, 1885.

Wells, Wallace, tenor rocalist, horn at Dilham, Norfolk, 1842. Edreated at R.A.M. Sang at the Saered Harmonic, and other Lon-
WESCHÉ.

don eoncerts; Birmingham Festival, 1879, in Rossini's " Moses in Foypt," ete. Principal tenor at Marylebone Rectory Church, and for thirteen years at st. Andrew's, Wells Street. Professor of Singing at G.S.M., and other edueational institutions.

Welsh, John, musician of latter part of last eentury, issued "Saered Hamony. . eonsisting of psalm and hymn tunes," London 1800 .

Welsh, Thomas, bass rocalist, teacher and composer, born at Wells, somcrsetshire, 1770. He was a chorister in Wells Cathedral, and also studied under J. B. Cramer and Baumgarten. First appeared in opera in Att. wood's "Prisoner," 1792. Eugaged by Linley to sing in oratorio at Haymarket Theatre, London, 1796. Gentleman of Chapel Royal. Celebrated as a vocal teacher in London, and numbered among his pupils John simelair, Charles Horn, Miss Stephens, and Miss Mary Anme Wilson who became his seeond wife. He died at Brighton, Janualy 31, 1848.

Works. - Music to "The Green Eyed Monster" ; Twenty years ago, 1810; Kamschatka, and other dramatic pieces. Somatas for $\mathrm{pf}$. [1819]. Part-songe, glees, and duets: Hark, 'tis the whistling wnd; Come, jorial friends; Fairy feast; Hence, away! ye sirens; Nery gipsies; Shed not yourweets. Songs: Harry Bluff, ete. Vocal Instructor, or the art of singing exemplified in fifteen lessons leading to forty progressive exercises, I ondon [1825].

His wife, bom MARY AxNe WILsox, Was a native of London, born in 1802. She studied moler her husband and first appeared as Mandane in Arne"s "Artaxerses" at Drury Lane, Jannary 18, 1821. She sang in many important concerts in ber day as a soprano, and died in 1867 .

Wensley, Frances Foster, pianist and compuer, who studied under Kalkbrenner. the married Alderman Garrett. Composer of "Four Songs" [1823]; variations on "God save the Oueen," etc.

Wesché, Walter, composer, piarist, and organist, born at Colombo, Ceylon, August 26, 1857. Studied under Oscar Beringer and Berthold Tours, and orchestration under F. H. Cowen. In 1879 he was appointed organist and choirmaster at the Loek Chapel, Pad. dington; then to St. Thomas's, Westbourne Grove; and, 1891, to St. Stephen's, South Hampstead. He is professor of hamony and composition at the Academy for the higher development of pf. playing (Osear Beringer); and professor of pf. at the Royal Normal College for the Blina, Norwood. He has given organ recitals at Gresham Hall, 1882; the Bow and Bromley Institute, 18-3, ete., but is now ehiefly engaged in teaching.

Worrs.-Orchestral: Symphony in C minor; Rhapsodies in $\mathrm{F}$ and $\mathrm{G}$; suite op. 18 , 
WESLEY.

prize, Westminster Orchestral Society, performed, March 16, 1ny2 ; Ballad, The Legend of Excalibur, Crystal l'alace, March 3, Is9t; Romance, Nellonme (Cowen), December 10, 1885. Concerto in A, 18.46; Andante and Allegro; both for pf. and orchestra. Overture, Dagmar, organ and orchestra, 1881. Idyll, organ and strings. Quintet in E minor; Trios in E flat and E minor for pf. and strings; sonata in B flat, pf. and violin; in E flat, pf. and 'cello. Canzonetta for' cello. Three Dances, pf. 4 hands. Three Rhapsodies, pf. solo, etc.

Wesley, Charles, organist and composer, born at Bristol, Deeember 11, 1757. Sin of the Rev. Chanles Wosley, and nephew of John Wesley, the Methodist leader. He studied under Roolie, Kelway, and Boyce, and became a teacher in Lndon, and organist of St Creorge's, Hanover Square. Organist in ordinary to George IV. Hegavesubscription coneerts at his louse in London. He died at London, Nay 2.9. 16:34. Composed "A Set of Eight Songs," 17xt; "A het of Nix roncertos for the Organ or Harpsichord"; Anthems in Page's "Harmonia Sacra," hymms, ete.

Wesley, Rev. John, 'lergyman and amatem musician, bom in 1703 , died in 1791 . The celelsated fom der of the Werlevan Methodist bods. He issized "A f ullection of Tumes, set to mmite as they ale commonly surge at the Fomndery," 1742 , and belonged to the sane fanily as the Weslevs, Charles, Samuel, ete., so celebrated in music.

Wesley, Samuel, orgunist and composer, born at Bristol, Felsuary 24, 1766. Hrother of Charles. He gave very early indications of a disposition for music, and wats a puptl of his brother Charles. From an early age he excited great interest among muscians by his extraordinary genius for nmis. He becane the greatent organist of his time, and was the first Englinhnon to nolie known the nunic of Bach. He was deputy momint for a time of the Abhey Chareh, Bath, and on coming to London as a teacher, he Jee anne organist of Camden Chapel, in 1824. He died at London, October 11, 1837 .

VVorks. Chaneh servere in F. Anthems and Motets: My soul hath patiently; Thou, O Grod, art praised in Zion; I rajd, J will take heed to my ways; loxit lmminns; Exultate I)eo; he exitu Istatel and other church music. Original Hymn Tures adapted to everv metre in the collection of the Rev. J. Wesley, London, n.d. Sunatas for pf. Organ volumtaries, fugues, ete. "O, svege unto $13 y$ romedelate," madrigal, ete. 'The Misanthrope, opera (MIS.). Letters of Samuel Wenter to Mr. Jacols, relating to the introdaction into this comentry of the works of Jach, edited by E. Wesley, Lomdon, $1 \times 78$.

Sere also "An accomnt of the remarkable
WEST.

musical talents of several members of the Wesley family, collected from original MSS. with nemorial introduction and notes by W. Winters," London, Is74.

Wesley, Samuel Sebastian, organist and comproser, born at London, Argust 14, 1810. Son of the preceding. He was a chorister in the Chapel Roval, and held in Londun the appointments of organist of St. Jannes, Hammetead Road, 1827; Sit. Giles', Camberwell, 1529; and st. John's, Waterloo Roud, and Hanpton-on-Thannes. He was afterwards successively organist of Hereford Cathedral, 1832; Exeter Cathedral, 1835; Lecds l'arish (hurch, 1842; Winchester Gathedral, 1849; (iloncester Cathedral, 1865. He graduated Mus. Siac, and Mus. Doc., Oxor., 1893. The died at Gloncester, April 19, 1876 , and is lmied in the old Cemetery, Ister, and a tablet in the Cathedral there notes his commetion with the town.

Works. Chmoh services in $\mathrm{F}$ (1845), F, $F$ (chant), aud G. Anthems: Ancribe unto the Lord; All go muto ore place; Blessed be the Lord; Blesiced lee the God and Father; Cast no not away; Give the King thy judgunents; (ilory be to frod on high: frod be mereiful; I an 'Thine; I will arise; Let us lift np onr heart; Man that is born of a Woman; Ogive thanks; () God, whose nature; O Lord, my (iod; O Lord, Thon art my God; Praise the Lord: The face of the Lord; The wi]derness: Thon wilt keep him in perfect peate; Wash ne thromghly; etc. The Psalter, with Chants, arranged for Daily Moming and Evening service, Leeds, 1843. Glees and l'art-songs: At that dread hour; I wish to tano my quiv'ring lyce; thall I tell ven whone 1 kove?; When fierec conflicting passions; ete. Songs: The butterfly; Orphan homs the rear is dead; There be none of leauty's dainghters; Wert thou like ne; ete. Organ: A studio for the Organ, exemplified in a series of exercines; Air composed for the Jolsworthy Chmoreh Bells; Andantes in G, A, E) minor, etc. Two sets $(6$ pieces) of Organ Pieces, ete. Melodia Sacra, Hamel's airs arranged for lif. The English Cathedral Service, its glory, its decline, and its designed extinction, Lomdon, 1845. A few words on Cathedal Mlusic and the musical system of the church, with a plan of reforms, Jondon, 1849. Selection of Psalms and Hvmns, aranged for the pulslic service of the (hurch of Fugland, ly the Rev. Charles Kemble, rector of l'ath, London, 186t, editer. The hymu-tmos "Anrelia," "St. Sebastian," "Badford," ". Wimbledon," etc., were also composid by Wesley.

West, Benjamin, organist and composer, of 1 sth century. Composer of "Sacra concerto, or the voice of melody, containing an introduction to the grounds of music, also 


\section{WEST.}

forty-one psalm tunes aud twelve anthems." London, 1769. 2nd edition.

West, George Frederick, organist, composer, and writer, born at Bath. In 1844 he was organist of St. George the Martyr, Southwark, in which year he published "The National Church Service" (12. Cocks). Anthor of "Questions relating to the theory of music" (London, 1864); Hints to young teachers of the pianoforte" (R. Cocks), and other works. He has written and arranged an immense amount of music for pf., chiefly of an educational type.

West, Henry, composer and writer. Autlor of "Singing Preceptor," London, 1846; "Accoldian 1'peceptor," London, 1846; Preceptor for the accoldion or flutina, London [1855]. Composer of Pretty little songs for pretty little sungers, a collection of nursery rhymes. Pf. music, songs, ete.

West, John Ebenezer, organist, composer, and conductor, born at South Hackney, London, Decomber 7, 1863. Som of William and Clara West (noticed below). Received his early instruction from his parents, later studying organ under Dr. J. F. Bridge, and composition at R.A.MI. under F. Pront, F.R.('.O. In 1894 he was appointed organist and C.M. of St. Mary's, Berkeley Square; and since 1891 has held sinilar positions at Sonth Hackney Parish Church. He has given organ recitals in various places, and is also known as a pianist. He is one of the musical advisers to the firm of Novello, Ewer and Co.

Morks.-C'antatas: The Healing of the Canaanite's Daughter, Hackney, Decenber 20, 1882; Seed-Time and Harrest, Choral Festival, St. Mary's, Newington, October 12, 1892; Psalm 130, N.E. London Choral Society, Jaunary 31, 1891. Anthems: The Lord is exalted, St. I'aul's Cathedral, May 24, 1883 ; Lord, I eall npon Thee; and others. Festival Evening Service in $\mathrm{E}$ flat, composed for Festival of London Church Choir Association, St. Paul's, 1890; Evening Service in A; Te Deam in B flat, etc. Songs, part-sollgs, incidental music to Longfellow's King Robert of Sicily (for declamation), Queen's Hall, October 8, 1896. Overture in E minor, 1881; Victoria, our Qneen, 1897, march, both for orchestra. Sonata in I minor, 1895 ; Fugue in E minor; Narch in G; Postlude in B flat, etc., for organ.

West, Rev. Lewis Renatus, clergyman and amatenr composer, born at London, May 3, 1753. He belonged to the Moravian brethren, and was in charge of the congregation at Dublin in 17\$4. He subsequently held other charges in Ireland and England in connection with the Moravian body. He died at Tytherton, Wiltshire, August 1,1826 . He composed some lyymms and other music for the Church Service.

\section{WESTBROOK.}

West, William, composer, teacher of singing, and lyric author, born at Hackney, London, September 17, 1830. He comes of an old Wiltshire family. His father was a musician, and his mother's father was the Samuel Hayter mentioned in the notice of Aaron Upjohn Hayter (q.v.) His early studies were devoted to singing, but his delicate organ gave way throngh over exertion, and he then gave himself un to teaching. In 1863 he founded the North-Fast London Academy of Music, which has been a successful and useful institution. For fifteen years he was organist of the Congregational Chureh, Bethnal (ireen Road, resigning in 1885 , and holding for a time a similar appointment at Hackney. He has composed hymn tunes, chants, Sanctuses, ete. Songs: Speak gently of the crring; Casabianca; Were I a little bird; The Christian's song; Life in Love; The Rivals (a proverb song); and others. His first pf. pieces, Welsh air, Cotillon, Fall of I'aris, duets, were written at the age of seven. Others are Le Garcon Volage, Sophie, valie, maznrka brillant, and varions operatic trinscriptions. He is the author of a number of lyrics, set by liis son and other composers. II is sister is the wife of Professor Prout.

MADAME Clara West, his wife, is a soprano rocalist, born at ('hathan, september 9, 18t4. Her maiden name was Ainsworth. She studied under her hushand, and Madame Rudersdorff. An excellent musician, she first came into notice about 1876 , through her ability to fill the place of other vocalists in inportant works at a moment's notice. She was long associated with the concerts of the Borough of Hackney Choral Association, and has sming throughout Great Britain. Invitations to visit America have been declined.

LotTIE WEst, daughter of the preceding, was born at Soutl Hackney, Novemuer 5, 1865. She is a contralto vocalut, pianist, and teacher. Received her musical ednca. tion chiefly at home, lut became a sudent for a time at the R.A.M., studying singing with Edwin Holland. Whe sang at concerts in London and the provinces with success from 188., but since her marriage to Mr. Millard she has practically retired from the concert platform. She is the composer of some songs, and a sketch for violin and pf.

Westbrook, William Joseph, composer, organist and writer, was born at London, Jannary 1, 1831. He was organist suecesively of Sit. Bartholomew, liethnal Green, 1849 ; St. Bartholonew, Sidemhan, 1851-84; and Crystal Palace (co-organist), 1860. From 1865 to 1878 he was ronductor of the Scuth Nolwood Musical Rociety, and he was also musical examiner to the college of Preceptors. 


\section{WESTLAKE.}

Mus. Bac., 1876, and MIus. Doc., 1878, Cambridge. With A. W. Hammond and John Crowdy he established the Musical Standard in 1862 . He died at sydenham, London, on March 24, 1894.

Works.-Jesus, oratorio, 1877 ; also Goldsmith's 1nstitute, London, 1892. The Lord is my shepherd, cantati, 1875. Serviees in G, D, ete. Anthems. Part-songs and trios; Songs, and other voeal music. Sonatas for organ in E flat, (;, ete. Voluntaries. The Organist, 1876, ete. ; Young Organist ; Practical Organist; Organ Journal; Ancient and Modern Fugues, 1565-80; New organ arrangements, and many similar eollections for organ and harmonium. Elementary Musie, a priner, London, 1879. Pratieal Organ Tutor, London, 1872 , ete. Alphalyet of Inusical Notation, London [1873]. Translations of De Beriot's, Dancla's, and Alard's Violin Sehools, and many other works.

Westlake, Frederick, composer and pianist, born at Romsey, Hants, February 25, 1840. Studied at R.A.M., 1855-9; eleeted Associate, then Fellow. Professsor of pf., R.A II., and Nember of the Philhamonie Society. He has played in publie with suecess, and at one of H. Holmes's " Musical Evenings" (St. George's Hall, October 22, 1873), performed, with Miss Channel, Chopin's Rondo, op. 73, for two pianos, probably for the first time in London. Teaching now chiefly oeeupies his time.

Wurks.-Mass in E flat; Mass of the IJoly Name, produced, Brompton Oratory, November 26,1893 (for voiees, orehestra, and organ). O Salutaris; Kyrie and Gloria (with orehestra); the first named sung by leslie's Choir, February 22, 1883. Tunes contributed to Hymns Ancient and Modern. She divelt among the untrodden ways; Evangela; and other songs. Part-songs, Lyra Studentium, etc. Duo Concertante, pf. and 'cello. Allegro con forza; Fugue in octaves; a set of nine episodes for pf. Completed Sterndale Bennett's edition of 13ach's 48 Preludes and Fugues.

Westmoreland, Jolin Fane, Earl of, known as LorI BURGHERSH, amateur composer, horn at London, Februiry 3, 1784. He entered the army in 1803, and became envoy at the Court of Florence in 1814. He studied music under Hague, Mayseder, PortogalJo, and Bianclii. He succeeded to the title in 1841. In 1841-51 he was the British Minister at Berlin. Ile established the Royal Academy of Music in 1822, and in 1861 a Scholarship was founded in his memory. He died at Apthorpe Honse, October 16, 1859.

Works.-Oprerus: Bajazet, Florenee, 1821, London, 1822; L'Froe di Lancastre, R.A.Al. pupils, 1826 ; Lo Scompiglio teatrale, Florence, 1836, published 1846; Catarina, London, 1830,

\section{WESTROP.}

also in English as Catherine, the Austrian eaptive; Fedra, Florence, 182s, pnblished at Berlin in 1848; Il Torneo, Florence, 1826, Loudon, 1838; Il Ratto di Proserpina, 1845. Three symphonies for orchestra; Quartets for strings; Pf. musie, ete. Cathedral Service, 1841 ; Messa Solenne. 1858; Requiem to the memory of Samuel Webbe; Six cantatas of Metastasio for solo voice and pf., 1831. Madrigals, glees, single songs.

Westrop, East John, composer and editor, born at liavenham, Suffolk, in 1804. $\mathrm{He}$ was a teacher and editor in London. $\mathrm{He}$ died at London, in 1856.

Works.-Domestie Psalmody, a selection of modern tunes for 1, 2, or 3 voices, 1851 . Carmina Saera, London, 1857. 100 Little Songs for little singers, Lnndon, 1857. Normal Singer, 1557. 200 Psalms and hymns, 1859 (with Wade). Eniversal Psamodist. London, 1856. Musical Serviees of the Church of England, for 4 voices, London [1845], 4 vols. The Antiphonal, a collection of anthems, 1856, etc. Comproser of quadrilles, miscellaneous pf. musie and songs.

Westrop, Henry John, conposer, violinist, organist and conductor, born at Lavenham, suffolk, July 22, 1812. He was orgunist suecessively of st. Stephen's Norwich; Little Stanmore, 18:31; Fitzroy Chapel, London, 1833; St. Edmund the King and Martry, Lomberd street, 1834. He was also violinist at the Italian operal and Philhamonie Society; conductor of the Choral Harmonist's Society; and a member of the Philharmonic Society and Ruyal society of Mosicians. He died at London, September 23, 1879.

Wonks. Ilaid of Bremen, opera, in MS. Srmphony for orchestra, 18iss; Quintets for pf. and strings in E flat, $1 \$ 43$, and ( minor, 1844; Quartetto concertante, for pf. and strings, in A flat, op. $2[1850]$; Sonata for pf. and flute in F, op. 6 (18t6) : Sonata for pf. and viola in E flat; (nartets for strings in $\mathrm{E}$ and E flat (10]. 1, 1835, ete.) Allegro in E flat for pf. Anthem, () taste and see; Winter, descriptive eantata for hass voice and orehestra, etc.

His daughter KATE, who is a pianist and organist of much ability, sneceeded him as organist of St. Edmund, Lombard Street, a position she resigned in 1Ast. Composer of "Four short voluntaries for organ" (1885); songs, and other works.

Westrop, Thomas, composer and writer, brother of the above, was born at Lavenham in 1s16. Died at Londom, December 17, 1881. He edited "120 selected short anthems," London, 1861; Psalms, hrmms, cte., 1862; Eishteen selected rocal duets, London, 1863; sacred songs, 1sers. Eniversal violin tutor, 1862. Complete organ tutor, 1863. Composer of a large number of comic and other songs, hymms, pf. pieces, etc. 
WETTON.

Wetton, Henry Davan, organist and composer, born at Brighton, July 18, 1862. Received his musieal training at Westminster Abbey, and from private teachers. F.R.C.O.; Mus. Bac., Durham, 1891. Organist of All Saints', Stoke Newington, 1877; Christ Church, Woburn Square, 1884 ; St. Gabriel's, Pimlico, 1886-9 and 1890-3; sub-organist, Vells Cathedral, 1890; organist of Finchley Parish Church, 1892. In 1892, succeeded M. B. Foster as organist and musical director at the Fomdling Hospital. He is head of the musical department of the Northampton Institute, Clerkenwell. Has given lectures at T.C.L., etc. His compositions are Psilm 9, for soli, chorus, strings and pf.; Te I eum and Benedictus; Evening service for men's vioces; anthems, carcls, songs, pf. pieces, etc.

Weyman, David, Irish eollector, was vicar-choral of St. P'atrick's, Inbblin, 1819. He died at Dublin in August, 1822. l'ublished "Melodia Sacra, or the Psalms of David, arranged for 1, 2, 3, or 4 voices," Dublin, 1812-14. Sequel in 3 vols., 1810-52. New edition edited by J. Smith. Hvmus and psalms as sung in the Magdalen Asylum, Leeson Street..Dublin [1822]; Hymms and anthems as sumg in Protestant Churches and Chapels throughout Ireland..Dublin. Fifty of the psalms of I avid, Inublin.

Wharton, Edward, bass vocalist, and teacher of singing, burn in Bimingham. Educated at Dulwich College, and solo choir boy. Sometime choirmaster and assistant organist to Sir A. S. Sullivan at St. Peter's, South Kensington. Organ pupil of George Cooper. Gained the first prize for bass vocalists at the National Music Meetings, ('rystal Palace, July 3, 1875 . Appeared at different concerts, and took part in the performance of Liszt's "St. Elisabeth," given by Walter Bache, February 24, 1876. Joined the staff of the Guildhall Schrool of Music in 1881, and has been successfully conducting large classes there since that time.

Wliatmoor, Freeman, pianist, organist, and composer, born at Bradford, Yorkshire, 1856. Stadied under Dr. Spark, F. IV. Hird, and, also, at the National Training Scloool, Kensington, where he won a scholarship. llas held organ appointments at Leeds and Gateshead; sometime assistant to llenry Farmer, at Harrow, now resident at Watford, as conductor and teather, etc. In 1887, he won the Musical Worll prize for an organ postlude. Graduated Mus. B., Cambridge, 1892. He has published some school songs, part-songs, pieces for pf., organ, etc. He has given chamber concerts and lectures, at Hemel-Hempstead, 1887. etc.

Herbert IV. Whatmoor (a brother?) is organist of Christ Chureh, Roxeth; he is also
WHITAKER.

a pianist, and has given chamber concerts, llarrow, 1888, etc.

Wheall, see Weale.

Wheeler, Richard, composer and organ1st, who was a teacher in Camlridge. He issued "Six Glees for three and four voices," Cambridge [1800]. These were originally published in the collections of Dr. Charles Hague.

Whelan, Rev. Ernest Hamilton, organist and composer, graduated Mus. B., 1887; M.A., Dublin. Was organist suceessively of Malahide Church, near Jublin, 186s; Swords Parish Church, 1869 ; Sit. Andrew's, Dublin, 1875-6. Conductor of Dublin Diocesan Choral Festival, 1875. Curate of Powerscourt, 1876-83; Rector of Kilbride, Bray, 1883. He has composed a setting of Ps. 100 for five roices and organ; Hymn tunes in Irish Church hymnal, and Children's Hymnal; sacred songs, ete.

Whichello, or Wichello, Abiell, organist and composer, of the 14th century, was deputy organist to Philip Hart. He afterwards became organist of Church of St. Itdmund the King. Played at Britton's concerts. He died about 1745 .

Woris. - Apollo and l)aphne, cantata, 1730; Vertummus and l'onona, cantata. Sonys: Charms of beauty; Haste, haste dear youth; Heart that's bleeding; So many charms; Ye virgin powers. Lessons for the Harpsichord or spinett [17201].

Whishaw, Frederick J., tenor vocalist and composer, born in 1854. Reeeived his musical training in St. Peter-burg and 1 ondon. He has published an Album of Seven Songs (Reid); an Allum of Russian Songs (Lueas); and two Albums of Russian Songs (Buosey). He has sung at concerts in different parts of the comtry; but devotes himself chiefly to literature, and is author of a number of lyrics, tales for $\mathrm{j}$ venile readers, novels, etc.

Whitaker, John, composer and organist, was born in 1776 . He was organist of St. Clement, Eastcheap, luondon; and in $180 \mathrm{~s}$ succeeded to C. H. Purday's business as a music-seller in t. Paul's Churchyard. He died at London, I lecenaber 4,1847 .

Woriss.-Music for plays, etc.: Boarding school miss, burletta, 1800; (try Mannering (with Bishop), 1s16; Heir of Groni, 1R17; Iwanowna, 1815; Sweethearts and wives, 1812; Up to trown, 1s11; Who's to have her? 1813 An "Epicedium" to the memory of Princess Charlotte (1817). Odes of Anacreon. Songs: Emigrant's farewell; Fly away dove; Indian maid; Let the epicure boast: Lily that blooms ; Mary's love; My poor dog Tray; Oh rest thee babe; Oh say not woman's heart is bought; Remember me; Thine an I my faithful fair; Wandering harper; Young Lochinvar. Glees: Winds, gently whisper; 


\section{WHITE.}

Sailor's return; etc. Fdited "Gems of Englisl harmony," with E. J. Loder, 5 vols; "The Reraph : a collection of sacred music, consisting of celebrated psalm and hymm tumes.... arranged for 4 voices, pf. or organ, and violoncello," Lonton, 1818, 2 vols.

White, Adolphus Charles, contrabassist, born in Canterlury, October 10, 1830. Chorister at the Cathedral there, and studied organ, violin, and other suljeets under I)r. Longhurst, and later in Freland. Returning to (anterbury he took up the study of the donlle-bass, and, proeeeding to London, received lessons from James I Iowell, for whom he soon deputised with marked success. In 1853 lie went with Jullian to America. After his leturn he was engaged at Her Majesty's oper, the Philharmonic and other eoncerts; and when Howell died, in 1879 , he sueceeded lim at the Handel, Leeds, Bimingham (1876-1888), and 'Three Choirs Festivals; and was also principal donble-bass at the Royal Italian opera to 1897 . He is professor of his instrmment at R.A.M., and R.C.M.; Hon. R.A.MI., 1877: and, in 1890, was appointed Musician in Ordinary to Her Majesty the Qneen. IVas for ' 22 years organist of St. Philip's, Waterloo Place. Served in the Volunteer force, retiring in 1889 with the rank of Major, roreiving a silver sword in acknowledgment of his services. His compositius include chureh music, carols, songs, pf. pieces, and solus for the domble-bass II is Primer for that instrument (Novello), with appendix for the four stringed lass, is of great merit.

White, Mamilton, organist and conductor, horn at Maryort, Cmmlerland, Oct. ober 1, 18:34. Has heid varions organ appointments, and was for some time at IIoly Trinity, Whitremsen, in 1872 removing to Wast Retford, Notts., where he has since resided, as organist of the I'arish Church. He is also conductor of a Chomal societr, and for many years has given concerts at leetford, Worksop, ete., as well as organ recitals. He is an active worker for music in the district.

White, Mrs. Harrison, see BABER, MIss Colborkne

White, Jolnn Jesse, violinist, organist, and eomposer, born at Pemomdsey, Lomdom, but at the age of righteen munths was taken by his parents to Bimingham. Psupil of James Stimpson, for organ and theory. Lie. cam mmical directer at Theatre lioyal, Birmingham, when twenty. Wont to Paris, and studied under Halévy. Was first violin in the orehestra of the Théêtre Lyrique, Paris, 1856-7. At the some time there was another violinist of the name in Paris (mentioned below), and they were distinguslued as $\mathrm{N}$. White le Blane, and M. White le Noir. In later years the two were together at Rio de

\section{WHITE.}

Janeiro, Brazil, and the eompositions of the one have at tinnes been taken as the work of the other. As musieal director, composer, and organist, J. J. White spent many years in Chili, Peru, La I'lata, and Sonth Ameriea generally, and his experiences have been far ont of the common. He had played in early Masses on the day of the great Festival at Lo Compania, Sautiago, when 3000 persons were lnimed to death, lecember 8, 1863, and but for a previons engagement, wonld have been in the orchestra in the crening. His deputy, a Spaniard, perished in the fire. A Spanish opera of his was performed in La Plata, and a Portuguese opera in Rio de Janeirn. In 1881 he was back again in Europe, aud appeared, for the first time as a soloist, at Bidyenth, May 13 ; was for a time a member of the Meiningen orehestra, nuder Hans rom Bïlow, and played at the production of "Parsifal," in 1882. Soon after this he returned to Fingland, lnut the change of climate caused a lomg and dangerous illness. He gave recitals and lectures in Bimninghim and neighbonrhood, in 1885 , and the sext year was appointed music director, Southport Winter (rardens. There he remained nine years, and some of his eompositions were introduced. In 1895, he remored to Sydenham, where he still resides.

Morks. Two Masses, of large dimensions, one produced, Rio de Janeiro, 1873; four smaller ones. Italian opera, I a Figlia della Dora, produced, Lima, P'eru, 186R; a French opera. Ode, Queen of the North, composed for the Centenary celeluation, Sonthport, and performed, Jume 18, 1892. Two symphonies; Concert overtme, Titania, Sonthport, November 12, 1887; Deseriptive piecos, Judah, the same, 1891. Concerto, Hedwig, violin and orchestra, perfomed at Mmmich. six string quartuts; pieces for violin, Delires de Sapho, ete.

The Juskph White referred to was born at Cuba. His grandfather was English. He was appointed professor to the Imperial Family of Frazil. He gave chamber concerts at Rio de Janeiro, as late as 1884, and has published violin pieces, etc.

White, Josepl1, organist of St. Sidwell's Church, Fxeter, is the composer of a sacred "antata, "The Magi," produced, Exeter, November 26, 1Rse; and a setting of Sonthey's "Frchcape Rock," produced, Exeter, 1891.

White, Matthew, organist and composer, of early part of the 17 th century. He was a bass singer of Wells ('athedra]; organist of Christ church, Oxford, 1611-161:3; and a gentleman of the Cluapel Royal till 1614. In 1629 he accmmlated the degrees of Biac. and Mus. I)oc., Oxford. Composer of authems and othor chmreh music.

White, Maude Valerie, composer, bom 


\section{WHITE.}

at Dieppe, of English parents, June 23, 1855. Studied under Oliver MLay and W. S. Rockstro. Entered 1R.A.M., 1876, and was elected Miendelssnhn scholar, 1879 , completing her studies in Viema. Resident in London, and Broadway, Worcestershire,

Works. - Mass (R.A.MI. concert, 1881). Songs: To Blossom; Montrose's Love Song; My soul is an enchanted boat; When passion's trance; Ye Cupid's drop; The devout lover; Absent, yet present; I prithee send me back my heart; Four songs from Tennyson's In Memoriam; Album of German Songs; Chantez, chantez (Hugo); and others. Pictures from Abroad, $14 \mathrm{pf}$. pieces; Scherzetto, etc., for $p f$. Naissance d'amour', pf. and 'cello, etc. Translator from the Swedish of Letters from a Nourning City, Naples during the autumn of 1884 , by Axel Munthe, London, MIurray, 1887 .

White, Mrs. Meadows, see Sirth, ALICE MARY.

White, Nathaniel Chandler, organist, was a son of $\mathbf{S}$. Phillips White, solicitor. He was organist of Tewhesbury Abbey Church, and of Bipple Church. He died at Tewkesbury, February 10, 1s69. Remarkable for his organ playing, and his memory, which enahled him to play entice oratorios by Handel, Spohr and IIendelssohn.

White, Robert, composer and organist of the 16th century. He was organint of West. minster Albey? and of Ely Cathectral in 1562, in succession to Tye. He was also master of the choristers in livestminster Abbey. Mus. Bace. Cambridge in 1561. He died in 1574. The Library of Christ Church College, Oxford, contains a momber of his compositions in MIs.

White, Tench James, teacher and dealer in musical instruments, born at Canterbury in 1830. Chorister in Canterhury Cathedrai, 1839, anel pupil of 'T. F. Jones, and I)r. Longhurst. Aftel leaving the Cathedral he became organist of st. Mildred's Chuch, Canterlury. Conductor, for many years, of the st. Lawrence Musical Society, Canterbury. Song composer and editor of "Tench White's organ, harmonium, and American organ library." Many of his songs were published under the nom de plume of Arthur Hare. He died at Canterbury, March 14, 1891.

White, W.J., composer and editor, issued "Sacred Melodies suitable for public and private devotion," London $[1820]$. "New sacred melodies," . London 1825$]$, 7 thedition. "The Bury melodies, adapted for public and family worship.." Jundon [18:30].

Whitehouse, Henry, hass rocalist, bom at Worcester, Janmar 15, 1823. Studied for a short time under. Sir George Smat, but was chiefly self-instructed. About 1849, he was appointed a Lay Vicar of Worcester Cathedral,

\section{WHITTEN.}

and a year later to St. Creorge's Chapel, Windsor, and Eton College. He held these appointments till about the rear 1857 , when he ras made Lay Fical of Westminster Abbey, and Gentleman of the Chapels Royal. He was for many years a menter of the Choir lienwolent Fund, and for some time served on the Committee. His roice was a true bass, but of extraordinary compass; and by long practice, be united the chest and head registers so that he could sing purely tenor songs like "The Message," with as fine effect as those appertinining to the bass voice proper. An adrocate for general culture on the part of singers, his own work exemplified his individual acenirements. He died in London, May 11, 1892. Three of his sons have attained more or less distinction in the musical profession:-Willan EdWari Whitehocse, violoneellist, bonn in London, May 20, 1soy. As a boy he studied the violin under Adolphus Griesbach; but later on, turnims to the violoncello, he took lesions from IValter lettit, whimately entering the R.A.MI.. 1 $\backsim 7$. There he had for instructors l'iatti and Pezze for violoncello, and $H$. C. Banister for halmony. He was first to take the Bonamy loolece Prize for violoncello playing, 1STS; and after carrying off acadentic honolms, was appointed Profestiol and A.R.A.MI, 184.5, and elected F.R.A.MI., 1895. In 1-91 he was made P'ofesior at the R.C.MI., and later at the Royal College of Music, Manchester. He is a member of the Royal Soeitery of Musicians I)intinguished as a solo and quartet player, he has appeared at the Popular Concerts sit. James' Hall (from 1S:1), and many high-class concerts in London and the provinces; whilst as a teacher he counts l'aul Ludwin, liate Onld, and other perfomers of repute, anong his pupils. Jases Fuenenich Whitehorse, hass rucalist, born at Windsor, 1-60). Chorister, St. George's C'hatpel; solo and hrad boy ; now Ticar choral, and of Her Majesty's Private Chapel, Windsol Castle. Tnown as a finished exponent of bach's roeal music, and as an alse teacher of singing, also ats violinist and pianist. AlFIED JoIn WHITEHOT se, studied at R.A.M. since 1sTr, organist and choirmaster, st. John`s, Pinlieo, and resident in London as teacher of pf., organ, and violin.

Whitfeld, see CLARKF-lihtTFEL.

Whitmore, Charles Shapland, amateur composer, hom at Colchester in 1805; died in 1877. He was a major in the army. Composer of the celebrated caratina, Isle of Beauty ("Shades of evening") first issued about 1830, arranged by T. A. Kawlings. This appears to be the only published song of any importance written by Whitmore.

Whitten, A., anthor of "The Music of the Ancients, a lecture delivered in the Nomal School, Caleutta, May 12,1866." Calcutta, 1866. 


\section{WHITTINGHAM.}

Whittingham, Alfred, organist and writer, was formerly in business as a dealer in old music, etc. Organist of St. Michael's, Bassishaw, London, from about 1878 until the closing of the church. He translated several works from Félis, Basevi, and others, which were published in the Orchestra, new series, from 1882. Author of Life and Works of Mozart, 1880; Life and Works of Handel, 1881, both published by IV. Reeves. Composed First Studies for the pf.; Musical Time, 20 easy studies in C, R. Cocks. Editor and arranger of music by various composers, and writer on general musical subjects. He died suddenly in May, 1895.

Whomes, joseph, nember of a noteworthy family of organists. His father was organist of Eltham Church, Kent; he died in 1838. Joseph Whones, the eldest son, was born in 1817, and in 1833 was appointed organist at Chrurlton-next-Woolwich, and afterwards to Eltham Church; Woohwich Parish Church; and lastly, st. George's Garrison Church, Woolwich, a post he still holds. His brother, Henry Whouss, born in 1829 , was appointed to St. Mary's, Cray, Kent, at the age of nine, and four years later, to Fltham, to which he twice returned after holding office for a time at Sidcup and North Cray. He was an organist for just fifty years, his last services being on Christmas Day, 1888 . Two days later he had a paralytic seizure, but partly recovered; on the 9th of April following, he was stricken a second time, and died April 11. He was a sound musician, but his retiring disposition caused him to be but hittle known. Jossph Wh Mes had two sons, organists: Joseph, who died in 1876; and Frederick, organist of the Dockyard Church, Woolwich, who was one of the unfortunate victims of the collision between the Bywell Castle, and the saloon boat, Princess Alice, Septemb \& 3, 1878, when the latter went down off Woolwich, more than 600 lives being lost. He was a thorough musician and able teacher, and only thirty years of age at the time of the sad disaster. A sister, Clara, was an excellent pianist, educated at the R.A.M. Settled in Sydney, Australia, she died there in 1884 , at the age of thirty-one. Enns, another dallghter of Joseph Whomes, is at the present time organist. of St. Nary's Parish Church, Woolwich; and EDyund, nephew of Joseph Whomes, is an organist and conductor at Bexley Heath.

Whyte, James, tenor vocalist and teacher, born at Strathmiglo, Fife, September 20, 1857. Studied under Oakey, McNaught, and others, and is a Fellow of the Tonic Sol-fa College. Precentor successively at Kilmany, 1877; Brechin, 1881; Free St. Bernard's, Edinburgh, 1888; and from 1892 at Dunoon, and conductor at the Curwen

\section{IVILD.}

Institute of Music. He has translated into 'I'onic Sol-fa notation Loder's Violin Tutor, and other works; and is editor of Köbler's Sol-fa violin music, etc.

Whythorne or Whithorne Thomas, composer of the 16th century, was born in 1531. He composed "Songes of three, fower, and five voyces . . . " London, Day, 1571. "Bassavo, Duos, or Songs for Two Voices," 1590.

Whytock, Janet $M$., see Patey.

Wichello, see Whichello.

Wigan, Arthur Cleveland, musician and author, was born at Loudon in 1815 . $\mathrm{He}$ composed songs, canzonets, and other vocal music, and issued a "Modulating dictionary, cousisting of 55:2 modulations with the returns," London, 1852 ; also Miscellaneous Music, vocal and iustrumental, London, [1839].

Wight, Arthur Norton, pianist and composer, born at Düsseldorf, on the Rhine, in 1858, his parents leing Euglish, and at the time travelling on the Continent. Studied under Otto Lessmam and Oscar Raif, Berlin. Settled in London, and since 1884, pianoforte master at Inlwich College. 11 is compositions consist of a symphony in G minor, written for the Symphony Orchestra, Washington, U.S.A., 1896 ; two overtures-"The village fair" (London, 1893) and "The Merry Month of May" (1894). Souata iu C, "Kirmess," duet, pf ; Berceuse, pf. and oboe; Six miniatures, pf. Part-songs and songs. Longfellow's "Norman Baron," for recitation, with pf. accompaniment, etc., etc. Several of his works have been produced with success on the Continent and in America.

Wilbye, John, composer of the 16th century. His biography is very obscure. In 1598 he was a teacher of music in Austin Friars, London. He composed "Madrigals to 3, 4, 5, and 6 Voices...." London, Este, 1598. leprinted by Musical Antiquarian Society, edited by James Turle, 1841." "The Second Set of Madrigals, to $3,4,5$, and 6 parts, apt both for Voyals and Voyces," Loudon, 1609. Reprinted by Musical Antiqnarian Society, edited by G. IW. Budd, 18t6. "The Lady Oriana," madrigal, is in the "Trimmphs of Oriana." Among his best-known madrigals are "Flora gave me fairest flowers," "Sweet honey-sucking bee," "Die, hapless man," " Wheu Chloris heard," "Stay, Corydon," "Lady, when I behold," "Why dost thou shoot," etc. These madrigals are among the sweetest, most appropriate, and fanciful pieces of pastoral music ever composed.

Wild, Margaret, pianist. Studied at the Leipzig Conservatorium, and played at the Hauptprifung in 1882. Gave concerts in London, 1885 , and also played in the provinces. 


\section{WILKES.}

Studied under Madame Schumann, 1886-8. Returned to London, and appeared at the Monday Popular Concerts, November 28, 1888. Has given eoncerts at Princes' and St. James's Halls, annually, and has gained a good position among the younger pianists of the day

Wilkes, John, organist and composer, was organist at Monkland Church, near Leominster, about 1860 . He studied at the R.A.M., and composed the well-known hymn tune, "Lyte," first contributed to "Hymus Aneient and Modern," 1861.

Wilkins, Matthew, organist and composer, who was born at Great Milton, Oxford, about July, 1704, and died there in August, 1772. He was a butcher, but also taught music. Compiler of "Book of Psalmody, containing some easy instructions for young beginners, to which is added a select number of psalm tunes, hymns, and anthems" $[1730]$.

Wilkinson, Sarah, see MIountain, SaraH.

Willard, N. Augustus, author, was a captain in the army in India. Author of "Treatise on the Music of Hindoostan, with ancient and modern practice," Caleutta, 1834.

Willems, Miss, see AdDison, John.

Williams, Aaron, teacher and publisher of psalmody, was born in 1731. He was a music engraver in West Smithfield, as well as a teacher, and acted as clerk to the Scotch Church in London Wall, London. He died at London in 1776. He compiled and published "The Universal Psalmodist, containing 1. A complete introduction to psalmody.... 2. A choice and valuable collection of tunes.." London, n.d., 3rd edition, 1765 ; 4 th edition, 1770. "New Universal Psalmodist," 1770. "Harmonia Coelestis, or the harmony of heaven imitated, a collection of scarce and much esteemed anthems...." London, n.d., 6th edition [1775]. "Psalmody in miniature, in 3 books, containing the tenor and bass of all the tunes generally used in ehurches, chapels, or dissenting eongregations, London. 1778. Royal Harmony, or the beanties of chureh music.., London [1780].

Williams, Albert, bandmaster and composer, born at Newport. Monmouthshire, March 14, 1863. Joined the Depôt of the 61st Regiment, at Bristol, alout 1878; went to India in 1880 as euphonium player in the band. Received instruction from Barthmann, the bandmaster, and at the Military Exhibition held at Poona, 1884, carried off first and second prizes for composition and arrangement. Left India in December, 1885, for Kneller Hall ; and in February, 1888, was appointed bandmaster of the 10th Hussars. Graduated Mus. Bac., Oxford, 1891, and received his degree wearing the uniform of the 10th Hussars. In 1892 he succeeded John Winterbottom as bandmaster of the lioyal Marine Artillery, and did good work at Portsmouth, where he remained

\section{WILLIANS.}

until 1896 , when he was appointed bandmaster of the Grenadier Guards in succession to Dan Godfrey. His compositions inelude Psalm 30 , for soli, chorus, and orchestra. Overtures, Heloise and Abelard, Proserpine, and Plutus, for orchestra. Grand marches, Processional and Eeclesiastical; waltzes, etc. Arrangements for military bands.

Williams, Anna, soprano vocalist, born at Campden 1Iill, London. Daughter of IV. Smith Villiams, literary adviser to Smith, Elder, and Co., publishers. She received lessons from H. C. Deacon and J. B. Welch, and took the first soprano prize at the National Music Meetings, Crystal Palace, June 27, 1872. Studied at Naples under Domenico Scafati, and made her first appearance on her return at the Crystal Palace, January 27,1874 . She was soon engaged in coneert work; sang in the revival of Handel's "Susannah," Alexandra Palace, April 1, 1876 , etc. Her first festival engagement was at Worcester, 1878, then at Birmingham, 1879 , and Leeds, 1880 . As an oratorio singer especially she gained a high position. At the Birmingham Festival of 1891, she received a handsome present from the Committee, in acknowledgment of her readiness in taking extra work-Stanford's "Eden," etc.-on aceount of the illness of Madame Albani. She has appeared in opera, but her reputation has been greatest in the concert room. In 1896 she joined the teaching staff of the R.C.M. and G.S.M.

Williams, Anne and Martha, known as the Misses Williams, soprano and contralto vocalists, born at Bitterley, Salop, in 1818 and 1821, respectively. Studied under T. S. Cooke and Luigi Negri. Sang at Stafford, Shrewsbury. and other places, 1839-40; at the Hereford Festivals, 18 $40-43$; (Hloncester, 184t; Worcester, 1845; and Birmingham, 1846, taking part in the first performance of "Elijah." The sisters were engaged for the Wednesday concerts, Exeter Hall, from the commencement, November 22, 1848. Though of repute in oratorio, they were more celebrated for their finished duet singing. Anne married, Nay 13, 1850, Mr. Alfred Price, of Gloneester, and retired; Nartha sang at the Hereford Festival, 1852; was married to Charles Lockey, tenor vocalist $(q \cdot v$.$) , May 24$, 1553 , but continued her professional career to 186.5 . She is now resident at Brighton, with her husband.

Williams, Annie, Welsh eontralto vocalist, who appeared successfully as a concert singer. For some time she was organist of the Welah Chapel, Jewin Street. London. She died at London, October 16, 1890.

Williams, Charles Francis Abdy, composer and organist, horn at Dawlish, Devon, July 16,1855 . Educated for the Church, at 
WILLIAMS.

Cambridge, stndying music as an amatenr. Was on the committee of University Musical Society, 1876-K, and played violin iu its concerts. In 1s79 he went to New Zealand, and was organist of St. Mary's Church, Auckland. On his return he became music master of Dover College, 1481. Graduated B.A., 1879; M.A., 1882, Cambridge. In 1882 he went to Leipzig, and remained three years at the Conservatorinm, besides taking private lessons from Reinecke, l'apperitz, Grell, and others. Organist and chuimanter of St. Mary Boltons, Sorth Kensingten1, 1885-91. Graduated Mus. Bac., Oxford, 1889; Mus. Bac., Cambridge, 1891. Since 1895 he has been organist and music master at Bradfield College.

Works. Psaln 21, and 29, for soli, chorts and strings; Conmunion service in $\mathrm{E}$ flat; Evening service in F; Chants for Benedicite, etc. Music to Euripides' Alcestis, written in Greek modes, and for Greek flutes and eithara produced at Bradfield College, June, 1895. Love's philosophy; My true love hath my heart, and other songs. Quartet in D minor (1887); Sonata in F, pf. and 'cello (1888): Four canons, pf., violin, and clarinet (1889), Musical Artists' Society. Author of A short historical account of the Degrees in Musie at Oxford and Cambridge, with a Chronological List of Gradnates in that Faculty, from the year 1463, London, Novello, 1893. Contributions on Greels Musie to the classical Rexieu; Musical Times; and Musical Puarterly Rexien; on Rhythm, to Musical Nen's, 1891. Papers on various sulvects, Mnsical Association, 1891, and 93; on Elements of Plain Song, I'lain Song and Medireval Music Society, 1895, ete.

Williams, Charles Lee, organist, conposer, and conductor, horn May 1, 1852, fouth son of Rev. Havid Willians, rector of Barnes, Wiltshire. Chorister of New College, Oxford, 1861-5. Pupil of J). G. B. Anold, and assistant organist Winchester Cathedral, 1865-70 ; organist of Upton Church, Torruay, 1870 ; tutor and organist, St. Columba College, Dublin, 1873. Gradnated Mus. Bac., Oxford, 1876. F.R.C.O. Acting organist for a time (in 1976) at Winchester C'athedral, during an ilness of $\mathrm{Dr}$. Annold; then appointed to Llandaff Cathedral the same year; and in 1892, became organist of rloucester Cathedral, in sncession to C. Harford Lloyd. He also took the conductorshipuf the Glonester Choral Society, the first concert under lis direction taking place, December 12, 188:2. The next year he conducted the frloncester Festival, showing great ability; and continned in that until his resignation, owing to failing health, in November, 1896. He also condnctet the Worctster Festival of 1890. From 1846 he gave antulal series of organ recitals in Gloucester (athedral, with the addition of

\section{WILLIAMS.}

choral music, and large congregations attended. Various societies in Gloucester were improved through his help. He is an Hon. R.A.M., and Associate of the Philharmonic Society.

Works. - Church cantatas, Bethany, Gloucester Festival, 1889; Gethsemane, the same, 1892; and A Dedication, the same, 1895. A Ilarvest Song of Praise, Tewkesbury Festival, 1895. Te Deum, composed for South Shropshire Choral Association Festival, 1895; Morning and evening services; Thou wilt keep him; To Thee, O Lord; and other anthems. Mnsic, a choral song, Cheltenham Festival, 1893; Twilight; Kindred hearts; If douglity deeds; The song of the Pedlar; and other part-songs, some of which are extensively popular; Songs, carols, etc.; Gavotte and minnet; the Gloncester minuet, both for strings. Chimes of Gloncestel Cathedral, arranged for pf., ete.

Williams, Evan, Welsh musician and harpist of first half of the 1sth century. He edited "Antient British Nusic," 1772, in association with Parry of Ruabon.

Williams, Frederick Williams, author, vocalist and conductor, born in London (?), 1860. Studied at G.S.M. and P.C.M. Took the Toronto degree of Mus. Bac., 1889. F.S.A. of Scotland. Gave frequent lectures. on musical suljjects, 1886-7. Contributed to the musical press, and was the composer of some pf. pieces. Author of a History of Music for Students; and the Five Great Schools of Composition, Stanley Lucas, 1889. He died at Hastings, 1 ebruary 7, 1891, at the early age of 31 .

Williams, George Ebenezer, composer and organist, was born in 1783 . He was a chorister of St. Paul's Cathedral under R. Bellamy, and in 1814 he became deputyorganist of Westminster Abbey. He died at London, April 17, 1819. He composed "Sixty Chants, single and double," and some church and secular vocal music. Author of "An Introduction to the art of playing on the pf." London $\lceil 1810]$; 2nd eclition, 1815. Exercises for the pf. and examining questions for school classes. London 1815?

Williams, Hamerton John, musieian and composer. Edited "Muser Sacres, conlsisting of Hymns, Psalms, and Sacred Songs for one, two, or three voices." London [18399].

Williams, Joseph, clarinet player and composer, born in 1795. He was a director of the Philhamonic Society, and a member of the Queen's private band. lied at London in April, 1875. He composed a concerto for the clarinet, produced at a I Hereford Festival, some dance music, and wrote an instruction book for the clarinet. Edited "Christmas minstrelsy of carols, anthems, and chants.. revised by Gauntlett." London [1865]. 


\section{WILLIAMS.}

Williams, Joseph (Florian PASCAL), composer, born in London, 1850. Son of the late Joseph Williams, music publisher. Studied at Zurich and Stutgart.

Works.-Comic Operas: Cymbia, or the Magic 'Thimble, Strand Theatre, Narch 24, 1883; Gipsy Gabriel, Theatre Royal, Brad. ford, November 3, 1887. The Sirens of the Sea, soprano solo, female chorus and orchestra ; cantata, The Dream Ship; Six sacred songs. Songs: For children of all ages; May Morn; Captain's Daughter; More than all, ete. Songs of the Upper. Thames (William Mackay), 1896. Six vocal duets; Masque of Flowers, little suite for treble voices; overtures; sultes for orchestra ; trios, pf. and strings; pieces for 'cello and pf., etc.; Six Scandinavian Sketches, pf.

Williams, Lucas, bass vocalist, born at Treforest, Glamorganshire, February 17, 1852. In his eleventh year he removed to Stockton-on-Tees, where for some time he was a roller in the ironworks. As a boy he had a good contratto voice, and was taught by Joln Thomas (q.l.) ; learued the Tovic Sol-Fa from William Harris, at Stockton; took the elementary and intermediate certificates from John Roberts $(q . v$. $)$; and learnt harmony analysis throngh the postal classes of the Tonic Sol-Fa College. While engaged as a workman he conducted a choir, and was the wimner of prizes in local Eisteddfodau. In 1875 he won the baritone prize at the Pwllheli National Eisteddfod, and entered the R.A.M. the next year. After a few months at the Academy he went under Georg Henschel, and, later, studied under Randegger. He soon gained a reputation as an oratorio singer, and his popularity in the North of England is very great. $\mathrm{He}$ has been on tour with Sims Reeves, and has sung at the Royal Albert Hall Concerts the part of Semacherib in Mancinelli's "Isaias" (February 20, 1889), and appeared in many importaut works; he has also acted as adjudicator at Eisteddfodau.

Williams (Maria Jane), Llinos, soprano singer and editor, born in Glamorgan, October 9, 1793; died November 10, 1873. Compiler of "Ancient national airs of Gwent and Morganwg: being a collection of original Welsh nelodies hitherto unpublished....." Llandovery, 1844. This work, in a less perfect state, was awarded a prize at the Abergavenny Eisteddfod of 1838 .

Williams, Owen, composer and editor, was a native of Anglesey. Issued " Brenhinal Ganialau Sion, neu Gyughanedd newydd gymraeg yn cynwrs..." London [1830], arranged by $S$. Wesley and $V$. Novello.

Williams, Owen Jones, musician, who published in parts a work entitled, "Psal.
WILLIANS.

modia Cambro Britannica, or the original English and Welsh psalmody," London $[1826]$.

Williams, Sidney, violinist and composer, borm at Newport, Mommonthshire, in 1844. Appeared as soloist when eleven years of age. Was sometime leader of the band at Sadler's Wells, and afterwards at the surrey Theatre. Ocenpied the position of musical director of the Cheltenham Theatre for many years, and composed the music for a number of pantomimes. Organist of the Unitarian Church, Cheltenham, and teacher of the vislin. He bas composed a number of pieces for violin, Swing song, Eventide, Lelia, and others.

Williams, Thomas, musician of 18th century, compiled "Psalmodia Frangelica, a complete set of psalm and hymm tumes for public worship," 1789.

Another Thomas Williams, or pertaps the same, who lived on Clerkenwell Green, London, issued "Instractions in miniature for learuing Pralmody," London [1800].

Williams, Thomas, Hafrexyd, born at Llanidloes, Montgomery, Ilecember $7,1807$. Published a number of collections of tunes, anthems (1845, 1852, 1860, etc.), and the chornses of the Great Masters arranged to Welsh words, and which were of much service. He also published a Mnsical Grammar and Dictionary. He died at Llanidloes, December 16,1894 .

Williams, Thomas E., composer, who was borm in latter part of last century, and died at London in November, 1854, at an advanced age. He composed the Larboard Watch, dnet, and a large number of songs: Army and navy; Bright sword no more in anger drawn; Call to battle; Devil and st. Anthony; First vid de grace; Kiss, dear maid; Lord L'lin's danghter: Not a drmm was heard; Pride of the ocean, ete. He also wrote quadritles, and other minsic for the pf.

Williams, Warwick, composer and bandmaster, born at Holbom, London, in 1846. His father was in the East India Company's service, and the boy went with him to India in 1856, remaining there four pears, during the period of the mutiny. He learned to play the comet, and after being in several orchs tras, hecame bandmaster of the 3rd West Forkshire Volmtcer Regiment in 1869. He joined the Mohawk Minstrels, for which association he componed more than a hundred songw and ballads. Was eo-conductor of the London Military Pand, 1891, while D. Crodfrer, Junior, was in South Africa; and in 1893 was appointed professional num ical adviner to the London Comty Comseil regarding bands in parks, ete. Editor of the Eiclipse Joumal for bands, since its establishment. He has composed the overtures, On 


\section{WILLIAMS.}

the momtains, Eclipse, Norimo, and others; and much dance nusic of a popular kind, besides songs, etc.

Williams, W. Langton, composer and didactic writer, born about 1832 . Author of Esop's Fables, versified and arranged for pf. Composer of pf. album, Home pictures, twelve pieces; numerons sougs, etc. He died of apoplexy, December 23, 1896, aged 64 .

Williams, William Aubrey, GWilym Gwent. Born at Tredegar, Monmouth, July 28,1834 . A working miner who gained the reputation of being the best Glee writer Wales has produced. Lacking in musical culture and scholarship, he had a rich furd of melody, and an intuitive grasp of the characteristics of various forms. He was a prolific writer, and probably competed more, and won more prizes, than any other Welsh composer. His compositions included several cantatas, to one of which, "The Prodigal Son," was awarded a prize at the National Eisteddfod, Aberystwith, 1865. He also produced anthems, choruses, trios, duets, hymn tunes, glees, and part-songs. In 1872 he emigrated to America, and died at Plymonth, Pennsylvania, July 3, 1891. In 1895, by public subscription, a monument was erected over his grave in Hollenback Cemetery, Wilkesbarre, Pa.

Williamson, T. G., musician, published "Twelve original Hindoostance airs" op. 4. London [1797]; and a "Second collection of twelve original Hindoostanee airs," op. 9. London, 1798. Composer of Six favourite sonatinas for the pf., op. 1; Six grand troops with six quicksteps, op. 6. Thirty little airs for two flutes or violins, op. 7. Ten easy lessons for the pf., op. 8. Songs: Bird's nest, Gipsey, Lubin's return, Pretty Nell, Wooden leg.

Willing, Christopher Edwin, organist and conductor, born in Devon, February 28, 1830. Son of Christopher Willing, alto vocalist and Assistant-Geutleman of the Chapel Royal (borm 1804; died May 12, 1840). Chorister of Westminster Abbey, under Jas. Turle, 1839. Organist of Blackheath Park Church; and assistant-organist, Westminster Abbey. Organist of Foundling Hospital, May 11,1848 , and musical director shortly after, resigning in November, 1879; also organist concurrently at St. Panl's, Covent Garden, 1857, and All Saints', Margaret Street, 18601868. Organist, Her Majesty's Theatre, 1848-57, and chorus-master at Covent Garden Opera. In 1883 Sir Michael Costa presented him with a collection of bâtons as a sonvenir of their official conncction. In 1882 he formed, from the old Sacred Harmonic, a choir bearing his name, and gave concerts, 1882-5. Later he was conductor of the St. Alban's Choral Union, and its trienuial

\section{WILSON.}

festivals. He has composed some songs, the well-known hymn tune "Alstone" ("We are but little children"), and other works.

Willis, Mary, mezzo-soprano vocalist, pupil of Madam Sainton-Dolby. Made her first public appearance at a concert of Nadame Dolby's Vocal Academy, December 14, 1882. Sang at various concerts, and took the part of Gipsy in Macfarren's "Jessy Lea," 1890. Has given concerts in Steinway Hall, 1891, etc.

Willman, Thomas Lindsay, clarinet player, son of a German, who in the latter half of the 1sth century came to England as a military bandmaster. Neither date nor place of the son's birth are known. lle be. came principal clarinet of the Opera and other orchestras about 1816 , and was master of the Grenadier Guards' band. From 1817 to 1839 he played solos at the Philharmonic Concerts, and was considered the most delicate and finished player of his time. He died in London, November 28, 1840, at the stated age of 56 , but he was supposed to have been much older.

Willmore. Walter Graham, organist, born in London, May 24, 1851, son of the late Arthur Willmore, the eminent line engraver. Chorister at Cbapel Royal, Whitehall, 1860-3, and pupil, for organ, of George Cooper. Went to United States of America, and was organist of St. Mark's, Plriladelphia, 1874-6, and of the Roosevelt organ built for the Centennial Exhibition of 1876 . Two years later he was established as organist of All Saints' Brisbane, Australia, a position he retained till 1893. He visited England in 1883, and, as a member of the College of Organists, keeps up relation with the mother country.

Willoughby, Robert, musician of latter part of last and beginning of the present centuries. Edited "Social Harmony, being a choice collection of catches, glees, etc., for two, three, and fonr voices. . " London, [1810], 2 vols. "Sacred Harmony, consisting of a collection of Anthems," London [1800]. A short and easy introduction to vocal music, London [1802].

Willy, John Thomas, violinist, was born at London, July 24, 1812. He established au orchestra in London, which gave concerts for some years. With T. Cooke he was principal violin at the Birmingham Festival of 1846, and played also at the Three Choir Festivals. Composed music for the "Yomng Widow," 1843. Died at Clapham, London, Angust 8, 1885. His son, J. H. WILLY, who was an organist, died at Madras, October 12, 1869.

Wilson, Mrs. Cornwall Baron, composer and lyric poet of the present century. In 1837 she gained the prize of the Melodist's Club, and also medals at Bardic Festivals in Wales. She died at London, Jammary 12, 


\section{WILSON.}

1846. Composer of Songs of the ship; Water music, a collection of national melodies.. arranged with a guitar accompaniment, London [1835]. The lyrist's Offering. She also wrote many detached songs to her own words; wrote the poetry for Parry's Welsh Melodies, vol, 3; and edited Memoirs of the Duchess of sit. Albans.

Wilson, Daniel Ferguson, organist and composer, born at Kilmarnock, Uctober 6 , 1859. Studied moder A. L. Peace and others. Graduated Mus. Bac., 18s6; Mus. Doe., 1894. Oxford. Otganist of St. Marnock's Parish Chureh, 1874; Parish Chureh, Ayr, 1878; and of Arr Town Hall, 1880. His compositions are Psahm 30, for soli, chorus and strings; ('antata. Legend of the I) rachenfels. He has' arranged as part-songs. John Anderson, ny Jo: My heart is sair, ete.

Wilson, Haydn, organist and composer of the first half of the present century. He was organist of St. Mary's, Newingtom, London. Composer of Six Overtmes for pf., with accompaniment for flute, violin and violoncello [1828]. Six Waltzes for pf. [1850]. Other instrumental and vocal pieees.

Wilson, Hilda (Matilda Ellen), contralto rocalist, born at Monmouth, April $7,1860$. 'The daughter of a musician (her father, Janles Whison, was bandmaster of the Mommonth Volunteer Corps, and afterwards held important posts at Gloucester), her earliest childhood was deroted to the art. Her parents removing to Gloucester. she became a member of the choir of sit. Michael's Church, and appeared as a solo vocalist at concerts of the Gloucester Choral Society, 1874-5. In 1879 she entered the R.A.M., and was Westmorland Scholar, 1880-1; and Parepa-Rosa Prizeholder, 1882. Elected A.R.A.M. She sung in the quartets, etc., in "Elijalı," and in Palestrina's Stabat Mater, at the Gloucester Festival of 1880 ; was second contralto at Worcester, 1s81; at Hereford, 1882; added to her reputation at the Leeds Festival, 1883 ; and was first contralto at Norwich Festival, 1887. She had by that time aequired a leading position, and at the Philharmonic concerts, Birmingham Festival, 1891, and the chief concerts in the Kingdom, worthily sustained it. In 1890 she began a series of vocal recitals, assisted by her sister and two brothers, at Steinway Hall.

AgNes Wilson, her sister, also a contralto vocalist, was born at Glomeester, October 8 , 1864. She stulied at the G.S.M. under Visetti, and at R.A.M under IV. Shakespeare. Appeared at concerts in 1887 ; has sung with success at the Lincoln and Hovingham Festivals; and took part in the Hereford Festival of 1894 . She has also sung at the principal London and provincial concerts. She is a professor of singing at the Blackheath

\section{WILSON.}

Conservatoire, and, with her brother IV. S. Wilson, director and professor of the West Loudon Conservatuire of Music.

H. J. LANE WILsox, pianist, organist, and composer, was born at Gloncester. Removed to London in 1882, and studied under F, G. Cole. Later he studied at R.A.M., singing under A. Oswald, and composition under $\mathrm{F}$. Corder. In 1888 he was engaged as accompanist on Madame Minnie Hauk's tour, and has had much work of that kind, besides touring with Madame Alhani in America, 1895-6. He has composed a Meditation for strings, performed at Cheltenham Festival, 1893, ete. ; an Ave Muria for soprano, with pf., riolin, and organ, sung by Madame Albani, Queen's Hall, April 20, 1895; A mother's vigil; Voices of the Angels; Annette; and other songs.

W. Strroud Wilson, violinist, and baritone vocalist was boru at Gloucester, May 20, 1868. Studied the violin under his father, and later at the Guildhall Scloool and 1R.A.M. under the late Franeis Ralph. He was engaged by $\mathrm{Mr}$. Coweu for the orchestral concerts at Melbourne Exhibition, 1888-9; has also toured in America. Was leader in Madame Marie Roze's "Carmen" tour, and is a member of the orehestras of the Royal Italian opera, Crystal Palace, Queen's Hall Promenade concerts, and the provincial festivals. He is solo baritone in the choir of Holy Trinity, Sloane Square, and director and professor of thelVest London Conservatoire of Musie.

Wilson, Hugh, shoemaker and amateur composer, was born at Fenwick, Ayrshire, in 1764. He was originally a shoemaker with his father in Fenwick, and occasionally acted as precentor in the Secession Chureh there. He afterwards went to Pollokshaws, near Glasgow, and subsequently resided at Duntocher in Dumbartonshire as manager in a mill. He died at Duntocher, August 14, 1824 , and is buried in the churchyard of Old Kilpatrick. He composed a number of psalm tunes, but his chief claim to remembrance lies in his well-known tune "Martyrdom," which for many years has been a favourite with congregations in Scotlaud.

Wilson, James W., musician and editor, issued "Mrusical Cyclopedia, being a collection of songs with appropriate music. To which is added an essay on the first principles of Music," London 1835]. New edition, 1852. The essay is by IV. Grier (q.v.).

Wilson, John, composer and lute player, boru at Faversham, Kent, April 5, 1594. He was made Mus. Doc., Oxon., 1644. Afterwards he resided with the family of Sir IVm. Walter of Sarsden, Oxfordshire, as music master, from 1646. He was professor of musie at Oxford University, 1656-1662. Gen- 


\section{WILSON.}

tleman of the Chapel Royal, and chamber musieian to Charles II., 1662. He died at Westminster, February 22, 1673. Supposed by Rimbault to have been the Jack Wilson who sang in shakespeare's plays. He eomposed "Psalterium Carolium, the devotions of his Saered Majestie in his solitude and sufferings, reudered in verse, set to musick for thre: voices, and an organ or theorbo," London, 1657; "Cheerful Airs or Ballads, first eomposed for one single voiee, and since set for three voices," Oxford, 1660 ; "Aires for a voice alone to a theorbo or bass viol. Divine services and anthems," 1663; "Fantasias for viols."

Wilson, John, tenor vocalist and eomposer, was born in the Canongate, Edinburgh, December 25, 1800. He was apprentieed to the printing trade in 1810 , and afterwards beeame reader for the press in Ballantyne's printing office, Edinburgl.. He studied music under John Mather and B. Gleadbill, and was a ehoir-singer in Duddingston Parish Church, where the Rev. John Thomson was pastor. He was married about 1820 , and beeame precentor of the Relief Chureh, Roxburgh Place, Edinburgh, and of St. Mary's, 182.5. He sang at coneerts in Edinburgl, and studied for a time under Finlay Dun, aud singing in I ondon, under Lanza, 1827, and Crivelli, 1830; also harmony under Aspull. First appeared in opera, as Harry Bertram in "Guy Mannering," Edinburgl, March, 1830. Sang in opera in London, from 1830, and beeame lighly successful in English opera at Covent Garden, Drury Lane, and other theatres. He afterwards travelled in Britain giving his Songs of Scotland entertainment, and appeared as a eoncert and opera singer till 1838. Appeared in the United Siates, 1838, and visited Canada in 1849 . He died at Quebec, July 8, 1849.

One of the most suecessful Scottish singers. His entertainments consisted of Nights with Burns; Jacobite songs; Lady of the Lake, 1848; Nary, Queen of Scots, 1847, etc.; and were very well patronised wherever he appeared. He published "Wilson's edition of the Songs of Seotland, as sung by him at his entertainments on Seottish Music and Song," London, 1842, 3 books. A Selection of Psalm tunes, sanctures, doxologies, ete., for the use of the eongregation of St. Mary's Chureh, Edinburgh, 1825. The songs Love wakes and weeps. Hail to the Chief, Bomie Bessie Lee, Auld Joe Nicolson's bonıy Nannie, ete., were introduced by him, and by many are believed to be his own compositions.

Wilson, Joseph William, eomposer of the present time. He has written a church oratorio, "The Earthly and Heavenly Har. vest," produced at St. Mary's Church, Wandsworth, April 10, 148s; aliso an opera, "Domna Theresa," performed, Wandsworth, 1885.

\section{IVINDSOR.}

Wilson, Leigh, professional name of William ÉnWARD Cocliram, a tenor vocalist, who was born at Bristol in 1836 . He was son of John Coekram, music-seller there. He was a singer of great promise and made a very good impression when he first appeared. Inied in London, of brain ferer, in February, 1870, aged 34.

Wilson, Marmaduke Charles, composer and pianist, was born at London in 1796. Teacher and pianist in London. He died after 1870. Composer of Sonata for pf. op. 10; Duet for harp and pf. op. 15; Rondoletto for pf. op. 7; Polonaise for pf. op. 12; Les plaisirs de Printemps, pf. Duets, songs, etc.

Wilson, Mary Ann, see sub. WELSH Tiromas.

Wilson, Matthew, Scottish amateur composer, who flourished in Glasgow in the first half of the present eentury. He studied music under John Tumbull and appear's to have heen an accompanist at free and easy concerts in Glasgow. To the "Lyrie Gems of Scotland" and other eollections he contributed a number of songs, among which may be named "Meet me on the gowan lea," " "Sweet Jessie o' the dell," "Mary and me," "Morag"s Faery (iten," "O far may ye roam." He also wrote several hymn tunes, among which may be named "Diumelog."

Wilson W., author of a "New Dietionary of Musie," London [18:30].

Wilton, Fanny W., see Lablache, FANNY IV.

Wilton, Thomas Egerton, and Earl of, composer, bom Iecember 30, 1799 ; aied March 7, 188*. Composer of "Hymn to Eros;" "O, praise the Lord;" anthem, ehants, and other voeal musie.

Winchester, Ernest Charles, organist and composer, bom at Osborne, May 22, 1554. Organist and C.21., Christ Clureh, Sonthwark. Compositions: If ye love Me; The Lord is my shepherd; I will give thanks; and other anthems. Te Denm and Benedictus; Fight settings of the Te I eum; Jubilate; Preces and responses; Communion Service, Kyries, Offertory sentences, ete. Six original hymn tunes; Litanies, ete.; Crowning the Nay Queen, trio.

Windle, Walter Wardle, organist, bom at Chesterfield. Chorister when eight at Chesterfield l'arish Church, and pupil of Thomas Tallis Trimmell, and later of Tr. Spark. Organist of Parish Church, Brimington, when sixteen; and sinee 1882 of Belper Parish Church. In 1886 he was appointed eonduetor of Ripley (Derby) Choral Union. He lias given organ reeitals in many places. Composer of Supplemental Hymn tunes, Kyries, doxologies, aud ehants; Six Kyries, ete.

Windsor, James W., composer and 


\section{WINGHAM.}

pianist, was born at London in 1776. He was a teacher in Bath, and died there on January 28, 1853. He harmonized a number of popular songs and compcsed some vocal music.

Wingham, Thomas, pianist and eomposer, born in London, January 5, 1816. When ten years old he became organist of St. Michael's Mission Chnreh, Sonthwark. Studied at London Acadeny of Music, 1863 ; entered R.A.M., 1s67, studying mder W. S. Bemnett and Harold Thomas. In 1871 he was appointed a professor of the pf. there, and afterwards elected a Fellow. He was also a professor at the G.S.MI. In 1864 he was app inted organist of All Saints', Paddington; and he was musical director at the Oratory, Brompton, from 1882 until the time of his death, which tooli place in London, March 24, 1893.

Wonks.-Mass in D, produced, Antwerp Cathedral, 1876; Mass, Brompton, 1887; Te Demm, for voices, orchestra and organ, Bronipton, 16st; Notets, offertories (composed for Antwerp, (athedral), and other chuch music. Songs. Orchestral: Symphons, No. 1, in D minor (eomposed at R.A.M., 1869); No. 2, in B Hat, Crystal Palace, March 23, 1872; No. 3, in E minor, with che ral finale, 1873; No. 4, Crystal 1'alace, April 28, 883. Concert overture. No. 1, in C, composed for the Jubilce of the R.A.M., 1872; No. 2, in F, Eros, Crystal Palace, November 27, 1875 ; No. 3. in D, choral, Alexandra Palace, Nay 10, 1877; N., t, in F, Fair langhs the mom, Crystal Palace, February 16, 1878 ; No. 5, in A, Brighton Festival, 1879; No.6, in D, Mors Janna Vite, Leeds Festival, 18s0. Elegy on the death of Stemdale Fennett, Crystal Palace, March 6, 1875; Seremade in E flat Pliiharmonic Society, Narch 26, 1885. Concert Capriccio, pf. and orchestra; String quartets, in B tlat and G minor. Septet for pl., strings, and wind, and an opera Nala and Dimayanti, left mufinished. Only a Barcarolle for ph., and ane or two songs by this composer have been pulslished.

Winn, Rowland Melior, pimist, organist and composer, hom in Birminghan, April 24, 1856. Descended from masical fantilies, by both parents, his mother's nuiden name being Mellor. Articled pupil of A. IR. Craul. Ciratduated Mus. B., 1876; Mus. I)., 1883, Oxford. F.R.C.O. Urganist and choirnaster, Harborne P'arish Clutch, from 1874. Has appeared as solo pranist at $11 \%$. Stockley's Orchestral, and other concerts, and is widely known as an able acoompanist. He has compoined an oratorio, "The siea of Galilee," and has published part songs and pf. pieces; also "vixty-one Melodies and unfigured lasses" (Novello), 18!)1.

Winn, William, baritone rocalist and composer, boln at Bram ham, Yorlishire, Mays,

\section{WINTERBUTTOM.}

18:3. Gentleman of Clapel Royal, 1604. Vicar choral of St. Panl's London, 1807. He died at Willesden, near London, June 4, 1888 , aged 60 . Well-known as a baritone singer of great ability, and for his connection with rarions Glee and Quartet parties in London and elsuwhere. Composer of Glees: Antumn (1868); Go rose, prize glee, 1870 . Lile: Who falls in fight, etc. Somgs: England's gallant defenders, Evening thoughts, ('ipss chams, Her pathway strewn with flowers, Nothing more, Old ice king, Quite ly ehance, Who wins the bride, Wild old woods, ate.

His daughter, Florexce Wixs, made her debut as a contralto singer at a concert of her father's in st. James' Hall, London, May 31 , 1881.

Winny, H., organist and concluctor, for many years an active musical worker in South Africa. As pianist he assisted in concerts at Grahans Town from 186:; and eonducted the Handel Ficeutenary Festival in the Town Hall there, whe: "I irael in Egypt" was performed for the first time in South Africa, Jume 3, 1885. In 1846 he was elected organist of St. (iterge's Cathedral, Grahams Town; aud after some years remosed to a similar post at St. Winian's Catliedral, Pretoria. He died at Grallams Town, from heart disease, July, 1895.

Winter, Pattie, soprano rocalist. Pupil of William Carter. Made her début at the Royal Albert Hall, Kensington, Apr.l z:, 1852. Sang at the Alexandra Palace the same year, and at various concerts up to 1888 , when she went to Milan and stuclied under Sangiovanni. On her return she sang at St. James' Hall, April 3, 1889, and has established herself among the accepted rocalists of the time.

Winterbottom, a remarkalle family of military musicians, consisting of five brothers, soms of $\mathrm{JOHN}$ Winterbottom, of the 1s L Life Guards, who fought at Waterloo, and was, on his retirement from the service, appointed one of the wardens of the Tower of London. He died in 1855. Thomas IVIN7ERpotton, the eldest son, was in the band of the lioyal Horse Guards nine years, and afterwards lindmaster of the lioyal Marine Light Infantry, Plymouth Division, for seventeen years. He died at Plymoutl in 1,669 Willian WinterbotTon, born about 182., was a trombone player in the band of the 1st Life Guards. Then lie was handmaster of the Woolwich Division, and succeted his brother at Plymouth, thence exchanging to the 2nd Life Guards. He died at bonlognesur-Mer, September 29, 1889. JunN WixrerBotrom, the eelebrated bassoon-player, was born about 1817. Ife was a member of the famous Jullien orchestra when a young man. From about 1852 he was in Australia, giving 


\section{WINTERBOTTOM.}

promenade concerts at Melboume, Sydney, and elsewhere. On his return to England he was appointed to organize the band of the Royal Marine Artillery. This was in 1870 , as he completed twenty-one years' service November, 1891, and retired March 31,1892 . He then beeame bandmaster of the Artists' Rifle Corps, London. He died at Putmey, May 18, 1897. Henry Winterвоттом was bandmaster of the 7 th Royal Fusiliers, the 1sth Royal Irish, and the Royal Marines, Woohwich. Ammon Winterвотrom was a double-bass player, member of the Queen's private band, Philharmonic orchestra, ete. He died in 1891.

Frank Winterbotton, son of the last named, was born in London in 1861. Edu. cated at Bruce Castle, Tottenham. Studied music nnder his father and his mele William. Held appointments as professor of music at Duhwich College, and eonduetor of orchestral societies at Croydon, Clapham, etc. In 1890 was appointed bandmaster Plymouth L,vision Royal Narine Light Infantry, a position he still holds. He gives symphony concerts in the Town Hall, Stonehouse, during the winter months, also entertain sents in the divisional theatre, etc. His compositions inelude: Overture and ballet music, "Jorinda ;" interlude, "Plraulos;" Illustration of Shakespeare's "Seven Ages," Portsmouth, 1892; a descriptive fantasia, "V.R." Also string quartets; pieces for violoncello, upon which instrument he is a skilled porformer; seleetions, arrangements, etc.

Winterbottom, James, musician, born at Glossop, in 1si6. He was sexton of All Saints' Church, Glossop, an office his family had held for 200 years. In addition he was organist of the clureh for 20 years. He died at Glossop, in January, Ist9.

Wise, Charles Stanley, organist and composer. Studied under private teachers, and graduated Mus. B., Cambridge, 1890. Was appointed organist of Petworth Church, 1876 ; Godalming, 187s; St. Michael's, Alnwick, 1881. He is conductor of a ehoral Society at Wooler, Northumberland, and gave the first performance of an oratorio ("Creation") in that place, February 21, 1896. He has composed orchestral pieces, string quartet, songs; anthems, chureh services, etc.

Wise, Michael, composer and organist, born at Salisbury in 1638. He was a chorister in the Chapel Royal under Cook. In 166 s he was appointed organist and choirmaster of Salisbury Cathedral, and in 1675 he became Gentleman of the Chapel Royal. He was made almoner and master of the choristers of St. Paul's Cathedral, London, 16siti-87. He was killed at Salishury, in a midnight brawl with the watch, on August 24, 1687. Composer of a magnificat in li flat. Anthems-

\section{WOOD.}

Prepare ye the way of the Lord; Awake, put on thy strength; Blessed is He; Awake up. my glory; The ways of Zion do mourn; Thy beauty, O Israel, etc.

Woakes, W. H., organist and author, was organist at Hereford early in the present century. He wrote "A Catechism of Music," Hereford, 1s17; "A Cateehism of Thoroughbass, catcehism on music and dictionary," Hereford, 1\$20. He also wrote "Ten glees for three and four roices," [1830]; Songs and anthems, and dance music for the pf.

Woffington, Margaret or Peg, a celebrated actress and singer, was born at Dublin, in 1718. First appeared in London, in 1738. She died in 1760. Her life is given at large in Reade's novel, "l'eg Woffington," in Molloy's biographical work, the "Thespian Dictionary," etc. Best known as an aetress.

Wolstenholme, William, organist and composer, hom at Blackbum, February 24, 1665. Showed remarkable powers when in aite foung; and the late Henry smart promised to take him as a propil, but he died just at tho period agreed upon. Blind from his birth, he was educated at the Worcester College for the Blind sons of Gentlemen, and was musically trained by [1r. I one. He appeared in public while at Worcester, giving organ recitals, and be plaved Mendelssohn so Concerto in G minor at a concert of the Worcester Philharmonic society, December 4, 1885. (iraduated Mus. B., Oxford, 1887, and in his preparatory work committed to memory and transeribed into Braille the score of Beethoren's "Fidelio." In 1888 he was appointed organist and choirmaster of St. Paul's Cburch, Blackburn, in which town he is settled as teacher, ete.

Works, - Cantata, Lord Cllin's langhter, for soli, chorts, and strings; Anthem for Easter; To talie the air, madrigal, 5 voices; Part-song; The voice of love; Thon art high abose me, lady; and other sungs. Organ: Sonata in D, in the style of IJandel; Canzona; Ninnet; Cantilena in F minor ; Finale in B flat; l)ie Frage und die Antwort; Volkslied, ete. Pianoforte: A Collection of pieces in 3 hooks; Minuet in I); Allegro allic burla in F; Wedding marcls; Nocturne; Sicherzo in F; and other's. Also detached pieces for harp, violiu, oboe, viola, and for mandolin anl guitar.

Wood, Anthony à, antiquary and writer, horn at Oxford, leecmber 17, 16:32; died there, Norember 29, 1695. From his writings many biugraphies of the older musician have leen taken. His "Athente Oxoniensis....," Lindon, 1691-92, 2 vols., eontains notices of musicians who were educated at Oxford, and there exists in MS. in the Ashmolean Museum a work entitled "Some Materials towards a IIistory of the Lives and Compositions of all 


\section{WOOD.}

English Musicians." "A Wood," as he styles himself, was a great amateur musician.

Wood, Charles, composer and organist, born at Armach, Ireland, June 15, 1866, son of 'harles Vood, a lay vicar in the (athedral. Obtained the Morley Scholarship for composition, 12.C.M.. 1893, and was appointed professor of harmony, etc., 1888. In 1889, he won the Organist Scholarship, Cains College, Cambridge; and graduated MIus. B. and B.A., 1890; Mus. D. and M.A., 1894, in which last year he was made Fellow of (ronville and Cains College. A.R.C.M. While a student at the R.C.MI. he wrote a pf. concerto, string quartet, and other works. He won the Musical World Prize, 1857, by a setting of Alex. Grant's "Through the Twilight"; the Iadrigal Suciety's prize and gold medal, 18.88, with five-part inadrigal, "slow, slow, fresh fount" : and, in 1889, the prize offered by the Vind Instrument Chamber Music Society for a Quintet for wind. He has written incidental music to lenripides" “Ion," and "Iphigenia in Tauris," produced, at Theatre livyal, Cambridge, 1890 and 1894 ; also set sheller's "Ode to the West Wind," for tenor solo, ehorus and orchestra (op). 3, Cambridge, 1889); and Swinhurne's "Ode to Music," for soprano solo, chorus and orchestra, written for. and performed at the opening of the New Building, IR.C.M., Jay 2, 1s94. He has further published chtrch music, songs, partsongs, and edited a collection of Irish folksongs, Pooser, 1897.

His elder brother, Willasi Gr. Woon, was a distinguished organist. He was borll at Amagh, Jannary 16, 1859, and received his early musical training at the Cathedral, where he was depatyorganist, 1873-7. Heafterward entered the R.A.Ml., and won the Lucas Prize for composition, 1882. Wis pofesisor of the organ, and F.P.A.M., F.R.C.(). While a student, he was appointed organist of Christ Church, Woburn Square (1880): gave frequent organ recitals, appearing at $B$ w and Bromley Institute (1883), and elsewhere; played the organ at the first concert held in the (zueen's Hall, 1)ecenley 2, 1893. In 1886 he was appointed organist and music master of llighgate Grammar School, a post he retained nutil his death, september 25,1895 . He composed an operetta, The liride of Cambus (1883), and published three settings of the Magniticat and Nunc dimittis. He wrote a concert overture for orchestra, and much music for the organ: Fantasia and Fugue in C minor; Simata in D minox; Three Canous, ete., etc., ly which he will be long rementhered.

Wood, Daniel Joseph, organist, conductor and composer, lorn at Brompton, near Chatham, Kent, August 25, 1849. Chorister at Rochester Cathedral, and pupil of J. Hopkins, 1859-64. Appointed organist of Iloly

\section{WUOD.}

Trinity, Brompton, Kent, 1864; Parish Church, Cranbrook, 1866; Lee, Kent, 186s; Boston, Lincolnshire, 1869; ('hichester Cathedral, 1875; and of Exeter Cathedral, 1876. This appointment he holds to the present time. F.C.O., 1873; Mus. B., Oxford, 1874 ; and in 1896 received the Mus. I), Cantuar. He has been instrumental in prectring a fine new organ for the Cathedral, and one in Victoria Hall, to which he was ayprinted organist in 1882. He is also teacher of harmony at Exeter Tniversity Extension College, and has done much for music in Exeter. Was one of the promoters of the Westem Comnties' Musical Association, and has been conductor of its Annual Festivals since its formation in 1880 . His compositions are eonfined to church and organ music, with tunes contributed to the Hymmal Companion (joint editor of the new edition), and chants for the Chant Book Companion.

Wood, Ernest, organist, was elected to the post of organist and precentor of St. Paul's c'athedral, Melbomme, Australia, 1885. Previonsly be was known in England as a clever performer on the organ. He gave recitals with much success at Melbonrue, 1891 ; in 1893 was appointed conductor of the lioval Metropolitan Liedertafel, Melboune; and in 1894 introdued the performance of oratorios in Meslbonrue Cathedral. He gave the first performance of Bach's Matthew "Passion Musice" at Melbourne, in April, 1897 , and has done good work in the cause of musical education there.

Wood, Henry Joseph, composer and conductor, burn in L.mon. Received his early training from his father, and was deputy organist of Sit. Nary's, Aldermanlury, when ten vears old. Gave organ recitals at the "Fisheries," and other exhibitions, South kensington, 188:3-5. Futerad the R.A.MI. in 18s6, studring under E. Prout, Dy. Steggall, It. Macfarren, Manzel Gaveia, and others. On leaving the Academy he lecame conductor of varions societics; also of the Ronsbey opera Company, 1890; the Carl Rosa provincial tour, 189]-2; the (teorgina Purns "Cinderella" towr, 1892; and Lago's season at the New Olympic, 1892. In 1894 be was eonductor during Madame Marie lioze's farewell tour. His career at the (uteen's Hall leegan with the promenade concert season of 1895 , the programmes of which were of the highest class. He has since conducted the symphony Concerts there, and his work has heen characterised hy entorprise and distingnished ability. All this time he has also been occupied as a teacher of singing, espredally for the stage, whilst as a composer he has done a considerable amoint of work.

Works.-Mass, performed, St. Mary's, Bayswater, December, 1892; Mass in F flat, 


\section{WOOI).}

op. 55, St. Joseph's Retreat, Highgate, June, 1896. Authems. Dramatic oratorio, Dorothea, (irosvenor Hall, Feleuary 15, 18s9; Dramatic cantata, Nacoochee, 1890. Operettus: 1)aisy, 1890; Retuming the complinuent; Conic opera, Zuleika, the Turkish slave, 18.00; One humdred years ago, Royalty Thentre, June 16, 18\%2. Romance, violin and pf., 1887. Songs: The sea lath its pearls; six songs, op. 15; The king and the niller; To one I love; Will her heart to me ineline? and others. Anthor of a work on his method of vocal teaching, Breathing, Tones, and their qualities, London, 1896.

Wood, John Muir, writer and musicpublisher, was horn at Edinburgh, July 31, 1805. He established music-publishing businesses in Edinburgh and Flasgow, and was associated with Chopin and other great artists who visited Scotland on concert giving enterprizes. His firm published for a time the Scottish Monthly Musical Times, a joumal which lived only for a slust time $1870-78$. He edited a new edition of (rraham's "Songs of Seotland" (1854), and contributed important Scottish matter to Grove's "I Iictionary of Music." He died at Cove, Tombartonshire, June 25, 1892.

Wood, Joseph, tenor vocalist, was horn at Crigglestone, Yorkslire, on Marcis 1, 1801. He appeared in opera and at concerts, and in 1 s.31 married Mary Ann I'aton (q.r.); and some time after her death Sarah I)olson, a singer. He died at Ifarrogate, in September, 1890.

Wood, Mrs. Joseph, see Paton, Mary Anne.

Wood, Mary Lowisa, organist and teacher. Appointed to St. 'Thomas's Church, Douglas, Isle of Man, 157T; now of St. German's Parish Church in that town. S'ometime couductor of Castletown Choral Society. Has done much for the promotion of music in the island, and given frequent organ recitals. Is an Associat of the Royal College of Organists. Slie read a paper on the "Liturgy of the Clunch from the musical point of view," at the Sodor and Man Diocesan Conference, December, 1896. In August 1895 , she was presented with an address and testimonial in acknowledgment of her work in the canse of numsic and charity.

Woodcock, Robert, English composer of the linth century. He composed "XII. Cuncertos in eight liarts . .," n.d., eliefly for strings and flutes and oboe.

Woodcock, R. J., nusician and teacher, author of " Progrensive system of Chass-singing. cte," I London [1843].

Woodcock, William, organist and composer, born in 1754. He was organist and singing man of new College, Oxford, from $\mathbf{1 7 9 9}$ to 1825 ; Graduated Mus. B., Oxford,

\section{WOOBWART).}

1806 ; and was clerk of Magdalen College from 1784 to 1818. Died at Oxford in 1825.

Woodd, Rev. Basil, clergyman and musician, born at Richmond, Surrey, August 5,1760 . He was educated at Oxford, aud after acting as morning preacher at Bentinck Chapel, Lisson Grove, London, 1785, was minister of Drayton, Beauchamp, Bucks., from 1808 to 1830 . He died at London, April $12,18: 31$. He wrote "A new metrical version of the Psalms of Tavid," etc., and composed "Paddington," a psalm tune, contained in the "Bentiuck Cliapel Collection," 1800.

Woodham, Joseph, double-bass player, was born in 1768 . He was a member of the Royal Society of Musicians for 45 years, and played the double-bass in the orchestra of Covent Garden Theatre, for over 40 years. Died at London, Jamuary 25, 1841.

Woodman, Rev. W., author of "Singing at sight made easy, a complete coursc of instruction," London, 1860.

Woods, Francis Cunningham, organist and composer, born in London, August 29, 1862. Studied at National Training Sehool, Kensington, 1-77-80, under Sullivan, Stainer, Prout, and others. Organist, Brasenose College, Oxford, 1883-6; appointed organ seholar, Exeter College, 1sit. Graduated M.A., 1890; Mus. B., 1891, Oxford. F.R.C.O. In 1891 was appointed private organist to the Iluke of Marlborough, at 13lewheim; and from 1895, organist and music master, Highgate School. Recitalist and teacher. Conductor of Oxford Choral and Philhamonic (1893); Bicester Choral; and Lineoln and Exeter College Musical Societies. Lecturer for Sir John Stainer; to the British Association (Oxford, 1894); Oxford University Exteusionists (1895). Associate of the Philharmonic Society.

Published Compositions. - Cantata, King Harold, produced, C'rystal Palace, June 6, 1896; A Greyport l-egend, men's cliorus, with solo Jass, and orchestra; anthems; madrigal, Lie duwn, poor heart; Carmen Exoniense (Fxeter College song); six songs, op. 1, in MS. Incidental music to Two Gentlemen of Verona (0xford, 1893); to The Tempest (Oxford, January, 1894). Suite in D, for string orcliestra: in C minor, for military band; Minuet, for small orehestra; liomance in F, violin and orchestra: in G, for violin, organ, and pf. Morning and evening service. Anthems, songs, etc.

Woodward, Edwin George, violinist, organist, and conductor, born at Bath, Dec. eniber 10, 1895. Was a chorister of Ciloncester Cathedral, and studied the violin under G. Martin of that city, and harmony with $\mathrm{J}$. Uglow, of Cheltenham. Resided in Ciloncester many years as teacher, and organist of St. Mary's, St. Joln's, and All Saints', resigning the last in 1s+9. The still conducts the 


\section{WOODWARD.}

Gloneester Orehestral Society, and has had other soeieties under his direction. Sueceeded Henry Blagrove as leader of the old Cheltenham Philharmonie, an office he retained until the dissolntion of the soeiety. He has been a member of the Birmingham Festival Orchestra; is still member of the Three Choirs' Festival Orchestra; and leader of the Cheltenham F'estival, Cardiff, Swansea, Newport, and other soeieties. He is a Mason, P.M., and organist, and has composed some music for Nlasonie service, ehureh hymn. tunes, etc. Resident in Cheltenham.

Woodward, Rev. H. H., clergyman and eomposer, born at The Friars, near Liverpool, in 1847. Educated at Radley College, and Corpus Christi College, Oxford. Studied music under Rev. Dr. Hayne, Oxford. Spent a year and a half at Cuddesdon Theologieal College, and was ordained in the Diocese of Oxford, beeoming eurate and precentor of Wantage. Remained there eleven years, working as assistant priest under Dr. Butler, afterwards Dean of Lincoln. In 1881 he was appointed a minor eanon of Worcester Cathedral, and in 1890 sueceeded the Rev. E. V. Hall (q.v.), as preeentor. From 1869 to the present time he has published a complete Morning, Evening, and Communion Service in $\mathrm{E}$ flat; a second in $\mathrm{D}$; Communion Service (unison) in A; Te Deum in B flat. The kadiant Morn; The Sun shall be no more thy light; Behold, the lays come; The souls of the righteous; Rejoice greatly; and other anthems, most of which have been much in use.

Woodward, Richard, organist and eomposer, born at Dublin, about 1744 . He was made Bac. Mus., Dublin in 1768, and Doe. Mus. in 1771. Vicar-ehoral, St. Patriek's Cathedral, 1772. Organist of Christ Chureh Cathedral, 1765. Master of ehoristers, St. Patrick's and Christ Church Cathedrals. $\mathrm{He}$ died at Dublin, November 22, 1777. Composed "Cathedral Musie in Score," op. 3. Anthems. "Songs, Catehes, and Canons," n.d., ete.

Woodward, William Wolfgang, orgavist and conductor, born in 1822. He was organist of the Catholic Chureh, and conduetor of the Choral Union, Derby. Died at Derby, August 4, 1882.

Woodyatt, Emily, soprano vocalist, who was born at Hereford in 1814 . She appeared at many of the principal concerts of her time, in London and the provinces. Narried Mr. William Loder, and retired.

Woolf, Sophia Julia, pianist and composer, born in London, 1831. Commenced learning music when five years old, and afterwards, upon the advice of Cipriani Potter, entered the R.A.M., 1846, beeoming his pupil. Elected ling's Seholar that year, and again in 1848, and on learing was made

\section{WORGAN.}

an Associate, and later, eleeted a Fellow. Narried a Mr. Isaneson. She composed pieces for pf., and songs; also a conie opera, "Carina," preduced at the Opéra Comique, London, September 27, 1888. She died at West Hampstead, November 20, 1893. Potter's last letter was written to her.

Woolhouse, Wesley S. B., mathema. tician and writer on music, born at North Shields, May 6, 1809. He beeame Head Assistant on the Nantical Almanac Establishment and while in that position pullished his "Essay on Musical Intervals, Harmonics, and the Temperament of the Musical Seale," London, Souter, 1835. Second edition, Charles Woolhouse, 1888, issued as "Treatise on musical intervals, temperament, and the elementary principles of music." Aiso author of "A Catechism of musie," London, 18t3; "Treatise on Singing," London, n.d. He also composed some instrumental music, and edited works ly Spohr, Raff, ete. He was elected F.R.A.S. He made a fine collection of violins, and was a man of great scientific attaimments. Iried at Canonbury, London, August 12, 1893. His daughter, Fuma MLY, was a pianist, and married Dr. Willian Rea (q.x.); his son EDMcxd is a violoncellist, of the I'hilharmonic and festival orchestras; and Charles is the well-known London musie publisher.

Woolnoth, Charles Hall, pianist and composer, born at frlasgow, April 15, 1860. Son of Charles N. Woolnoth, a distinguished landscape painter. He studied under Reinecke and E. F. Richter in Germany, and John Farrar Howden (horn, Leeds, 1818; died at (łlasgow, December 25, 1875), in Glasgow, whose daughter he married. $\mathrm{He}$ was for many years an active figure in the musical life of Glasigow, but alout 1891 he went to London, where he is a teacher and pianist. Composer of a cantata, "Il Penseroso": "The sleleton in armonr." choral ballad, Crlasgow, 1889. Part-songs. Musie for pf., ete.

Wordsworth, W. A., musician and teacher. He contributed papers to the Dramatic and Musical Review, 18t2. Lectured in London on English composers, 1844-5. Died. January 25, 1846. Author of "Treatise on Singing, embodying with a course of initiatory exereises, a eritical analysis of the prineiples of the art," London, 1837. Conposer of some ballads, etc.

Worgan, George, musieian, who was a grandson of I)r. John Worgan, was born in 1802. He went to New Zealand, and died at Wellington on April 2, 18s8. He issued "Gems of sacred melody : a choice eollection of psalm and hymm tunes," London, 1841. Songs and other works.

Worgan, John, organist and eomposer, 


\section{WORGAN.}

born at London, 1724. He studied under Rosingrave and Geminiani. Organist and composer to Vauxhall Gardens, 1751-74. Organist of St. Andrew's, Undershaft, with St. Nary Axe, 1749 ; St. Botolph's, Aldgate, London, 1758; and St. John's Chapel, Great James Street, Bedford Row, 1760. Mus. Bac., Cantab., 1748. Mus, Doc., 1775. He died at London, August 24, 1790, and is buried in St. Andrew's, Undershaft.

Worrs.-Oratorios: Hannah, op. 1, 1761: Manasseh. Anthems. Hymns in Riley's collection. Agreeable Choice, a collection of sougs, London [1760]; A collection of new songs ard ballads, sung at Valuxhall, London, 1752, 1754, 1771, etc. Six canzonets for 2 and 3 volces, London [1785]; Three new English cantatas, 1750. Songs and Duets : Bright Plrebus, Cordelia, Hark! the loud drums, I fill not the glass, Jockey and Jenny, Neptune's resiguation, Nun and Friar, Port and Sherry, The thief, To the nightingale, etc. Pieces for the harpsichord [1780]; Six sonatas for the harpsichord, London, 1769. Organ and other pieces.

His brother, James WORGAN, born at Isondon in 1715 ; died there in 1753 , was also a composer. He wrote Sappho's Hymn to Venus, 1750 ; With beauteous Araminta ranging, and other songs, etc.

Worgan, Thomas Danvers, son of John Worgan, was born at Londun in 1774 . He was a teacher and anthor in Lon lon. Brotherin-law of Sir William Parsons. I ied at ('roydon, in 1832. Author of "Rouge et noire de musique, or harmonic pastimes, being games of cards constructed on the principles of music," London, 1807; The Musical Reformer, comprising an apology for intellectual music, Iondon, 1829 ; The composer or contrapuntist, with explanatory notes, London [1826. Composer of Yocal Sonatinas, furming a coalition of rocal and instrumental harmony, 1820, issued in parts. The Heroe's welcome, a motet, comprising 45 parts, 1824. Songs, etc.

His lorother, JoHN Worgax, jun., composed marches for the pf., and Alsence, Emma $[1709]$, Soft downy sleep, and other songs. Other members of the family were MARY WORGAN, who composed a number of songs about 1750-60, and Ricliari, Worgax, who published a "Set of Sonnets, etc," in 1810.

Worrell, Marie, horn Iuval, soprano vocalist, lyorn in London(?), March 3, 1856. Studied at R.A.11. Westmorland Scholar, 1875. A.R.A.M. Sang at concerts in Birmingham and elsewhere while still a student, and both in London and the provinces achieved much success as a concert vocalist. She died at Tulse Hill, London, February 12, 1895.

Wotton, William Bale, bassoonist, horn at Torquay, September 6, 1832 . Son of a

\section{WRIGHT.}

Corporal-major in the 1st Life Guards, he entered the band of the regiment when he was thirteen. Studied at R.A.MI. under Chas. Lucas. Remained in the band of the Life Guards until 1s6f, when lic joined the orehestra of the Crystal Palace. $\mathrm{He}$ is principal bassoon of the Philharmonic, and festival orchestras, and has played in ehamber concerts in many places. He is professor of the bassoon at the R.A.M. and R.C.M. II is sons, L. V. IVottox and T. E. Wotton, are both bassoon players of repute.

Woycke, Emmy Drechsler, violinist, daughter of Adam Hamilton (q.x.), was born at Edinburgh. Appeared at concerts as soloist from hor eleventh year. Played at the Gewandhaus concerts, Leipzig (with her sister Bertha, also a violinist), October 21, 1869. Is now an artist of repute in Edinburgh. In 1871 she was married to Herr EugeN Woycke, a German composer and pianist, settled in Edinburgh. Their son, Victor Woycke, horn in Ediuburgh, in 1872, is a violinist. He was taught at home, and made his first appearance at , concert given by his parents, November 30, 18s9. In 1892 he went to New lork, where he is established as a soloist of the first rank; and where he was also professor of the violin at the National Conservatory of Music.

Wragg, Jo, flute player, composer, and writer, of end of last and early part of present century. Author of The Flute preceptor, or the whole art of playing the Geman flute. London [1790]; Improved Flute preceptor, or the whole art of playing the German Flute rendered perfectly casy without the aid of a master, op. 6. London, 1806. Oboe preceptor, 1792 These works went through several editions. He composed duets, solos, and other pieces for the flute: songs; arrangements and other works.

Wrenshall, $\mathcal{C}$. L., pianist and composer. Studied under Henri Herz. For many years resided at Birkenhead as teacher. Died at Rock Ferry, near Birkenhead, at a great age, in November (?), 1892. He wrote a good deal of music for the pf.. lout it is now forgotten.

Wrenshall, William, an organist at Liverpool, was the eomposer of some anthems. He died in 1854.

Wright, Adam, organist and composer, born at Birmingham, Angust 5, 1810. Was for more than to year's organist of Carr's Lane Chapel, Bimingham; now living in retirement at Erdington. He edited "The Congregational Tume-Book, a comprehensive collection of psalm and hymn tmes.." London, 1847. Sacred melodies for 4 voices [1855]. "Church Music". . 1861. Hrmms for" Home [1868]. He composed many pf. pieces, marches, polkas, gavottes, up to op. 124; some part-songs; The Santus, harmonized; 


\section{WRIGHT.}

and a cantata, "Phyllis," produced at Erdington Public Hall, May 29, 1888. Author of "Pianoforte Students' Daily Practice," London $\lceil 1876\rceil$.

Wright, Elizabeth, see ARNE, MichaEL. Wright, Ellen, song composer, born in London, daughter of an American engineer, George Riley. Married to Mr. Wright, solicitor, London. At first guided only by her natural talent, she began to compose, and ber flrst songs were published in 1891. Afterwards she studied harmony with Henry Gadsby, and instrumentation under F. W. Davenport. Among the songs she has composed are: She walks in beanty; Queen of my days; Had I but known; Love's entreaty; set of six songs (poetry by Prior, Burns, ete.), sung by Mr. Santley at the Saturday Popular Concerts, March 10, 1894; Three songs, the same, December 1; The dawn of life (with orchestral accompaniment), and others.

Wright, Henry Smith, anthor of "An Introduction to the study of Mrasic, with historical and other references," London [1872], 3rdedition, 1882. Composer of part-songs, etc.

Wright, Thomas, organist and composel, born at Stockton-on-Tees, September 18, 1763. Assistant organist to Garth and Eldion of Durhan. Organist at Sedgefield, $1755-97$ : afterwards organist at Stockton in suceession to his father, Robert Wright, an organist of some repute, 1797-1818. He died at Wyelilit Rectory, near Barnard Castle, November 24, 1829. Composer of "Rusticity," an operetta, 1800 ; Anthems, songs, and psum tmes, "Stockton," ete. Fifth ode of the first book of Horace [1796]. Concerto for harpischord or pf. and 2 violius, 2 obes, 2 horns, a tenor and hass [1795

Wright, Thomas Herry, author of "New l'receptor for the Harp, including a series of extreises. . and suceeded by preludes, and progressive lessuns. . London, 1825 ; also f 8.35 . Instructions for the harp, London [1866]. Composer of Fantasias and arrangement. for the harp.

Wrighton, W. T., Fnglish conlymer, born in 1816 . Died at Tumbridge Wells, July 13, 1880. He composed numerous popmlar. songs, among which may he naned Hex hright smile hamts me still [1856]; Approach of Spring; A wish; April showers; Days gont by ; Ever with thee; Faded Rose; My mother"s nanse; Norah ; Onir English rose; Postman's bnock [1855]; She sang annong the Huwers [1863]; Yon need na' come conrting o' ne; Shylie Bawn [1863], etc. With Ienry Wolfgang Amadeus Beale he edited "Congregational Psalmody, a eollection of ancient and modern tunes, chants and sentences.." London f858.

Wrigley, James Grimwood, organist, pianist, and conductor, born at Rochdale,
WRIGLET.

April 16, 1849. Studied pf, under Thomas Ashworth, T. Mekin, and Ed. Dammeuther; organ and harmony under Henry Stevens and Dr. J. F. Bridge. F.R.C.O., 1873; Mus. B., Cambridge, 1878. Was the first organist of St. Mary's Balderstone (1871-3); then of Christ Churull, J3lackpool (1873-5); and for twenty years, from 1875, organist and choirmaster of the Parish Church, High Wycombe. Was conductor of the Black pool Yocal Soeiety, 187.4.5; and is now conductor of the High Wycombe Choral Association, an appointment held since 1875, and of the Maidenhead Philharmonic Society, from 1879. The concerts given under his direction have been noted for the produetion of works by British composers. Mr. Wrigley has given organ recitals in many parts of the country, and appeared at the Bow and Bromley Institute in 1852; he is also known as a solo pianist. He has composed a setting of Ps. 23, for soli, chorus and orehestra ; and published church music, songs, and part-songs.

His brother, Willadr Alfreil Wrigley, graduated Mus. B., Oxford, 16s:?. Has held the office of organist at St. Mary's Rochdale (1871); Christ Church, Nanchester (1879); Holy Innocents', Fallowfield (1882) ; and of Todmorden P'arish Church since 1884. His compositions include Ps. 4 ; , for soli, chorus, and orchestra; part-songs, ete.

Wrigley, John, pianist, organist, composer, and vocalist, born at Ashton-underLyne, Lancastrire, September 29, 1830. Received his first instruction in music from his father, who was organist of Ashtom Parish Church. After some study under Richard H, Andrews and others, he chtered the R.A.M. in 1849 , studying composition under Cipriani Potter. In 1853 he was elected an Associate and in 1887 a fellow of R.A.MI. Many years of his life were spent in Manchester, as a teacher and lecturer; he was also sometime organist of St. Savionr's Church, Chorltonon-Medlock. He begau his eareer as a composer in 1sts, and gave a concert in fot9, before proceeding to the R.A.M.. since 1876 he has been local examine' for R.A.M., and also R.C.M. since its foundation. He has been President of the Tictoria Glee Club, and in 1890 was elected a Vice-President of the Manchester Vocal Unim, which society has performed his larger choral workt. His pf. compositions have been played by F. I I wson and other distinguished pianists. He gave pf. recitals up to 1885 , but of late years he has relinquished active work, remaining hon. local representative of R.A.MF

Worns.-Anthems: Make a joyful noise; Iloly, Holy, Iloly; He brought down my strength (all for soli, quartet, and chorus, and perforned in the Gentlemens' Concert Room, Manchester). Spring time, part-song; 


\section{WLRII.}

O, merry lark, glee; The lover's choice; $O$, give me music; Ave Maria, and other sougs. Jubilee march (performed at opening of Manchester Exhilsition, 1887). Introduction and variations, Gobury thy sonrow, organ. Pianoforte: Somata No. 1, in A (1670); No. 2, in G (1892); Grand waltz; Sprites' Frolic; Tarantella in $\mathrm{t}$ minor; Allegretto grazioso in C; Allegro de concert; and other pieces.

Wurm, Marie J. A., pianist and composer, loorn at Somthamptom, May 18, 1460. Her father, J. F. Wnm, was a jistist and concert giver in that town. He died, 1s9. Marie Wurm studied at the stuttgart ('onservatorim, and also with F. Taylor, Madame Selommann, J. liaff, and others. In 1894 the wom the Mendelssoln fiebolarslyp, and studied under sir Arthur Sullivan, Irs. Ftanford and J. F. bridge. She played schmmam's pianoforte concerto at the Crystal Palace, November 11, 188.2, and alpreared at the Monday Popmlar Concerts in 1884. In this year sle appenerl at her father's concert, Southampters, witl her sister Alice, also a pianist. She luas given recitals in Lomdon, and played in Leipzig, Berlin, Mesningen, and other places with grat suceess. Her compositions comprise a lif. concerto in I, minor, and an over. ture (burlin, 1sit); String fluated in P flat, op. 40 (London, 1894); Sonata, pf. and violonerslo; Fonr pf. fluets, op). 24; Pf. pieces, part-songs, and ducts, ete. Ifer sistere,

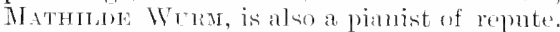
She has given recitals in Siteinway Hall, Lundon: Chamber concelts in Princes' IIall; and played at the Saturday l'opular Concerts (Jammary, 1845), and alsewhere. In 1893 she adonted the name of Verne.

Wydow, or Wedow, Robert, clelgyman and musictan of the 15th centurv, was a native of Thaxted, in Hsiex. He watseducated at Oxford, and berante Mus. B. there, and at Cambridge in 150). He was presented to the living of Thaxted les Edward $1 \mathrm{~T}$. in $1 \mathrm{l}$ si, and lueld it till 1489). In 1497 hesuccerdod Alyngdom as suceentor of Wells Cathedral. He died in 15015 .

Wylde, Henry, composer and witer, horn at Busher, Hertfordshire, in 182.2. Fon of Honry Wride, gentleman in ordinary to fieorge it. He was orgmist of St. Ams's. Aldersgate Street, london, in 184t, and in 1852 he fommded the New Philhamonic Sueiety, at which le prodneed Liszt's "sit. Elizalieth" in 1s70, and other modern wollis. In 187 the establisherl the Jondon Arademy of Music. Mhus. I). (autal), 1651 (atecummilated degrees). (tresham l'rofessor of music

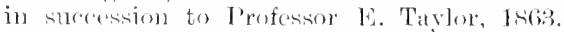
Assoreiateof R.A.M., ete. He died at lomdon, Mared 1:, 18!30. Anthor of "Harmmony, and the heience of Mosic," Iundon, 186.5 and 1572; "Music in its At Mrsteries," I Dondon,
IV INNE.

1867 ; "Modern Counterpoint in major keys," London, 187:3; "Oceult Prineiples of Misic," 18st ; "Musie as an Educator..," 1892. Evolution of the Beantiful in Siomed, Man(chester, 1887. ('omposer of l'raise and praver, op. 1t, and Paradise lost (selections), 1850, cantatas; a l'ianoforte Concerto in F minor; Somatas for ple. ole. 1 and 7 ; Rhapsody for pf., op. 2. Selection of Chants.., Londom [1864].

His brother, Jases Wrube, was a happist in London.

Wynne, John, vocal composer, of the $18 \mathrm{th}$ century, composed, among other works, "'w lve English Songs," London 1750$].$

Wynne, Kate, contralto vocalist, sister of undernoted, was born at Holywell, Flintshire. Her countrymen gave her the title of Llinos Ginnedl-The Linnet of Wales. With her sister she las a peared at many concerts in I ondon and the provinces. At St. George's Hall, the sisters introlnced to a London audience John Thomas's cantata, "The Bride of Neath Valley," Felmary 12, 1867. After her marriage with MIr. Jenry Matthison, of Bimingham, she still sang a good deal in pulblic, and was a great favourite in the l'rincipality, receiving compliments from I rord Penrliyn and others. She retired from the pro'ession abont the year 1877 .

Wynne, Sarah Edith, Eos Cranu Pwendmes, The Nightingale of Wales. Soprano vocalist, born at Holywell, Flintsline, March 11, 184\%. Sang, at the age of nine, at a concert of the llolywell Plhilhammonic Society, and a few years later was placed under Mrs. Sicarisbrick, of Liverpool. In 1862 (July 4), she made her first appearance in London, at a concert of Welslı music, given by Mr. John Thomas. Aloont this time we entered the R A.M., and in 1803 won the Westmorland Sicholarship. Iler reputation rapidly spread, and she was engaged for the principal concerts. In 186 , she studied for a short time inder Romani, of Florence. She sang at the Pirminghan Musical Festival of 1870 , and ufterwards at other like celebrations, and in 1s71, visited America. From this time her career was an unlroken success. In 1872 she sang at a State concert, and, two years later, was the recipient of a flattering testimonial at the Hanver Square Rooms. A marble bust of herself was presented to her by Sir Watkin W. Wynn, and a diamond bracelet hy Mr. Oshome Morgan. She was married to Mr. Aviet Agabeg at the Savoy Chapel Royal, November 16, 1675, since when her time has been chicfly devoted to tnition in singing, but she occasionaly ap) rared in public, singing at St. James's Ifall so late as July, 1894 , and at Aberystwith in the summer of 1896. She lad some little stage experience, singing in the first per- 


\section{WYVILL.}

formance of Macfarren's "Jessie Lea," at the Gallery of Illustration, November 2, 1863; in "Maritana," and other English operas, at the Crystal Palace, from 1869, for a season or two. She also took part in the performance of the second part of King Henry IV, at Drury Lane in 1864, when she interpolated the Welsh song, "The Bells of Aberdovey." It was, however, in the simple ballad that her greatest charm was exercised. This eminent artist died suddenly in London, January $23,1897$.

Wyvill, Zerubbabel, composer and organist, born at Maidenhead, Berks., in 1763. He was a teacher of music at Maidenhead, and organist of the Chapel of St. Mary Magdalene and Andrew there. Resided at Inwood House, Hounslow, and was twice married. In 1828 he was involved in Chancery proceedings concerning the estate of his father-in-law. He died at Hounslow Middlesex, May $14,1837$.

Works.-A collection of pialms and hymus for four vo.ces, London, n.d. A collection of catches and glees for 3 and 4 voices, London, n.d. Anthem, two hymns, and two dismissions, selected and composed for the (ieneral Thanksgiving, June 1, 1802. In this appears the well-known hymm tune "Eaton." Berkshire March, in 8 parts, London, 1793. Armed Yeoman, song [1795], etc.

His son ROBERT, born 1789; died at Maidenhead in August, 1869, was organist of St. Mary's Chapel there, and published a Collection of hymn tunes and chants; and "A second set of Hymus arranged for the pf. or organ," London, 1840.

Another musician of the name of J. WrithL, composed "Friar John in his cell," an epigram, London $[1780]$, and other rocal music.

Wyse, John, musician, issued "MLusic of the hymus, anthems, and litanies, intended for the use of the co-fraternities of La Salette, established in England," London, 1855.

Xiniwe, Paul, bass vocalist, and momber of the South African Choir that visited Great Britain in 1891. He was edncated at the Lovedale Institution, Cape Colony, has a fine bass voice, is remarkably intelligent, and acted as the spokesman of the choir, which saug by command before the Queen. While in England he olntained the Elementary and Intermediate Certificate of the Tonic Sol-fa College, and is now exercising his skill in his native district.

Yarwood, Joseph, composer and bass singer, born at Manchester, May 6, 1829. Composer of anthems Glees: Our jolly tars; Merry boys at sea; Town and trade; Fill the goblet; Hail to the woods; Welcone brothers ; etc. Also polkas and otler pf. music.
YOLNG.

Yates, William, composer, whoflourished in the latter half of the 1sth centnr. $\mathrm{He}$ wrote among other works a "Collection of moral songs or hymus, by I. Watts," London, 1769. "New musical address to the town on the opening of Marylebone Gardens," London

1763 ; "Collection of songs sung at Vauxhall and Marylebone Gardens," London [176t]. Songs : Colin's address: Haughty 1)elia; Tell-tale, etc. Six easy sonatas for harpsichord, op. 3 [1770].

Yonge, Nicholas, musician of the 16th and 17th conturies. Published "Musica Transalpina, madrigales translated, of 4,5 , and 6 parts, chosen ont of divers excellent authors...." London, 1588. "Musica Trausalpina, the second book of madrigates to 5 and 6 voices, trinslated out of sundry Italian anthors.. ." London, 1597.

Youll, Henry, a composer of madrigals and other vocal music, who flomished at the end of the 16th and beginning of the 17 th centuries. He issued " Canzonets to three rosces," London, 160 r.

Young, Anne, see Gexs, Axwe.

Young, Cecilia, see sub. Ame, Thomas A.

Young, Rev. Edward, anthor of "The Harp of (rod," twelve lectures on liturgical music, its import, history, present state and reformation," London, 1861. Composer of A moming and evening service, Te dem, jubilate, magnificat, and nume dinittis, hymn tunes, etc.

Young, Harriet Maitland, composer, of the present time, who has written several operettas: "An Artist's Proof, produced Brighton, Felmruary 4, 1s-2 ; "The Queen of Heart.," Dartford, February 6, 188.; " The Holly Branch," and "When one door shuts, anuther opens," produced at Bradford, November $2 s, 1896$. Also composer of Tell ne so; A passing cloud, and othel songs.

Young, Isabella (Mrs. LAnpe), soptano rocalist, sister of Mrs. T. A. Arne, and danghter of Charles Foumg, organist of All Hallows, Barking. She sang at concerts, and after her marriage to Juham Friederich Lampe (1703-1751) she sing on the stage in works by her husband and others.

Young, John Matthew Wilson, organist and composer, born at I)urham, December 17,1822 . Was principal solo boy in the cathedral choir; pupil of Dr. Henshaw, and afterwards lis assistant. For six rears he was music-master at the York and Ripon Training College. In 1 fiso he was appointed organist of Lincoln Cathedral. When the Peterborough and Linenln "Oratorion Festival "was established, in 1888, Mr. Fonng was joint conductor with the organist of Peterborough Cathedral, the first Lincoln Festival oecurring Jume 19, 1889. After holding his appointment at Lincohn Cathed ral for 45 years, he retired in 


\section{TOUNG.}

1895, and removed to London. He died at West Norwood, March 4, 1897. His works include a sacred cantata, "The Return of Fsrael to Palestine," produced at the Lincoln Festival, Jume 15, 1892; "F will extol my Cod," and other anthems; a Festival Service in C: Moming Service in D; several settings of the Te Deum, and other Church musie.

Young, Mary, Mrs. Barthelemon, soprano voealist, was born about 1745 . She was tanght singing in London, and appeared at Drury Lane in "The Spring," pastoral, in 1762. In 1766 she married F. H. Barthelemon, the French violinist and composer. She was the original Nysa in O'Hara's "Miklas." Died September 20, 1799.

Young, Rev. Matthew, elergyman and musician, born at Roscommon, 1750. Died in 1800 . Author of "Inquiry into the principal phenomena of sounds and musical strings," London, 1784.

Young, William James, organist and eomposer, lrother of J. M. W. Young, born at Durham, April 18, 1835. Chorister, Durham Cathedral, 1843. From 1852 studied moder his lrother at Lincoln; assistant organist, Lincoln Cathedral, 1857-8. Organ. ist of st. John's, Longsight, Nanchester, 1858-71: St. Peter's, Levenshume, 1871-80; St. James', Birch-in-Rusbohme, 1880; and St. Elizabeth's, Reddish (rreen, near Stockport, 1895. Composer of a large number of part-songs, Gaily thro' the greenwood; F love the merry splingtime; Hail! merry christmas; O, welcome, merry May, ete., most of which have been widely popular. He has also composed some sougs, "The Winter King" (with orehestra); and marches for orchestra which have been perfermed at Manehester, Scarborongh Spa, ete.

\section{ZUCCHELLI.}

Younger, Montague, organist, born at Sydney, New South Wales. Pupil of C. S. Paeker. Has been organist of St. Andrew's Angliean Cathedral, Sydney, sinee 1868. Condueted a performance of Benediet's "St. Peter" (the first in Australia), at the Sydney International Exhibition, April 10, 1880.

Zerbini, John Baptist, violinist and pianist, son of an Italian musieian (J. B. Zerbini, memler of the London Philharmonic orchestra, died December 27, 1889), was born in Loudon in 1839. He began his eareer in the band at Drury Lane when he was seventeen, and in 1867 joined Mr. Chappell's string quartet at the Popular Concerts as viola player, and also as pianoforte aceom. panist. He married Anna Patey, who was for a long time amanueusis and seeretary to the eminent geologist, Sir Charles Lyell. His wife died in June, 1884, and Zerbini, in failing health, went to Australia. $\mathrm{He}$ soon established himself as a teacher of repute; direeted Chamber concerts at Vietoria, in 1887; and died at Melboume, November 28, 1891. He was a man of quiet, unassuming manners, an exeellent accompanist, and a gond all-round musieian.

His brother, EAanier, a native of London, was a vocalist and composer.

Zotti, Carlo, see Croal, George.

Zucchelli, Carlo, bass singer, born at London, of Italian parents, Jamuary 28, 1793. In 1814 he sang at Novara, and afterwards sang in other Italian towns till 1818. He made his début at the King's Theatre in April, 1822, and also appeared at the Aneient Concerts. He sang in Paris in 1825, and other continental towns. He died at Bologna, in February, 1879. 


\section{APPENDIX.}

\section{ADDITIONS AND CORRECTIONS.}

Albertazzi, Emma, page 5. Correct toDied September 25, 1847.

Allon, Henry Erskine, page 8. AddCantata, "Oak of Geismal", was produced by the Highbury Phitharmonic, Jamuary 26, 1897. After undergoing an operation for abscess, Allon died suddeuly at London, April 3, 1897 , aged 32 .

Alquin, F. C. d', page 9. Should beALQUFN.

Anne, Susanna Maria, page 13, should be ARNE.

Beale, Thurley, page $36 . A d d$-Died in London, Nay 5, 1897.

Bennett, Sir W. S., page 42. Correct from line $T$ of notice to He resided at Leipzig, 1836-7, at the suggestion and expense of the firm of Broadwood and sons, in order that he might gain experience, and profit by the influence and companionship of Meudelssohn and other great artists.

Best, W. T., page 44. Add date of death-May 10, 1897 .

Bowling, page 55. Correct year of birthJohn Bowling, to 1817. Date of deathJ. O. Bowling, to July 10, 1856.

Bridge, J. F., page $60.4 d d$-Knighted by Queen Victoria, in Jume, 1897. Additional Jorks-." The Flag of England" (Rudrarch Kipling), for soprano solo, chorus, and orehestra, produced, R yal Allert Hall, May 6, 1897.

Buswell, John, page $72 . \quad A d d-\mathrm{He}$ was a Gentleman of the Chapel Royal, and died November $14,1763$.

Carr, Frank O., page 79 . Add-Born near Bradford, April 23, 1858.
Corfe, John Davis, organist, born at Salishury, in 1804. Son of Arthur Thomas Corfe. He was for more than half a century organist of Bristol Cathedral, and conductor of the Bristol Madrigal Society for many years. He died at Bristol, January 23, 1876.

Culwick, James C., p. 111. Add to Worls-Overture for orchestra, prize, "Feis Ceoil," Dublin, May, 1897.

Flower, Sara, eoutralto, p. 148. The date of birth, February 22, 1805, is that of the Sarah Flower of the preceding paragraph. The singer made her debut, when a young girl, at Drury Lane, January 7,1843 , in an English version of "La Gazza Ladra." She had been a student at the R.A.M.

Gadsby, H. R., p. 154. Add to Works.. Concerto for organ and orchestra, produced, Crystal Palace, January 24, 1874.

Garrett, G. M., p. 156. Add-After a long illness, he died at Cambridge in the night of April 8, 1897.

McGuckin, Barton, p. 262. After Theatre Royal, add Birmingham.

Mann, Arthur H., p. 269. Adl-He was appointed organist to the University of Cambridge, May, 1897, in succession to the late Dr. Garrett.

Martin, Dr. C. G., p. 273. Add-Knighted by Queen Vietoria in 1897.

Parry, C. H. H., p. 310. Add to JorksTheme and variations, orchestra, produced Philharmonic Society, June 3, 1879.

Stanford, Charles V., p. 389. AddAppointed Conductor of Leeds Philharmonic Society, June, 1897.

DERBY :

Printed by Chadfield \& Son, Ltd., "Friary Works. 



$$
\text { - }
$$





$$
\left.4^{4}\right\}^{3}+
$$


